US Army Corps of Engineers $s_{\circledast}$

Engineer Research and

Development Center

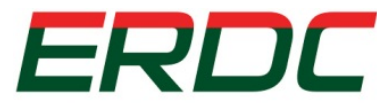

INNOVATIVE SOLUTIONS for a safer, better world

\title{
Character-Defining Features of Contributing Buildings and Structures in the Fort Gordon, Georgia, Signal School Campus Historic District
}

Sunny E. Adams and Adam D. Smith

July 2016
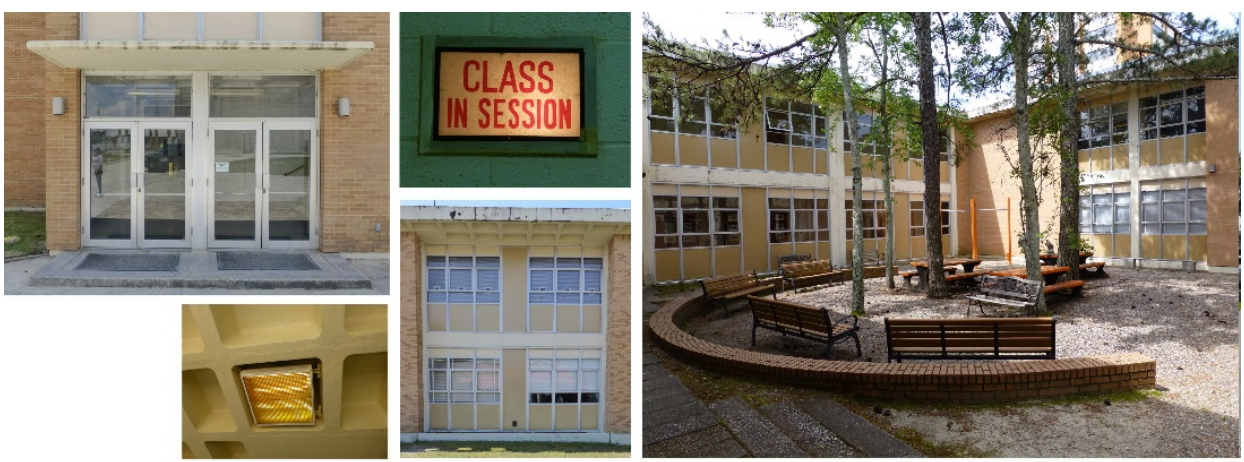

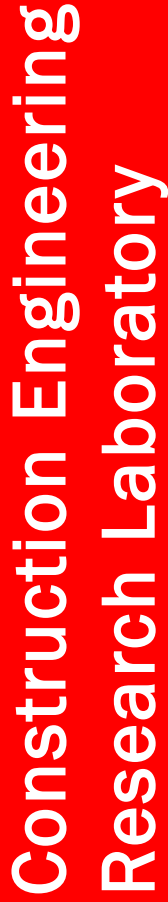
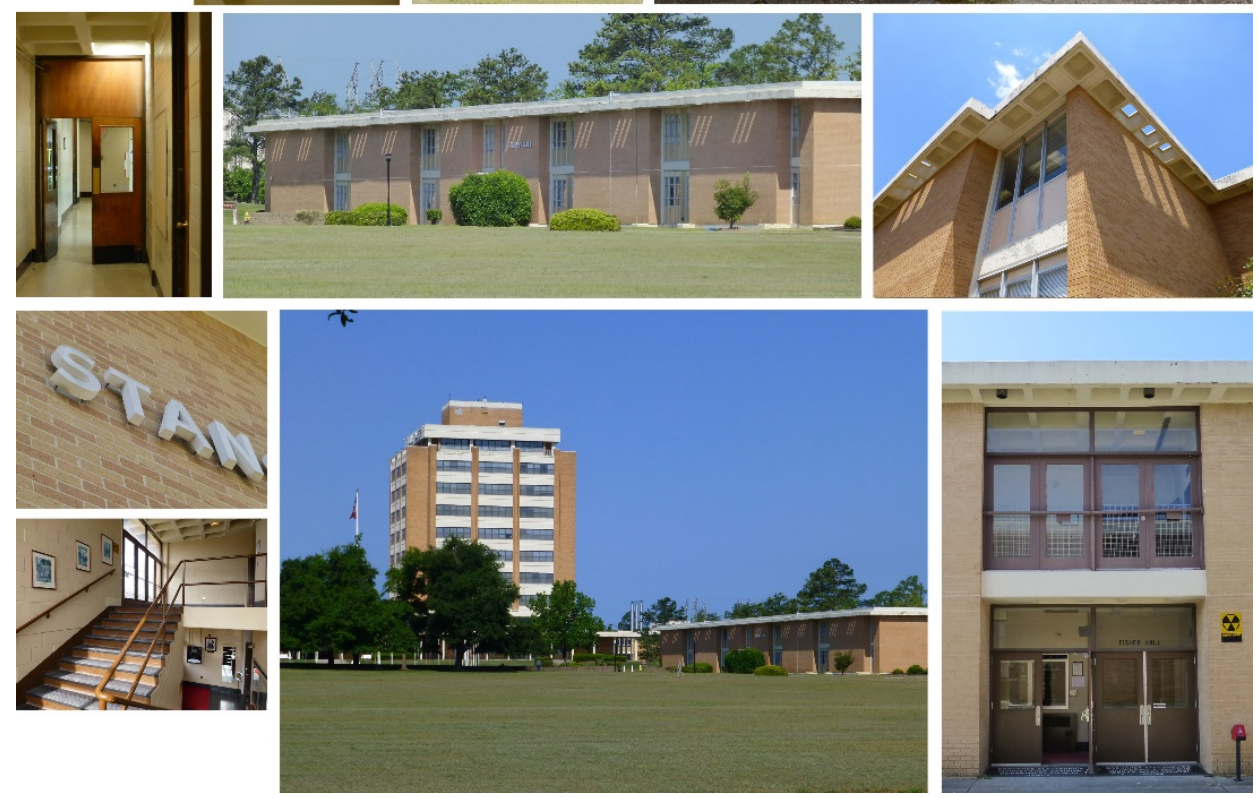

Approved for public release; distribution is unlimited. 
The U.S. Army Engineer Research and Development Center (ERDC) solves the nation's toughest engineering and environmental challenges. ERDC develops innovative solutions in civil and military engineering, geospatial sciences, water resources, and environmental sciences for the Army, the Department of Defense, civilian agencies, and our nation's public good. Find out more at www.erdc.usace.army.mil.

To search for other technical reports published by ERDC, visit the ERDC online library at http://acwc.sdp.sirsi.net/client/default. 
Character-Defining Features of Contributing Buildings and Structures in the Fort Gordon, Georgia, Signal School Campus Historic District

Sunny E. Adams and Adam D. Smith

Construction Engineering Research Laboratory

US Army Engineer Research and Development Center

2902 Newmark Drive

Champaign, IL 61822

Final report

Approved for public release; distribution is unlimited.

Prepared for Cultural Resources

Directorate of Public Works

Fort Gordon, GA 30905

Under Project 450904, "NHPA Building Evaluations at Fort Gordon” 


\section{Abstract}

This document is an architectural survey of character-defining features for the contributing features of the Signal School Campus Historic District located at Fort Gordon, Georgia. This survey satisfies Section 110 of the National Historic Preservation Act of 1966 as amended, and it was used to determine which elements of the buildings and structures of the historic district are character-defining features for the elements that are eligible for the National Register of Historic Places.

DISCLAIMER: The contents of this report are not to be used for advertising, publication, or promotional purposes. Citation of trade names does not constitute an official endorsement or approval of the use of such commercial products. All product names and trademarks cited are the property of their respective owners. The findings of this report are not to be construed as an official Department of the Army position unless so designated by other authorized documents. 


\section{Contents}

Abstract.............................................................................................................. ii

Figures and Tables.........................................................................................................

Preface .......................................................................................................................... XXX

Unit Conversion Factors.............................................................................................. XXxi

Abbreviations............................................................................................................. xxxii

1 Methodology ............................................................................................................ 1

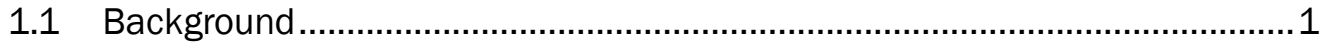

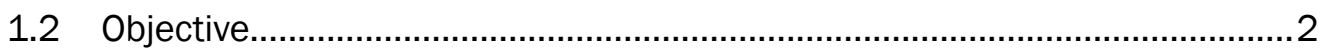

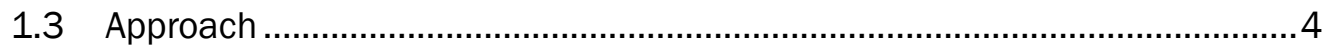

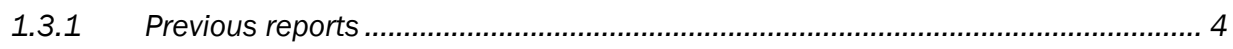

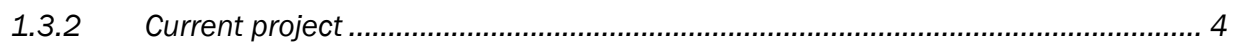

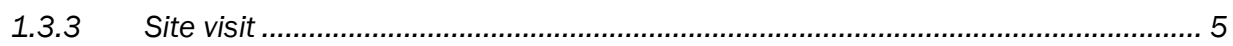

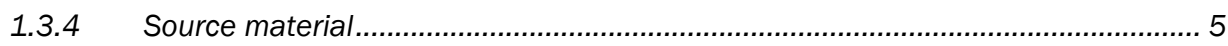

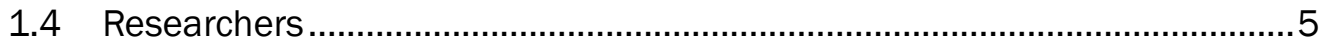

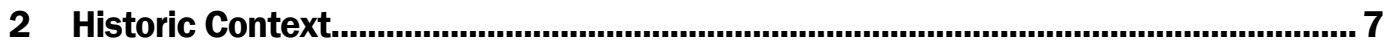

2.1 Fort Gordon development pre-1965 ....................................................... 7

2.21965 to 1975 development of the Signal School Campus ..........................

3 Character-Defining Features for the Signal School Campus..................................23

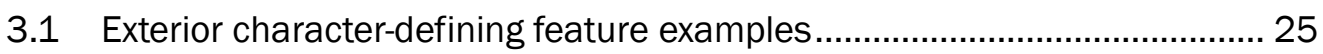

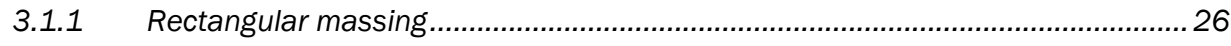

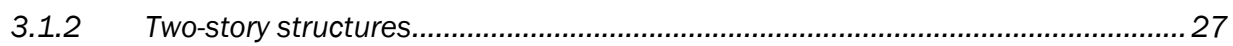

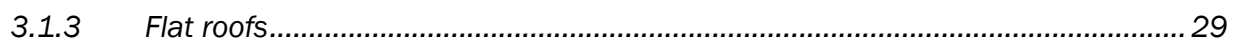

3.1.4 Brick veneer exteriors ................................................................................... 30

3.1.5 Overhanging eaves with perforated waffle .......................................................... 31

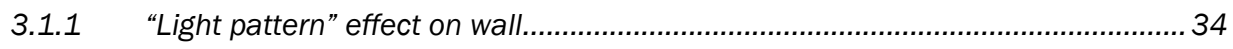

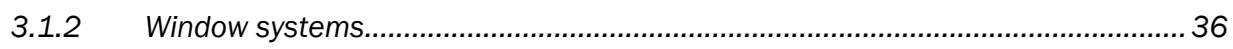

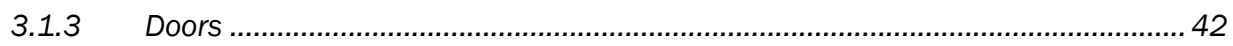

3.1.4 Exposed concrete structural system ...................................................................46

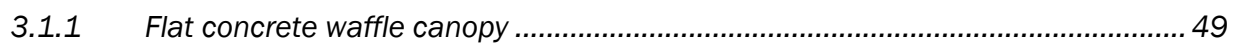

3.1.2 Flat concrete canopy above entries................................................................. 51

3.1.3 Cylinder exterior light fixtures......................................................................... 54

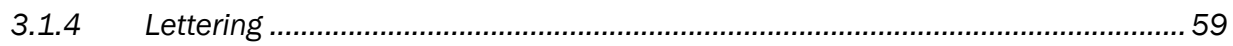

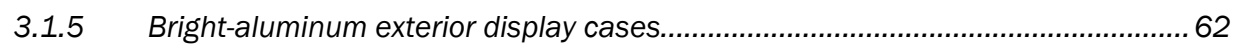

3.1.1 Metal handrails and poured-in-place concrete retaining walls .............................62 62

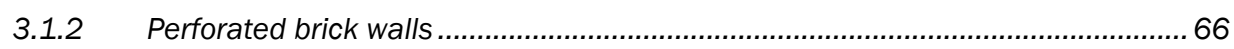

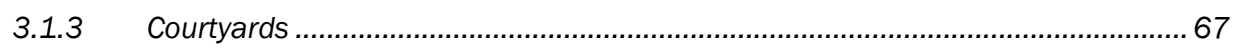

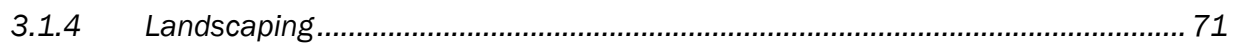


3.1.5 Relationship to other buildings within campus ................................................... 78

3.1.6 Signal School Campus features; sidewalks and exterior light poles...................... 81

3.2 Interior character-defining feature examples.......................................... 84

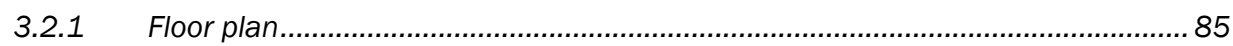

3.2.2 Hallways with waffle ceilings and concrete block walls........................................ 86

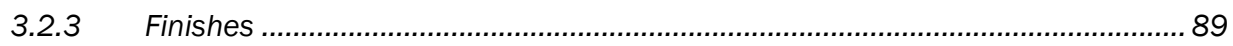

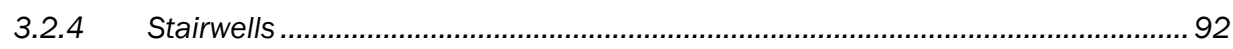

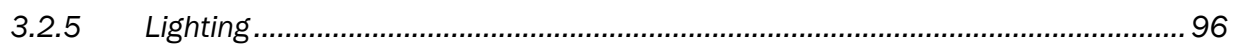

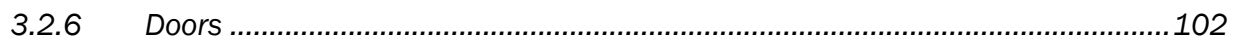

3.2.7 Bright-aluminum display cases ................................................................107

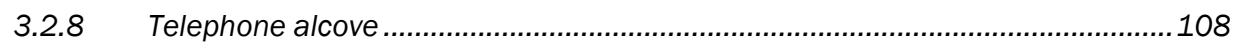

3.2.1 Vending alcove ............................................................................................... 109

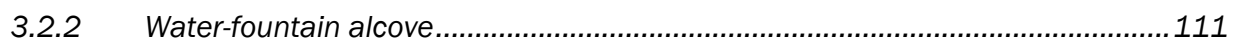

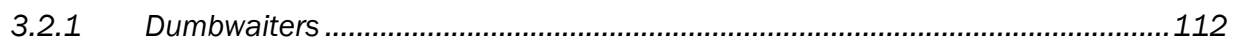

3.2.2 Fire hydrant display cases ............................................................................ 114

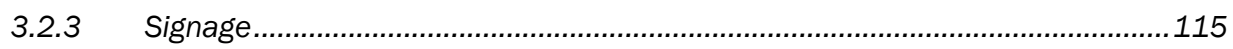

3.3 Buildings.................................................................................. 118

3.3.1 Building 25810, Brant Hall (1973) .............................................................118

3.3.2 Building 29801, Nelson Hall (1969)..........................................................132

3.3.3 Building 29802, Moran Hall [south] (1973)................................................... 144

3.3.4 Building 29803, Moran Hall north (1973) ........................................................ 153

3.3.5 Building 29805, Alexander/Olmstead Halls (1970)........................................... 164

3.3.6 Building 29807, Museum [Conrad Hall] (1970) ................................................179

3.3.7 Building 29808, Signal Towers (1970) ........................................................... 189

3.3.8 Building 29809, Greely Hall (1966).................................................................205

3.3.9 Building 29810, Burkhardt Hall (1970) .........................................................229

3.3.10 Building 29811, Saltzman Hall (1966)...........................................................242

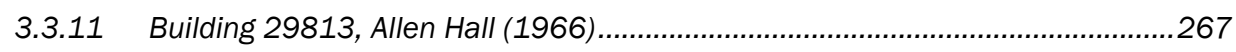

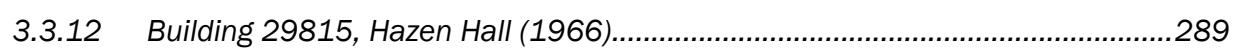

3.3.13 Building 29816, Fisher Hall (1966)..............................................................303

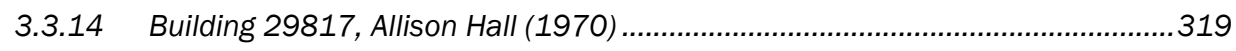

3.3.15 Building 29818, Johnston Hall (1966) ..............................................................334

3.3.16 Building 29819, Stansell Hall (1970)..................................................................350

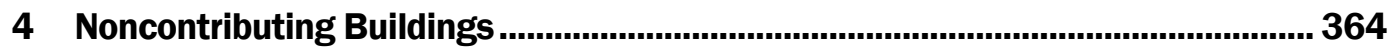

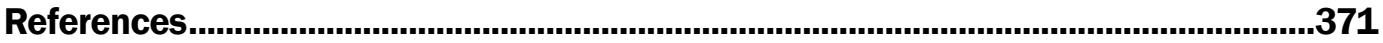

\section{Report Documentation Page}




\section{Figures and Tables}

\section{Figures}

Figure 1. Boundary outline and location of Fort Gordon, Georgia, southwest of Augusta (www.google.com, accessed June 2016).

Figure 2. Location and boundary for Signal School Campus Historic District (U.S.

Geographical Survey [USGS] map, district outline added).

Figure 3. The layout of Camp Gordon, with north to the left, 1943 (Fort Gordon DPW).

Figure 4. Northern side of the WWII cantonment (Fort Gordon DPW).

Figure 5. Original master plan for the Southeastern Signal School in 1966 (Fort Gordon DPW).

Figure 6. New barracks and mess hall plan for the south side of Chamberlain Avenue in outlined box (Fort Gordon DPW).

Figure 7. Aerial view of the Signal School Campus, with the completion of the six Phase I classroom buildings (light rectangular roofs in photo's center), the beginning construction of Phase II, 1968 (barracks buildings at center left of photo) and the construction of Building 33800 (bottom center) (Signal Corps Historian Office).

Figure 8. Elevations for the enlisted women's barracks designed by Southeastern Architects and opened in 1968 (Fort Gordon DPW).

Figure 9. Aeck rendering of the Southeastern Signal School, 1963 (Fort Gordon DPW).

Figure 10. Aeck rendering of the administration building (Building 29808) on the west side of the Signal School area, 1963 (Fort Gordon DPW).

Figure 11. Forms for the concrete waffles at Fort Gordon, 1963 (Fort Gordon DPW).

Figure 12. Allison Hall (Building 29817) in the new Signal School complex, May 1970 (Signal Corps Historian Office).

Figure 13. Greely Hall (Building 29809), one of the Signal School classroom buildings, December 1966 (National Archives at College Park, MD).

Figure 14. Auditorium (Building 29805) and Signal School Headquarters (Building 29808) on the west side of the campus [the library, which is now a museum, is hidden between the two buildings in this view], April 1978 (National Archives at College Park, MD).

Figure 15. Signal School landscaping plan east side, 1966 (Fort Gordon DPW)...............16

Figure 16. Signal School landscaping plan west side, 1966 (Fort Gordon DPW).

Figure 17. General view of Phase I construction of the Signal School, March 1966 (National Archives at College Park, MD).

Figure 18. Building 29811, Saltzman Hall, March 1967, with some characteristic landscaping in place (National Archives at College Park, MD). 18

Figure 19. General view of the campus, showing landscaping and looking northeast towards Saltzman Hall (Building 29811) on the left, Allen Hall (Building 
29813) middle, and Allison Hall (Building 29817) right, April 1978 (National

Archives at College Park, MD).

Figure 20. Landscaping drawing for courtyard to the east of the library (Building 29807) (Fort Gordon DPW).

Figure 21. Landscape planting list, 1966 (Fort Gordon DPW).........................................19

Figure 22. Courtyard design \#H-111, 1966 (Fort Gordon DPW). .......................................20

Figure 23. Courtyard design \#H-143, 1966 (Fort Gordon DPW). .......................................21

Figure 24. Detail drawings for various designed elements used within the courtyards, 1966 (Fort Gordon DPW).

Figure 25. Signal School Campus Historic District boundary (www.google.com, accessed January 2016).

Figure 26. Rectangular massing, Building 29802, Moran Hall south (ERDC-

CERL, 2015). 26

Figure 27. Rectangular massing, Building 29805, Alexander/Olmsted Halls (ERDC-CERL, 2015).

Figure 28. Rectangular massing, Building 29809, Greely Hall (ERDC-CERL, 2015).

Figure 29. Rectangular massing, Building 29815, Hazen Hall (ERDC-CERL, 2015).

Figure 30. Two-story classroom building, Building 29811, Saltzman Hall (ERDCCERL, 2015).

Figure 31. Two-story classroom Building 29813, Allen Hall (ERDC-CERL, 2015)..............28

Figure 32. Flat roof construction of Building 29810, Burkhardt Hall (ERDC-CERL, 2015).

Figure 33. Flat roof construction of Building 29816, Fisher Hall (ERDC-CERL, 2015).

Figure 34. Brick veneer exterior walls, Building 29813, Allen Hall (ERDC-CERL, 2015)

Figure 35. Close-up of an example of the brick veneer exterior walls, Building 29819, Stansell Hall (ERDC-CERL, 2015).

Figure 36. Concrete waffle ceiling structure that extend out to form an overhang,

Building 25810, Brant Hall (ERDC-CERL, 2015).

Figure 37. Perforated concrete waffle overhang, Building 29803, Moran Hall north (ERDC-CERL, 2015).

Figure 38. Typical concrete waffle overhang on the classroom buildings, Building 29813, Allen Hall (ERDC-CERL, 2015).

Figure 39. Close-up of concrete waffle overhang, Building 29819, Stansell Hall (ERDC-CERL, 2015).

Figure 40. Building 29805, Alexander/Olmsted Halls, constructed with precast concrete T-beams (ERDC-CERL, 2015).

Figure 41. Example of the "light pattern" created by the perforated waffle overhang, Building 29801, Nelson Hall (ERDC-CERL, 2015).

Figure 42. The "light pattern" displayed across the entire second floor of the south elevation, Building 29809, Greely Hall (ERDC-CERL, 2015). 
Figure 43. The "light pattern" changes in size as the sun rises and sets, Building 29813, Allen Hall (ERDC-CERL, 2015).

Figure 44. Typical four-bay window system designed with bright-aluminum frames, three-pane awning windows, and insulated panels, Building 29810, Burkhardt Hall (ERDC-CERL, 2015)

Figure 45. Typical seven-bay window system with bright-aluminum frames, six three-pane awning windows separated by insulated panels and sandwiched by insulated panels, Building 29811, Saltzman Hall (ERDC-CERL, 2015).

Figure 46. Typical window bay system with bright-aluminum frames, three-pane awning windows, and insulated panels, Building 29813, Allen Hall (ERDC-CERL, 2015).

Figure 47. Modified window pattern with the removal of the original awning window and the addition of the newer insulated panel, Building 25810, Brant Hall (ERDC-CERL, 2015).

Figure 48. Modified window openings with newer panel inserts, Building 29816, Fisher Hall (ERDC-CERL, 2015).

Figure 49. Bright-aluminum fixed-pane window system above entry bay, Building 29813, Allen Hall (ERDC-CERL, 2015).

Figure 50. Example of three window systems: bright-aluminum framed awning windows with insulated panels, bright-aluminum framed fixed-pane windows, and concrete panel inserts, Building 29816, Fisher Hall (ERDC-CERL, 2015).

Figure 51. Some of the Signal School buildings were designed with bays of insulated panel inserts, for example Building 29819, Stansell Hall (ERDC-CERL, 2015).

Figure 52. Bright-aluminum fixed-pane clerestory windows, Building 29807, Museum/Conrad Hall (ERDC-CERL, 2015).

Figure 53. Replacement anodized-bronze aluminum one-over-one windows,

Building 29808, Signal Towers (ERDC-CERL, 2015).

Figure 54. Paired bright-aluminum and plate-glass entry doors with transoms above, Building 25810, Brant Hall (ERDC-CERL, 2015).

Figure 55. Bright-aluminum and plate-glass doors with sidelights and transom, Building 29805, Alexander/Olmsted Halls (ERDC-CERL, 2015).

Figure 56. A set of metal doors with pane, sidelights, glass transom, and insulated panel above, Building 29801, Nelson Hall (ERDC-CERL, 2015)..

Figure 57. Two sets of metal doors with pane and transoms above separated by exposed concrete structure, Building 29815, Hazen Hall (ERDC-CERL, 2015).

Figure 58. Metal doors with pane and transom above, Building 29809, Greely Hall (ERDC-CERL, 2015).

Figure 59. Entry bay that consists of two sets of metal doors with pane and transom on the first floor and two sets of metal and plate-glass doors with transoms above on the second floor, Building 29815, Hazen Hall (ERDC-CERL, 2015).

Figure 60. Metal doors with an insulated panel placed in the transom above, Building 29816, Fisher Hall (ERDC-CERL, 2015)..

Figure 61. Typical doors located on the north and south walls entering the courtyards, Building 29811, Saltzman Hall (ERDC-CERL, 2015). 
Figure 62. Exposed concrete structure dividing the first and second-floor doors and separating the sets of doors vertically, Building 29811, Saltzman Hall (ERDC-CERL, 2015).

Figure 63. Close-up of the exposed concrete structural system framing the doors and window bays, Building 29815, Hazen Hall (ERDC-CERL, 2015).

Figure 64. Exposed concrete structural element, located at the corner of the building and framing the corner window system, Building 29807, Museum (Conrad Hall) (ERDC-CERL, 2015).

Figure 65. Close-up of the flat concrete waffle canopy highlighting the main entry into Building 25810, Brant Hall (ERDC-CERL, 2015).

Figure 66. Extensive wrap-around concrete waffle canopy connects the main administration buildings: Building 29805, Alexander/OImsted Halls; Building 29807, Museum (Conrad Hall); and Building 29808, Signal Towers (ERDC-CERL, 2015)

Figure 67. Flat concrete canopy above a set of metal entry doors on Building 29801, Nelson Hall (ERDC-CERL, 2015).

Figure 68. Flat concrete canopy extending over doors and a bay of windows on Building 29811, Saltzman Hall (ERDC-CERL, 2015).

Figure 69. Flat concrete canopy extending over entry doors and a bay of concrete panels on Building 29813, Allen Hall (ERDC-CERL, 2015).

Figure 70. Close-up of the concrete canopy detail, Building 29817, Allison Hall (ERDC-CERL, 2015).

Figure 71. Wall-mounted light fixtures flanking either side of an entry, Building 25810, Brant Hall (ERDC-CERL, 2015).

Figure 72. Ceiling-mounted light fixture placed on the underside of the flat concrete canopy, Building 29801, Nelson Hall (ERDC-CERL, 2015).

Figure 73. Ceiling-mounted light fixtures are placed on the underside of the concrete waffle canopy structure that connects Building 29805, Alexander/OImsted Halls; 29807, Conrad Hall; and 29808, Signal Towers (ERDCCERL, 2015).

Figure 74. Ceiling-mounted light fixtures placed under the recessed ceiling of the entry into Building 29805, Alexander/Olmsted Halls (ERDC-CERL, 2015).

Figure 75. Example of a wall-mounted light fixture that flanks either side of a window bay, Building 29810, Burkhardt Hall (ERDC-CERL, 2015).

Figure 76. Example of a wall-mounted light fixture near an entry into a courtyard, Building 29817, Allison Hall (ERDC-CERL, 2015)...

Figure 77. Ceiling-mounted light fixtures located under the concrete overhang at an entry bay on Building 29817, Allison Hall (ERDC-CERL, 2015).

Figure 78. Ceiling-mounted light fixture placed within the concrete waffle overhang above an entry bay on Building 29818, Johnston Hall (ERDC-CERL, 2015).

Figure 79. In-kind replacement cylinder-bronze wall-mounted light fixturelocated near the main entry on the south elevation of Building 25810, Brant Hall (ERDC-CERL, 2015).

Figure 80. Example of the uniform lettering, Building 29801, Nelson Hall (ERDCCERL, 2015). 
Figure 81. Example of the uniform lettering, Building 29805, Alexander Hall (ERDC-CERL, 2015).

Figure 82. Close-up of the uniform lettering, Building 29819, Stansell Hall (ERDC-CERL, 2015).

Figure 83. The larger scale of the lettering located at the top of Building 29808,

Signal Towers (ERDC-CERL, 2015).

Figure 84. Bright-aluminum exterior display case, Building 29811, Saltzman Hall (ERDC-CERL, 2015).

Figure 85. Example of typical poured-in-place concrete retaining walls and metal handrails framing the exterior basement access points, Building 29813, Allen

Hall (ERDC-CERL, 2015).

Figure 86. Example of the metal pipe handrail located near the entries for

Building 25810, Brant Hall (ERDC-CERL, 2015).

Figure 87. Curved poured-in-place concrete retaining wall system topped with metal pipe handrails, Building 29808, Signal Towers (ERDC-CERL, 2015).

Figure 88. Poured-in-place concrete retaining walls framing driveway to walkout basement for Building 29810, Burkhardt Hall (ERDC-CERL, 2015).

Figure 89. Metal balustrade placed between concrete supports surrounding Building 29808, Signal Towers (ERDC-CERL, 2015).

Figure 90. Example of the decorative perforated brick wall, Building 29813, Allen

Hall (ERDC-CERL, 2015).

Figure 91. Close-up of the perforated brick wall showing the same type of brick used as the building's brick-veneer exterior wall, Building 29817, Allison Hall (ERDC-CERL 2015).

Figure 92. Interior view of the west courtyard in Building 29813, Allen Hall, showing the window bays and parallel brick sitting walls. Note the absence of vegetation that has been removed and replaced with gravel infill (ERDC-CERL, 2015)

Figure 93. Interior view of the east courtyard in Building 29813, Allen Hall, showing the designed landscape of the four trees placed within the courtyard (ERDC-CERL 2015).

Figure 94. Interior view of the east courtyard in Building 29813, Allen Hall, showing the designed landscape of the four trees placed within the courtyard (ERDC-CERL 2015).

Figure 95. Interior view of the west courtyard in Building 29809, Greely Hall, showing the designed landscape plan of the trees and the curved brick-sitting wall (ERDC-CERL, 2015).

Figure 96. Interior view of the east courtyard in Building 29809, Greely Hall, showing the designed landscape plan of the trees and the brick-sitting wall (ERDC-CERL, 2015).

Figure 97. Brick paved area located in front of a courtyard entry (ERDC-CERL, 2015)

Figure 98. Example of the original concrete bench located in most of the courtyards (ERDC-CERL, 2015).

Figure 99. Looking west at the open space of the campus plan, with few of the original trees intact (ERDC-CERL, 2015). 
Figure 100. Example of trees flanking either side of a window bay, Building 29813, Allen Hall (ERDC-CERL, 2015).

Figure 101. Landscaping between Building 29810, Burkhardt Hall, and the sidewalk (ERDC-CERL, 2015).

Figure 102. South entry of Building 29811, Saltzman Hall, with two original crabapple trees flanking either side of the entry (ERDC-CERL, 2015).

Figure 103. American Holly bushes lining the sidewalk leading to the entry on the south elevation of Building 29801, Nelson Hall (ERDC-CERL, 2015).

Figure 104. East side of Building 29811, Saltzman Hall, the most intact brick plaza with the four original oak trees (ERDC-CERL, 2015).

Figure 105. East side of Building 29813, Allen Hall, looking at the brick plaza where all the original trees have been removed (ERDC-CERL, 2015).

Figure 106. West side of Building 29813, Allen Hall, looking at the brick plaza and three trees (ERDC-CERL, 2015).

Figure 107. Designed brick plaza that connects the main administration buildings together, Buildings 29805, Alexander Hall/Olmsted Hall; 29807, Conrad Hall; and 29808, Signal Towers; and the concrete planter bench located in the middle of the plaza (ERDC-CERL, 2015).

Figure 108. Crepe Myrtle is planted at the center of Dwarf Yaupon Holly shrubs which line the east and west sides of the administration area including Buildings 29805, Alexander/Olmsted Halls; 29807, Museum (Conrad Hall); and 29808, Signal Towers (ERDC-CERL, 2015).

Figure 109. Looking east from the brick plaza at the administration area toward the flagpole and the openness of the campus plan, dotted with few of the original trees (ERDC-CERL, 2015).

Figure 110. While trees can be found on the landscaping plan from 1966, this large flag plaza is not present on that plan (ERDC-CERL 2015).

Figure 111. Group of trees located just east of Building 29815 on the east side of the open campus plan (ERDC-CERL, 2015).

Figure 112. View looking west with Building 29816, Fisher Hall, on the left and Building 29817, Allison Hall, on the right (ERDC-CERL, 2015).

Figure 113. View looking west across the campus plan with Building 29811, Saltzman Hall, on the right and Building 29809, Greely Hall, in the background (ERDC-CERL, 2015).

Figure 114. View looking west with Building 29815, Hazen Hall, on left and Building 29816, Fisher Hall, on right (ERDC-CERL, 2015)..

Figure 115. View looking west with Building 29809, Greely Hall, on the right and Building 29808, Signal Towers, in the background (ERDC-CERL, 2015).

Figure 116. Looking west from Chamberlain Avenue toward the Signal School Campus with Building 29815, Hazen Hall, on the right and the tall Building 29808, Signal Towers, in the background (ERDC-CERL, 2015).

Figure 117. Looking east down the sidewalk running in front of Building 29819, Stansell Hall (ERDC-CERL, 2015).

Figure 118. Looking west toward Building 29808, Signal Towers, at some of the connecting sidewalks (ERDC-CERL, 2015). 
Figure 119. Comparison of the original design and materials detail drawing of the sidewalk lights from 1966 [left] to the current condition of the same style of light fixture (ERDC-CERL, 2015).

Figure 120. An example of one type of the replacement sidewalk lights (ERDCCERL, 2015).

Figure 121. An example of one type of the replacement sidewalk lights (ERDCCERL, 2015).

Figure 122. Examples of character-defining space in the interior (gray area) include vestibules, stairwells, hallways, vending space, phone alcoves, drinking fountain alcoves, and, in this example, the interior courtyard, 1964 (Fort Gordon DPW).

Figure 123. Examples of character-defining space in the interior (gray area) include vestibules, stairwells, hallways, vending space, phone alcoves, and drinking fountain alcoves (Fort Gordon DPW).

Figure 124. Transverse section through a typical classroom building, showing the detail of the exposed concrete waffle ceiling/roof system, 1964 (Fort Gordon DPW).

Figure 125. Transverse section through a typical classroom building, with courtyards showing the detail of the exposed concrete waffle ceiling/roof system, 1964 (Fort Gordon DPW).

Figure 126. Example of an interior view looking down a central hallway with the exposed concrete waffle ceiling and concrete block walls (ERDC-CERL, 2015).

Figure 127. Example of painted exposed concrete block walls, painted exposed waffle ceiling, and vinyl composition tiled floor in classroom building hallways (ERDC-CERL, 2015).

Figure 128. Example of unpainted, exposed brick in vestibules (ERDC-CERL, 2015).

Figure 129. Example of full-height blue sanitary tile in drinking fountain alcove and painted wallboard in Building 29805 [a more "public" building than the classroom buildings] (ERDC-CERL, 2015).

Figure 130. Example of painted, exposed concrete block wall, partial height blue glazed concrete block in drinking fountain alcove, and blue glazed concrete block baseboard in classroom buildings (ERDC-CERL, 2015).

Figure 131. Example of glazed concrete block utilized as a baseboard (ERDCCERL, 2015).

Figure 132. Stair detail for buildings with metal and plate-glass doors on second floor, 1964 (Fort Gordon DPW).

Figure 133. Stairwell plans, elevations, and details, 1964 (Fort Gordon DPW).

Figure 134. Interior view of typical stairwell with second-floor metal and plateglass doors showing concrete switchback stairs, metal handrails, exposed concrete walls, and exposed concrete waffle ceiling (ERDC-CERL, 2015).

Figure 135. Interior view of the south stairwell in Building 29816, showing concrete switchback stairs, metal handrails, exposed concrete walls, and exposed concrete waffle ceiling (ERDC-CERL, 2015).

Figure 136. Interior view of typical stairwell that has been modified with carpet covering the landing areas (ERDC-CERL, 2015). 
Figure 137. Typical stairwell (ERDC-CERL, 2015).

Figure 138. Interior stairwell - comparison of the original design and materials detail drawing from 1964 [left] to the current condition of an interior stairwell [right] (ERDC-CERL, 2015).

Figure 139. Light-fixture details and schedule for the Signal School buildings, 1964 (Fort Gordon DPW).

Figure 140. Light-fixture details and schedule for the Signal School buildings, 1964 (Fort Gordon DPW).

Figure 141. Original interior wall-mounted light fixture located in a stairwell (ERDC-CERL, 2015).

Figure 142. Replacement in-kind, square, ceiling-mounted light fixture set within the waffle ceiling (ERDC-CERL, 2015).

Figure 143. Original, square, ceiling-mounted light fixture set within the waffle ceiling (ERDC-CERL, 2015).

Figure 144. Typical original wall-mounted light fixture (ERDC-CERL, 2015).

Figure 145. Typical original ceiling-mounted pendant light fixture (ERDC-CERL, 2015).

Figure 146. Ceiling-mounted pendant light fixture - comparison of the original design drawing and light fixture type from 1966 [left] to the current condition of the metal ceiling-mounted pendant light fixture [right] (ERDC-CERL, 2015). 100

Figure 147. Ceiling-mounted light fixture set within the waffle ceiling comparison of the original design drawing and light fixture type from 1966 [left] to the current condition of the metal ceiling-mounted light fixture [right] (ERDCCERL, 2015). 101

Figure 148. Ceiling-mounted pendant light fixture - comparison of the original design drawing and light fixture type from 1966 [left] to the current condition of the replacement ceiling-mounted light fixture [right] (ERDC-CERL, 2015).

Figure 149. Wall-mounted pendant light fixture - comparison of the original design drawing and light fixture type from 1966 [left] to the current condition of the wall-mounted light fixture [right] (ERDC-CERL, 2015).

Figure 150. Details of typical interior doors found in the Signal School buildings, 1964 (Fort Gordon DPW).

Figure 151. Typical metal security doors with one small pane, leading from the stairwell into the central hall (ERDC-CERL, 2015).

Figure 152. Typical interior wood doors with large pane and wood transom, located in the hallway [left] and typical wood door with wood transom leading into room off hallway [right] (ERDC-CERL, 2015).

Figure 153. Typical wood doors with a large pane and wood transom, leading from stairwell into the central hallway (ERDC-CERL, 2015).

Figure 154. Doors leading from the lobby into the Alexander Hall auditorium space in Building 29805 (ERDC-CERL, 2015).. 105

Figure 155. Interior wood door with large light in Building 29807, Museum (Conrad Hall) (ERDC-CERL, 2015). 105

Figure 156. Typical metal door with small pane - comparison of the original design drawing from 1964 [left] to the current condition of the metal doors [right] (ERDC-CERL, 2015). 
Figure 157. Typical wood door with large pane and wood transom - comparison of the original design drawing from 1964 [left] to the current condition of the wood doors and transom [right] (ERDC-CERL, 2015)...

Figure 158. Close-up of typical bright-aluminum directory display case (ERDCCERL, 2015).

Figure 159. Another typical bright-aluminum directory display case (ERDC-CERL, 2015).

Figure 160. Example of an original telephone alcove, which is no longer being used for its original purpose (ERDC-CERL, 2015). 108

Figure 161. Telephone alcove - comparison of the original drawing from 1964 [left] to the current condition of the alcove [right] (ERDC-CERL, 2015). 109

Figure 162. Example of a vending area with concrete block wall and exposed concrete waffle ceiling (ERDC-CERL, 2015).

Figure 163. Example of a modified open vending area (ERDC-CERL, 2015).

Figure 164. Water fountain alcove in Building 29805 (ERDC-CERL, 2015).

Figure 165. Typical water fountain alcove found in the Signal School classroom buildings (ERDC-CERL, 2015).

Figure 166. Example of an original dumbwaiter in the classroom buildings (ERDC-CERL, 2015).

Figure 167. Close-up of the push-button mechanism to run the dumbwaiter (ERDC-CERL, 2015).

Figure 168. Example of a metal fire hydrant display case set within the concrete block exterior wall (ERDC-CERL, 2015)..

Figure 169. Fire hydrant display case, comparison of the original drawing from 1964 [left] to the current condition of the display case [right] (ERDC-CERL, 2015)

Figure 170. Example of exit signs found throughout the Signal School buildings, 1966 (Fort Gordon DPW)

Figure 171. Example of specialty signs located in some of the Signal School buildings, 1966 (Fort Gordon DPW).

Figure 172. Typical suspended exit sign (ERDC-CERL 2015).

Figure 173. Class in session sign - comparison of the original drawing [left] to the current condition of the sign located in the Signal School classroom buildings [right] (ERDC-CERL, 2015).

Figure 174. Signal School Campus map, with Building 25810, Brant Hall highlighted in red, 2015 (Fort Gordon DPW, modified by ERDC-CERL).

Figure 175. Building 25810, Brant Hall, south [front] elevation (ERDC-CERL, 2015).

Figure 176. Building 25810, Brant Hall; left is the northwest wing and right is the west side of the south wing (ERDC-CERL, 2015).

Figure 177. Building 25810, Brant Hall, east elevation of the east wing (ERDCCERL, 2015).

Figure 178. North side of the six-sided middle structure (ERDC-CERL, 2015)...

Figure 179. Interior view of the six-sided middle structure (ERDC-CERL, 2015). 
Figure 180. Building 25810, Brant Hall, floor plan of the south wing, 1973 (Fort Gordon DPW).

Figure 181. Building 25810, Brant Hall, floor plan for the middle section of the building, 1973 (Fort Gordon DPW).

Figure 182. Building 25810, Brant Hall, elevations, 1973 (Fort Gordon DPW).

Figure 183. Building 25810, Brant Hall, window schedule for the first and second-floor windows, 1973 (Fort Gordon DPW).

Figure 184. Building 25810, Brant Hall, door details for interior and exterior doors, 1973 (Fort Gordon DPW).

Figure 185. Main entry on the south elevation - comparison of the original drawing detail from 1973 [left] to the current condition of the bright-aluminum and plate-glass windows and doors [right] (ERDC-CERL, 2015).

Figure 186. Paired entry doors with concrete canopy - comparison of the original drawing detail from 1973 [left] to the current condition of the bright-aluminum and plate-glass doors [right] (ERDC-CERL, 2015).

Figure 187. Large group of windows and panel inserts on the northwest elevation of the north wing - comparison of the original drawing detail from 1973 [left] to the current condition of the bright-aluminum fixed windows and panel inserts on the first floor and the modified window openings with newer panel inserts [right] (ERDC-CERL, 2015).

Figure 188. Second-floor windows - Comparison of the original drawing detail from 1973 [left] to the current condition of the bright-aluminum fixed windows and panel inserts on the second floor [right] (ERDC-CERL, 2015).

Figure 189. Wall mounted exterior light fixture type "H" - comparison of the original drawing detail from 1966 [left] to the current condition of the light fixture [right] (ERDC-CERL, 2015).

Figure 190. Signal School Campus map, with Building 29801, Nelson Hall highlighted in red, 2015 (Fort Gordon DPW, modified by ERDC-CERL).

Figure 191. South elevation of Building 29801, Nelson Hall (ERDC-CERL, 2015). ........ 134

Figure 192. East elevation of Building 29801, Nelson Hall (ERDC-CERL, 2015)............ 134

Figure 193. Left side of the north elevation of Building 29801, Nelson Hall (ERDC-CERL, 2015).

Figure 194. West elevation of Building 29801, Nelson Hall (ERDC-CERL, 2015). 135

Figure 195. Building 29801, Nelson Hall, window details, 1966 (Fort Gordon DPW).

Figure 196. Typical classroom elevations and details for Building 29801, Nelson Hall, 1966 (Fort Gordon DPW).

Figure 197. Light fixtures details and schedule, 1966 (Fort Gordon DPW). 138

Figure 198. Landscaping plan for Building 29801, Nelson Hall, 1966 (Fort Gordon DPW).

Figure 199. East entrance bay - comparison of the original drawing detail from 1966 [left] to the current condition of metal and glass doors with transom above on the first floor and the bright-aluminum awning windows with panel inserts on the second floor [right] (ERDC-CERL, 2015). 
Figure 200. Northeast window/door bay - comparison of the original drawing detail from 1966 [left] to the current condition of concrete panels, metal and glass doors with transom above on the first floor and the bright-aluminum awning windows with panel inserts on the second floor [right] (ERDC-CERL, 2015).

Figure 201. South elevation window bay - comparison of the original drawing detail from 1966 [left] to the current condition of the bright-aluminum awning windows with panel inserts separated by the concrete structure [right] (ERDCCERL, 2015).

Figure 202. Ceiling mounted light fixture set within the waffle overhang comparison of the original drawing detail, no date [left] to the current condition of the light fixture [right] (ERDC-CERL, 2015).

Figure 203. Ceiling mounted light fixture under the concrete canopy -

Comparison of the original drawing detail, from 1966 [left] to the current condition of the light fixtures [right] (ERDC-CERL, 2015).

Figure 204. Signal School Campus map, with Building 29802, Moran Hall south, highlighted in red (Fort Gordon DPW, modified by ERDC-CERL, 2015).

Figure 205. Southeast oblique of Building 29802, Moran Hall south (ERDCCERL, 2015).

Figure 206. Northeast oblique of Building 29802, Moran Hall south (ERDCCERL, 2015).

Figure 207. West elevation of Building 29803 [left] and Building 29802 [right] (ERDC-CERL, 2015).

Figure 208. Detail elevations and plans for Building 29802, Moran Hall south, 1966 (Fort Gordon DPW).

Figure 209. Typical lighting plans, light fixture details, and schedule for Building 29802, Moran Hall south, no date (Fort Gordon DPW).

Figure 210. Landscaping plan for Buildings 29802 and 29803, 1966 (Fort Gordon DPW).

Figure 211. Entry bays on the east and west elevations - comparison of the original drawing detail from 1966 [left] to the current condition of the brightaluminum framing panel inserts and the replacement solid metal doors and metal panels [right] (ERDC-CERL, 2015).

Figure 212. Wall-mounted light fixtures - comparison of the original drawing detail from 1966 [left] to the current condition of the wall-mounted light fixtures on the east and west elevations [right] (ERDC-CERL, 2015).

Figure 213. Signal School Campus map, with Building 29803 (Moran Hall north) highlighted in red, 2015 (Fort Gordon DPW, modified by ERDC-CERL).

Figure 214. North elevation of Building 29803, Moran Hall north (ERDC-CERL, 2015).

Figure 215. East entry for Building 29803, Moran Hall north (ERDC-CERL, 2015)........ 155

Figure 216. West elevation of Building 29803 [left] and Building 29802 [right] (ERDC-CERL, 2015).

Figure 217. Typical lighting plans, light fixture details, and lighting schedule for Building 29803, Moran Hall north, no date (Fort Gordon DPW).

Figure 218. Detail elevations and plans for Building 29803, Moran Hall north, 1966 (Fort Gordon DPW). 
Figure 219. Landscaping plan for Buildings 29802 Moran Hall south and 29803, Moran Hall north, 1966 (Fort Gordon DPW).

Figure 220. Large group of windows on north elevation - comparison of the original drawing detail from 1966 [left] to the current condition of the brightaluminum awning windows and panel inserts and the modified brick infill [right] (ERDC-CERL, 2015).

Figure 221. Window bay - comparison of the original drawing detail from 1966 [left] to the current condition of the bright-aluminum awning windows and panel inserts [right] (ERDC-CERL, 2015)..

Figure 222. Window bay - comparison of the original drawing detail from 1966 [left] to the current condition of the replacement bright-aluminum windows [right] (ERDC-CERL, 2015).

Figure 223. Wall-mounted light fixture - comparison of the original drawing detail from 1966 [left] to the current condition of the wall-mounted light fixtures located on the east and west elevations [right] (ERDC-CERL, 2015).

Figure 224. Signal School Campus map, with Building 29805, Alexander/OImstead Halls, highlighted in red, 2015 (Fort Gordon DPW, modified by ERDC-CERL).

Figure 225. West elevation of Building 29805, Alexander/OImstead Halls (ERDCCERL, 2015).

Figure 226. South elevation of Building 29805, Alexander/Olmstead Halls (ERDC-CERL, 2015). 166

Figure 227. East elevation of Building 29805, Alexander/OImstead Halls (ERDCCERL, 2015).

Figure 228. Concrete waffle canopy structure that encompasses Building 29805 and connects it to Buildings 29807 and 29808 (ERDC-CERL, 2015).

Figure 229. Bright-aluminum and plate-glass doors, sidelights, and transoms on the north elevation leading into the lobby of Building 29805 (ERDC-CERL, 2015).

Figure 230. Brick-paved plaza located on the north side of Building 29805 connecting to Buildings 29807 and 29808 (ERDC-CERL, 2015).

Figure 231. Doors into the Alexander Hall auditorium from the lobby of Building 29805 (ERDC-CERL, 2015).

Figure 232. Alexander Hall, auditorium inside Building 29805 (ERDC-CERL, 2015).

Figure 233. East elevation of Building 29805, Alexander/Olmstead Halls, April 1978 (National Archives at College Park, MD).

Figure 234. General view of the east elevations of the administration complex of Buildings 29805 [left], 29807 [middle], and 29808 [right], April 1978 (National Archives at College Park, MD)

Figure 235. Overall view of the plaza connecting Building 29805 [left], Building 29807 [center], and Building 29808 [right] (ERDC-CERL, 2004).

Figure 236. Roof detail of Building 29805, Alexander/Olmstead Halls (ERDCCERL, 2004).

Figure 237. First-floor plan for Building 29805, Alexander/OImstead Halls, 1966 (Fort Gordon DPW). 
Figure 238. Second-floor plan for Building 29805, Alexander/OImstead Halls, 1966 (Fort Gordon DPW)

Figure 239. Door elevations and window details for Building 29805, Alexander/OImstead Halls, 1966 (Fort Gordon DPW).

Figure 240. Door schedule for Building 29805, Alexander/OImstead Halls, 1966

(Fort Gordon DPW).

Figure 241. Section thru auditorium in Building 29805, Alexander/Olmstead Halls, 1966 (Fort Gordon DPW).

Figure 242. Main entry on the north elevation - comparison of the original drawing detail from 1966 [left] to the current condition of the bright-aluminum and plate-glass doors, sidelights, and transoms [right] (ERDC-CERL, 2015).

Figure 243. Ceiling-mounted light fixture - Comparison of the original drawing detail from 1966 [left] to the current condition of the ceiling-mounted light fixture under the concrete waffle canopy [right] (ERDC-CERL, 2015).

Figure 244. Interior auditorium doors - Comparison of the original drawing detail from 1966 [left] to the current condition of the acoustical doors [right] (ERDCCERL, 2015).

Figure 245. Signal School Campus map, with Building 29807, Conrad Hall highlighted in red, 2015 (Fort Gordon DPW, modified by ERDC-CERL).

Figure 246. Looking at the main entry into Building 29807, Conrad Hall on the east elevation (ERDC-CERL, 2015).

Figure 247. Brick plaza connecting Buildings 29805, 29807, 29808 on the east side (ERDC-CERL, 2015).

Figure 248. West side of Building 29807 with single entry doors and the concrete waffle canopy that connects to Buildings 29805 and 29808 (ERDC-CERL, 2015)....... 181 Figure 249. Building 29807, exposed waffle ceiling and clerestory windows (ERDC-CERL, 2015).

Figure 250. Building 29807, close-up of corner window detail (ERDC-CERL, 2015).

Figure 251. Building 29807, single-entry bright-aluminum and plate-glass door (ERDC-CERL, 2015).

Figure 252. Floor plan for Building 29807, Conrad Hall, 1966 (Fort Gordon DPW)

Figure 253. Door elevations and window details for Building 29807, Conrad Hall, 1966 (Fort Gordon DPW).

Figure 254. Close-up of door elevations and window details for Building 29807, Conrad Hall, 1966 (Fort Gordon DPW)

Figure 255. Main entry on the east elevation - comparison of the original drawing detail from 1966 [left] to the current condition of the bright-aluminum and plate-glass entry doors, bright aluminim framed windows and insulated panels [right] (ERDC-CERL, 2015).

Figure 256. Ceiling-mounted light fixture - comparison of the original drawing detail from 1966 [left] to the current condition of the ceiling-mounted light fixture under the concrete waffle canopy [right] (ERDC-CERL, 2015).

Figure 257. Signal School Campus map, with Building 29808, Signal Towers highlighted in red, 2015 (Fort Gordon DPW, modified by ERDC-CERL). 
Figure 258. Southeast oblique of Building 29808, Signal Towers (ERDC-CERL, 2015)

Figure 259. West elevation of Building 29808, Signal Towers (ERDC-CERL, 2015)

Figure 260. Brick plaza connects Buildings 29805, 29807, and 29808 (ERDC-

CERL, 2015).

Figure 261. First-floor concrete waffle canopy structure that surrounds Building 29808, Signal Towers, and connects it to Buildings 29805 and 29807 (ERDCCERL, 2015).

Figure 262. Basement level and loading area on the north side of Building 29808, Signal Towers (ERDC-CERL, 2015).

Figure 263. Building 29808, Signal Towers, April 1978 (National Archives at College Park, MD).

Figure 264. First-floor plan for Building 29808, Signal Towers, 1966 (Fort Gordon DPW).

Figure 265. Detail elevations and plans for Building 29808, Signal Towers, 1966

(Fort Gordon DPW).

Figure 266. Door and window elevation details for Building 29808, Signal

Towers, 1966 (Fort Gordon DPW).

Figure 267. Door and window schedule for Building 29808, Signal Towers, 1966

(Fort Gordon DPW).

Figure 268. Building 29808, Signal Towers, comparison of the original windows

[left] and the replacement windows [right] (Signal Corps Historian Office).

Figure 269. Entry bay for Building 29808, comparison of the original drawing detail from 1966 [left] to the current condition of the bright-aluminum and plateglass doors and windows with insulated panels [right] (ERDC-CERL, 2015).

Figure 270. Ceiling-mounted light fixture - comparison of the original drawing detail from 1966 [left] to the current condition of the ceiling-mounted light fixture under the concrete waffle canopy [right] (ERDC-CERL, 2015).

Figure 271. Wall-mounted light fixture - comparison of the original drawing detail from 1966 [left] to the current condition of the wall-mounted interior light fixture [right] (ERDC-CERL, 2015).

Figure 272. Signal School Campus map, with Building 29809, Greely Hall

highlighted in red, 2015 (Fort Gordon DPW, modified by ERDC-CERL).. 207

Figure 273. South elevation of Building 29809, Greely Hall (ERDC-CERL, 2015) .......... 207

Figure 274. North elevation of Building 29809, Greely Hall (ERDC-CERL, 2015)........... 208

Figure 275. East elevation of Building 29809, Greely Hall (ERDC-CERL, 2015)............. 208

Figure 276. Building 29809, Greely Hall, one of the Signal School classrooms,

December 1966 (National Archives at College Park, MD). 209

Figure 277. First-floor plan [left side] for Building 29809, Greely Hall, 1964 (Fort Gordon DPW).

Figure 278. First-floor plan [right side] for Building 29809, Greely Hall, 1964

(Fort Gordon DPW). 210

Figure 279. Elevations for Building 29809, Greely Hall, 1964 (Fort Gordon DPW)........ 211 
Figure 280. Door and window schedule for Building 29809, Greely Hall, 1964 (Fort Gordon DPW).

Figure 281. Partial longitudinal section of Building 29809, Greely Hall, 1964 (Fort Gordon DPW).

Figure 282. Transverse section of Building 29809, Greely Hall, 1964 (Fort Gordon DPW).

Figure 283. Sections of Building 29809, Greely Hall showing concrete waffle ceiling and roof construction, 1964 (Fort Gordon DPW).

Figure 284. Brick screen detail for exterior staircases on the east and west elevations of Building 29809, Greely Hall, 1964 (Fort Gordon DPW).

Figure 285. Typical courtyard landscaping plans and details, 1966 (Fort Gordon DPW)

Figure 286. Typical classroom elevations and details for Building 29809, Greely Hall, 1966 (Fort Gordon DPW).

Figure 287. Interior stairwell details of Building 29809, Greely Hall, 1964 (Fort Gordon DPW).

Figure 288. Latrine plans, elevations, and details for Building 29809, Greely Hall, 1964 (Fort Gordon DPW)

Figure 289. Light fixture details for Building 29809, Greely Hall, 1966 (Fort Gordon DPW).

Figure 290. Landscaping plan for Building 29809, Greely Hall (Fort Gordon DPW).

Figure 291. Second-floor window bay on the north and south elevations comparison of the original design and materials from 1964 [left] to the current condition of bright-aluminum three-pane awning-style-windows and insulated panels [right] (ERDC-CERL, 2015).

Figure 292. North entry bay second-floor windows - comparison of the original design and materials from 1964 [left] to the current condition of bright-aluminum fixed-pane windows [right] (ERDC-CERL, 2015).

Figure 293. Window bay located on the left and right sides of the north and south elevations - comparison of the original design and materials from 1964 to the current condition of the three-pane awning-style windows sandwiched between insulated panels (ERDC-CERL, 2015).

Figure 294. Doors on the east and west elevations - comparison of the original design and materials from 1964 [left] to the current condition of the metal doors with pane and transoms on the first floor and the metal and plate-glass doors with security bars on the second floor [right] (ERDC-CERL, 2015).

Figure 295. North wall of the right courtyard and south wall of the left courtyard comparison of the original design and materials from 1964 [left] to the current condition of the metal doors, canopy, and window system [right] (ERDC-CERL, 2015)

Figure 296. East and west walls of the courtyards - comparison of the original design and materials from 1964 [left] to the current condition of the window system [right] (ERDC-CERL, 2015). 
Figure 297. Ceiling-mounted light fixtures under waffle overhang - comparison of the original design and materials from 1966 [left] to the current condition of the ceiling-mounted light fixture [right] (ERDC-CERL, 2015)

Figure 298. Ceiling-mounted light fixture under flat concrete canopy comparison of the original design and material from 1966 [left] to the current condition of the ceiling-mounted light fixture [right] (ERDC-CERL, 2015).

Figure 299. Signal School Campus map, with Building 29810, Burkhardt Hall highlighted in red, 2015 (Fort Gordon DPW, modified by ERDC-CERL).

Figure 300. North elevation of Building 29810, Burkhardt Hall (ERDC-CERL, 2015).

Figure 301. East elevation of Building 29810, Burkhardt Hall (ERDC-CERL, 2015)

Figure 302. South elevation of Building 29810, Burkhardt Hall (ERDC-CERL, 2015)

Figure 303. West elevation of Building 29810, Burkhardt Hall (ERDC-CERL, 2015).

Figure 304. Window elevation details for Building 29810, Burkhardt Hall, 1966 (Fort Gordon DPW).

Figure 305. Door and window schedule for Building 29810, Burkhardt Hall, 1966 (Fort Gordon DPW).

Figure 306. Typical classroom elevations and details for Building 29810, Burkhardt Hall, 1966 (Fort Gordon DPW).

Figure 307. Landscaping plan for Building 29810, Burkhardt Hall, 1966 (Fort Gordon DPW, modified by ERDC-CERL).

Figure 308. Window group with six windows and one large insulated panel comparison of the original design and materials from 1966 [left] to the current condition of the bright-aluminum framed three-pane awning-style windows with insulated panel inserts [right] (ERDC-CERL, 2015).

Figure 309. Entry bays on the east and west elevations - comparison of the original design and materials from 1966 [left.] to the current condition of the three-story entry bay with metal doors with pane and transom above and groups of four bright-aluminum framed three-pane awning-style windows sandwiched between insulated panels [right] (ERDC-CERL, 2015).

Figure 310. Wall-mounted exterior light fixture - comparison of the original design and materials from 1966 [left] to the current condition of the wallmounted light fixture located on the east and west elevations [right] (ERDC-CERL, 2015).

Figure 311. Signal School Campus map, with Building 29811, Saltzman Hall highlighted in red, 2015 (Fort Gordon DPW, modified by ERDC-CERL).

Figure 312. Southeast corner of Building 29811, Saltzman Hall, (ERDC-CERL, 2015).

Figure 313. Left side of the south elevation of Building 29811, Saltzman Hall (ERDC-CERL, 2015).

Figure 314. Main entry bay on the south elevation of Building 29811, Saltzman Hall (ERDC-CERL, 2015).

Figure 315. East elevation of Building 29811, Saltzman Hall (ERDC-CERL, 2015)........ 246 
Figure 316. West elevation of Building 29811, Saltzman Hall (ERDC-CERL, 2015)....... 246

Figure 317. View of the Signal School construction, southeast corner of Building 29818 in the front with Buildings 29813, 29811, and 29809 at the back left of photo, March 1966 (National Archives at College Park, MD).

Figure 318. Building 29811, Saltzman Hall, March 1967 (National Archives at College Park, MD).

Figure 319. View looking northeast, Building 29811 is on the left and Building 29817 is on distant right, April 1978 (National Archives at College Park, MD).

Figure 320. First-floor plan [left side] for Building 29811, Saltzman Hall, 1964

(Fort Gordon DPW).

Figure 321. First-floor plan [right side] for Building 29811, Saltzman Hall, 1964 (Fort Gordon DPW).

Figure 322. Elevations for Building 29809, Greely Hall [left side] and Building 29811, Saltzman Hall [right side], 1964 (Fort Gordon DPW)..

Figure 323. Door and window schedule for Building 29811, Saltzman Hall, 1964

(Fort Gordon DPW).

Figure 324. Partial longitudinal section of Building 29811, 1964 (Fort Gordon DPW)

Figure 325. Transverse section of Building 29811, Saltzman Hall, 1964 (Fort Gordon DPW). 253

Figure 326. Sections of Building 29811, Saltzman Hall, showing concrete waffle ceiling and roof construction, 1964 (Fort Gordon DPW)..

Figure 327. Brick screen detail for exterior staircase on the east and west elevations of Building 29811, Saltzman Hall, 1964 (Fort Gordon DPW).

Figure 328. Courtyard landscaping plans and details, 1966 (Fort Gordon DPW)........... 254

Figure 329. Typical classroom elevations and details for Building 29811,

Saltzman Hall, 1966 (Fort Gordon DPW).

Figure 330. Interior stairwell details of Building 29811, Saltzman Hall, 1964 (Fort Gordon DPW).

Figure 331. Latrine plans, elevations, and details for Building 29811, Saltzman Hall, 1964 (Fort Gordon DPW).

Figure 332. Light fixture types and schedule, 1966 (Fort Gordon DPW).

Figure 333. Landscape plan for Building 29811, Saltzman Hall, 1966 (Fort Gordon DPW).

Figure 334. Southeast oblique - comparison of the original design and materials for Building 29811 from March 1967 [left] to the current condition of the building [right] (ERDC-CERL, 2015).

Figure 335. Second-floor window bay on the north and south elevations Comparison of the original design and materials from 1964 [left] compared to the current condition of bright-aluminum three-pane awning style-windows and insulated panels [right] (ERDC-CERL, 2015).

Figure 336. Window bay located on the left and right sides of the north and south elevations -original design and materials from 1964 [left] compared to the current condition of the three-pane awning-style windows sandwiched between insulated panels [right] (ERDC-CERL, 2015). 
Figure 337. Doors on the east and west elevations - comparison of the original design and materials from 1964 [left] to the current condition of the metal doors with pane and transoms on the first floor and the metal and plate-glass doors with security bars on the second floor [right] (ERDC-CERL, 2015).

Figure 338. North wall of the right courtyard south wall of the left courtyard comparison of the original design and materials from 1964 [left] to the present day [right] (ERDC-CERL, 2015).

Figure 339. East and west walls of the courtyards - comparison of the original design and materials from 1964 [left] to the present day [right] (ERDC-CERL, 2015).

Figure 340. Ceiling-mounted light fixture under the waffle overhang comparison of the original design and material from 1966 [left] to the current condition of the ceiling-mounted light fixture [right] (ERDC-CERL, 2015). 266

Figure 341. Ceiling-mounted light fixture under flat concrete canopy comparison of the original design and material on the left from 1966 to the current condition of the replacement ceiling-mounted light fixture [right] (ERDCCERL, 2015). 266

Figure 342. Signal School Campus map, with Building 29813, Allen Hall highlighted in red, 2015 (Fort Gordon DPW, modified by ERDC-CERL)............................268

Figure 343. South elevation of Building 29813, Allen Hall (ERDC-CERL, 2015).............. 268

Figure 344. North elevation of Building 29813, Allen Hall (ERDC-CERL, 2015)............. 269

Figure 345. East elevation of Building 29813, Allen Hall (ERDC-CERL, 2015)................. 269

Figure 346. West elevation of Building 29813, Allen Hall (ERDC-CERL, 2015). .............. 270

Figure 347. View of the Signal School construction, southeast corner of Building 29818 in the front and Buildings 29813, 29811, and 29809 at back left of photo, March 1966 (National Archives at College Park, MD). 270

Figure 348. First-floor plan [left side] for Building 29813, Allen Hall, 1964 (Fort Gordon DPW).

Figure 349. First-floor plan [right side] for Building 29813, Allen Hall, 1964 (Fort Gordon DPW).

Figure 350. Elevations of Building 29813, Allen Hall [left side] and Building 29815, Hazen Hall [right side], 1964 (Fort Gordon DPW).

Figure 351. Door and window schedule for Building 29813, Allen Hall, 1964 (Fort Gordon DPW). 274

Figure 352. Partial longitudinal section of Building 29813, Allen Hall, 1964 (Fort Gordon DPW).

Figure 353. Transverse section of Building 29813, Allen Hall, 1964 (Fort Gordon DPW).

Figure 354. Sections of Building 29813, Allen Hall showing concrete waffle ceiling and roof construction, 1964 (Fort Gordon DPW). 275

Figure 355. Brick screen detail for exterior staircases on the east and west elevations of Building 29813, Allen Hall, 1964 (Fort Gordon DPW). 276

Figure 356. Courtyard landscaping plans and details for Building 29813, Allen Hall, 1966 Fort Gordon DPW) 
Figure 357. Typical classroom elevations and details for Building 29813, Allen Hall, 1966 (Fort Gordon DPW).

Figure 358. Interior stairwell details of Building 29813, Allen Hall, 1964 (Fort Gordon DPW).

Figure 359. Latrine plans, elevations, and details for Building 29813, Allen Hall, 1964 (Fort Gordon DPW).

Figure 360. Light fixture types and schedule, for Building 29813, Allen Hall, 1966 (Fort Gordon DPW).

Figure 361. Landscape plan for Building 29813, Allen Hall, 1966 (Fort Gordon DPW).

Figure 362. Southeast oblique - comparison of the original design and materials for Building 29811 and construction in 1966 [left] to the current condition of the south elevation of Building 29813, Allen Hall [right] (ERDC-CERL, 2015).

Figure 363. Second-floor window bay on the north and south elevations comparison of the original design and materials from 1964 [left] to the current condition of bright-aluminum three-pane awning style-windows and insulated panels [right] (ERDC-CERL, 2015).

Figure 364. Window bay located on the left and right sides of the north and south elevations - comparison of the original design and materials from 1964 [left] to the current condition of the three-pane awning-style windows sandwiched between insulated panels [right] (ERDC-CERL, 2015).

Figure 365. Doors on the east and west elevations - comparison of the original design and materials from 1964 [left] to the current condition of the metal doors with pane and transoms on the first floor and the metal and plate-glass doors with security bars on the second floor [right] (ERDC-CERL, 2015).

Figure 366. North wall of the right courtyard comparison of the original design and materials from 1964 [left] to the present-day [right] (ERDC-CERL, 2015).

Figure 367. East and west walls of the courtyards - comparison of the original design and materials from 1964 [left] to the present-day [right] (ERDC-CERL, 2015)

Figure 368. Ceiling-mounted light fixture under the waffle overhang comparison of the original design and material from 1966 [left] to the current condition of the ceiling-mounted light fixture [right] (ERDC-CERL, 2015).

Figure 369. Ceiling-mounted light fixture under flat concrete canopy comparison of the original design and material from 1966 [left] to the current condition of the replacement ceiling-mounted light fixture [right] (ERDC-CERL, 2015).

Figure 370. Signal School Campus map, with Building 29815, Hazen Hall highlighted in red, 2015 (Fort Gordon DPW, modified by ERDC-CERL)...

Figure 371. South elevation of Building 29815, Hazen Hall (ERDC-CERL, 2015)........... 290

Figure 372. East elevation of Building 29815, Hazen Hall (ERDC-CERL, 2015)............. 291

Figure 373. West elevation of Building 29815, Hazen Hall (ERDC-CERL, 2015)............ 291

Figure 374. Construction of Building 29815, Hazen Hall, March 1966 (National Archives at College Park, MD). 292

Figure 375. Section detail of concrete waffle ceiling and roof construction for Building 29815, Hazen Hall, 1964 (Fort Gordon DPW). 
Figure 376. Elevations of Building 29815, Hazen Hall [right side], 1964 (Fort Gordon DPW).

Figure 377. Stairwell details for Building 29815, Hazen Hall, 1964 (Fort Gordon DPW).

Figure 378. Typical classroom elevations and details for Building 29815, Hazen

Hall, 1966 (Fort Gordon DPW).

Figure 379. Latrine plans, elevations, and details for Building 29815, Hazen Hall, 1964 (Fort Gordon DPW)..

Figure 380. Light fixture types and schedule, 1966 (Fort Gordon DPW).

Figure 381. Landscape plan for Building 29815, Hazen Hall, 1966 (Fort Gordon DPW).

Figure 382. Southeast oblique - comparison of the original design and materials for Building 29815 construction in 1966 [left] to the current condition of the southeast oblique of Building 29815, Hazen Hall [right] (ERDC-CERL, 2015).

Figure 383. Large six-window bay - comparison of the original design and materials from 1964 [left] to the current condition of bright-aluminum three-pane awning-style windows and insulated panels [right] (ERDC-CERL, 2015).

Figure 384. East and west elevations - comparison of the original design and materials from 1964 [left] to the current condition of the metal doors with panes and transoms above and the three-pane awning-style windows sandwiched between insulated panels on the second floor [right] (ERDC-CERL, 2015).

Figure 385. Ceiling-mounted light fixture under the waffle overhang comparison of the original design and material from 1966 [left] to the current condition of the ceiling-mounted light fixture [right] (ERDC-CERL, 2015).

Figure 386. Signal School Campus map, with Building 29816, Fisher Hall highlighted in red, 2015 (Fort Gordon DPW, modified by ERDC-CERL). 305

Figure 387. Southeast oblique of Building 29816, Fisher Hall (ERDC-CERL, 2015)

Figure 388. South elevation of Building 29816, Fisher Hall (ERDC-CERL, 2015)............306

Figure 389. East elevation of Building 29816, Fisher Hall (ERDC-CERL, 2015)............. 306

Figure 390. North elevation of Building 29816, Fisher Hall (ERDC-CERL, 2015). ........... 307

Figure 391. West elevation of Building 29816, Fisher Hall (ERDC-CERL, 2015)............ 307

Figure 392. Elevations of Building 29816, Fisher Hall, 1964 (Fort Gordon DPW).......... 308

Figure 393. Section detail of concrete waffle ceiling and roof construction for Building 29816, Fisher Hall, 1964 (Fort Gordon DPW).. 309

Figure 394. Stairwell details for Building 29816, Fisher Hall, 1964 (Fort Gordon DPW).

Figure 395. Typical classroom elevations and details for Building 29816, Fisher Hall, 1966 (Fort Gordon DPW).

Figure 396. Latrine plans, elevations, and details for Building 29816, Fisher Hall, 1964 (Fort Gordon DPW).

Figure 397. Light fixture types and schedule, 1966 (Fort Gordon DPW).

Figure 398. Landscape plan for Building 29816, Fisher Hall, 1966 (Fort Gordon DPW). 
Figure 399. East window group - comparison of the original design and materials from 1964 [left] to the current condition of the bright-aluminum sash windows, insulated panels, and concrete panels [right] (ERDC-CERL, 2015).

Figure 400. Large window group - comparison of the original design and materials from 1964 [left] to the current condition of the bright-aluminum threepane awning-style windows with insulated panels and exposed concrete structure [right] (ERDC-CERL, 2015)

Figure 401. Ceiling-mounted light fixture under the waffle overhang comparison of the original design and material from 1966 [left] to the current condition of the ceiling-mounted light fixture [right] (ERDC-CERL, 2015).

Figure 402. Signal School Campus map, with Building 29817, Allison Hall, highlighted in red, 2015 (Fort Gordon DPW, modified by ERDC-CERL).

Figure 403. Northeast oblique of Building 29817, Allison Hall (ERDC-CERL, 2015)

Figure 404. East elevation of Building 29817, Allison Hall (ERDC-CERL, 2015).

Figure 405. South elevation of Building 29817, Allison Hall (ERDC-CERL, 2015).......... 322

Figure 406. West elevation of Building 29817, Allison Hall (ERDC-CERL, 2015)............ 322

Figure 407. South elevation of Building 29817, Allison Hall, May 1970 (Signal Corps Historian Office).

Figure 408. View looking northeast of the Signal School Campus, Building 29811, Saltzman Hall, is on the left and Building 29817, Allison Hall, is on distant right (Allen Hall is between), April 1978 (National Archives at College Park, MD).

Figure 409. Window detail elevations for "Building H", [future Allison Hall], 1966 (Fort Gordon DPW).

Figure 410. Section of Buildings A, B, and C, showing concrete waffle ceiling and roof construction (the design of Building 29817 followed this plan), 1964 (Fort Gordon DPW)

Figure 411. Window and door schedule for "Building H", [future Allison Hall], 1966 (Fort Gordon DPW).

Figure 412. Brick screen detail for exterior staircases on the east and west elevations of Buildings A, B, and C (the design of Building 29817 followed this plan), (Fort Gordon DPW).

Figure 413. Courtyard plans and details "Building H", [future Allison Hall], 1966 (Fort Gordon DPW).

Figure 414. Typical classroom elevations and details, 1966 (Fort Gordon DPW).

Figure 415. Landscape plan for "Building H", [future Allison Hall], 1966 (Fort Gordon DPW).

Figure 416. South elevation - comparison of a historic photograph from 1970 [left] to the current condition of the bright-aluminum frames, insulated panels, "light pattern," entry, and concrete canopy [right] (ERDC-CERL, 2015).

Figure 417. Main entry on the south elevation - comparison of the original design and materials detail drawing from 1966 [left] to the current condition of the concrete canopy, bright-aluminum framed insulated panels, and replacement metal entry doors [right] (ERDC-CERL, 2015). 
Figure 418. Entry bay on the north elevation - comparison or the original design and materials detail drawing from 1966 [left] to the current condition of the metal doors, concrete panels, concrete canopy, and bright-aluminum framed insulated panels [right] (ERDC-CERL, 2015)

Figure 419. Entry bays on the east and west elevations - comparison of the original design and materials detail drawings from 1966 [left] to the current condition of the metal entry doors with insulated panels above and brightaluminum framed insulated panels on the second floor [right] (ERDC-CERL, 2015).

Figure 420. Large window bay on the north and south elevations - comparison of the original design and materials from 1966 [left] to the current condition of the bright-aluminum framed insulated panels [right] (ERDC-CERL, 2015).

Figure 421. Ceiling-mounted light fixture under concrete canopy - comparison of the original ceiling-mounted light fixture detail drawing from 1966 [left] to the current condition of the replacement light fixture [right] (ERDC-CERL, 2015).

Figure 422. Signal School Campus map, with Building 29818, Johnston Hall highlighted in red, 2015 (Fort Gordon DPW, modified by ERDC-CERL).

Figure 423. North elevation of Building 29818, Johnston Hall (ERDC-CERL, 2015).

Figure 424. East elevation of Building 29818, Johnston Hall (ERDC-CERL, 2015). ....... 336

Figure 425. Southwest oblique, Johnston Hall (ERDC-CERL, 2015).

Figure 426. Left side of the south elevation of Building 29818, Johnston Hall (ERDC-CERL, 2015).

Figure 427. View of Signal School construction, southeast corner of Building 29818 in the front then 29813, 29811, and 29809 back left photo, March 1966 (National Archives College Park, MD)...

Figure 428. Elevations of Building 29816, Fisher Hall [left side] and Building 29818, Johnston Hall [right side], 1964 (Fort Gordon DPW).

Figure 429. First-floor plan and window schedule for Building 29818, Johnston Hall, 1964 (Fort Gordon DPW).

Figure 430. Section detail of concrete waffle ceiling and roof construction for Building 29818, Johnston Hall, 1964 (Fort Gordon DPW).

Figure 431. Stairwell plans and sections for Building 29818, Johnston Hall, 1964

Fort Gordon DPW).

Figure 432. Typical classroom elevations and details for Building 29818, Johnston Hall, 1966 (Fort Gordon DPW).

Figure 433. Latrine plans, elevations, and details for Building 29818, Johnston Hall, 1964 (Fort Gordon DPW).

Figure 434. Light fixture types and schedule, 1966 (Fort Gordon DPW).

Figure 435. Landscape plan for Building 29818, Johnston Hall, 1966 (Fort Gordon DPW).

Figure 436. East window group - comparison of the original design and materials from 1964 [left] to the current condition of the bright-aluminum sash windows and insulated panels [right] (ERDC-CERL, 2015)...

Figure 437. Large window group - comparison of the original design and materials from 1964 [left] to the current condition of the bright-aluminum three- 
pane awning-style windows with insulated panels and exposed concrete structure [right] (ERDC-CERL, 2015).

Figure 438. East and west entries - comparison of the original design and materials detail drawing from 1964 [left] to the current condition of the metal and pane doors with transom and the metal and plate-glass doors with transoms [right] (ERDC-CERL, 2015).

Figure 439. Ceiling-mounted light fixture under the waffle overhang comparison of the original design and material from 1966 [left] to the current condition of the ceiling-mounted light fixture [right] (ERDC-CERL, 2015).

Figure 440. Signal School Campus map, with Building 29819, Stansell Hall, highlighted in red, 2015 (Fort Gordon DPW, modified by ERDC-CERL).

Figure 441. South elevation of Building 29819, Stansell Hall (ERDC-CERL, 2015)........ 351

Figure 442. East elevation of Building 29819, Stansell Hall (ERDC-CERL, 2015).......... 352

Figure 443. Southwest oblique of Building 29819, Stansell Hall (ERDC-CERL, 2015).

Figure 444. Elevations of Building 29819, Stansell Hall, 1966 (Fort Gordon DPW)

Figure 445. Window and door elevations for Building 29819, Stansell Hall, 1966 (Fort Gordon DPW).

Figure 446. Window and door details and schedule for Building 29819, Stansell Hall, 1966 (Fort Gordon DPW).

Figure 447. Typical classroom elevations and details, 1966 (Fort Gordon DPW)............. 356

Figure 448. Light fixture types and schedule, 1966 (Fort Gordon DPW).

Figure 449. Landscape plan for Building 29819, Stansell Hall, 1966 (Fort Gordon DPW).

Figure 450. West entry vestibule - comparison of the original design and materials detail drawing from 1966 [left] to the current condition of the one-story brick vestibule, metal doors, and insulated panels [right] (ERDC-CERL, 2015).

Figure 451. East elevation entry - comparison of the original design and materials detail drawing from 1966 [left] to the current condition of the metal doors and bright-aluminum framed insulated panels [right] (ERDC-CERL, 2015). 361

Figure 452. Northeast window bays - comparison of the original design and materials detail drawing from 1966 [left] to the current condition of the concrete panels and bright-aluminum framed insulated panels [right] (ERDC-CERL, 2015)

Figure 453. Large window bay on the north elevation - comparison of the original design and materials detail drawing from 1966 [left] to the current condition of the bright-aluminum framed insulated panels separated by exposed concrete structural system [right] (ERDC-CERL, 2015).

Figure 454. Ceiling-mounted exterior light fixture under waffle overhang comparison of the original design and materials details drawing from 1966 [left] to the current condition of the light fixture [right] (ERDC-CERL, 2015).

Figure 455. Map of noncontributing buildings, indicated in red (Fort Gordon DPW).

Figure 456. Building 25811 is a concrete pad supporting an IFR beacon that is not real property and was placed here in 1985 (ERDC-CERL 2015). 
Figure 457. Buildings 25812 and 25813 are covered storage areas to the west of Building 25810 (ERDC-CERL).

Figure 458. Building 29814 (left) is a covered training area, constructed in 1997; there is an unnumbered covered training area in the middle, constructed circa 2000; and 29812 on the right is a covered training area constructed in 2001 (ERDC-CERL 2015).

Figure 459. Building 29820 (to rear) is a covered training area constructed in 2009 and Building 29822 (in front) is a covered training area constructed in 2009 (ERDC-CERL, 2015).

Figure 460. Building 25910 Heating/AC Plant was constructed in 1966 and designed by Sewell and Associates (ERDC-CERL 2015).

Figure 461. Building 25910 AC Cooling Towers, north of the Heating/AC Plant (ERDC-CERL, 2015).

Figure 462. Building 25912 Water Storage Tank was constructed in 2000 (ERDC-CERL 2015).

Figure 463. An electrical substation was added to the complex in 1975 (ERDCCERL, 2015).

Figure 464. Examples of moveable sheds that are not real property (ERDC-CERL, 2015)

Figure 465. Covered Training Area (no number) on left, and two moveable sheds that are not real property in the center (ERDC-CERL, 2015)............................................. 370

Figure 466. Southwest oblique of Building 33800 (ERDC-CERL, 2015). 370

\section{Tables}

Table 1. List of buildings, 2015 (Fort Gordon Real Property Office)...................................... 3

Table 2. List of contributing and noncontributing properties (ERDC-CERL).........................24

Table 3. Images of character-defining features of Building 25810, Brant Hall (ERDC-CERL, 2015).

Table 4. Images of character-defining features of Building 29801, Nelson Hall (ERDC-CERL, 2015).

Table 5. Images of character-defining features of Building 29802, Moran Hall south (ERDC-CERL, 2015).

Table 6. Images of character-defining features of Building 29803, Moran Hall north (ERDC-CERL, 2015).

Table 7. Images of character-defining features of Building 29805,

Alexander/OImstead Halls (ERDC-CERL, 2015).

Table 8. Images of character-defining features of Building 29807, Conrad Hall (ERDC-CERL, 2015).

Table 9. Images of character-defining features of Building 29808, Signal Towers (ERDC-CERL, 2015).

Table 10. Images of character-defining features of Building 29809, Greely Hall (ERDC-CERL, 2015).

Table 11. Images of character-defining features of Building 29810, Burkhardt Hall (ERDC-CERL, 2015). 
Table 12. Images of character-defining features of Building 29811, Saltzman Hall

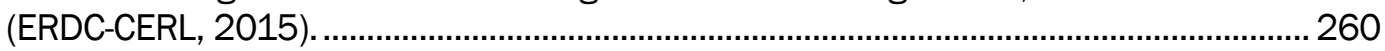

Table 13. Images of character-defining features of Building 29813, Allen Hall (ERDC-CERL, 2015).

Table 14. Images of character-defining features of Building 29815, Hazen Hall (ERDC-CERL, 2015).

Table 15. Images of character-defining features of Building 29816, Fisher Hall (ERDC-CERL, 2015). 315

Table 16. Images of character-defining features of Building 29817, Allison Hall (ERDC-CERL, 2015). 329

Table 17. Images of character-defining features of Building 29818, Johnston Hall (ERDC-CERL, 2015).

Table 18. Images of character-defining features of Building 29819, Stansell Hall (ERDC-CERL, 2015). 


\section{Preface}

This study was conducted for the Cultural Resources office in the Directorate of Public Works (DPW) at Fort Gordon, Georgia, under Project 450904, "NHPA Building Evaluations at Fort Gordon." The technical monitor was Ruth "Renee" Lewis (Archaeologist, DPW).

The work was performed by the Land and Heritage Conservation Branch (CNC) of the Installations Divisions (CN), U.S. Army Engineer Research and Development Center - Construction Engineering Research Laboratory (ERDC-CERL). At the time of publication, Dr. Michael S. Hargrave was Chief, CEERD-CNC; and Ms. Michelle J. Hanson was Chief, CEERD-CN. The Deputy Director of ERDC-CERL was Dr. Kirankumar Topudurti, and the Director was Dr. Ilker Adiguzel.

COL Bryan S. Green was the Commander of ERDC, and Dr. Jeffery P. Holland was the Director. 


\section{Unit Conversion Factors}

\begin{tabular}{|c|c|c|}
\hline Multiply & By & To Obtain \\
\hline acres & $4,046.873$ & square meters \\
\hline feet & 0.3048 & meters \\
\hline inches & 0.0254 & meters \\
\hline miles (US statute) & $1,609.347$ & meters \\
\hline square feet & 0.09290304 & square meters \\
\hline yards & 0.9144 & meters \\
\hline
\end{tabular}




\section{Abbreviations}

$\begin{array}{ll}\text { Term } & \text { Meaning } \\ \text { AC } & \text { air-conditioning } \\ \text { CRM } & \text { Cultural Resources Manager } \\ \text { DPW } & \text { Directorate of Public Works } \\ \text { ERDC- } & \text { Engineer Research and Development Center - Construction } \\ \text { CERL } & \text { Engineering Research Laboratory } \\ \text { GA SHPO } & \text { Georgia State Historic Preservation Officer } \\ & \\ \text { MIPR } & \text { Military Interdepartmental Purchase Request } \\ \text { NHPA } & \text { National Historic Preservation Act } \\ \text { NPS } & \text { National Park Service } \\ \text { NRHP } & \text { National Register of Historic Places } \\ \text { USGS } & \text { U.S. Geographic Survey } \\ \text { WWII } & \text { World War II }\end{array}$




\section{Methodology}

\subsection{Background}

Congress codified the National Historic Preservation Act of 1966 (NHPA), the nation's most effective cultural resources legislation to date, in order to provide guidelines and requirements for preserving tangible elements of our nation's past. This was done primarily through the creation of the National Register of Historic Places (NRHP) in 1966. Contained within the NHPA (Sections 106 and 110) are requirements for federal agencies to address their cultural resources, which are defined as any prehistoric or historic district, site, building, structure, or object. Section 110 requires federal agencies to inventory and evaluate their cultural resources. Section 106 requires determination of the effects of federal undertakings on properties deemed eligible or potentially eligible for the NRHP. The U.S. Army first established Fort Gordon in the Augusta, Georgia, area as a World War II (WWII) temporary camp. It was nearing deactivation at the close of WWII; however, the Signal Corps Training Center relocated to Fort Gordon in 1948, preventing its closure. Currently, Fort Gordon remains home to the U.S. Army Signal Center. Fort Gordon is located in east-central Georgia, directly southwest of Augusta. Most of Fort Gordon is within Augusta-Richmond County, with small portions in Columbia, McDuffie, and Jefferson Counties. The Signal School Campus Historic District lies entirely within Augusta-Richmond County (Figure 1). 
Figure 1. Boundary outline and location of Fort Gordon, Georgia, southwest of Augusta (www.google.com, accessed June 2016).

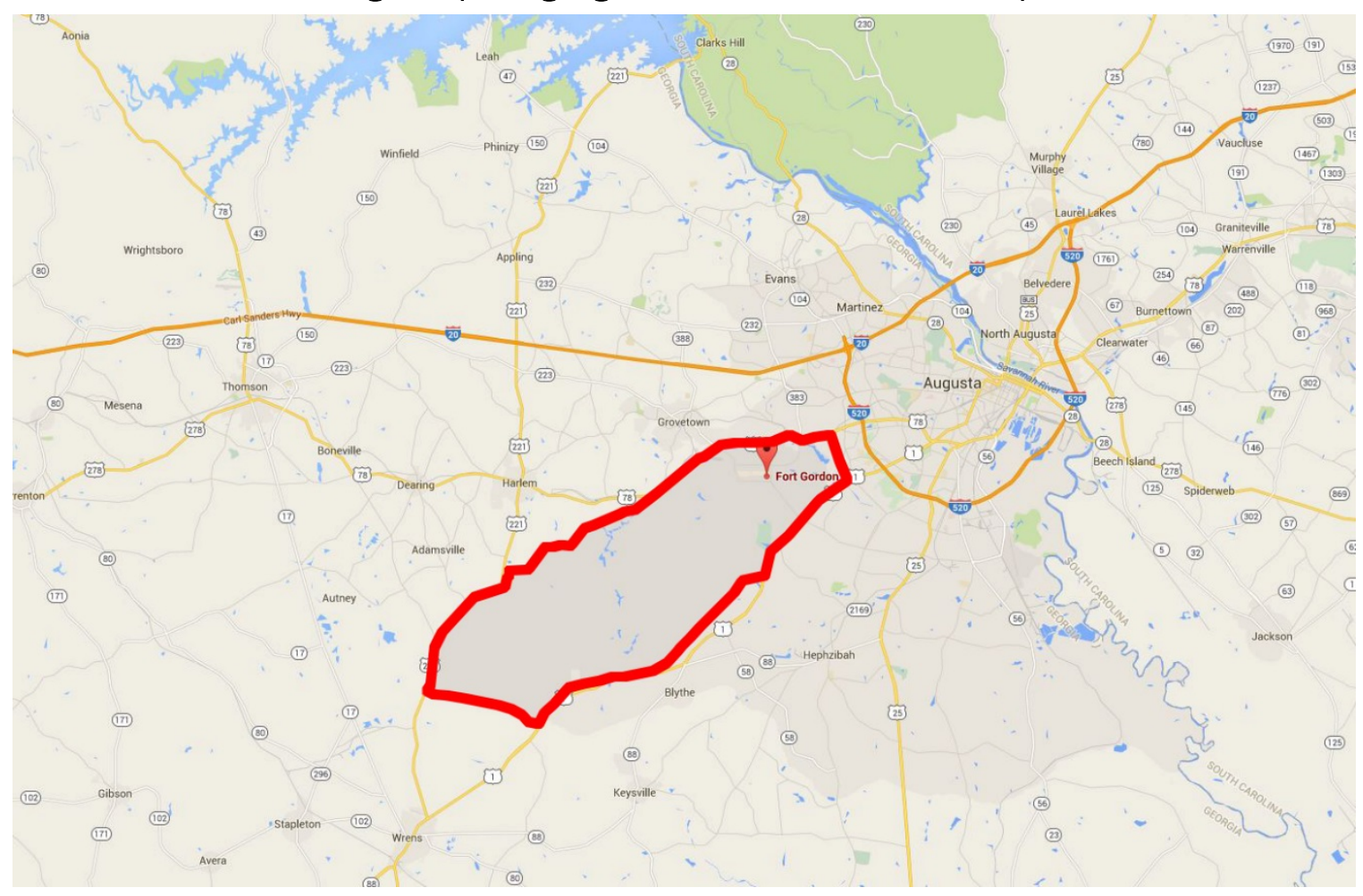

\subsection{Objective}

The objective of this effort was to inventory and assess all features of the buildings and structures within the Signal School Campus Historic District within and bordering the boundaries of $8^{\text {th }}$ Avenue on the north and east, Chamberlain Avenue on the south, and the alley to the west of Brant Hall on the west (Figure 2).

The Signal School Campus Historic District encompasses a group of buildings of various property types (administrative, academic, museum, laboratory, and utility; see Table 1) that form a defined space in which the individual elements are similar in materials, architectural details, and physical proportions, and that collectively exhibit a unity of exterior design that creates a cohesive visual environment. The Signal School Campus is eligible for the NRHP under Criterion $\mathrm{C}$ for its New Formalist-derived campus design by Aeck Associates of Atlanta. It is eligible for the NRHP under Criterion A as the nation's only federally-owned educational facility for the advanced instruction of electronic communication. The Criterion $\mathrm{C}$ period of significance for the historic district is from 1966 to 1973 (date of first construction until date of construction of Brant Hall, Building 25810). 
Figure 2. Location and boundary for Signal School Campus Historic District (U.S. Geographical Survey [USGS] map, district outline added).

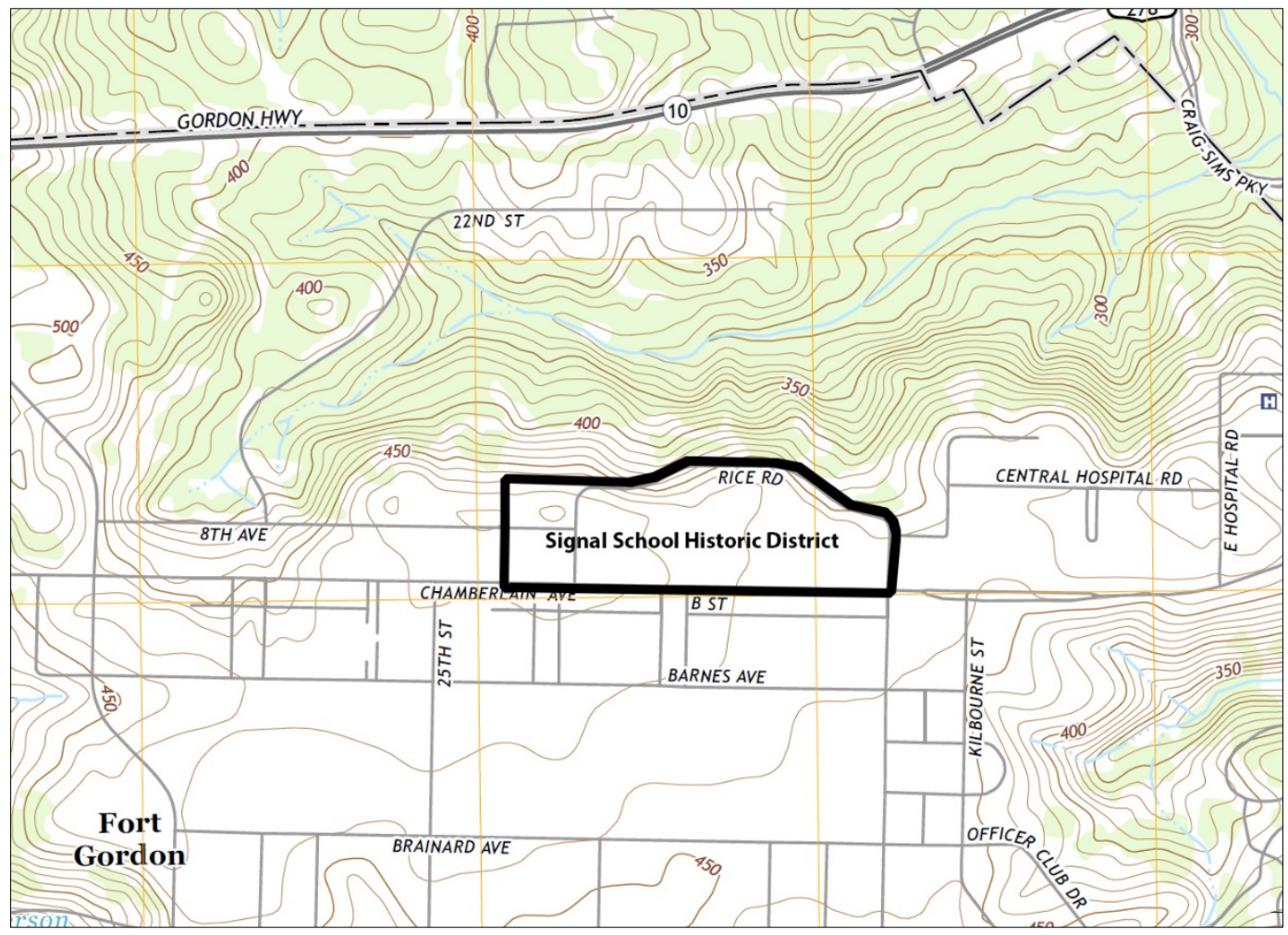

Table 1. List of buildings given to the research team to assess character-defining features for the U.S. Signal School, 2015 (Fort Gordon Real Property Office).

\begin{tabular}{|l|l|l|}
\hline Facility \# & Year Built & Description \\
\hline 25810 & 1973 & Brant Hall \\
\hline 25811 & 1985 & Pad (IFR Beacon is not Real Property) \\
\hline 25812 & 1985 & Covered Storage \\
\hline 25813 & 1985 & Covered Storage \\
\hline 25910 & 1966 & Heating and air-conditioning plant \\
\hline 25910 & 2000 & Cooling Tower \\
\hline 25911 & 2001 & Mechanical Room \\
\hline 25912 & 2000 & Water Storage Tank \\
\hline SUBST & 1975 & Electrical Substation \\
\hline 29801 & 1969 & Nelson Hall \\
\hline 29802 & 1973 & Moran Hall south \\
\hline 29803 & 1973 & Moran Hall north \\
\hline 29804 & 1985 & Shed \\
\hline 29805 & 1970 & Alexander/Olmstead Halls \\
\hline 29807 & 1970 & Museum (Conrad Hall) \\
\hline 29808 & 1970 & Signal Towers \\
\hline
\end{tabular}




\begin{tabular}{|l|l|l|}
\hline Facility \# & Year Built & Description \\
\hline 29809 & 1966 & Greely Hall \\
\hline 29810 & 1970 & Burkhardt Hall \\
\hline 29811 & 1966 & Saltzman Hall \\
\hline 29812 & 2001 & Covered Training Area \\
\hline 29813 & 1966 & Allen Hall \\
\hline 29814 & 1997 & Covered Training Area \\
\hline (No number) & Unknown & Storage Shed (between 29812 and 29814) \\
\hline 29815 & 1966 & Hazen Hall \\
\hline 29816 & 1966 & Fisher Hall \\
\hline 29817 & 1970 & Allison Hall \\
\hline 29818 & 1966 & Johnston Hall \\
\hline 29819 & 1970 & Stansell Hall \\
\hline 29820 & 2009 & Covered Training Area \\
\hline 29822 & 2014 & Covered Training Area \\
\hline (No number) & Unknown & Covered Training Area \\
\hline 33800 & 1968 & Enlisted Women's Barracks with Mess \\
\hline
\end{tabular}

\subsection{Approach}

\subsubsection{Previous reports}

Fort Gordon has performed one previous architectural inventory of the Signal School area per Section 110 of the NHPA. In 2005, the U.S. Army Corps of Engineers, Engineer Research Development Center-Construction and Engineering Research Laboratory (ERDC-CERL) wrote Fort Gordon Cold War Architectural Survey: Volumes 1 through 5. Volume 1 contained the historic context and overall historic evaluation results while Volume 2 was specifically on the Signal School buildings. The Georgia State Historic Preservation Officer (GA SHPO) accepted the findings of the five volumes in a letter dated 30 November 2005.

\subsubsection{Current project}

Under a Military Interdepartmental Purchase Request (MIPR), the ERDCCERL was retained by the Fort Gordon Directorate of Public Works cultural resources office to complete a list of character-defining features for the buildings and landscapes included within the Signal School Campus Historic District. 


\subsubsection{Site visit}

The researchers conducted one site visit in May 2015 to inventory the character-defining features of the buildings and structures with the Signal School Campus Historic District.

\subsubsection{Source material}

ERDC-CERL researchers conducted a review of books, archival repositories, and online resources related to Fort Gordon, the Signal School, the architect, and New Formalism. The following places were contacted and/or searched:

- National Archives at College Park, Maryland

- University of Illinois at Urbana-Champaign Library

- ERDC Library

- General online searches

- Signal Corps Historian

- Fort Gordon Library

- Fort Gordon Directorate of Public Works (DPW)

\subsection{Researchers}

This project was conducted by ERDC-CERL in Champaign, Illinois. The researchers were Adam Smith (M.Arch), with 18 years of experience in military architectural history and Sunny Adams (M.Arch), with 12 years of experience in military architectural history. 
(This page intentionally blank.) 


\section{Historic Context}

\subsection{Fort Gordon development pre-1965 ${ }^{1}$}

Camp Gordon was formally established on 18 October 1941, when the official groundbreaking and flag-raising ceremony took place. Although facilities were incomplete, on 17 December 1941 the 4th Division arrived at Camp Gordon for combat training from Fort Benning, Georgia. The design of the cantonment followed the standard U.S. Army Quartermaster plans of a large parade field surrounded by wooden WWII temporary buildings (Figure 3). The cantonment, located in the northeastern portion of the installation, was separated into distinct areas: the administrative/community area on the eastern edge of the parade field, the station hospital area in the northeastern part, barracks compounds to the north and south of the parade field (a dogleg containing barracks compounds extended to the southeast of the parade field), recreational facilities on the western edge of the parade field, and a warehouse/maintenance area on the far west separated from the main cantonment by McCoys Creek (Figure 3). The original layout of the cantonment remained intact until the mid-1960s as the new Signal School buildings were constructed. On 21 March 1956, Camp Gordon became a permanent Army post and was redesignated as Fort Gordon.

\subsection{5 to 1975 development of the Signal School Campus}

A major reorganization at Fort Gordon occurred in June 1964. The Third United States Army redesignated the U.S. Army Garrison at Fort Gordon as the U.S. Army School/Training Center, Fort Gordon. The U.S. Army Signal Training Center became the U.S. Army Training Center, Signal, and basic training was redesignated the U.S. Army Training Center, Infantry. By the end of 1964, Fort Gordon contained the U.S. Army School/Training Center, the U.S. Army Hospital, the U.S. Army Civil Affairs School, the U.S. Army Military Police School, the U.S. Army Southeastern Signal School, and the U.S. Army Criminal Investigation Laboratory.

\footnotetext{
${ }^{1}$ For a full historic context of the history of Fort Gordon prior to 1957 please refer to the Fort Gordon Architectural Survey: 1942 to 1956 by Smith and Stone and/or A History of Fort Gordon by Stokes.
} 
Figure 3. The layout of Camp Gordon, with north to the left, 1943 (Fort Gordon DPW).

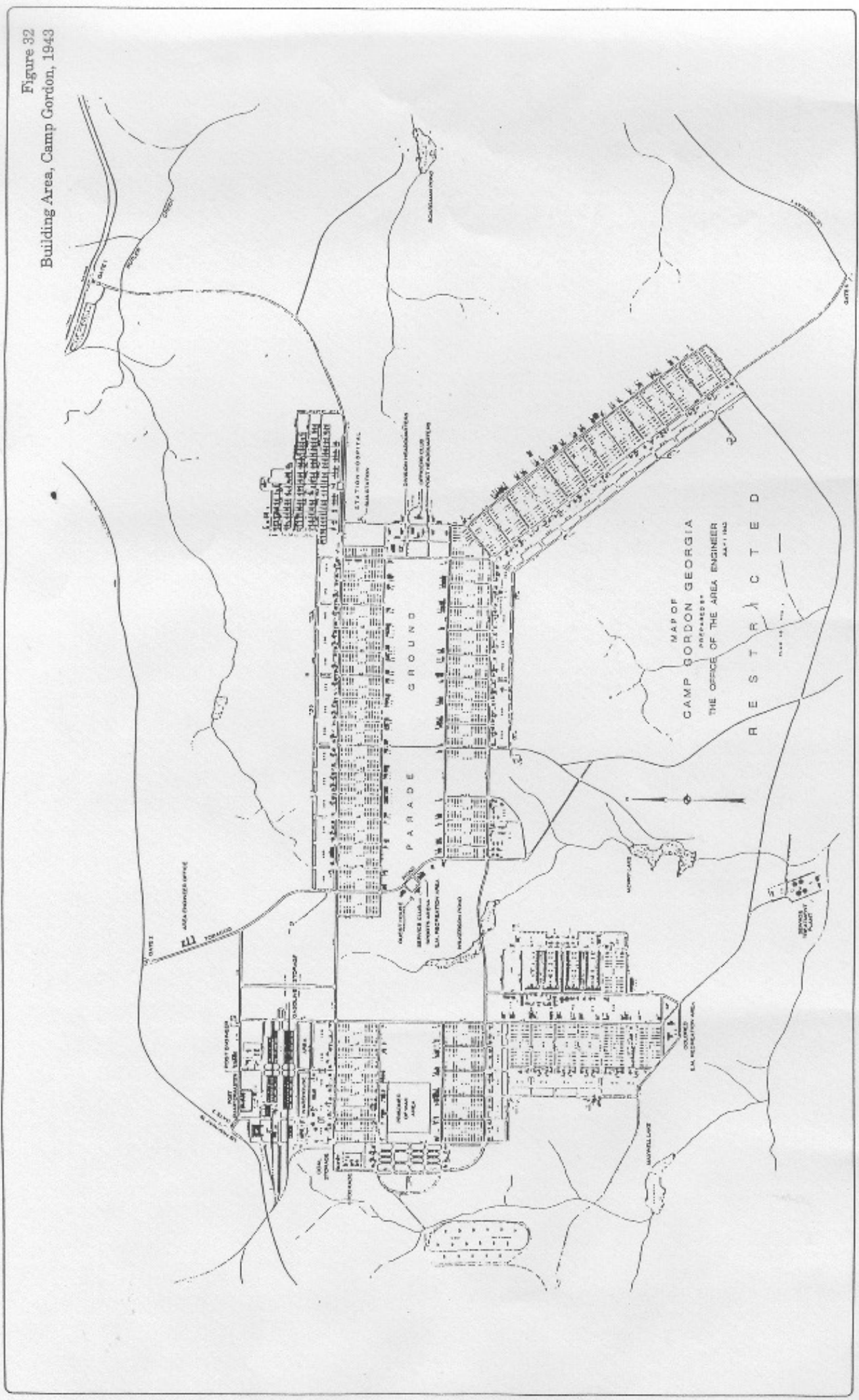


The Signal School was housed in 400 WWII temporary buildings spread throughout the northern side of the cantonment (Figure 4). To the north of Chamberlain Avenue and to the west of the WWII post hospital was a series of WWII-era motor pools that had served the company areas to the south of Chamberlain Avenue. This area was relatively flat, already had water and sewer service, and was close to the center of the cantonment of Fort Gordon. This area was chosen to house the new Southeastern Signal School.

Figure 4. Northern side of the WWII cantonment (Fort Gordon DPW).

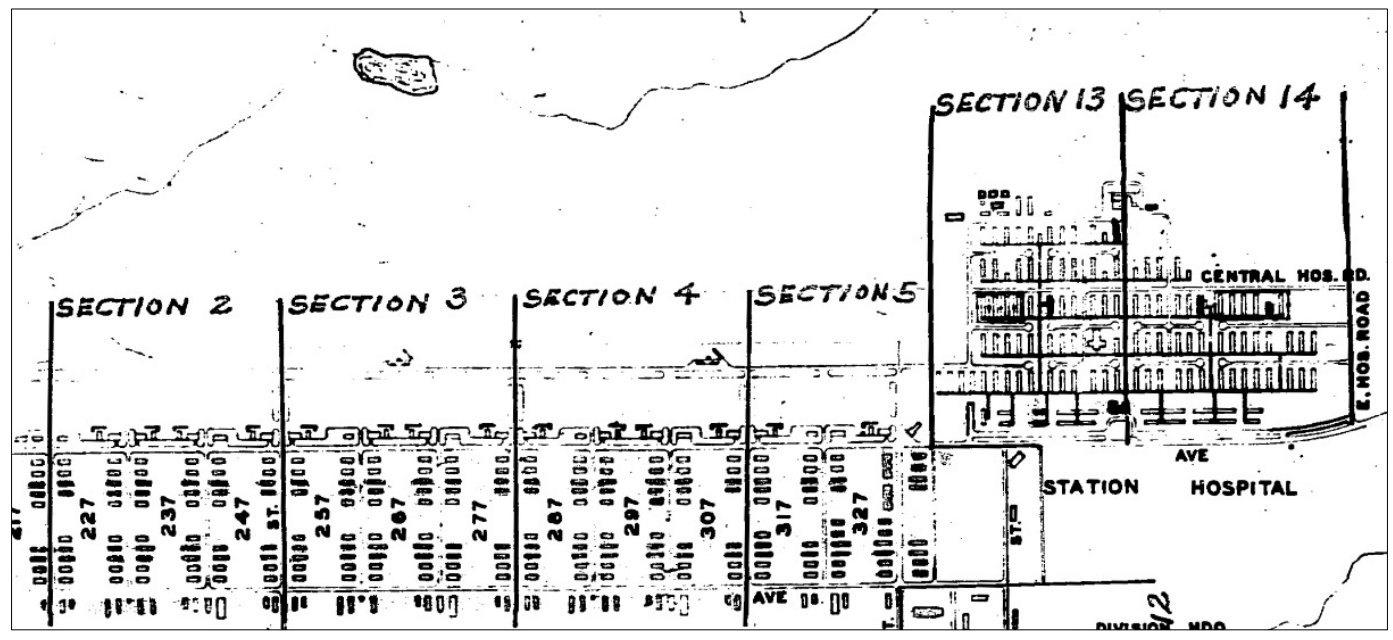

The Corps of Engineers Savannah District let a contract to Aeck Associates of Atlanta, Georgia (Richard Aeck was principal architect) for the master plan of the new campus and its associated buildings (Figure 5), and also to Zimmerman, Evans \& Leopold of Atlanta, Georgia, in 1963 for the engineering needed for construction of the buildings.

Richard Aeck received his Bachelor of Science in architecture from Georgia Tech in 1936. He was a consulting architect for a university in Cambodia under the government of Prince Norodom Sihanouk in the 1950s, and he designed elementary schools throughout Georgia and university buildings in Augusta and Statesboro. Aeck was known for expressing structure through the design of his buildings and he continued this tradition in the design of his buildings at the Southeastern Signal School (Craig 2015, 2016).

On 16 October 1964 , construction began on a $\$ 5,983,800$ contract for Phase I for the six two-story signal instruction classrooms designed by Aeck. A heating and air-conditioning (AC) plant designed by Sewell and 
Associates was under a separate contract and was not part of the Aeck master plan. The seven buildings opened on 1 June 1966. They were equipped with the latest sophisticated communication-electronics equipment. Ground was broken on 4 August 1967 for Phase II, which included the Signal School administration building and six other buildings which opened in 1969 and 1970. By the end of 1970, the Signal School had fourteen buildings. The Army consolidated all communications training at Fort Gordon in 1974.

Figure 5. Original master plan for the Southeastern Signal School in 1966 (Fort Gordon DPW).

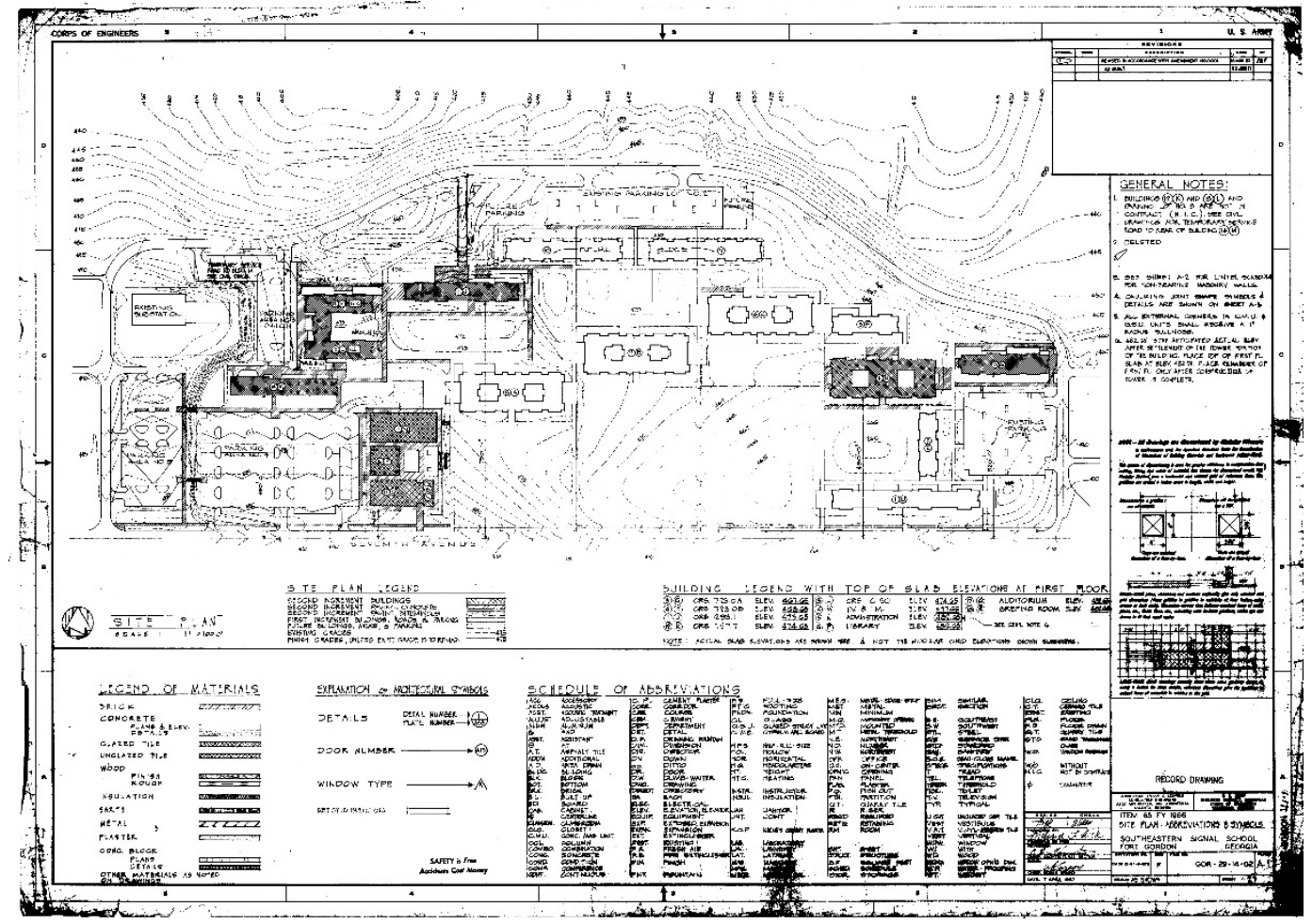

Concurrent with the planning and design of the Southeastern Signal School Campus to the north of Chamberlain Avenue, the Corps of Engineers Savannah District planned the rebuild of the area south of Chamberlain with new barracks ("rolling pin" type), mess halls, company and battalion administration buildings, and chapels (Figure 6 and Figure 7). A women's enlisted barracks (Building 33800) was planned at the same time, and construction was finished in 1968 (Figure 8). None of these plans and buildings were part of the Aeck master plan for the Signal School. 
Figure 6. New barracks and mess hall plan for the south side of Chamberlain Avenue in outlined box (Fort Gordon DPW).

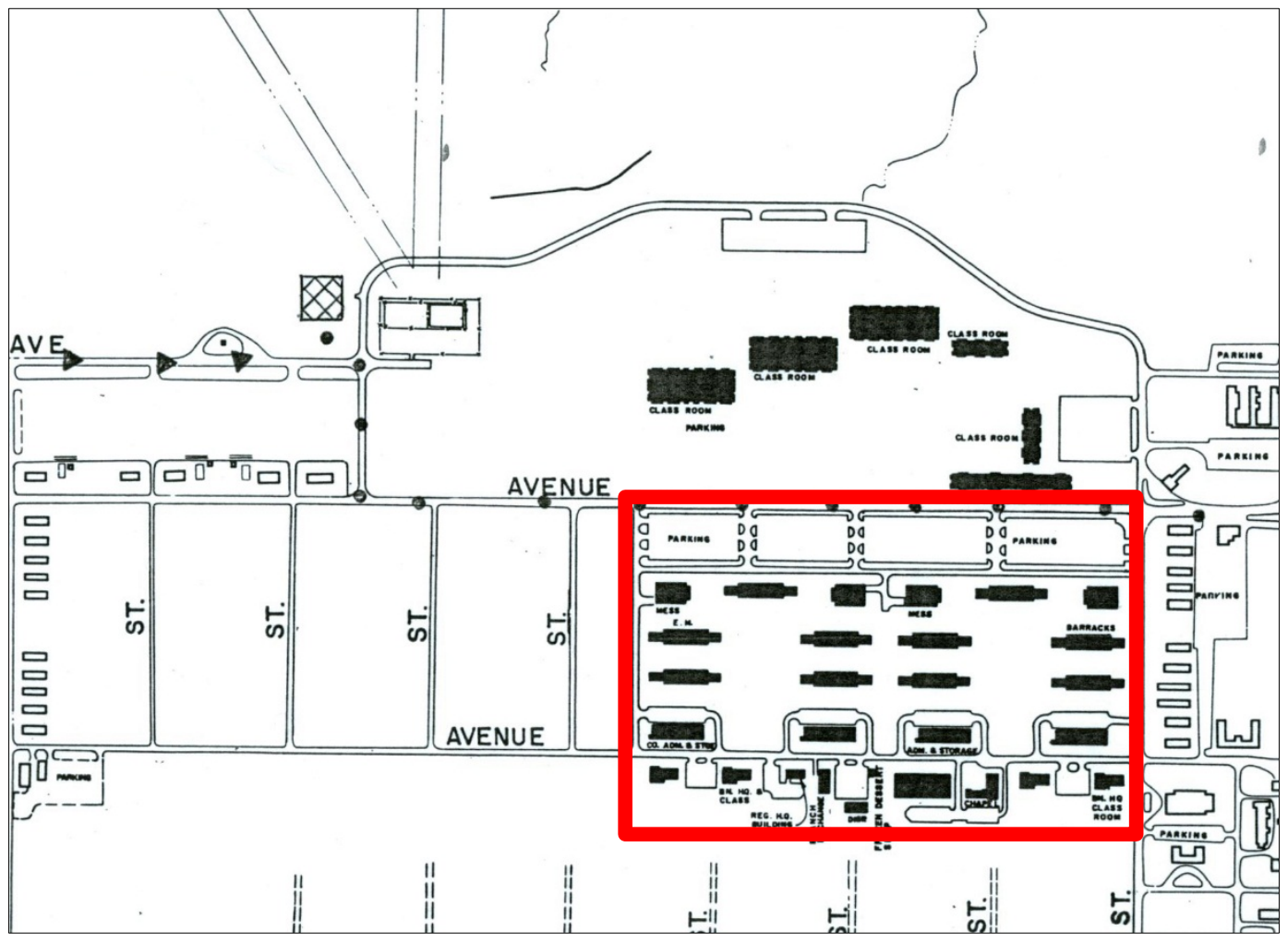

Figure 7. Aerial view of the Signal School Campus, with the completion of the six Phase I classroom buildings (light rectangular roofs in photo's center), the beginning construction of Phase II, 1968 (barracks buildings at center left of photo) and the construction of Building 33800 (bottom center) (Signal Corps Historian Office).

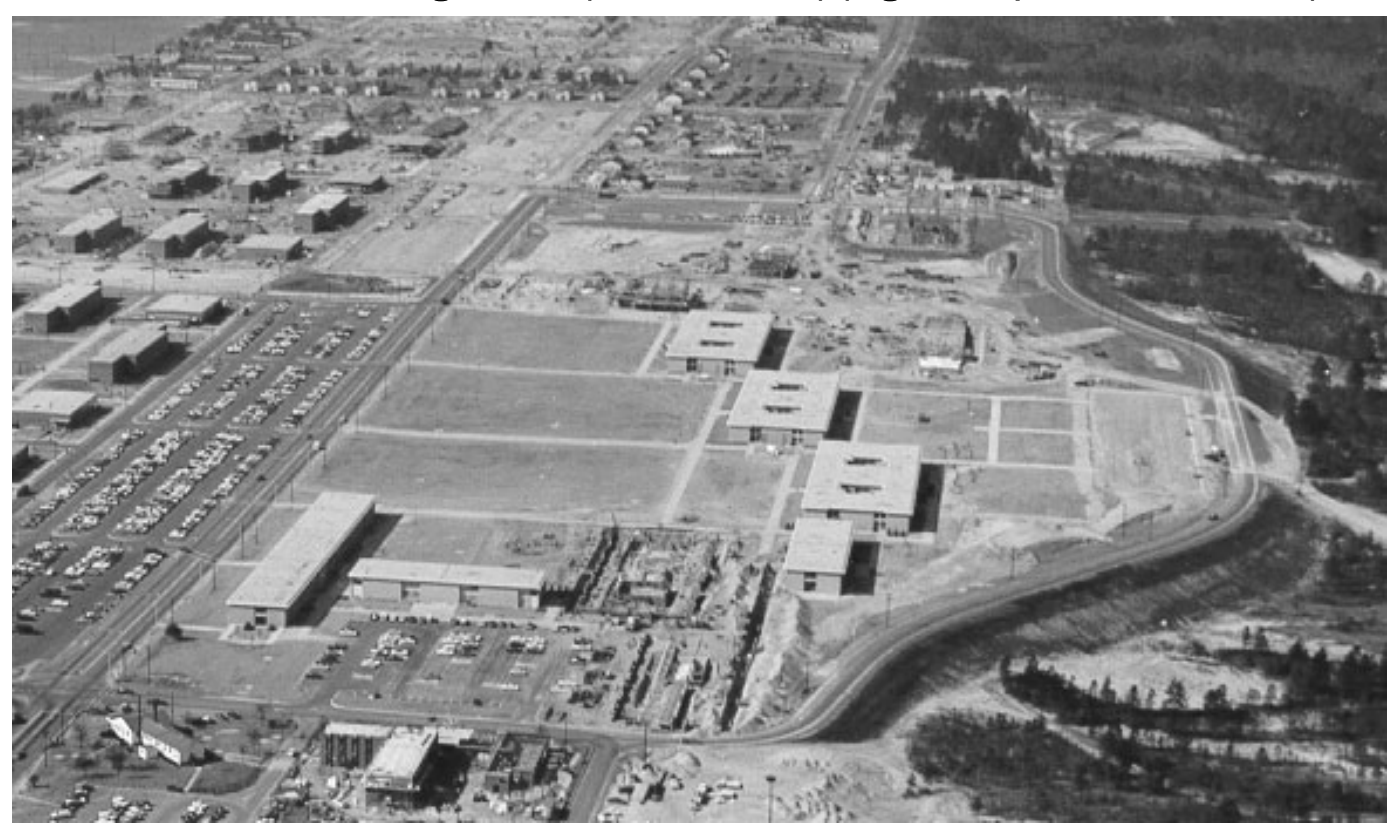


Figure 8. Elevations for the enlisted women's barracks designed by Southeastern Architects and opened in 1968 (Fort Gordon DPW).

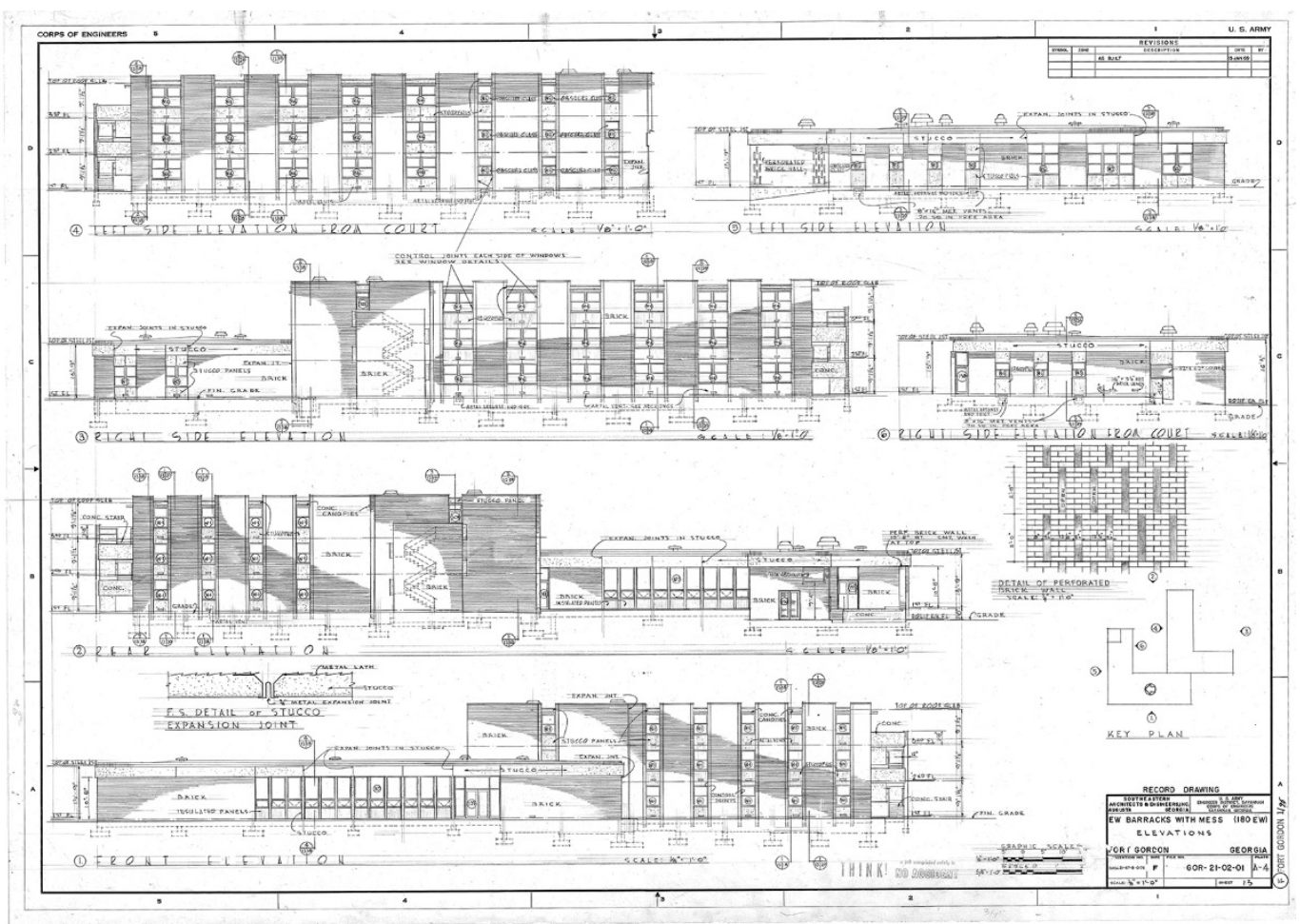

The master plan for the Signal School had a series of classroom buildings surrounding a grassy open area that fronted on Chamberlain Avenue (Figure 9). The new barracks and mess halls to the south of Chamberlain gave this open area its fourth side although they were not designed by Aeck. The open area was capped on the west by the tall headquarters building (Signal Towers, Building 29808) (Figure 10).

Figure 9. Aeck rendering of the Southeastern Signal School, 1963 (Fort Gordon DPW).

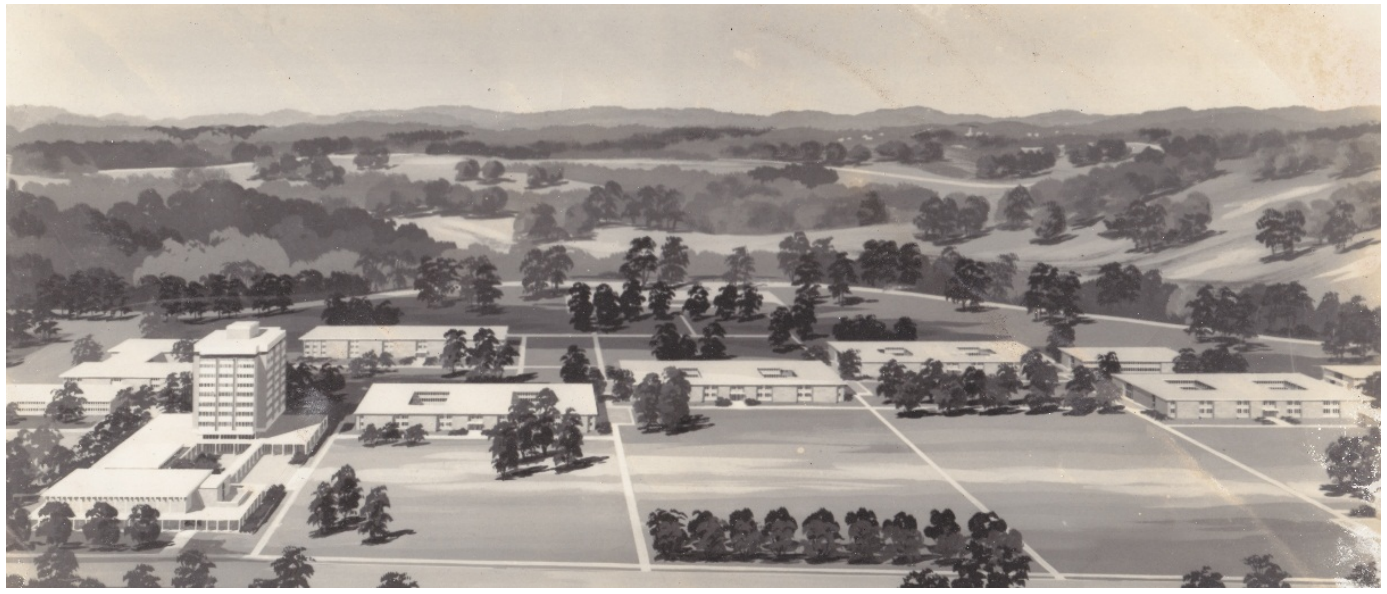


Figure 10. Aeck rendering of the administration building (Building 29808) on the west side of the Signal School area, 1963 (Fort Gordon DPW).

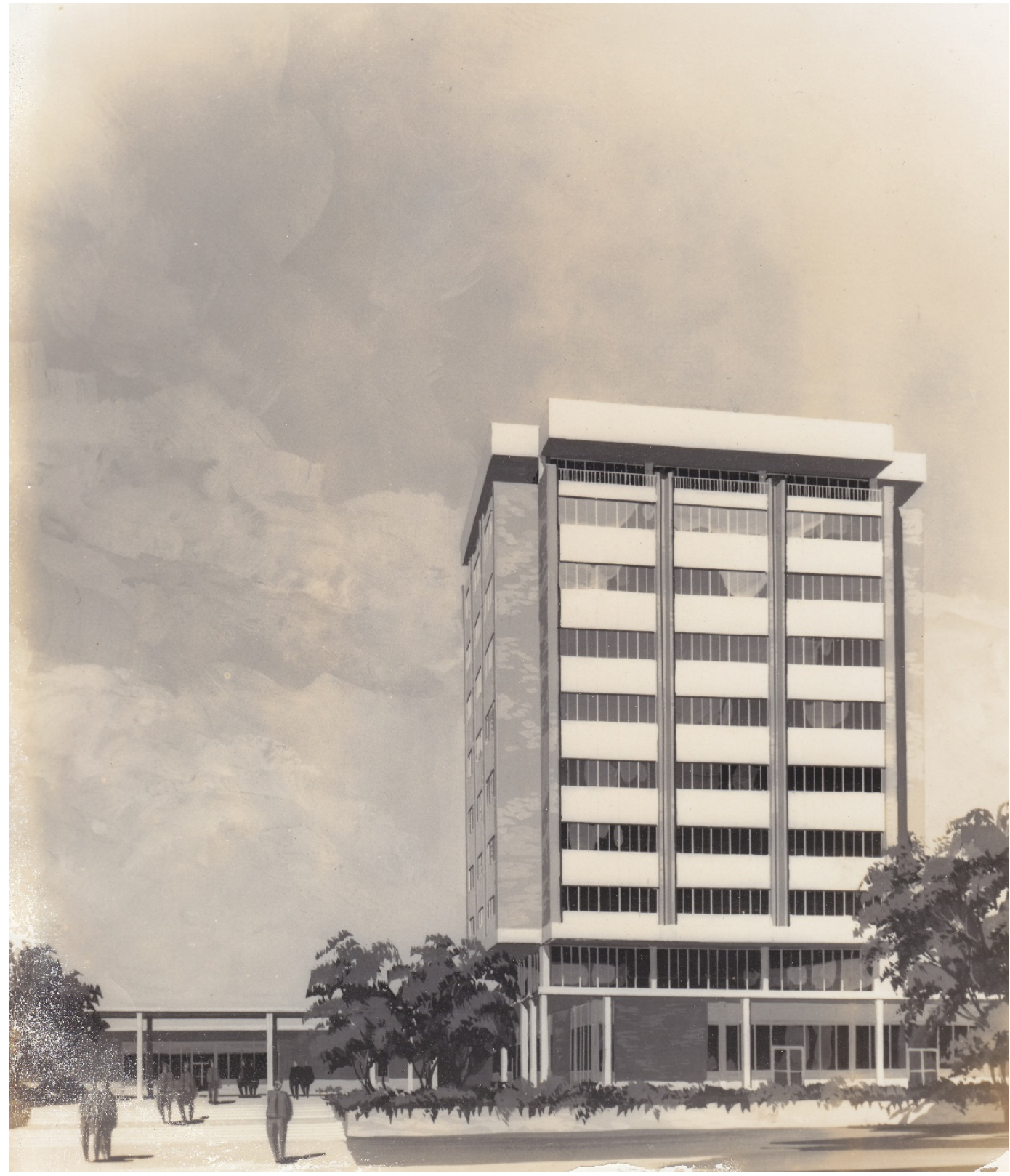

There was one last major expansion, Phase III, with Buildings 25810, 29802, and 29803 constructed in 1973. Since 1973, several storage facilities, smoking shelters, and moveable sheds have been added to the complex.

The structure of all of the buildings was cast-in-place concrete columns supporting cast-in-place concrete waffles (Figure 11). Concrete block was used to infill the area between the concrete columns, and this block was covered by pink/yellow brick on the outside and left exposed on the inside. 
The concrete waffle roof extended out from the walls on all four sides and some of the waffles were perforated to allow sunlight to shine through the perforation (Figure 12 and Figure 13).

Figure 11. Forms for the concrete waffles at Fort Gordon, 1963 (Fort Gordon DPW).

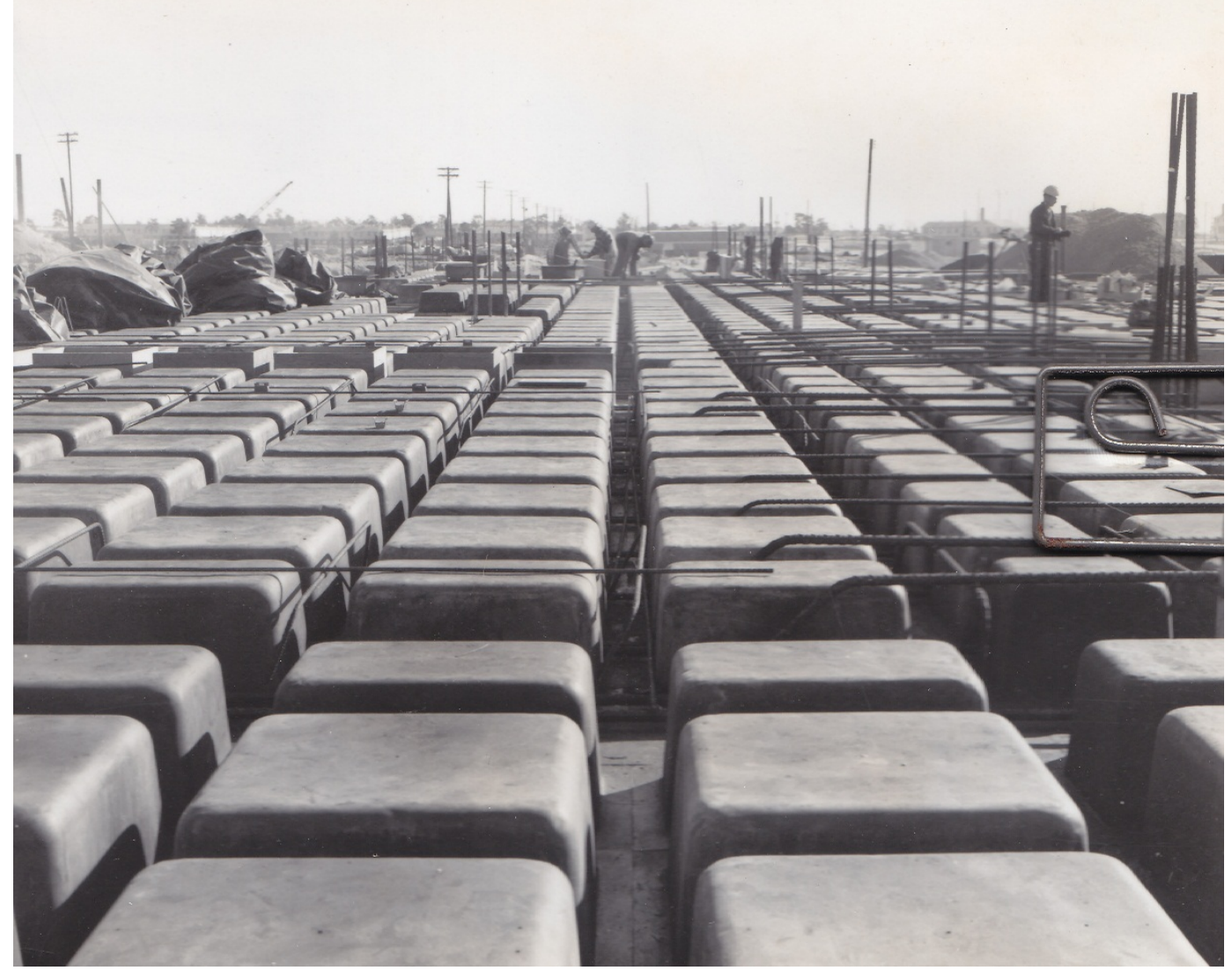

Figure 12. Allison Hall (Building 29817) in the new Signal School complex, May 1970 (Signal Corps Historian Office).

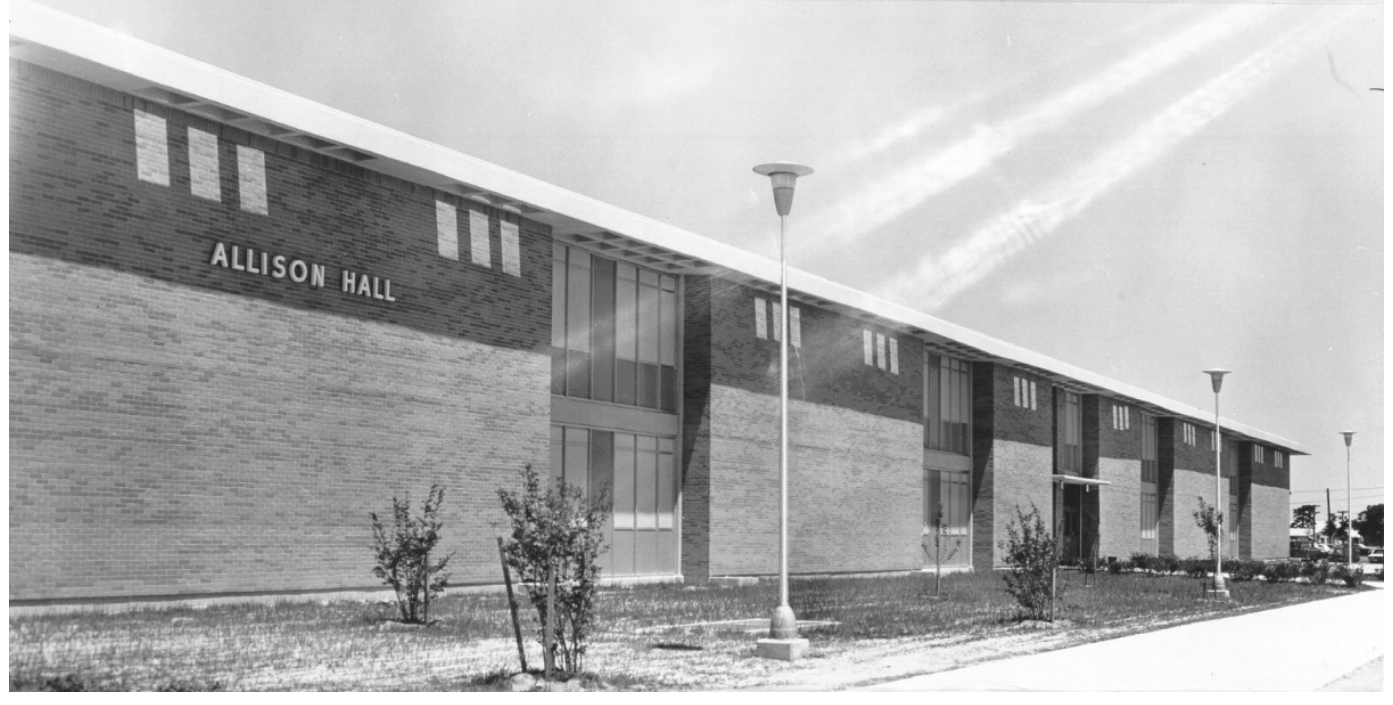


Figure 13. Greely Hall (Building 29809), one of the Signal School classroom buildings, December 1966 (National Archives at College Park, MD).

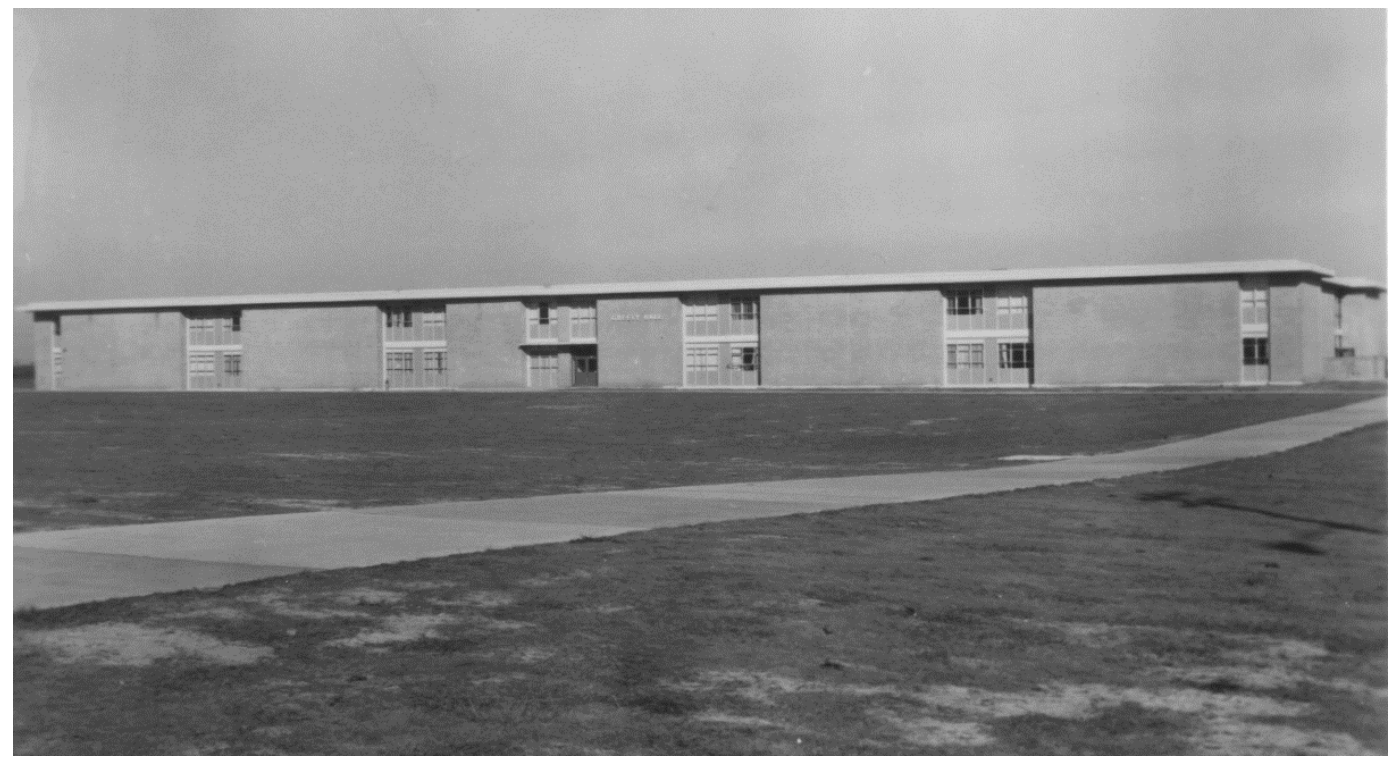

Aeck planned for the western side of the campus to have the main administration building in a tower, a large auditorium, and a library that were connected to each other with a plaza and a concrete waffle-roofed walkway (Figure 14). A large parking lot to the west of these buildings was installed for use by the staff of the buildings.

Figure 14. Auditorium (Building 29805) and Signal School Headquarters (Building 29808) on the west side of the campus [the library, which is now a museum, is hidden between the two buildings in this view], April 1978

(National Archives at College Park, MD).

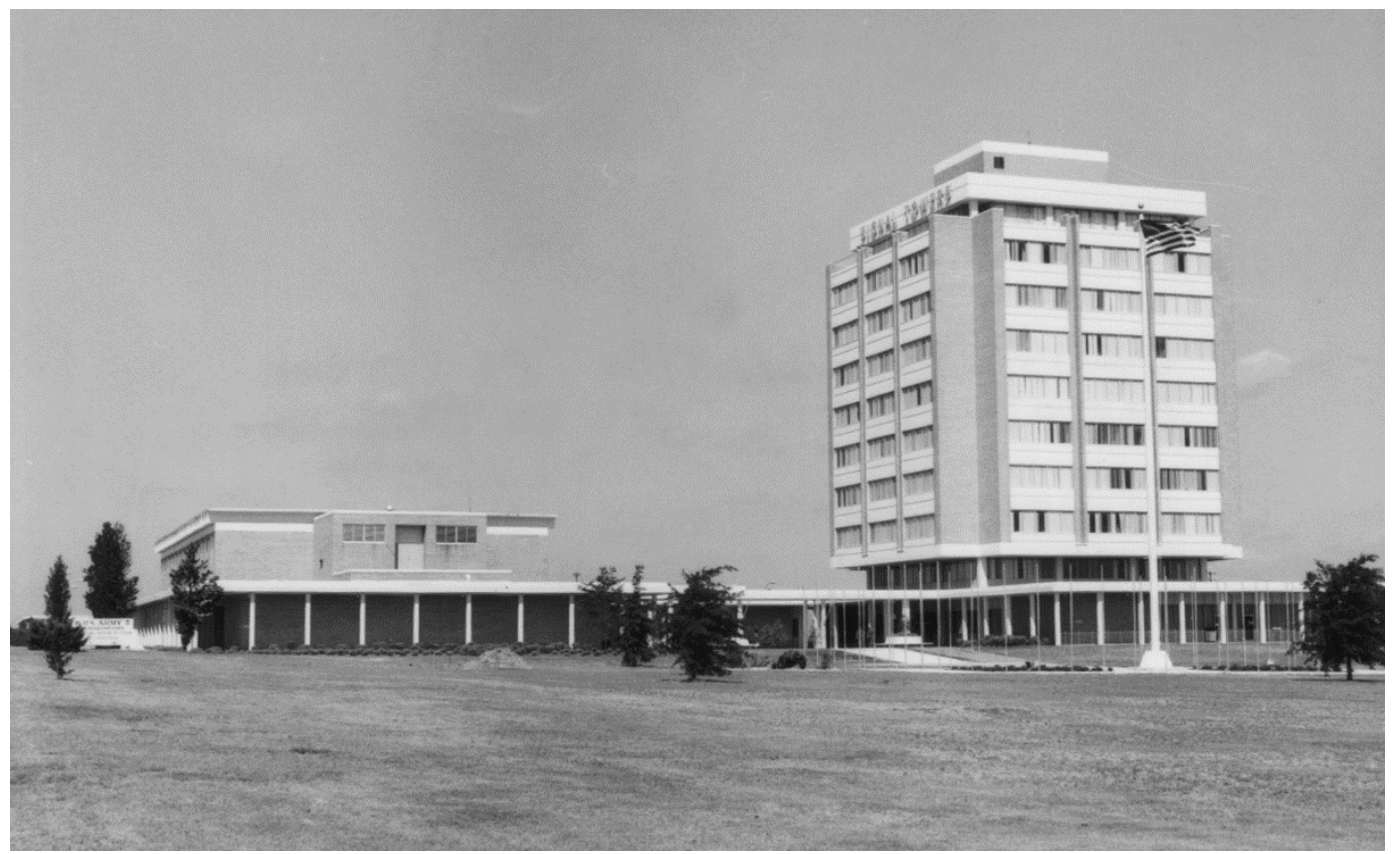


Aeck developed a simple landscaping scheme for the entire campus, with most of the landscaped elements located between the buildings and the large open area, which was mostly grass. Rectilinear sidewalks traversed this grassy area at regular intervals to allow students direct access to the school buildings from the new barracks constructed south of Chamberlain Avenue (Figure 9, Figure 15, and Figure 16). Generally, small trees and shrubs lined the edges of sidewalks closest to building walls (Figure 17, Figure 18, and Figure 19) and a more complicated planting plan was designed for areas directly between building entrances (Figure 20). For such a large campus, the planting list is short (Figure 21).

Figure 15. Signal School landscaping plan east side, 1966 (Fort Gordon DPW).

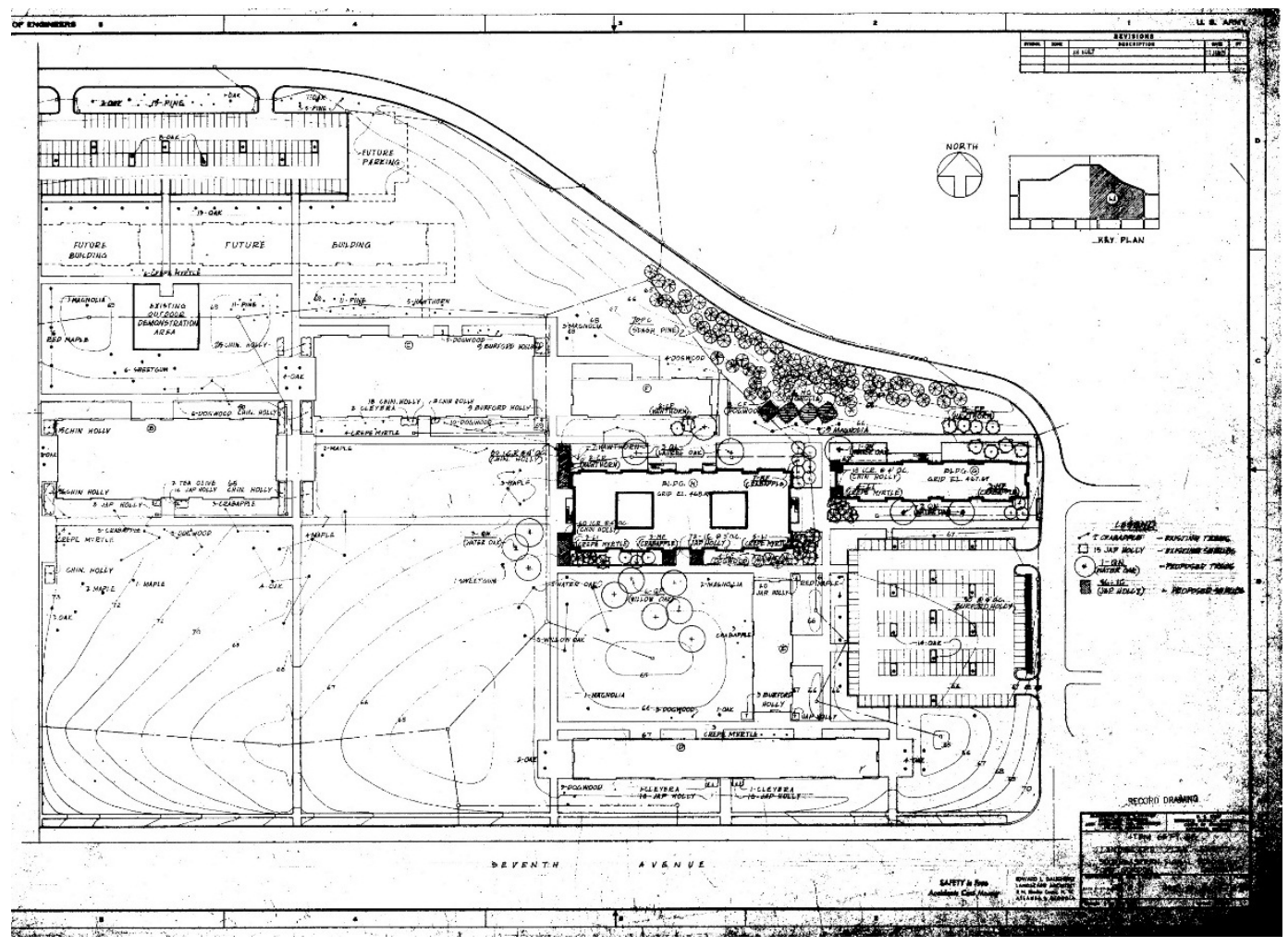


Figure 16. Signal School landscaping plan west side, 1966 (Fort Gordon DPW).

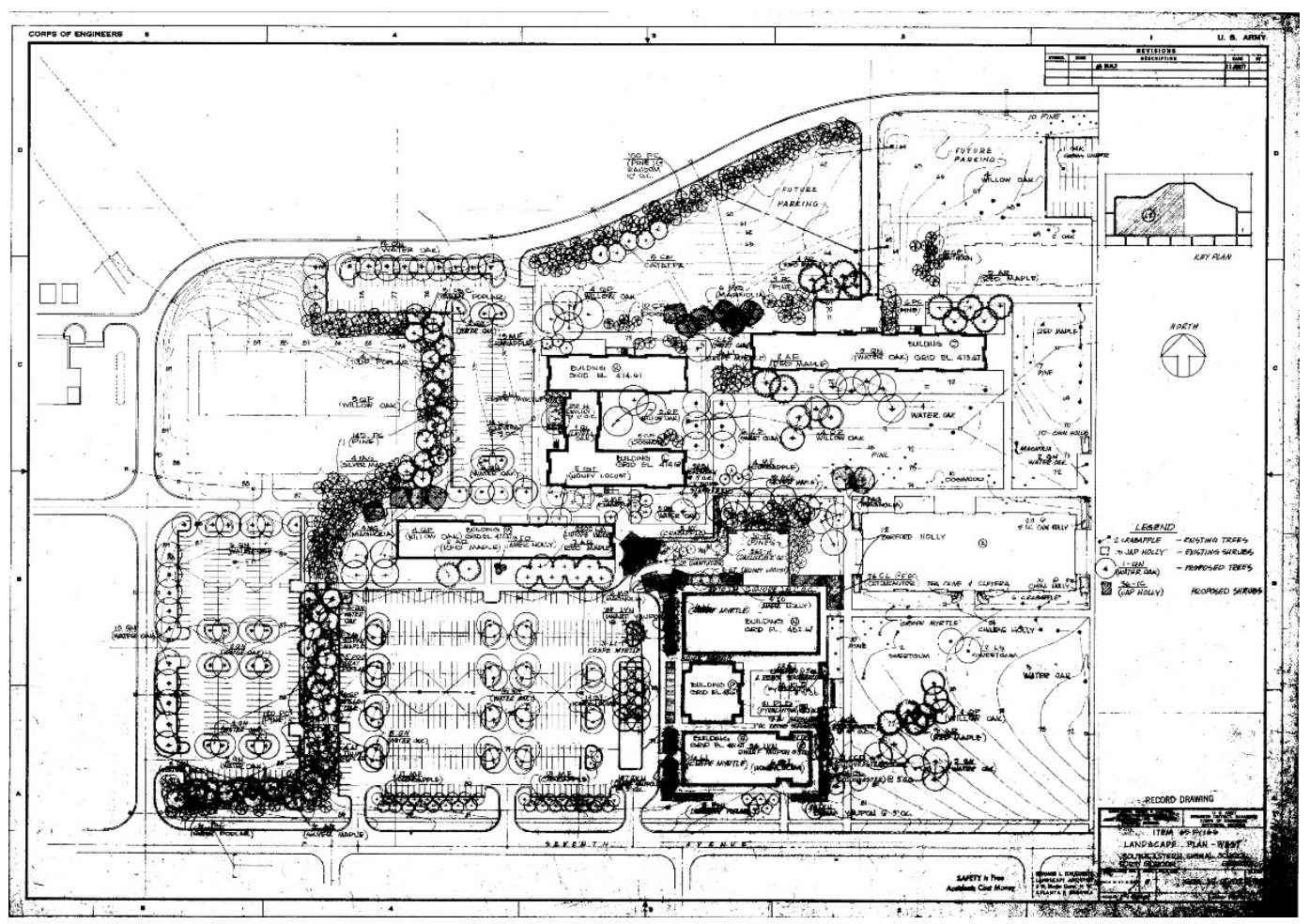

Figure 17. General view of Phase I construction of the Signal School, March 1966 (National Archives at College Park, MD).

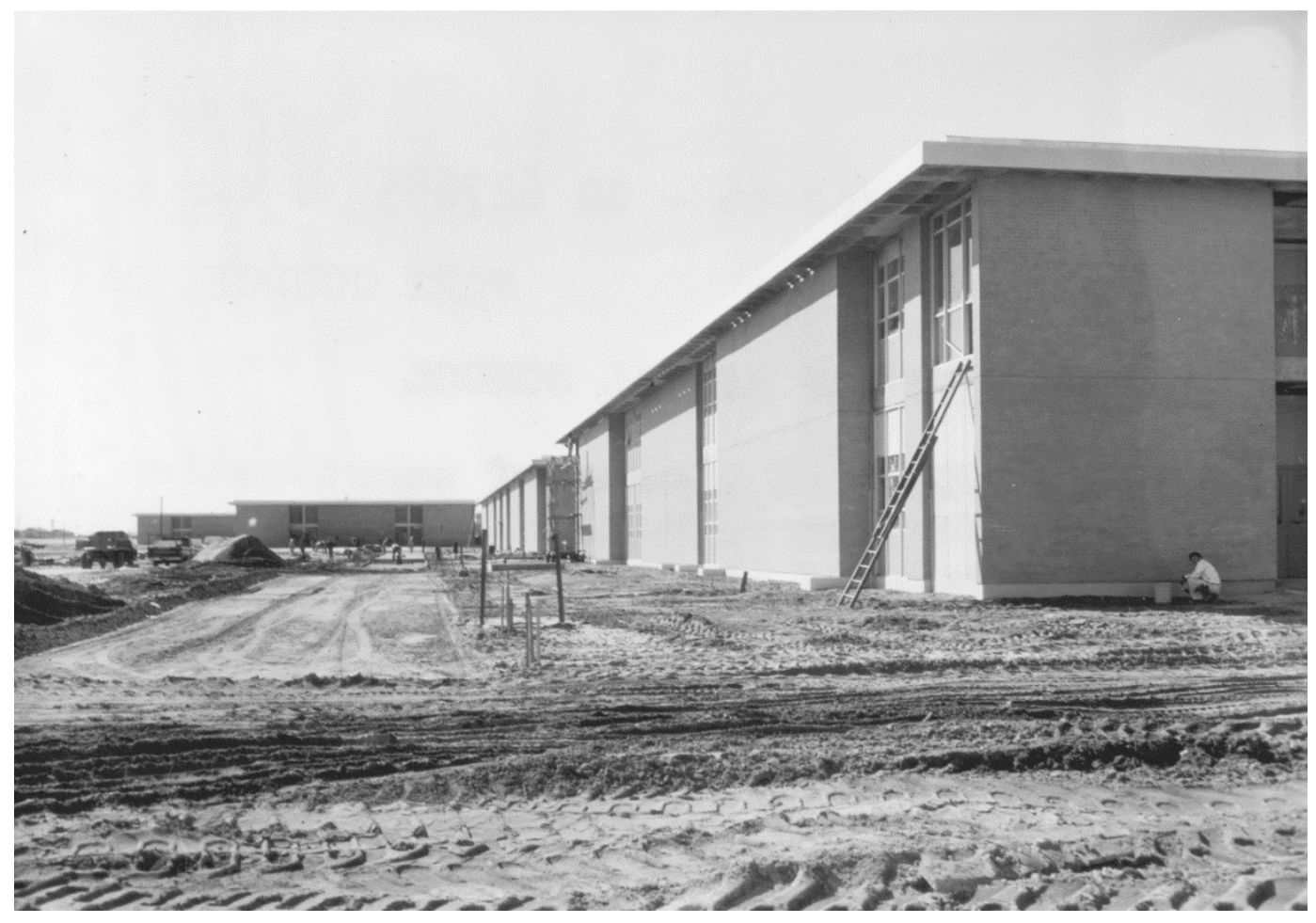


Figure 18. Building 29811, Saltzman Hall, March 1967, with some characteristic landscaping in place (National Archives at College Park, MD).

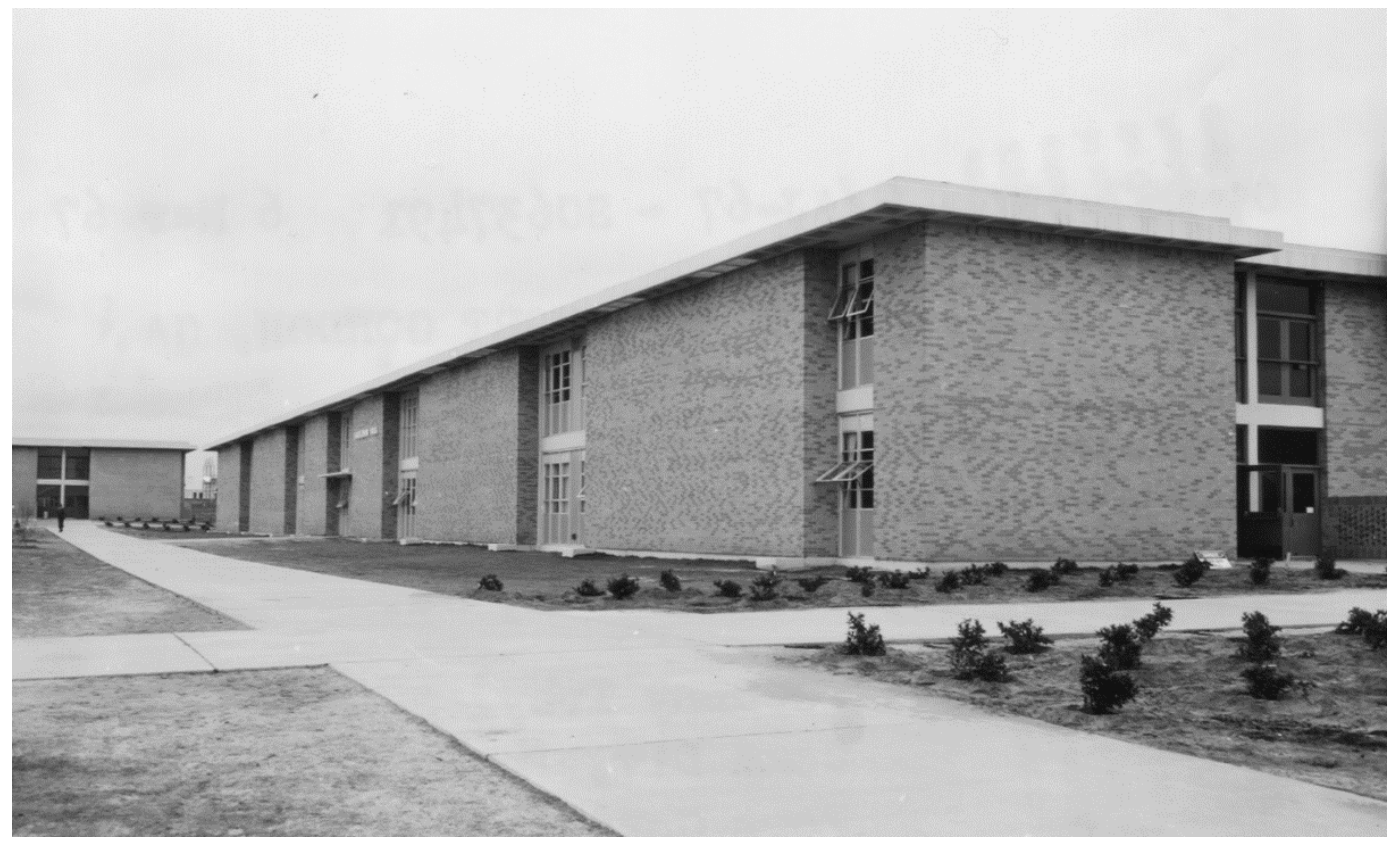

Figure 19. General view of the campus, showing landscaping and looking northeast towards Saltzman Hall (Building 29811) on the left, Allen Hall (Building 29813) middle, and Allison Hall (Building 29817) right, April 1978

(National Archives at College Park, MD).

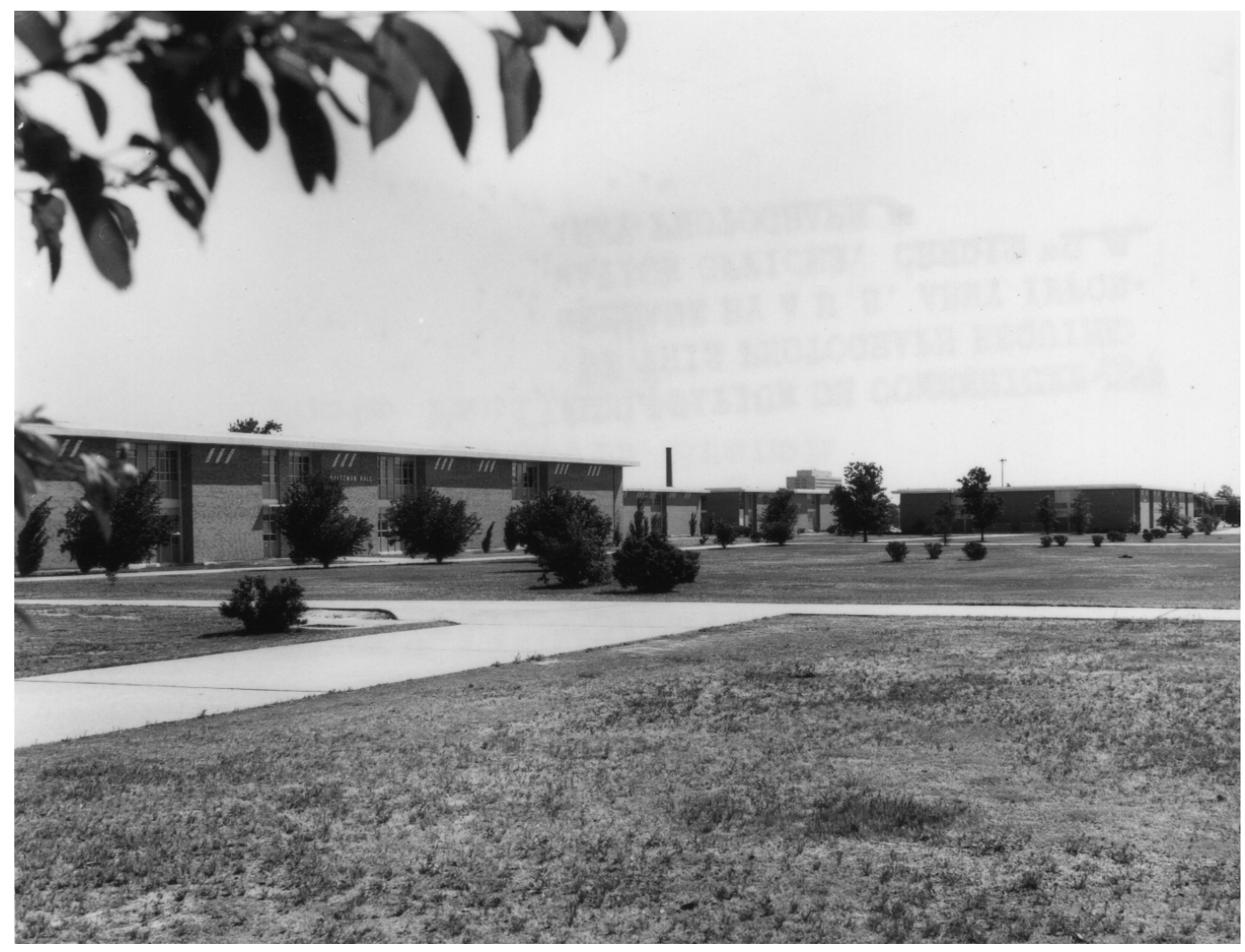


Figure 20. Landscaping drawing for courtyard to the east of the library (Building 29807) (Fort Gordon DPW).

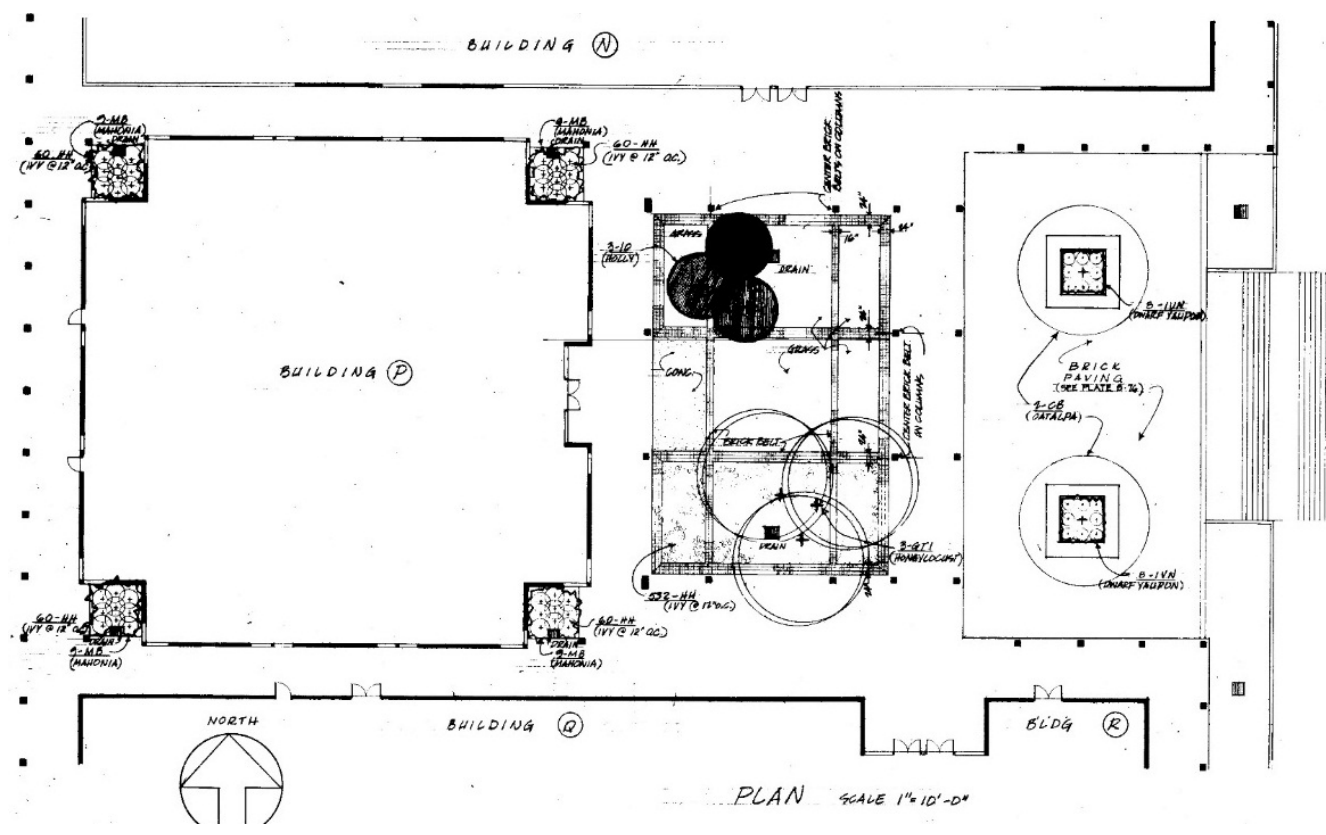

Figure 21. Landscape planting list, 1966 (Fort Gordon DPW).

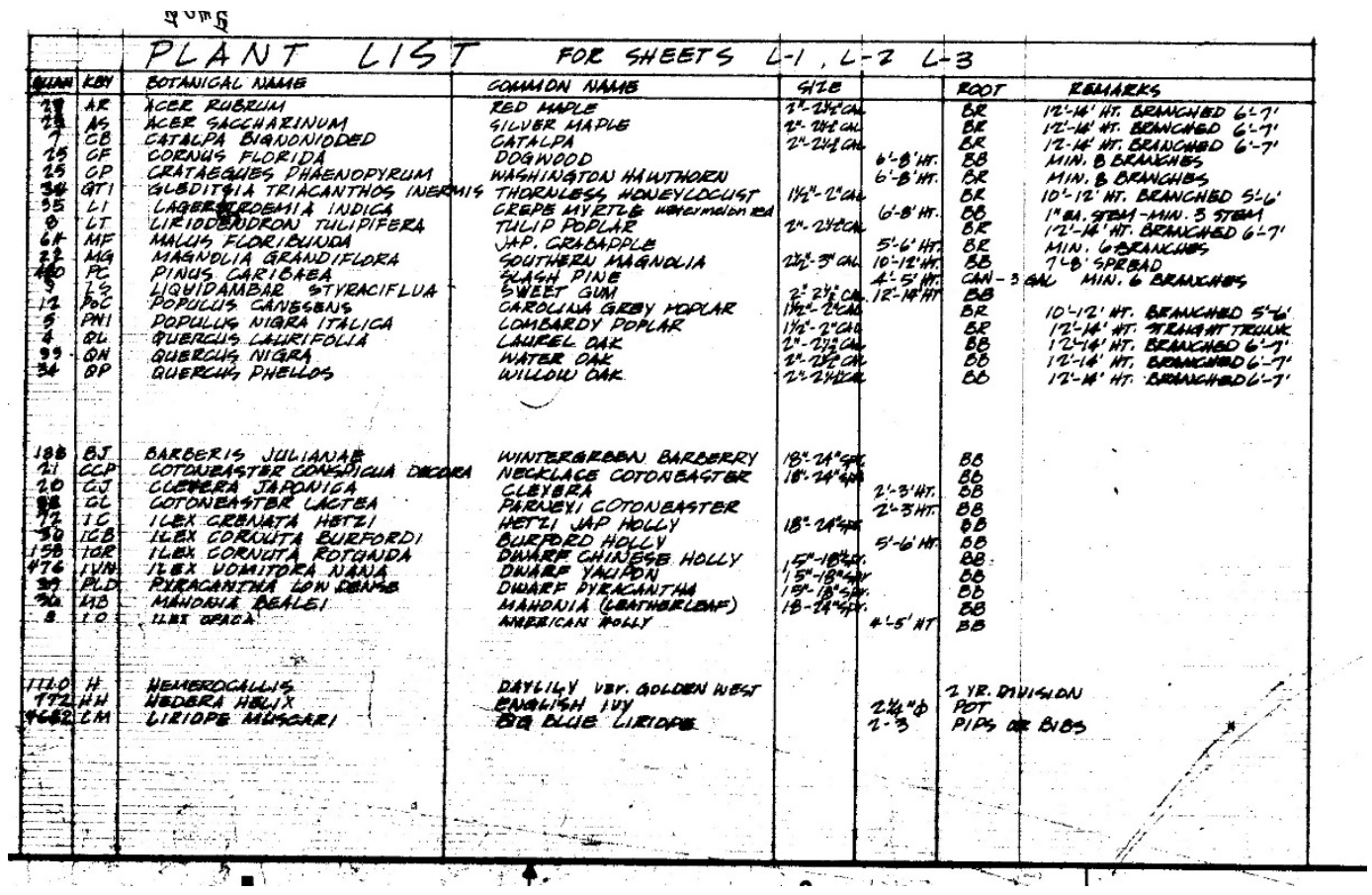

The four largest classroom buildings (Allison, Allen, Greely, and Saltzman Halls) were each designed with classrooms on either side of two primary hallways. Between these two classroom blocks were two large landscaped courtyards. Each of them had a different plan, with different seating and planter arrangements (Figure 22 and Figure 23). Designed elements 
within each courtyard were concrete benches, brick walls, and concrete planters and pots (Figure 24).

Figure 22. Courtyard design \#H-111, 1966 (Fort Gordon DPW).

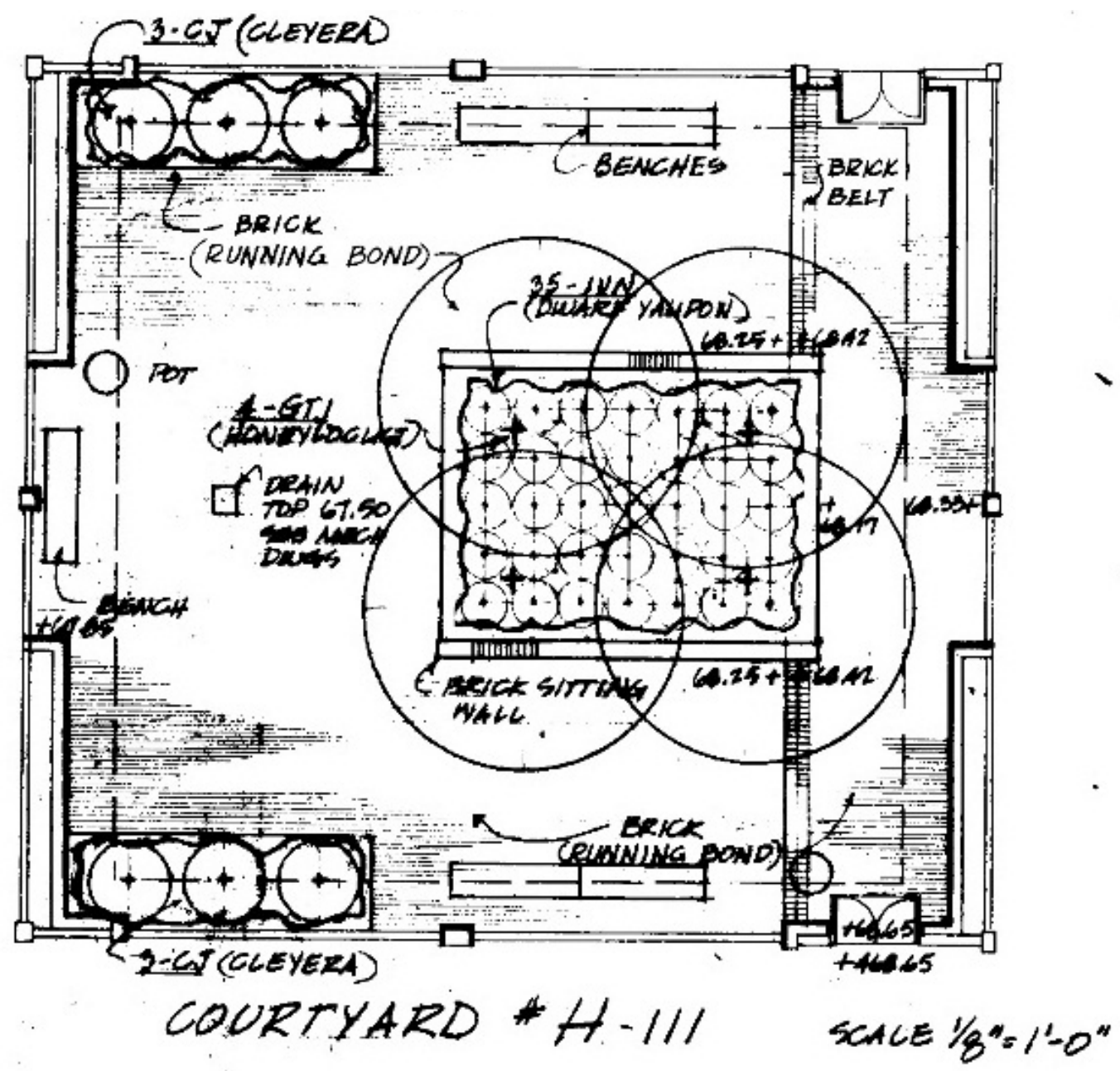


Figure 23. Courtyard design \#H-143, 1966 (Fort Gordon DPW).

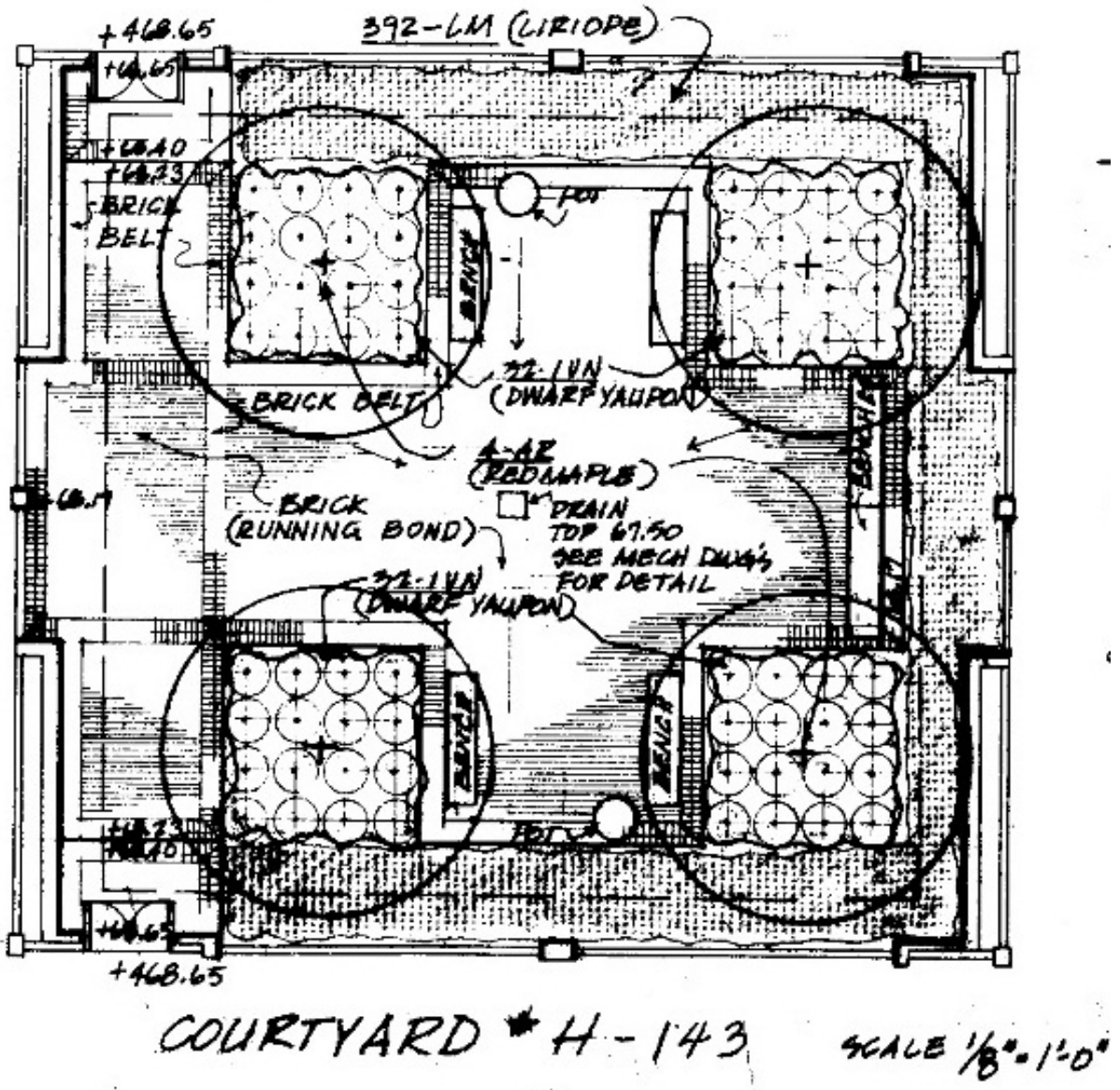


Figure 24. Detail drawings for various designed elements used within the courtyards, 1966 (Fort Gordon DPW).

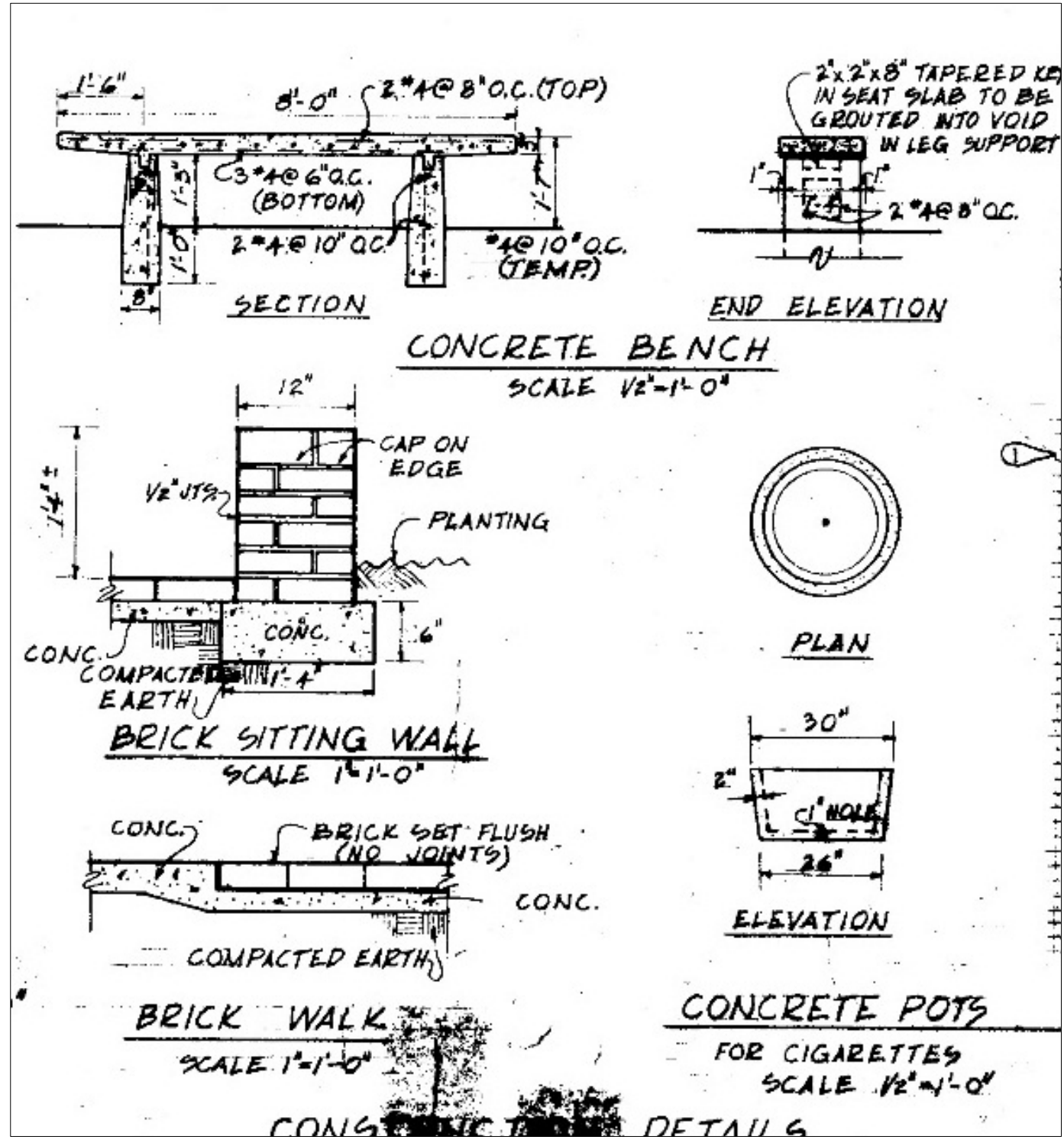




\section{Character-Defining Features for the Signal School Campus ${ }^{2}$}

The Secretary of the Interior's Standards for the Treatment of Historic Properties (National Park Service [NPS] 1995) embody two important goals: (1) the preservation of historic materials, and (2) the preservation of a building's distinguishing character. Every old building is unique, with its own identity and its own distinctive character. Character refers to all of those visual aspects and physical features that comprise the appearance of every historic building. Character-defining elements include the overall shape of the building, its materials, craftsmanship, decorative details, interior spaces and features, as well as the various aspects of its site and environment.

If the various materials, features, and spaces that give a building its visual character are not recognized and preserved, then essential aspects of its character may be damaged in the process of change. A building's character can be irreversibly damaged or changed in many ways; examples are: repointing brickwork inappropriately, removing a distinctive side porch, changing the window sash, altering the setting around the building, changing the major room arrangements, introducing an atrium, and painting previously unpainted woodwork.

There are 34 contributing and noncontributing properties located within and adjacent to the historic district boundaries (Table 2). One building (33800 which is located east of $8^{\text {th }}$ Avenue) was determined not to be part of the Aeck master plan for the Signal School, nor designed by Aeck, and had a separate mission than the Signal School. The researchers placed it outside the historic district boundary. The overall feeling and character of the historic district is derived from the two-story massing of the classroom buildings surrounding the grassy area and capped off to the west by the large monolithic form of Building 29808, Signal Towers. The predominant use of pink/yellow brick veneer, flat exposed concrete waffle roofs with perforated overhangs, bright-aluminum window muntins, and insulated panel inserts on all of the contributing buildings only enhances the feeling

2 Based on Nelson, n.d. 
that this campus is an important piece of architecture for the New Formalism era in U.S. architectural history.

Table 2. List of contributing and noncontributing properties (ERDC-CERL). ${ }^{3}$

\begin{tabular}{|l|l|l|}
\hline $\begin{array}{l}\text { Feature Type } \\
\text { and Building } \\
\text { Number }\end{array}$ & Description of Feature & $\begin{array}{l}\text { Contributing or } \\
\text { Noncontributing } \\
\text { Status }\end{array}$ \\
\hline Site (1 contributing) & \multicolumn{2}{|l|}{} \\
\hline 1 & $\begin{array}{l}\text { Topography, landscape, viewsheds, layout, } \\
\text { and circulation }\end{array}$ & Contributing \\
\hline Buildings (16 contributing, 4 noncontributing) & \multicolumn{2}{|l|}{} \\
\hline 25810 & Brant Hall & Contributing \\
\hline 25910 & Heating \& AC Plant & Noncontributing \\
\hline 29801 & Nelson Hall & Contributing \\
\hline 29802 & Moran Hall south & Contributing \\
\hline 29803 & Moran Hall north & Contributing \\
\hline 29804 & Shed & Noncontributing \\
\hline 29805 & Alexander/OImsted Halls (Auditorium) & Contributing \\
\hline 29807 & Museum (Conrad Hall) & Contributing \\
\hline 29808 & Signal Towers & Contributing \\
\hline 29809 & Greely Hall & Contributing \\
\hline 29810 & Burkhardt Hall & Contributing \\
\hline 29811 & Saltzman Hall & Contributing \\
\hline 29813 & Allen Hall & Contributing \\
\hline$($ No number) & Storage Shed (between 29812 and 29814 & Noncontributing \\
\hline 29815 & Hazen Hall & Contributing \\
\hline 29816 & Fisher Hall & Contributing \\
\hline 29817 & Allison Hall & Contributing \\
\hline 29818 & Johnston Hall & Contributing \\
\hline 29819 & Stansell Hall & \multicolumn{2}{l|}{ Contributing } \\
\hline 33800 & Enlisted Women's Barracks & Nontributing \\
\hline
\end{tabular}

3 Noncontributing buildings are discussed in Chapter 4. 


\begin{tabular}{|l|l|l|}
\hline $\begin{array}{l}\text { Feature Type } \\
\text { and Building } \\
\text { Number }\end{array}$ & Description of Feature & $\begin{array}{l}\text { Contributing or } \\
\text { Noncontributing } \\
\text { Status }\end{array}$ \\
\hline Structures (0 contributing, 12 noncontributing) & \multicolumn{2}{|l|}{} \\
\hline 25811 & Pad for IFR Beacon & Noncontributing \\
\hline 25812 & Covered Storage & Noncontributing \\
\hline 25813 & Covered Storage & Noncontributing \\
\hline 25911 & Mechanical Room & Noncontributing \\
\hline 25912 & Water Storage Tank & Noncontributing \\
\hline 25910 & Cooling Tower & Noncontributing \\
\hline SUBST & Electrical Substation & Noncontributing \\
\hline 29812 & Covered Training Area & Noncontributing \\
\hline 29814 & Covered Training Area & Noncontributing \\
\hline 29820 & Covered Training Area & Noncontributing \\
\hline 29822 & Covered Training Area & Noncontributing \\
\hline (No number) & Covered Training Area & Noncontributing \\
\hline Objects (1 contributing, O noncontributing) & \multicolumn{2}{|l}{} \\
\hline (No number) & Flagpole & Contributing \\
\hline
\end{tabular}

\subsection{Exterior character-defining feature examples}

The overall layout of the Signal School Campus Historic District is itself a character-defining feature. The layout was designed with buildings surrounding the large grassy area that fronts Chamberlain Avenue, parking to the north along $8^{\text {th }}$ Avenue, and then classrooms on the east, administration in the center, and laboratory/testing on the west (Figure 25).

Figure 25. Signal School Campus Historic District boundary (www.google.com, accessed January 2016).

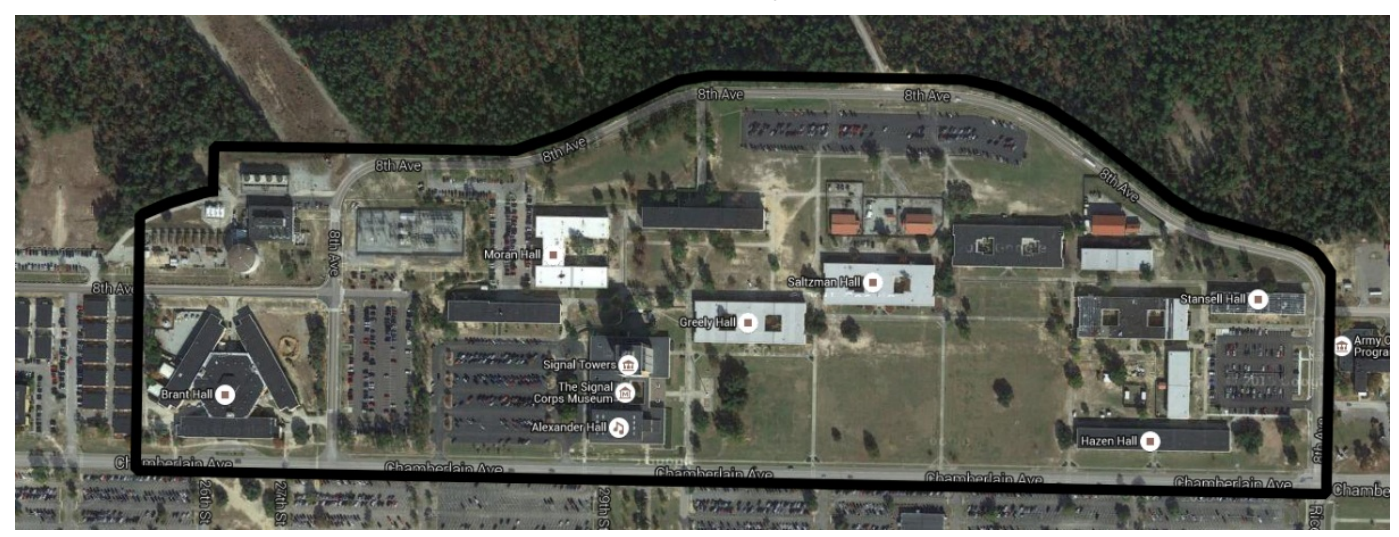




\subsubsection{Rectangular massing}

All of the building in the Signal School Campus were designed with rectangular massing. The following images are a few examples of the characterdefining feature (Figure 26-Figure 29).

Figure 26. Rectangular massing, Building 29802, Moran Hall south (ERDC-CERL, 2015).

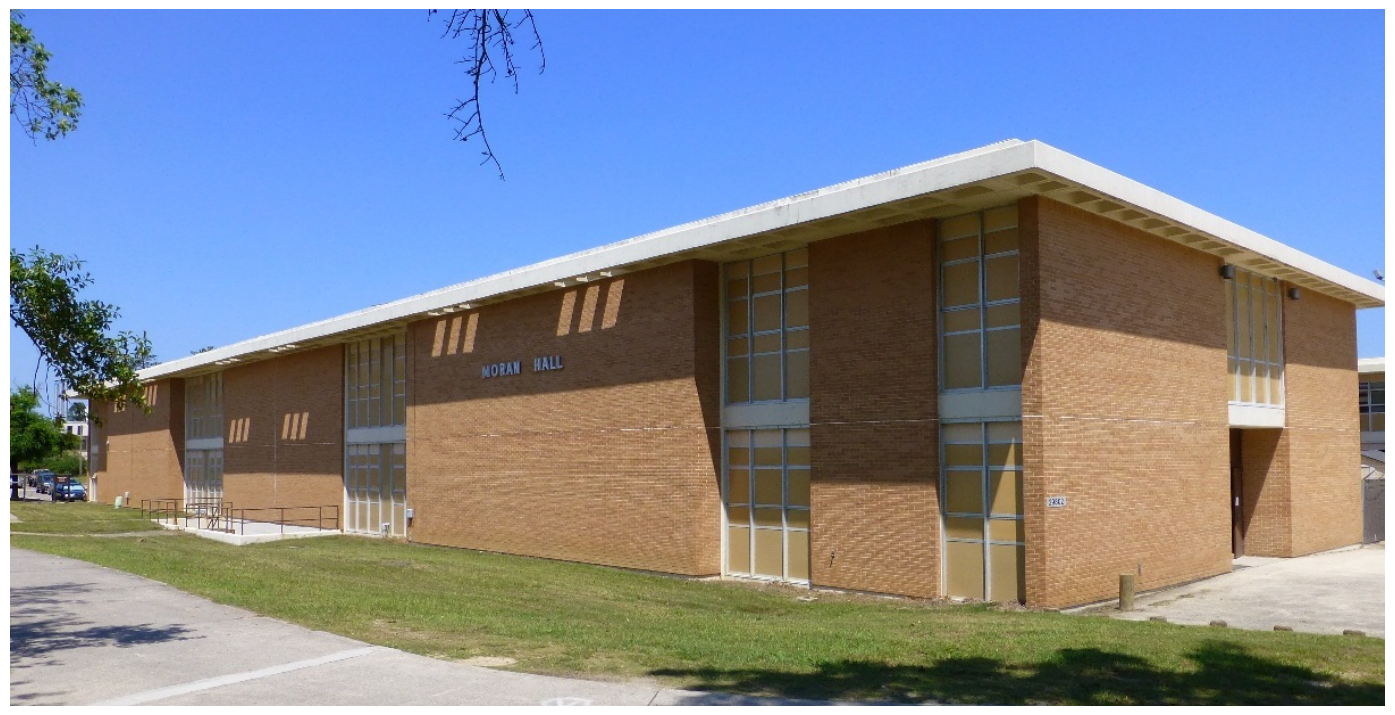

Figure 27. Rectangular massing, Building 29805, Alexander/OImsted Halls (ERDC-CERL, 2015).

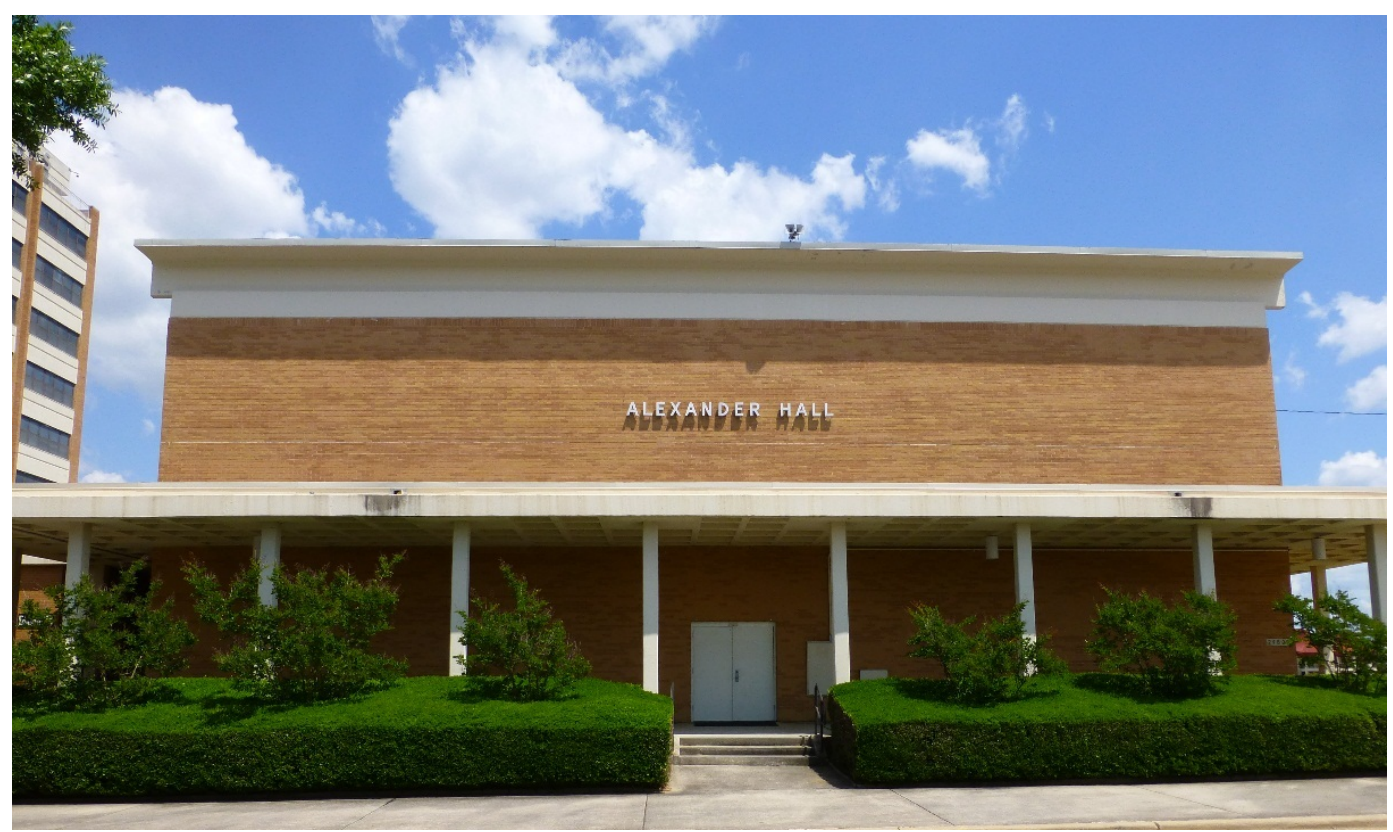


Figure 28. Rectangular massing, Building 29809, Greely Hall (ERDC-CERL, 2015).

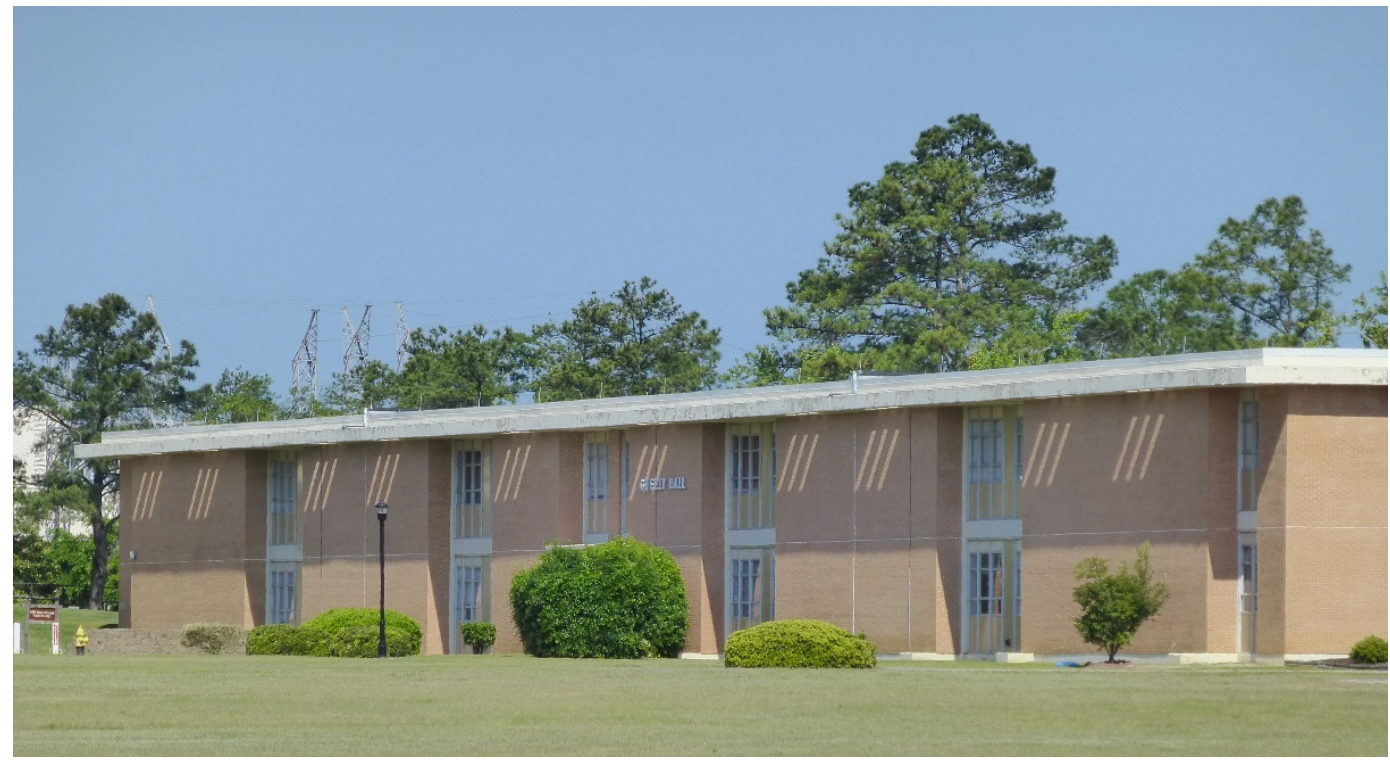

Figure 29. Rectangular massing, Building 29815, Hazen Hall (ERDC-CERL, 2015).

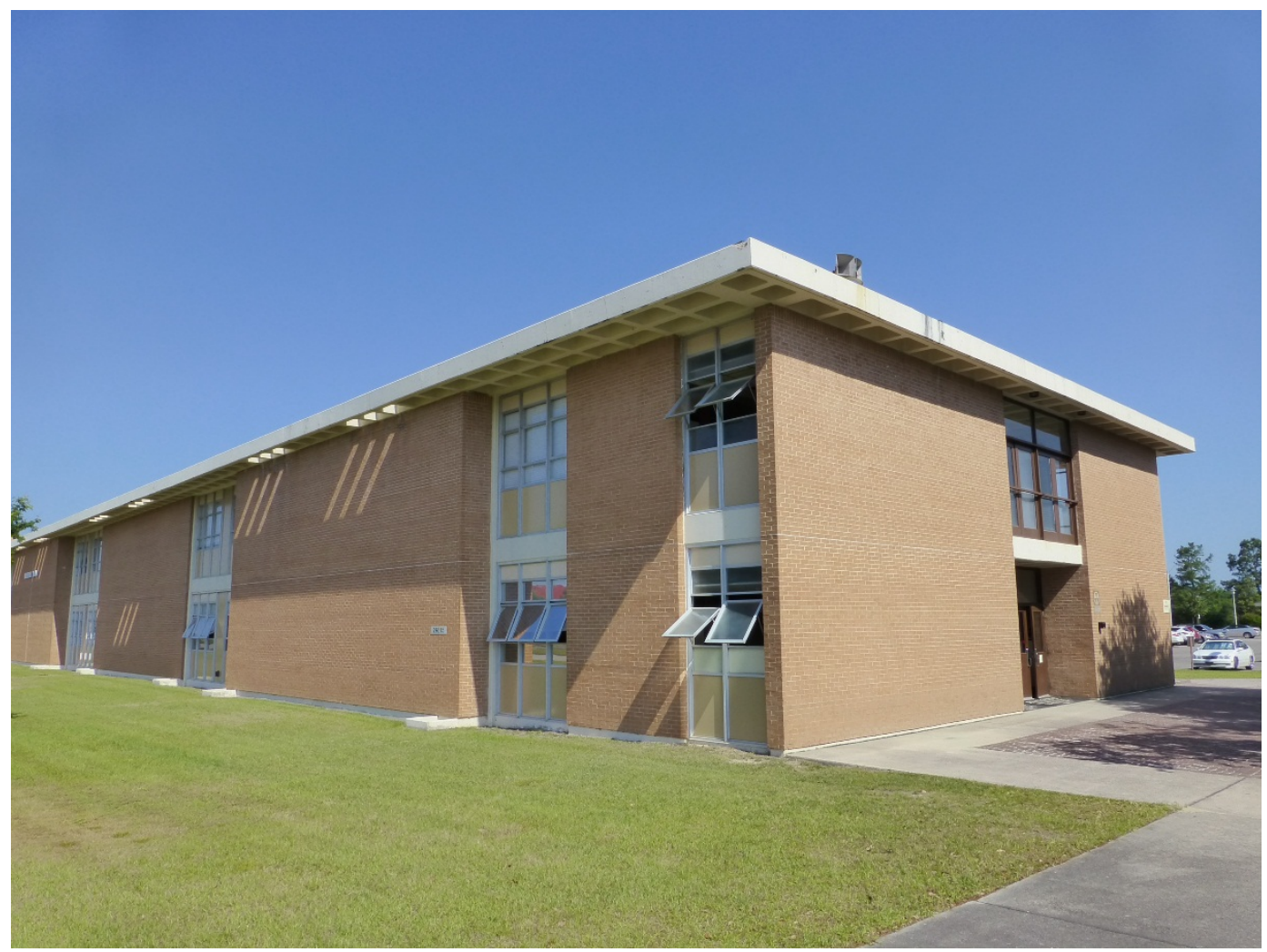

\subsubsection{Two-story structures}

The majority of the Signal School Campus buildings were designed as twostory structures with basements. The exceptions are Building 29805, Alexander/Olmstead Halls, which was constructed as one-story/double-height 
auditorium building. Building 29807, Museum (Conrad Hall) was built as a one-story structure. Building 29808, Signal Towers was built as a tall ten-story structure. Building 29810, Burkhardt Hall, was constructed as a three-story structure. The following figures are examples of the two-story classroom buildings constructed at the campus (Figure 30 and Figure 31).

Figure 30. Two-story classroom building, Building 29811, Saltzman Hall (ERDC-CERL, 2015).

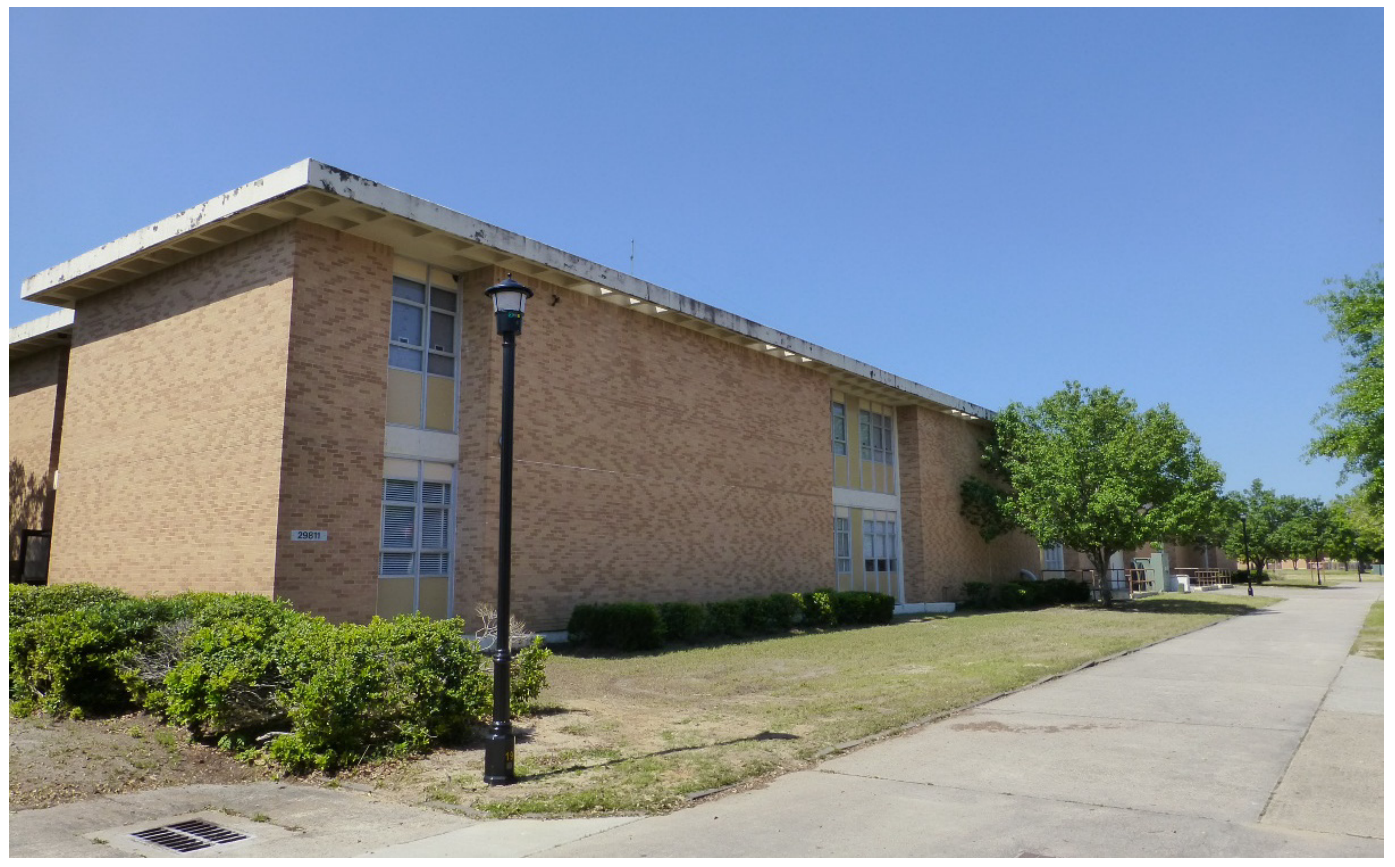

Figure 31. Two-story classroom Building 29813, Allen Hall (ERDC-CERL, 2015).

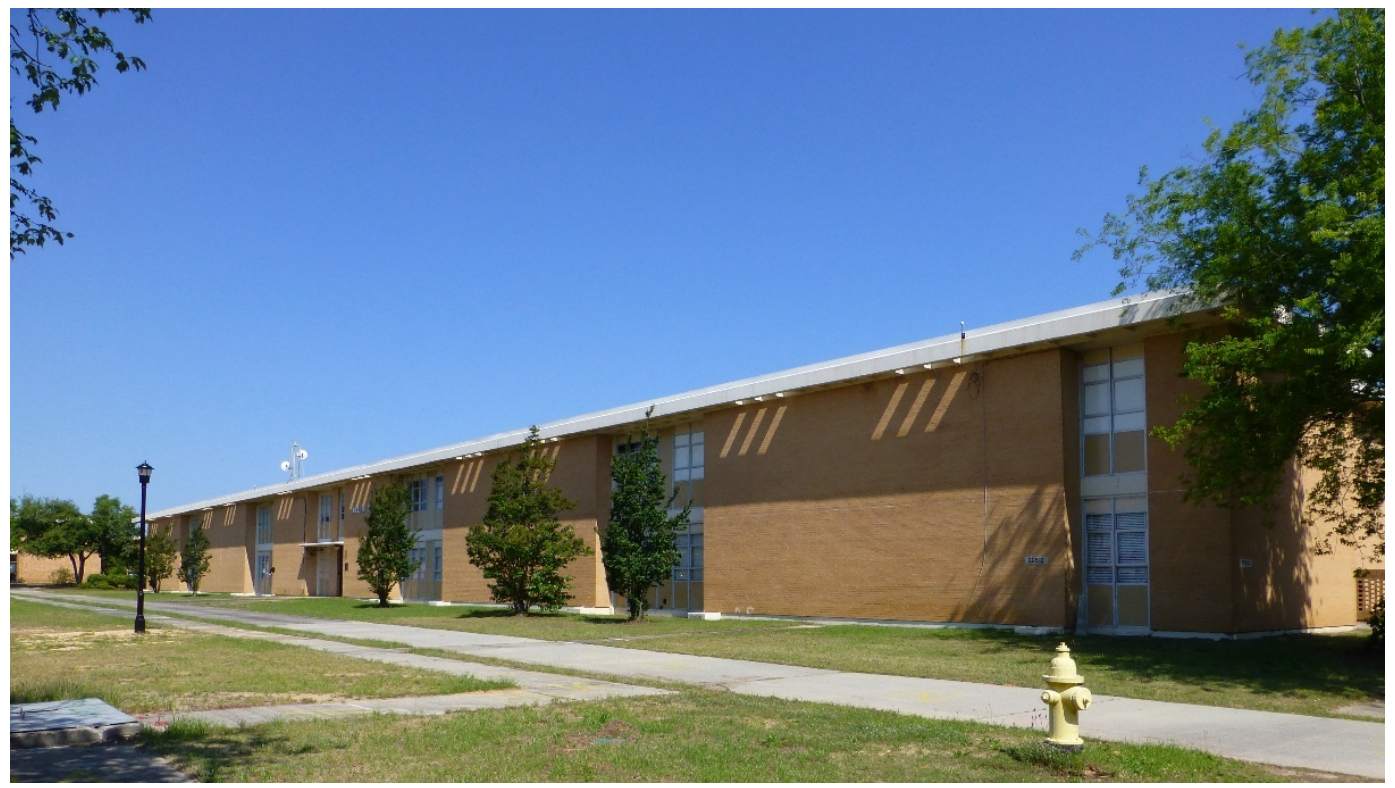




\subsubsection{Flat roofs}

All of the Signal School Campus buildings were designed and constructed with flat roofs. The following figures are examples of flat roof construction of these buildings (Figure 32 and Figure 33).

Figure 32. Flat roof construction of Building 29810, Burkhardt Hall (ERDC-CERL, 2015).

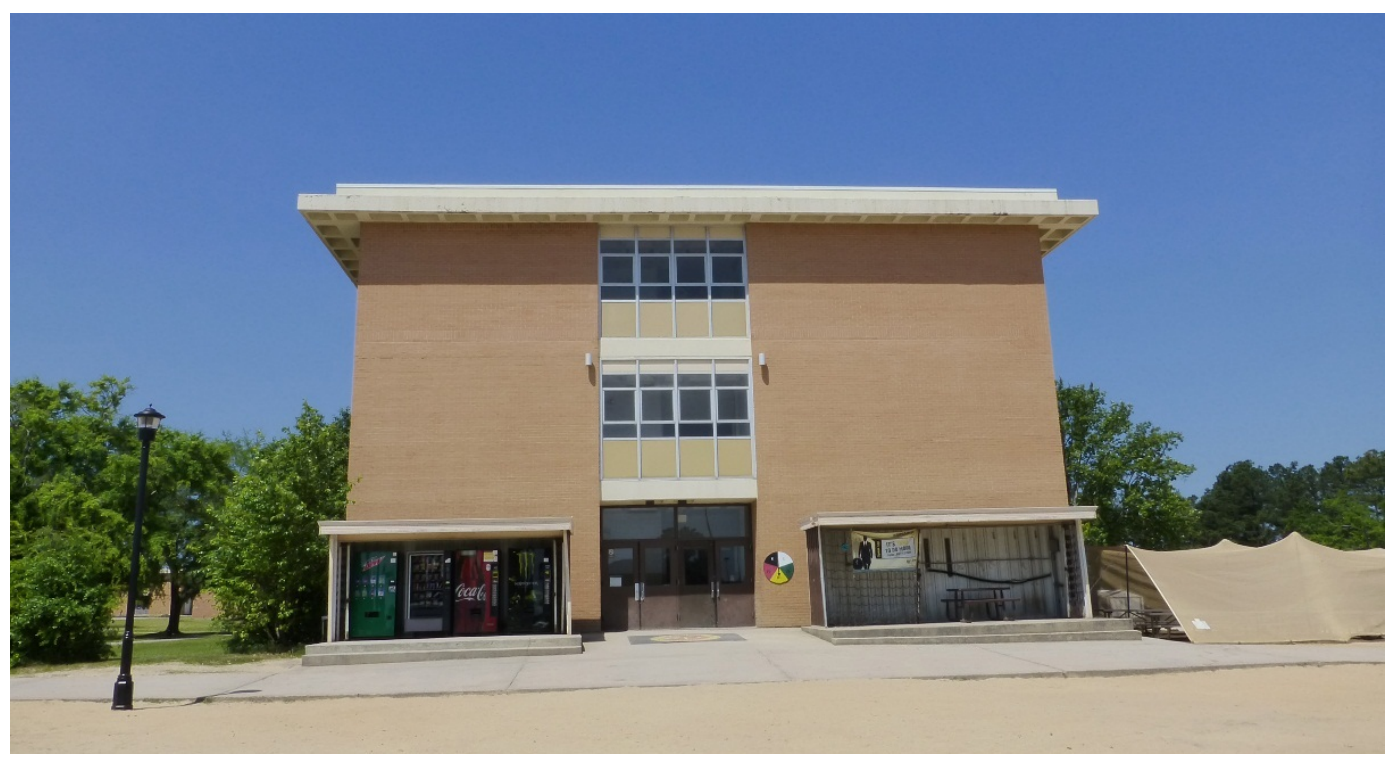

Figure 33. Flat roof construction of Building 29816, Fisher Hall (ERDC-CERL, 2015).

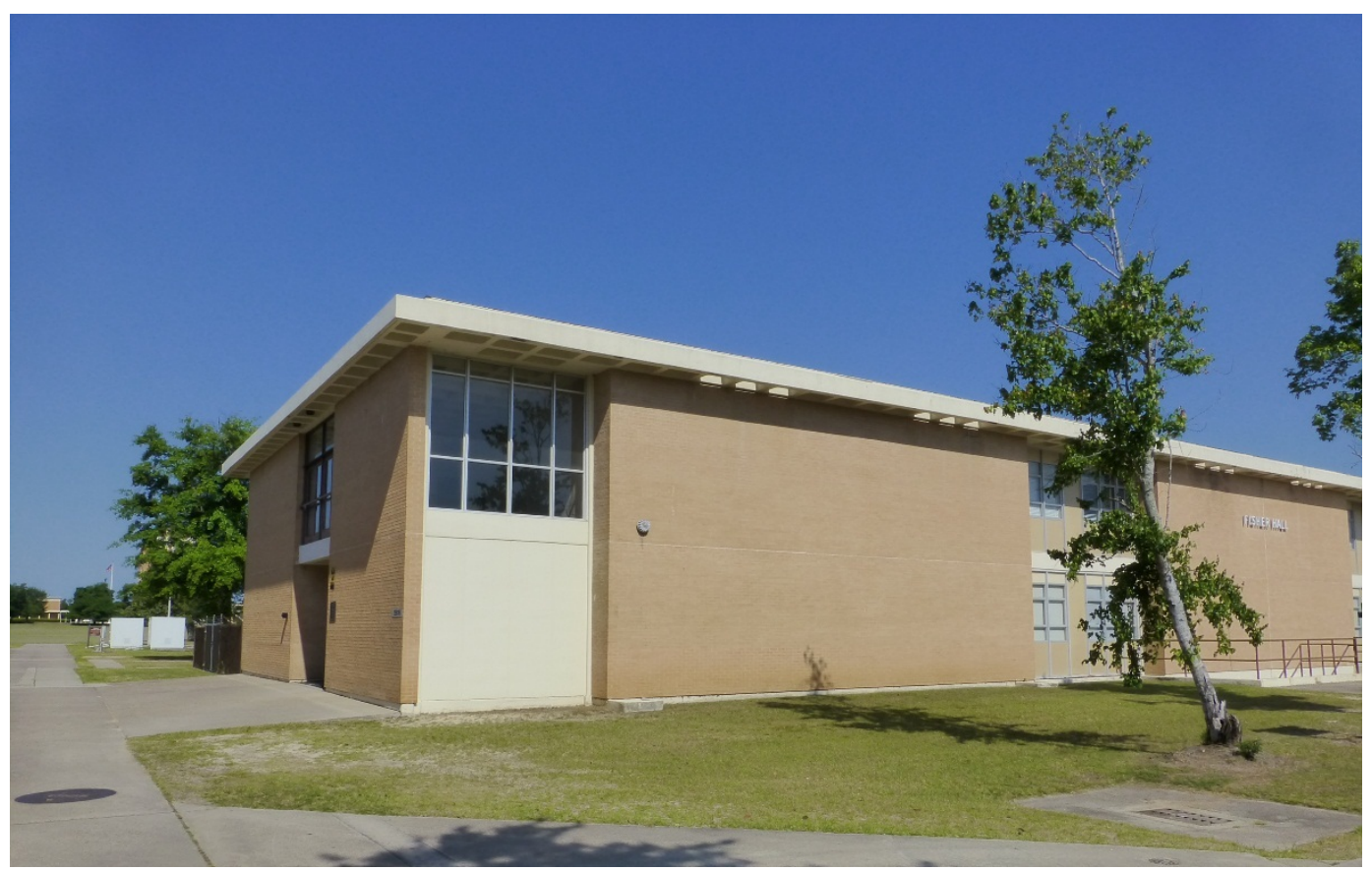




\subsubsection{Brick veneer exteriors}

All of the Signal School Campus buildings were constructed with a pink/yellow brick veneer exterior. The following figures are examples of the use of brick veneer on these buildings (Figure 34 and Figure 35).

Figure 34. Brick veneer exterior walls, Building 29813, Allen Hall (ERDC-CERL, 2015).

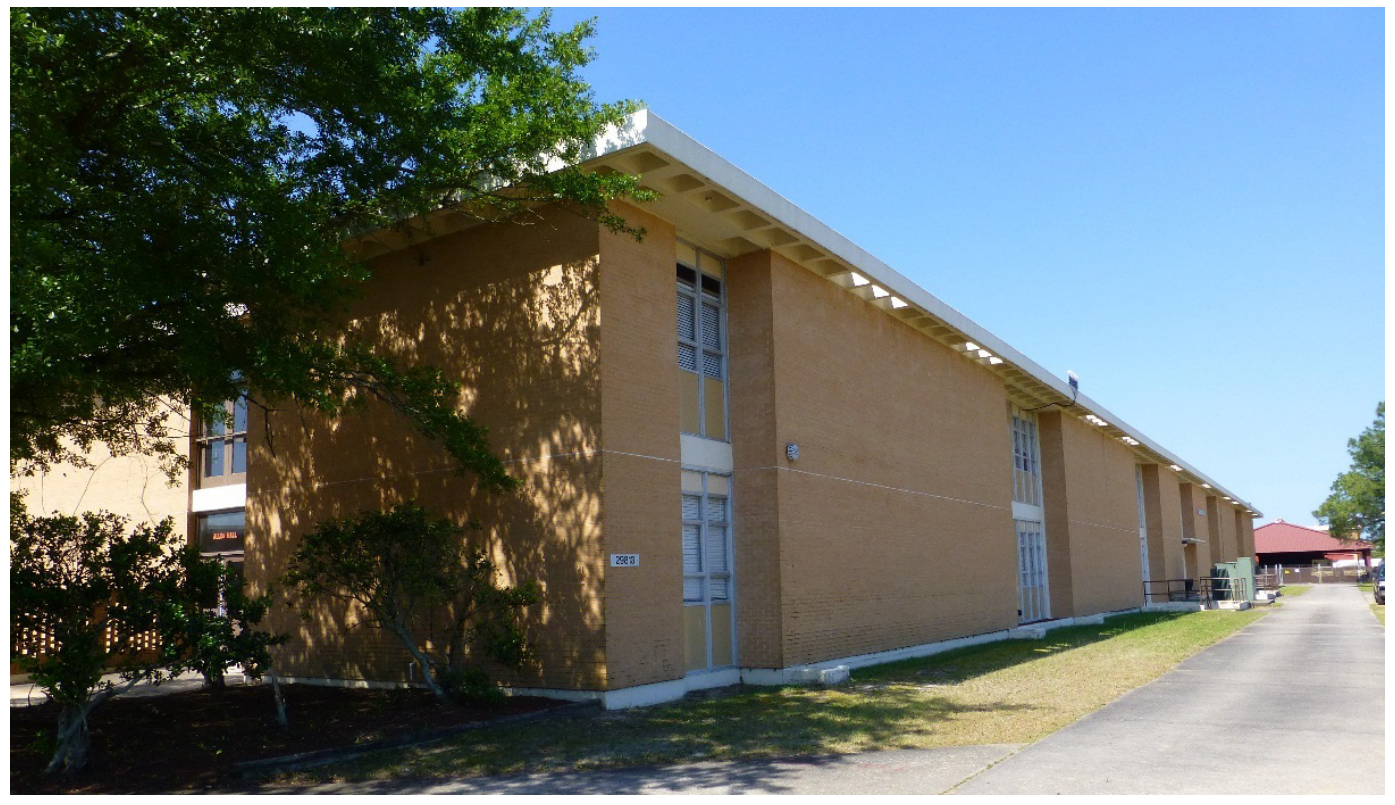

Figure 35. Close-up of an example of the brick veneer exterior walls, Building 29819, Stansell Hall (ERDC-CERL, 2015).

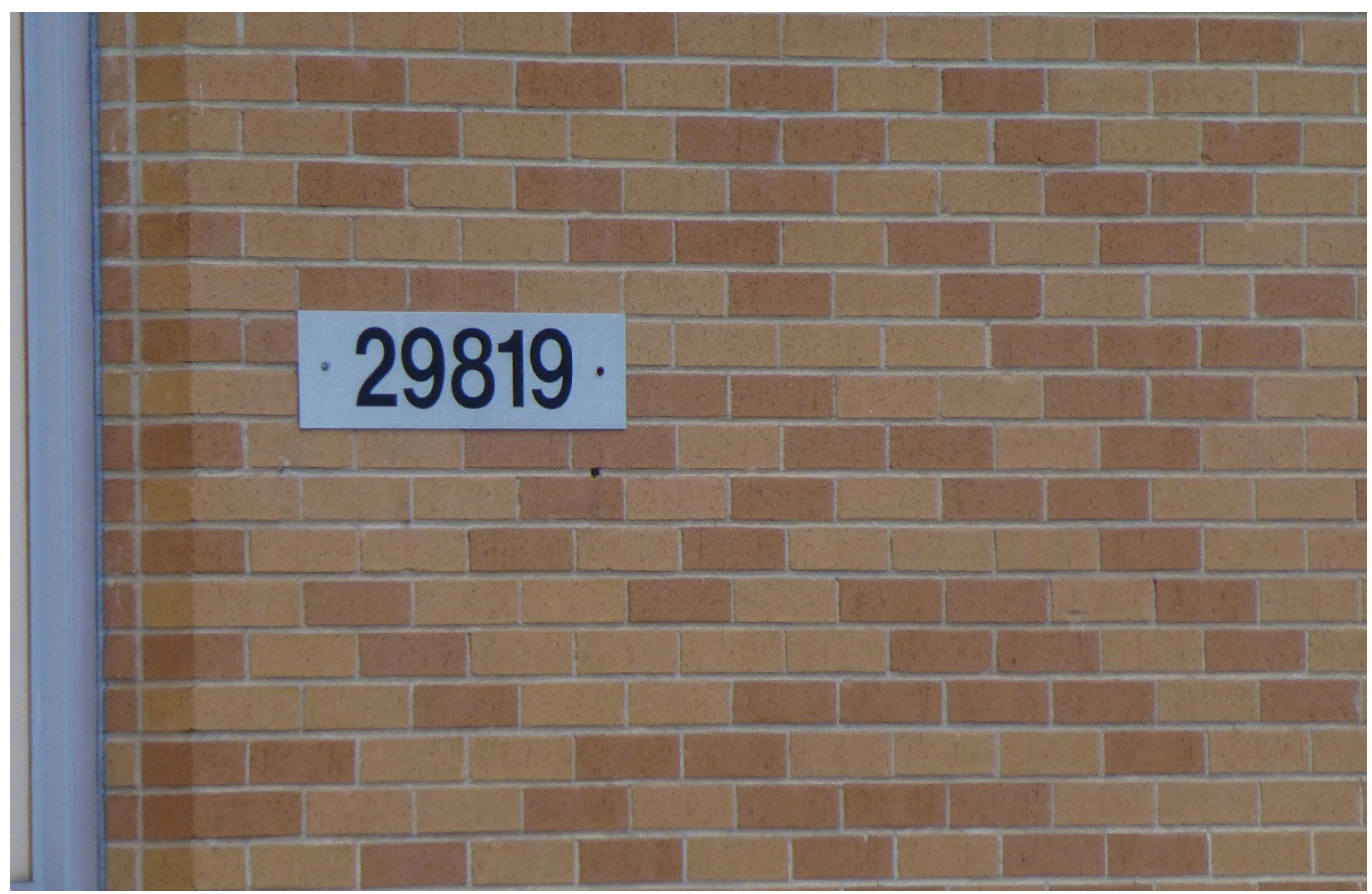




\subsubsection{Overhanging eaves with perforated waffle}

All of the Signal School Campus buildings were constructed of cast-inplace concrete columns with a waffle floor/ceiling structure. The floor waffle system is set within the structure, but the roof waffles extend out to form an overhang (Figure 36-Figure 39). Building 29805, Alexander/Olmsted Halls, was constructed with large precast T-beams that extend from the north to south on the structure (Figure 40). Buildings 29807, Museum (Conrad Hall), and 29808, Signal Towers, do not have overhangs.

Figure 36. Concrete waffle ceiling structure that extend out to form an overhang, Building 25810, Brant Hall (ERDC-CERL, 2015).

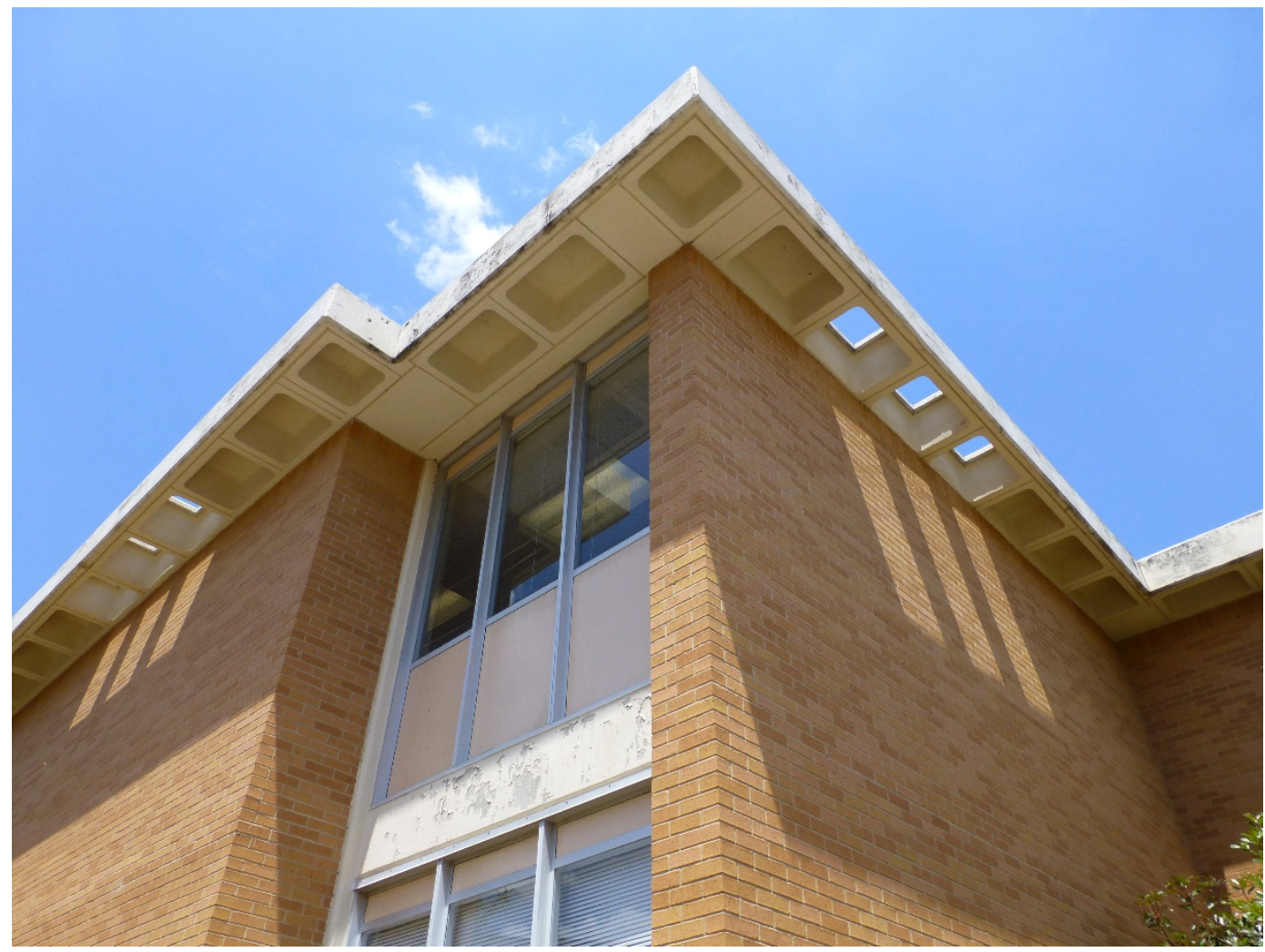


Figure 37. Perforated concrete waffle overhang, Building 29803, Moran Hall north (ERDC-CERL, 2015).

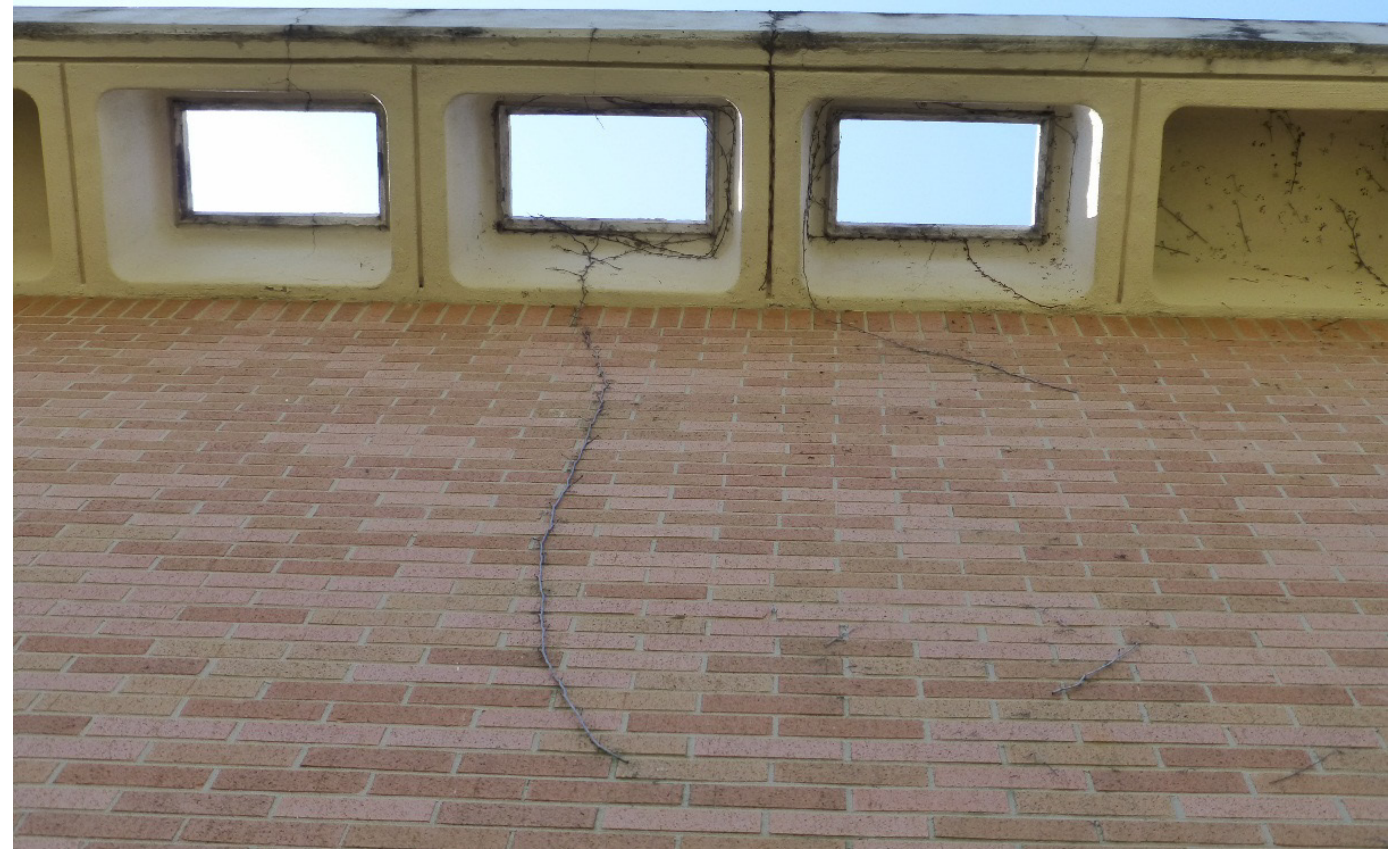

Figure 38. Typical concrete waffle overhang on the classroom buildings, Building 29813, Allen Hall (ERDC-CERL, 2015).

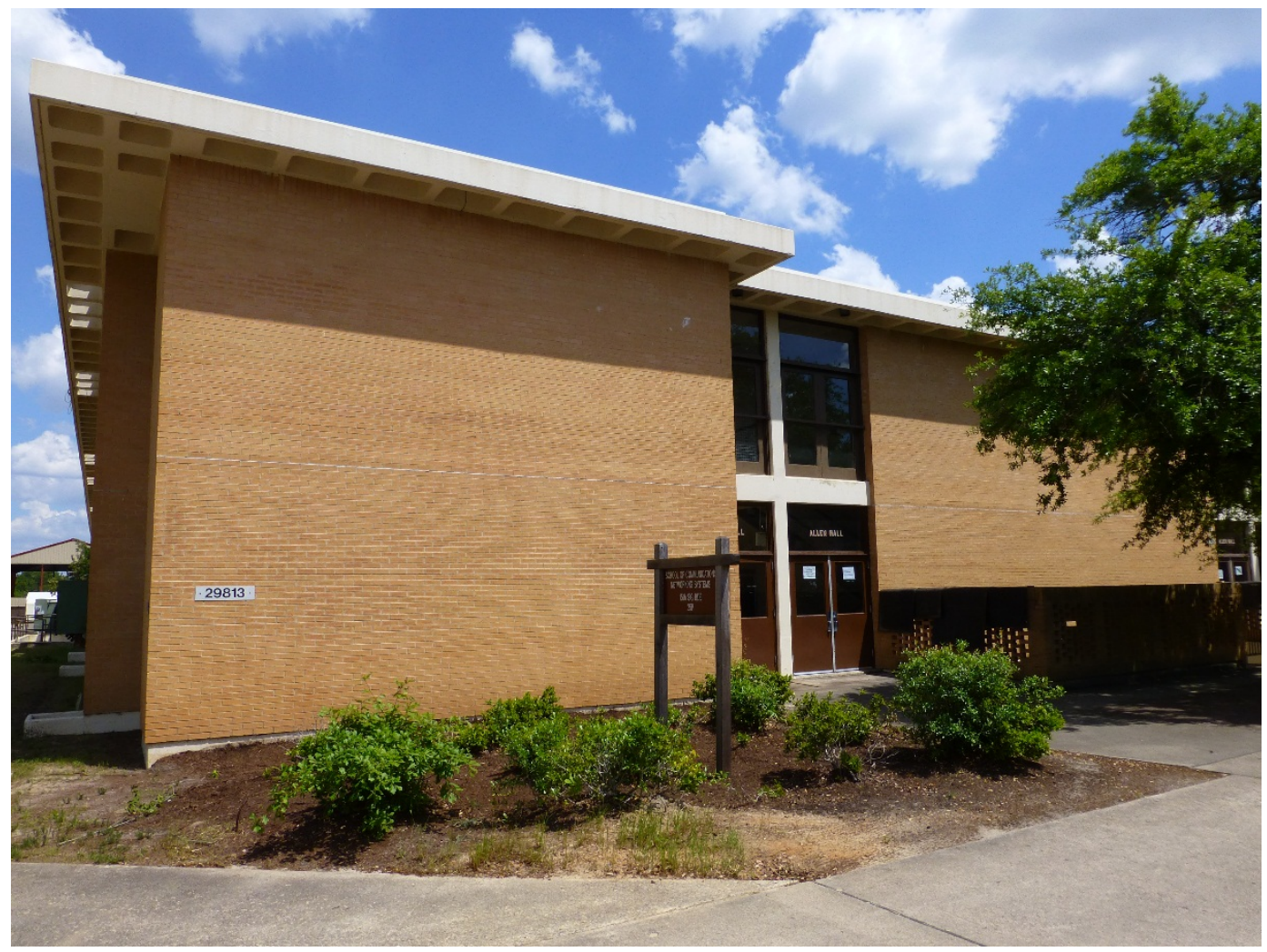


Figure 39. Close-up of concrete waffle overhang, Building 29819, Stansell Hall (ERDC-CERL, 2015).

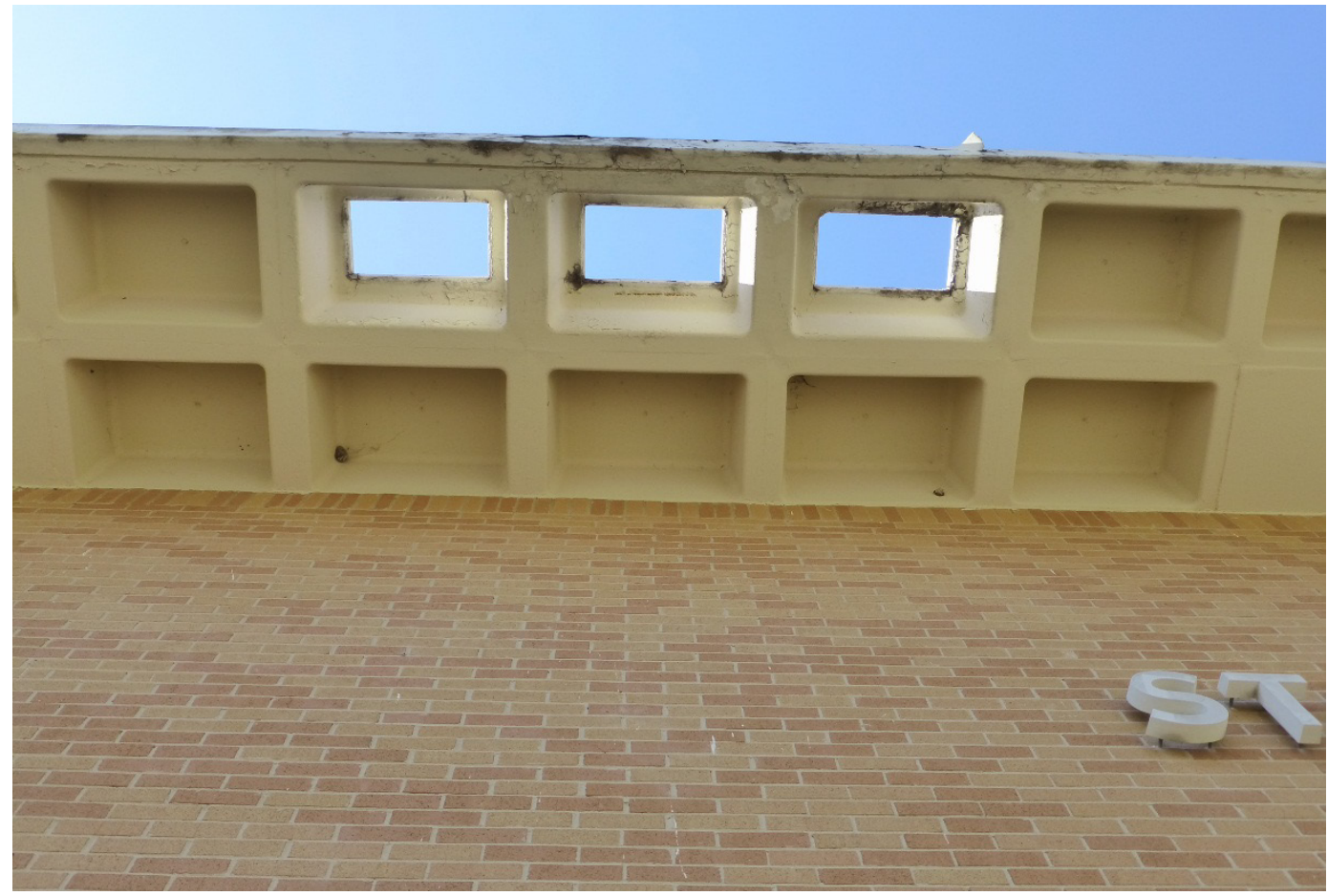

Figure 40. Building 29805, Alexander/OImsted Halls, constructed with precast concrete T-beams (ERDC-CERL, 2015).

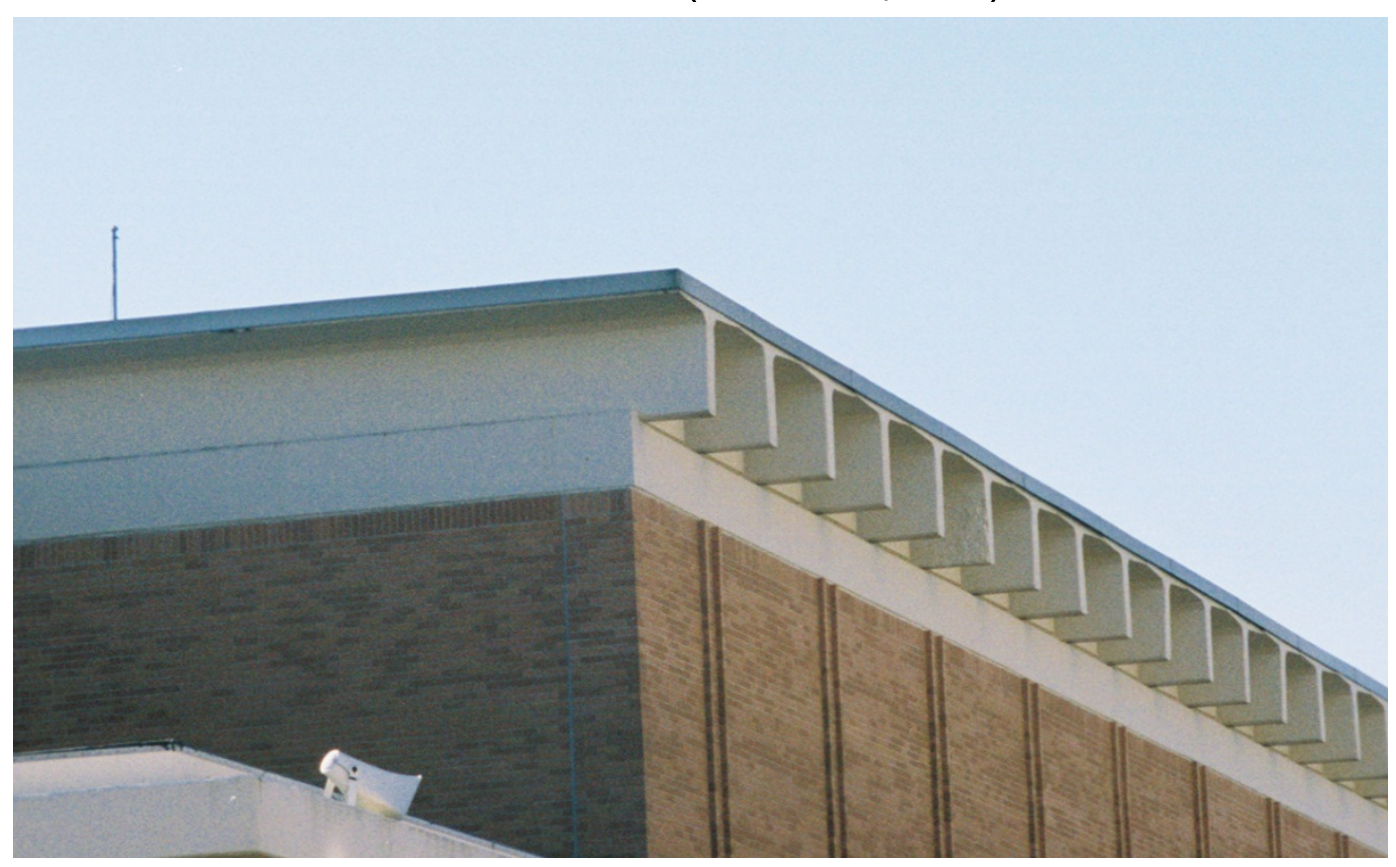




\subsection{1 "Light pattern" effect on wall}

The typical Signal School building is of cast-in-place concrete columns with a waffle floor/ceiling structure. The floor waffle system is set within the structure, but the roof has the waffles extend out to form an overhang. Some of the waffles of the overhang have been perforated, which creates a "light pattern" on the second floor of the brick exterior walls (Figure 41Figure 43). Buildings 29805, Alexander/Olmsted Halls; Building 29807, Conrad Hall; and Building 29808, Signal Towers; do not have these perforated overhanging eaves.

Figure 41. Example of the "light pattern" created by the perforated waffle overhang, Building 29801, Nelson Hall (ERDC-CERL, 2015).

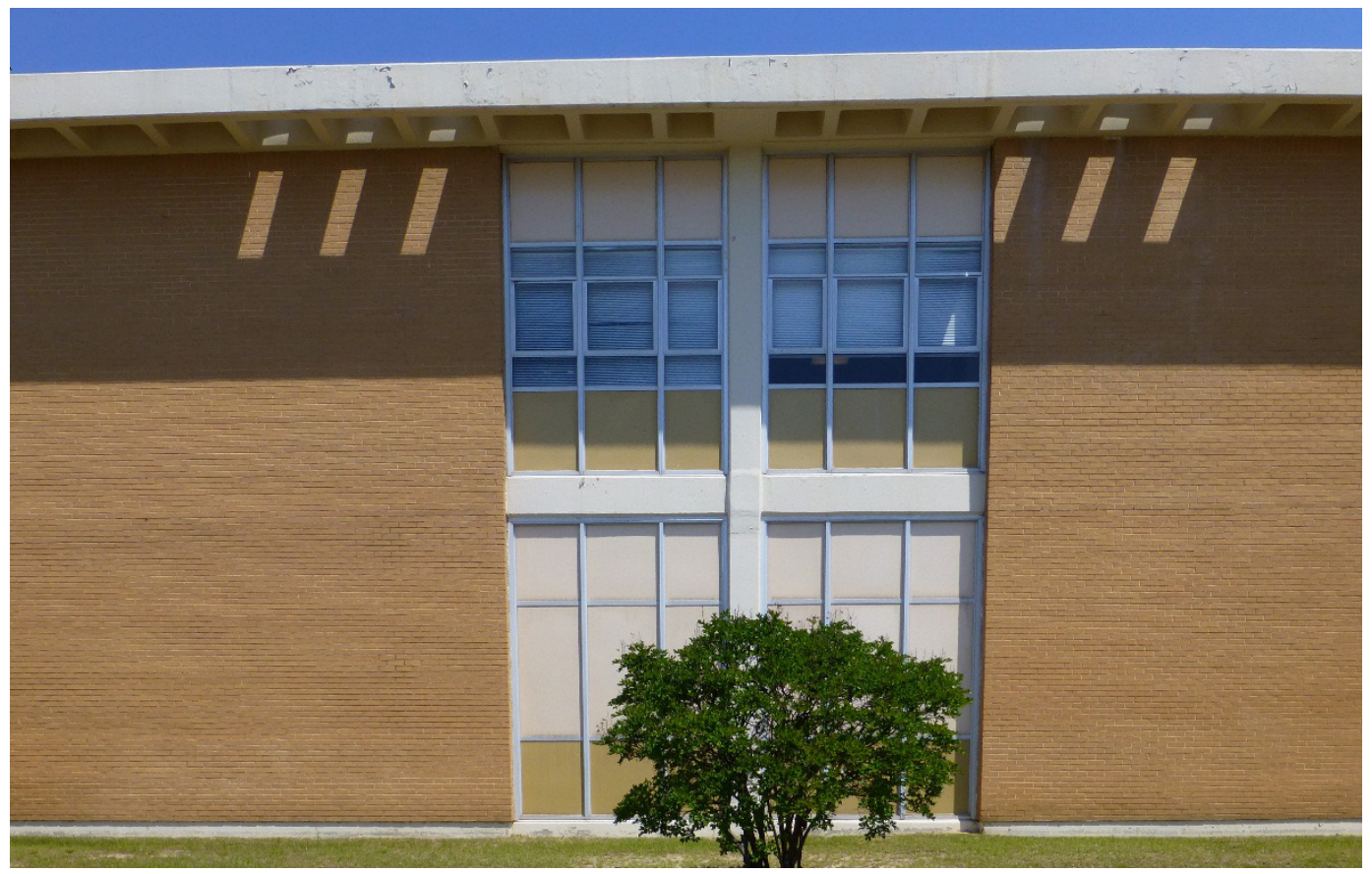


Figure 42. The "light pattern" displayed across the entire second floor of the south elevation, Building 29809, Greely Hall (ERDC-CERL, 2015).

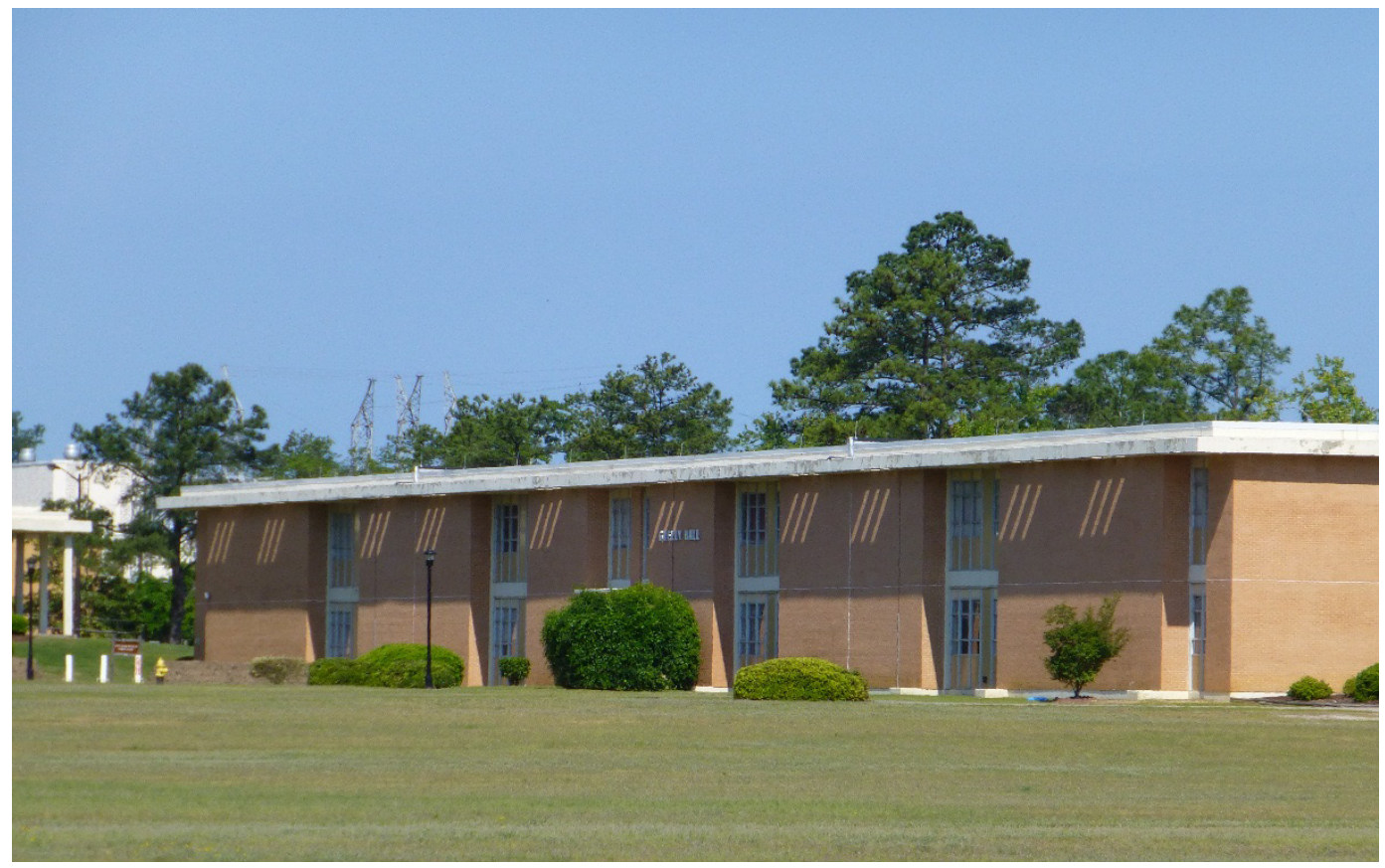

Figure 43. The "light pattern" changes in size as the sun rises and sets, Building 29813, Allen Hall (ERDC-CERL, 2015).

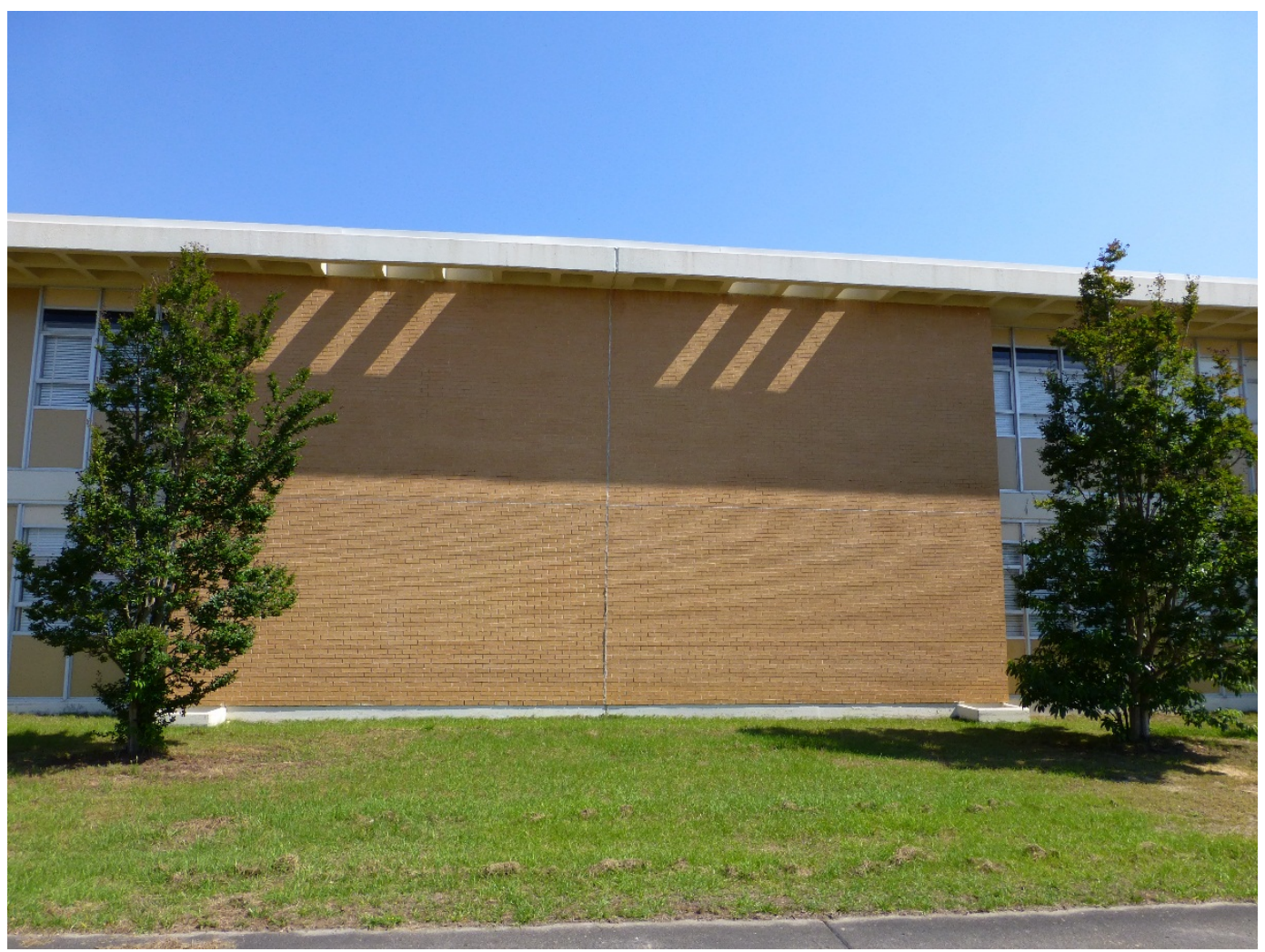




\subsubsection{Window systems}

The window systems extend the full height of the building and are inset into the brick veneer. The window systems for the Signal School buildings are composed of bright-aluminum window frames that enclose insulated panels and three-pane awning windows. Tan-colored panels are above and below the windows (Figure 44-Figure 46). In some buildings, the original awning windows have been removed and replaced with a newer insulated panel; for example, Building 25810, Brant Hall, and Building 29816, Fisher Hall (Figure 47 and Figure 48). In other cases, the building was designed without awning windows, but it maintained the same configuration as the other window patterns of the other Signal School buildings (Figure 49 and Figure 50). Building 29802, Moran Hall; Building 29817, Allison Hall; and Building 29819, Stansell Hall were designed with the same window-panel system as the other buildings. However, in these three buildings, insulated panels were placed in lieu of the three-pane awning windows (Figure 51).

Some of the Signal School buildings were built with bays of bright-aluminum fixed-pane windows. These buildings include Building 25810, Hall; Building 29801, Nelson Hall; Building 29803, Moran Hall north; Building 29809, Greely Hall; Building 29811, Saltzman Hall; Building 29813, Allen Hall; Building 29815, Hazen Hall; Building 29816, Fisher Hall; and Building 29818, Johnston Hall.

Building 29807, Conrad Hall, was designed with bright-aluminum framed fixed-pane clerestory windows (Figure 52). Building 29808, Signal Towers, was designed with bright-aluminum framed windows, but these have since been replaced with one-over-one anodized-bronze aluminum windows. The windows have been replaced in-kind, however, to the original window pattern and style of window (Figure 53).

In lieu of windows or panels, some window bay systems were designed with concrete panel inserts. These include Building 29801, Nelson Hall, Buildings 29802, Moran Hall, Building 29803, Moran Hall north, Building 29815, Hazen Hall, Building 29816, Fisher Hall, and Building 29819, Stansell Hall. 
Figure 44. Typical four-bay window system designed with bright-aluminum frames, three-pane awning windows, and insulated panels, Building 29810, Burkhardt Hall (ERDC-CERL, 2015).

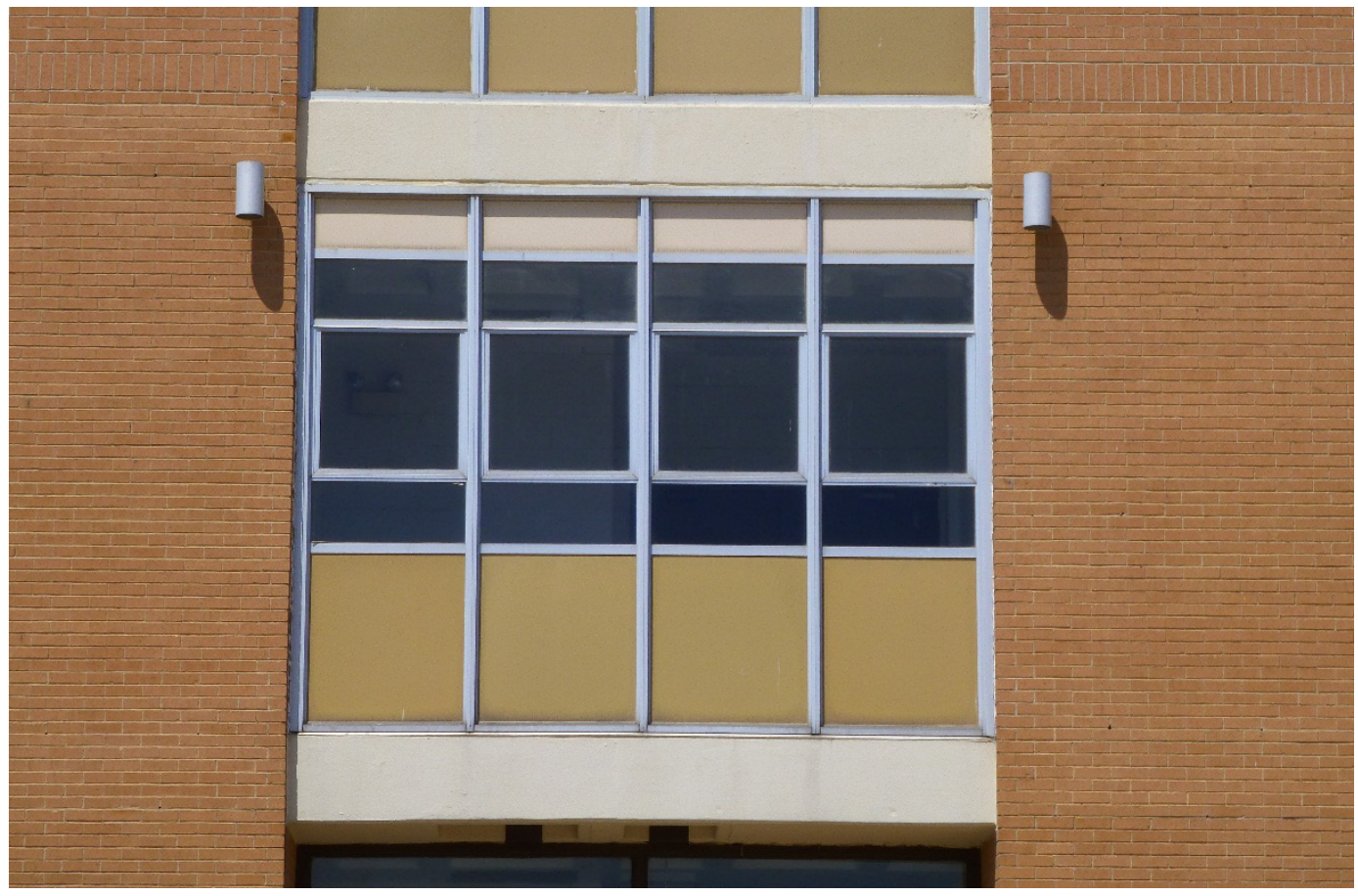

Figure 45. Typical seven-bay window system with bright-aluminum frames, six threepane awning windows separated by insulated panels and sandwiched by insulated panels, Building 29811, Saltzman Hall (ERDC-CERL, 2015).

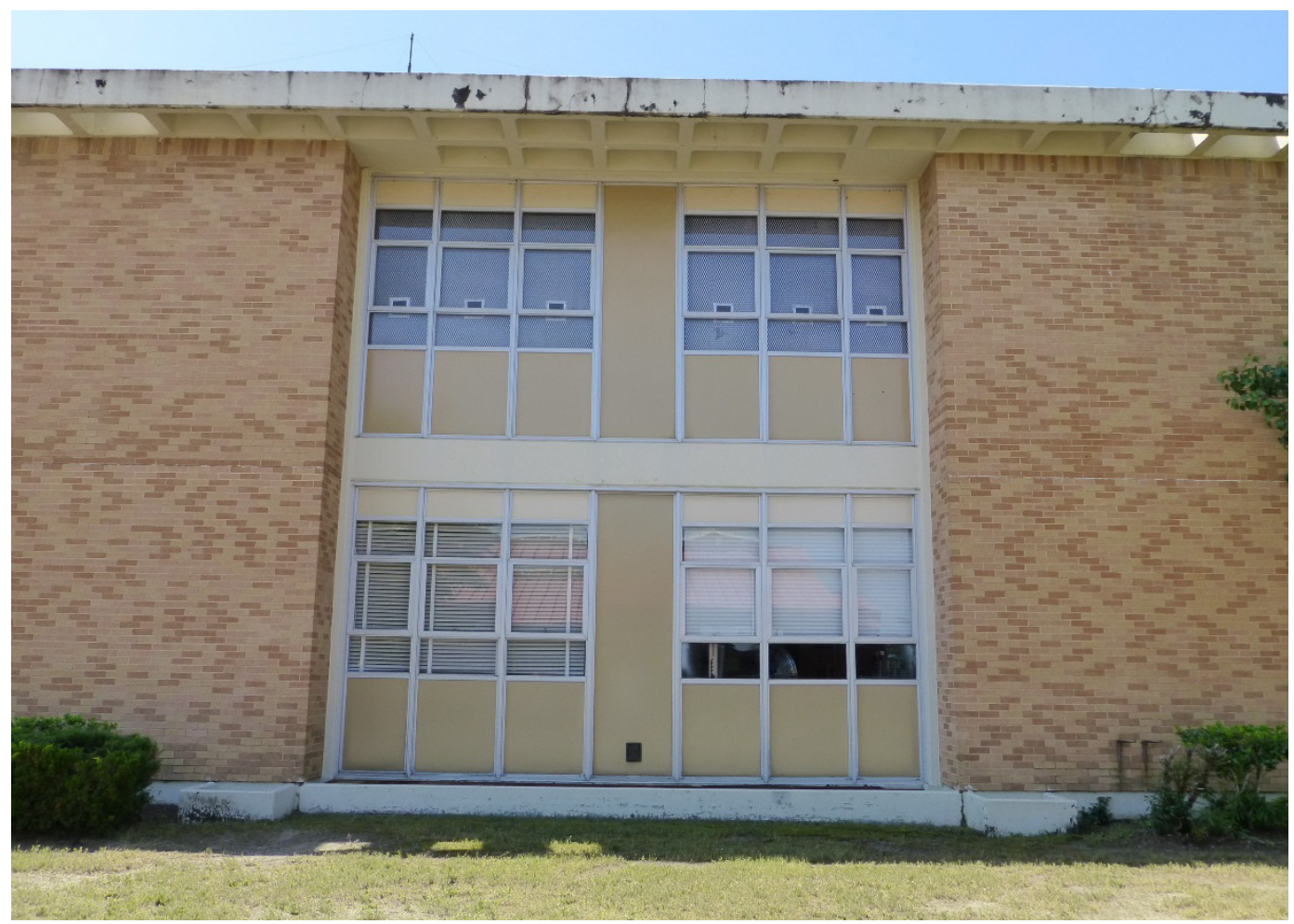


Figure 46. Typical window bay system with bright-aluminum frames, three-pane awning windows, and insulated panels, Building 29813, Allen Hall (ERDC-CERL, 2015).

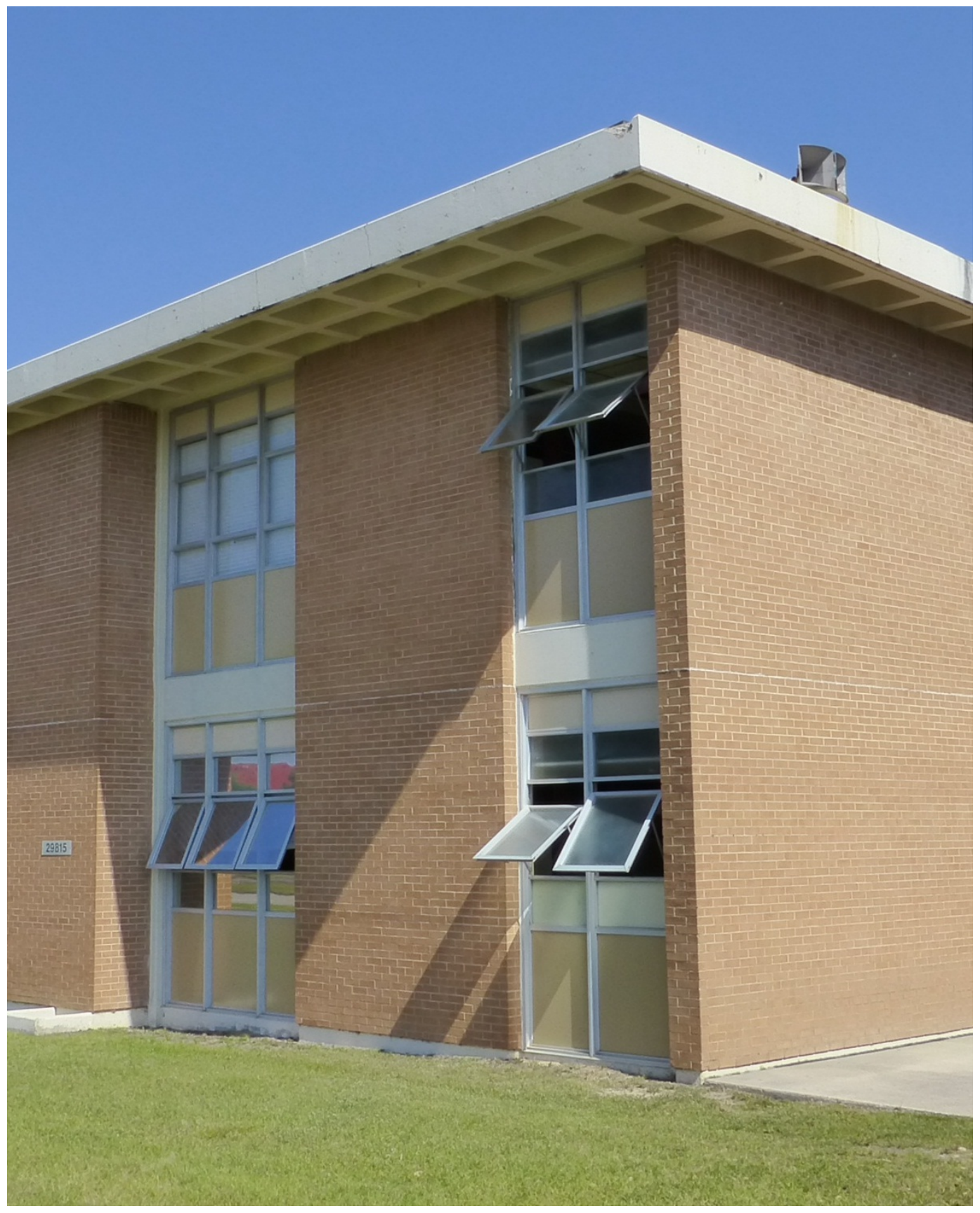


Figure 47. Modified window pattern with the removal of the original awning window and the addition of the newer insulated panel, Building 25810, Brant Hall

(ERDC-CERL, 2015).

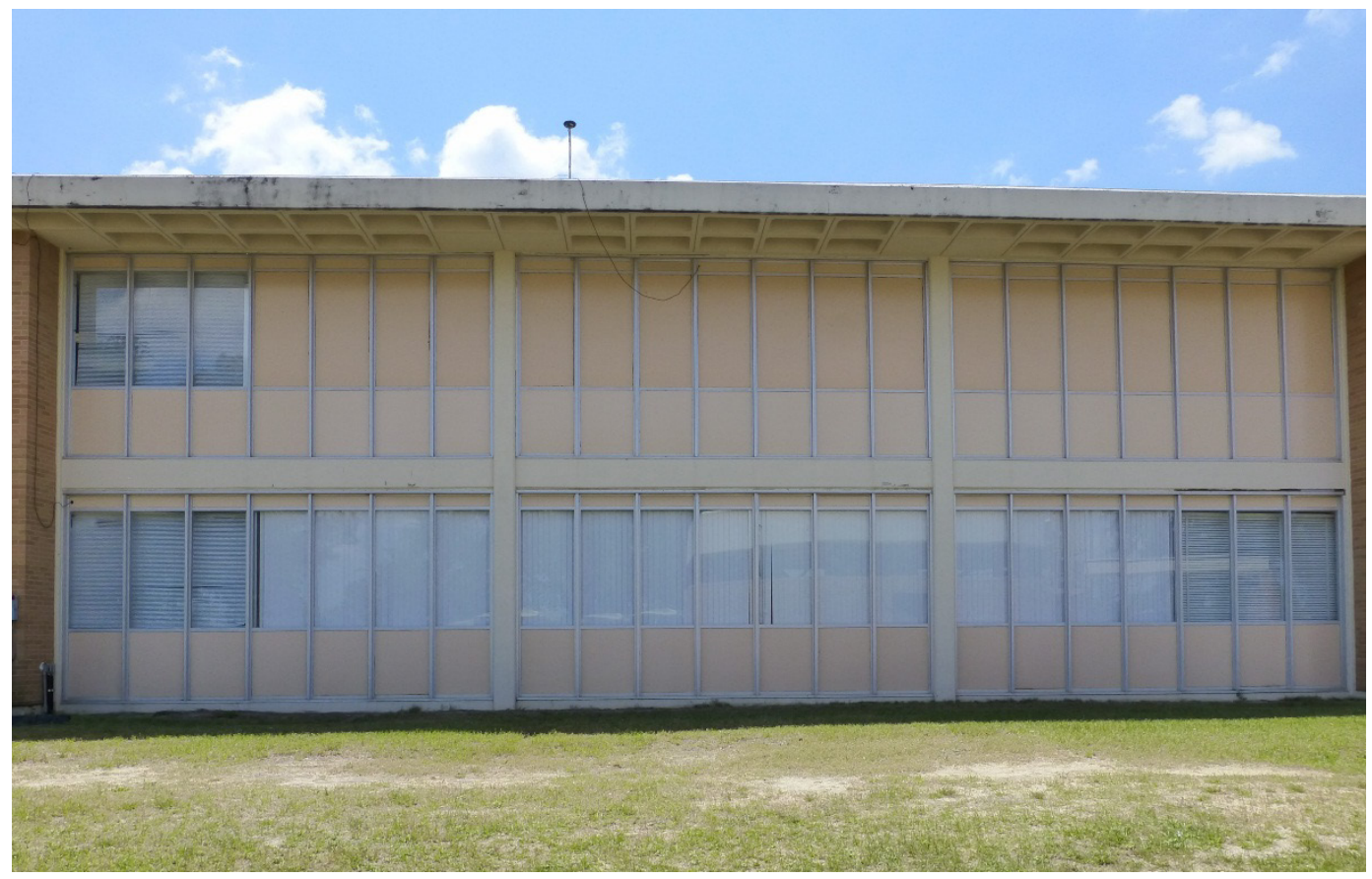

Figure 48. Modified window openings with newer panel inserts, Building 29816, Fisher Hall (ERDC-CERL, 2015).

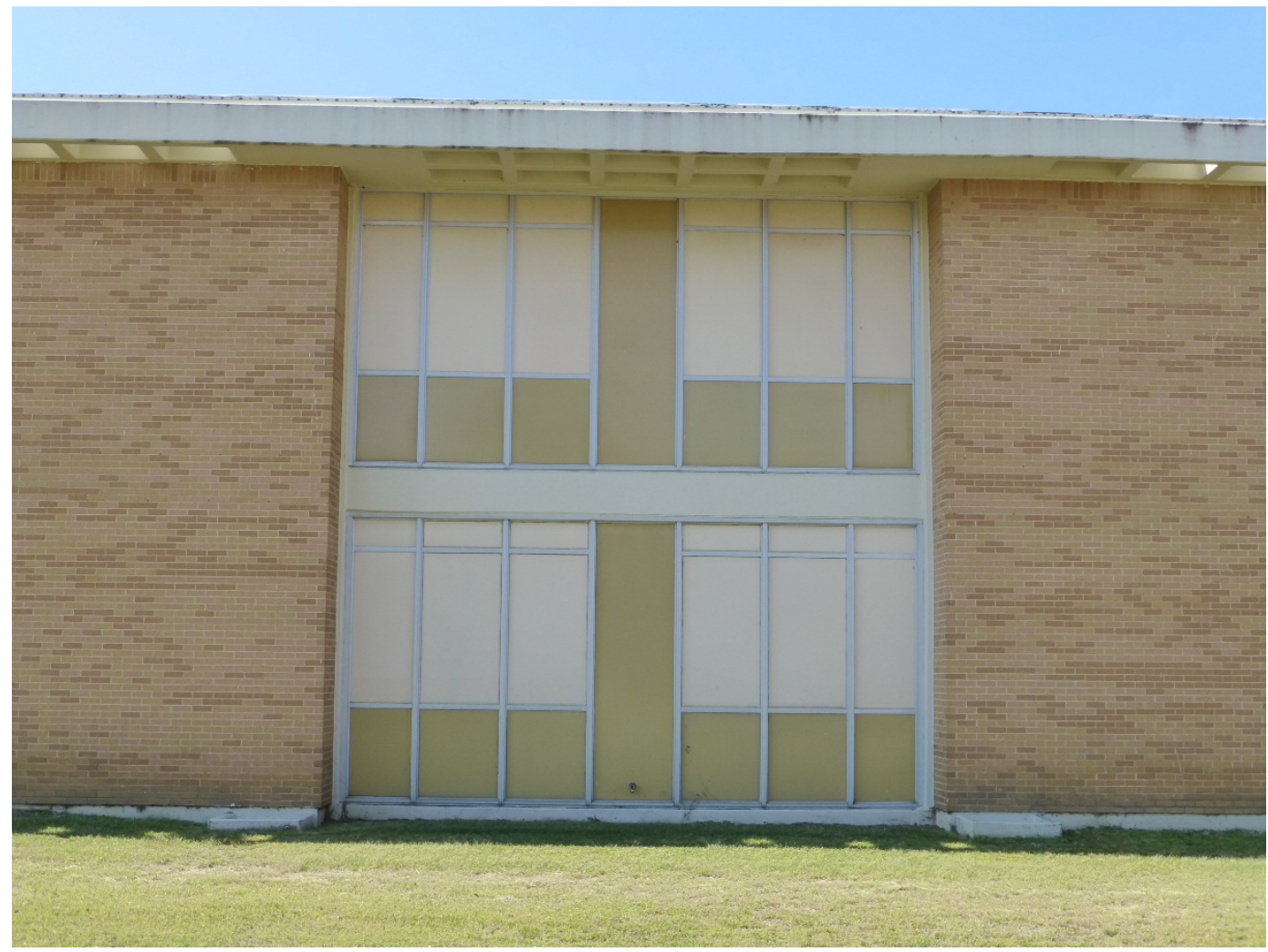


Figure 49. Bright-aluminum fixed-pane window system above entry bay, Building 29813, Allen Hall (ERDC-CERL, 2015).

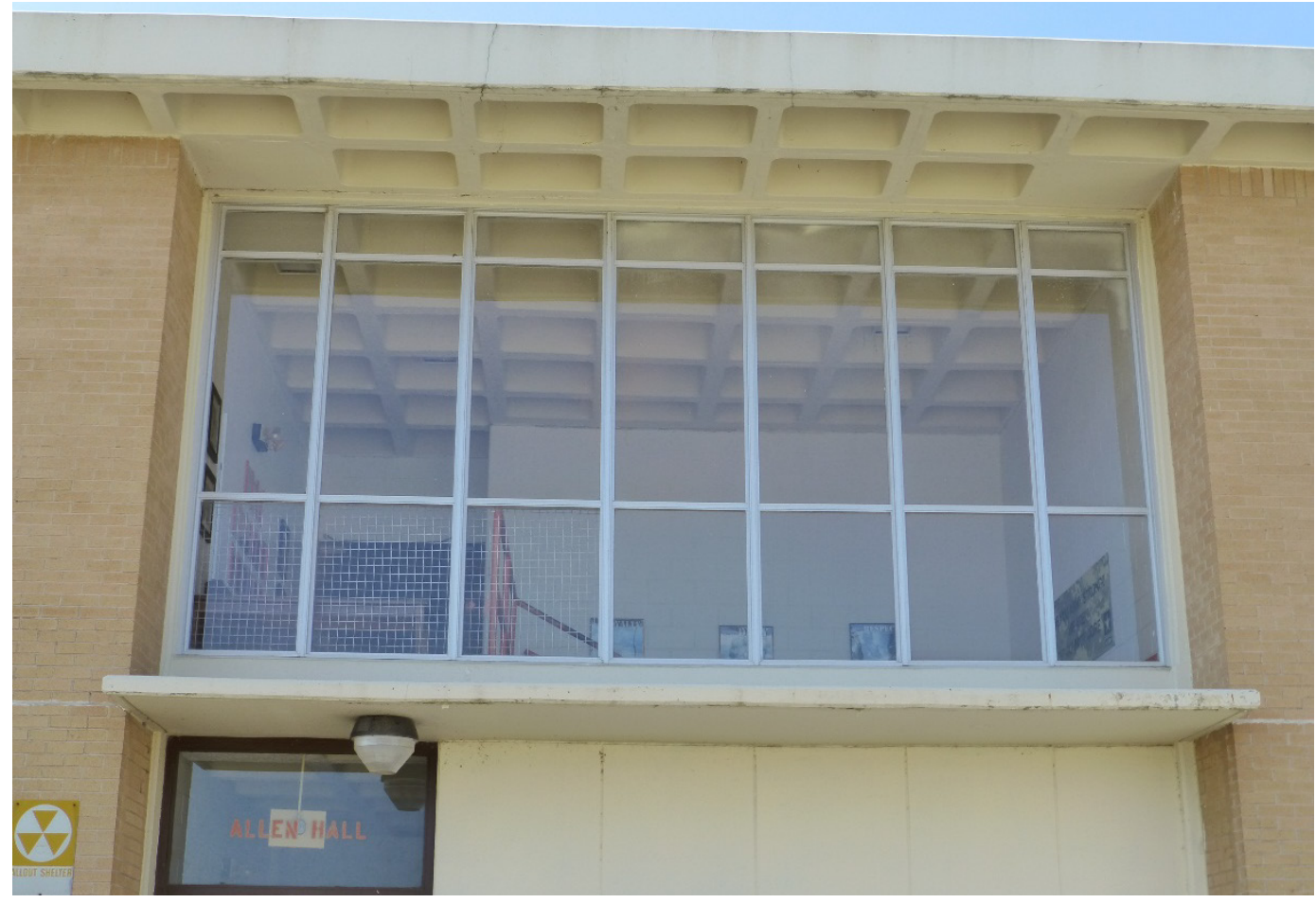

Figure 50. Example of three window systems: bright-aluminum framed awning windows with insulated panels, bright-aluminum framed fixed-pane windows, and concrete panel inserts, Building 29816, Fisher Hall (ERDC-CERL, 2015).

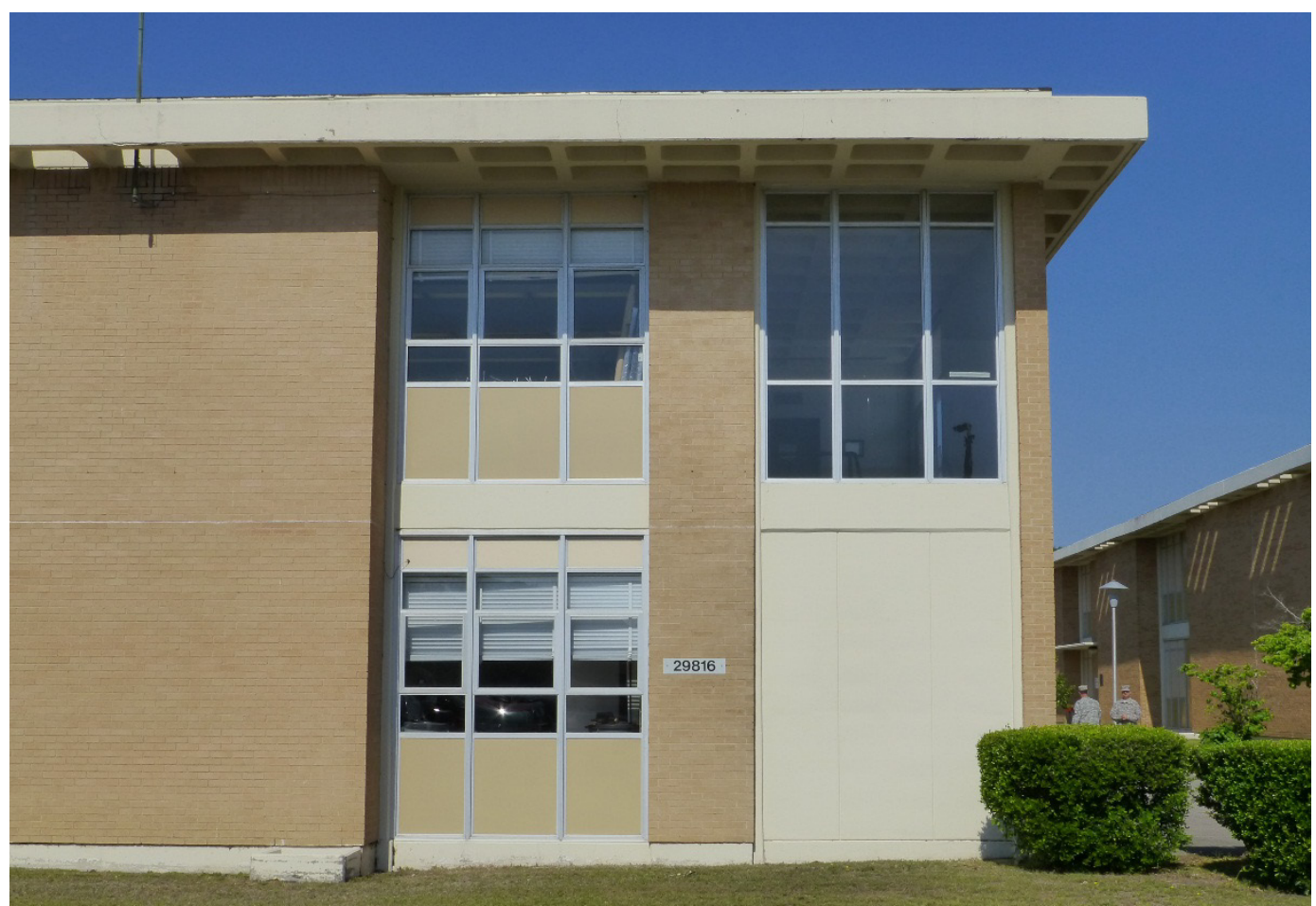


Figure 51. Some of the Signal School buildings were designed with bays of insulated panel inserts, for example Building 29819, Stansell Hall (ERDC-CERL, 2015).

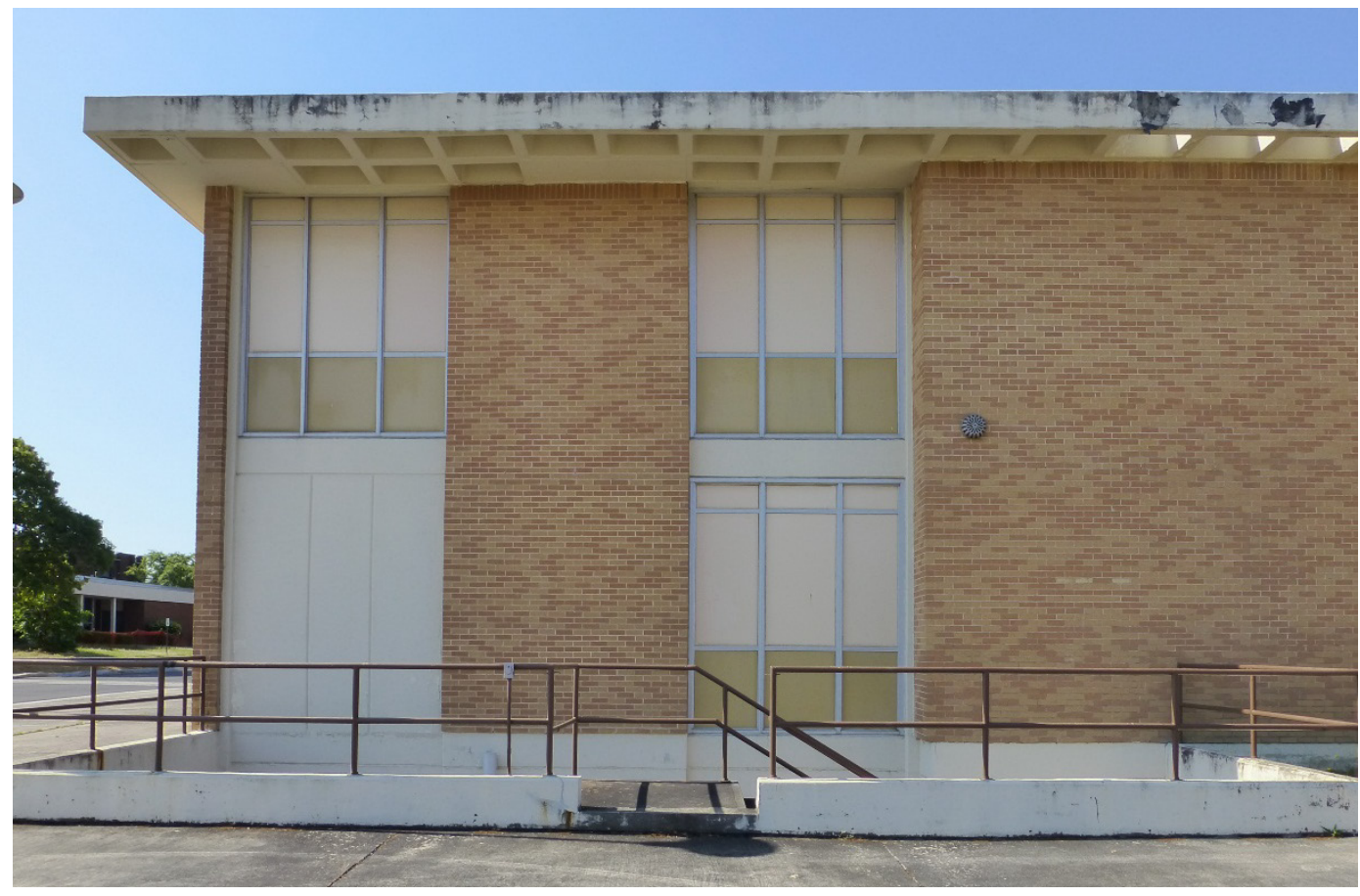

Figure 52. Bright-aluminum fixed-pane clerestory windows, Building 29807, Museum/Conrad Hall (ERDC-CERL, 2015).

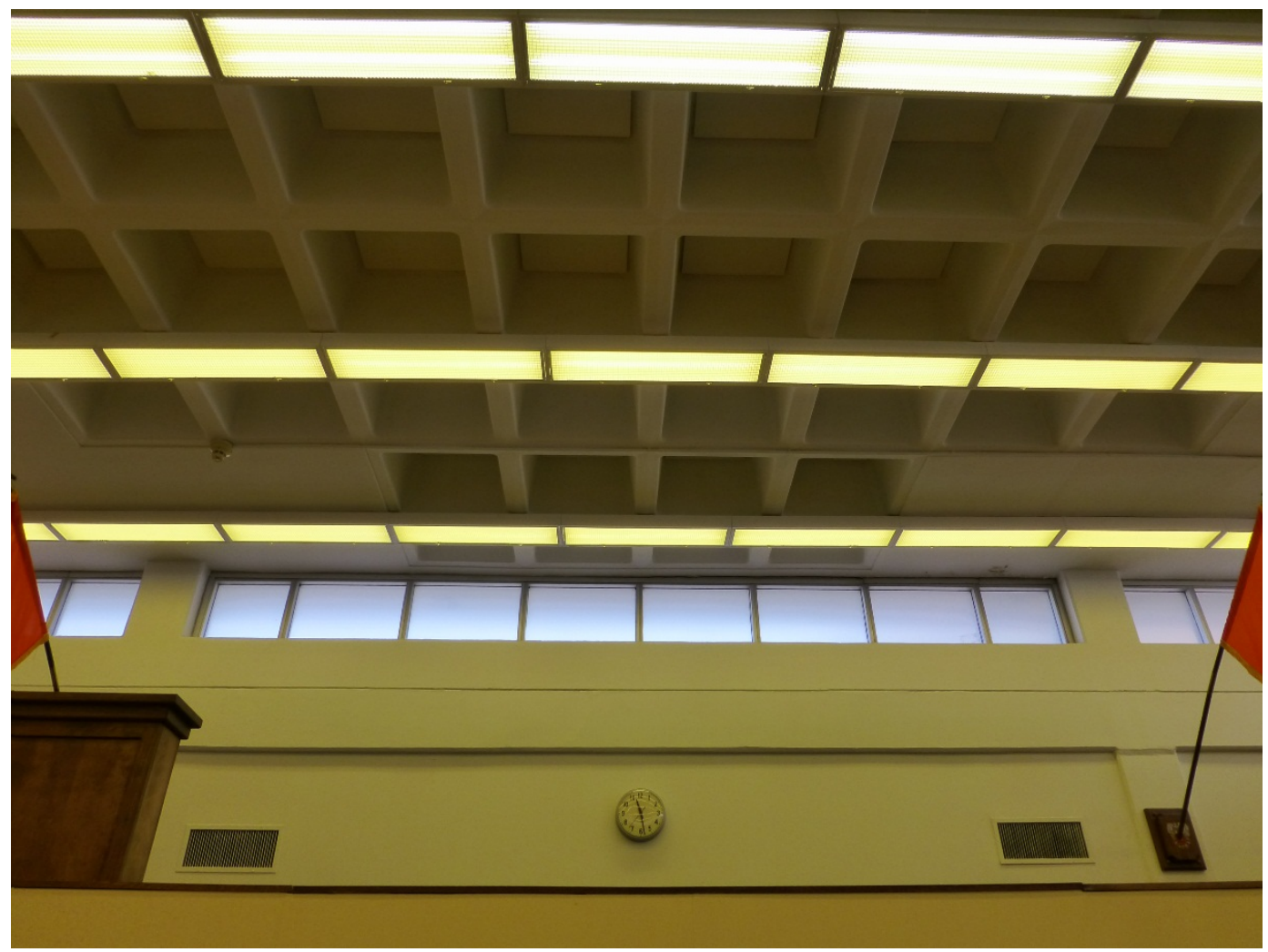


Figure 53. Replacement anodized-bronze aluminum one-over-one windows, Building 29808, Signal Towers (ERDC-CERL, 2015).

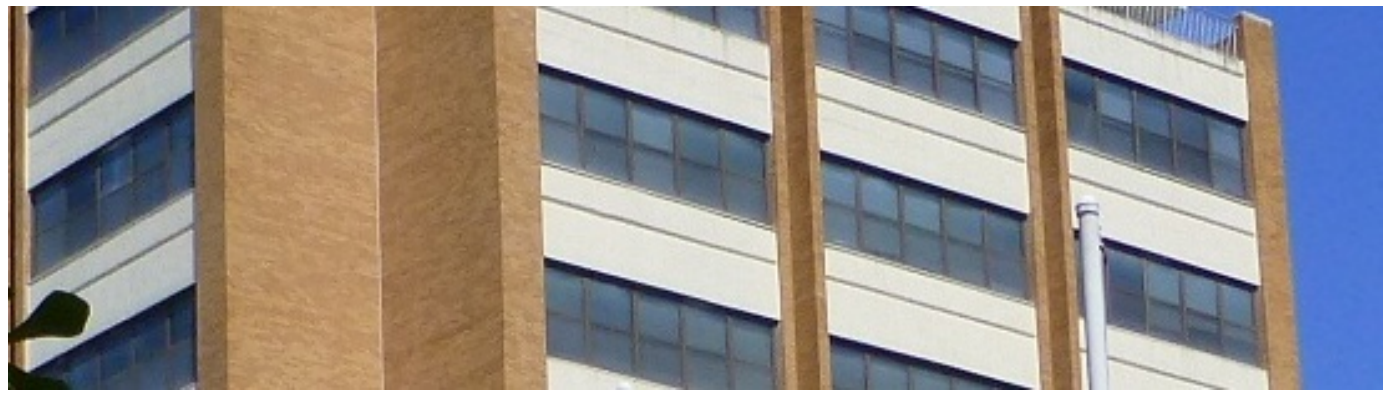

\subsubsection{Doors}

A variety of exterior doors are located on the Signal School buildings. These include bright-aluminum and plate-glass doors with transoms (Figure 54), bright-aluminum and plate-glass doors with transoms and sidelights (Figure 55), metal doors with a pane, sidelights, and transoms (Figure 56 and Figure 57); metal and plate-glass doors with transoms above (Figure 58); metal doors with pane and transom on the first floor and two sets of metal and plate glass doors with transoms above on the second floor (Figure 59); and metal doors without inset panes and an insulated panel transom above (Figure 60).

Figure 54. Paired bright-aluminum and plate-glass entry doors with transoms above, Building 25810, Brant Hall (ERDC-CERL, 2015).

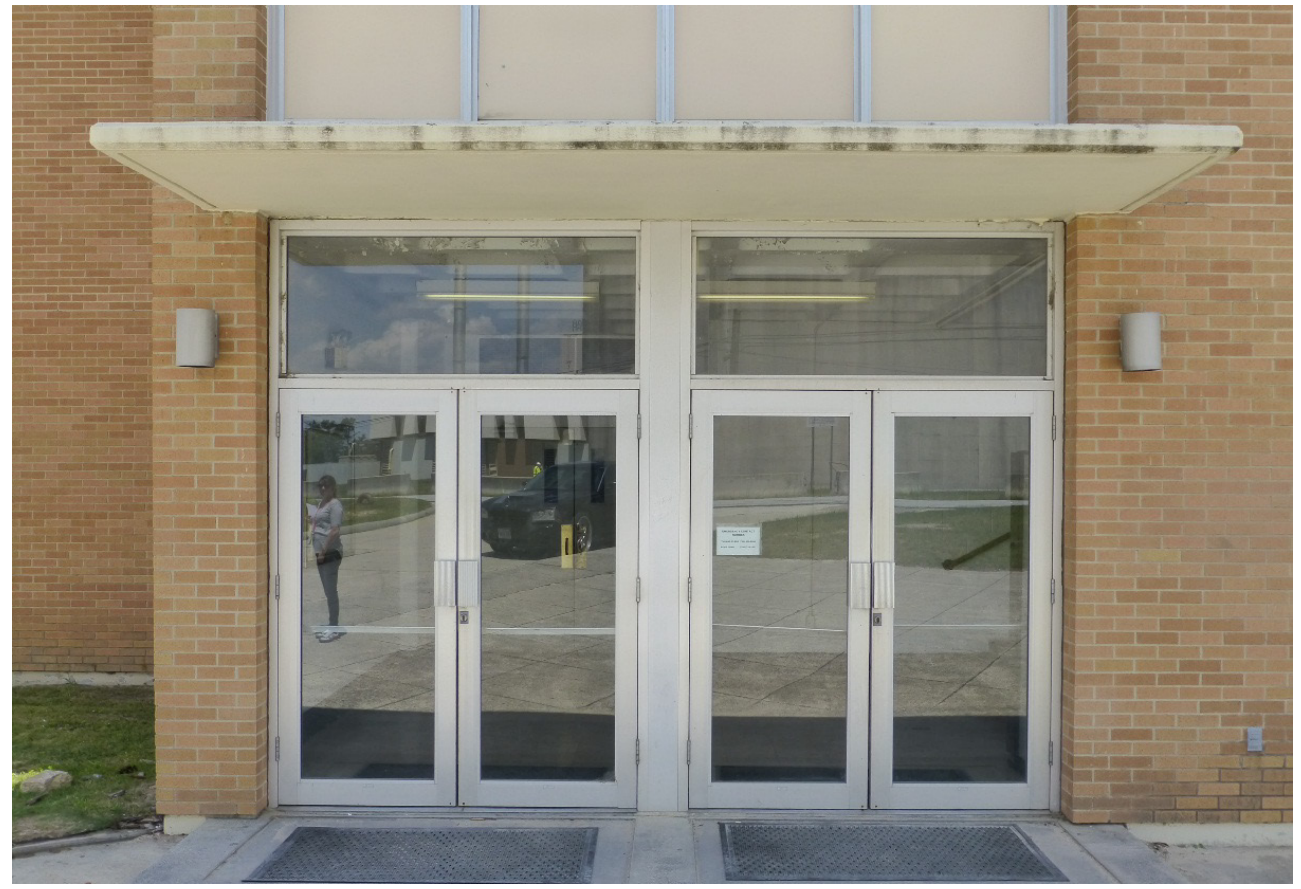


Figure 55. Bright-aluminum and plate-glass doors with sidelights and transom, Building 29805, Alexander/Olmsted Halls (ERDC-CERL, 2015).

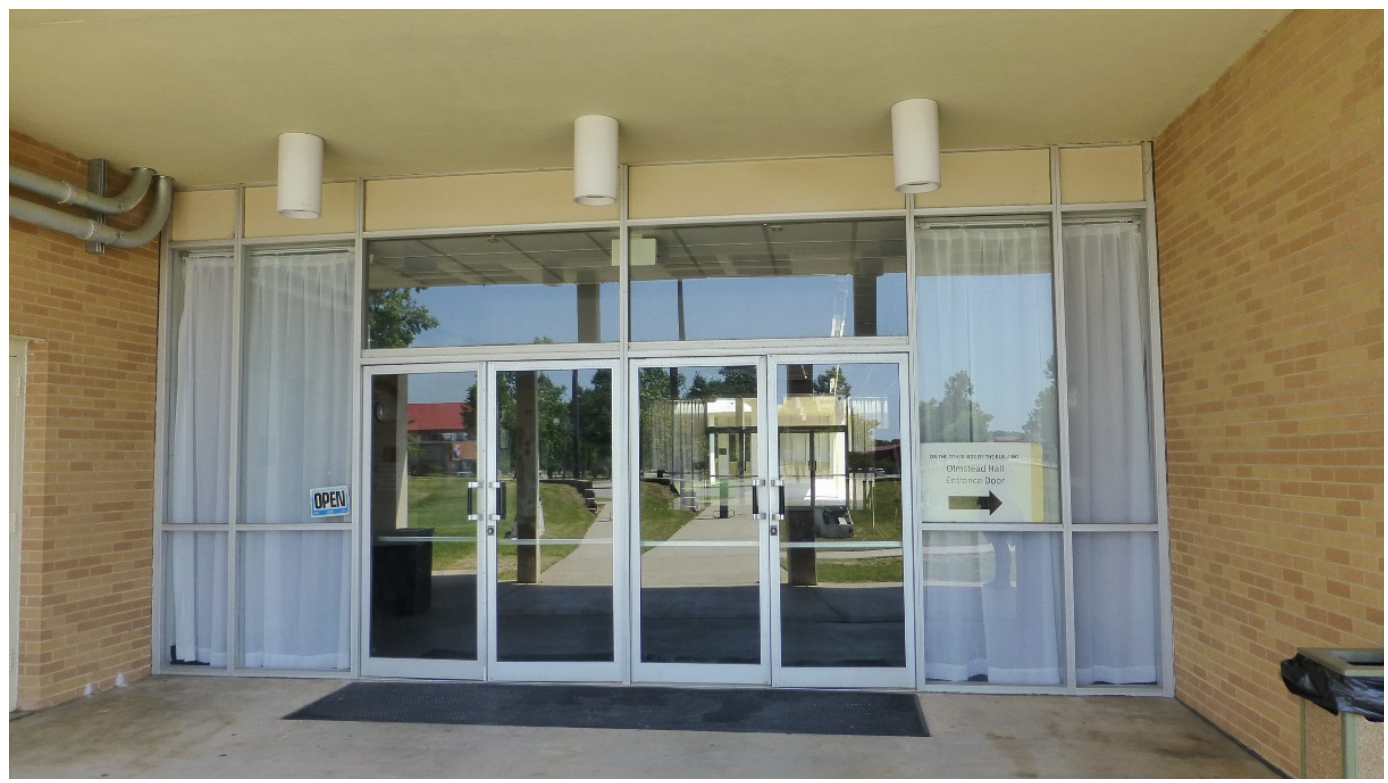

Figure 56. A set of metal doors with pane, sidelights, glass transom, and insulated panel above, Building 29801, Nelson Hall (ERDC-CERL, 2015).

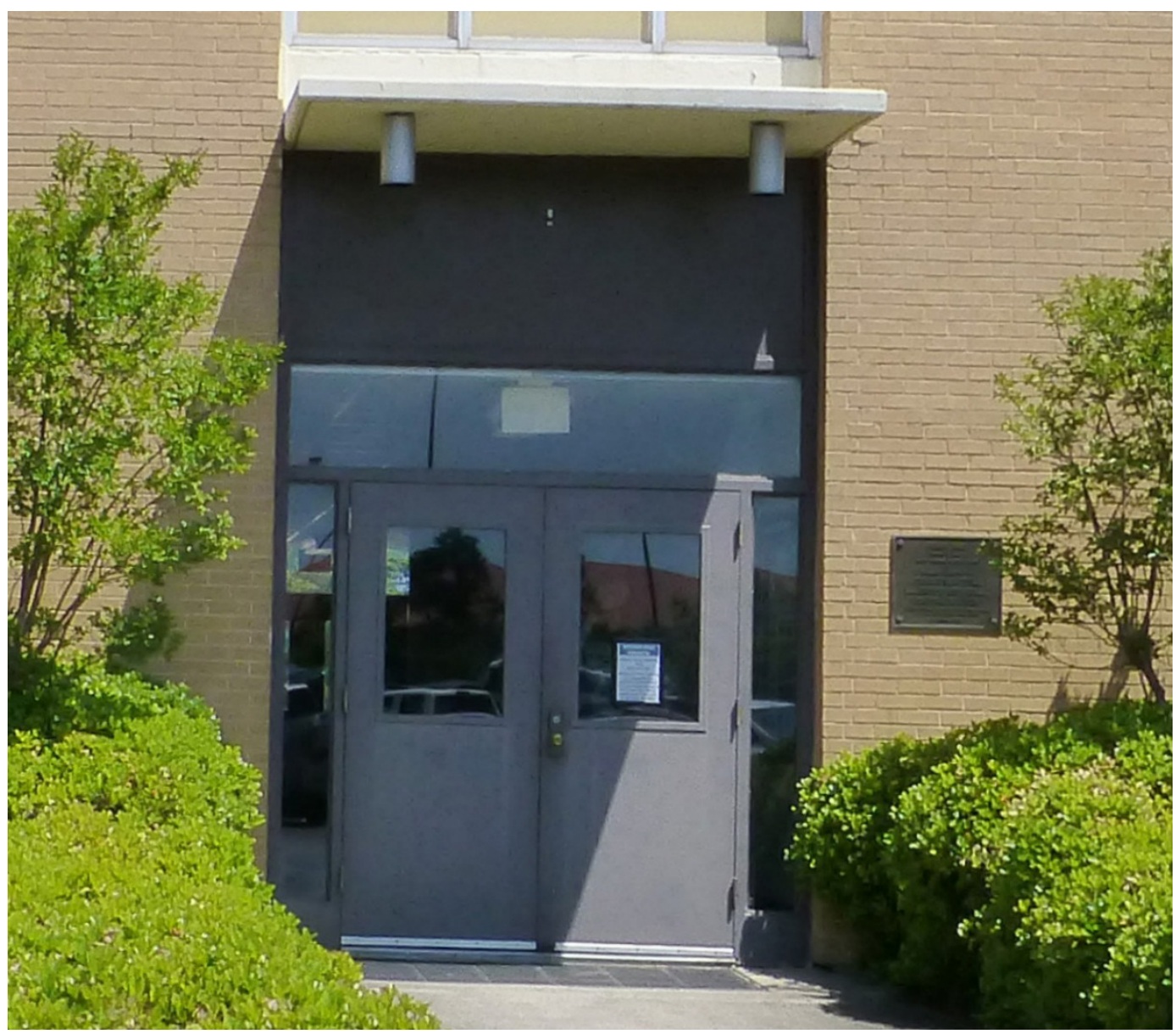


Figure 57. Two sets of metal doors with pane and transoms above separated by exposed concrete structure, Building 29815, Hazen Hall (ERDC-CERL, 2015).

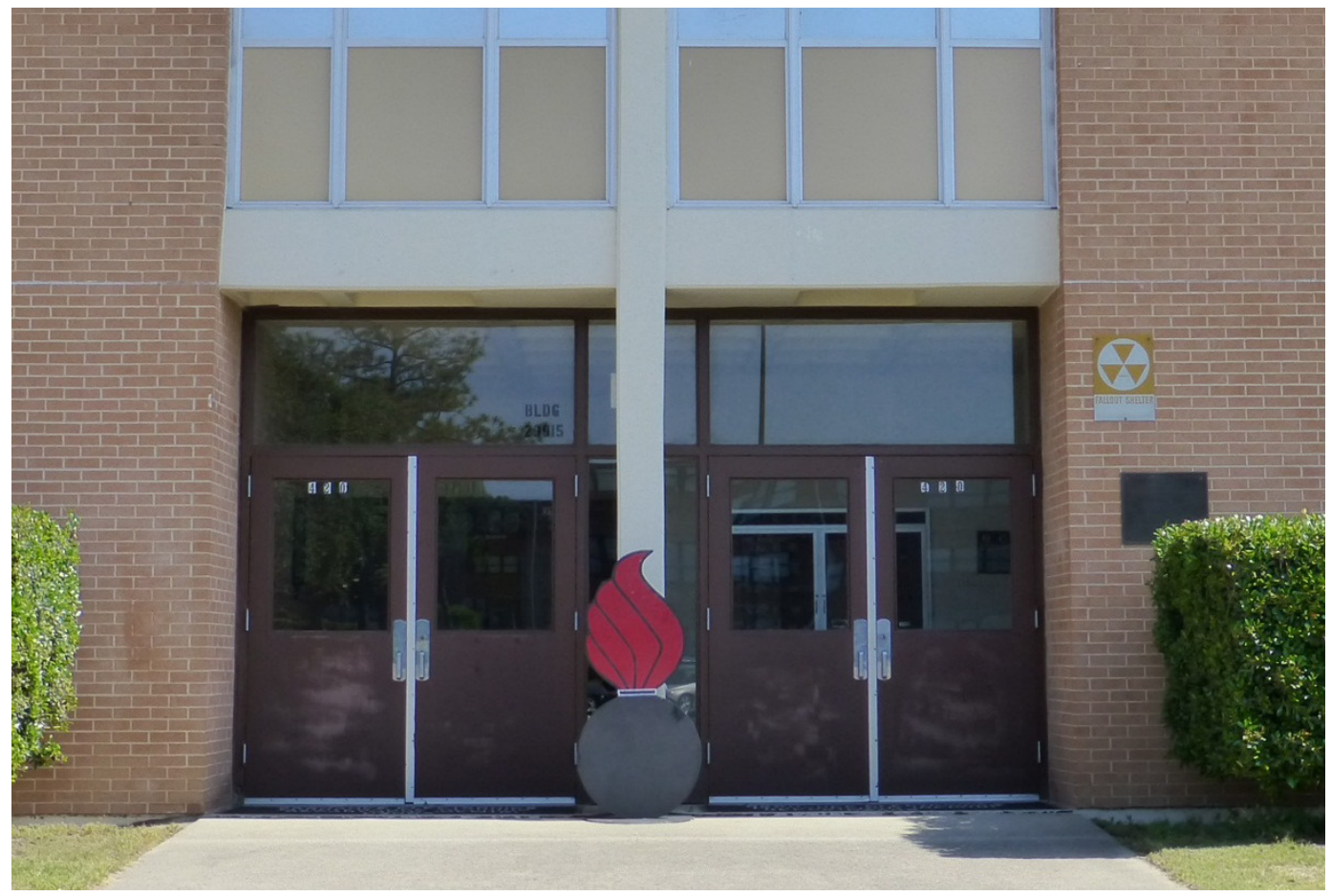

Figure 58. Metal doors with pane and transom above, Building 29809, Greely Hall (ERDC-CERL, 2015).

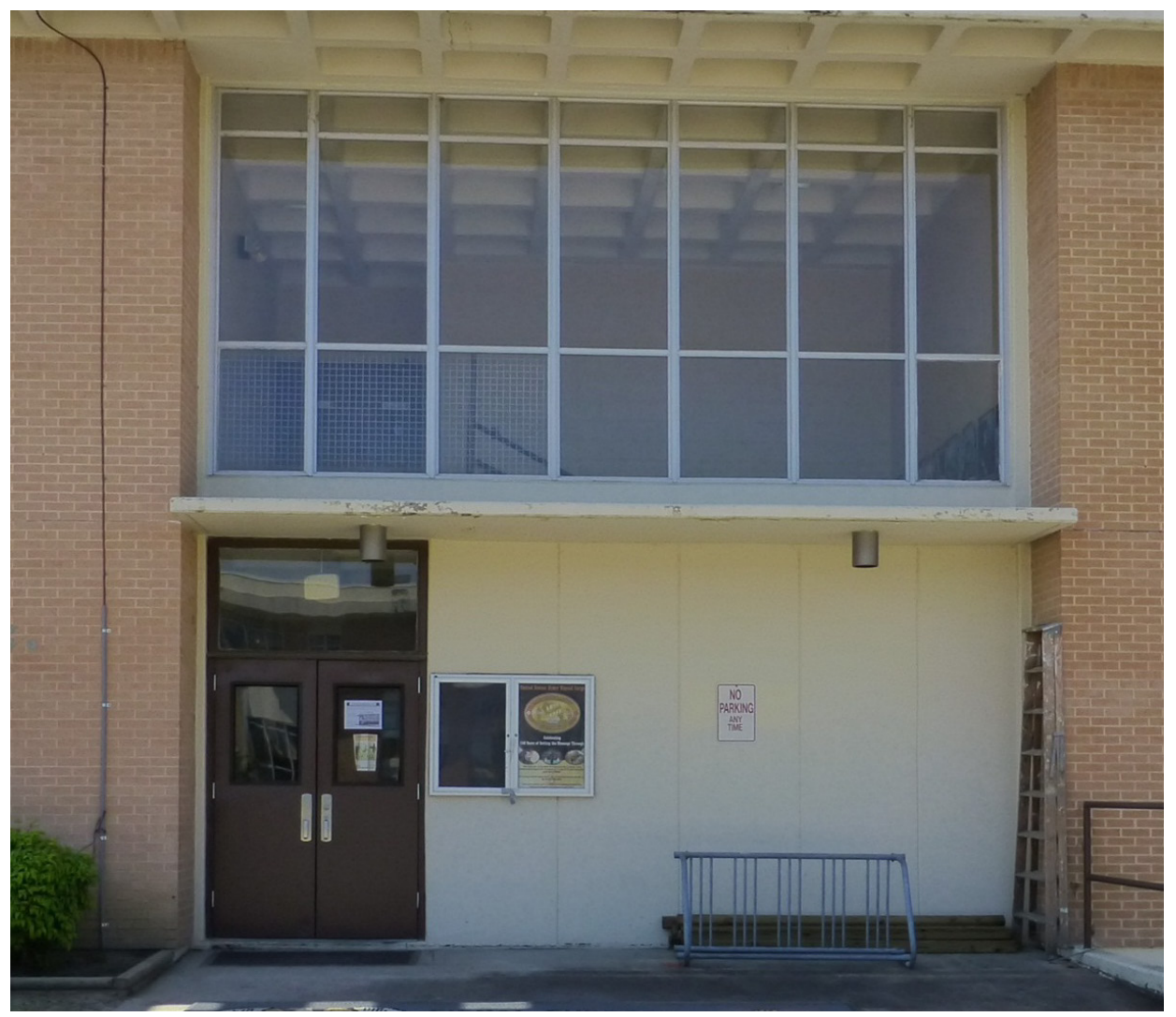


Figure 59. Entry bay that consists of two sets of metal doors with pane and transom on the first floor and two sets of metal and plate-glass doors with transoms above on the second floor, Building 29815, Hazen Hall (ERDC-CERL, 2015).

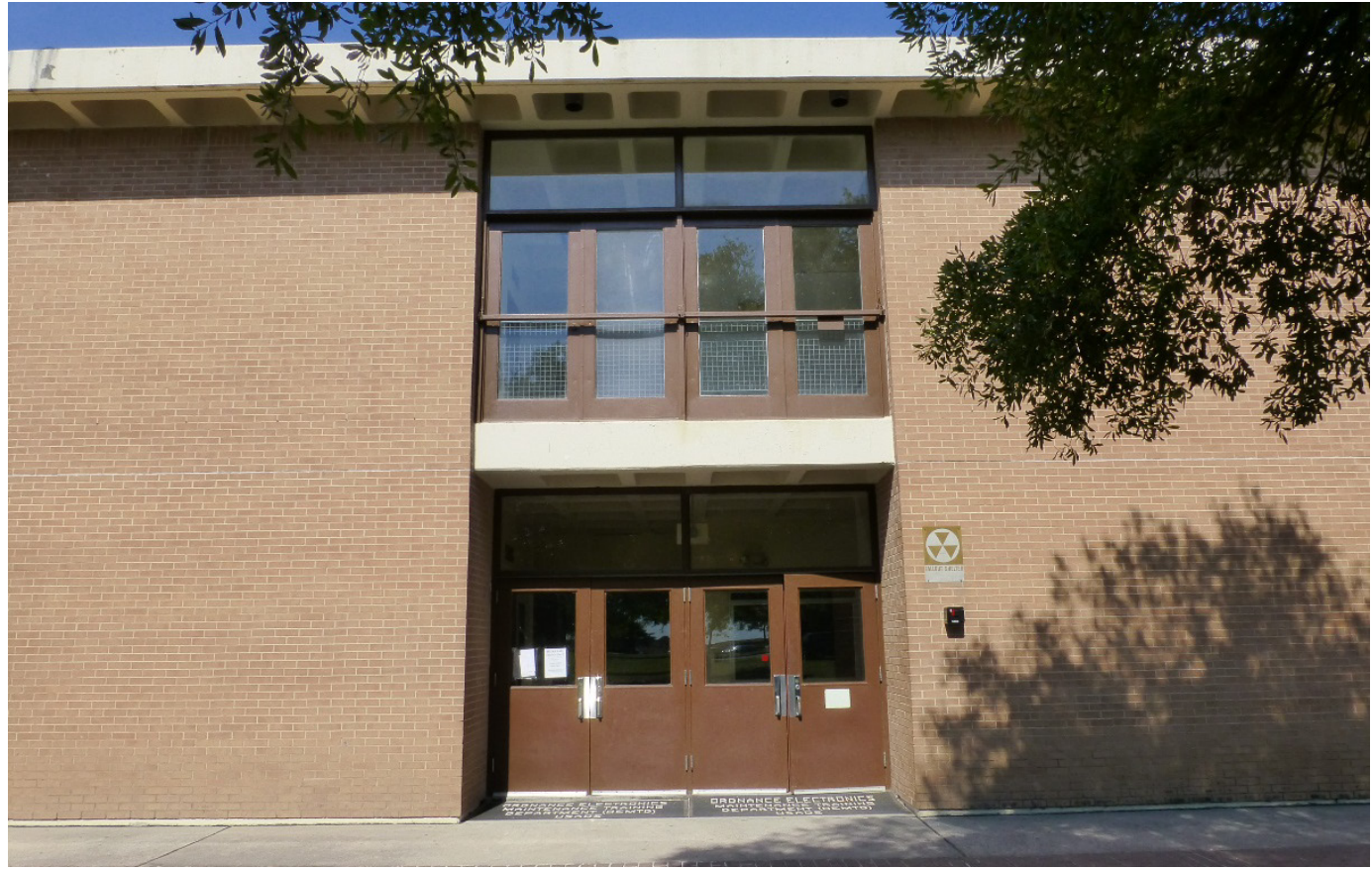

Figure 60. Metal doors with an insulated panel placed in the transom above, Building 29816, Fisher Hall (ERDC-CERL, 2015).

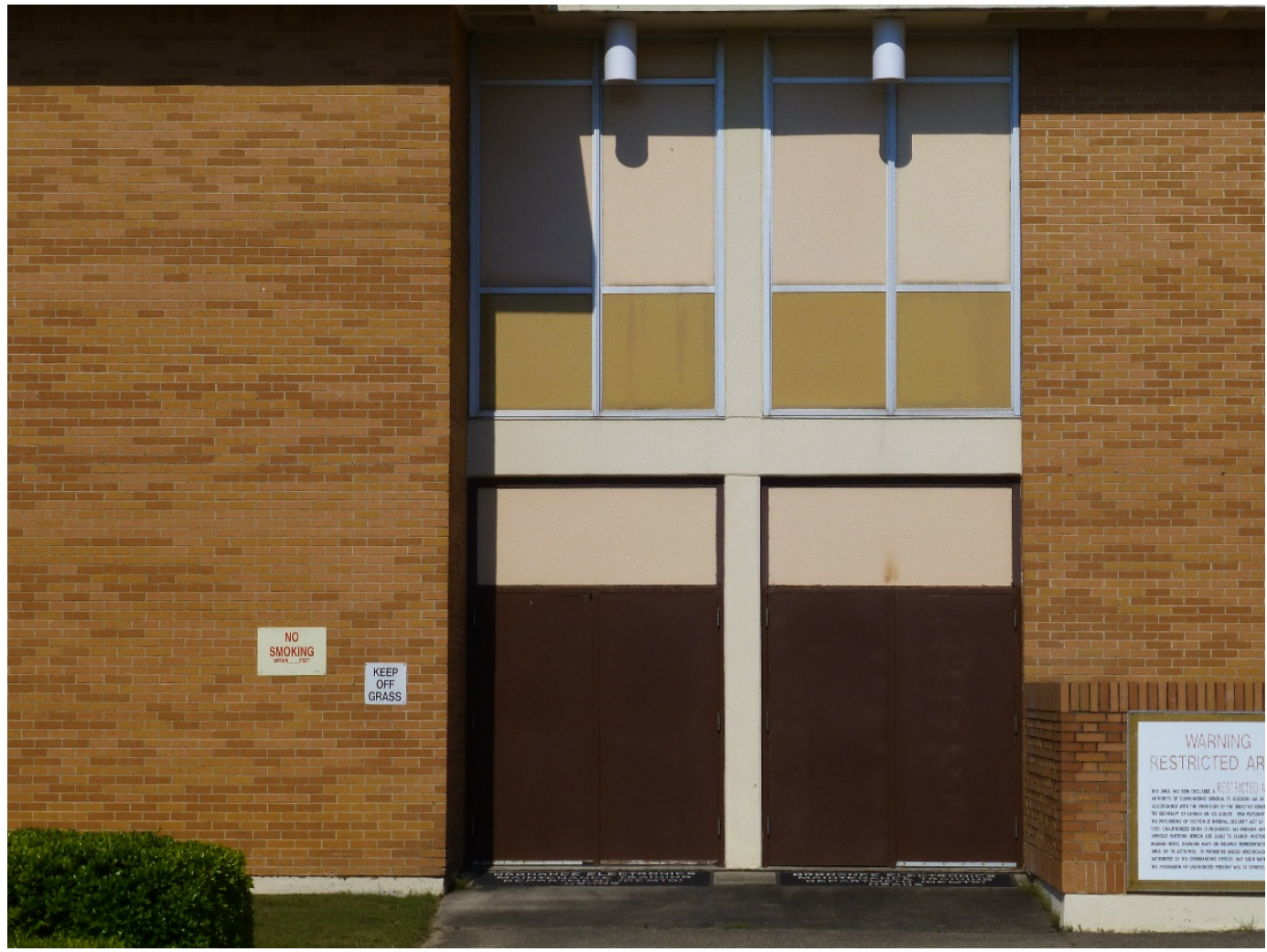


Buildings 29809, Greely Hall, Building 29811, Saltzman Hall, Building 29813, Allen Hall, and Building 29817, Allison Hall, each have two courtyards. There are entry doors on the north and south courtyard walls (Figure 61).

Figure 61. Typical doors located on the north and south walls entering the courtyards, Building 29811, Saltzman Hall (ERDC-CERL, 2015).

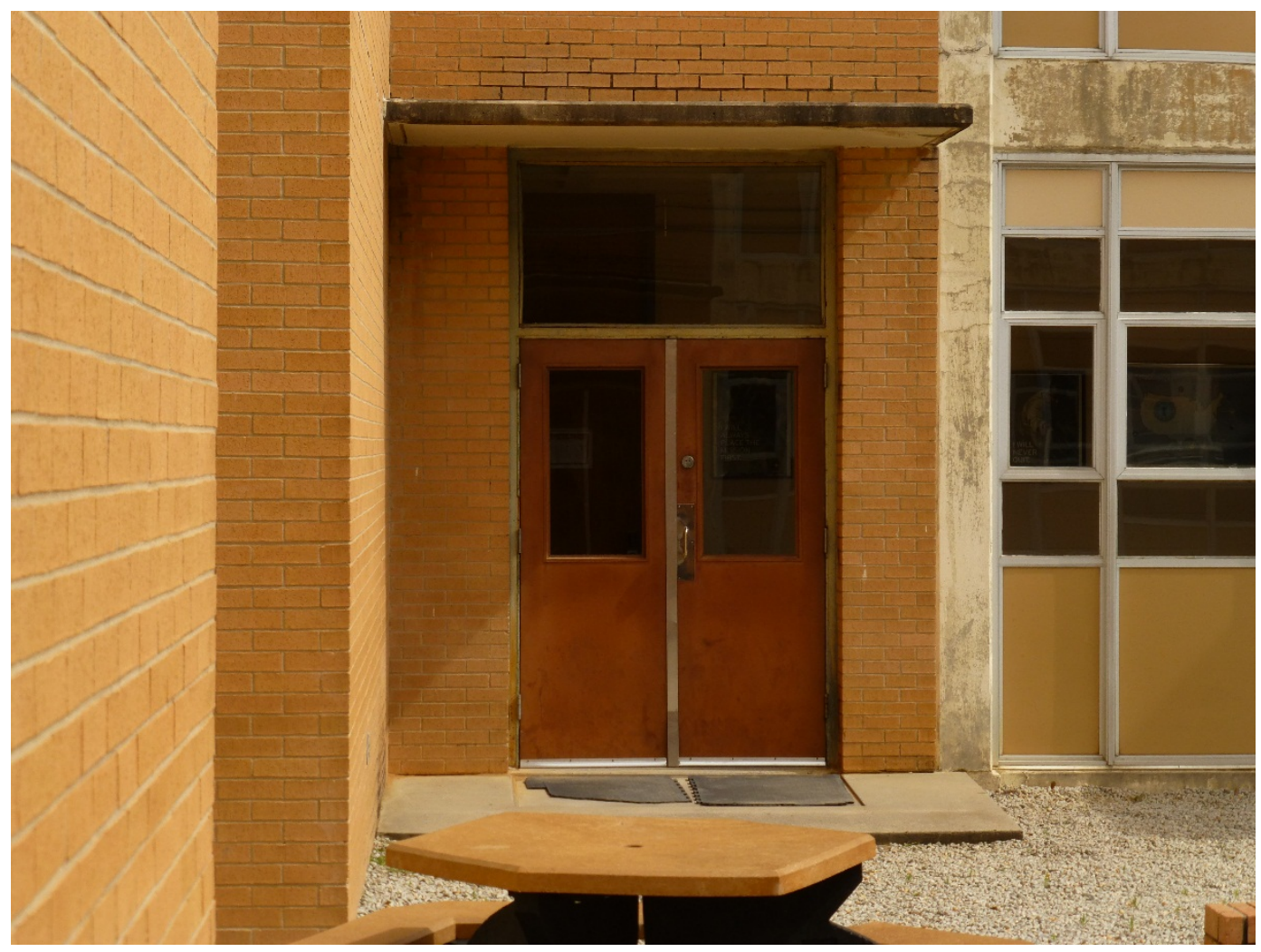

\subsubsection{Exposed concrete structural system}

The structure of all the Signal School Campus buildings is constructed of cast-in-place concrete columns with a waffle floor/ceiling structure. The exposed structure is found at window and door bays, separating the first and second floors and dividing individual bays (Figure 62 and Figure 63). Building 29807, Conrad Hall, and Building 29808, Signal Towers, also have exposed concrete structural elements at the corners of the building (Figure 64). 
Figure 62. Exposed concrete structure dividing the first and second-floor doors and separating the sets of doors vertically, Building 29811, Saltzman Hall

(ERDC-CERL, 2015).

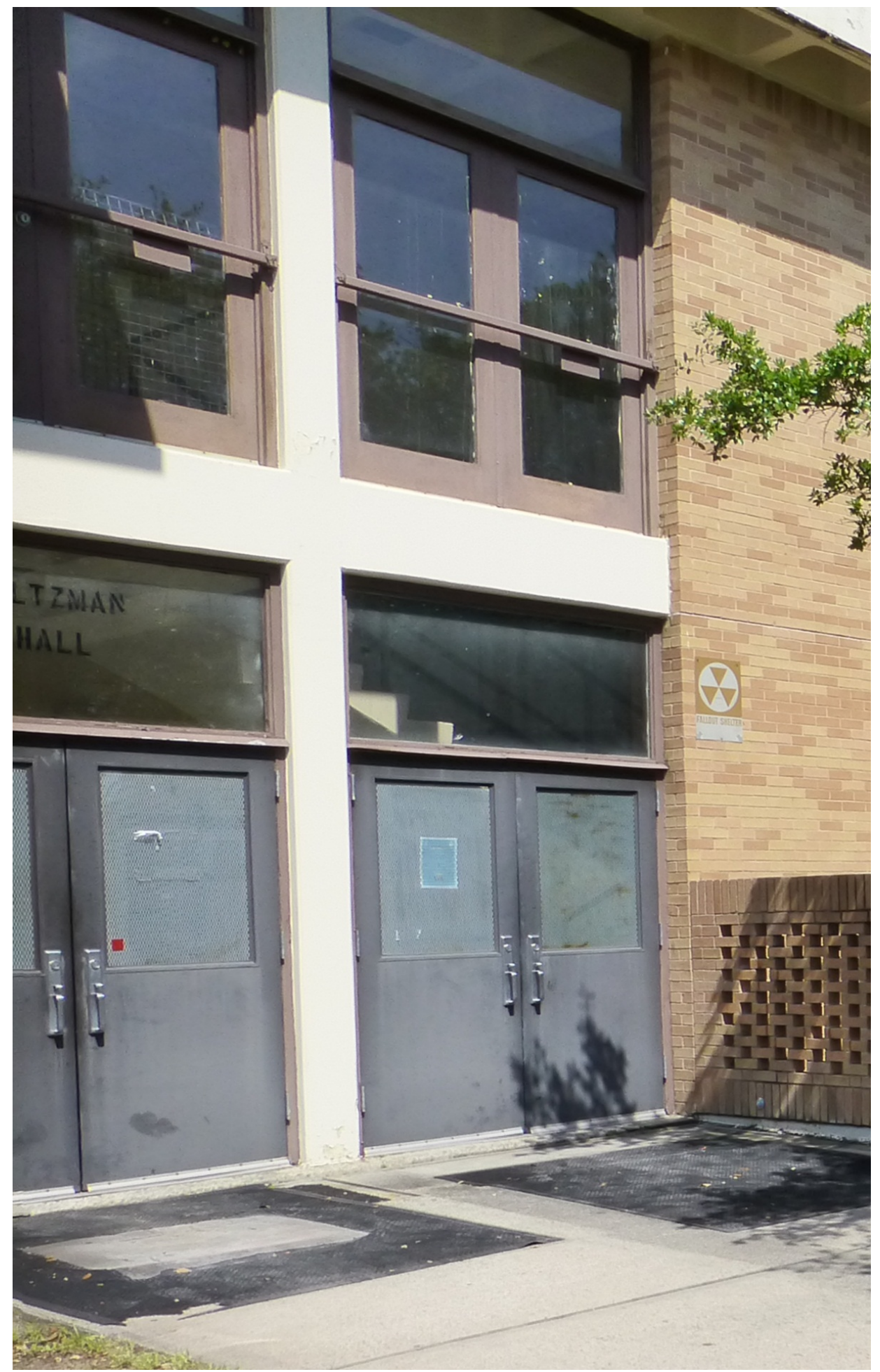


Figure 63. Close-up of the exposed concrete structural system framing the doors and window bays, Building 29815, Hazen Hall (ERDC-CERL, 2015).

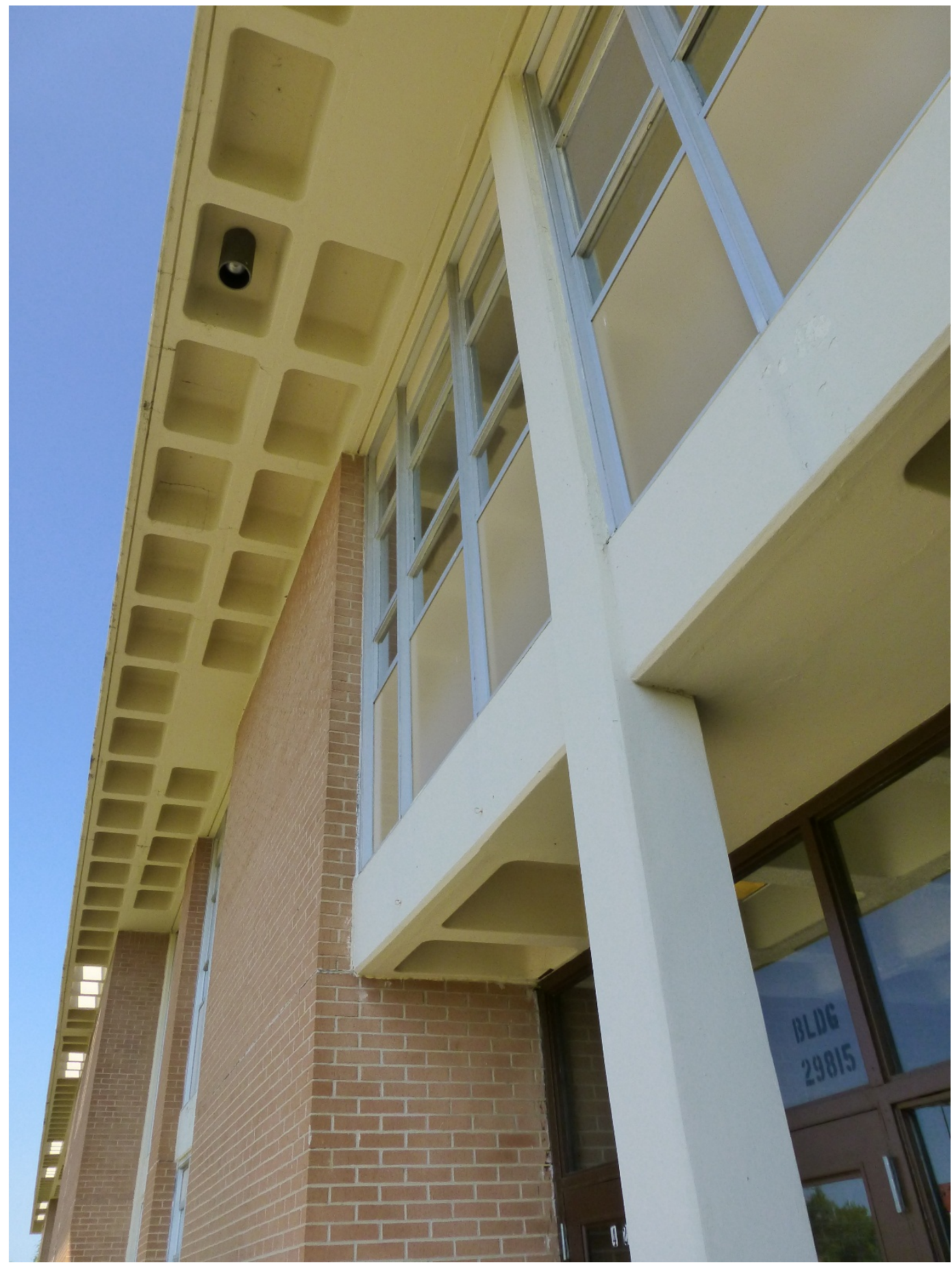


Figure 64. Exposed concrete structural element, located at the corner of the building and framing the corner window system, Building 29807, Museum (Conrad Hall)

(ERDC-CERL, 2015).

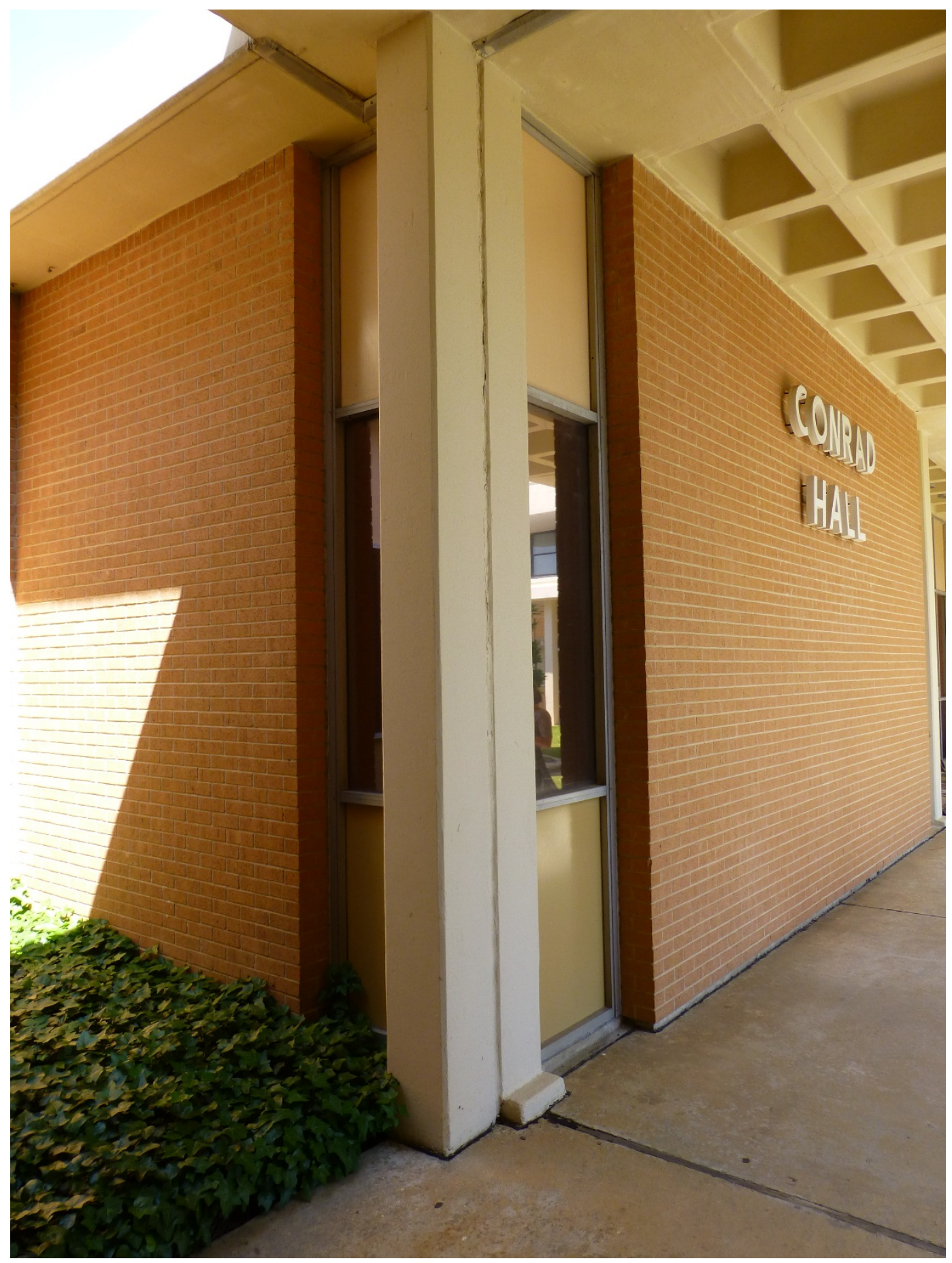

\subsubsection{Flat concrete waffle canopy}

In keeping with the overall design scheme of the Signal School Campus buildings, Building 25810, Brant Hall, has a feature calling out the main 
entry on the south elevation. A flat concrete waffle canopy supported by concrete columns stretches in front of the entry (Figure 65). The main administration group buildings of the campus: Building 29805, Alexander/Olmsted Halls, Building 29807, Museum (Conrad Hall), and Building 29808, Signal Towers, are defined and connected to each other by an extensive wraparound, flat concrete, waffle canopy structure that is supported by concrete columns (Figure 66).

Figure 65. Close-up of the flat concrete waffle canopy highlighting the main entry into Building 25810, Brant Hall (ERDC-CERL, 2015).

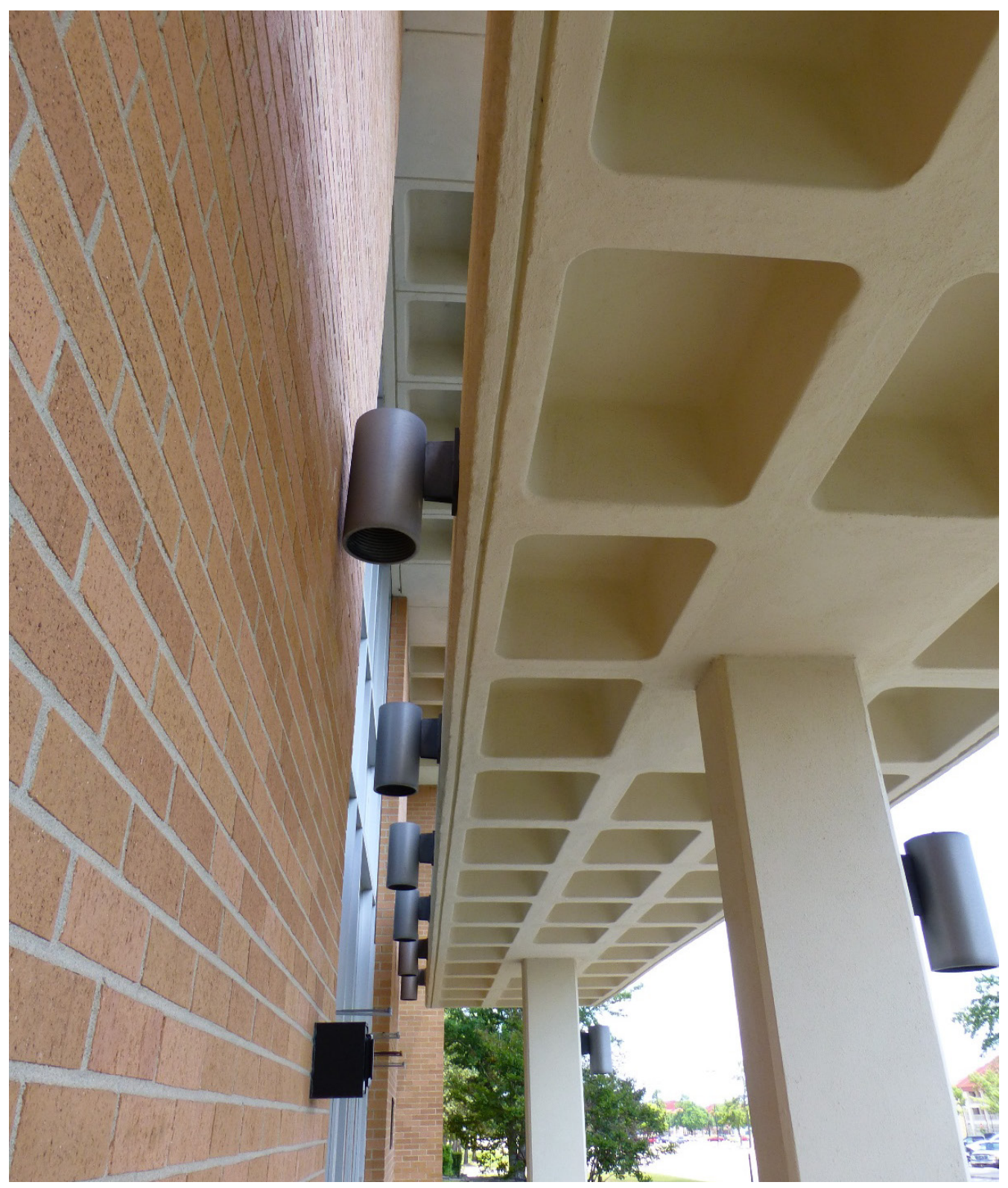


Figure 66. Extensive wrap-around concrete waffle canopy connects the main administration buildings: Building 29805, Alexander/Olmsted Halls; Building 29807, Museum (Conrad Hall); and Building 29808, Signal Towers (ERDC-CERL, 2015).

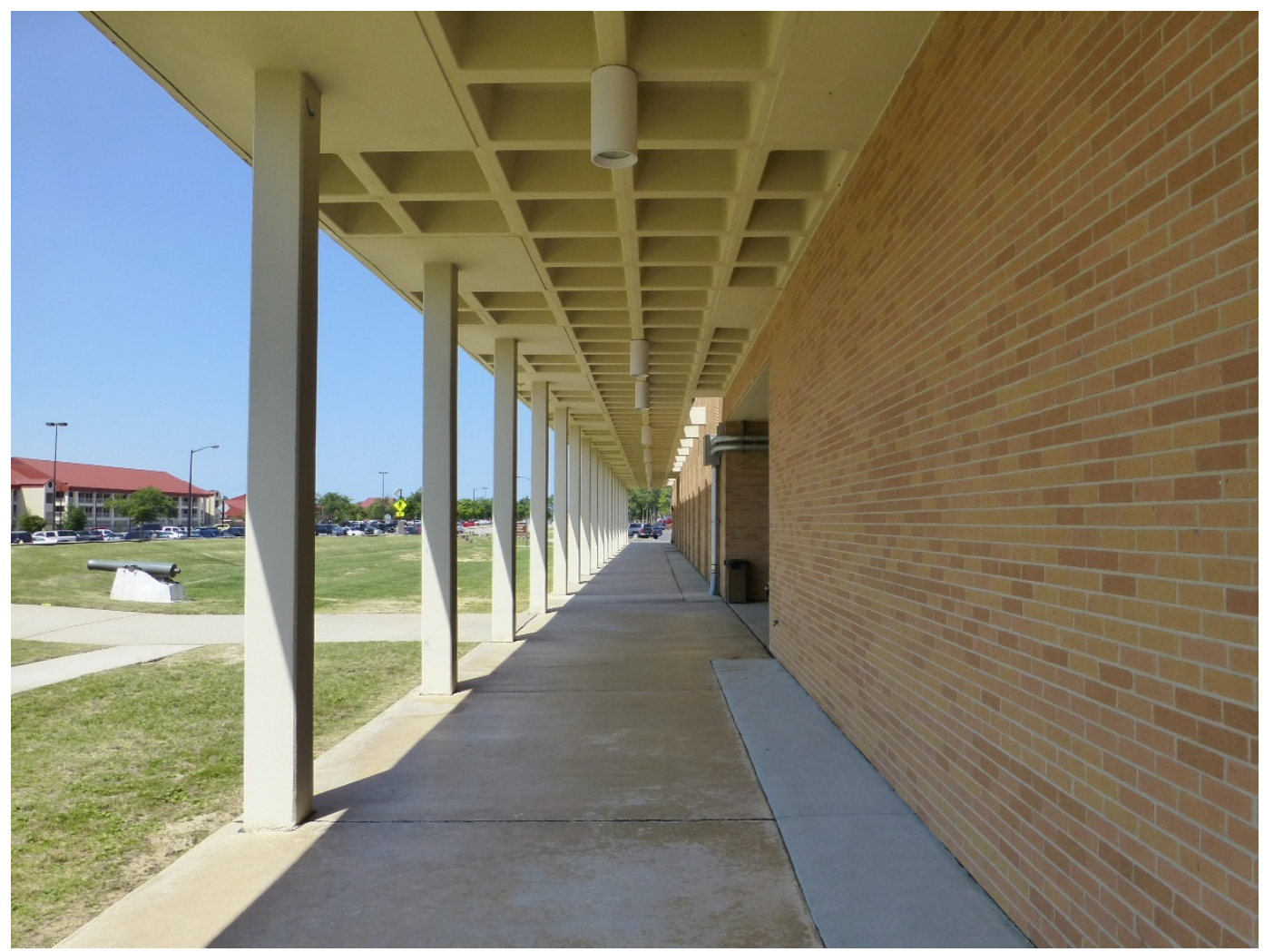

\subsubsection{Flat concrete canopy above entries}

Some of the entries into the Signal School Campus buildings are protected by flat concrete canopies (Figure 67-Figure 70). Some of the canopies are placed just above entry doors, while others extend over the doors and a bay of windows, or else doors and a bay of concrete panels. Building 25810, Brant Hall; Building 29801, Nelson Hall; Building 29809, Greely Hall; Building 29810, Burkhardt Hall; Building 29811, Saltzman Hall; Building 29813, Allen Hall; and Building 29817, Allison Hall, all have flat concrete canopies. 
Figure 67. Flat concrete canopy above a set of metal entry doors on Building 29801, Nelson Hall (ERDC-CERL, 2015).

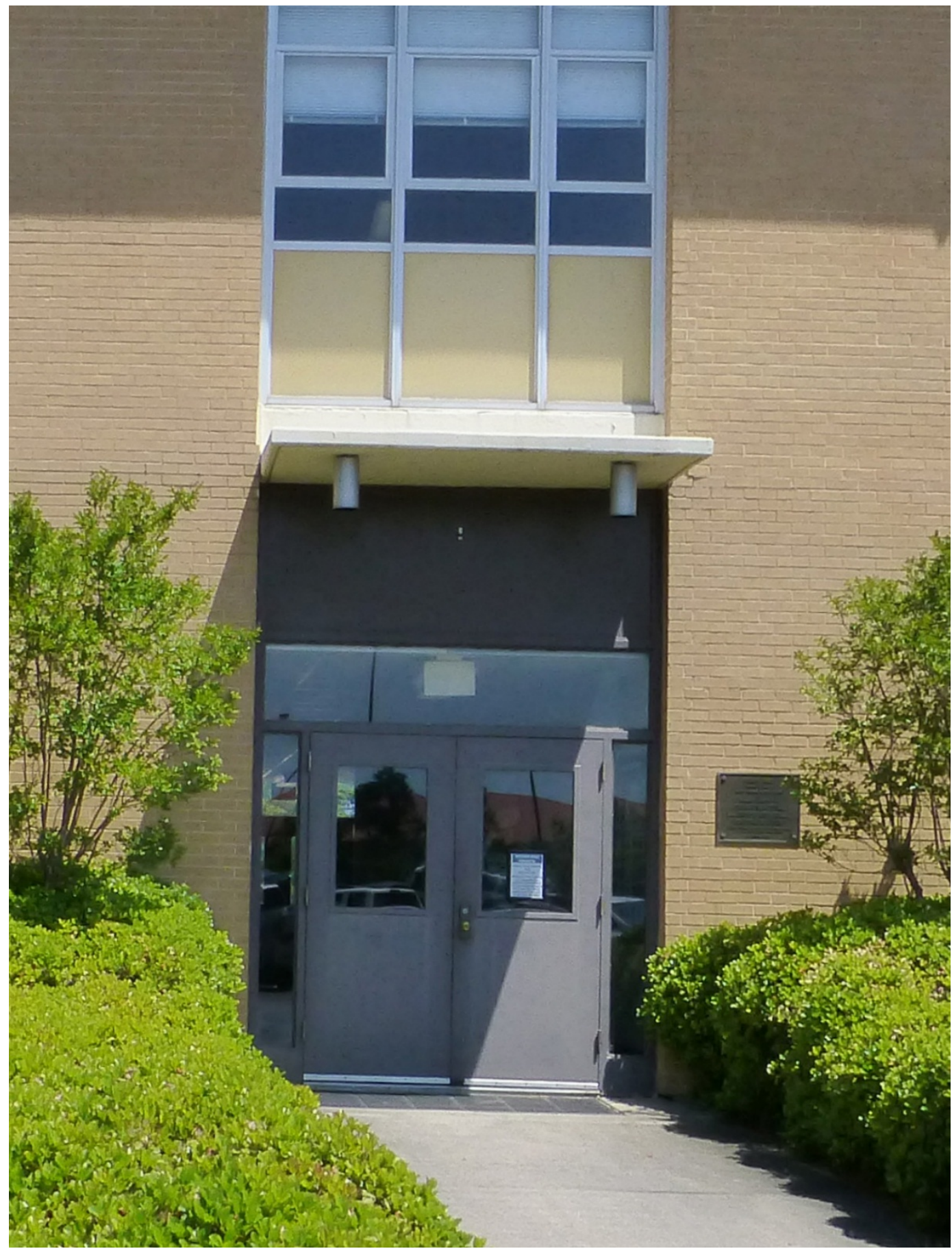


Figure 68. Flat concrete canopy extending over doors and a bay of windows on Building 29811, Saltzman Hall (ERDC-CERL, 2015).

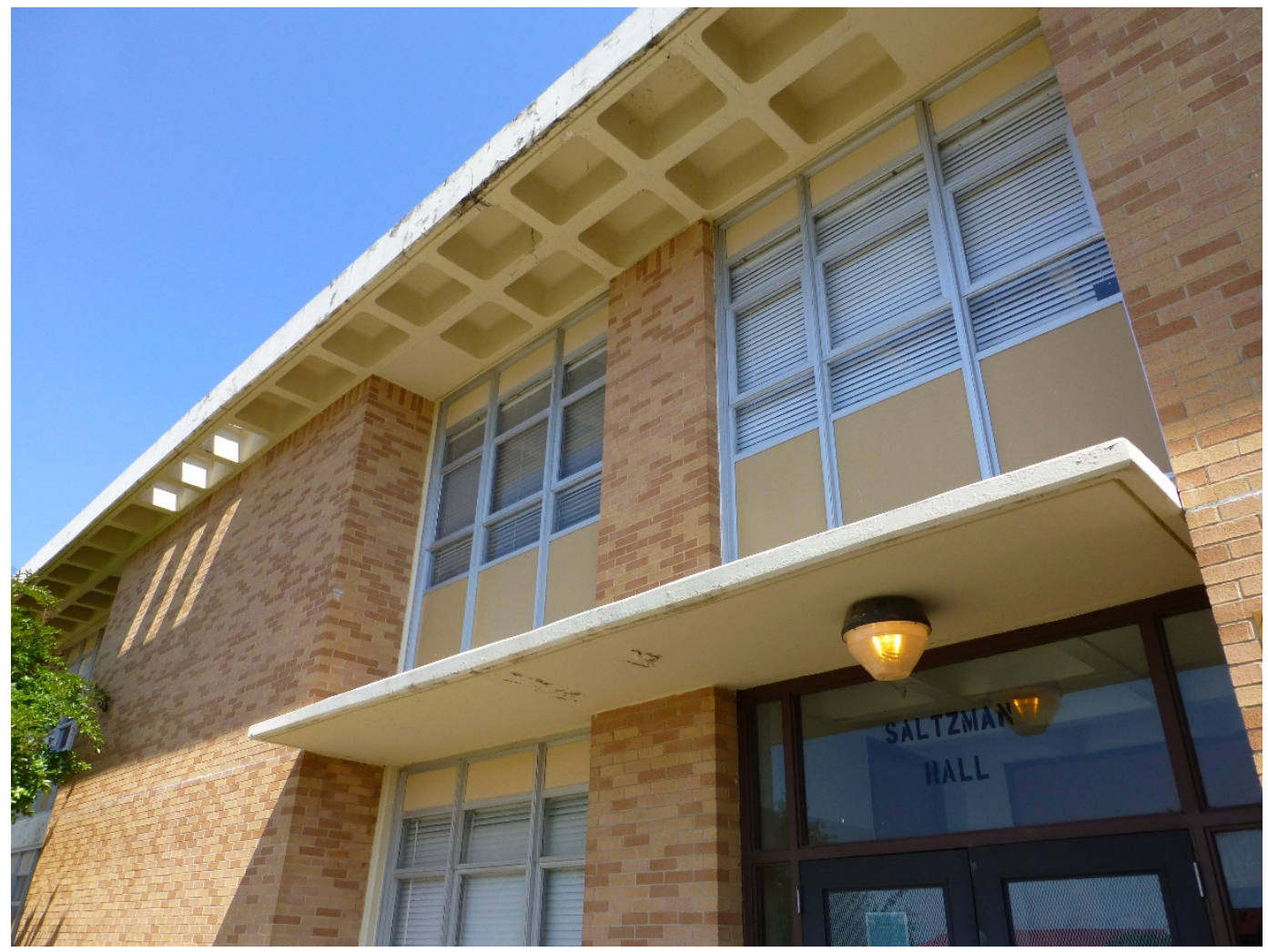

Figure 69. Flat concrete canopy extending over entry doors and a bay of concrete panels on Building 29813, Allen Hall (ERDC-CERL, 2015).

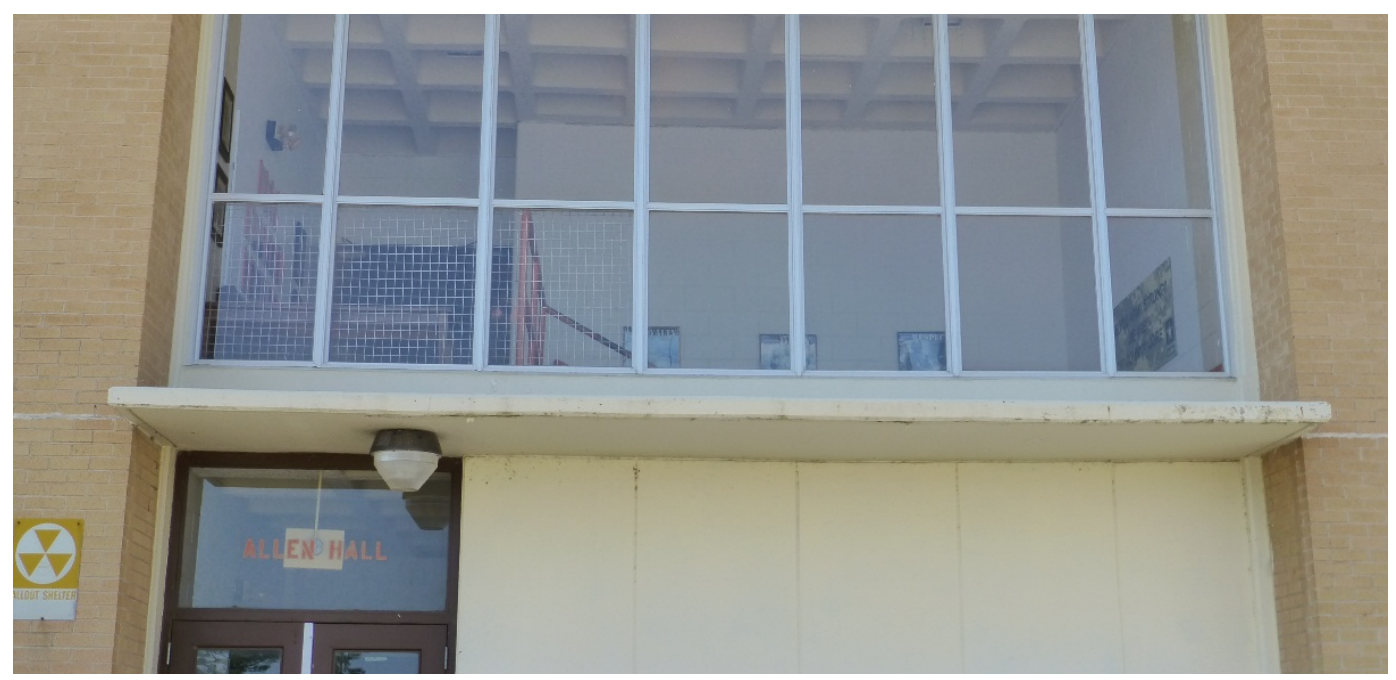


Figure 70. Close-up of the concrete canopy detail, Building 29817, Allison Hall (ERDC-CERL, 2015).

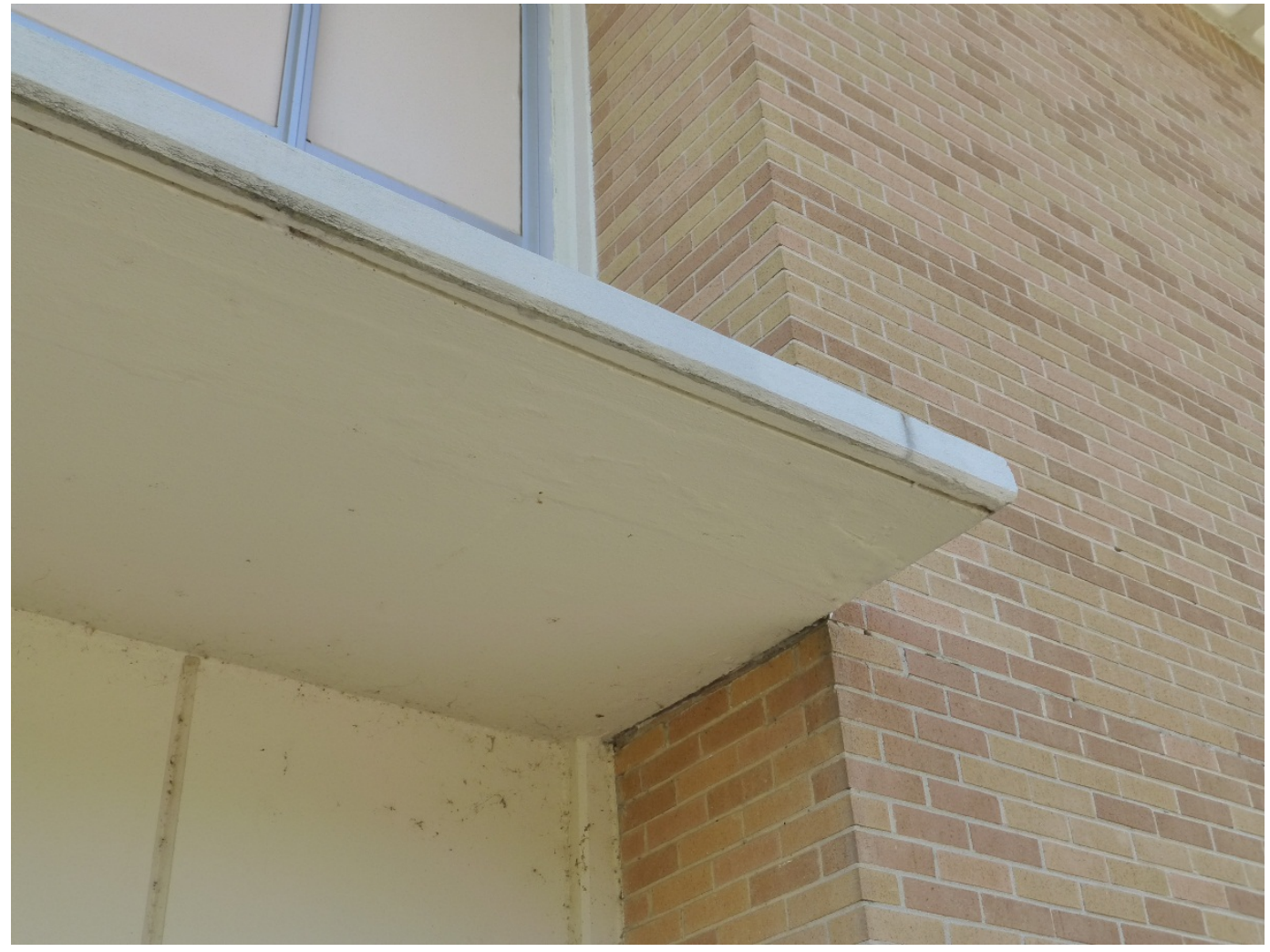

\subsubsection{Cylinder exterior light fixtures}

There are several types of exterior light fixtures located on the Signal School Campus buildings. These fixture types are either ceiling-mounted or wall-mounted. They are cylinder-shaped fixtures (Figure 71-Figure 78). The ceiling-mounted ones are placed under the flat roof canopies, within in the waffle overhang or on the underside of the waffle canopy. The wallmounted fixtures are located on either side of an entry bay or flanking a window bay on the end elevations of a building. Due to the number of these types of light fixtures, it is hard to know which ones have been replaced; if it appears they have been replaced, however, it is with in-kind fixtures (Figure 79). 
Figure 71. Wall-mounted light fixtures flanking either side of an entry, Building 25810, Brant Hall (ERDC-CERL, 2015).

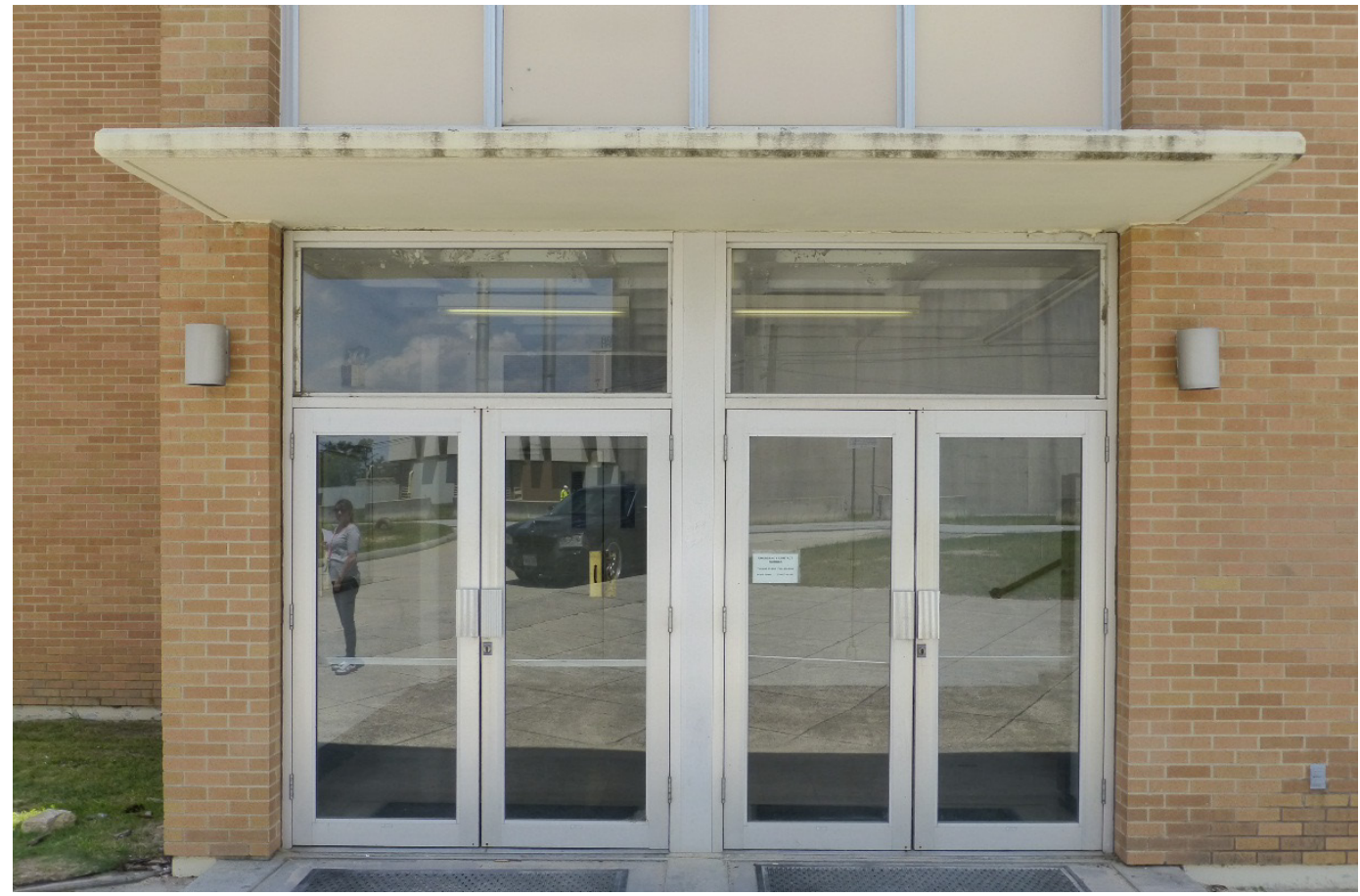

Figure 72. Ceiling-mounted light fixture placed on the underside of the flat concrete canopy, Building 29801, Nelson Hall (ERDC-CERL, 2015).

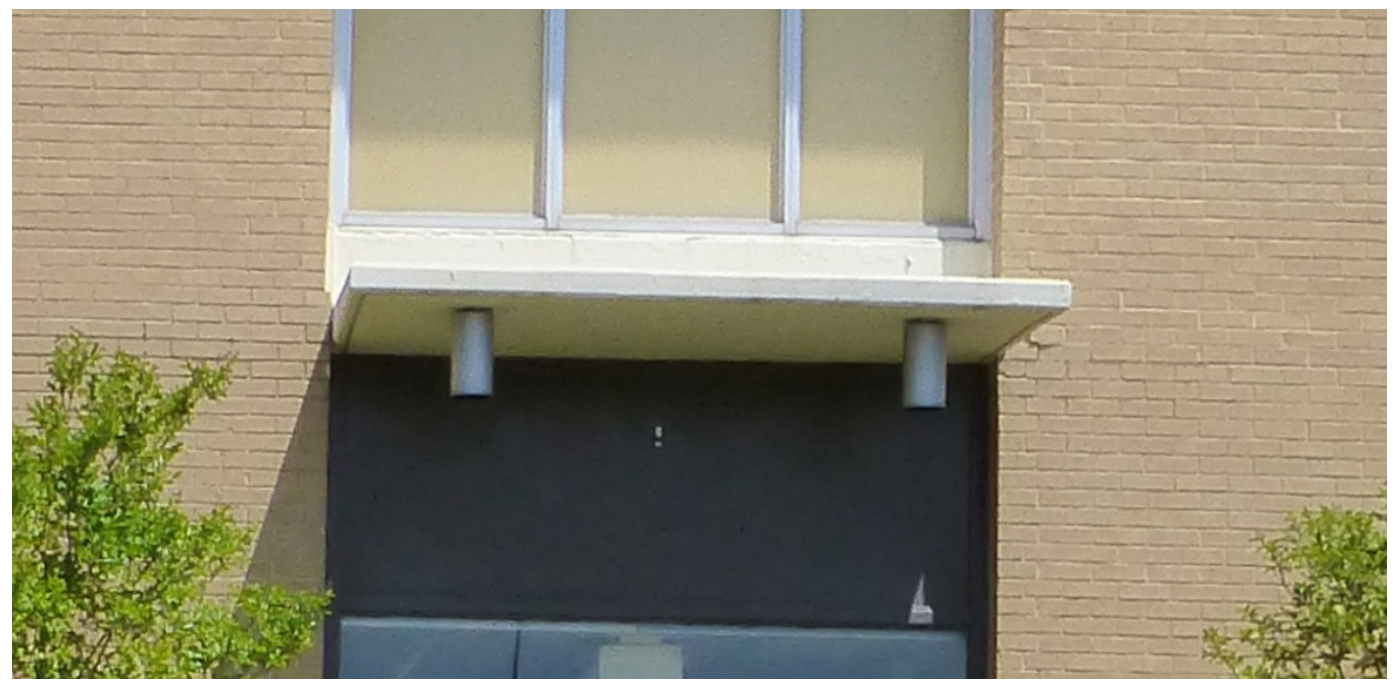


Figure 73. Ceiling-mounted light fixtures are placed on the underside of the concrete waffle canopy structure that connects Building 29805, Alexander/OImsted Halls;

29807, Conrad Hall; and 29808, Signal Towers (ERDC-CERL, 2015).

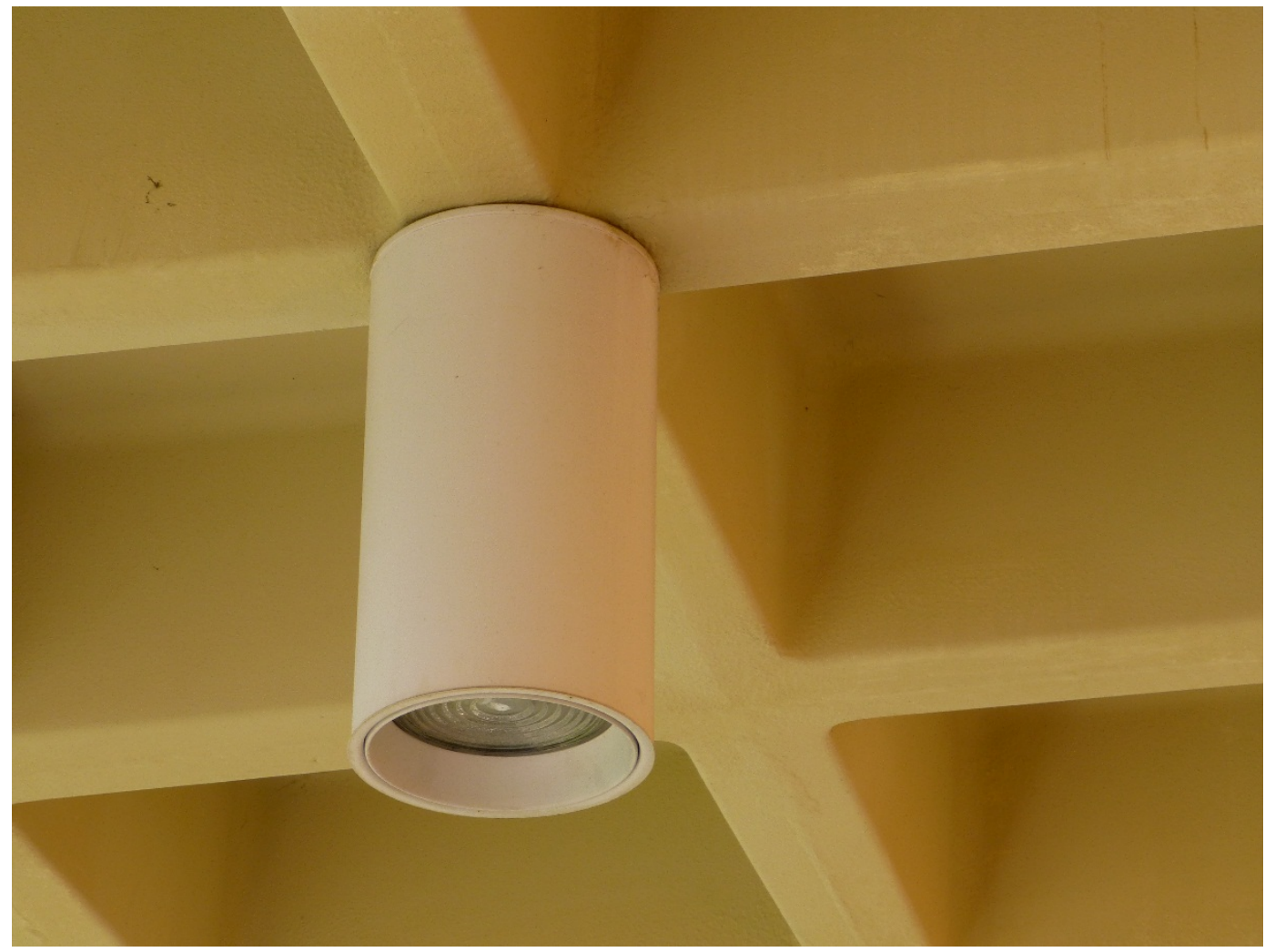

Figure 74. Ceiling-mounted light fixtures placed under the recessed ceiling of the entry into Building 29805, Alexander/OImsted Halls (ERDC-CERL, 2015).

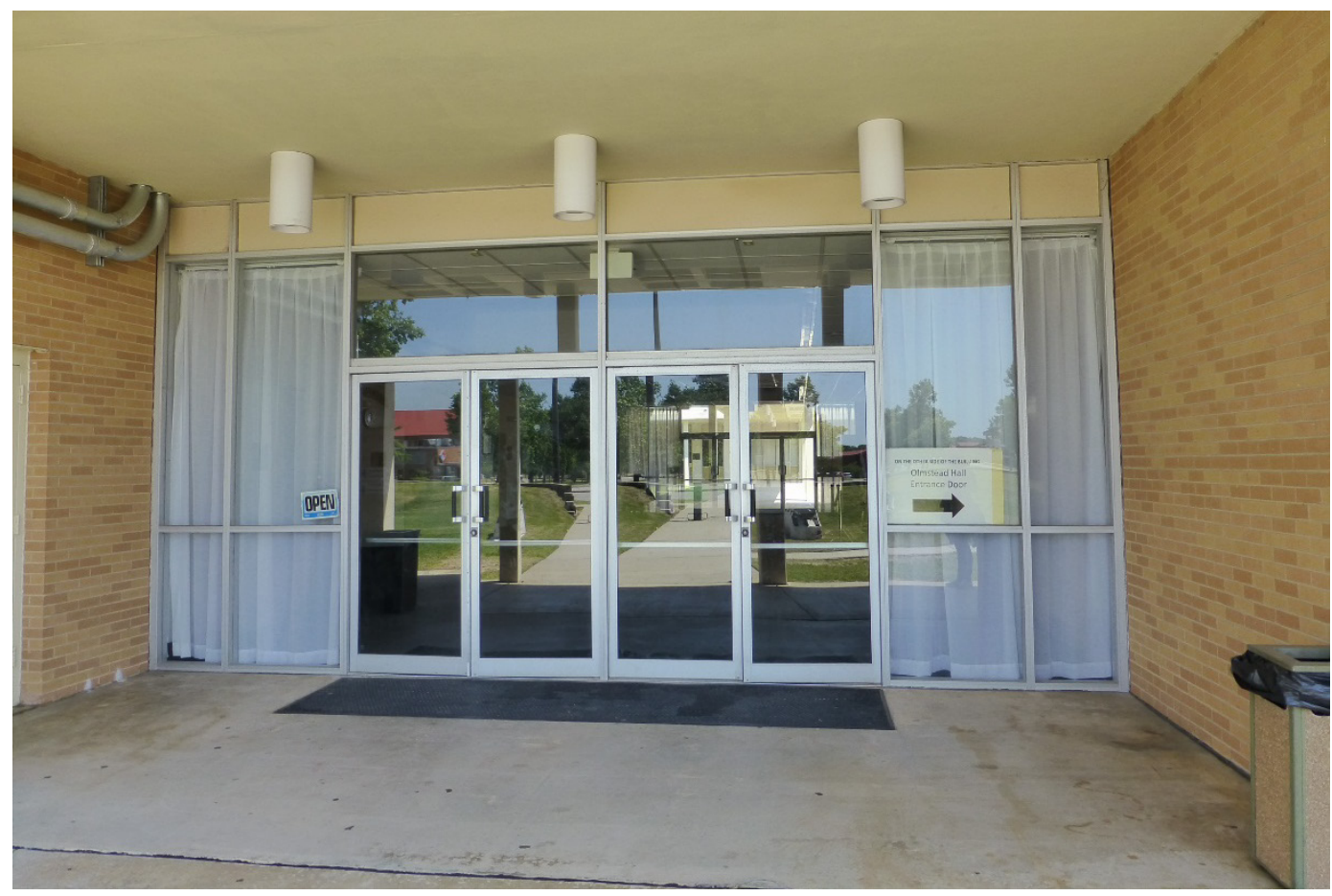


Figure 75. Example of a wall-mounted light fixture that flanks either side of a window bay, Building 29810, Burkhardt Hall (ERDC-CERL, 2015).

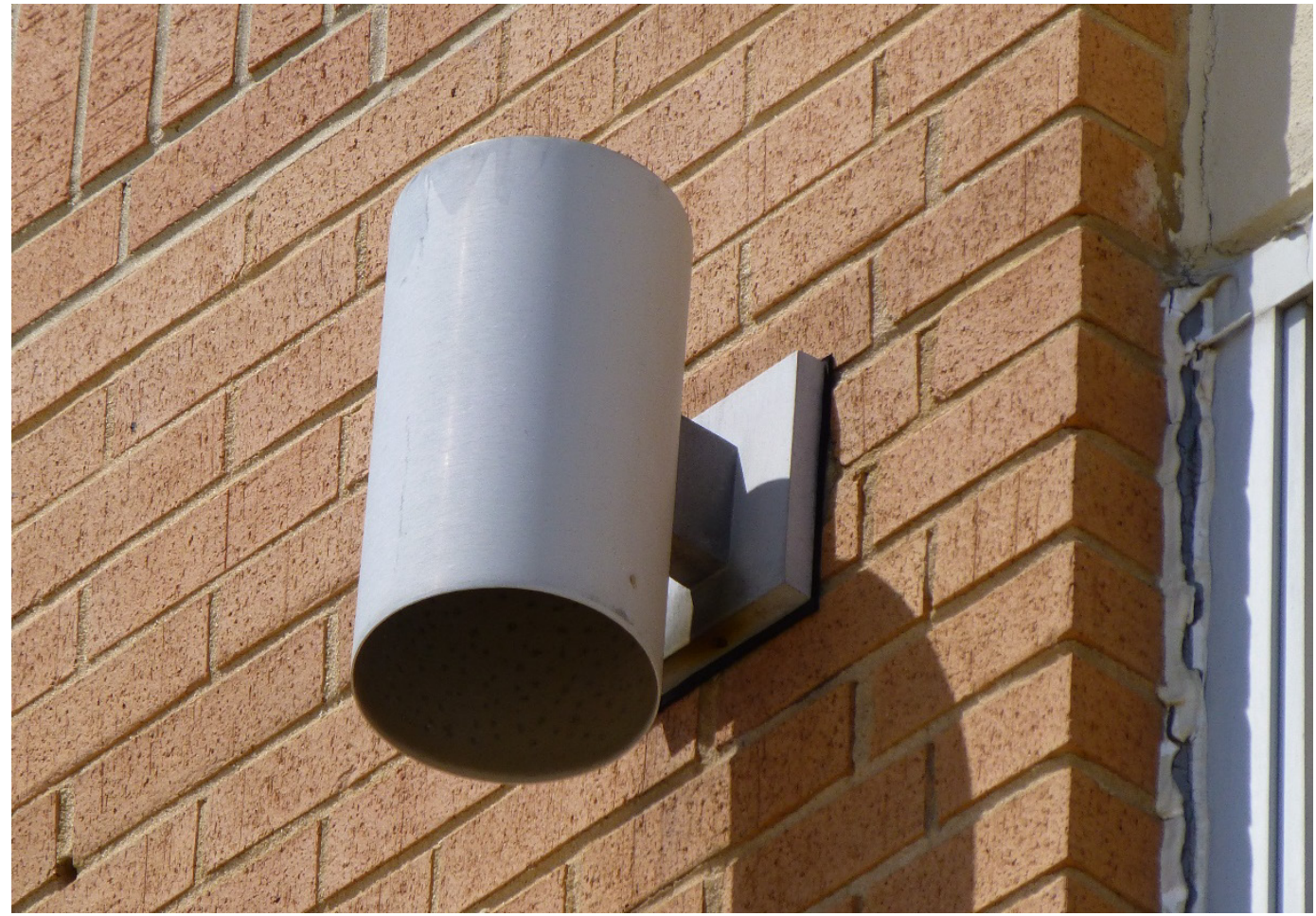

Figure 76. Example of a wall-mounted light fixture near an entry into a courtyard, Building 29817, Allison Hall (ERDC-CERL, 2015).

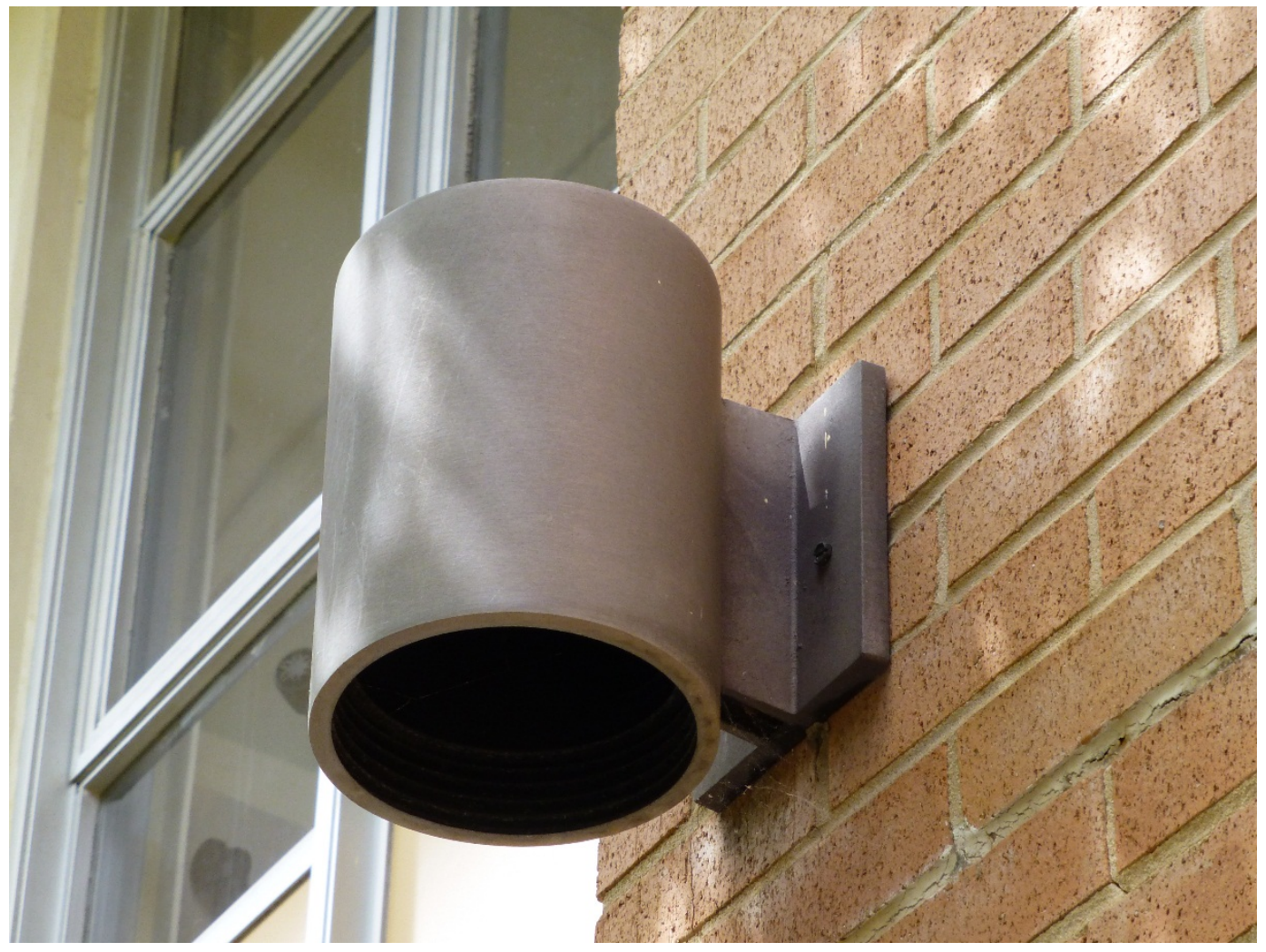


Figure 77. Ceiling-mounted light fixtures located under the concrete overhang at an entry bay on Building 29817, Allison Hall (ERDC-CERL, 2015).

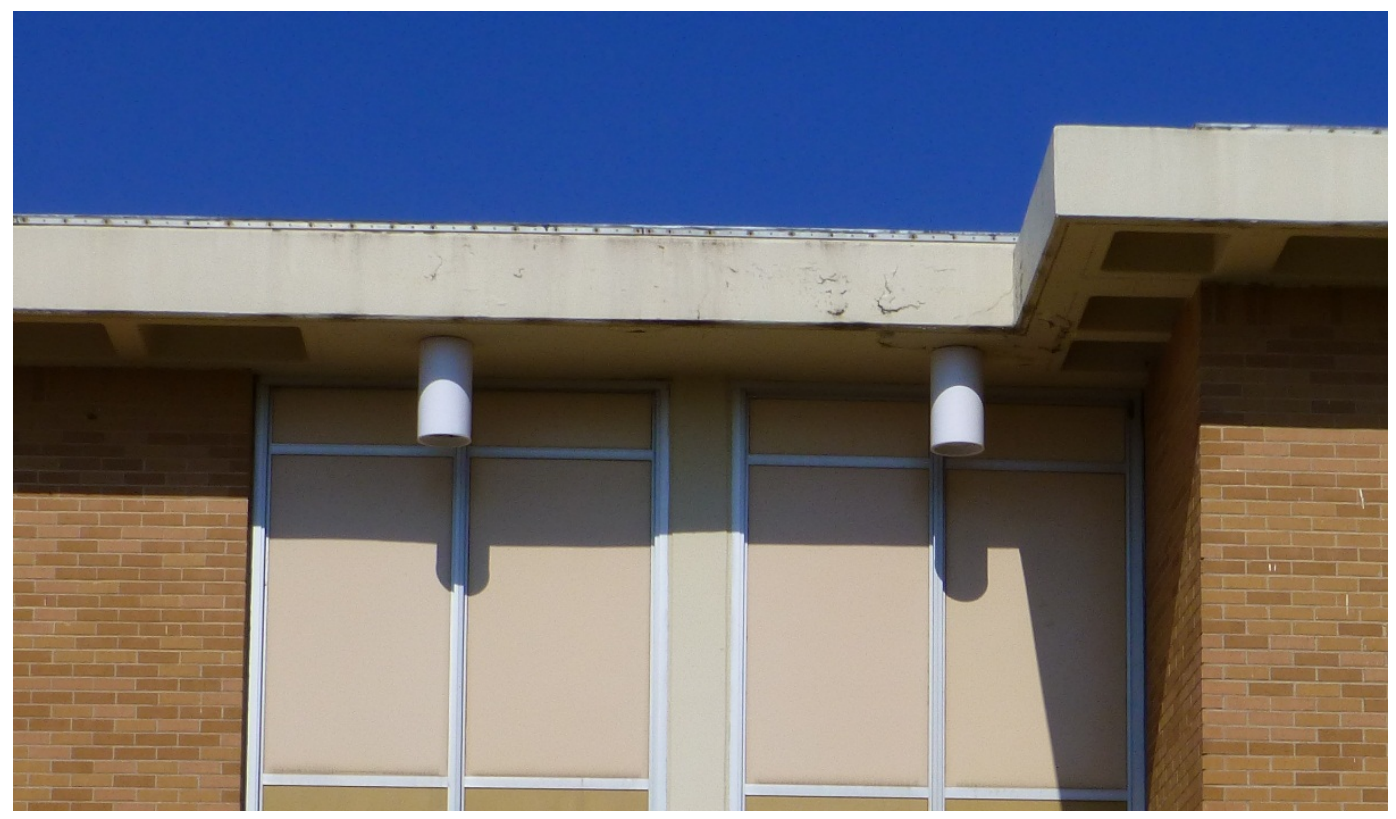

Figure 78. Ceiling-mounted light fixture placed within the concrete waffle overhang above an entry bay on Building 29818, Johnston Hall (ERDC-CERL, 2015).

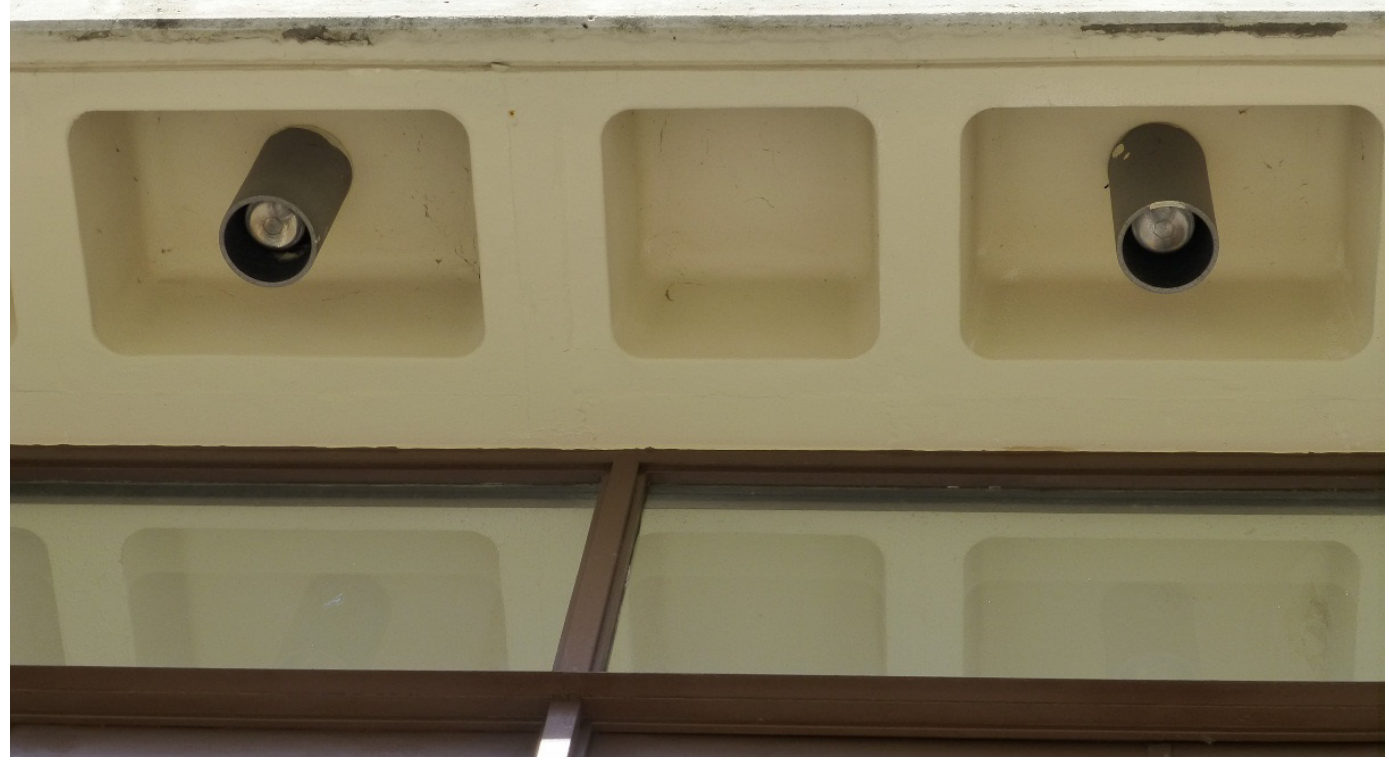


Figure 79. In-kind replacement cylinder-bronze wall-mounted light fixture-located near the main entry on the south elevation of Building 25810, Brant Hall

(ERDC-CERL, 2015).

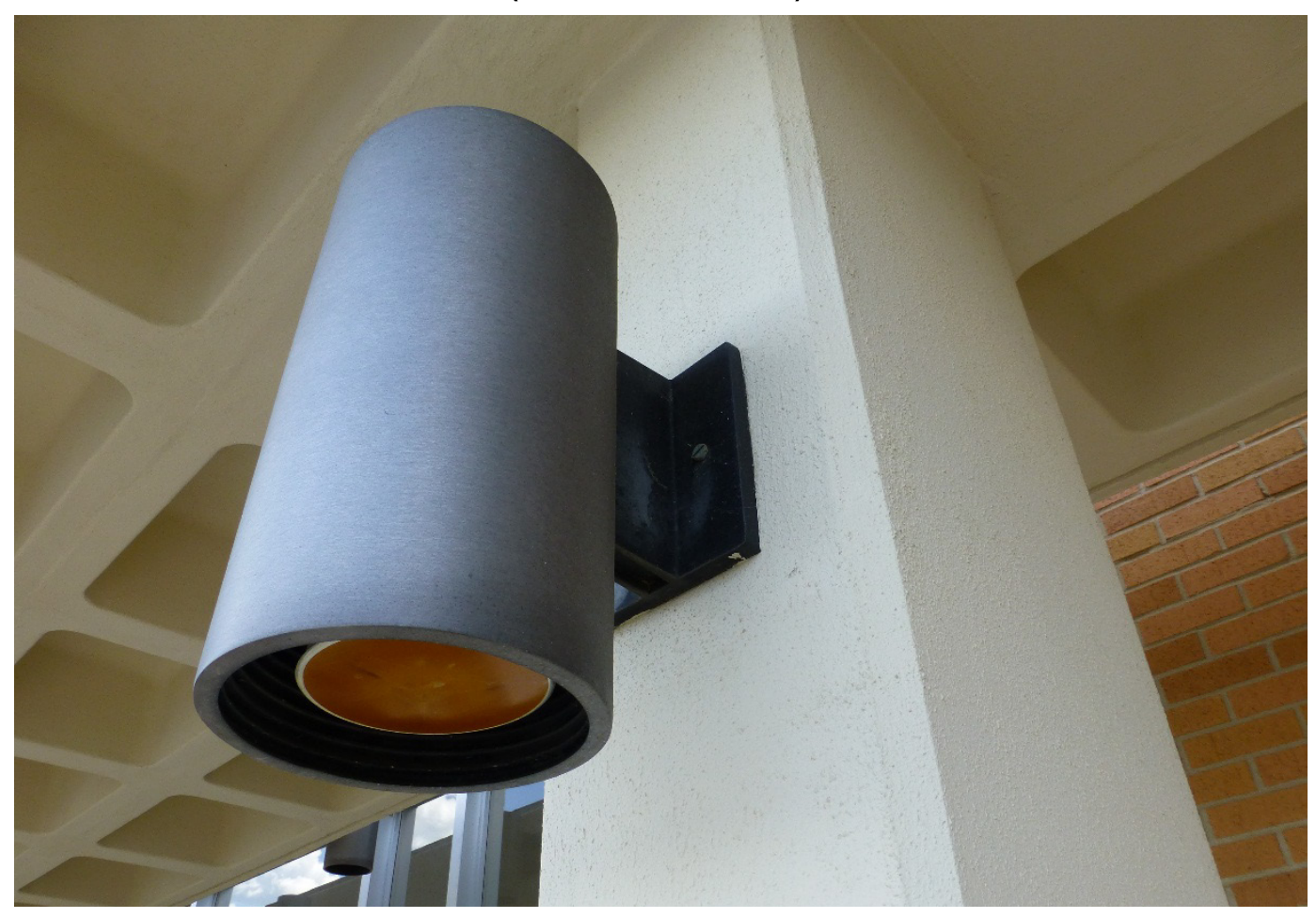

\subsubsection{Lettering}

Each of the Signal School buildings is not only identified with a building number but also with lettering because the building name is placed on two elevations of the building (Figure 80-Figure 82). This lettering is uniform on all of the buildings with the exception of the Building 29808, Signal Towers, for which the lettering is larger in scale and placed at the top of the tall structure on the south elevation (Figure 83). 
Figure 80. Example of the uniform lettering, Building 29801, Nelson Hall (ERDC-CERL, 2015).

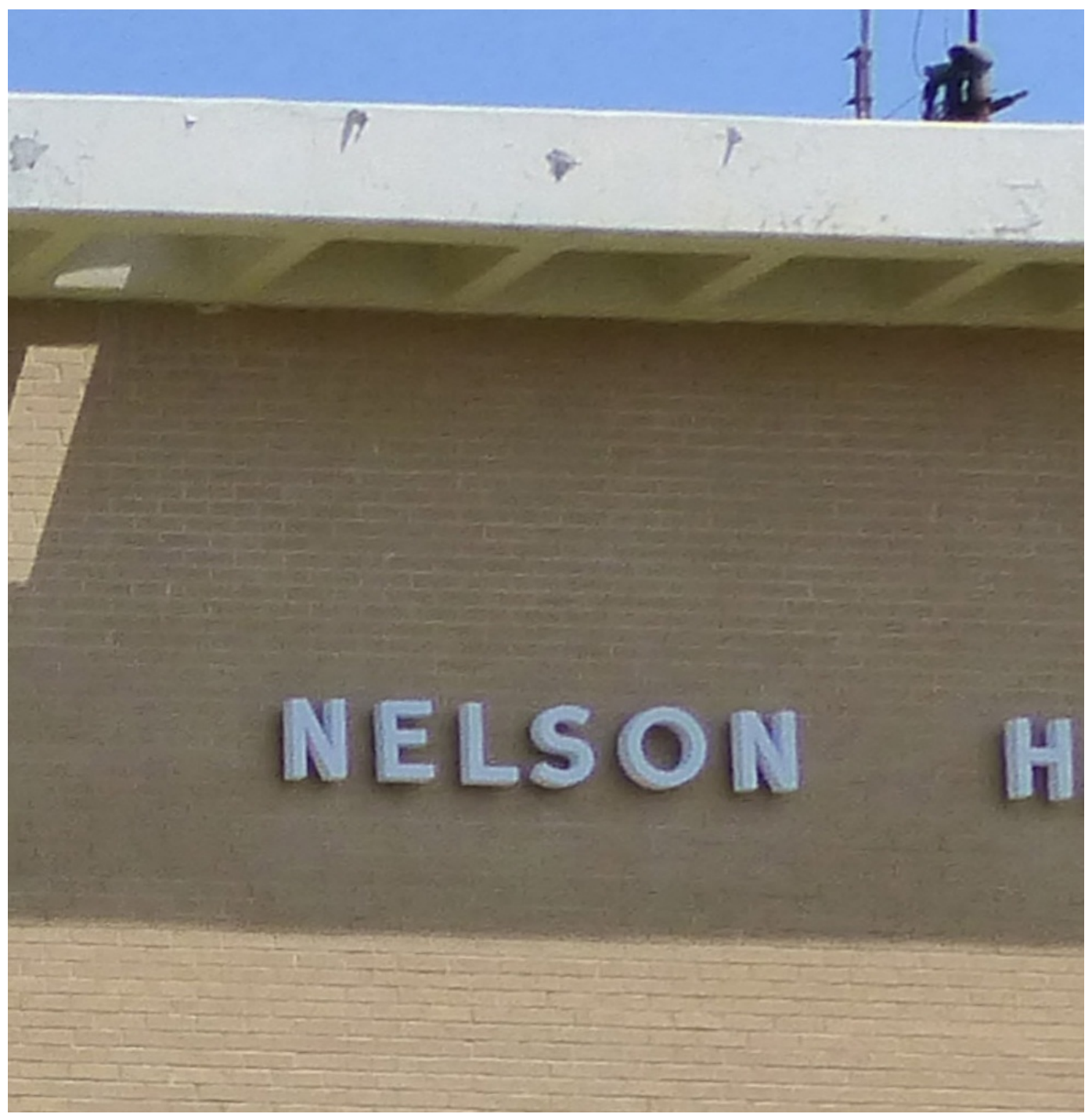

Figure 81. Example of the uniform lettering, Building 29805, Alexander Hall (ERDC-CERL, 2015).

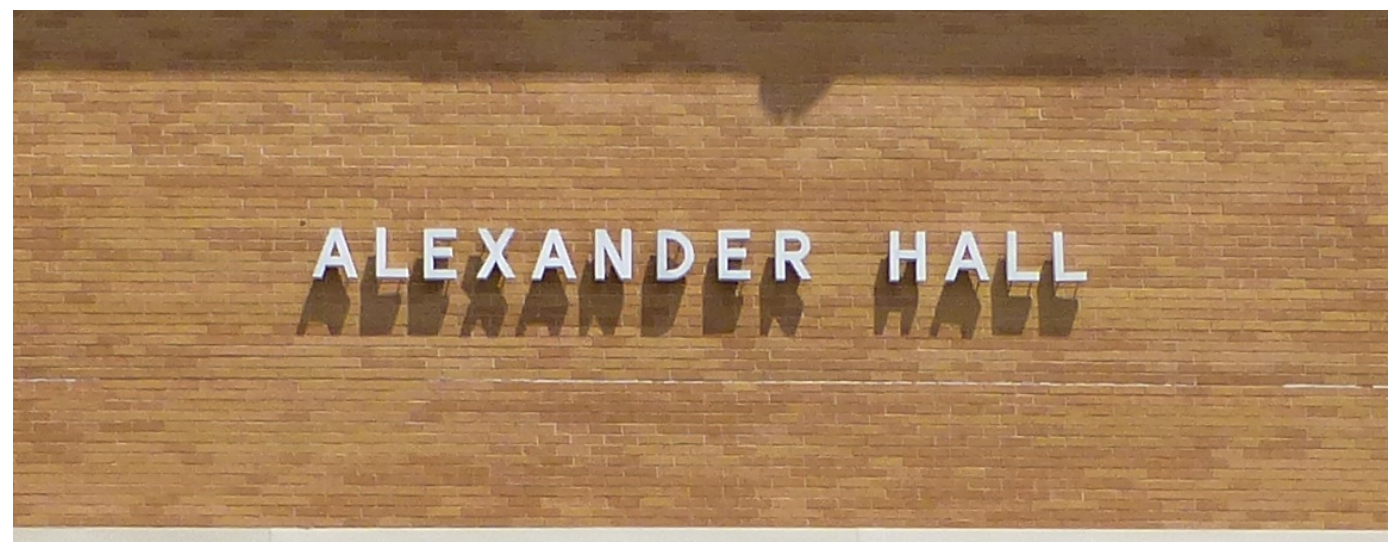


Figure 82. Close-up of the uniform lettering, Building 29819, Stansell Hall (ERDC-CERL, 2015).

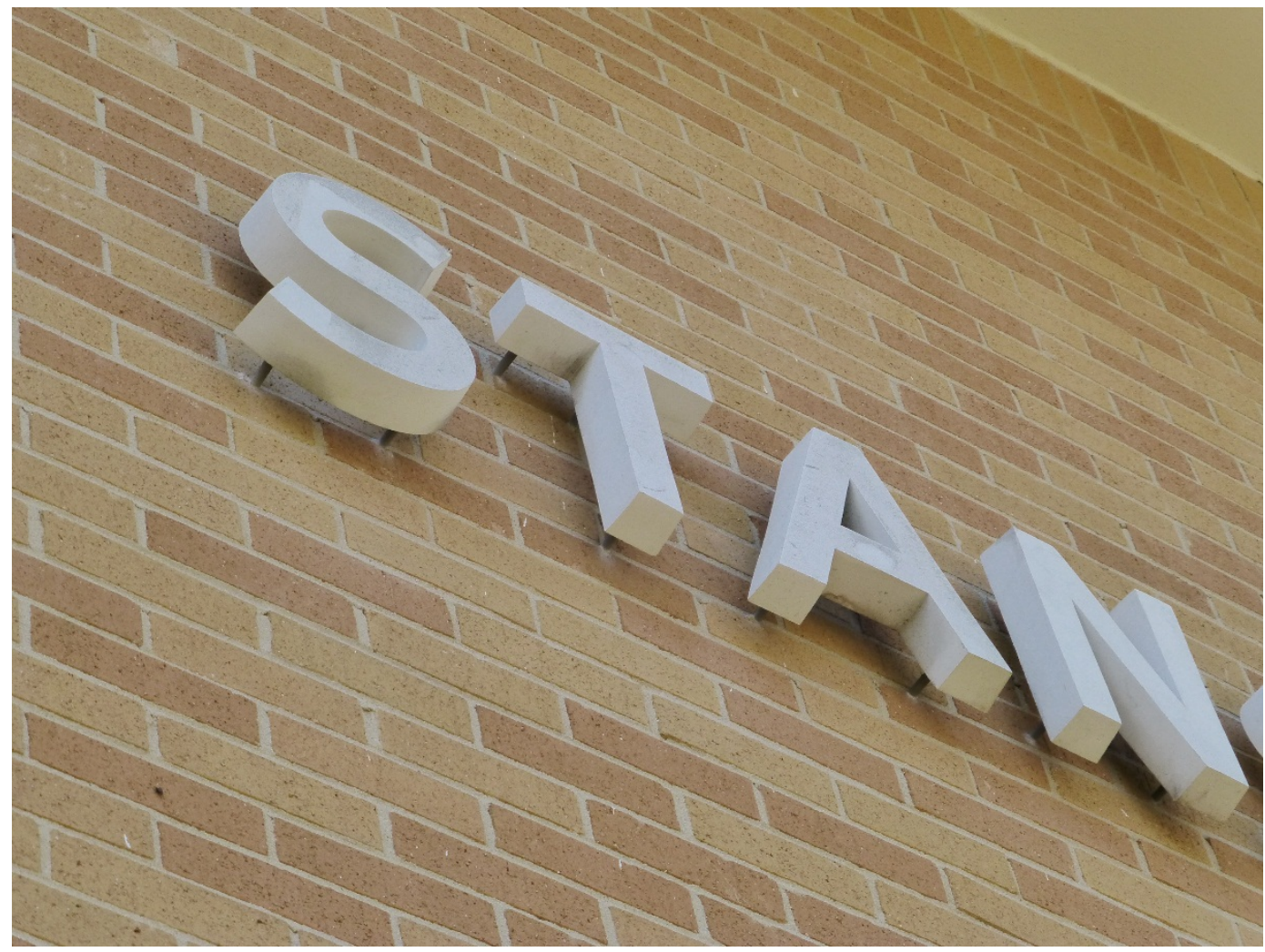

Figure 83. The larger scale of the lettering located at the top of Building 29808, Signal Towers (ERDC-CERL, 2015).

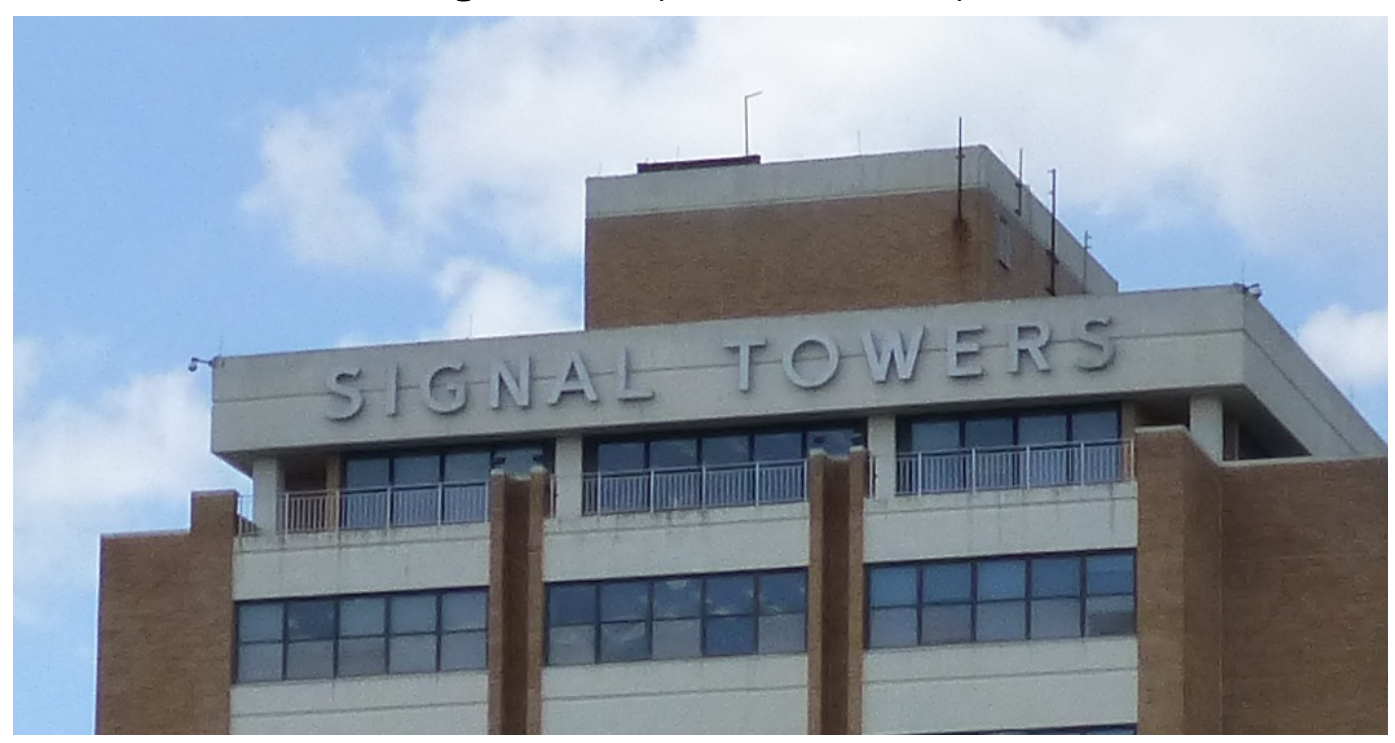




\subsubsection{Bright-aluminum exterior display cases}

It is unclear if all of the Signal School buildings originally had an exterior bright-aluminum display case. Building 29809, Greely Hall, and Building 29811 Saltzman Hall, are the only two that have these display cases intact (Figure 84).

Figure 84. Bright-aluminum exterior display case, Building 29811, Saltzman Hall (ERDC-CERL, 2015).

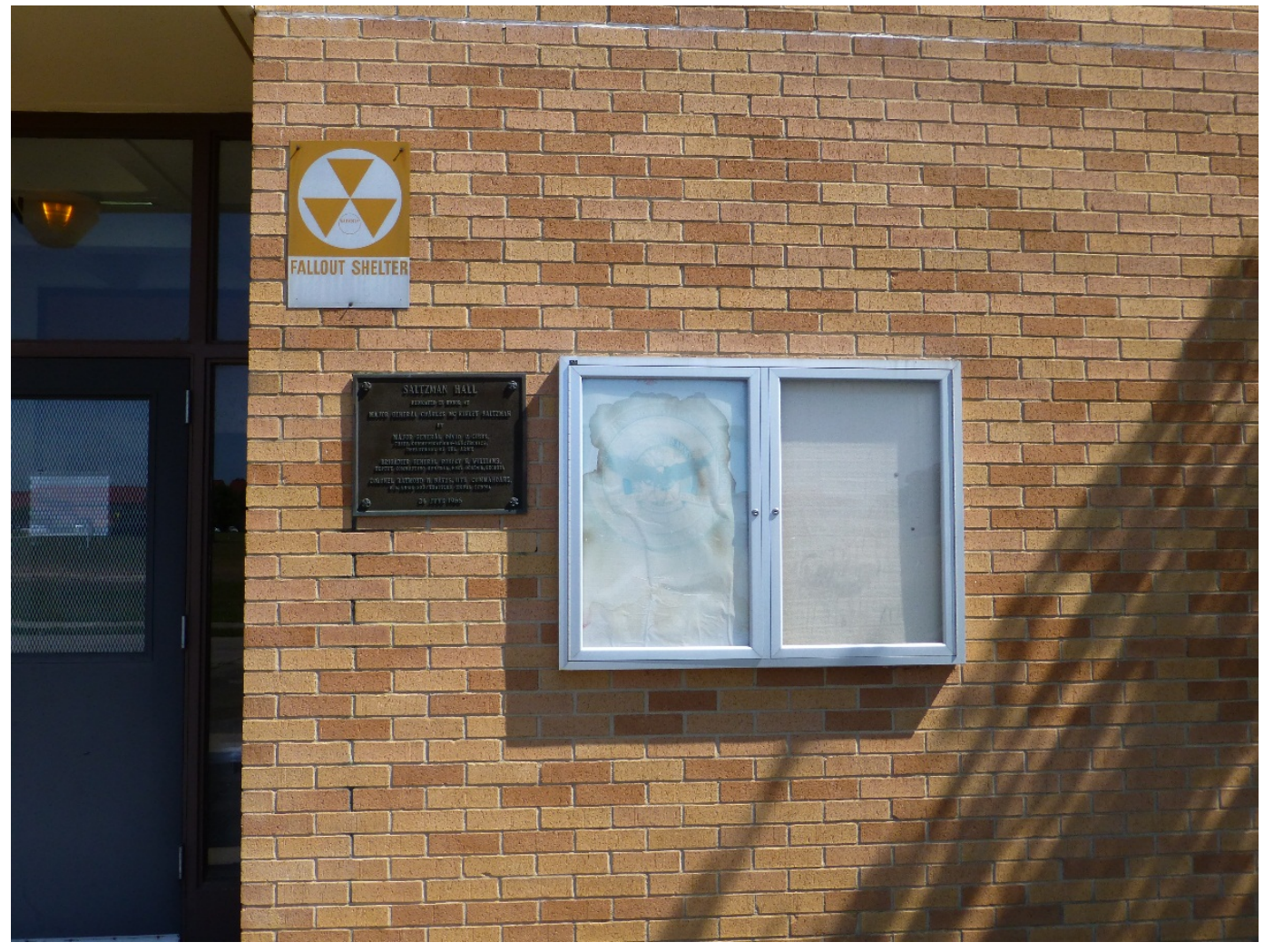

\subsubsection{Metal handrails and poured-in-place concrete retaining walls}

Metal pipe handrails highlight poured-in place concrete walls that mainly define the exterior basement access (Figure 85). For buildings that have steps to an entrance, metal pipe handrails are placed on the steps (Figure 86). Building 29808, Signal Towers, has a more extensive poured-in-place concrete wall system that curves to frame the entry into the basement level on the north side of the building (Figure 87). In addition, Building 29810, Burkhardt Hall has a more poured-in-place walls framing the driveway into the walkout basement on the north side of the building (Figure 88). 
Other metal pipe handrails are located at Building 25810, Brant Hall, near the entries. A metal balustrade is placed between the concrete column supports of the canopy structure surround Building 29808, Signal Towers (Figure 89). However, the majority of this type of railing has been removed.

Figure 85. Example of typical poured-in-place concrete retaining walls and metal handrails framing the exterior basement access points, Building 29813, Allen Hall (ERDC-CERL, 2015).

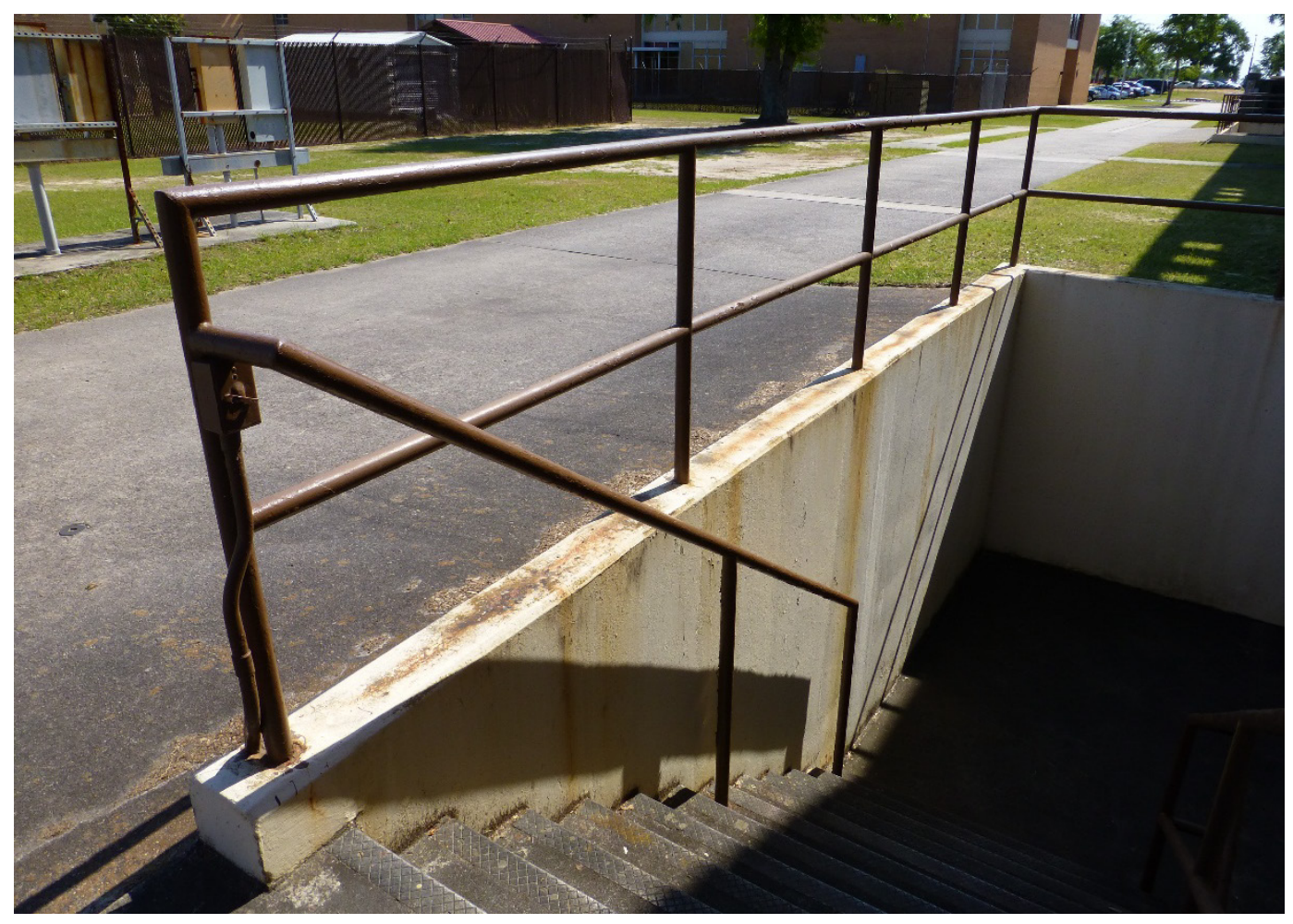


Figure 86. Example of the metal pipe handrail located near the entries for Building 25810, Brant Hall (ERDC-CERL, 2015).

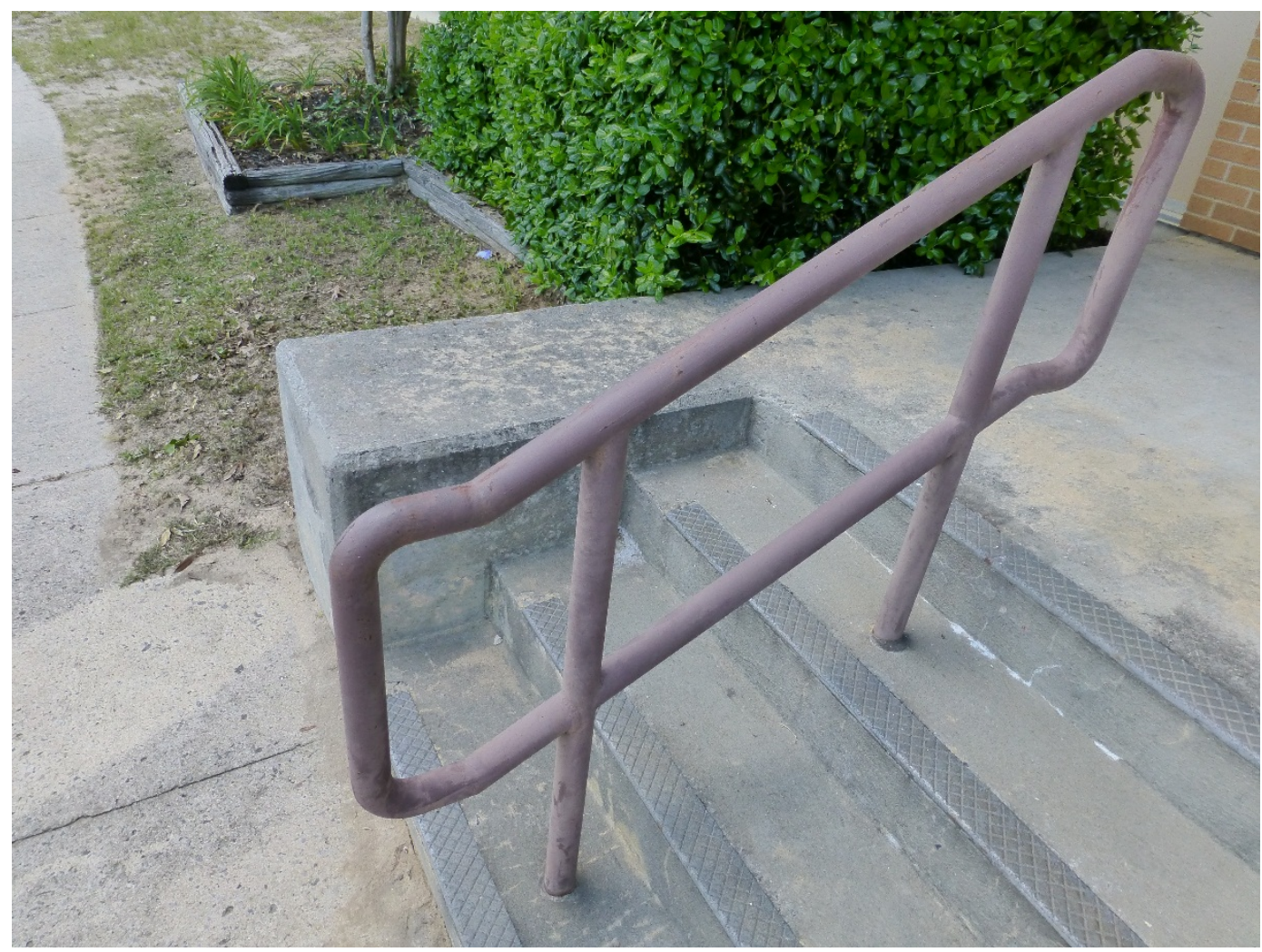

Figure 87. Curved poured-in-place concrete retaining wall system topped with metal pipe handrails, Building 29808, Signal Towers (ERDC-CERL, 2015).

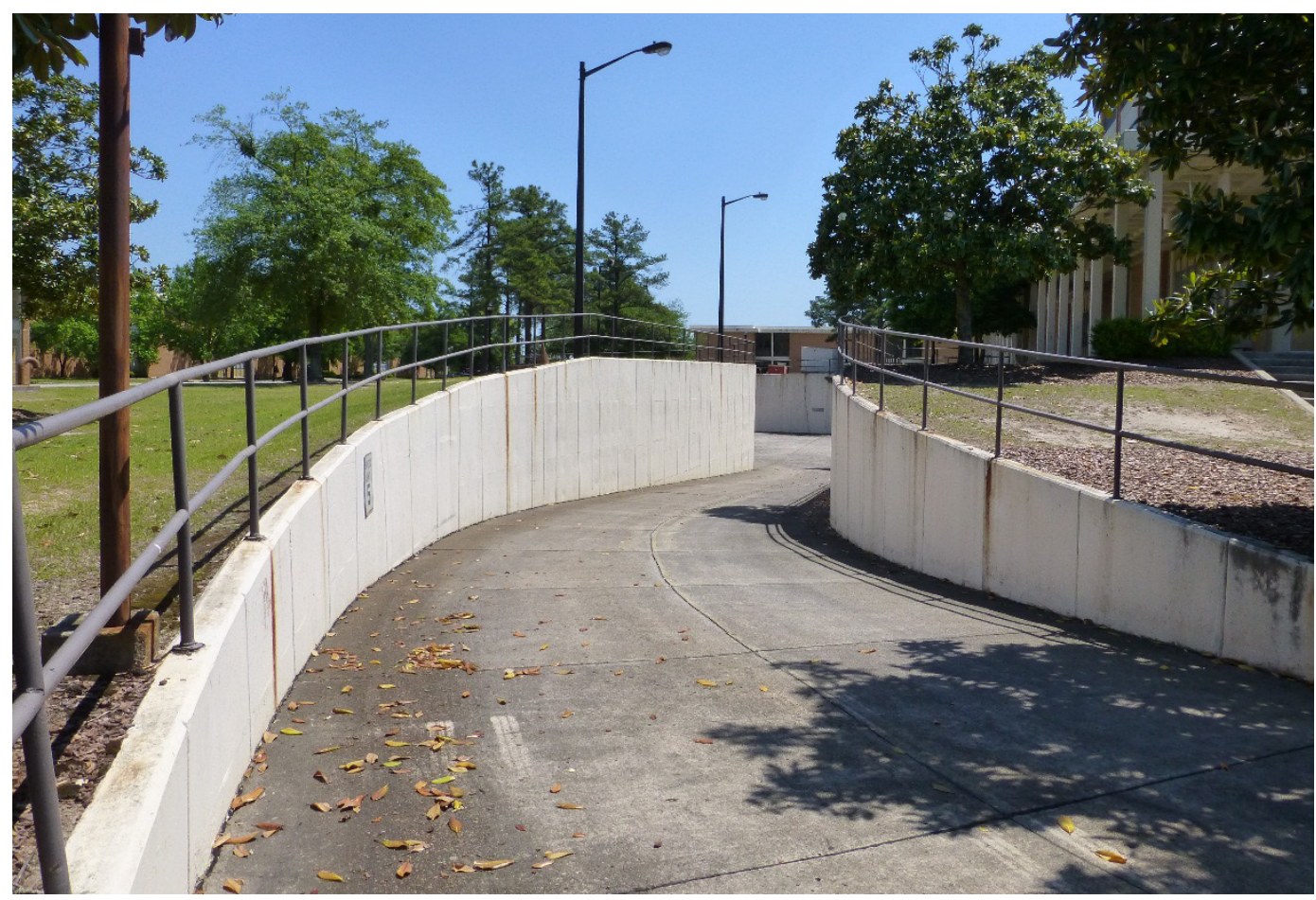


Figure 88. Poured-in-place concrete retaining walls framing driveway to walkout basement for Building 29810, Burkhardt Hall (ERDC-CERL, 2015).

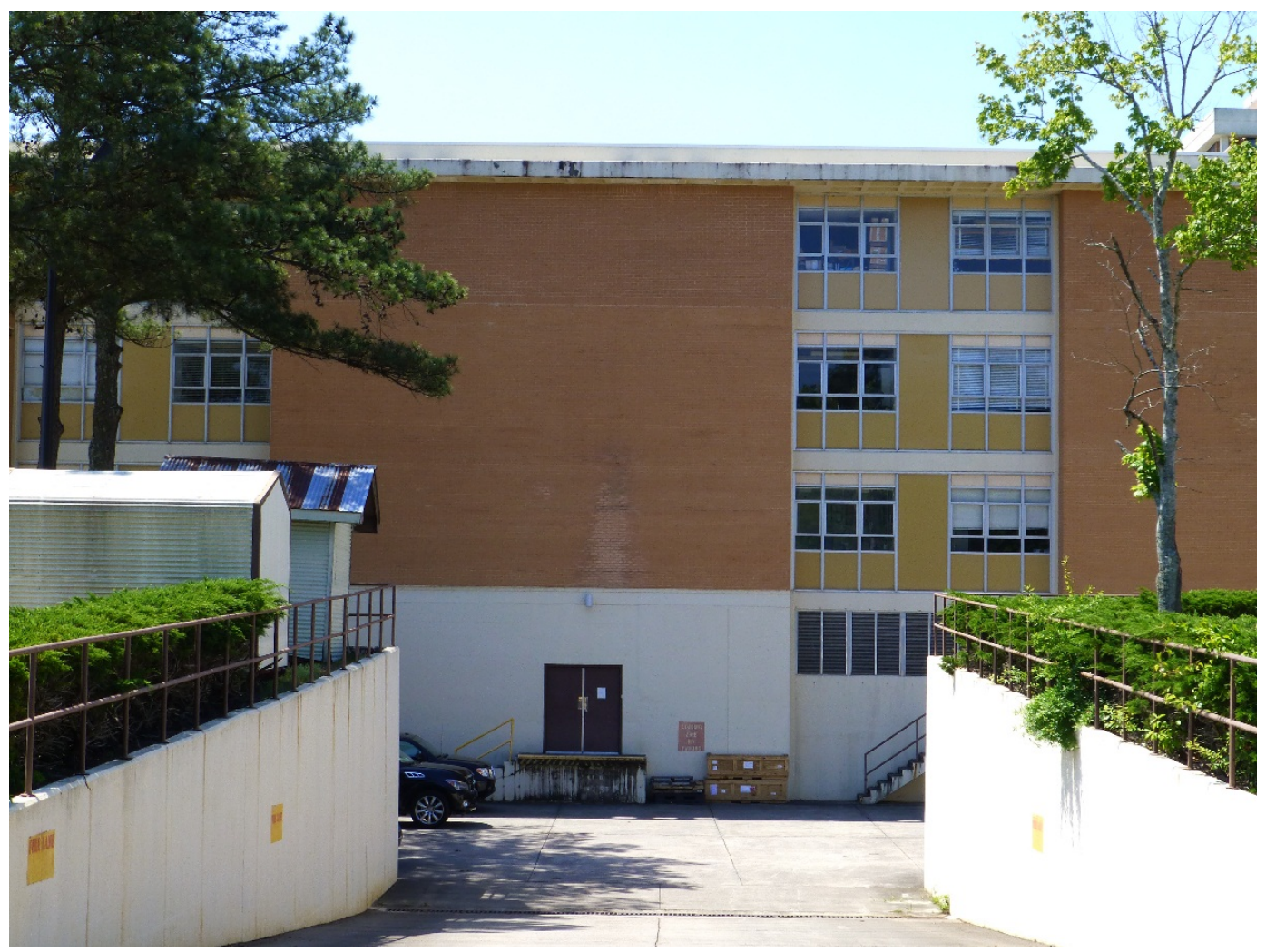

Figure 89. Metal balustrade placed between concrete supports surrounding Building 29808, Signal Towers (ERDC-CERL, 2015).

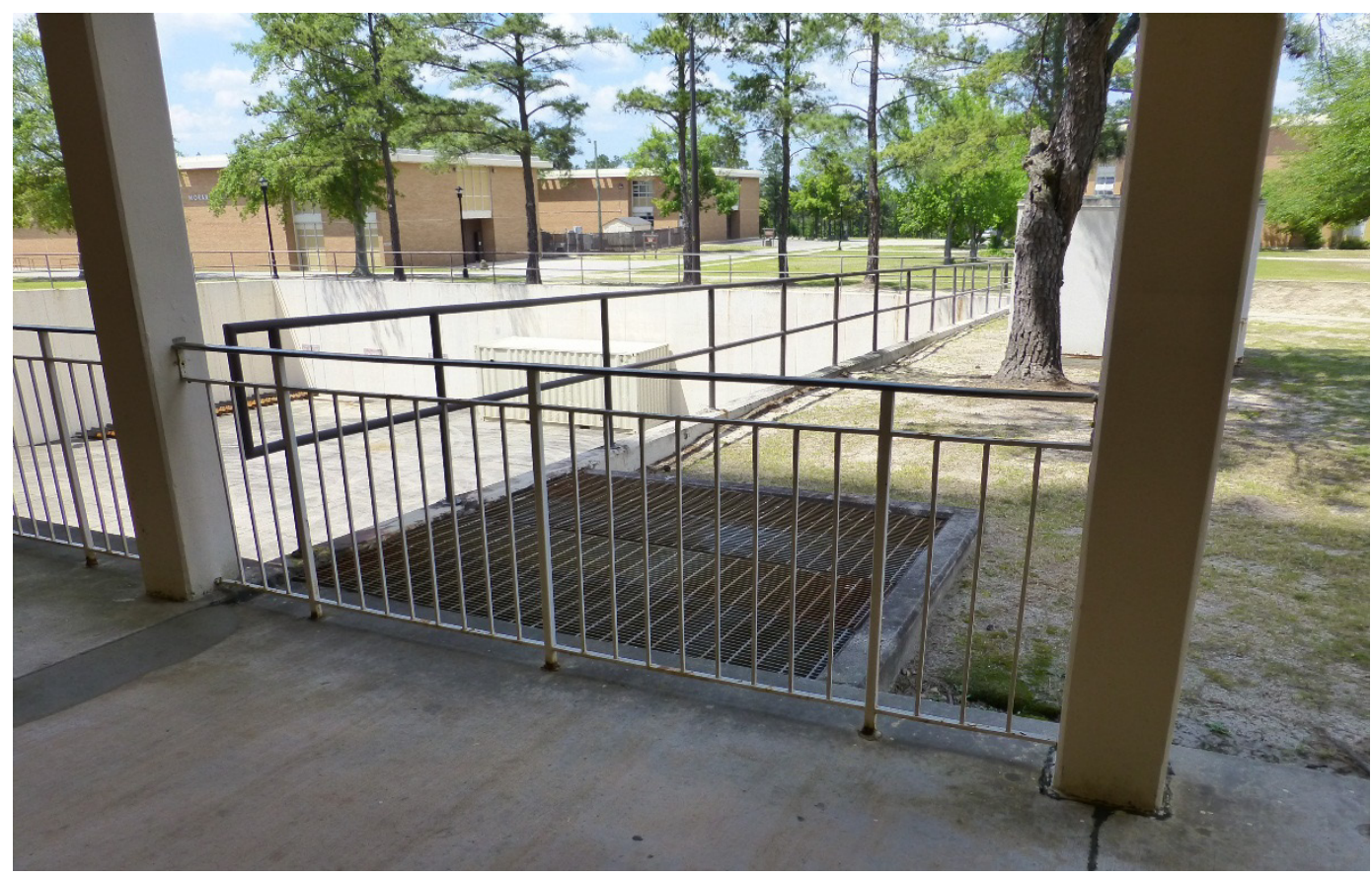




\subsubsection{Perforated brick walls}

Some of the Signal School buildings were designed with a more decorative wall into the basement-level entry points. The same type of brick was used to build these walls as the pink/yellow brick-veneer exterior walls of the buildings (Figure 90 and Figure 91). These perforated walls were located on the east and west elevations of the classroom buildings: Buildings 29809, Greely Hall; 29811, Saltzman Hall; 29813, Allen Hall; and 29817, Allison Hall.

Figure 90. Example of the decorative perforated brick wall, Building 29813, Allen Hall (ERDC-CERL, 2015).

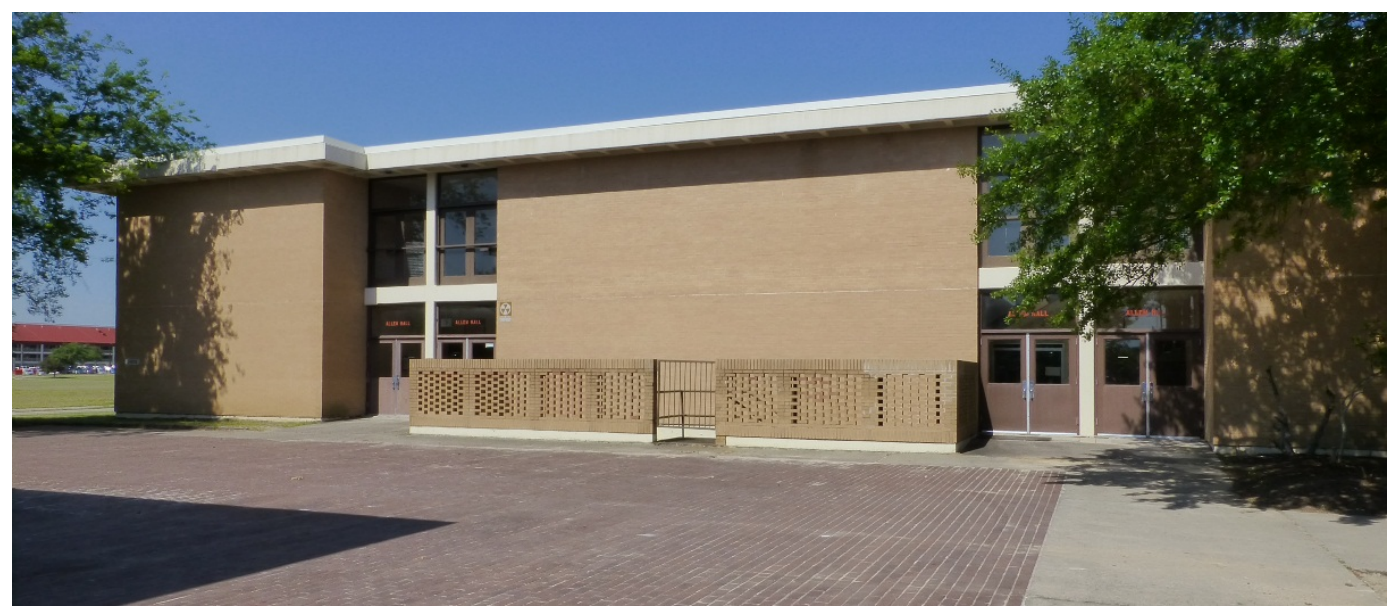

Figure 91. Close-up of the perforated brick wall showing the same type of brick used as the building's brick-veneer exterior wall, Building 29817, Allison Hall

(ERDC-CERL 2015).

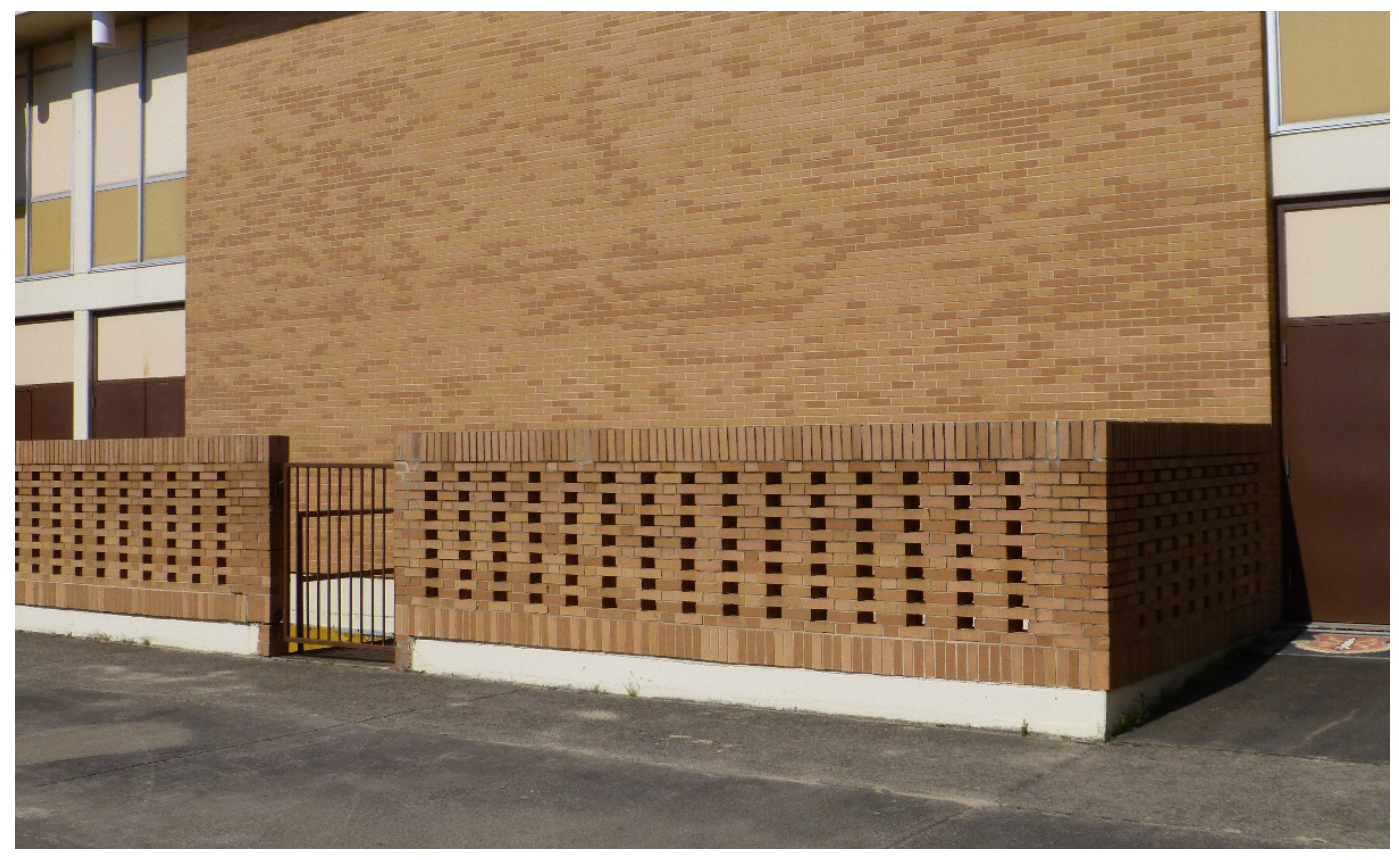




\subsubsection{Courtyards}

Four of the largest classroom buildings: 29809, Greely Hall; 29811, Saltzman Hall; 29813, Allen Hall; and 29817, Allison Hall were designed with two interior courtyards. These courtyards are square in plan and have entry points on the north and south sides. A large window bay of six windows, separated by an insulated panel, is located adjacent the metal entry doors. The east and west walls each have a window bay of six windows per floor separated by the exposed concrete structural system, creating two groups of three windows (Figure 92-Figure 98). Each courtyard had its own landscaping plan to include: vegetation both shrubbery and trees, concrete benches, brick sitting walls, and concrete planters. A brick paved area is located in front of the entry doors. Currently, most of the courtyards are covered with gravel infill.

Figure 92. Interior view of the west courtyard in Building 29813, Allen Hall, showing the window bays and parallel brick sitting walls. Note the absence of vegetation that has been removed and replaced with gravel infill (ERDC-CERL, 2015).

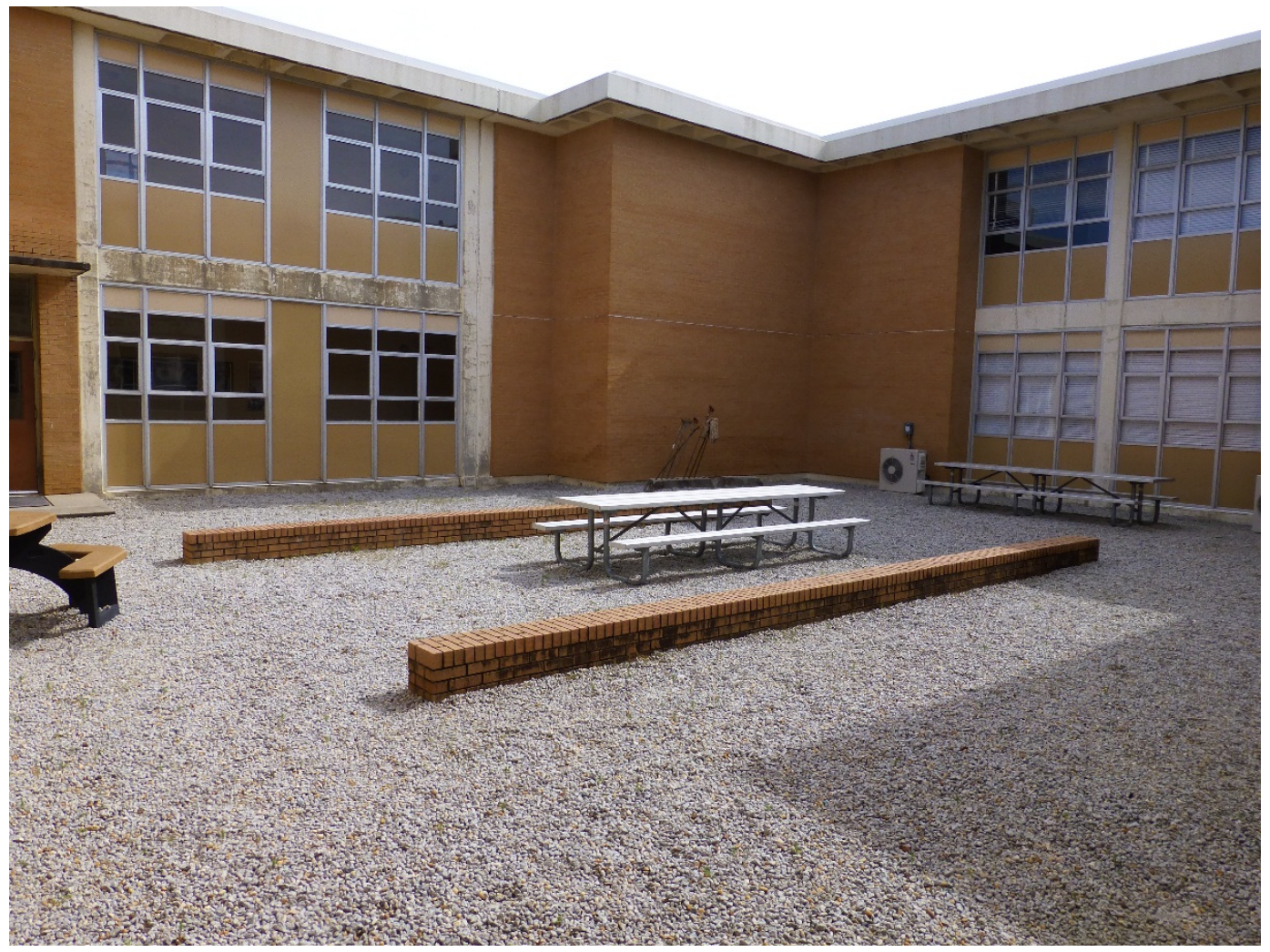


Figure 93. Interior view of the east courtyard in Building 29813, Allen Hall, showing the designed landscape of the four trees placed within the courtyard

(ERDC-CERL 2015).

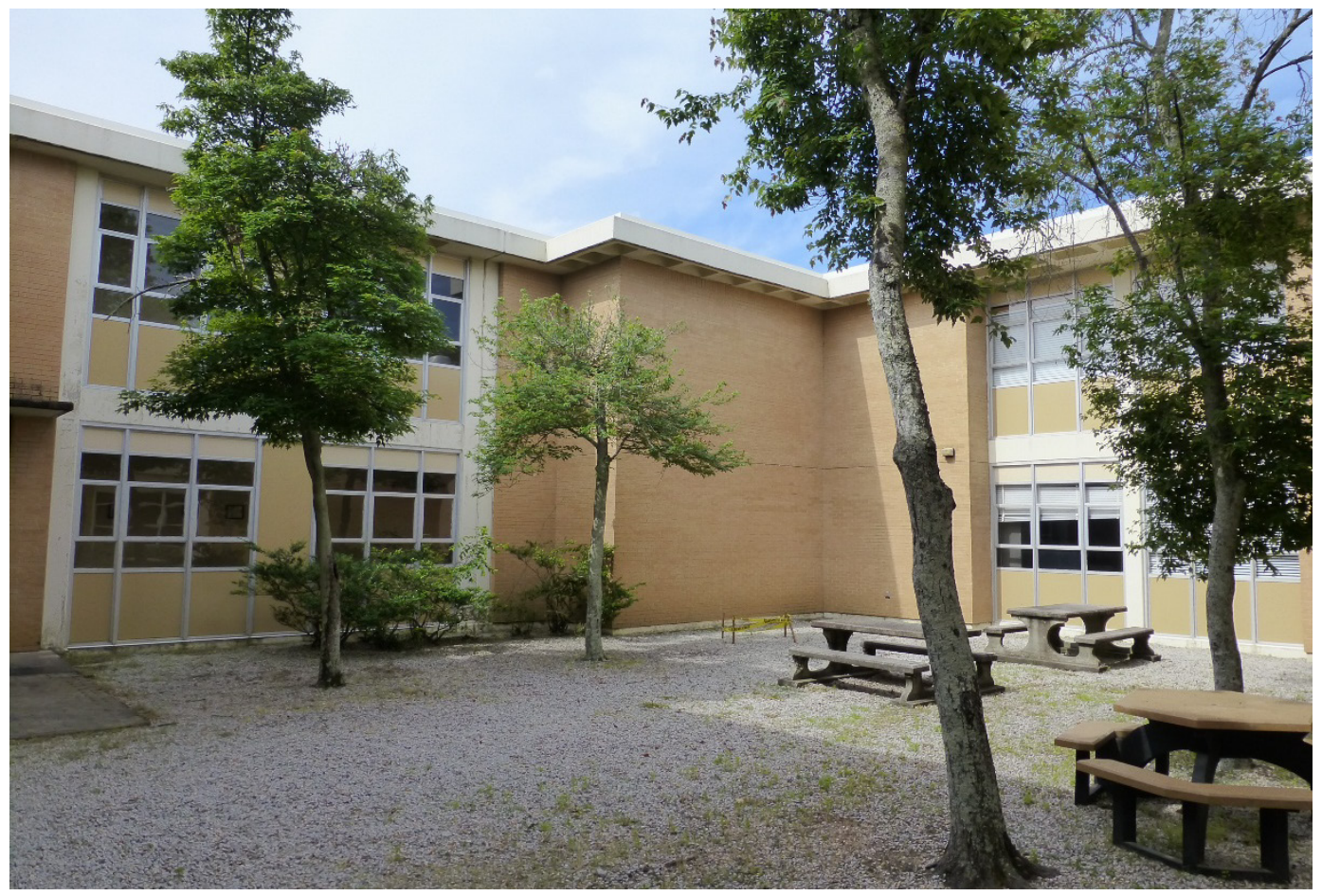

Figure 94. Interior view of the east courtyard in Building 29813, Allen Hall, showing the designed landscape of the four trees placed within the courtyard

(ERDC-CERL 2015).

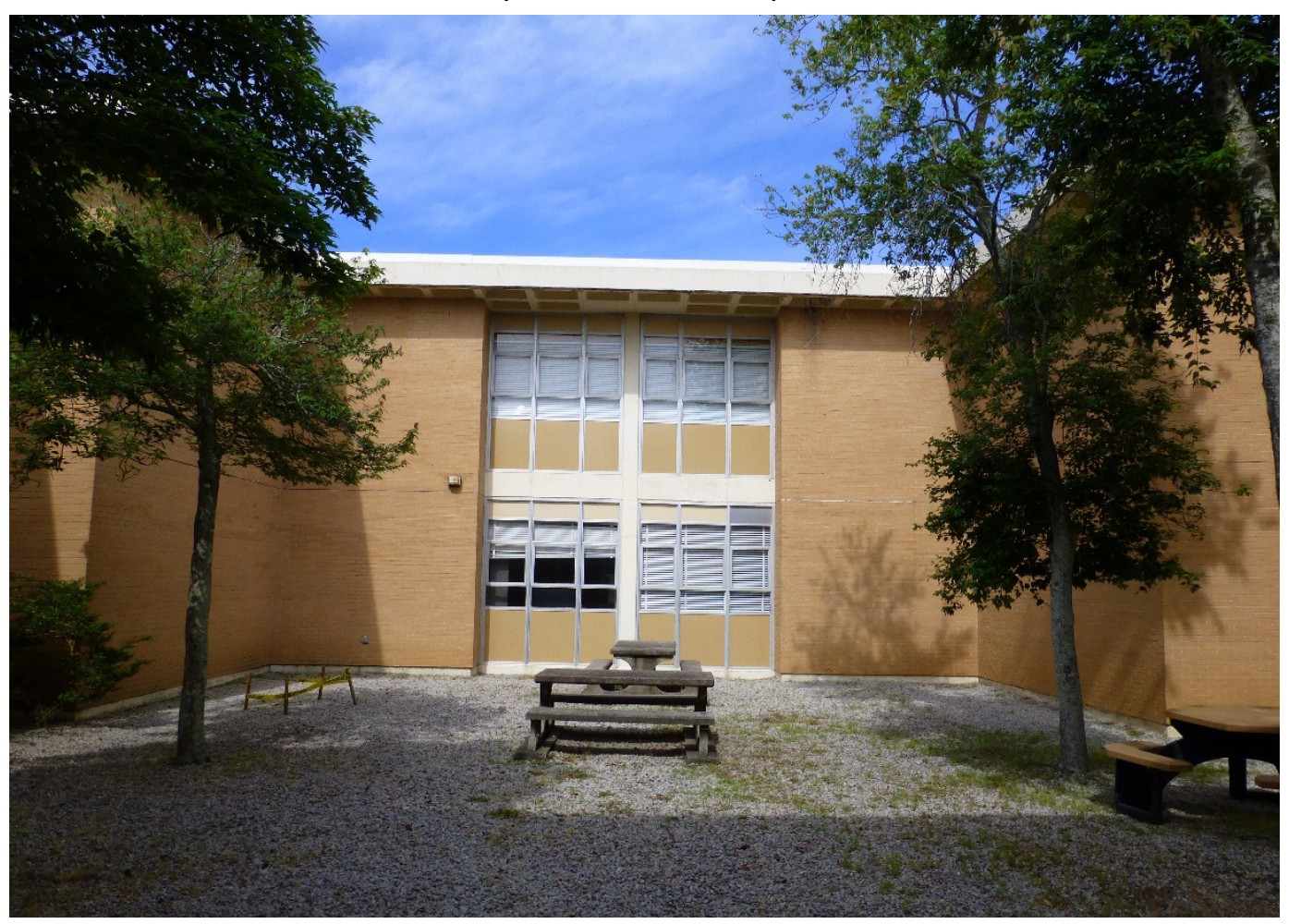


Figure 95. Interior view of the west courtyard in Building 29809, Greely Hall, showing the designed landscape plan of the trees and the curved brick-sitting wall (ERDC-CERL, 2015).

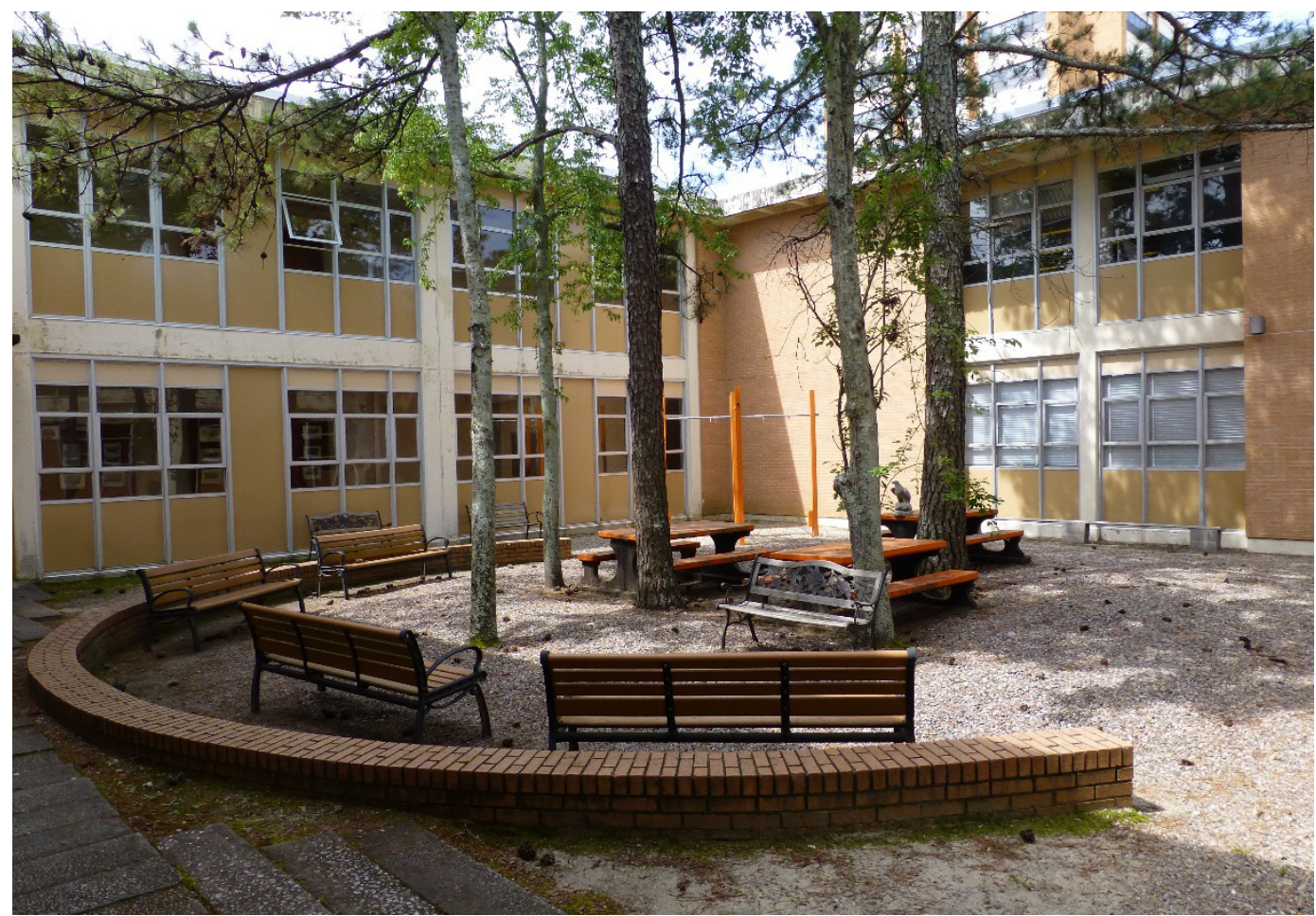

Figure 96. Interior view of the east courtyard in Building 29809, Greely Hall, showing the designed landscape plan of the trees and the brick-sitting wall

(ERDC-CERL, 2015).

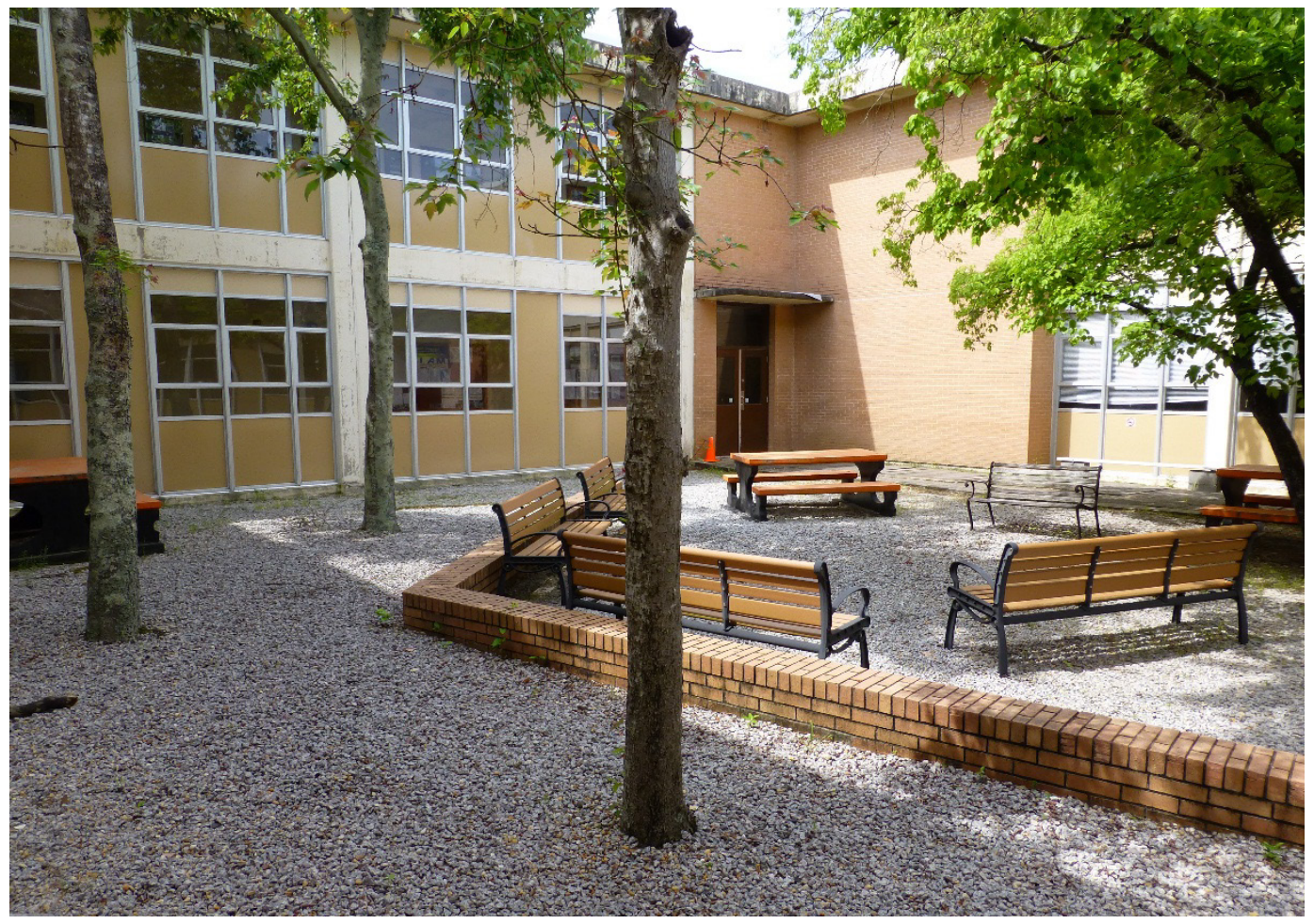


Figure 97. Brick paved area located in front of a courtyard entry (ERDC-CERL, 2015).

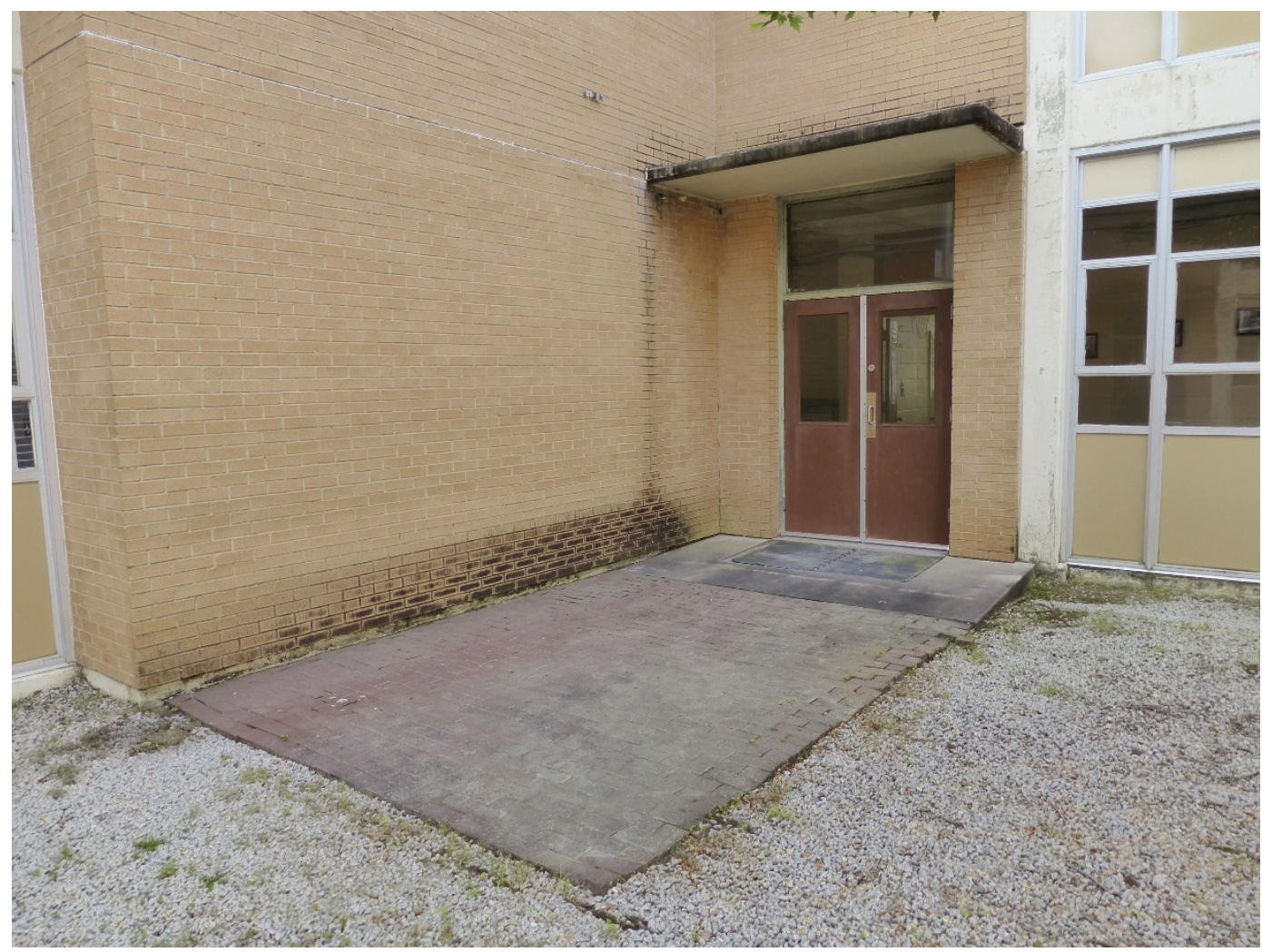

Figure 98. Example of the original concrete bench located in most of the courtyards (ERDC-CERL, 2015).

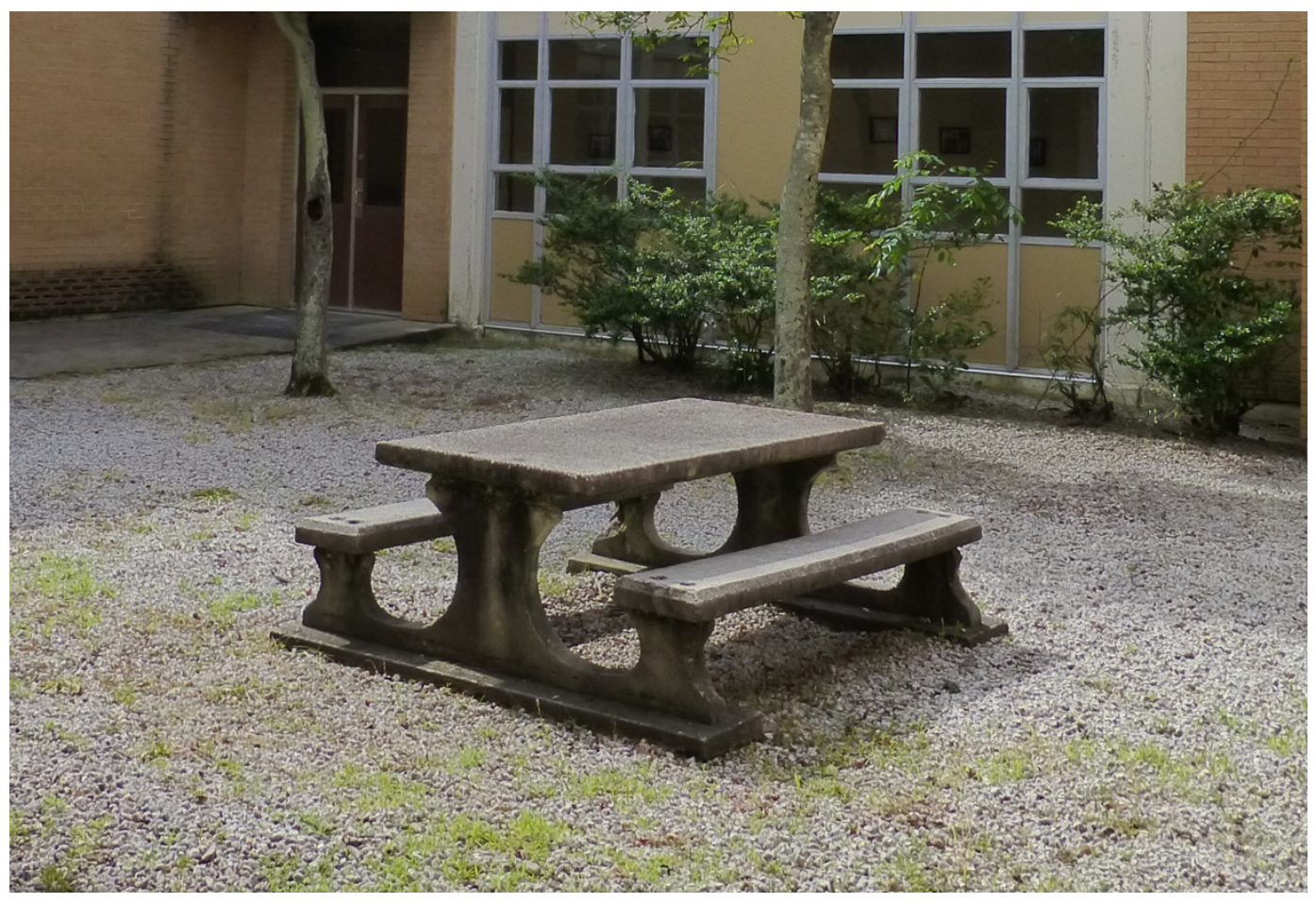




\subsubsection{Landscaping}

A simple landscaping scheme was developed for the entire Signal School Campus, with most of the landscaped elements located between the buildings and the large open area, which was mostly grass (Figure 99). Generally, small trees and shrubs lined the edge of the sidewalk, which was closest to a building wall (Figure 100 and Figure 101), with a more complicated planting plan for areas at the entrances of buildings (Figure 102 and Figure 103) and areas directly between building entrances (Figure 104Figure 106).

Figure 99. Looking west at the open space of the campus plan, with few of the original trees intact (ERDC-CERL, 2015).

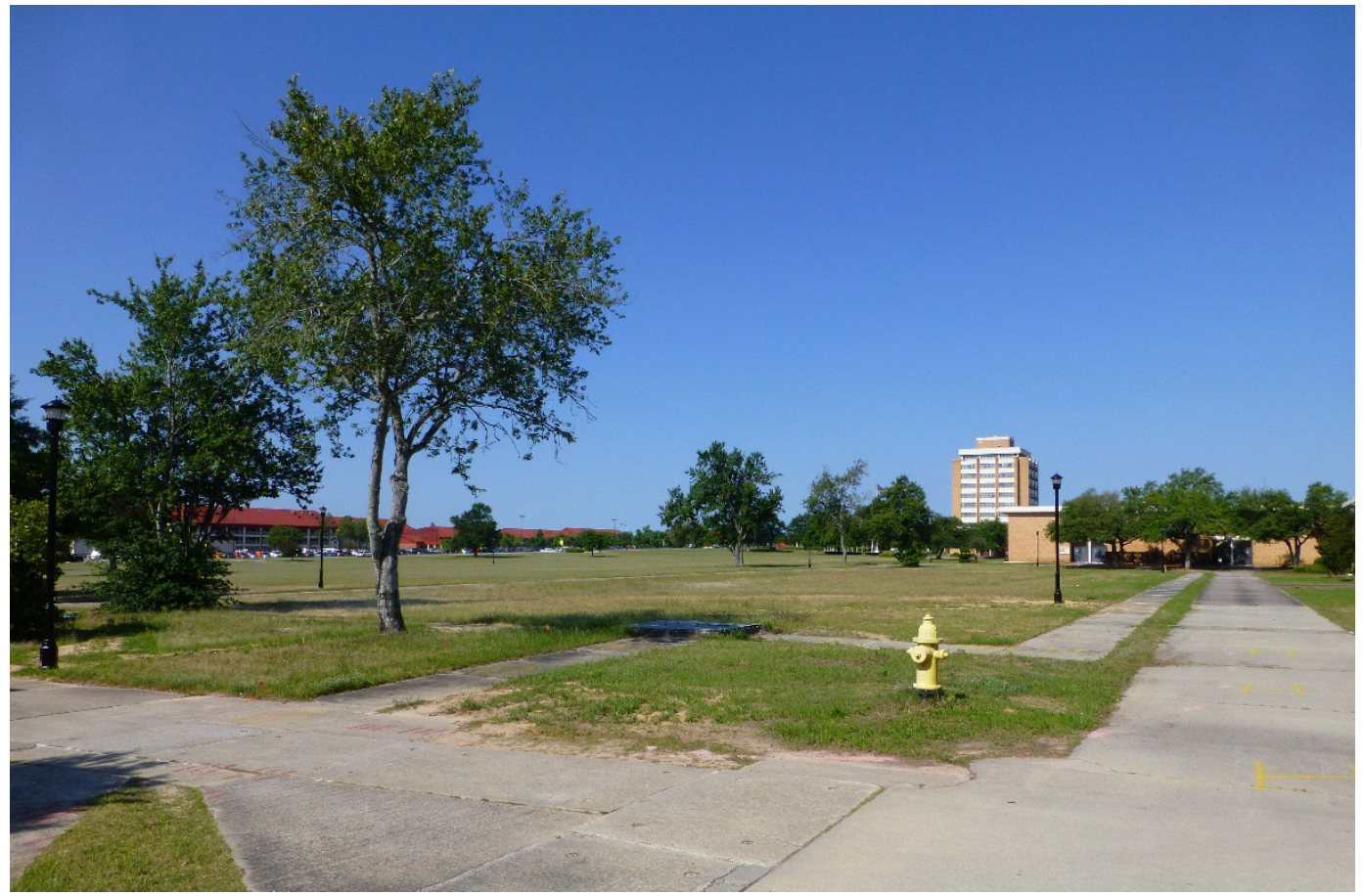


Figure 100. Example of trees flanking either side of a window bay, Building 29813, Allen Hall (ERDC-CERL, 2015).

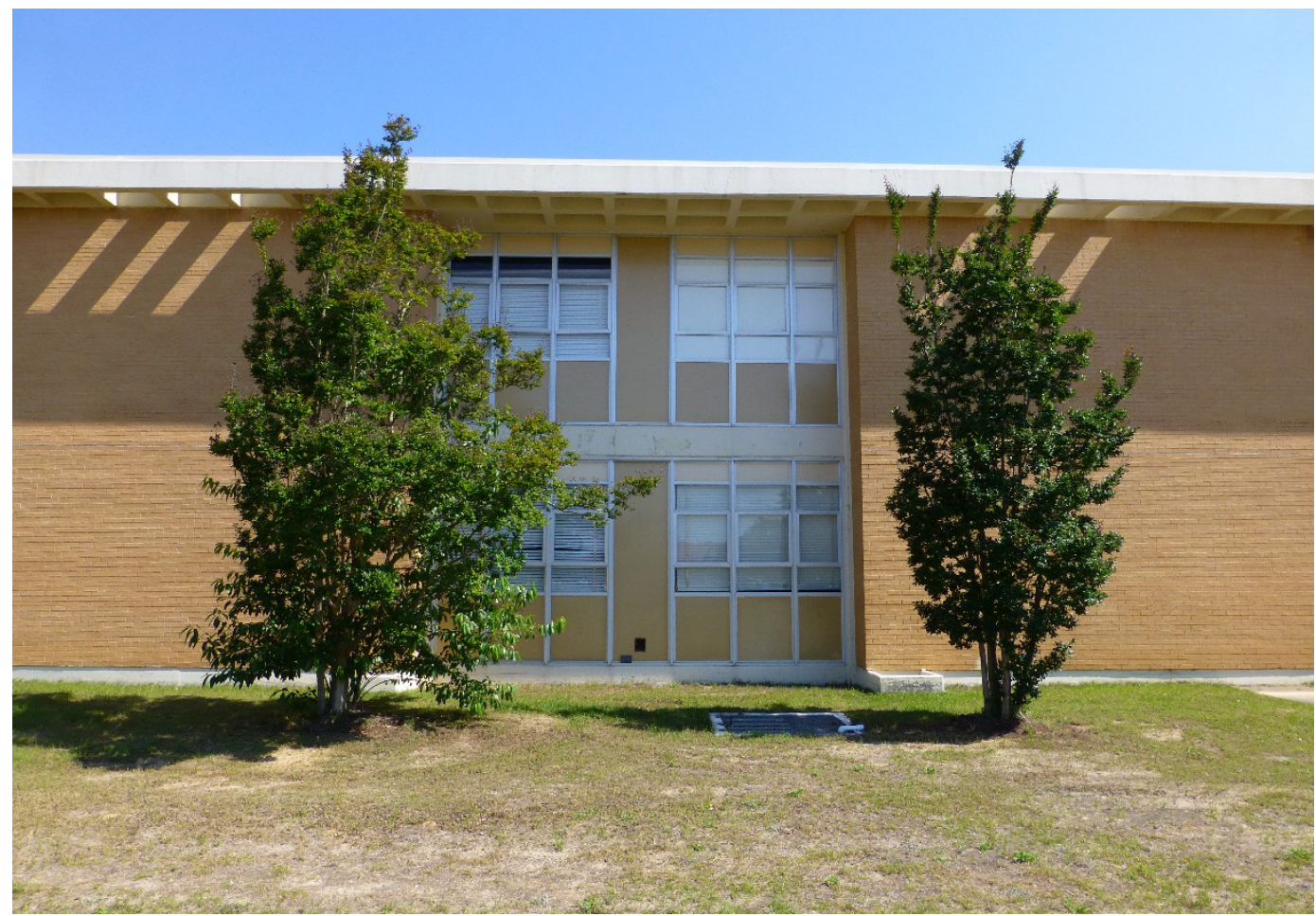

Figure 101. Landscaping between Building 29810, Burkhardt Hall, and the sidewalk (ERDC-CERL, 2015).

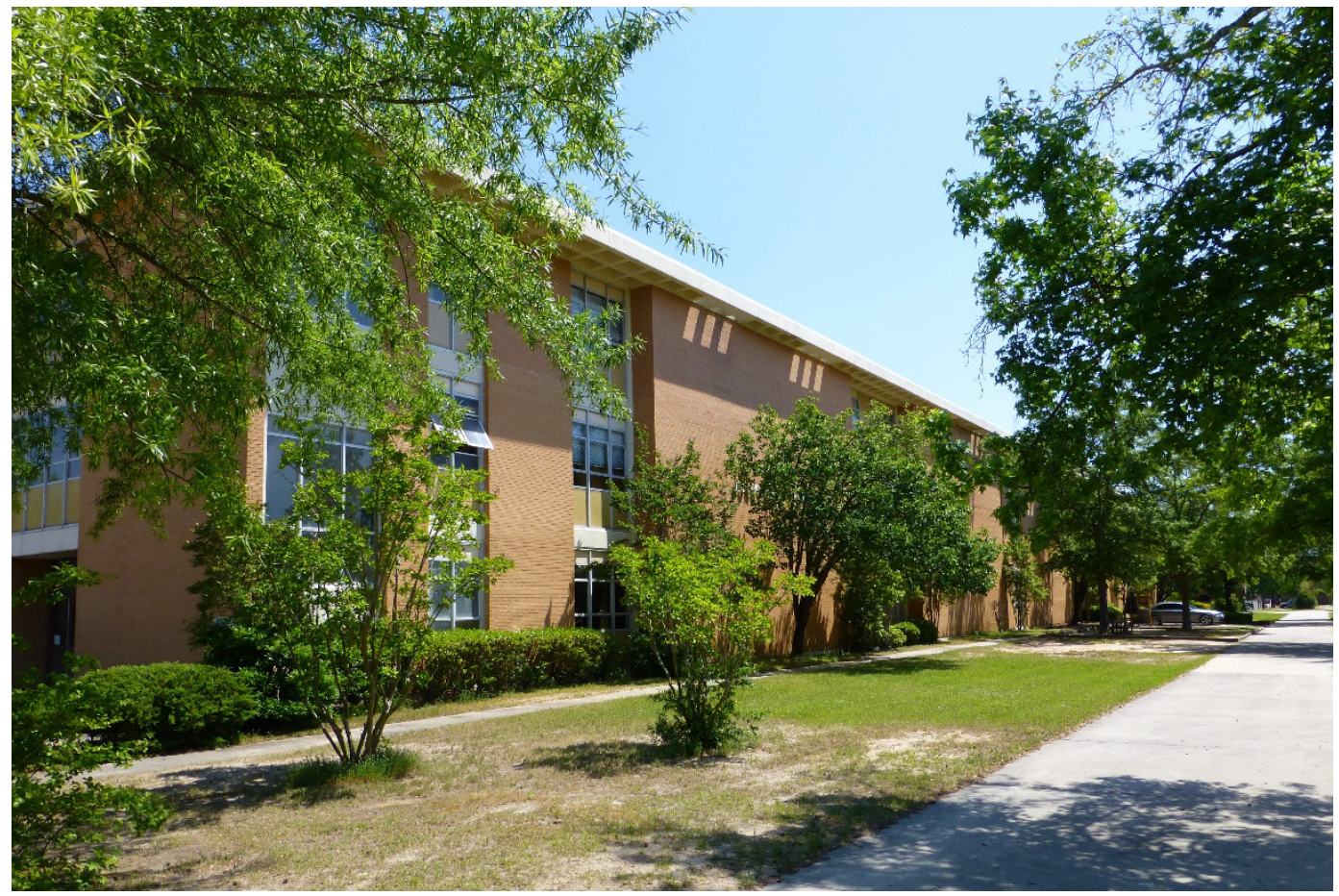


Figure 102. South entry of Building 29811, Saltzman Hall, with two original crabapple trees flanking either side of the entry (ERDC-CERL, 2015).

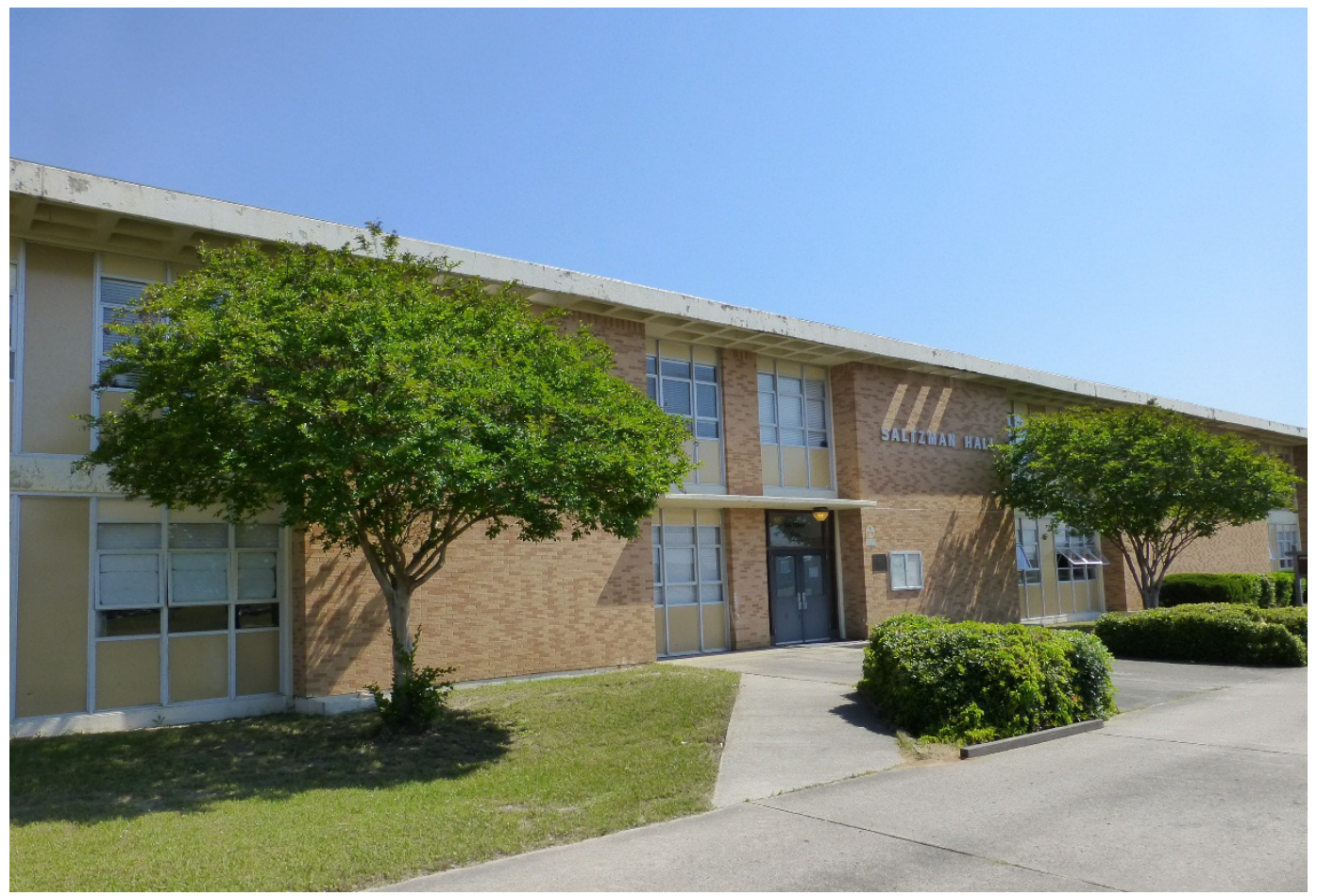

Figure 103. American Holly bushes lining the sidewalk leading to the entry on the south elevation of Building 29801, Nelson Hall (ERDC-CERL, 2015).

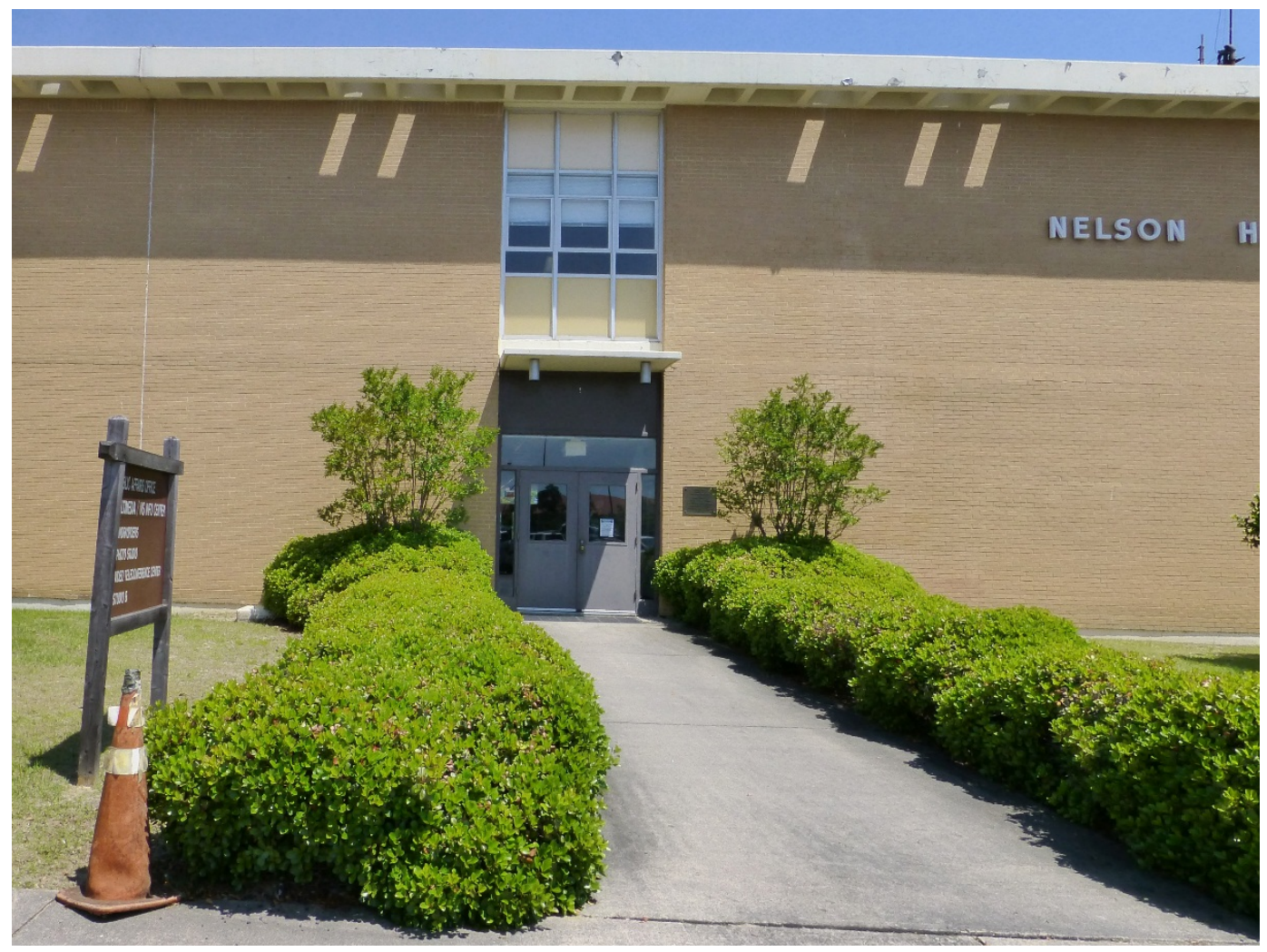


Figure 104. East side of Building 29811, Saltzman Hall, the most intact brick plaza with the four original oak trees (ERDC-CERL, 2015).

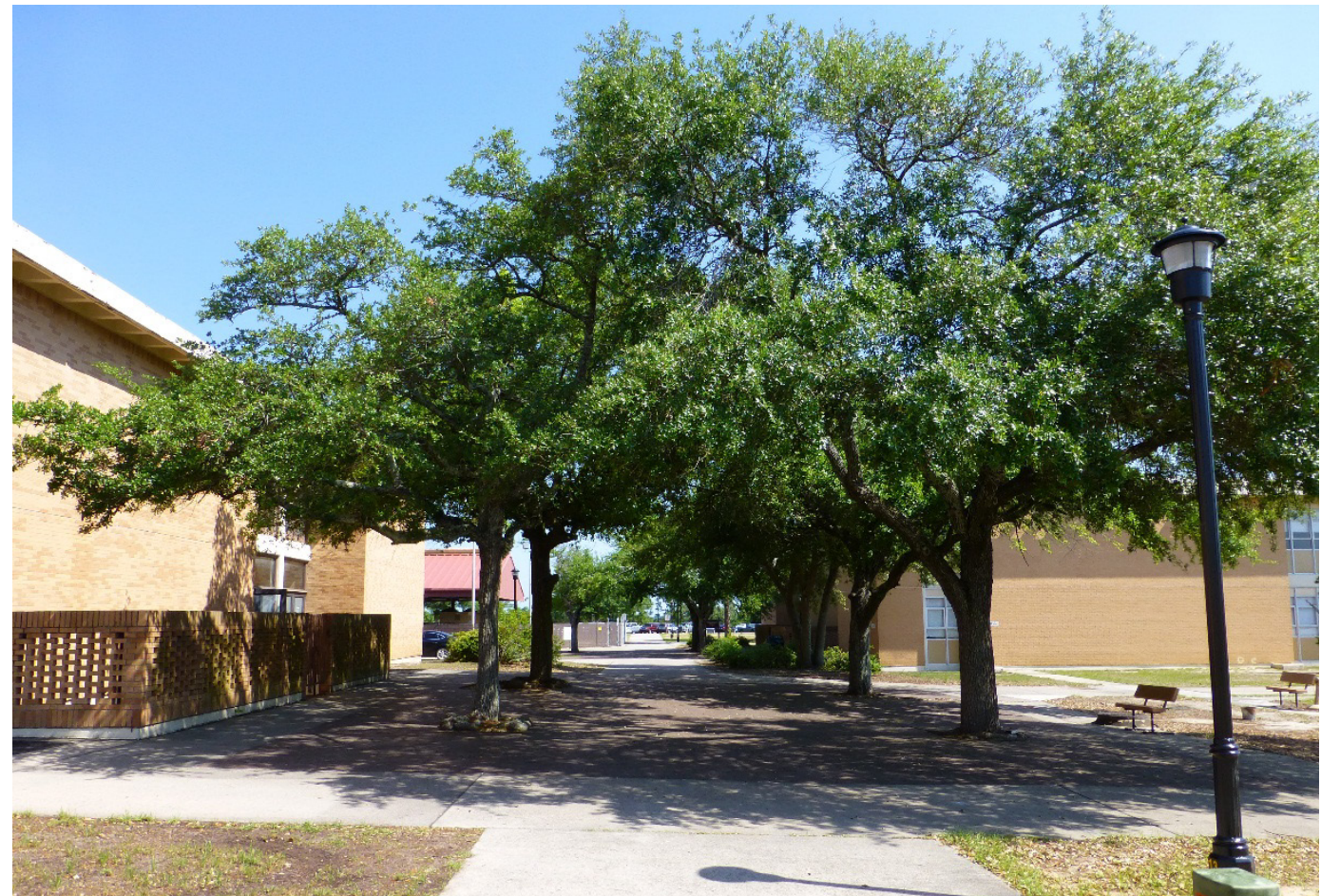

Figure 105. East side of Building 29813, Allen Hall, looking at the brick plaza where all the original trees have been removed (ERDC-CERL, 2015).

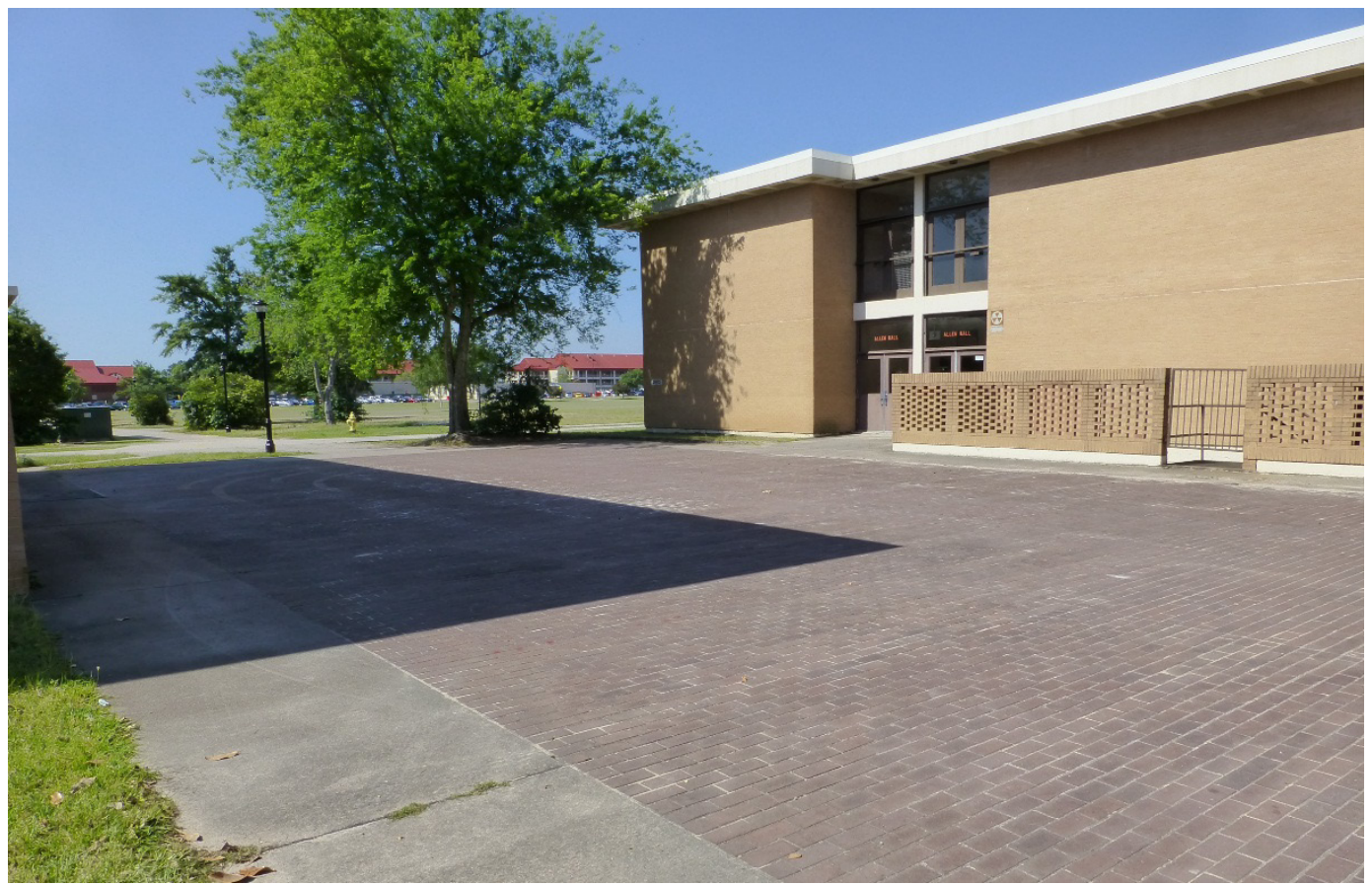


Figure 106. West side of Building 29813, Allen Hall, looking at the brick plaza and three trees (ERDC-CERL, 2015).

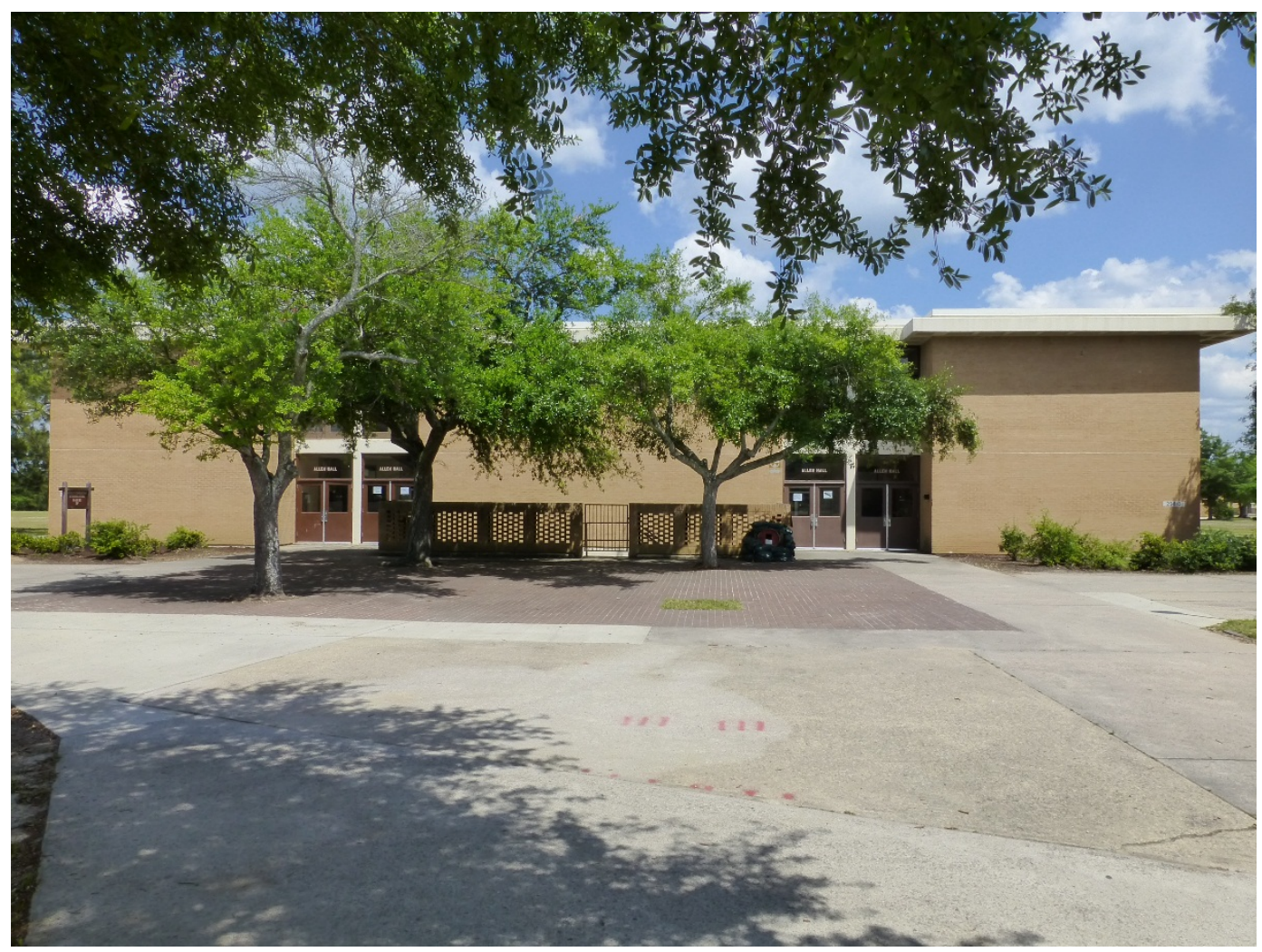

The area surrounding Buildings 29805, Alexander/Olmsted Halls; 29807, Conrad Hall; and 29808, Signal Towers; the west parking lot; and the embankment between the parking lot and Building 25810, Brant Hall, is a designed landscape offering paved areas between the main buildings (Figure 107) and landscaped areas buffering the buildings from the parking lot (Figure 108). There is a large paved plaza with multiple flagpoles surrounded by trees on the east side of the administration buildings (Figure 109-Figure 110). The landscaping plan did not have this area for flagpoles, but the plan does show some large trees between the buildings and the large grassy area (refer to Figure 16). Since the west landscape plan dated 1966 is distorted and hard to read, it cannot be determined where architect Aeck intended a flagpole to be located.

An area to the east of Building 29815 contains a "rock art" feature that was placed there in the last few years (Figure 111). South of this feature is a grouping of trees in their original configuration. 
Figure 107. Designed brick plaza that connects the main administration buildings together, Buildings 29805, Alexander Hall/OImsted Hall; 29807, Conrad Hall; and 29808, Signal Towers; and the concrete planter bench located in the middle of the plaza (ERDC-CERL, 2015).

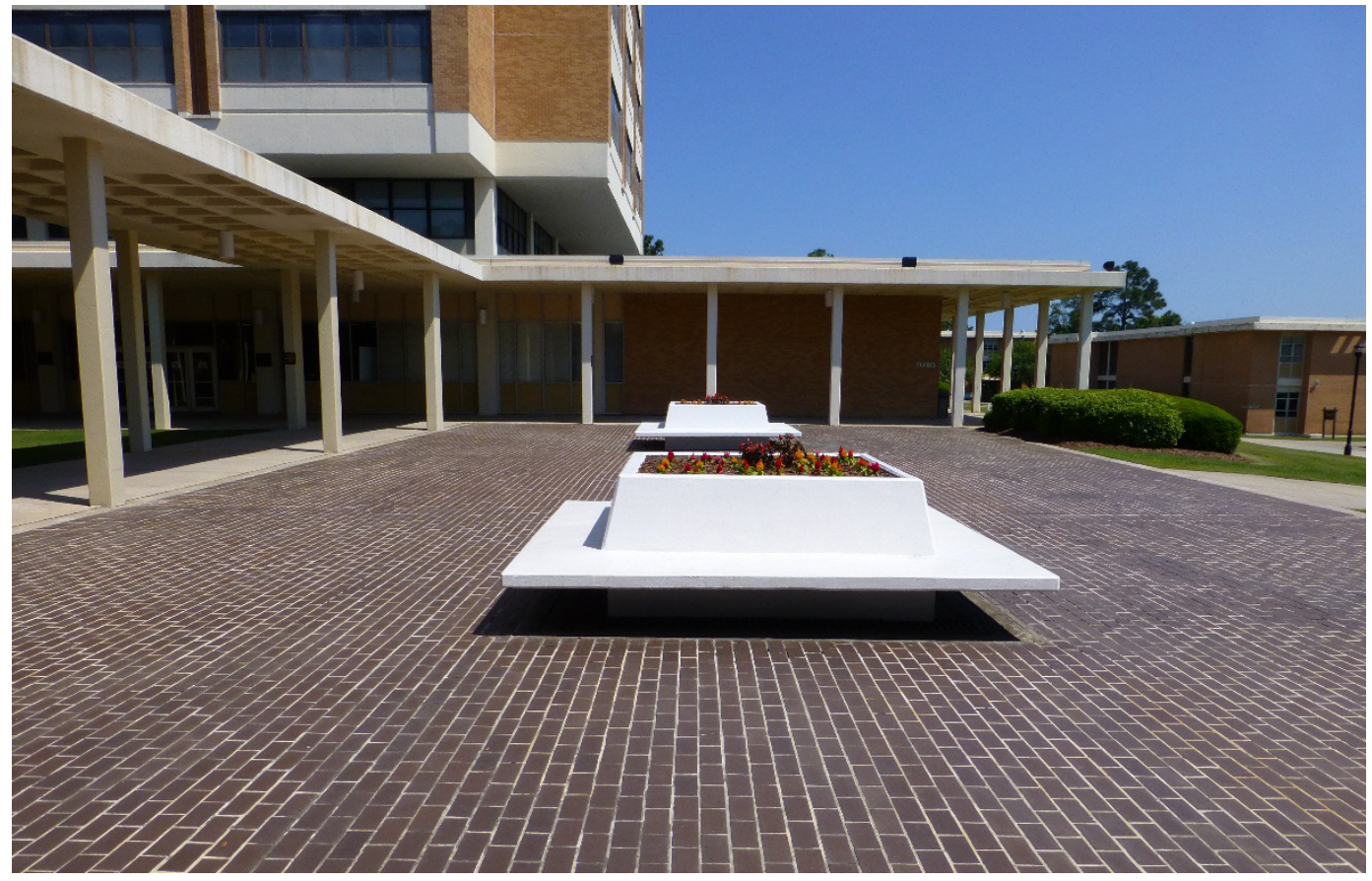

Figure 108. Crepe Myrtle is planted at the center of Dwarf Yaupon Holly shrubs which line the east and west sides of the administration area including Buildings 29805, Alexander/OImsted Halls; 29807, Museum (Conrad Hall); and 29808, Signal Towers (ERDC-CERL, 2015).

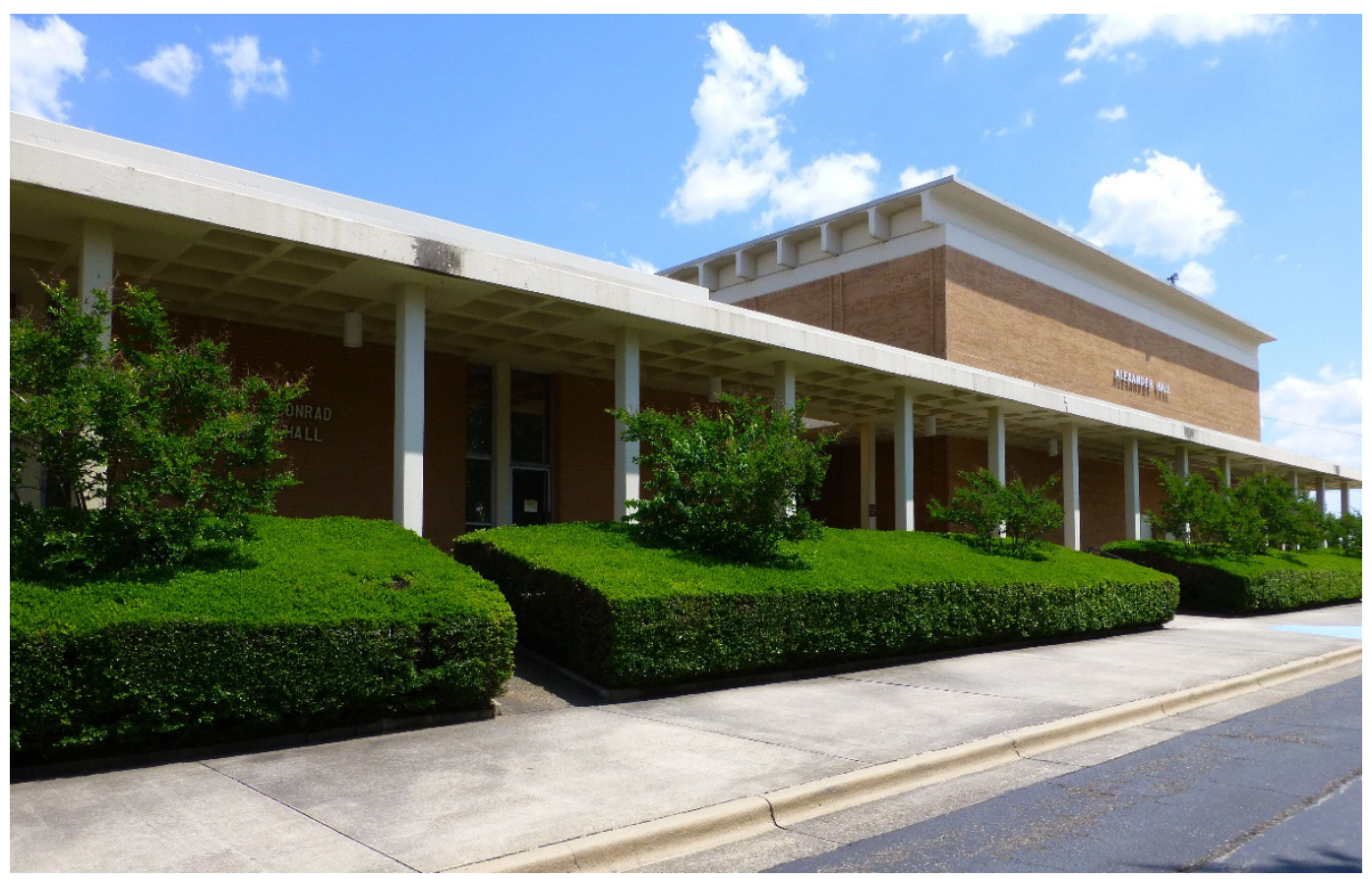


Figure 109. Looking east from the brick plaza at the administration area toward the flagpole and the openness of the campus plan, dotted with few of the original trees (ERDC-CERL, 2015).

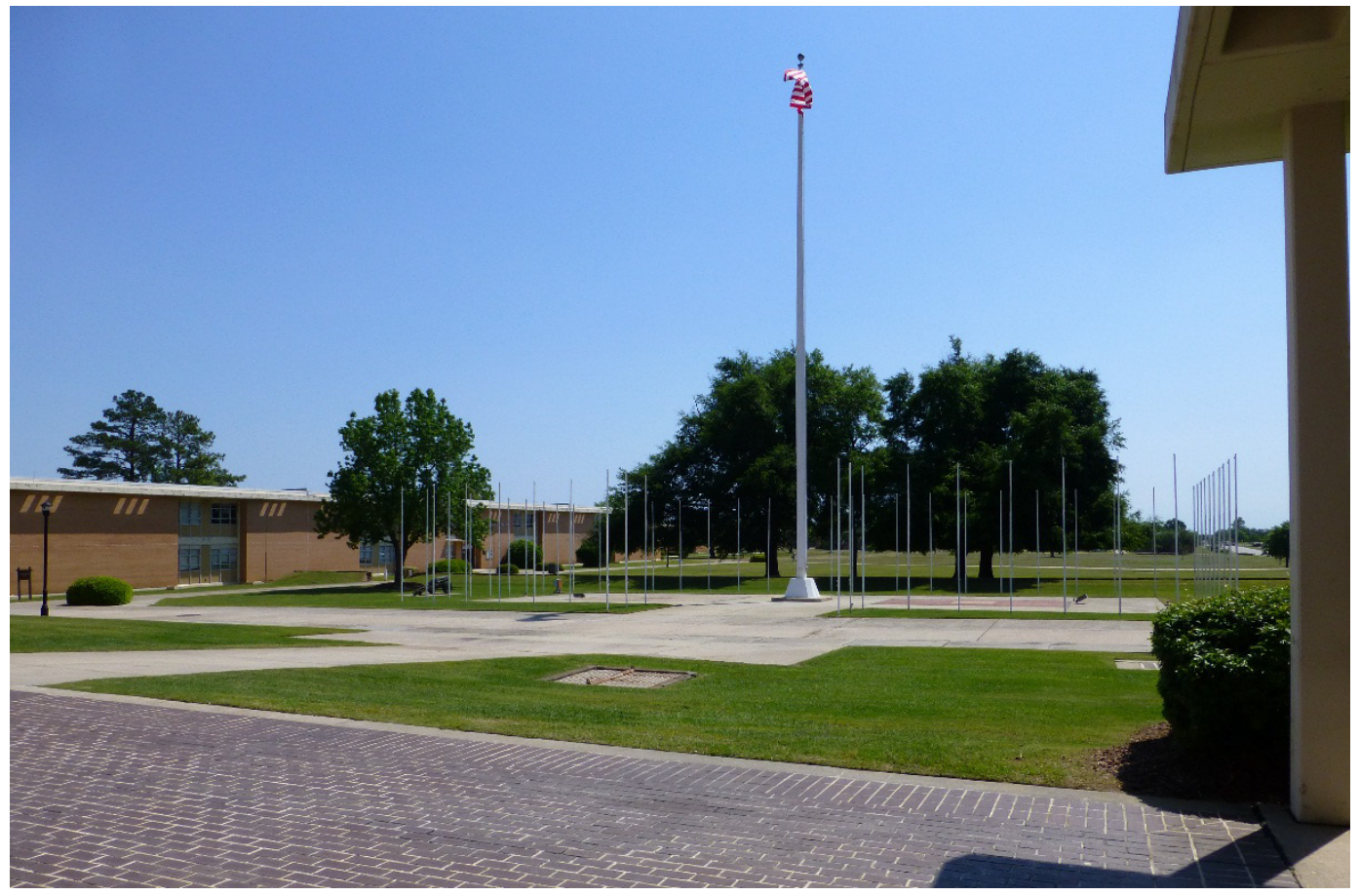

Figure 110. While trees can be found on the landscaping plan from 1966, this large flag plaza is not present on that plan (ERDC-CERL 2015).

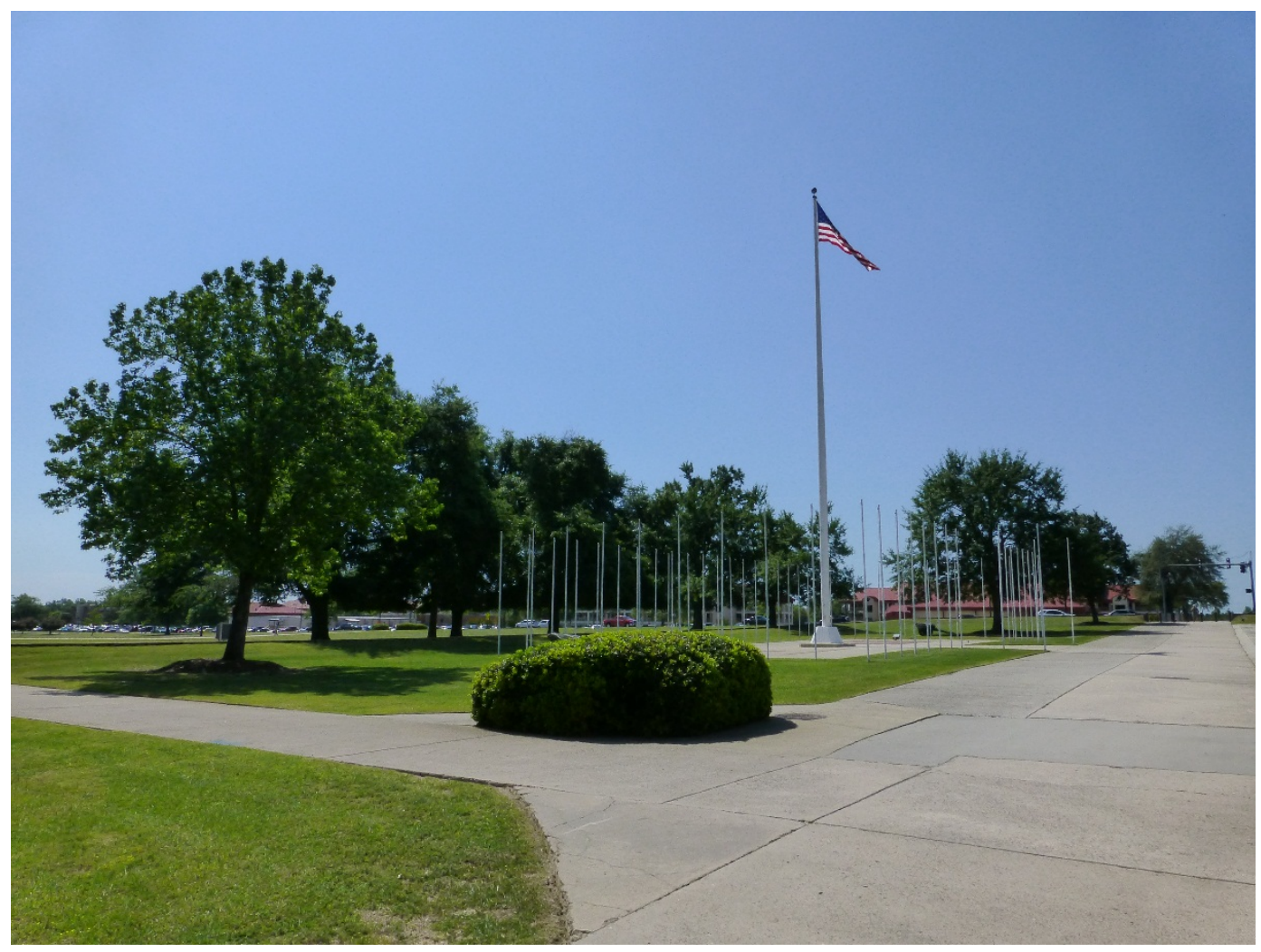


Figure 111. Group of trees located just east of Building 29815 on the east side of the open campus plan (ERDC-CERL, 2015).

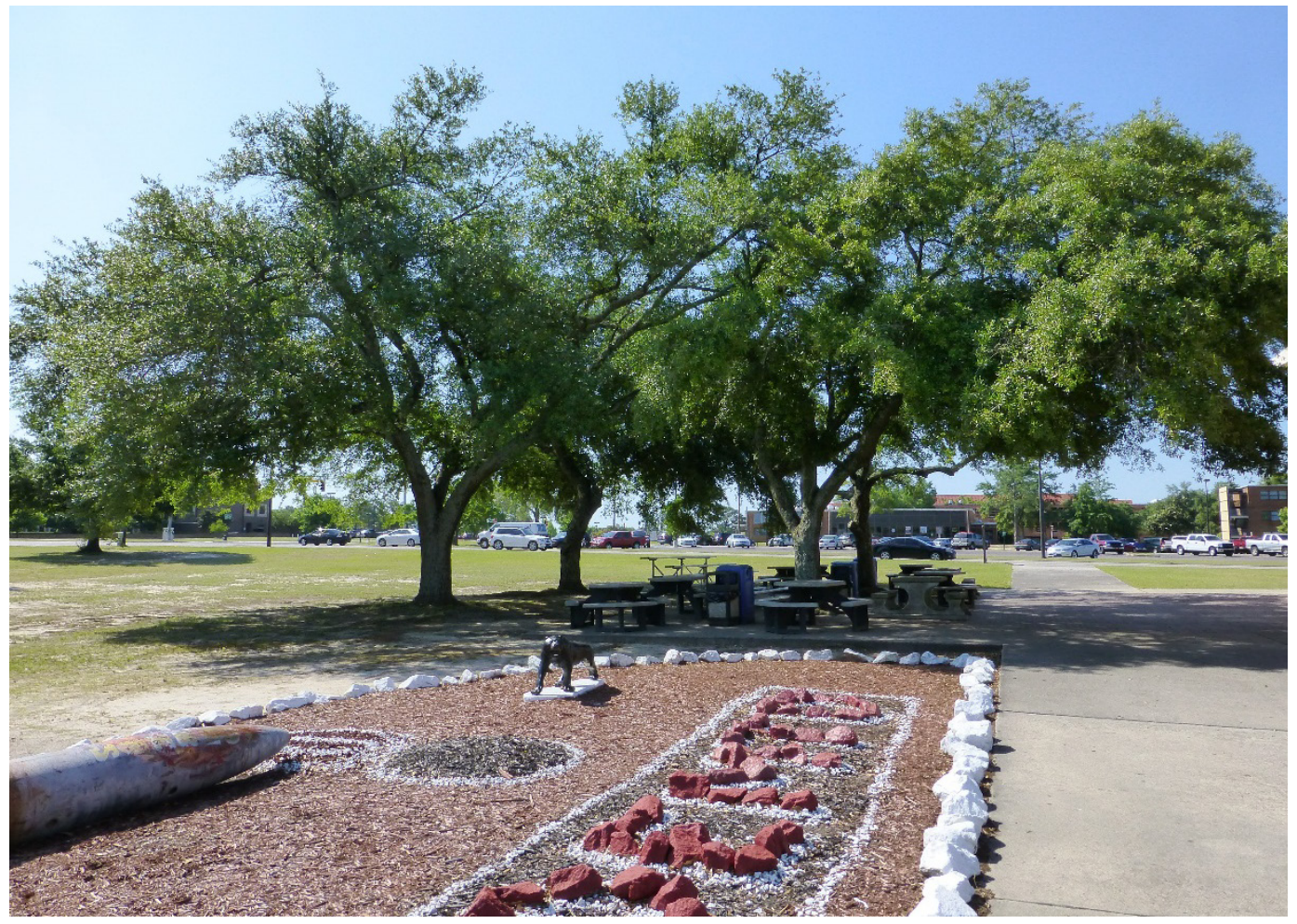

\subsubsection{Relationship to other buildings within campus}

The master plan for the school had a series of classroom buildings surrounding a grassy open area that fronted on Chamberlain Avenue. The buildings north of the grassy area are placed in regular order (Figure 112Figure 114). The open area was capped on the west by the tall headquarters Building 29808, Signal Towers (Figure 115 and Figure 116).

Figure 112. View looking west with Building 29816, Fisher Hall, on the left and Building 29817, Allison Hall, on the right (ERDC-CERL, 2015).

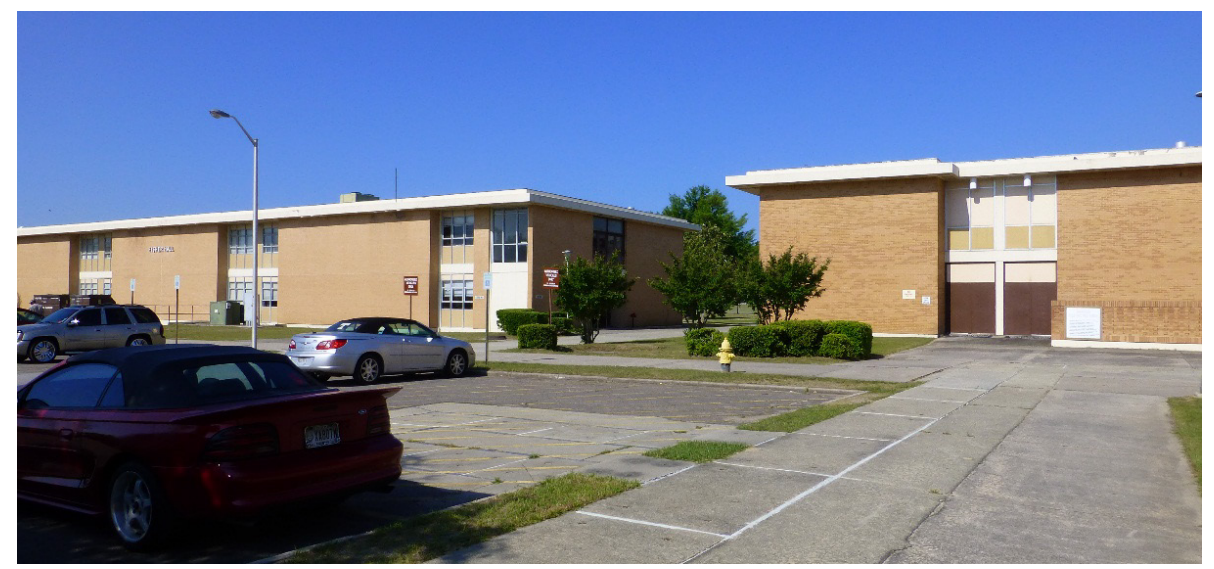


Figure 113. View looking west across the campus plan with Building 29811, Saltzman Hall, on the right and Building 29809, Greely Hall, in the background (ERDC-CERL, 2015).

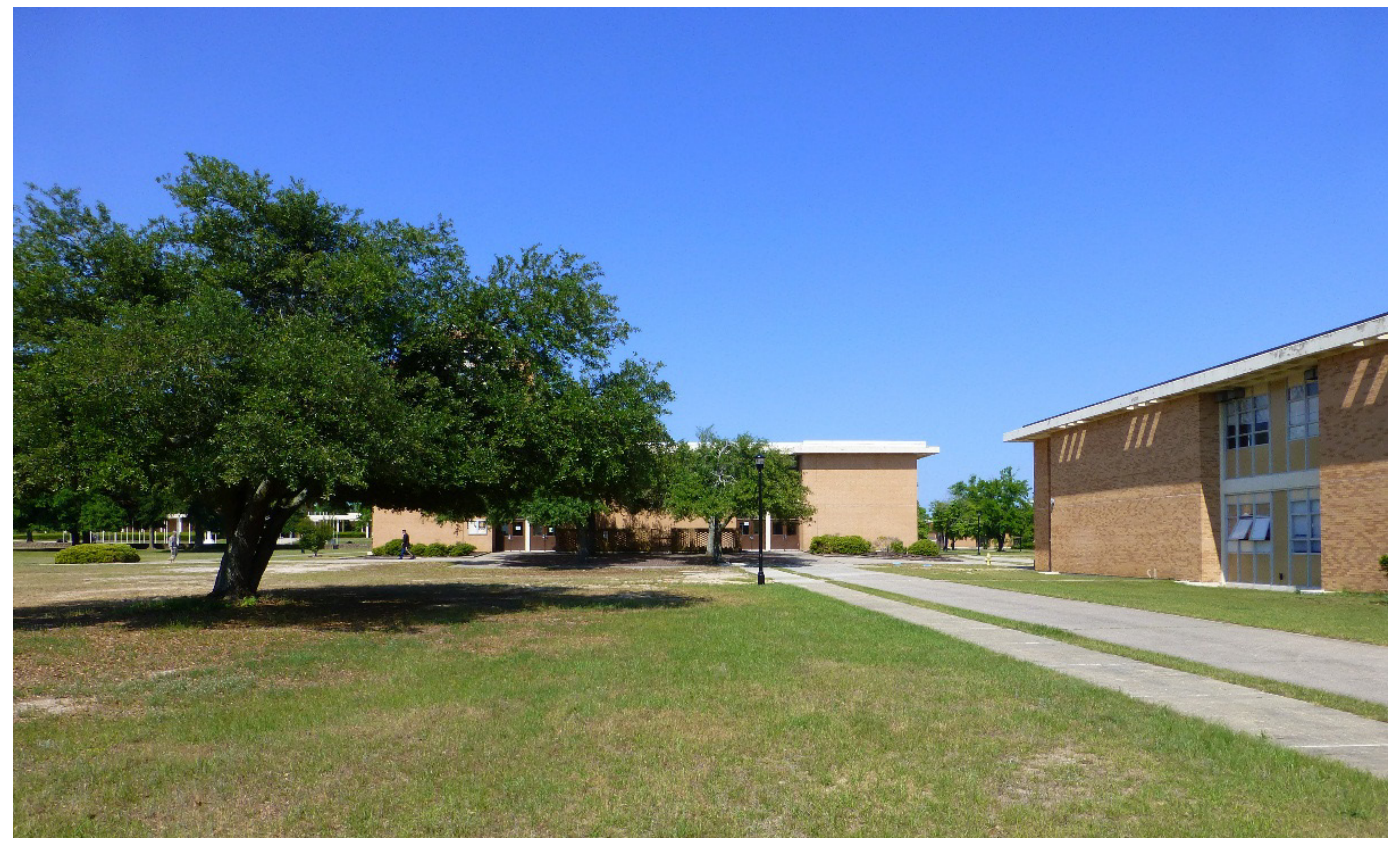

Figure 114. View looking west with Building 29815, Hazen Hall, on left and Building 29816, Fisher Hall, on right (ERDC-CERL, 2015).

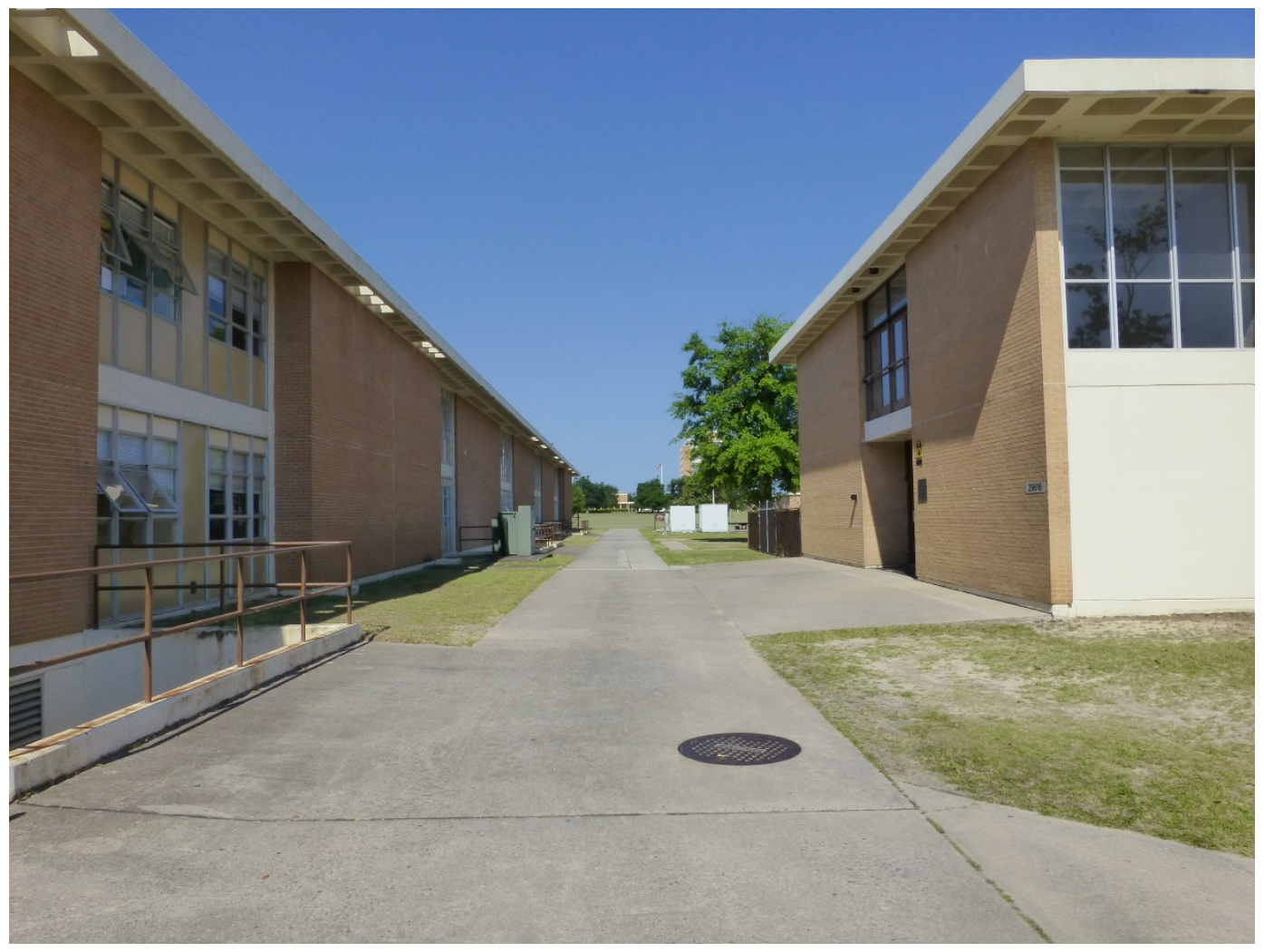


Figure 115. View looking west with Building 29809, Greely Hall, on the right and

Building 29808, Signal Towers, in the background (ERDC-CERL, 2015).

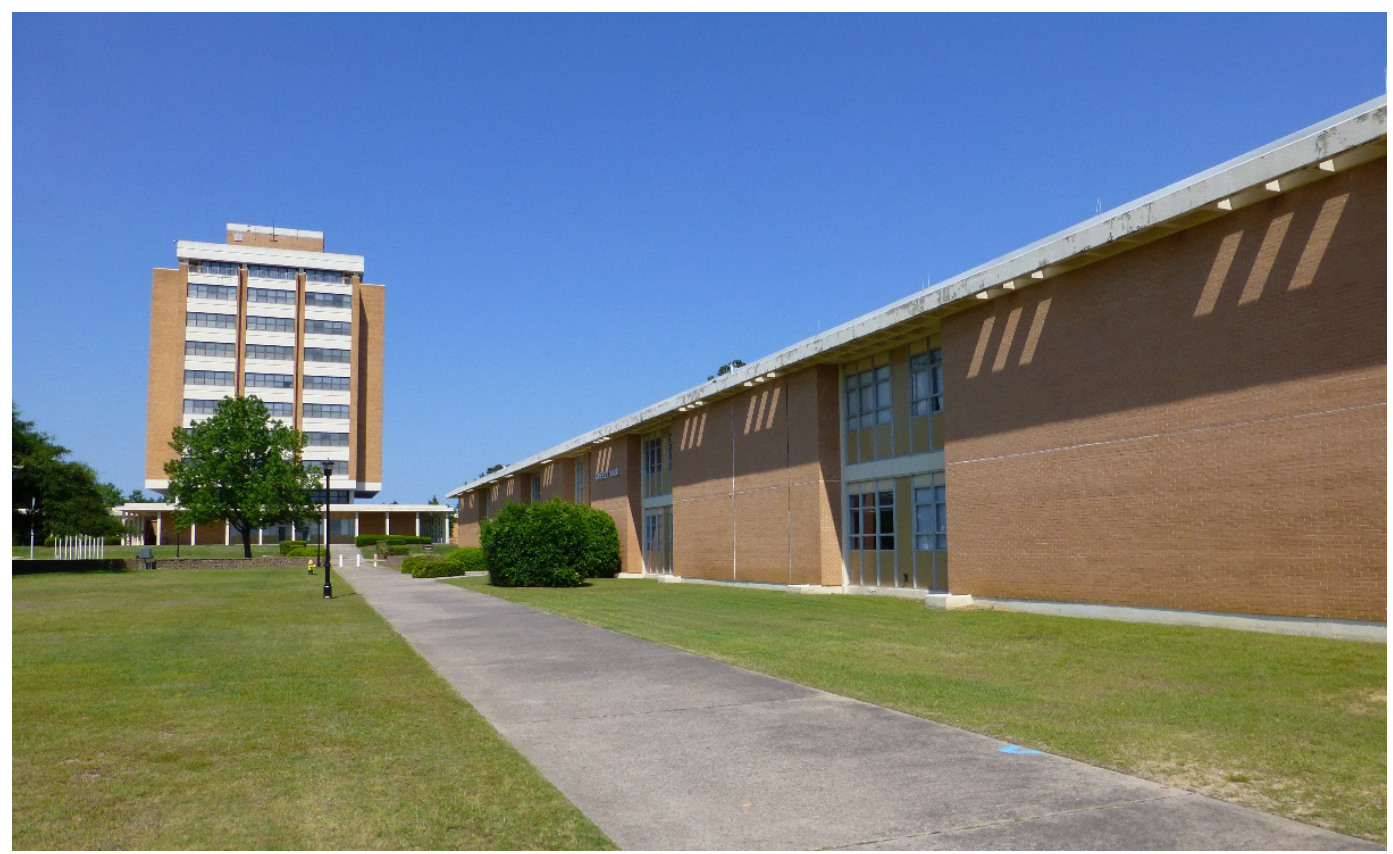

Figure 116. Looking west from Chamberlain Avenue toward the Signal School Campus with Building 29815, Hazen Hall, on the right and the tall Building 29808, Signal Towers, in the background (ERDC-CERL, 2015).

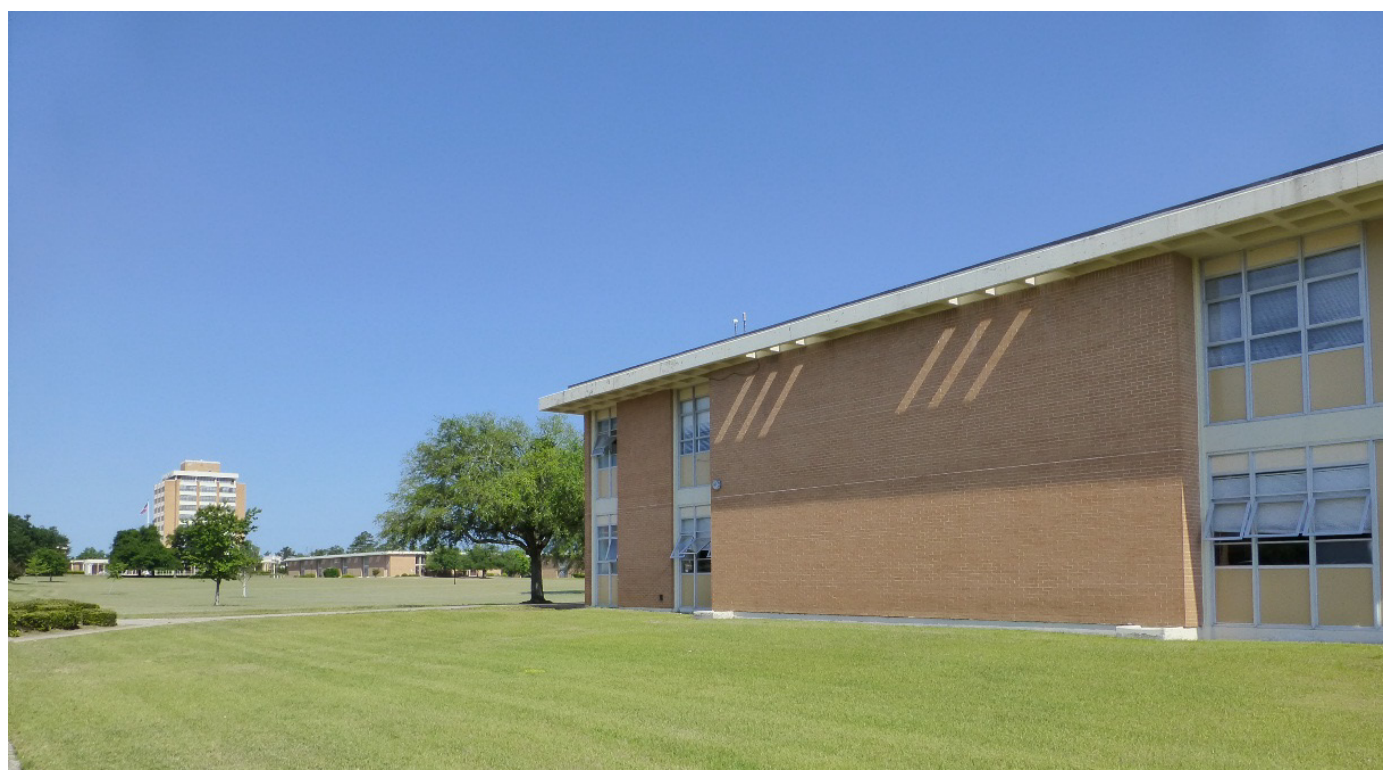




\subsubsection{Signal School Campus features; sidewalks and exterior light poles}

The overall campus design plan was laid out in a way to connect all of the classroom buildings to the main administration buildings. Sidewalks traversed this area to allow students direct access from the new barracks constructed south of Chamberlain Avenue. These sidewalks run in east-west and north-south patterns (Figure 117 and Figure 118).

Figure 117. Looking east down the sidewalk running in front of Building 29819, Stansell Hall (ERDC-CERL, 2015).

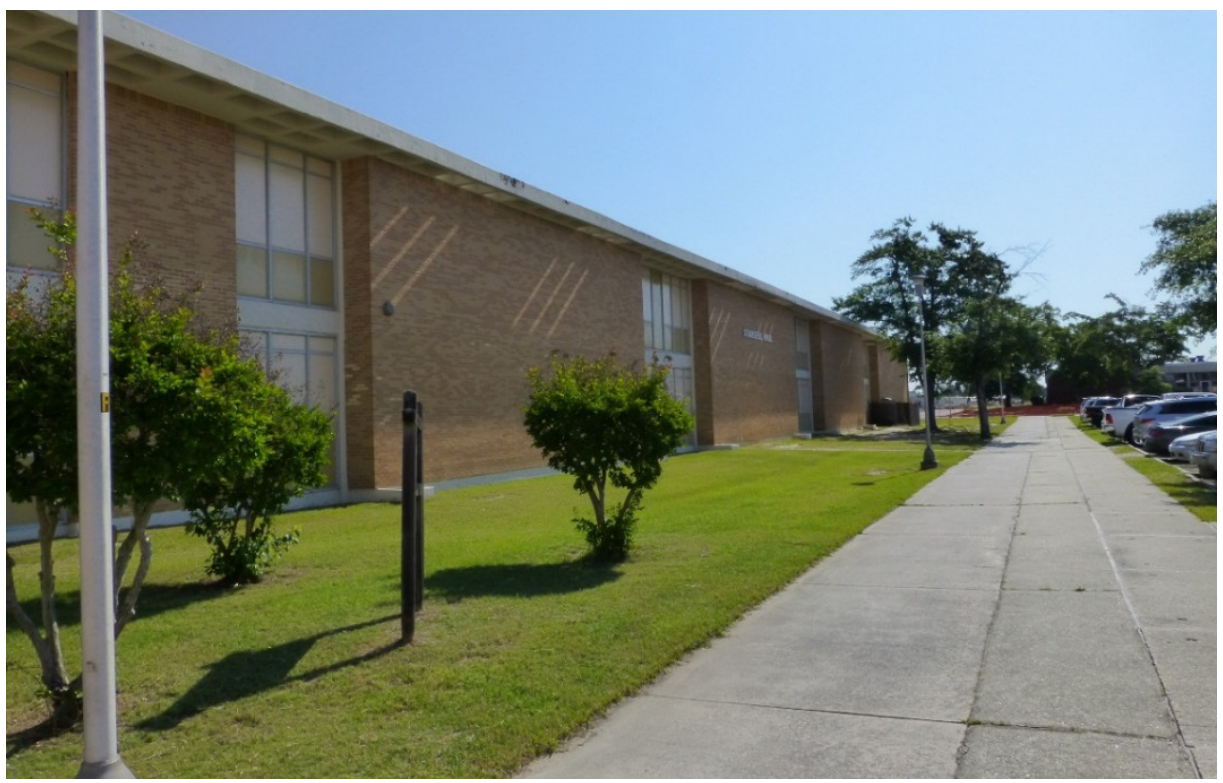

Figure 118. Looking west toward Building 29808, Signal Towers, at some of the connecting sidewalks (ERDC-CERL, 2015).

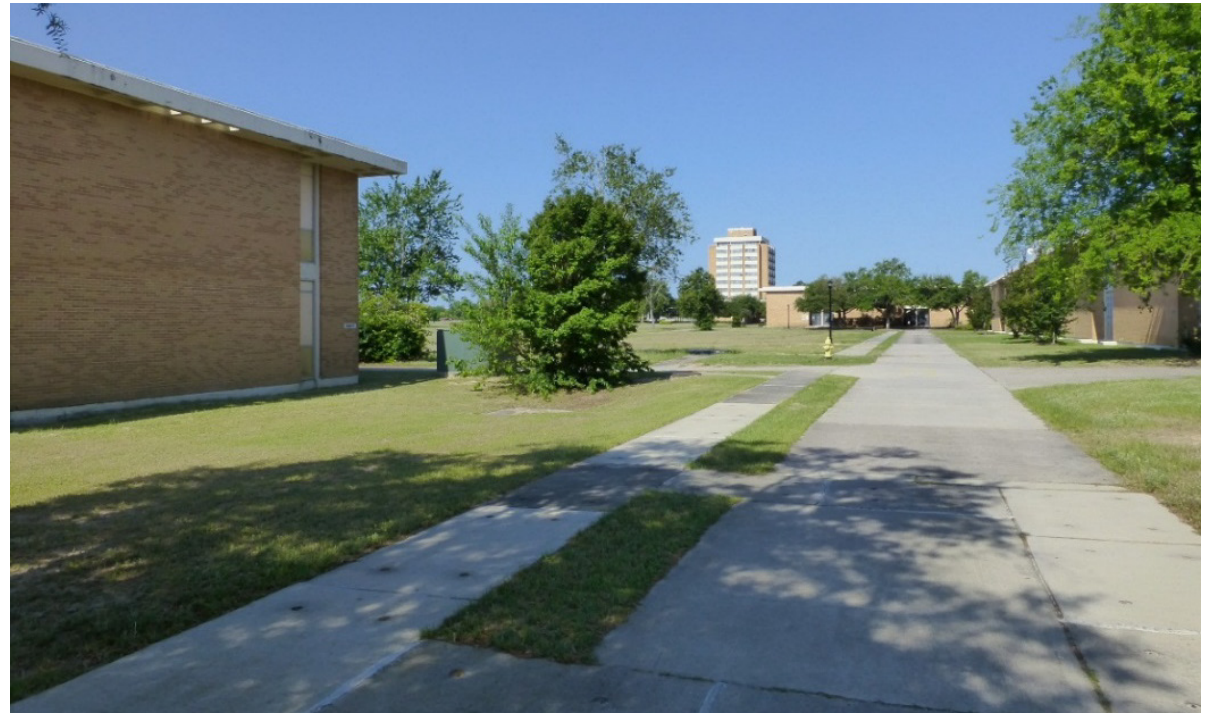


Aeck specified a light standard for illuminating the sidewalks that consisted of an aluminum pole capped by the fixture and then an aluminum "hat" (Figure 119). Some of these are extant, but many of them have been replaced by two types of light standards (Figure 120 and Figure 121).

Figure 119. Comparison of the original design and materials detail drawing of the sidewalk lights from 1966 [left] to the current condition of the same style of light fixture (ERDC-CERL, 2015).
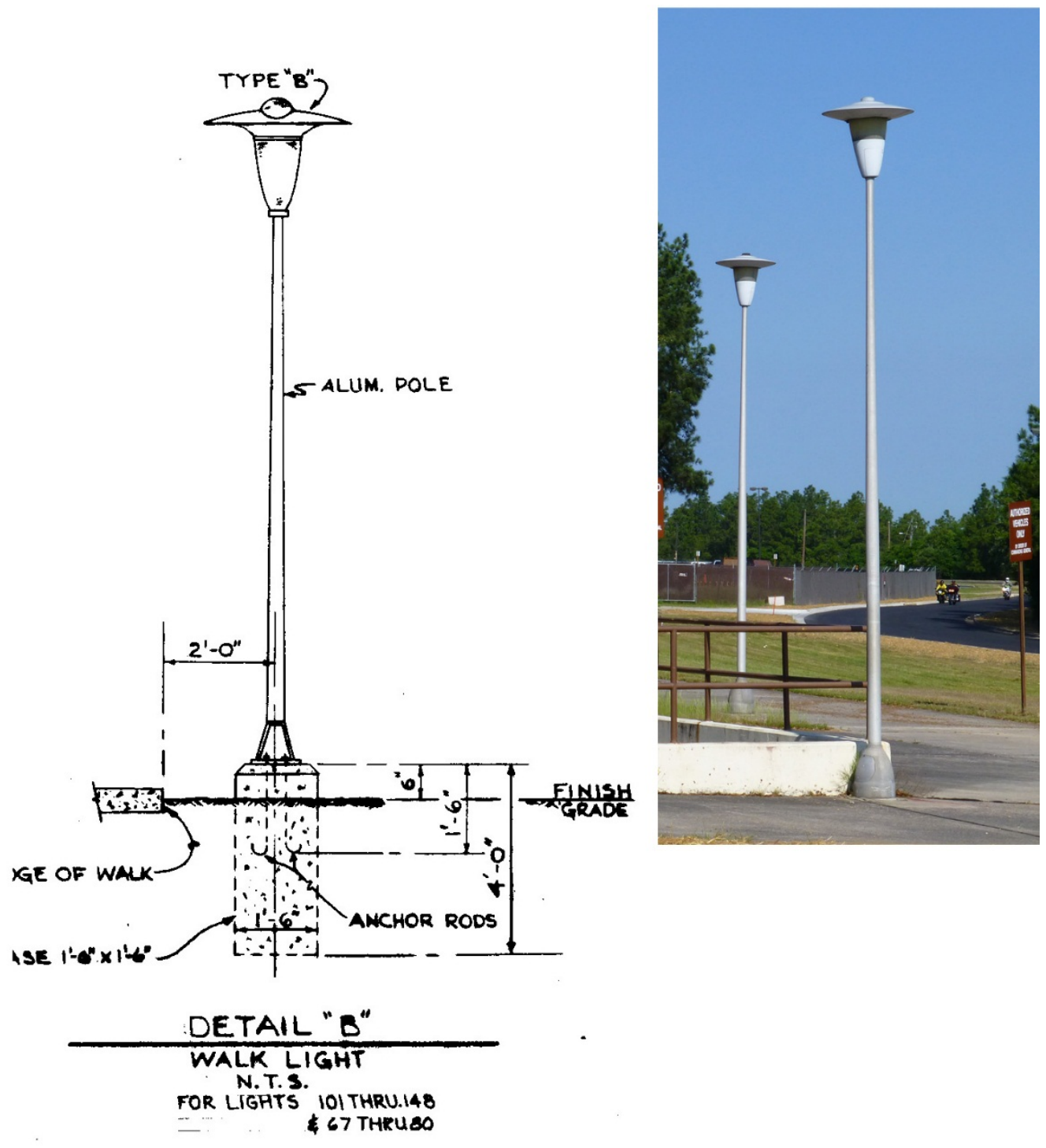
Figure 120. An example of one type of the replacement sidewalk lights (ERDC-CERL, 2015).

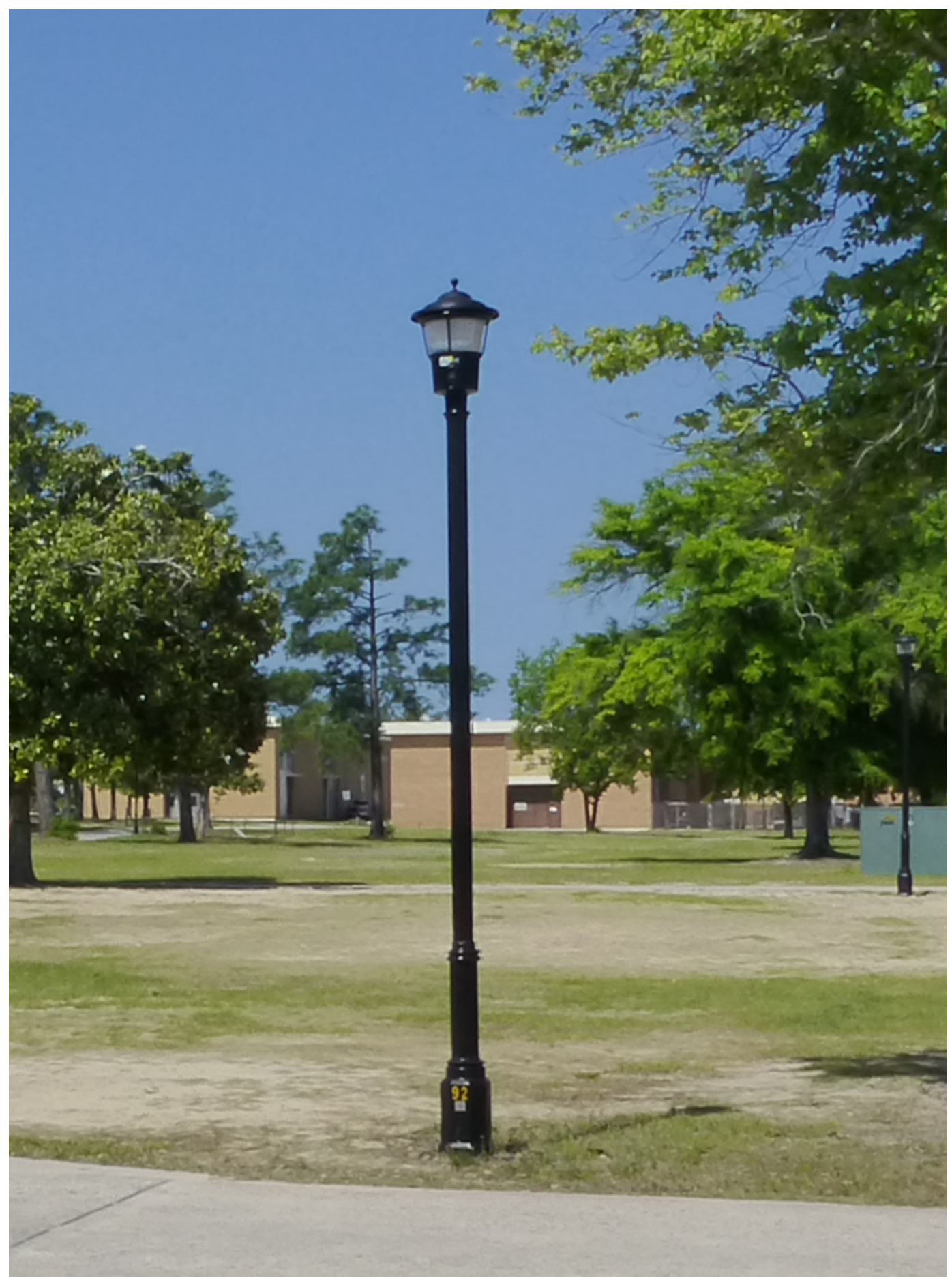


Figure 121. An example of one type of the replacement sidewalk lights (ERDC-CERL, 2015).

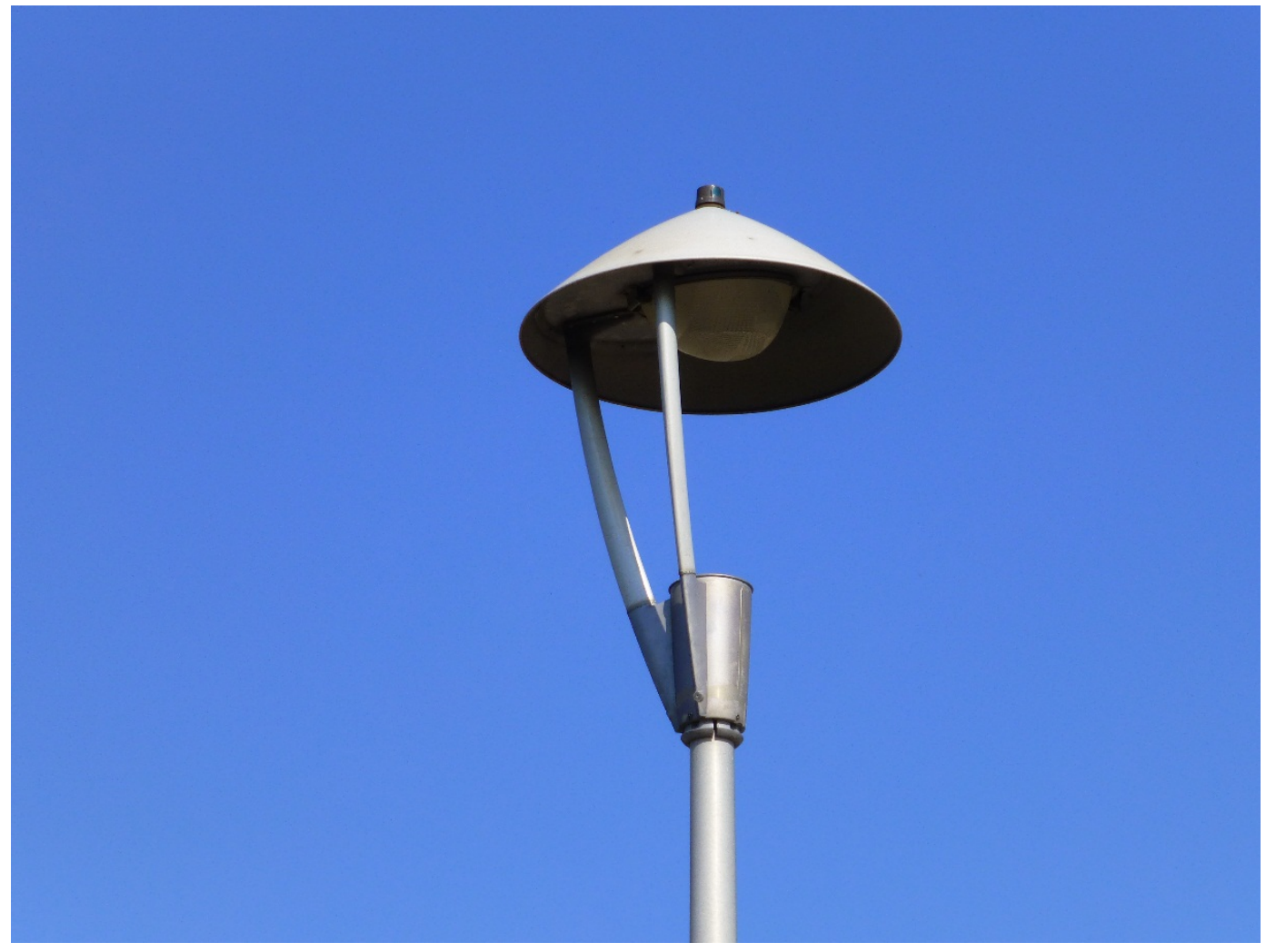

\subsection{Interior character-defining feature examples}

Perceiving the character of interior spaces can be somewhat more difficult than exterior spaces. The importance of interior features and finishes to the character of the building should not be overlooked, however. The primary visual aspects may be in features such as floor plans, hallways, spaces, exposed structural system/ceiling, staircases, lighting fixtures, or signage. In assessing the interior visual character of any historic building, it is necessary to ask whether there are spaces or features that are important to the character of this particular building, even if the building is a simple or utilitarian structure. If the ceiling were to be lowered to provide space for heating ducts, or if the stairways were to be enclosed for code reasons, the shape and character of this space or features would be damaged, even if there was no permanent physical damage. Such changes can easily destroy the visual character of an individually important interior space. Thus, it is important that the visual aspects of a building's interior character be recognized before planning any changes or alterations. 
The overall feeling and character of the interior of these Signal School Campus buildings is derived from the floor plans, hallways with waffle ceilings, stairwells, lighting, doors, bright-aluminum display cases, telephone alcoves, vending-area alcoves, water fountain alcoves, dumbwaiters, fire hydrant display cases, and signage. Some of the buildings were constructed to include all of these features, and some were constructed with a few of these features. In any case, it is important that the visual aspects and the character-defining features of interiors listed below be recognized before planning any changes or alterations to the space or feature.

\subsubsection{Floor plan}

As seen on two typical classroom building floor plans (Figure 122 and Figure 123), the gray-highlighted areas of each floor plan call out the main character-defining features such as entry vestibules, central hallways (with concrete block wall and exposed concrete waffle ceiling), stairwells, vending spaces, phone alcoves, and drinking fountain alcoves are all characterdefining features. Their identification, retention, protection, and repair should be given consideration. Caution should be exercised in developing plans that would radically change these character-defining spaces. For example, if an original open vending area is going to be turned into an office, this change would be an adverse effect on the character-defining feature of that space. 
Figure 122. Examples of character-defining space in the interior (gray area) include vestibules, stairwells, hallways, vending space, phone alcoves, drinking fountain alcoves, and, in this example, the interior courtyard, 1964 (Fort Gordon DPW).

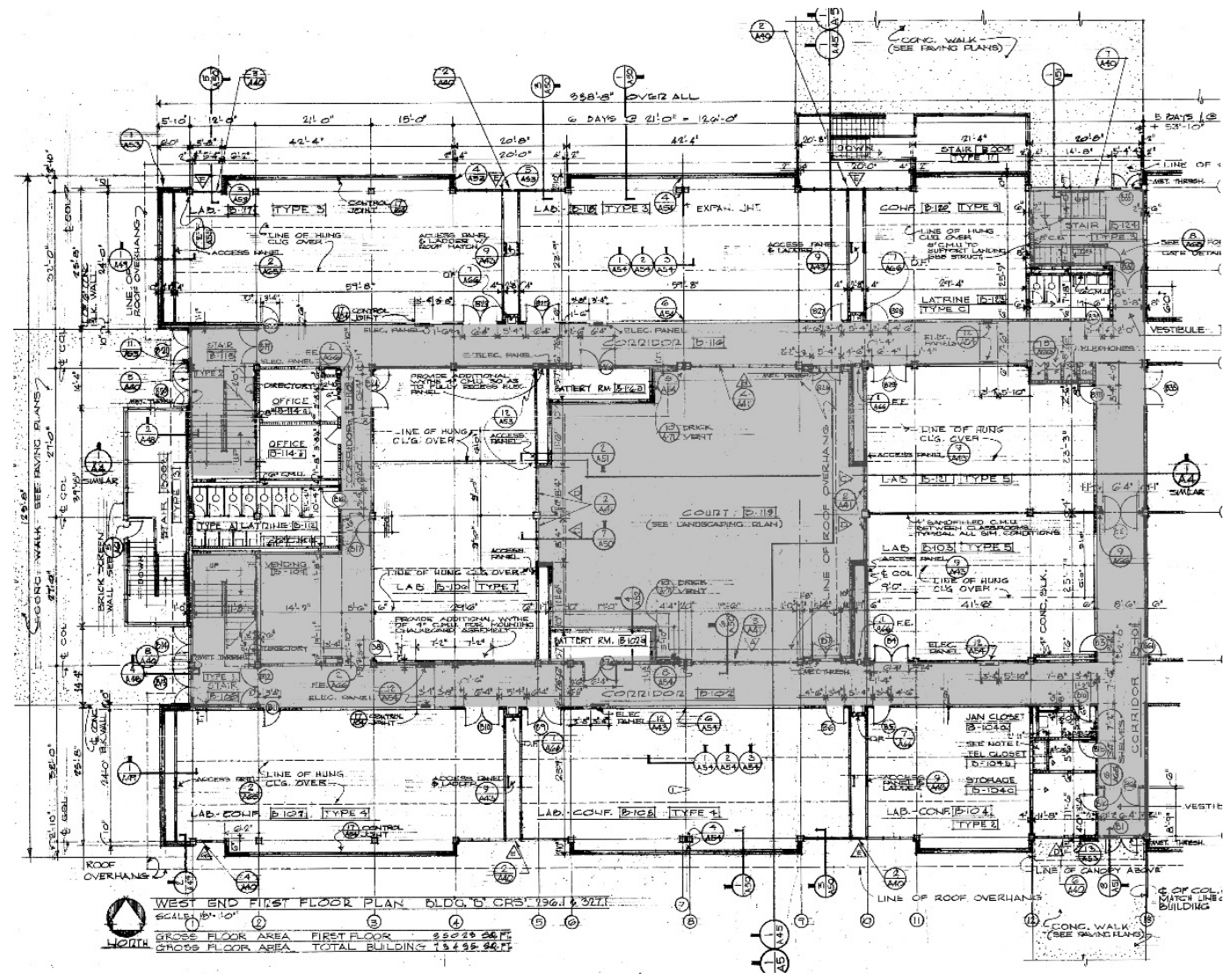

Figure 123. Examples of character-defining space in the interior (gray area) include vestibules, stairwells, hallways, vending space, phone alcoves, and drinking fountain alcoves (Fort Gordon DPW).

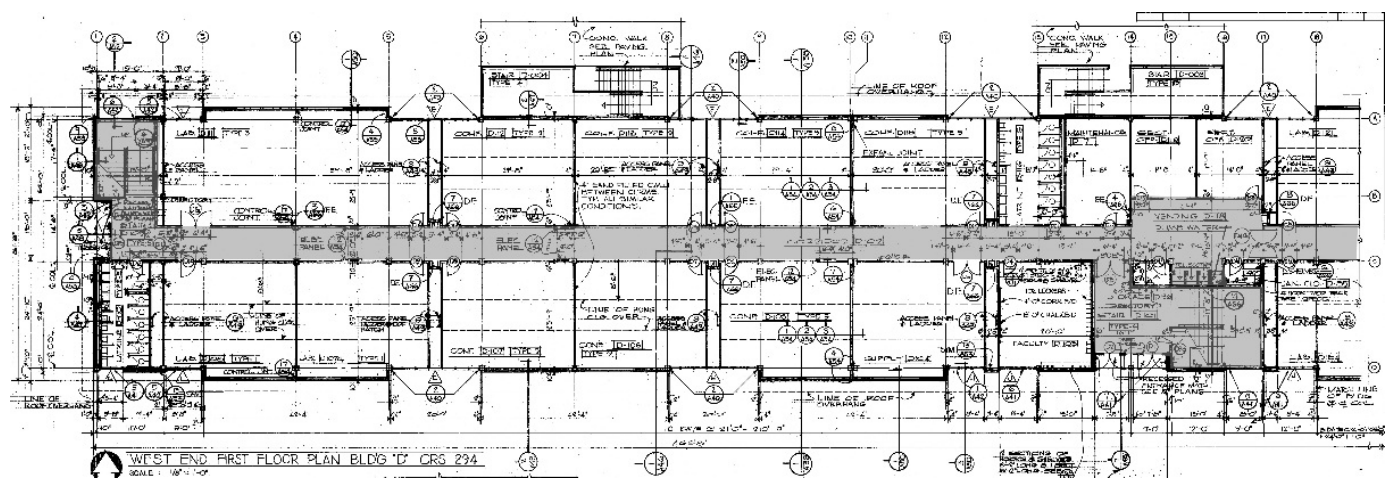

\subsubsection{Hallways with waffle ceilings and concrete block walls}

All of the Signal School Campus buildings are of cast-in-place concrete columns with a waffle floor/ceiling structure (Figure 124 and Figure 125). In most cases, the concrete waffle system is left exposed in the hallways 
(Figure 124). If the ceiling were to be lowered to provide space for heating ducts, the shape and character of this space or features would be damaged, even if there was no permanent physical damage. Such changes can easily destroy the visual character of an individually important interior space. Thus, it is important that the visual aspects of a building's interior character be recognized before planning any changes or alterations. Please refer to Figure 126 for an example of this character-defining feature.

Figure 124. Transverse section through a typical classroom building, showing the detail of the exposed concrete waffle ceiling/roof system, 1964 (Fort Gordon DPW).

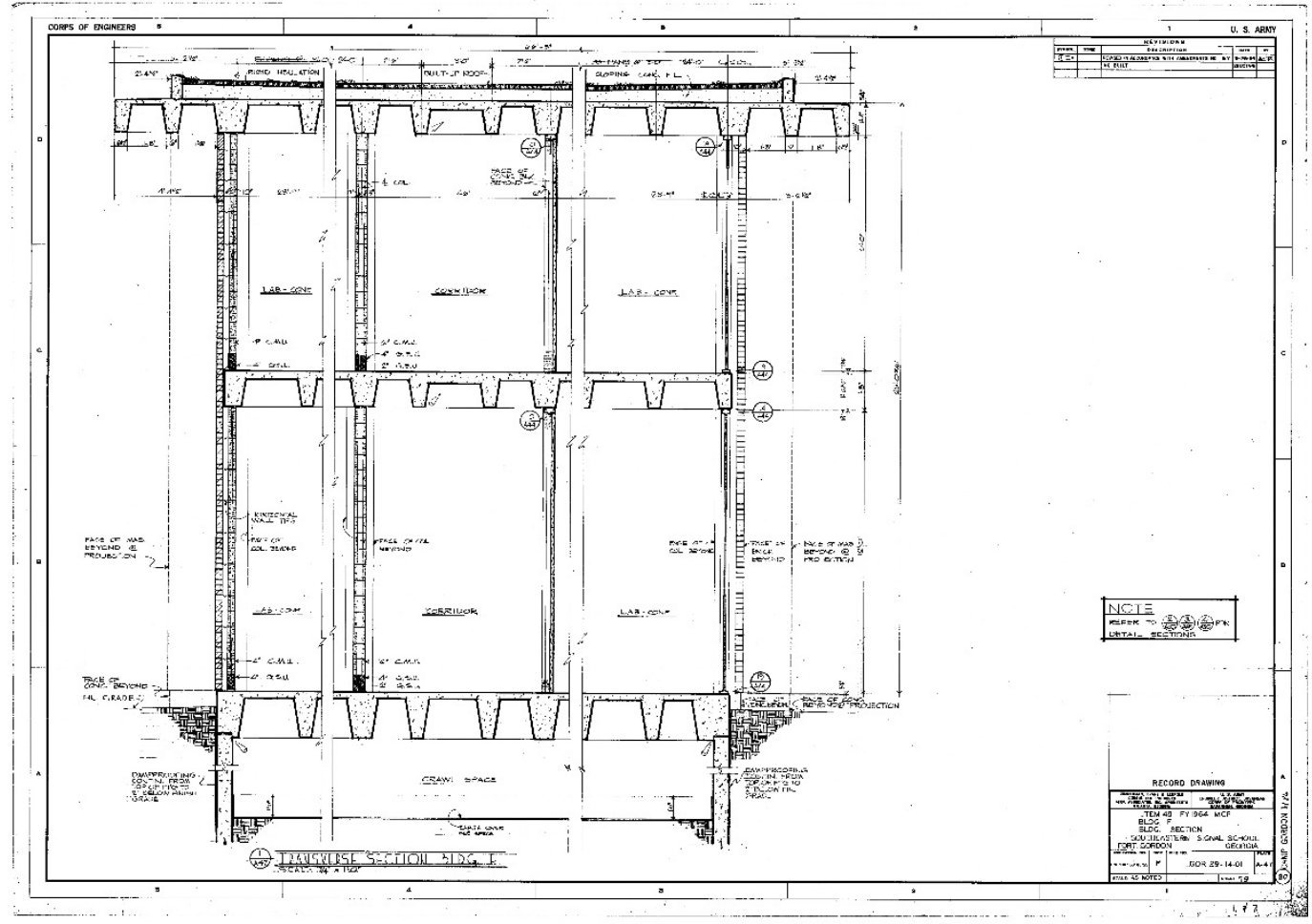


Figure 125. Transverse section through a typical classroom building, with courtyards showing the detail of the exposed concrete waffle ceiling/roof system, 1964

(Fort Gordon DPW).

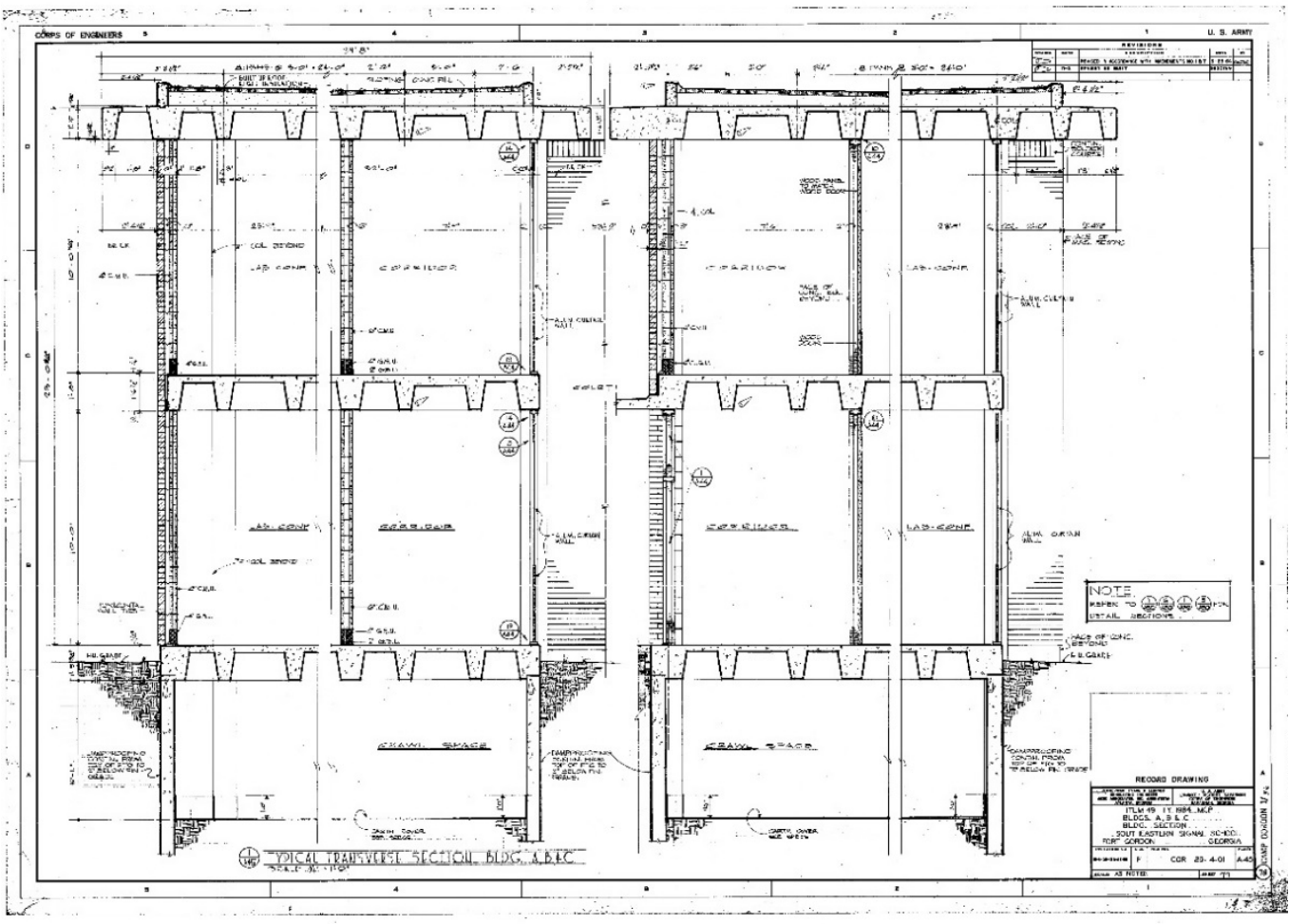

Figure 126. Example of an interior view looking down a central hallway with the exposed concrete waffle ceiling and concrete block walls (ERDC-CERL, 2015).

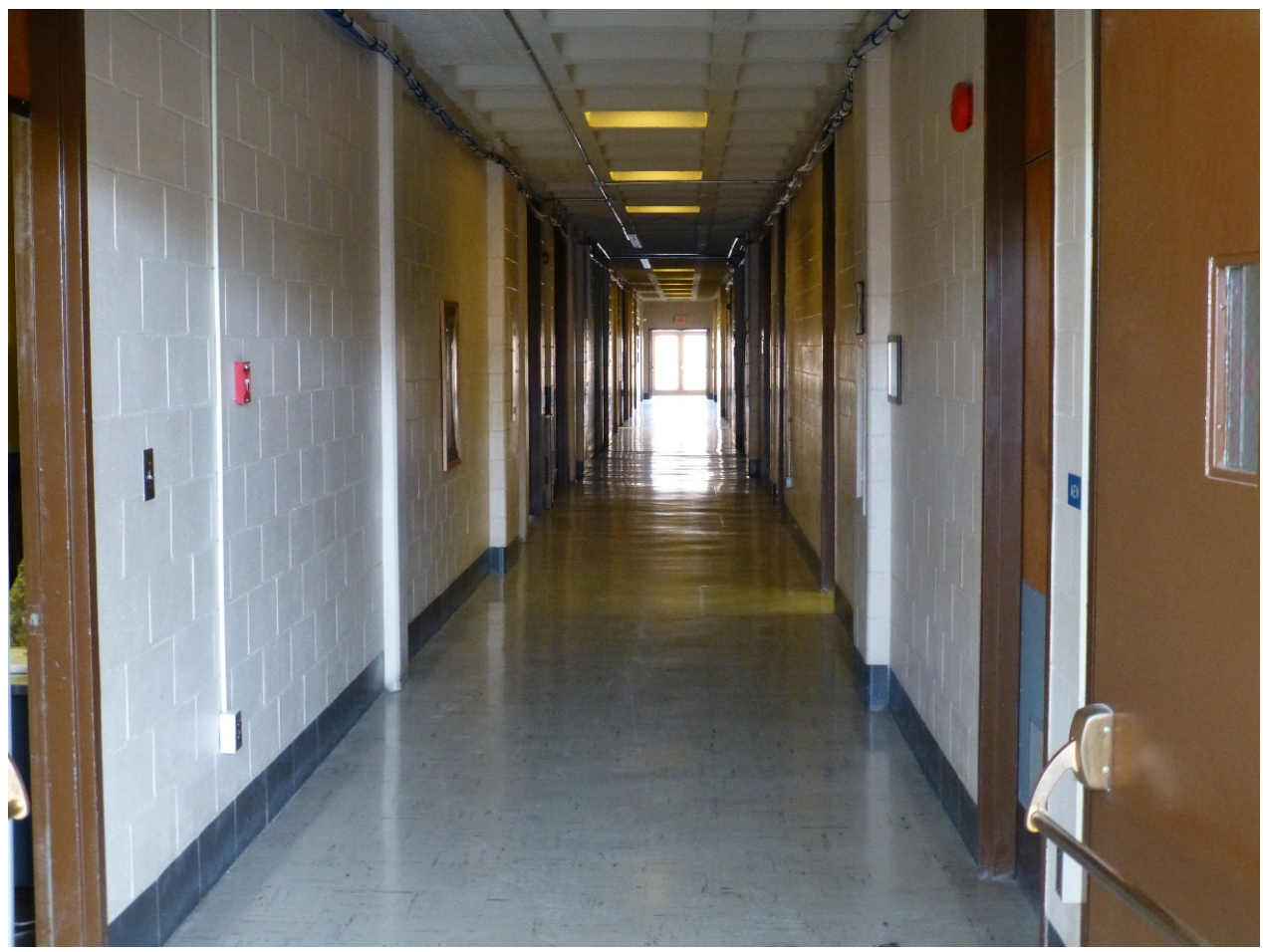




\subsubsection{Finishes}

Finishes are an important part of character-defining feature identification. Generally the more public buildings like 29805, 29807, and 29808 would characteristically have finer finishes like drywall, carpet, and terrazzo, whereas the classroom buildings would have simpler finishes like exposed concrete block walls and vinyl composition tiled floors (Figure 127-Figure 131). It is important that the visual aspects and character-defining features be recognized before planning any changes or alterations to the space or feature; their identification, retention, protection, and repair should be given consideration. Caution should be exercised in developing plans that would radically change these character-defining spaces. For example, covering the painted exposed concrete block walls with drywall would have a significant effect on the character-defining feature of the classroom hallways as would installing a dropped ceiling to cover the painted exposed waffle ceiling.

Figure 127. Example of painted exposed concrete block walls, painted exposed waffle ceiling, and vinyl composition tiled floor in classroom building hallways (ERDC-CERL, 2015).

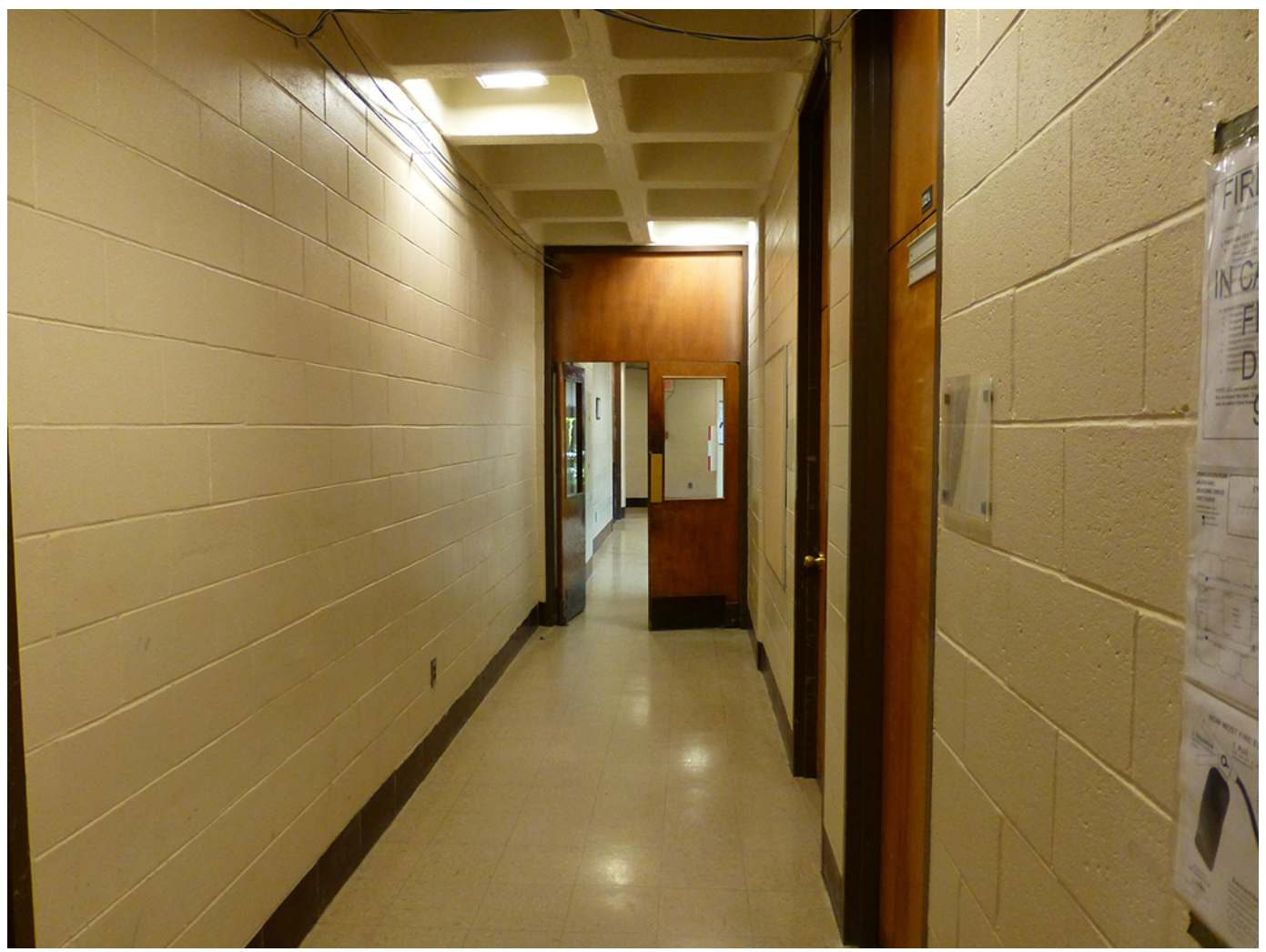


Figure 128. Example of unpainted, exposed brick in vestibules (ERDC-CERL, 2015).

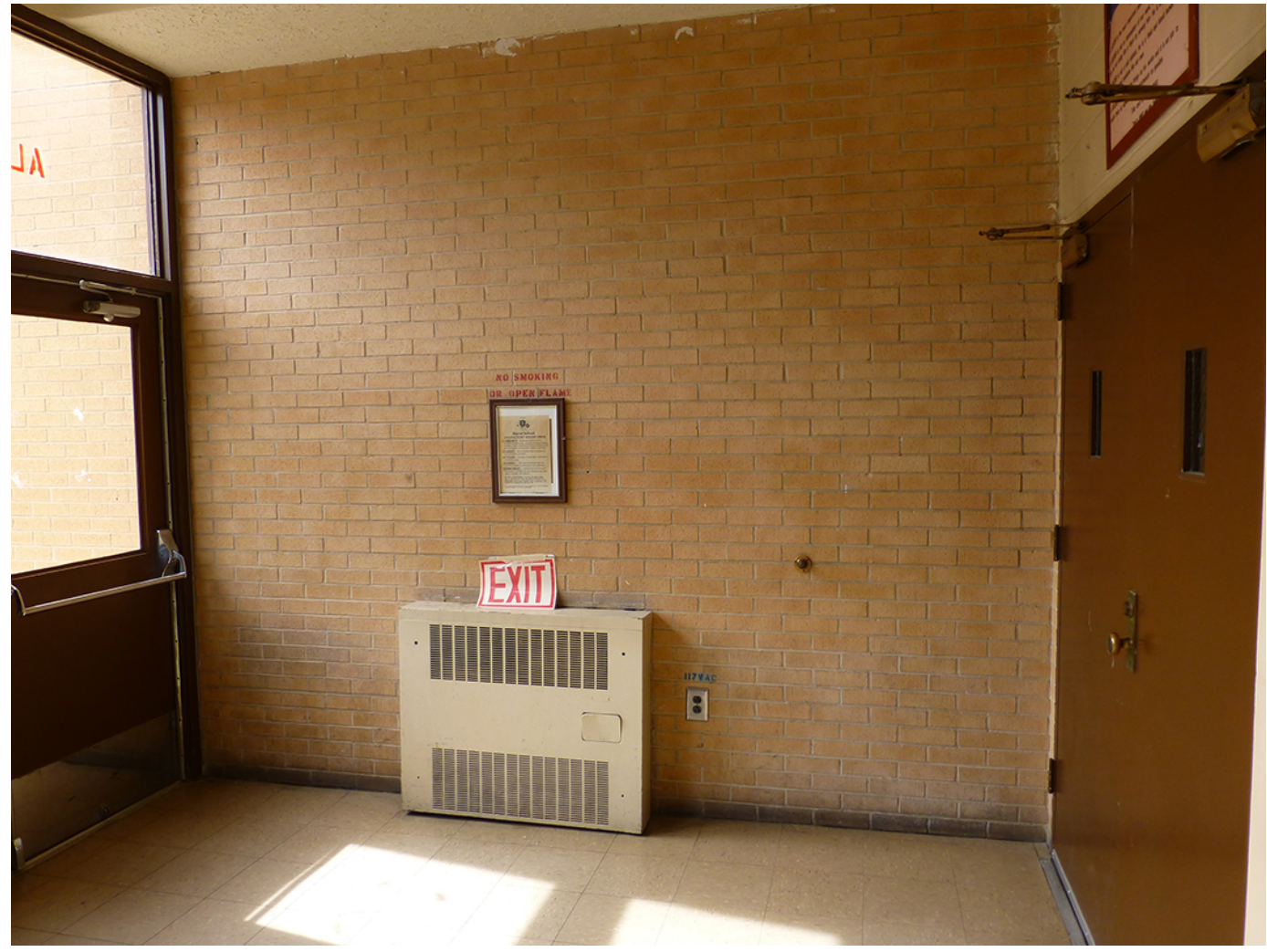

Figure 129. Example of full-height blue sanitary tile in drinking fountain alcove and painted wallboard in Building 29805 [a more "public" building than the classroom buildings] (ERDC-CERL, 2015).

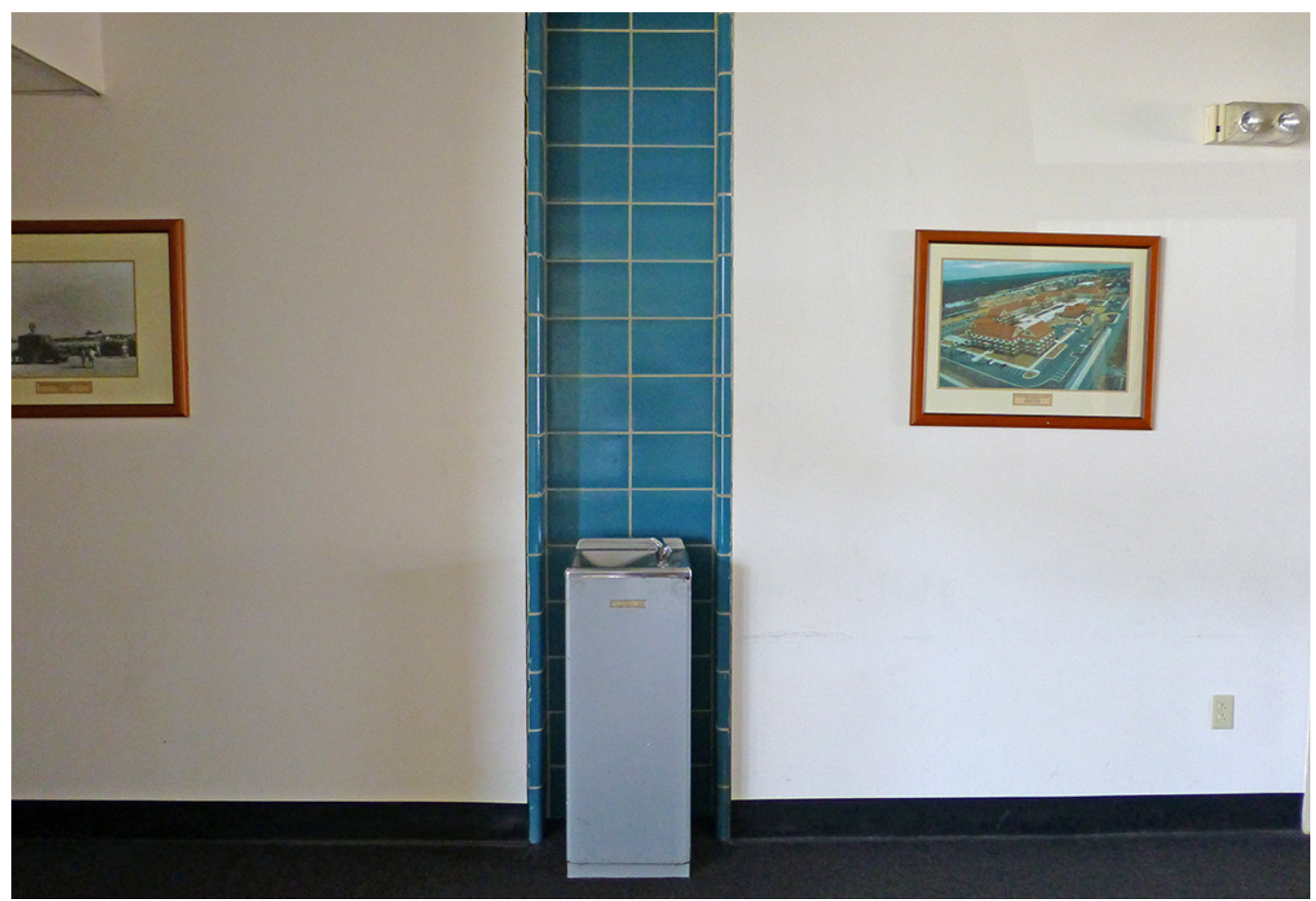


Figure 130. Example of painted, exposed concrete block wall, partial height blue glazed concrete block in drinking fountain alcove, and blue glazed concrete block baseboard in classroom buildings (ERDC-CERL, 2015).

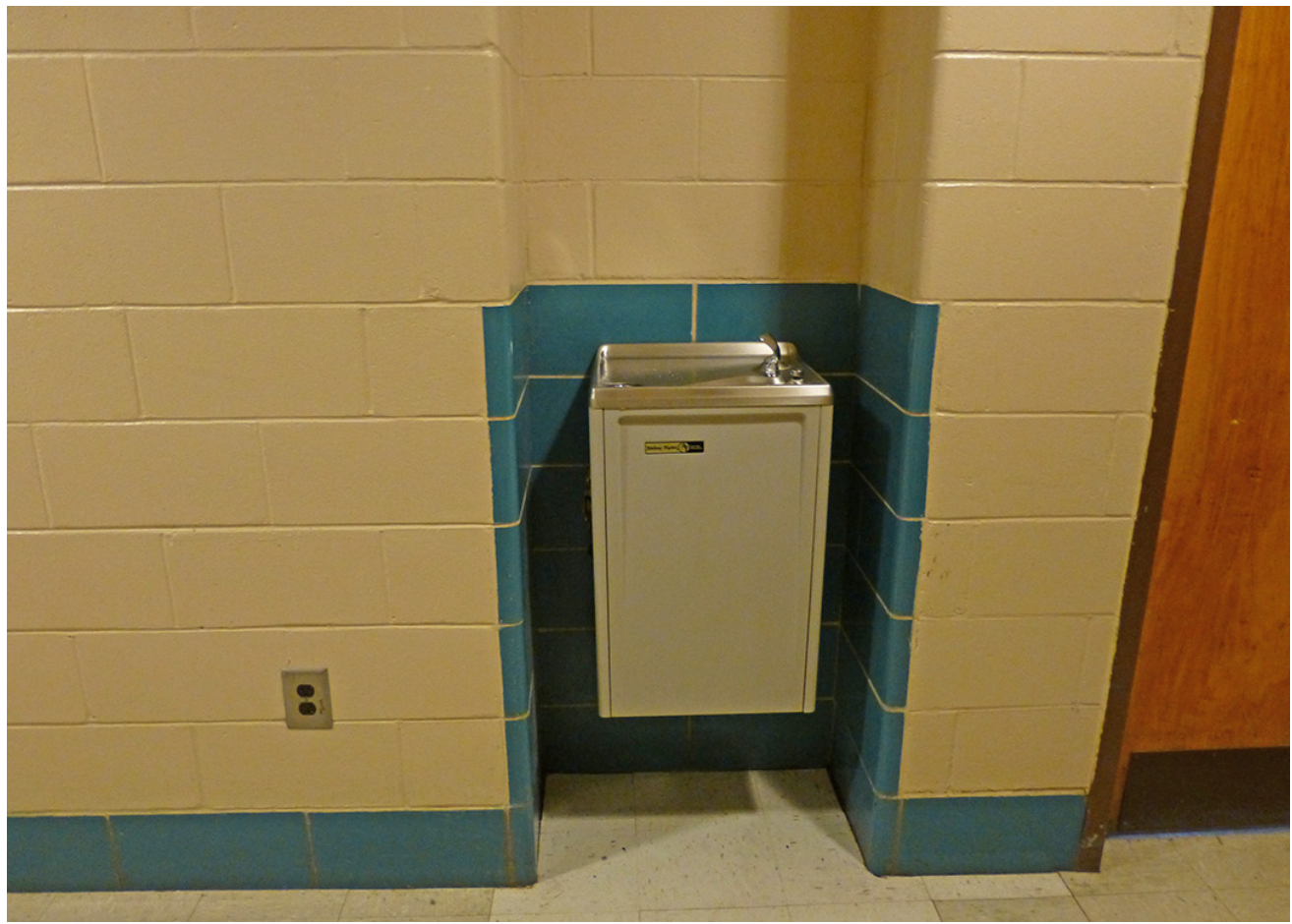

Figure 131. Example of glazed concrete block utilized as a baseboard (ERDC-CERL, 2015).

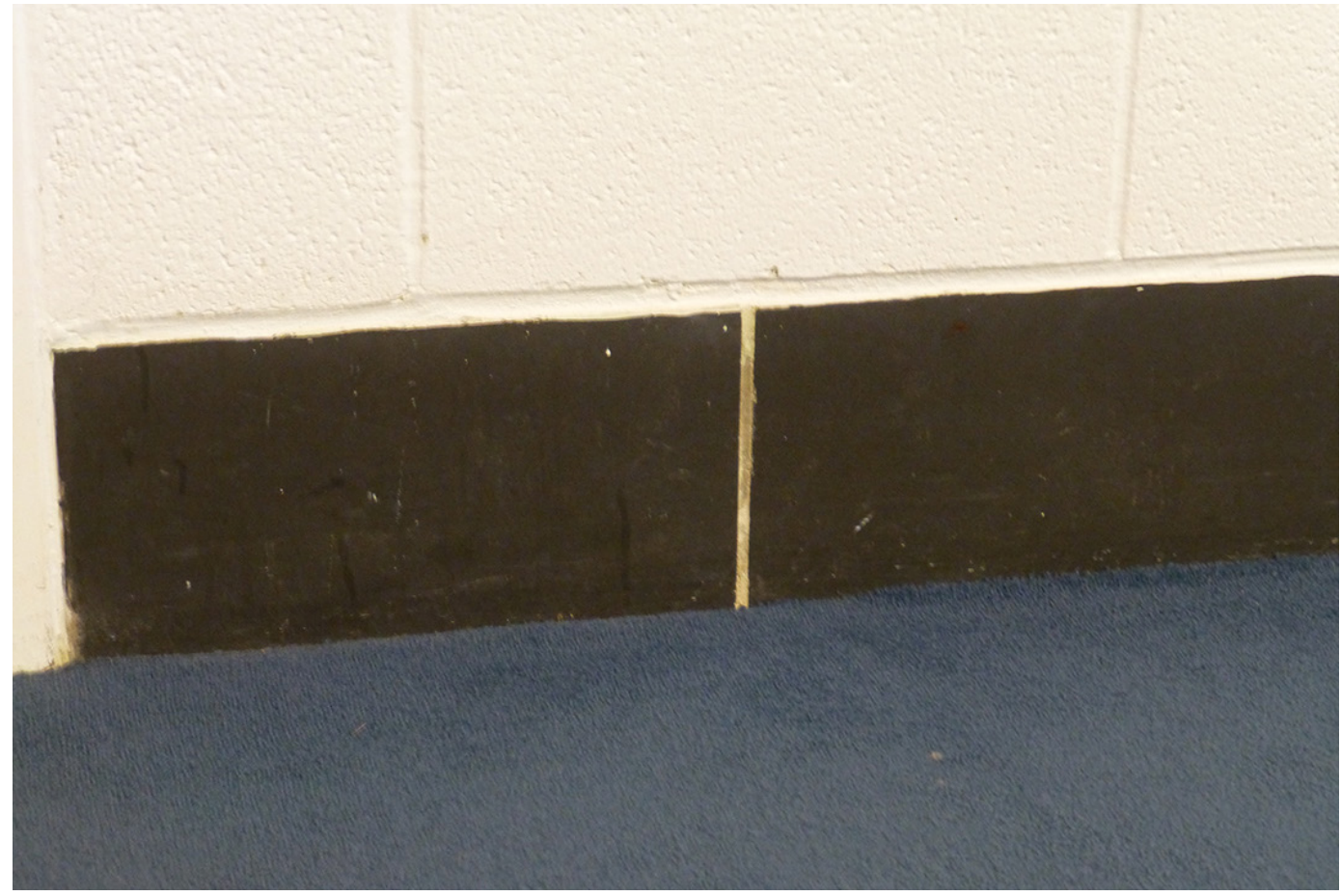




\subsubsection{Stairwells}

All of the Signal School buildings are two-stories tall (with the exception of Buildings 29805, 29807, 29808, and 29810), with stairwells located at each end of the building and in the middle of the building (Figure 132 and Figure 133). These stairwells are a two-story open space with a concrete switchback staircase, metal pipe handrails, exposed concrete block walls, and exposed concrete waffle ceiling (Figure 134-Figure 135). If the stairways were to be enclosed for code reasons, the shape and character of this space or features would be damaged, even if there was no permanent physical damage. Such changes can easily destroy the visual character of an individually important interior space. Thus, it is important that the visual aspects of a building's interior character be recognized before planning any changes or alterations. Please refer to the following figures for examples of stairwells located in the Signals School buildings (Figure 136-Figure 137) and a comparison of originally designed to existing conditions (Figure 138).

Figure 132. Stair detail for buildings with metal and plate-glass doors on second floor, 1964 (Fort Gordon DPW).

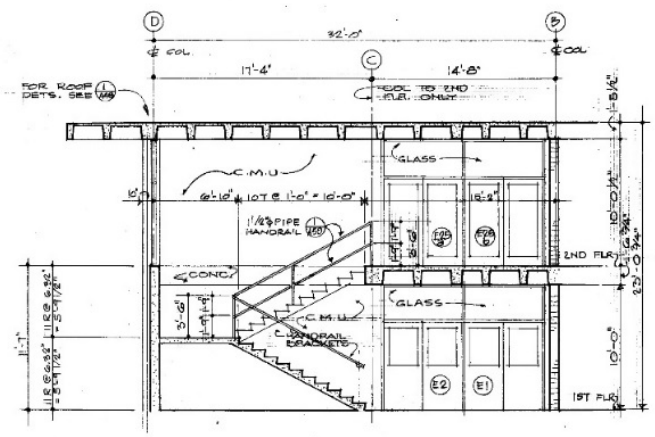

SECTION

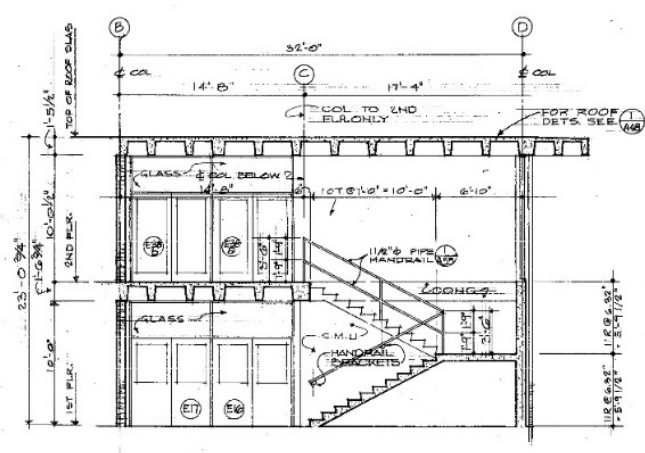


Figure 133. Stairwell plans, elevations, and details, 1964 (Fort Gordon DPW).

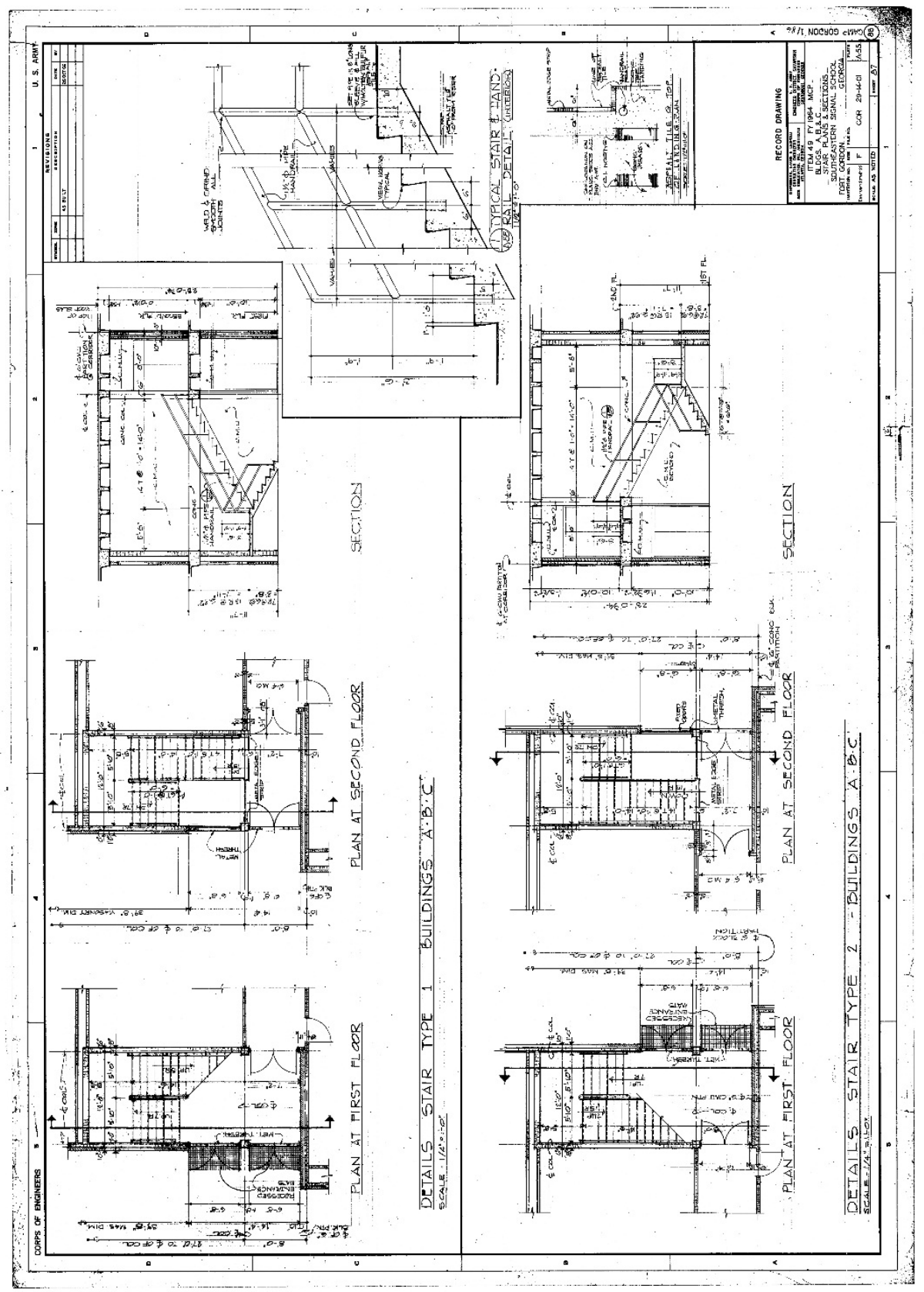


Figure 134. Interior view of typical stairwell with second-floor metal and plate-glass doors showing concrete switchback stairs, metal handrails, exposed concrete walls, and exposed concrete waffle ceiling (ERDC-CERL, 2015).

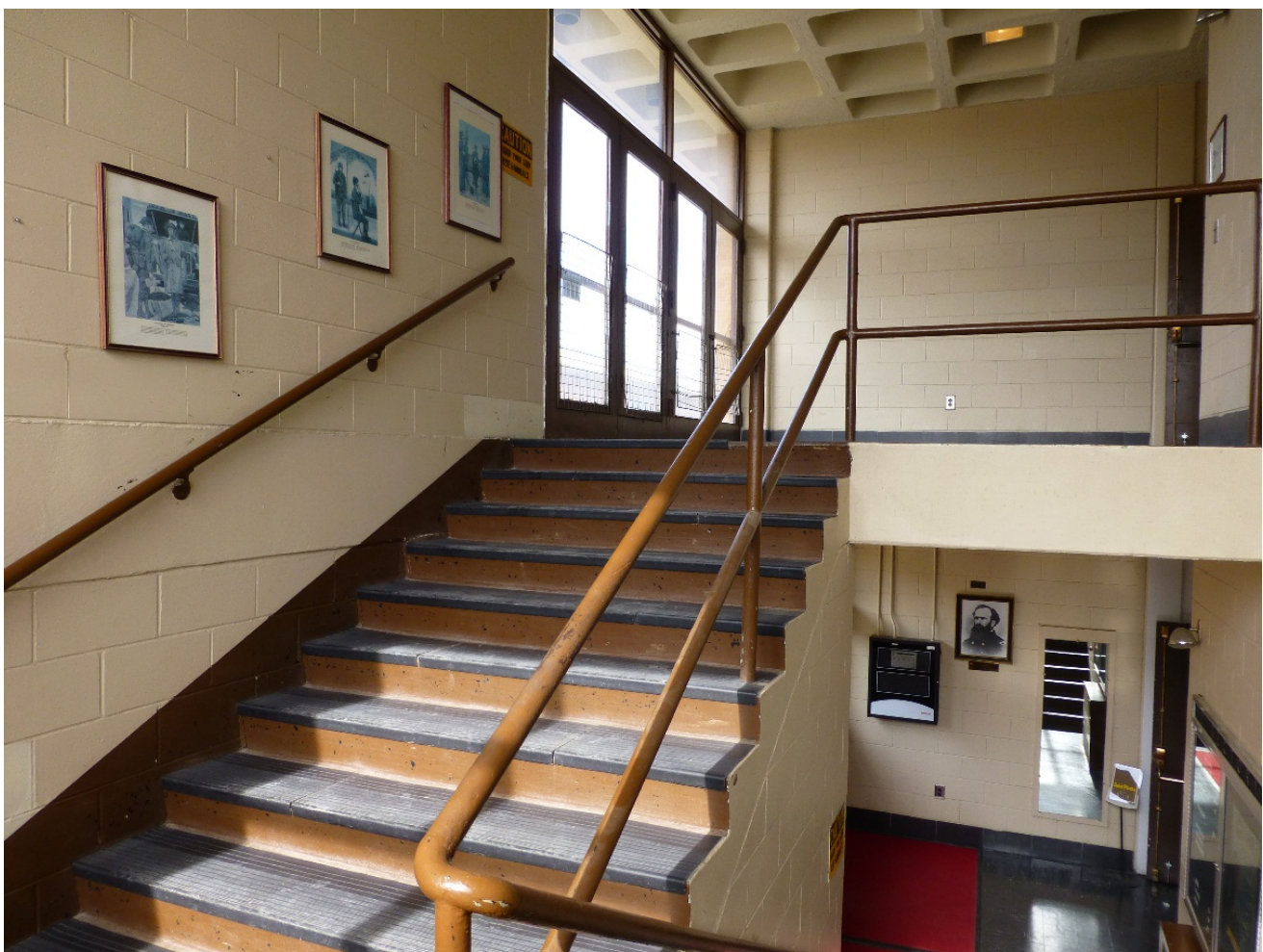

Figure 135. Interior view of the south stairwell in Building 29816, showing concrete switchback stairs, metal handrails, exposed concrete walls, and exposed concrete waffle ceiling (ERDC-CERL, 2015).

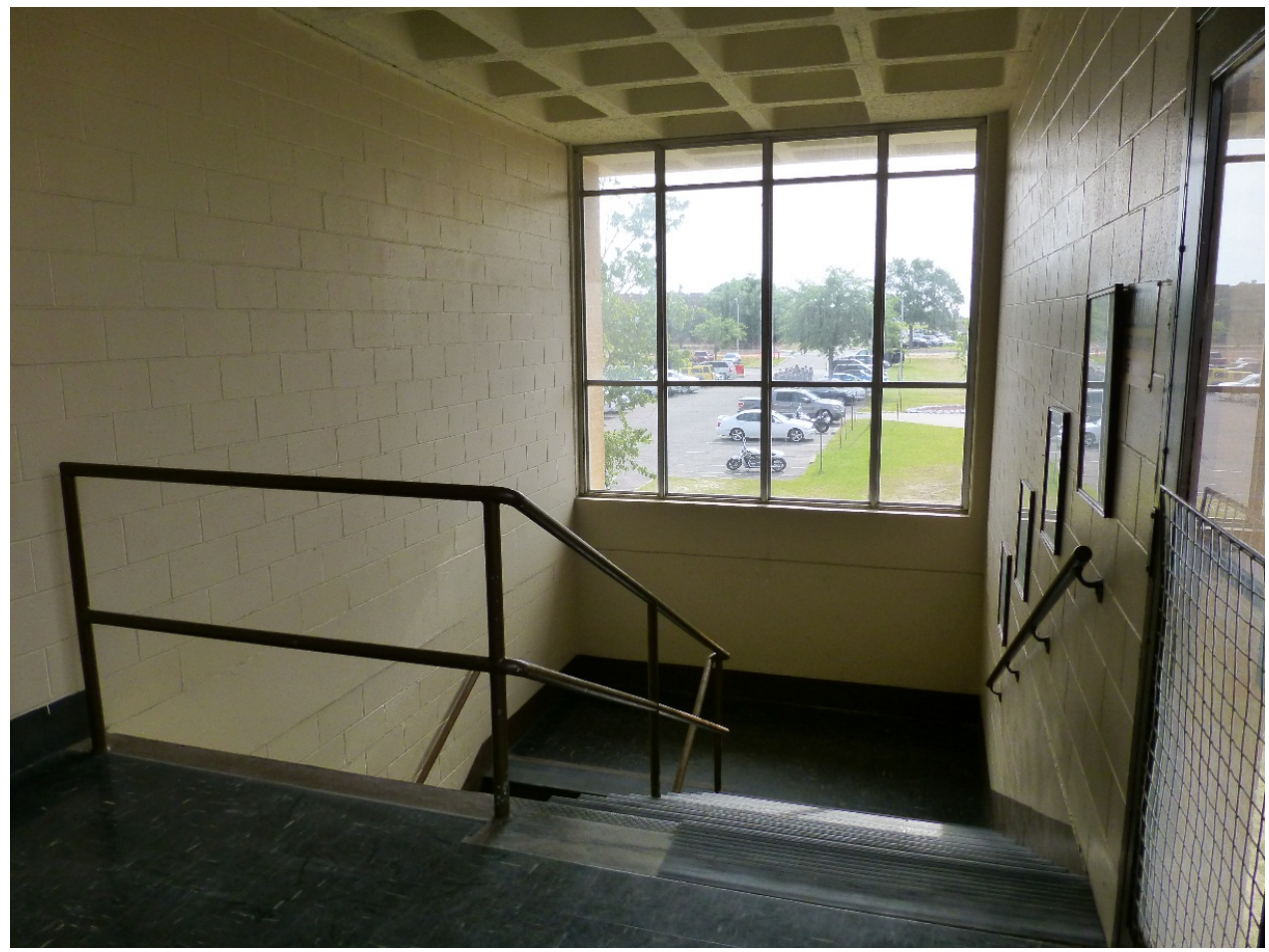


Figure 136. Interior view of typical stairwell that has been modified with carpet covering the landing areas (ERDC-CERL, 2015).

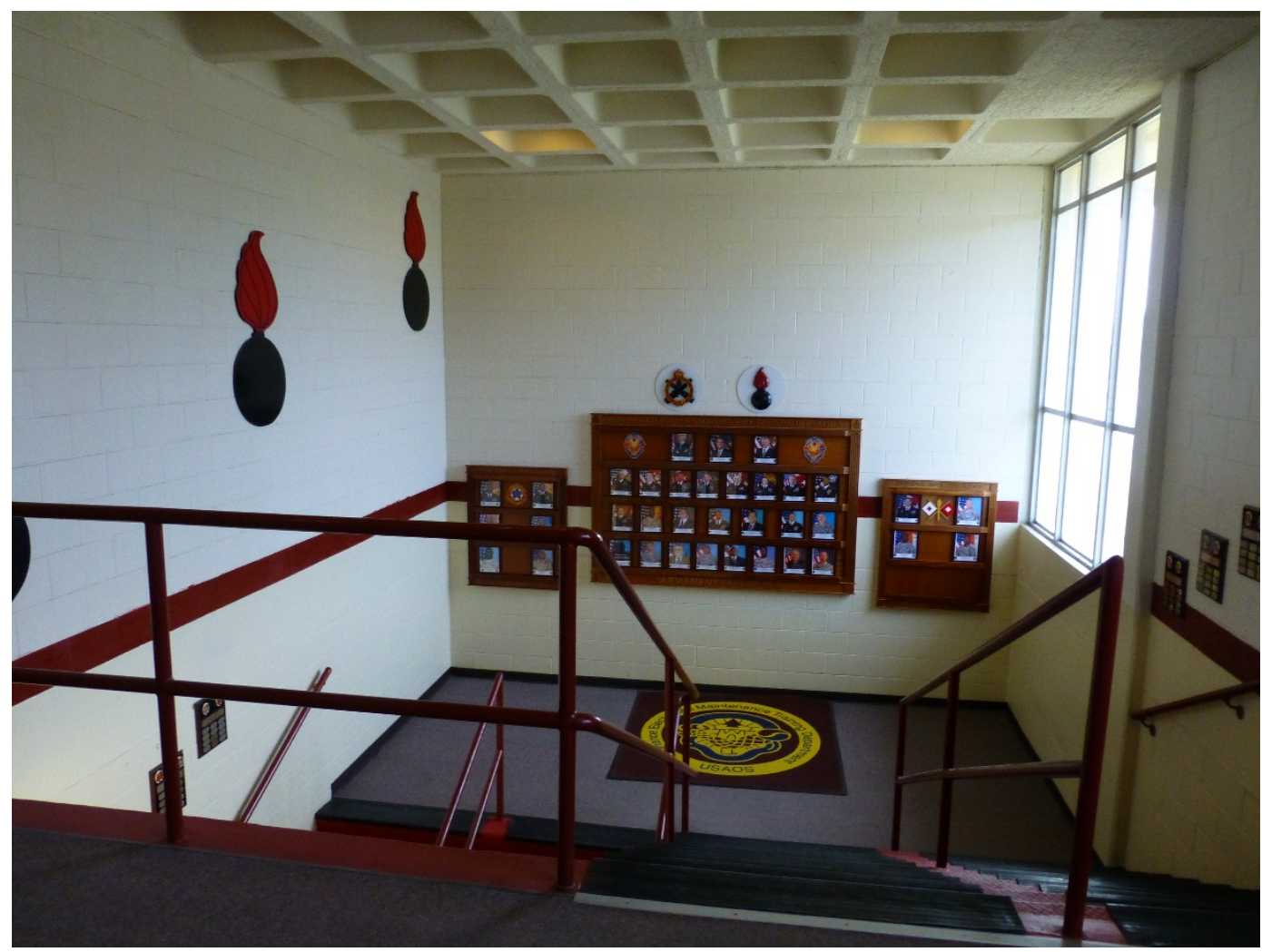

Figure 137. Typical stairwell (ERDC-CERL, 2015).

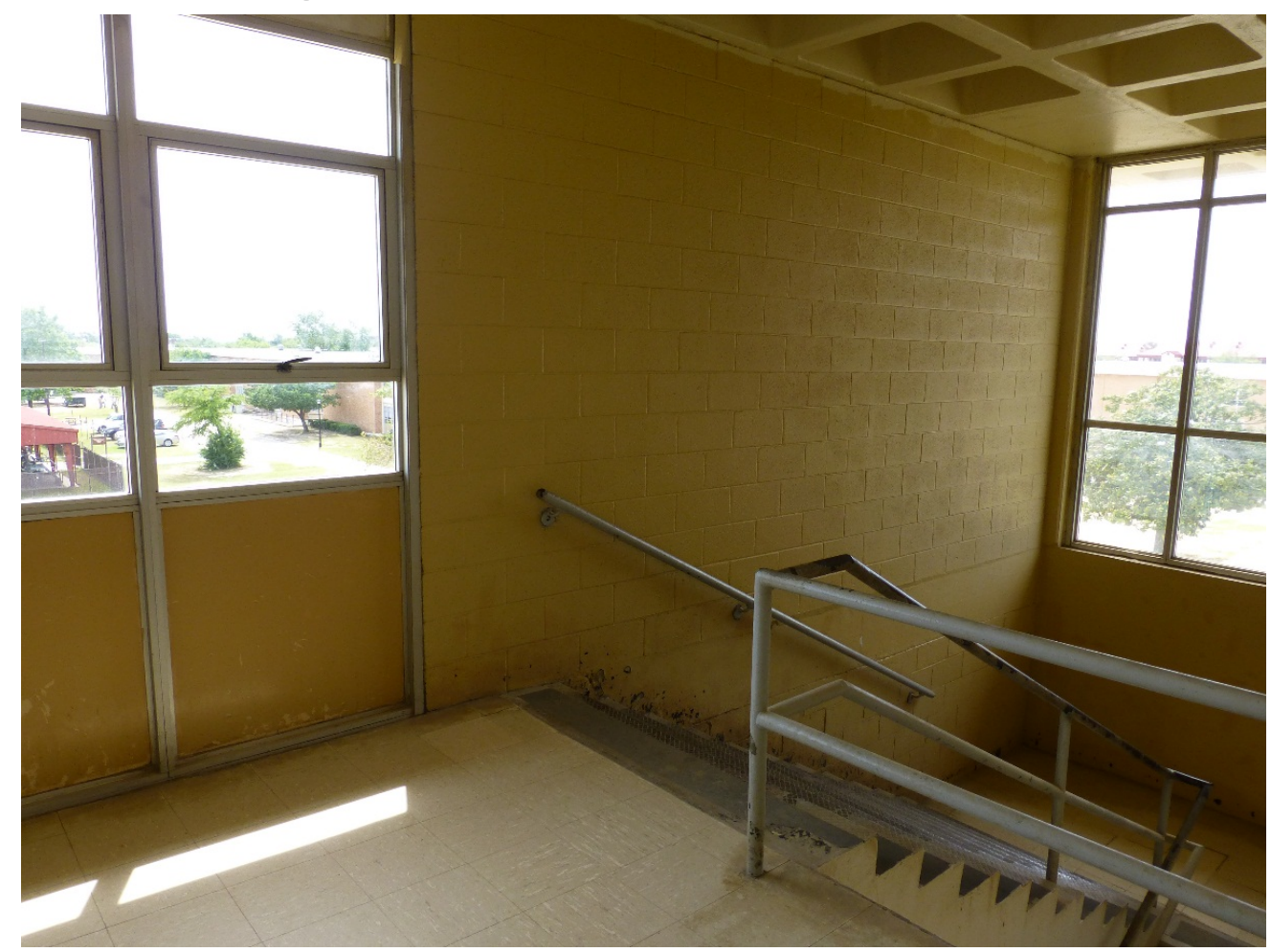


Figure 138. Interior stairwell - comparison of the original design and materials detail drawing from 1964 [left] to the current condition of an interior stairwell [right]

(ERDC-CERL, 2015).
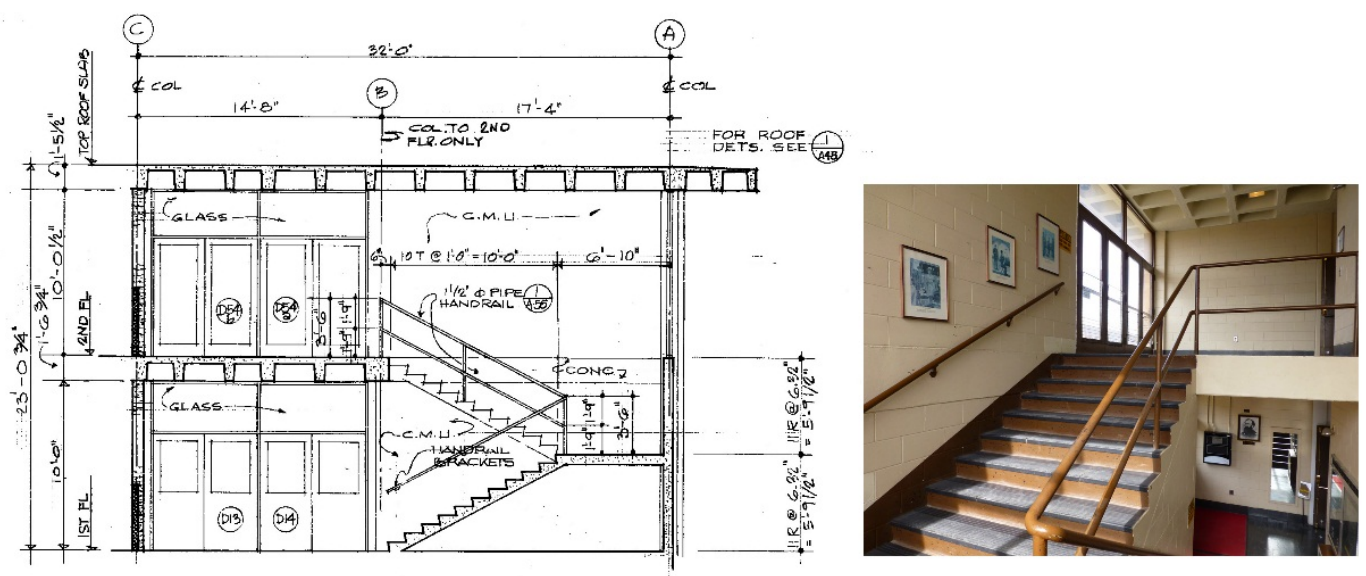

\subsubsection{Lighting}

A variety of ceiling-mounted and wall-mounted interior light fixtures styles are found throughout the Signal School Campus buildings in the historic district (Figure 139-Figure 149). Some of the buildings have them all, while others have only a few. However, these light fixtures are considered character-defining features and need to be noted in each building. If replacement is necessary, the light fixture must be replaced in-kind to the original. 
Figure 139. Light-fixture details and schedule for the Signal School buildings, 1964 (Fort Gordon DPW).

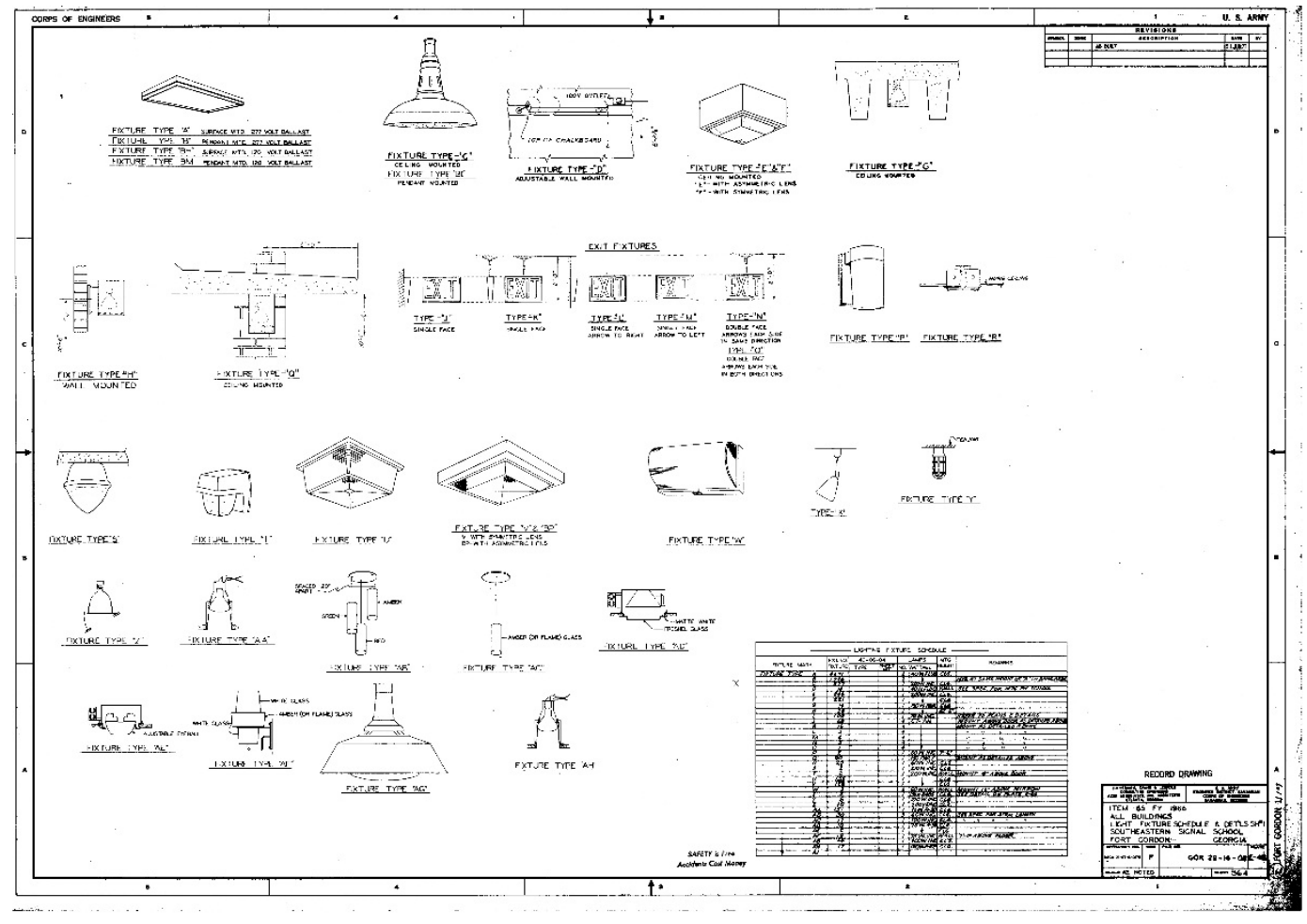

Figure 140. Light-fixture details and schedule for the Signal School buildings, 1964 (Fort Gordon DPW).

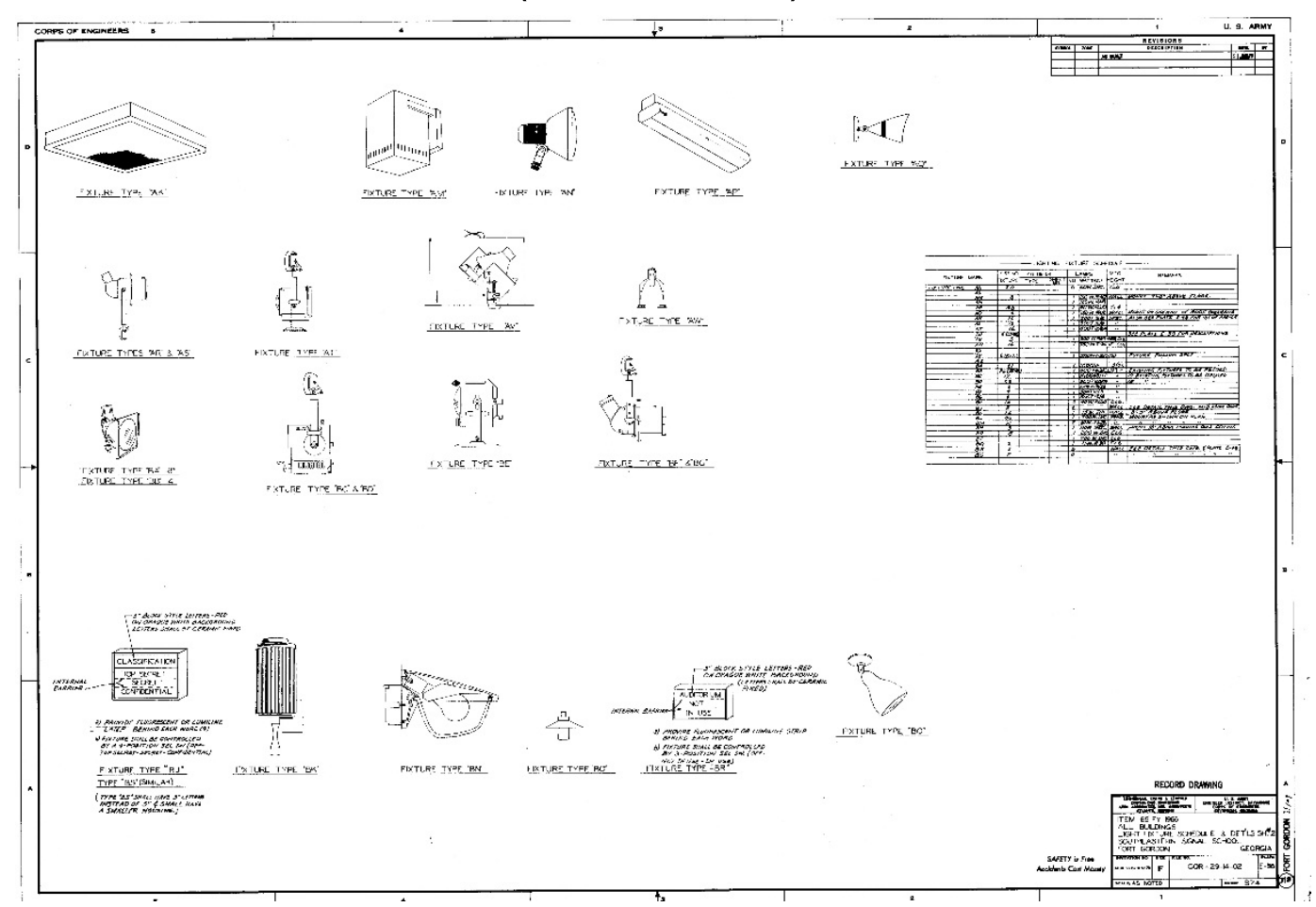


Figure 141. Original interior wall-mounted light fixture located in a stairwell (ERDC-CERL, 2015).

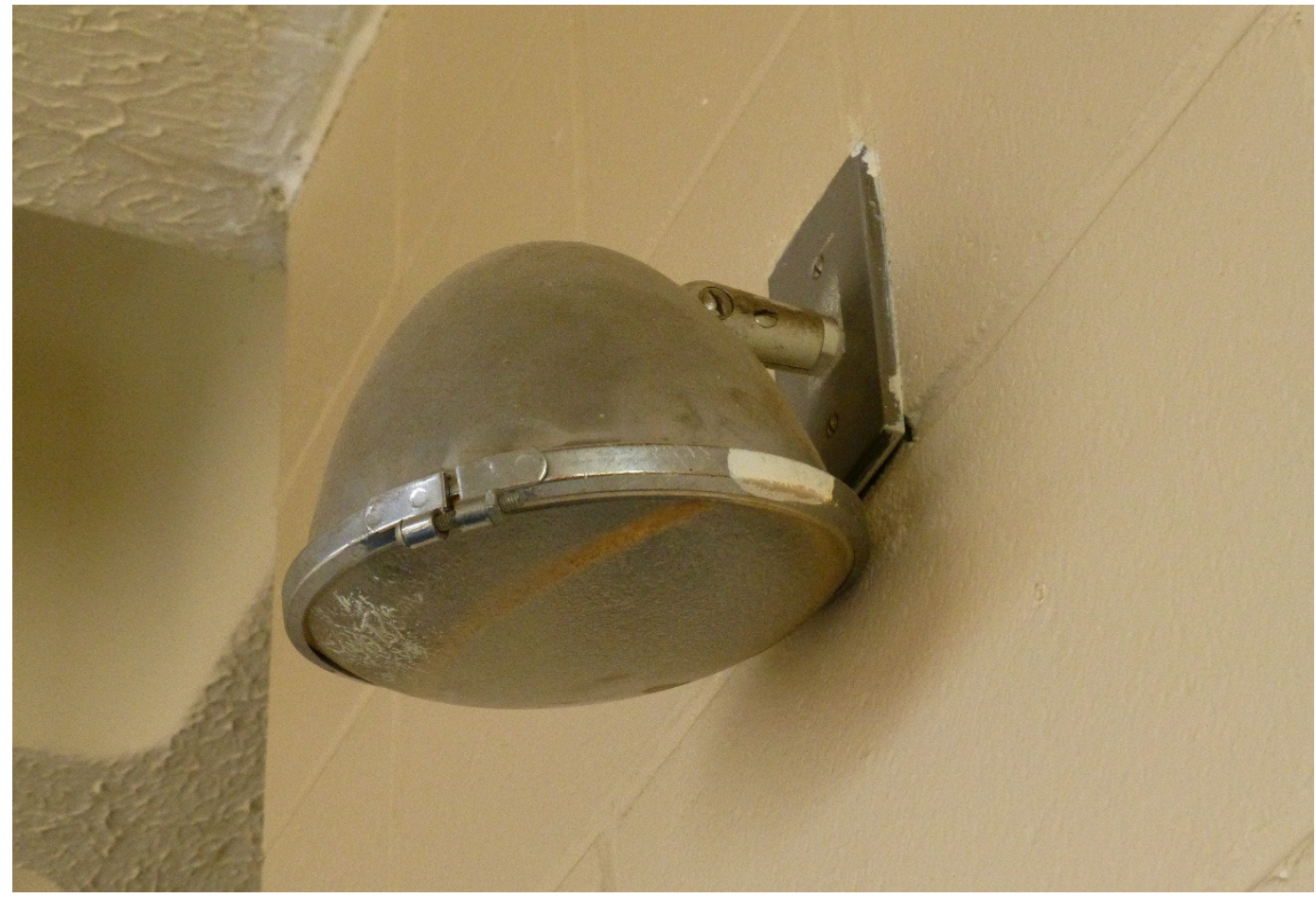

Figure 142. Replacement in-kind, square, ceiling-mounted light fixture set within the waffle ceiling (ERDC-CERL, 2015).

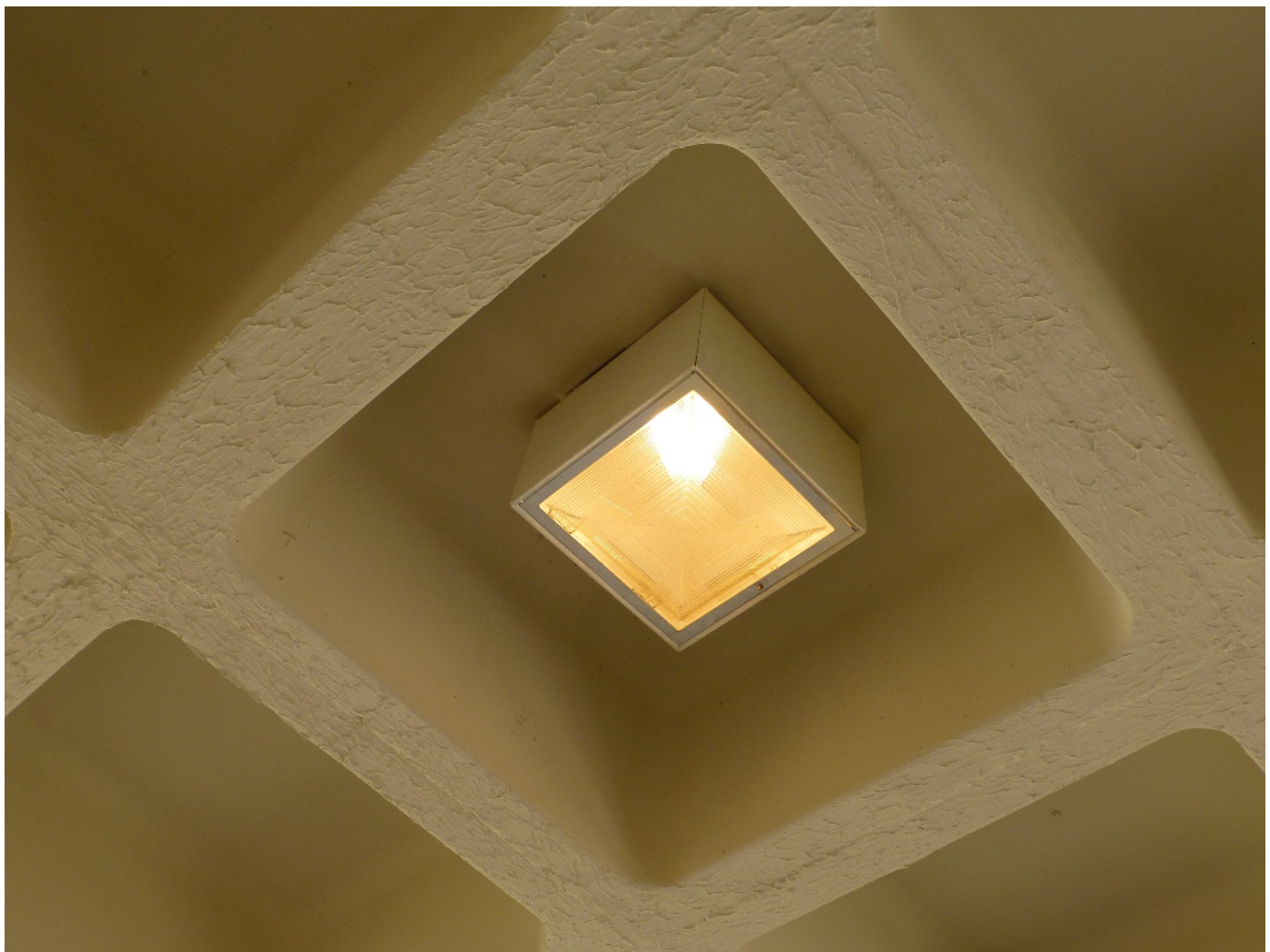


Figure 143. Original, square, ceiling-mounted light fixture set within the waffle ceiling (ERDC-CERL, 2015).

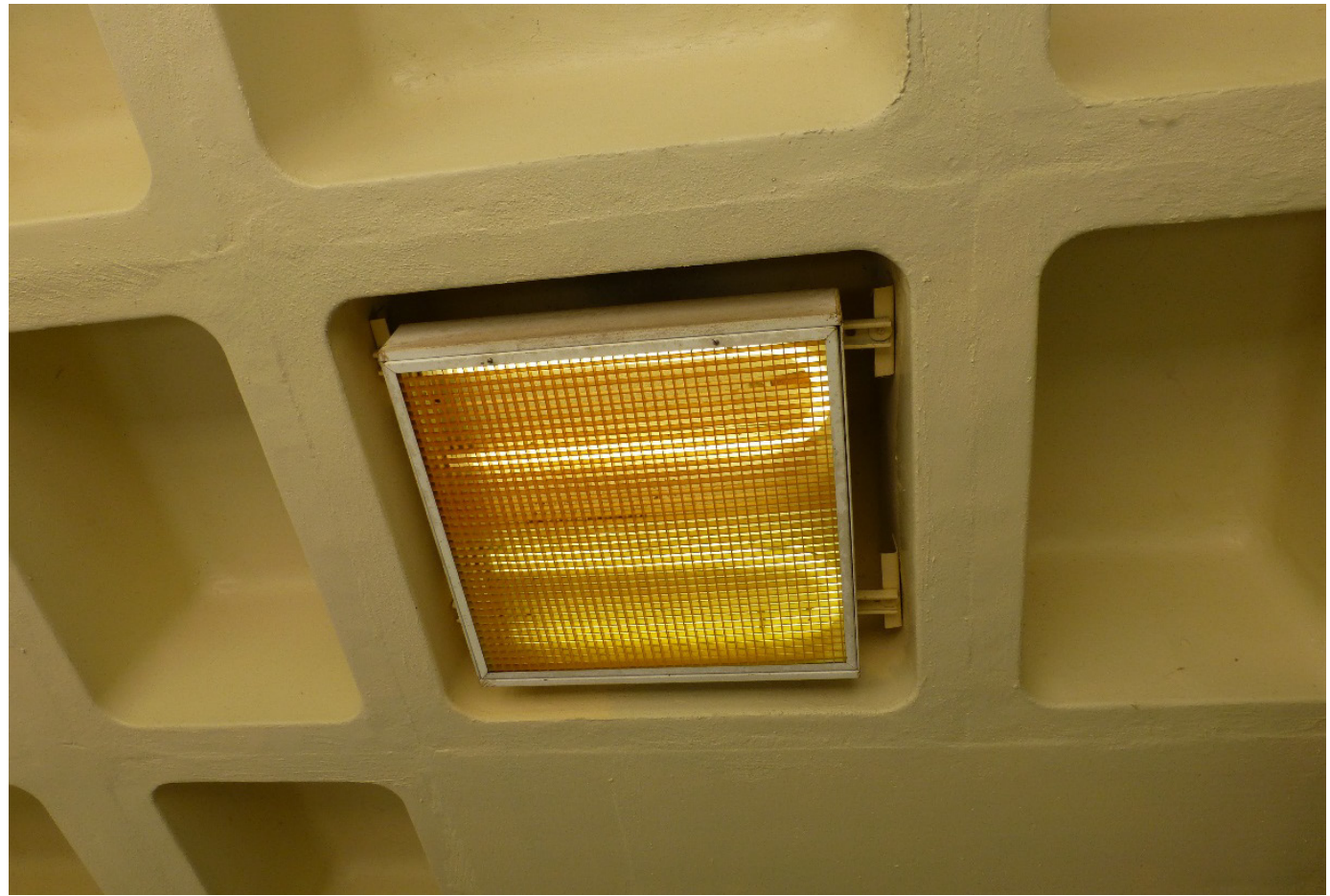

Figure 144. Typical original wall-mounted light fixture (ERDC-CERL, 2015).

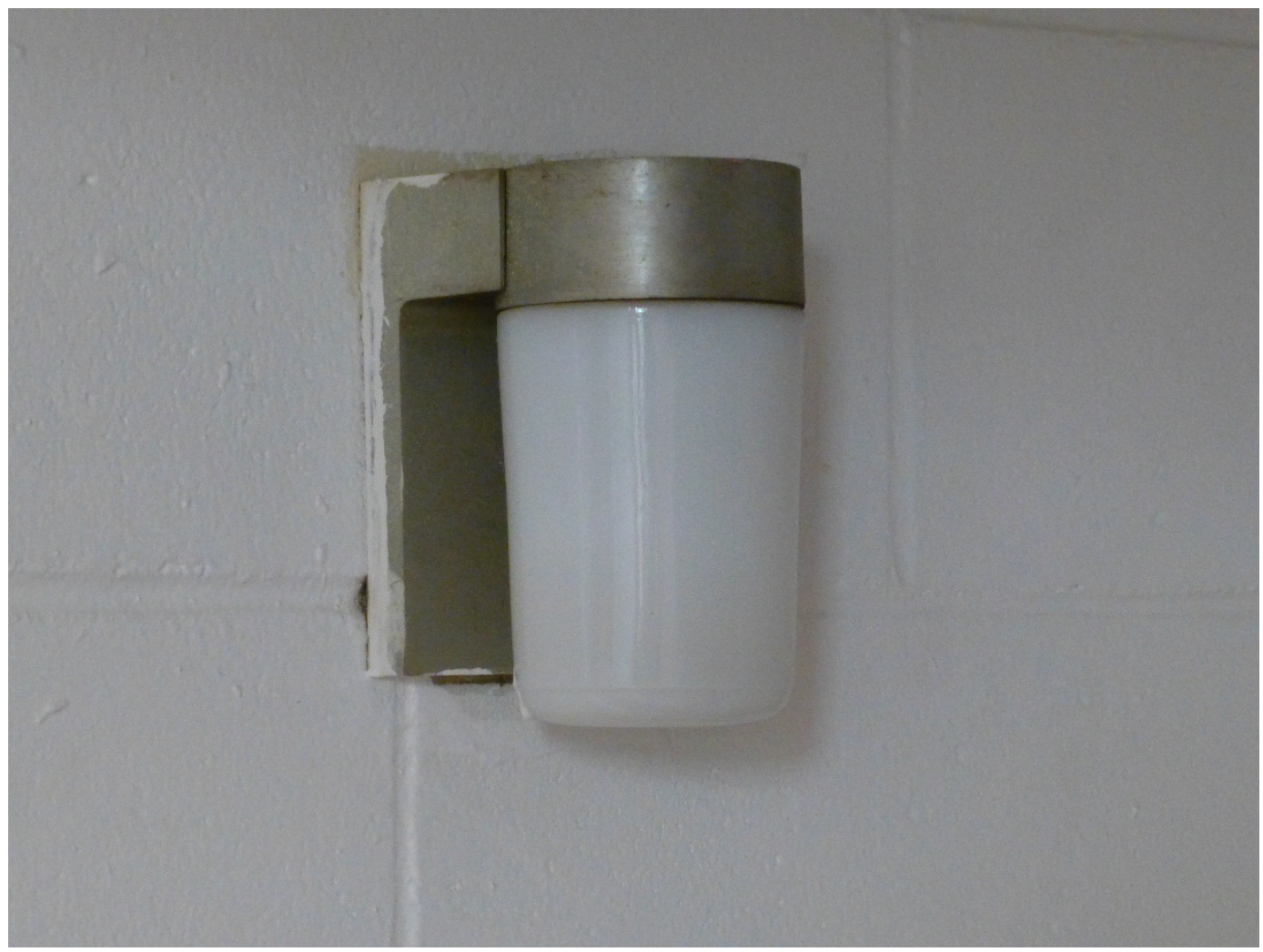


Figure 145. Typical original ceiling-mounted pendant light fixture (ERDC-CERL, 2015).

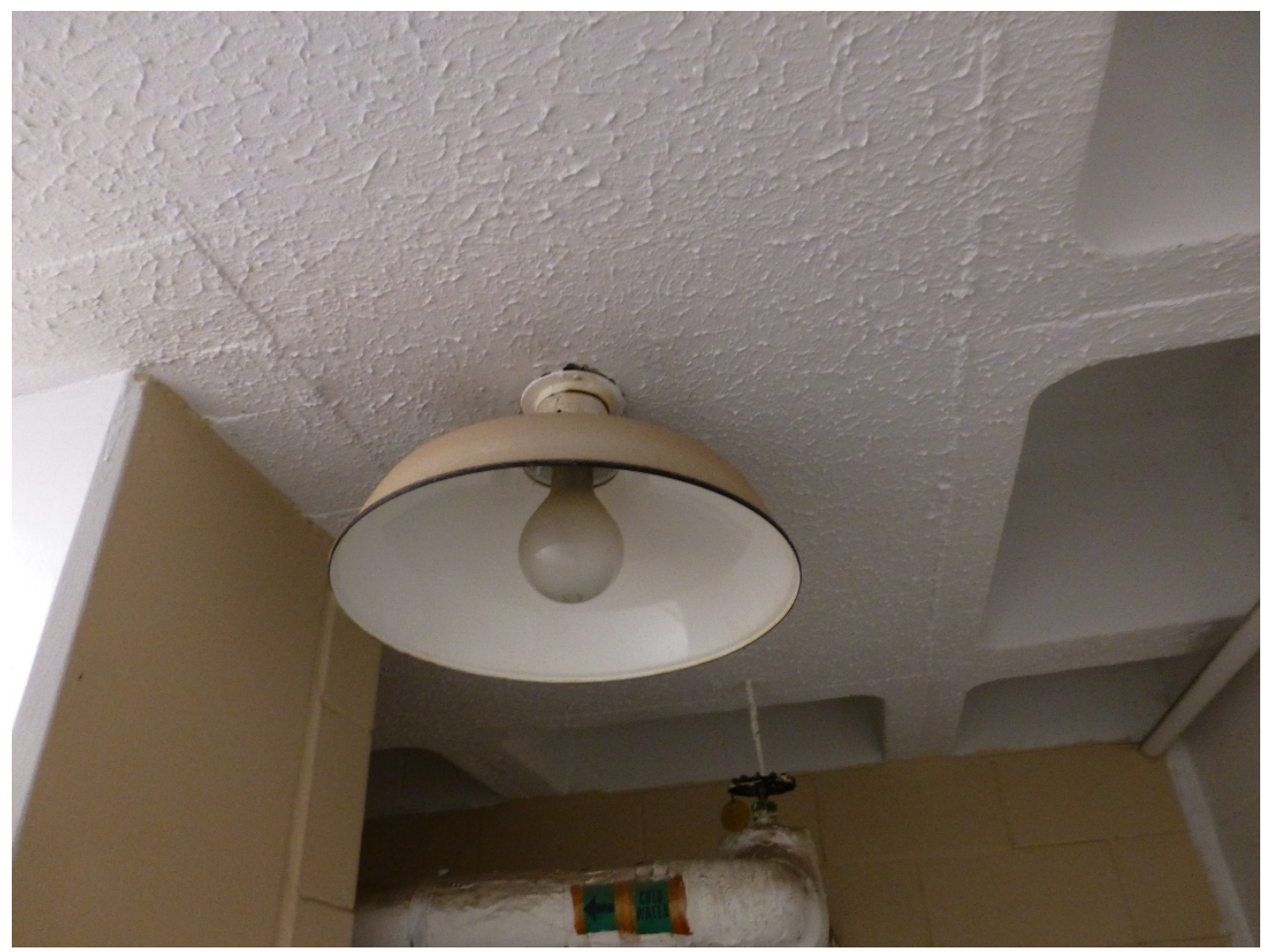

Figure 146. Ceiling-mounted pendant light fixture - comparison of the original design drawing and light fixture type from 1966 [left] to the current condition of the metal ceiling-mounted pendant light fixture [right] (ERDC-CERL, 2015).
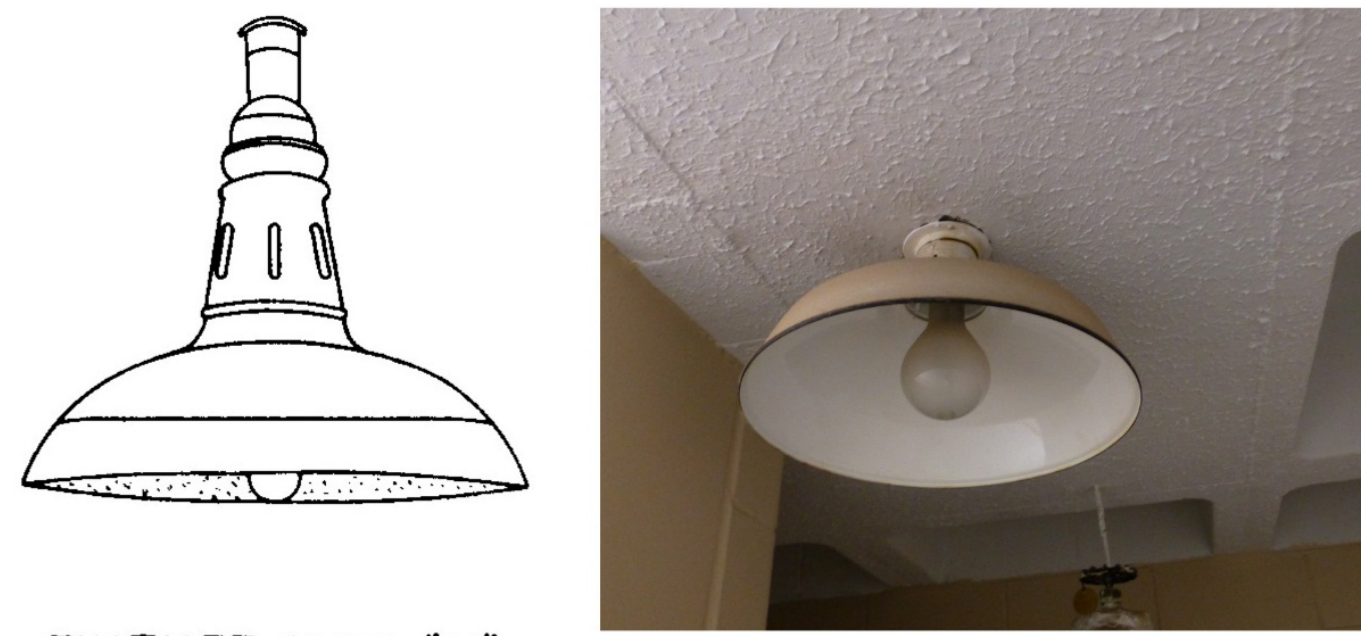

FIXTURE TYPE-"C"

CEILING MOUNTED

FIXTURE TYPE "BL"

PENDANT MOUNTED 
Figure 147. Ceiling-mounted light fixture set within the waffle ceiling - comparison of the original design drawing and light fixture type from 1966 [left] to the current condition of the metal ceiling-mounted light fixture [right] (ERDC-CERL, 2015).
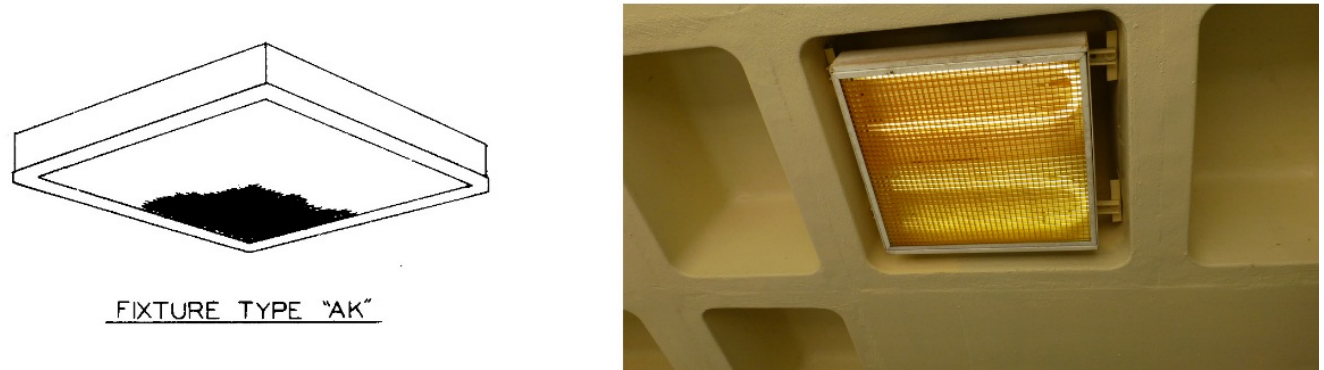

Figure 148. Ceiling-mounted pendant light fixture - comparison of the original design drawing and light fixture type from 1966 [left] to the current condition of the replacement ceiling-mounted light fixture [right] (ERDC-CERL, 2015).

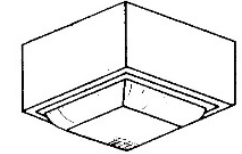

FIXTURE TYPE "E" 8 "F" CEILING MOUNTCD
"E"-WITH ASYMMETRIC LENS -F" - WITH SYMMETRIC LENS

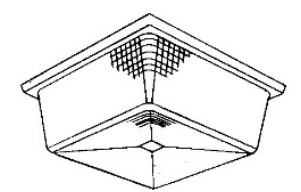

FIXTURE TYPE " $U$ "

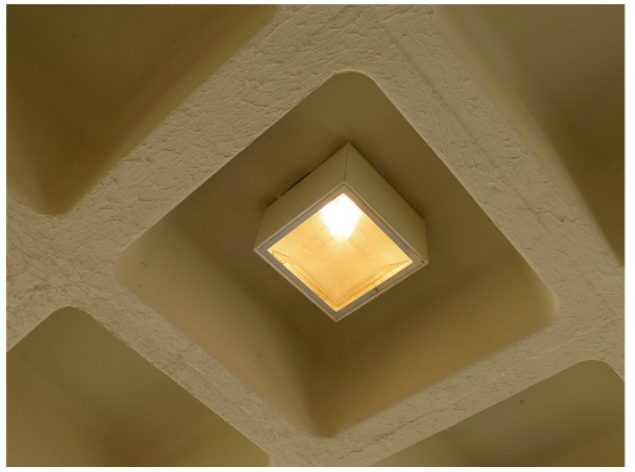

Figure 149. Wall-mounted pendant light fixture - comparison of the original design drawing and light fixture type from 1966 [left] to the current condition of the wallmounted light fixture [right] (ERDC-CERL, 2015).
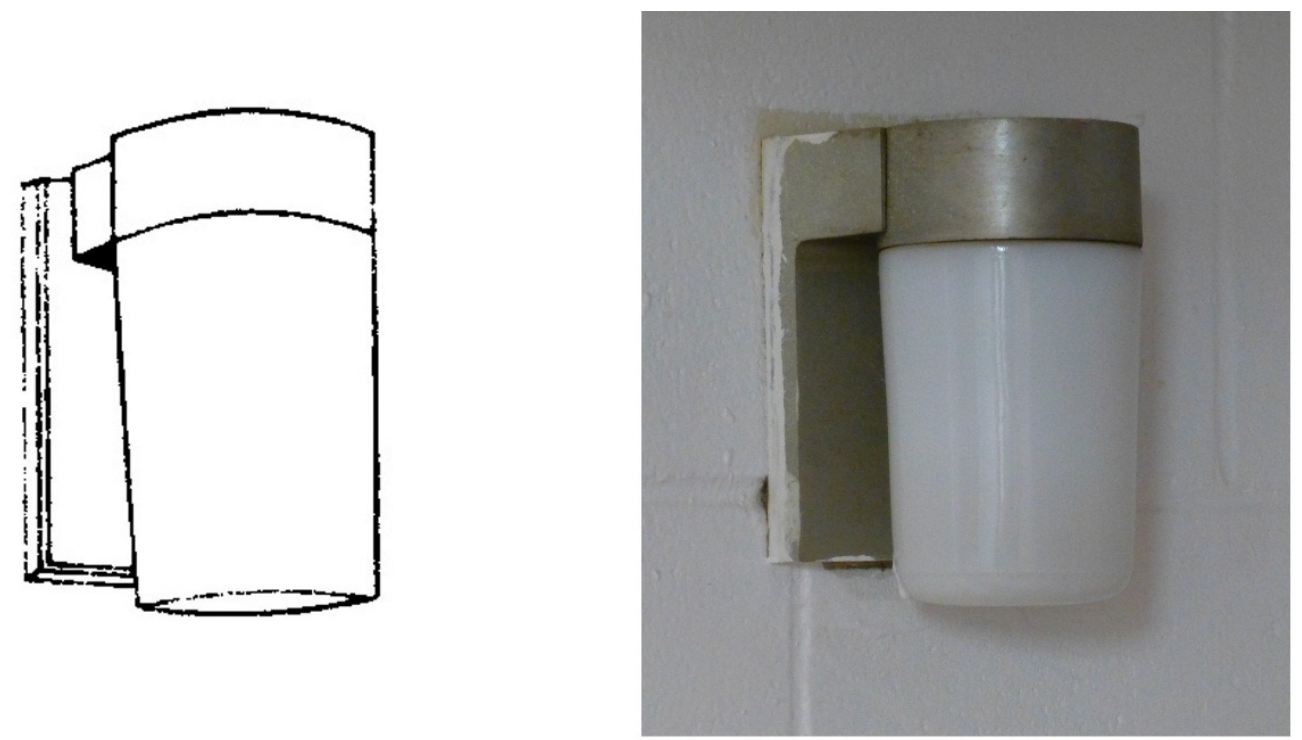

FIXTURE TYPE "P" 


\subsubsection{Doors}

A variety of interior door styles are found throughout the Signal School Campus buildings in the historic district. Some of these include wood doors with a glass pane and a wood transom above, solid wood doors with wood transom, and metal security doors with a small glass pane (Figure 150-Figure 157). Some of the buildings have them all, while others have only have a few. However, these doors are considered character-defining features and need to be noted in each building. If replacement is necessary, the door must be replaced in-kind to the original.

Figure 150. Details of typical interior doors found in the Signal School buildings, 1964 (Fort Gordon DPW).

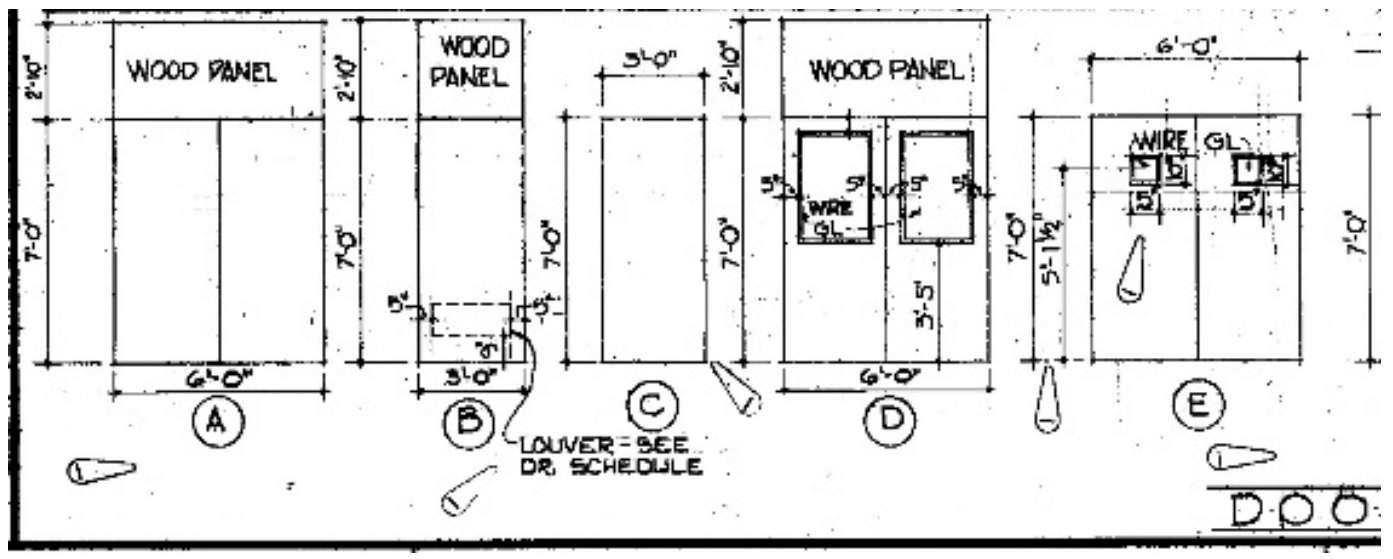


Figure 151. Typical metal security doors with one small pane, leading from the stairwell into the central hall (ERDC-CERL, 2015).

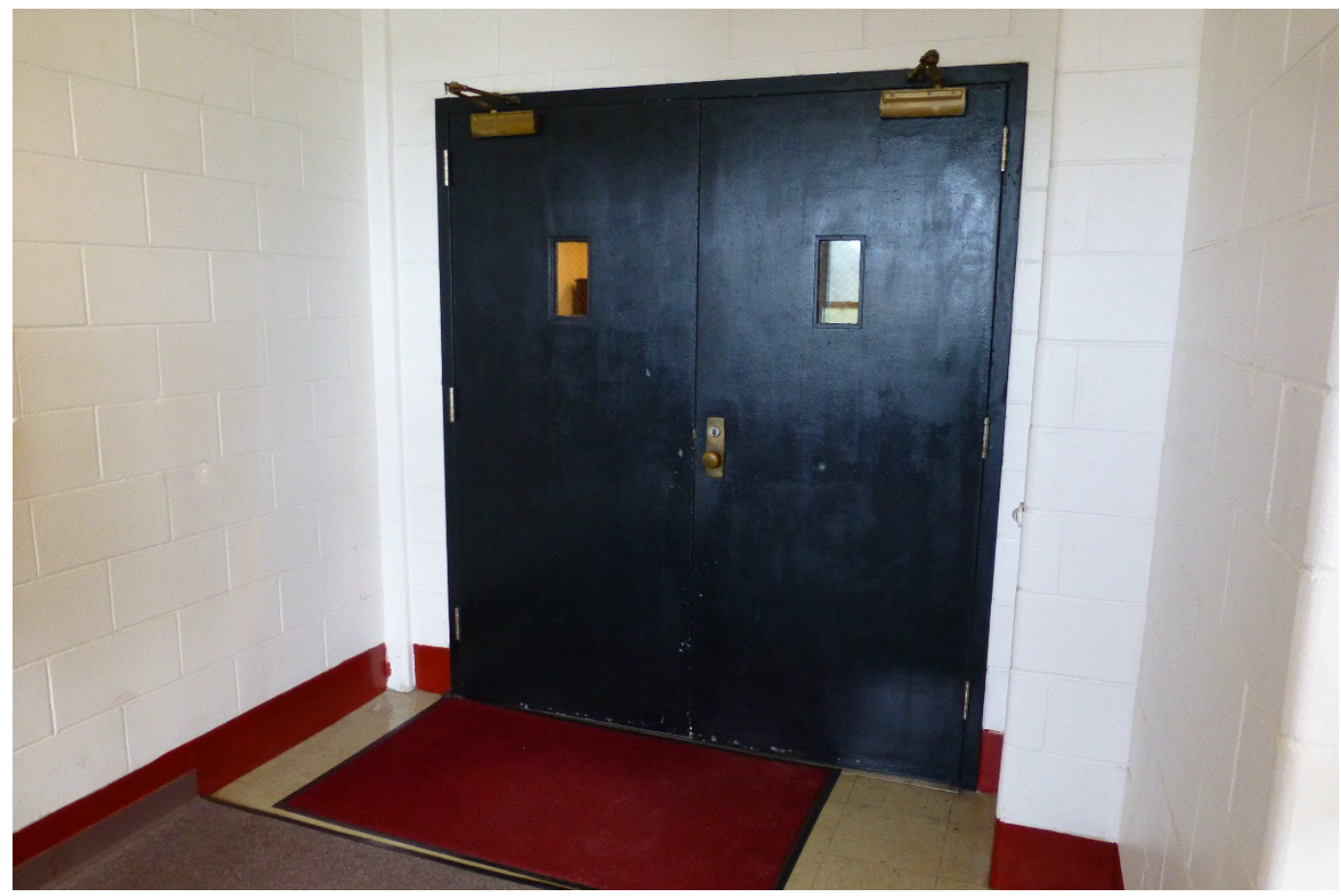

Figure 152. Typical interior wood doors with large pane and wood transom, located in the hallway [left] and typical wood door with wood transom leading into room off hallway [right] (ERDC-CERL, 2015).

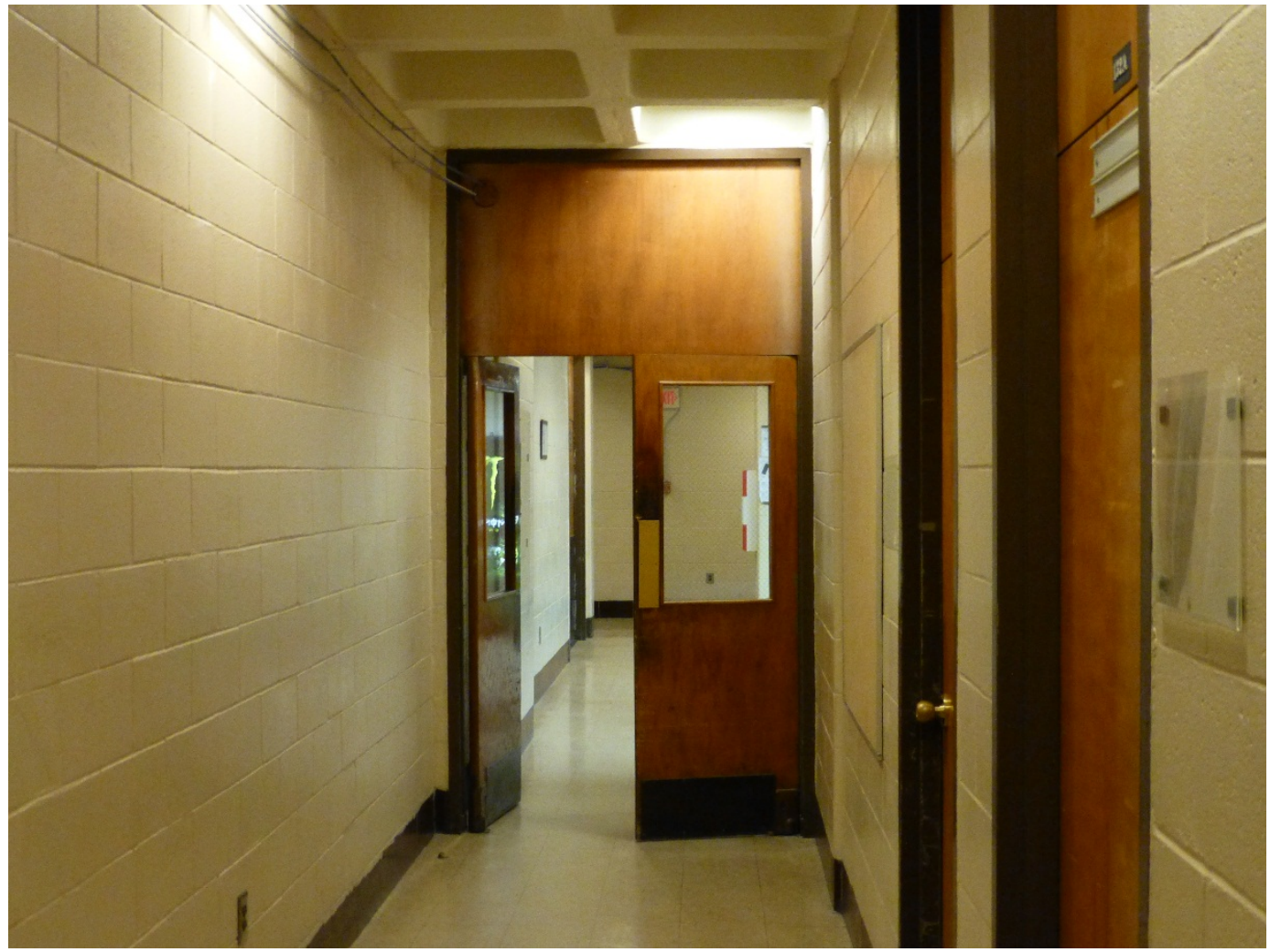


Figure 153. Typical wood doors with a large pane and wood transom, leading from stairwell into the central hallway (ERDC-CERL, 2015).

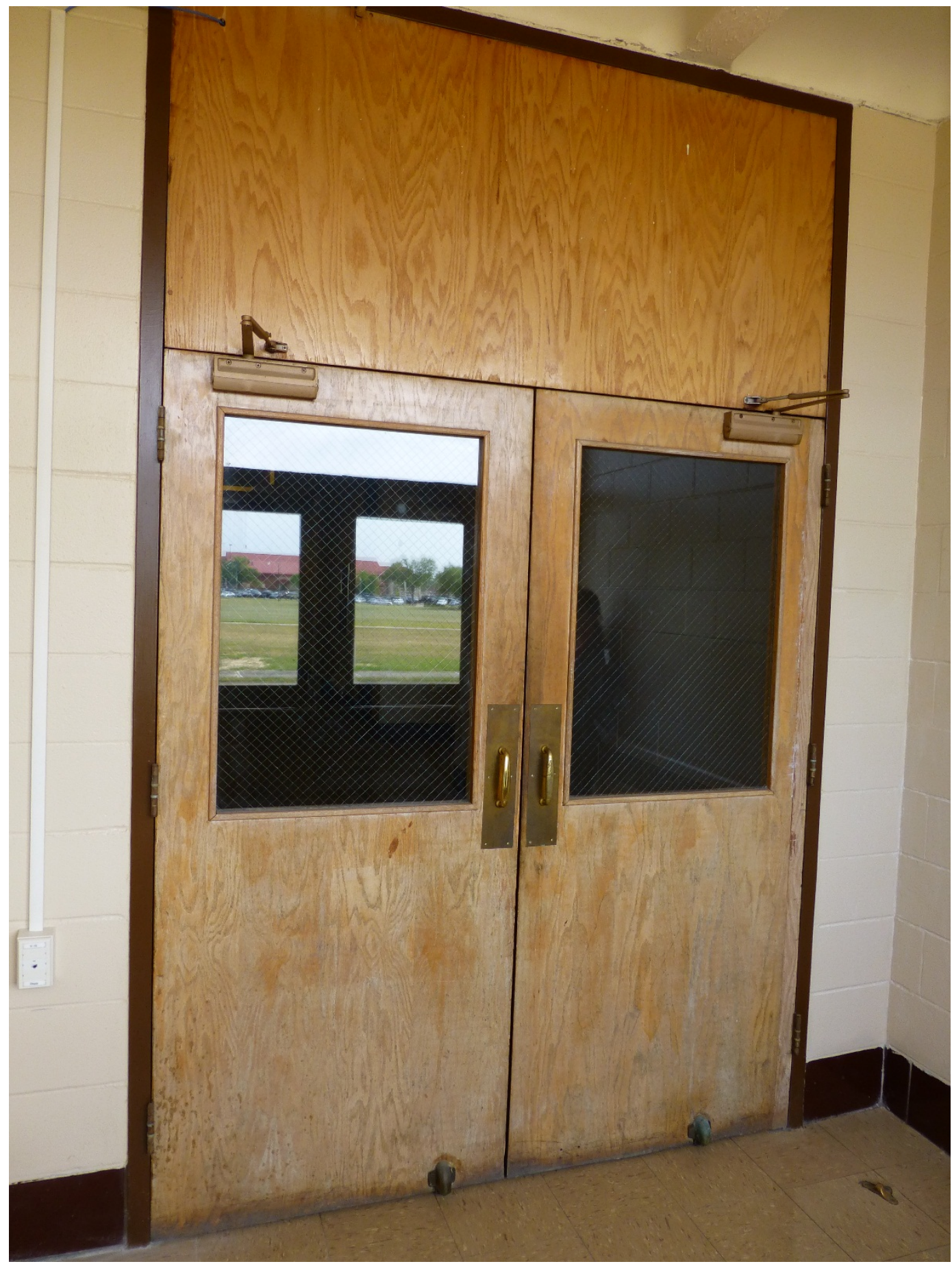


Figure 154. Doors leading from the lobby into the Alexander Hall auditorium space in Building 29805 (ERDC-CERL, 2015).

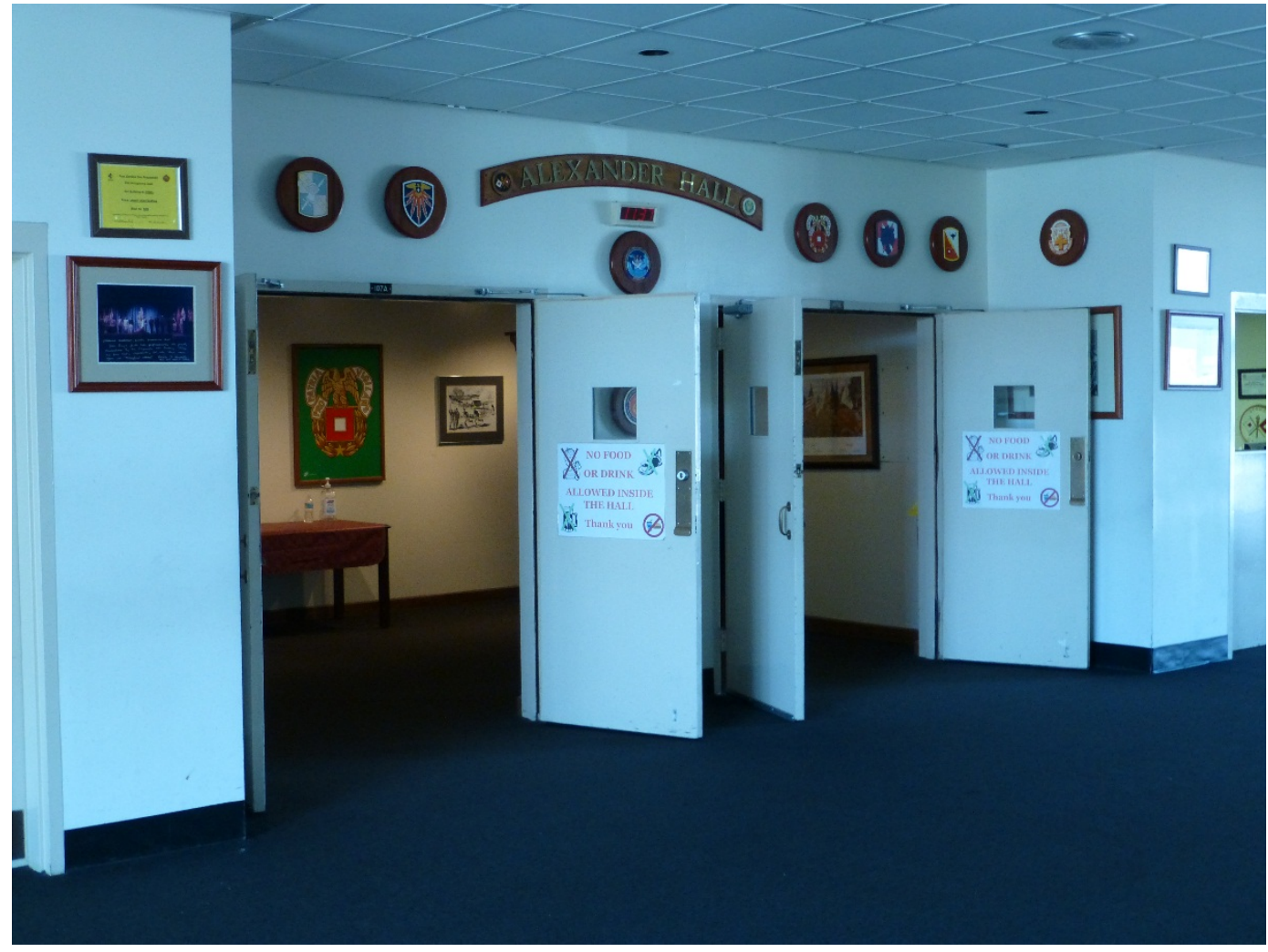

Figure 155. Interior wood door with large light in Building 29807, Museum (Conrad Hall) (ERDC-CERL, 2015).

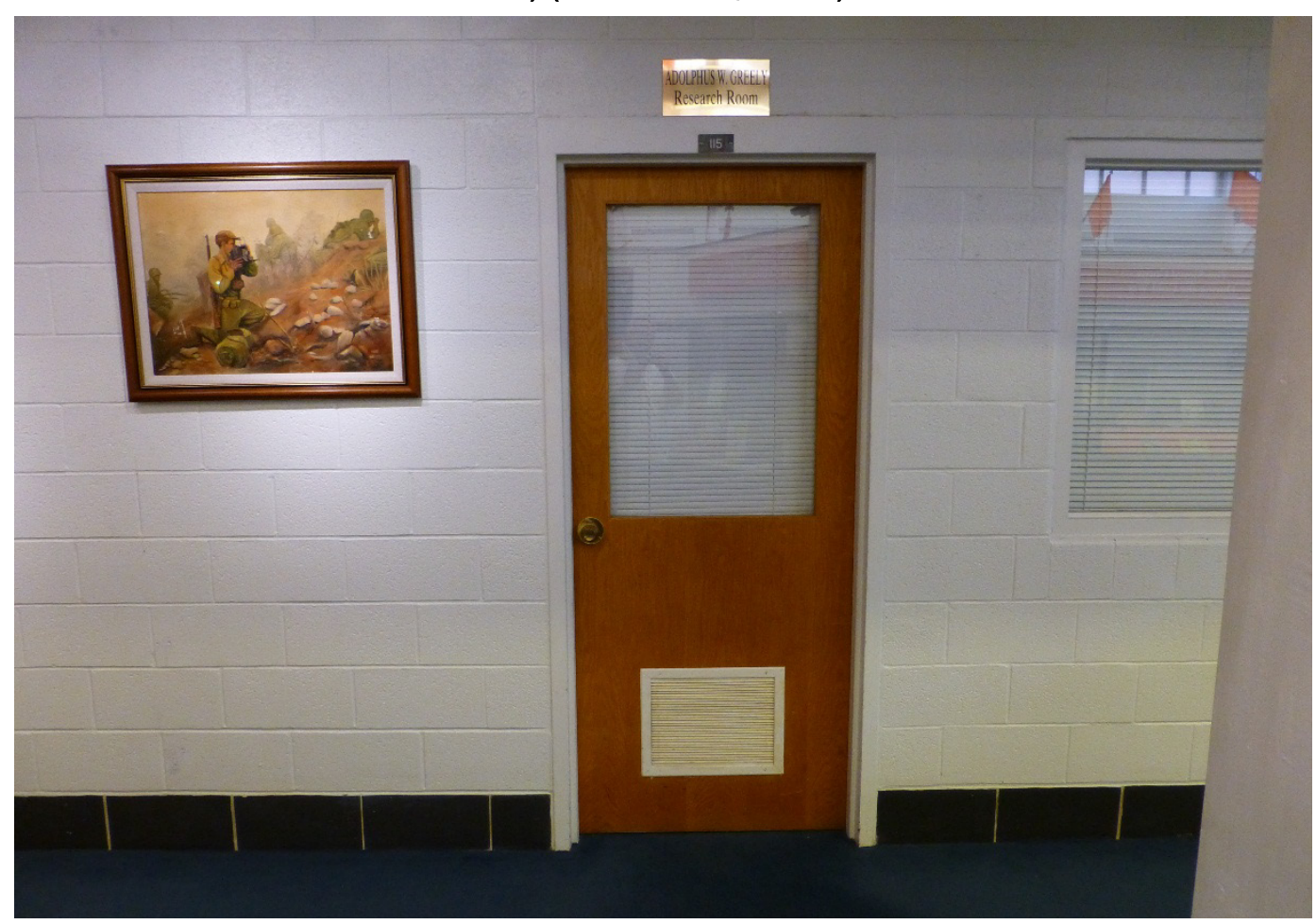


Figure 156. Typical metal door with small pane - comparison of the original design drawing from 1964 [left] to the current condition of the metal doors [right]

(ERDC-CERL, 2015).

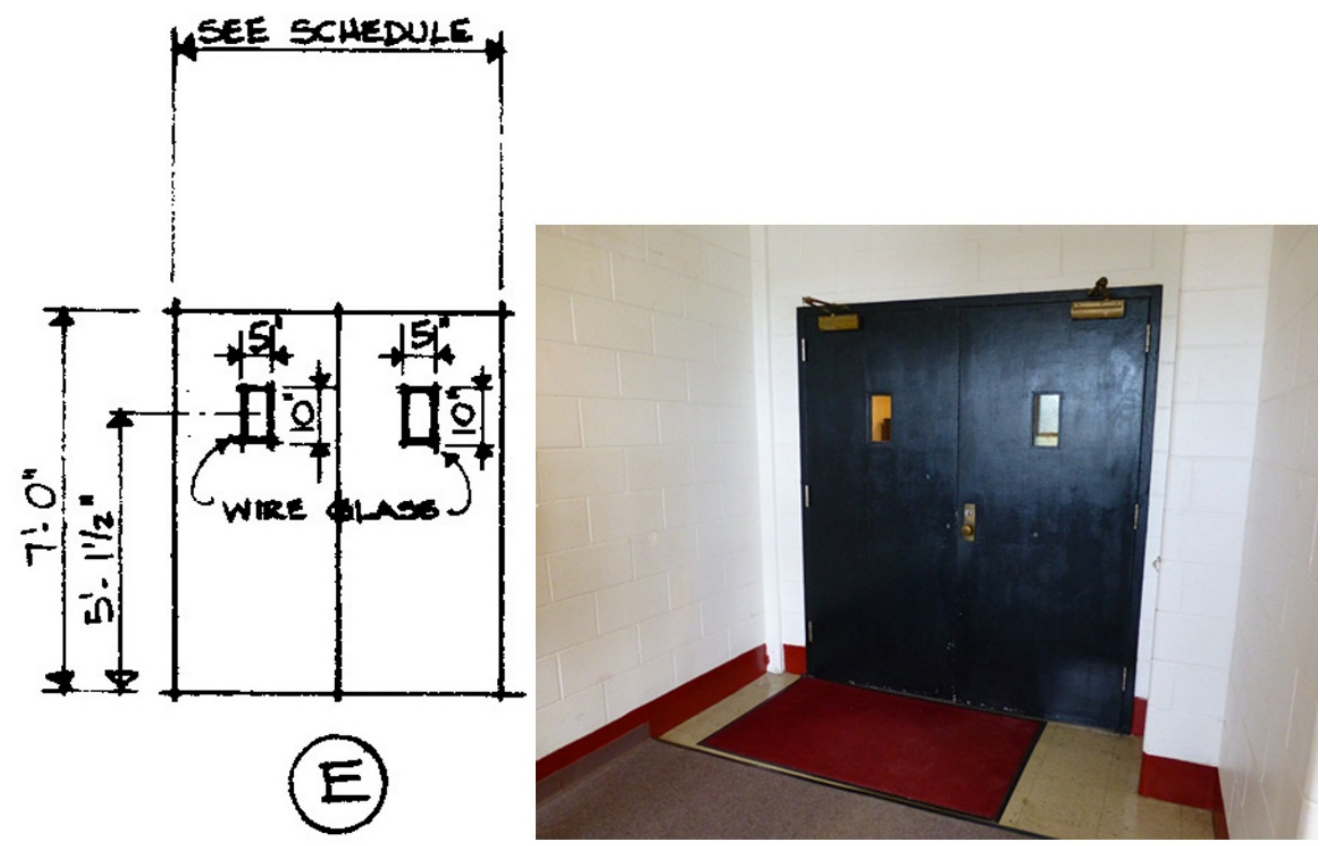

Figure 157. Typical wood door with large pane and wood transom - comparison of the original design drawing from 1964 [left] to the current condition of the wood doors and transom [right] (ERDC-CERL, 2015).
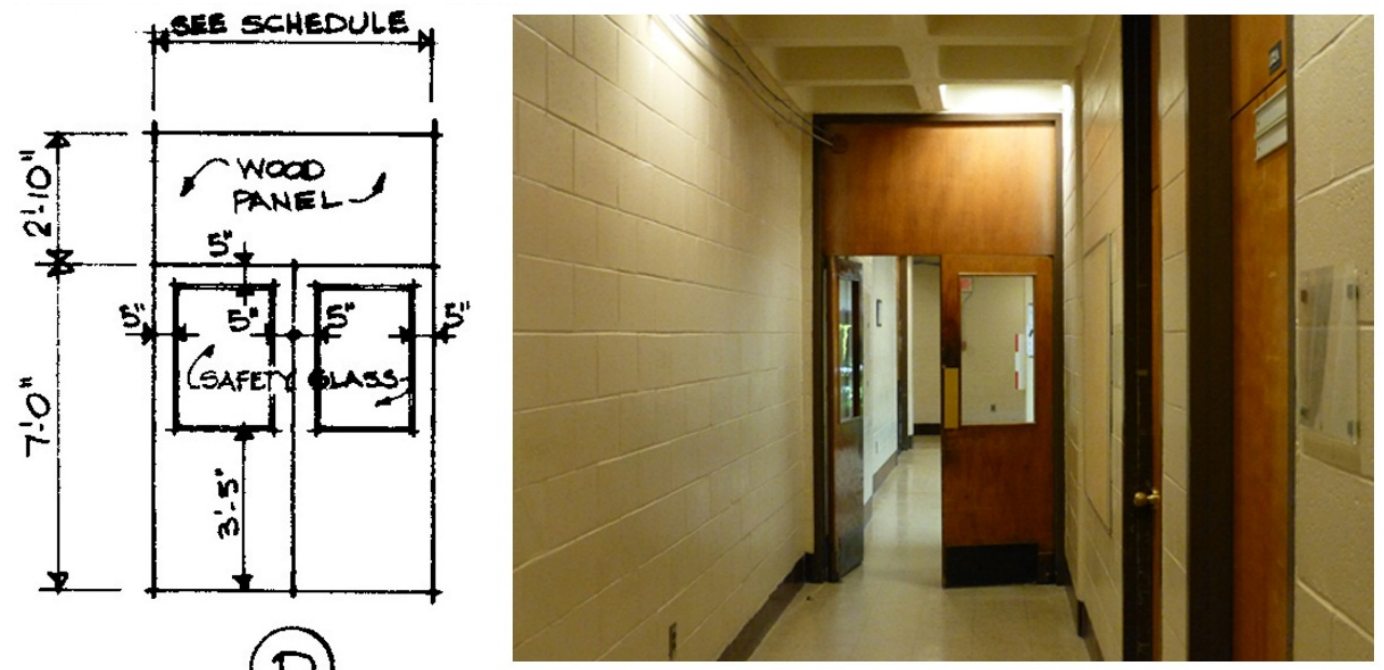

(D) 


\subsubsection{Bright-aluminum display cases}

Most of the Signal School classroom buildings have a directory display case framed in bright-aluminum. These display cases are located near a main entry on the first floor in the stairwell (Figure 158 and Figure 159).

Figure 158. Close-up of typical bright-aluminum directory display case (ERDC-CERL, 2015).

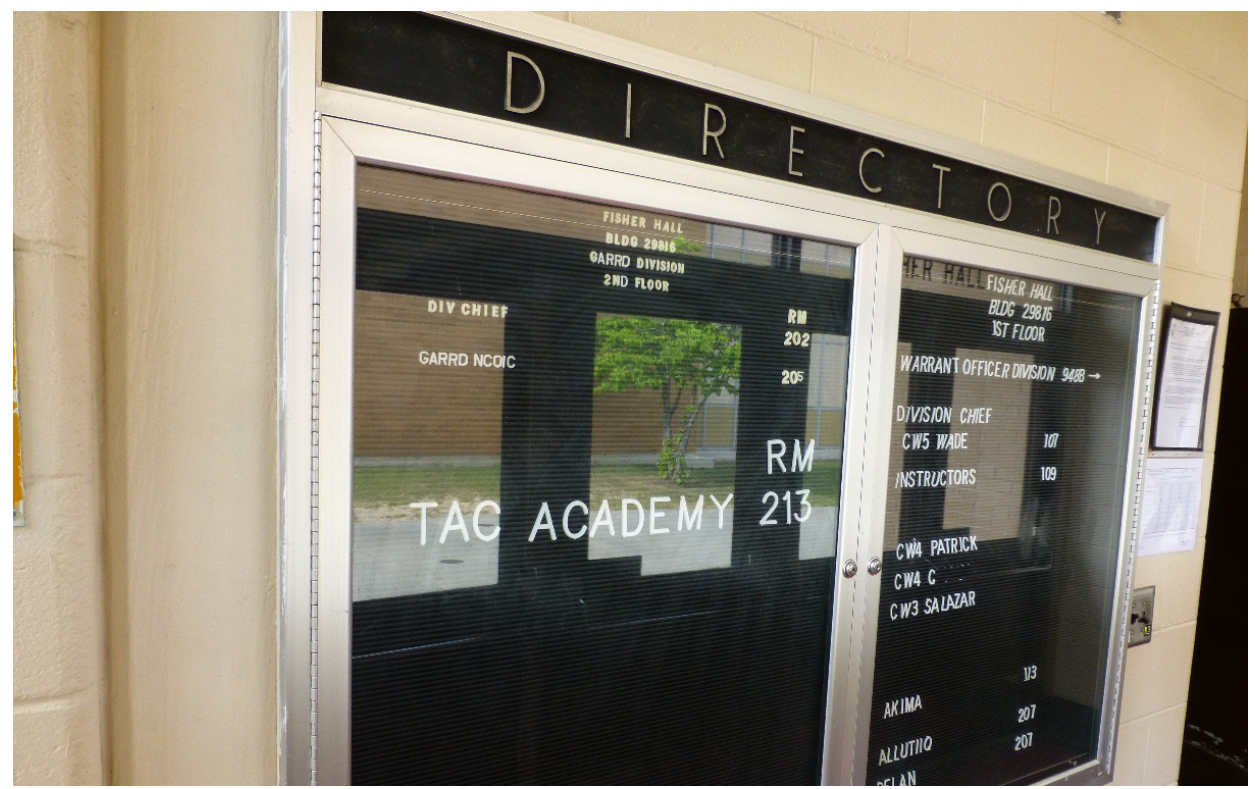

Figure 159. Another typical bright-aluminum directory display case (ERDC-CERL, 2015).

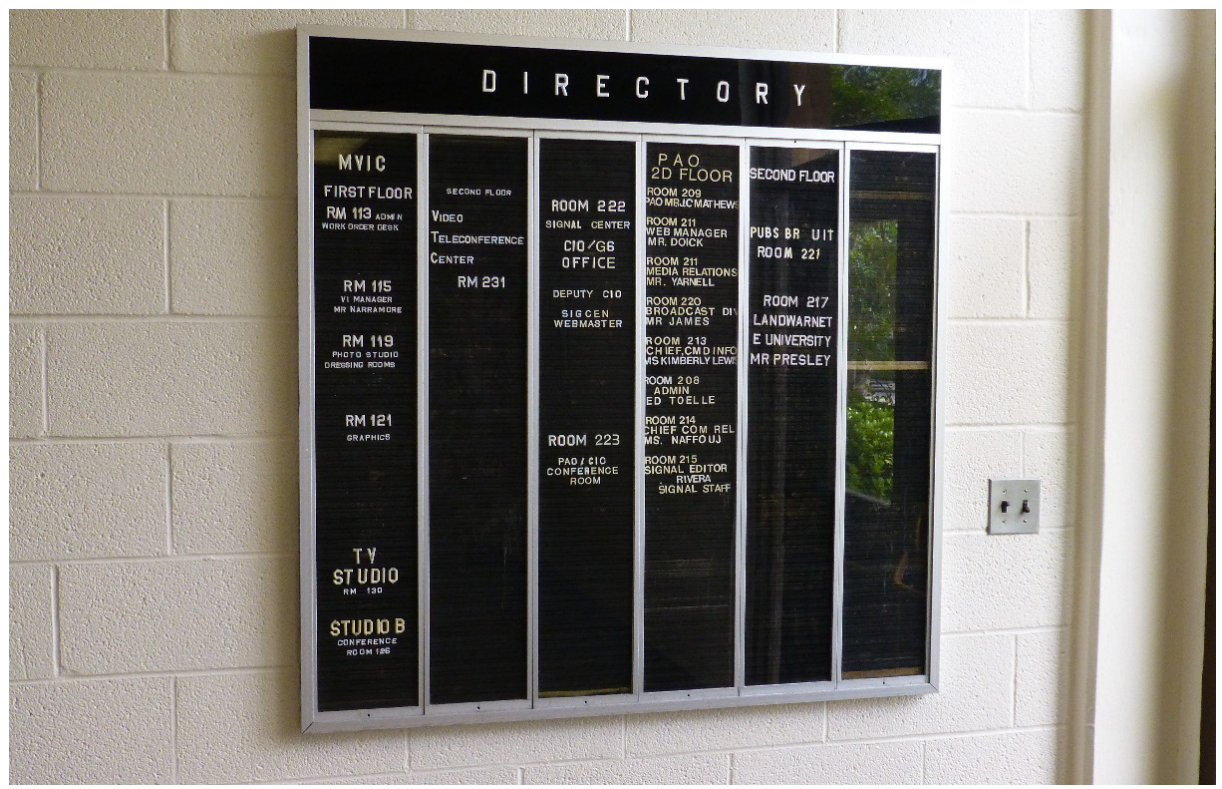




\subsubsection{Telephone alcove}

Some of the Signal School buildings were constructed to include telephone alcoves (Figure 160 and Figure 161). It is important that the visual aspects and character-defining features be recognized before planning any changes or alterations to the space or feature. Their identification, retention, protection, and repair should be given consideration. Caution should be exercised in developing plans that would radically change these character-defining spaces.

Figure 160. Example of an original telephone alcove, which is no longer being used for its original purpose (ERDC-CERL, 2015).

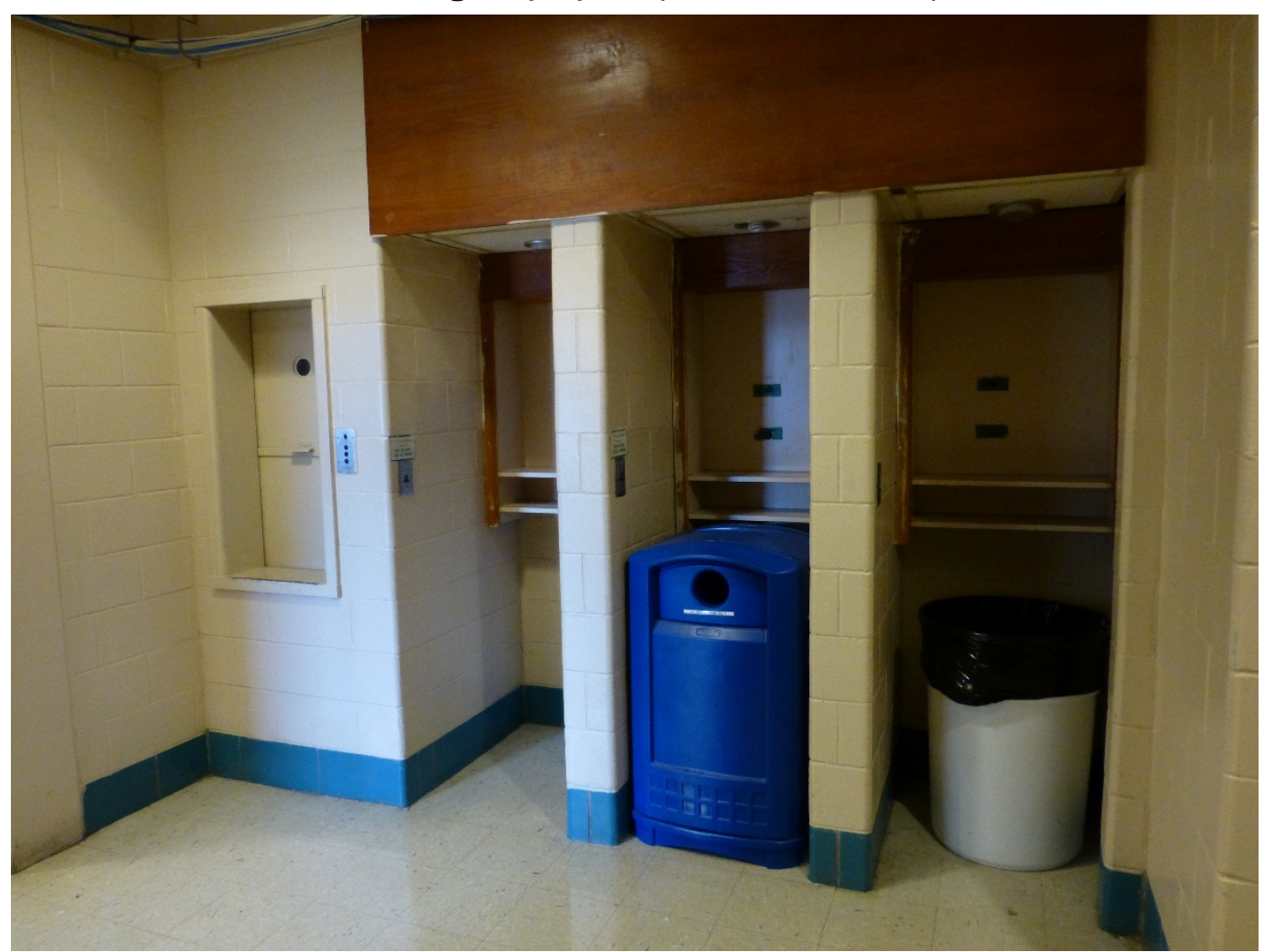


Figure 161. Telephone alcove - comparison of the original drawing from 1964 [left] to the current condition of the alcove [right] (ERDC-CERL, 2015).
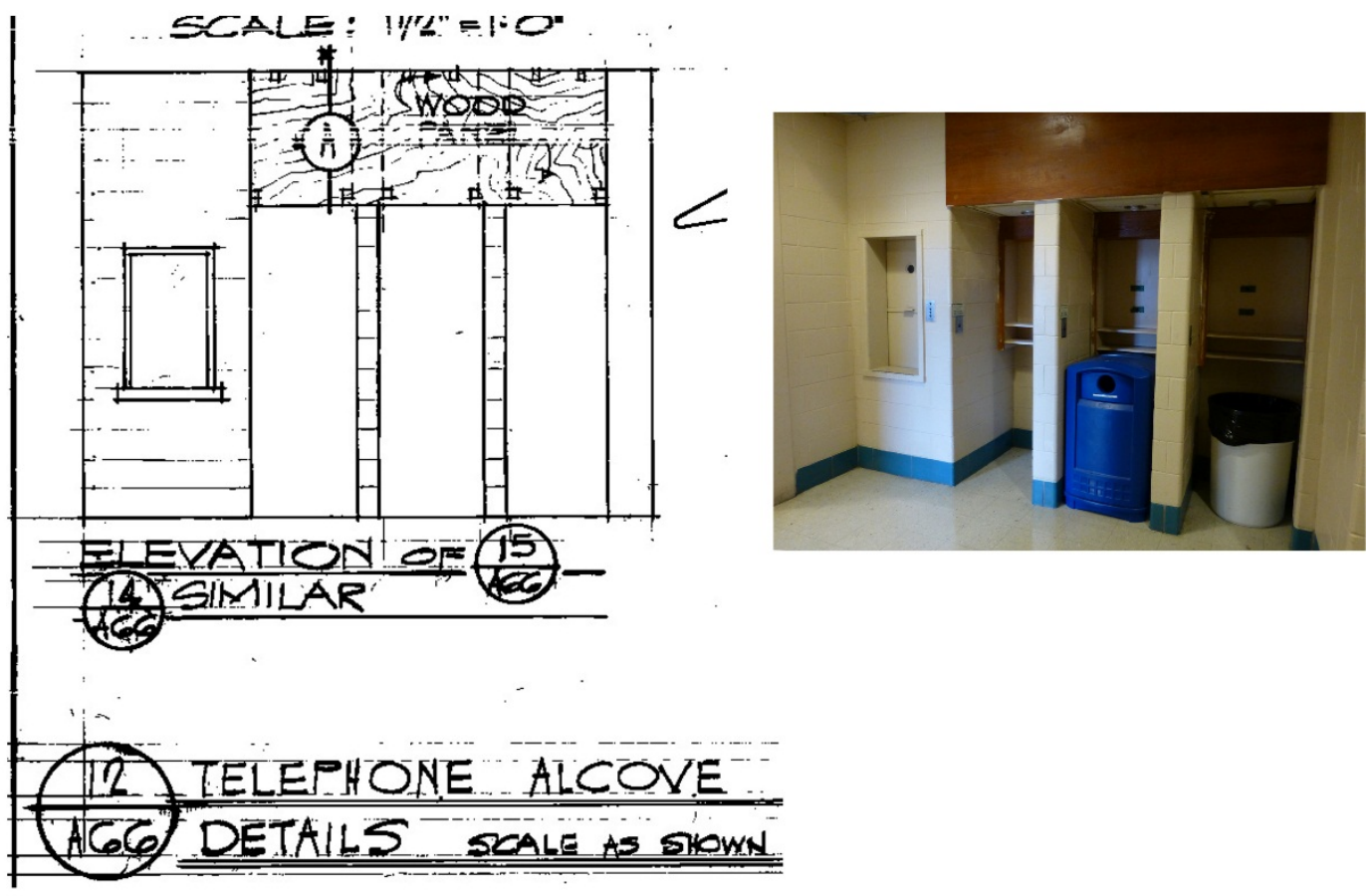

\subsubsection{Vending alcove}

Some of the Signal School buildings were constructed to include vending alcoves. These vending areas were typically located on the first floor at either end of the classroom building and near the stairwells. They were left as an open space adjacent the hallway, with concrete block walls and exposed concrete waffle ceiling (Figure 162 and Figure 163). It is important that the visual aspects and character-defining features be recognized before planning any changes or alterations to the space or feature. Their identification, retention, protection, and repair should be given consideration. Caution should be exercised in developing plans that would radically change these character-defining spaces. For example, if an original open vending area is going to be turned into an office, this would be an adverse effect on the character-defining feature of that space. 
Figure 162. Example of a vending area with concrete block wall and exposed concrete waffle ceiling (ERDC-CERL, 2015).

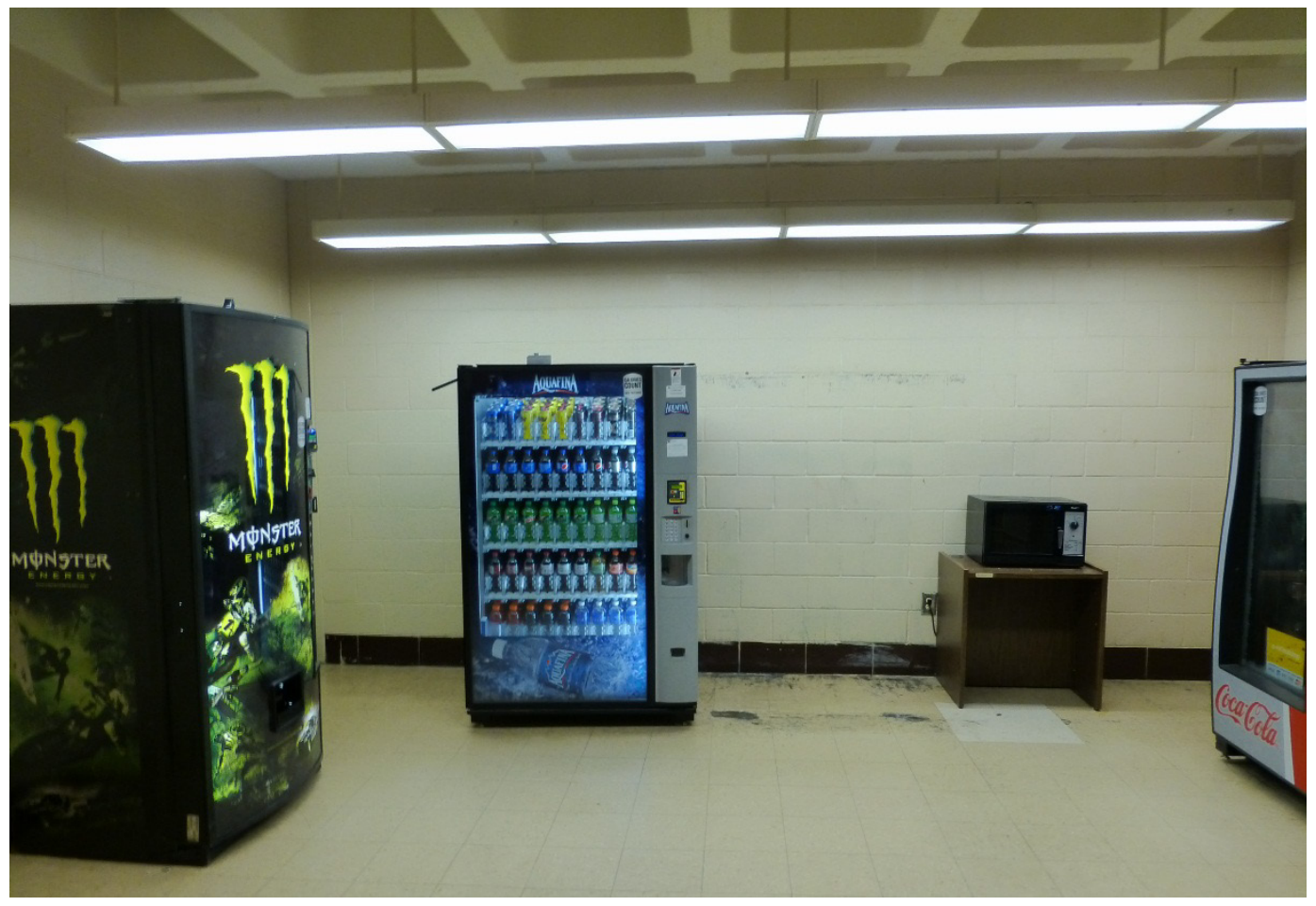

Figure 163. Example of a modified open vending area (ERDC-CERL, 2015).

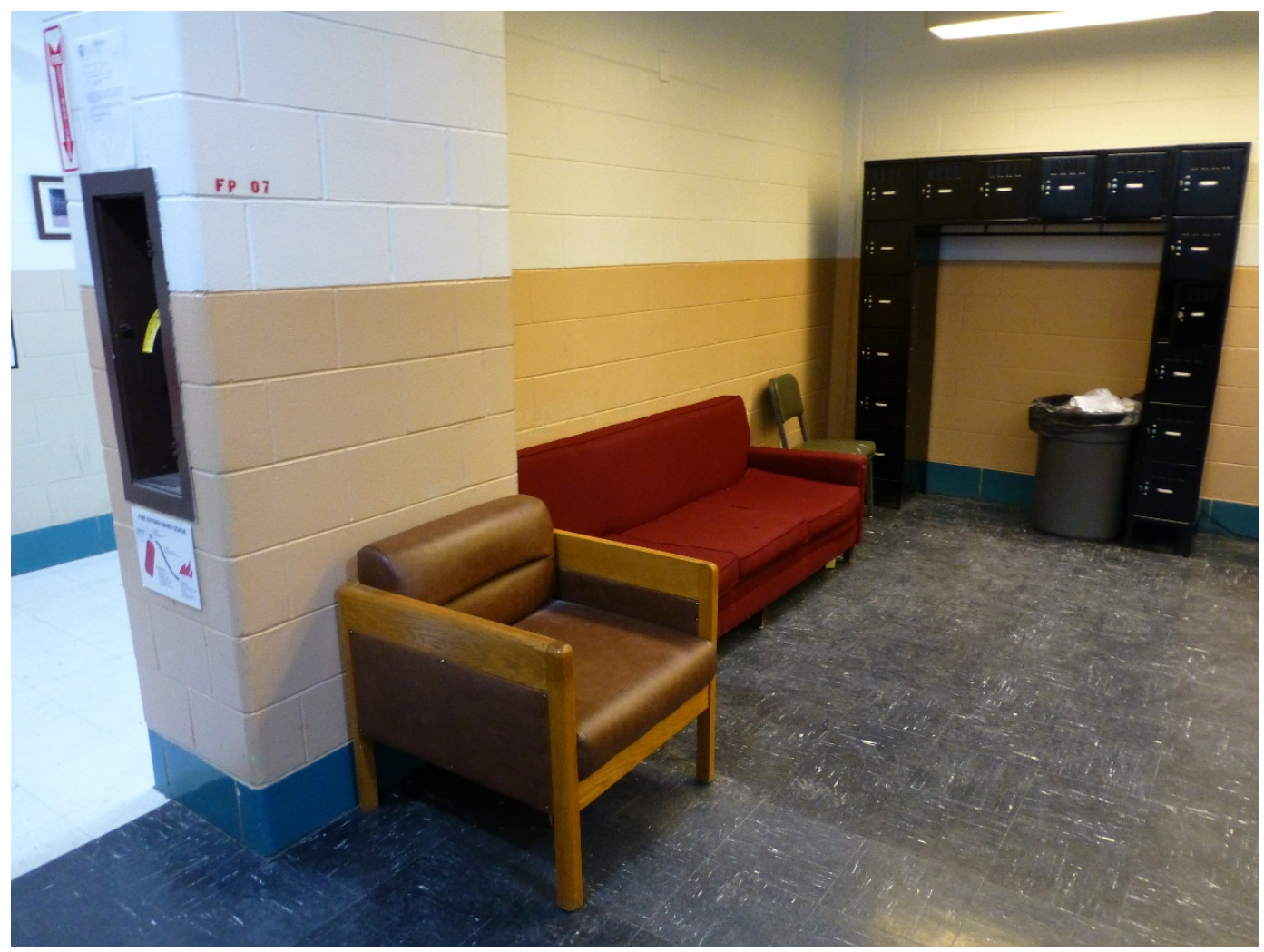




\subsubsection{Water-fountain alcove}

All of the Signal School buildings were designed with water-fountain alcoves (Figure 164 and Figure 165). These little alcoves were small niches located in the walls of the hallways and defined by a blue glazed concreteblock backsplash around the fountain.

Figure 164. Water fountain alcove in Building 29805 (ERDC-CERL, 2015).

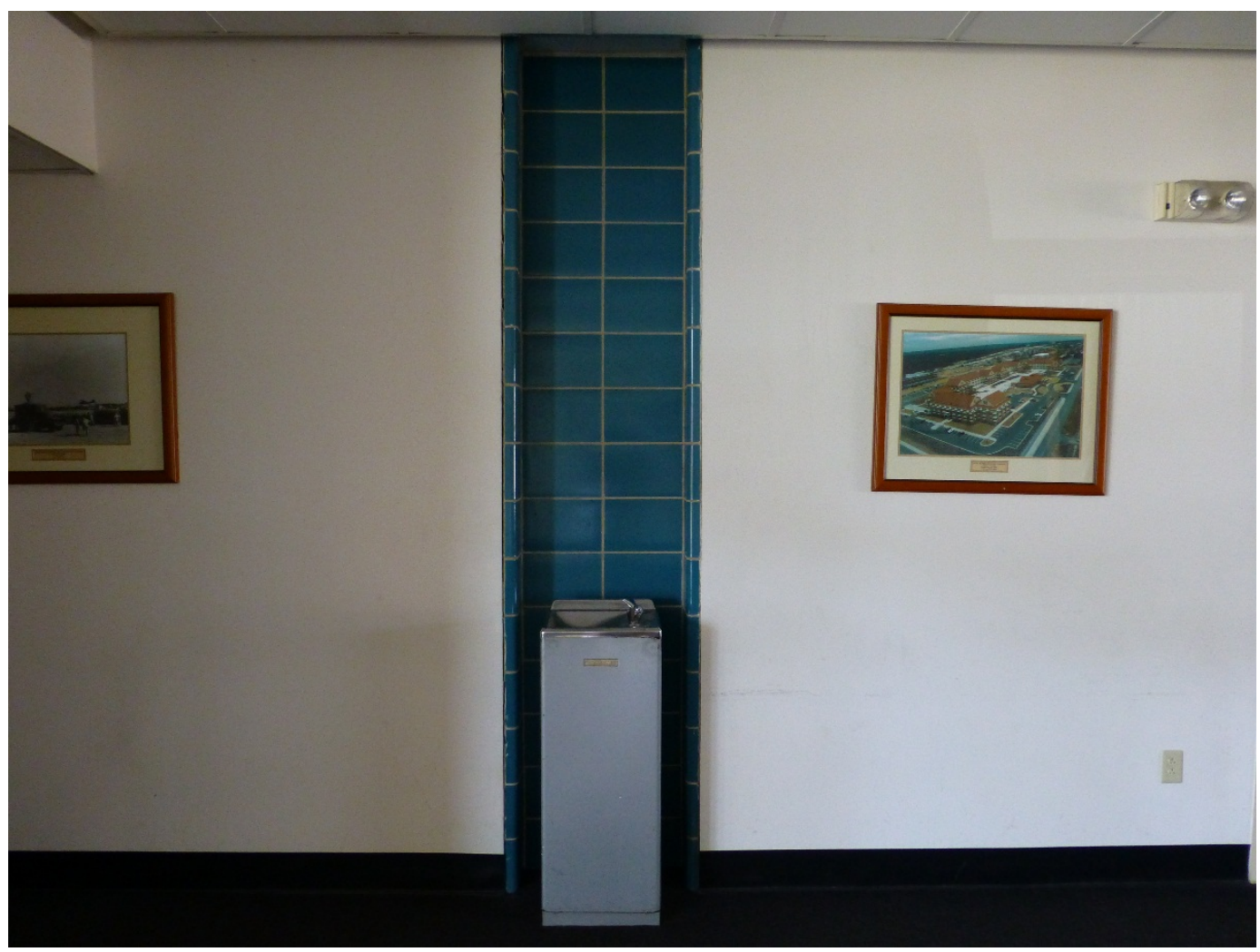


Figure 165. Typical water fountain alcove found in the Signal School classroom buildings (ERDC-CERL, 2015).

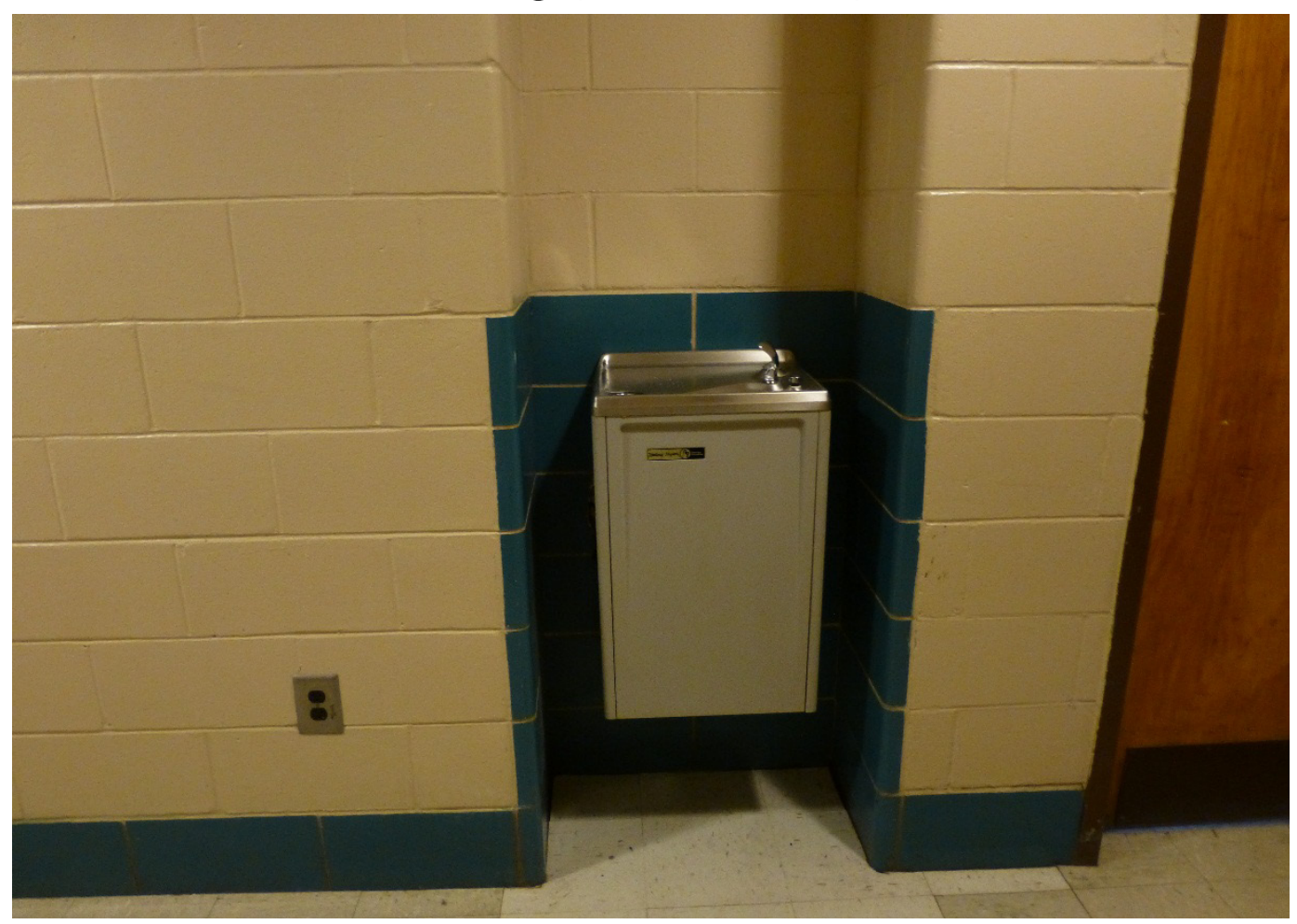

\subsubsection{Dumbwaiters}

Not every Signal School building was designed with a dumbwaiter system (Figure 166). Most of the classroom buildings had one that was located near the telephone alcove. Most of these dumbwaiters are still intact, including the original push-button mechanism to operate the dumbwaiter (Figure 167). 
Figure 166. Example of an original dumbwaiter in the classroom buildings (ERDC-CERL, 2015).

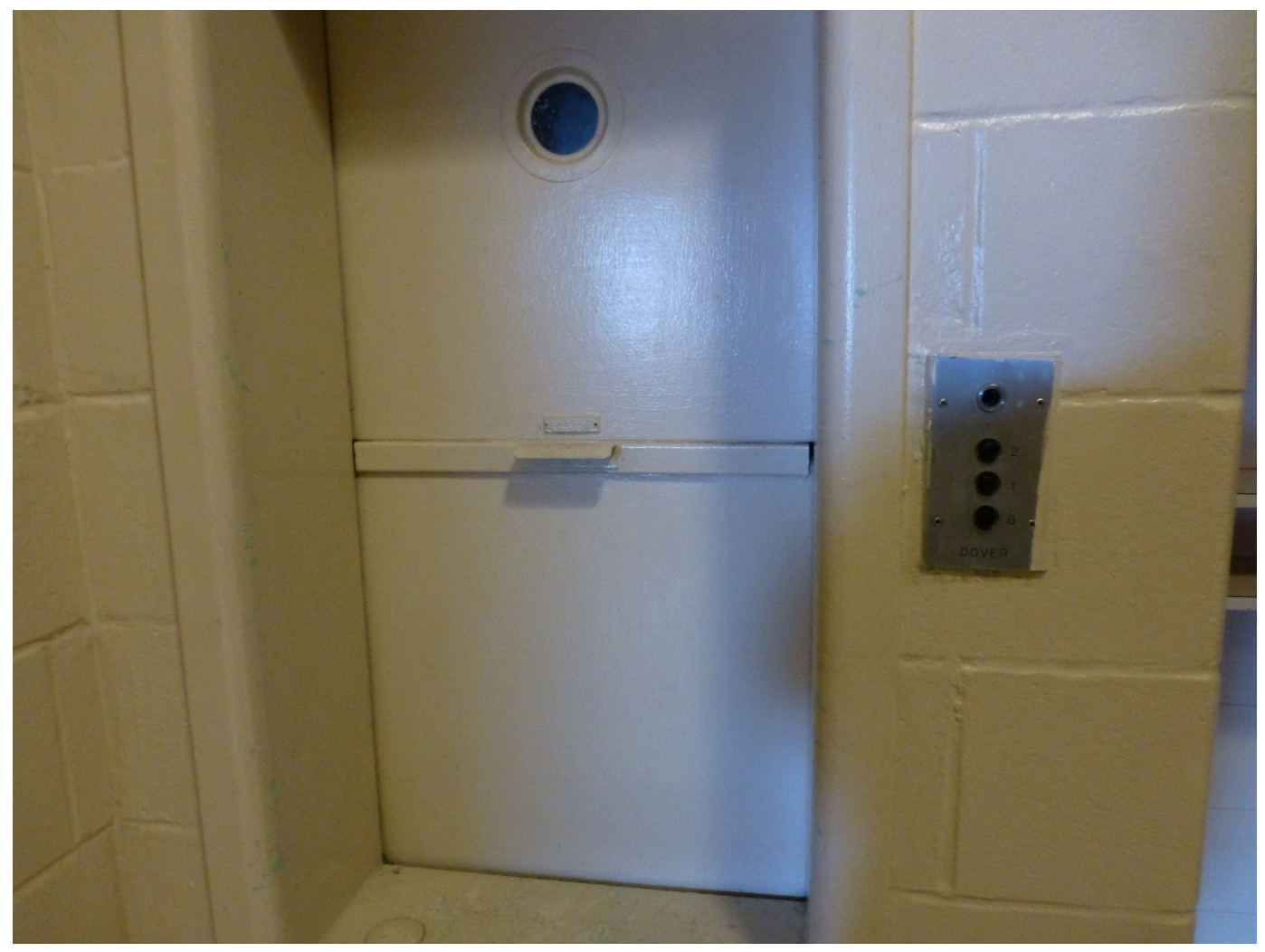

Figure 167. Close-up of the push-button mechanism to run the dumbwaiter (ERDCCERL, 2015).

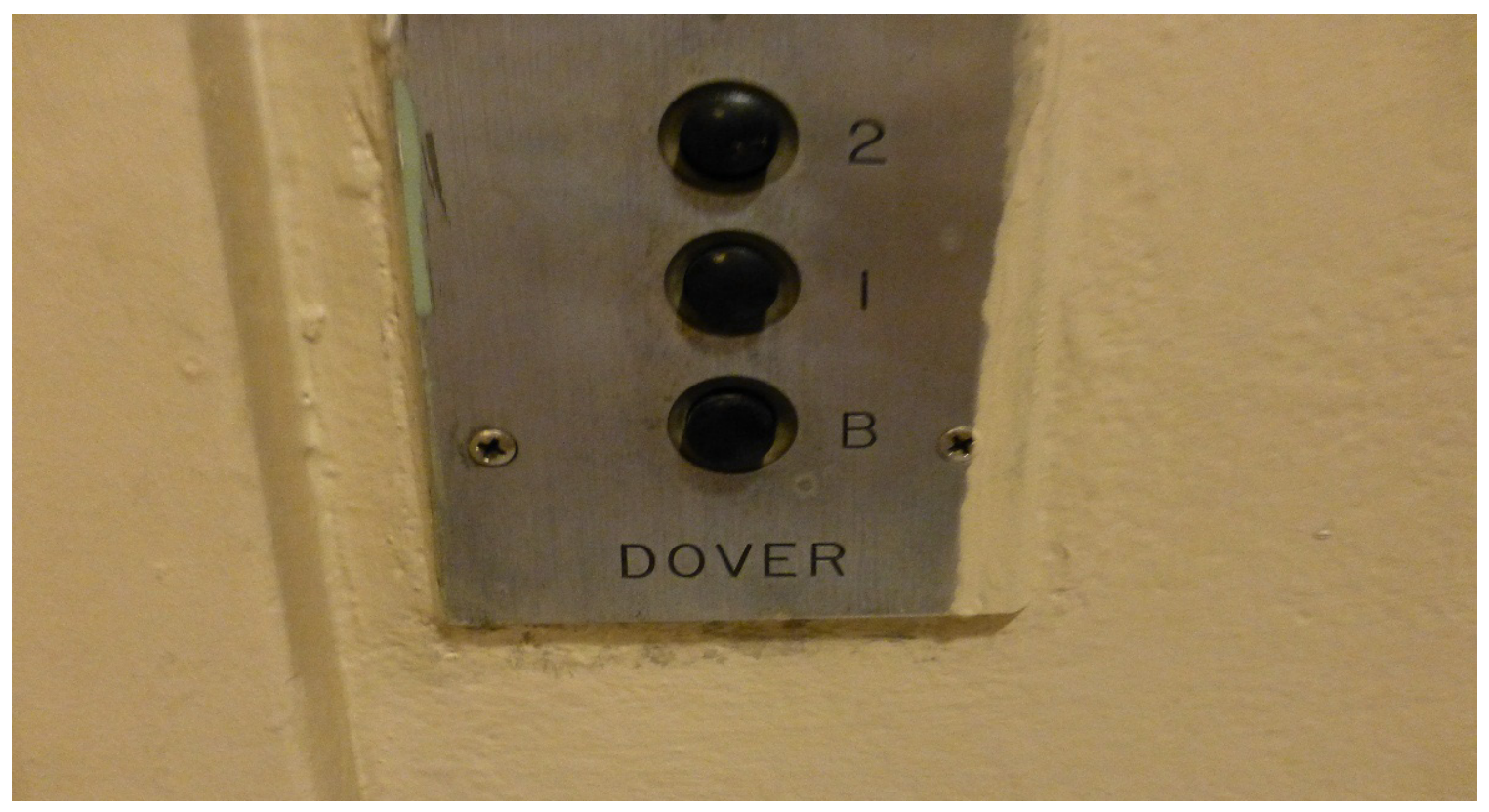




\subsubsection{Fire hydrant display cases}

All of the Signal School buildings were designed with several fire hydrant display cases (Figure 168 and Figure 169). These were a metal case with glass front that were set within the concrete block interior walls. In most instances, these cases were located in the central hallways of the buildings.

Figure 168. Example of a metal fire hydrant display case set within the concrete block exterior wall (ERDC-CERL, 2015).

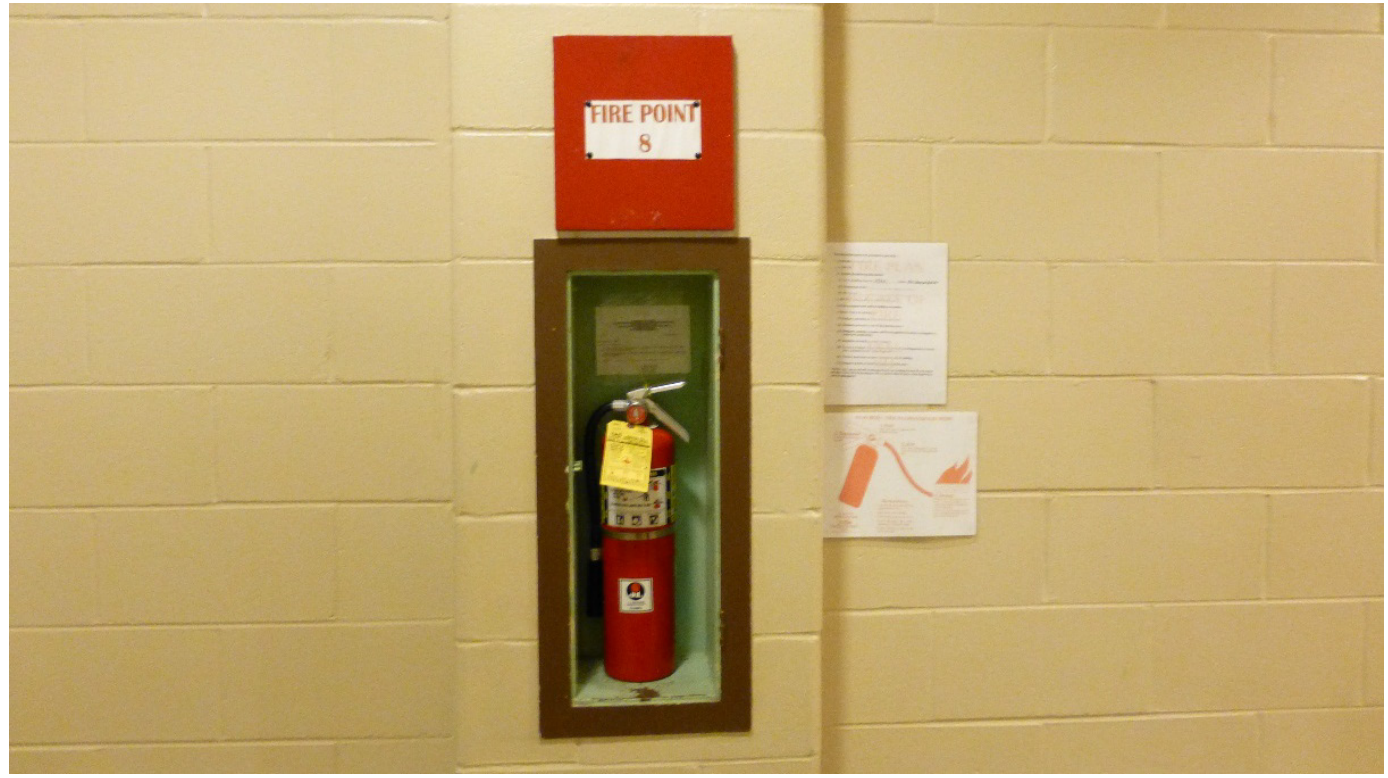


Figure 169. Fire hydrant display case, comparison of the original drawing from 1964 [left] to the current condition of the display case [right] (ERDC-CERL, 2015).

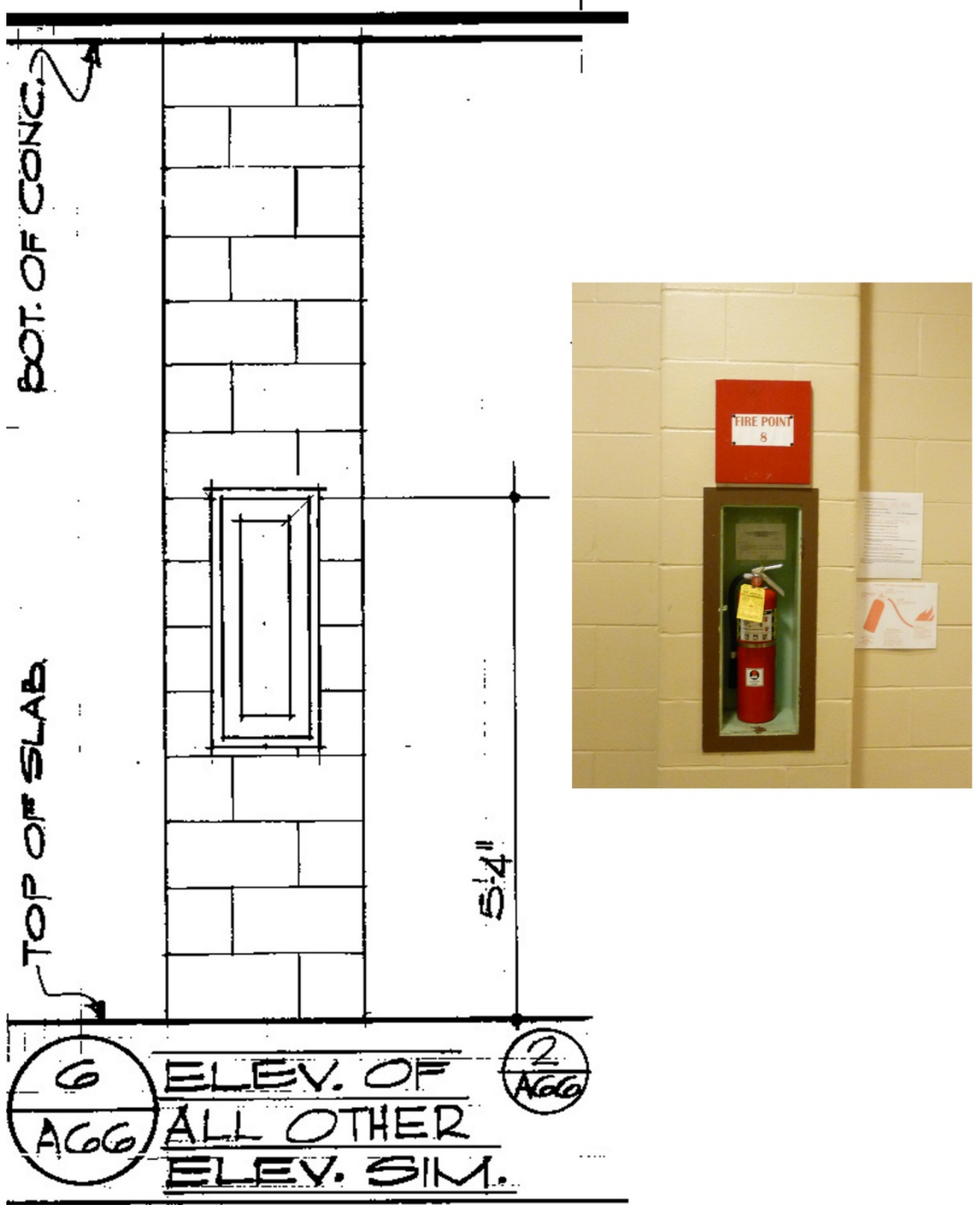

\subsubsection{Signage}

There are a few different styles of interior signage found throughout the Signal School buildings (Figure 170-Figure 173). One type is a bright-aluminum "EXIT" sign with red lettering. This type of sign was either wallmounted or a pendant hung from the ceiling. Another type was a wall- 
mounted box-shaped fluorescent "CLASSIFICATION" sign with red letters on an opaque white background. This sign was placed outside of certain secured rooms. Another type was a wall-mounted box-shaped fluorescent "AUDITORIUM" sign with red letters on an opaque white background. The most common sign found in the Signal School classroom buildings was a rectangular sign that was flush-mounted within the concrete block wall. This sign was a fluorescent-lit sign with red letters on an opaque white background spelling out "CLASS IN SESSION."

Figure 170. Example of exit signs found throughout the Signal School buildings, 1966 (Fort Gordon DPW).

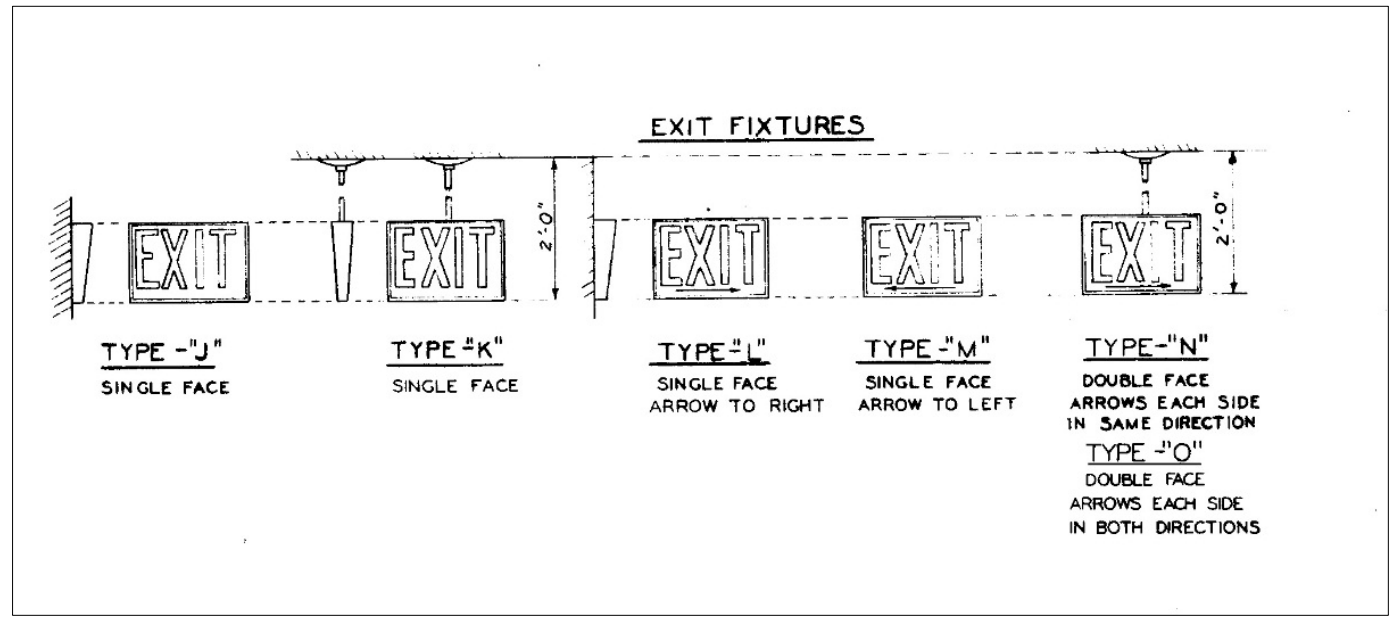

Figure 171. Example of specialty signs located in some of the Signal School buildings, 1966 (Fort Gordon DPW).

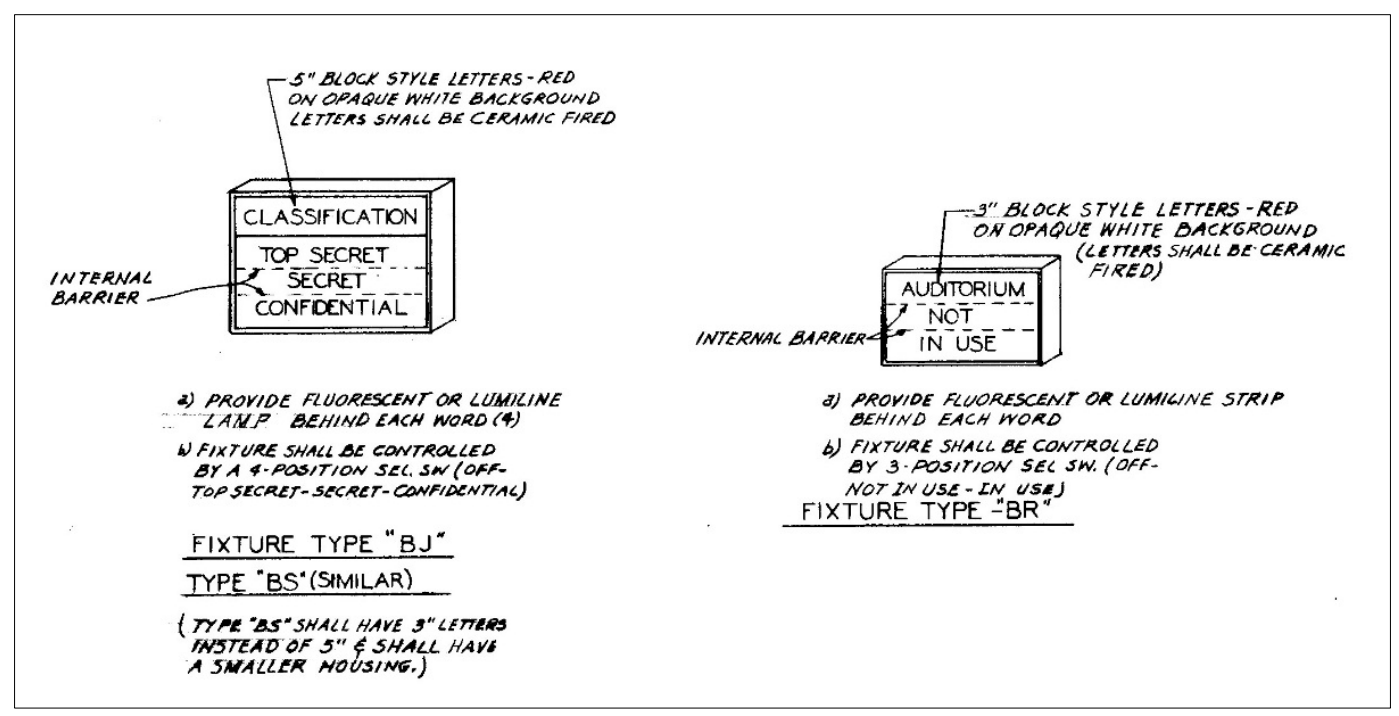


Figure 172. Typical suspended exit sign (ERDC-CERL 2015).

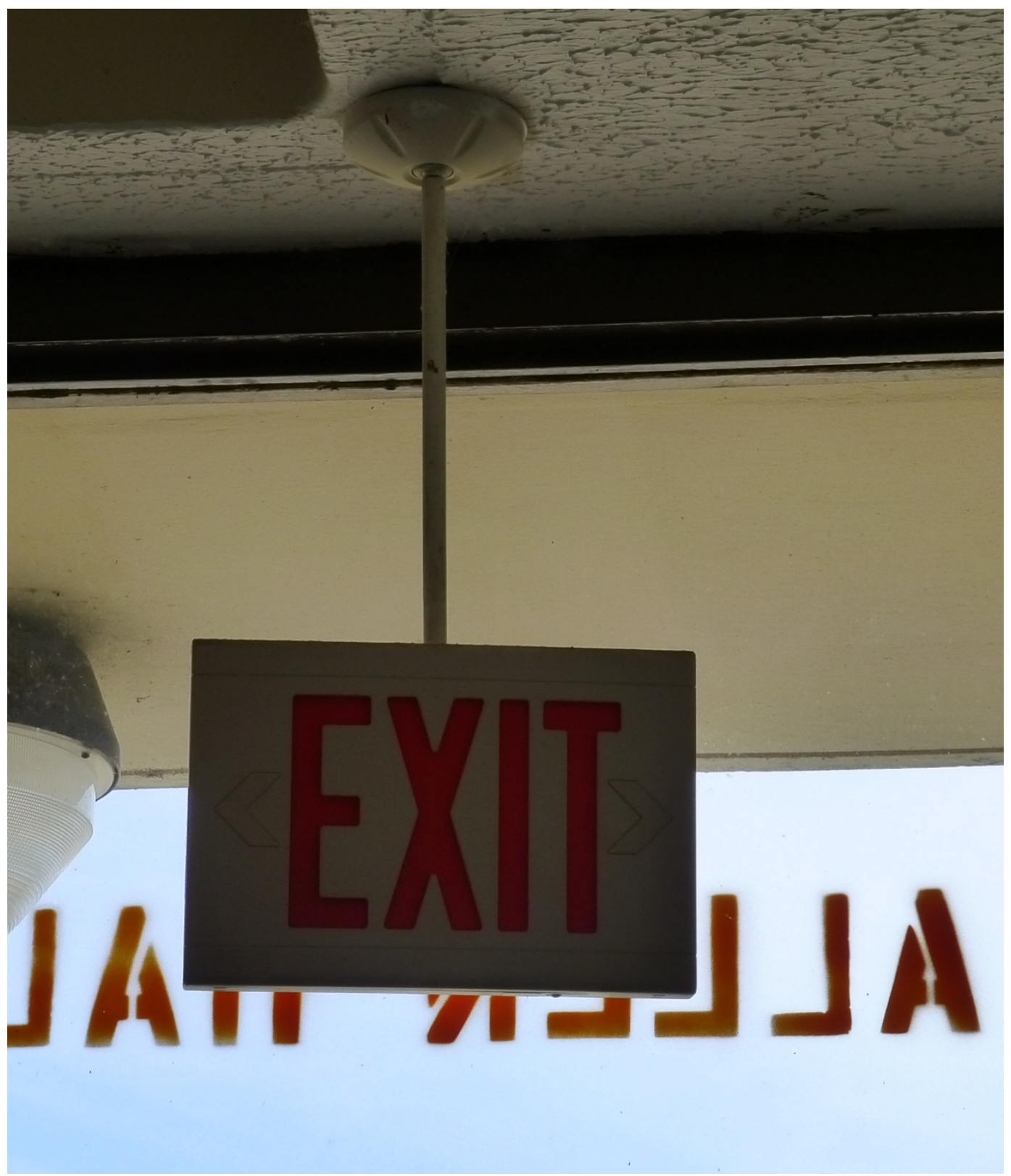


Figure 173. Class in session sign - comparison of the original drawing [left] to the current condition of the sign located in the Signal School classroom buildings [right] (ERDC-CERL, 2015).

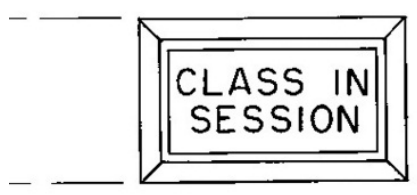

RED LETTERS $13 / 4$ "HIGH ON OPAQUE BACKGROUND W/ ALUMINUM TRIM. FLUSH MTD. TFT. UP W/8W, T-5 FLOURESCENT LAMP FOR 277 VOLTS.

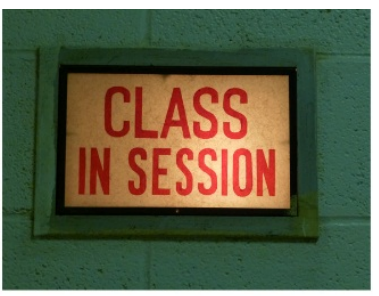

FIXTURE TYPE "SP"

WALL MOUNTED

\subsection{Buildings}

The remainder of this chapter describes the contributing buildings and structures of the Signal School Campus Historic District by listing the character-defining features that remain, the character-defining features that have been removed (if any), and the nonhistoric features (if any). 4 Various photos that highlight these features are included with each subsection. The buildings are discussed in Fort Gordon building number order rather than construction date for consistency.

\subsubsection{Building 25810, Brant Hall (1973)}

Building 25810 is a contributing feature of the Signal School Campus Historic District. The interior is also contributing. Building 25810 was constructed in 1973 as part of the Signal School's Phase III construction. The overall design of Building 25810 follows the methodology of the older buildings in the Signal School Area. There is a poured-in-place concrete post that supports a concrete waffle second floor and roof structure. The waffle is perforated periodically around the building's perimeter overhang. These perforated openings cast "light strips" onto the second-floor brick exterior walls. The area between the posts is infilled with concrete block, and a variegated pink/yellow brick veneer is placed over the concrete block. The windows system is placed typically next to a concrete post and

\footnotetext{
${ }_{4}^{4}$ Features of the character-defining objects are not discussed in the subsections because the entire object itself is character defining.
} 
consists of bright-aluminum frames, large plate glass, and insulated panels. The systems are in a three-, four-, or seven-window configuration and are recessed within the brick veneer exterior walls. The primary design change from the earlier classroom buildings is that there are no operable windows. The concrete of the second floor is the horizontal dividing line in the window system. All fixed glass and insulated panels within each window type are equal to each other in width. All concrete is painted beige.

The overall building is composed of four parts. There are three two-story rectangular classroom wings that radiate around an enclosed two-story six-sided structure in the center. The entrances to the three classroom wings are located at either end of each rectangular wing. The entrances project out and are defined with two sets of bright-aluminum and plateglass doors protected with a flat-roof concrete canopy and a group of four bright-aluminum with fixed panes and insulated panels on the second floor. The front wing has a large main entrance that consists of two sets of bright-aluminum and plate-glass doors, sidelights, and transoms, with a group of large fixed-pane windows on the second floor. A flat concrete waffle canopy stretches in front of the main entry and is supported by two concrete columns. The main entry fronts a small parking area off Chamberlain Avenue.

Three sides of the six-sided middle structure are connected to the wings, while the other three sides each have a large metal overhead door with a band of stucco above the door openings. Metal louvered panels are located to the left of the overhead door and a set of metal doors with fixed transom is located to the right of the overhead door. The exterior brick walls of these three sides have brick pilaster details (Figure 174-Figure 184).

Figure 174. Signal School Campus map, with Building 25810, Brant Hall highlighted in red, 2015 (Fort Gordon DPW, modified by ERDC-CERL).

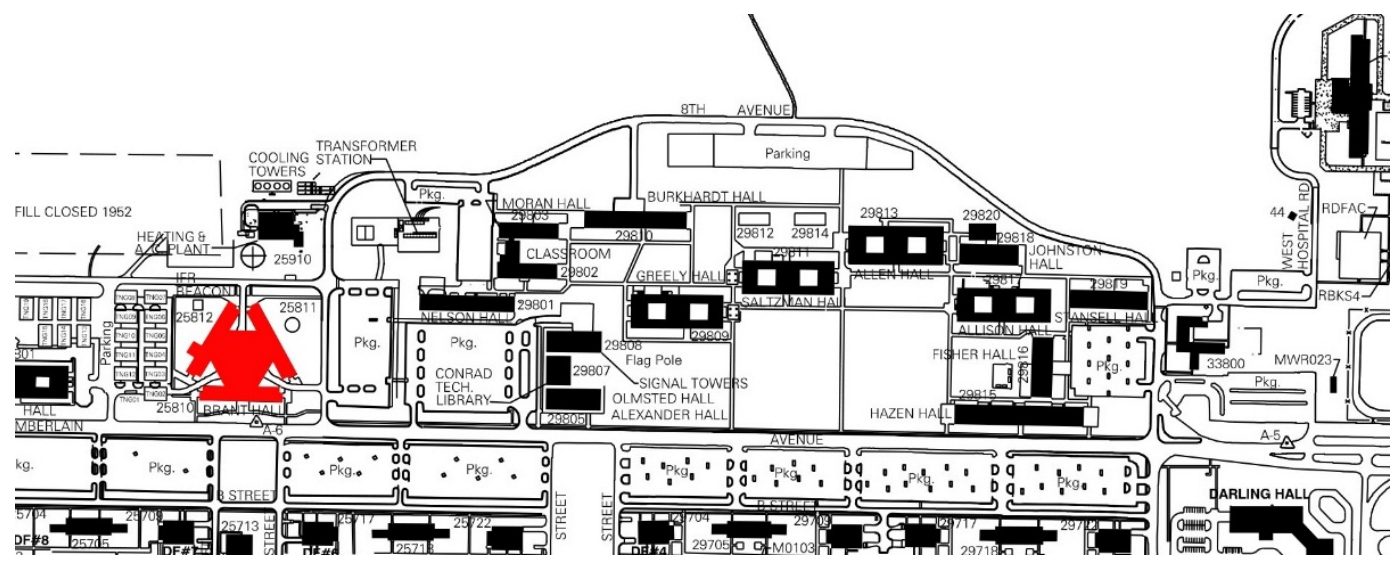


Figure 175. Building 25810, Brant Hall, south [front] elevation (ERDC-CERL, 2015).

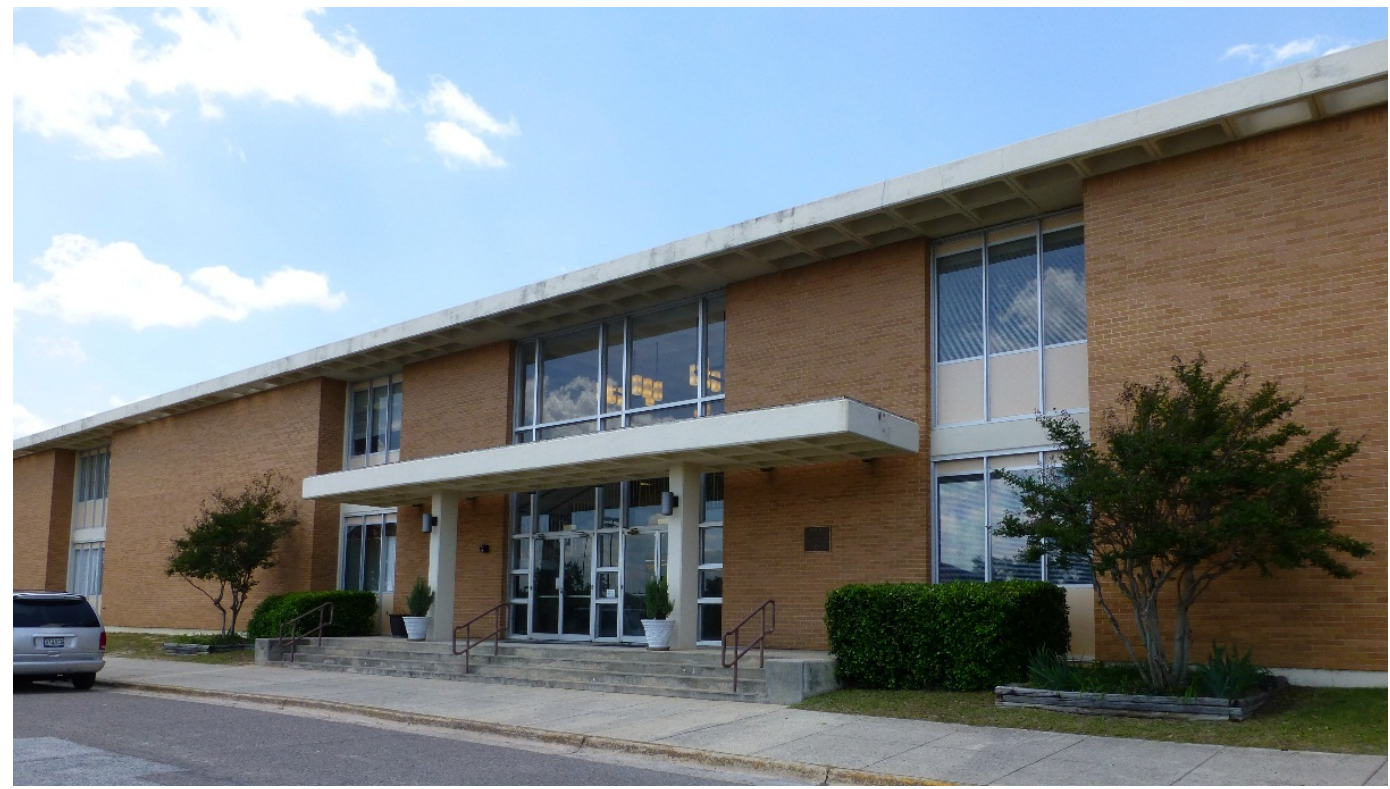

Figure 176. Building 25810, Brant Hall; left is the northwest wing and right is the west side of the south wing (ERDC-CERL, 2015).

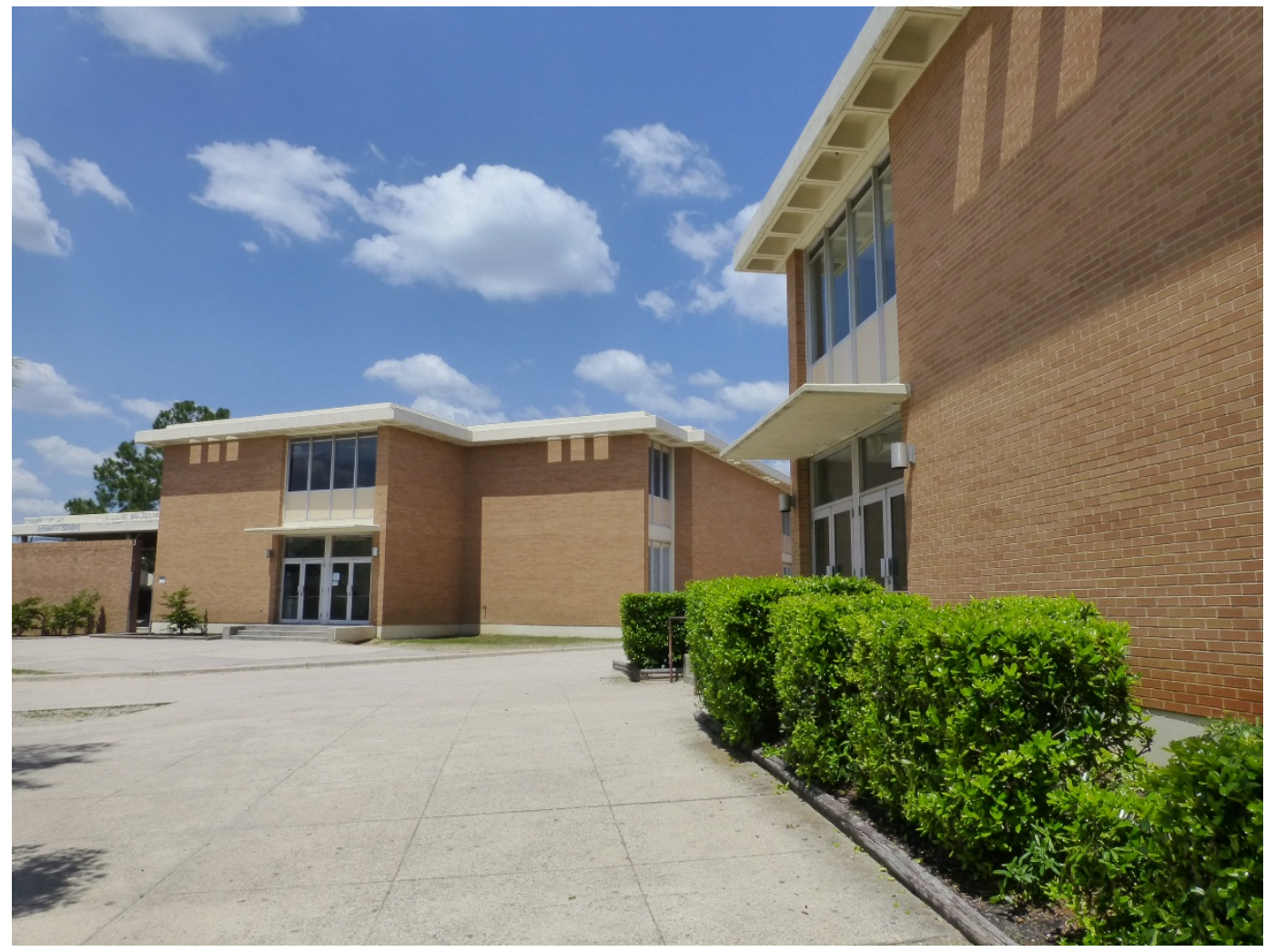


Figure 177. Building 25810, Brant Hall, east elevation of the east wing (ERDC-CERL, 2015).

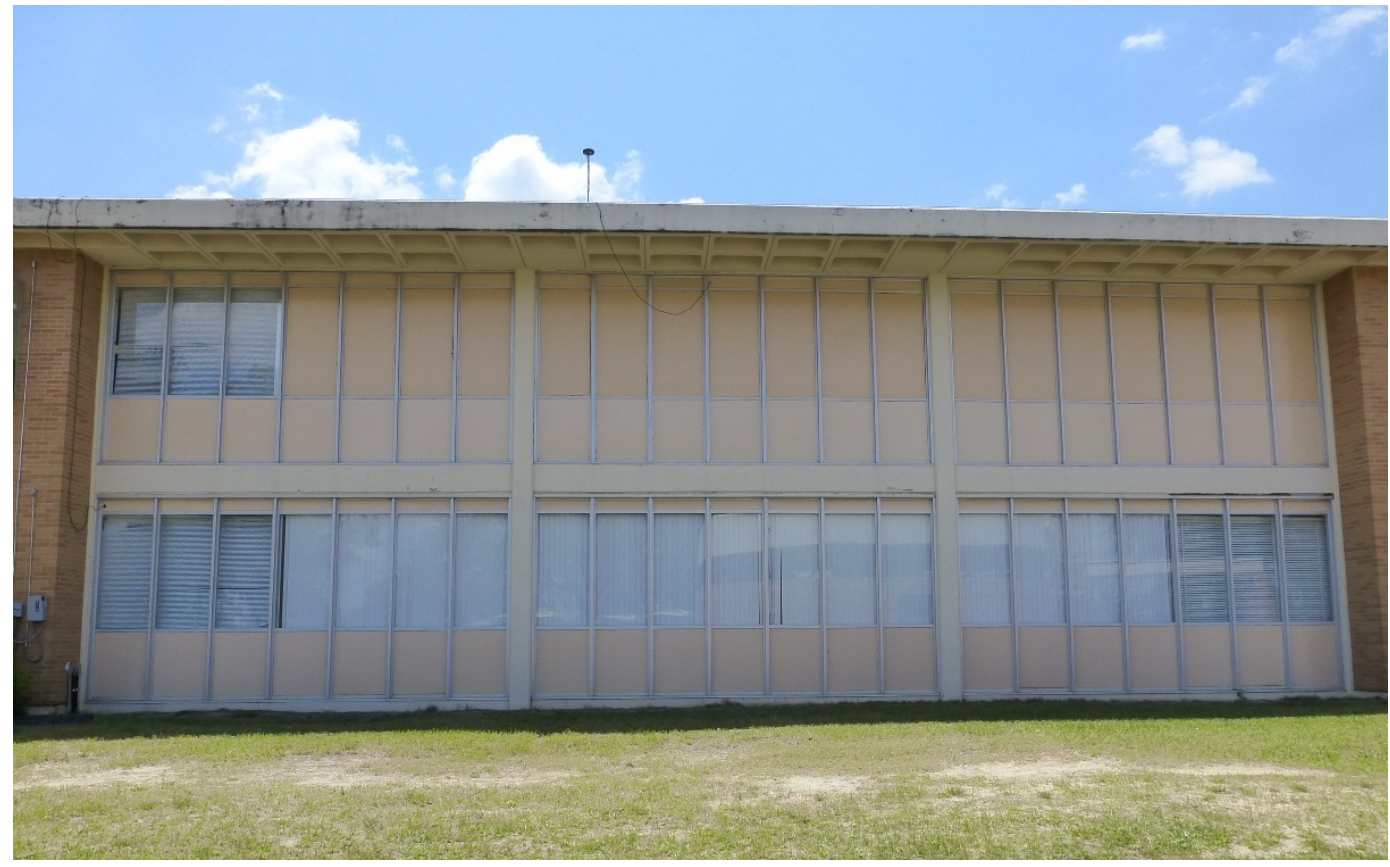

Figure 178. North side of the six-sided middle structure (ERDC-CERL, 2015).

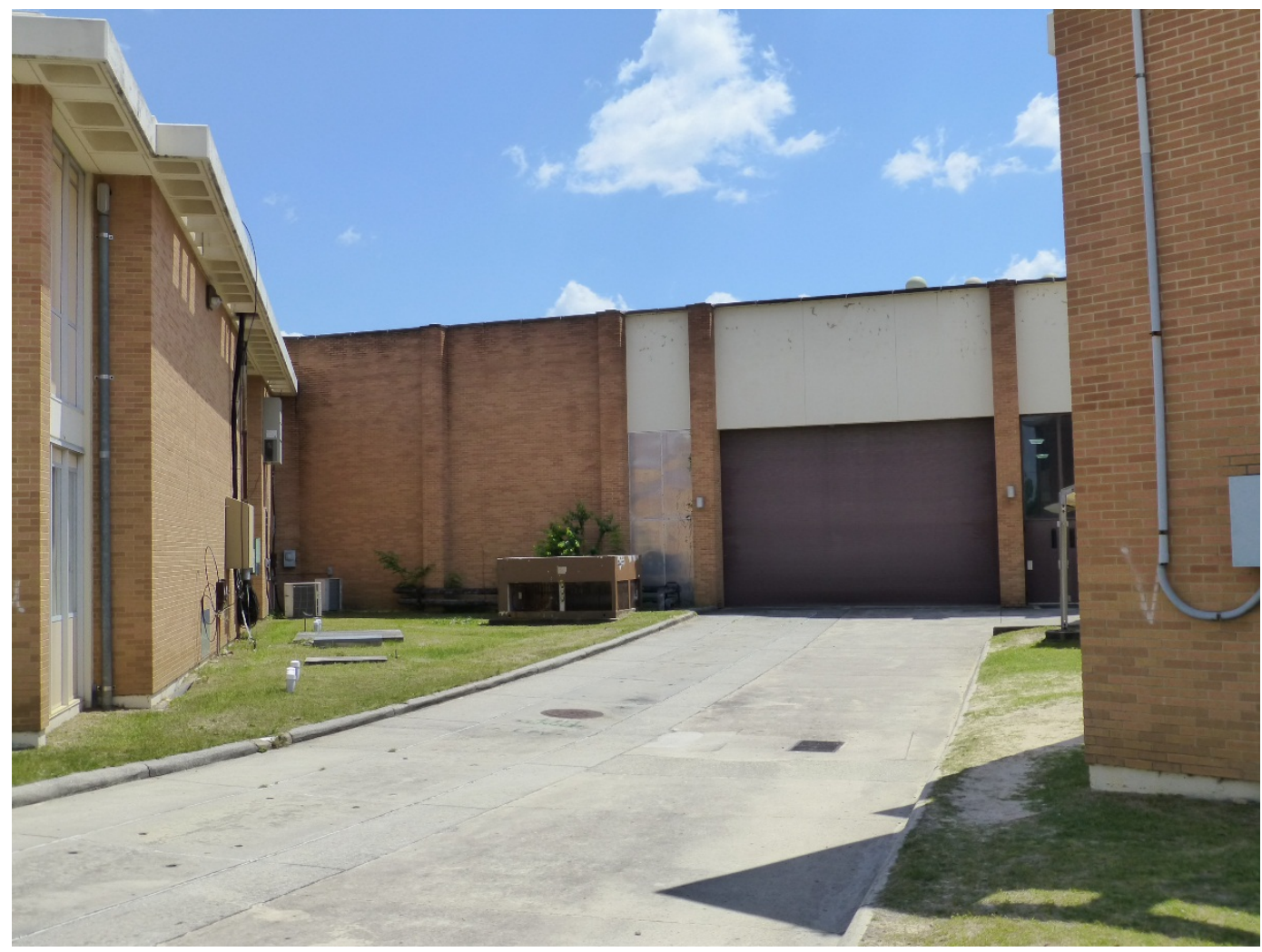


Figure 179. Interior view of the six-sided middle structure (ERDC-CERL, 2015).

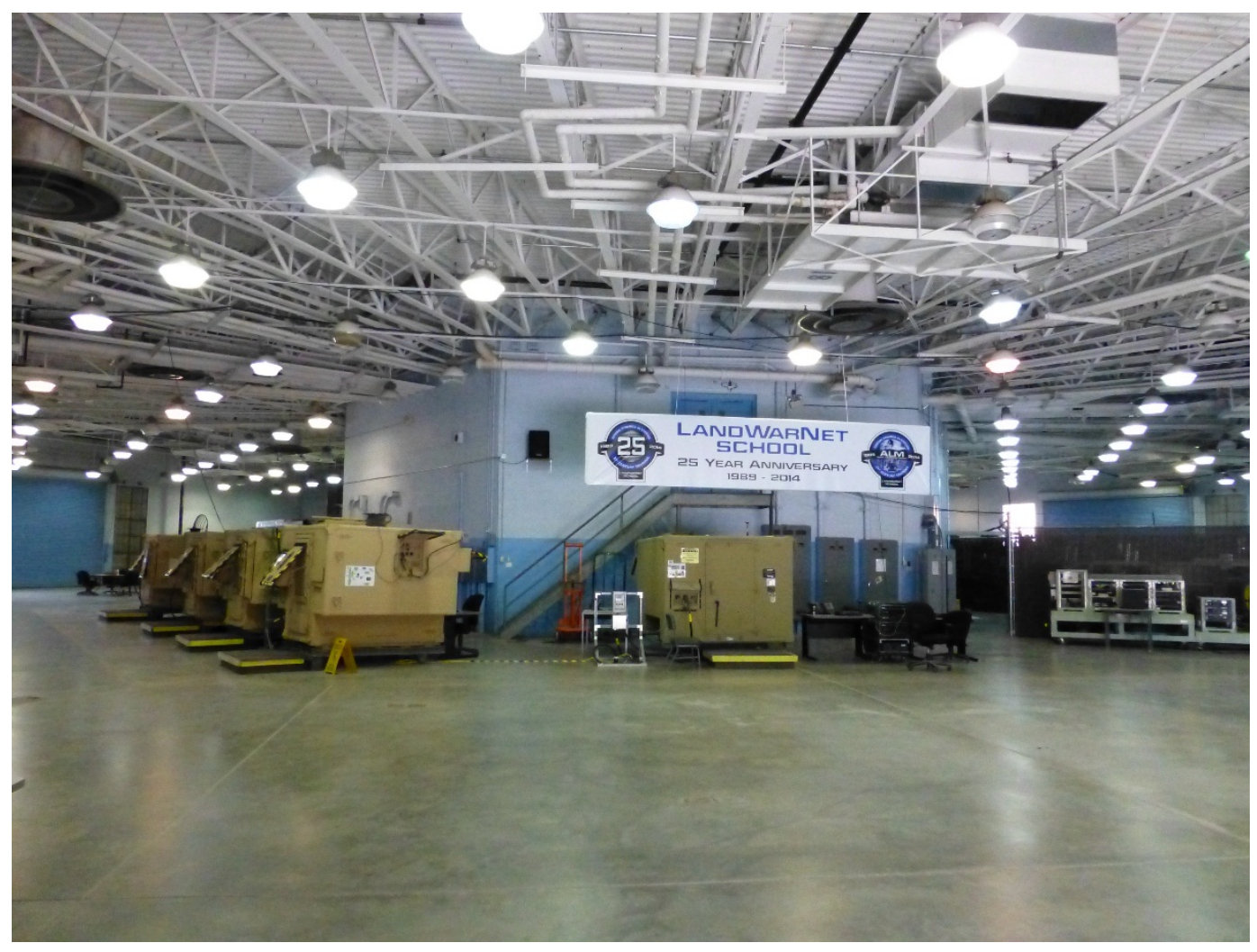


Figure 180. Building 25810, Brant Hall, floor plan of the south wing, 1973 (Fort Gordon DPW).

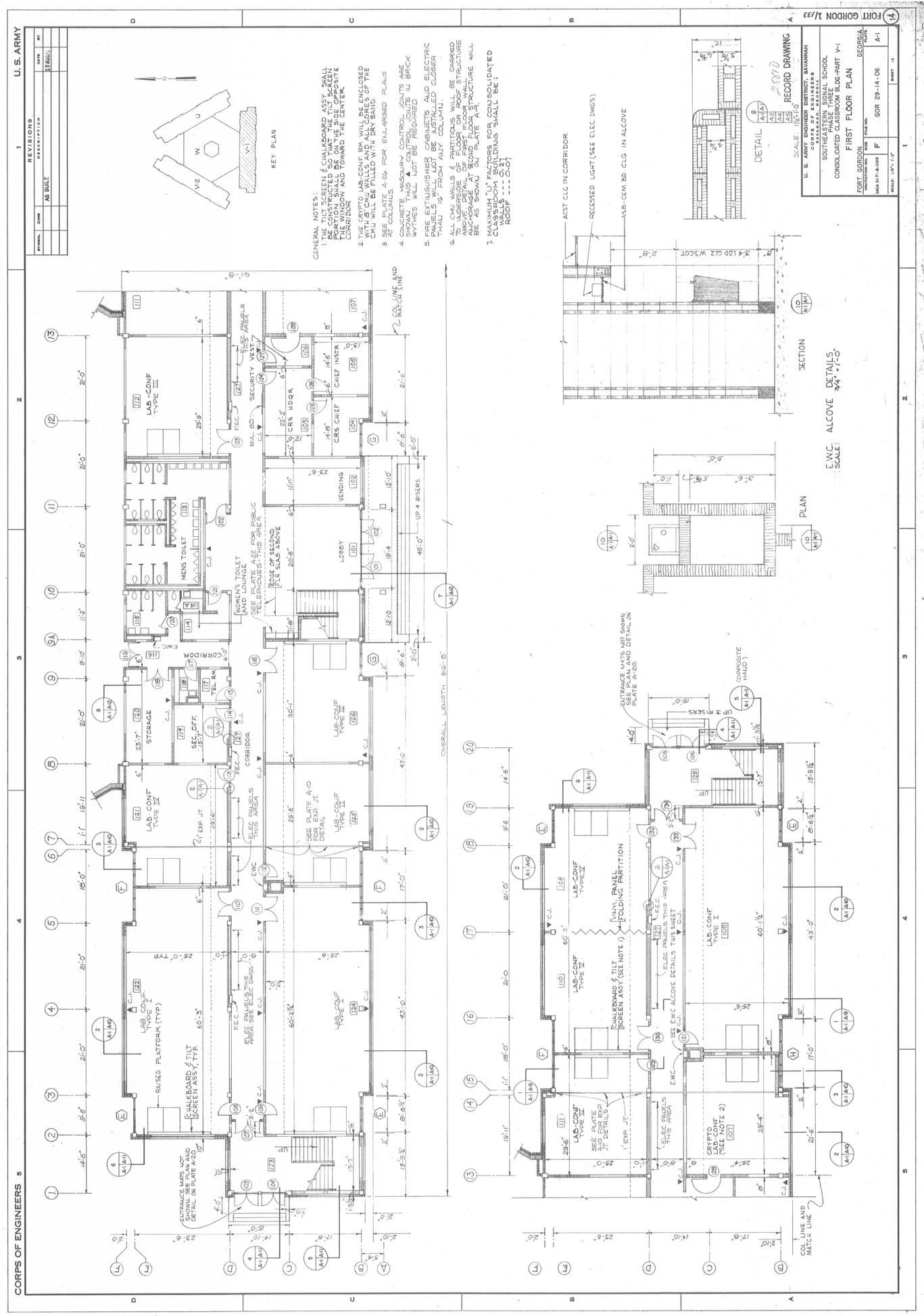


Figure 181. Building 25810, Brant Hall, floor plan for the middle section of the building, 1973 (Fort Gordon DPW).

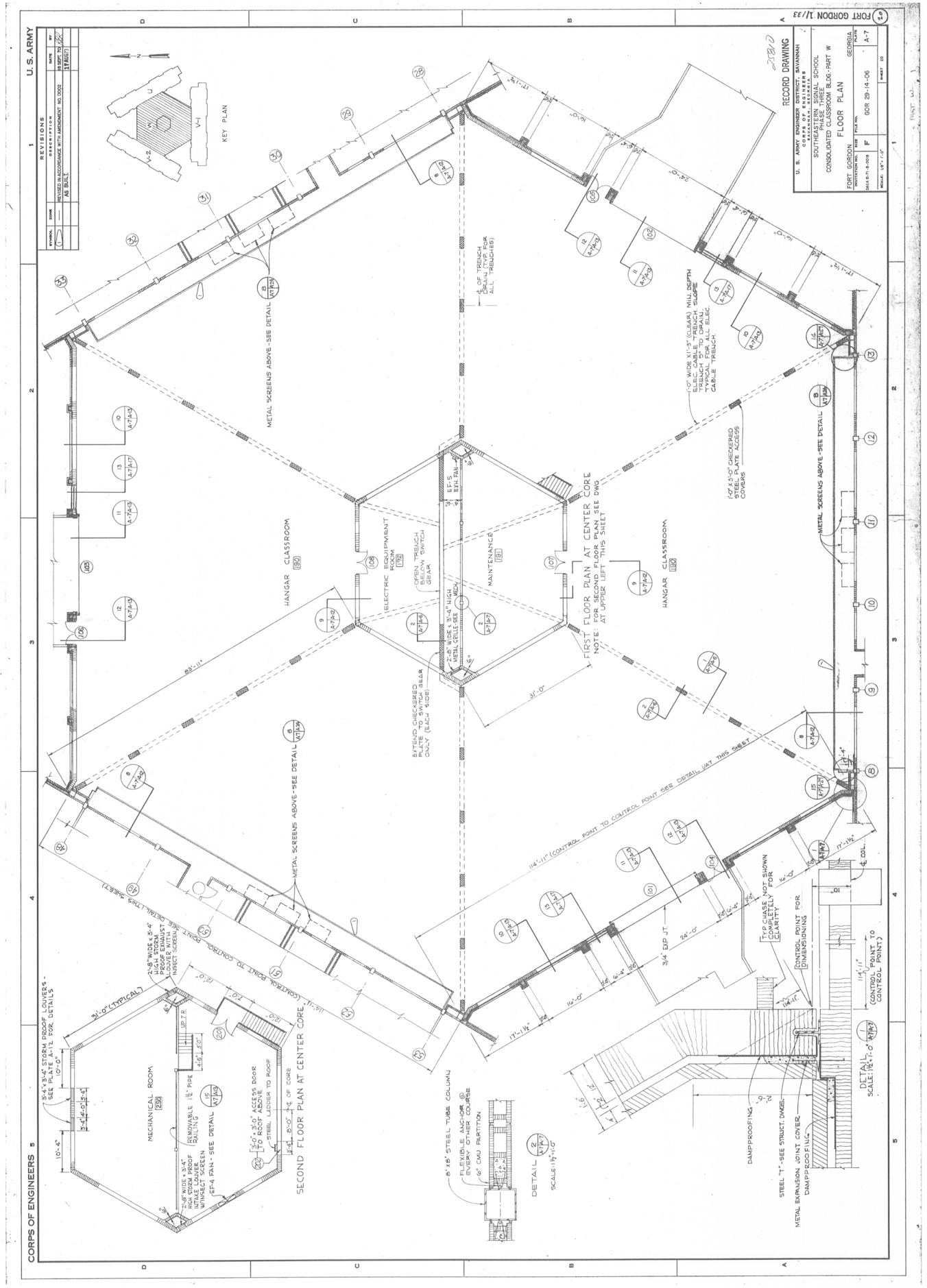


Figure 182. Building 25810, Brant Hall, elevations, 1973 (Fort Gordon DPW).

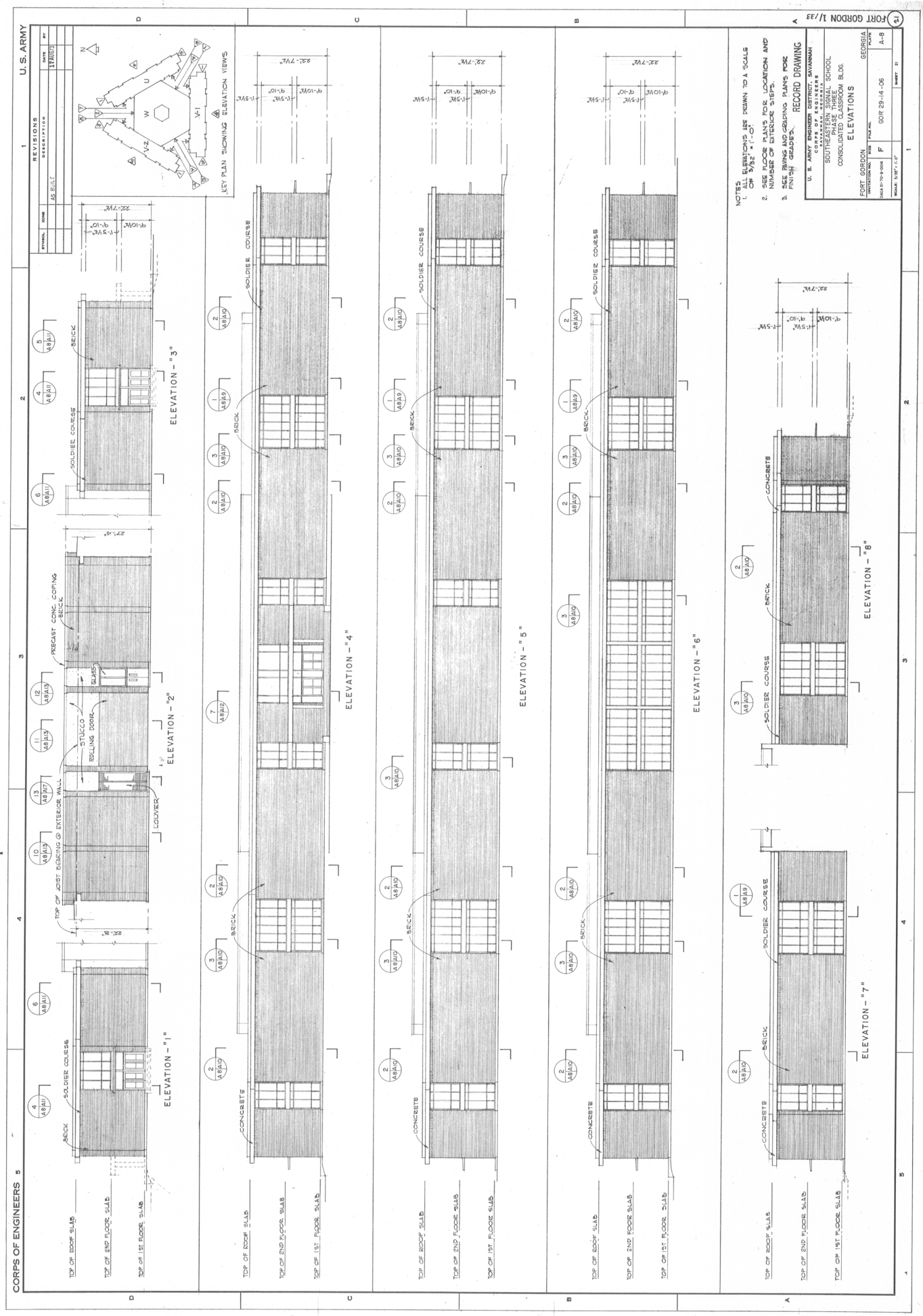


Figure 183. Building 25810, Brant Hall, window schedule for the first and secondfloor windows, 1973 (Fort Gordon DPW).
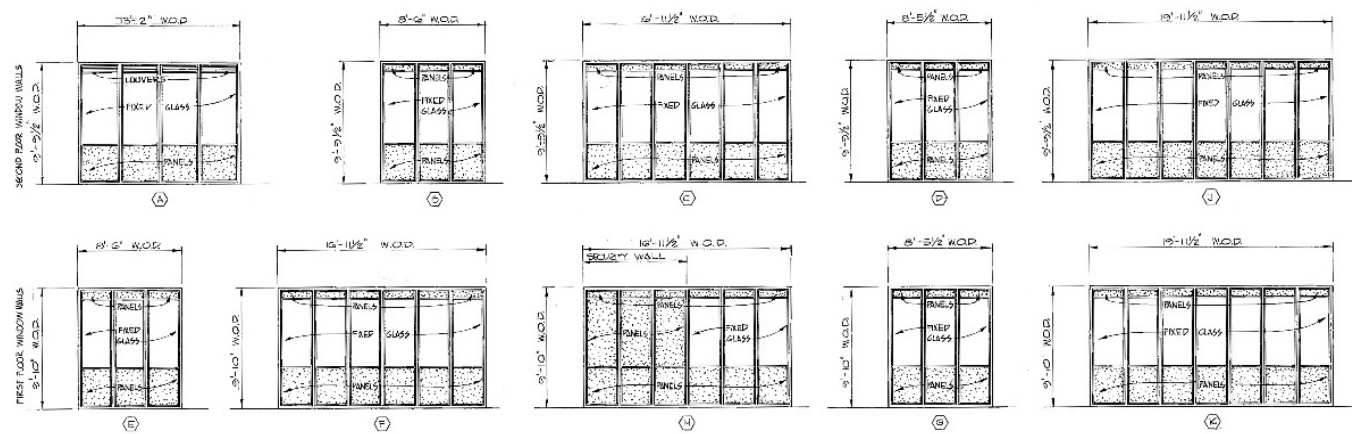

Figure 184. Building 25810, Brant Hall, door details for interior and exterior doors, 1973 (Fort Gordon DPW).

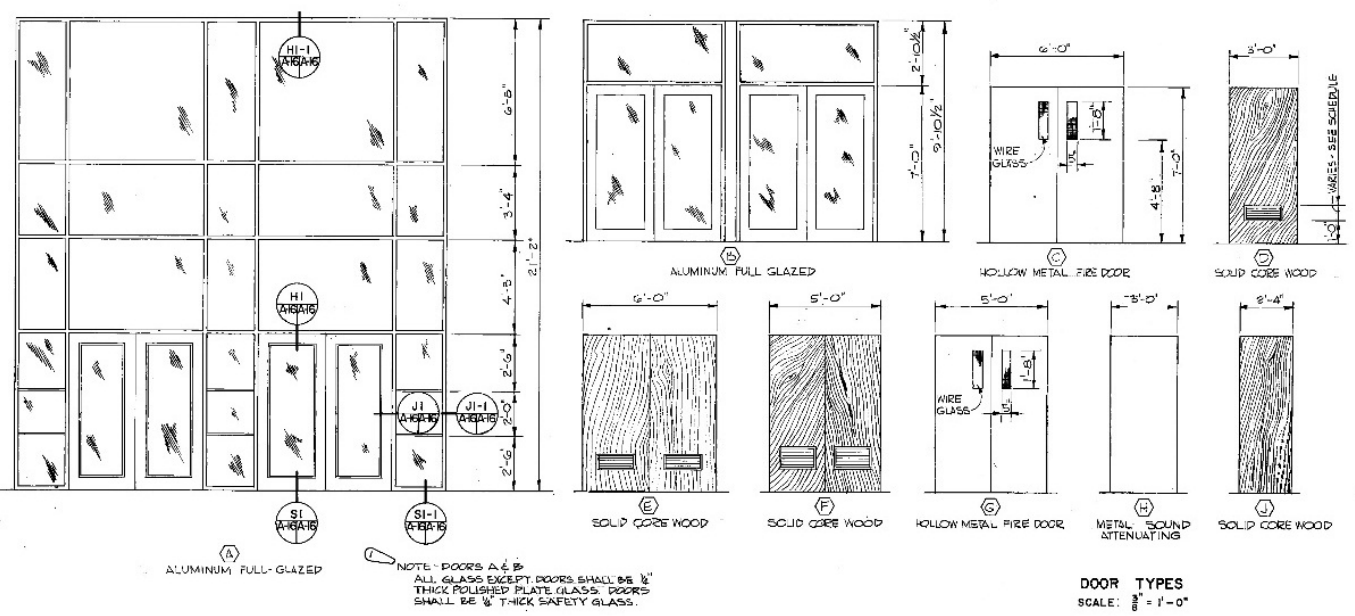

\subsubsection{Character-defining features}

Repair, renovation, and replacement of Building 25810, Brant Hall, must be coordinated with the GA SHPO (Table 3).

\section{Exterior:}

- Overall massing

- Footprint

- Roof shape

- Brick veneer

- Overhanging eaves with perforated waffle construction casting "light pattern" on exterior brick walls

- Exposed concrete structure framing window and door openings

- Flat concrete canopy above secondary entries

- Flat concrete waffle canopy near main entry 
- Recessed groups (three, four, or seven) of bright-aluminum sash windows with fixed panes and insulted panel inserts

- Wall-mounted bronze, cylinder light exterior light fixtures

- Lettering

- Metal handrails

- Landscaping

\section{Interior:}

- Overall plan

- Main stairwells

- Main hallways

- Two-story lobby in the south wing

- Lighting

- Doors

- Signage

- Waffle ceiling in stairwells

- Dropped ceiling in hallways (it could not be determined if they were original)

- Open double-height interior space of the middle section of the building

Table 3. Images of character-defining features of Building 25810, Brant Hall (ERDC-CERL, 2015).

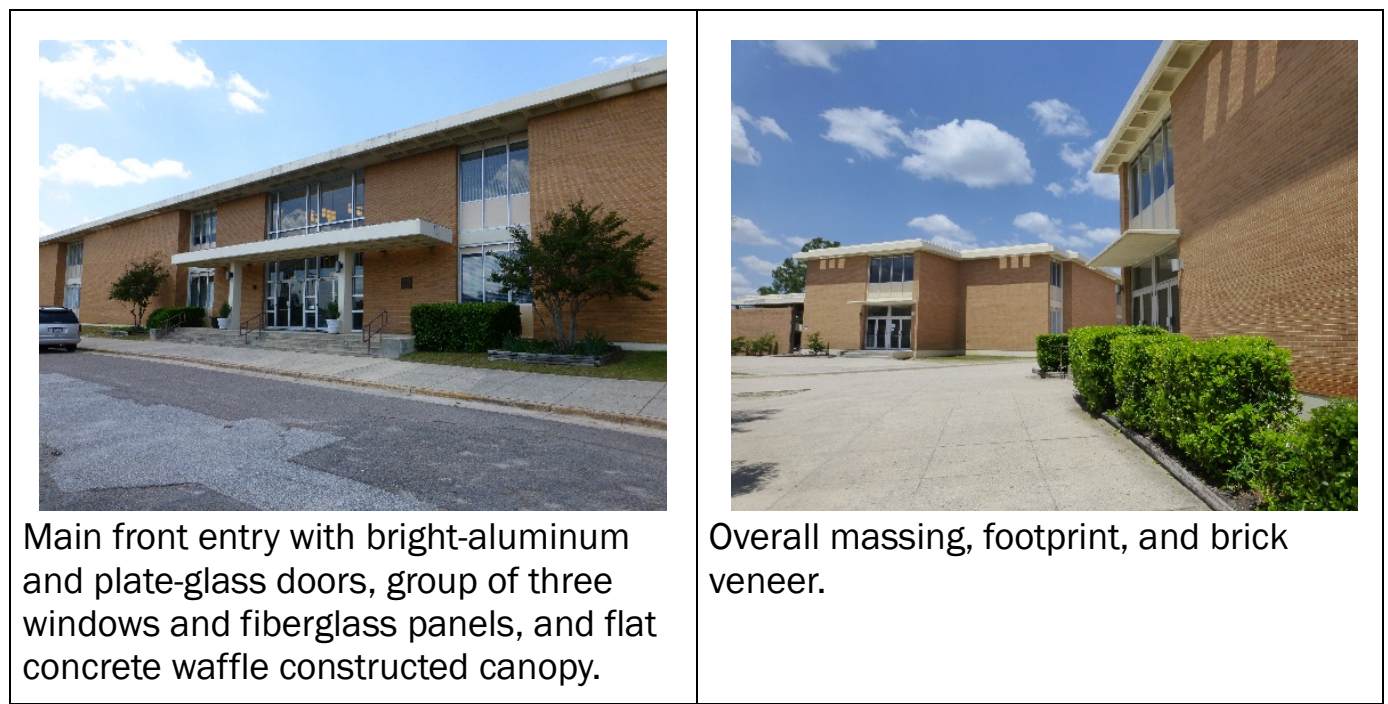




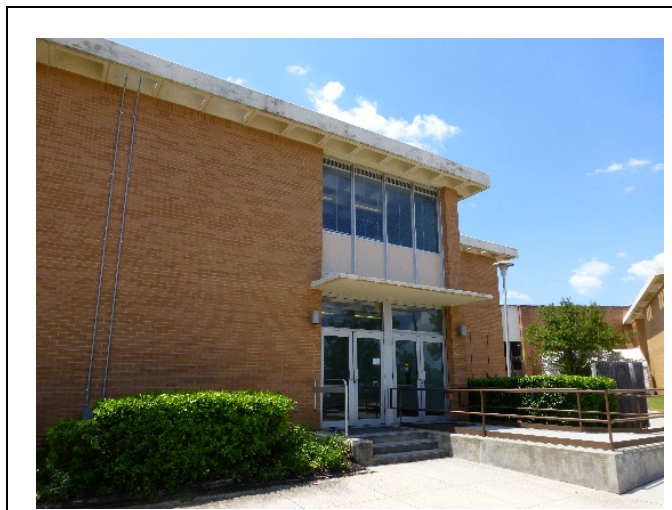

Secondary entrances at the end of the rectangular classroom wings and landscaping.

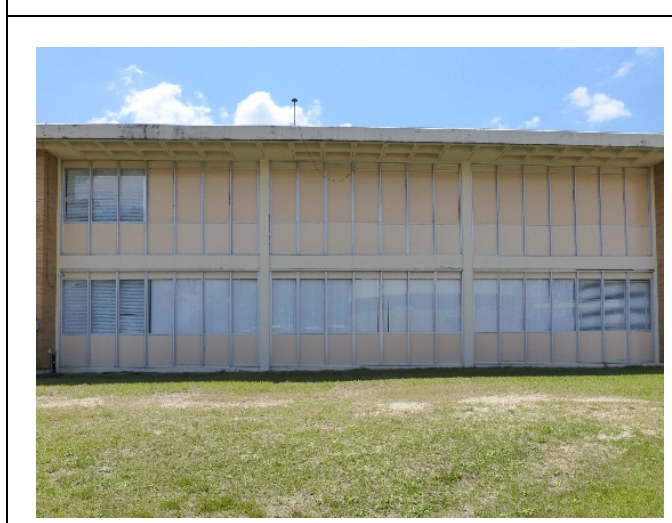

Groups of windows; bright-aluminum frame with fixed panes and insulated panels divided by concrete columns and beam. *Note: the removal of the secondfloor windows replaced with new panel inserts.

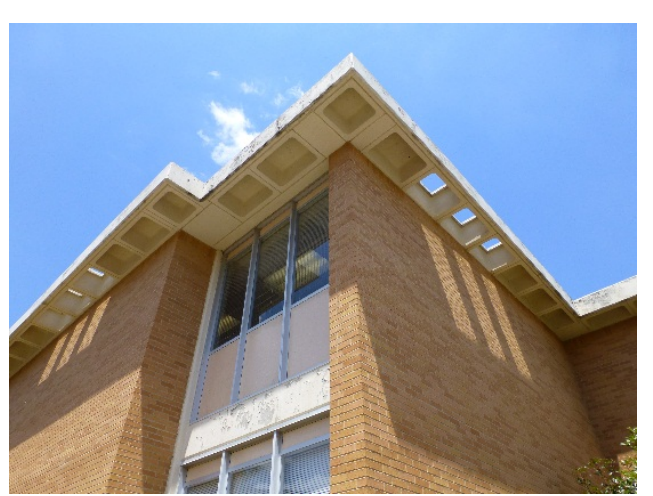

Overhanging eaves (waffle construction) with perforated waffles casting a "light pattern" on the second floor of the brick walls.

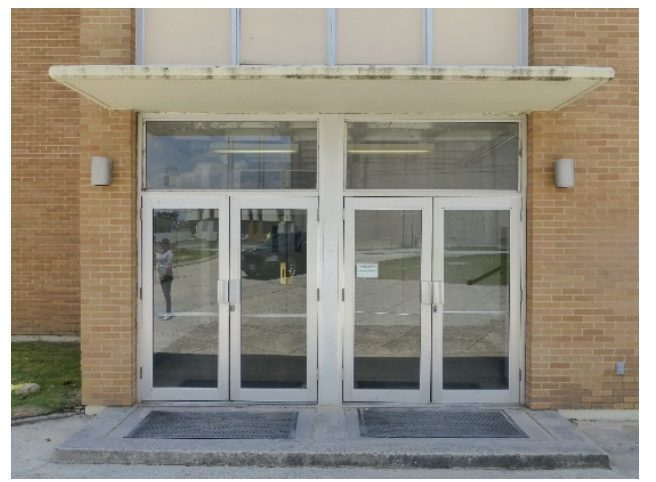

Bright-aluminum and plate-glass doors with transoms protected by a flat concrete canopy. 


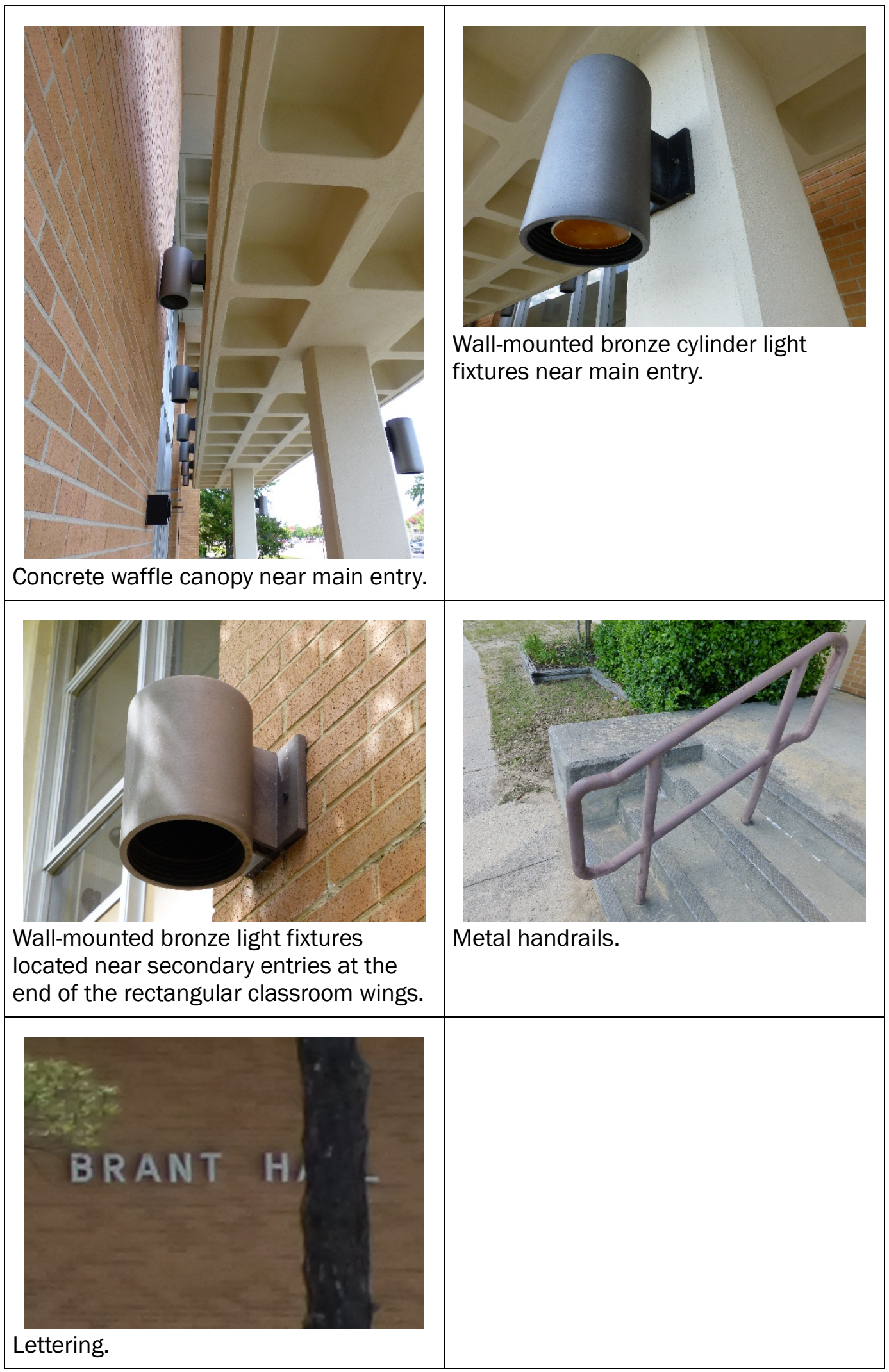




\subsubsection{Character-defining features that have been removed}

- None.

\subsubsection{Nonhistoric features}

- None.

\subsubsection{Comparison images}

Comparison images utilizing either the original drawings or historic photographs, when juxtaposed against present-day images, are a useful tool in developing the historic "feel" of a property and how much of that historic feeling is still present today (Figure 185-Figure 189).

Figure 185. Main entry on the south elevation - comparison of the original drawing detail from 1973 [left] to the current condition of the bright-aluminum and plate-glass windows and doors [right] (ERDC-CERL, 2015).
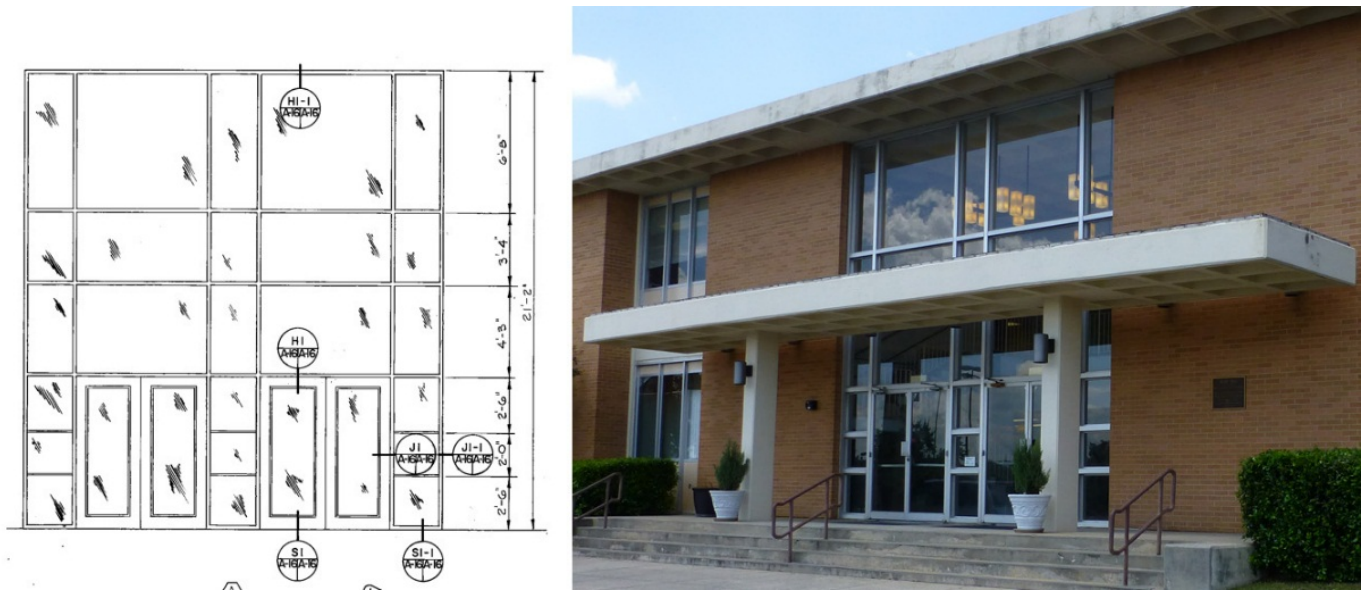

Figure 186. Paired entry doors with concrete canopy - comparison of the original drawing detail from 1973 [left] to the current condition of the bright-aluminum and plate-glass doors [right] (ERDC-CERL, 2015).
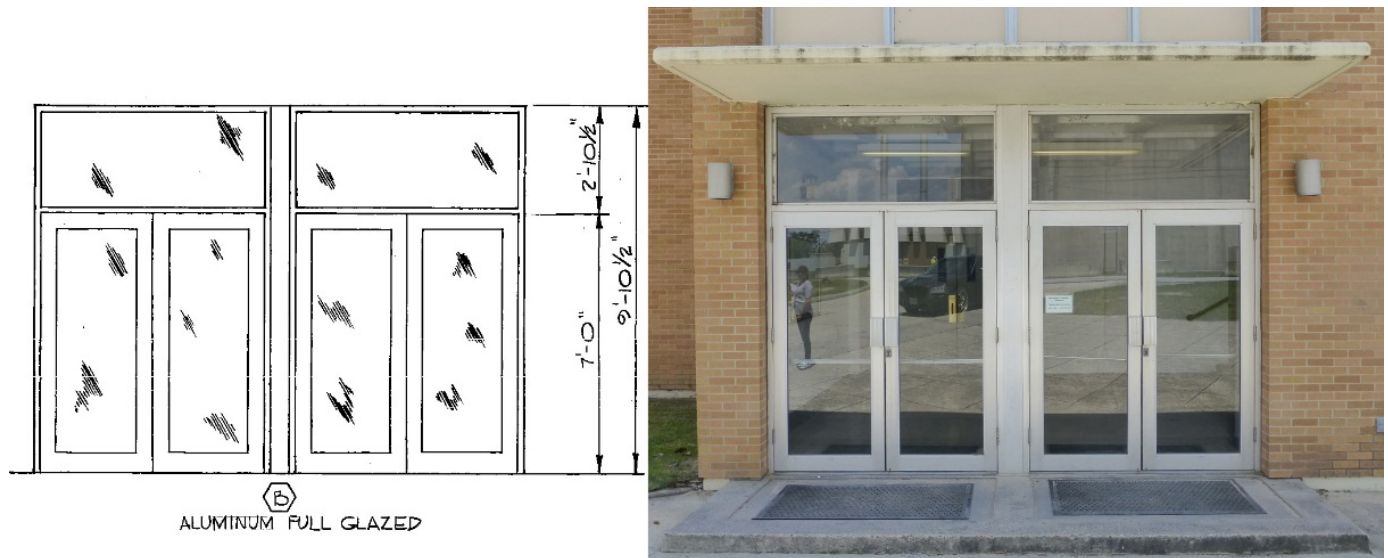
Figure 187. Large group of windows and panel inserts on the northwest elevation of the north wing - comparison of the original drawing detail from 1973 [left] to the current condition of the bright-aluminum fixed windows and panel inserts on the first floor and the modified window openings with newer panel inserts [right]

(ERDC-CERL, 2015).

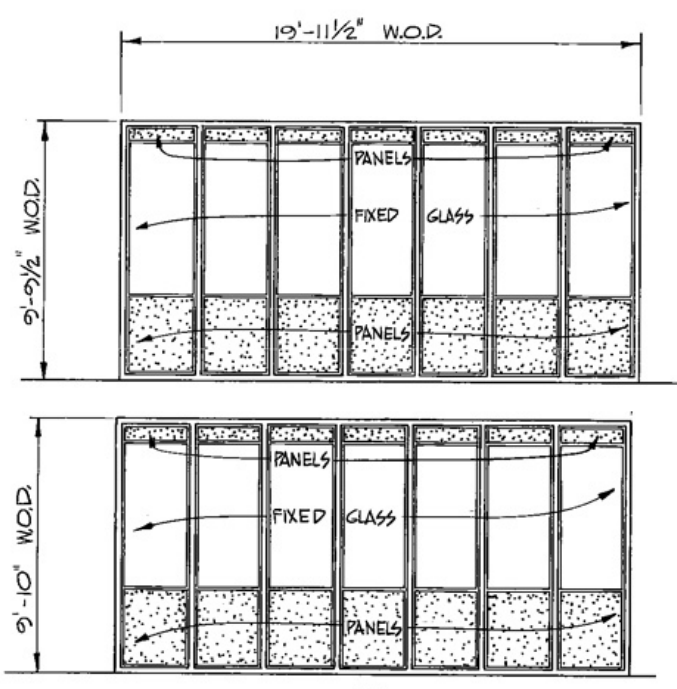

(《)

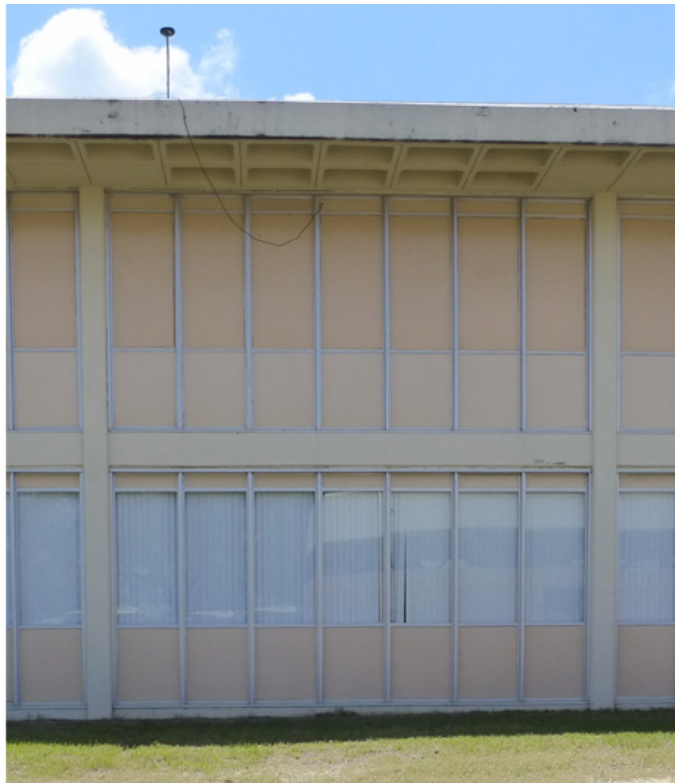

Figure 188. Second-floor windows - Comparison of the original drawing detail from 1973 [left] to the current condition of the bright-aluminum fixed windows and panel inserts on the second floor [right] (ERDC-CERL, 2015).

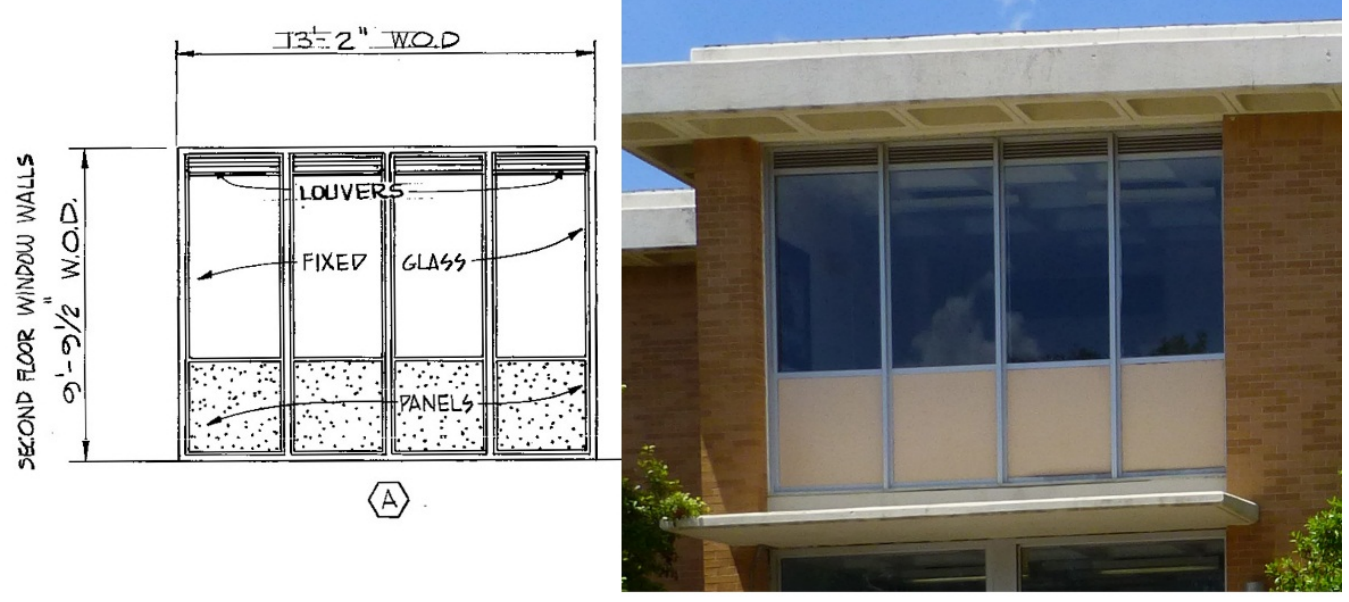


Figure 189. Wall mounted exterior light fixture type "H" - comparison of the original drawing detail from 1966 [left] to the current condition of the light fixture [right]

(ERDC-CERL, 2015).
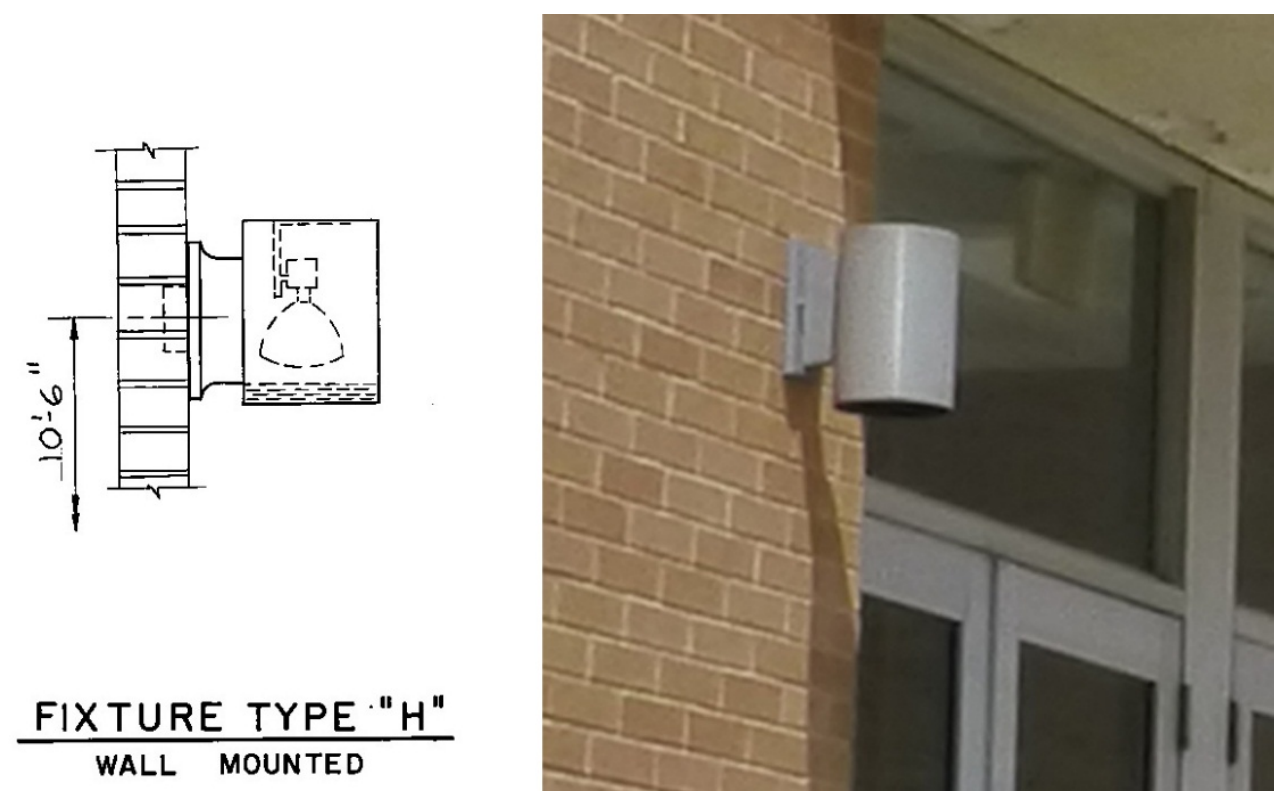

\subsubsection{Building 29801, Nelson Hall (1969)}

Building 29801, Nelson Hall, is a contributing feature to the Signal School Campus Historic District. The interior is also contributing. The building was constructed in 1969 as part of Phase II construction for the Signal School Campus. It is a long rectangular classroom building on the western edge of the campus, north of the western parking lot. It is two stories high. The structure is cast-in-place concrete columns with a waffle floor/ceiling system. The second-floor waffle system is set within the structure, but the roof has the waffles extending out to form an overhang. Some of the waffles have been perforated, casting a "light pattern" on the second-floor brick walls. The window systems extend the full height of the building and are inset into the brick veneer. The window systems are composed of bright-aluminum window frames that enclose a three-pane awning-style window that is sandwiched between two panels. The windows are in groups of three or four. The main entrances are located on the south and east elevations. The entrance on the east facade is composed of two sets of double steel doors with large fixed-pane transoms above, and a group of four plate-glass awning-style windows and fiberglass panels set into bright-aluminum framing above on the second floor. The entrance on the south elevation only has one set of double steel doors with sidelights and transom, and a concrete canopy above. Above the canopy are plate-glass awning-style windows and insulated panels set into bright-aluminum 
framing. Crepe myrtles frame the entry, while shrubs line the sidewalk leading to the entry. To the left of this entrance there is no fenestration. To the right of this entry are three groups of windows. Each window group is composed of two sets of three windows divided by a concrete column. Original "NELSON HALL" lettering is located on the south elevation. The west facade also has no fenestration. The north facade has a window bay on the left side that consists of three vertical concrete panels on the first floor separated by a concrete beam to the bright-aluminum fixed-pane windows above. A concrete column divides this group from the adjoining window bay that consists of metal doors with side lights, transom, a large insulated panel, and a flat roof canopy of the first floor and a group of three windows with plate-glass and awning-style windows with insulated panels on the second floor. Large double steel service doors are on the right side of the facade (Figure 190-Figure 198).

Figure 190. Signal School Campus map, with Building 29801, Nelson Hall highlighted in red, 2015 (Fort Gordon DPW, modified by ERDC-CERL).

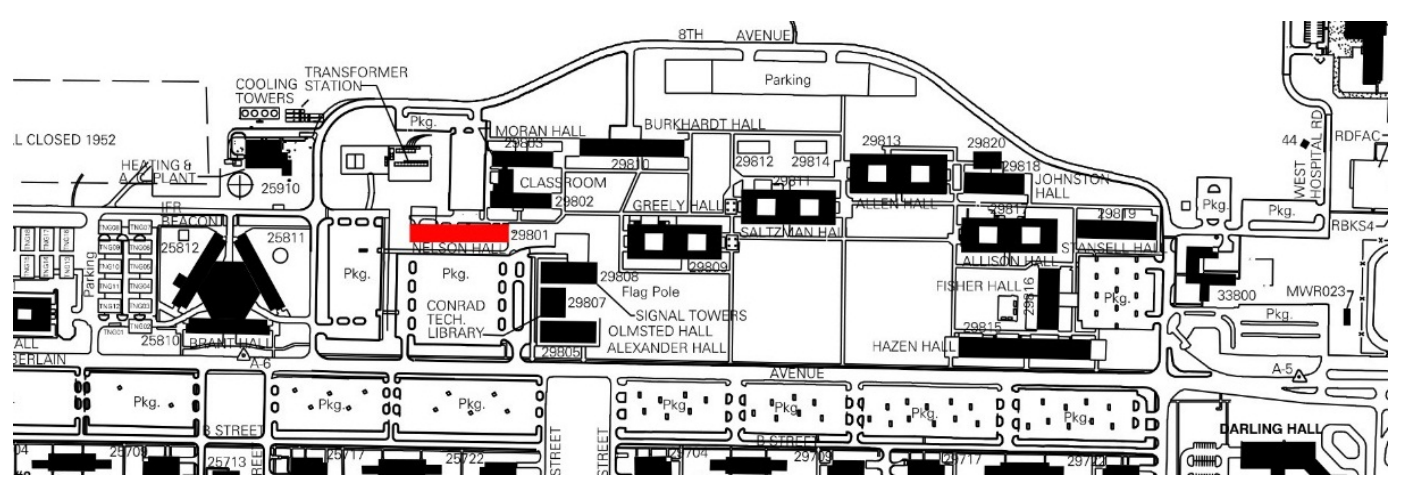


Figure 191. South elevation of Building 29801, Nelson Hall (ERDC-CERL, 2015).

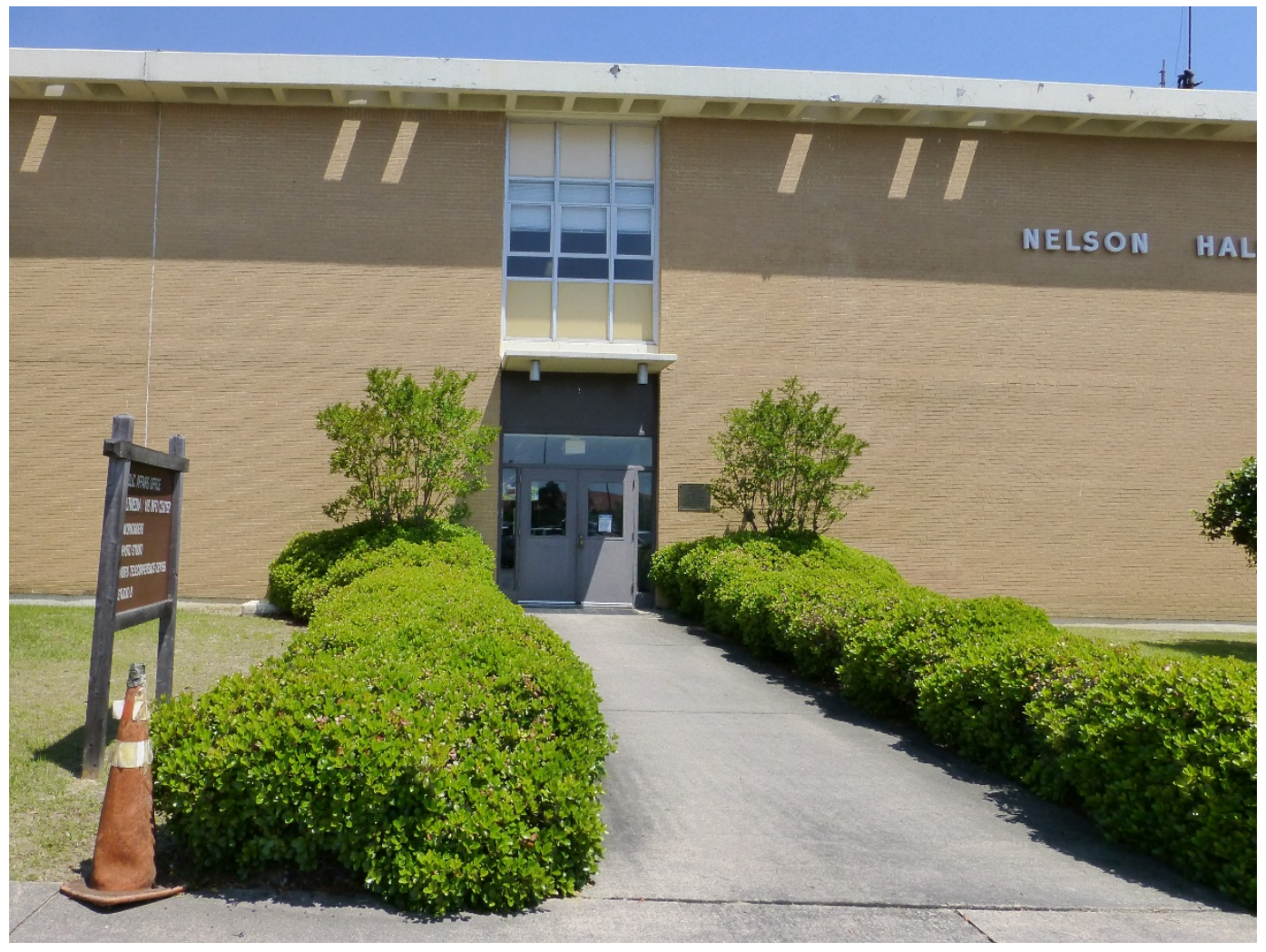

Figure 192. East elevation of Building 29801, Nelson Hall (ERDC-CERL, 2015).

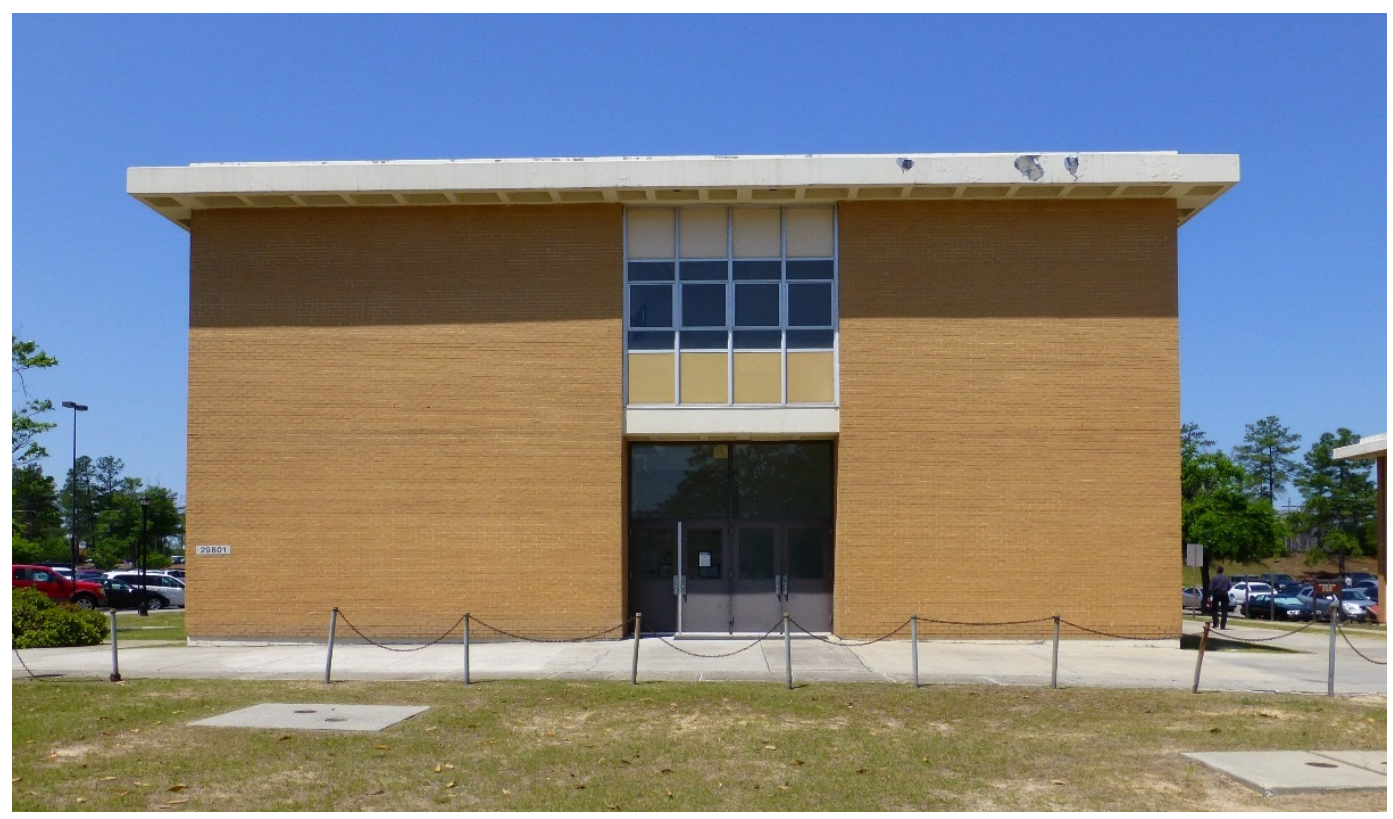


Figure 193. Left side of the north elevation of Building 29801, Nelson Hall (ERDC-CERL, 2015).

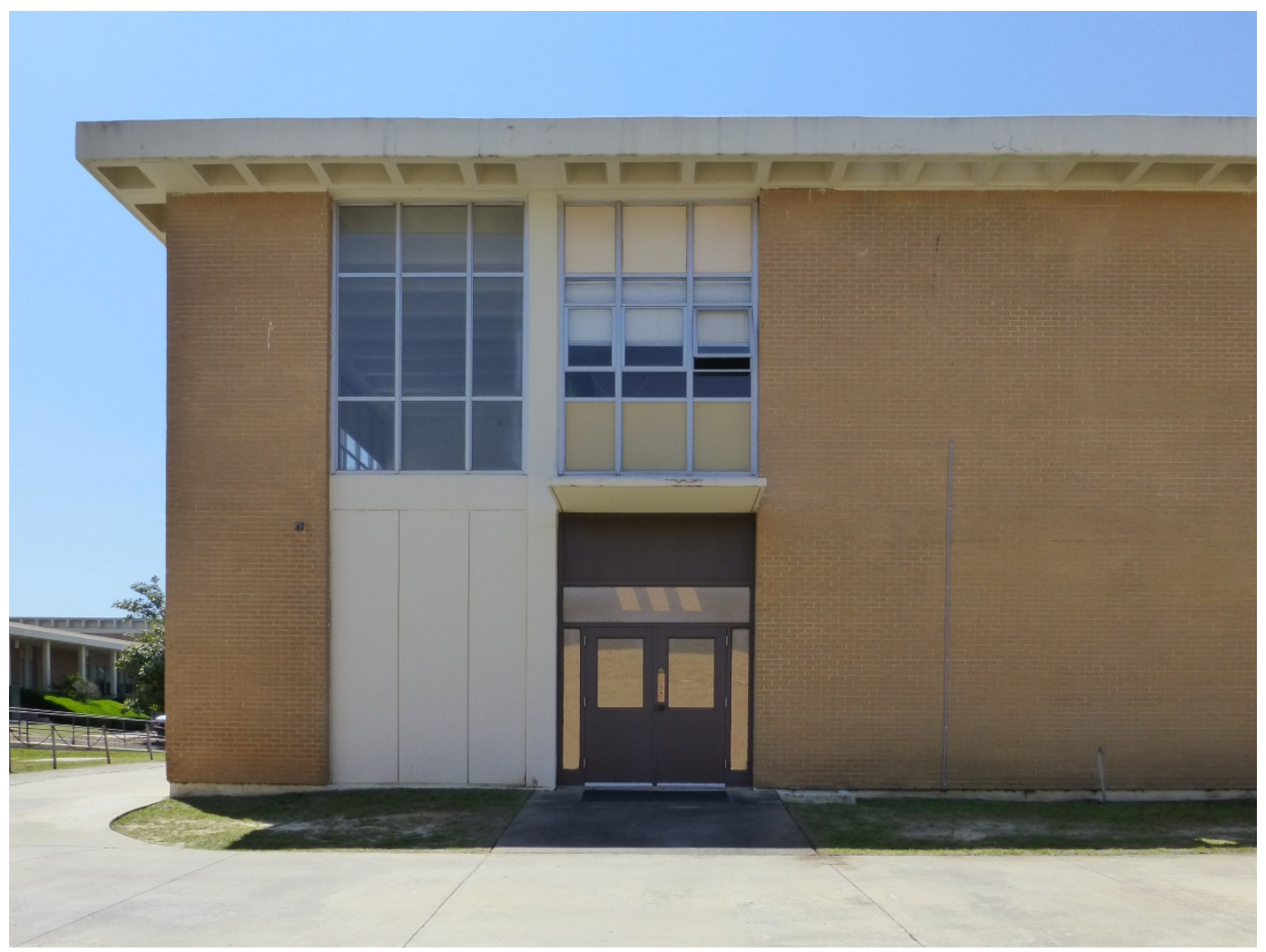

Figure 194. West elevation of Building 29801, Nelson Hall (ERDC-CERL, 2015).

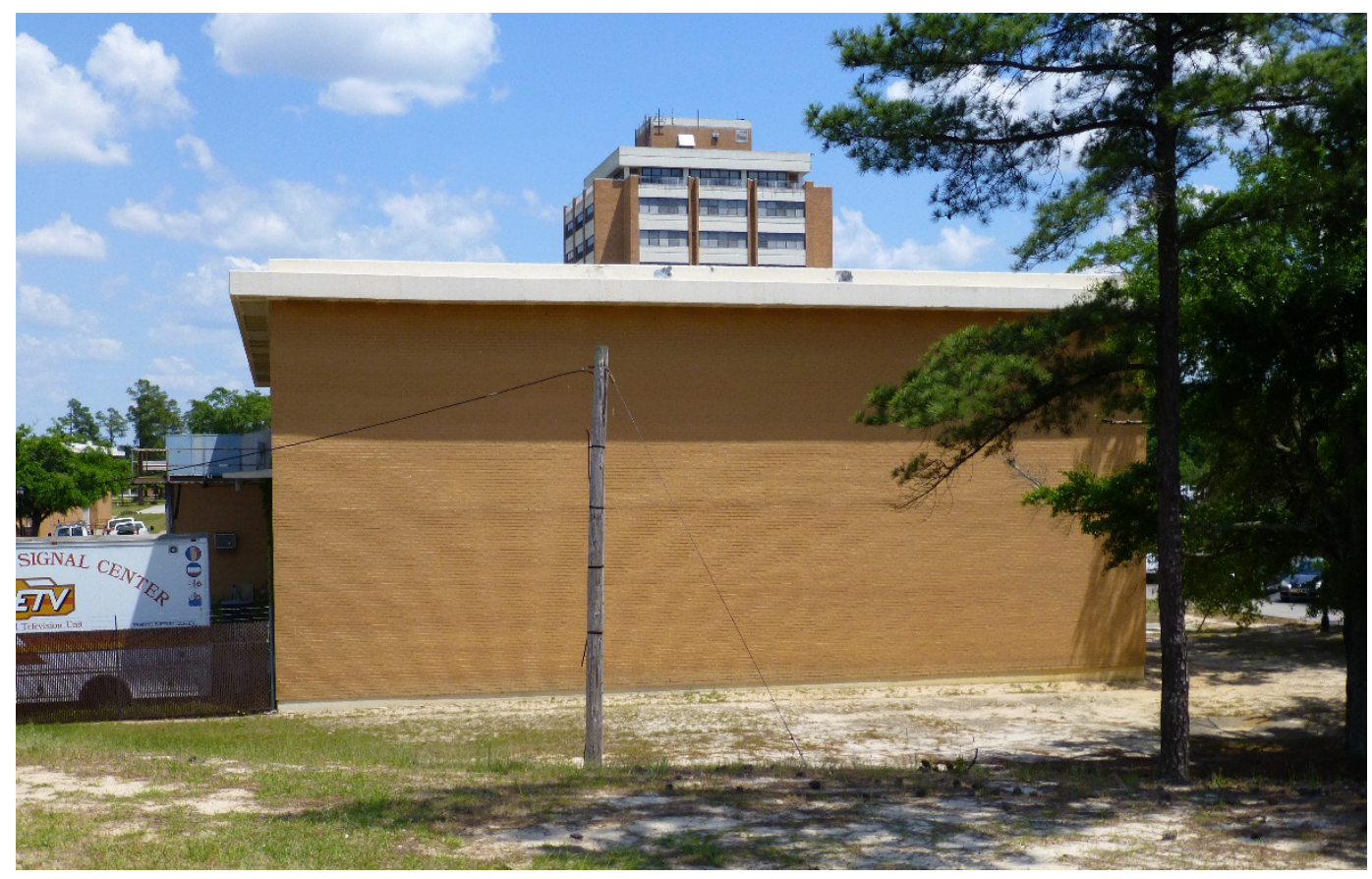


Figure 195. Building 29801, Nelson Hall, window details, 1966 (Fort Gordon DPW).

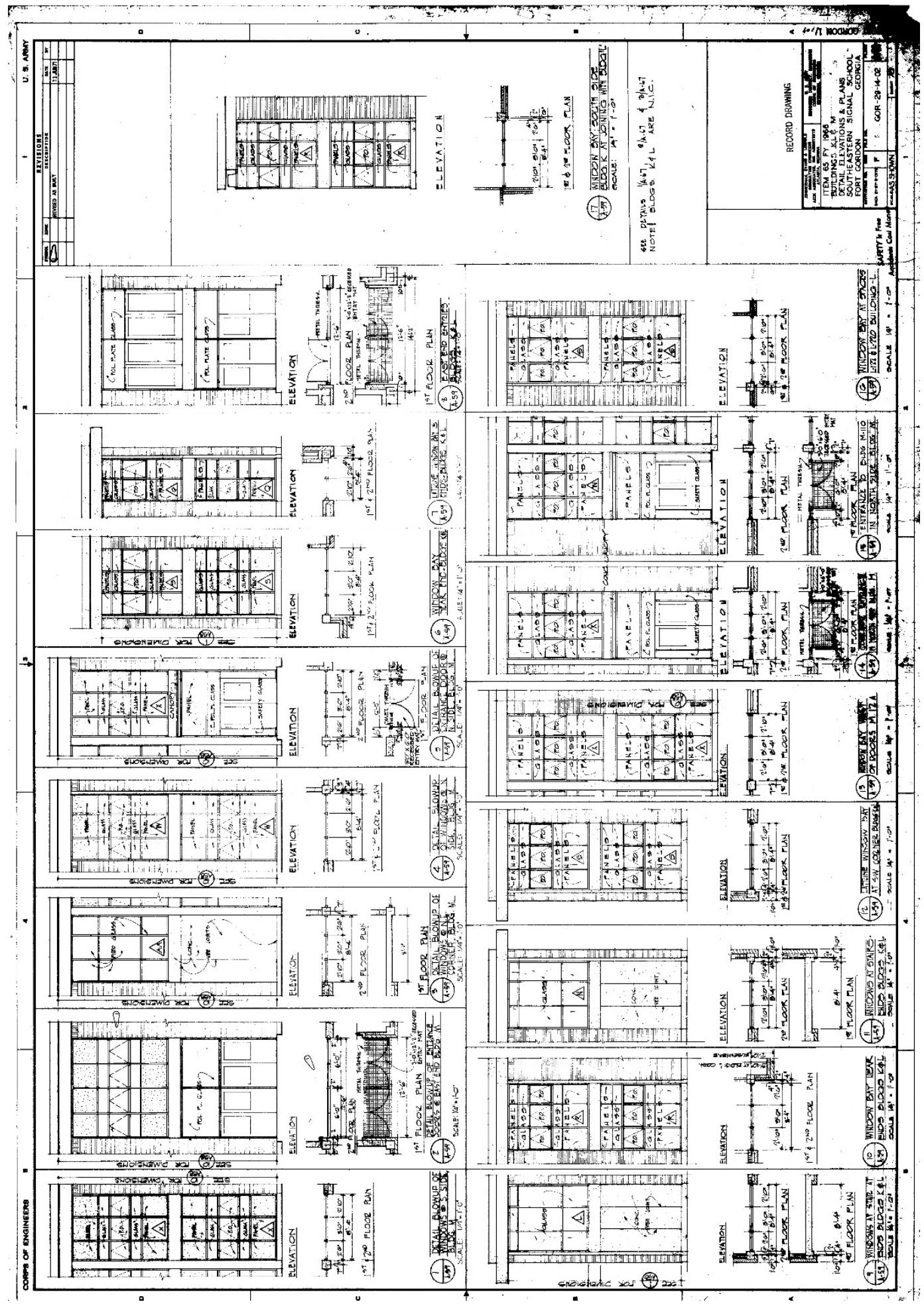


Figure 196. Typical classroom elevations and details for Building 29801, Nelson Hall, 1966 (Fort Gordon DPW).

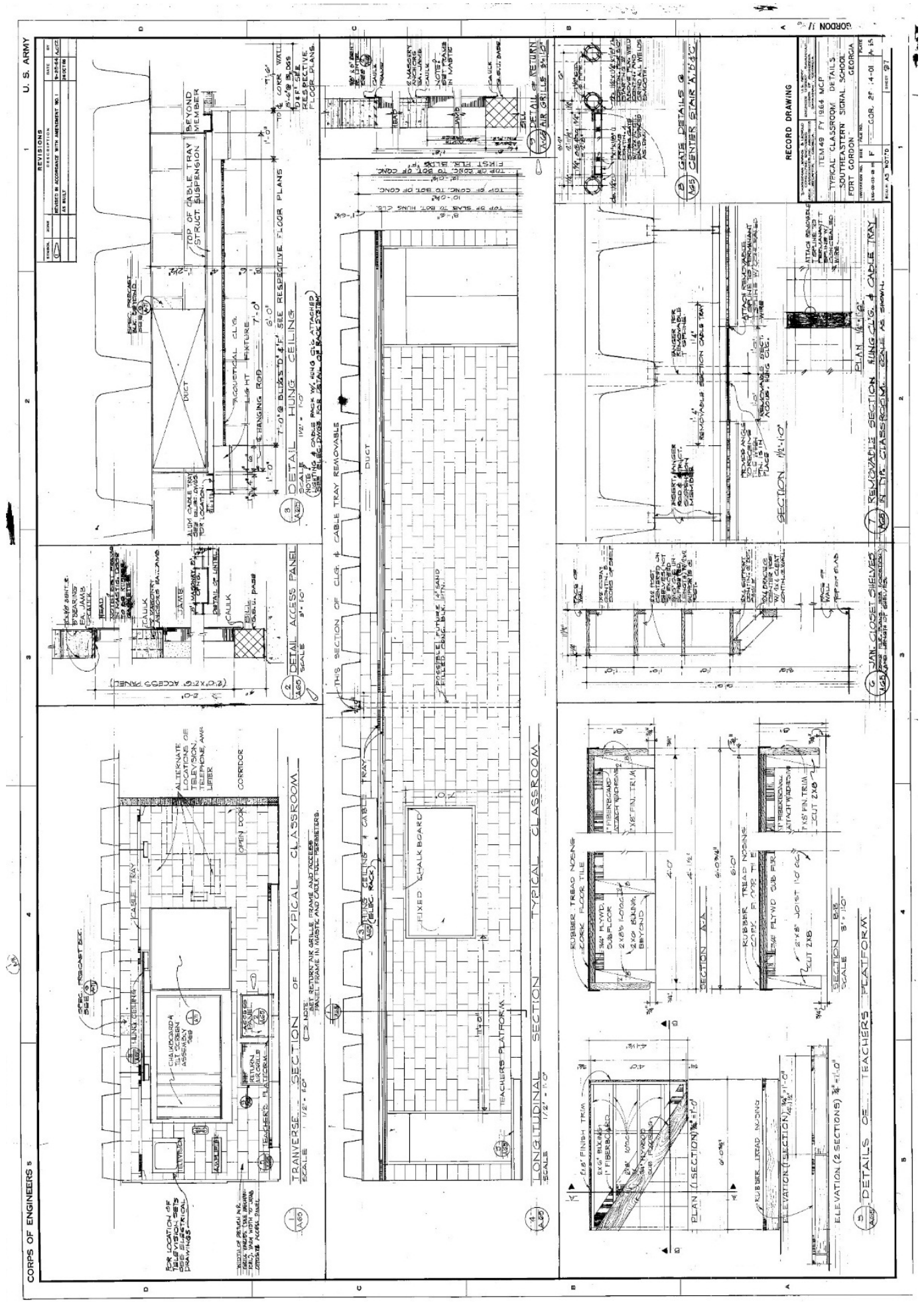


Figure 197. Light fixtures details and schedule, 1966 (Fort Gordon DPW).

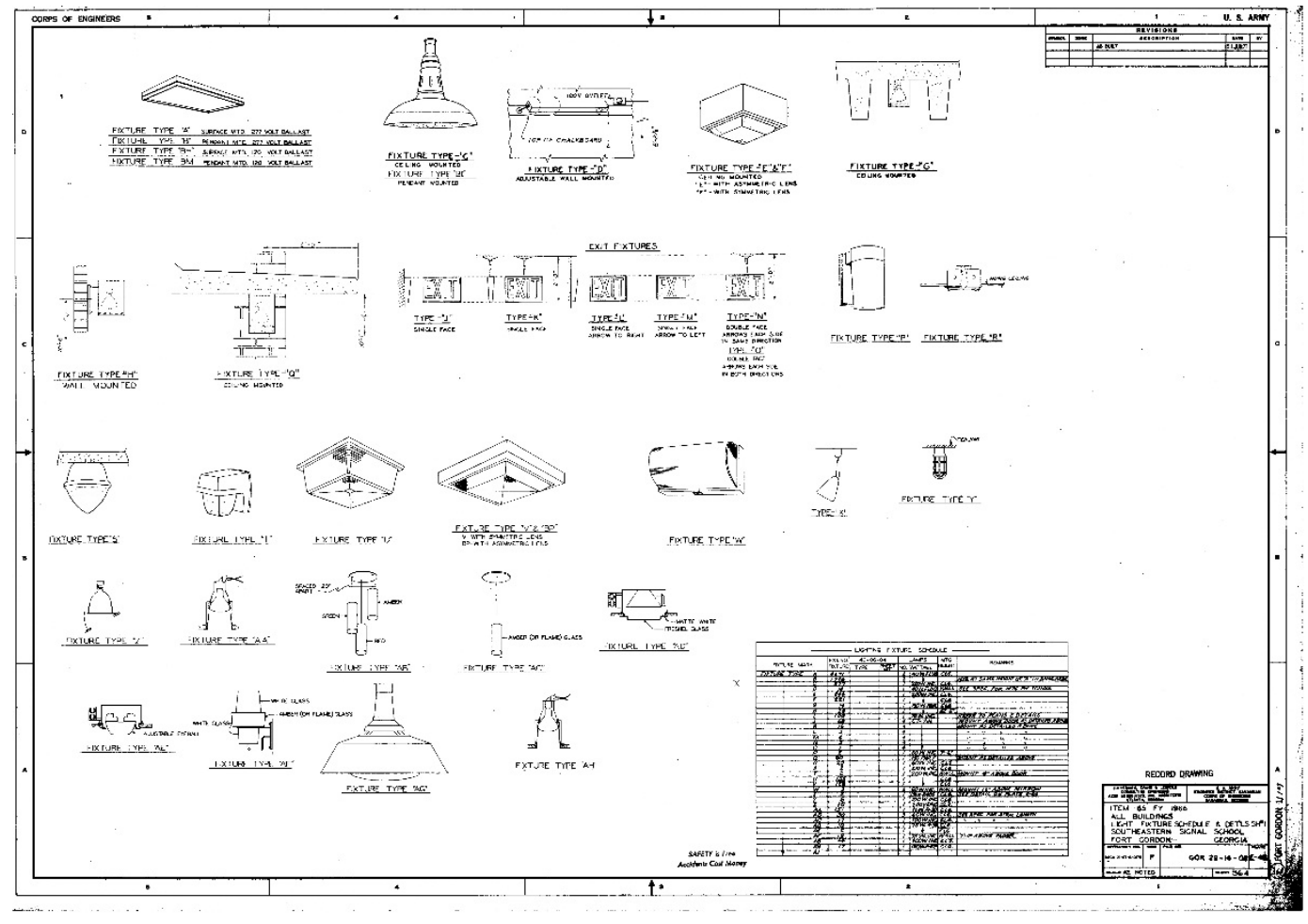

Figure 198. Landscaping plan for Building 29801, Nelson Hall, 1966 (Fort Gordon DPW).

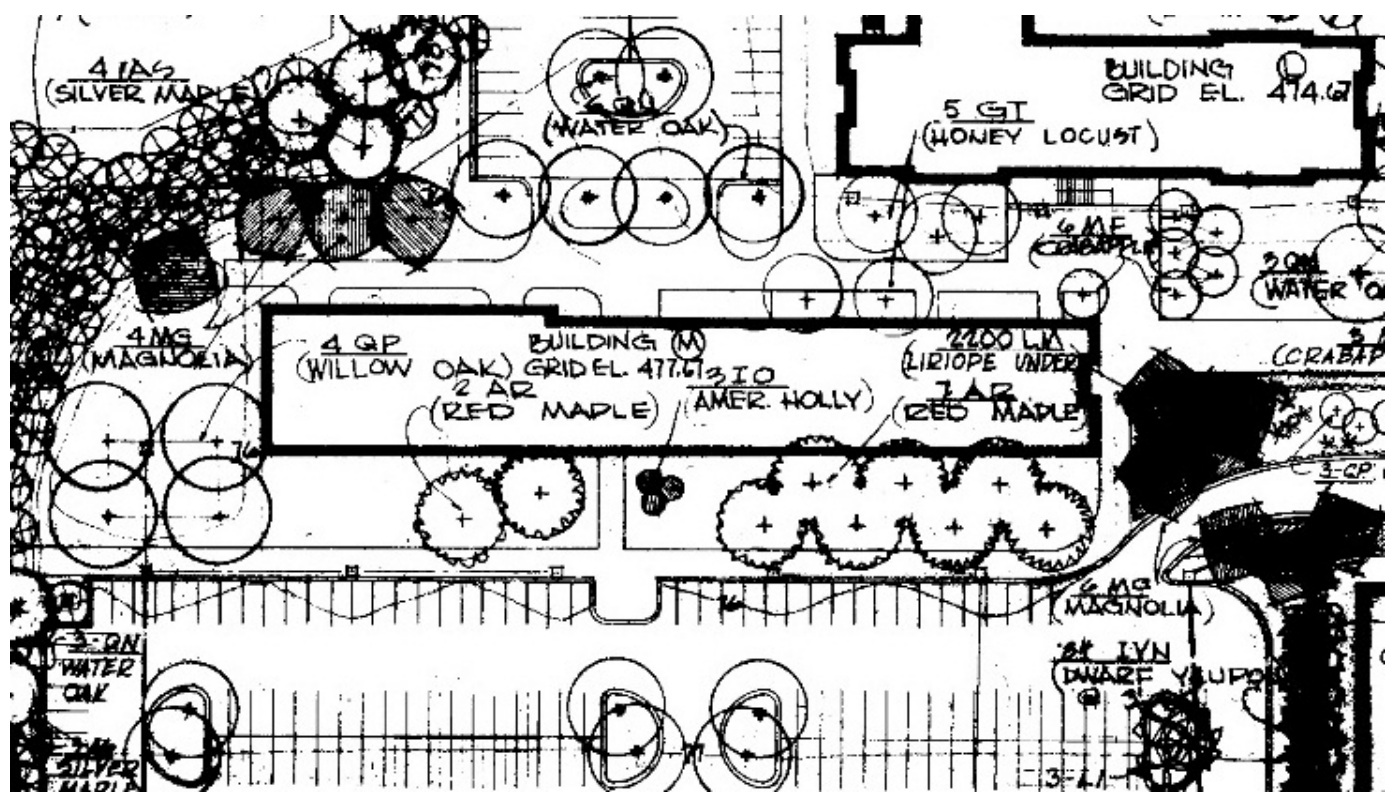

\subsubsection{Character-defining features}

Repair, renovation, and replacement of Building 29801, Nelson Hall, must be coordinated with the GA SHPO (Table 4). 


\section{Exterior:}

- Overall massing

- Footprint

- Roof shape

- Brick veneer

- Overhanging eaves with perforated waffle construction casting "light pattern" on exterior brick walls

- Exposed concrete structure framing window and door openings

- Flat concrete canopy above secondary entries

- Flat concrete waffle canopy near main entry

- Recessed groups (three or four) of bright-aluminum sash three-pane awning-style windows with fixed panes and insulated panel inserts

- Ceiling-mounted bronze, cylinder light exterior light fixtures

- Lettering

- Landscaping

\section{Interior:}

- Overall plan

- Main stairwells

- Main hallways

- Lighting

- Doors

Table 4. Images of character-defining features of Building 29801, Nelson Hall (ERDC-CERL, 2015).

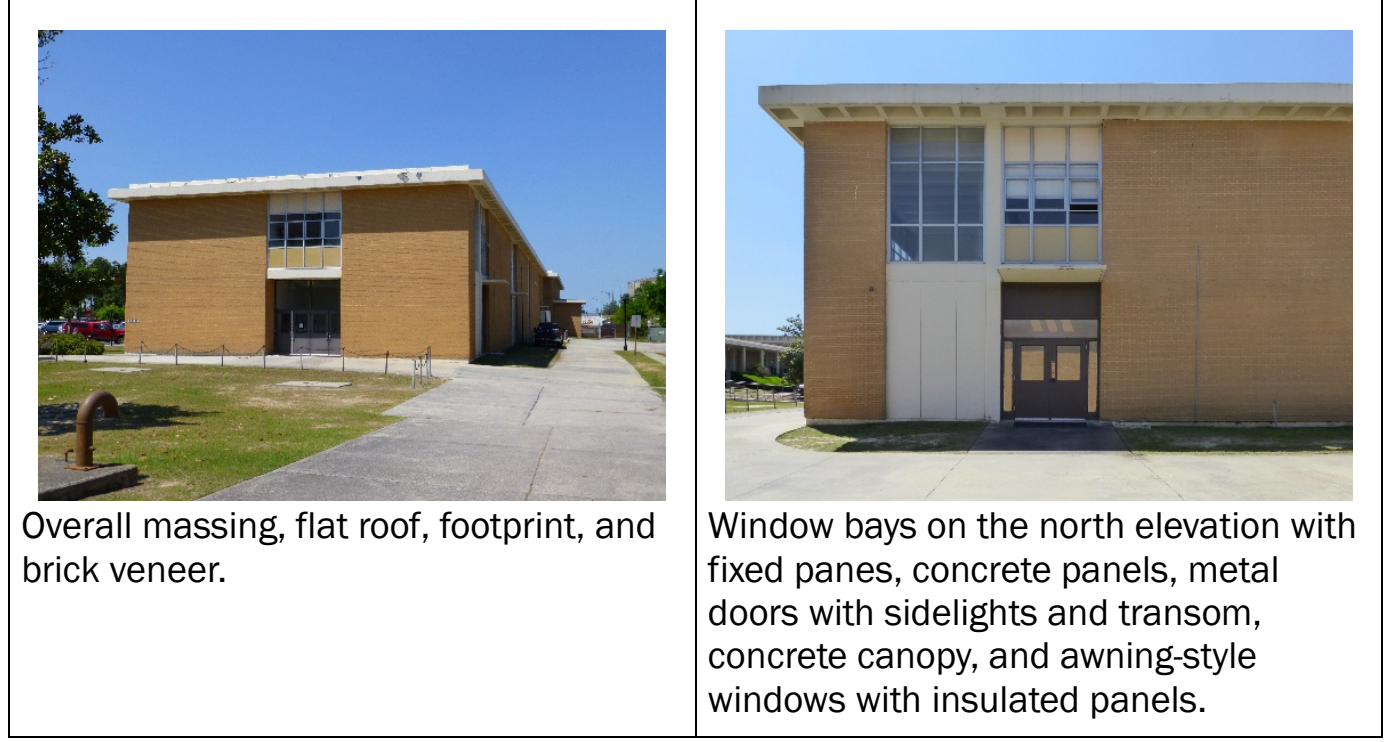




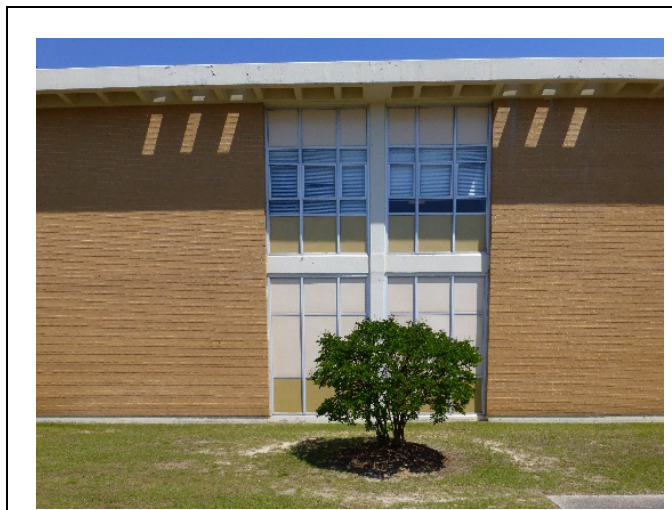

Window bays on the south elevation and "light pattern" cast from the perforated waffle roof overhang.

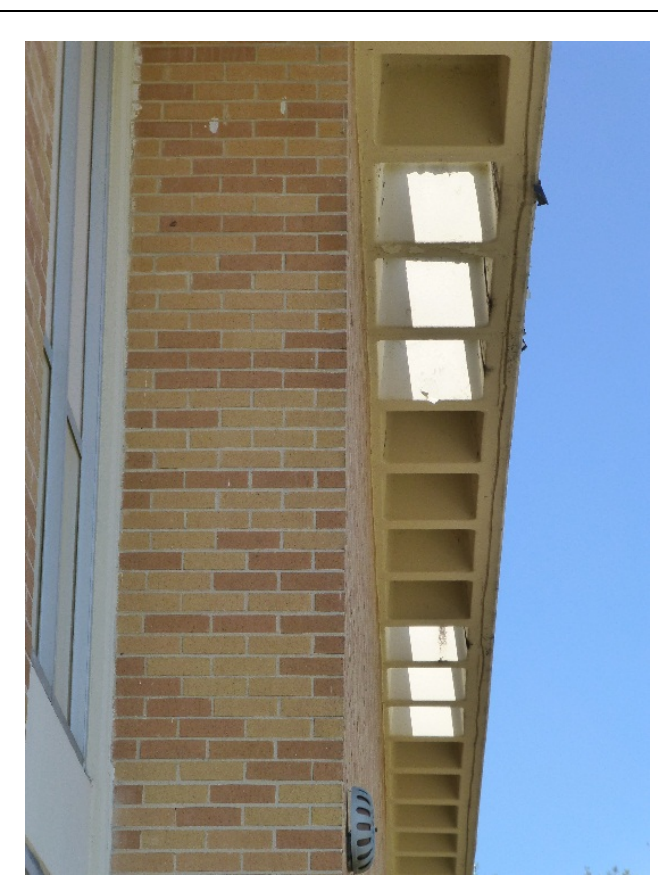

Concrete overhang with perforated waffle.

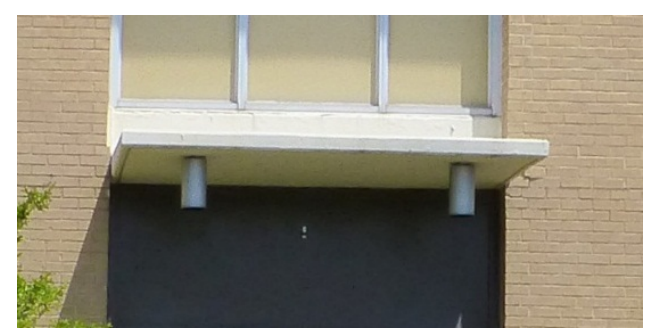

Concrete canopy with ceiling-mounted bronze light fixtures.

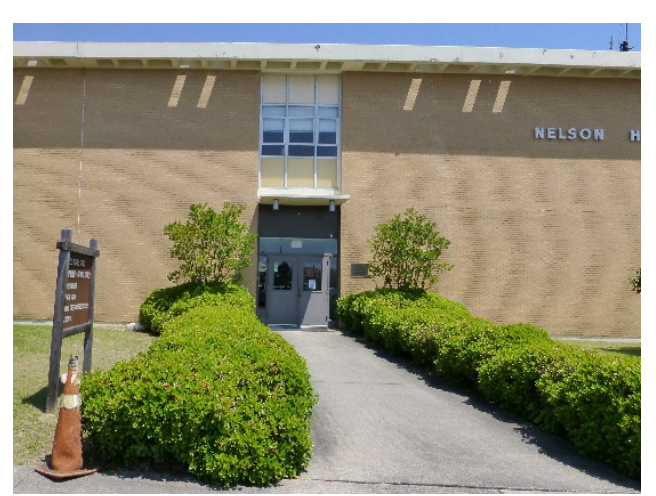

Entry bay on the south elevation with landscaping.

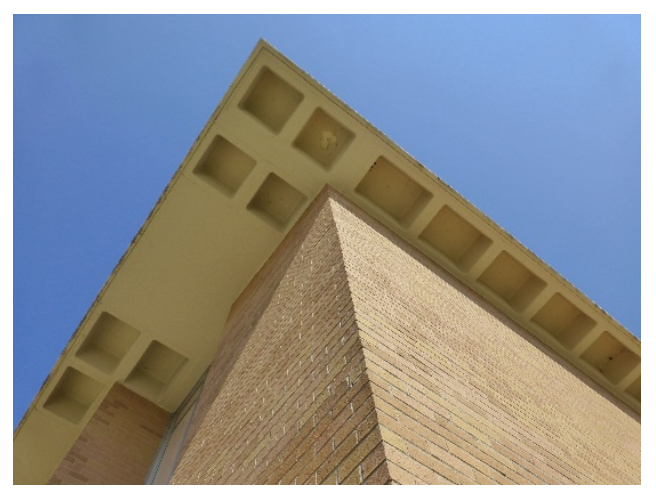

Concrete overhang in waffle construction.

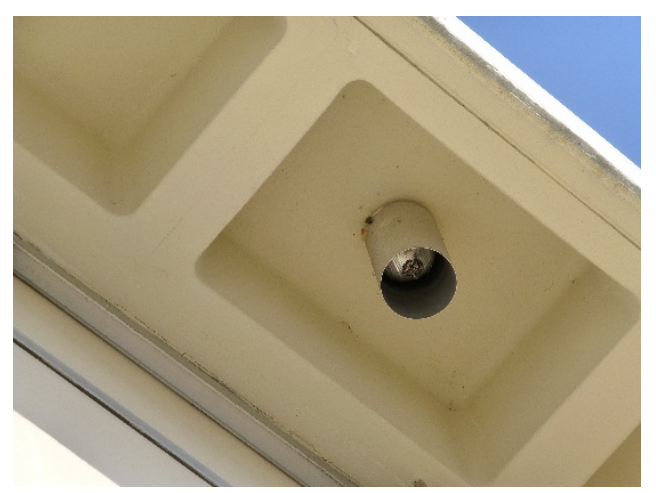

Ceiling-mounted light fixtures set within a waffle overhang. 


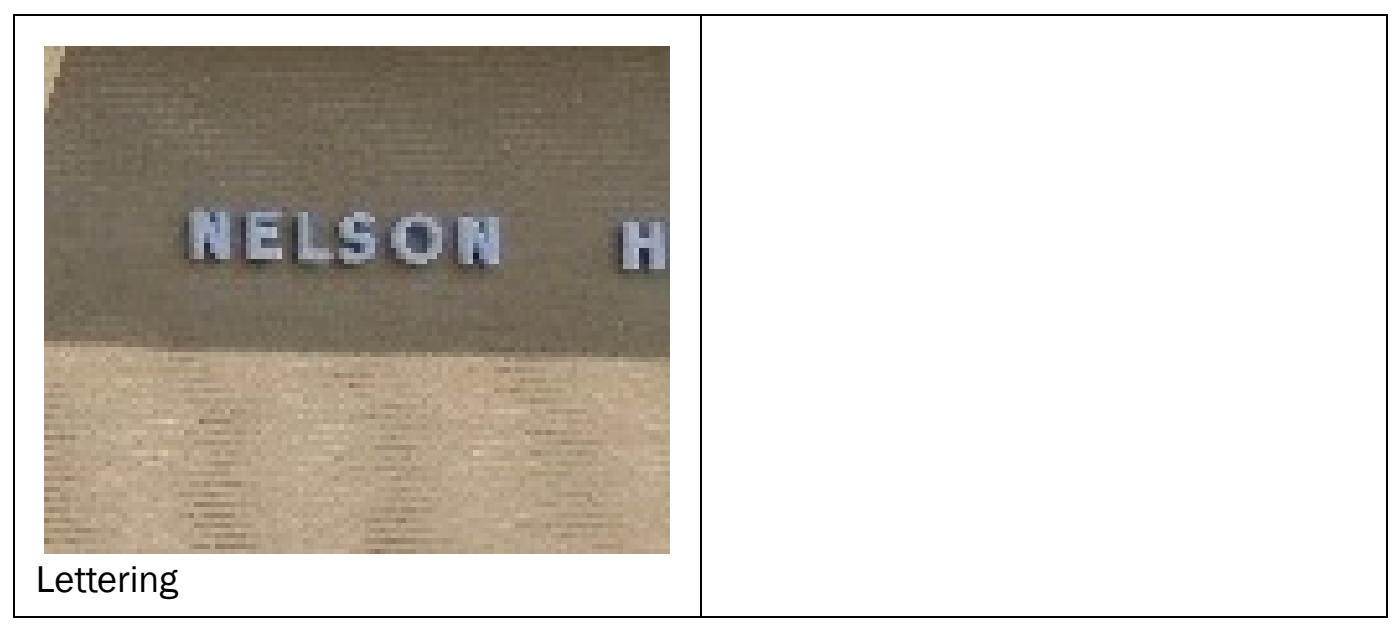

3.3.2.2 Character-defining features that have been removed

Listed below are character-defining features of Building 29801, Nelson Hall that have been removed or replaced over the years; as future renovations occur, these need to be replaced with elements that replicate the original character-defining features of the building. The original drawing will guide this process in coordination with the GA SHPO.

- Windows on the north elevation that have been replaced with panel inserts

\subsubsection{Nonhistoric features}

- None.

\subsubsection{Comparison images}

Comparison images utilizing either the original drawings or historic photographs, when juxtaposed against present-day images, are a useful tool in developing the historic "feel" of a property and how much of that historic feeling is still present today (Figure 199-Figure 203). 
Figure 199. East entrance bay - comparison of the original drawing detail from 1966 [left] to the current condition of metal and glass doors with transom above on the first floor and the bright-aluminum awning windows with panel inserts on the second floor [right] (ERDC-CERL, 2015).
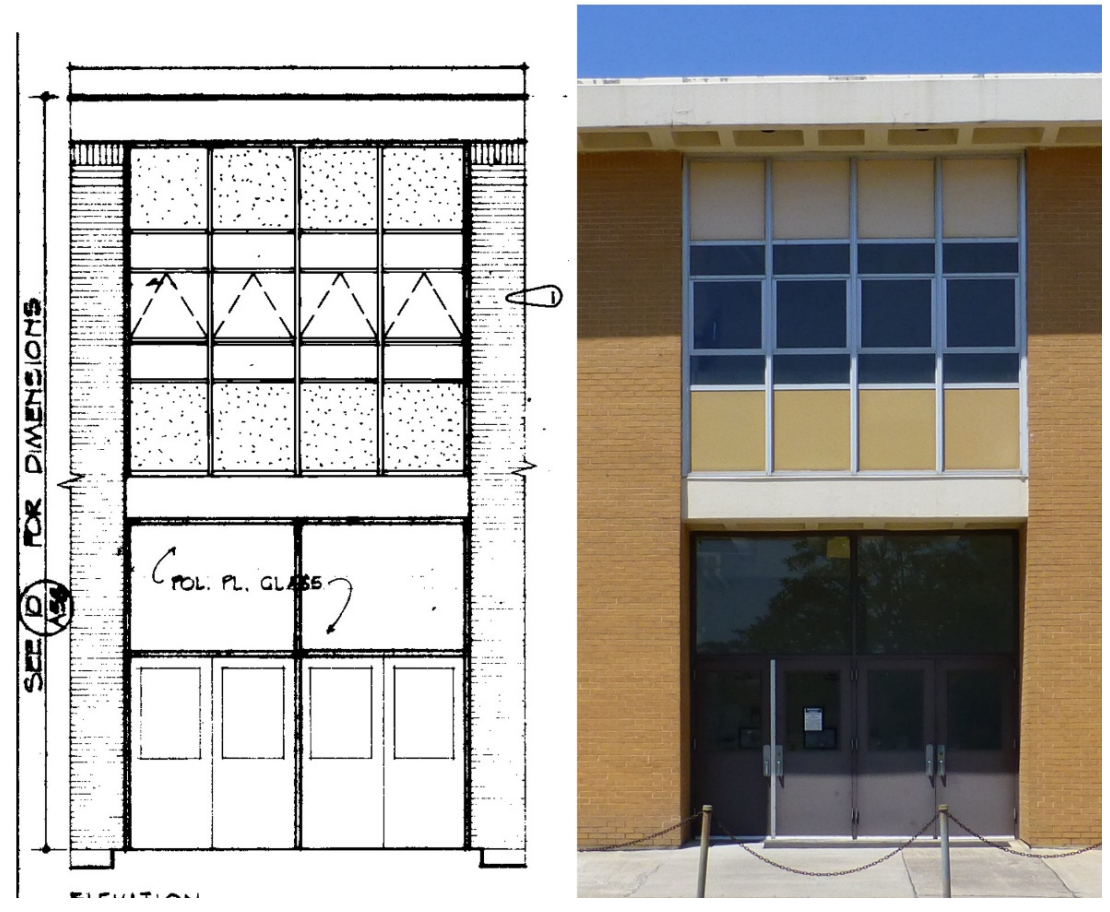

Figure 200. Northeast window/door bay - comparison of the original drawing detail from 1966 [left] to the current condition of concrete panels, metal and glass doors with transom above on the first floor and the bright-aluminum awning windows with panel inserts on the second floor [right] (ERDC-CERL, 2015).
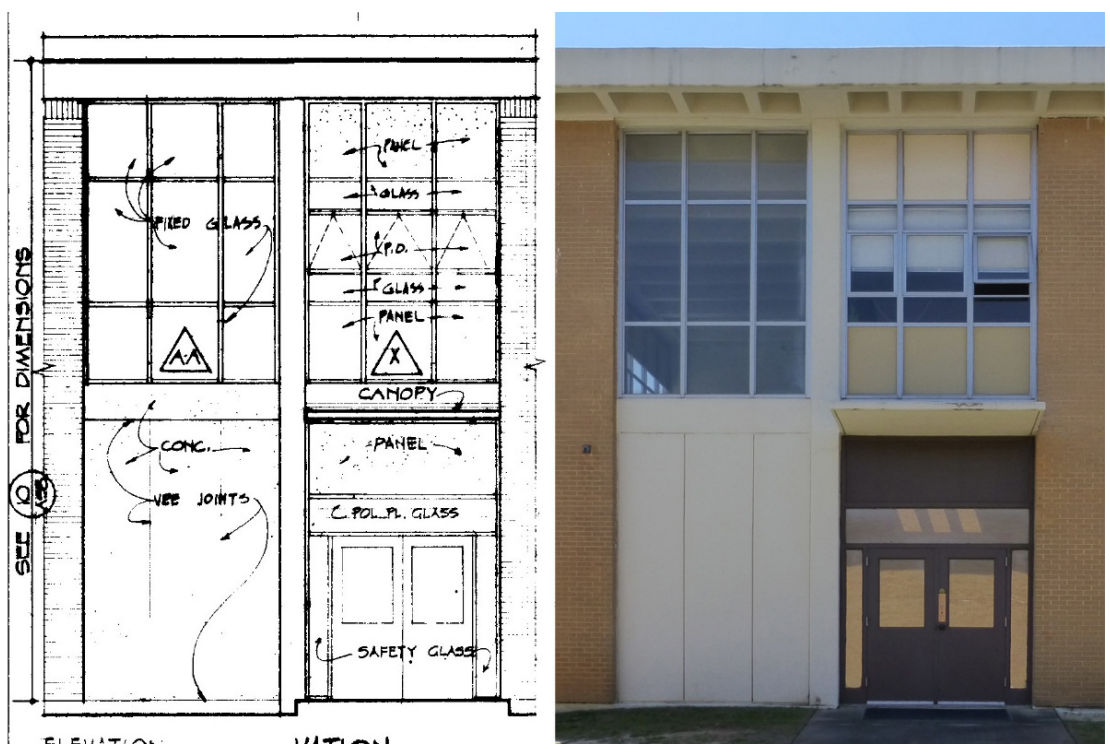
Figure 201. South elevation window bay - comparison of the original drawing detail from 1966 [left] to the current condition of the bright-aluminum awning windows with panel inserts separated by the concrete structure [right] (ERDC-CERL, 2015).
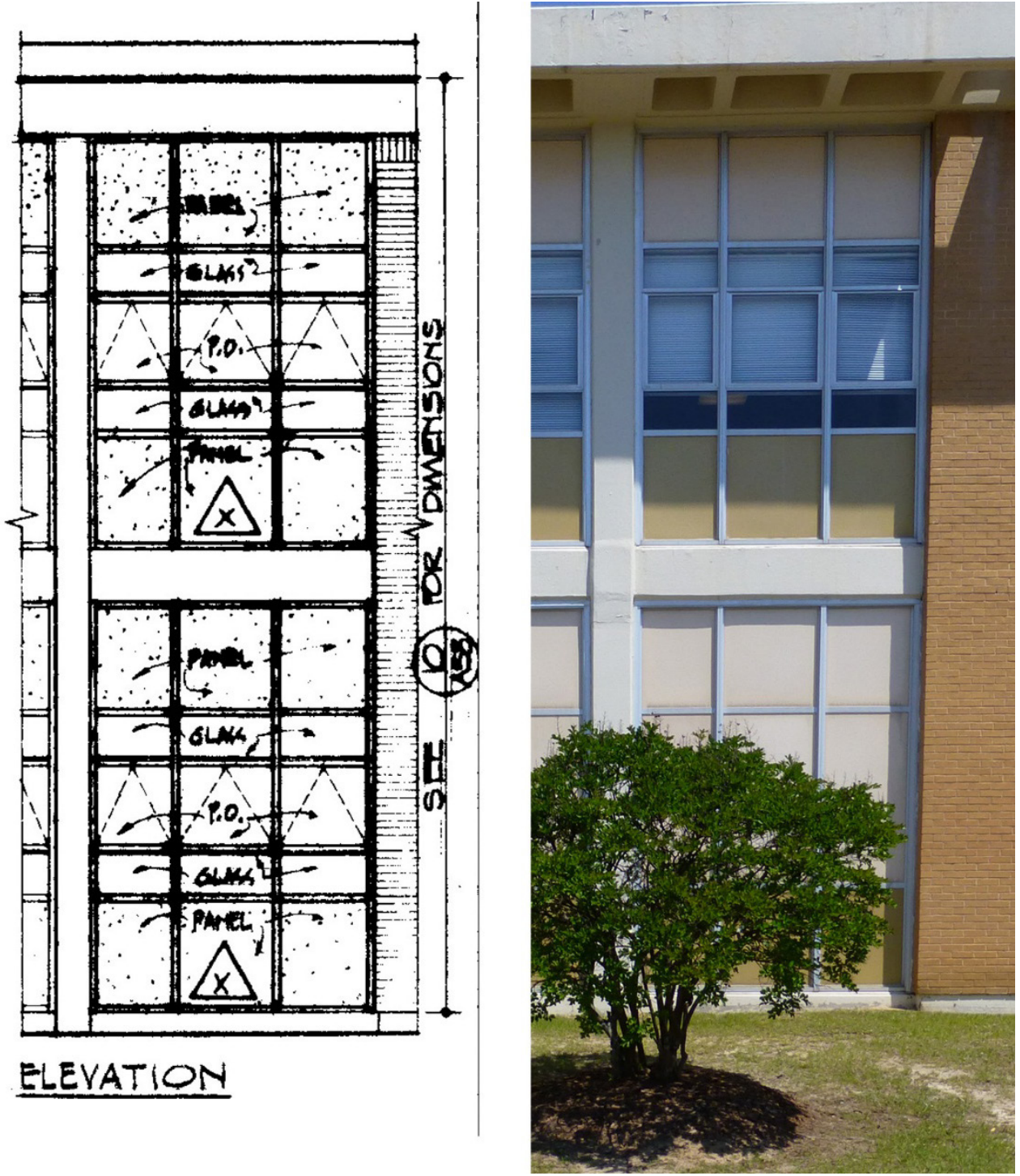
Figure 202. Ceiling mounted light fixture set within the waffle overhang - comparison of the original drawing detail, no date [left] to the current condition of the light fixture [right] (ERDC-CERL, 2015).
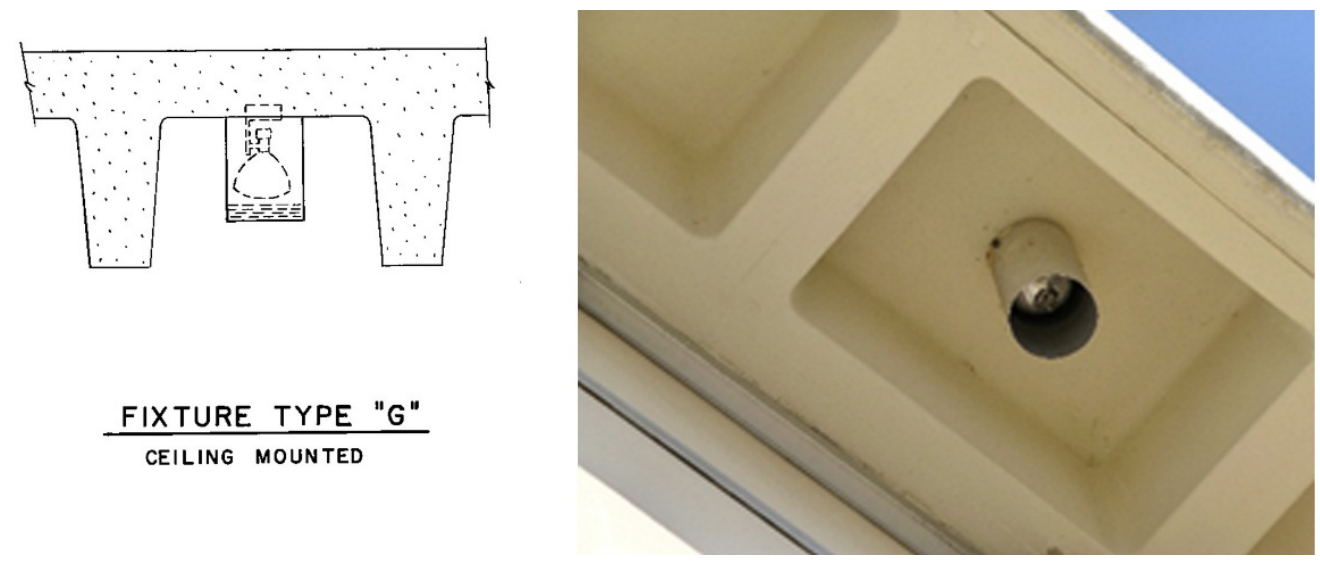

Figure 203. Ceiling mounted light fixture under the concrete canopy - Comparison of the original drawing detail, from 1966 [left] to the current condition of the light fixtures [right] (ERDC-CERL, 2015).
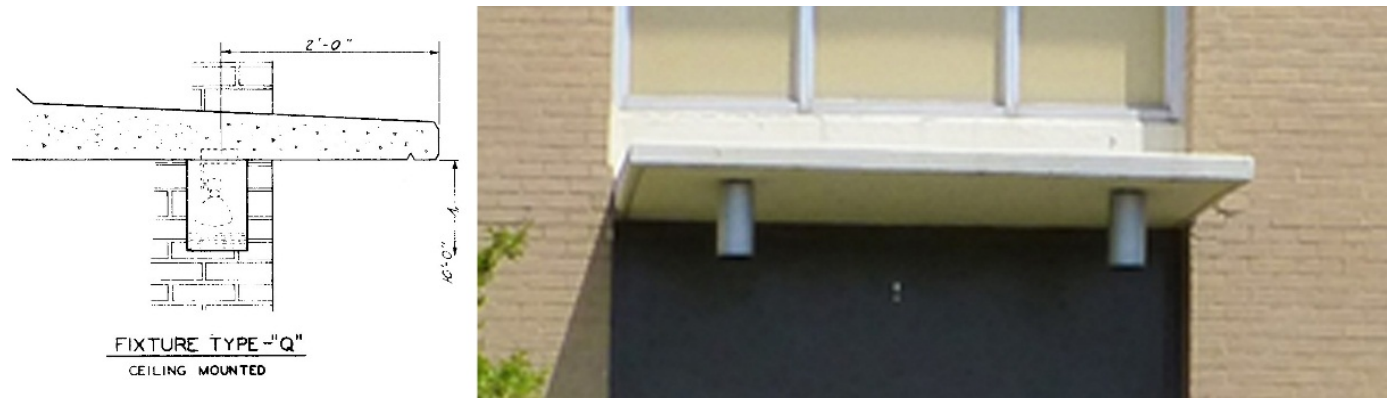

\subsubsection{Building 29802, Moran Hall [south] (1973)}

Building 29802, Moran Hall (south), is a contributing feature to the Signal School Campus Historic District. The research team was not granted access to the interior; the interior character-defining features are unknown, but for undertakings that effect the interior the Cultural Resources Manager (CRM) should use examples from the other interiors to guide identification and mitigation. The building was constructed in 1973 as part of Phase III construction for the Signal School Campus and was designed by architects Aeck Associates from Atlanta, Georgia; and Zimmerman, Evans, and Leopold Consulting Engineers from Augusta, Georgia. Building 29802 is a long rectangular classroom building that is connected via a hyphen to Building 29803, Moran Hall north. It is two stories high with a basement. The structure is cast-in-place concrete columns with a waffle floor/ceiling system. The second-floor waffle system is set within the structure, but the 
roof has the waffles extending out to form an overhang. Some of the waffles have been perforated, to cast a "light pattern" on the second-floor brick walls. The window systems extend the full height of the building and are inset into the brick veneer. The window systems are composed of bright-aluminum window frames that enclose insulated panels. The windows are in groups of two, three, or six. The main entrances are located on the east and west elevations. The entrances consists of recessed metal doors with metal panel inserts adjacent and above on the doors on the first floor and a group of four window openings that are filled with panel inserts on the second floor. Wall-mounted light fixtures flank these windows. The south elevation is symmetrical. The left and right sides of the elevation each have two window bays. One is two window openings wide and the other is three. The middle of the elevation has two large bays of six window openings. All of the window openings are filled with panel inserts. Poured concrete steps provide access to the basement level on the south elevation. Original "MORAN HALL" lettering is located on the south elevation. The north elevation has a window bay on the left side that consists of three vertical concrete panels on the first floor. Bright-aluminum fixedpane windows are on the second floor. In addition, a bay of three windows filled with panels is adjacent this bay. Two large six-window bays are located near the center of the elevation. Two window bays similar to the ones located on the left side of the elevation are located on the right side. The north elevation is where Building 29802 is connected to the hyphen that joins Building 29802 and 29803 (Figure 204-Figure 210).

Figure 204. Signal School Campus map, with Building 29802, Moran Hall south, highlighted in red (Fort Gordon DPW, modified by ERDC-CERL, 2015).

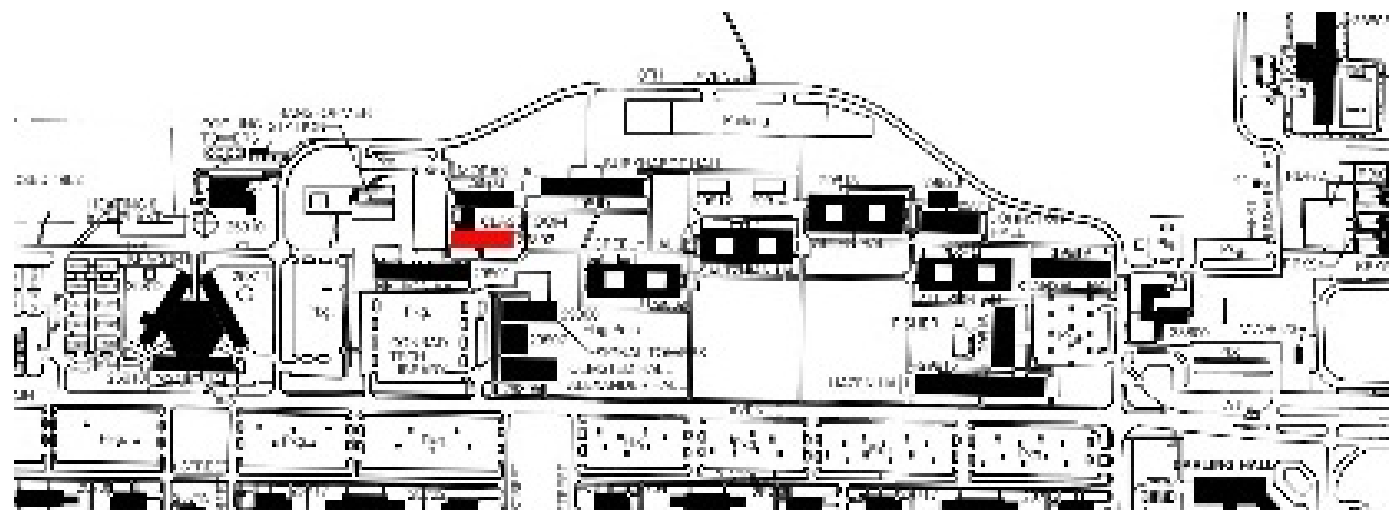


Figure 205. Southeast oblique of Building 29802, Moran Hall south (ERDC-CERL, 2015).

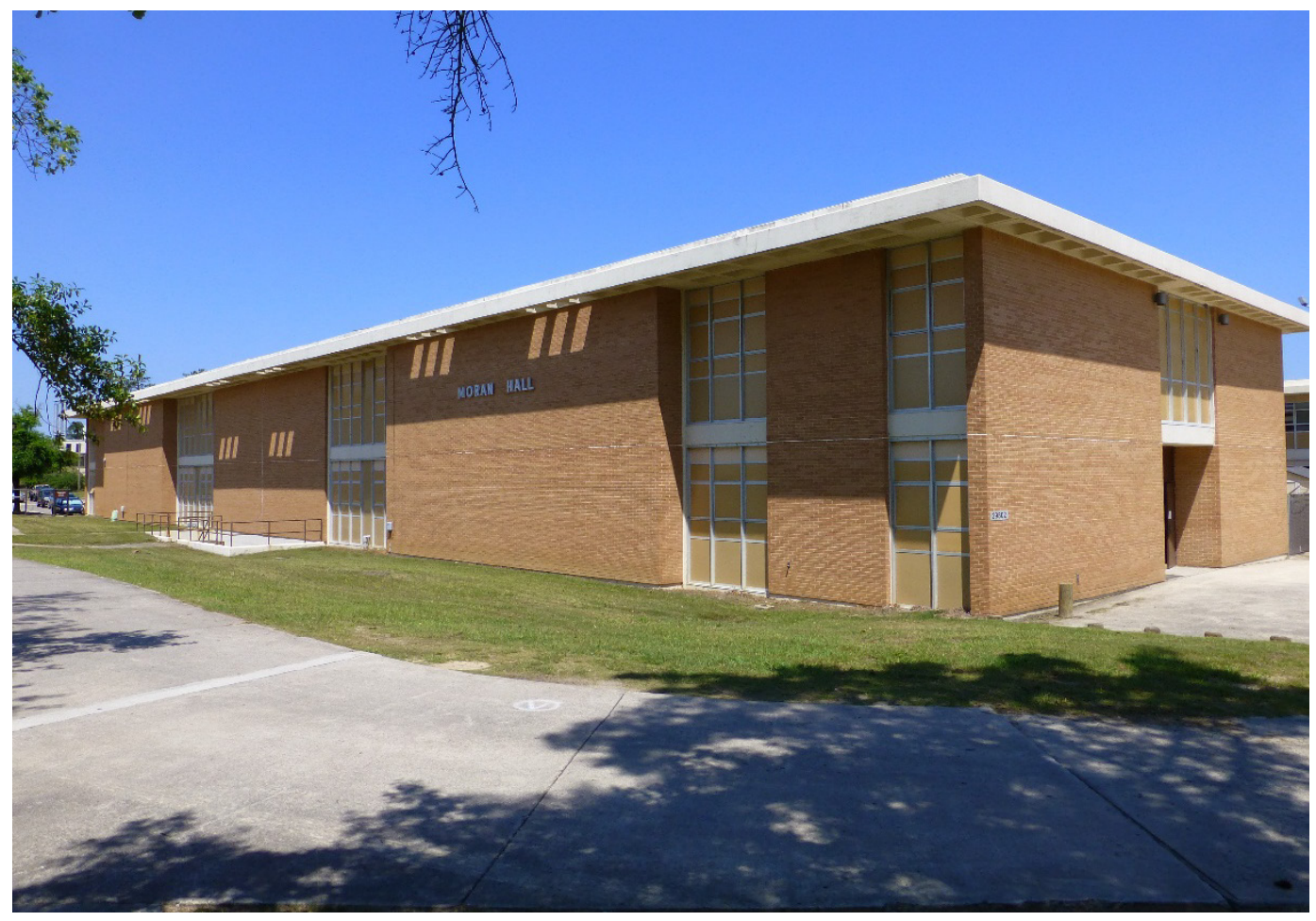

Figure 206. Northeast oblique of Building 29802, Moran Hall south (ERDC-CERL, 2015).

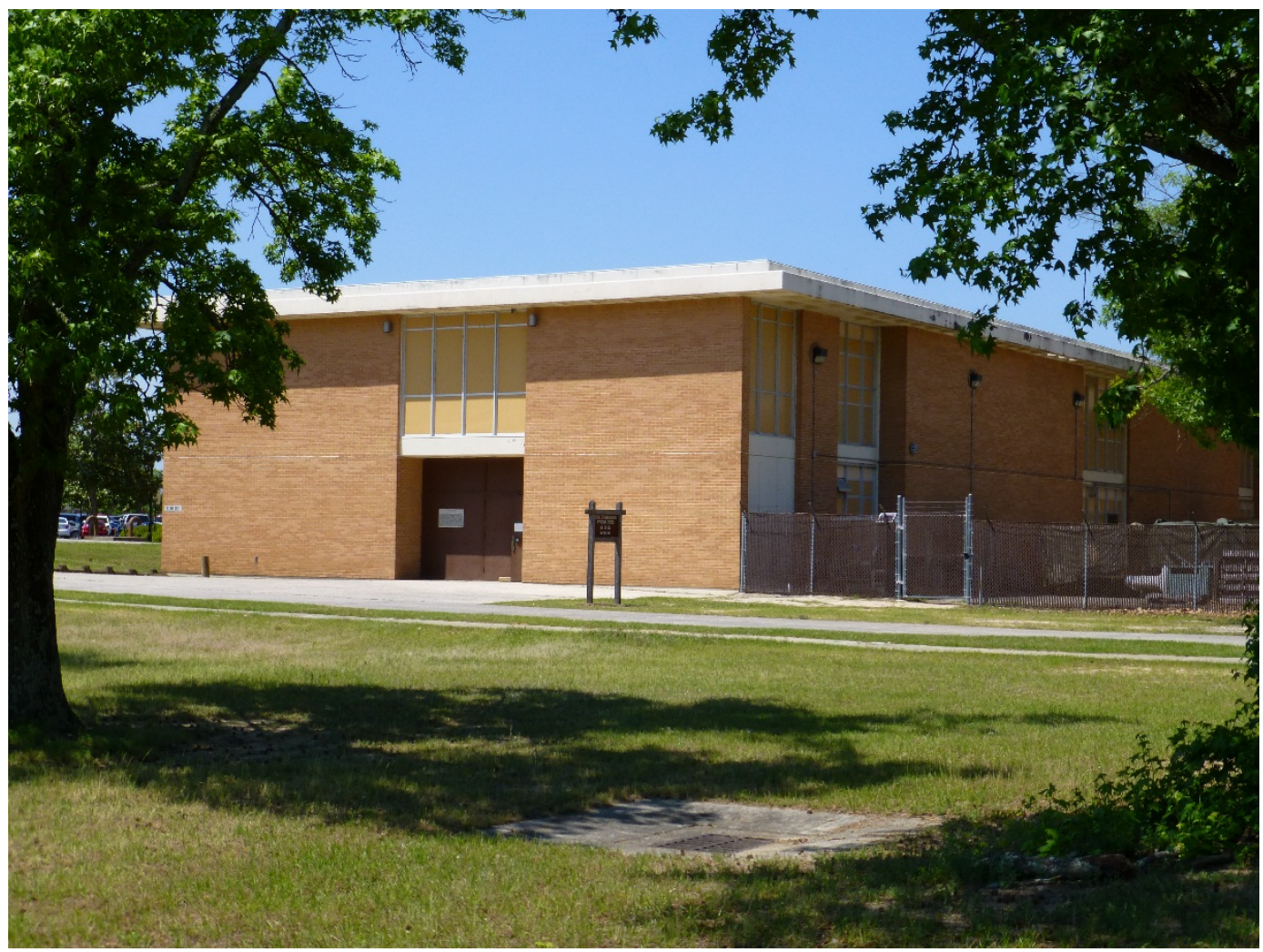


Figure 207. West elevation of Building 29803 [left] and Building 29802 [right] (ERDC-CERL, 2015).

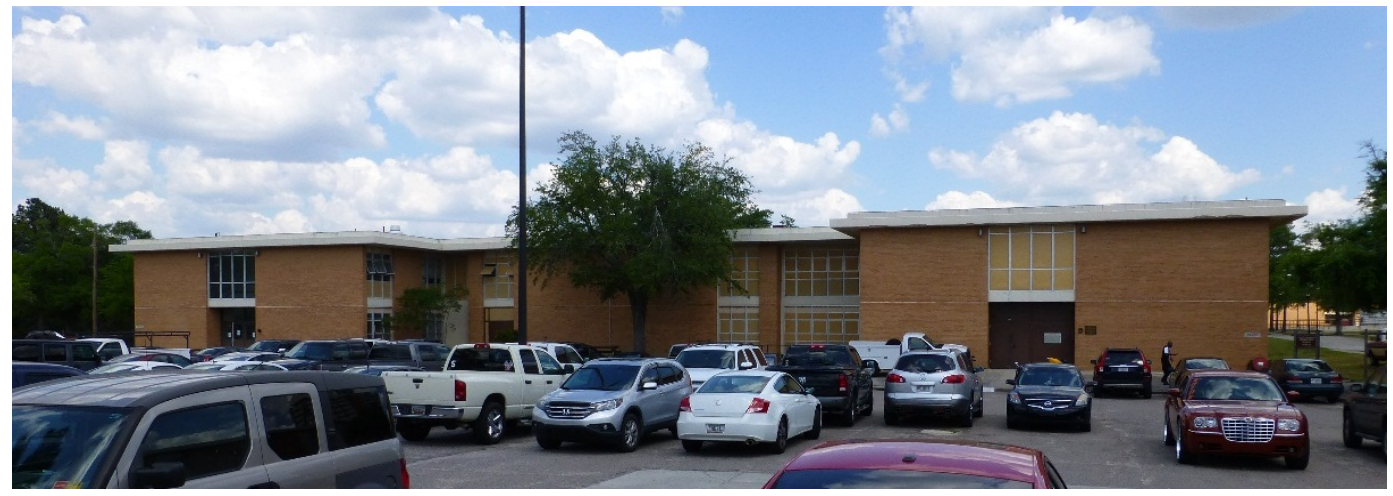

Figure 208. Detail elevations and plans for Building 29802, Moran Hall south, 1966 (Fort Gordon DPW).

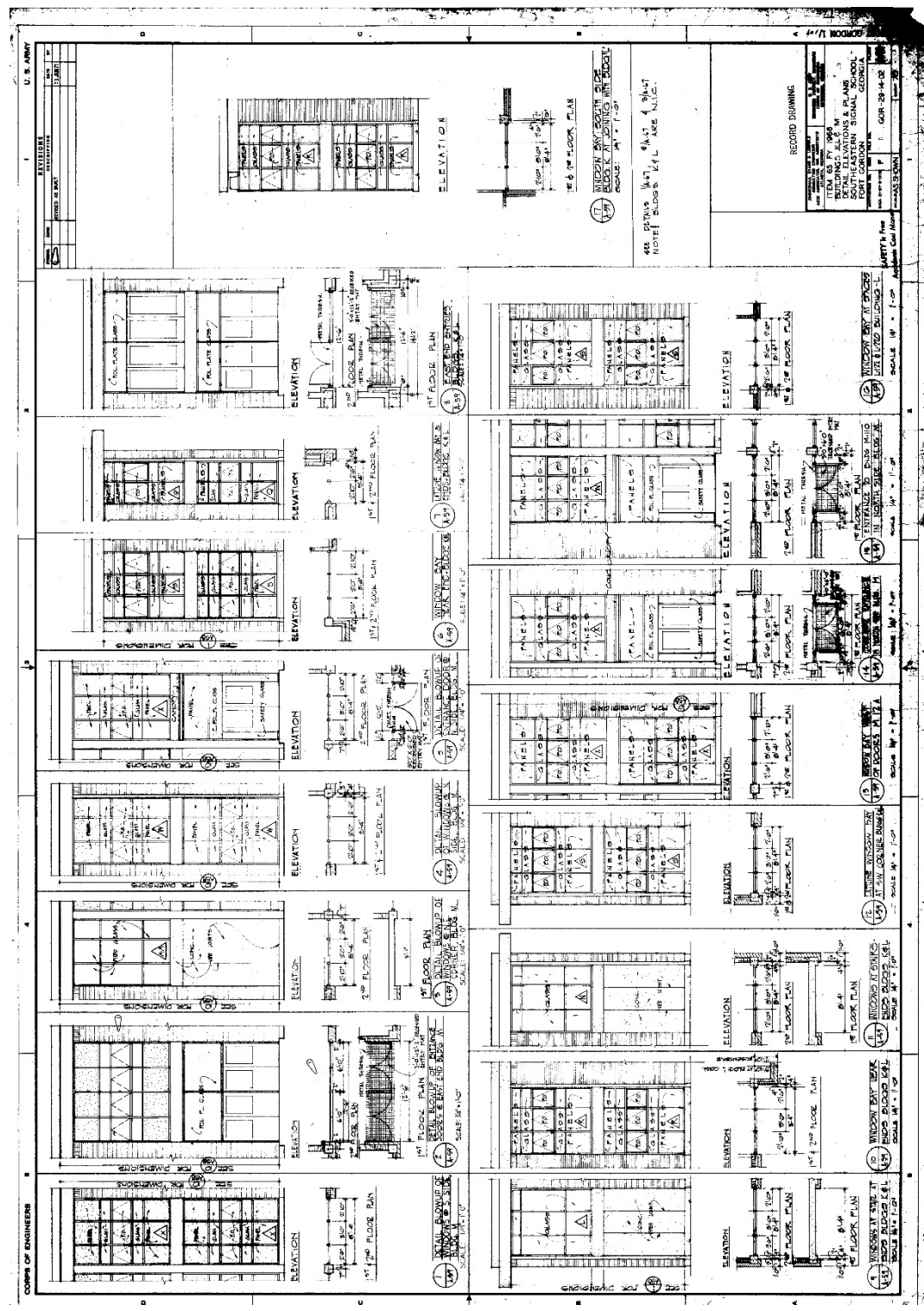


Figure 209. Typical lighting plans, light fixture details, and schedule for Building 29802, Moran Hall south, no date (Fort Gordon DPW).

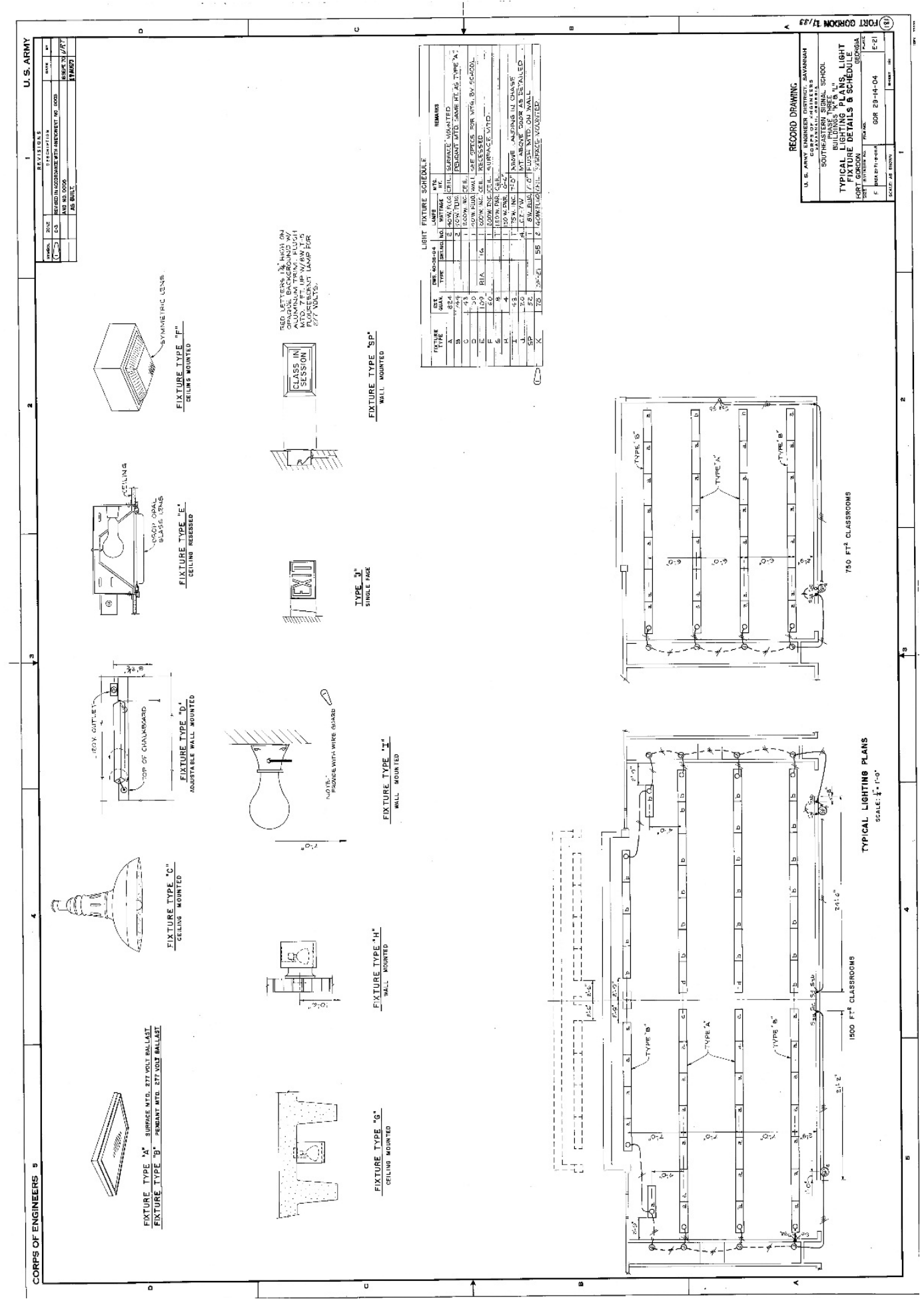


Figure 210. Landscaping plan for Buildings 29802 and 29803, 1966 (Fort Gordon DPW).

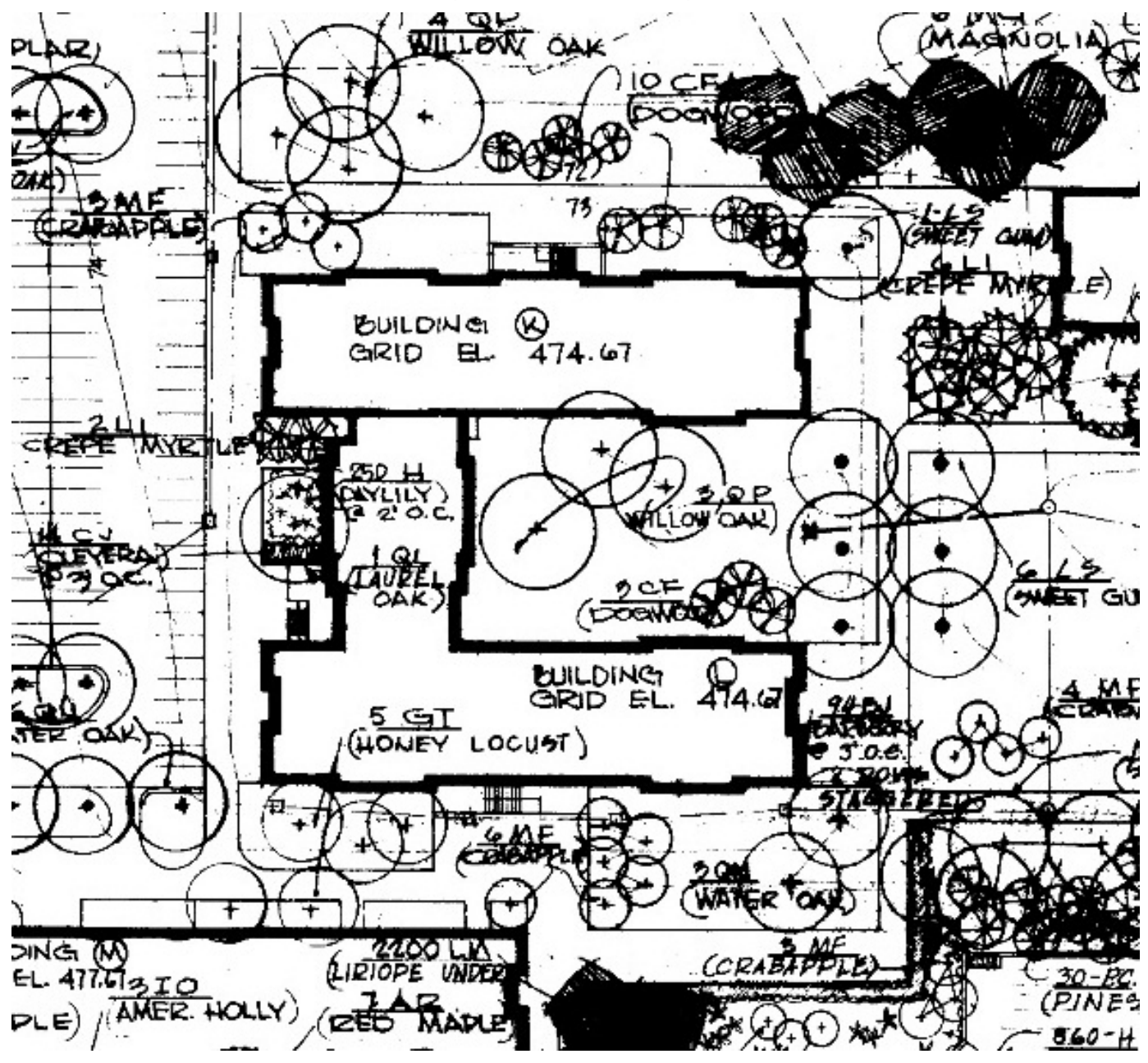

\subsubsection{Character-defining features}

Repair, renovation, and replacement of Building 29802, Moran Hall south, must be coordinated with the GA SHPO (Table 5).

\section{Exterior:}

- Overall massing

- Footprint

- Roof shape

- Relationship to other buildings set within the Signal School Campus

- Brick veneer

- Overhanging eaves with perforated waffle construction casting "light pattern" on exterior brick walls

- Exposed concrete structure framing window and door openings 
- Window bays (two, three, or six) of bright-aluminum frames enclosing insulated panel inserts

- Wall-mounted bronze, cylinder light exterior light fixtures

- Lettering

\section{Interior:}

The team was not allowed access to the interior.

Table 5. Images of character-defining features of Building 29802, Moran Hall south (ERDC-CERL, 2015).

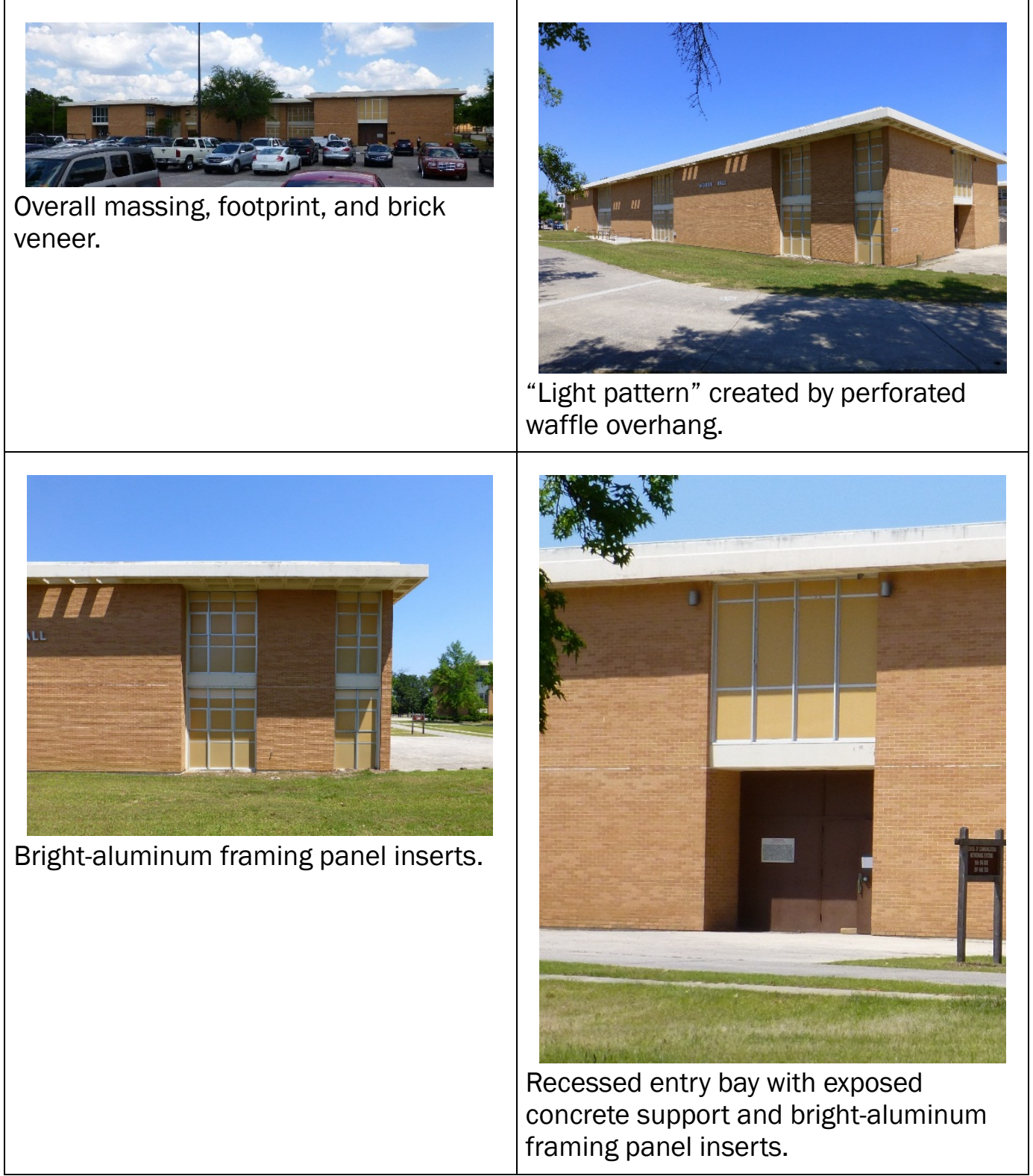




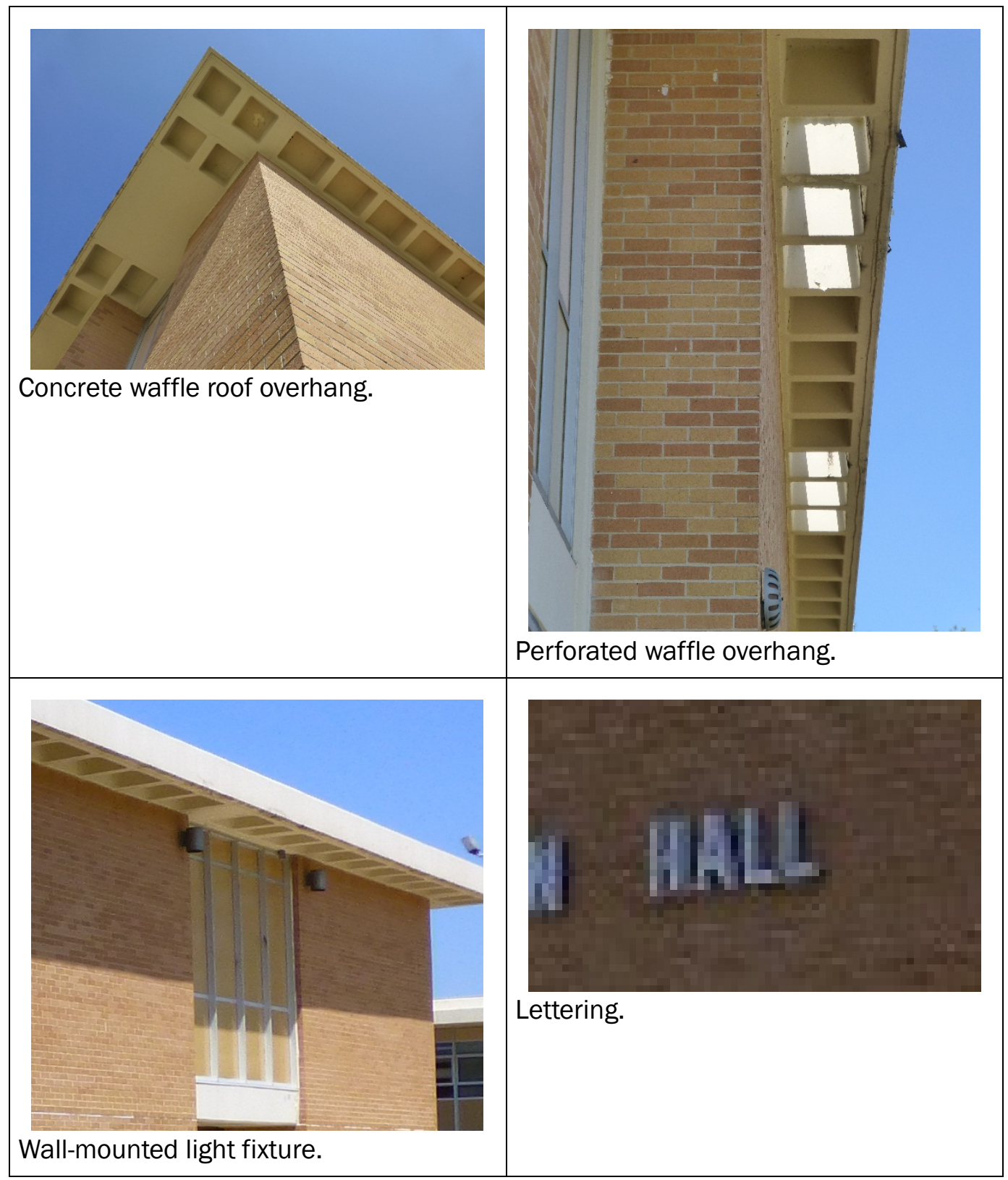

3.3.3.2 Character-defining features that have been removed

Listed below are character-defining features of Building 29802, Moran Hall south, that have been removed or replaced over the years; as future renovations occur, these need to be replaced with elements that replicate the original character-defining features of the building. The original drawings and comparison images (below) will guide this process in coordination with the GA SHPO.

- Three-pane awning-style windows have been replaced with insulated panel inserts in original window openings. 
- Windows - according to the original drawings there were metal and plate-glass door on the east and west elevations above the entry doors. These have been removed and replaced with newer framing and panel window system.

- Landscaping has mostly been removed and not replaced.

\subsubsection{Nonhistoric features}

- None.

\subsubsection{Comparison images}

Comparison images utilizing either the original drawings or historic photographs, when juxtaposed against present-day images, are a useful tool in developing the historic "feel" of a property and how much of that historic feeling is still present today (Figure 211 and Figure 212).

Figure 211. Entry bays on the east and west elevations - comparison of the original drawing detail from 1966 [left] to the current condition of the bright-aluminum framing panel inserts and the replacement solid metal doors and metal panels [right] (ERDC-CERL, 2015).
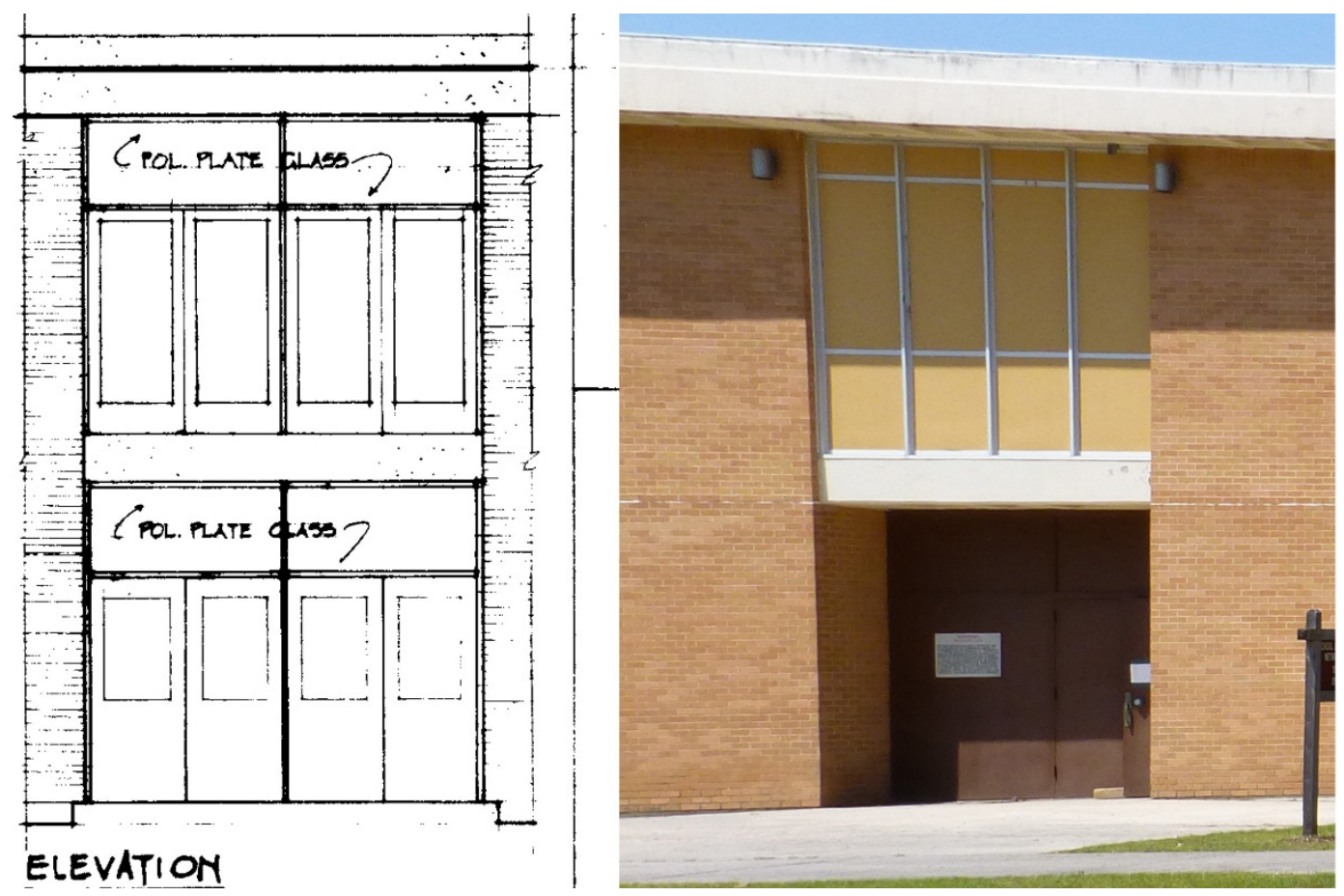
Figure 212. Wall-mounted light fixtures - comparison of the original drawing detail from 1966 [left] to the current condition of the wall-mounted light fixtures on the east and west elevations [right] (ERDC-CERL, 2015).
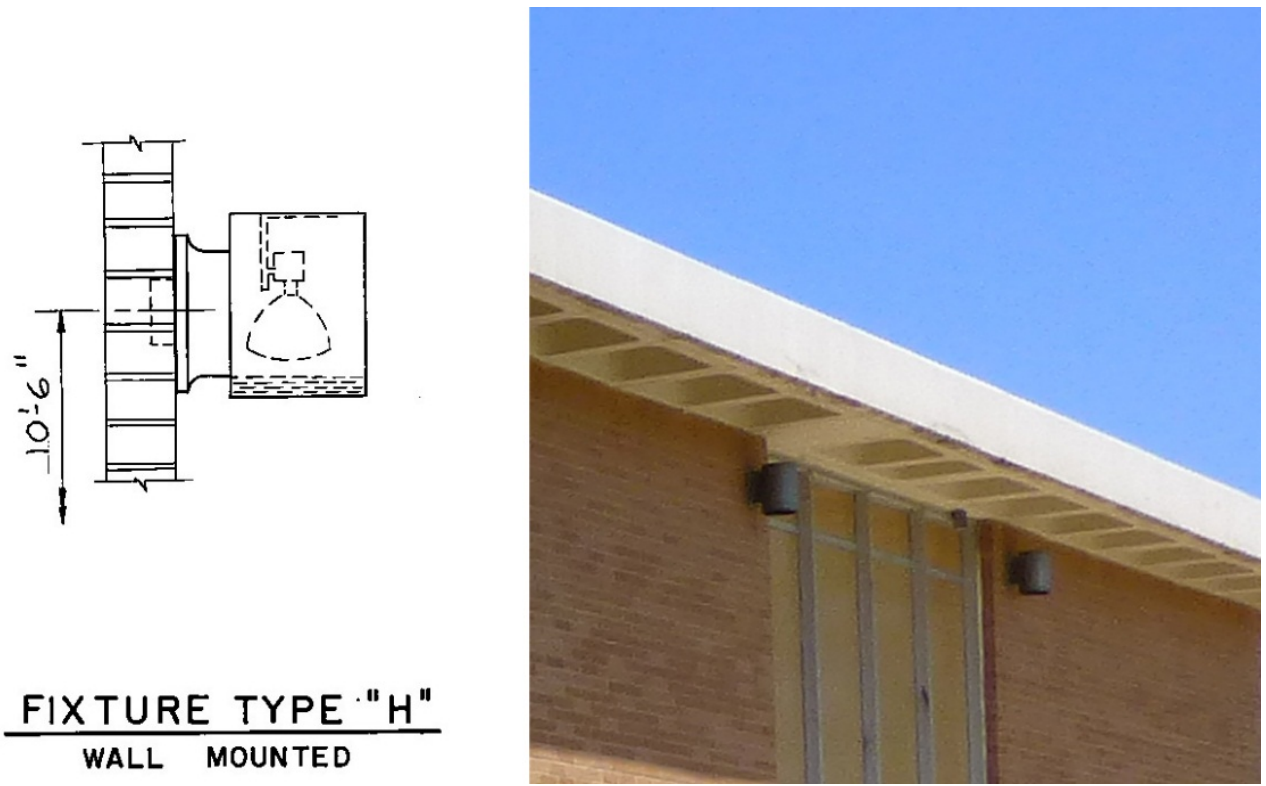

\subsubsection{Building 29803, Moran Hall north (1973)}

Building 29803, Moran Hall north, is a contributing feature to the Signal School Campus Historic District. The research team was not granted access to the interior; the interior character-defining features are unknown but for undertakings that effect the interior, the CRM should use examples from the other interiors to guide identification and mitigation. It was constructed in 1973 as part of Phase III construction for the Signal School Campus and was designed by architects Aeck Associates from Atlanta, Georgia, and Zimmerman, Evans, and Leopold Consulting Engineers from Augusta, Georgia. Building 29803 is a long, rectangular classroom building that is connected via a hyphen to Building 29802, Moran Hall south. Building 29803 is two stories high with a basement. The structure is castin-place concrete columns with a waffle floor/ceiling system. The secondfloor waffle system is set within the structure, but the roof has the waffles extending out to form an overhang. Some of the waffles have been perforated and cast a "light pattern" on the second-floor brick walls. The window systems extend the full height of the building and are inset into the brick veneer. The window systems are composed of bright-aluminum window frames that enclose three-pane awning-style windows sandwiched between insulated panels. The windows are in groups of two, three, or six. The main entrances are located on the east and west elevations. The en- 
trances consists of two sets of recessed metal doors with large fixed transoms above and group of four fixed-pane windows set within bright-aluminum framing. Wall-mounted light fixtures flank these windows. The north elevation is symmetrical. The left and right sides of the elevation each have two bays. One bay consists of concrete panels on the first floor and three fixed windows on the second floor, while the other bay consists of threepane awning-style windows sandwiched between insulated panels. The middle of the elevation has two large bays of six window openings. Poured concrete steps provide access to the basement level on the north elevation. The south elevation has two window bays on the left side, and each consists of three awning-style windows sandwiched between insulated panels. Two large six-window bays are located near the center of the elevation. Two window bays are located on the right side of the elevation. One bay is three windows wide, and the other bay is two windows wide. The two-window bay has concrete panels on the first floor instead of windows. The south elevation is where Building 29803 is connected to the hyphen that joins Buildings 29802 and 29803 (Figure 213-Figure 219).

Figure 213. Signal School Campus map, with Building 29803 (Moran Hall north) highlighted in red, 2015 (Fort Gordon DPW, modified by ERDC-CERL).

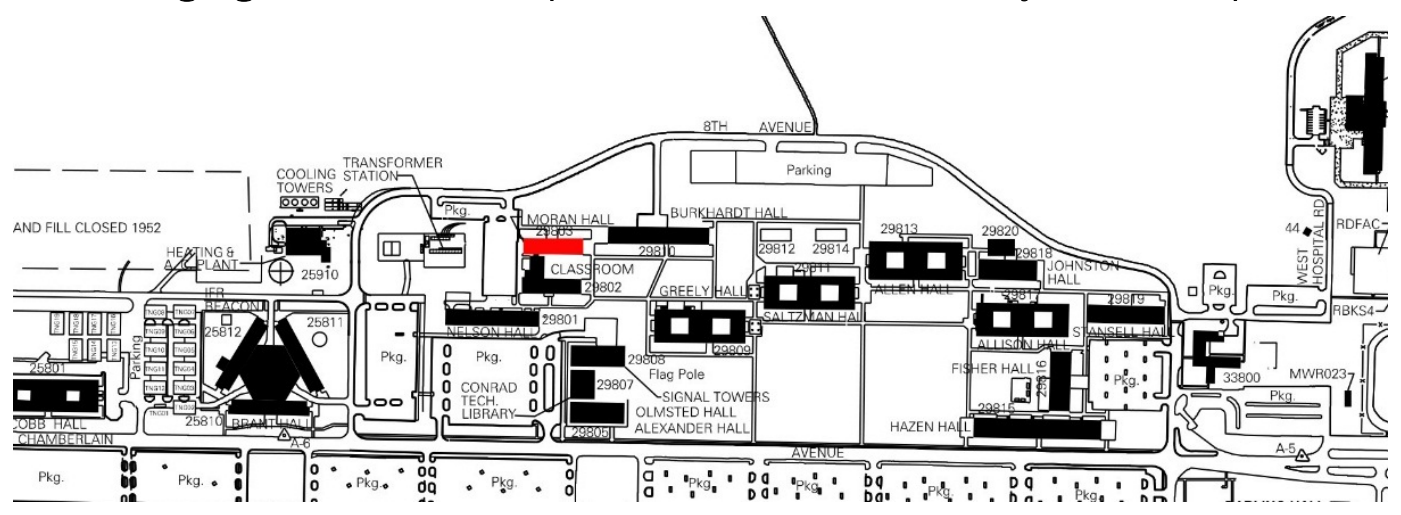


Figure 214. North elevation of Building 29803, Moran Hall north (ERDC-CERL, 2015).

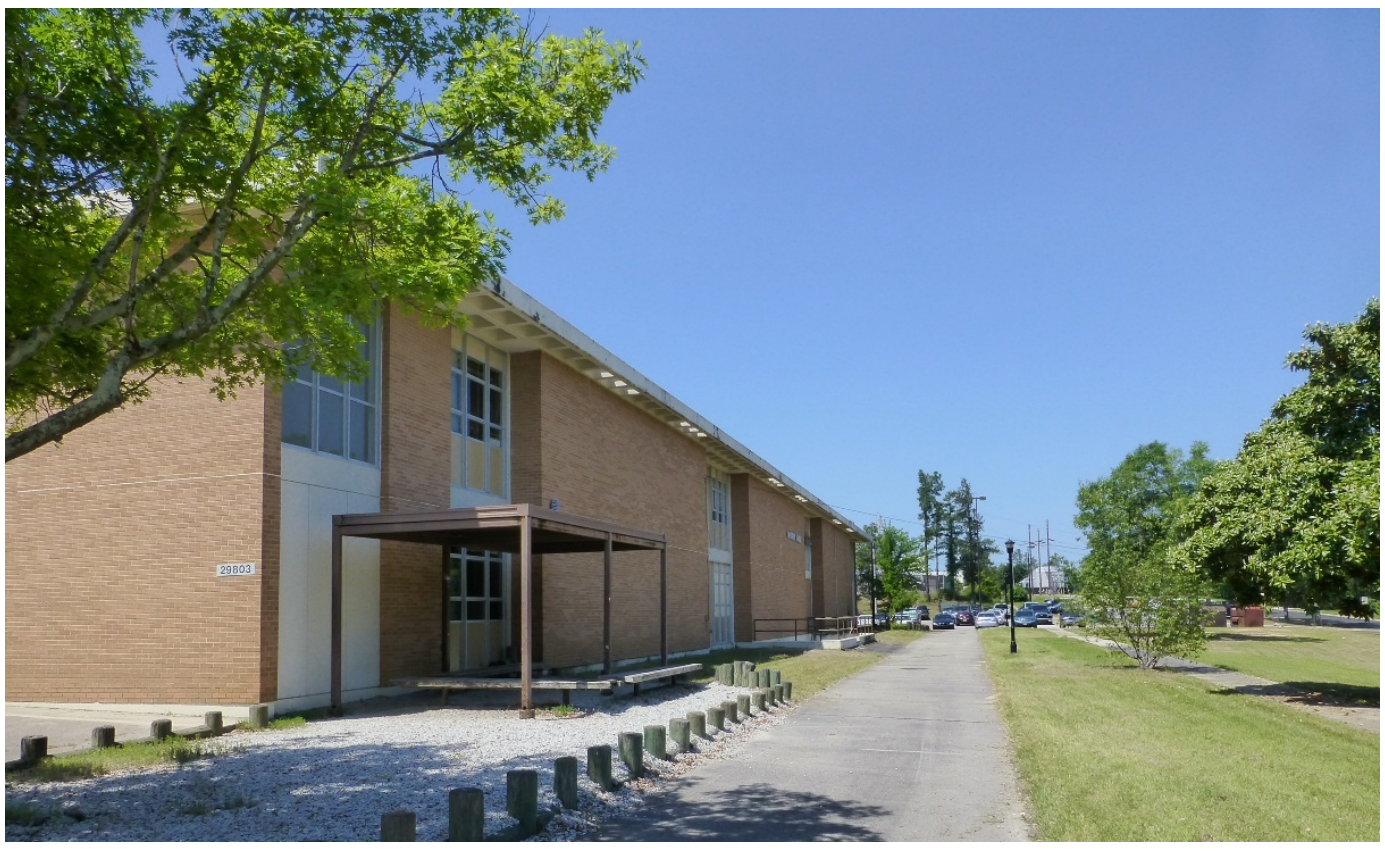

Figure 215. East entry for Building 29803, Moran Hall north (ERDC-CERL, 2015).

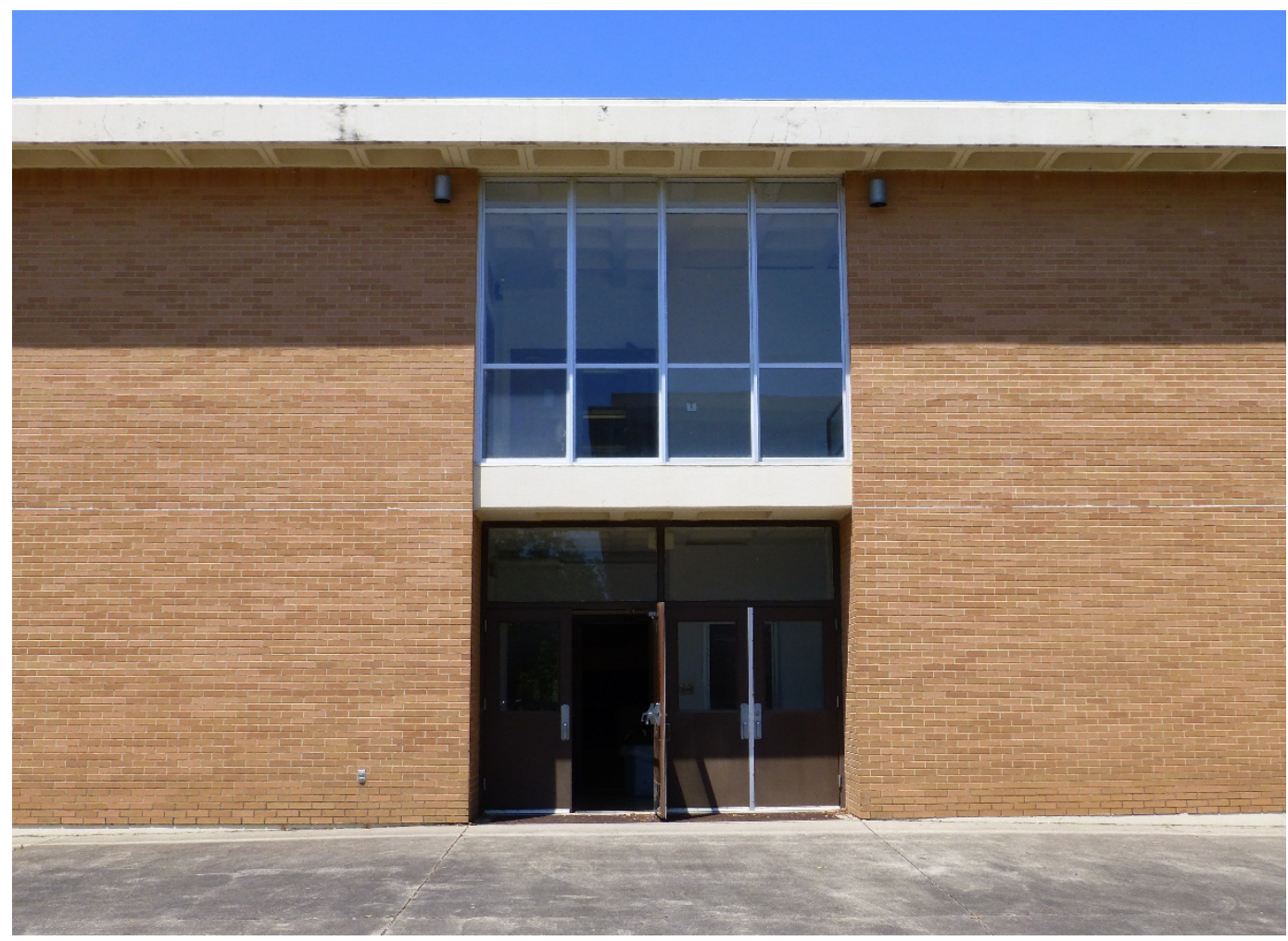


Figure 216. West elevation of Building 29803 [left] and Building 29802 [right] (ERDC-CERL, 2015).

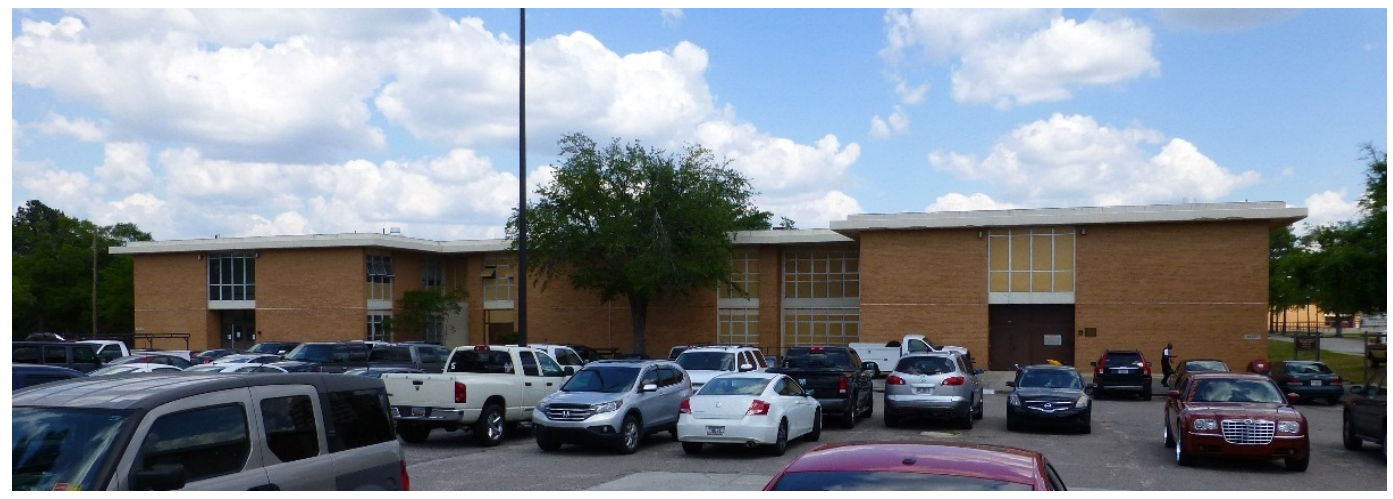

No floor plans or elevations were given to the team for this building.

Figure 217. Typical lighting plans, light fixture details, and lighting schedule for Building 29803, Moran Hall north, no date (Fort Gordon DPW).

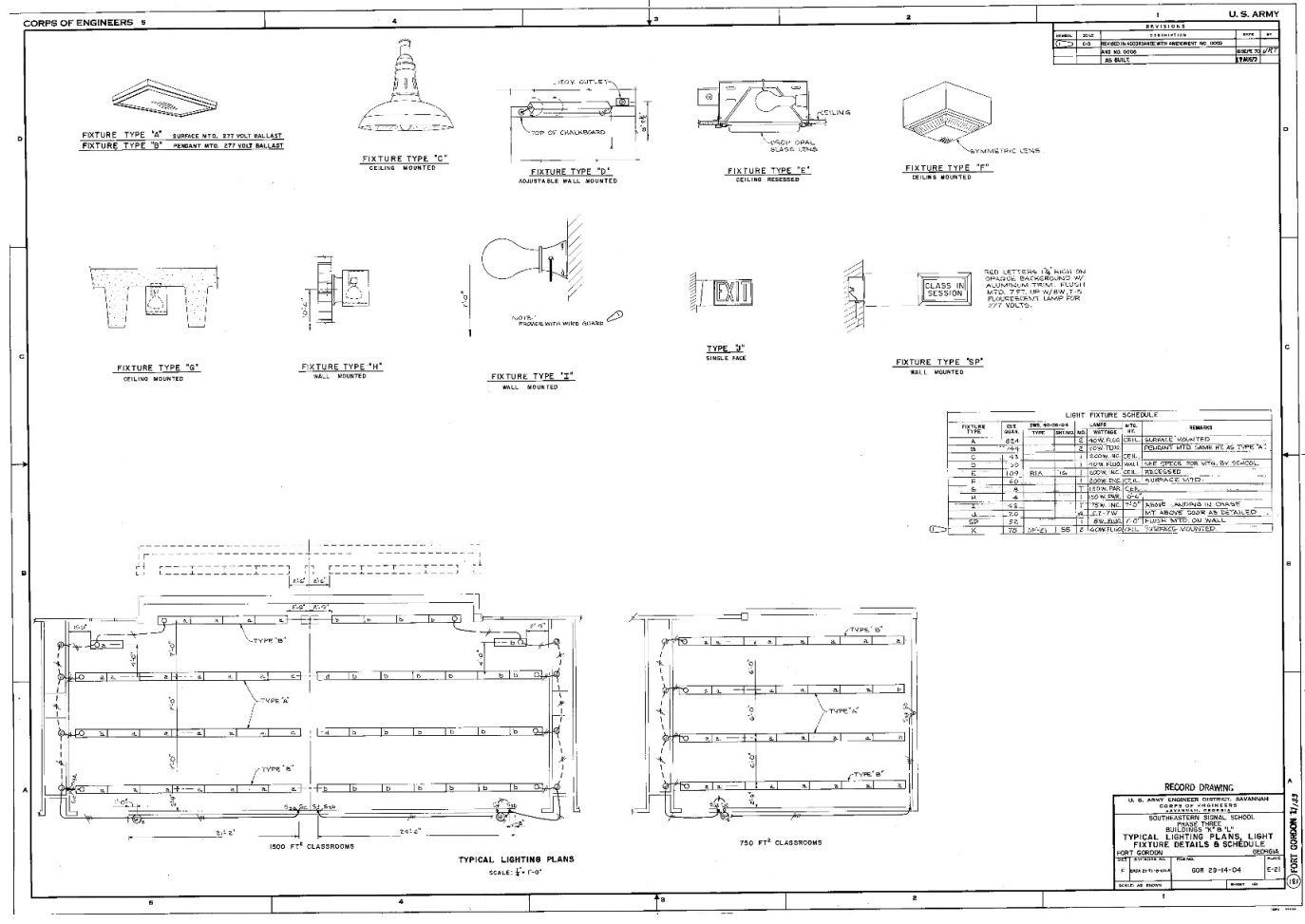


Figure 218. Detail elevations and plans for Building 29803, Moran Hall north, 1966 (Fort Gordon DPW).

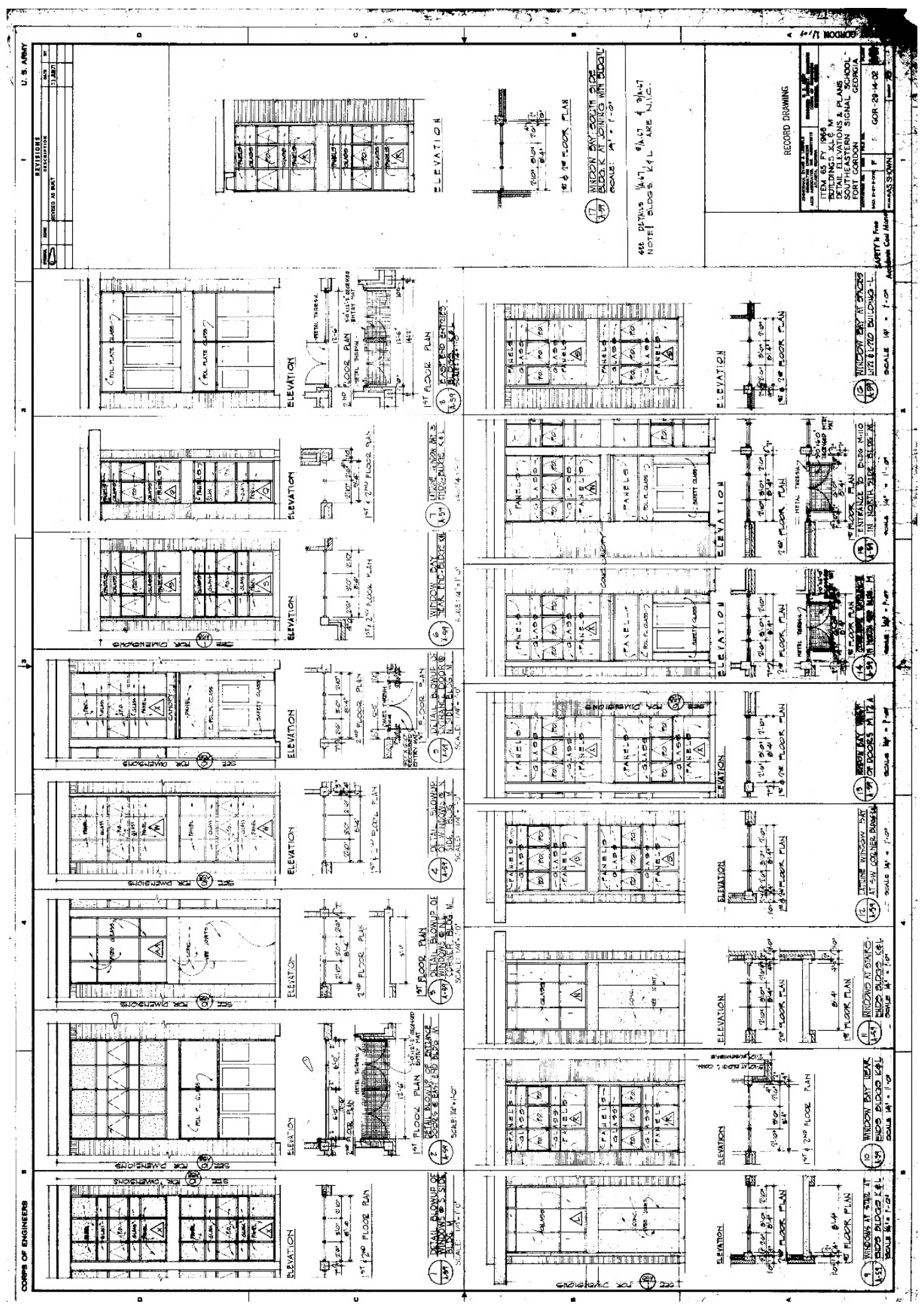


Figure 219. Landscaping plan for Buildings 29802 Moran Hall south and 29803, Moran Hall north, 1966 (Fort Gordon DPW).

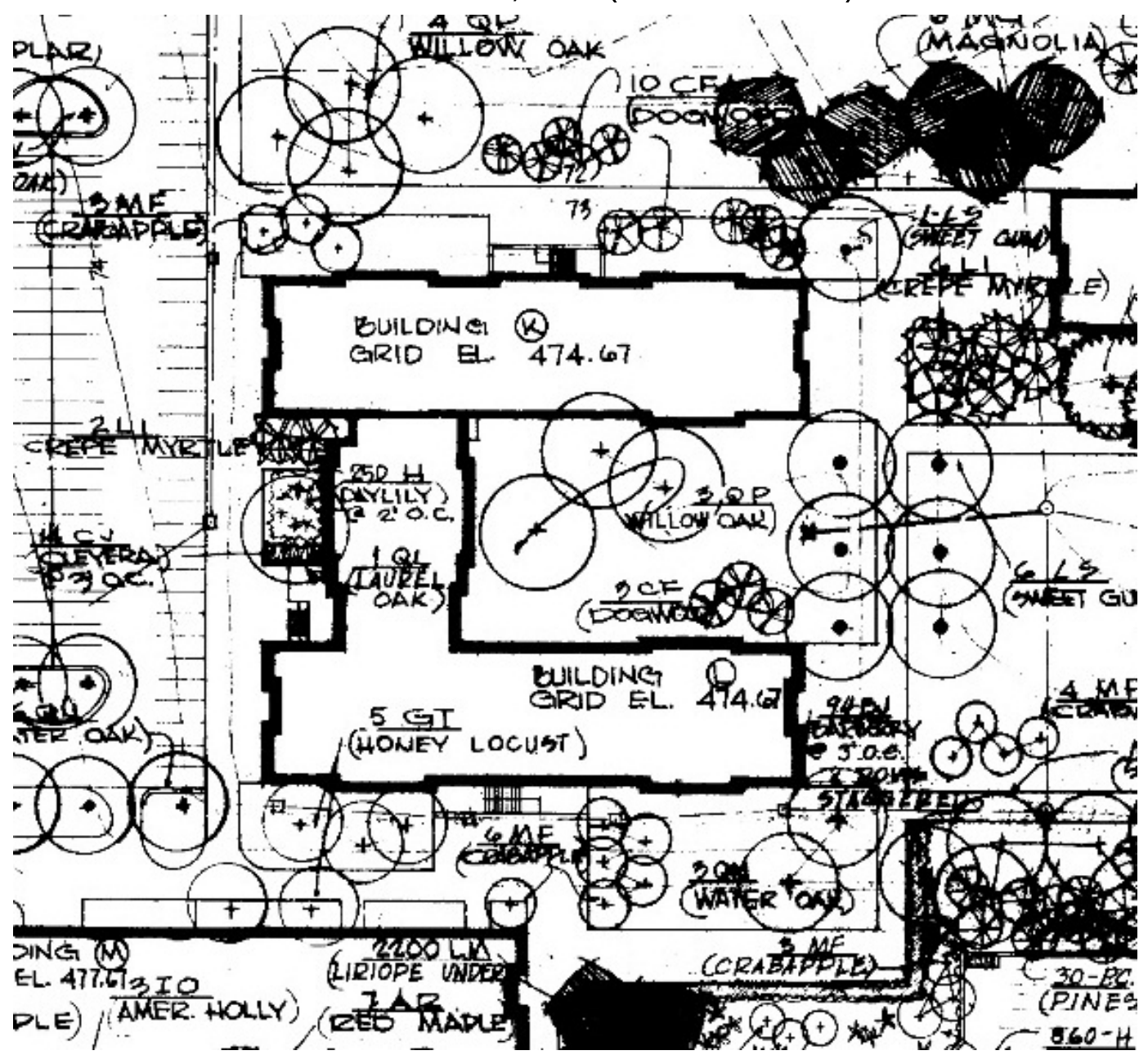

\subsubsection{Character-defining features}

Repair, renovation, and replacement of Building 29803, Moran Hall north must be coordinated with the GA SHPO (Table 6).

Exterior:

- Overall massing

- Footprint

- Roof shape

- Relationship to other Signal School Campus buildings

- Brick veneer

- Overhanging eaves with perforated waffle construction casting "light pattern" on exterior brick walls

- Exposed concrete structure framing window and door openings 
- Recessed groups (two, three) of bright-aluminum sash windows with three-pane awning-style windows and insulated panel inserts

- Wall-mounted bronze cylinder light exterior light fixtures

\section{Interior:}

The team was not allowed access to the interior.

Table 6. Images of character-defining features of Building 29803, Moran Hall north (ERDC-CERL, 2015).

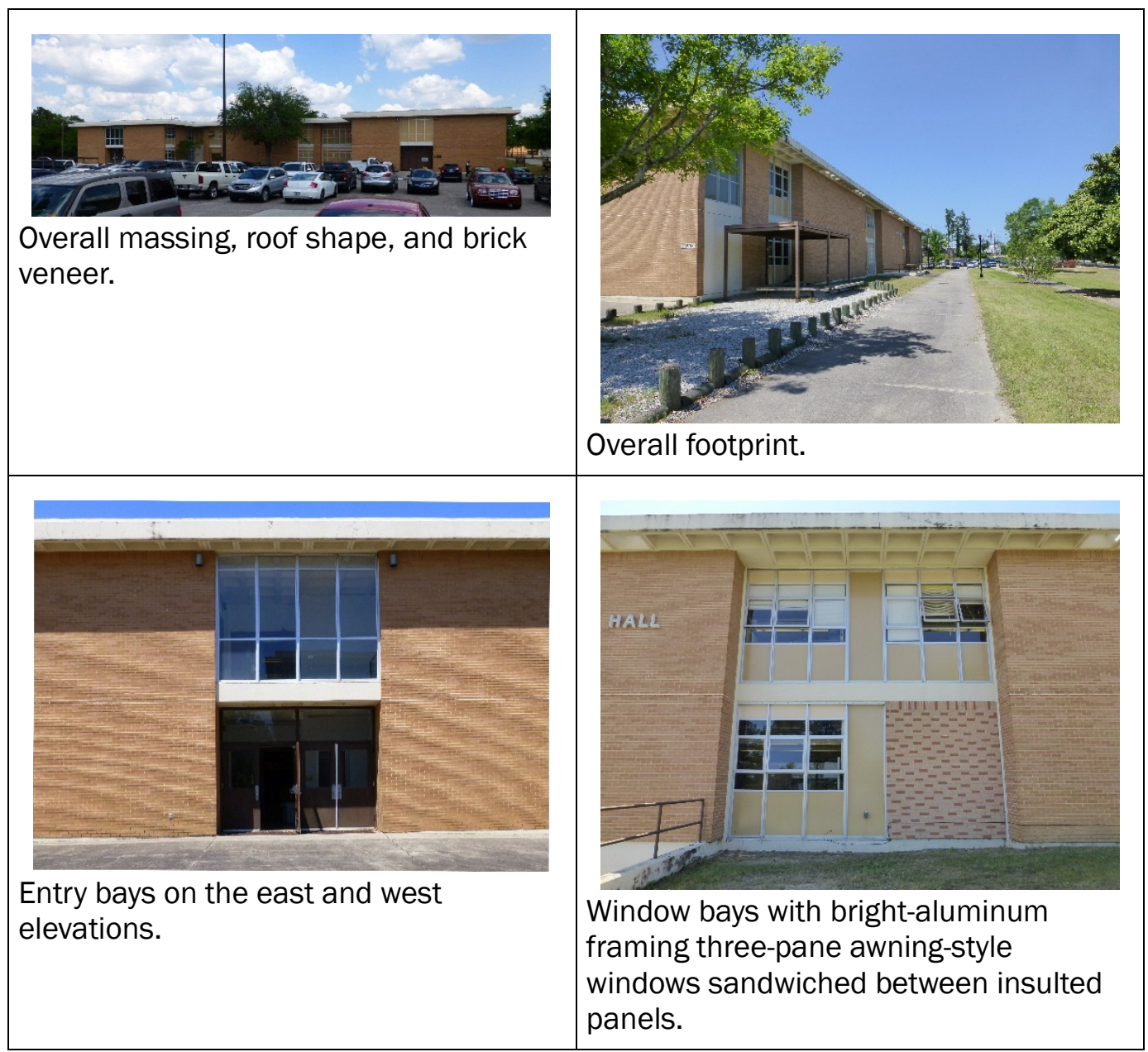




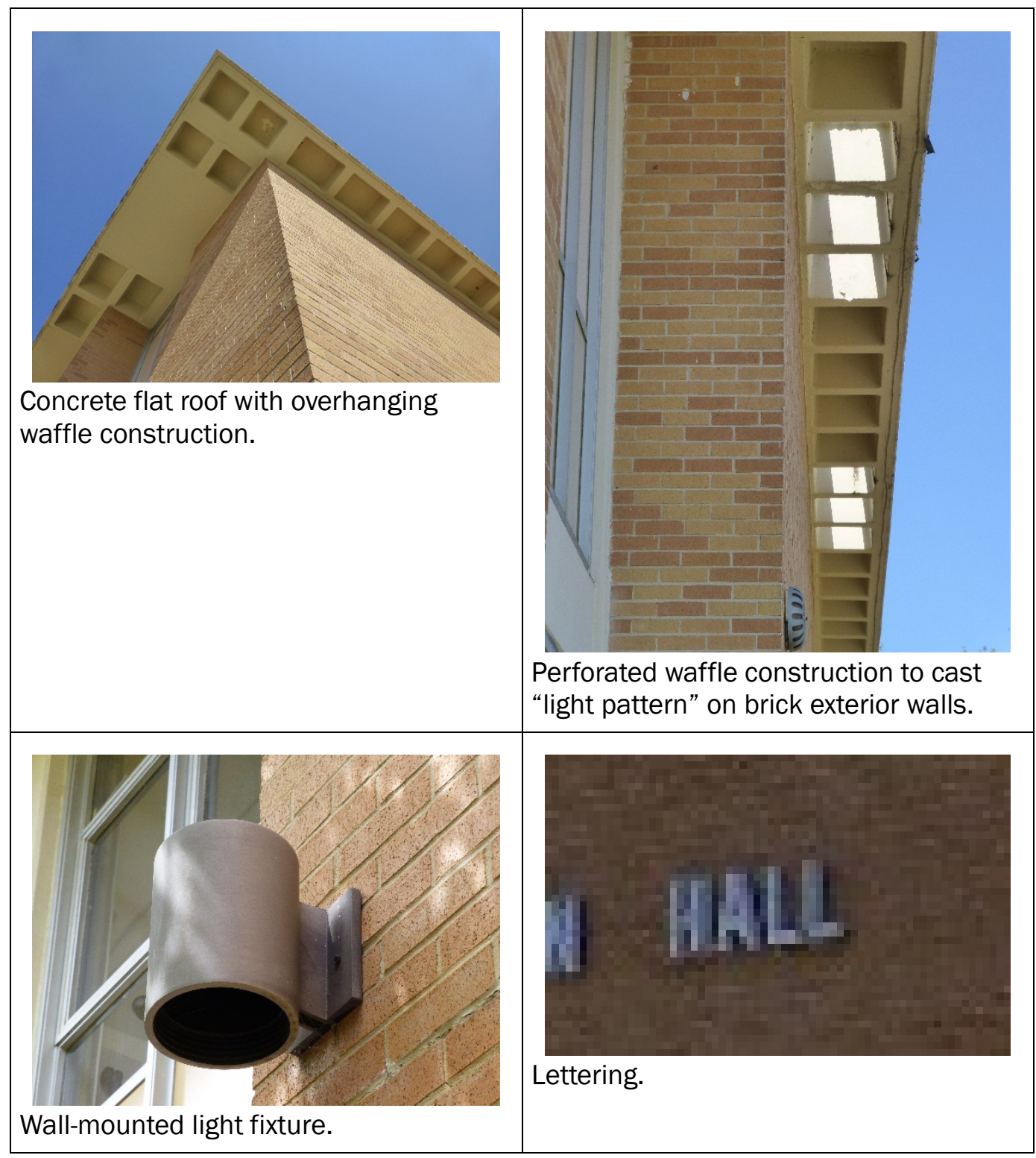

\subsubsection{Character-defining features that have been removed}

Listed below are character-defining features of Building 29803, Moran Hall north, that have been removed or replaced over the years; as future renovations occur, these need to be replaced with elements that replicate the original character-defining features of the building. The comparison images [below] will guide this process in coordination with the GA SHPO (Figure 220-Figure 223).

- Windows - some of them have been removed on the north elevation and filled with brick. 
- Windows - according to the original drawings, there were metal and plate-glass doors on the east and west elevations above the entry doors. These have been removed and been replaced with newer framing and window system.

\subsubsection{Nonhistoric features}

- None.

\subsubsection{Comparison images}

Comparison images utilizing either the original drawings or historic photographs, when juxtaposed against present-day images, are a useful tool in developing the historic "feel" of a property and how much of that historic feeling is still present today.

Figure 220. Large group of windows on north elevation - comparison of the original drawing detail from 1966 [left] to the current condition of the bright-aluminum awning windows and panel inserts and the modified brick infill [right]

(ERDC-CERL, 2015).
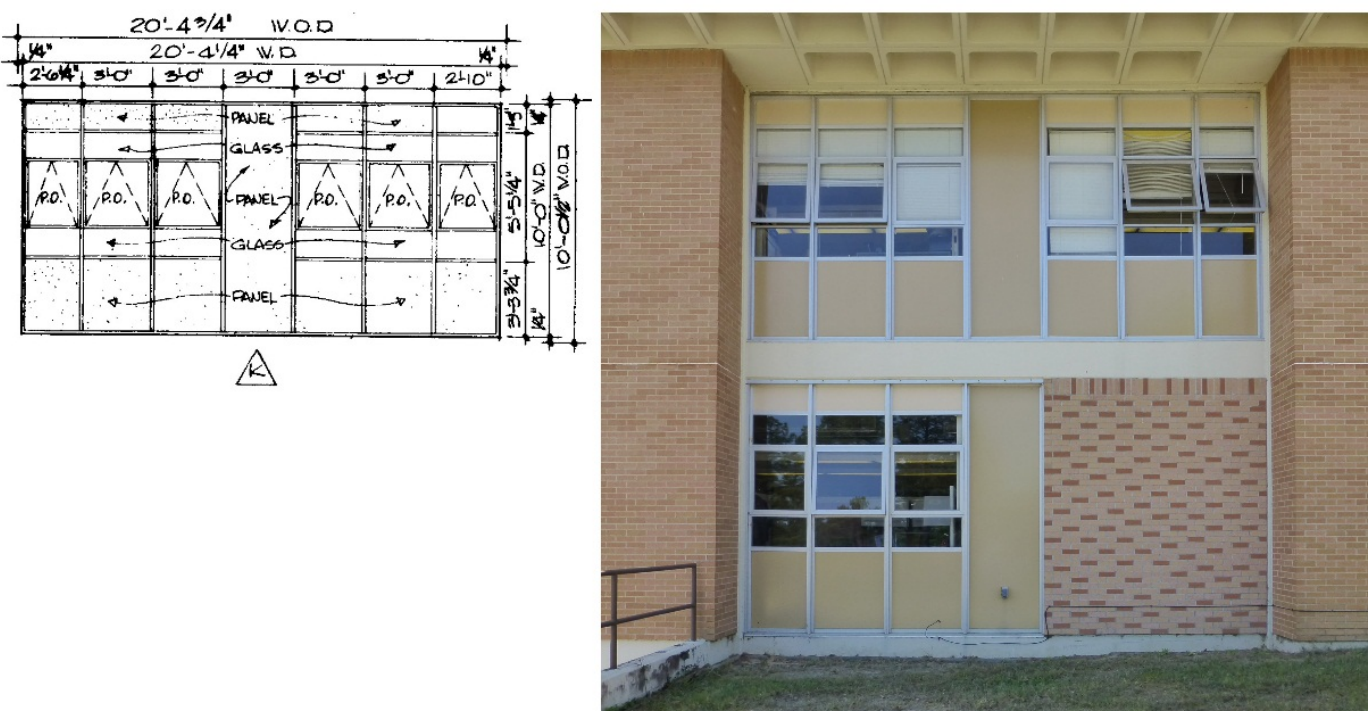
Figure 221. Window bay - comparison of the original drawing detail from 1966 [left] to the current condition of the bright-aluminum awning windows and panel inserts [right] (ERDC-CERL, 2015).

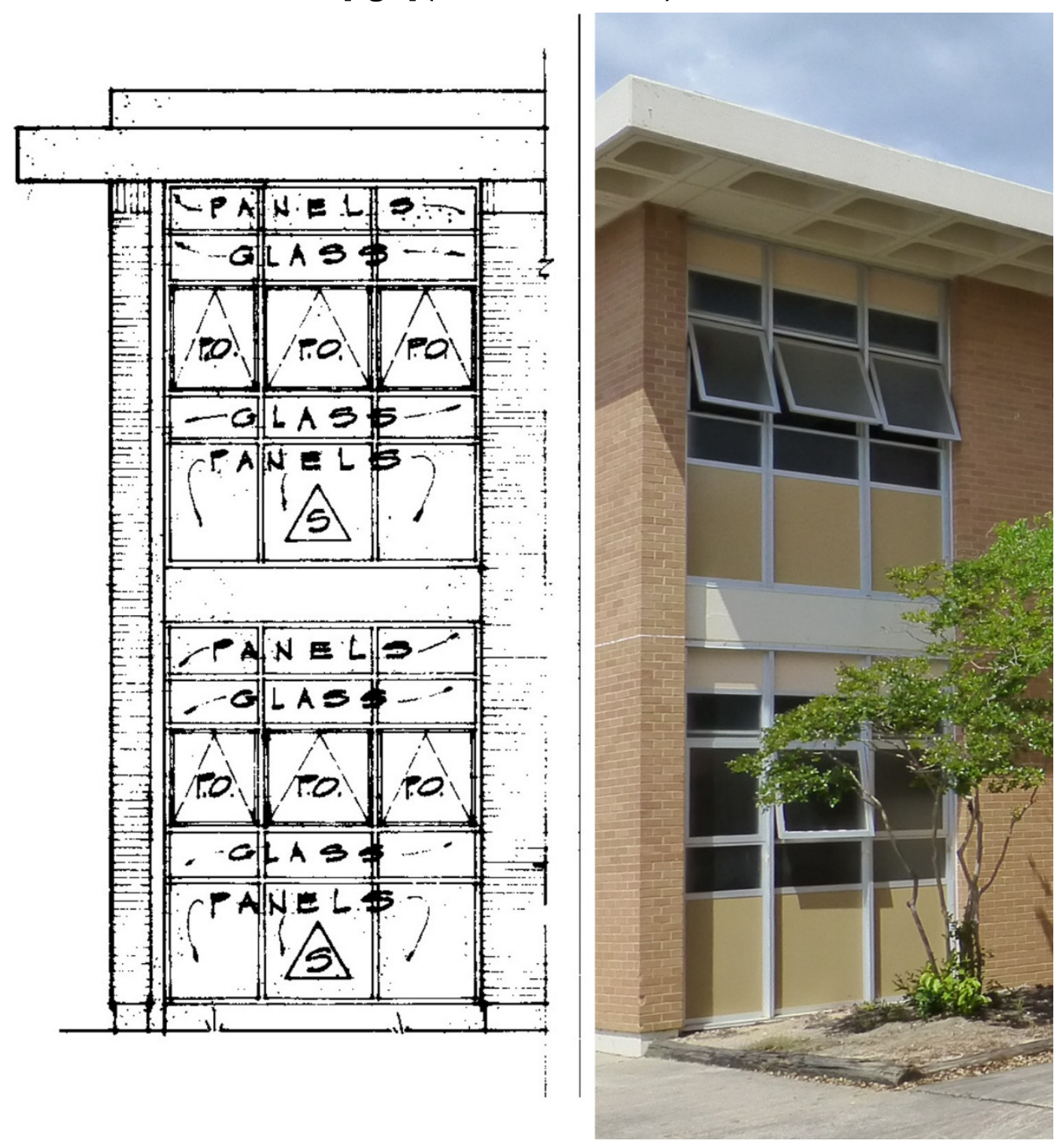


Figure 222. Window bay - comparison of the original drawing detail from 1966 [left] to the current condition of the replacement bright-aluminum windows [right] (ERDC-CERL, 2015).

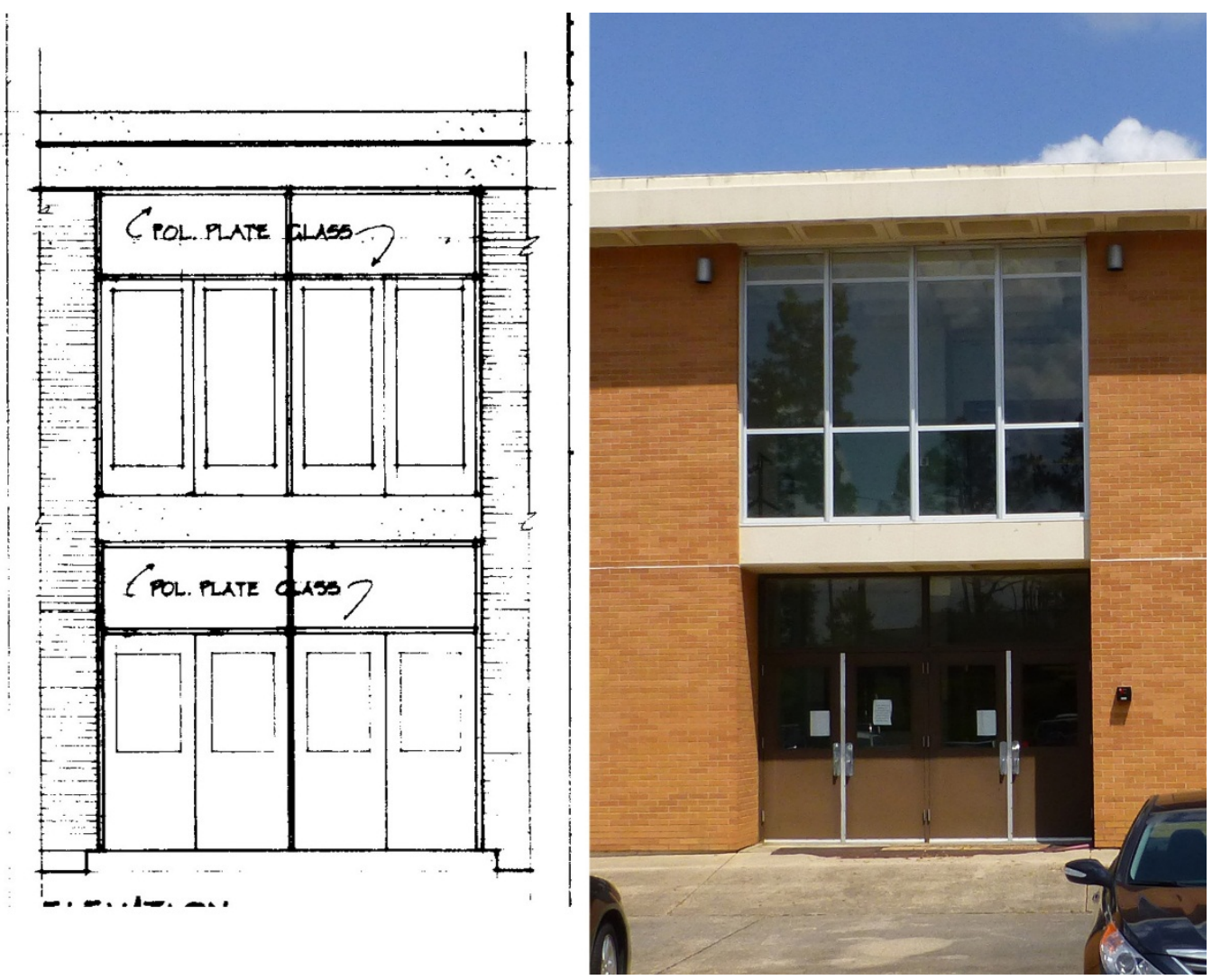

Figure 223. Wall-mounted light fixture - comparison of the original drawing detail from 1966 [left] to the current condition of the wall-mounted light fixtures located on the east and west elevations [right] (ERDC-CERL, 2015).
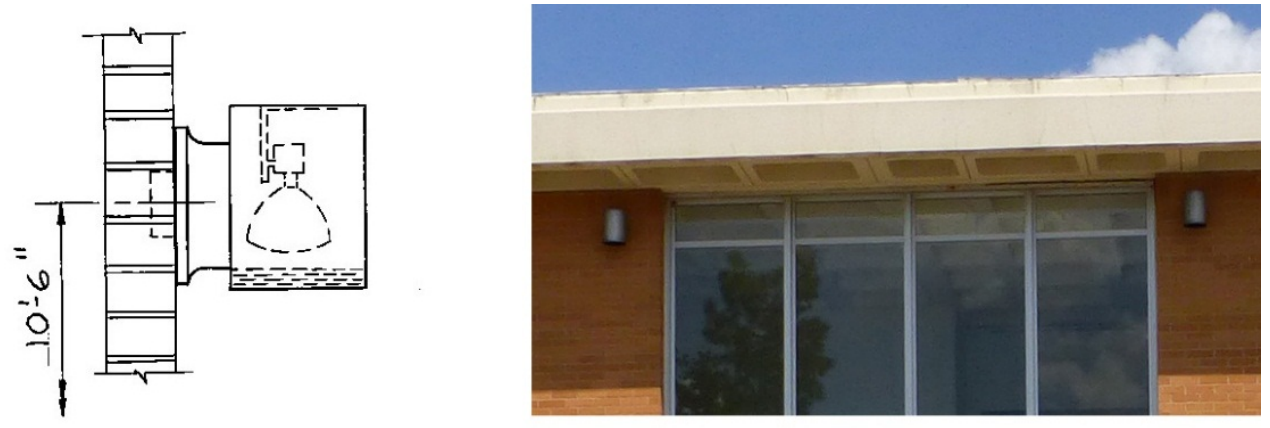

\footnotetext{
$\frac{\text { FIXTURE TYPE "H" }}{\text { WALL MOUNTED }}$
} 


\subsubsection{Building 29805, Alexander/OImstead Halls (1970)}

Building 29805, Alexander Hall/Olmstead Halls is a contributing feature to the Signal School Campus Historic District. The interior of the building is contributing. It was constructed in 1970 during Phase II. The building was designed by Aeck Associates founder Richard L. Aeck, FAIA of Atlanta, Georgia, and Zimmerman, Evans, and Leopold Consulting Engineers from Augusta, Georgia.

Building 29805 contains a large lecture hall (Alexander Hall) and a smaller lecture hall (Olmsted Hall) for the Signal School. It is east of the west parking lot. It is part of a large administrative complex that is the headquarters for the Signal Corps (Building 29808, Signal Towers) and the museum (Building 29807, Conrad Hall). A large waffle roof canopy/covered walkway connects all three buildings together. The primary entrance for Building 29805 is on the north side of the auditorium in line with the outer covered walkway that connects it to Building 29808. A large lobby allows access from this door to all of the various auditoriums and meeting rooms of the building as well as to a south entrance off Chamberlain Avenue. Building 29805 is constructed of poured-in-place concrete columns, concrete waffle floors, concrete block infill, and brick veneer. Large precast T-beams extend from the north to south on the primary structure. A mechanical room with large metal louvers is to the east of the primary structure, above the briefing room and latrine. The only detail the building has is double columns of bricks that extend out from the brick veneer at every second room T-beam. Both sets of primary entrance doors are bright-aluminum frames with plate glass. The ubiquitous tan panels are to either side and above the entrance doors. The other doors are steel service doors. The waffle roof canopy surrounds this building with large can ceiling lights. The west elevation faces a parking lot. Original "ALEXANDER HALL" lettering is located on the upper part of the south brick wall above the flat roof canopy (Figure 224-Figure 241). 
Figure 224. Signal School Campus map, with Building 29805, Alexander/OImstead Halls, highlighted in red, 2015 (Fort Gordon DPW, modified by ERDC-CERL).

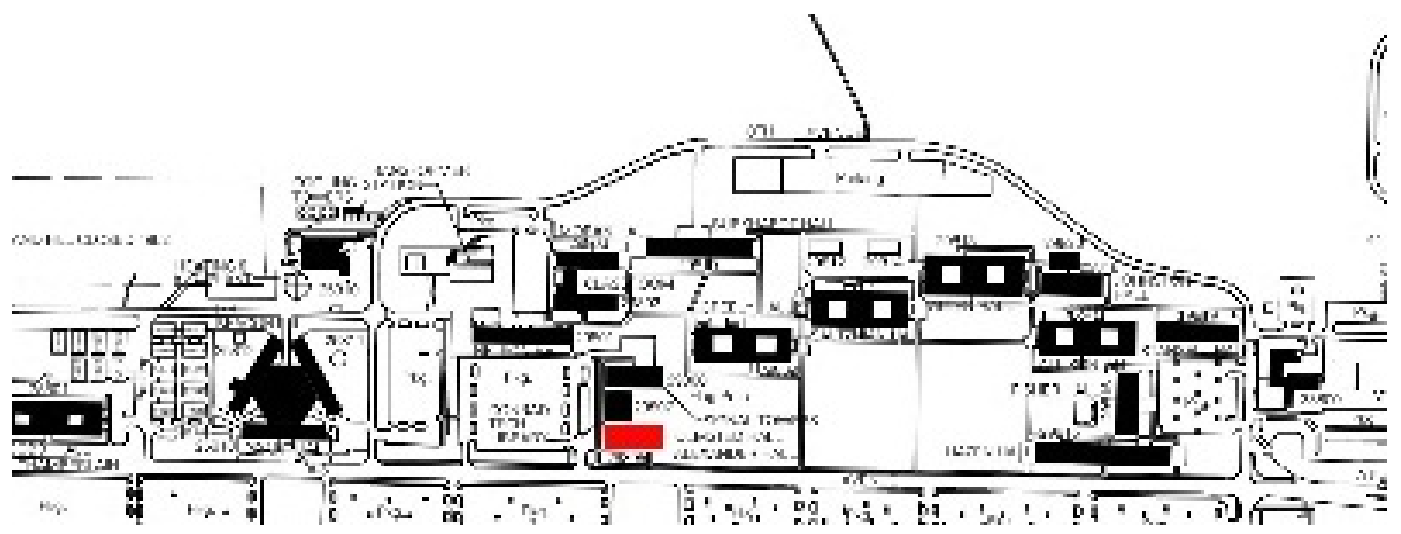

Figure 225. West elevation of Building 29805, Alexander/OImstead Halls (ERDC-CERL, 2015).

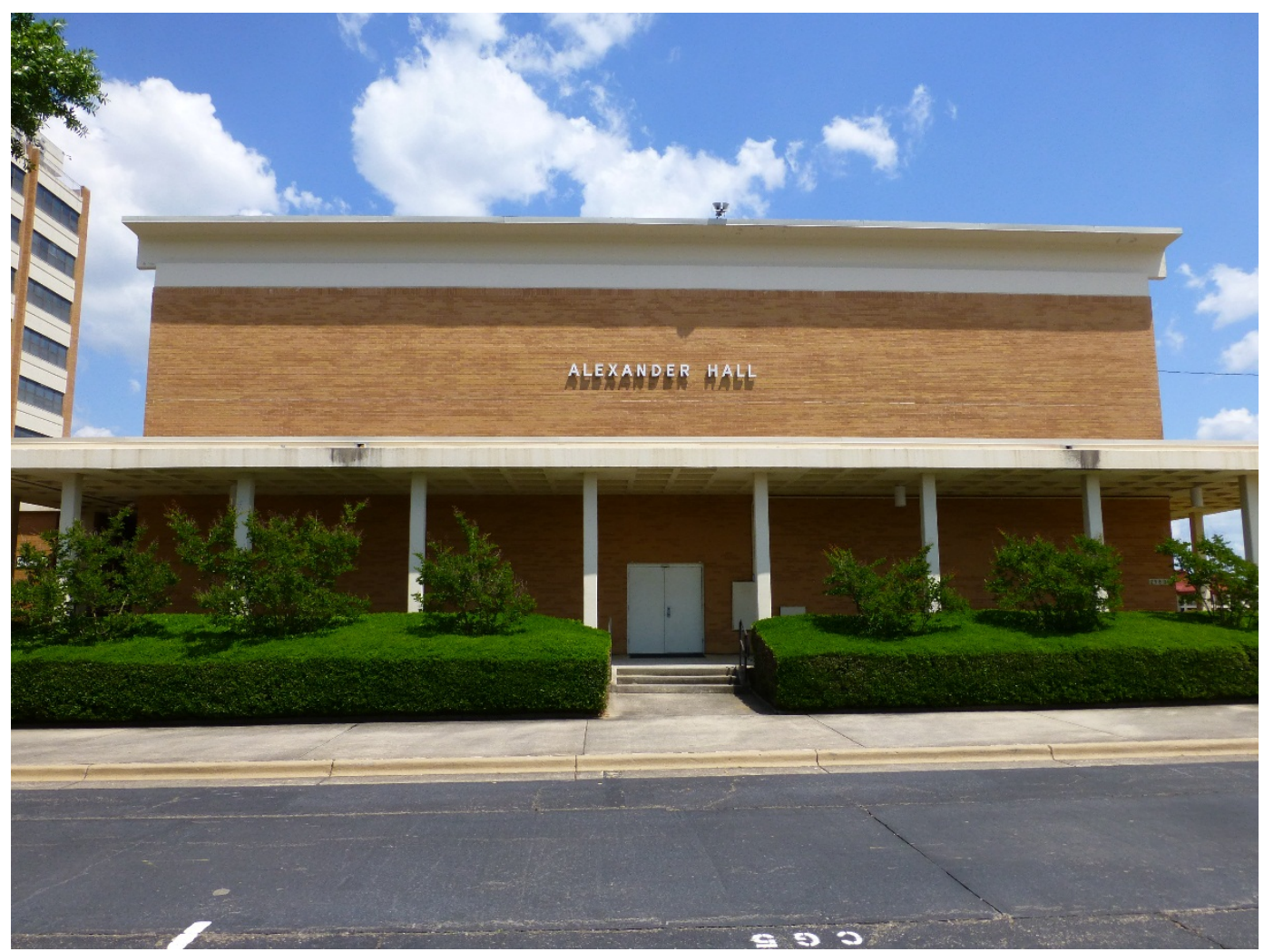


Figure 226. South elevation of Building 29805, Alexander/OImstead Halls (ERDC-CERL, 2015).

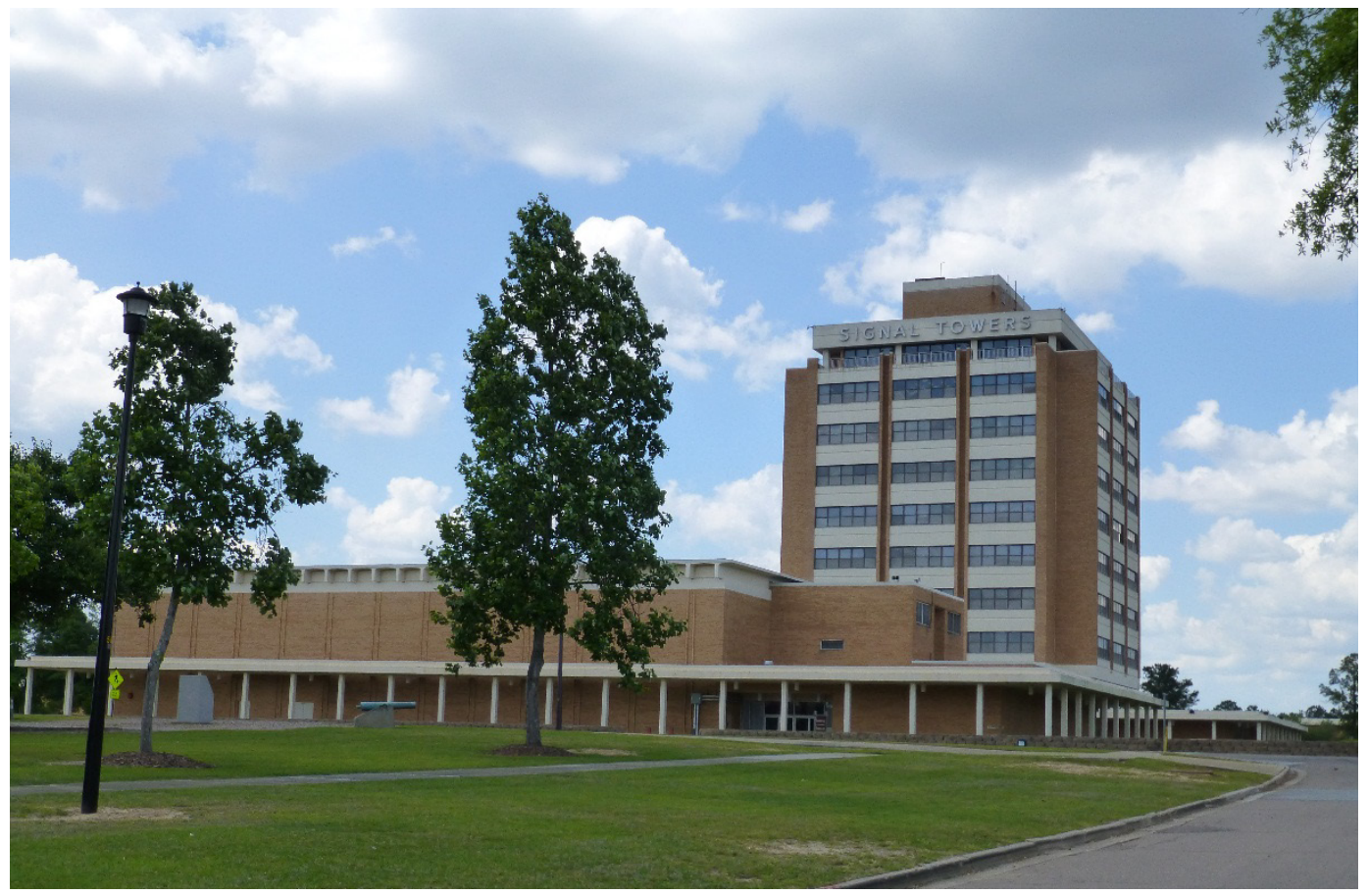

Figure 227. East elevation of Building 29805, Alexander/OImstead Halls (ERDC-CERL, 2015).

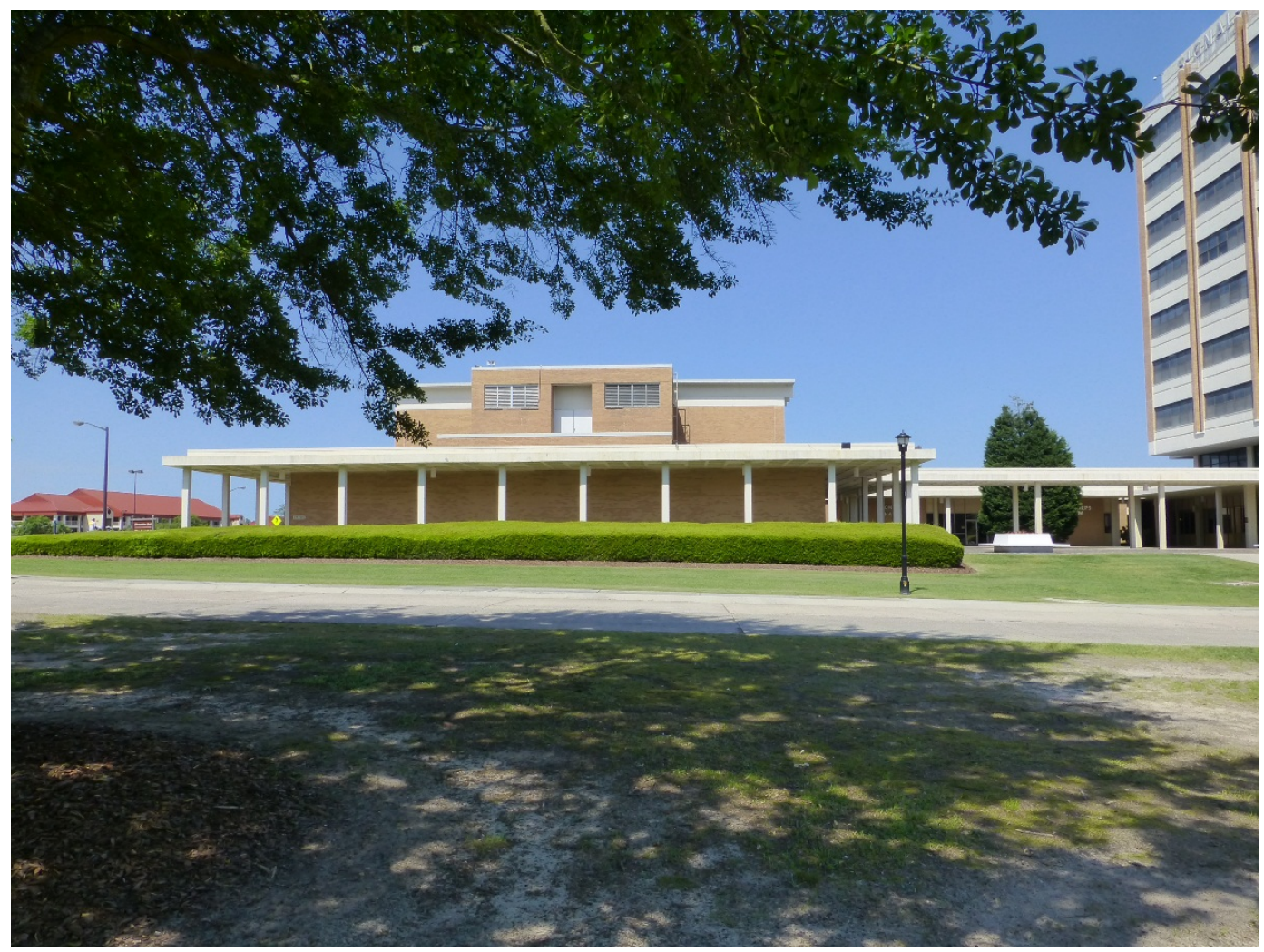


Figure 228. Concrete waffle canopy structure that encompasses Building 29805 and connects it to Buildings 29807 and 29808 (ERDC-CERL, 2015).

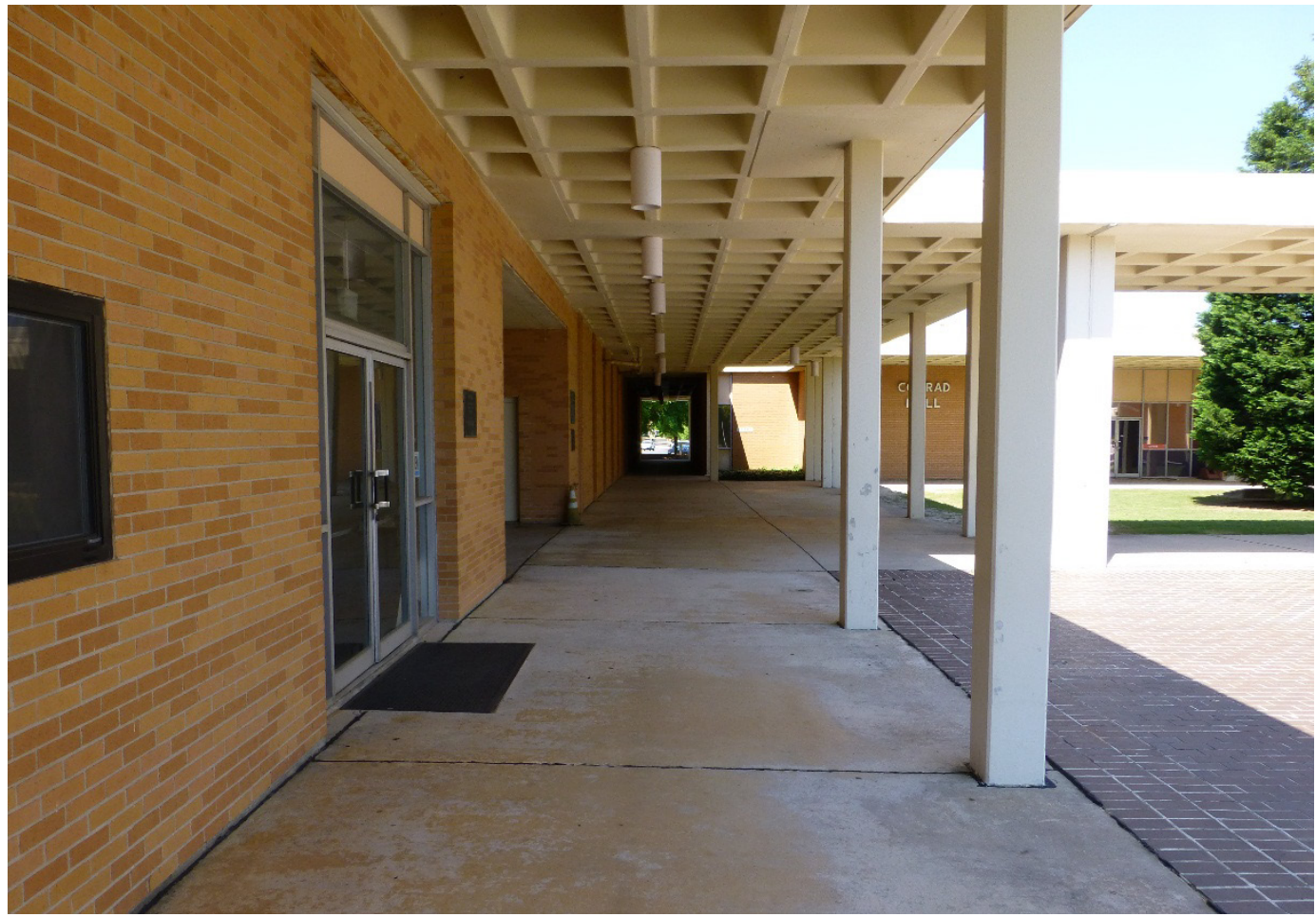

Figure 229. Bright-aluminum and plate-glass doors, sidelights, and transoms on the north elevation leading into the lobby of Building 29805 (ERDC-CERL, 2015).

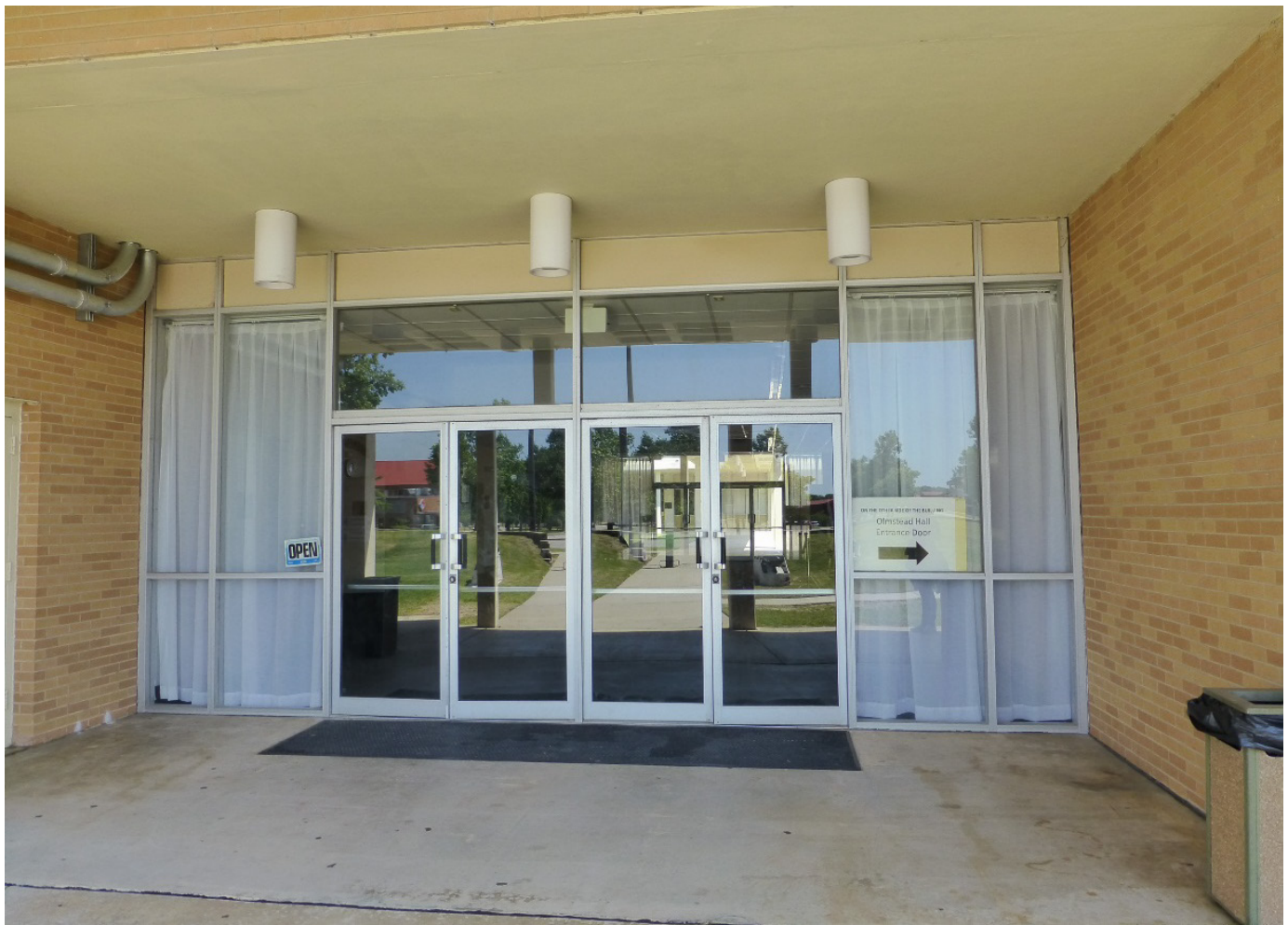


Figure 230. Brick-paved plaza located on the north side of Building 29805 connecting to Buildings 29807 and 29808 (ERDC-CERL, 2015).

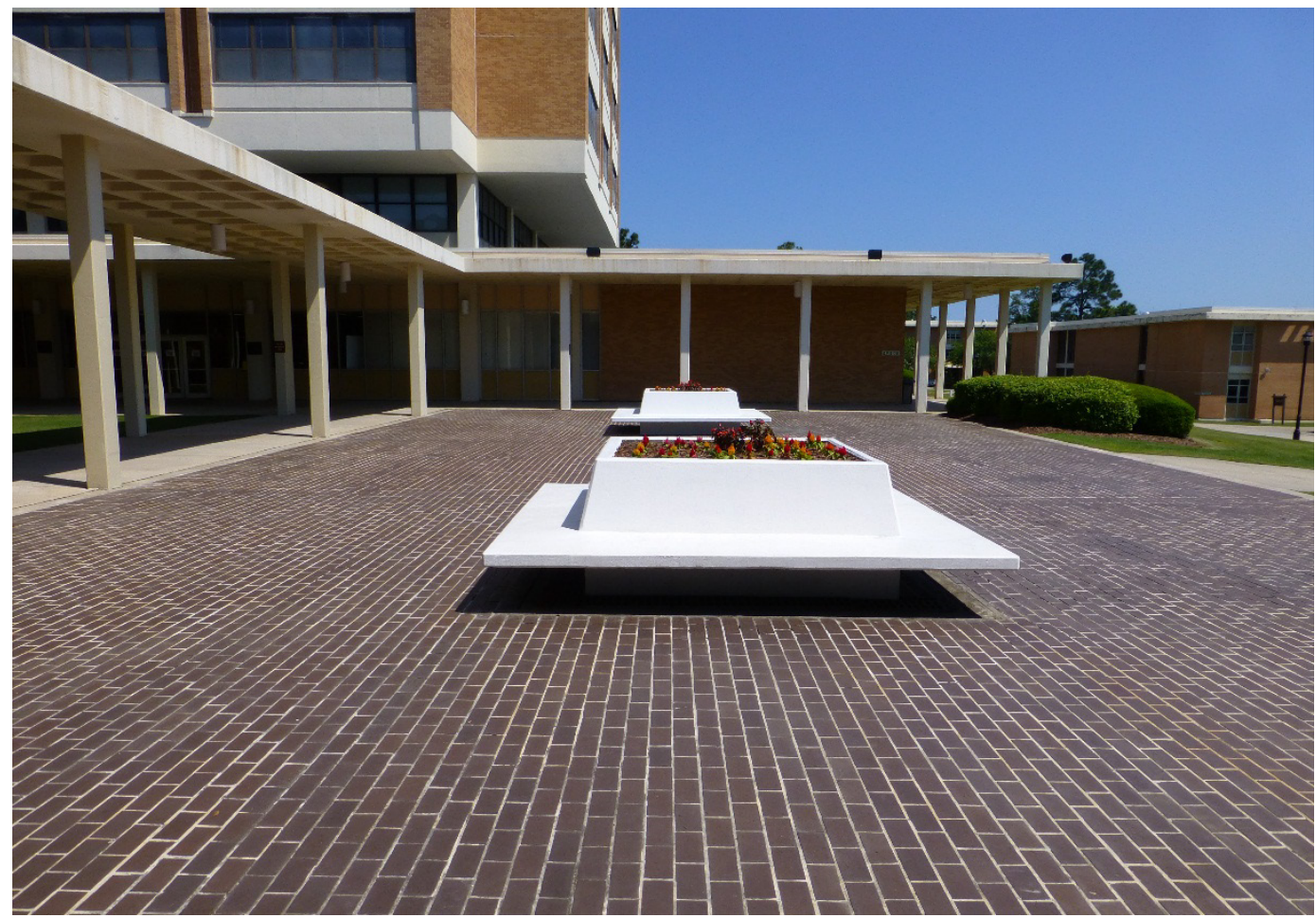

Figure 231. Doors into the Alexander Hall auditorium from the lobby of Building 29805 (ERDC-CERL, 2015).

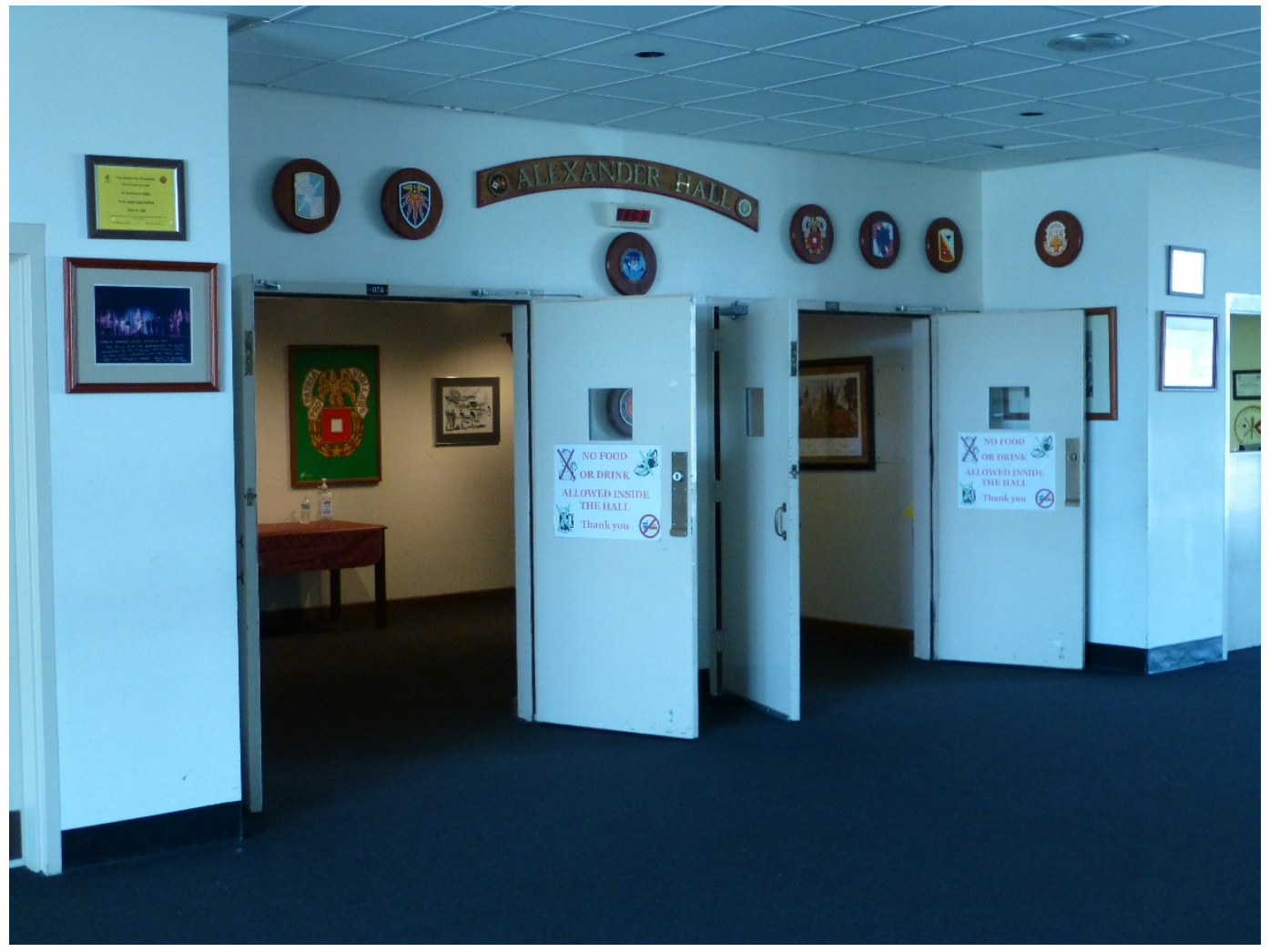


Figure 232. Alexander Hall, auditorium inside Building 29805 (ERDC-CERL, 2015).

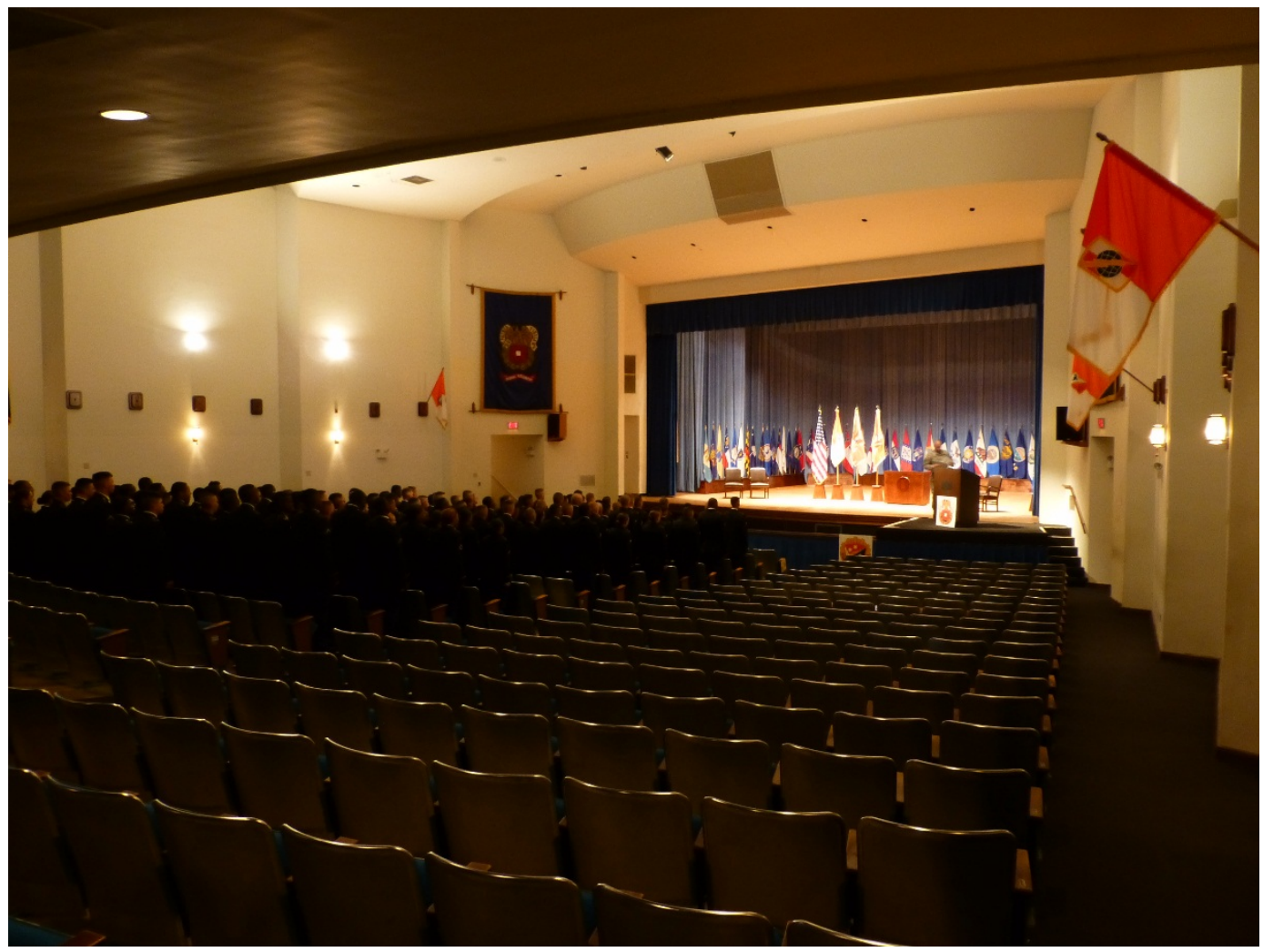

Figure 233. East elevation of Building 29805, Alexander/Olmstead Halls, April 1978 (National Archives at College Park, MD).

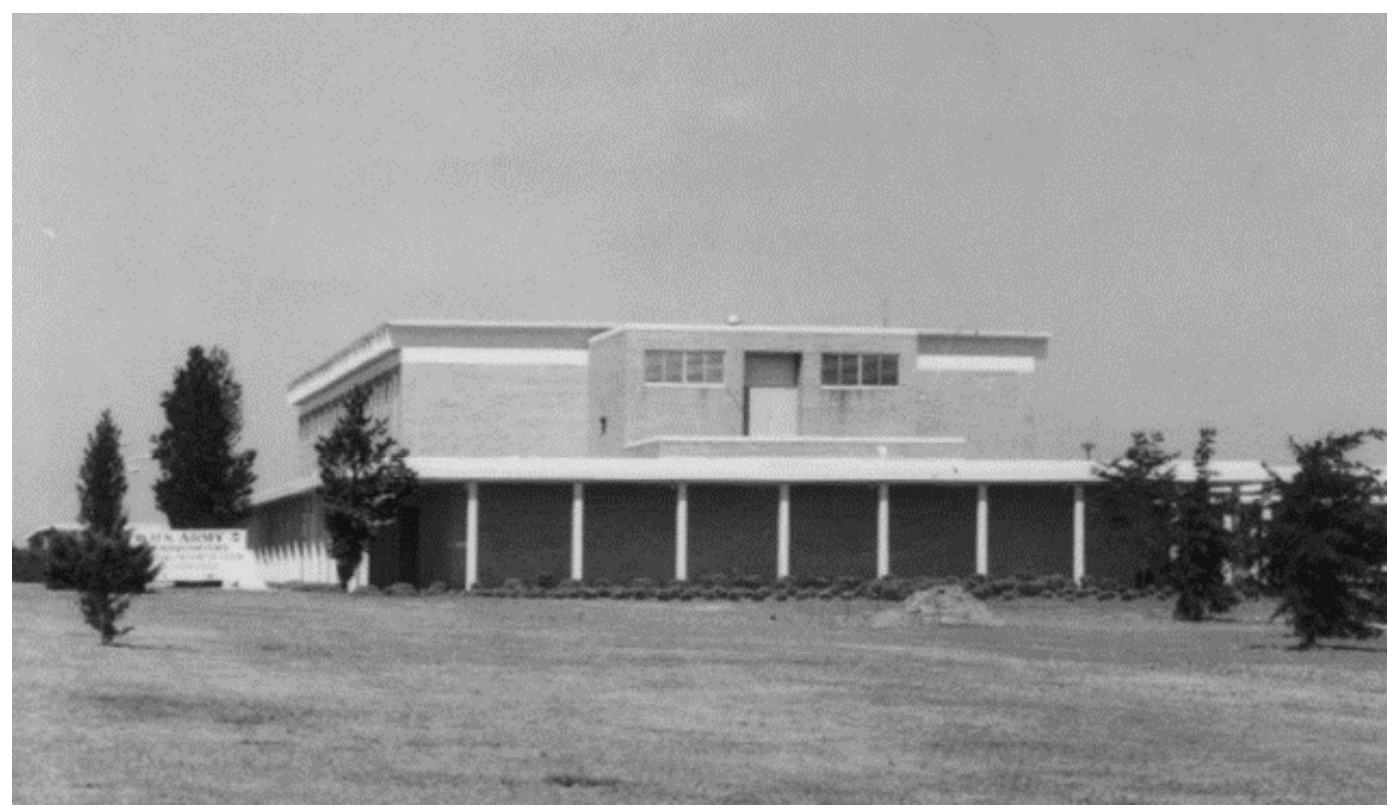


Figure 234. General view of the east elevations of the administration complex of Buildings 29805 [left], 29807 [middle], and 29808 [right], April 1978 (National Archives at College Park, MD).

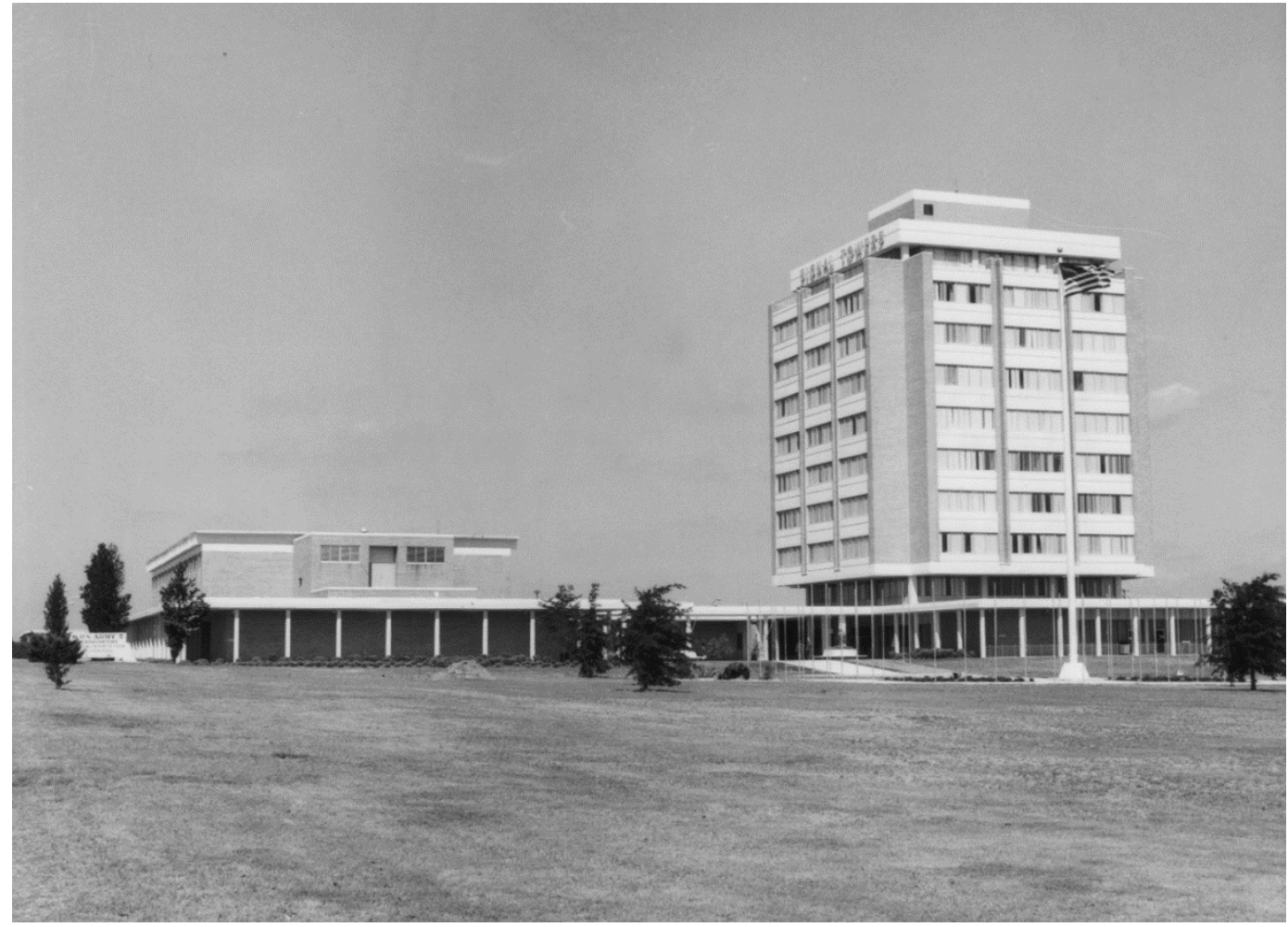

Figure 235. Overall view of the plaza connecting Building 29805 [left], Building 29807 [center], and Building 29808 [right] (ERDC-CERL, 2004).

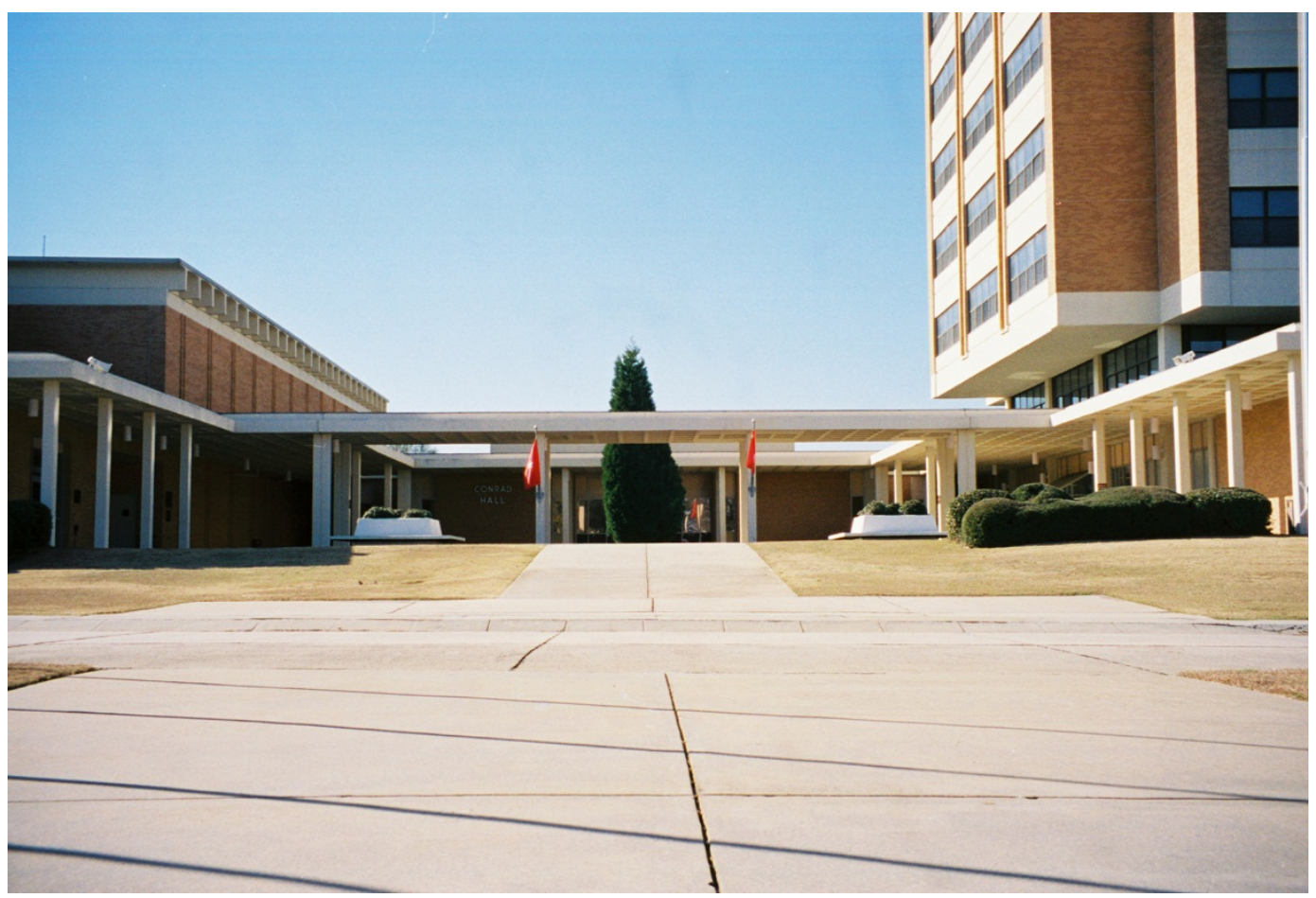


Figure 236. Roof detail of Building 29805, Alexander/OImstead Halls (ERDC-CERL, 2004).

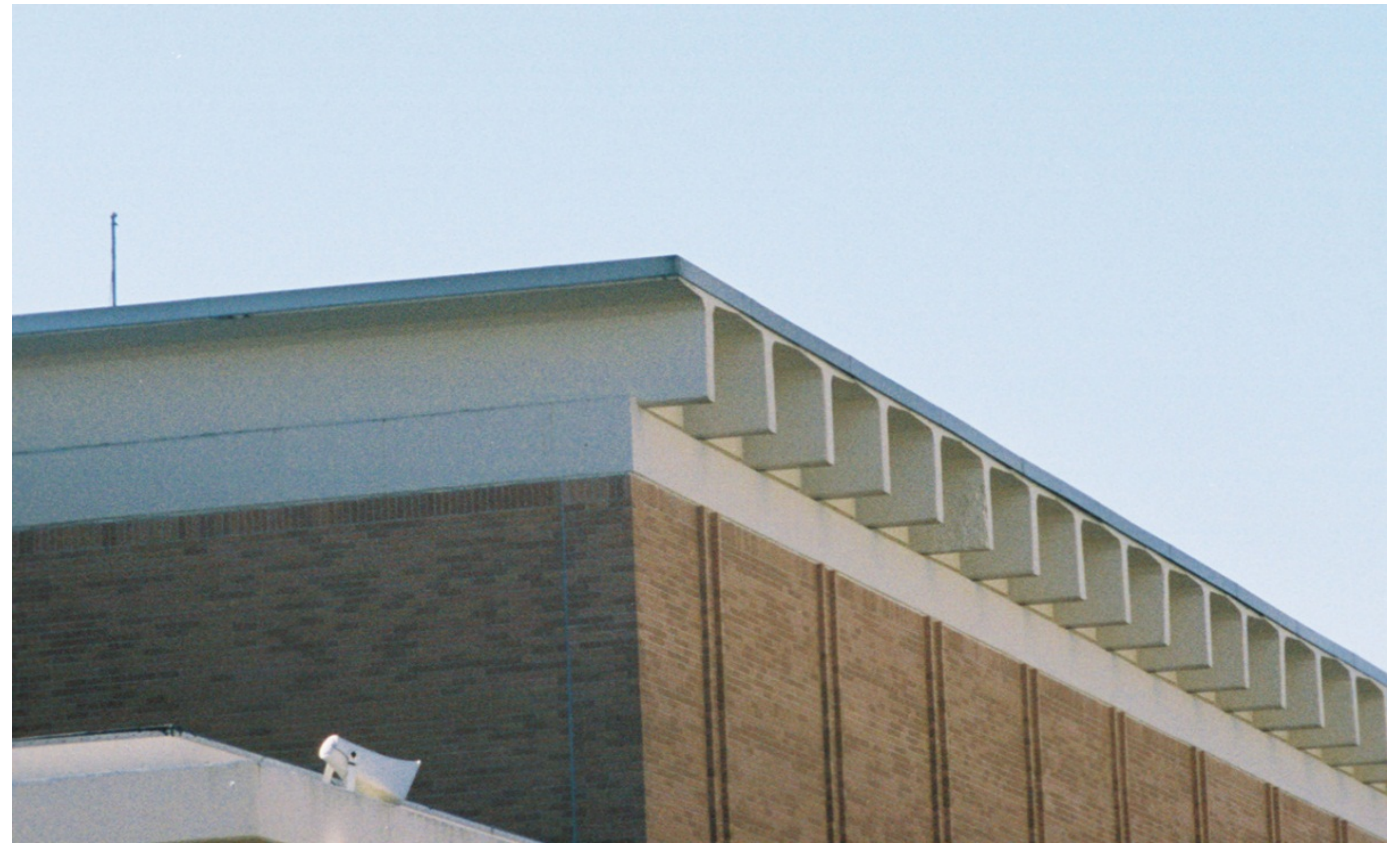

Figure 237. First-floor plan for Building 29805, Alexander/OImstead Halls, 1966 (Fort Gordon DPW).

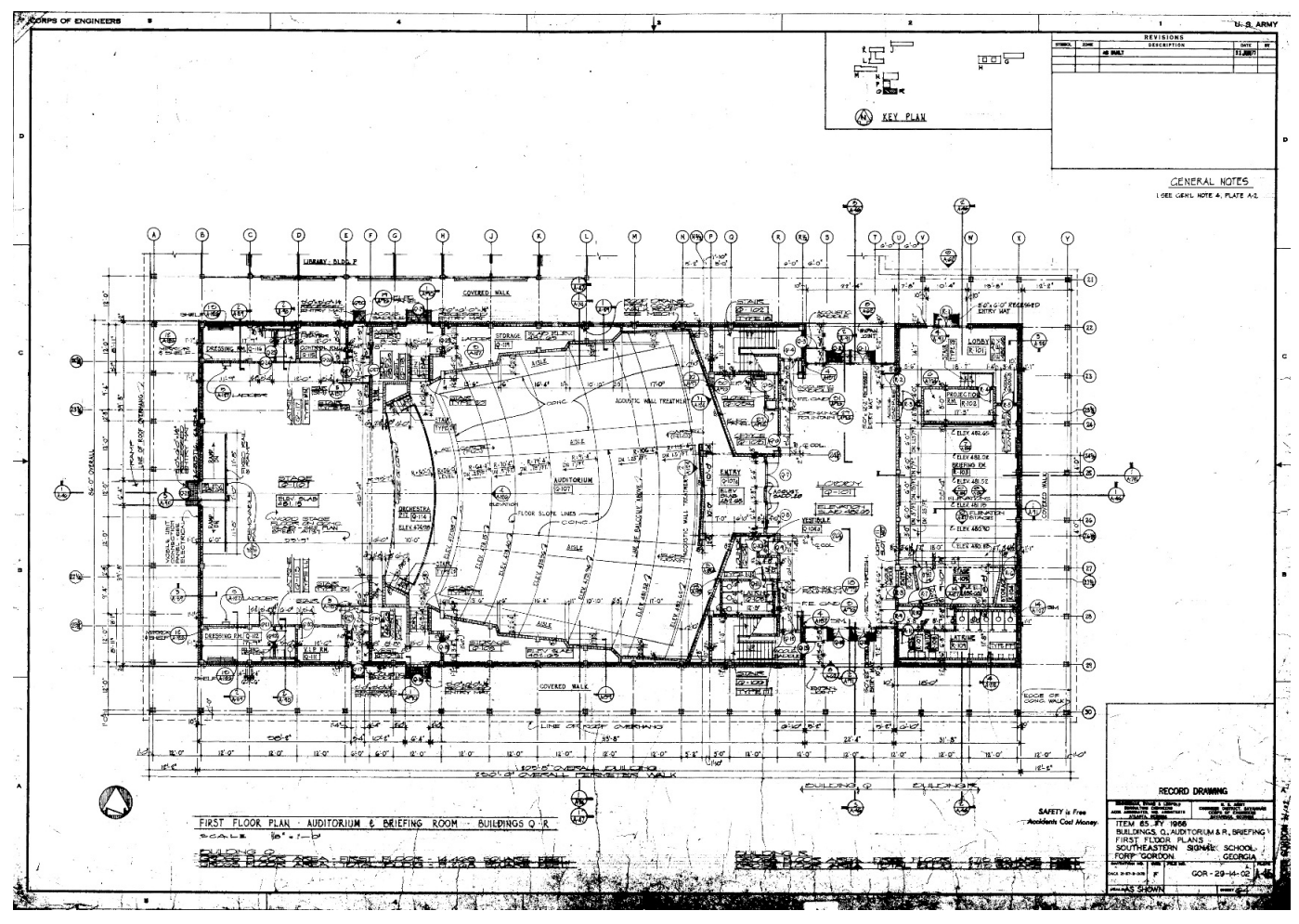


Figure 238. Second-floor plan for Building 29805, Alexander/OImstead Halls, 1966 (Fort Gordon DPW).

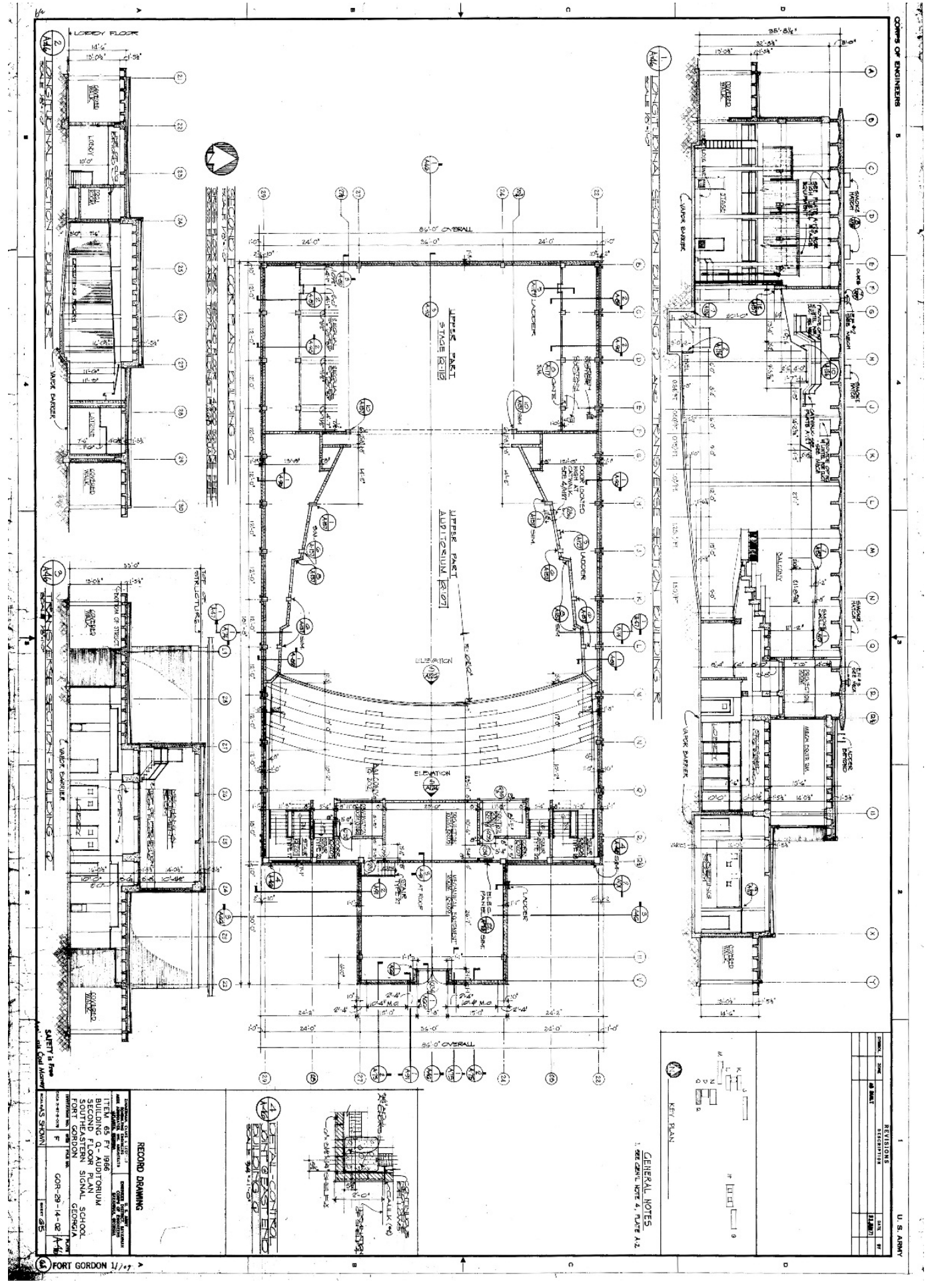

NOTE: Elevations were not given to the research team for this building. 
Figure 239. Door elevations and window details for Building 29805, Alexander/Olmstead Halls, 1966 (Fort Gordon DPW).

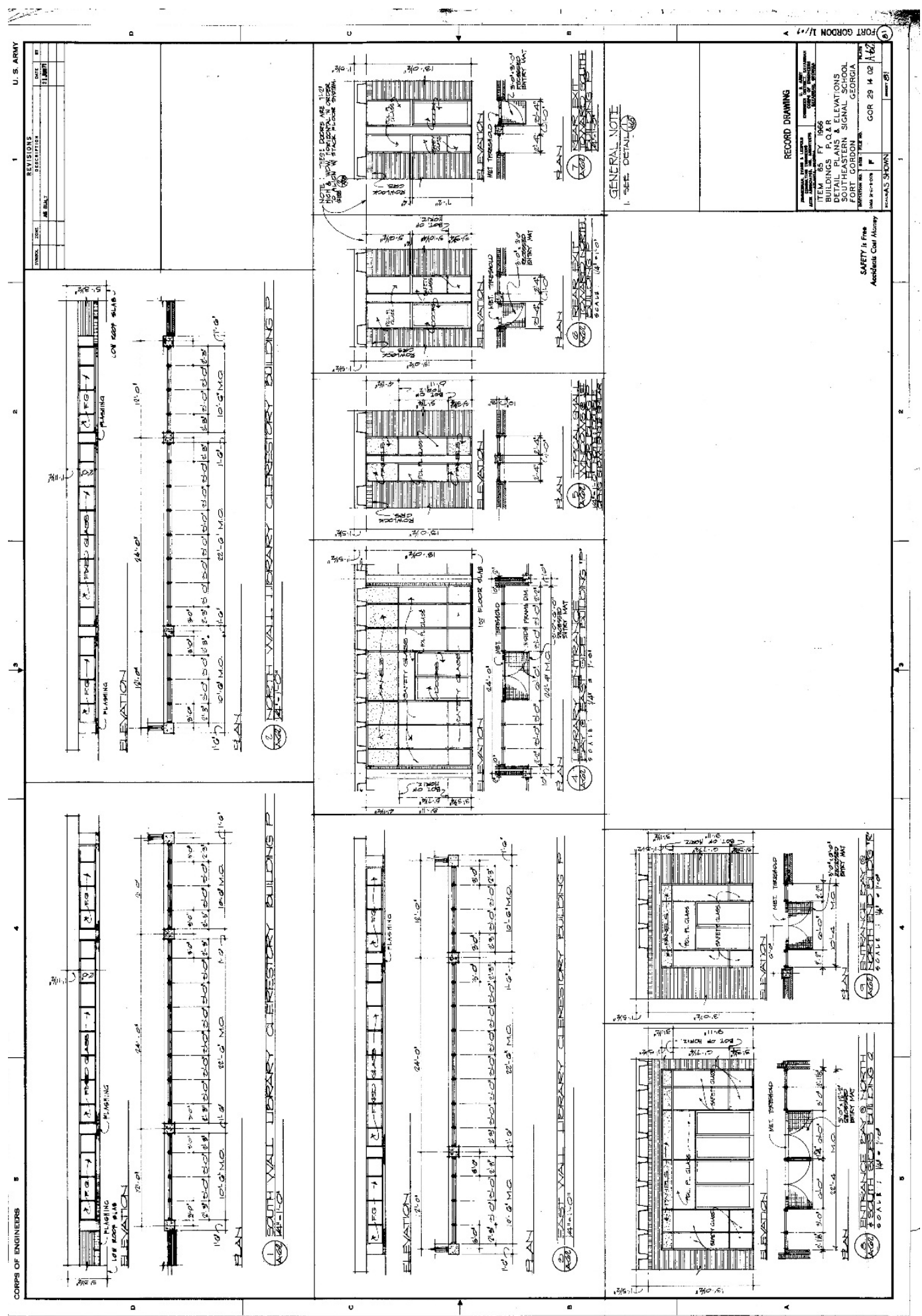


Figure 240. Door schedule for Building 29805, Alexander/OImstead Halls, 1966 (Fort Gordon DPW).

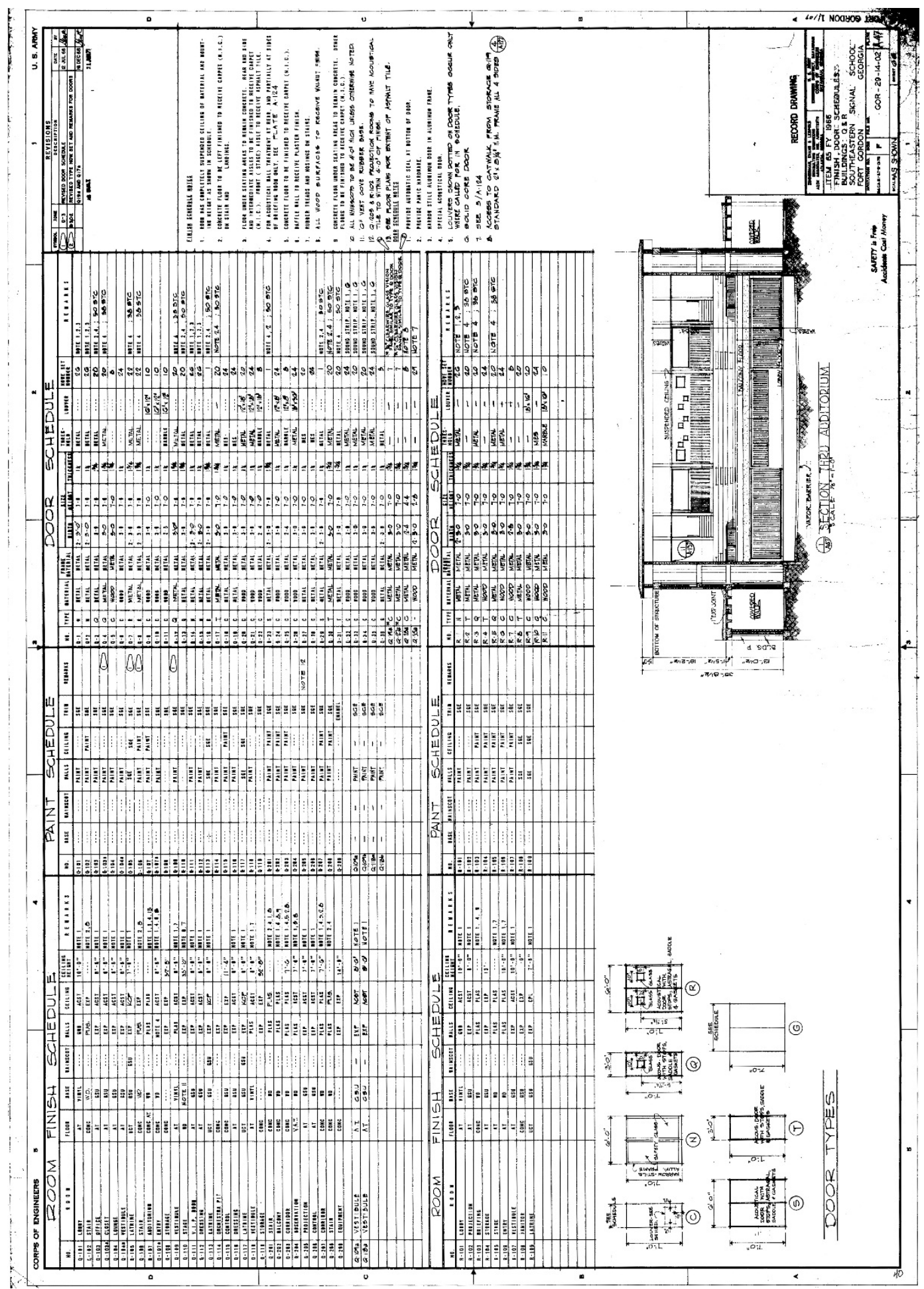


Figure 241. Section thru auditorium in Building 29805, Alexander/OImstead Halls, 1966 (Fort Gordon DPW).

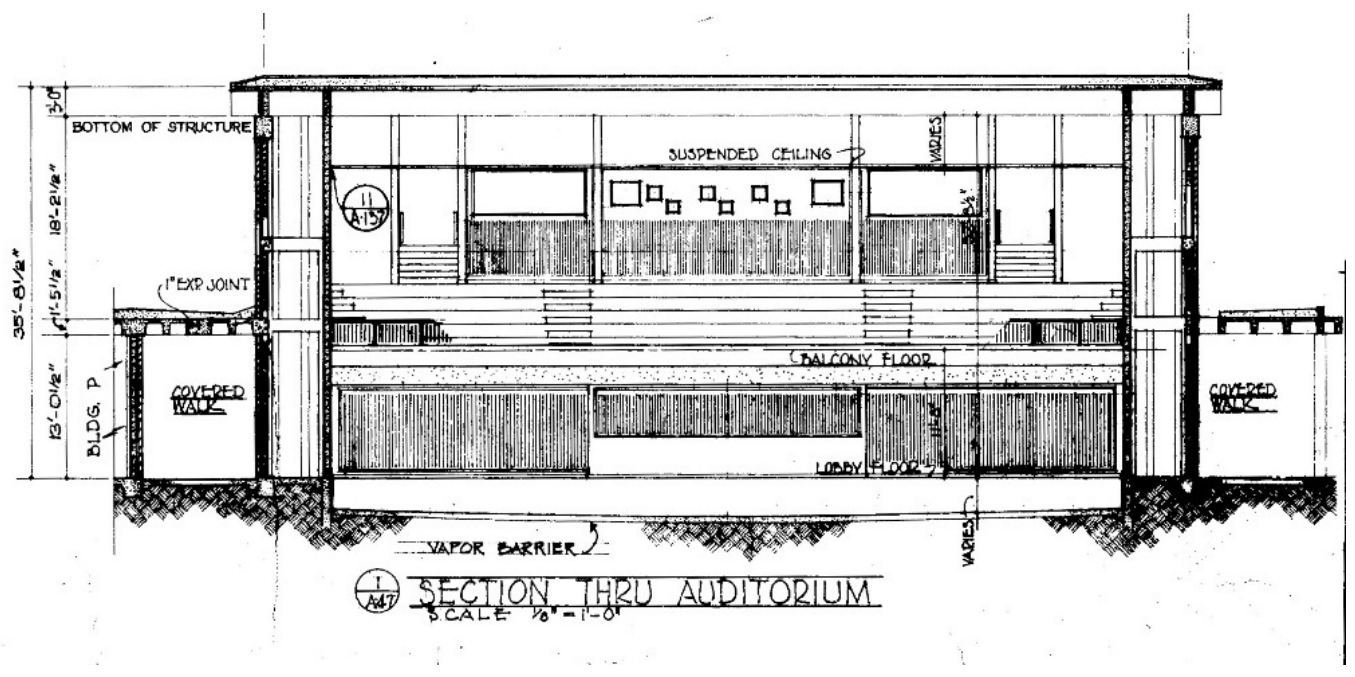

\subsubsection{Character-defining features}

Repair, renovation, and replacement of Building 29805, Alexander Hall/Olmstead Halls must be coordinated with the GA SHPO (Table 7).

\section{Exterior:}

- Overall massing

- Footprint

- Roof shape

- Brick veneer

- Relationship to adjacent Buildings 29807 and 29808

- Relationship to other Signal School Campus buildings

- Waffle roof canopy/covered walkway connects all three buildings together

- Poured-in-place concrete columns

- Large precast T-beams extend from the north to south

- Ceiling-mounted cylinder exterior light fixtures

- Metal handrails

- Landscaping

\section{Interior:}

- Overall plan

- Lobby

- Doors 
- Lighting

- Auditorium spaces

- Blue glazed concrete-block water fountain alcove

Table 7. Images of character-defining features of Building 29805, Alexander/Olmstead Halls (ERDC-CERL, 2015).

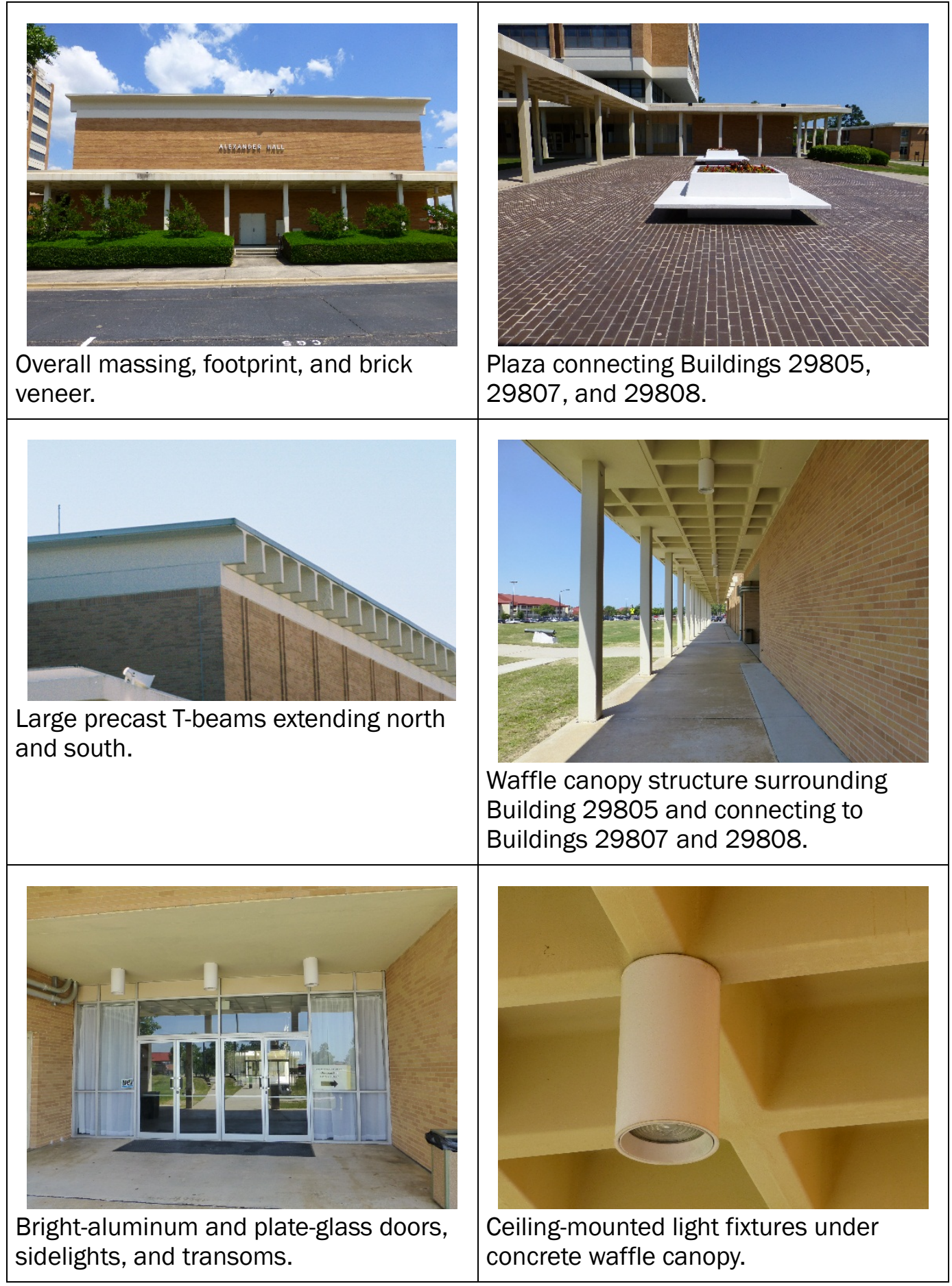




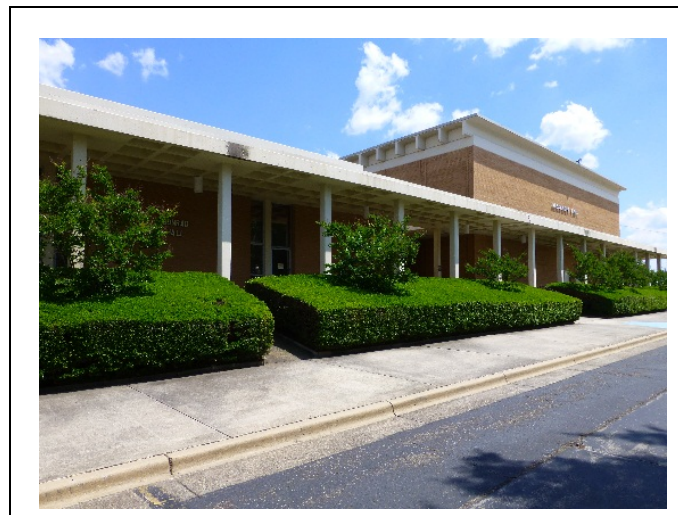

Landscaping surrounding Building 29805 and adjacent Buildings 29807, and 29808.

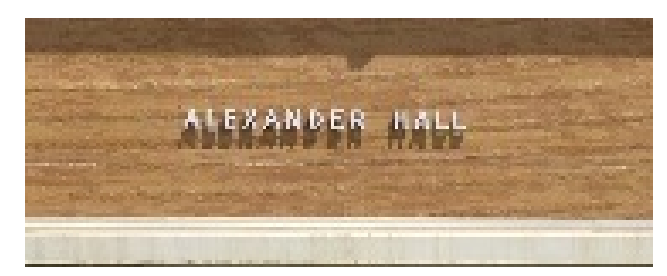

Lettering.

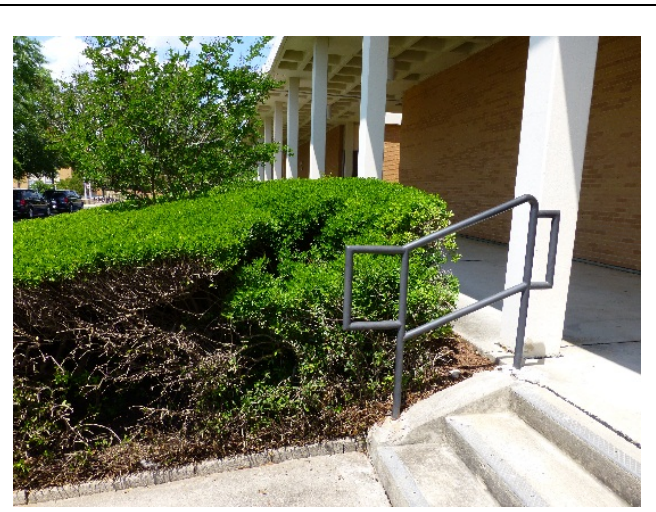

Metal handrails.

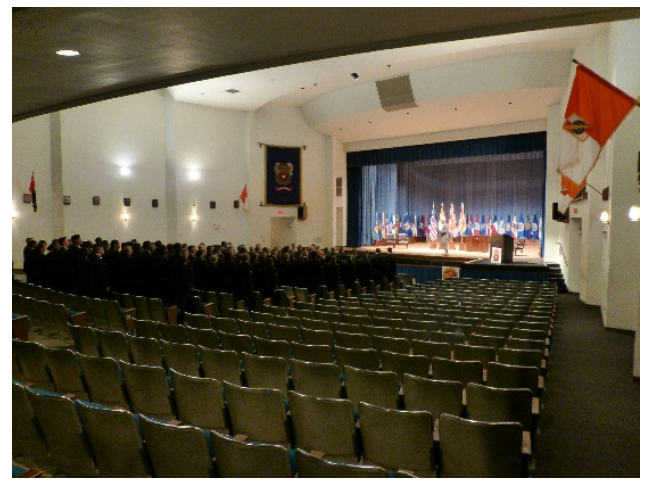

Open auditorium space.

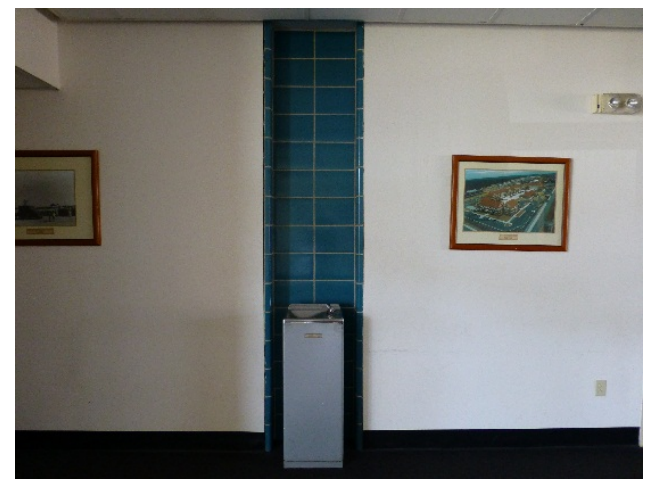

Blue glazed concrete block at water fountain niche.

\subsubsection{Character-defining features that have been removed}

- None.

\subsubsection{Nonhistoric features}

- None. 


\subsubsection{Comparison images}

Comparison images utilizing either the original drawings or historic photographs, when juxtaposed against present-day images, are a useful tool in developing the historic "feel" of a property and how much of that historic feeling is still present today (Figure 242-Figure 244).

Figure 242. Main entry on the north elevation - comparison of the original drawing detail from 1966 [left] to the current condition of the bright-aluminum and plateglass doors, sidelights, and transoms [right] (ERDC-CERL, 2015).
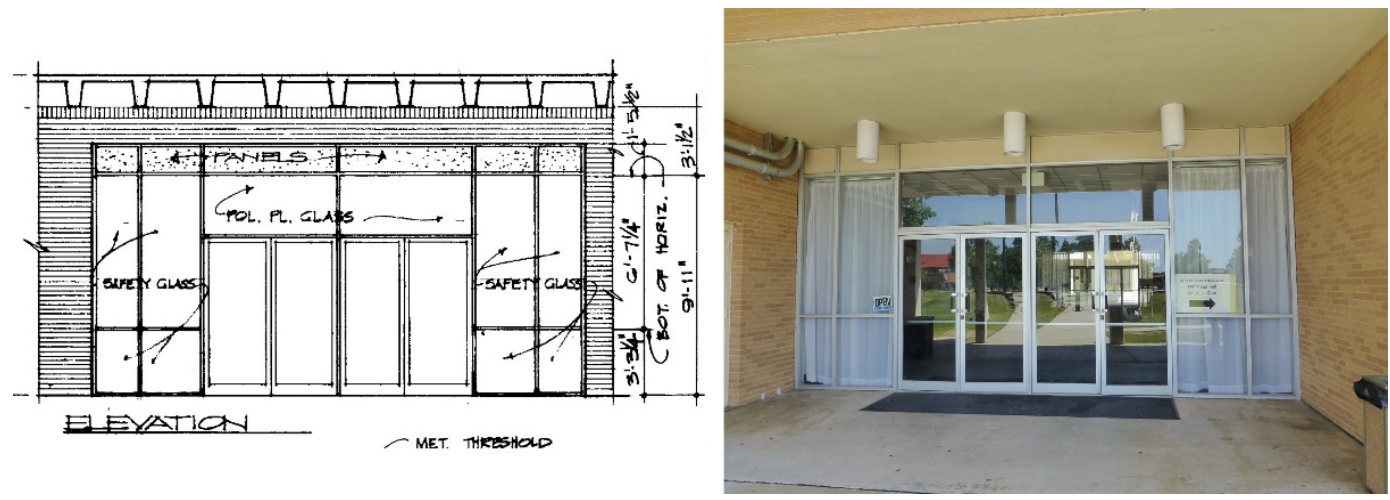

Figure 243. Ceiling-mounted light fixture - Comparison of the original drawing detail from 1966 [left] to the current condition of the ceiling-mounted light fixture under the concrete waffle canopy [right] (ERDC-CERL, 2015).
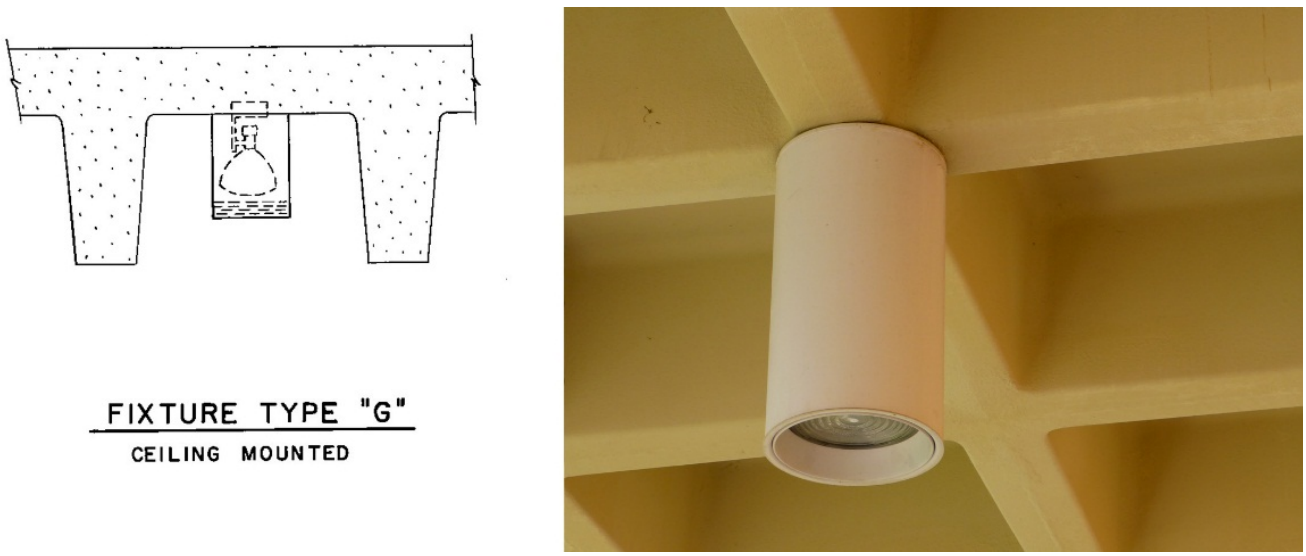
Figure 244. Interior auditorium doors - Comparison of the original drawing detail from 1966 [left] to the current condition of the acoustical doors [right]

(ERDC-CERL, 2015).

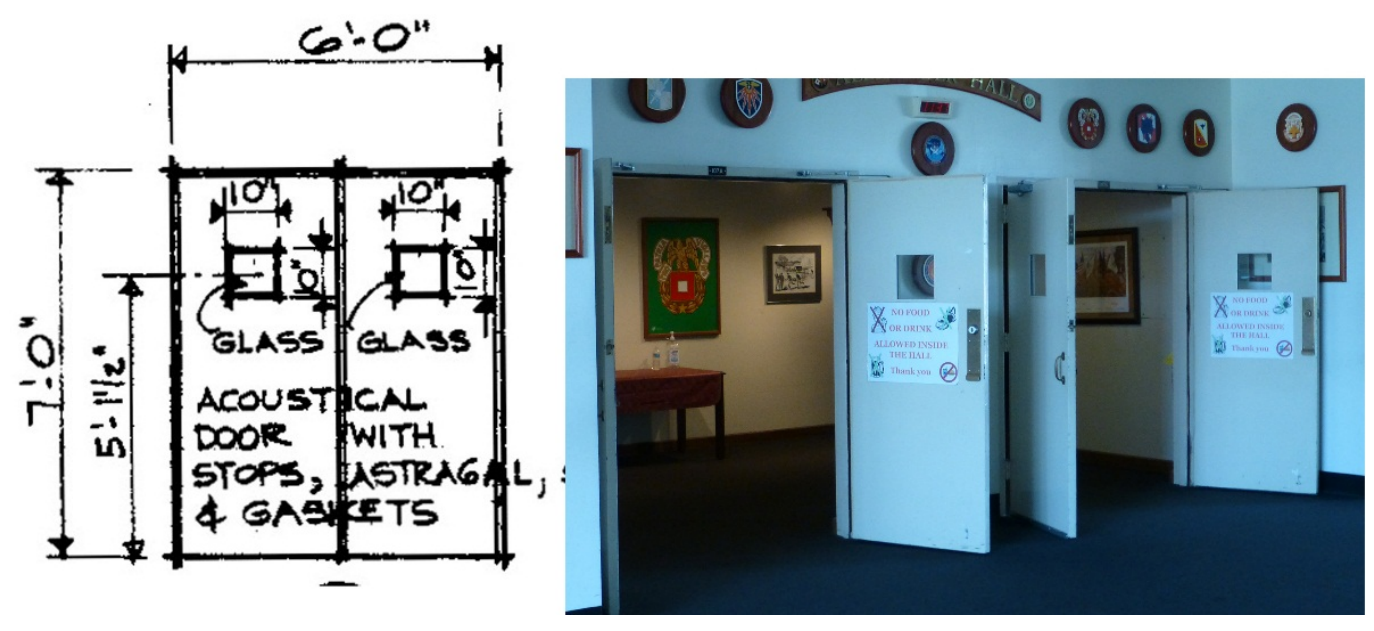

\subsubsection{Building 29807, Museum [Conrad Hall] (1970)}

Building 29807, Museum (Conrad Hall), is a contributing feature to the Signal School Campus Historic District. The interior is contributing. It is the Signal Corps Museum and was constructed in 1970 as part of the Phase II of the campus plan and was designed by architects Aeck Associates from Atlanta, Georgia, and Zimmerman, Evans, and Leopold Consulting Engineers from Augusta, Georgia. Conrad Hall is part of a large administrative complex that is the headquarters for the Signal Corps (Building 29808, Signal Towers) and the auditorium (Building 29805, Alexander/Olmsted Halls). Buildings 29805, 29807, and 29808 are all connected together by a large waffle roof canopy and covered walkway. Building 29807 is a onestory building with a mezzanine with the corners cut out from the plan. The windows are plate glass set into bright-aluminum frames, with an insulated panel above and below the pane. Generally, these are in single sets, but some are paired with service doors. The middle section of the building is slightly taller, and clerestory windows are located on the east and west elevations. The structure follows the methodology of the rest of the Signal School design with poured-in-place concrete columns, concrete waffle floors, concrete block infill, and brick veneer. The primary entrance to the building is on the east, facing the landscaped courtyard. This entry consists of bright-aluminum and plate-glass doors, sidelights, and insulated panel inserts. Original "CONRAD HALL" lettering is located to the left of the main entry doors on the east elevation (Figure 245-Figure 254). 
Figure 245. Signal School Campus map, with Building 29807, Conrad Hall highlighted in red, 2015 (Fort Gordon DPW, modified by ERDC-CERL).

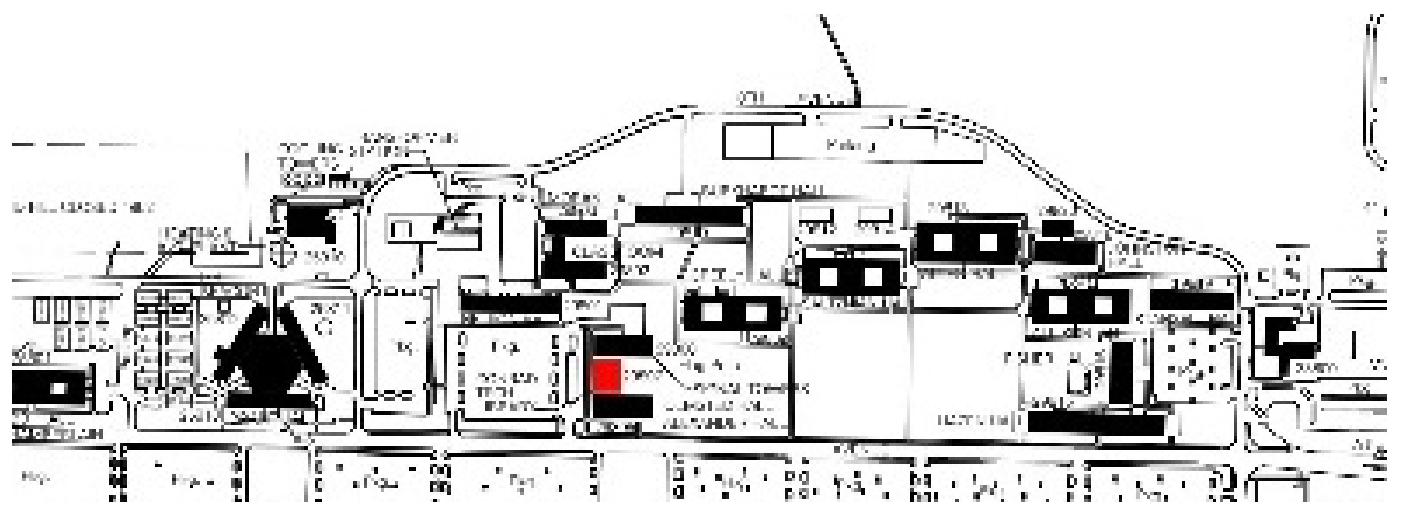

Figure 246. Looking at the main entry into Building 29807, Conrad Hall on the east elevation (ERDC-CERL, 2015).

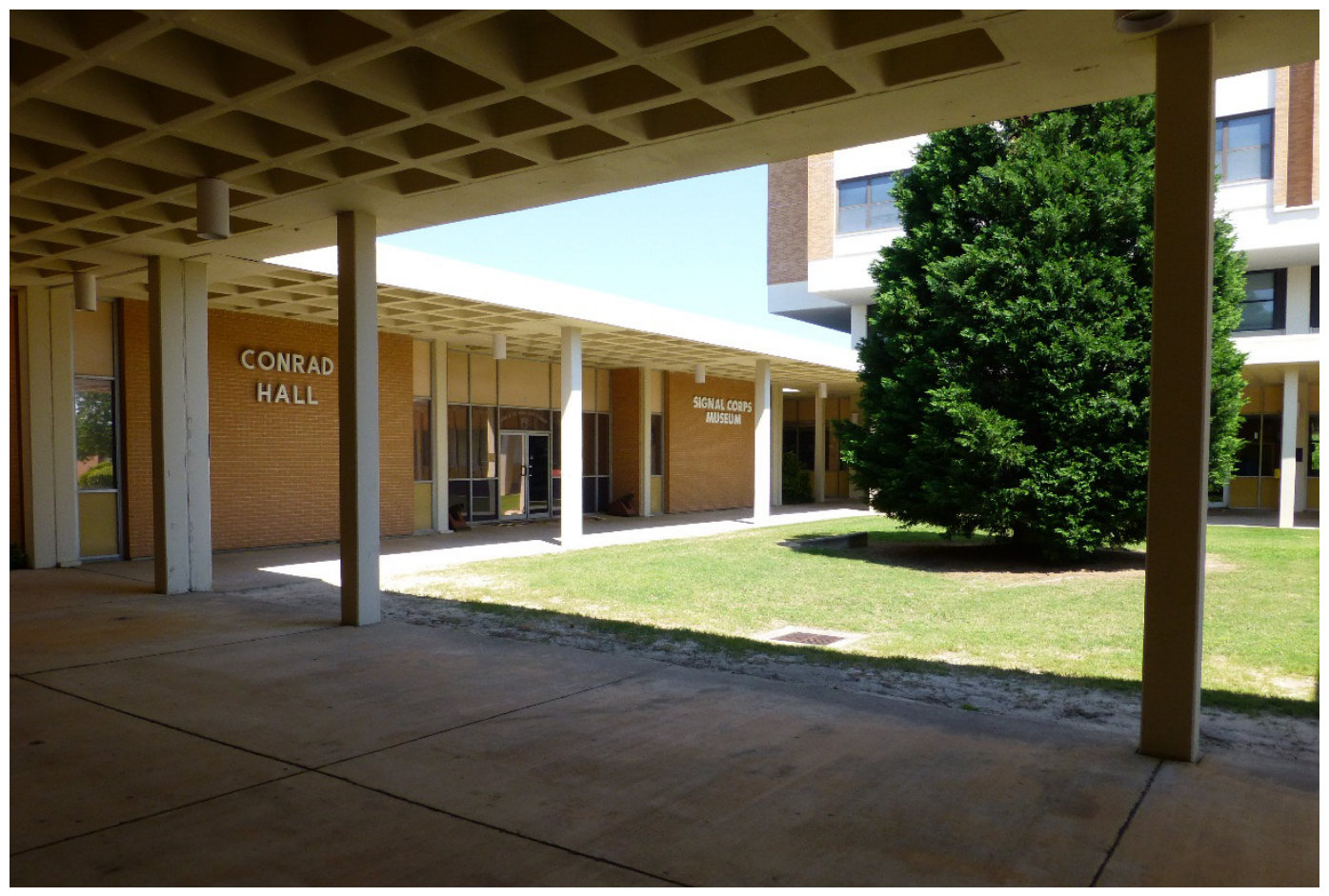


Figure 247. Brick plaza connecting Buildings 29805, 29807, 29808 on the east side (ERDC-CERL, 2015).

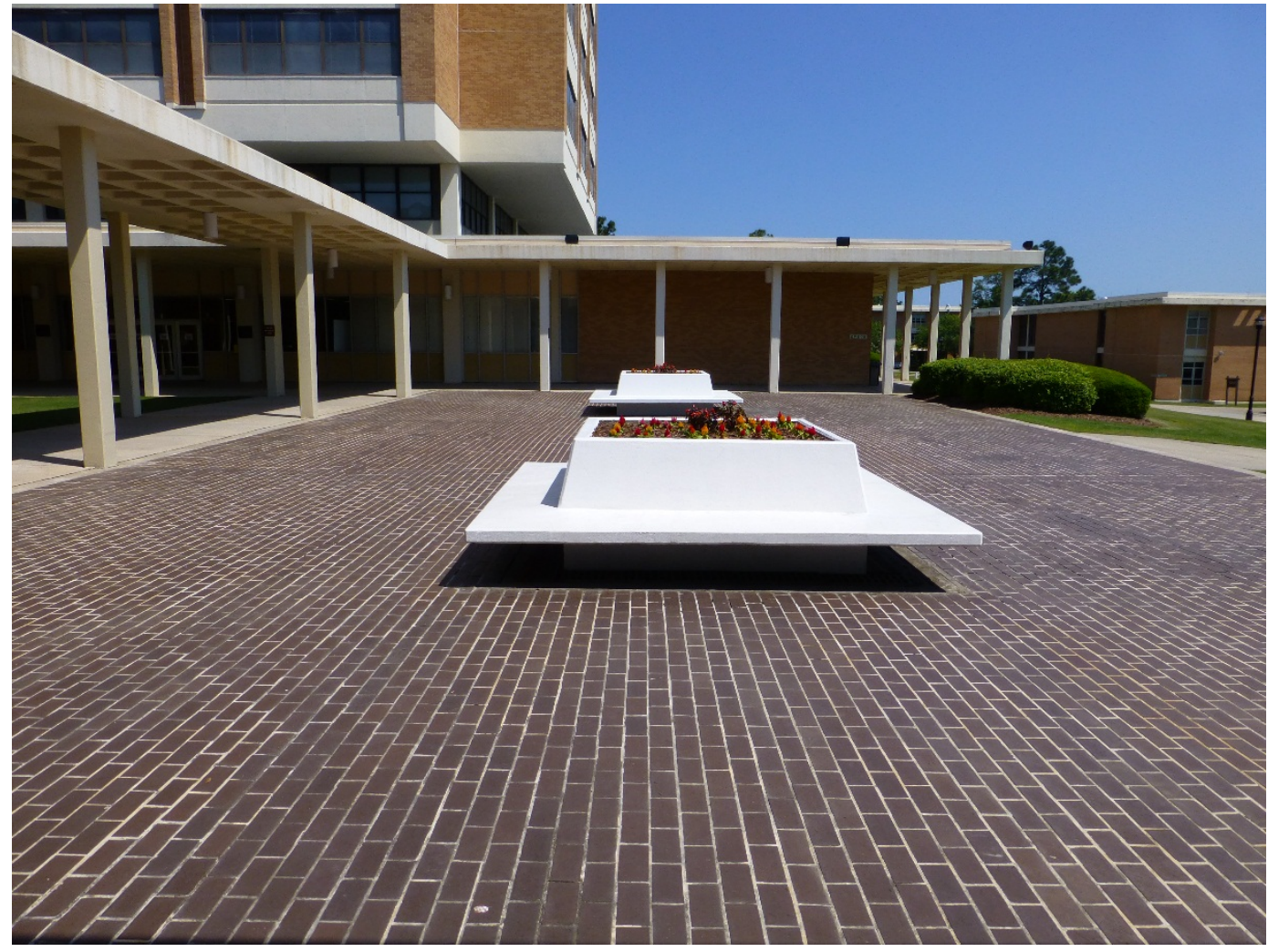

Figure 248. West side of Building 29807 with single entry doors and the concrete waffle canopy that connects to Buildings 29805 and 29808 (ERDC-CERL, 2015).

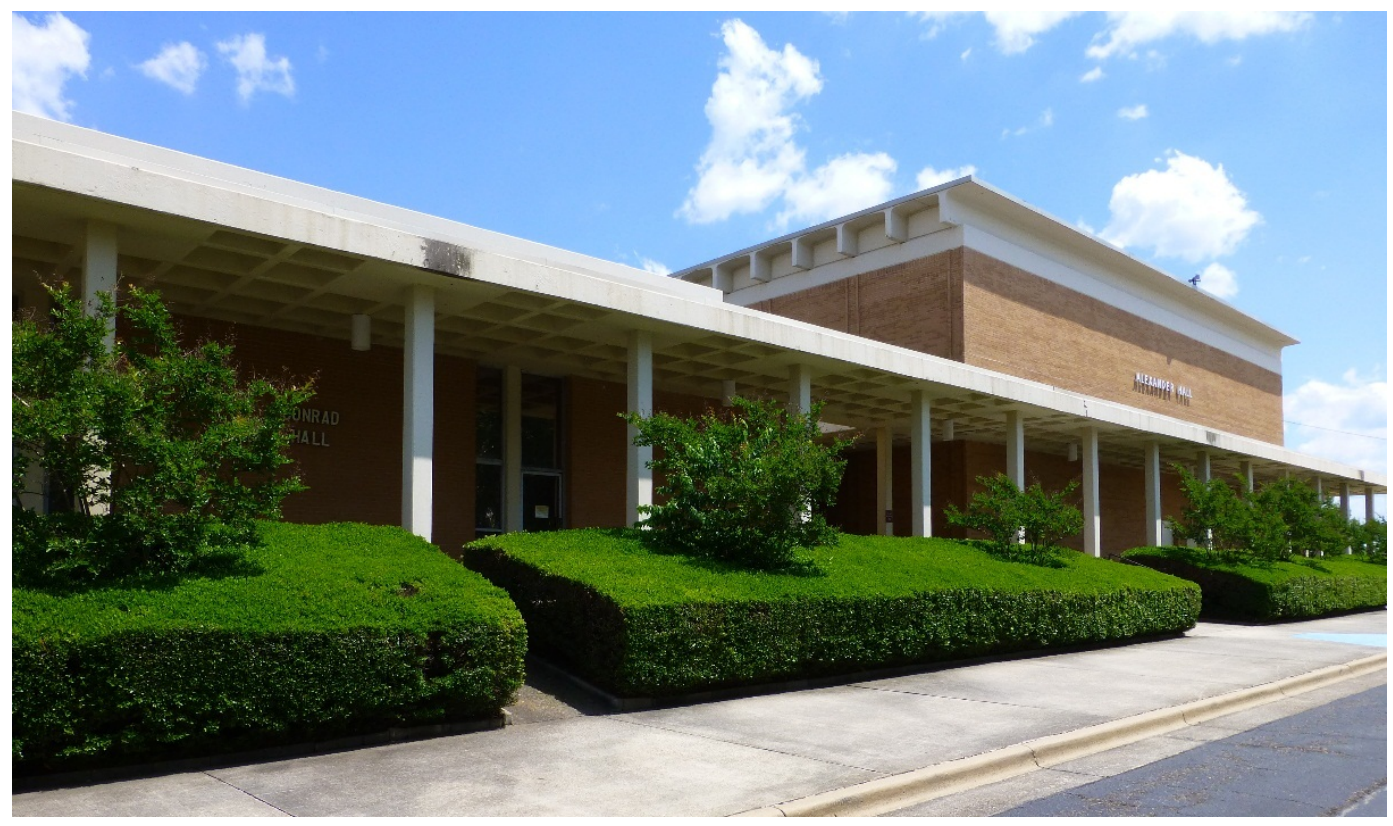


Figure 249. Building 29807, exposed waffle ceiling and clerestory windows (ERDC-CERL, 2015).

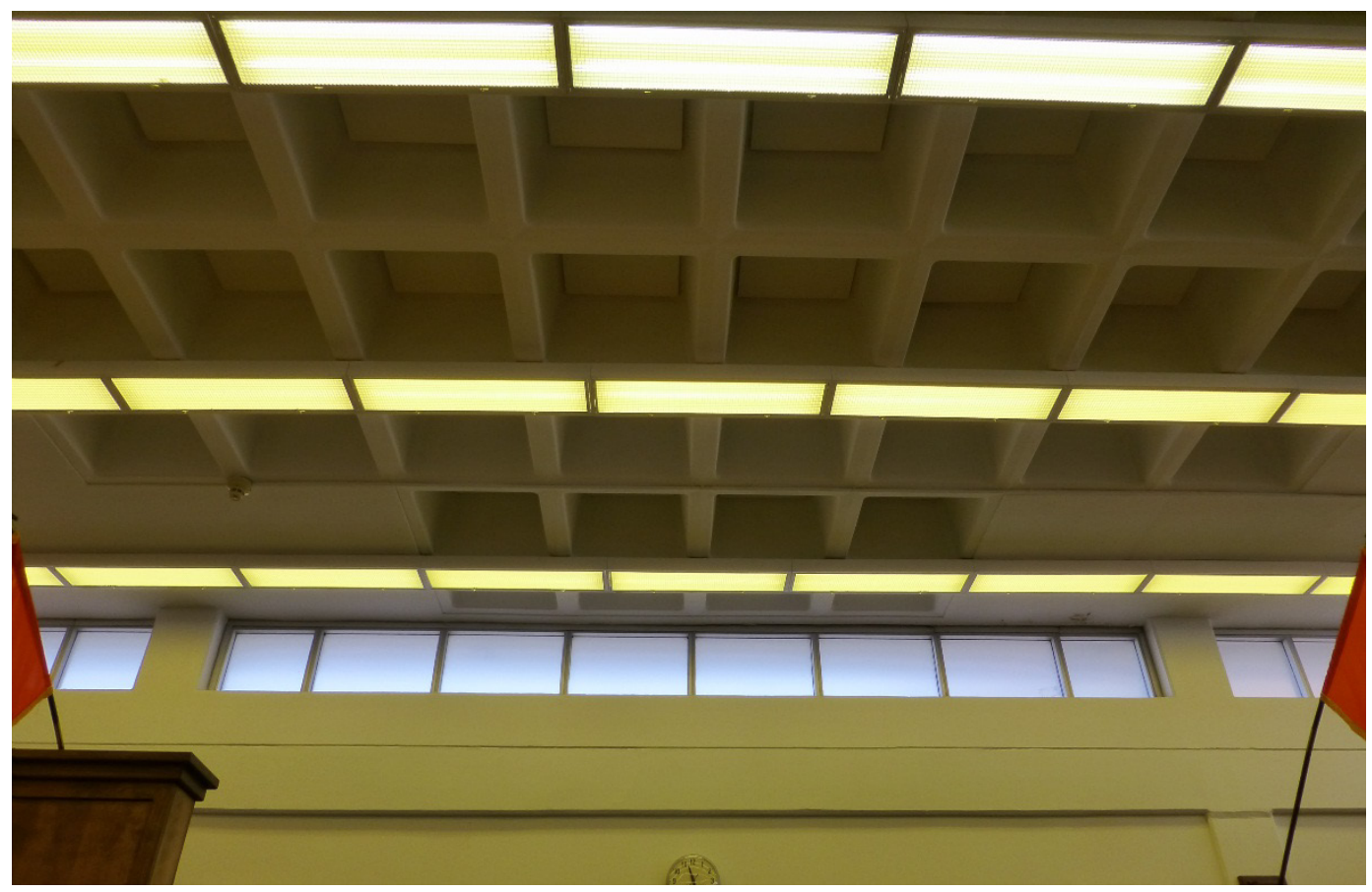

Figure 250. Building 29807, close-up of corner window detail (ERDC-CERL, 2015).

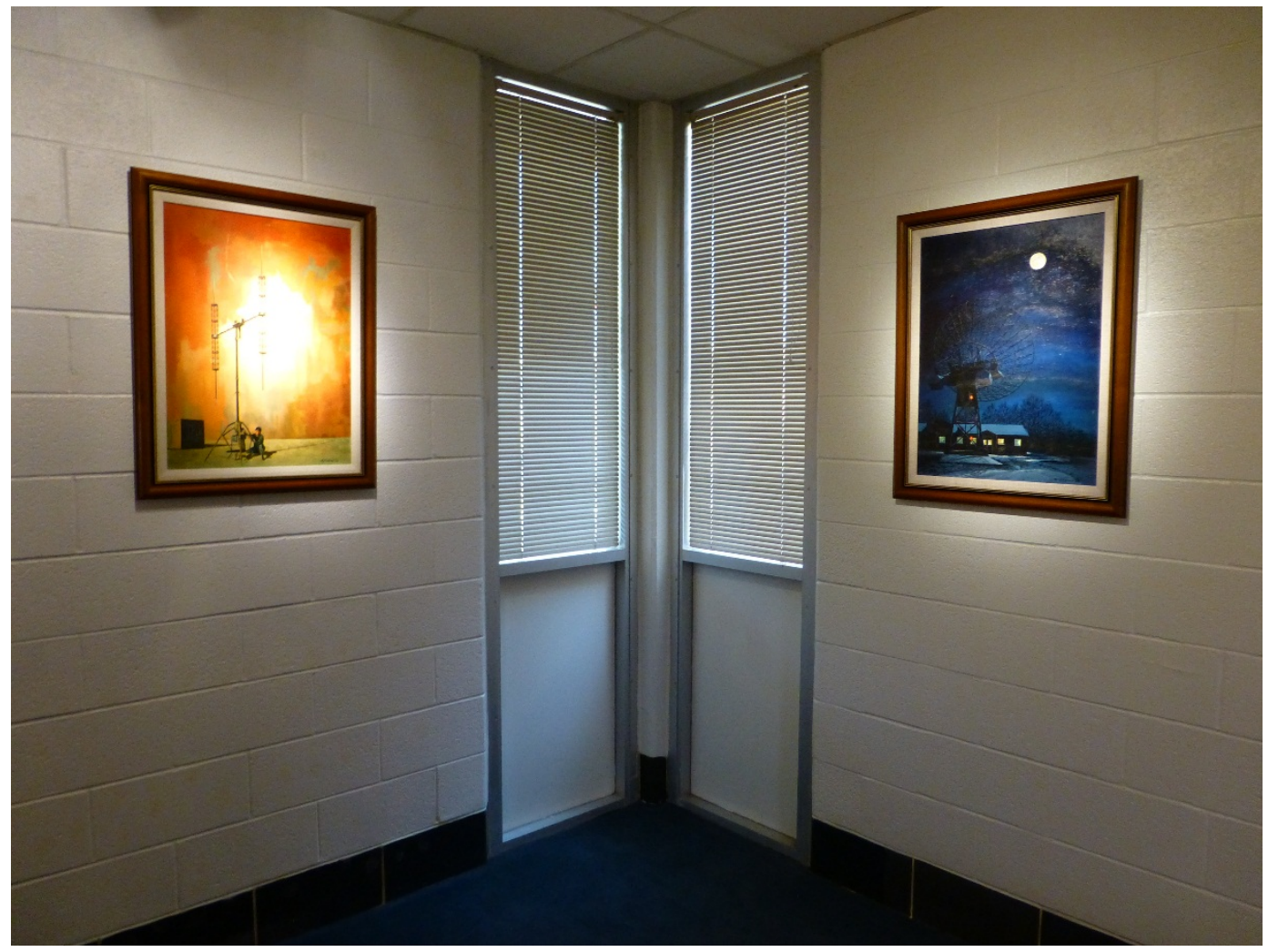


Figure 251. Building 29807, single-entry bright-aluminum and plate-glass door (ERDC-CERL, 2015).

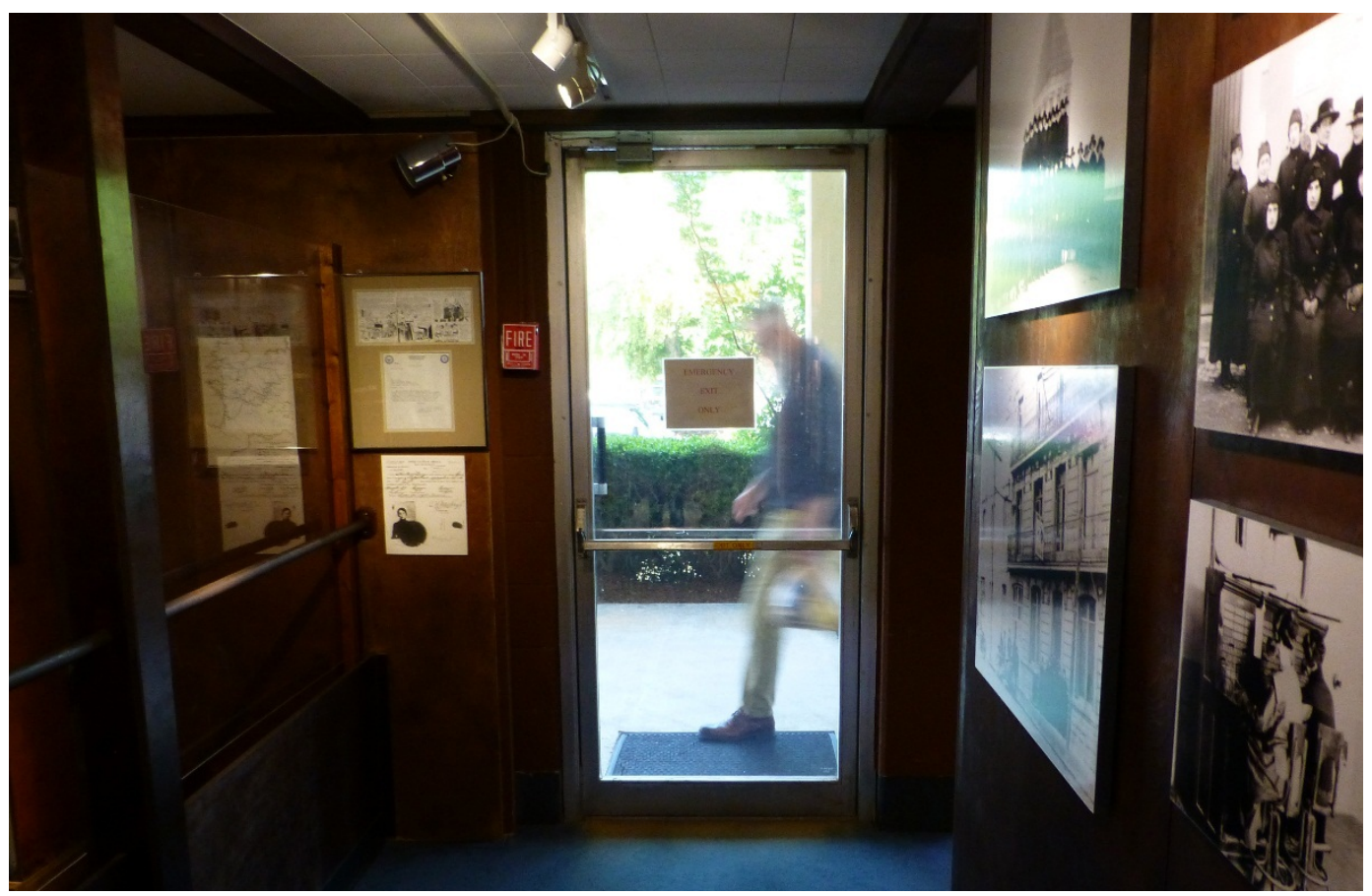

Figure 252. Floor plan for Building 29807, Conrad Hall, 1966 (Fort Gordon DPW).

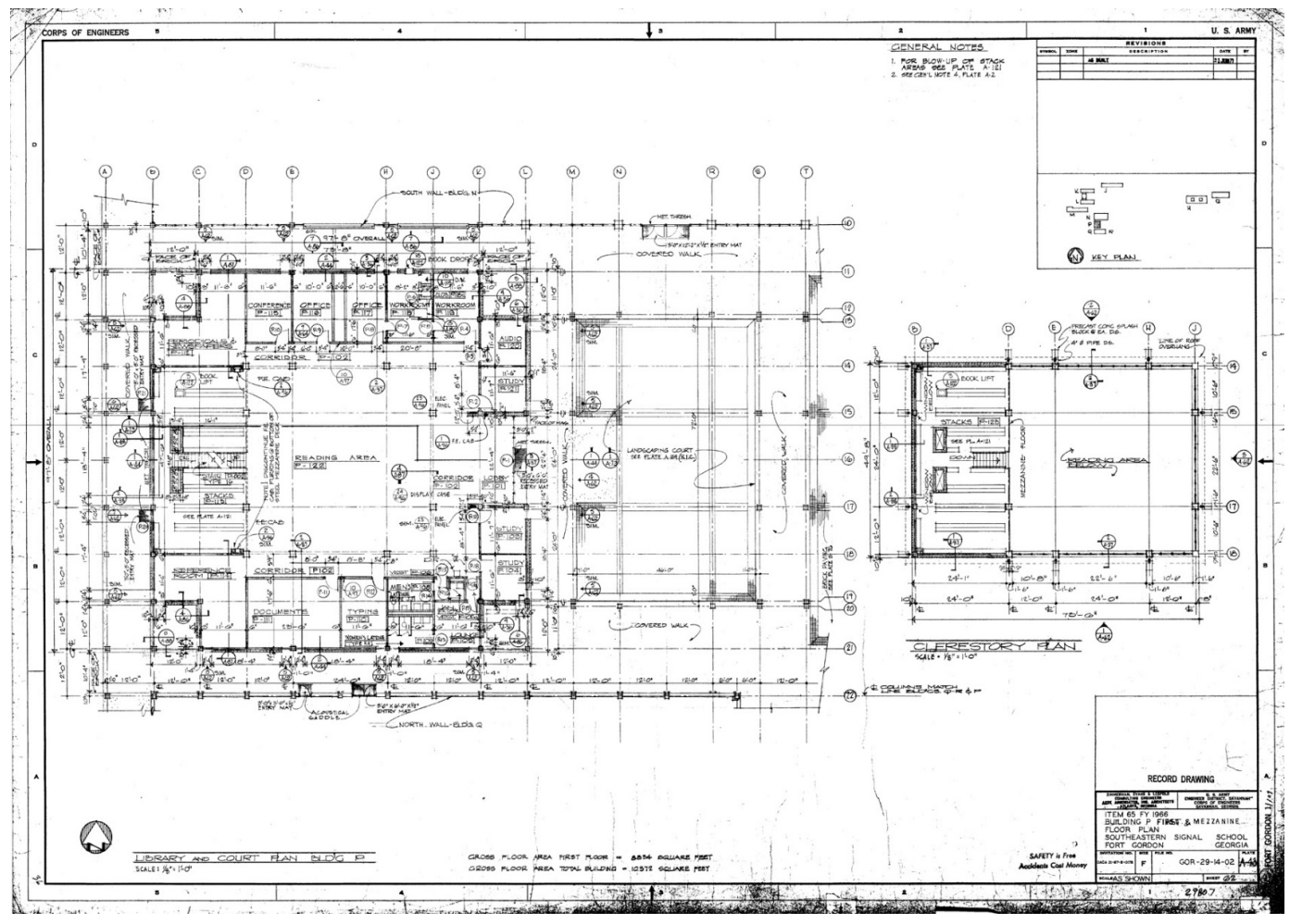


Figure 253. Door elevations and window details for Building 29807, Conrad Hall, 1966 (Fort Gordon DPW).

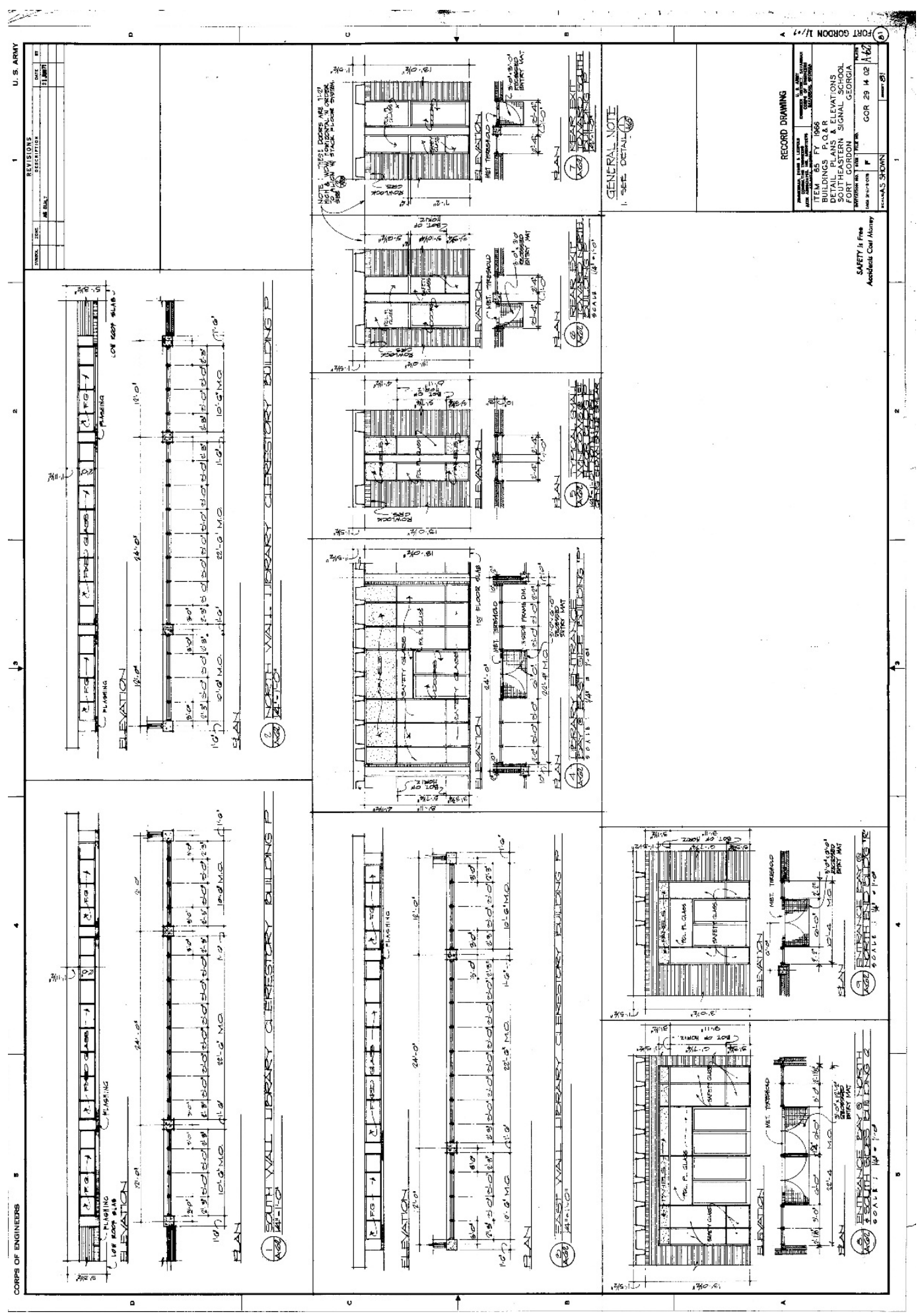


Figure 254. Close-up of door elevations and window details for Building 29807, Conrad Hall, 1966 (Fort Gordon DPW).

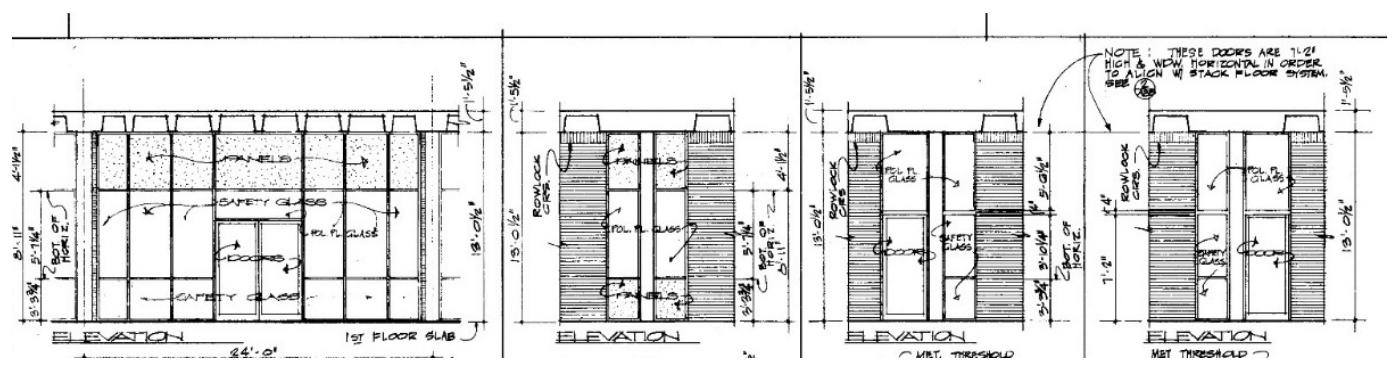

\subsubsection{Character-defining features}

Repair, renovation, and replacement of Building 29807, Conrad Hall must be coordinated with the GA SHPO (Table 8).

\section{Exterior:}

- Overall massing

- Footprint

- Roof shape

- Relationship between other Signal School Campus buildings

- Relationship between Buildings 29805 and 29807

- Brick veneer

- Exposed concrete waffle roof construction

- Exposed concrete structure framing window and door openings

- Bright-aluminum and plate-glass entry doors

- Bright-aluminum framing fixed pane sandwiched between insulated panels

- Fixed-pane clerestory windows

- Corner window detail

- Ceiling-mounted cylinder exterior light fixtures

- Metal handrails

- Lettering

- Landscaping

\section{Interior:}

- Overall plan

- Open space

- Lighting

- Exposed waffle-constructed ceiling

- Concrete block interior walls 
- Wood interior doors

Table 8. Images of character-defining features of Building 29807, Conrad Hall (ERDC-CERL, 2015).

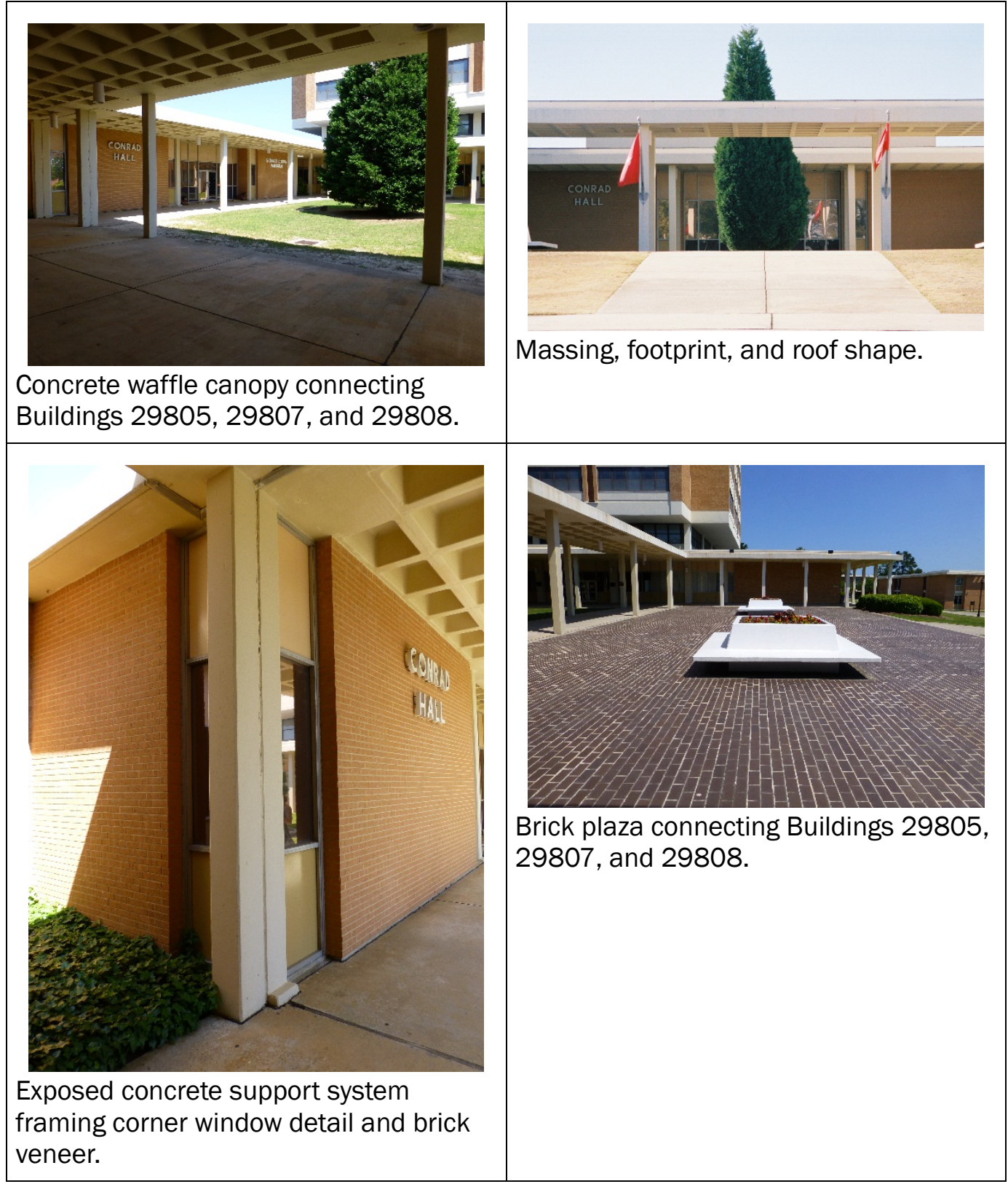




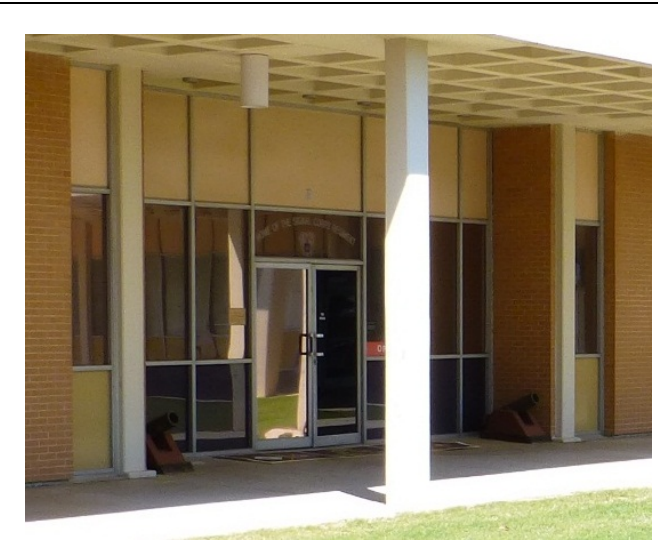

Bright-aluminum and plate-glass doors and sidelights with insulted panels.

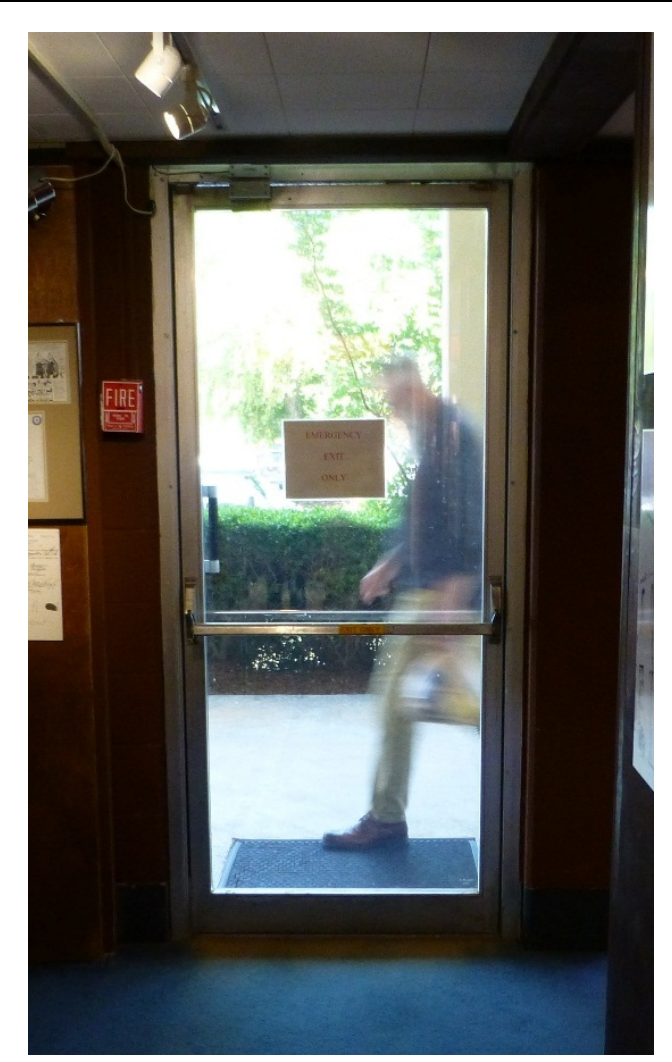

Bright-aluminum and plate-glass entry doors.

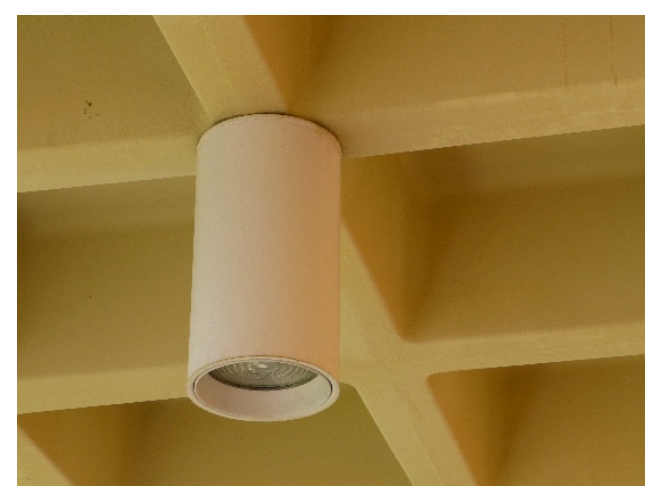

Ceiling-mounted light fixtures.

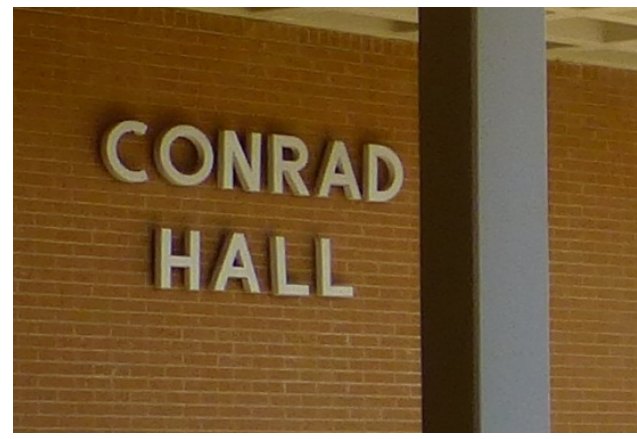

Lettering. 


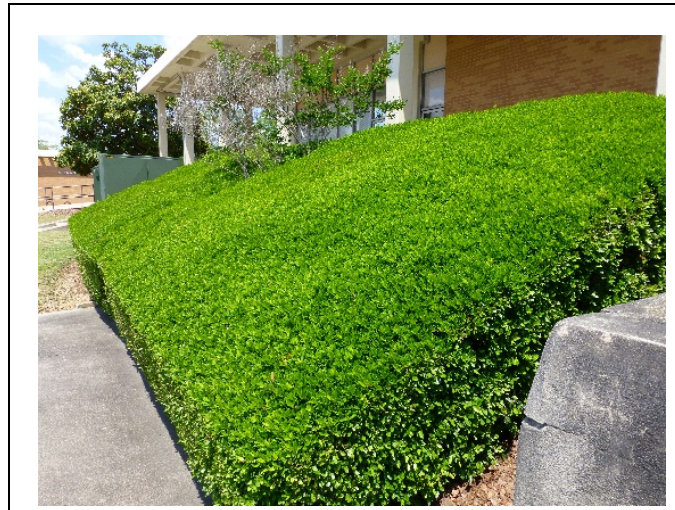

Landscaping surrounding the building.
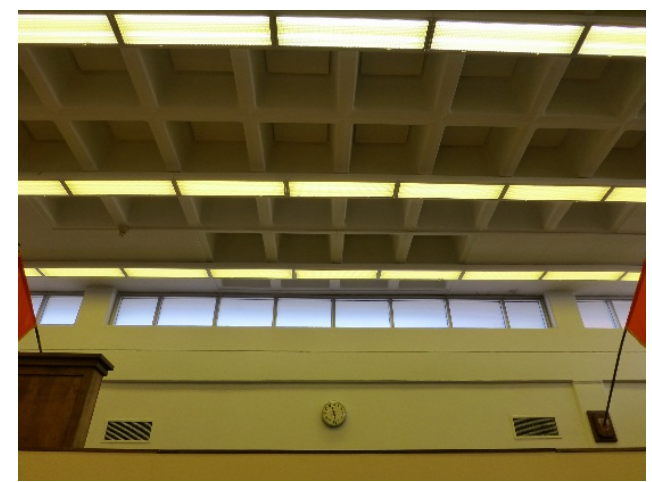

Fixed-pane clerestory windows.

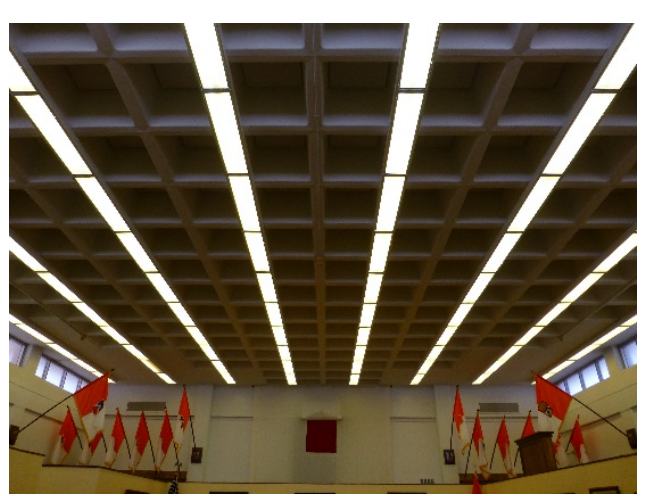

Exposed concrete waffle roof system.

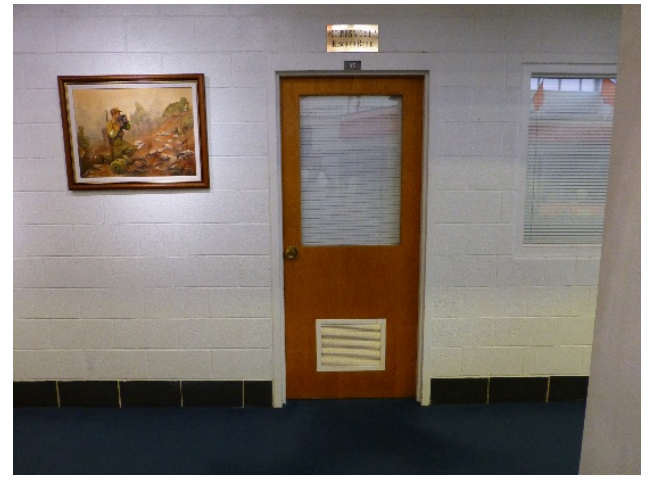

Concrete block interior walls, wood doors with pane, and glazed tile baseboards.

3.3.6.2 Character-defining features that have been removed

- None.

\subsubsection{Nonhistoric features}

- None.

\subsubsection{Comparison images}

Comparison images utilizing either the original drawings or historic photographs, when juxtaposed against present-day images, are a useful tool in developing the historic "feel" of a property and how much of that historic feeling is still present today (Figure 255 and Figure 256). 
Figure 255. Main entry on the east elevation - comparison of the original drawing detail from 1966 [left] to the current condition of the bright-aluminum and plateglass entry doors, bright aluminim framed windows and insulated panels [right]

(ERDC-CERL, 2015).
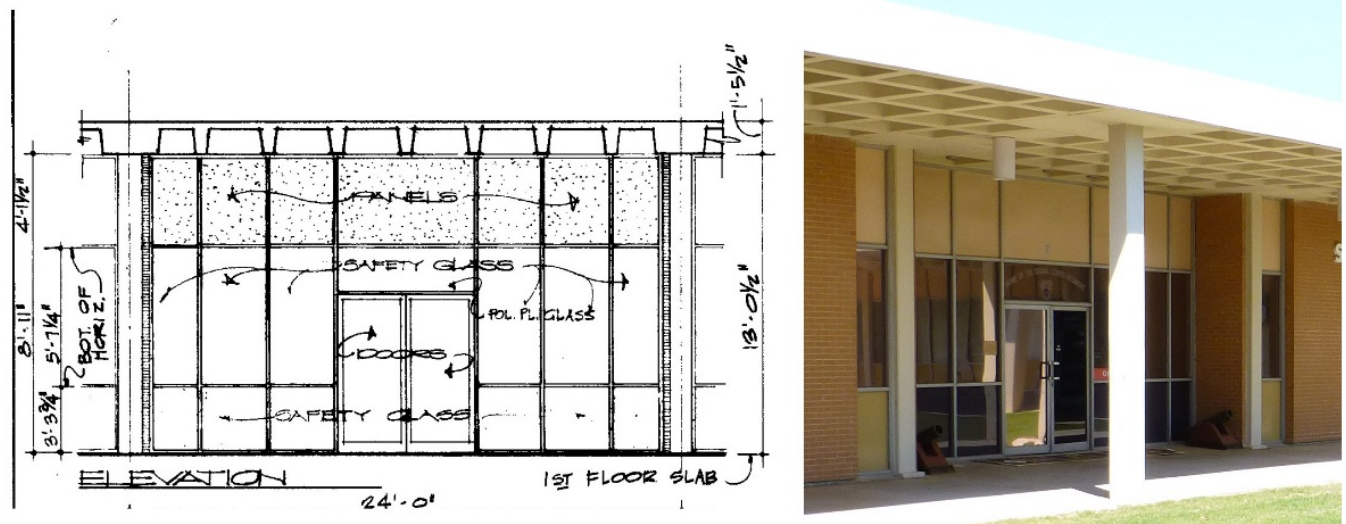

Figure 256. Ceiling-mounted light fixture - comparison of the original drawing detail from 1966 [left] to the current condition of the ceiling-mounted light fixture under the concrete waffle canopy [right] (ERDC-CERL, 2015).
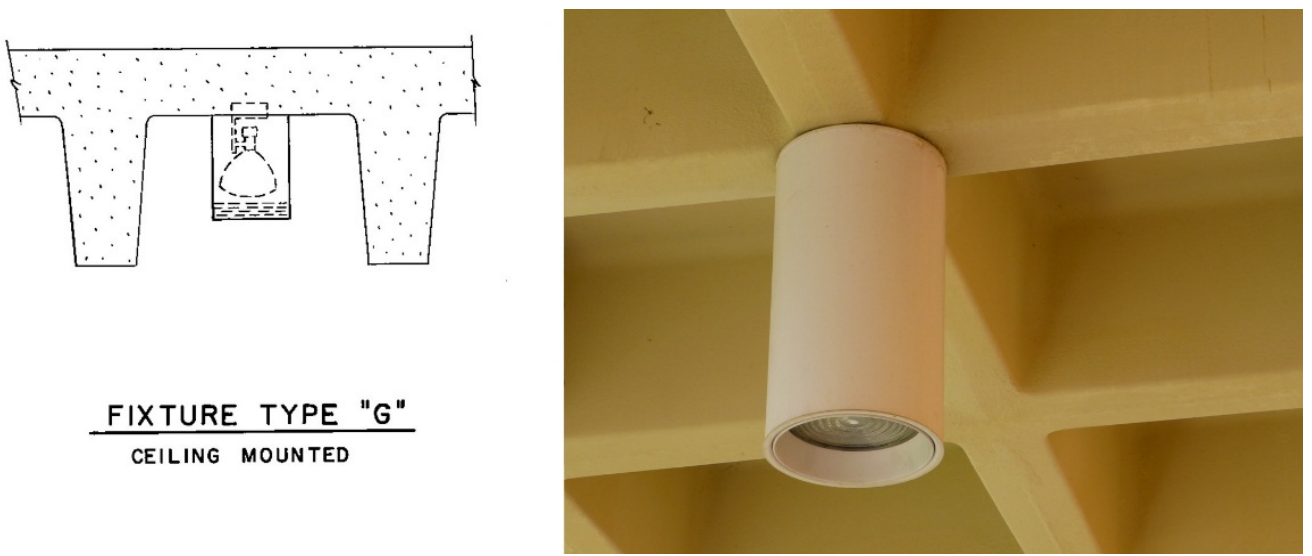

\subsubsection{Building 29808, Signal Towers (1970)}

Building 29808, Signal Towers, is a contributing feature to the Signal School Campus Historic District. The first floor has been heavily modified over the years, and the various features on the first floor do not have enough integrity or historical context for the space to be character-defining. The research team was not given access to the floors above the lobby, and the interior character-defining features are unknown for those floors, but for undertakings that effect the interior the CRM should use examples from the other interiors to guide identification and mitigation. Building 2908 was constructed in 1970 as part of Phase II for the Signal School 
headquarters building, and it was designed by Aeck Associates from Atlanta, Georgia, and Zimmerman, Evan, and Leopold Consulting Engineers from Augusta, Georgia. It is part of a large administrative complex for the Signal Corps (Building auditorium [Building 29805, Alexander /Olmsted Halls] and Building 29807 [Museum, Conrad Hall]). Buildings 29805, 29807 , and 29808 are all part of this complex and a large waffle roof canopy/covered walkway connects all three buildings together. Building 29808 is a large rectangular, eleven-story building with a basement. The first floor is larger in footprint than the upper floors. The basement is accessible from the north side of the building, where poured concrete retaining walls and pavement provide a loading area. The service doors at the basement level are paired steel doors, and they open up to an elevated loading dock. The main entrance is on the south side of the building, facing the landscaped courtyard with brick plaza and Buildings 29805 and 29807. The main entry is on the south side of the Building 29808. The entry consists of two sets of bright-aluminum and plate-glass doors, flanked on either side by plate-glass sidelights and above with transoms, all of which are framed in bright-aluminum. Insulated panels are located at the top and bottom of the transom and sidelights. On either side of the entry bay are two groups of eight fixed-pane windows sandwiched between insulated panels and set within bright-aluminum framing. On the north side, there are two sets of bright-aluminum and plate-glass entry doors. One set is placed within a group of two windows, while the other set is placed within a group of eight windows. Insulated panels are located above and below these fixed panes. Other window groups on the first floor include groups of four and seven bright-aluminum fixed-pane windows with a single entry plate-glass door. All of the windows on the first floor are fixedpane sandwiched between insulated panels and set into bright-aluminum framing. The first floor has the large waffle roof canopy/covered walkway surrounding it. The canopy is supported by concrete columns. Metal handrails encompass the outside part of the covered walkway on the north, east, and west sides. The second floor has one original window remaining on the north side of the building next to an original door. All other windows have been replaced on the building with anodized-bronze aluminum one-over-one windows. The second-floor windows are set into the elevation with the seven floors projecting out from the main structure; this treatment is similar to the floor plan of Building 29807 with the corners cut out. The windows on floors three through nine are ribbon windows. There are three sets of five anodized-bronze aluminum one-over-one windows. These sets are separated from each other by double columns of 
bricks that extend out from the concrete structure. The tenth floor windows are set back again from the extending bays, providing a balcony space. The windows on the tenth floor windows are also anodized-bronze aluminum one-over-one windows. A large concrete canopy tops the tenth floor with the words "SIGNAL TOWERS" on the south elevation of the canopy. A rectangular service core rises above the concrete canopy (Figure 257-Figure 267).

Figure 257. Signal School Campus map, with Building 29808, Signal Towers highlighted in red, 2015 (Fort Gordon DPW, modified by ERDC-CERL).

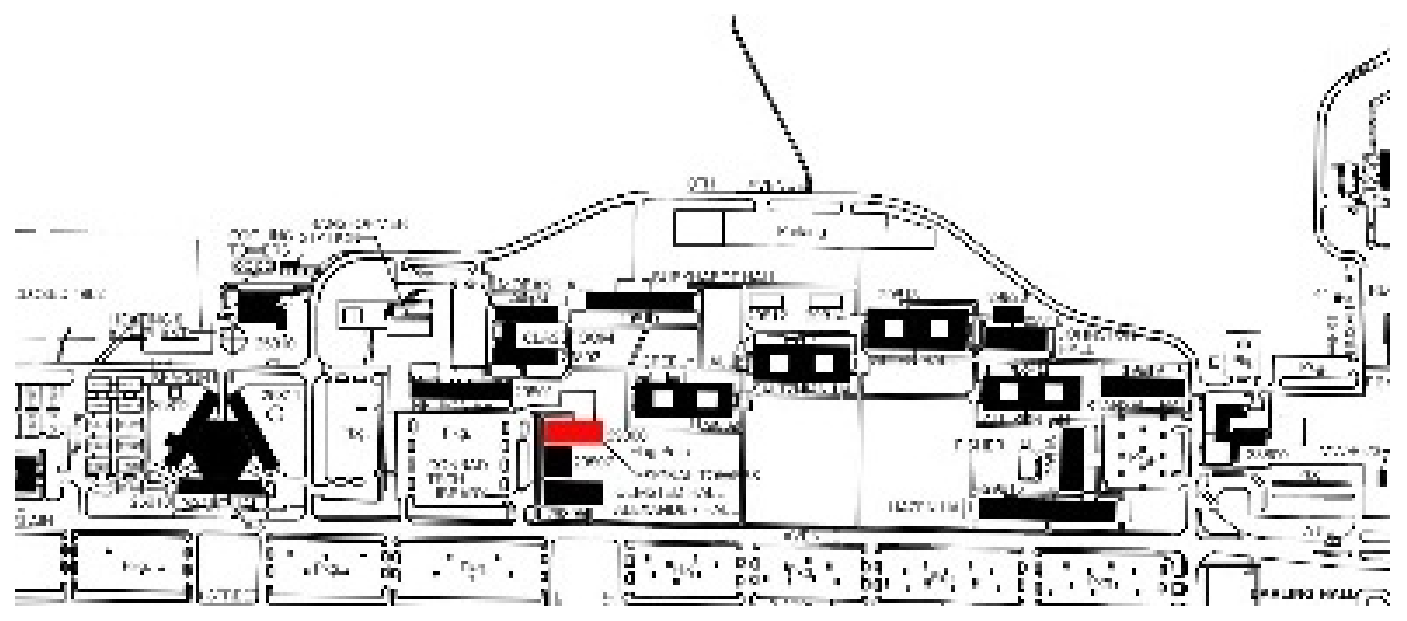


Figure 258. Southeast oblique of Building 29808, Signal Towers (ERDC-CERL, 2015).

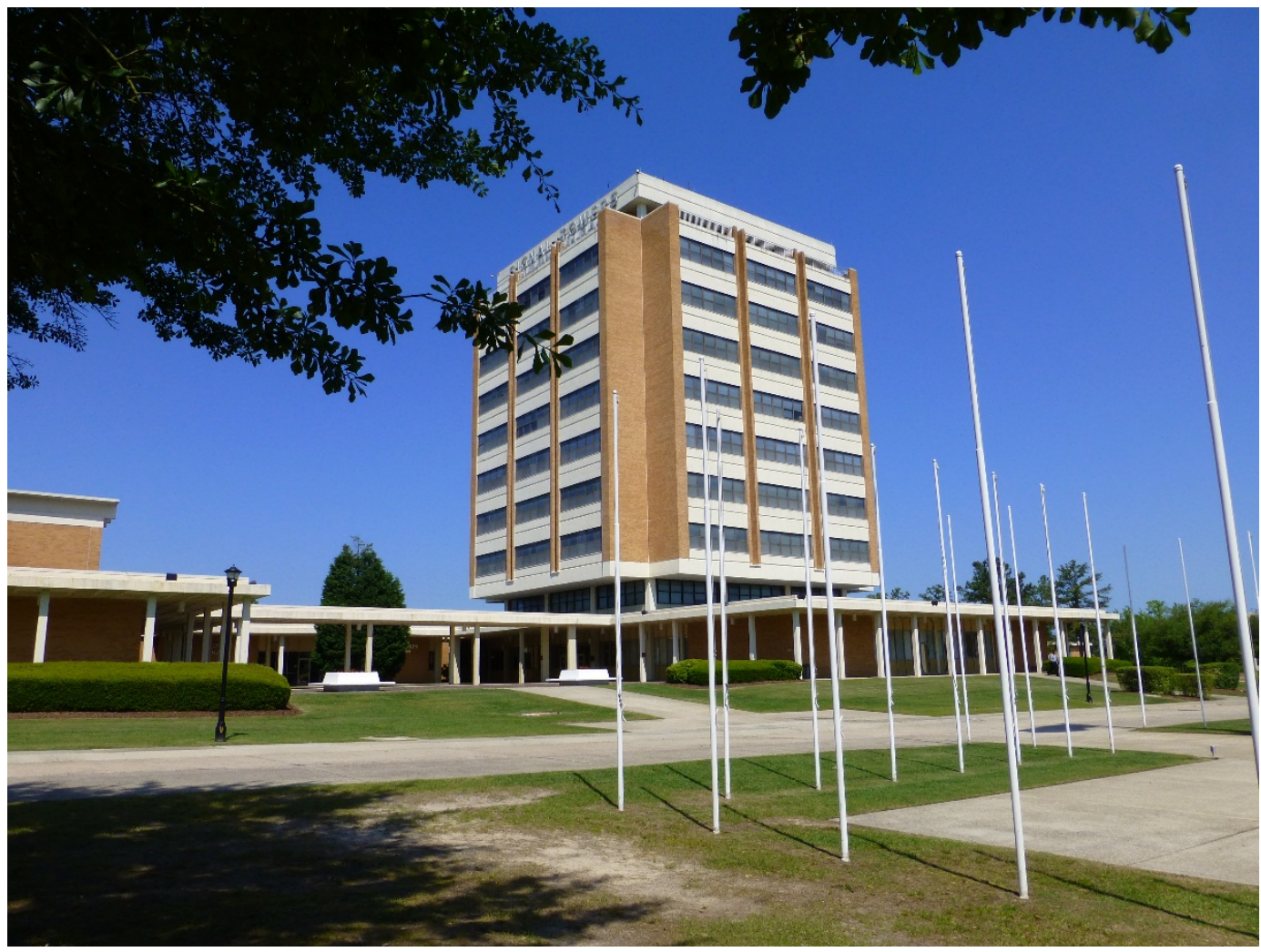

Figure 259. West elevation of Building 29808, Signal Towers (ERDC-CERL, 2015).

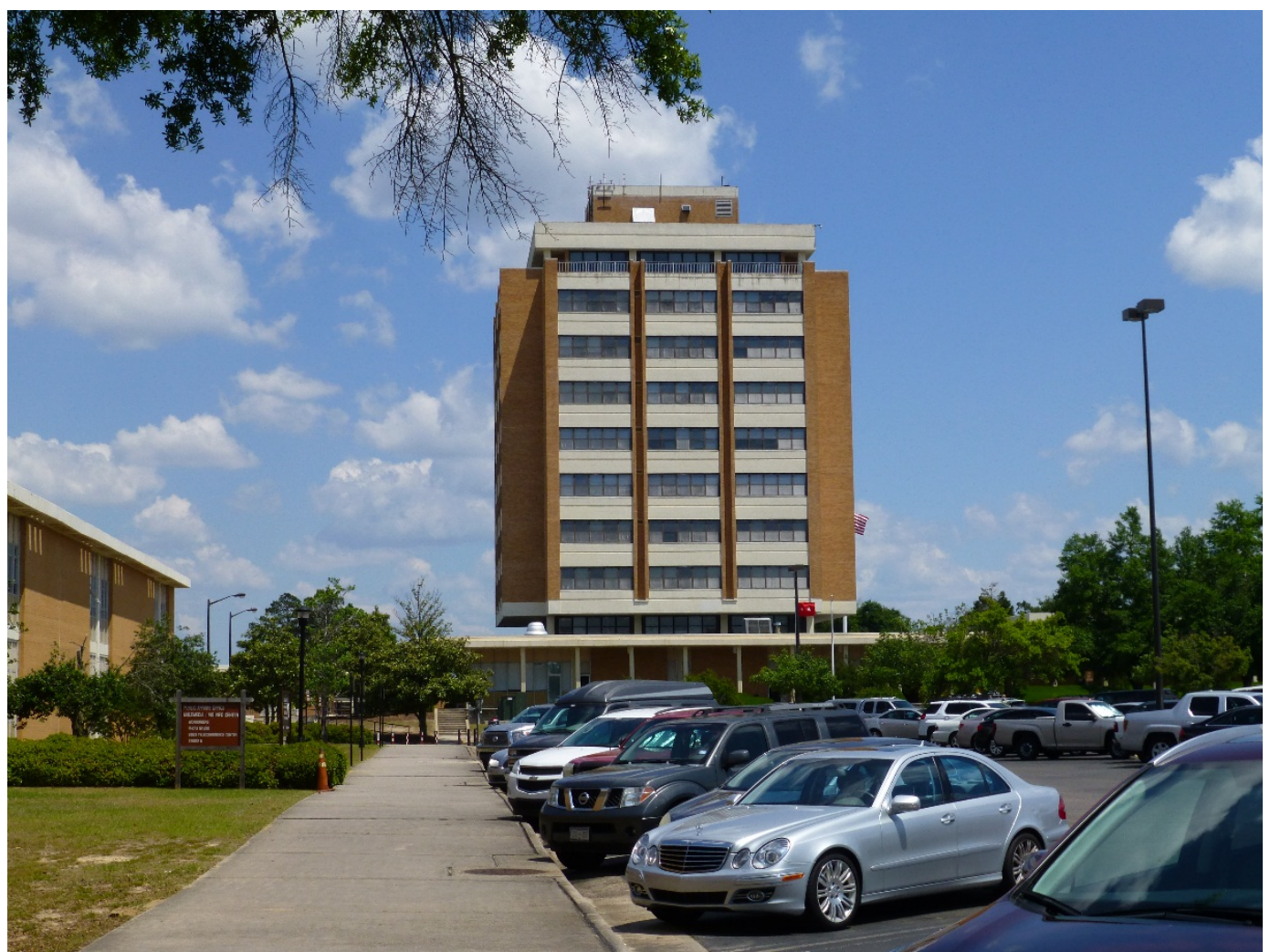


Figure 260. Brick plaza connects Buildings 29805, 29807, and 29808 (ERDC-CERL, 2015).

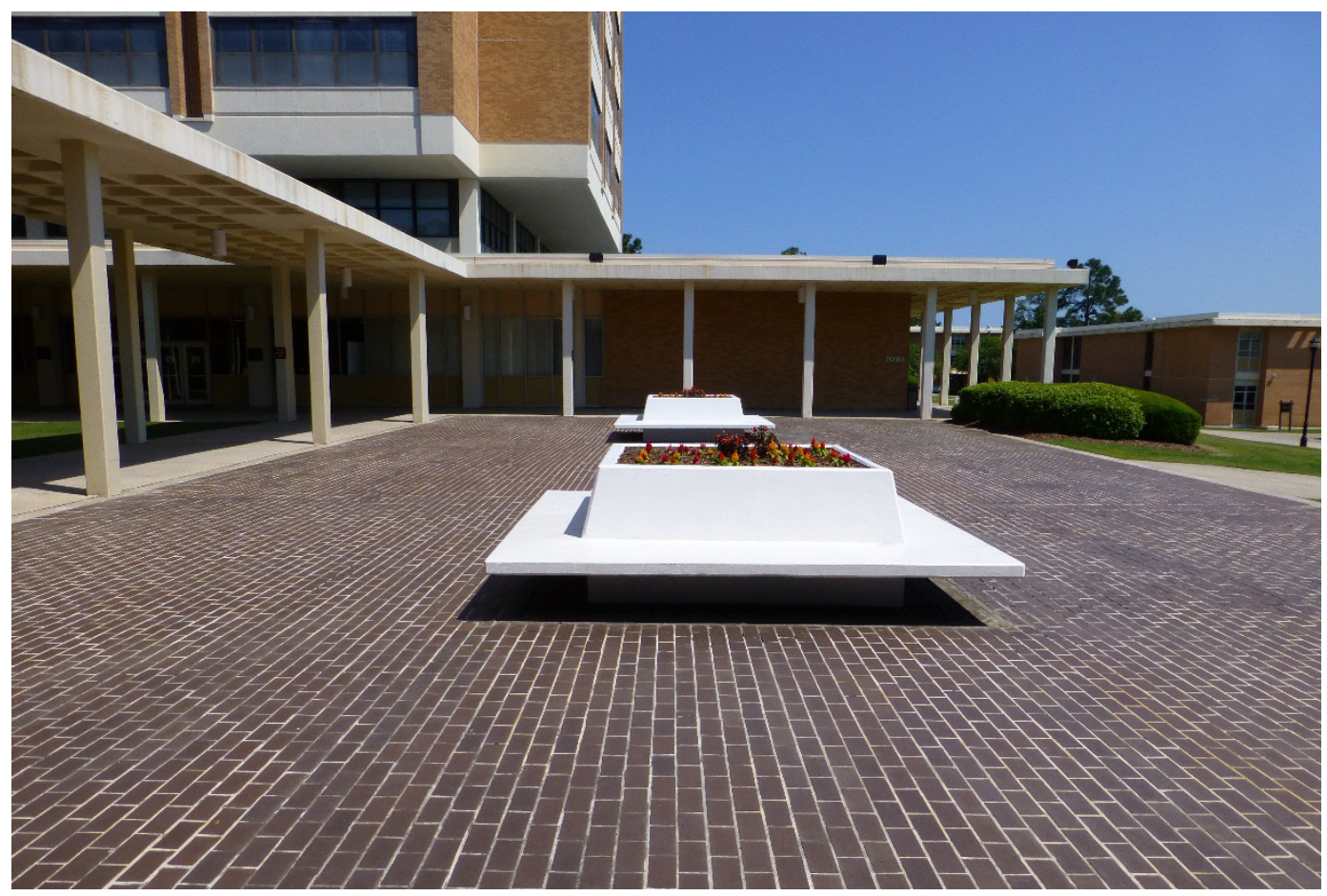

Figure 261. First-floor concrete waffle canopy structure that surrounds Building 29808, Signal Towers, and connects it to Buildings 29805 and 29807 (ERDC-CERL, 2015).

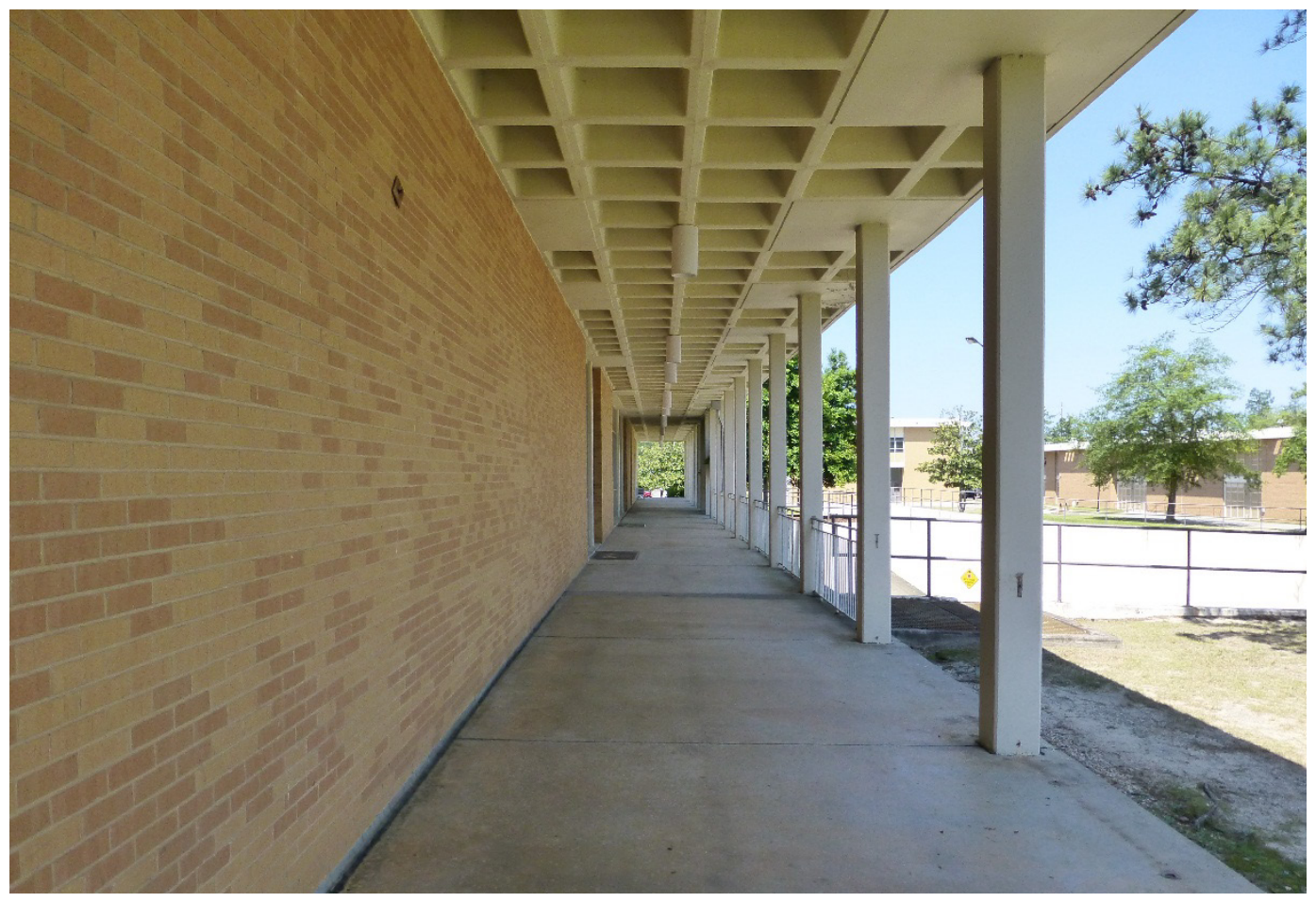


Figure 262. Basement level and loading area on the north side of Building 29808, Signal Towers (ERDC-CERL, 2015).

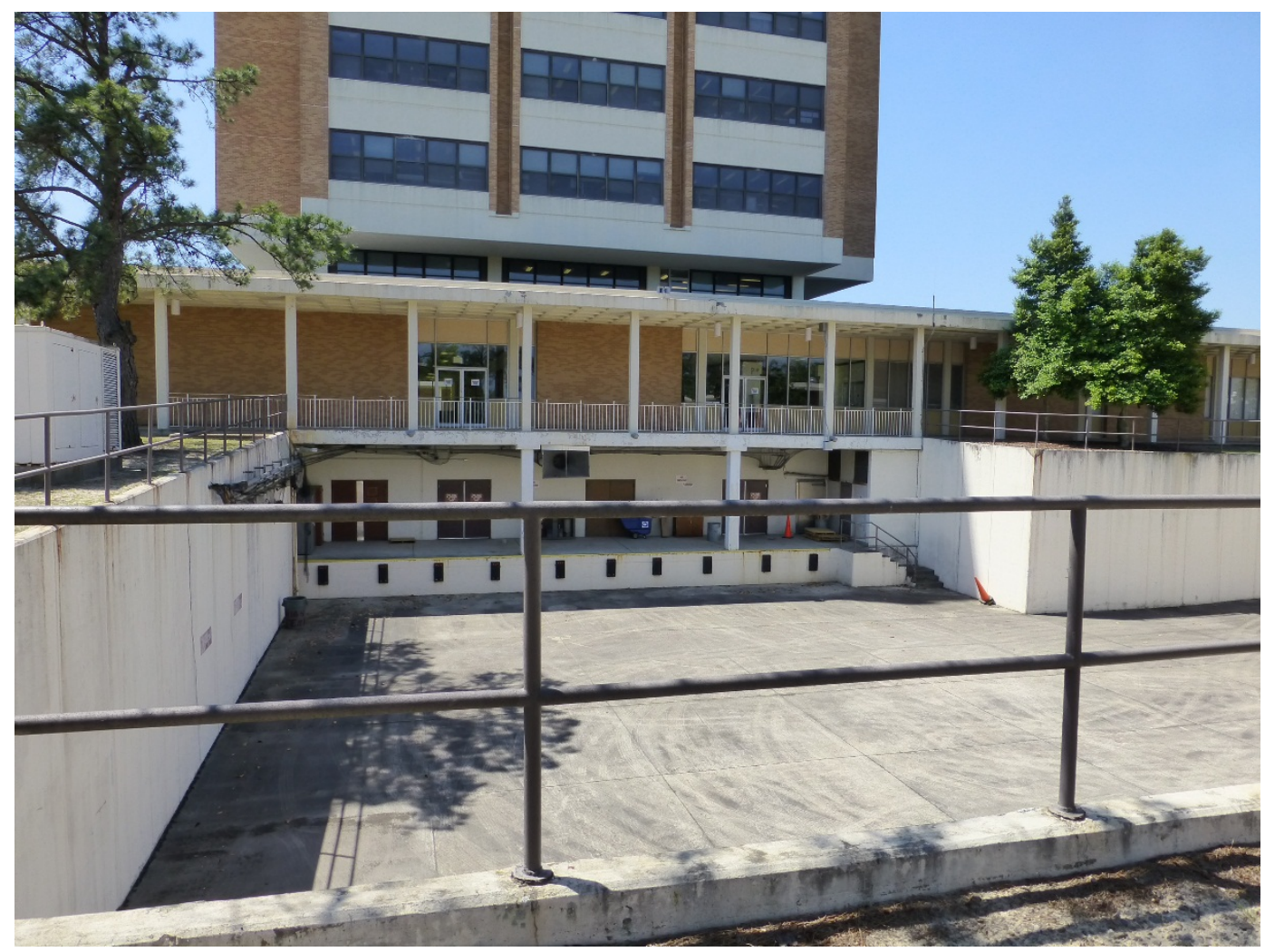


Figure 263. Building 29808, Signal Towers, April 1978

(National Archives at College Park, MD).

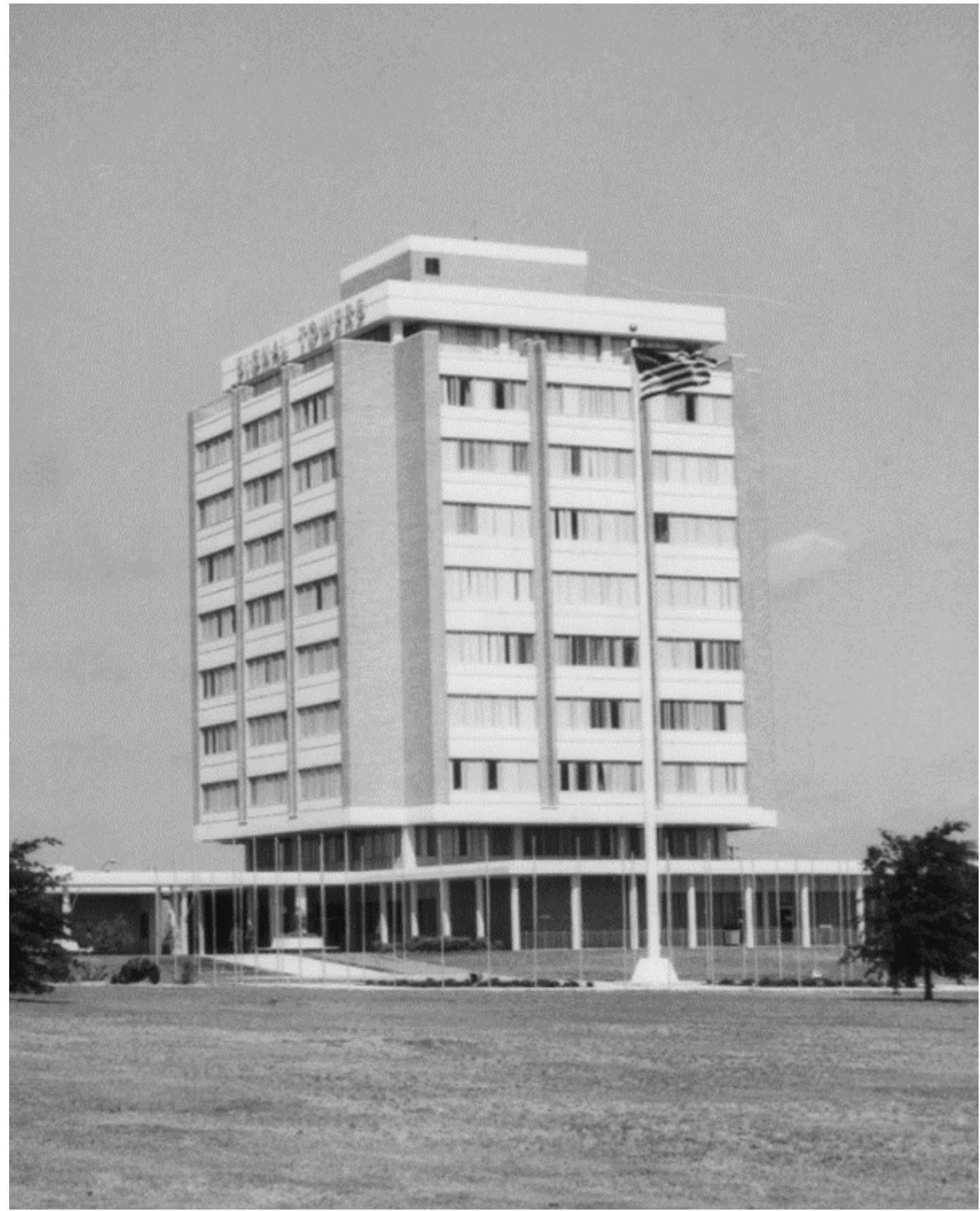


Figure 264. First-floor plan for Building 29808, Signal Towers, 1966 (Fort Gordon DPW).

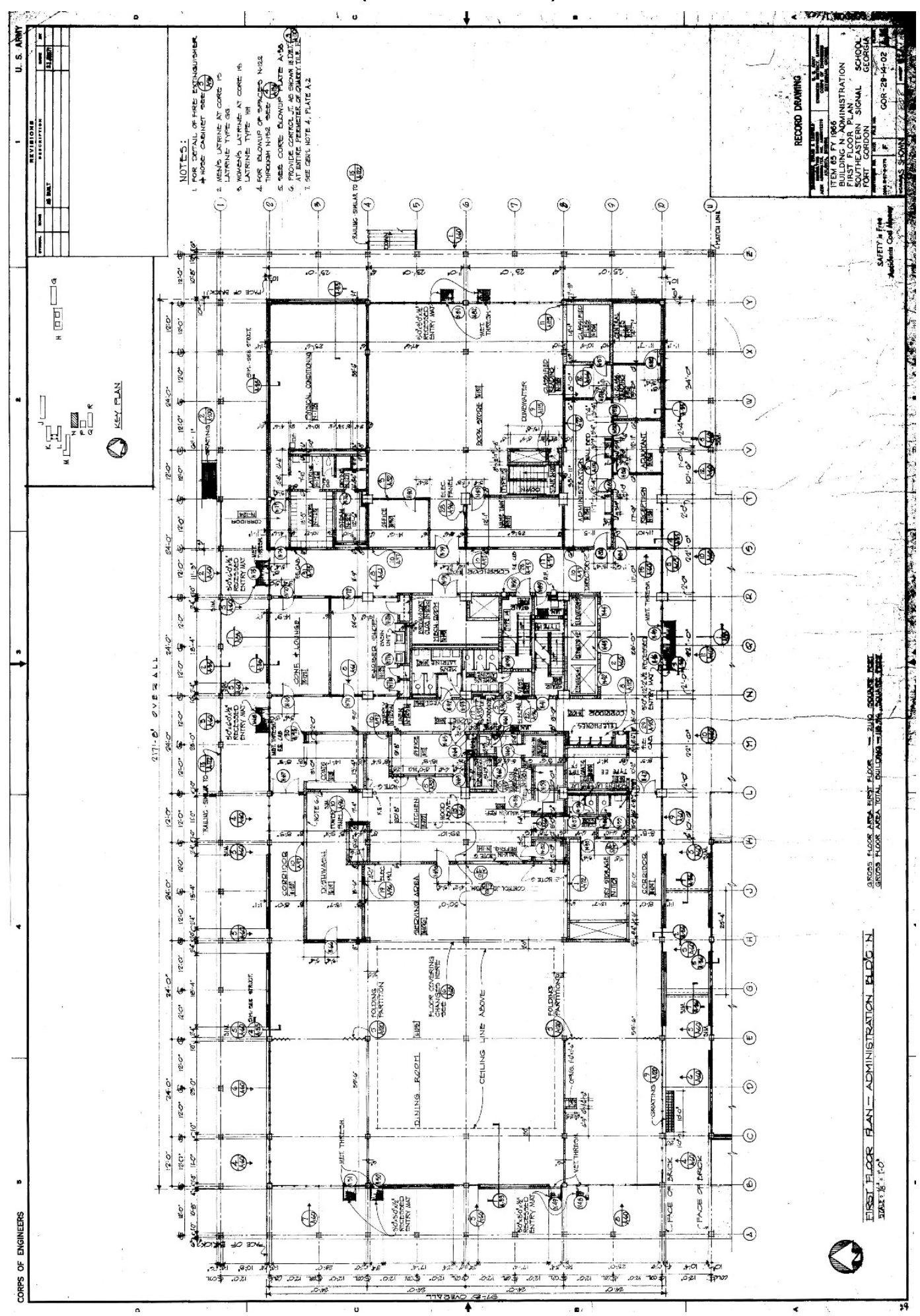


Figure 265. Detail elevations and plans for Building 29808, Signal Towers, 1966

(Fort Gordon DPW).

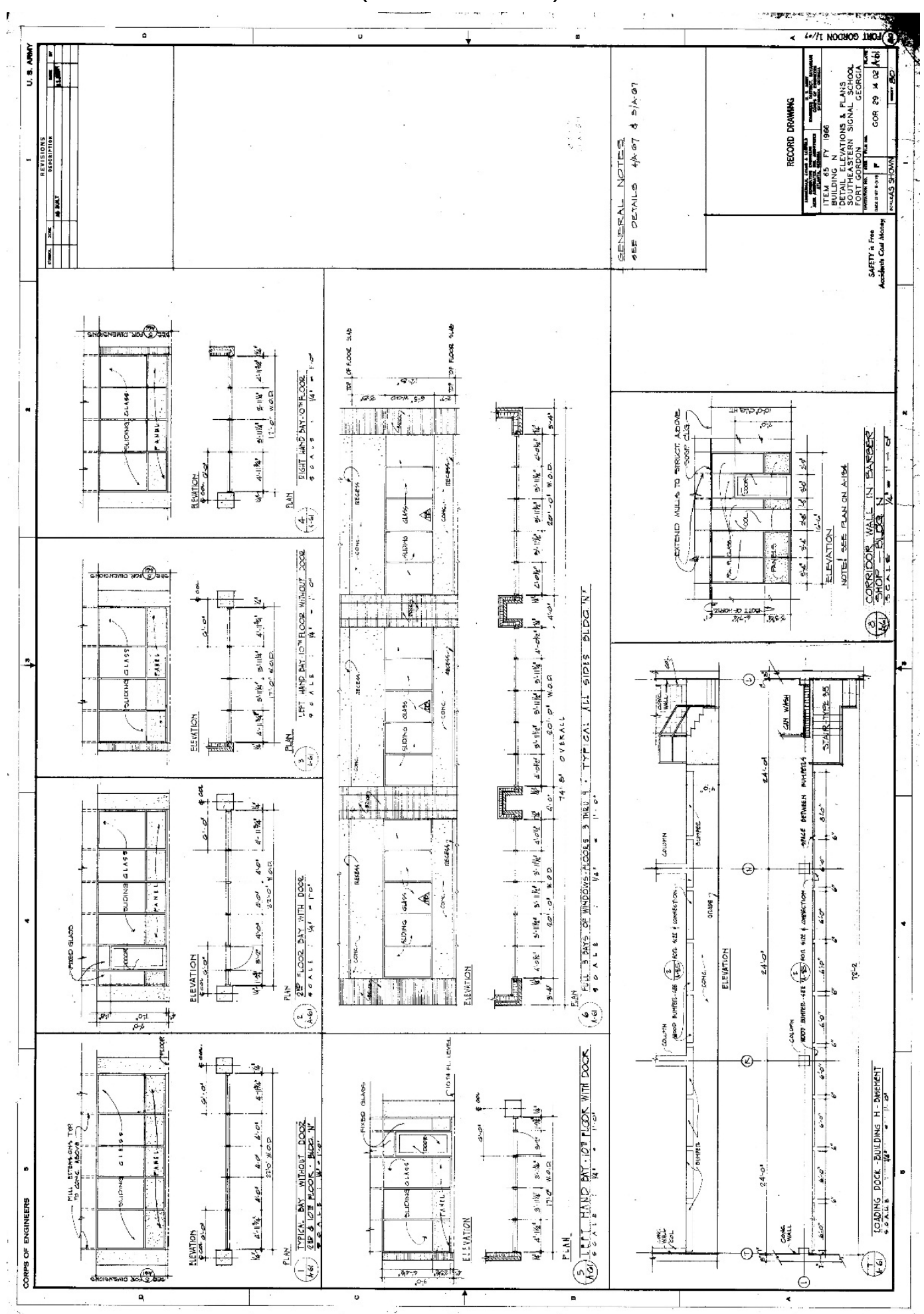


Figure 266. Door and window elevation details for Building 29808, Signal Towers, 1966 (Fort Gordon DPW).

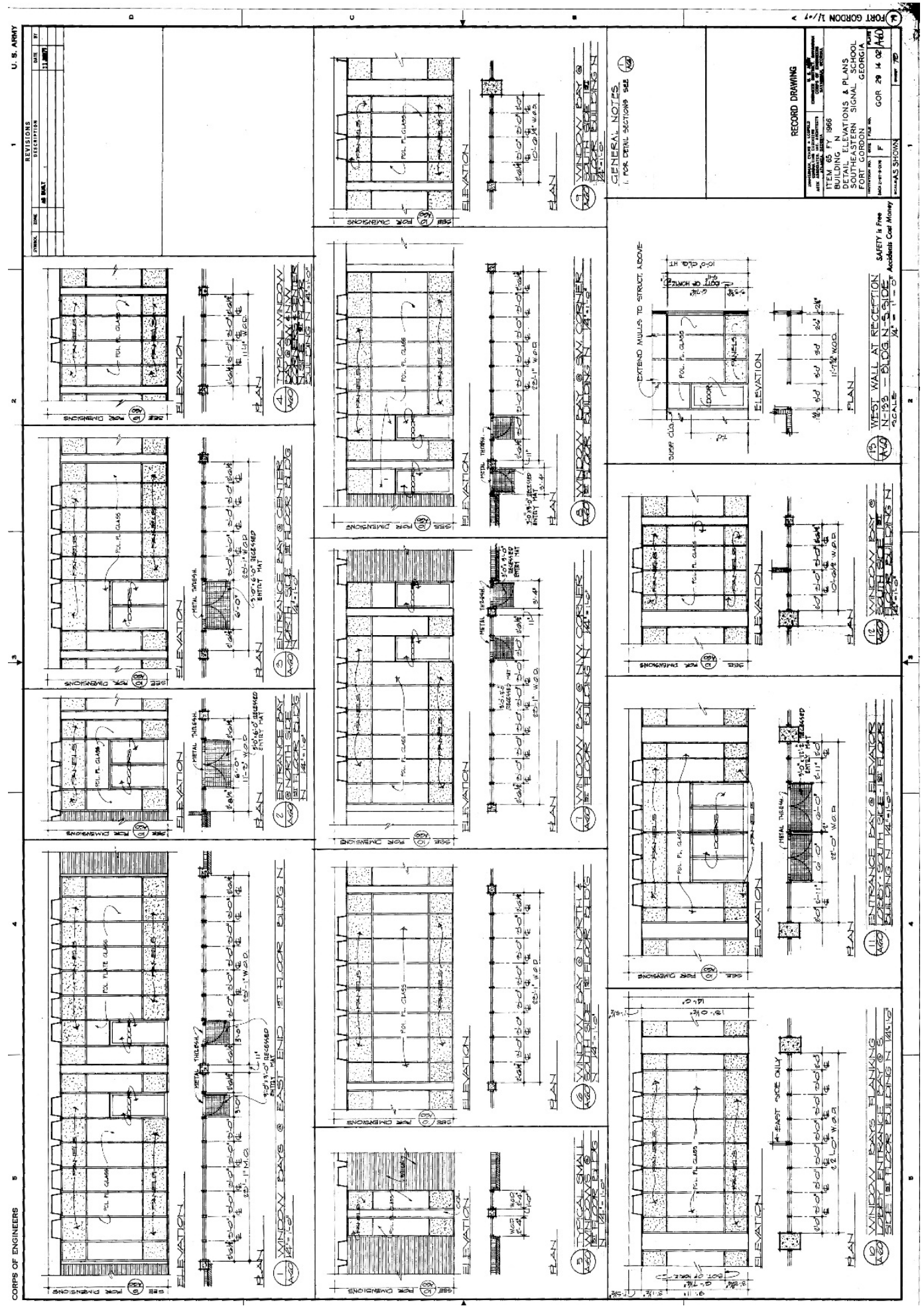


Figure 267. Door and window schedule for Building 29808, Signal Towers, 1966 (Fort Gordon DPW).

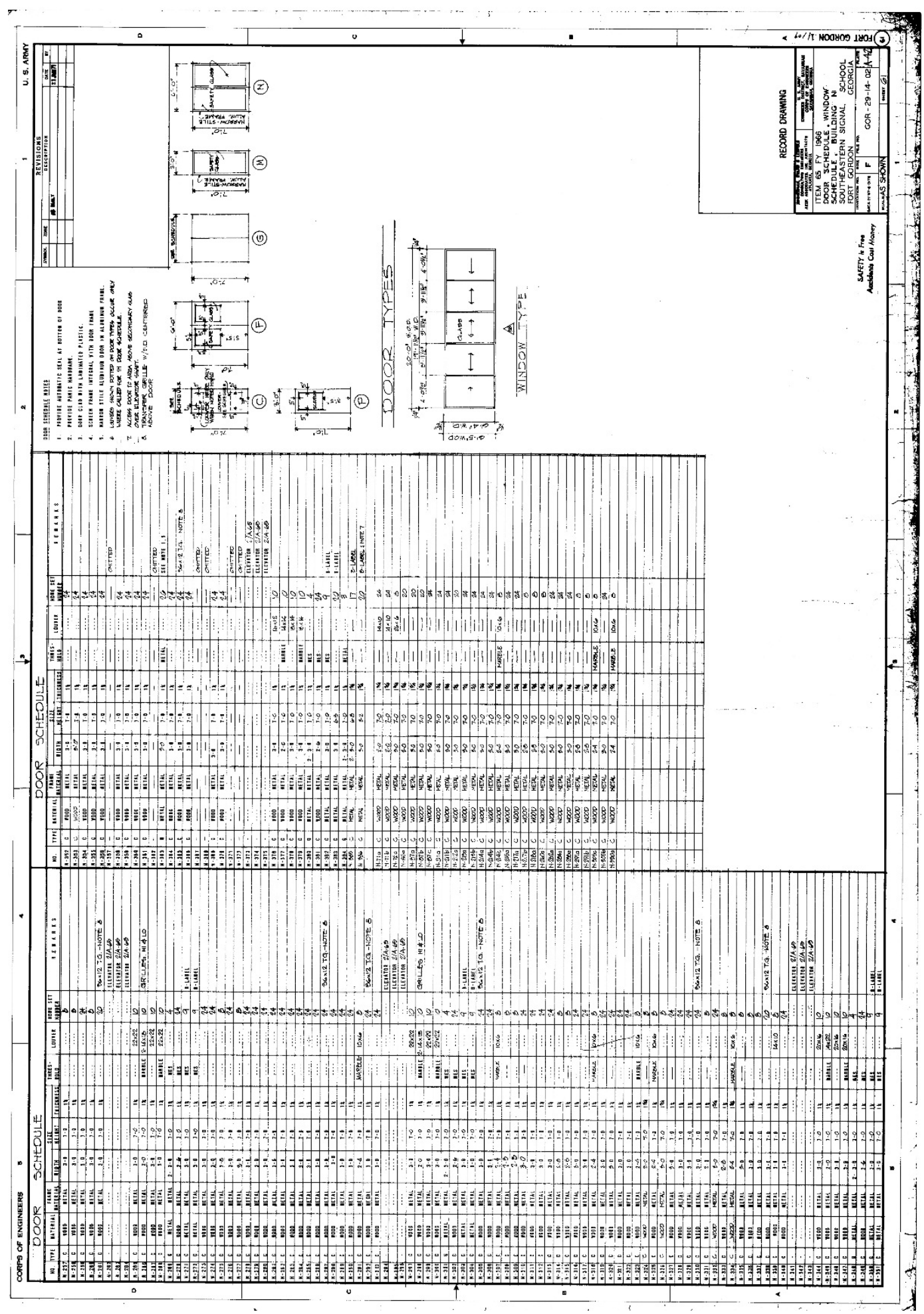




\subsubsection{Character-defining features}

Repair, renovation, and replacement of Building 29808, Signal Towers must be coordinated with the GA SHPO (Table 9).

\section{Exterior:}

- Overall massing

- Footprint

- Roof shape

- Relationship to other Signal School Campus buildings

- Relationship to adjacent Buildings 29805 and 29807

- Brick veneer

- Exposed concrete structure framing window and door openings

- Flat concrete waffle canopy surrounding building and connecting it to adjacent buildings

- Window pattern

- Bright-aluminum sash windows with fixed panes and insulted panel inserts

- Bright-aluminum and plate-glass entry doors

- Ceiling-mounted bronze, cylinder light fixtures

- Metal handrails

- Lettering

- Landscaping

- Plaza

\section{Interior:}

The interior does not have any character-defining features on the first floor (the research team was not given access to the upper floors). The lobby does have some original light fixtures, but not in any consistent manner. 
Table 9. Images of character-defining features of Building 29808, Signal Towers (ERDC-CERL, 2015).

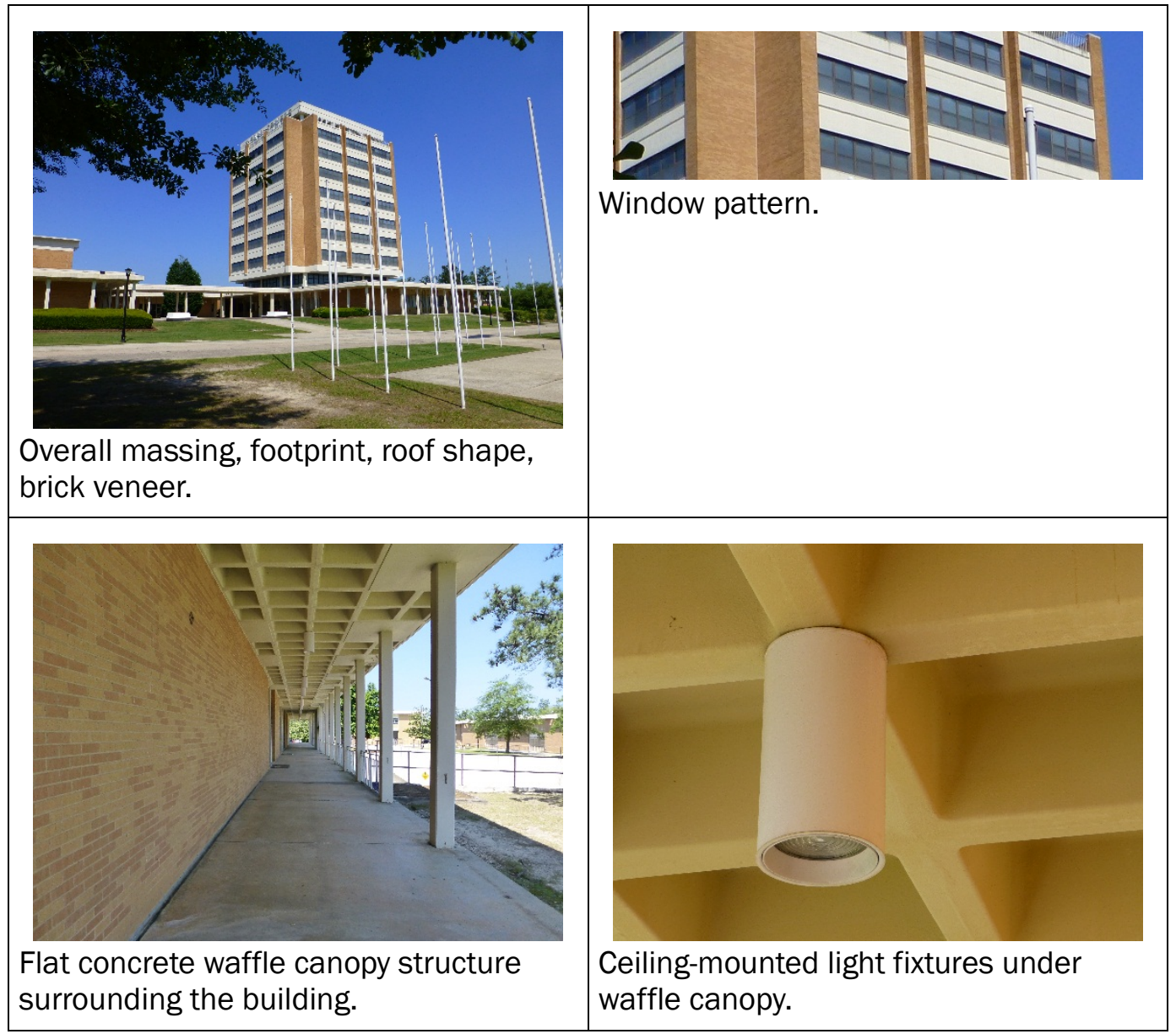



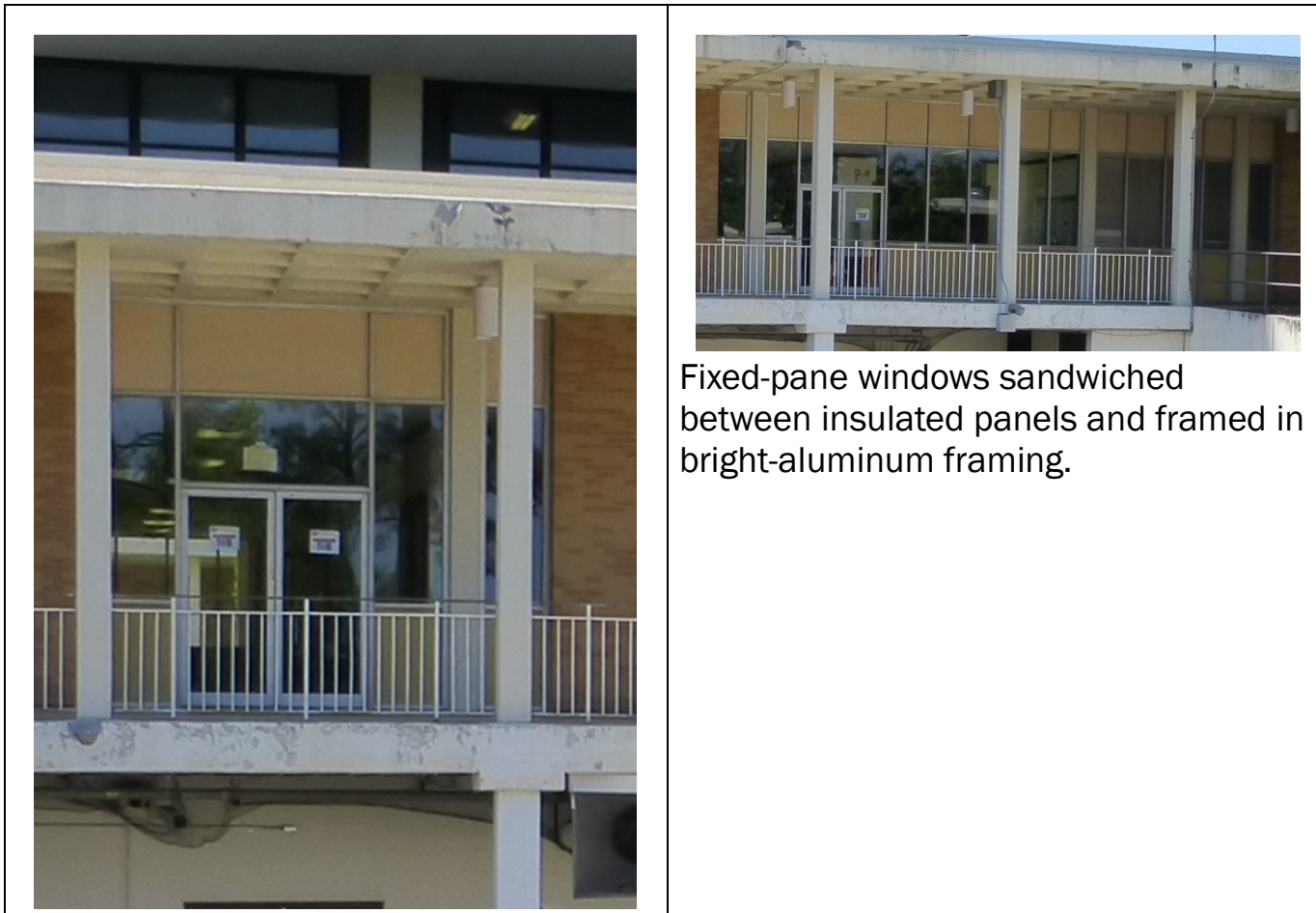

Fixed-pane windows sandwiched between insulated panels and framed in bright-aluminum framing.

Bright alumunium and plate-glass entry doors.

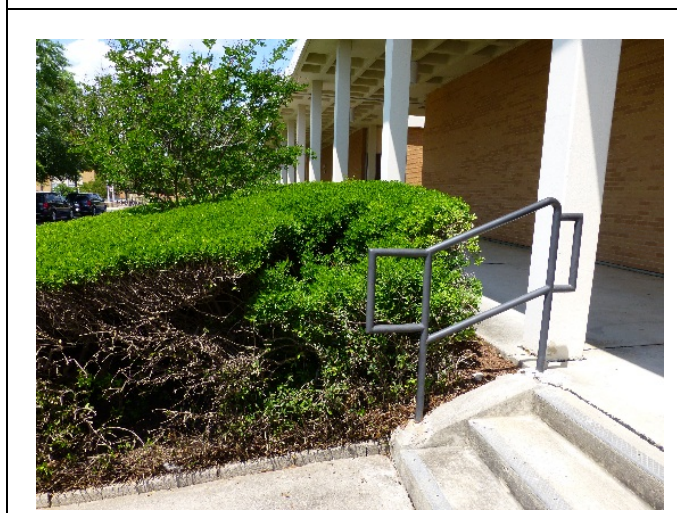

Landscaping surrounding the administration complex and handrails.
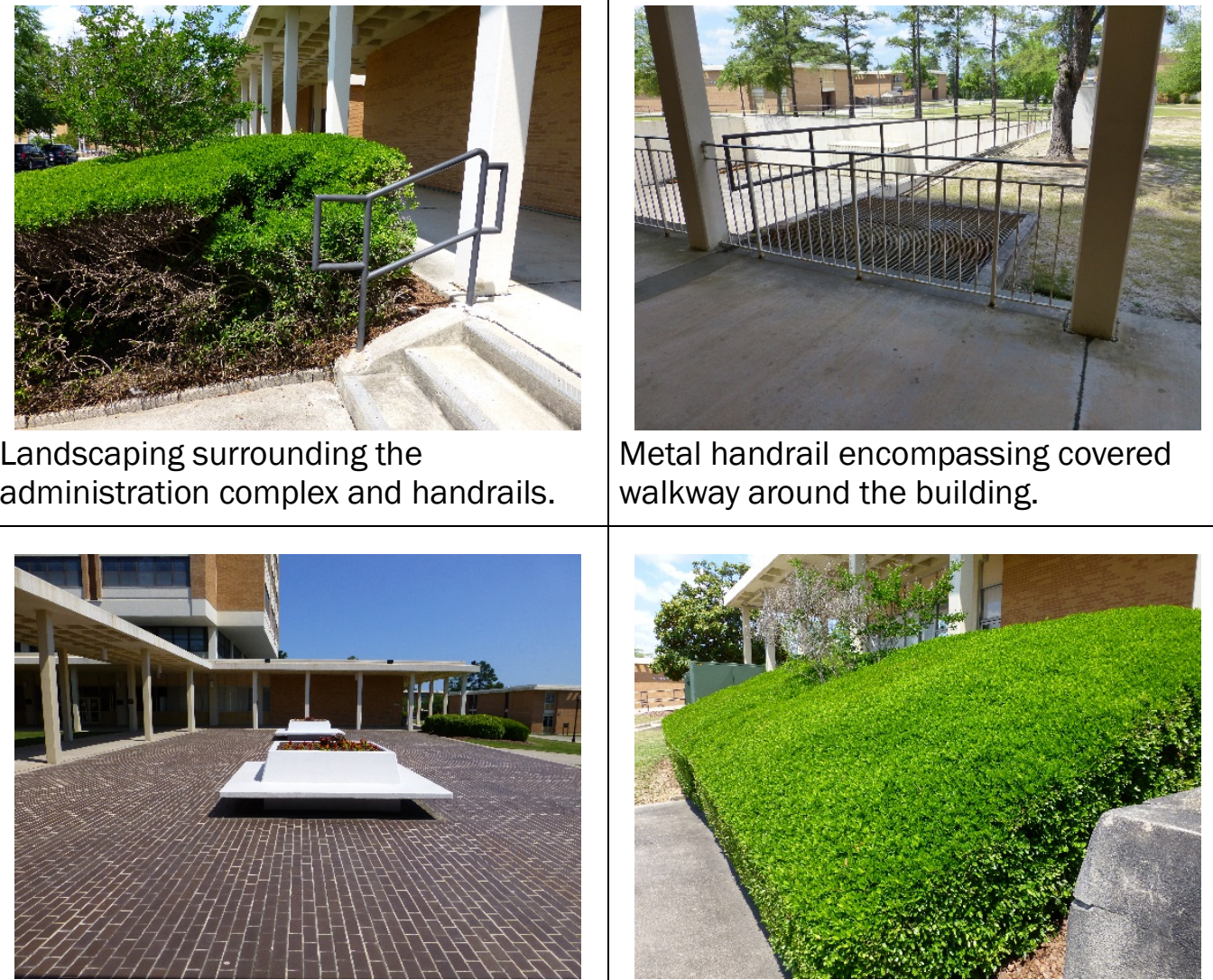

Metal handrail encompassing covered walkway around the building.

Brick plaza connecting Buildings 29805, 29807, and 29808.

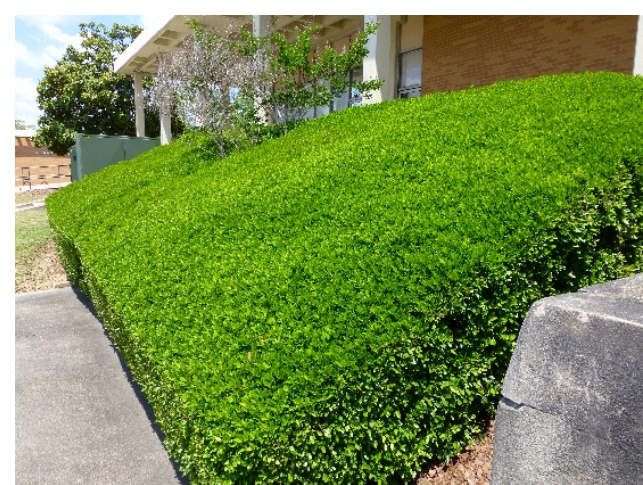

Landscaping around the administration complex. 


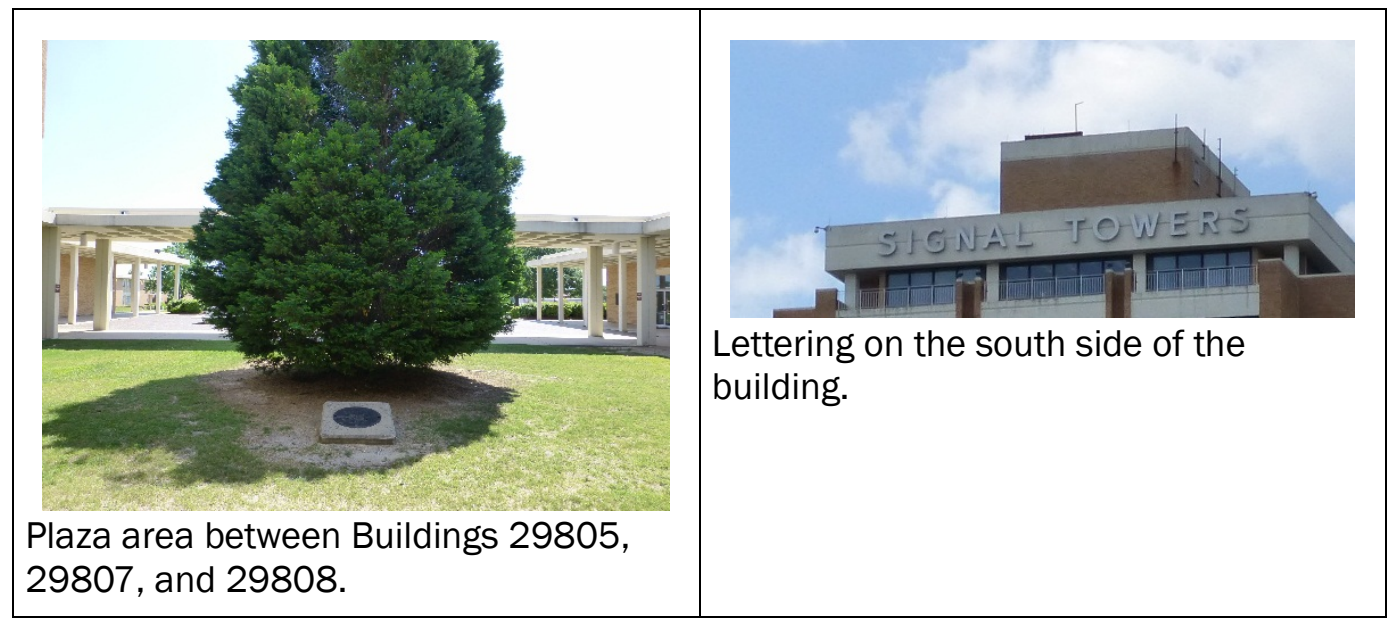

\subsubsection{Character-defining features that have been removed}

Listed below are character-defining features of Building 29808, Signal Towers, that have been removed or replaced over the years; as future renovations occur, these need to be replaced with elements that replicate the original character-defining features of the building. The historic photograph will guide this process in coordination with the GA SHPO.

- Windows - original bright-aluminum sash windows on floors 2-11 have been removed and replaced with one-over-one anodized-bronze aluminum windows/

- Metal handrails - some have been removed around the perimeter of the covered walkway.

- Most of the original features in the lobby design have been removed over the years.

\subsubsection{Nonhistoric features}

\section{- None.}

\subsubsection{Comparison images}

Comparison images utilizing either the original drawings or historic photographs, when juxtaposed against present-day images, are a useful tool in developing the historic "feel" of a property and how much of that historic feeling is still present today. Figure 271 is an example of an original light fixture, but there are not enough of these left to have integrity of the original design (Figure 268-Figure 271). 
Figure 268. Building 29808, Signal Towers, comparison of the original windows [left] and the replacement windows [right] (Signal Corps Historian Office).

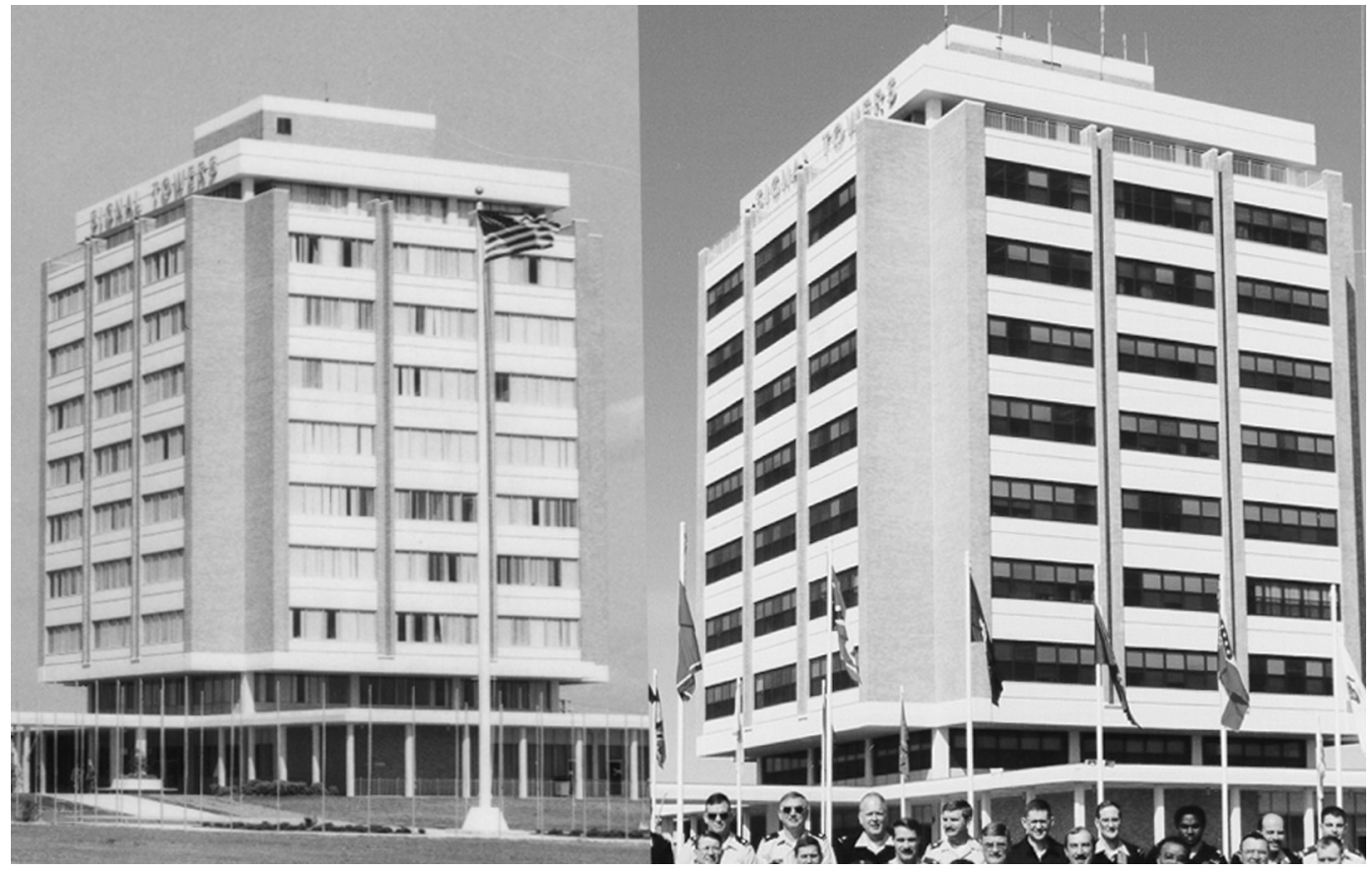

Figure 269. Entry bay for Building 29808, comparison of the original drawing detail from 1966 [left] to the current condition of the bright-aluminum and plate-glass doors and windows with insulated panels [right] (ERDC-CERL, 2015).
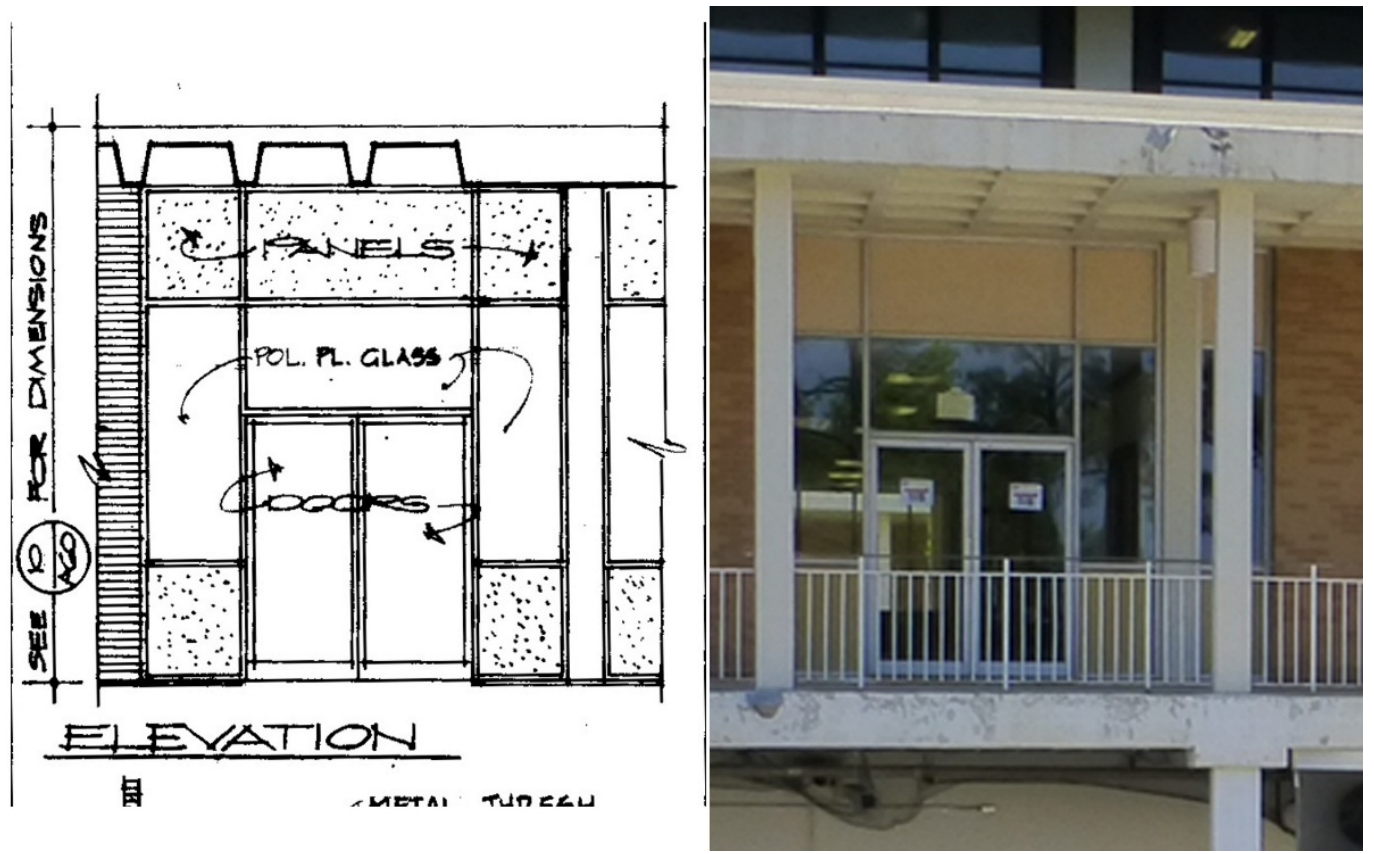
Figure 270. Ceiling-mounted light fixture - comparison of the original drawing detail from 1966 [left] to the current condition of the ceiling-mounted light fixture under the concrete waffle canopy [right] (ERDC-CERL, 2015).
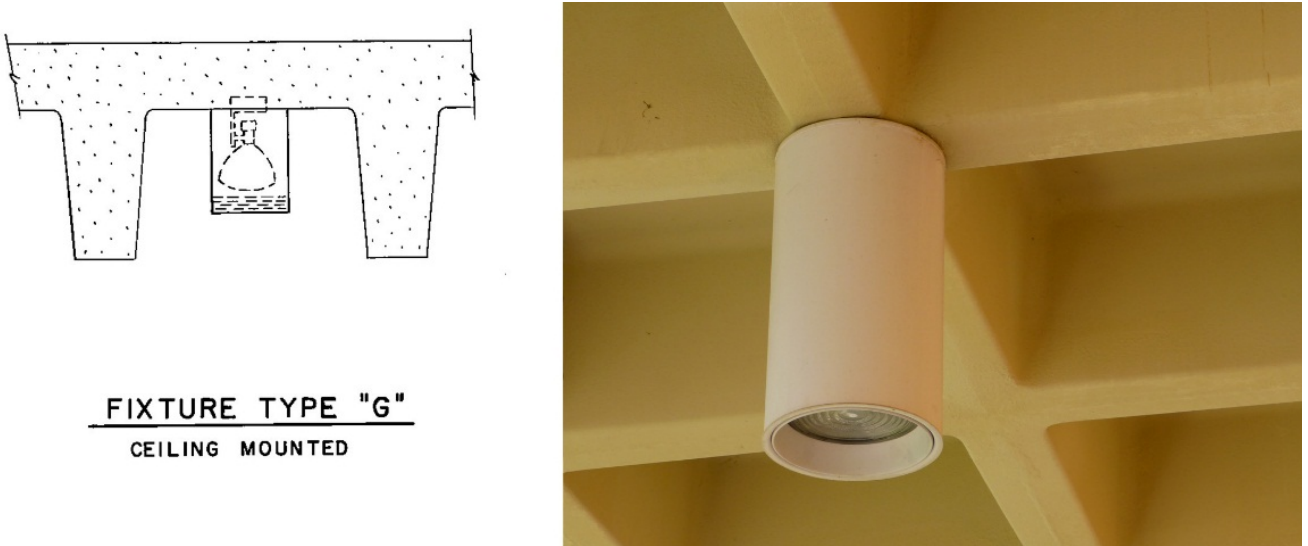

Figure 271. Wall-mounted light fixture - comparison of the original drawing detail from 1966 [left] to the current condition of the wall-mounted interior light fixture

[right] (ERDC-CERL, 2015).

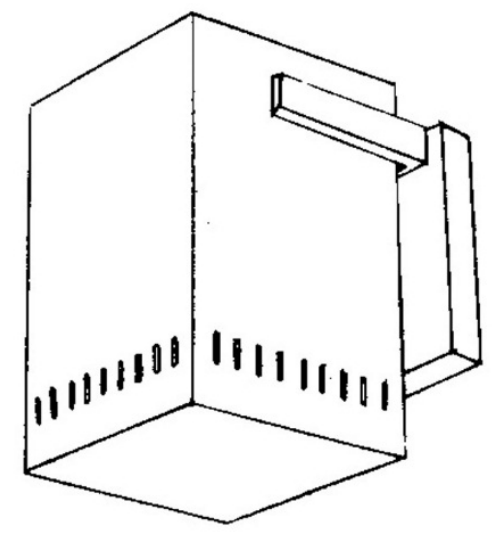

FIXTURE TYPE "AM"

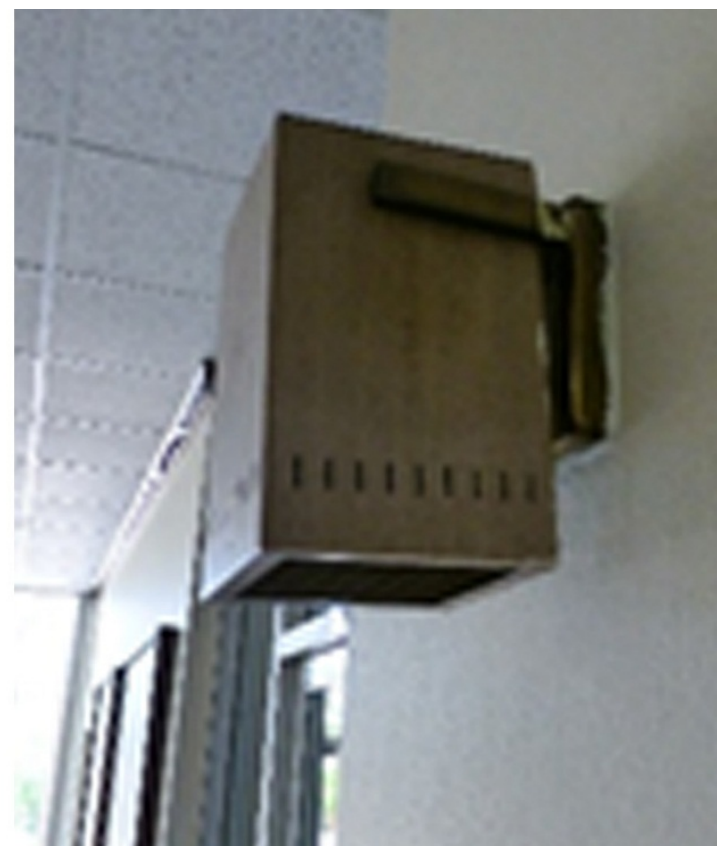

\subsubsection{Building 29809, Greely Hall (1966)}

Building 29809, Greely Hall is a contributing feature to the Signal School Campus Historic District. The interior is contributing. It was constructed in 1966 as part of Phase I construction for the campus by architect Aeck Associates from Atlanta, Georgia, and Zimmerman, Evans, and Leopold Consulting Engineers from Augusta, Georgia. It was built as a long rectilinear classroom building with two large courtyards. The building is two- 
stories high with a basement. The structure is of cast-in-place concrete columns with a waffle floor/ceiling structure. The second-floor waffle system is set within the structure, but the roof has the waffles extend out to form an overhang. Some of the waffles of the overhang have been perforated, which creates a "light pattern" on the second floor of the brick exterior walls. The window systems extend the full height of the building and are inset into the brick veneer. The window systems are composed of brightaluminum window frames that enclose insulated panels and awning-style windows. Tan-colored panels are above and below the windows. The window systems are in patterns of two, six, and seven. The window system is separated horizontally by the exposed concrete beam structural system of the building. The south elevation faces the open space of the Signal School Campus. This elevation is symmetrical and is defined by a central entry bay. A set of metal entry doors with a large pane is flanked by sidelights and a transom. A flat concrete canopy extends over the entry doors and adjacent window bay system on the first floor. Above the canopy are two bays of three windows. A bright-aluminum display case and original "GREELY HALL" lettering is to the right of the central bay. Trees flank either side of the entry bay sidewalk and shrubs are placed in front of the building. On either side of the central bay are two large bays of six windows each, with an insulated panel dividing them into groups of three. The far left and right sides of the elevation are slightly recessed and a bay of two windows is located at the corners. The entrances are on the east and west elevations consists of two entry bays. Each consists of two sets of metal doors with large panes and a large fixed-pane transom above each set of doors. Above these first-floor doors are sets of metal and plate-glass doors with a transom above each set of doors. These doors are welded closed with a steel bar across the middle. It appears bridges were meant to connect the various buildings together at the second-floor level. There is one bright-aluminum display case placed on each elevation. Basement access on the east and west is located between the main sets of doors, and the opening is protected by a perforated brick wall in the same brick as the building. On the east and west sides of the building are small landscaped brick plazas that are framed by four trees [east] and three trees [west]. The north elevation is symmetrical. There are five large window bays. The center bay is an entry bay with a set of metal doors with a large pane with transom above and five concrete panels on the first floor. A flat concrete canopy projects out above the doors and panels. Above the canopy on the second floor is a group of seven bright-aluminum three-pane fixed win- 
dows. The other four large bays consist of two groups of three windows divided by an insulated panel. The far left and right sides have a smaller twowindow bay systems and are recessed at the corners. There are two separate outside access points to the basement on the north side of the building. Poured concrete walls, concrete steps, and metal handrails indicate these points. Also on the north wall is lettering spelling out "GREELY HALL" lettering. Shrubs line the north wall perimeter (Figure 272-Figure 290).

Figure 272. Signal School Campus map, with Building 29809, Greely Hall highlighted in red, 2015 (Fort Gordon DPW, modified by ERDC-CERL).

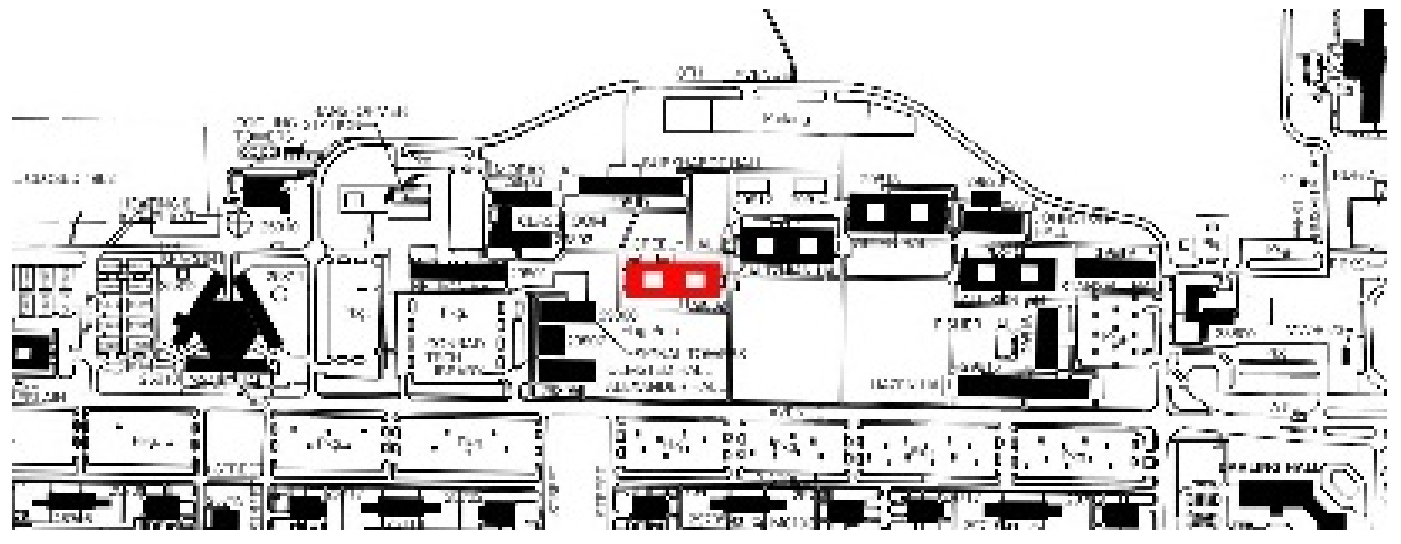

Figure 273. South elevation of Building 29809, Greely Hall (ERDC-CERL, 2015).

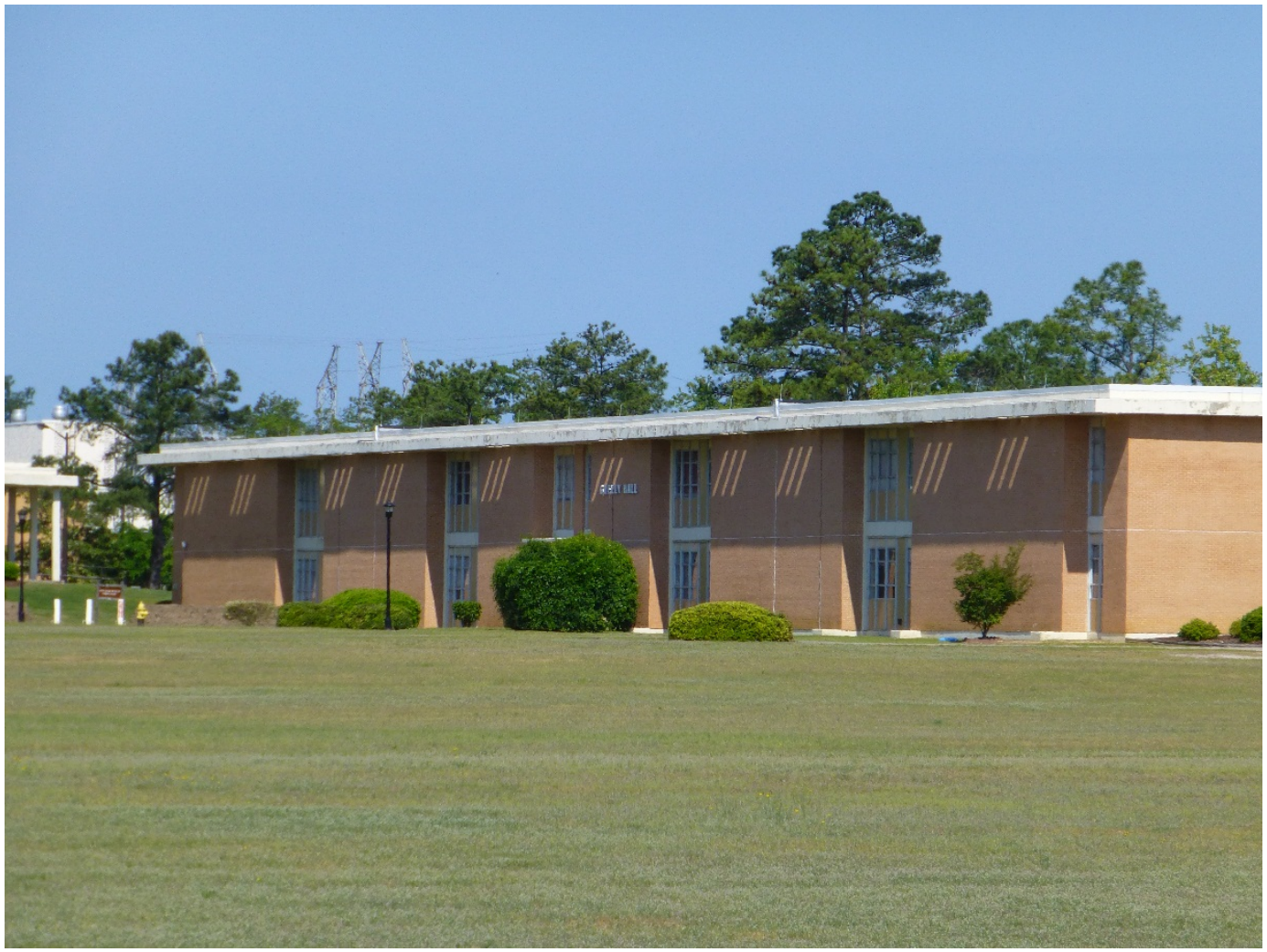


Figure 274. North elevation of Building 29809, Greely Hall (ERDC-CERL, 2015).

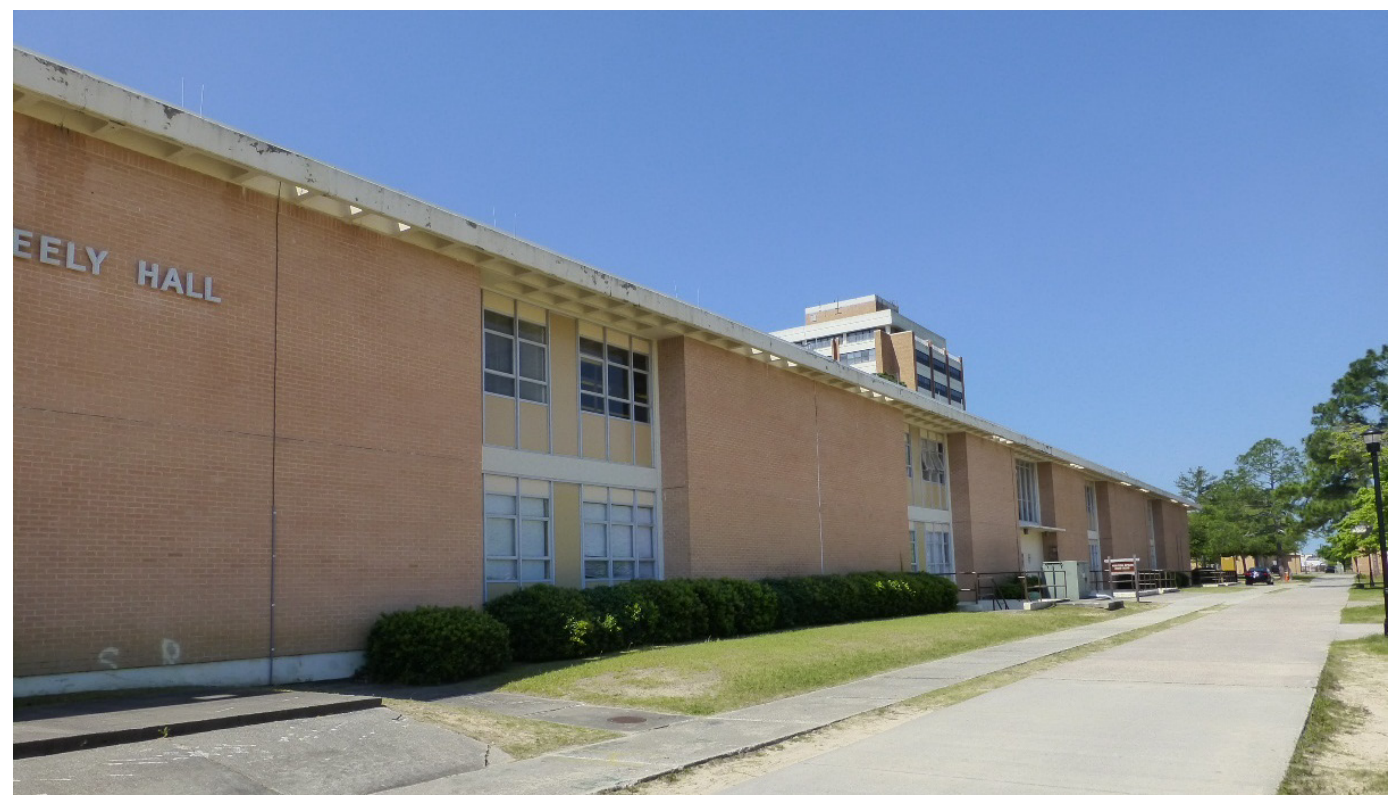

Figure 275. East elevation of Building 29809, Greely Hall (ERDC-CERL, 2015).

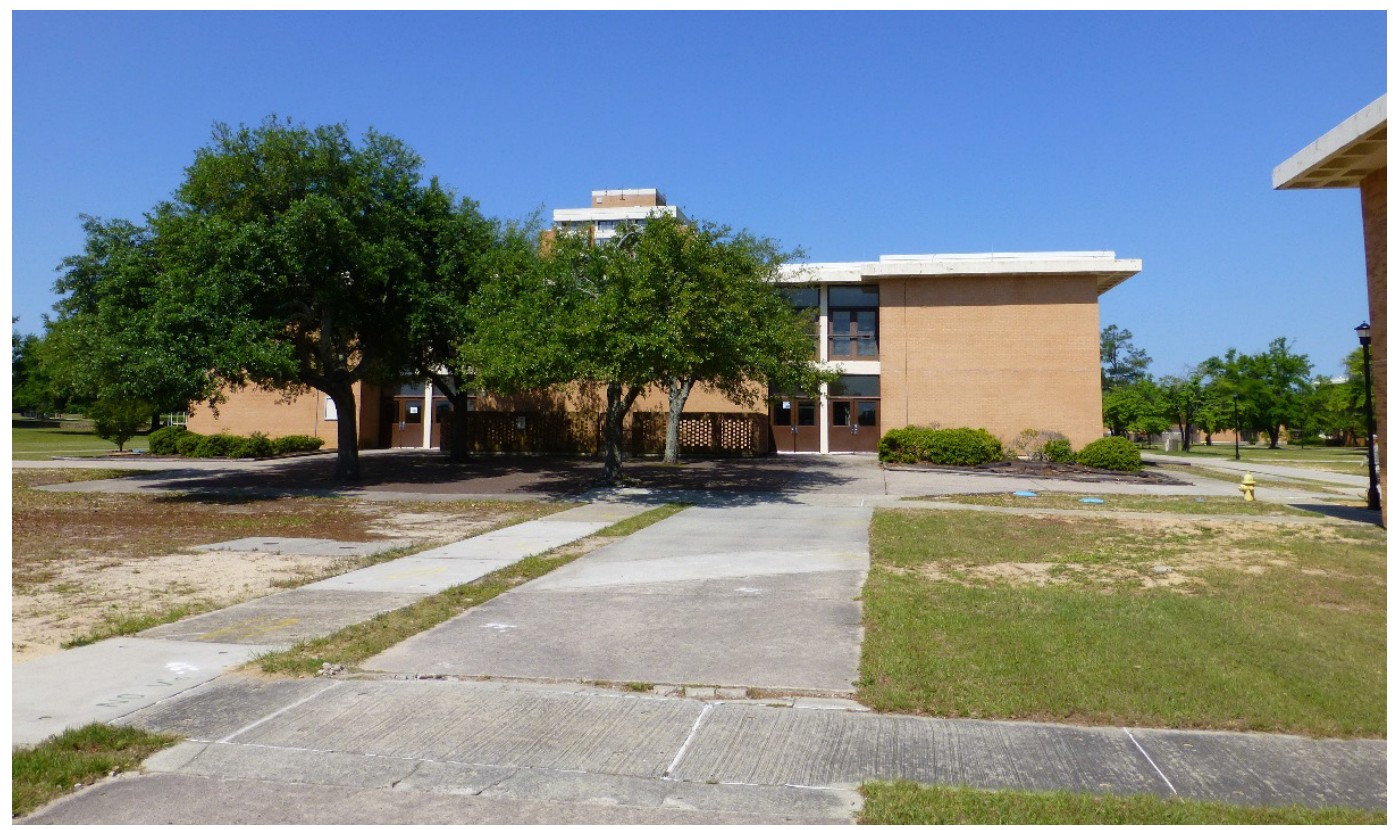


Figure 276. Building 29809, Greely Hall, one of the Signal School classrooms, December 1966 (National Archives at College Park, MD).

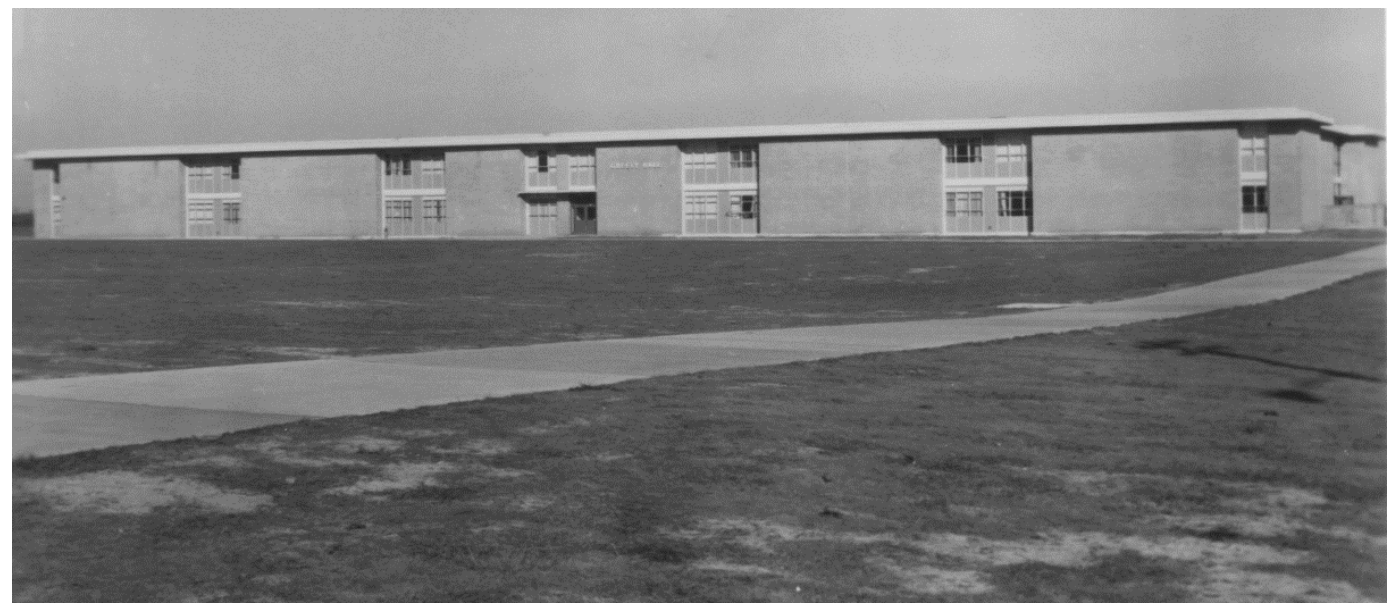

Figure 277. First-floor plan [left side] for Building 29809, Greely Hall, 1964 (Fort Gordon DPW).

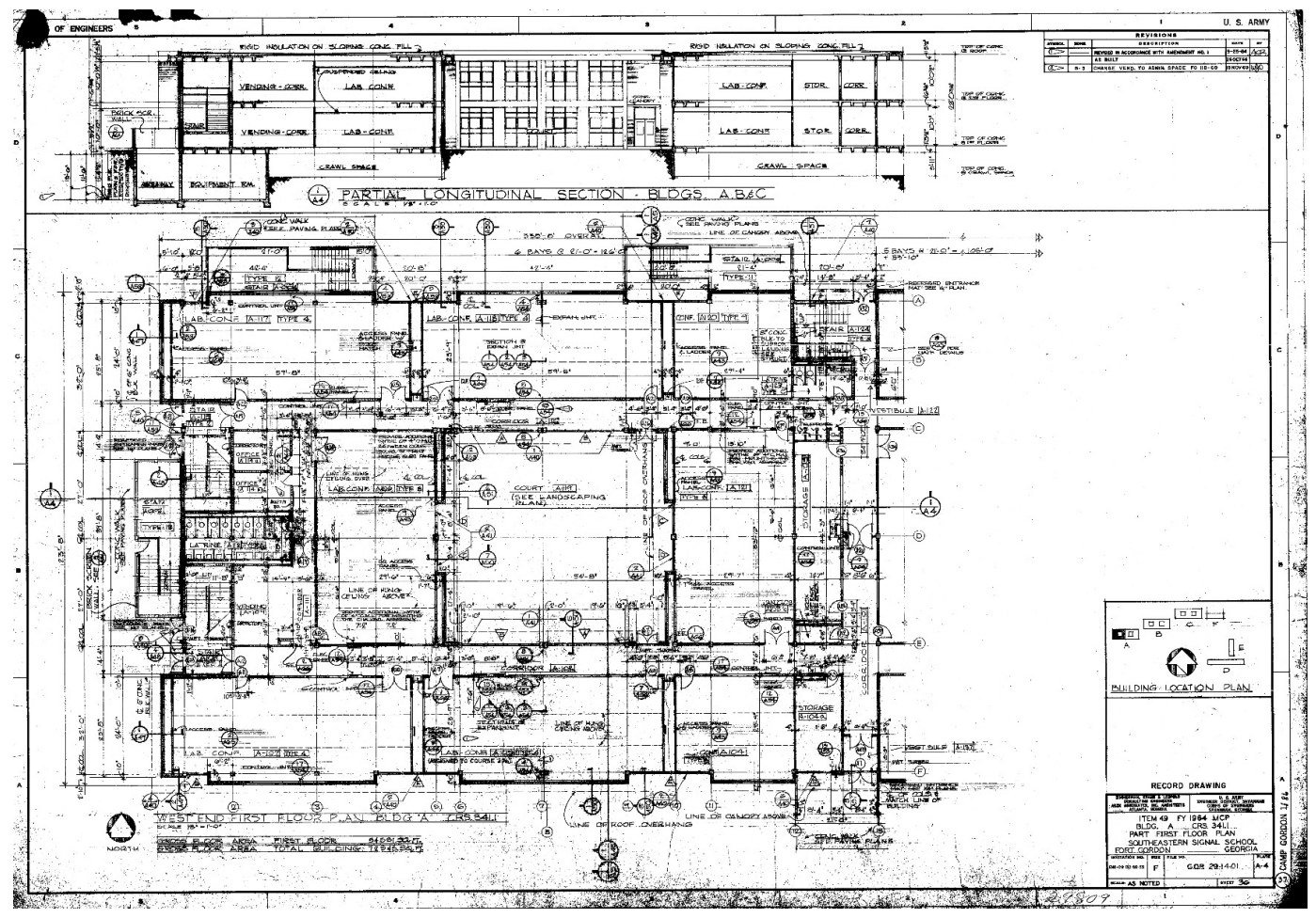


Figure 278. First-floor plan [right side] for Building 29809, Greely Hall, 1964 (Fort Gordon DPW).

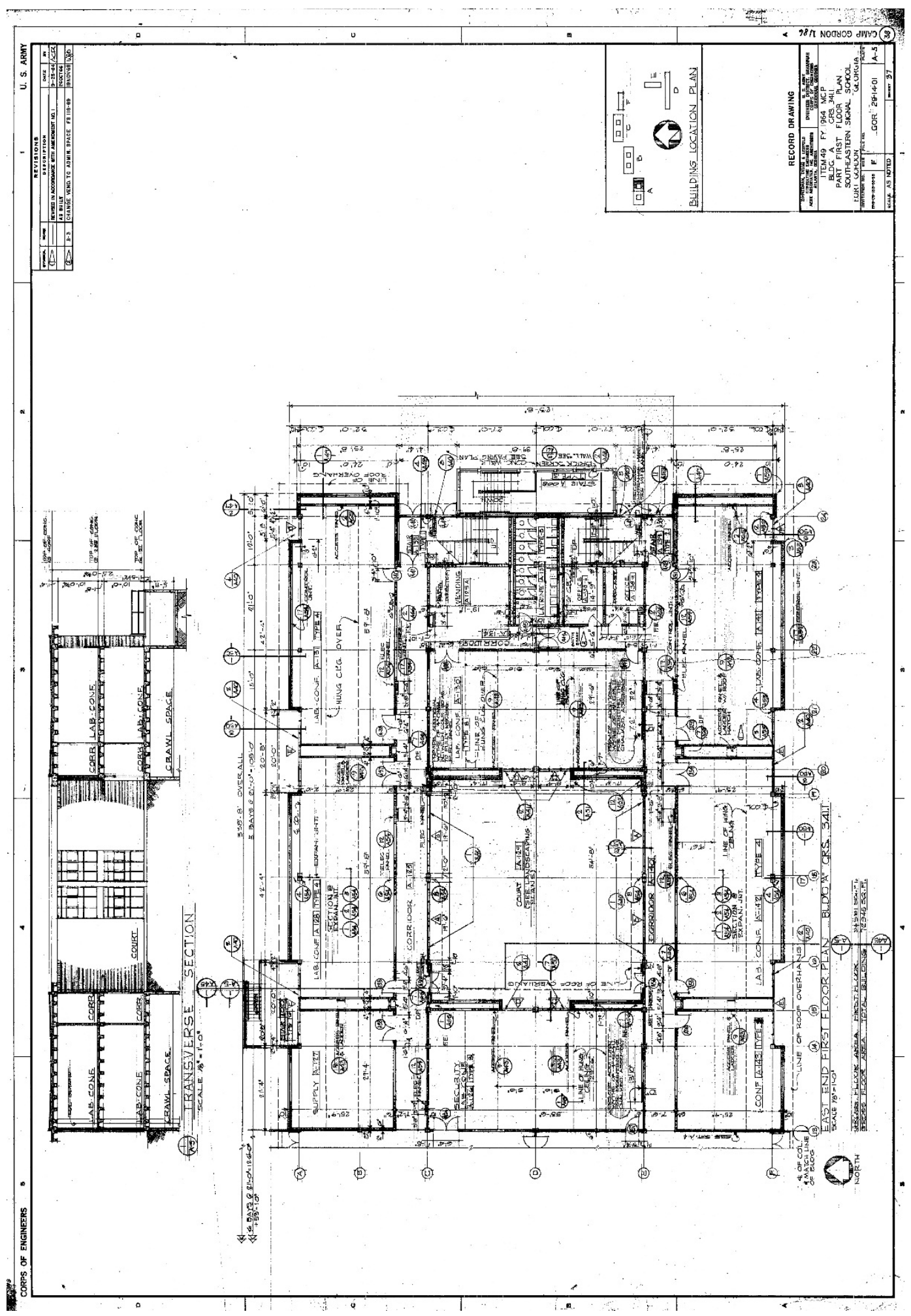


Figure 279. Elevations for Building 29809, Greely Hall, 1964 (Fort Gordon DPW).

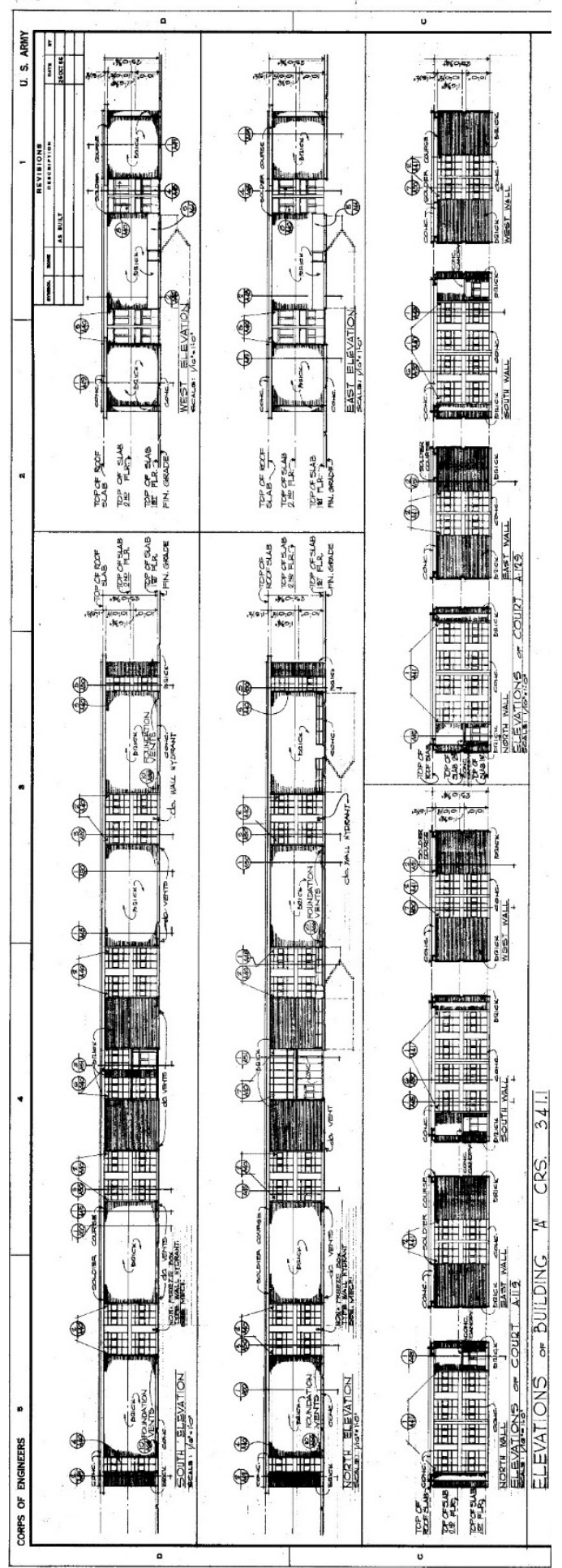


Figure 280. Door and window schedule for Building 29809, Greely Hall, 1964 (Fort Gordon DPW).

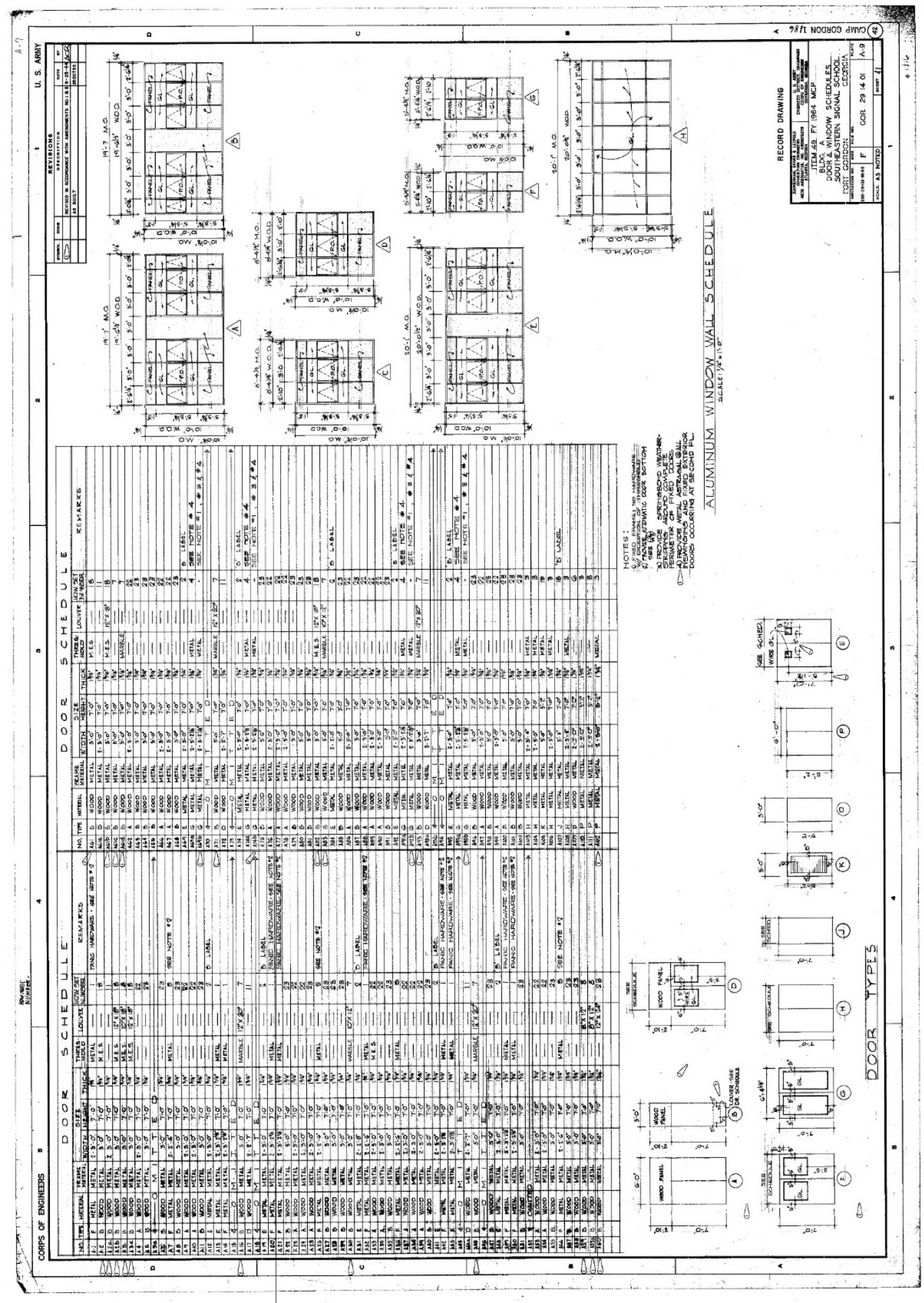


Figure 281. Partial longitudinal section of Building 29809, Greely Hall, 1964 (Fort Gordon DPW).

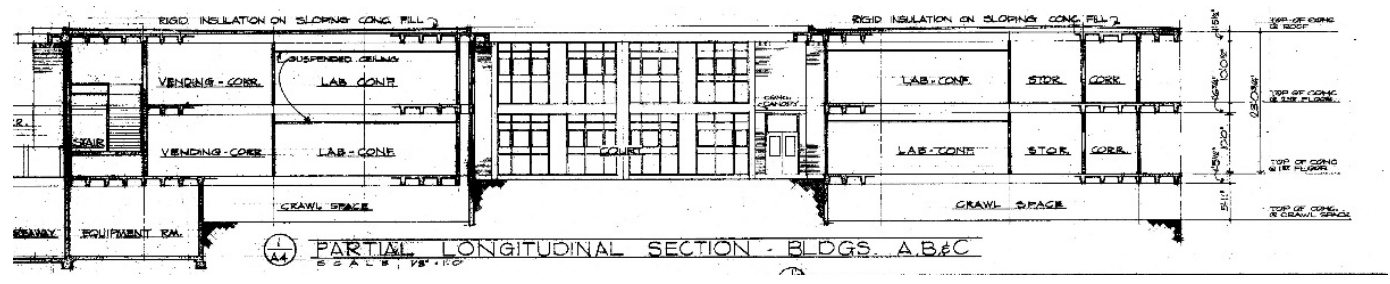

Figure 282. Transverse section of Building 29809, Greely Hall, 1964 (Fort Gordon DPW).

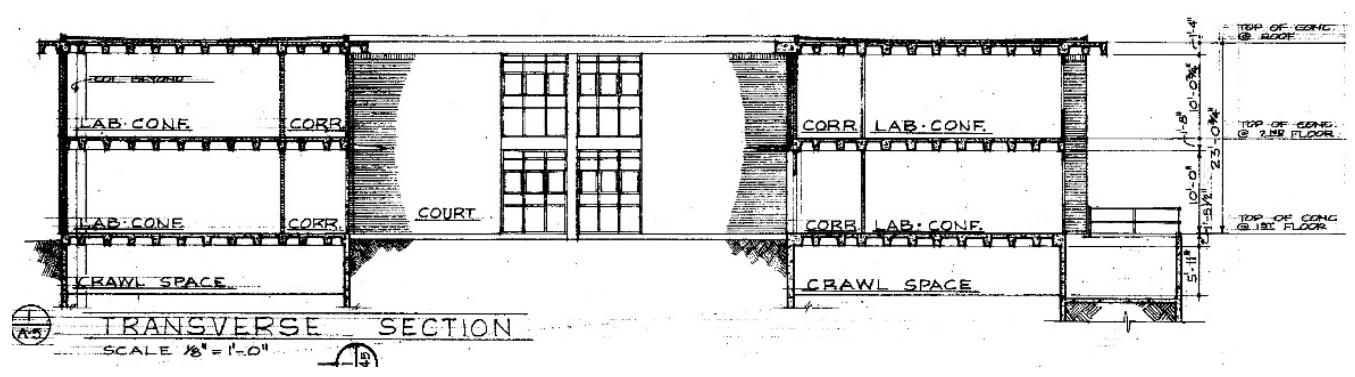

Figure 283. Sections of Building 29809, Greely Hall showing concrete waffle ceiling and roof construction, 1964 (Fort Gordon DPW).

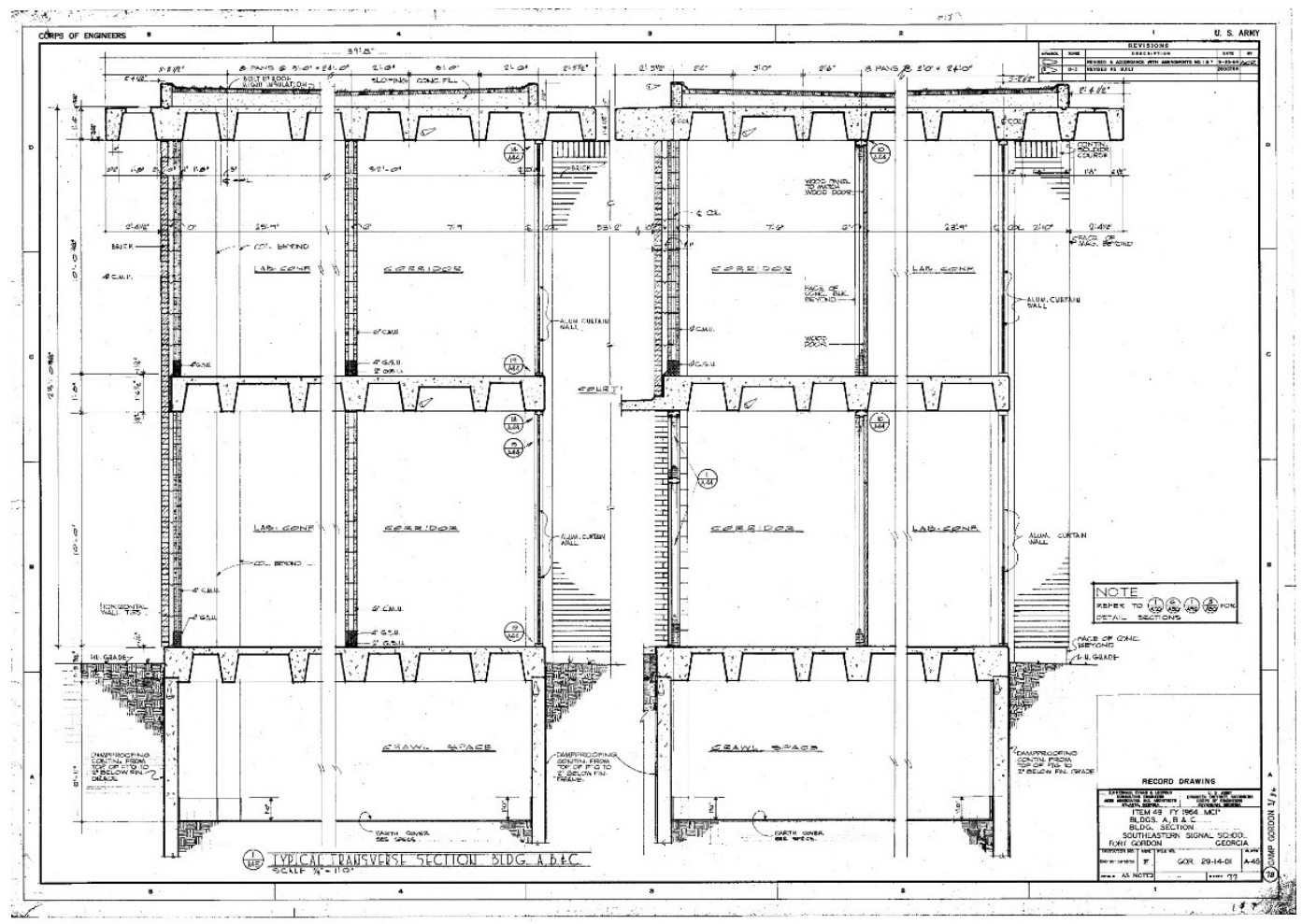


Figure 284. Brick screen detail for exterior staircases on the east and west elevations of Building 29809, Greely Hall, 1964 (Fort Gordon DPW).

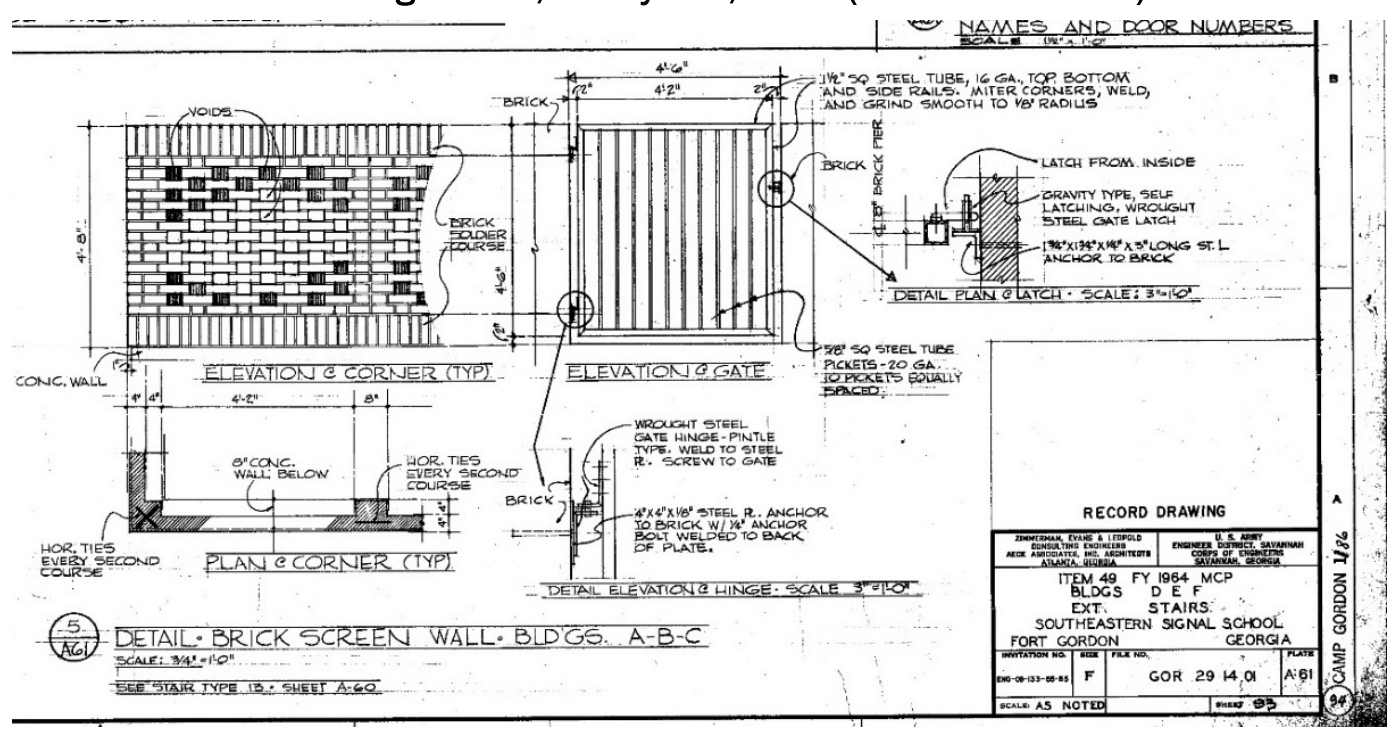


Figure 285. Typical courtyard landscaping plans and details, 1966 (Fort Gordon DPW).

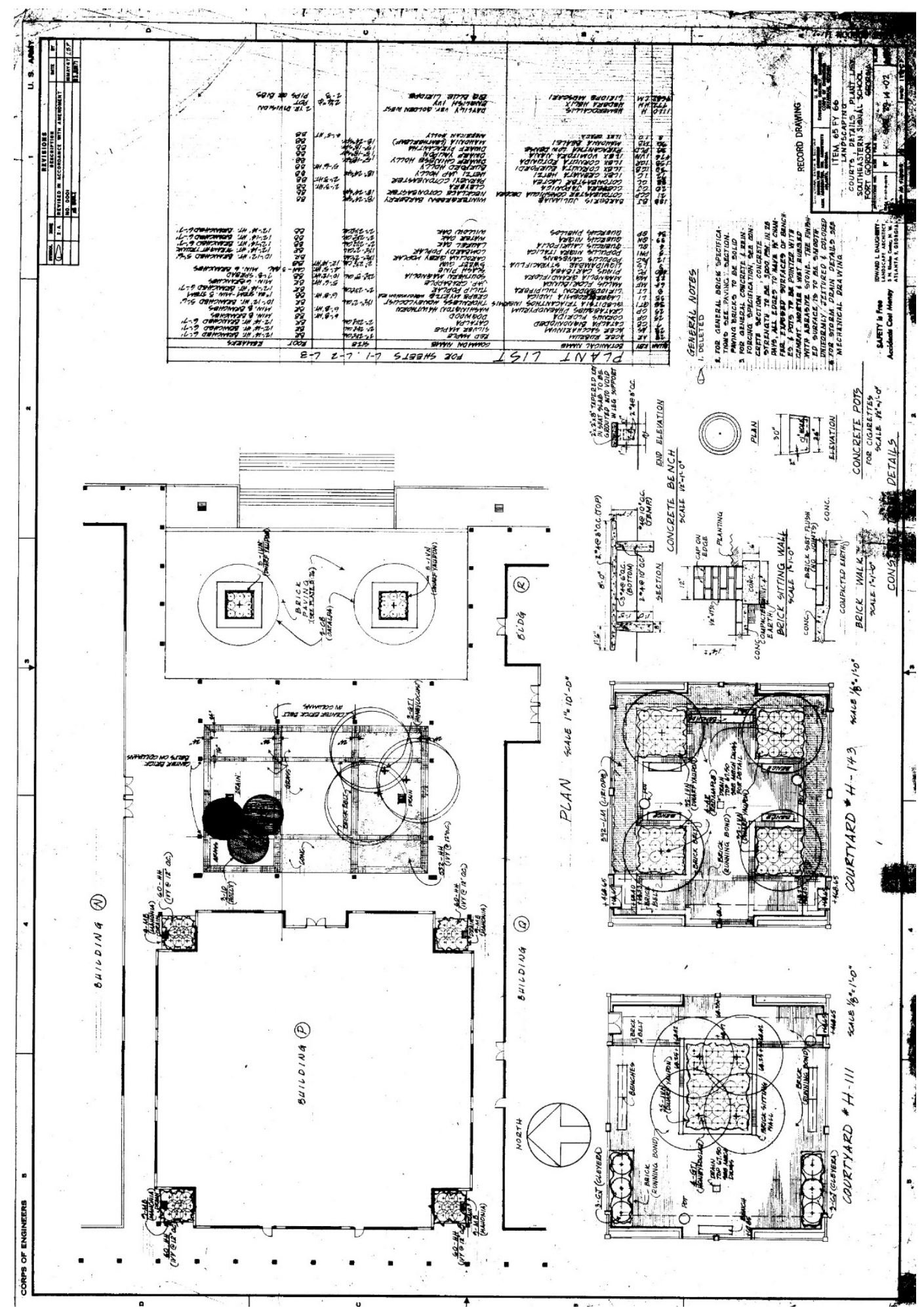


Figure 286. Typical classroom elevations and details for Building 29809, Greely Hall, 1966 (Fort Gordon DPW).

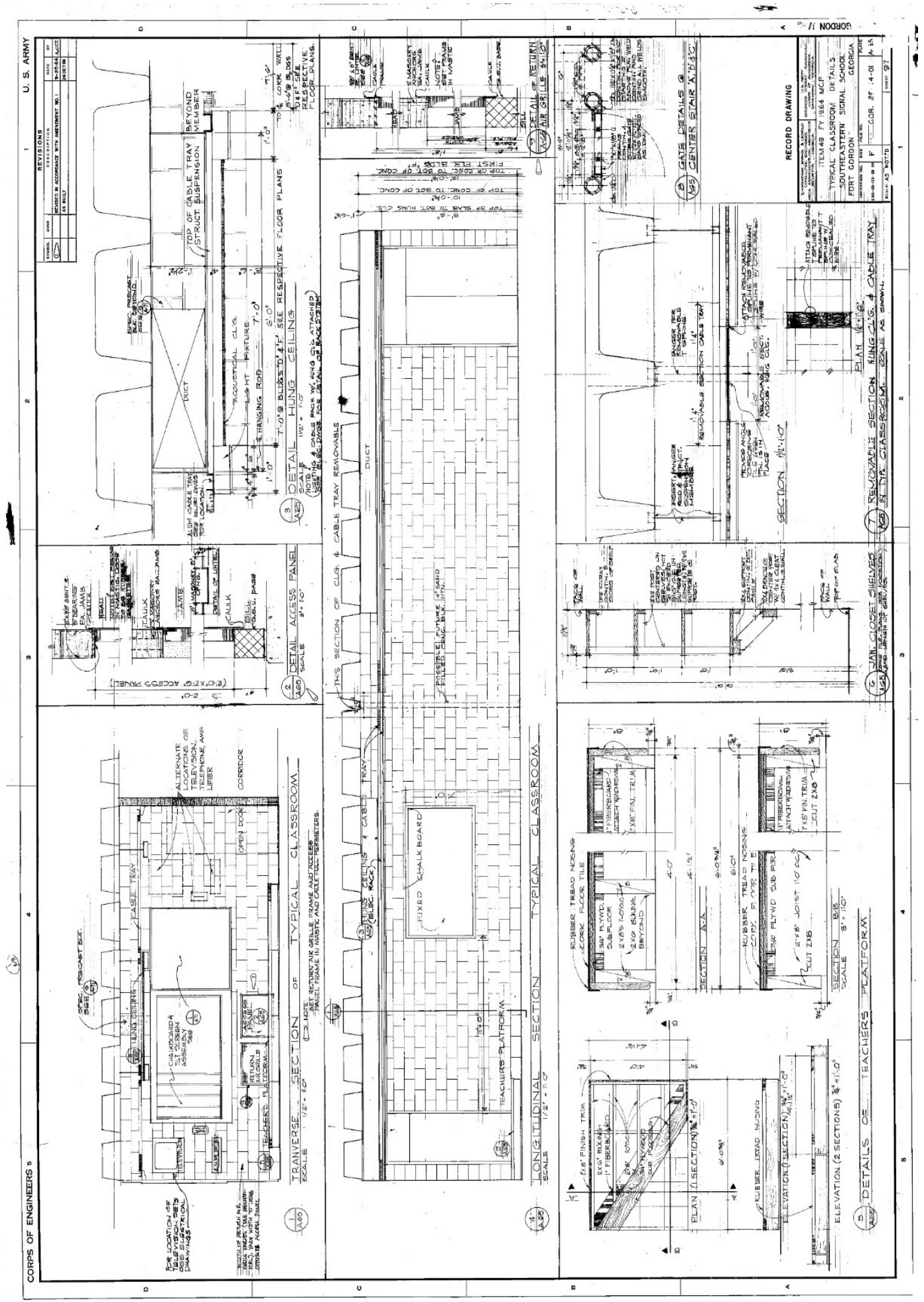


Figure 287. Interior stairwell details of Building 29809, Greely Hall, 1964 (Fort Gordon DPW).

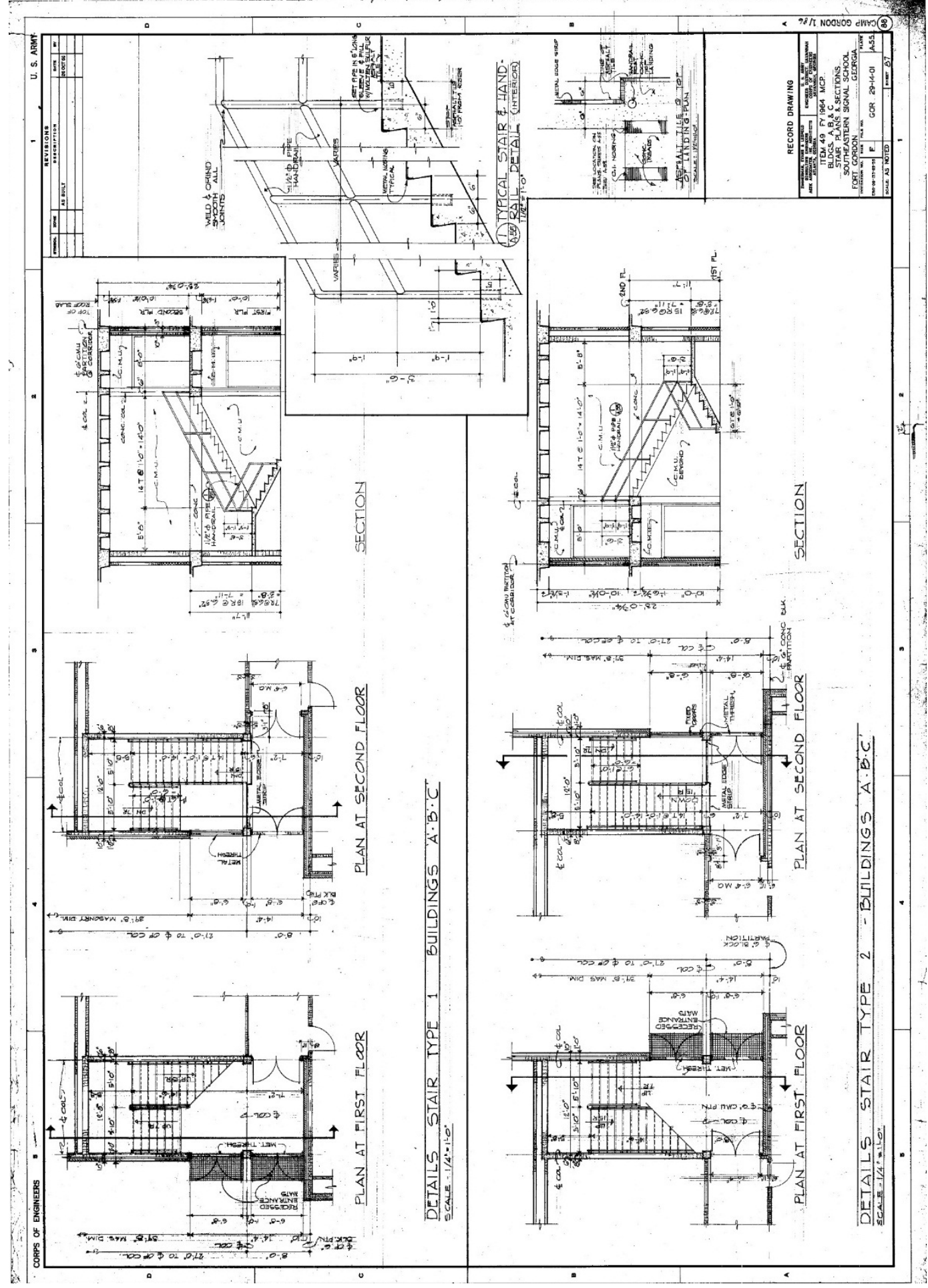


Figure 288. Latrine plans, elevations, and details for Building 29809, Greely Hall, 1964 (Fort Gordon DPW).

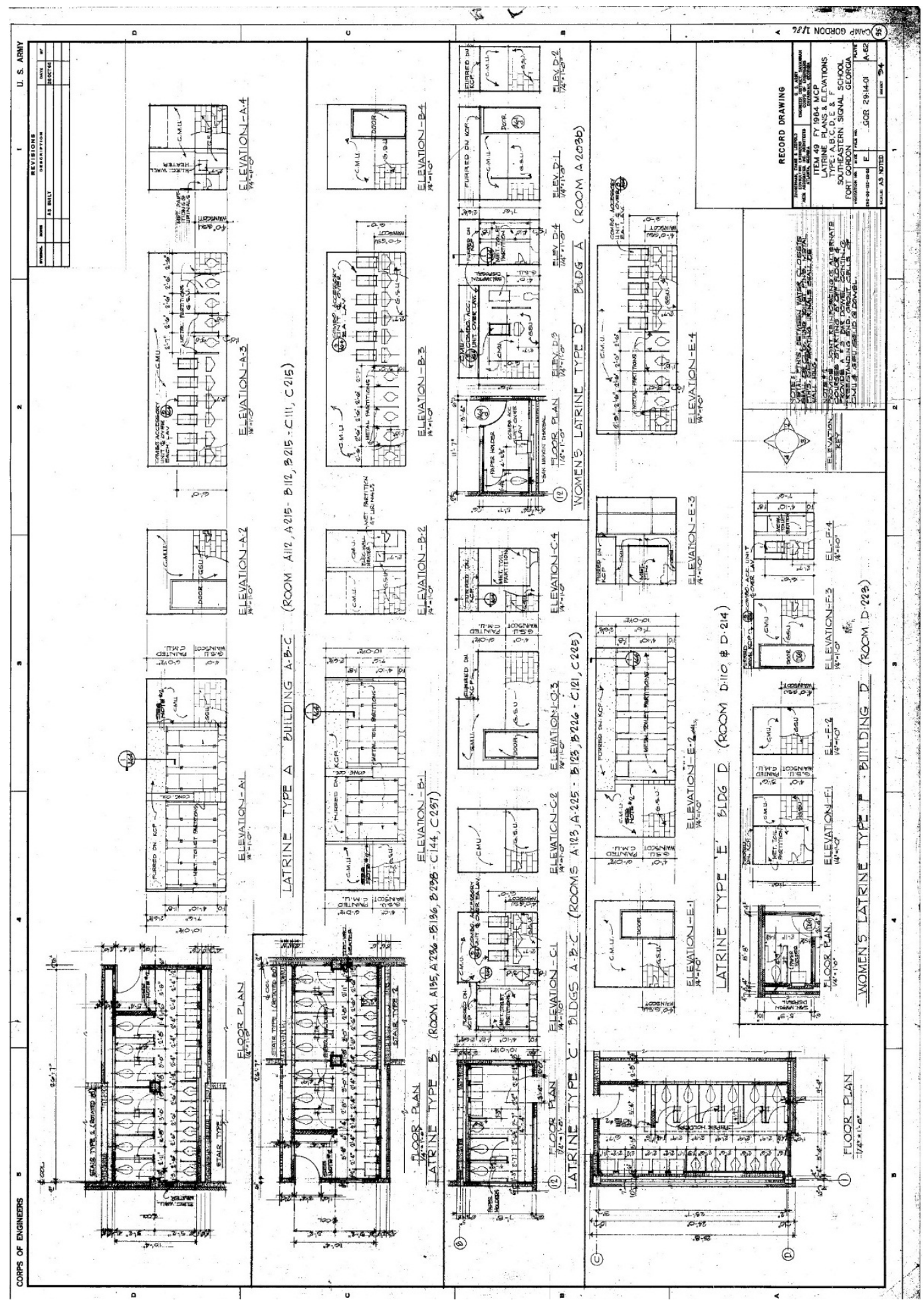


Figure 289. Light fixture details for Building 29809, Greely Hall, 1966 (Fort Gordon DPW).

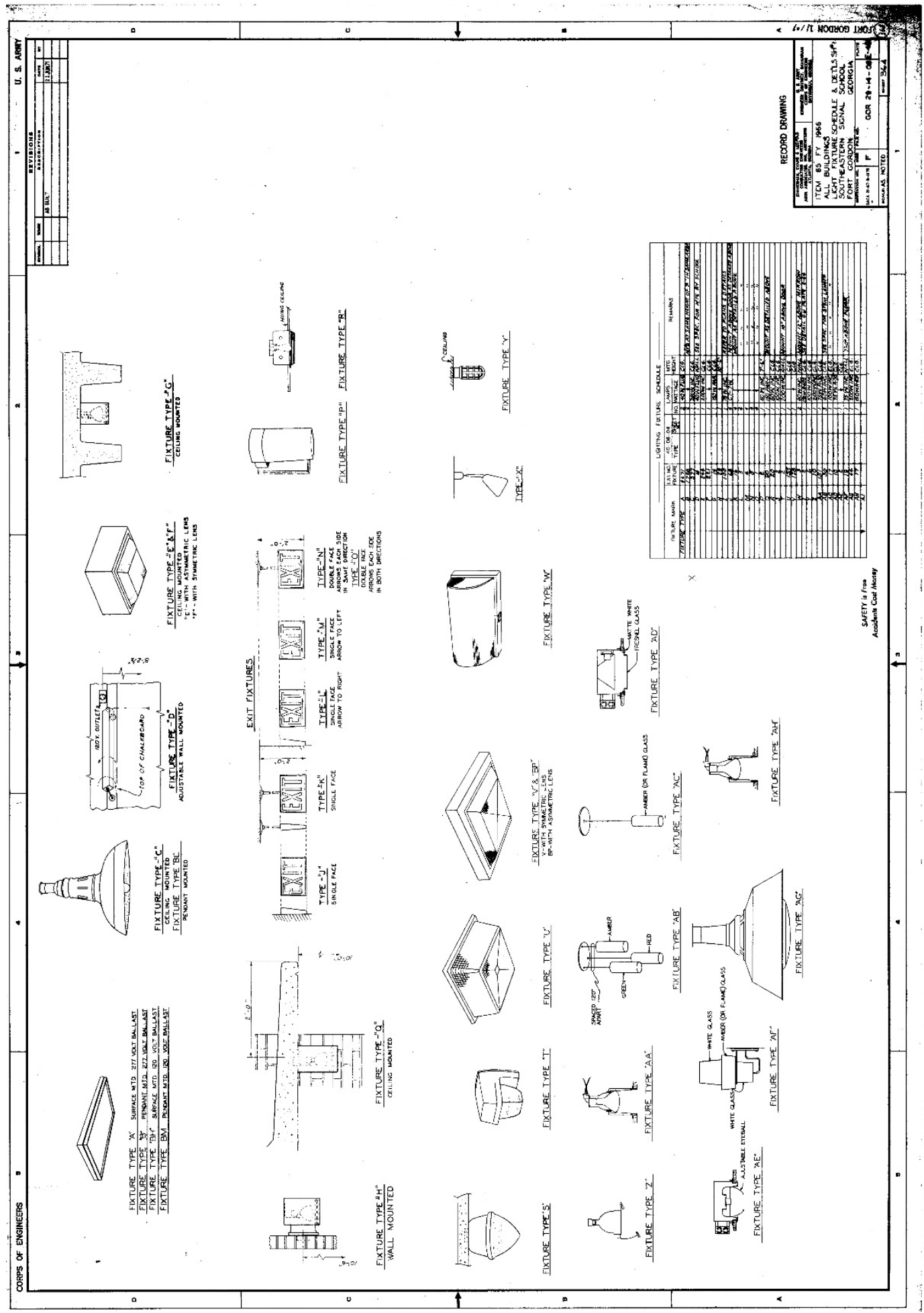


Figure 290. Landscaping plan for Building 29809, Greely Hall (Fort Gordon DPW).

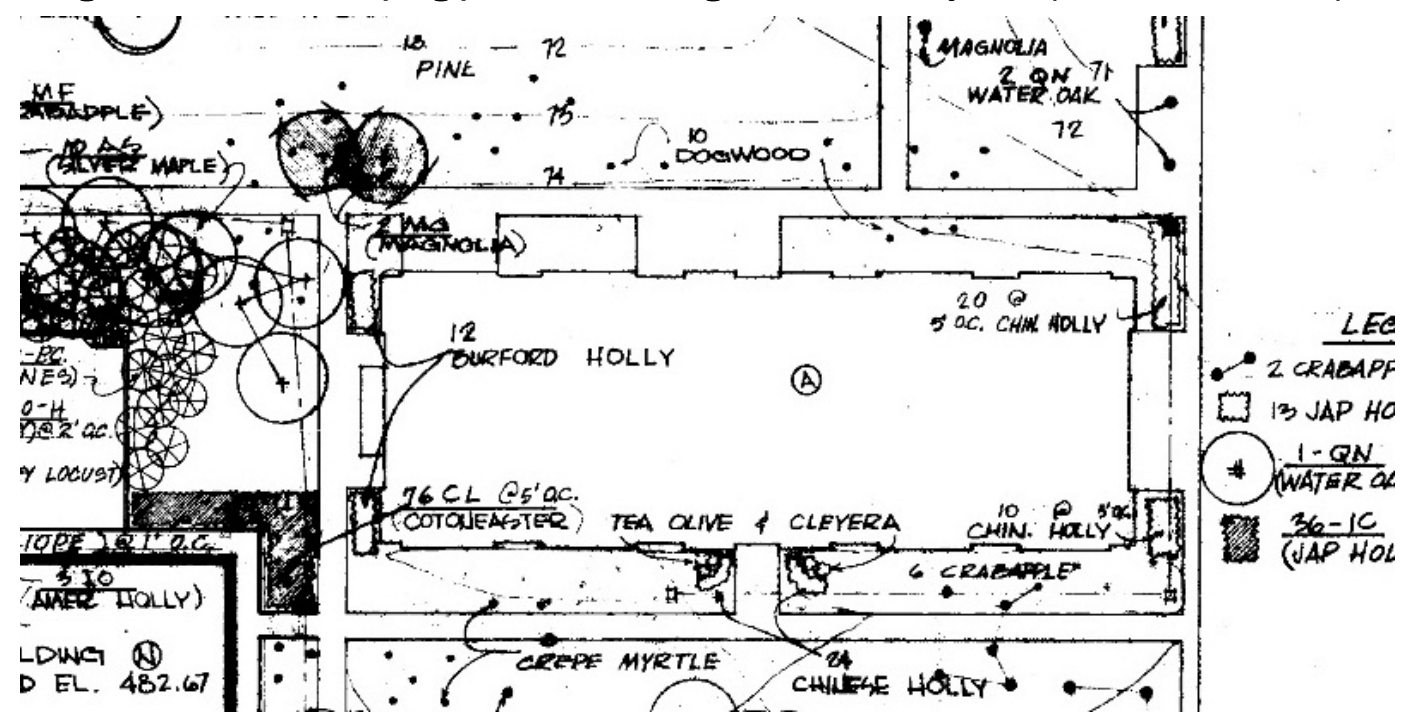

\subsubsection{Character-defining features}

Repair, renovation, and replacement of Building 29809, Greely Hall, must be coordinated with the GA SHPO (Table 10).

\section{Exterior:}

- Overall massing

- Footprint

- Roof shape

- Brick veneer

- Relationship to other Signal School Campus buildings

- Overhanging eaves with perforated waffle construction casting "light pattern" on exterior brick walls

- Exposed concrete structure framing window and door openings

- Flat concrete canopy over north and south entries

- Bays (two and six) of bright-aluminum sash windows with three-pane awning-style windows sandwiched between insulated panel inserts

- Entry bay on north elevation with metal doors, canopy, concrete panels, and group of seven fixed-pane windows with bright-aluminum sashes

- Metal doors with large pane and transom

- Metal and plate-glass doors on the east and west elevations

- Ceiling-mounted cylinder exterior light fixtures

- Metal handrails

- Lettering 
- Bright-aluminum display case near entry

- Landscaping

\section{Interior:}

- Overall plan

- Courtyards

- Main stairwells

- Main hallways

- Lighting

- Doors

- Bright-aluminum display cases

- Signage

- Vending machine alcove

- Telephone alcoves

- Tiled water fountain alcoves

Table 10. Images of character-defining features of Building 29809, Greely Hall (ERDC-CERL, 2015).

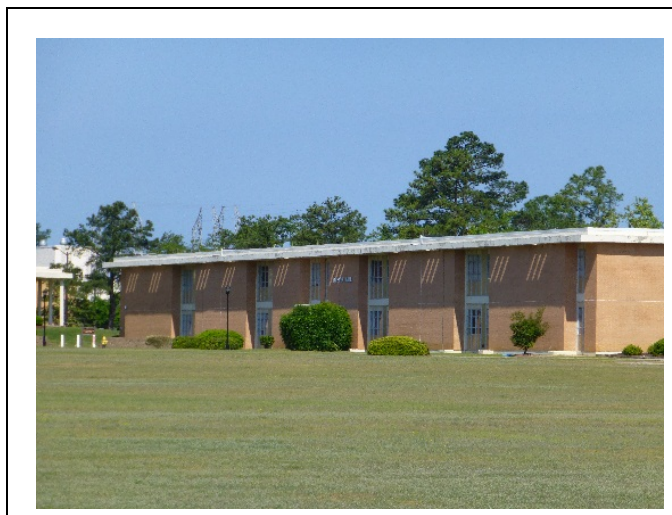

Overall massing, footprint, roof shape, and brick veneer.

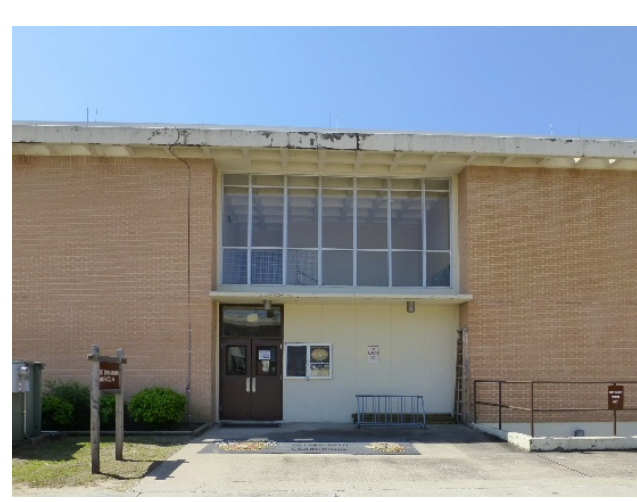

Bright-aluminum sash fixed-window bay, concrete canopy, metal door with pane. 


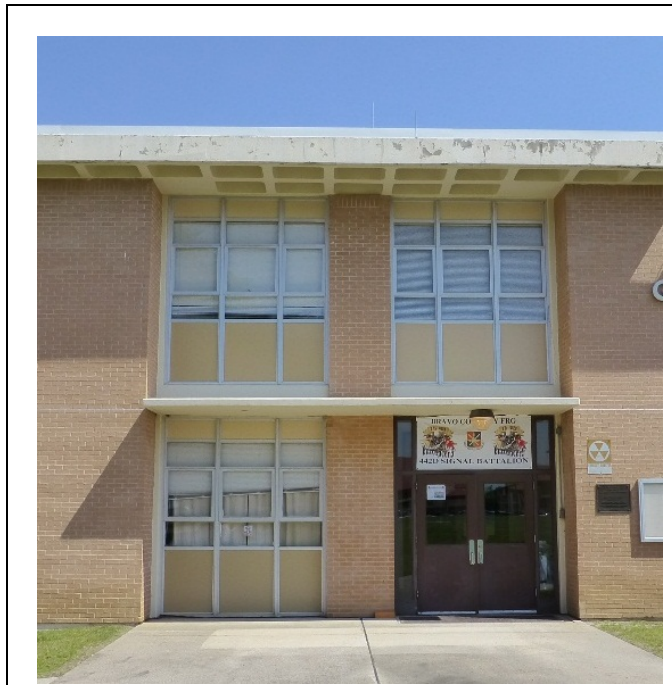

Entry bay with bright-aluminum framing three-pane awning-style windows sandwiched between insulated panels, flat concrete canopy, and metal doors with large pane.
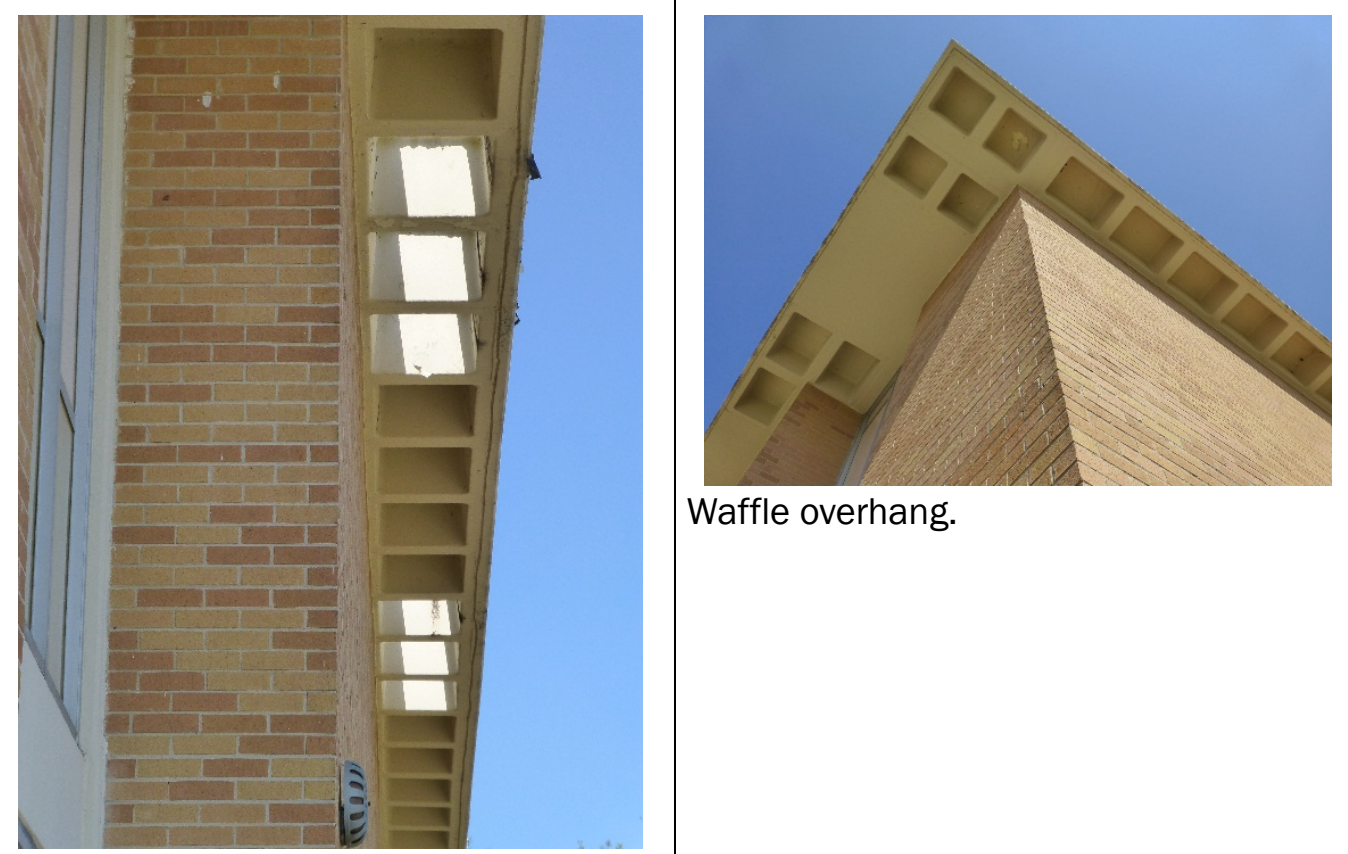

Waffle overhang.

Perforated concrete waffle overhang. 

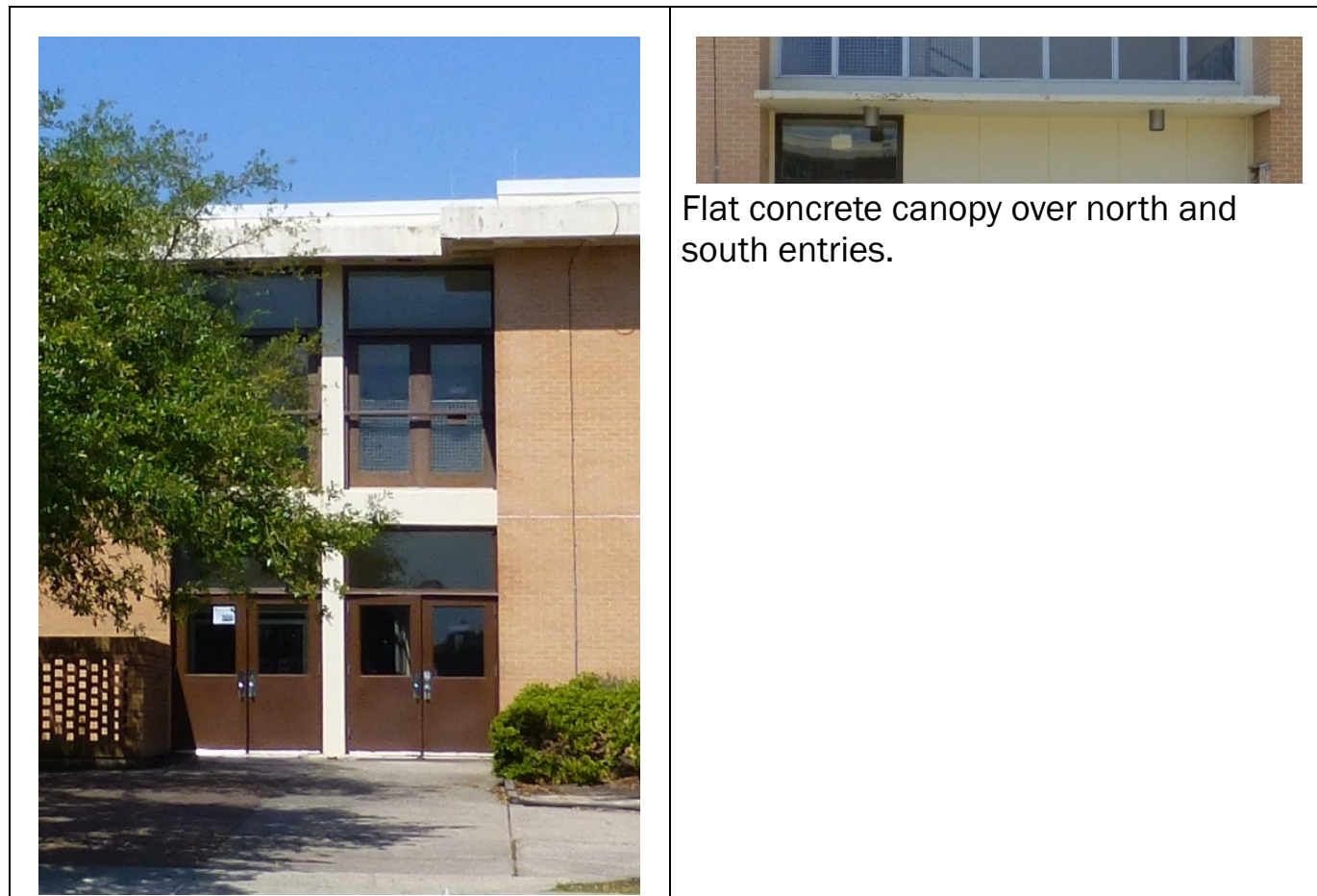

Flat concrete canopy over north and south entries.

Metal doors with pane and fixed transom on the first floor and paired metal and plate-glass doors on the seond floor.
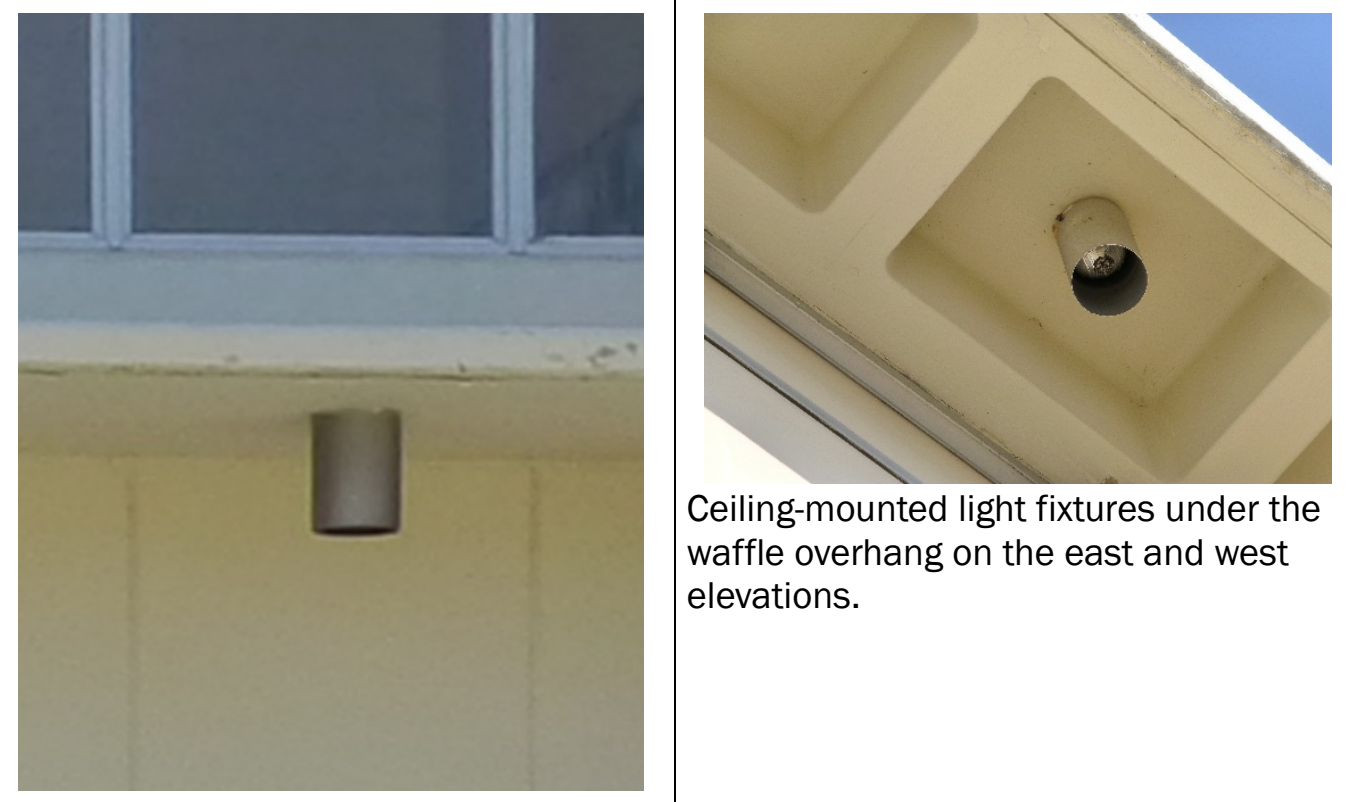

Ceiling-mounted light fixtures under the waffle overhang on the east and west elevations.

Ceiling-mounted light fixture under flat canopies. 


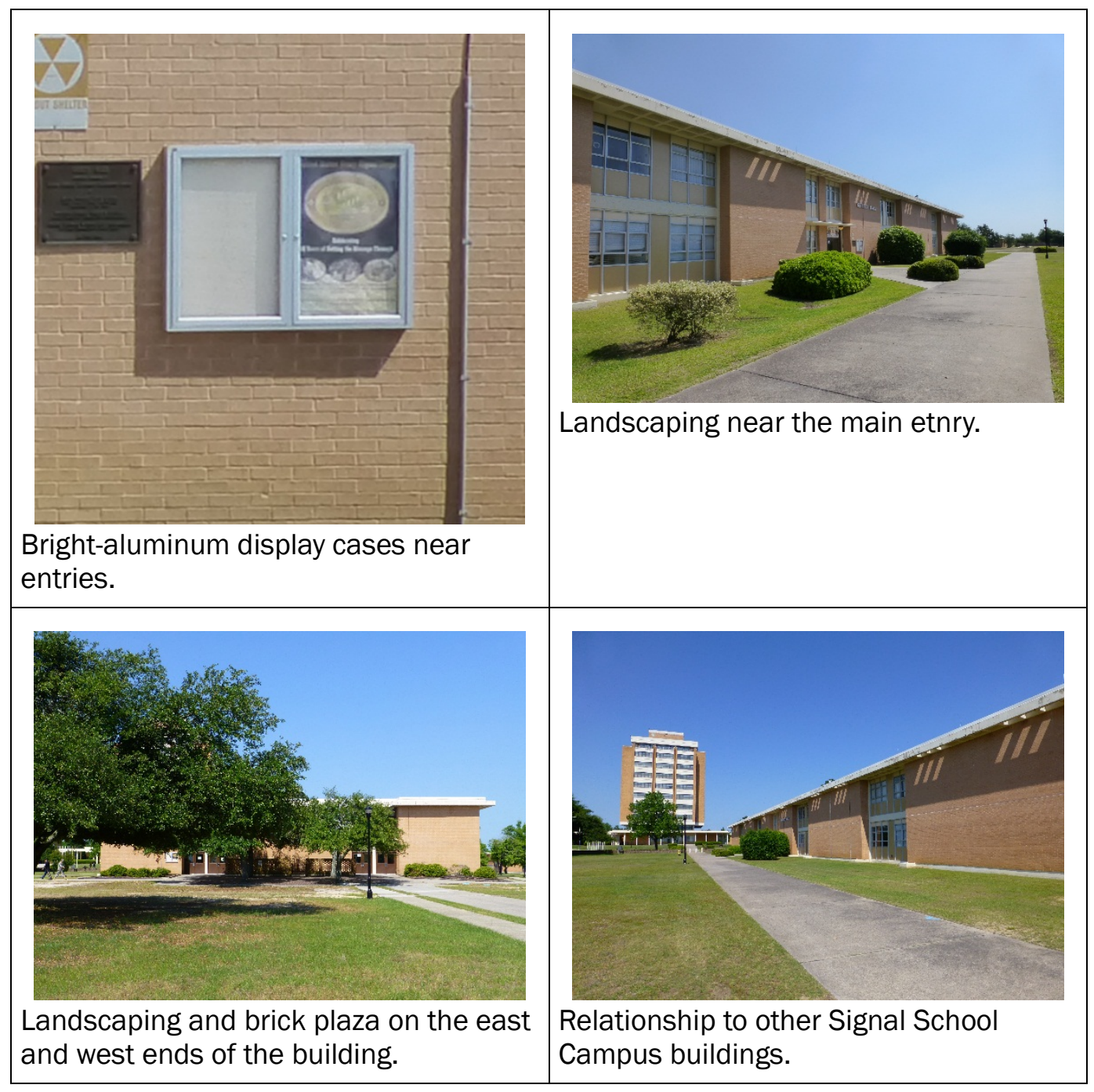

3.3.8.2 Character-defining features that have been removed

- None.

\subsubsection{Nonhistoric features}

- None.

\subsubsection{Comparison images}

Comparison images utilizing either the original drawings or historic photographs, when juxtaposed against present-day images, are a useful tool in developing the historic "feel" of a property and how much of that historic feeling is still present today (Figure 291-Figure 298). 
Figure 291. Second-floor window bay on the north and south elevations comparison of the original design and materials from 1964 [left] to the current condition of bright-aluminum three-pane awning-style-windows and insulated panels

[right] (ERDC-CERL, 2015).
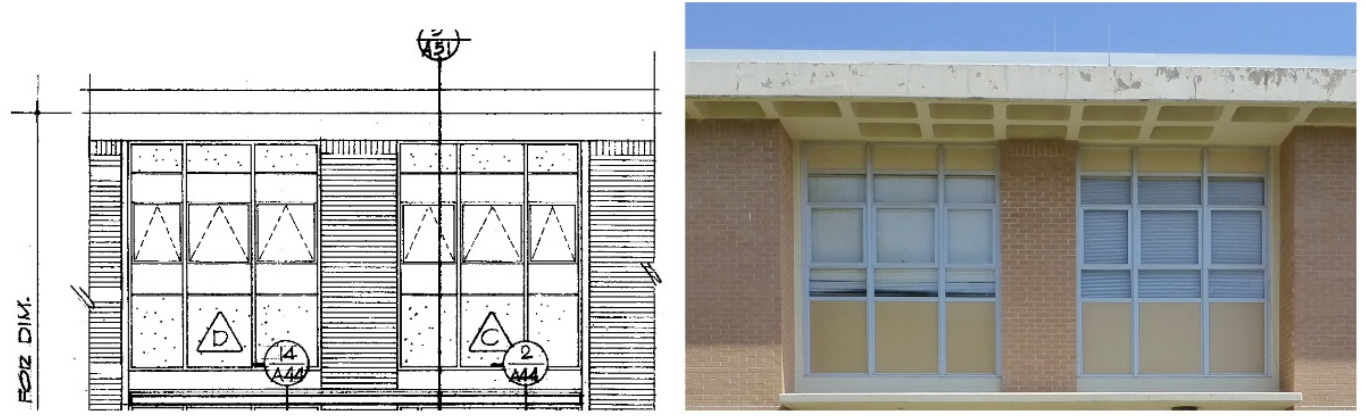

Figure 292. North entry bay second-floor windows - comparison of the original design and materials from 1964 [left] to the current condition of bright-aluminum fixed-pane windows [right] (ERDC-CERL, 2015).

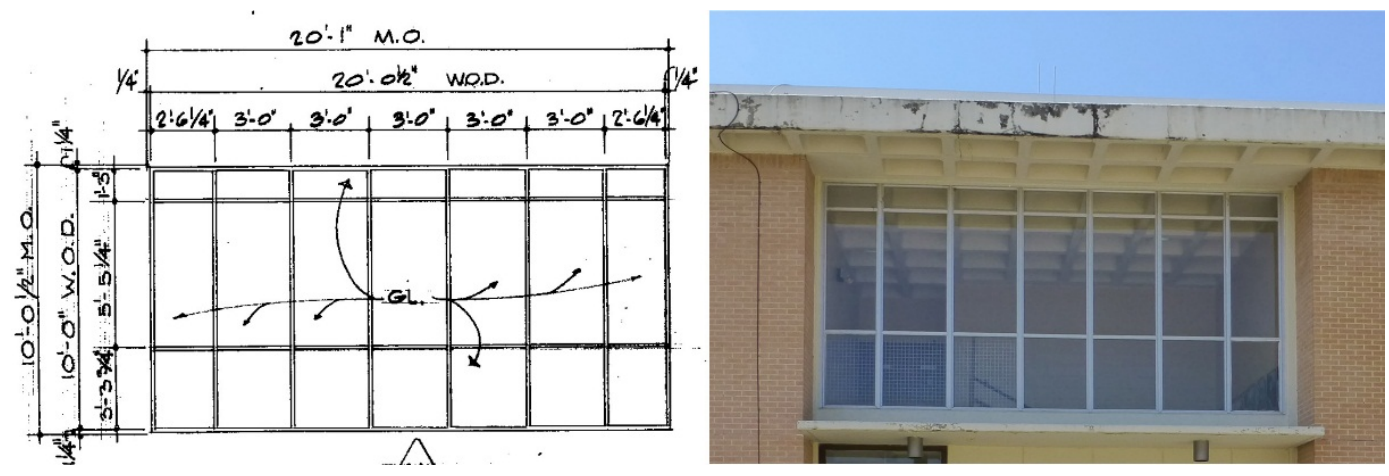


Figure 293. Window bay located on the left and right sides of the north and south elevations - comparison of the original design and materials from 1964 to the current condition of the three-pane awning-style windows sandwiched between insulated panels (ERDC-CERL, 2015).
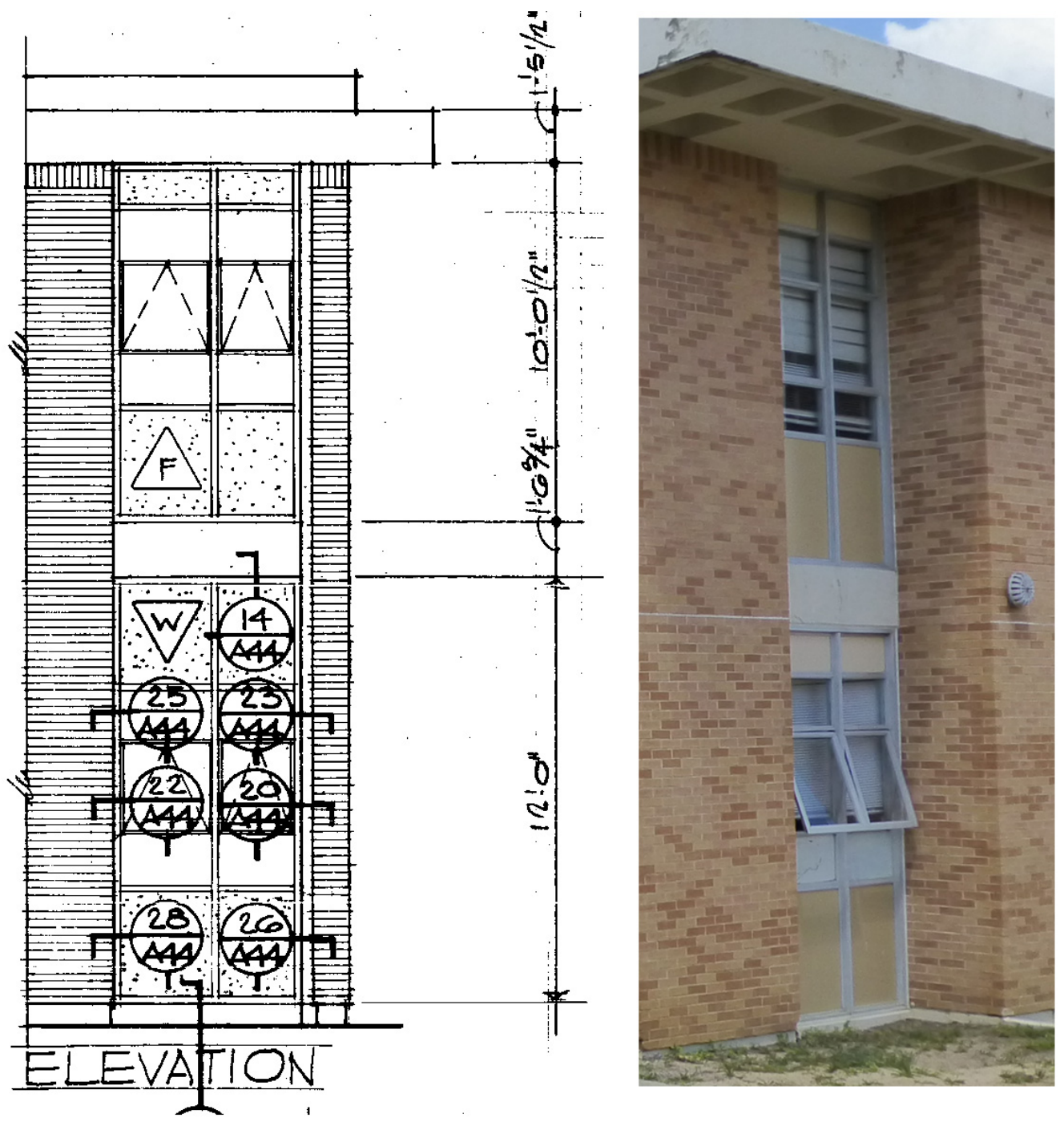
Figure 294. Doors on the east and west elevations - comparison of the original design and materials from 1964 [left] to the current condition of the metal doors with pane and transoms on the first floor and the metal and plate-glass doors with security bars on the second floor [right] (ERDC-CERL, 2015).
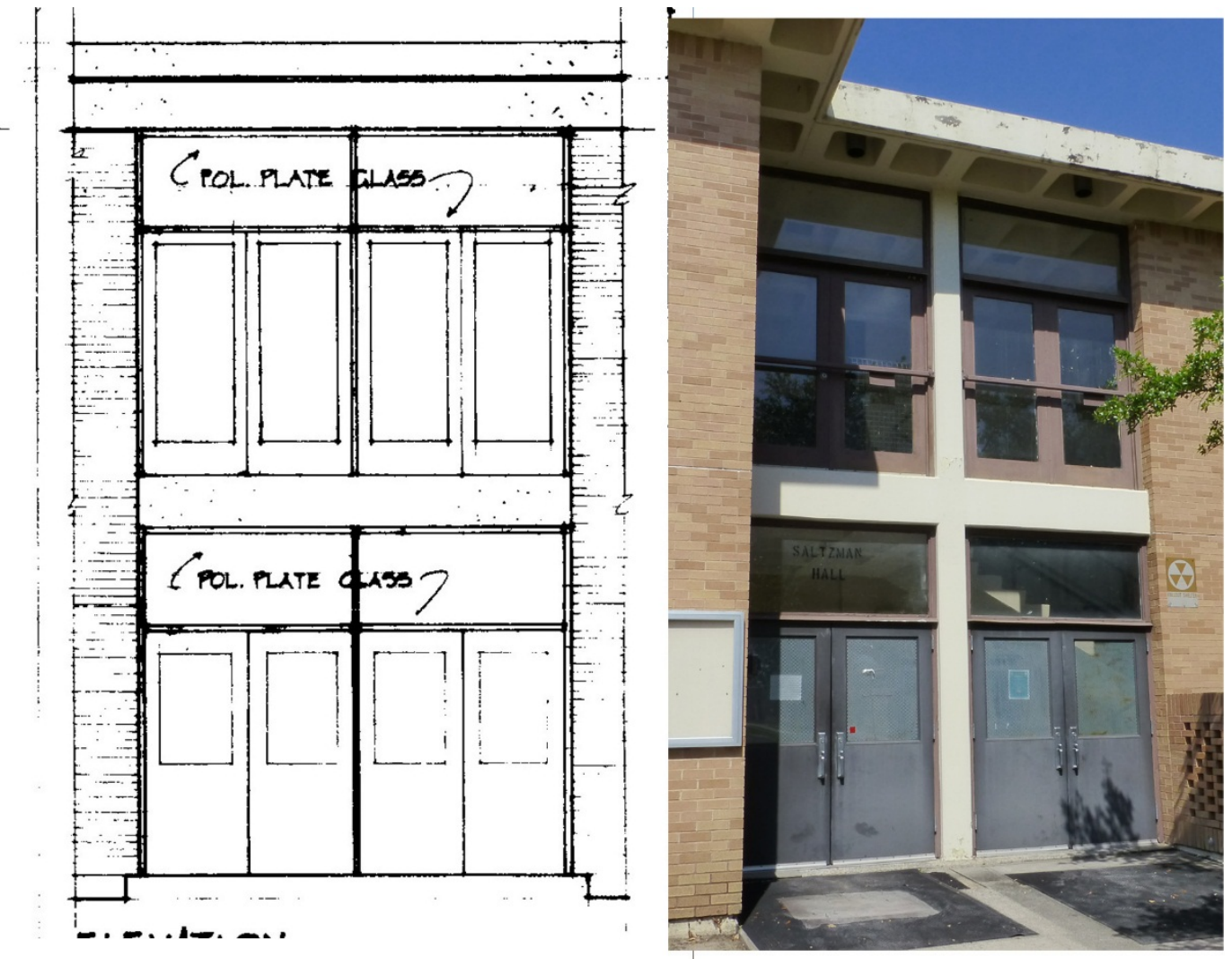

Figure 295. North wall of the right courtyard and south wall of the left courtyard comparison of the original design and materials from 1964 [left] to the current condition of the metal doors, canopy, and window system [right] (ERDC-CERL, 2015).
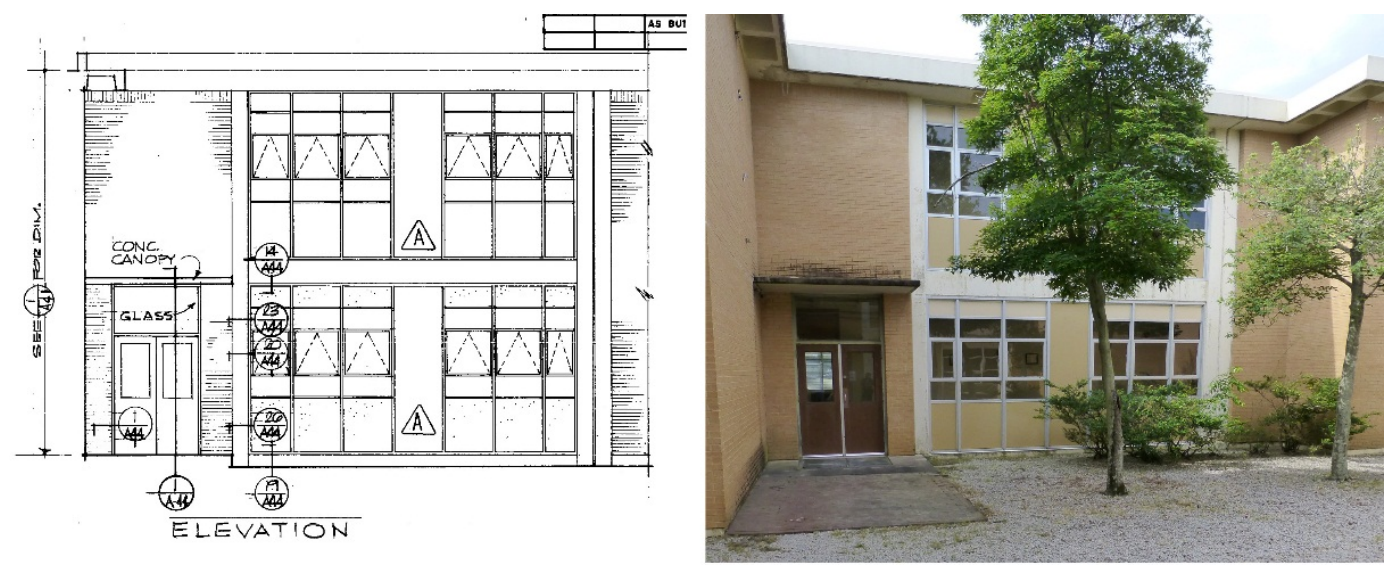
Figure 296. East and west walls of the courtyards - comparison of the original design and materials from 1964 [left] to the current condition of the window system [right]

(ERDC-CERL, 2015).
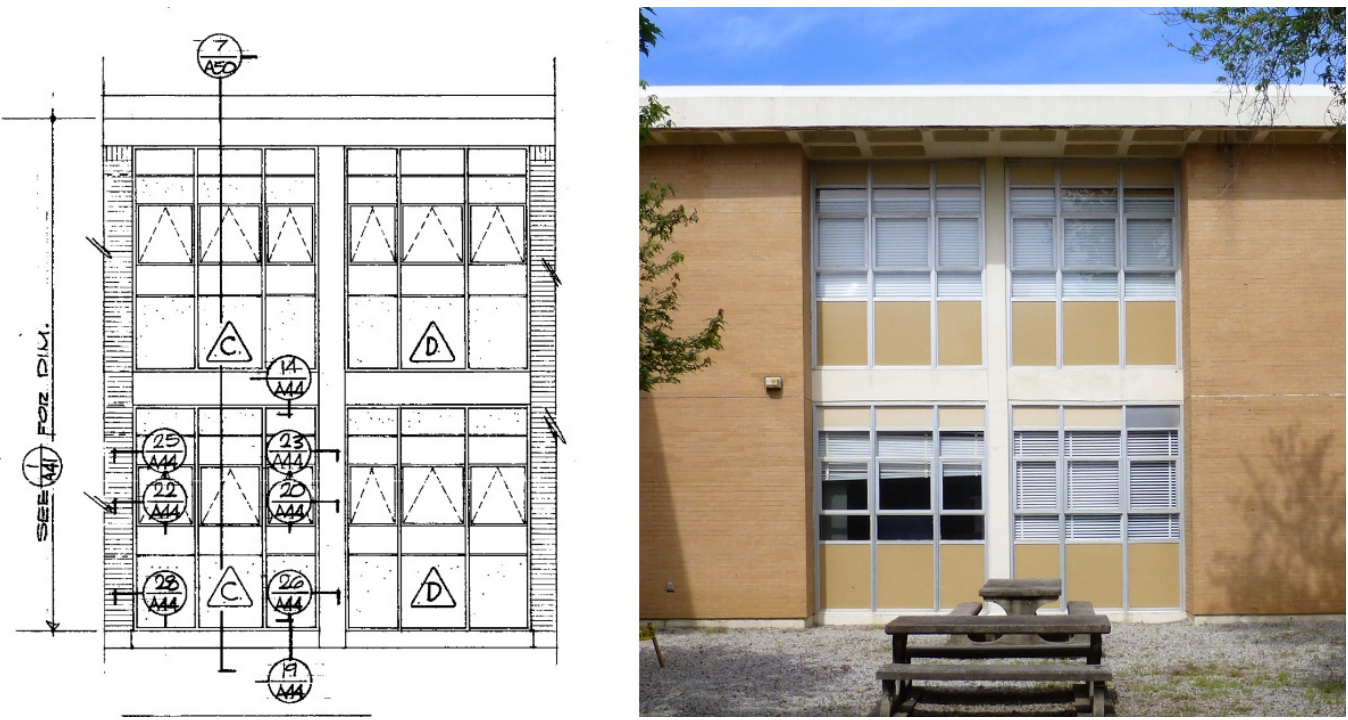

Figure 297. Ceiling-mounted light fixtures under waffle overhang - comparison of the original design and materials from 1966 [left] to the current condition of the ceilingmounted light fixture [right] (ERDC-CERL, 2015).
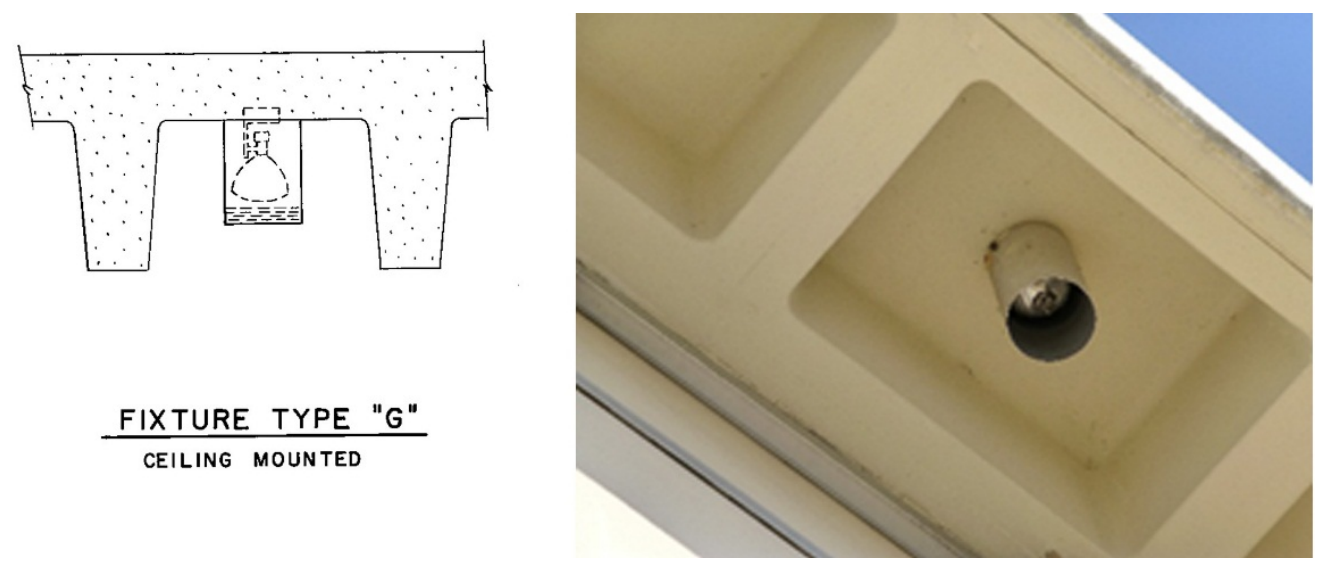

Figure 298. Ceiling-mounted light fixture under flat concrete canopy - comparison of the original design and material from 1966 [left] to the current condition of the ceiling-mounted light fixture [right] (ERDC-CERL, 2015).
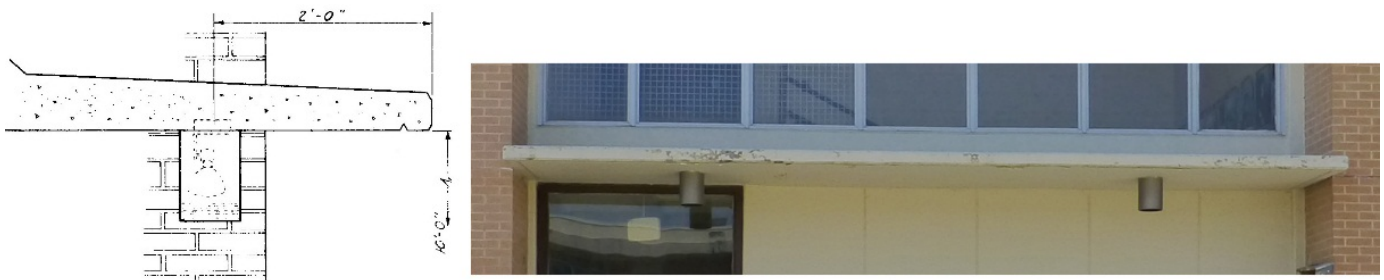

FIXTURE TYPE -"Q" 


\subsubsection{Building 29810, Burkhardt Hall (1970)}

Building 29810, Burkhardt Hall, is a contributing feature to the Signal School Campus Historic District. The interior is contributing. It was constructed in 1970 during Phase II construction and was designed by Aeck Associates from Atlanta, Georgia, and Zimmerman, Evans, and Leopold Consulting Engineers from Augusta, Georgia. The building is a long rectilinear classroom building on the northern edge of the school with its own service drive from 8 th Avenue. This service drive provides access to the walkout basement level that is defined by poured-in-place concrete walls, retaining wall topped with metal handrails and lined with shrubs, and metal service doors accessible poured concrete platforms. The building is three stories high with a partial basement. The third floor was added at an unknown date, but the original plans did allow for the construction of a third floor. The structure is cast-in-place concrete columns with a waffle floor/ceiling system. The second- and third-floor waffle systems are set within the structure, but the roof has the waffles extending out to form an overhang. Some of the waffles have been perforated, which creates a "light pattern" on the third floor brick exterior walls. The third floor has a slightly different color variation in the brick than the first two floors, and there is small mortar joint at this juncture. The window systems extend the full height of the building and are inset into the brick veneer. The window systems are composed of bright-aluminum window frames that enclose a tan-colored insulated panel above and below a three-pane awningstyle window. An exposed concrete beam structural system divides the window systems at each floor. The windows are set in groups of two, three, four, and six (with a panel insert). The main entrances are on the east and west elevations. Each entry is recessed and consists of two sets of metal door with panes and a fixed transom above on the first floor, and a group of four windows on the second and third floors. Wall-mounted light fixtures flank either side of the second-floor windows. There is also an entry located on the south elevation facing the campus. This entry consists of a set of metal doors with panes and a transom above. A group of three windows is adjacent the entry and separated by a brick column detail. The doors and windows are protected by a flat concrete canopy structure. Two ceiling-mounted light fixtures are placed on the underside of the canopy. Original lettering spelling out "BURKHARDT HALL" is placed on the north and south exterior walls. Landscaping is placed near the south entry, the south elevation perimeter, and along the right side of the north elevation (Figure 299-Figure 307). 
Figure 299. Signal School Campus map, with Building 29810, Burkhardt Hall highlighted in red, 2015 (Fort Gordon DPW, modified by ERDC-CERL).

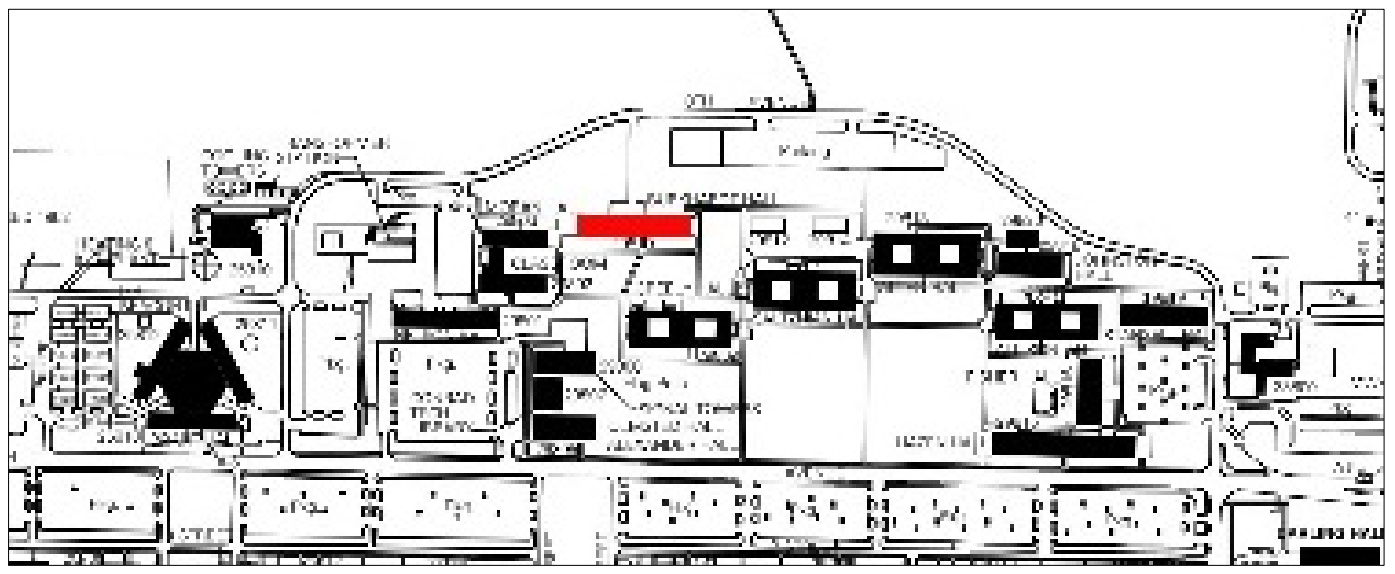

Figure 300. North elevation of Building 29810, Burkhardt Hall (ERDC-CERL, 2015).

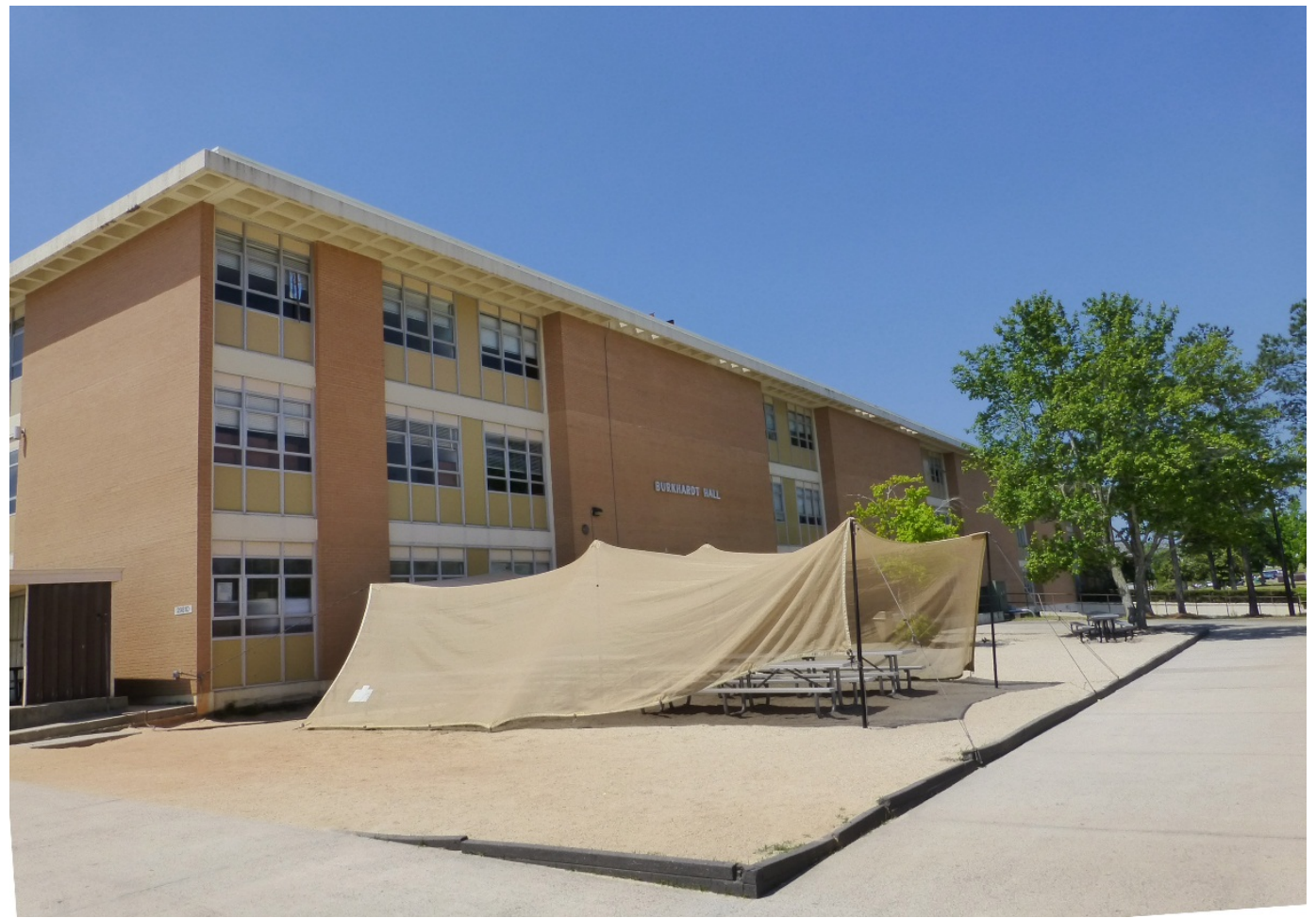


Figure 301. East elevation of Building 29810, Burkhardt Hall (ERDC-CERL, 2015).

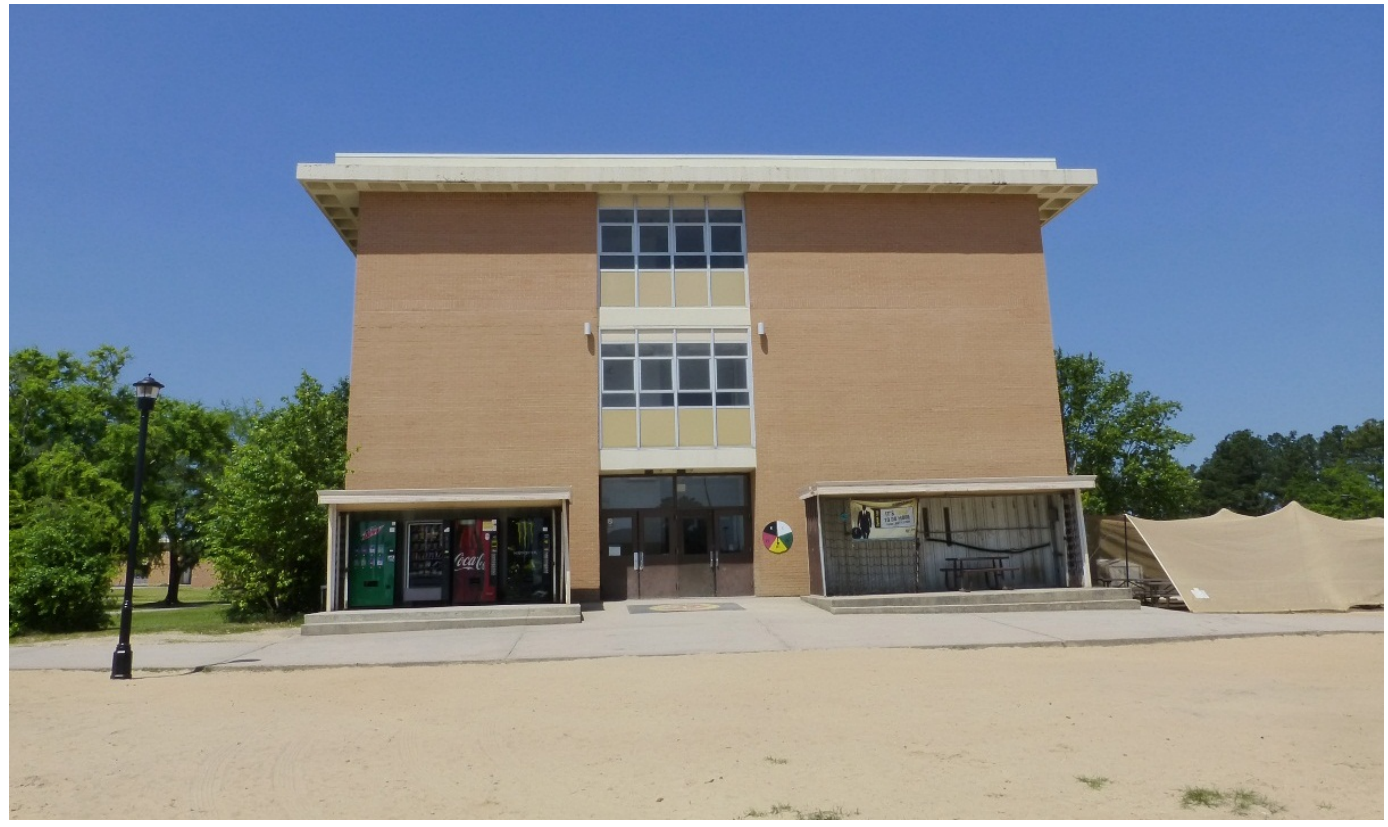

Figure 302. South elevation of Building 29810, Burkhardt Hall (ERDC-CERL, 2015).

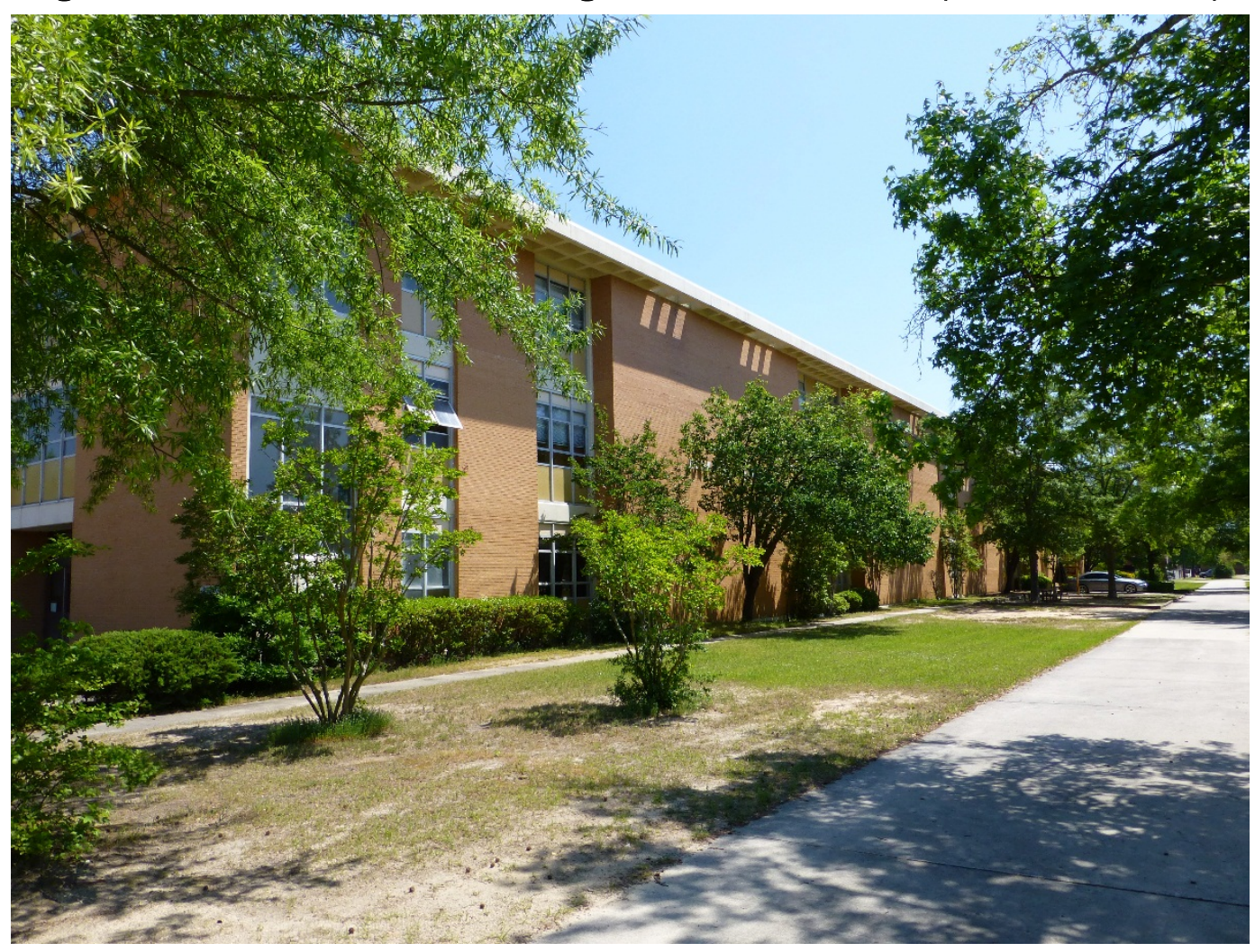


Figure 303. West elevation of Building 29810, Burkhardt Hall (ERDC-CERL, 2015).

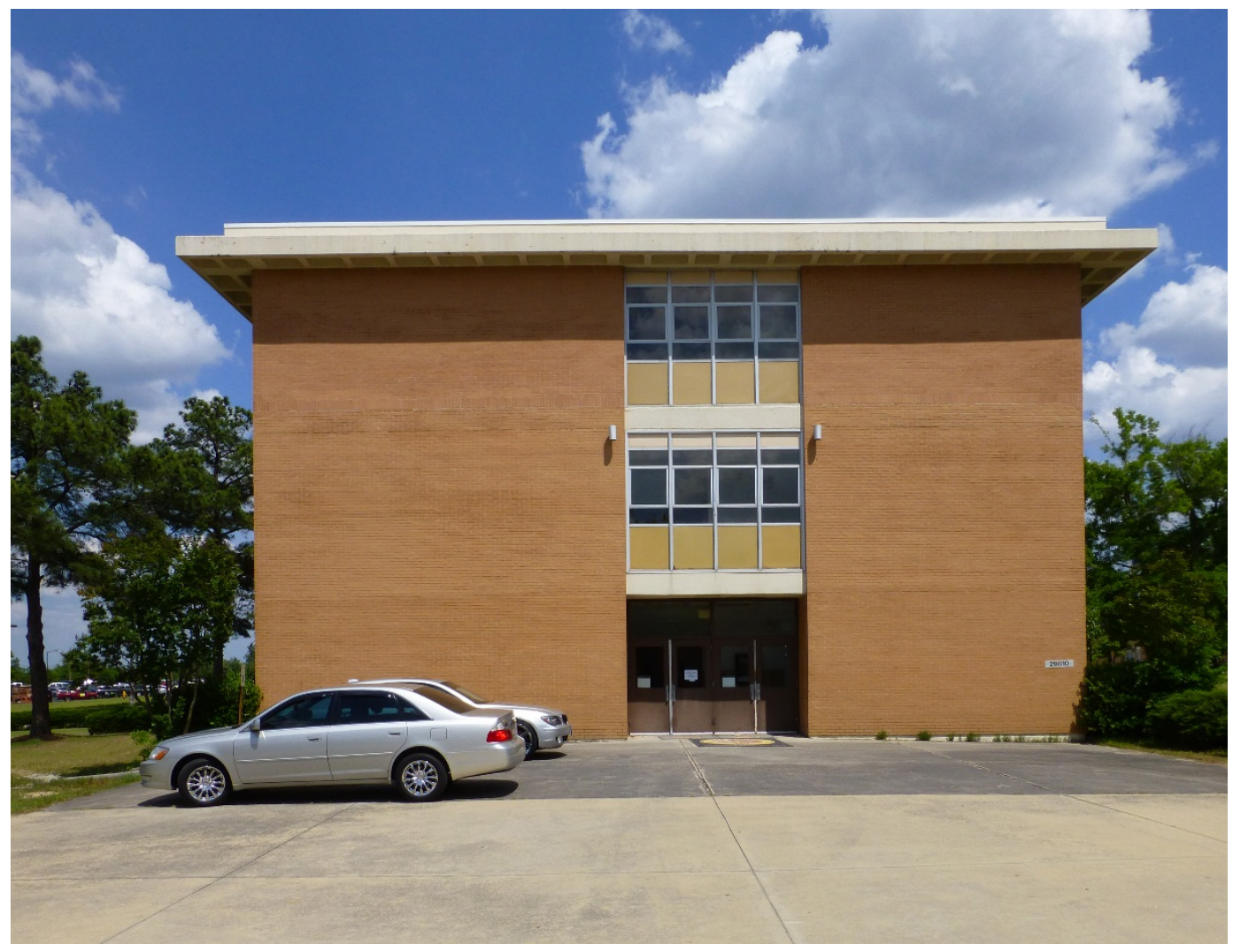

Figure 304. Window elevation details for Building 29810, Burkhardt Hall, 1966 (Fort Gordon DPW).

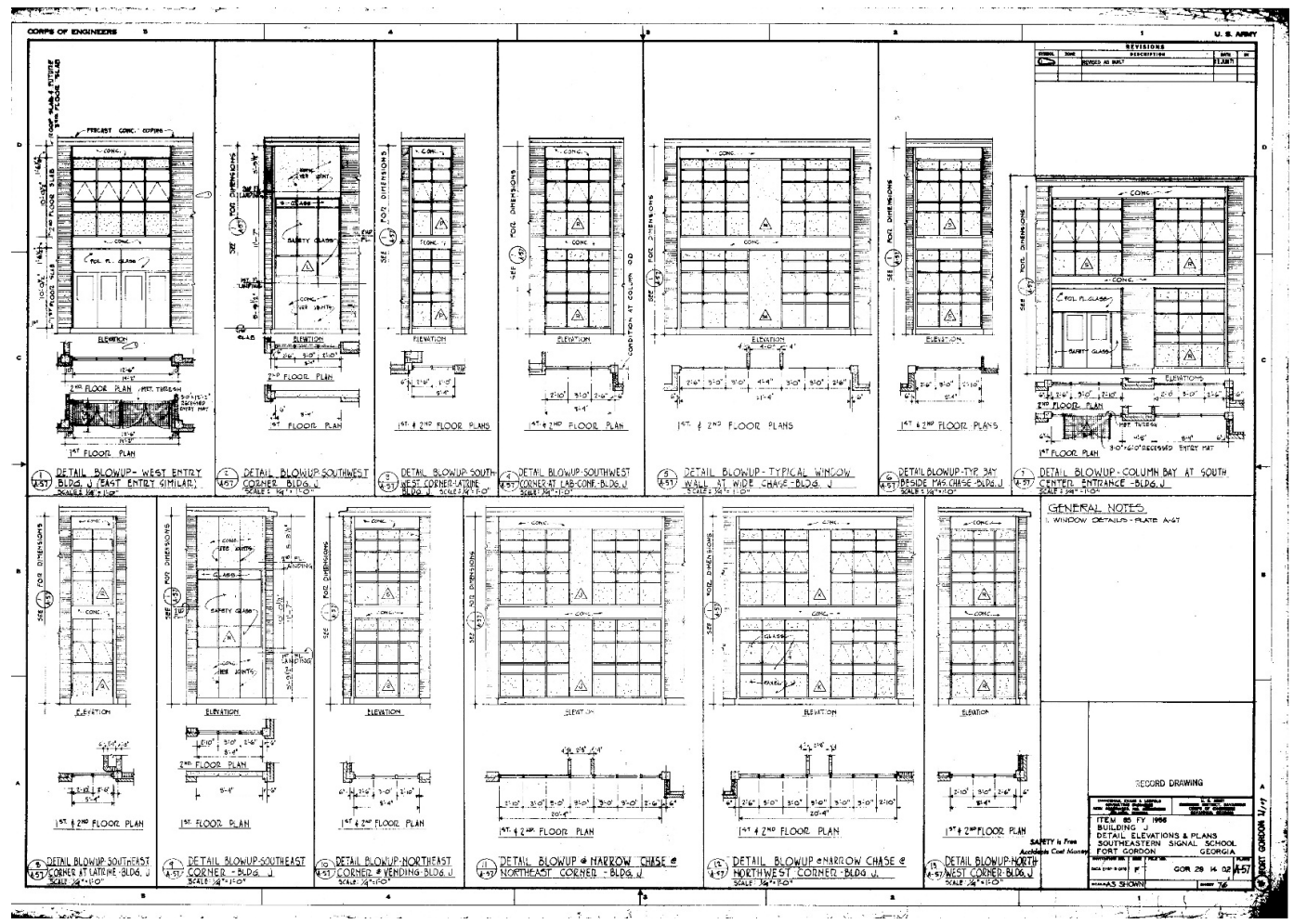


Figure 305. Door and window schedule for Building 29810, Burkhardt Hall, 1966 (Fort Gordon DPW).

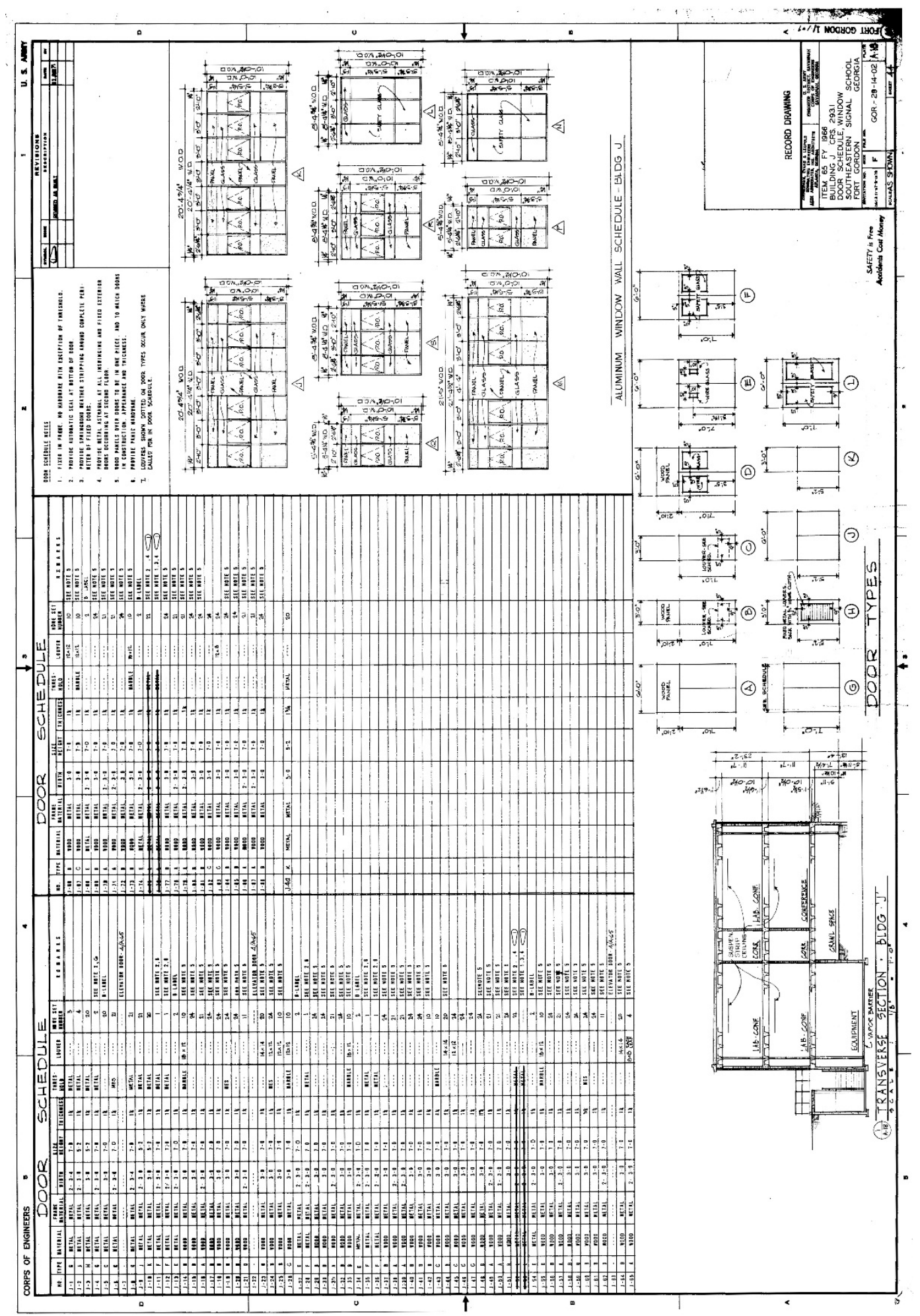


Figure 306. Typical classroom elevations and details for Building 29810, Burkhardt Hall, 1966 (Fort Gordon DPW).

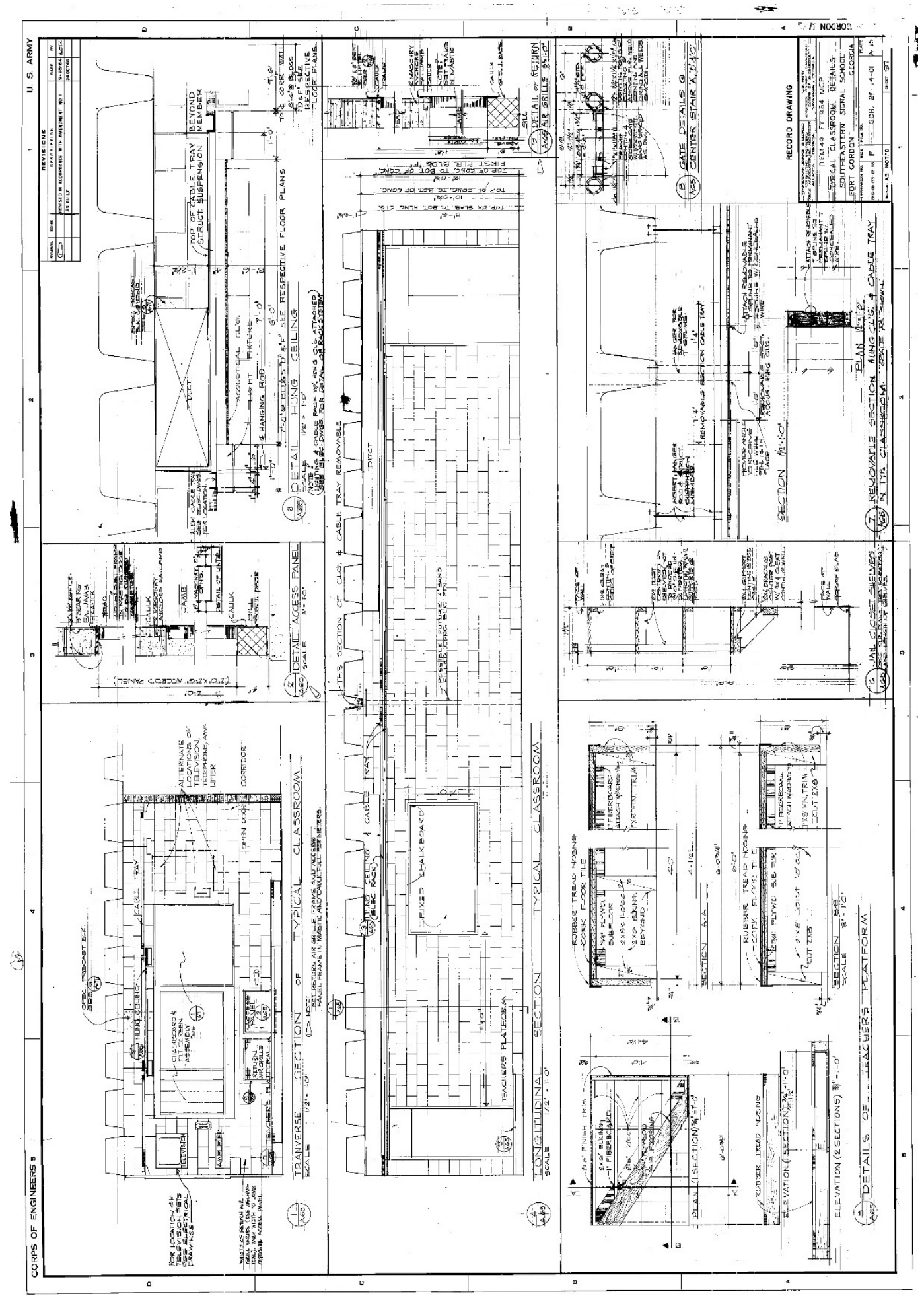


Figure 307. Landscaping plan for Building 29810, Burkhardt Hall, 1966 (Fort Gordon DPW, modified by ERDC-CERL).

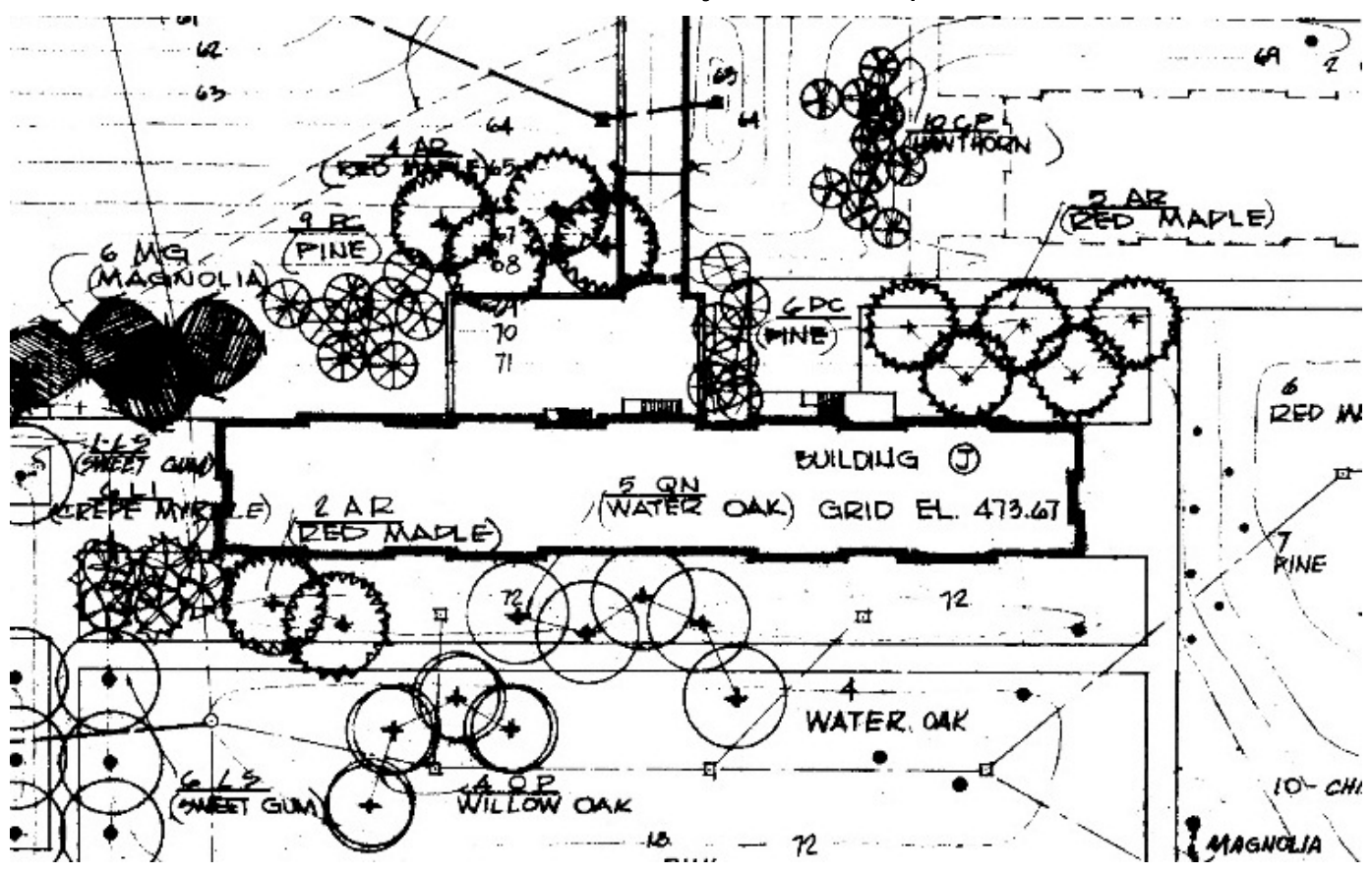

\subsubsection{Character-defining features}

Repair, renovation, and replacement of Building 29810, Burkhardt Hall must be coordinated with the GA SHPO (Table 11).

\section{Exterior:}

- Overall massing

- Footprint

- Roof shape

- Brick veneer

- Overhanging eaves with perforated waffle construction casting "light pattern" on exterior brick walls

- Exposed concrete structure framing window and door openings

- Flat concrete canopy above secondary entries

- Window pattern; recessed groups (two, three, four, or six) of brightaluminum sash windows with fixed panes and insulated panel inserts

- Metal doors with glass pane and fixed transom above

- Walk-out basement level with poured concrete retaining walls and metal handrails

- Wall-mounted cylinder exterior light fixtures

- Wall-mounted cylinder exterior light fixtures 
- Lettering

- Landscaping

\section{Interior:}

- Overall plan

- Main stairwells

- Main hallways

- Lighting

- Doors

- Signage

- Display cases

Table 11. Images of character-defining features of Building 29810, Burkhardt Hall (ERDC-CERL, 2015).

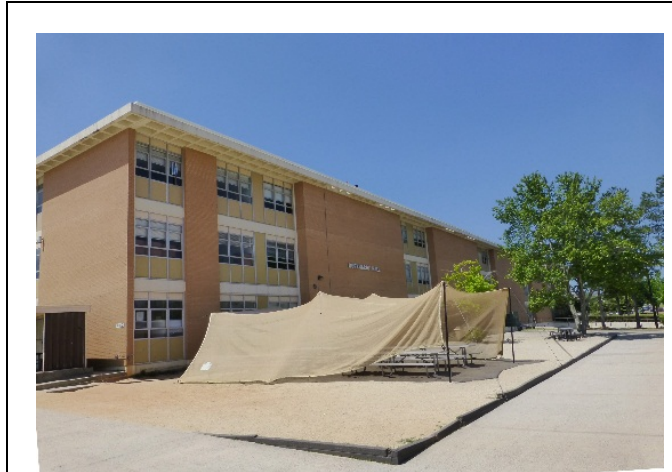

Overall massing, footprint, roof shape, and brick veneer.

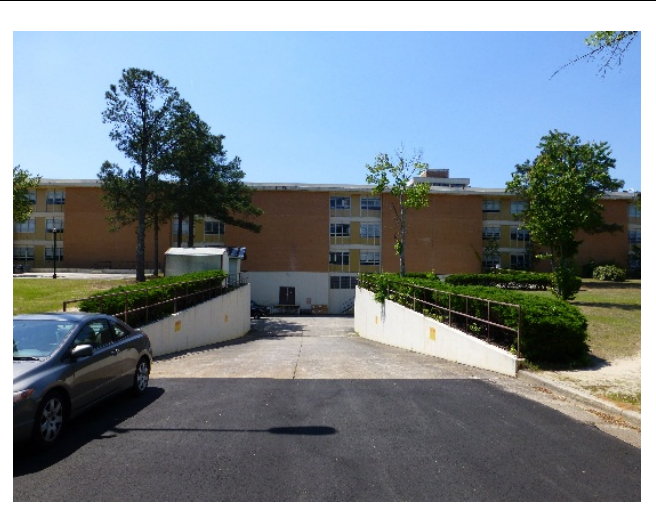

Basement level access on the north elevation with poured concrete retaining walls and metal handrails. 


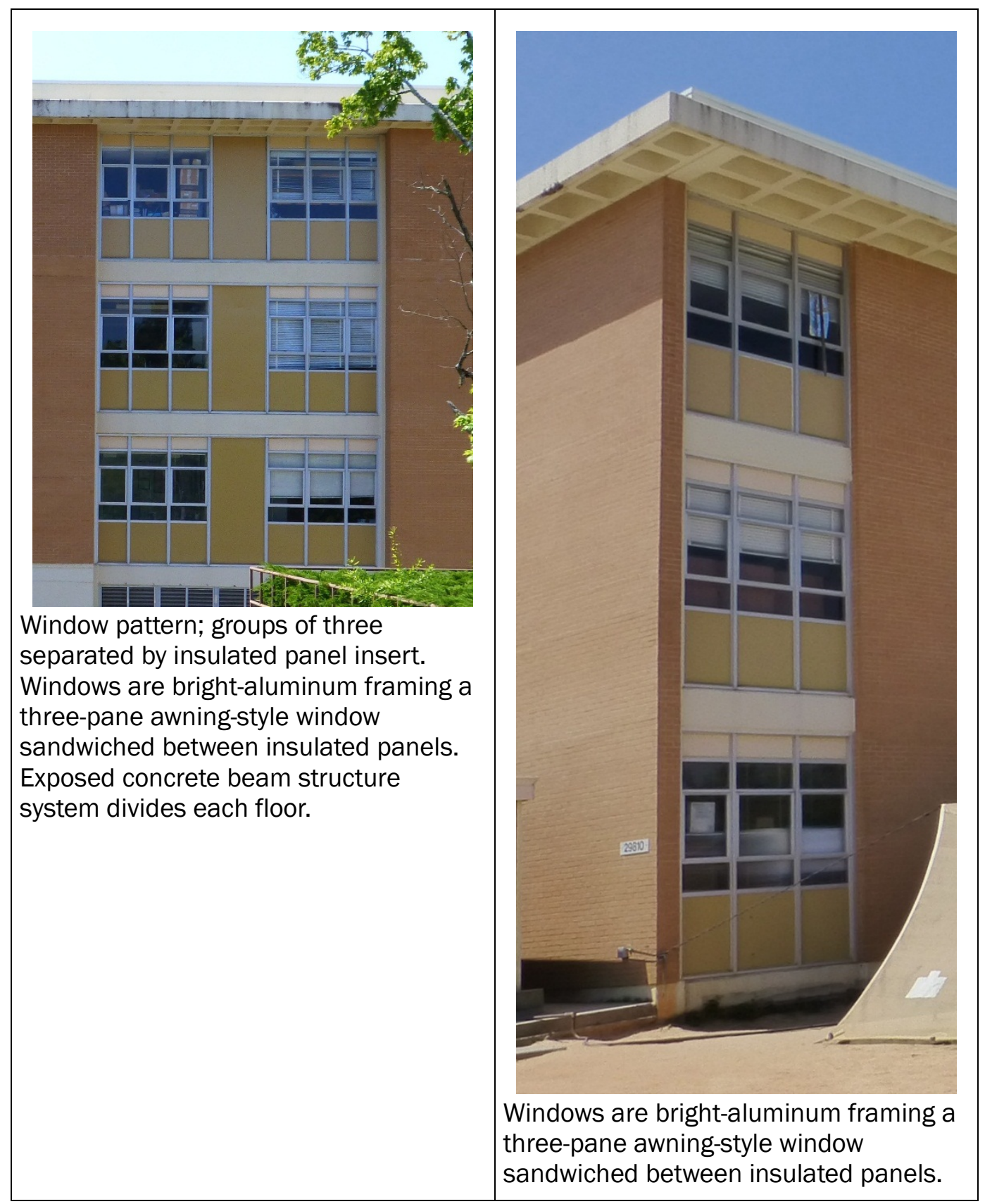




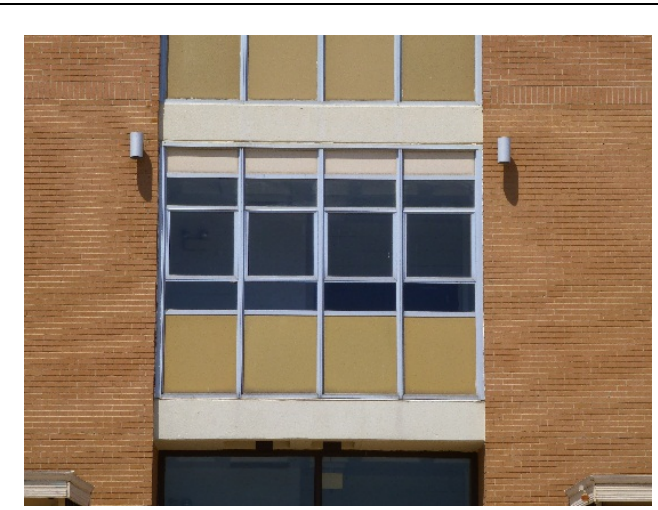

Group of four bright-aluminum-framed, three-pane awning-style windows are sandwiched between insulated panels that are located on the $2^{\text {nd }}$ and $3^{\text {rd }}$ floors of the east and west elevations above the entries.

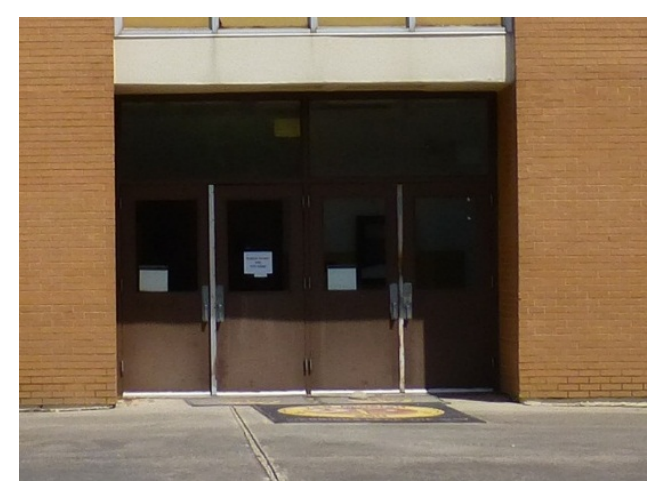

Recessed metal doors with a pane and a fixed transom above.

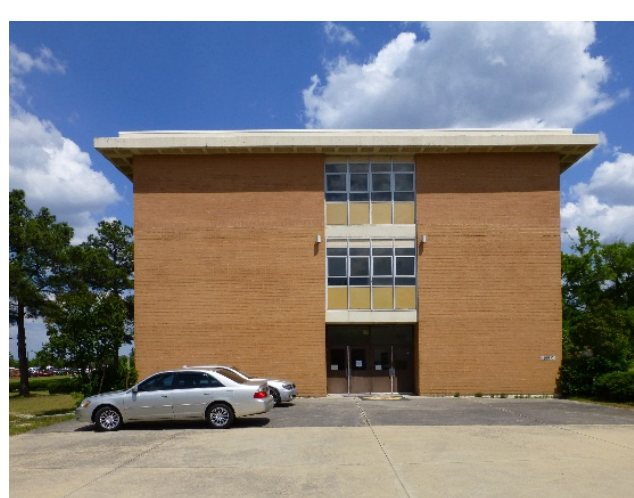

Main entries on the east and west elevations.

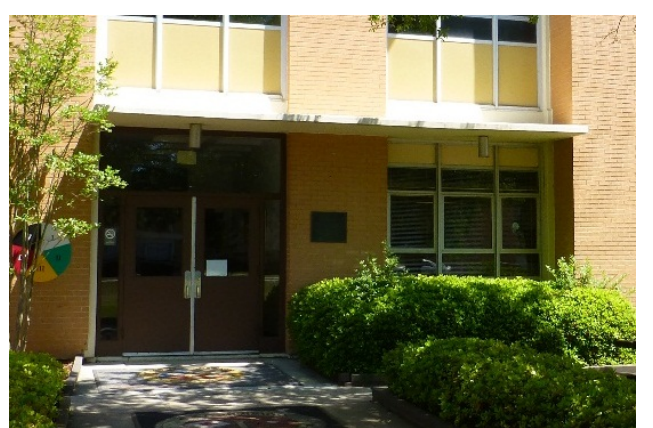

Entry bay on the south elevation with a flat concrete canopy and ceilingmounted light fixtures. 


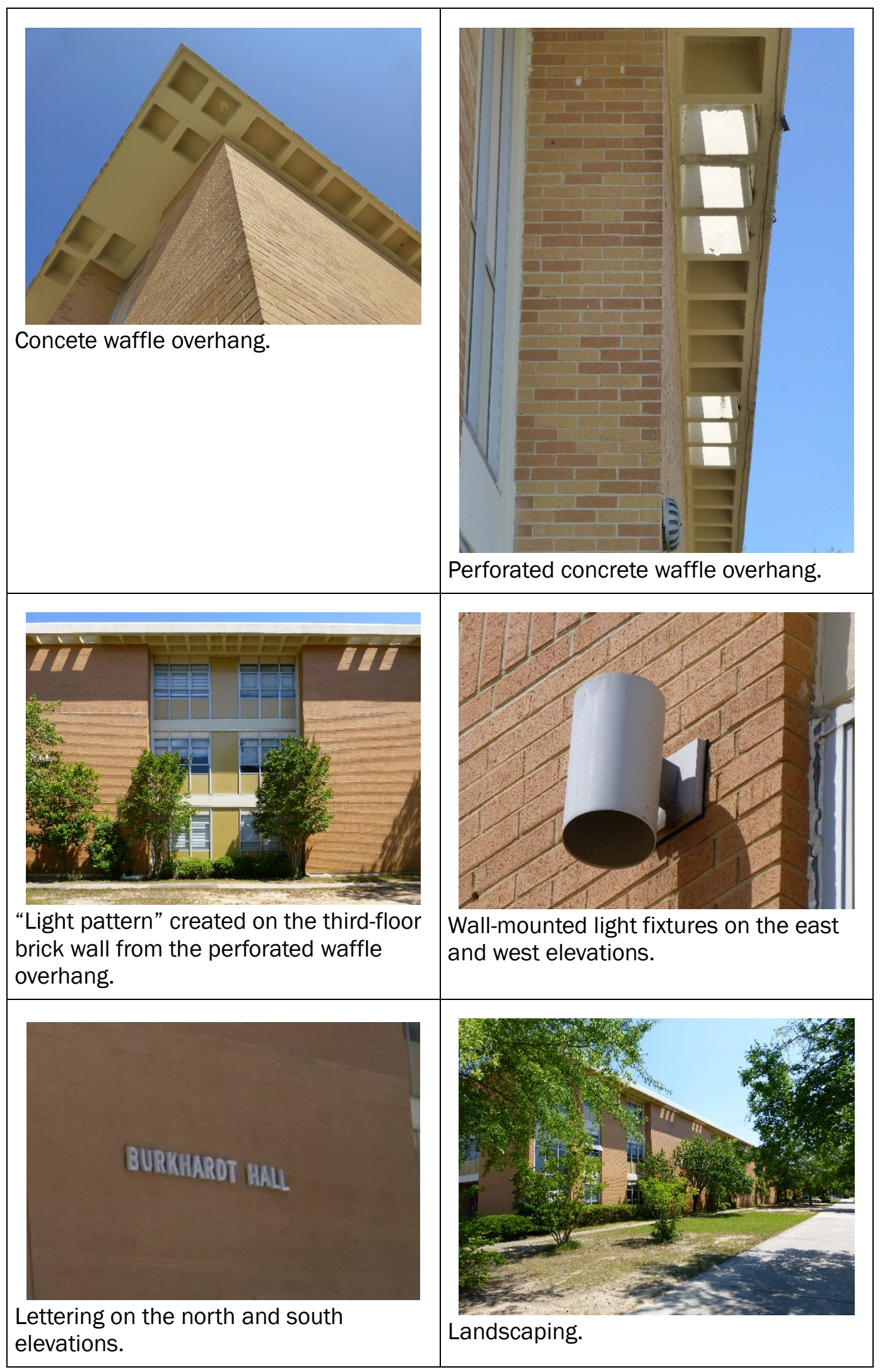




\subsubsection{Character-defining features that have been removed}

- None.

\subsubsection{Nonhistoric features}

- None

\subsubsection{Comparison images}

Comparison images utilizing either the original drawings or historic photographs, when juxtaposed against present-day images, are a useful tool in developing the historic "feel" of a property and how much of that historic feeling is still present today (Figure 308-Figure 310).

Figure 308. Window group with six windows and one large insulated panel comparison of the original design and materials from 1966 [left] to the current condition of the bright-aluminum framed three-pane awning-style windows with insulated panel inserts [right] (ERDC-CERL, 2015).

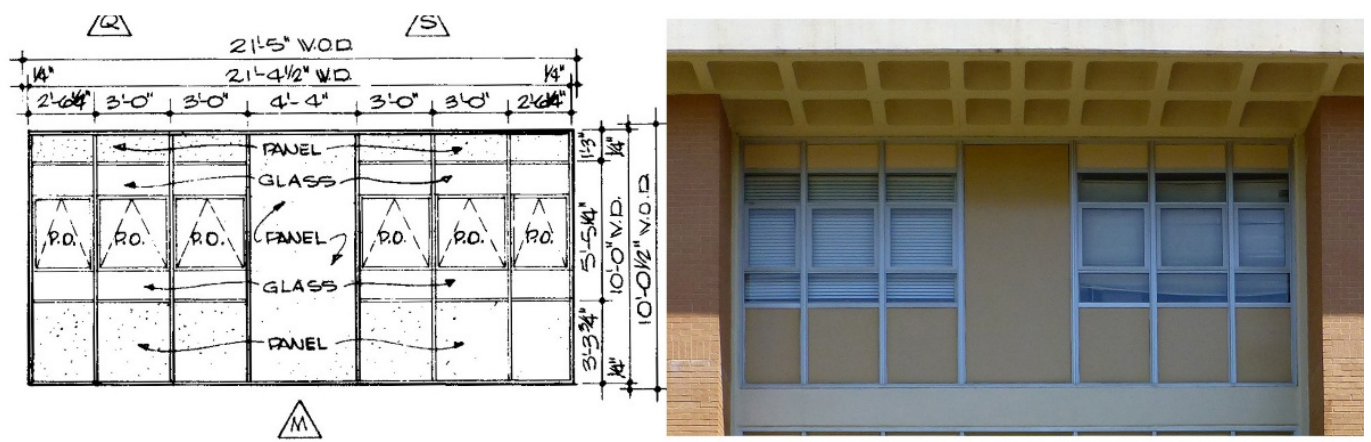


Figure 309. Entry bays on the east and west elevations - comparison of the original design ${ }^{5}$ and materials from 1966 [left.] to the current condition of the three-story entry bay with metal doors with pane and transom above and groups of four brightaluminum framed three-pane awning-style windows sandwiched between insulated panels [right] (ERDC-CERL, 2015).

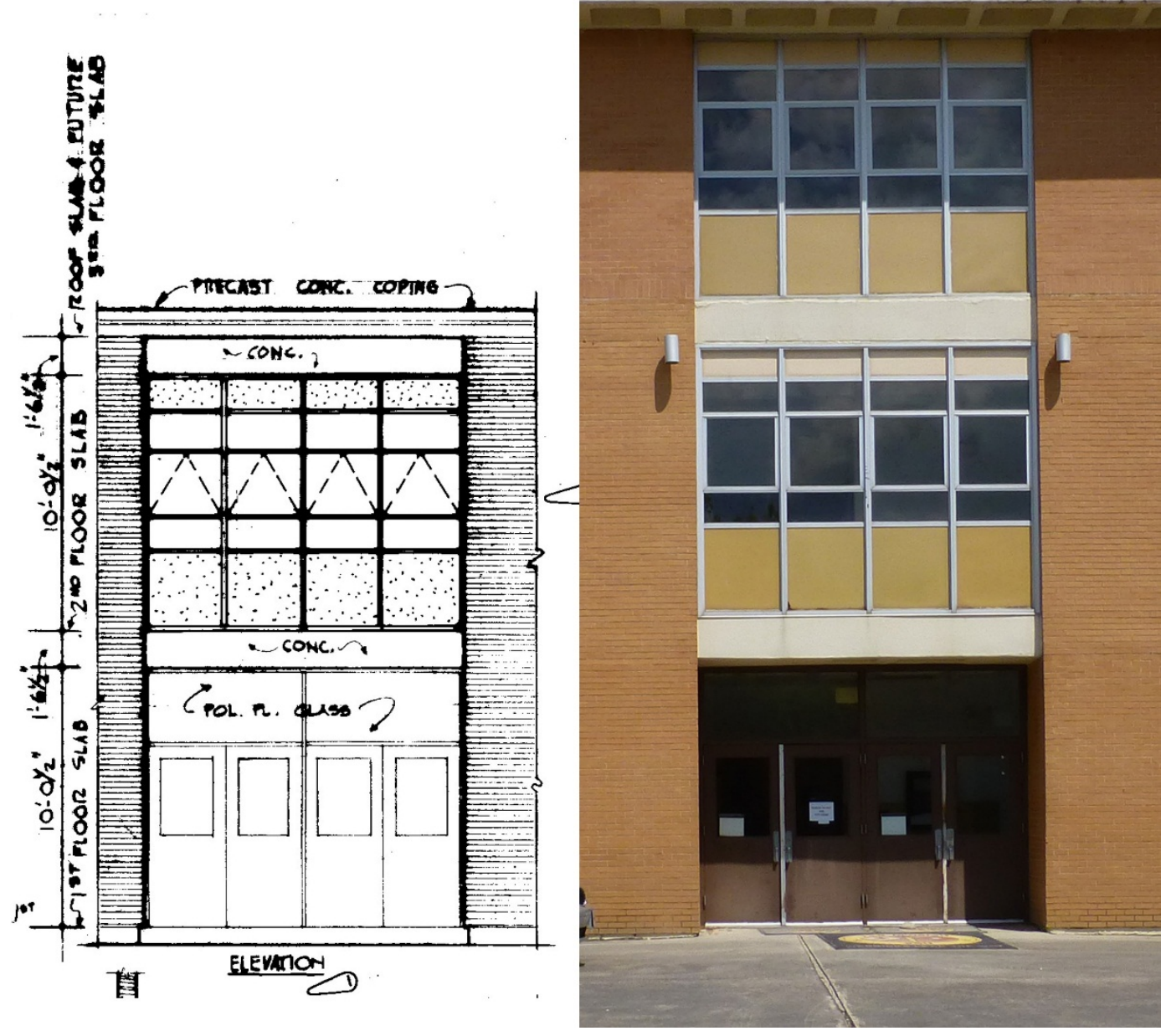

5 Note the drawing is only two stories tall, but it has a notation of "roof slab for future 3 rd floor slab." 
Figure 310. Wall-mounted exterior light fixture - comparison of the original design and materials from 1966 [left] to the current condition of the wall-mounted light

fixture located on the east and west elevations [right] (ERDC-CERL, 2015).
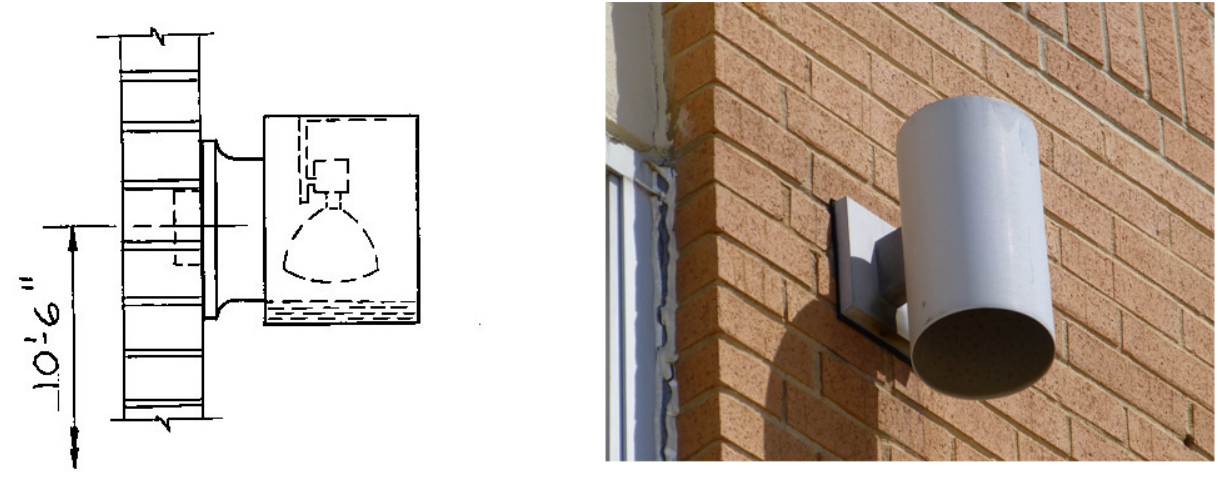

FIXTURE TYPE "H"

WALL MOUNTED

\subsubsection{Building 29811, Saltzman Hall (1966)}

Building 29811, Saltzman Hall, is a contributing feature to the Signal School Campus District. The interior is contributing. It was constructed in 1966 as part of Phase I construction for the campus by architect Aeck Associates from Atlanta, Georgia, and Zimmerman, Evans, and Leopold Consulting Engineers from Augusta, Georgia. It was built as a long rectilinear classroom building with two large courtyards. The building is two stories high with a basement. The structure is of cast-in-place concrete columns with a waffle floor/ceiling structure. The second-floor waffle system is set within the structure, but the roof has the waffles extending out to form an overhang. Some of the waffles of the overhang have been perforated, which creates a "light pattern" on the second floor of the brick exterior walls. The window systems extend the full height of the building and are inset into the brick veneer. The window systems are composed of brightaluminum window frames that enclose insulated panels and awning-style windows. Tan-colored panels are above and below the windows. The window systems are in patterns of two, six, and seven. The window system is separated horizontally by the exposed concrete beam structural system of the building. The south elevation faces the open space of the Signal School Campus. This elevation is symmetrical and is defined by a central entry 
bay. A set of metal entry doors with a large pane is flanked by sidelights and a transom. A flat concrete canopy extends over the entry doors, adjacent the window bay system on the first floor. Above the canopy are two bays of three windows. A bright-aluminum display case and original "SALTZMAN HALL" lettering is to the right of the central bay. Trees flank either side of the entry bay sidewalk, and shrubs are placed in front of the building. On either side of the central bay are two large bays of six windows each with an insulated panel dividing them into groups of three. The far left and right side of the elevation are slightly recessed and a bay of two windows is located at the corners. The entrances are on the east and west elevations consists of two entry bays. Each consists of two sets of metal doors with large panes and a large fixed-pane transom above each set of doors. Above these first-floor doors are sets of metal and plate-glass doors with a transom above each set of doors. These doors are welded closed with a steel bar across the middle. It appears bridges were meant to connect the various buildings together at the second-floor level. There is one bright-aluminum display case placed on each elevation. Basement access is on the east and west is located between the main sets of doors and the opening is protected by a perforated brick wall in the same brick as the building. On the east and west sides of the building are small landscaped brick plazas that are framed by four trees [east] and two trees [west]. The north elevation is symmetrical. There are five large window bays. The center bay is an entry bay with a set of metal doors with a large pane with transom above and five concrete panels on the first floor. A flat concrete canopy projects out above the doors and panels. Above the canopy on the second floor is a group of seven bright-aluminum three-pane fixed windows. The other four large bays consist of two groups of three windows divided by an insulated panel. The far left and right sides have smaller twowindow bay systems and are recessed at the corners. There are two separate outside access points to the basement on the north side of the building. Poured concrete walls, concrete steps, and metal handrails indicate these points. Also on the north wall is lettering spelling out "SALTZMAN HALL." Shrubs line the right side of the north wall's perimeter (Figure 311-Figure 333). 
Figure 311. Signal School Campus map, with Building 29811, Saltzman Hall highlighted in red, 2015 (Fort Gordon DPW, modified by ERDC-CERL).

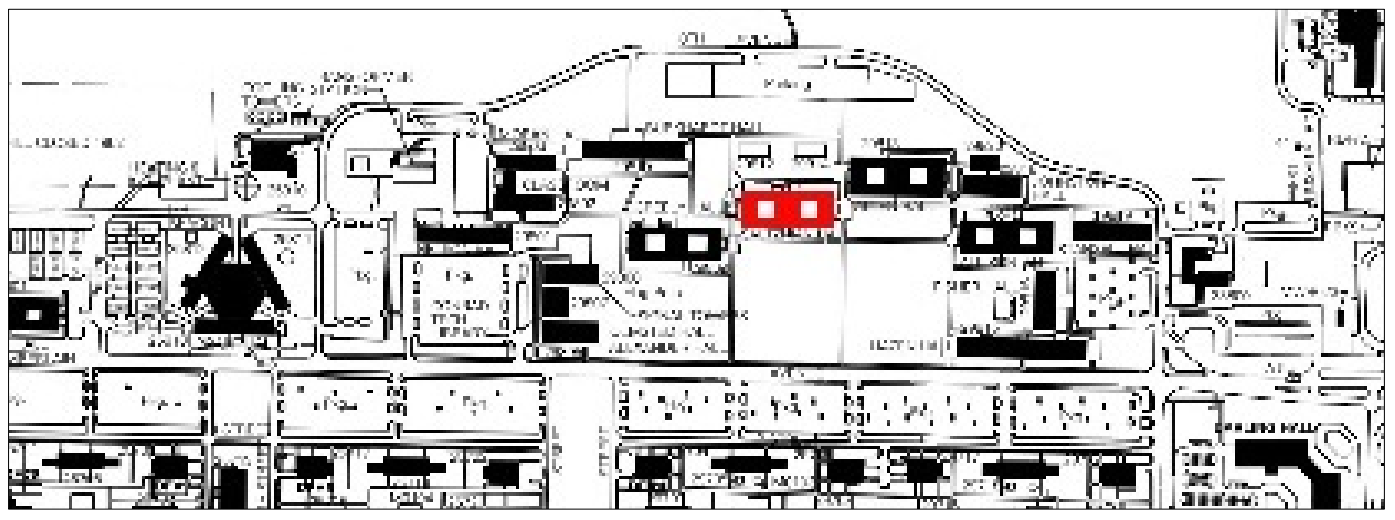

Figure 312. Southeast corner of Building 29811, Saltzman Hall, (ERDC-CERL, 2015).

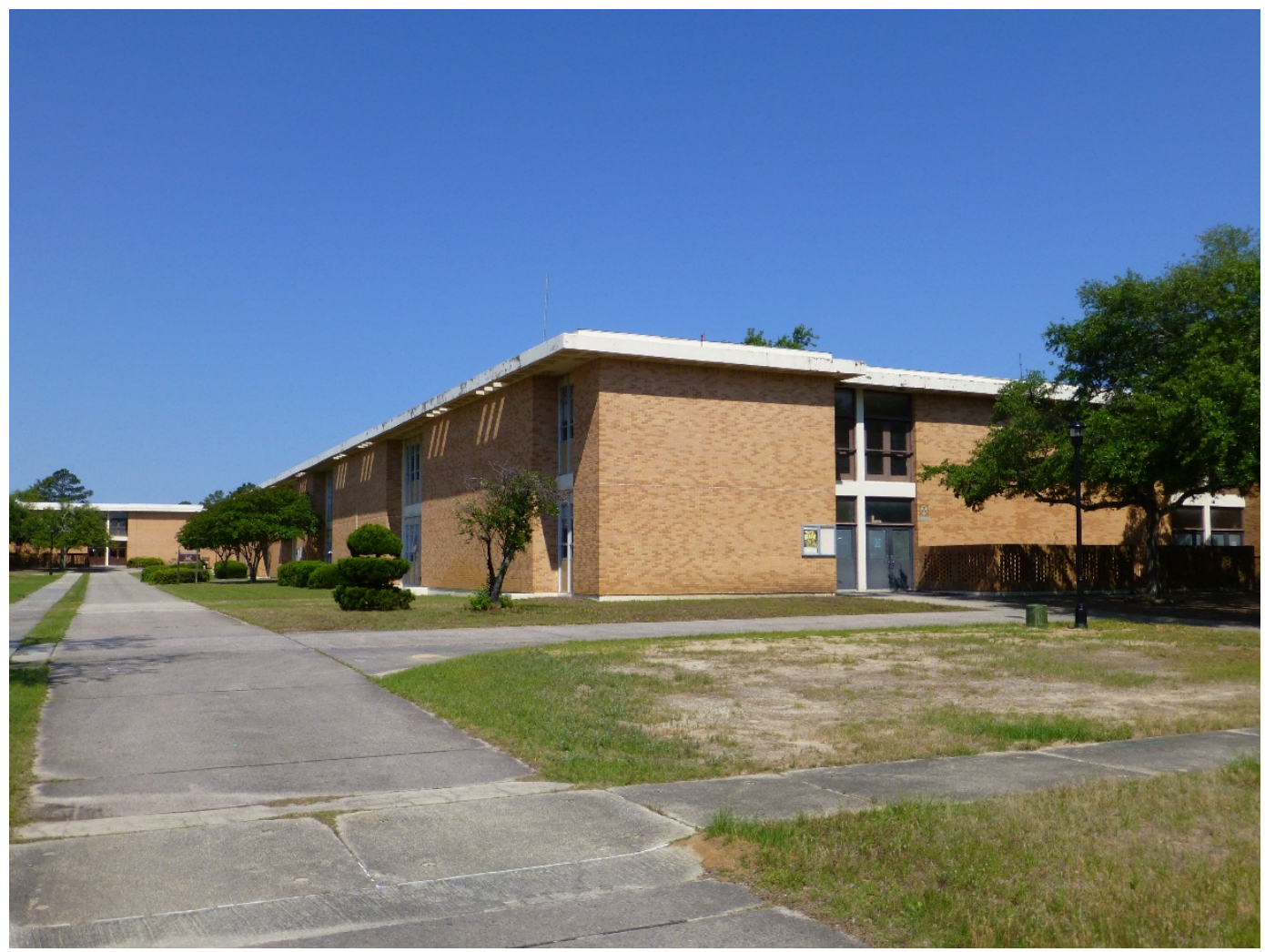


Figure 313. Left side of the south elevation of Building 29811, Saltzman Hall (ERDC-CERL, 2015).

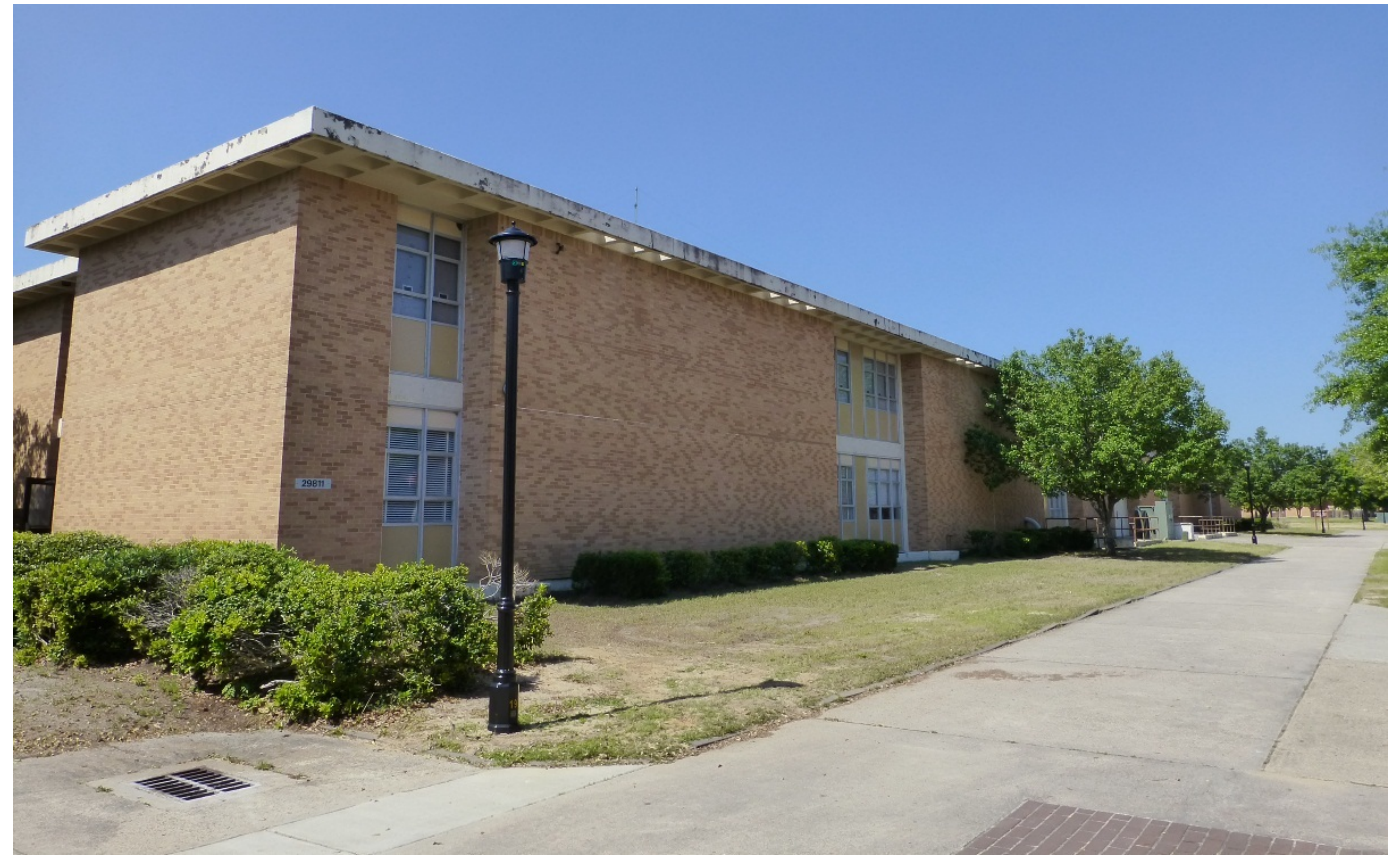

Figure 314. Main entry bay on the south elevation of Building 29811, Saltzman Hall (ERDC-CERL, 2015).

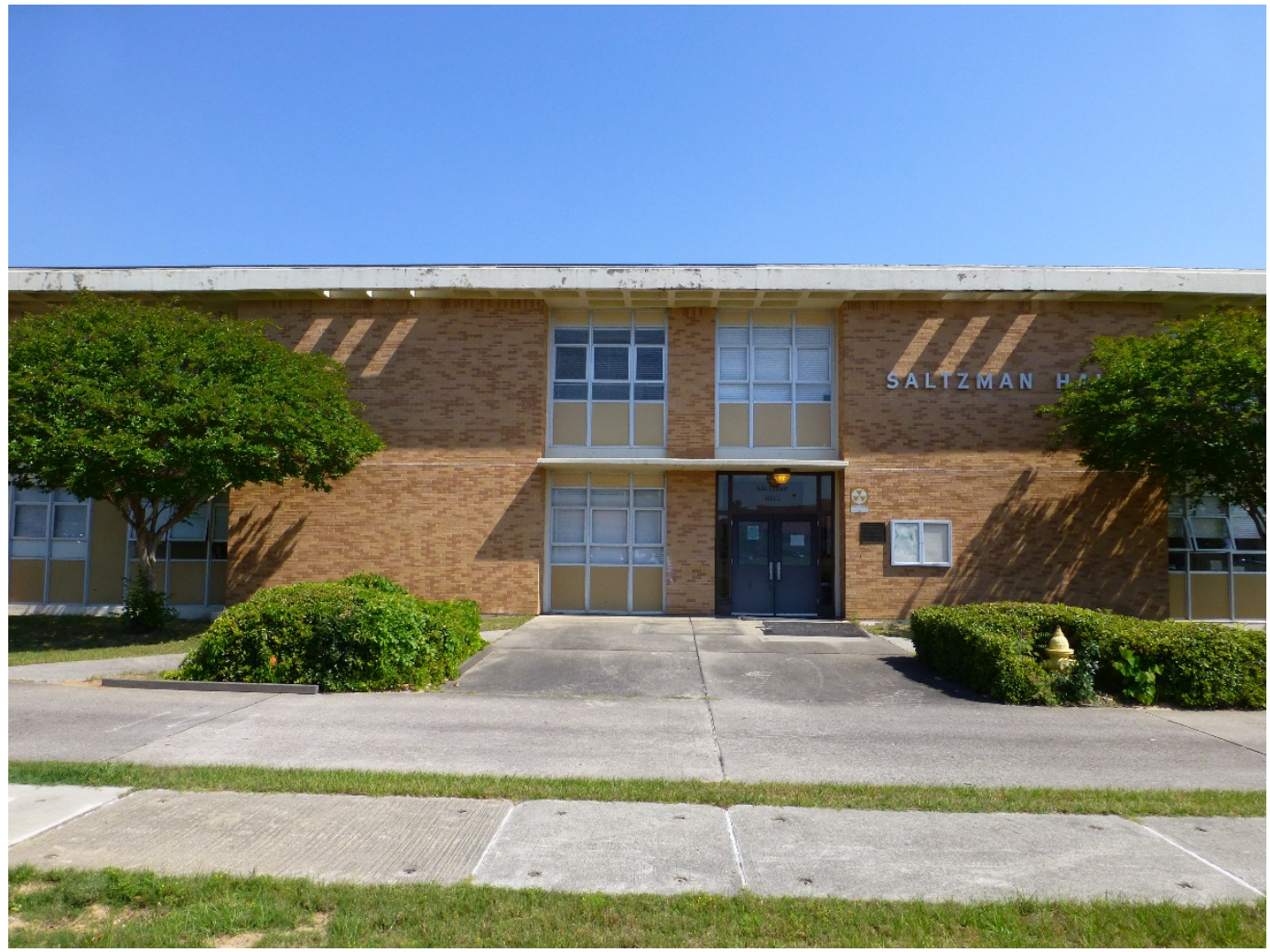


Figure 315. East elevation of Building 29811, Saltzman Hall (ERDC-CERL, 2015).

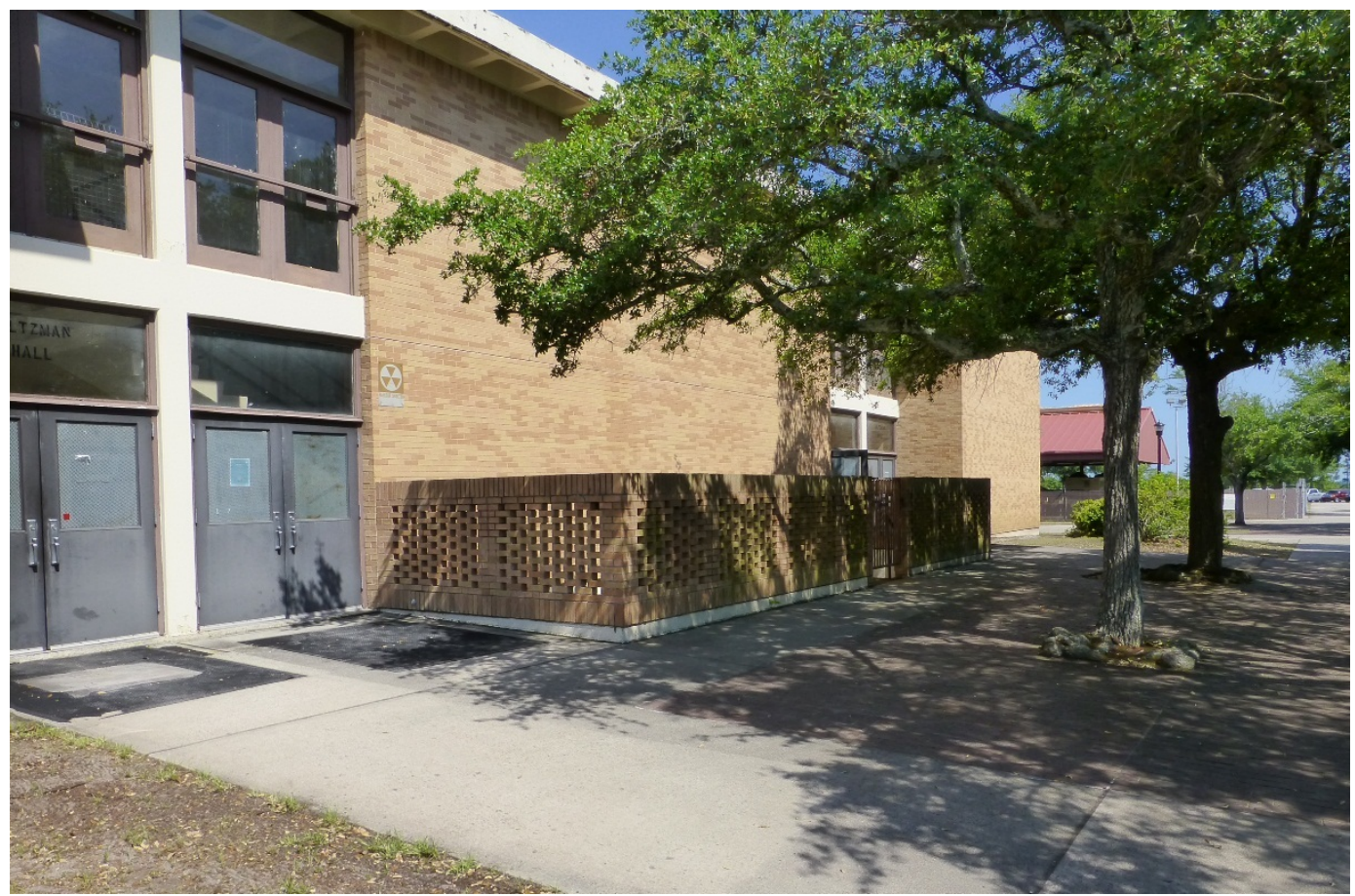

Figure 316. West elevation of Building 29811, Saltzman Hall (ERDC-CERL, 2015).

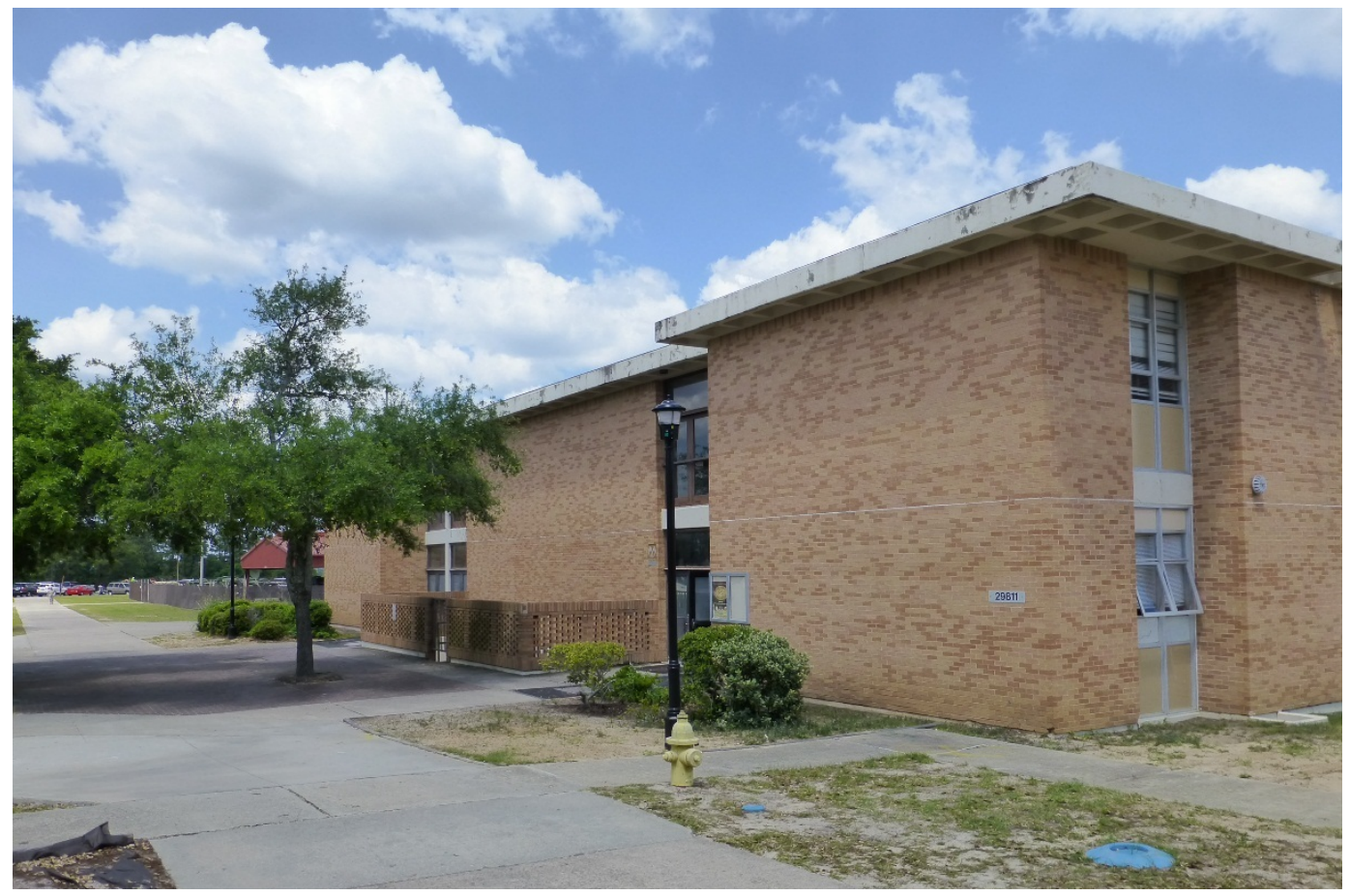


Figure 317. View of the Signal School construction, southeast corner of Building 29818 in the front with Buildings 29813, 29811, and 29809 at the back left of photo, March 1966 (National Archives at College Park, MD).

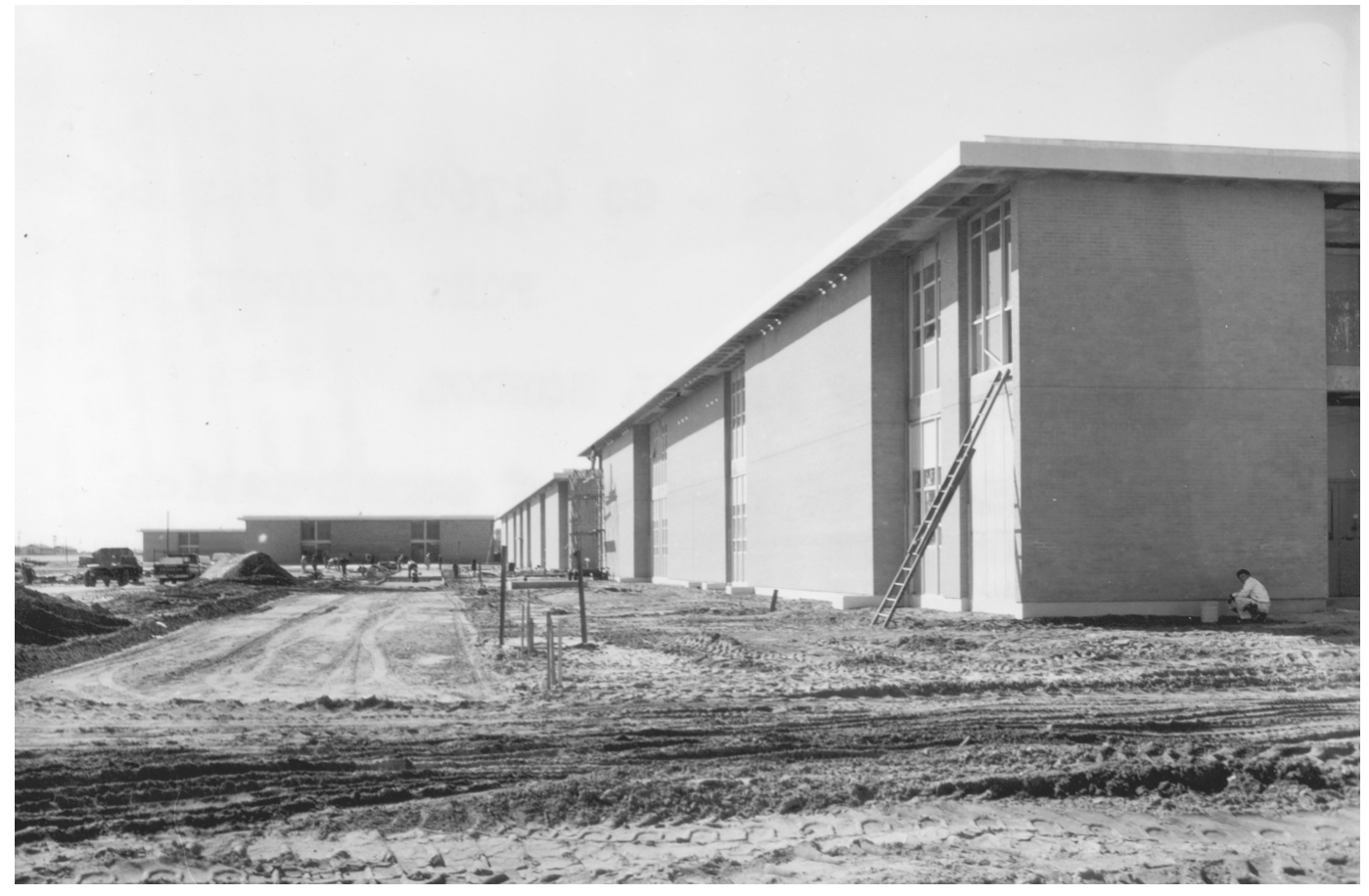

Figure 318. Building 29811, Saltzman Hall, March 1967 (National Archives at College Park, MD).

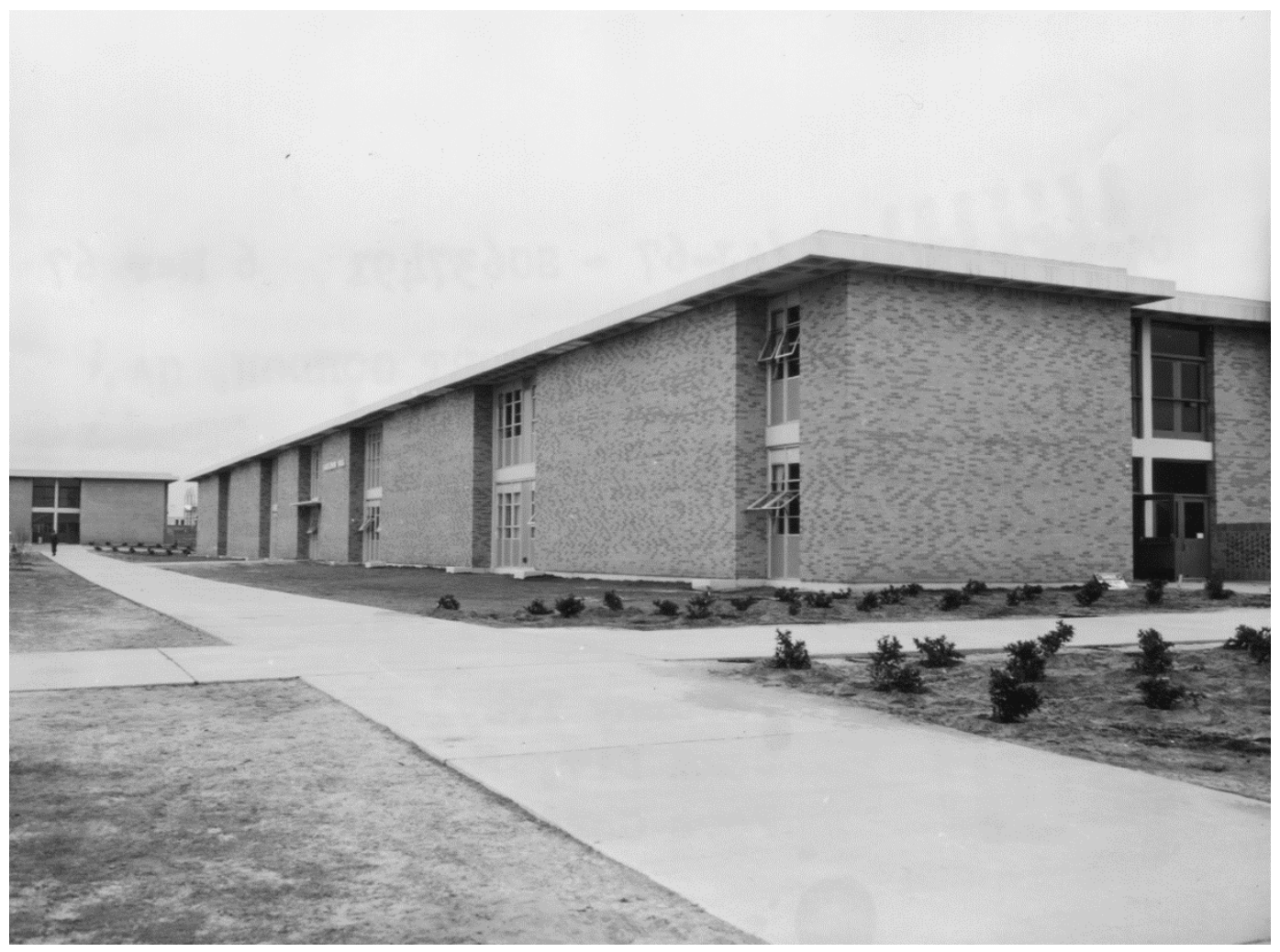


Figure 319. View looking northeast, Building 29811 is on the left and Building 29817 is on distant right, April 1978 (National Archives at College Park, MD).

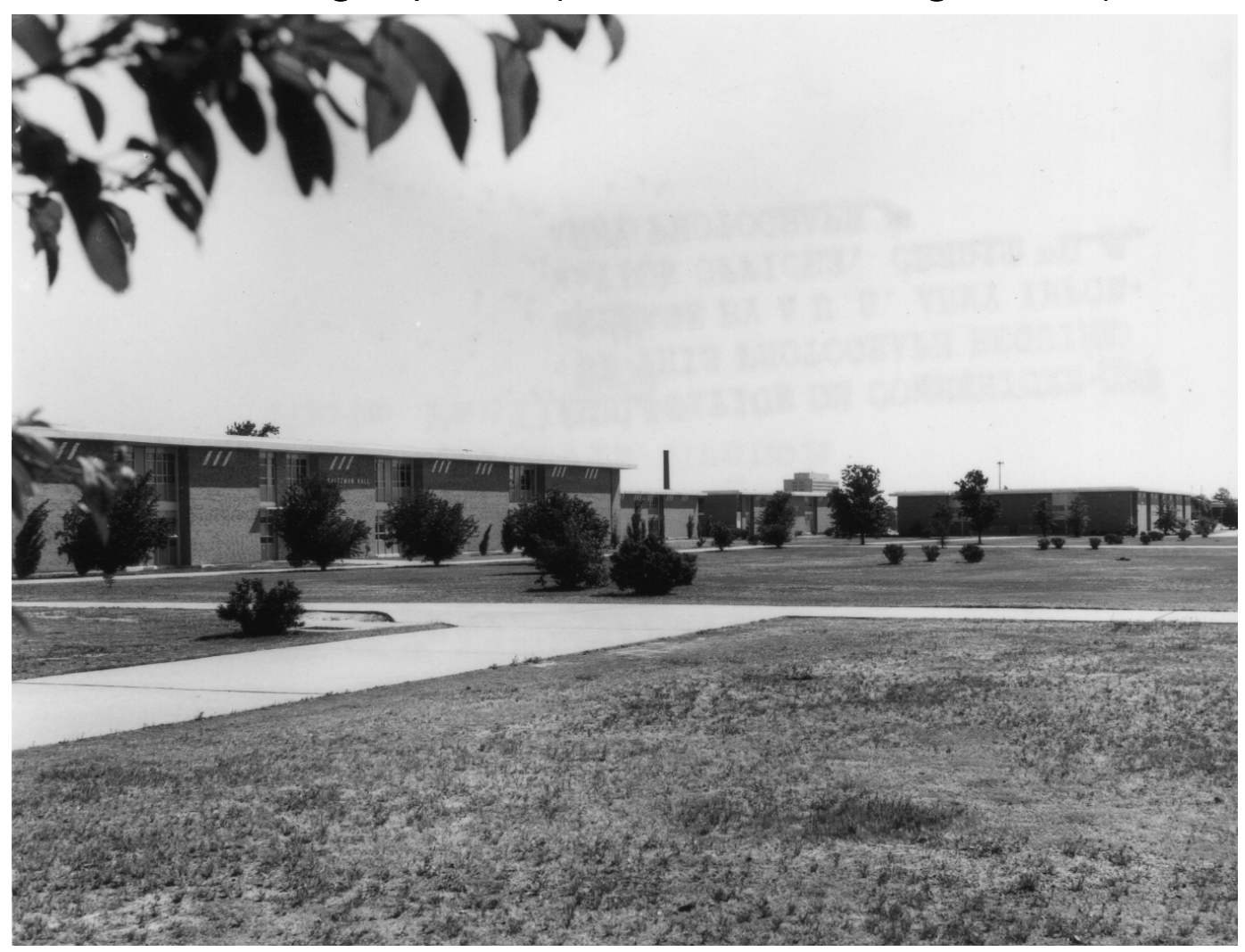


Figure 320. First-floor plan [left side] for Building 29811, Saltzman Hall, 1964 (Fort Gordon DPW).

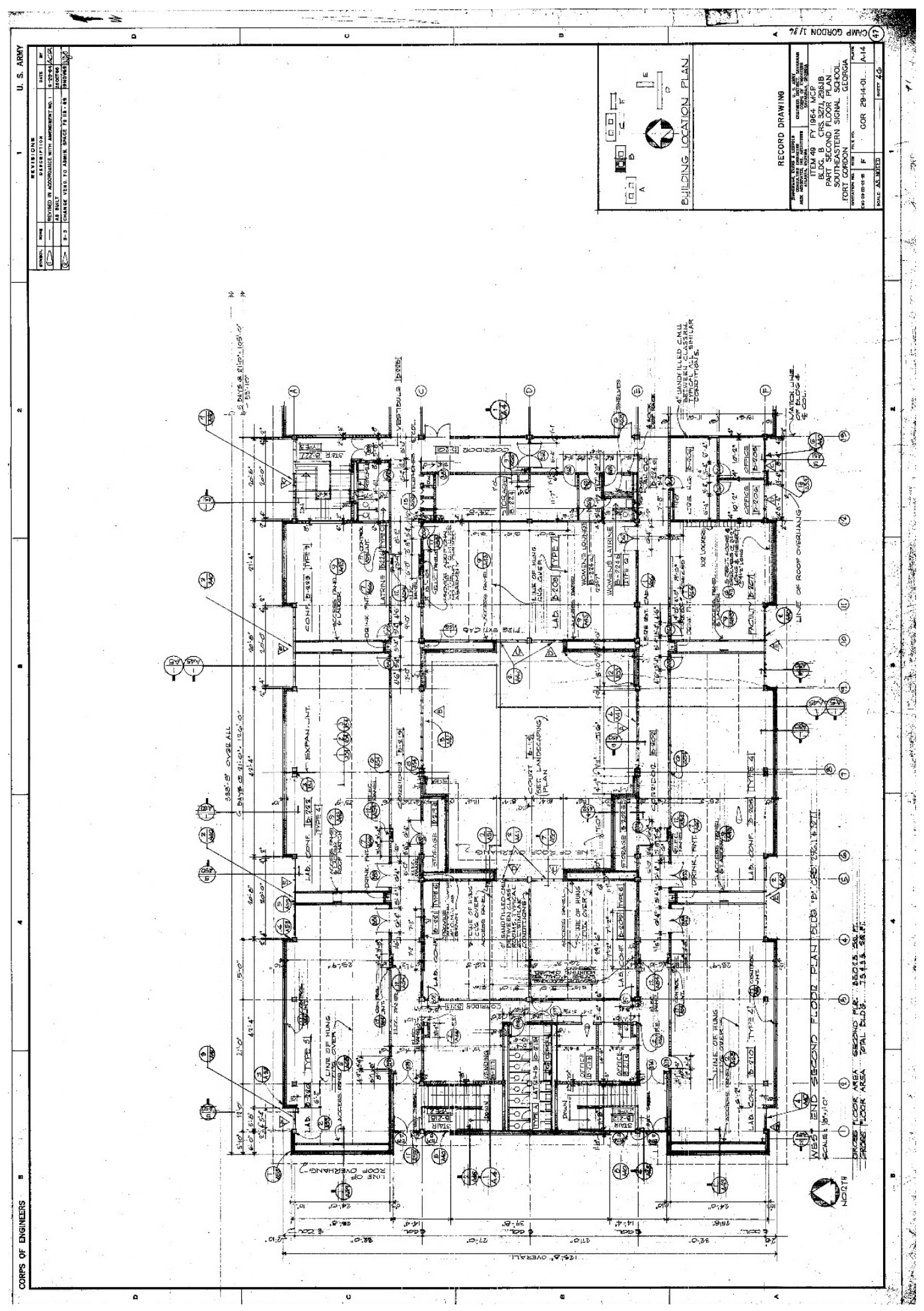


Figure 321. First-floor plan [right side] for Building 29811, Saltzman Hall, 1964 (Fort Gordon DPW).

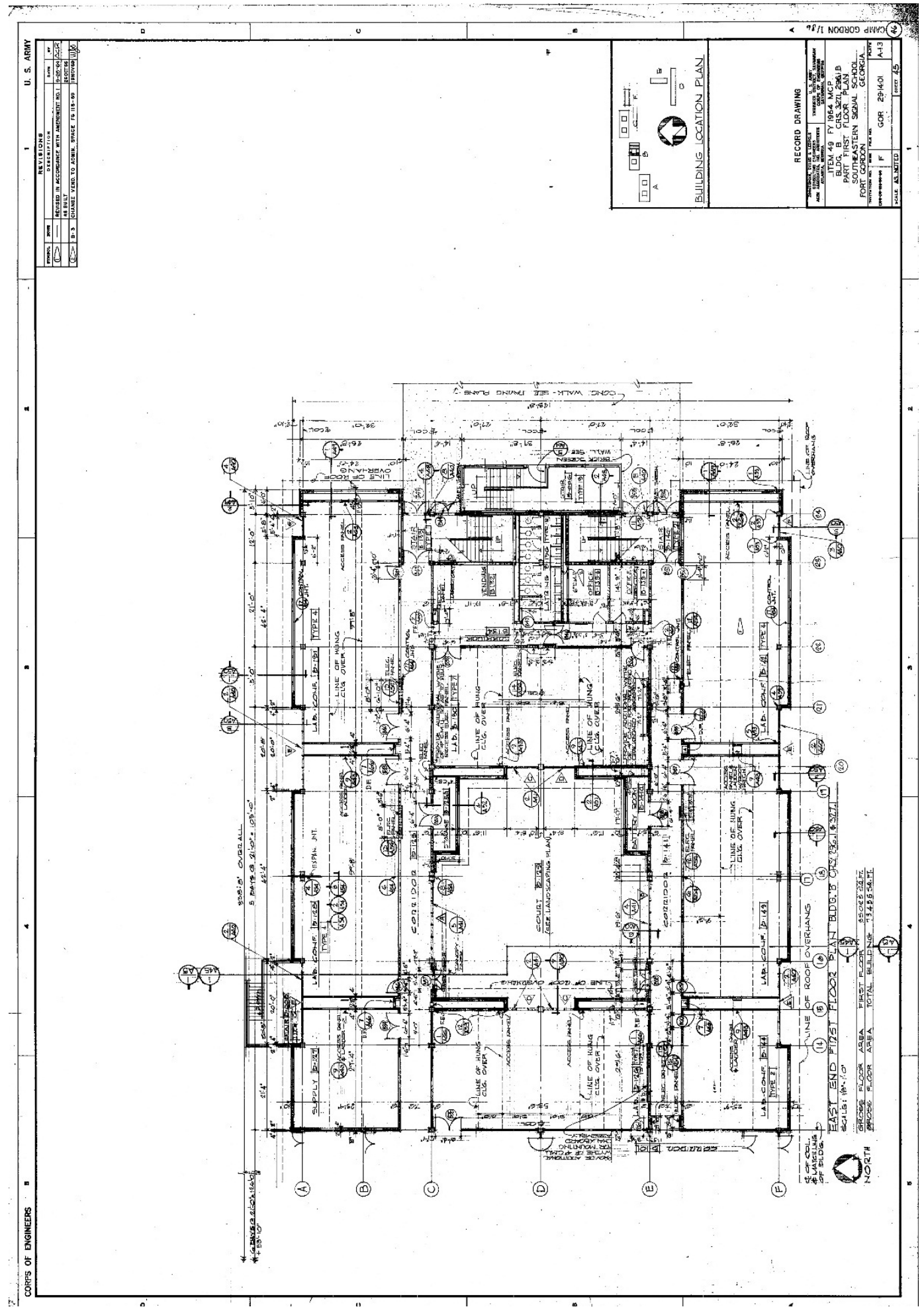


Figure 322. Elevations for Building 29809, Greely Hall [left side] and Building 29811, Saltzman Hall [right side], 1964 (Fort Gordon DPW).

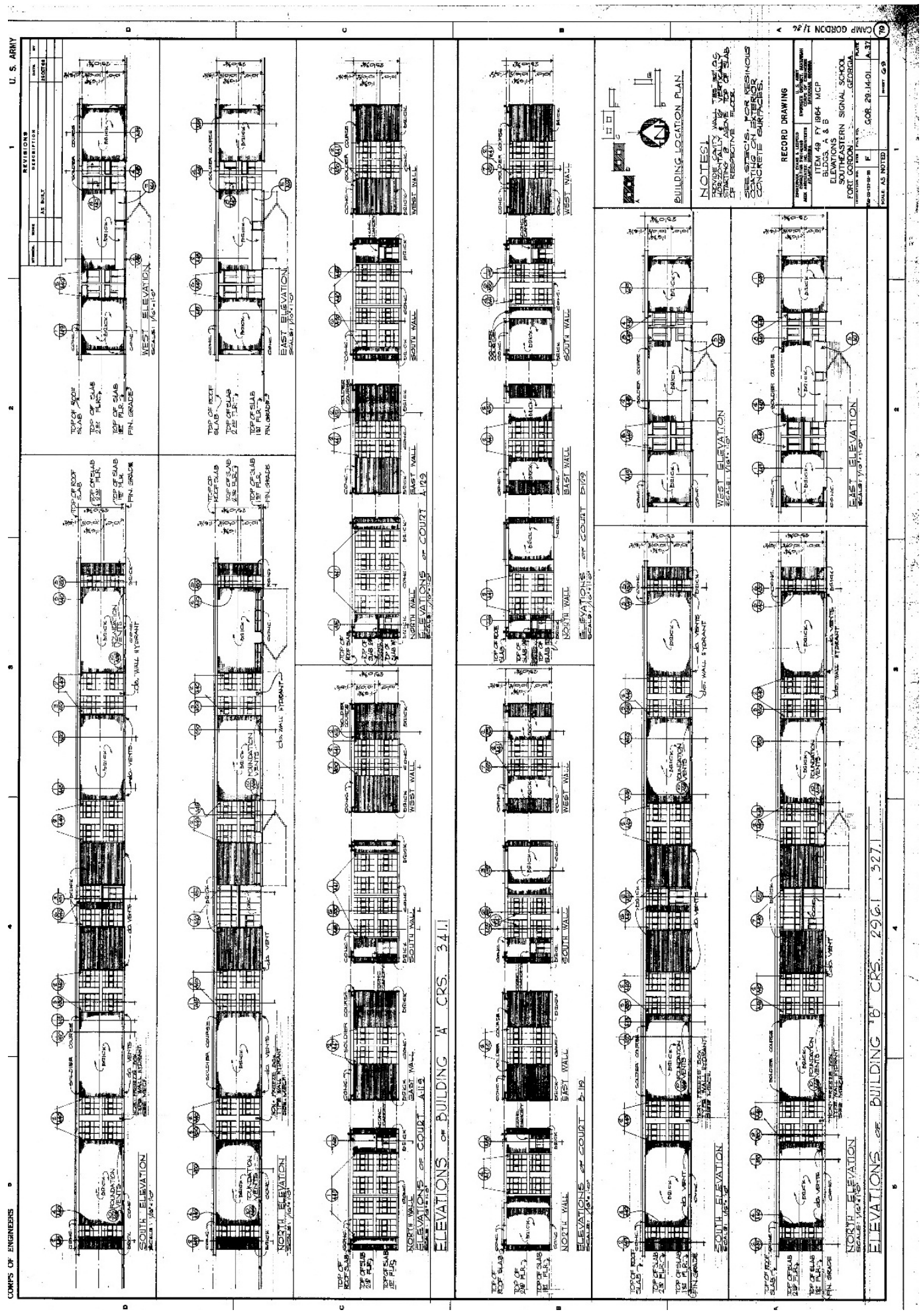


Figure 323. Door and window schedule for Building 29811, Saltzman Hall, 1964 (Fort Gordon DPW).

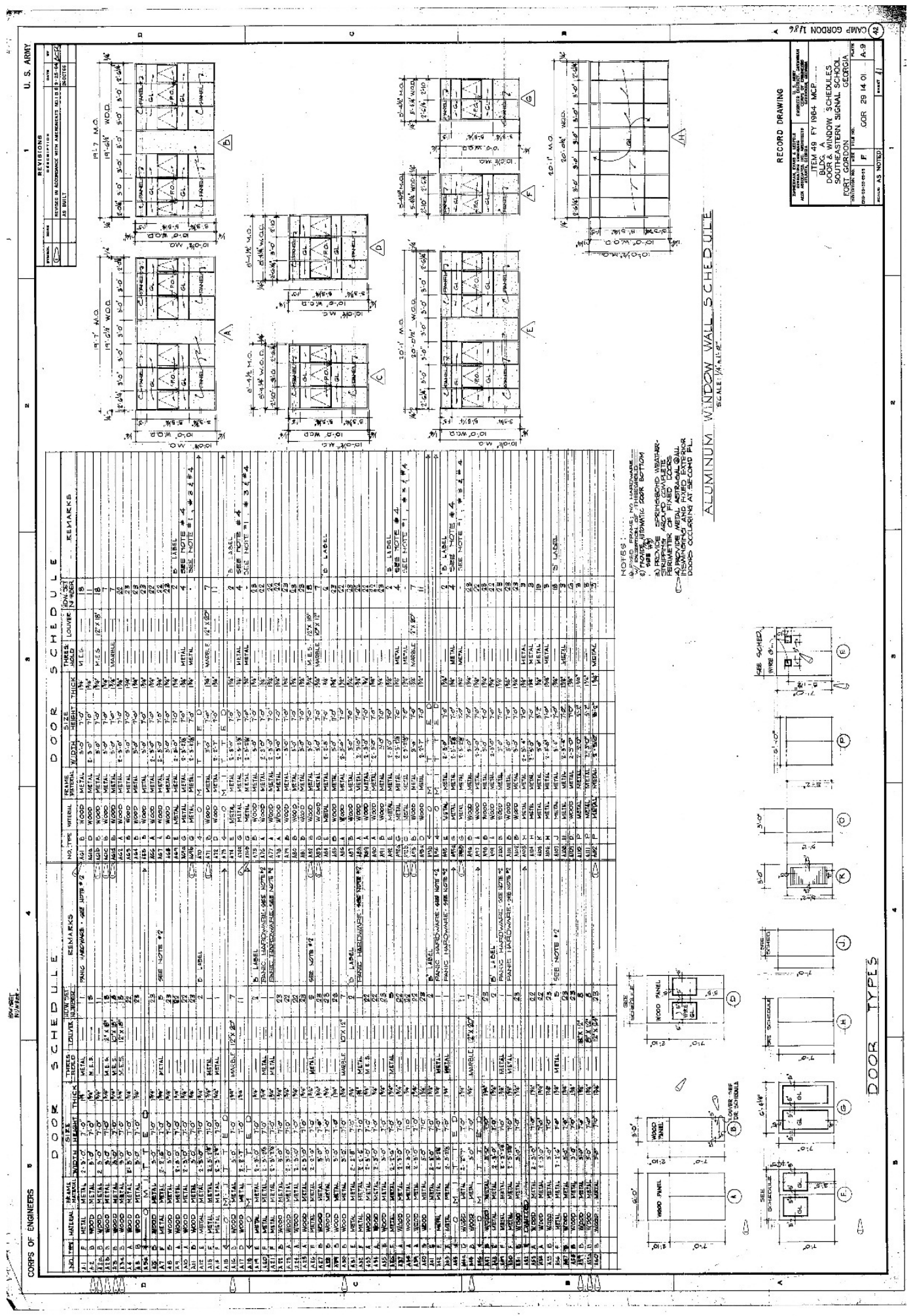


Figure 324. Partial longitudinal section of Building 29811, 1964 (Fort Gordon DPW).

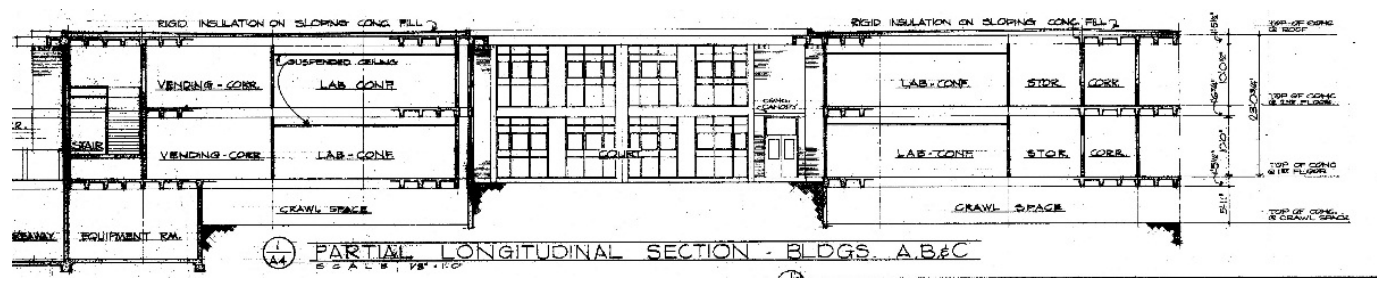

Figure 325. Transverse section of Building 29811, Saltzman Hall, 1964 (Fort Gordon DPW).

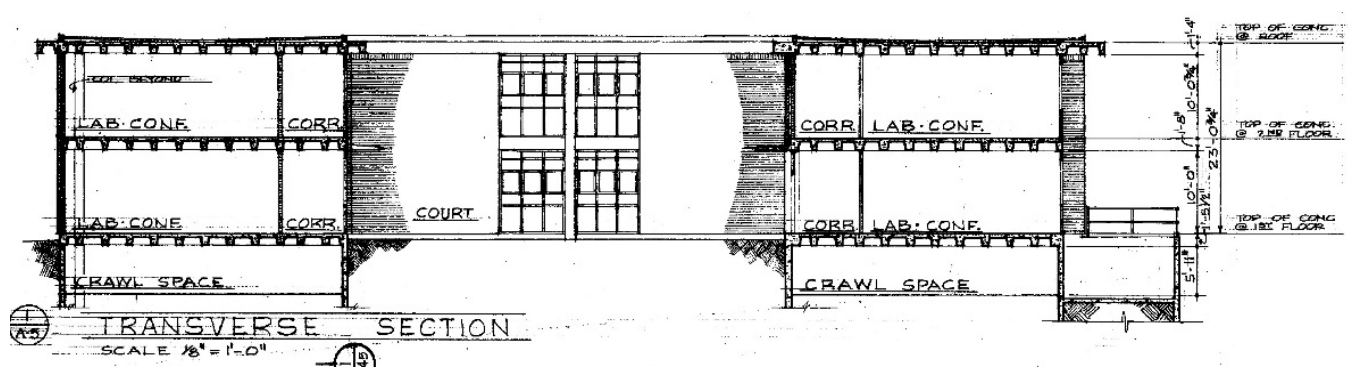

Figure 326. Sections of Building 29811, Saltzman Hall, showing concrete waffle ceiling and roof construction, 1964 (Fort Gordon DPW).

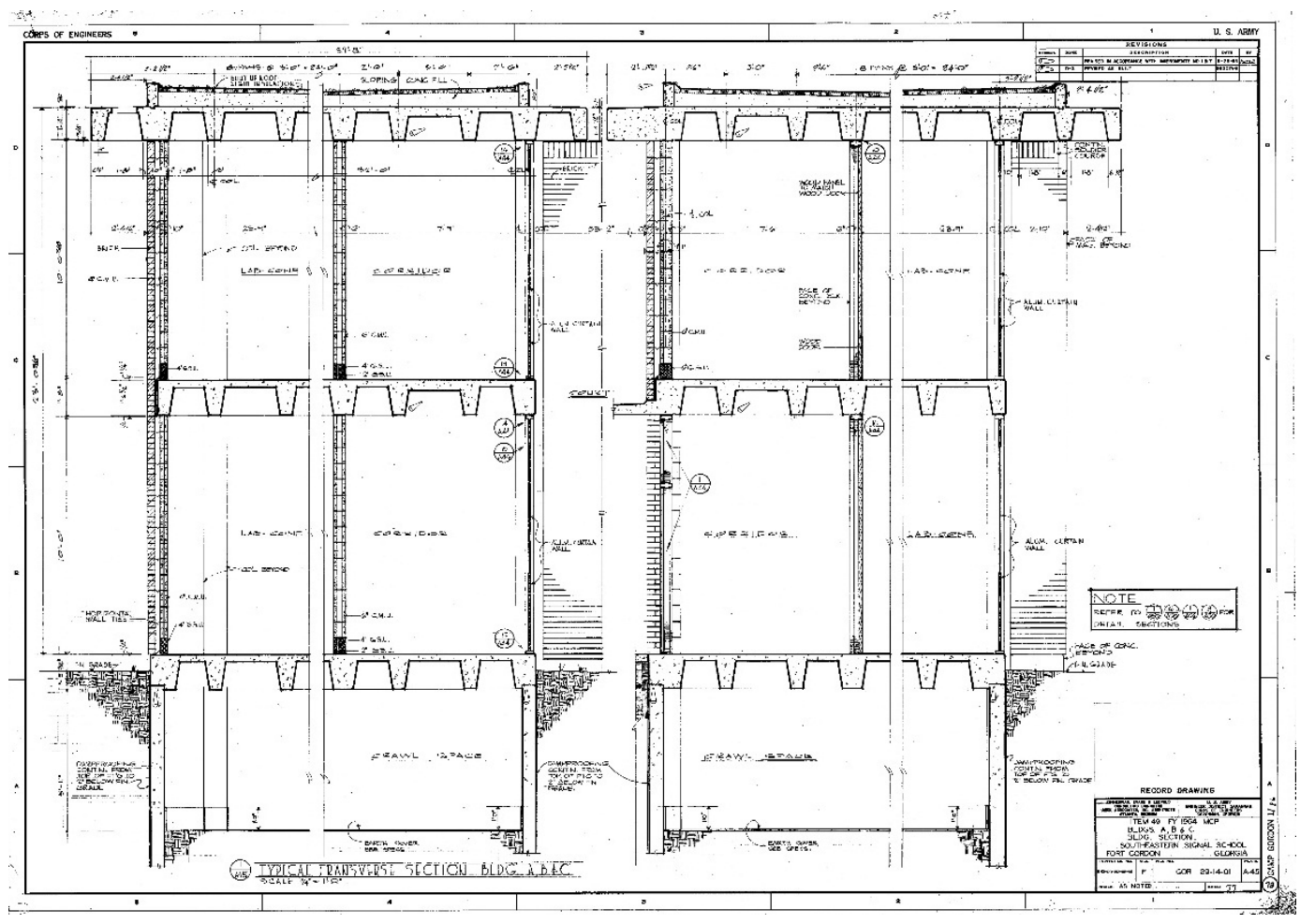


Figure 327. Brick screen detail for exterior staircase on the east and west elevations of Building 29811, Saltzman Hall, 1964 (Fort Gordon DPW).

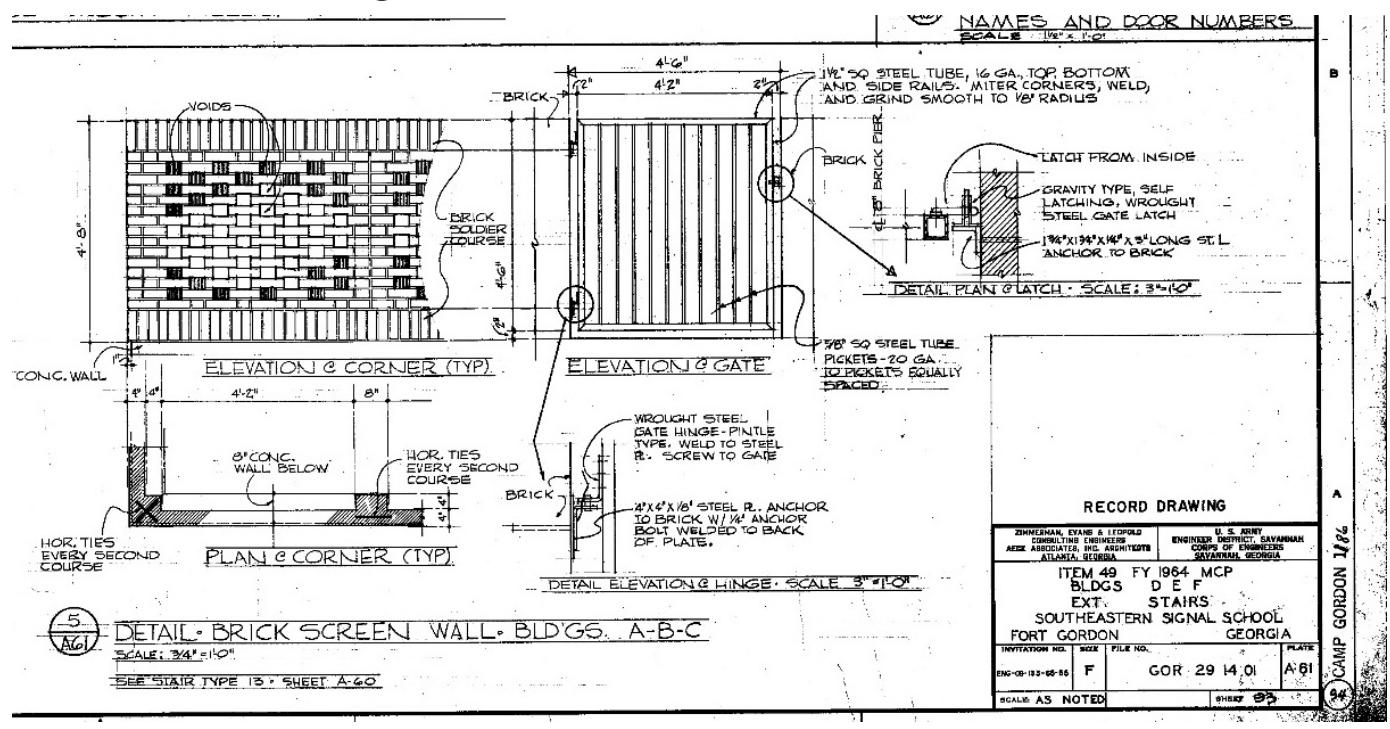

Figure 328. Courtyard landscaping plans and details, 1966 (Fort Gordon DPW).

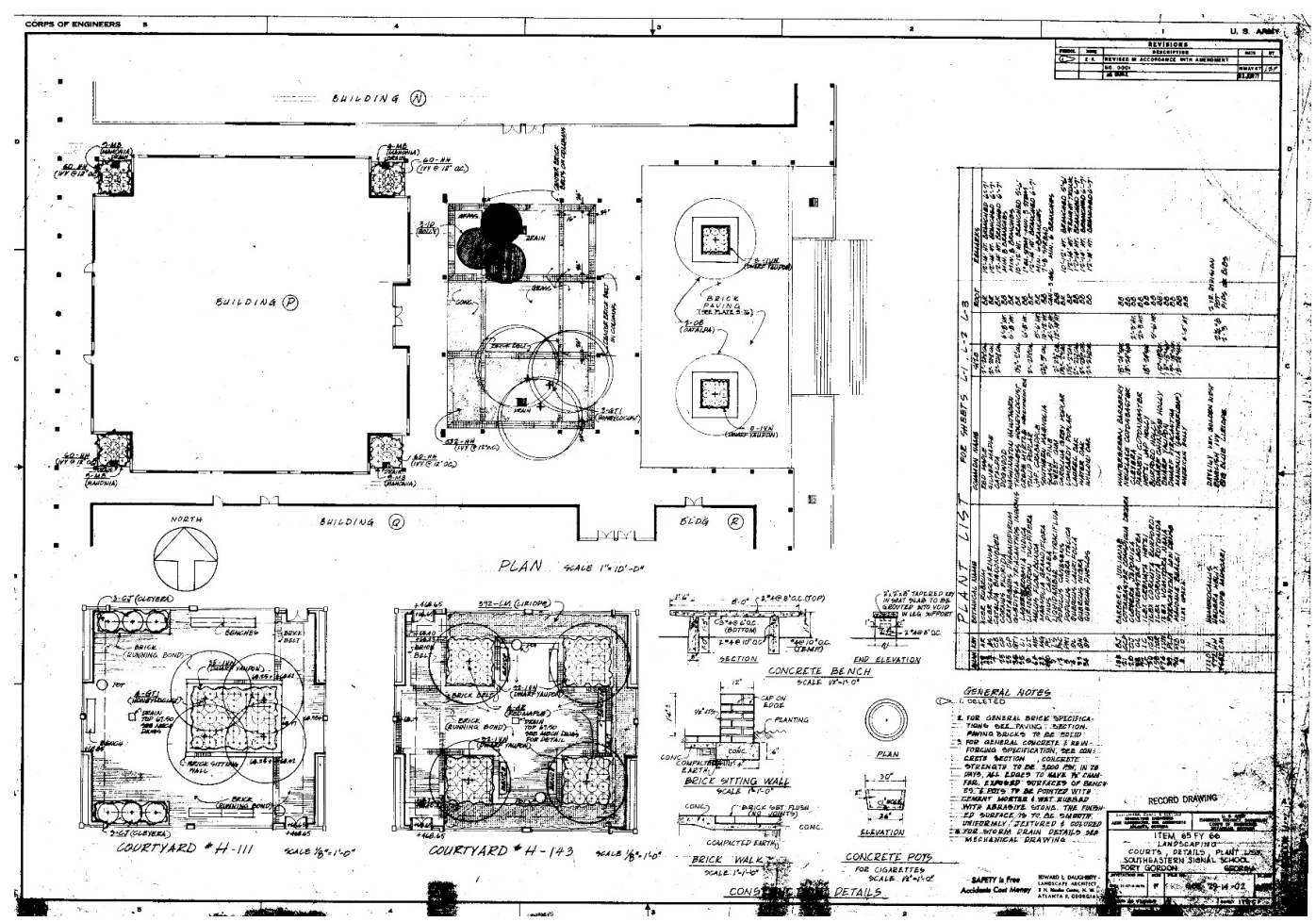


Figure 329. Typical classroom elevations and details for Building 29811, Saltzman Hall, 1966 (Fort Gordon DPW).

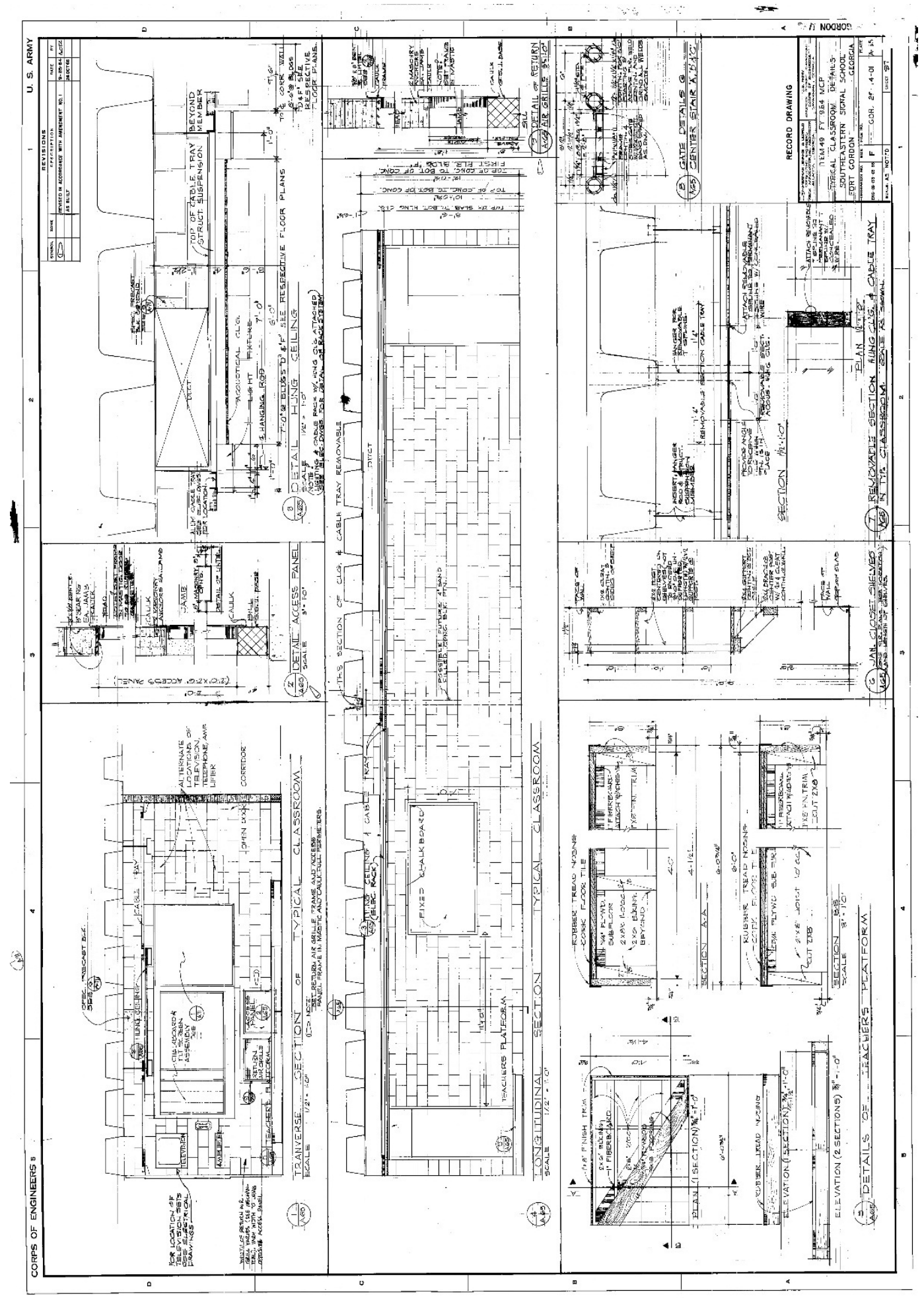


Figure 330. Interior stairwell details of Building 29811, Saltzman Hall, 1964 (Fort Gordon DPW).

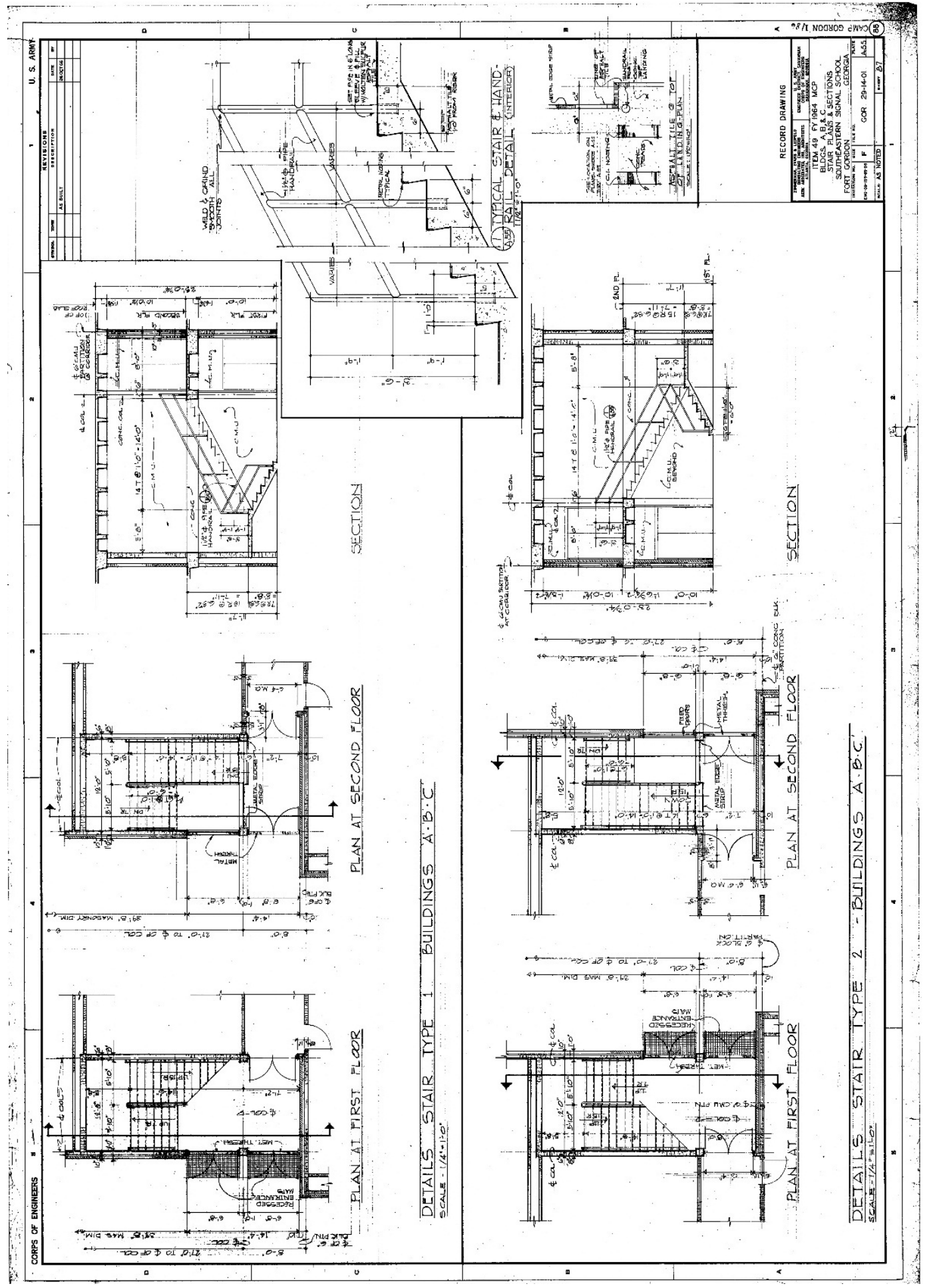


Figure 331. Latrine plans, elevations, and details for Building 29811, Saltzman Hall, 1964 (Fort Gordon DPW).

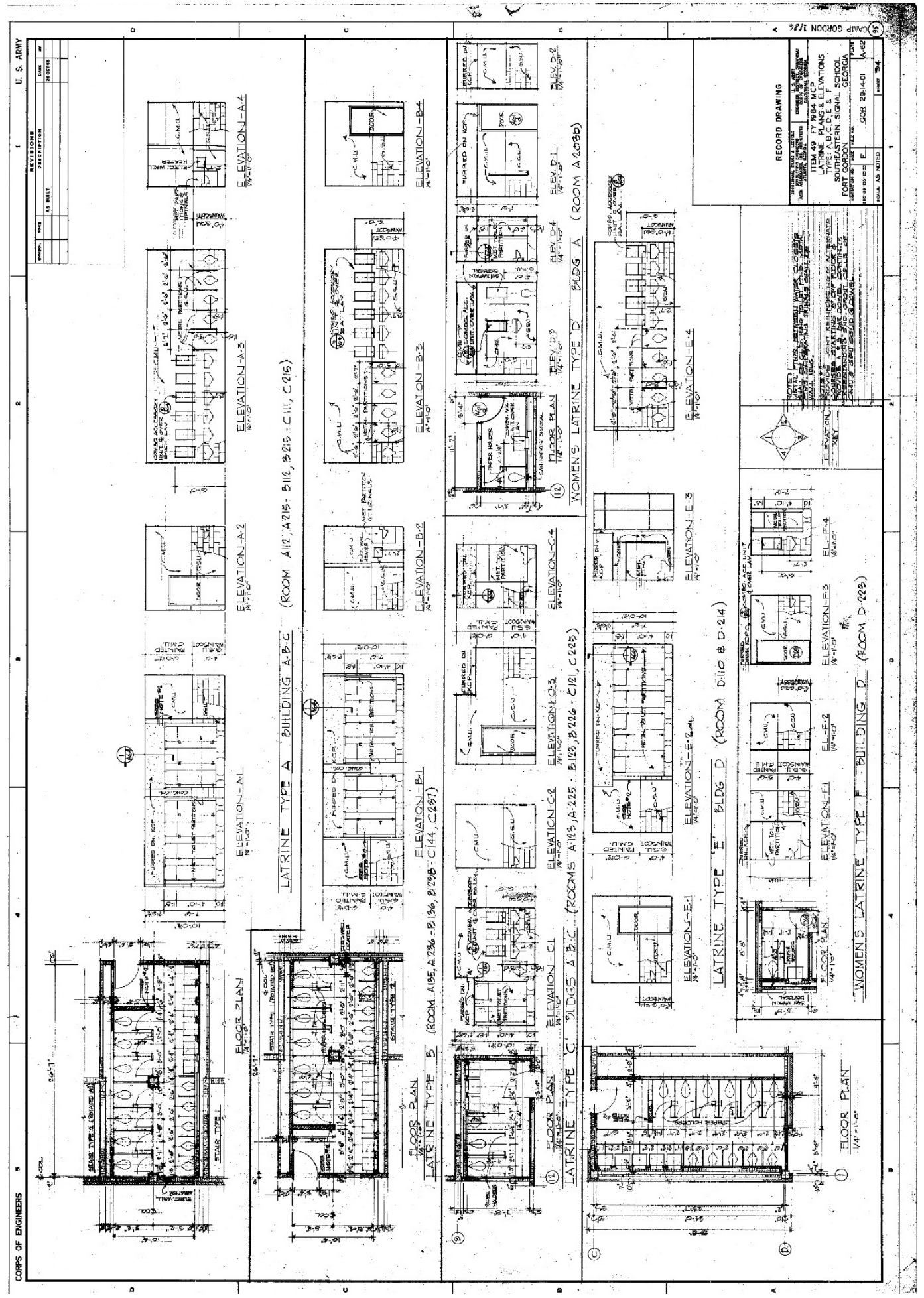


Figure 332. Light fixture types and schedule, 1966 (Fort Gordon DPW).

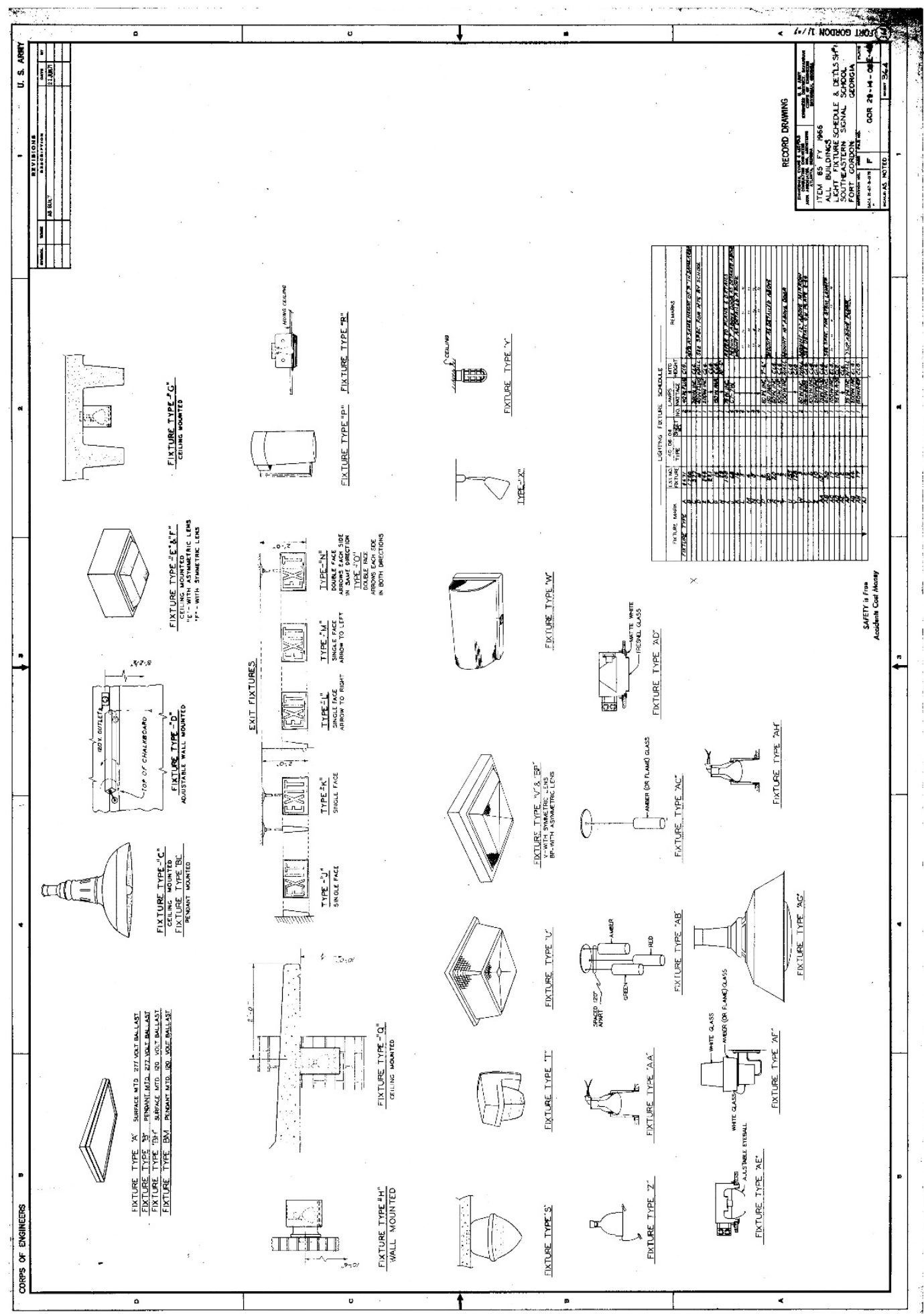


Figure 333. Landscape plan for Building 29811, Saltzman Hall, 1966

(Fort Gordon DPW).

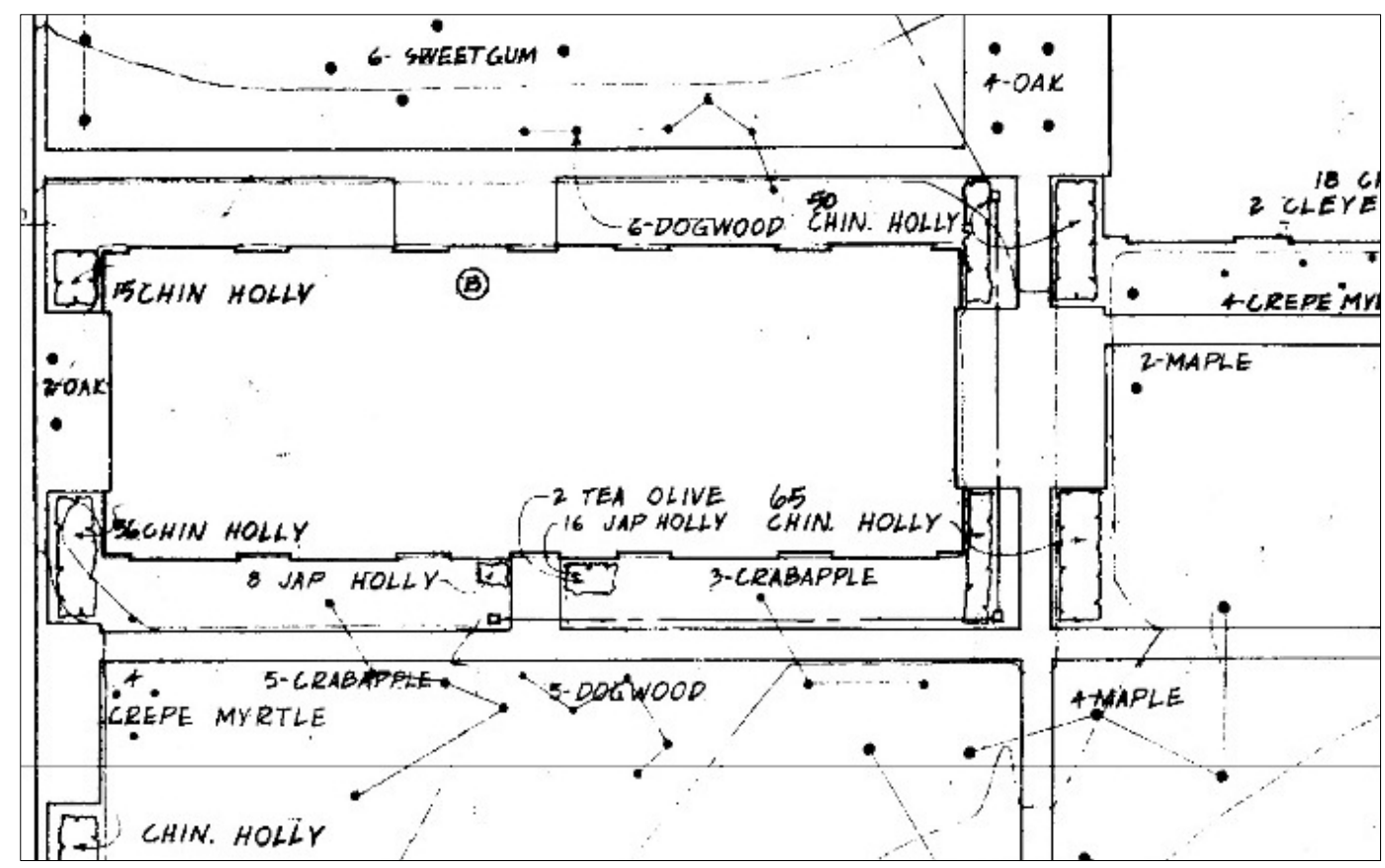

\subsubsection{Character-defining features}

Repair, renovation, and replacement of Building 29811, Saltzman Hall must be coordinated with the GA SHPO (Table 12).

\section{Exterior:}

- Overall massing

- Footprint

- Roof shape

- Brick veneer

- Relationship to other Signal School Campus buildings

- Overhanging eaves with perforated waffle construction casting "light pattern" on exterior brick walls

- Exposed concrete structure framing window and door openings

- Flat concrete canopy above entries

- Window pattern

- Recessed groups (two, three, or six) of bright-aluminum sash windows with three-pane awning-style windows sandwiched between insulated panels

- Metal doors with large pane 
- Metal doors with plate glass on east and west elevations

- Perforated brick walls on east and west elevations

- Ceiling-mounted exterior light fixtures set within the waffle overhang on the east and west elevations

- Lettering

- Bright-aluminum exterior display cases

- Metal handrails

- Landscaping

\section{Interior:}

- Overall plan

- Courtyards

- Main stairwells

- Main hallways

- Lighting

- Doors

- Display cases

- Signage

- Vending machine alcove

- Telephone alcoves

- Tiled water-fountain alcoves

Table 12. Images of character-defining features of Building 29811, Saltzman Hall (ERDC-CERL, 2015).

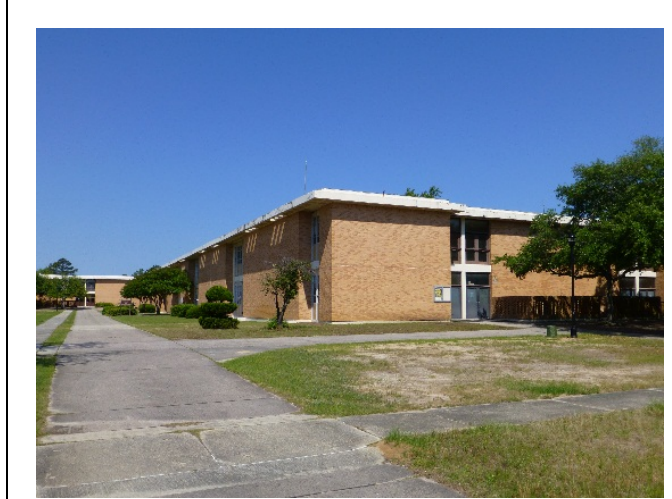

Overall massing, footprint, roof shape, and brick veneer.

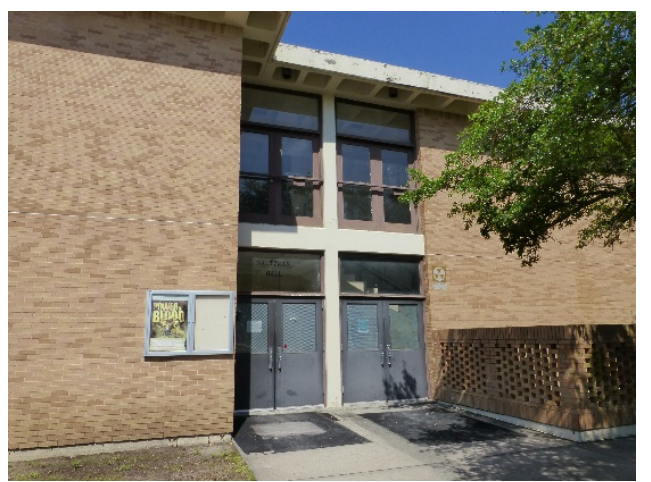

Metal doors with pane and transom on first floor, and metal and plate-glass doors on second floor, separated by exposed concrete structural system. Perforated brick wall encasing the basement opening (right of photo). 


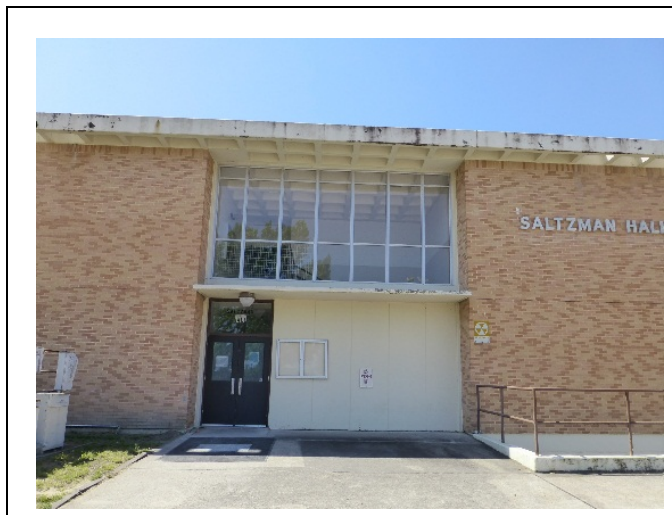

Entry bay on north elevation with concrete panels, metal doors, flat concrete canopy, and fixed windows framed with bright-aluminum sashes.

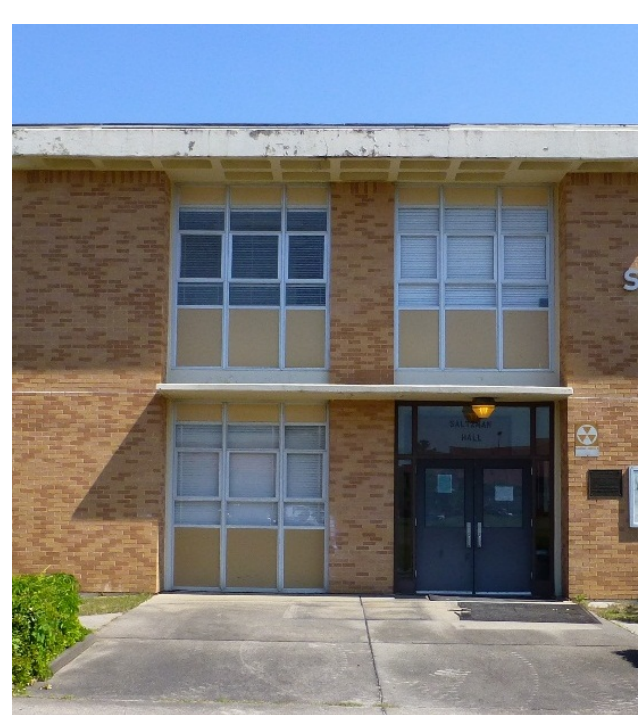

Main entry on the south elevation with groups of three windows, flat concrete canopy, and metal entry doors.
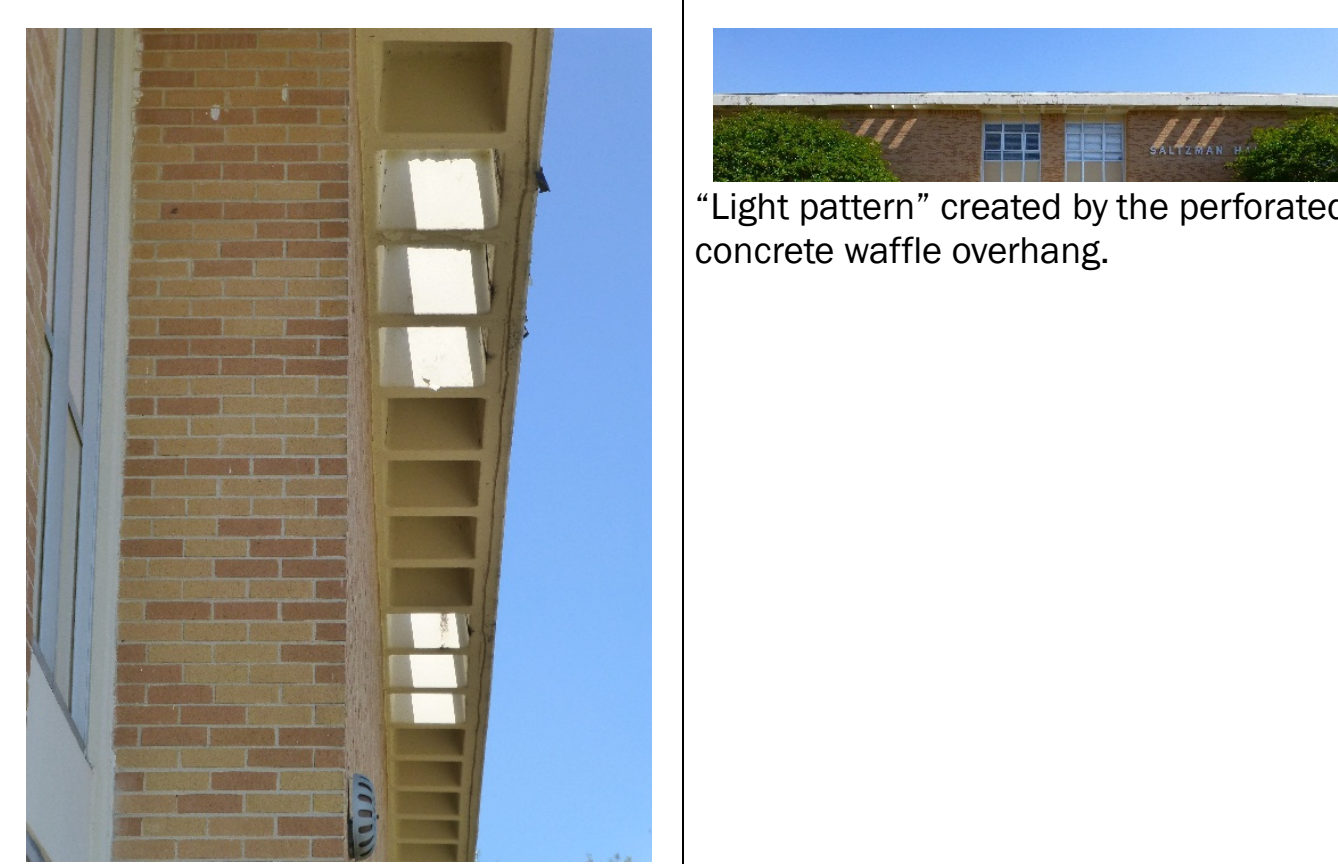

"Light pattern" created by the perforated concrete waffle overhang.

Perforated concrete waffle overhang. 

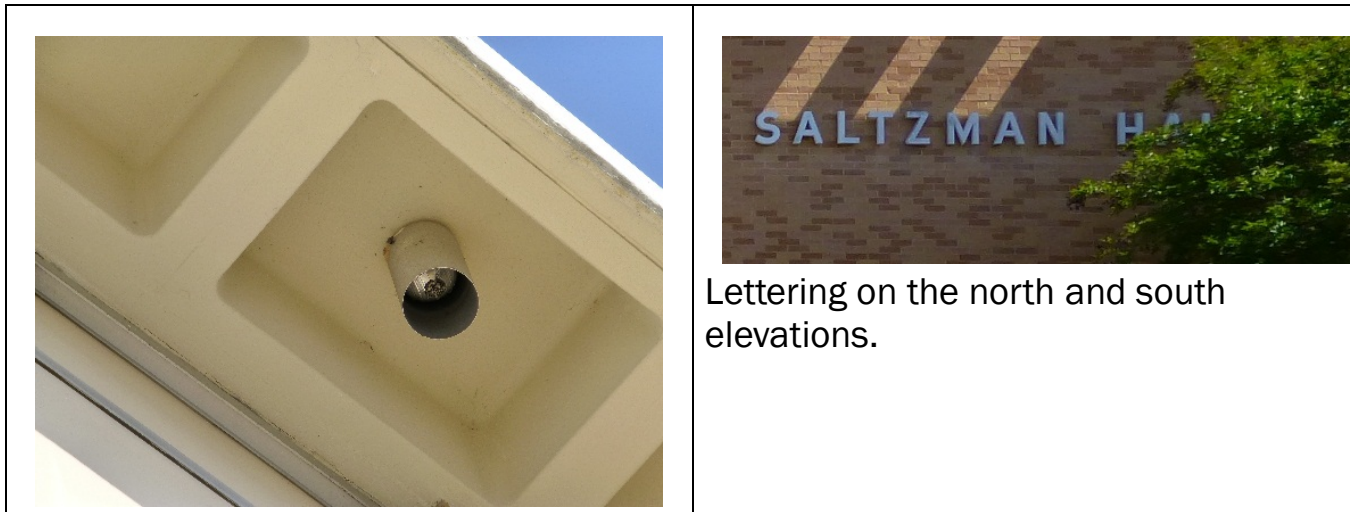

Lettering on the north and south elevations.

Ceiling-mounted light fixture under the waffle overhang on the east and west elevations.

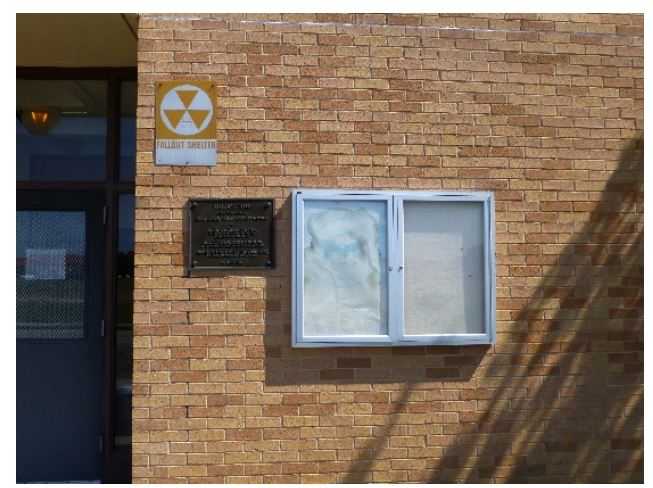

Bright-aluminum display cases located near the entries.

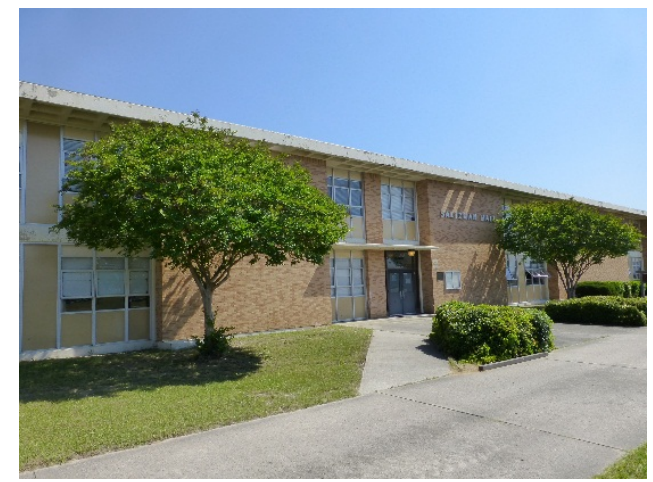

Landscaping near the main entry.

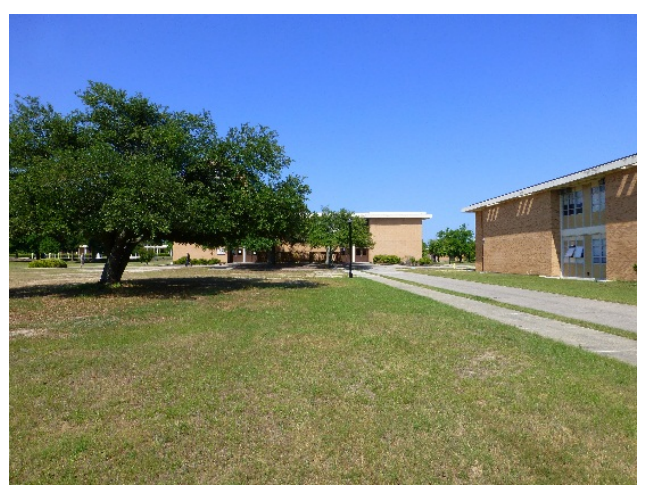

Relationship to other Signal School Campus buildings and campus layout.

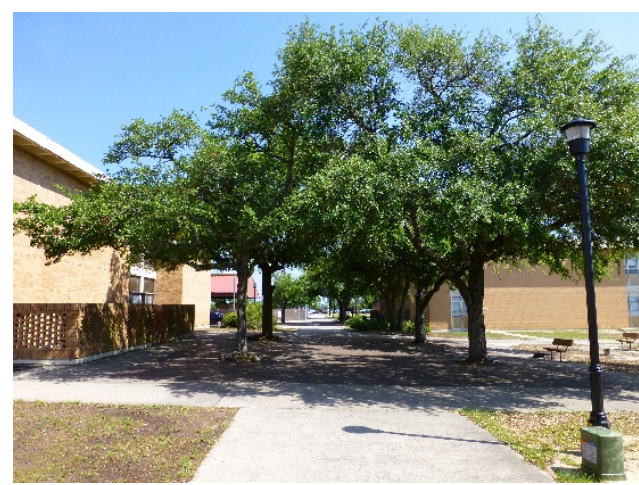

Landscaping at the east and west ends of the building.

\subsubsection{Character-defining features that have been removed}

\section{- None.}

\subsubsection{Nonhistoric features}

- None. 


\subsubsection{Comparison images}

Comparison images utilizing either the original drawings or historic photographs, when juxtaposed against present-day images, are a useful tool in developing the historic "feel" of a property and how much of that historic feeling is still present today (Figure 334-Figure 341).

Figure 334. Southeast oblique - comparison of the original design and materials for Building 29811 from March 1967 [left] to the current condition of the building [right] (ERDC-CERL, 2015).
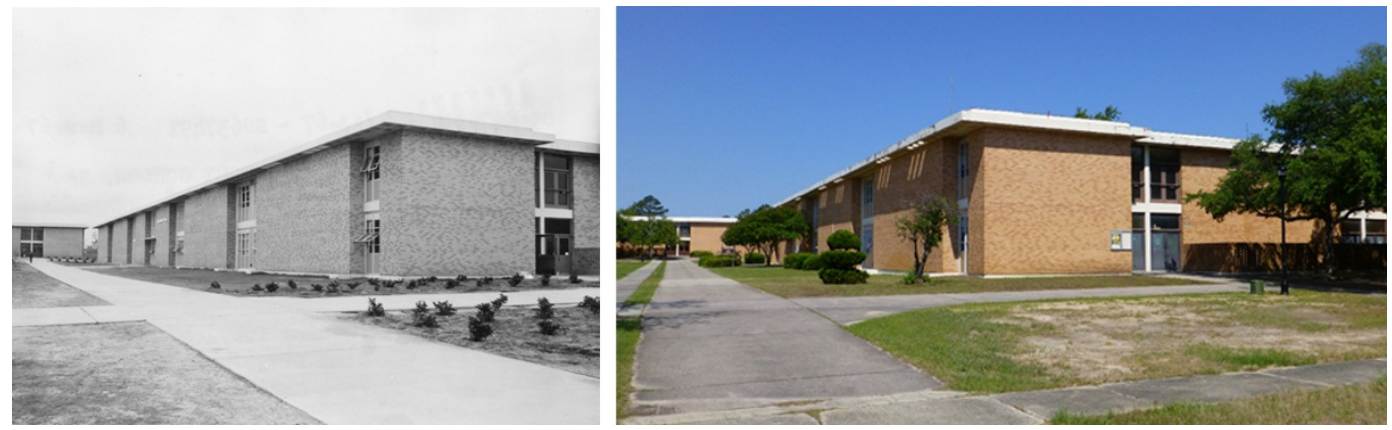

Figure 335. Second-floor window bay on the north and south elevations Comparison of the original design and materials from 1964 [left] compared to the current condition of bright-aluminum three-pane awning style-windows and insulated panels [right] (ERDC-CERL, 2015).
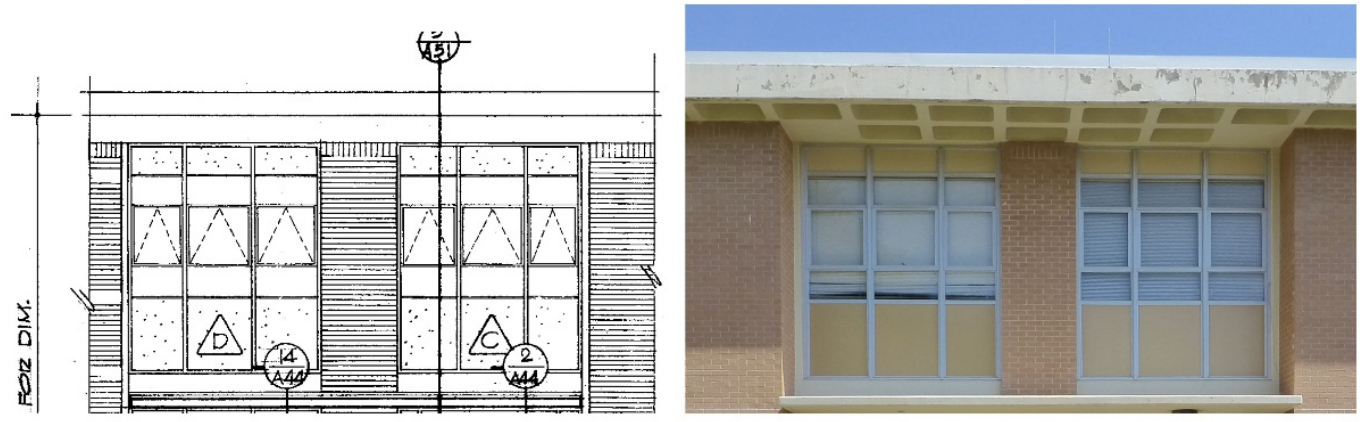
Figure 336. Window bay located on the left and right sides of the north and south elevations -original design and materials from 1964 [left] compared to the current condition of the three-pane awning-style windows sandwiched between insulated panels [right] (ERDC-CERL, 2015).
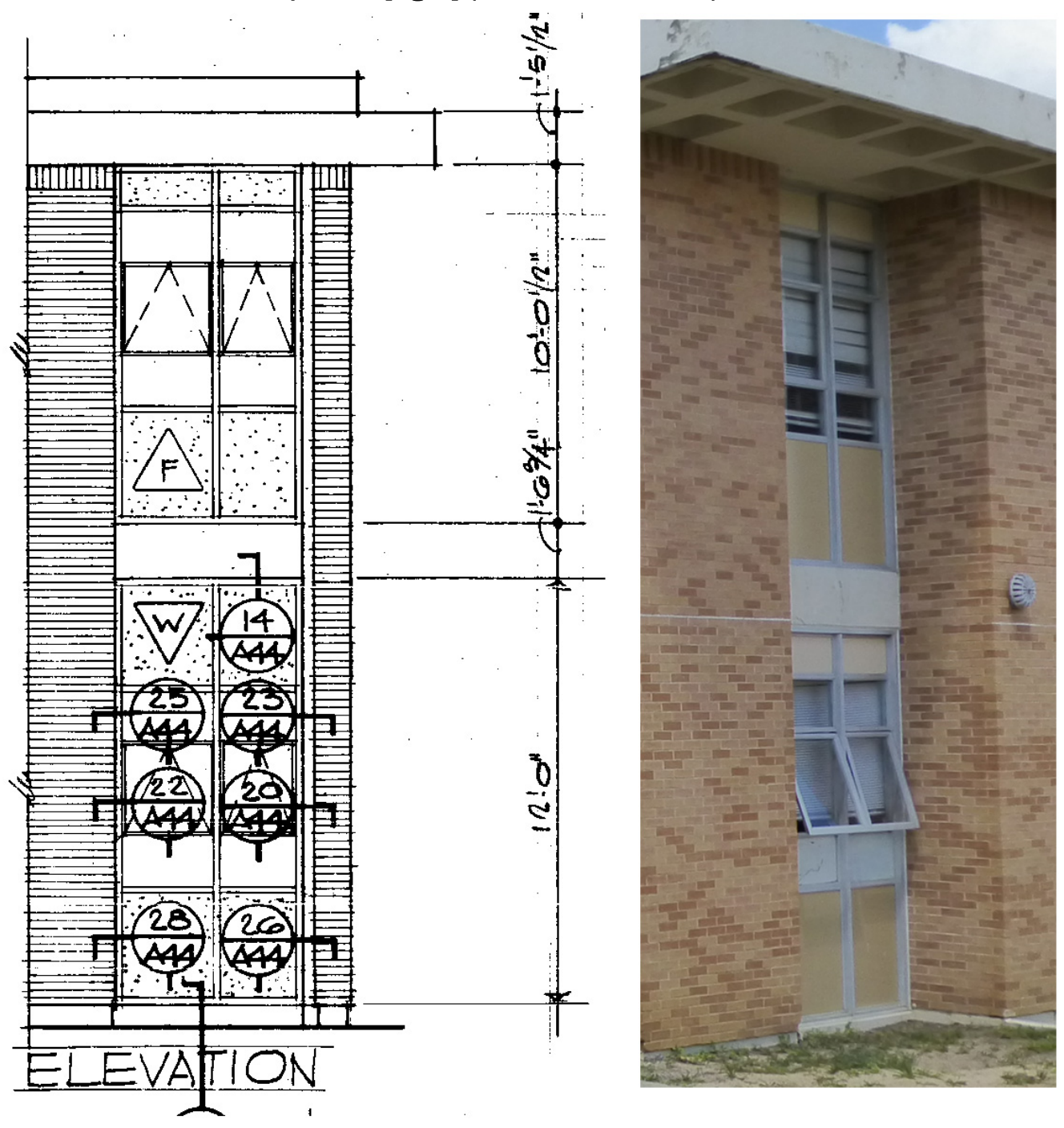
Figure 337. Doors on the east and west elevations - comparison of the original design and materials from 1964 [left] to the current condition of the metal doors with pane and transoms on the first floor and the metal and plate-glass doors with security bars on the second floor [right] (ERDC-CERL, 2015).
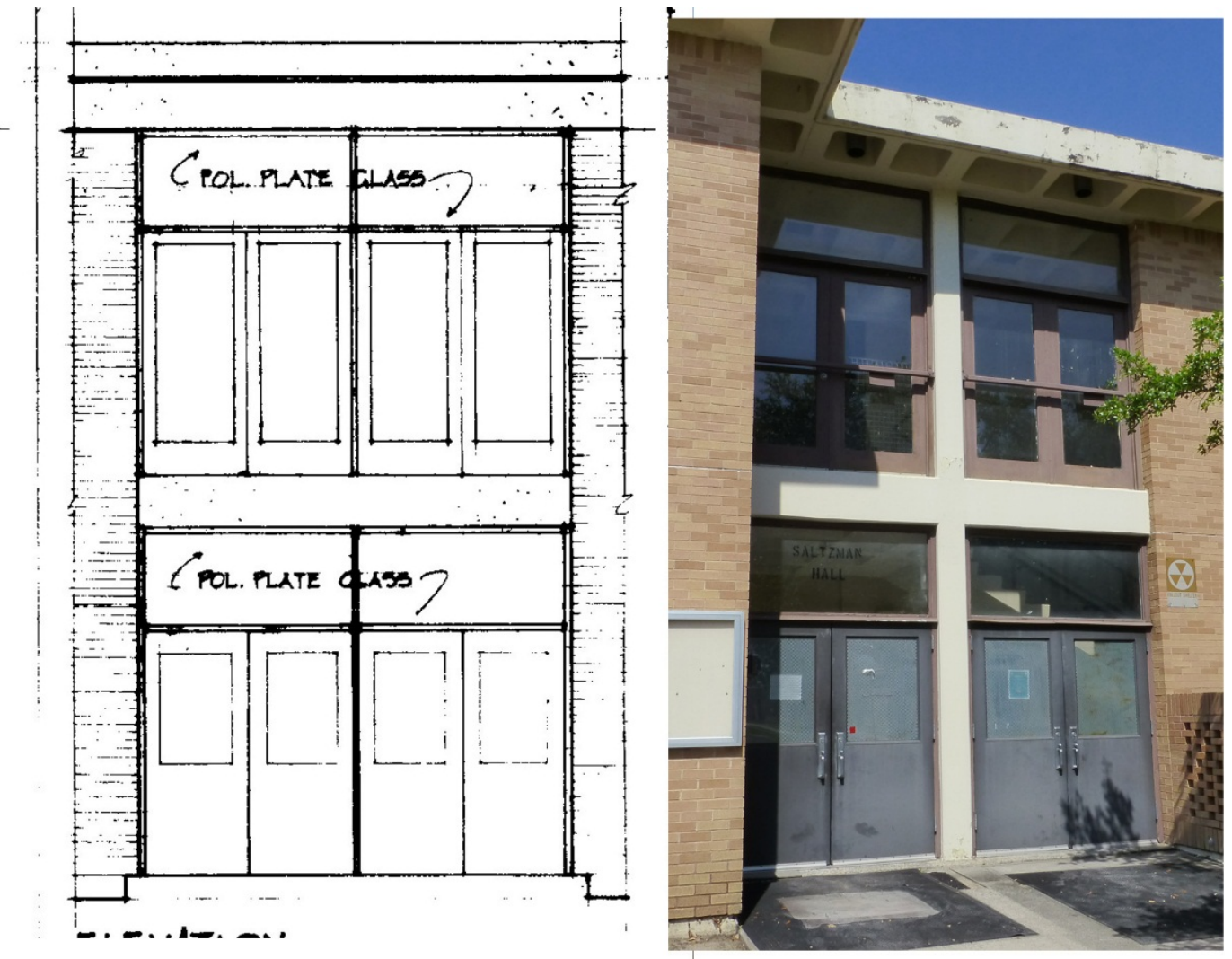

Figure 338. North wall of the right courtyard south wall of the left courtyard comparison of the original design and materials from 1964 [left] to the present day [right] (ERDC-CERL, 2015).

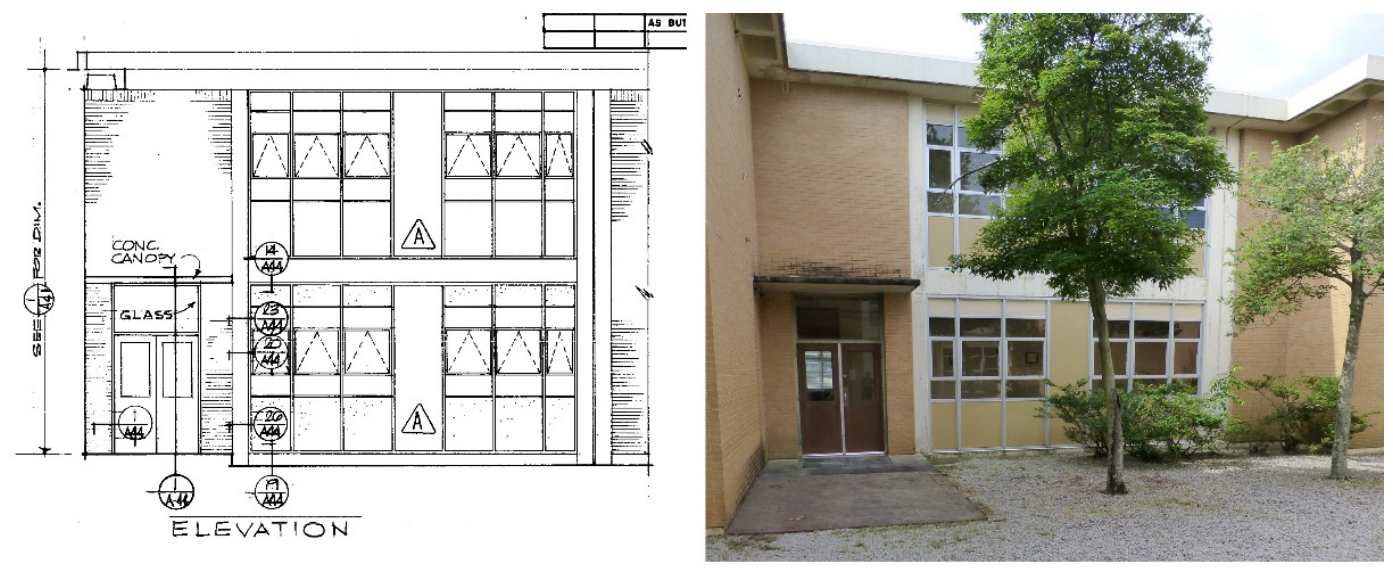


Figure 339. East and west walls of the courtyards - comparison of the original design and materials from 1964 [left] to the present day [right] (ERDC-CERL, 2015).
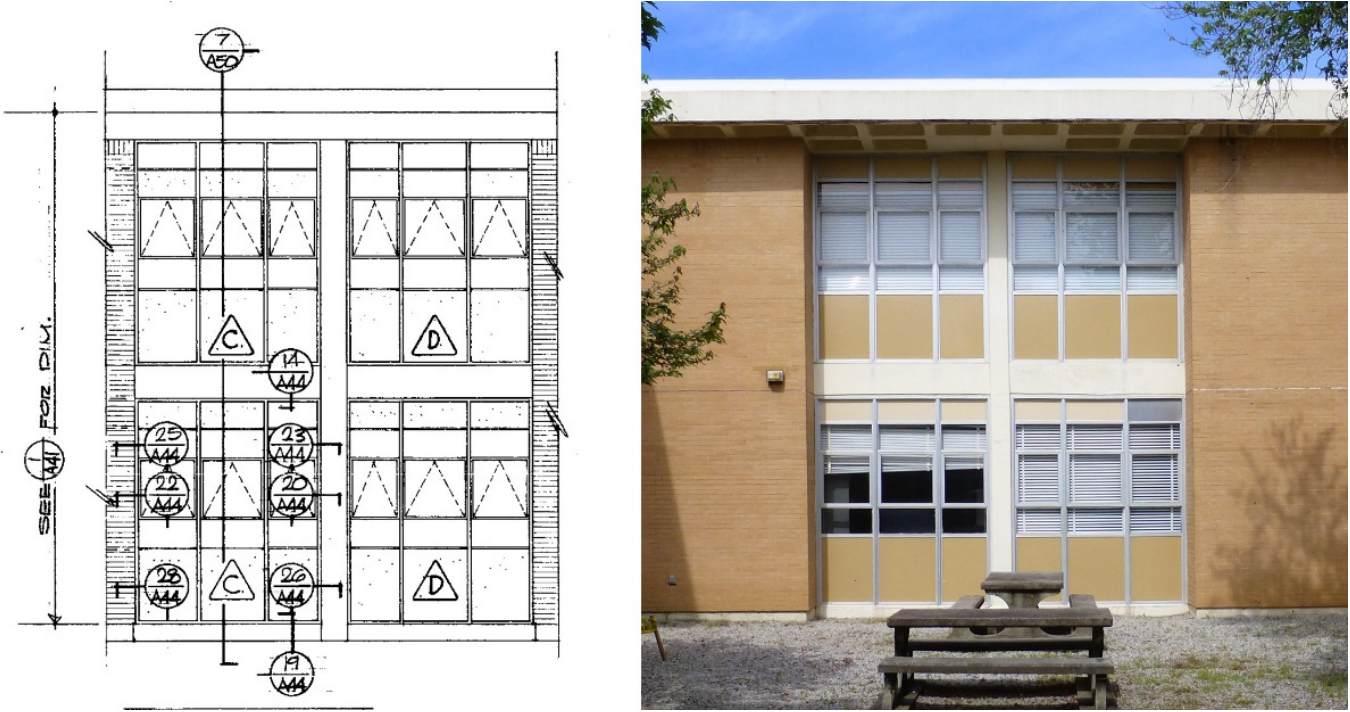

Figure 340. Ceiling-mounted light fixture under the waffle overhang - comparison of the original design and material from 1966 [left] to the current condition of the ceiling-mounted light fixture [right] (ERDC-CERL, 2015).
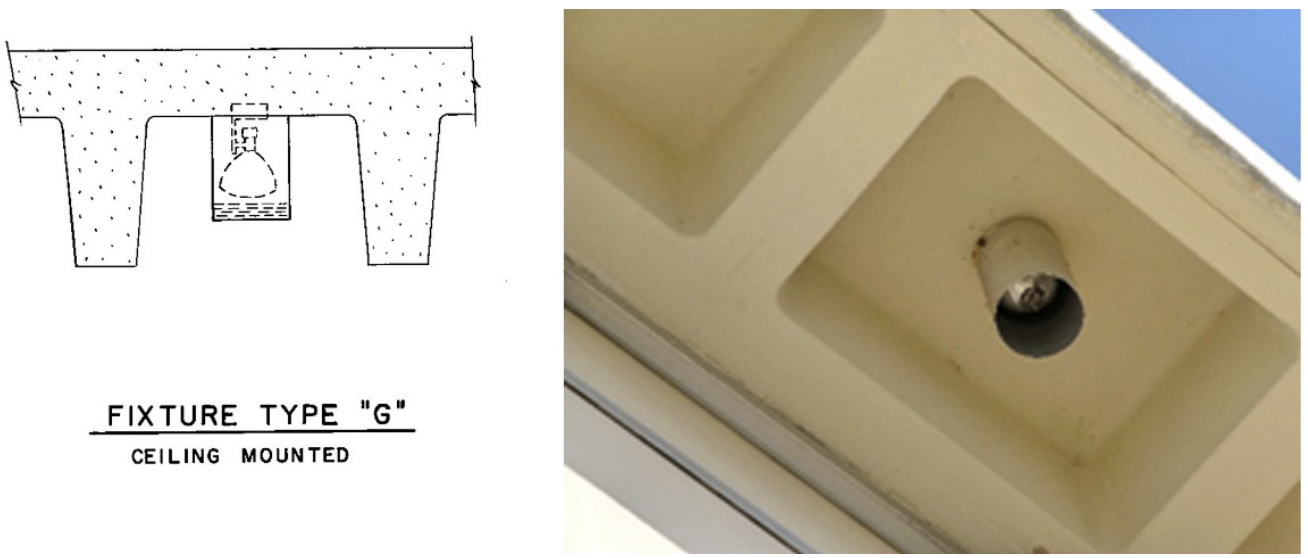

Figure 341. Ceiling-mounted light fixture under flat concrete canopy - comparison of the original design and material on the left from 1966 to the current condition of the replacement ceiling-mounted light fixture [right] (ERDC-CERL, 2015).
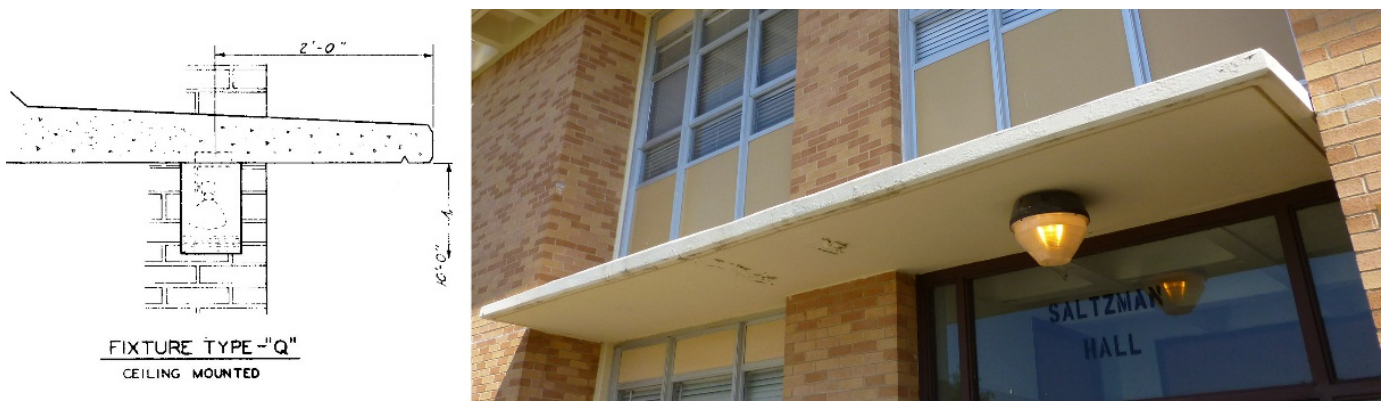


\subsubsection{Building 29813, Allen Hall (1966)}

Building 29813, Allen Hall, is a contributing feature to the Signal School Campus District. The interior is contributing. It was constructed in 1966 as part of Phase I construction for the campus by architect Aeck Associates from Atlanta, Georgia, and Zimmerman, Evans, and Leopold Consulting Engineers of August, Georgia. It was built as a long rectilinear classroom building with two large courtyards. The building is two-stories high with a basement. The structure is of cast-in-place concrete columns with a waffle floor/ceiling structure. The second-floor waffle system is set within the structure, but the roof has the waffles extending out to form an overhang. Some of the waffles of the overhang have been perforated, which creates a "light pattern" on the second floor of the brick exterior walls. The window systems extend the full height of the building and are inset into the brick veneer. The window systems are composed of bright-aluminum window frames that enclose insulated panels and awning windows. Tan-colored panels are above and below the windows. The window systems are in patterns of two, six, and seven. The window system is separated horizontally by the exposed concrete beam structural system of the building. The south elevation faces the open space of the Signal School Campus. This elevation is symmetrical and is defined by a central entry bay. A set of metal entry doors with a large pane is flanked by sidelights and a transom. A flat concrete canopy extends over the entry doors and adjacent window bay system on the first floor. Above the canopy are two bays of three windows. A bright-aluminum display case and original "ALLEN HALL" lettering is to the right of the central bay. Trees flank either side of the entry bay sidewalk and shrubs are placed in front of the building. On either side of the central bay are two large bays of six windows each, with an insulated panel dividing them into groups of three. The far left and right side of the elevation are slightly recessed, and a bay of two windows is located at the corners. The entrances on the east and west elevations consist of two entry bays. Each entry bay consists of two sets of metal doors with large panes and a large fixed-pane transom above each set of doors. Above these firstfloor doors are two sets of metal and plate-glass doors, with a transom above each set of doors. These doors are welded closed with a steel bar across the middle. It appears these bridges were meant to connect the various buildings together at the second-floor level. Basement access is on the east and west, located between the main sets of doors and the opening is protected by a perforated brick wall in the same brick as the building. On the east and west sides of the building are small, landscaped, brick plazas that are framed by three trees on the west and no trees on the east. The 
north elevation is symmetrical. There are five large window bays. The center bay is an entry bay with a set of metal doors with a large pane with a transom above and five concrete panels on the first floor. A flat concrete canopy projects out above the doors and panels. Above the canopy on the second floor is a group of seven bright-aluminum three-pane fixed windows. The other four large bays consist of two groups of three windows that are divided by an insulated panel. The far left and right sides have a smaller two-window bay system and are recessed at the corners. There are two separate outside access points to the basement on the north side of the building. Poured concrete walls, concrete steps, and metal handrails indicate these points. Also on the north wall is lettering spelling out "ALLEN HALL" (Figure 342-Figure 361).

Figure 342. Signal School Campus map, with Building 29813, Allen Hall highlighted in red, 2015 (Fort Gordon DPW, modified by ERDC-CERL).

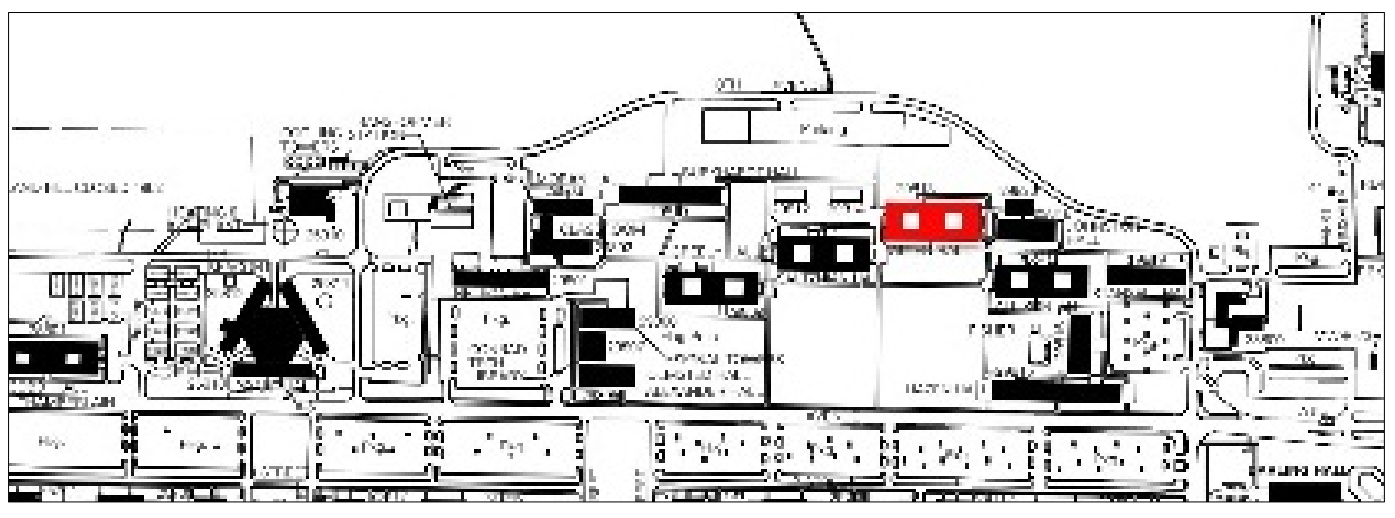

Figure 343. South elevation of Building 29813, Allen Hall (ERDC-CERL, 2015).

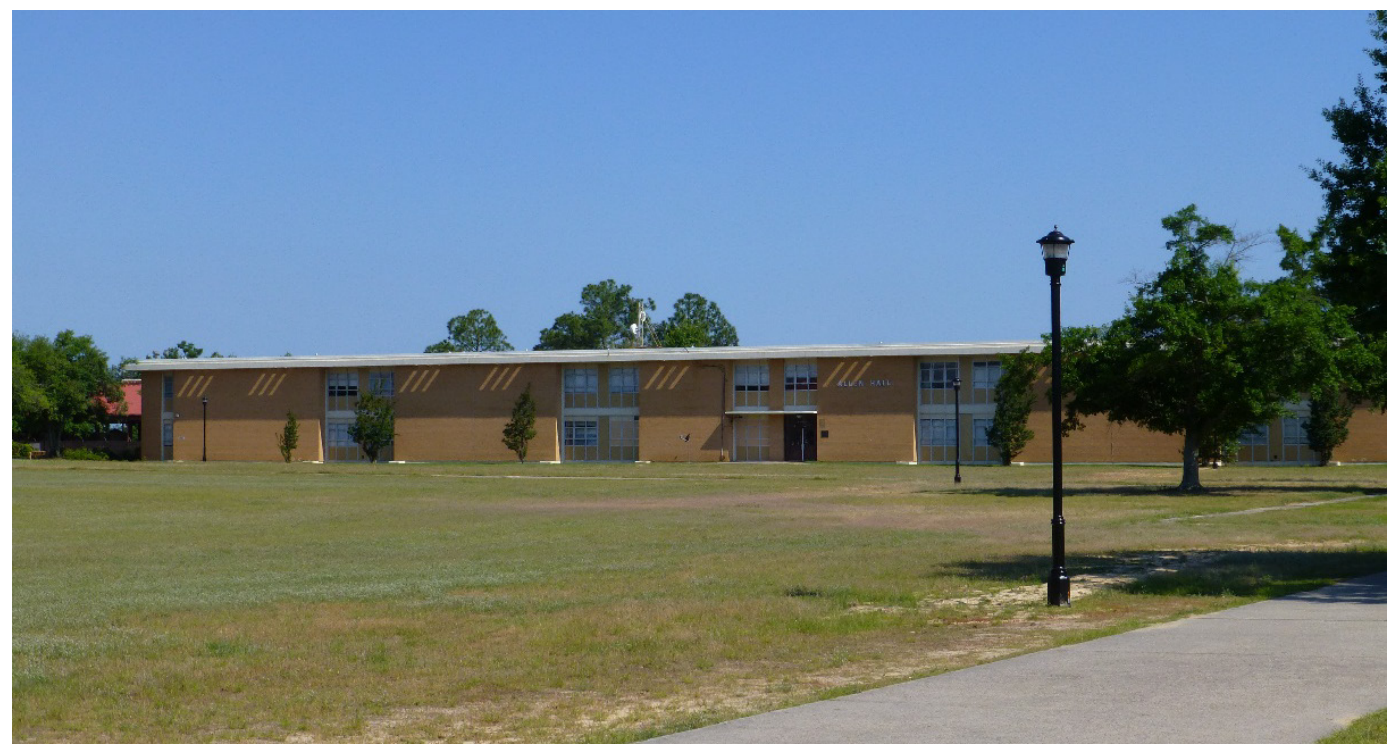


Figure 344. North elevation of Building 29813, Allen Hall (ERDC-CERL, 2015).

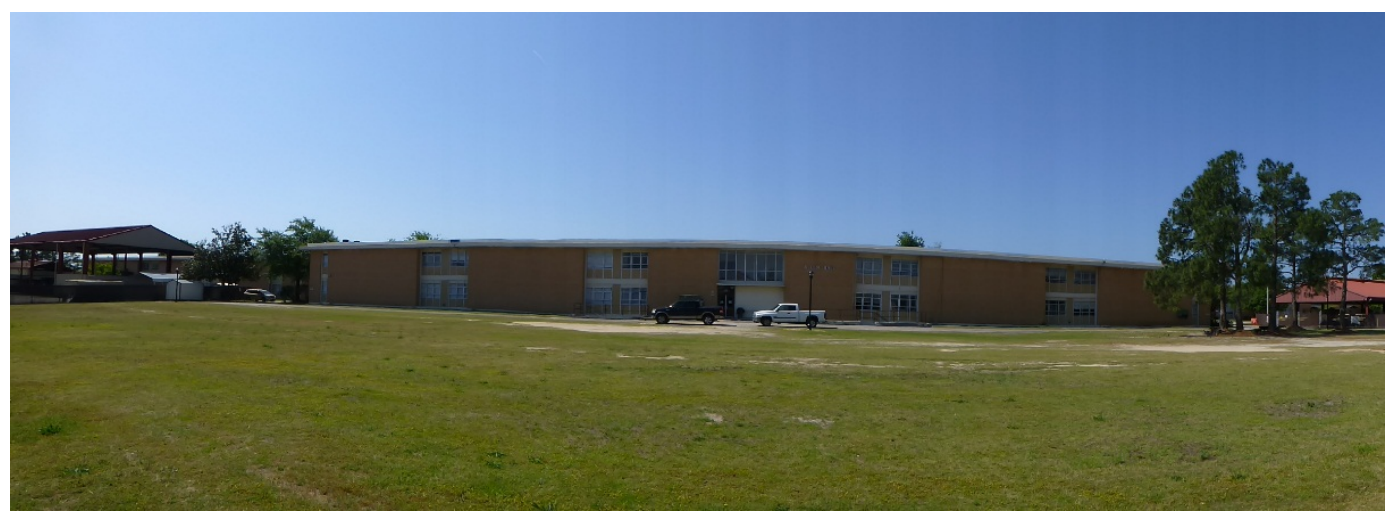

Figure 345. East elevation of Building 29813, Allen Hall (ERDC-CERL, 2015).

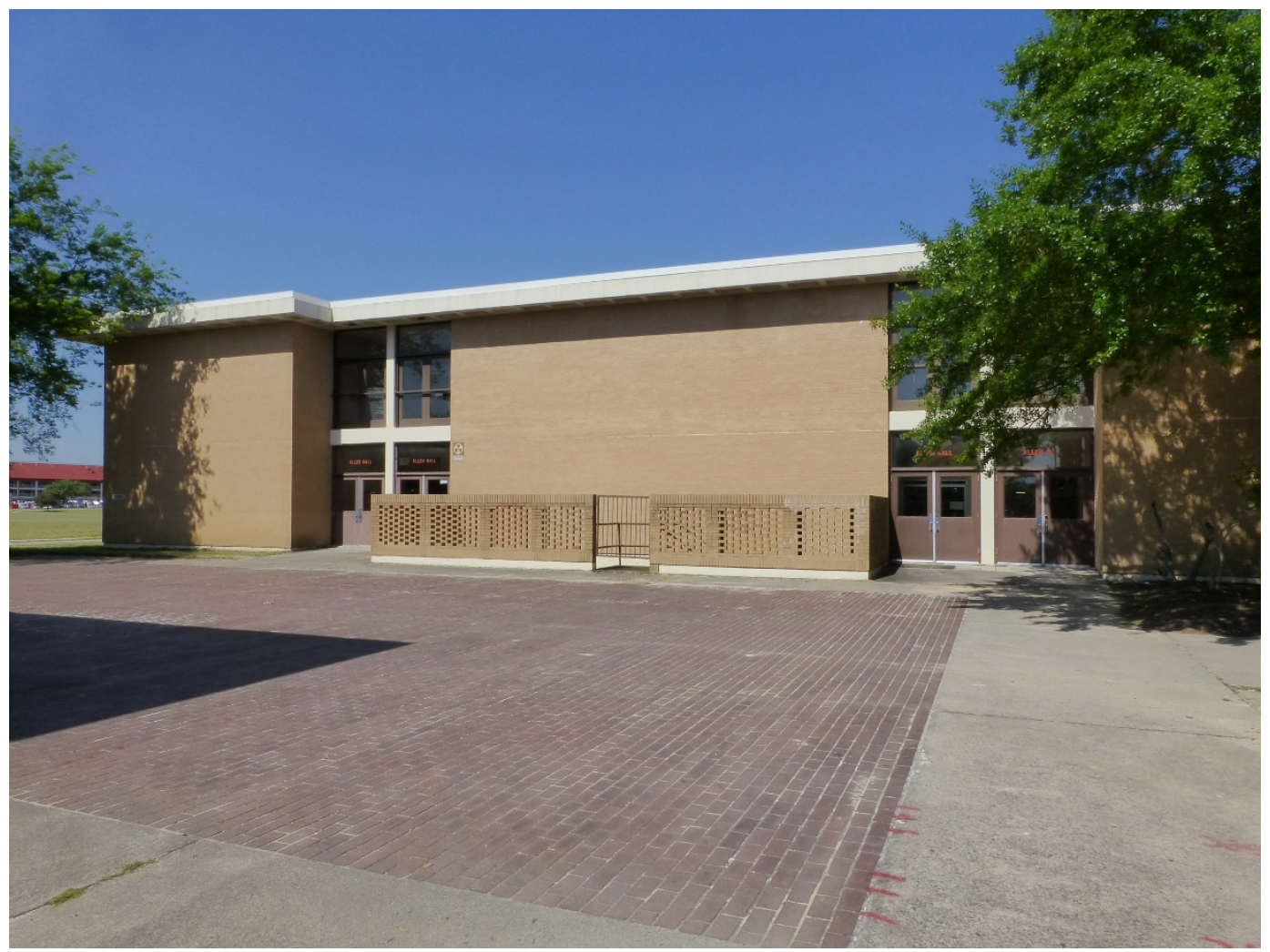


Figure 346. West elevation of Building 29813, Allen Hall (ERDC-CERL, 2015).

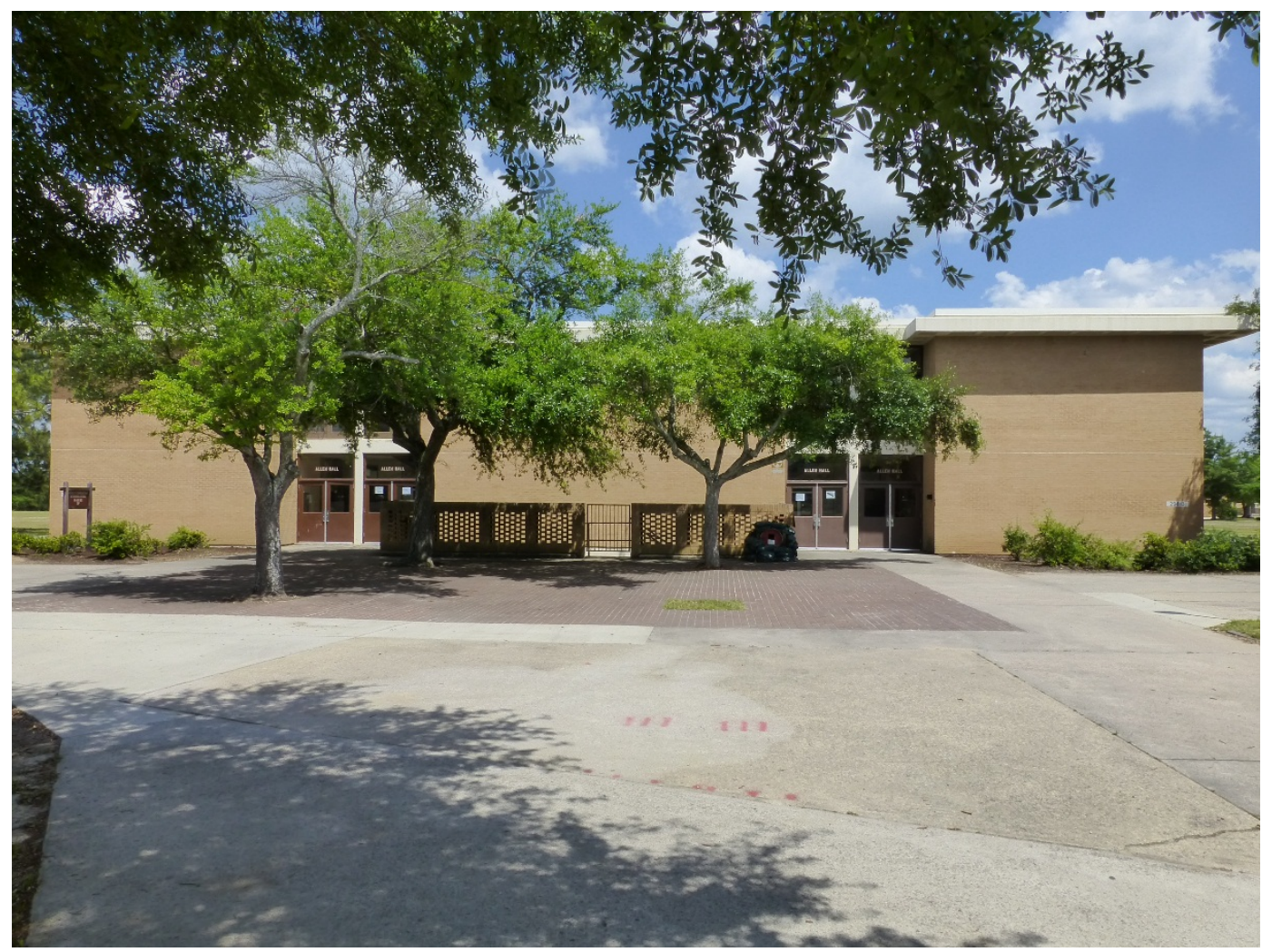

Figure 347. View of the Signal School construction, southeast corner of Building 29818 in the front and Buildings 29813, 29811, and 29809 at back left of photo, March 1966 (National Archives at College Park, MD).

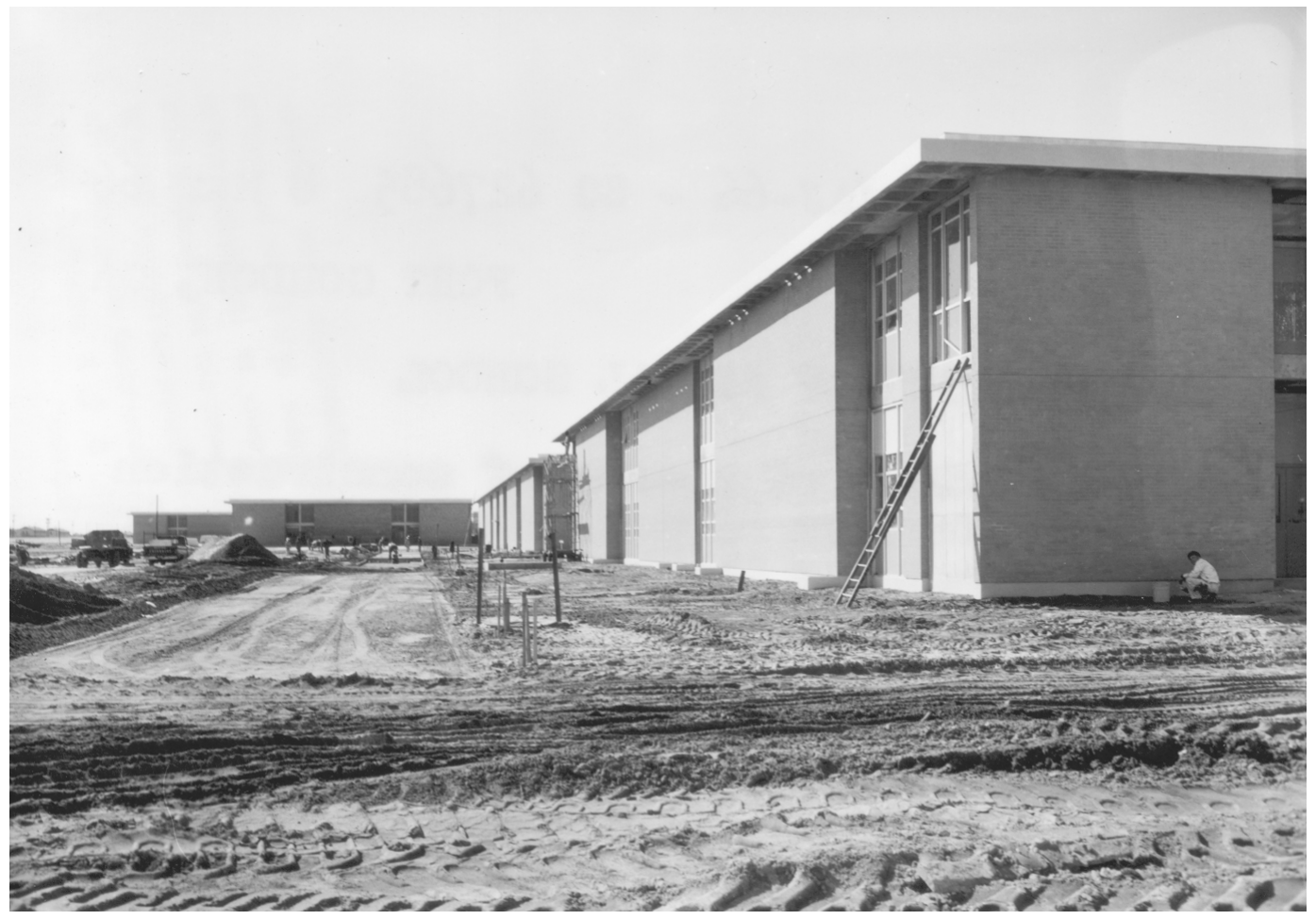


Figure 348. First-floor plan [left side] for Building 29813, Allen Hall, 1964 (Fort Gordon DPW).

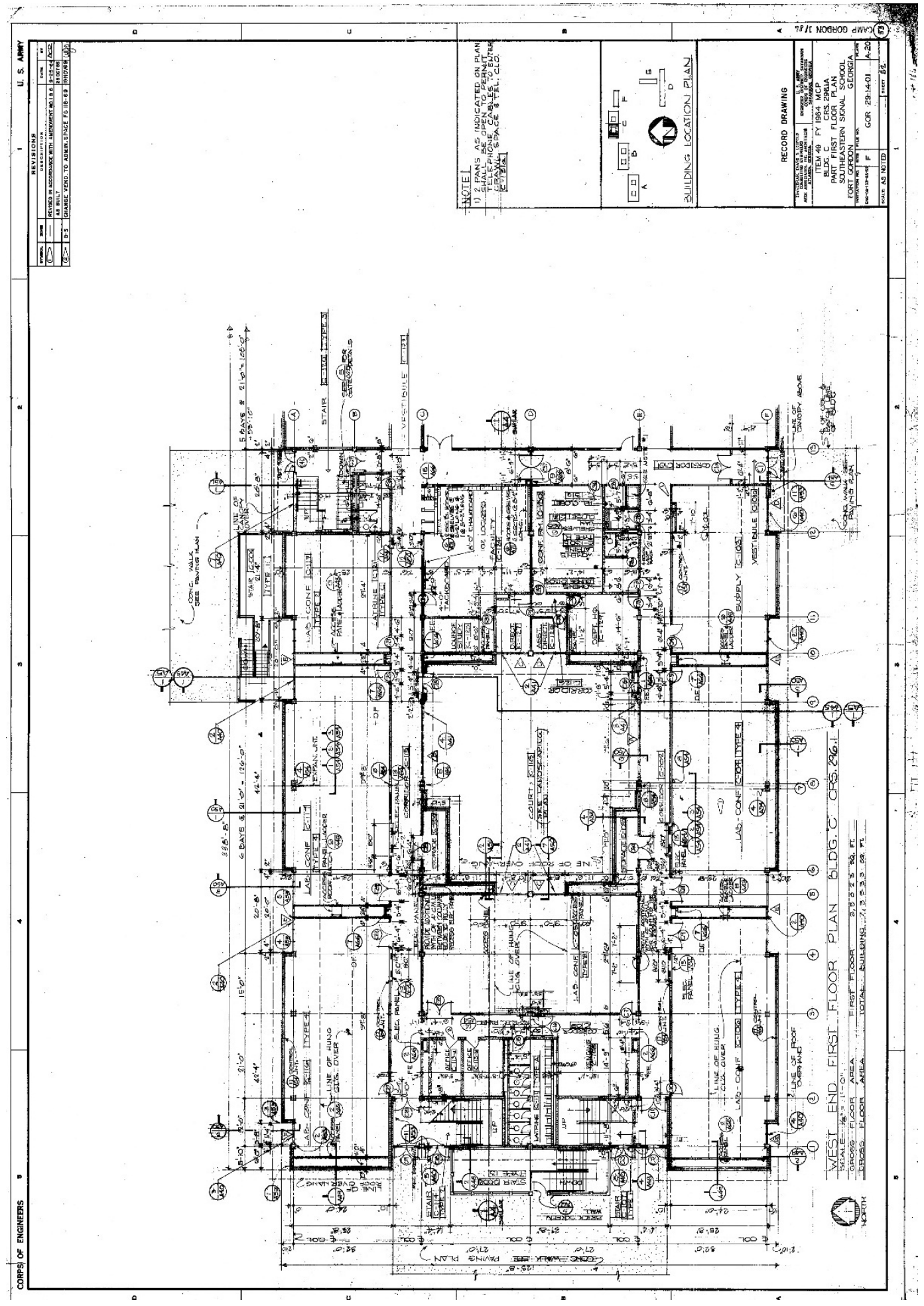


Figure 349. First-floor plan [right side] for Building 29813, Allen Hall, 1964 (Fort Gordon DPW).

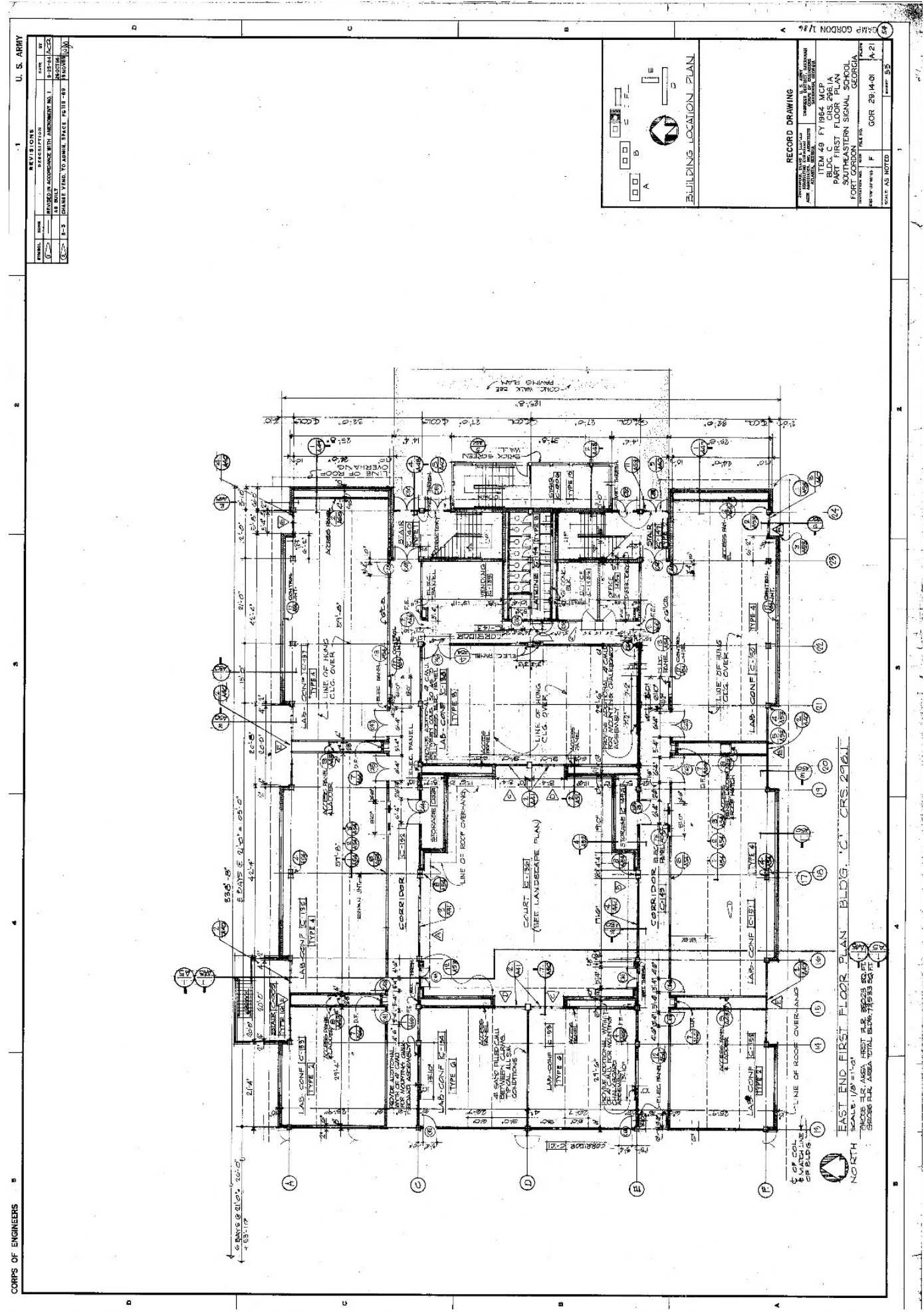


Figure 350. Elevations of Building 29813, Allen Hall [left side] and Building 29815, Hazen Hall [right side], 1964 (Fort Gordon DPW).

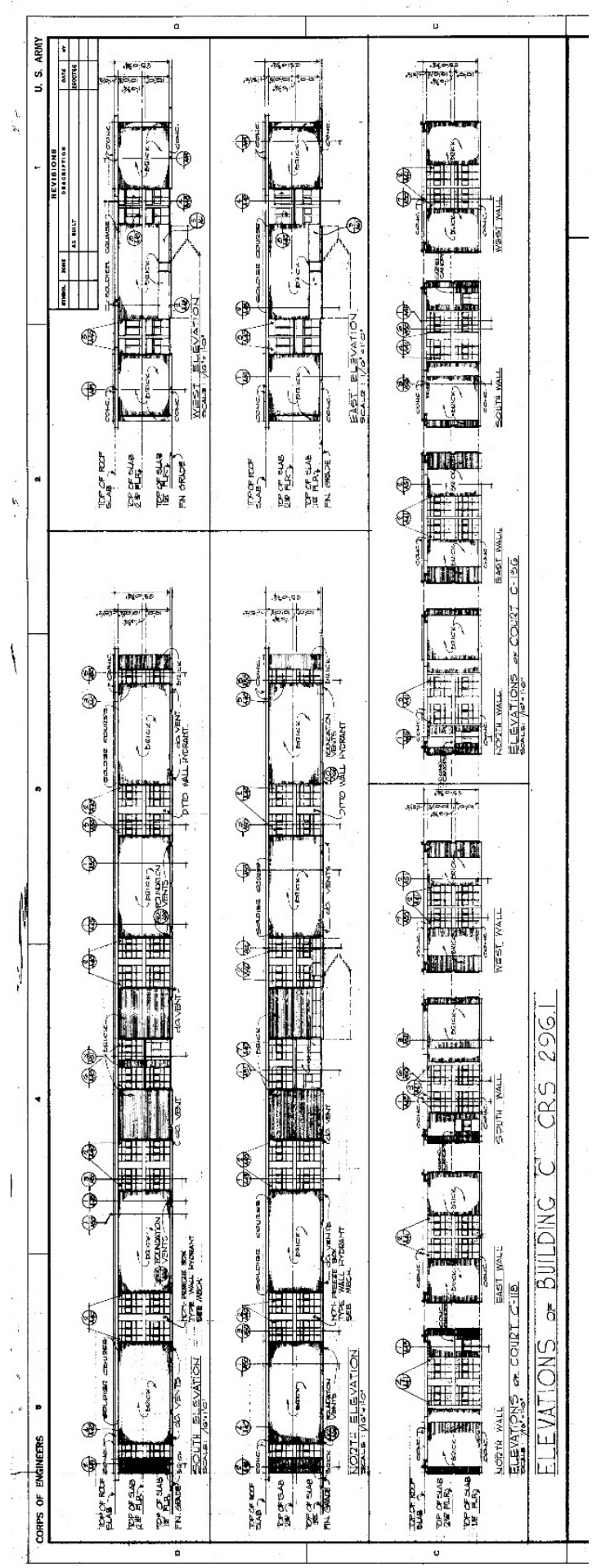


Figure 351. Door and window schedule for Building 29813, Allen Hall, 1964 (Fort Gordon DPW).

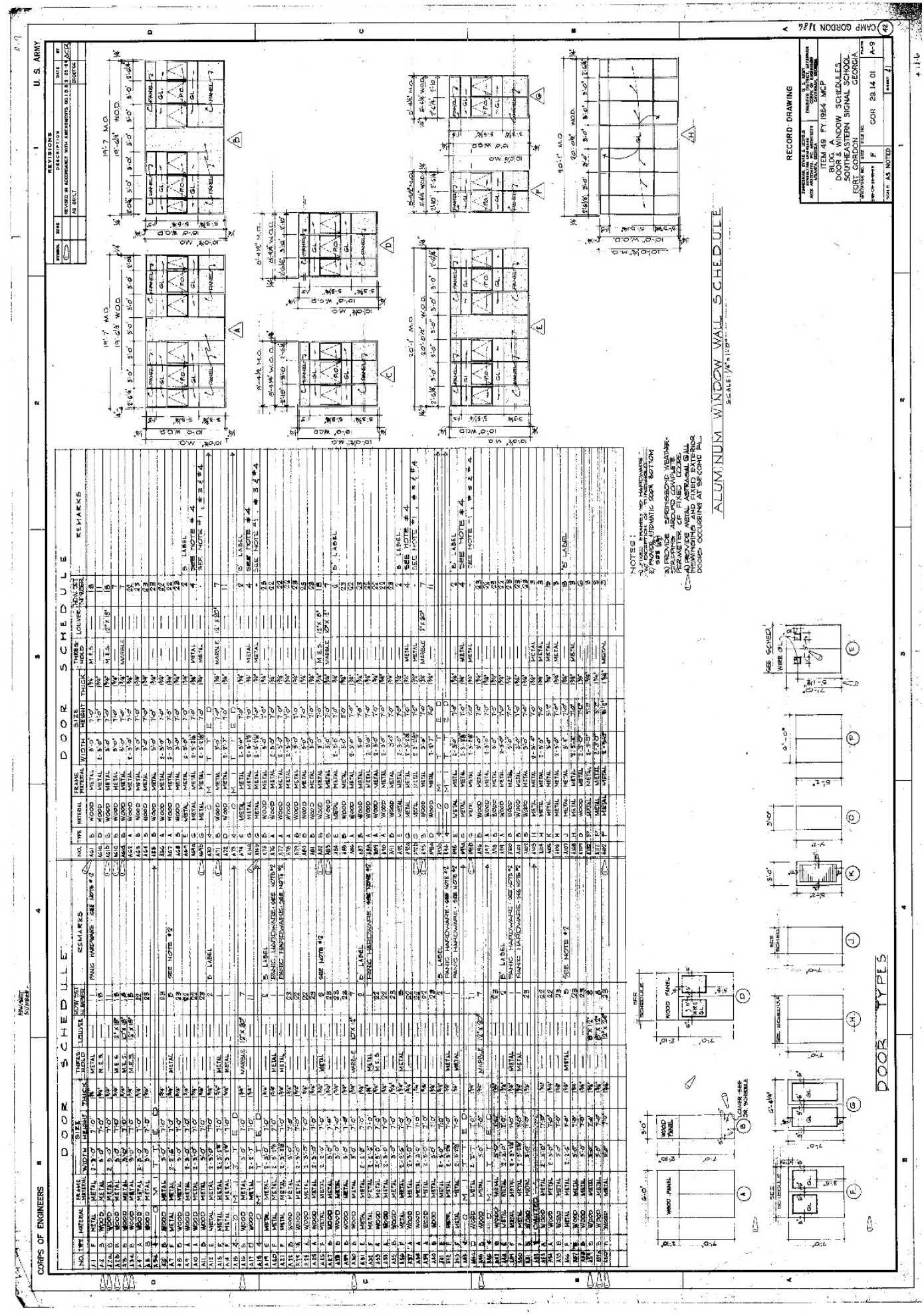


Figure 352. Partial longitudinal section of Building 29813, Allen Hall, 1964 (Fort Gordon DPW).

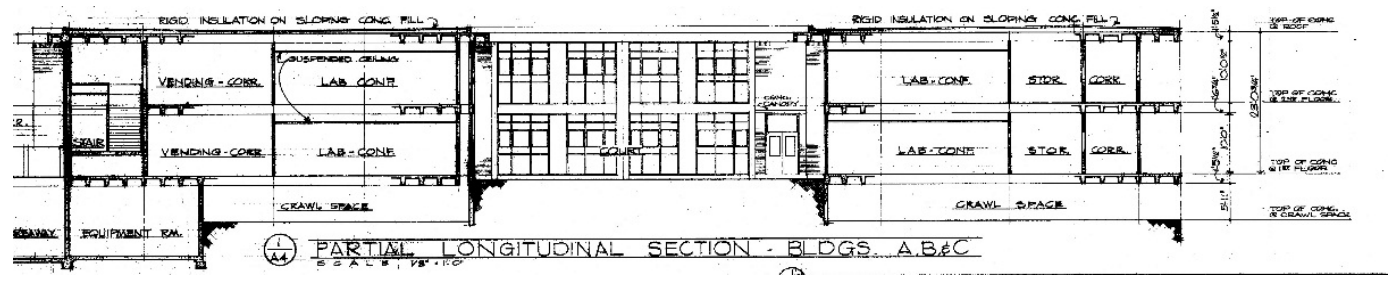

Figure 353. Transverse section of Building 29813, Allen Hall, 1964 (Fort Gordon DPW).

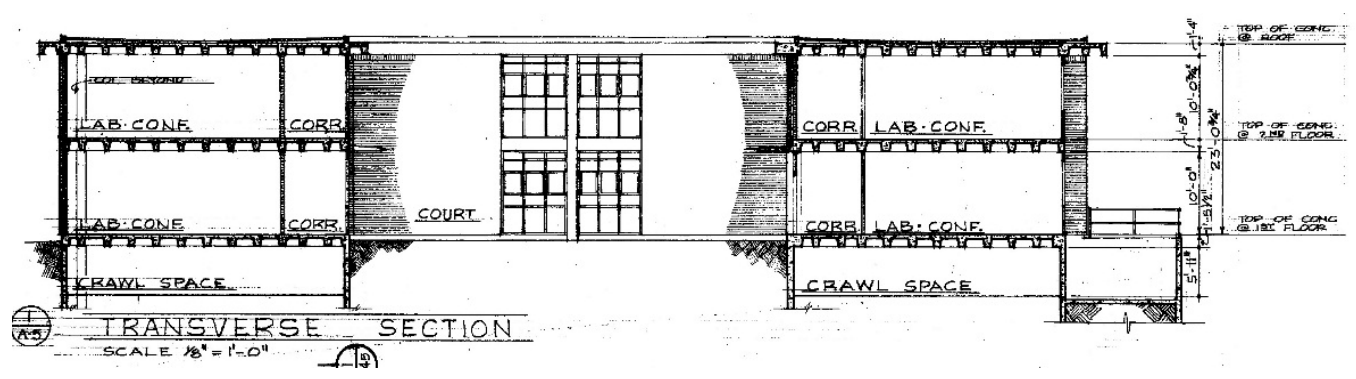

Figure 354. Sections of Building 29813, Allen Hall showing concrete waffle ceiling and roof construction, 1964 (Fort Gordon DPW).

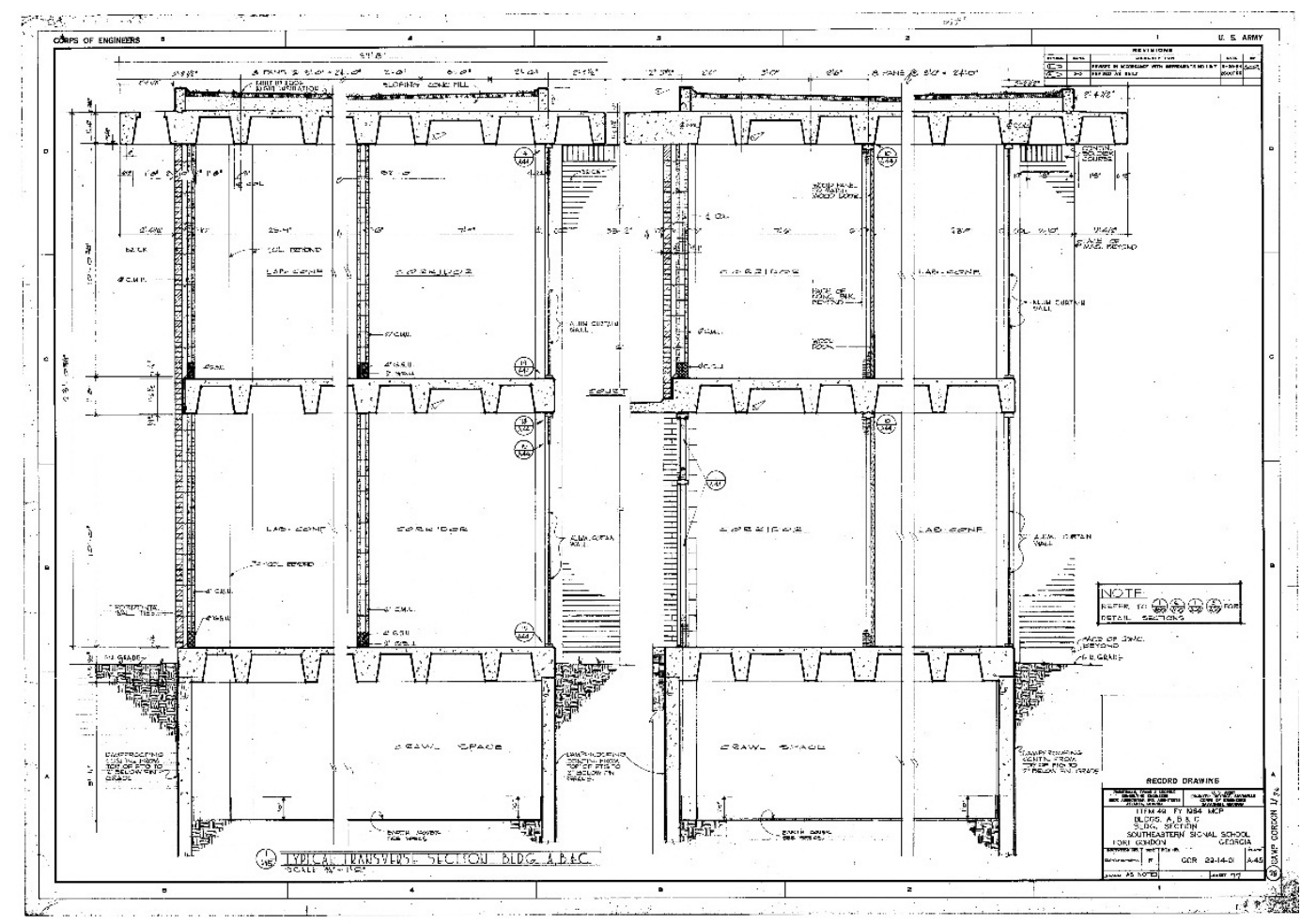


Figure 355. Brick screen detail for exterior staircases on the east and west elevations of Building 29813, Allen Hall, 1964 (Fort Gordon DPW).

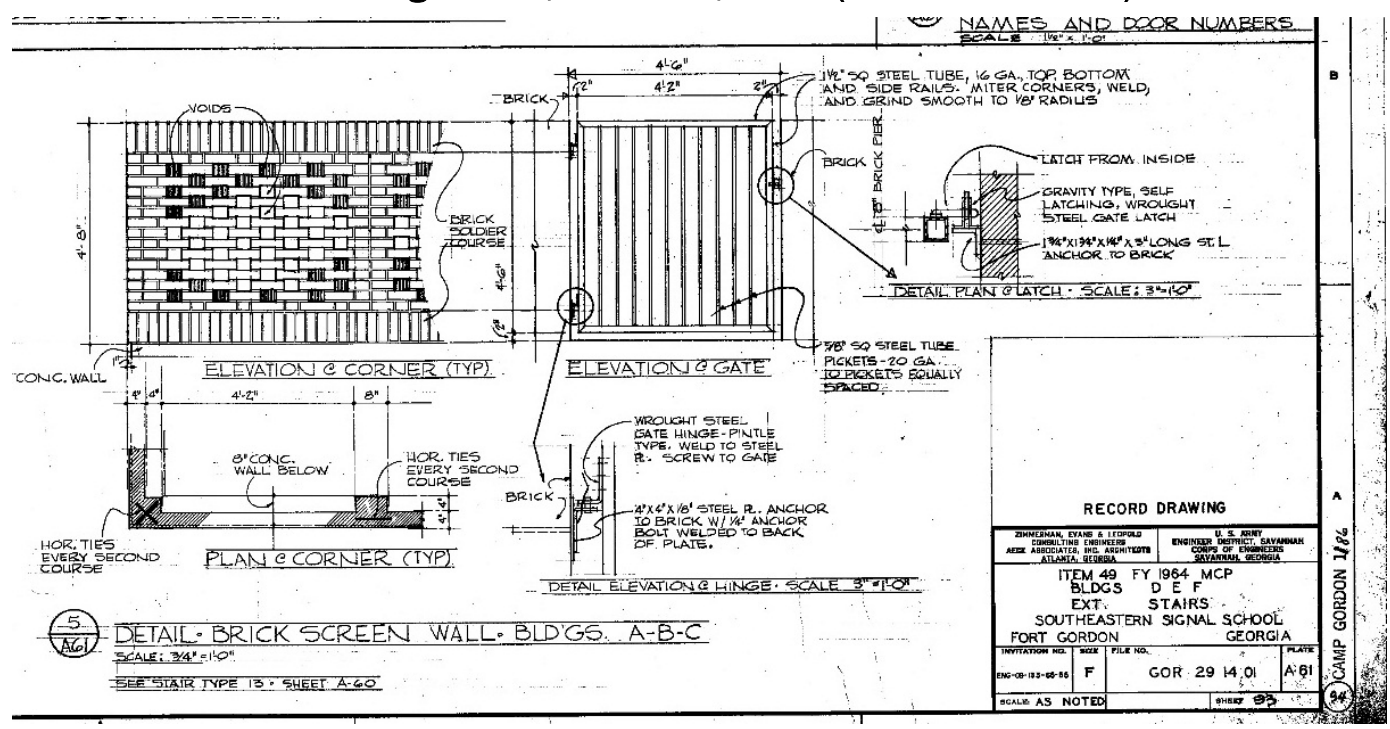

Figure 356. Courtyard landscaping plans and details for Building 29813, Allen Hall, 1966 Fort Gordon DPW).

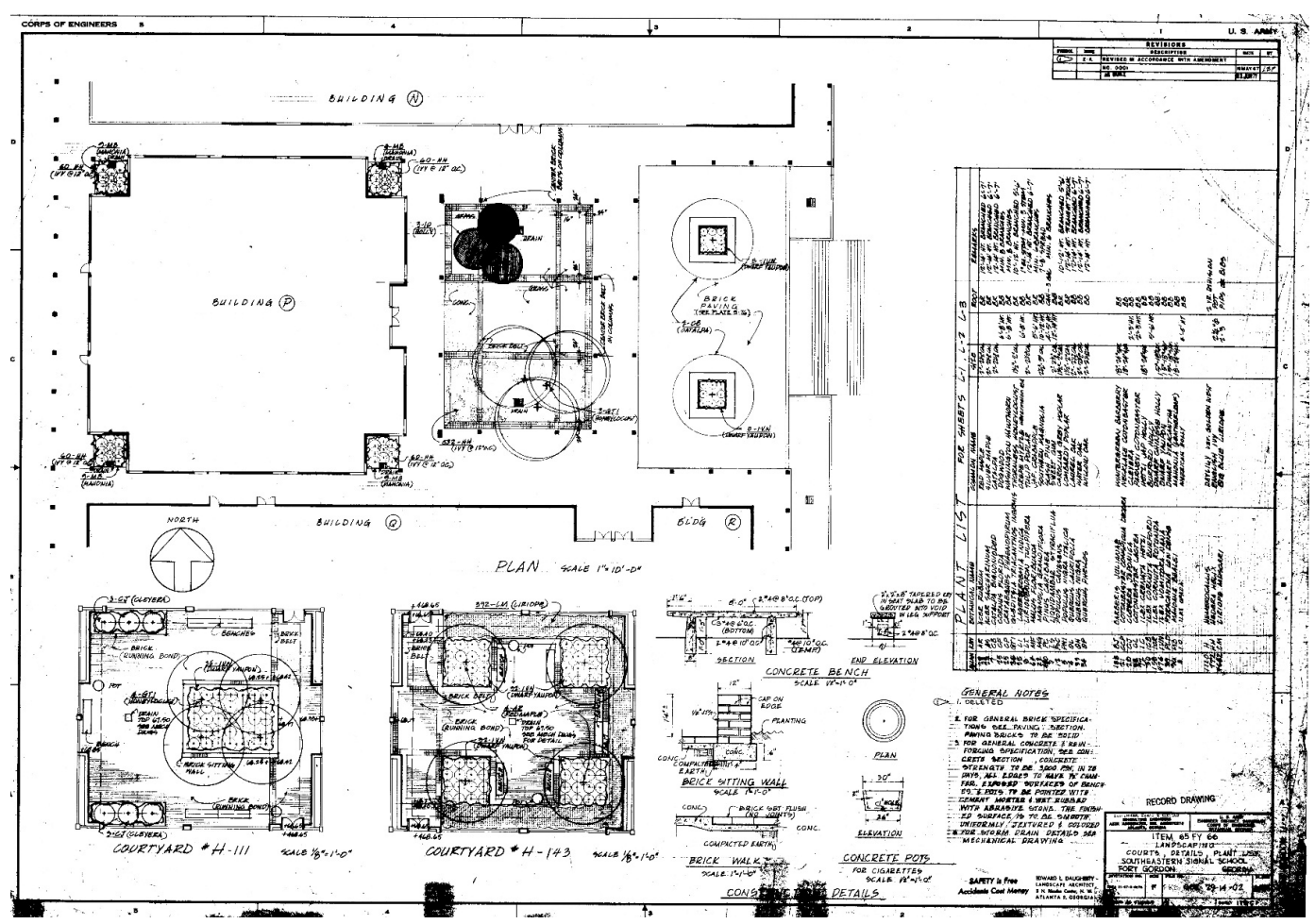


Figure 357. Typical classroom elevations and details for Building 29813, Allen Hall, 1966 (Fort Gordon DPW).

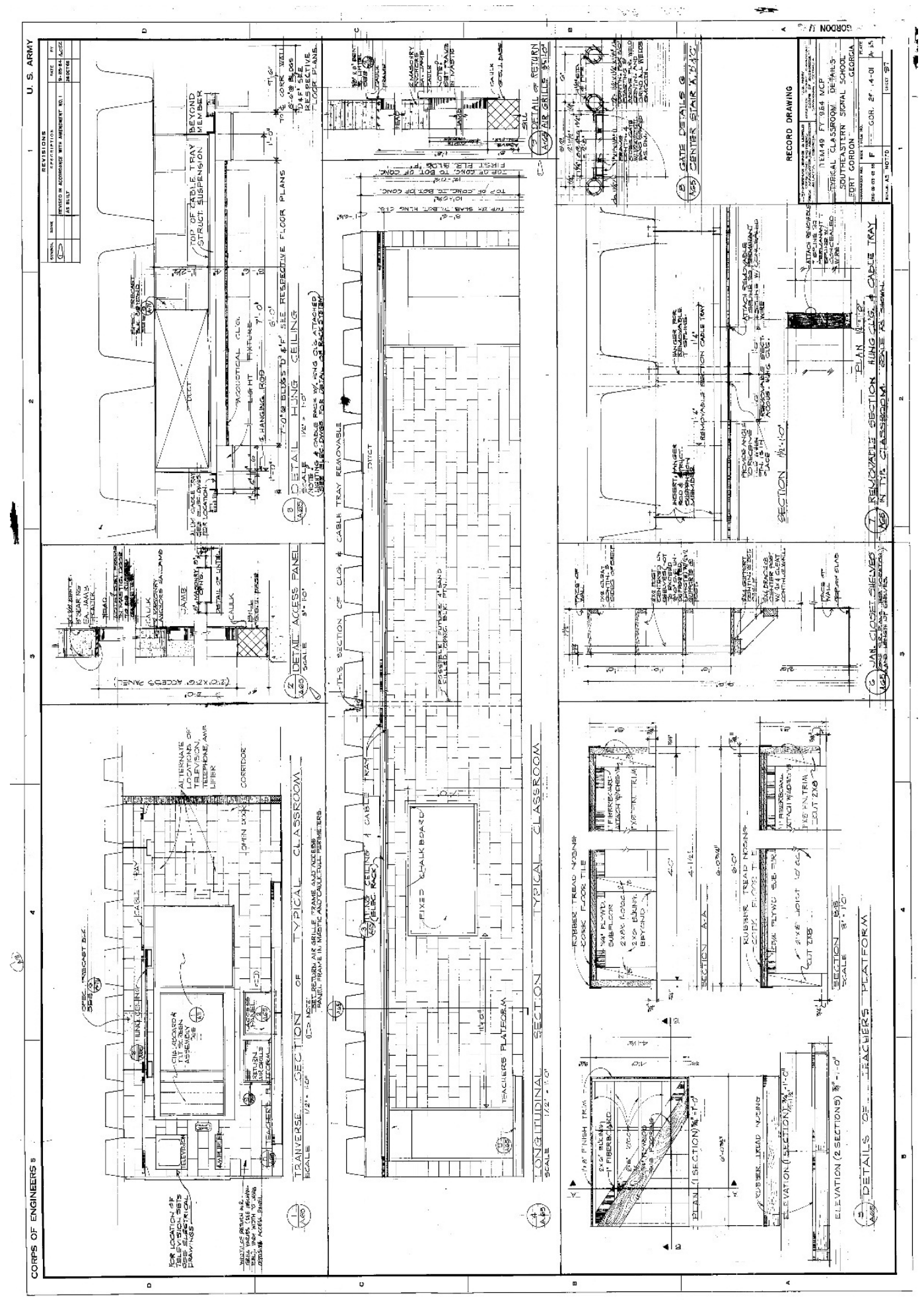


Figure 358. Interior stairwell details of Building 29813, Allen Hall, 1964 (Fort Gordon DPW).

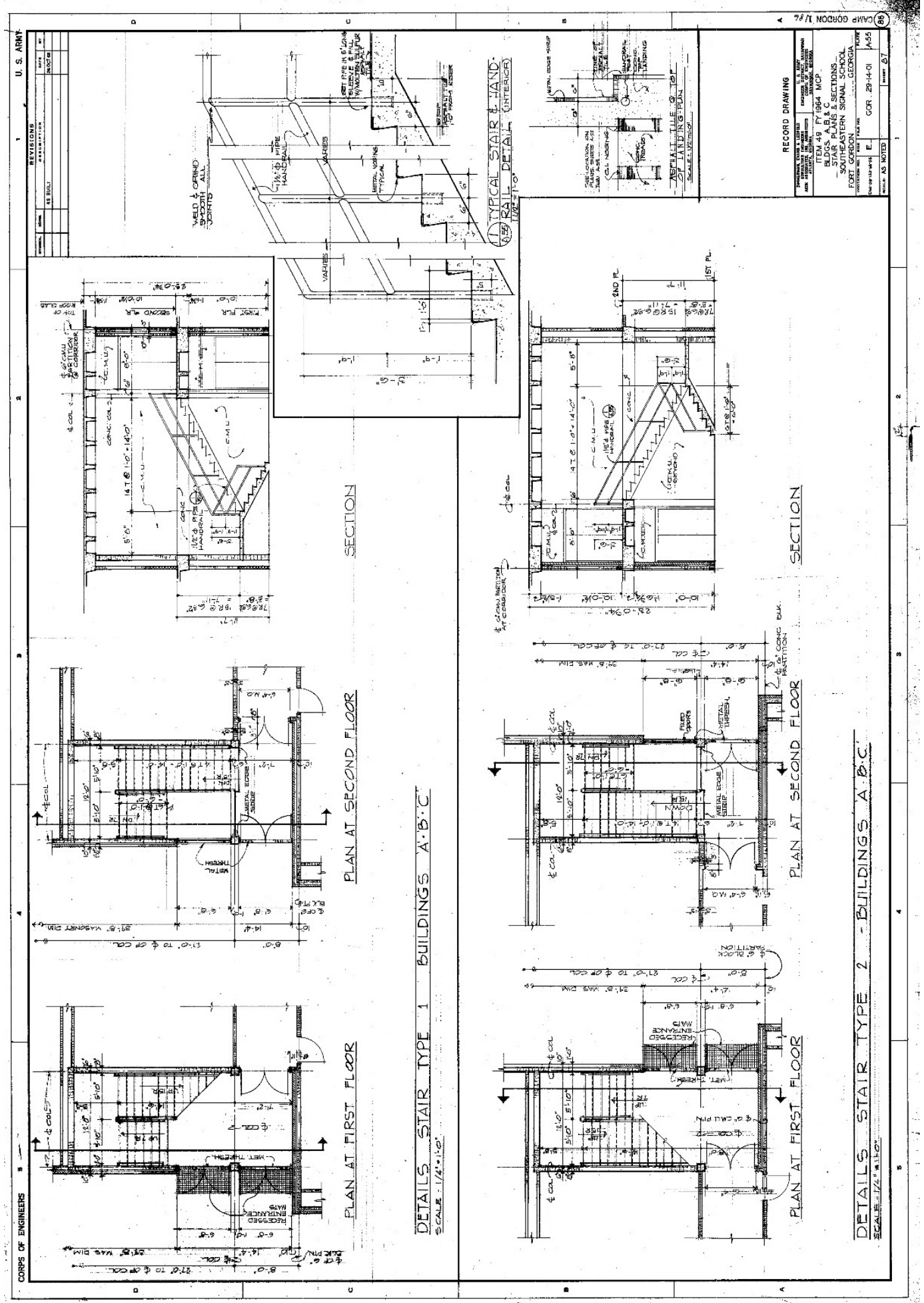


Figure 359. Latrine plans, elevations, and details for Building 29813, Allen Hall, 1964 (Fort Gordon DPW).

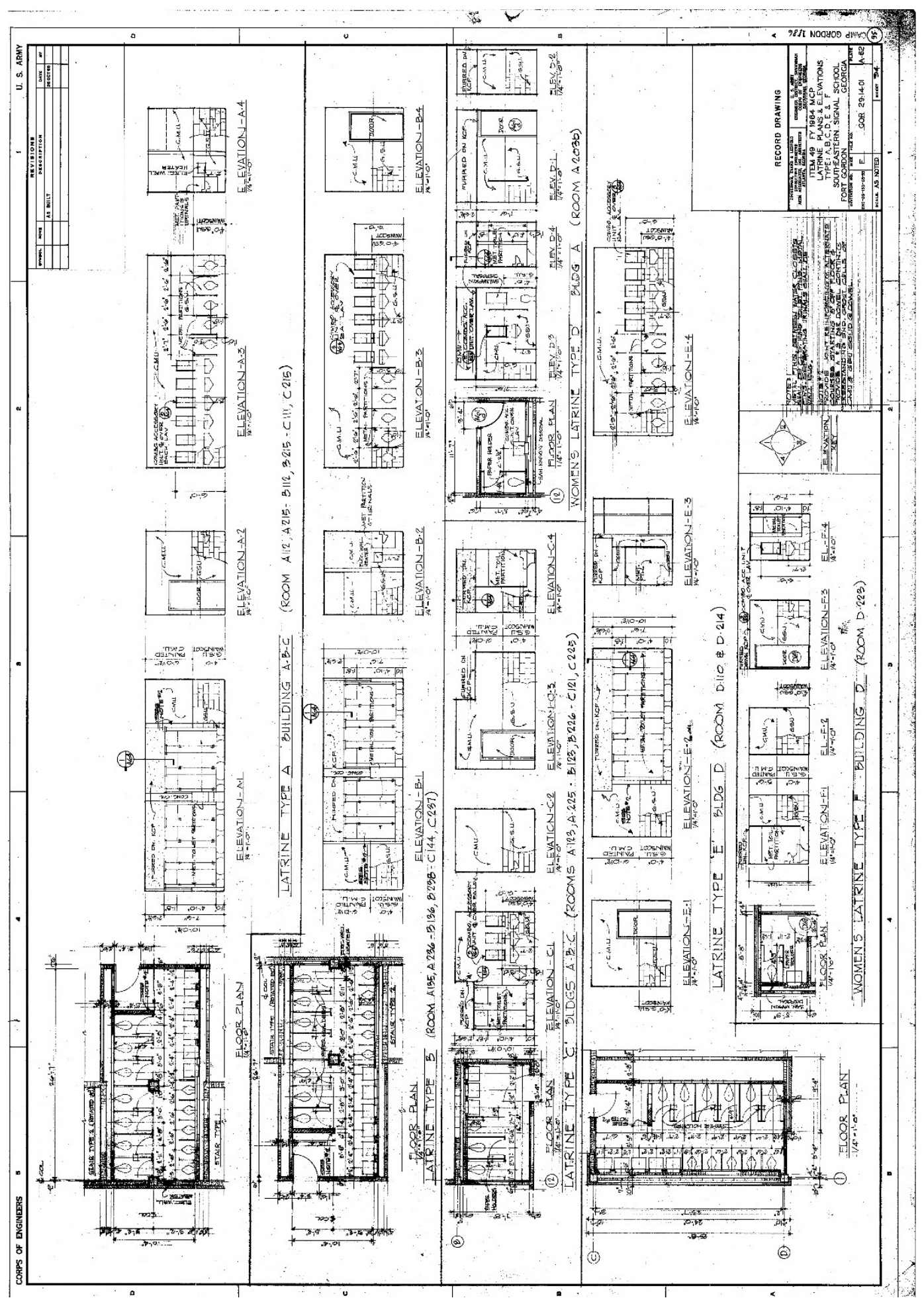


Figure 360. Light fixture types and schedule, for Building 29813, Allen Hall, 1966 (Fort Gordon DPW).

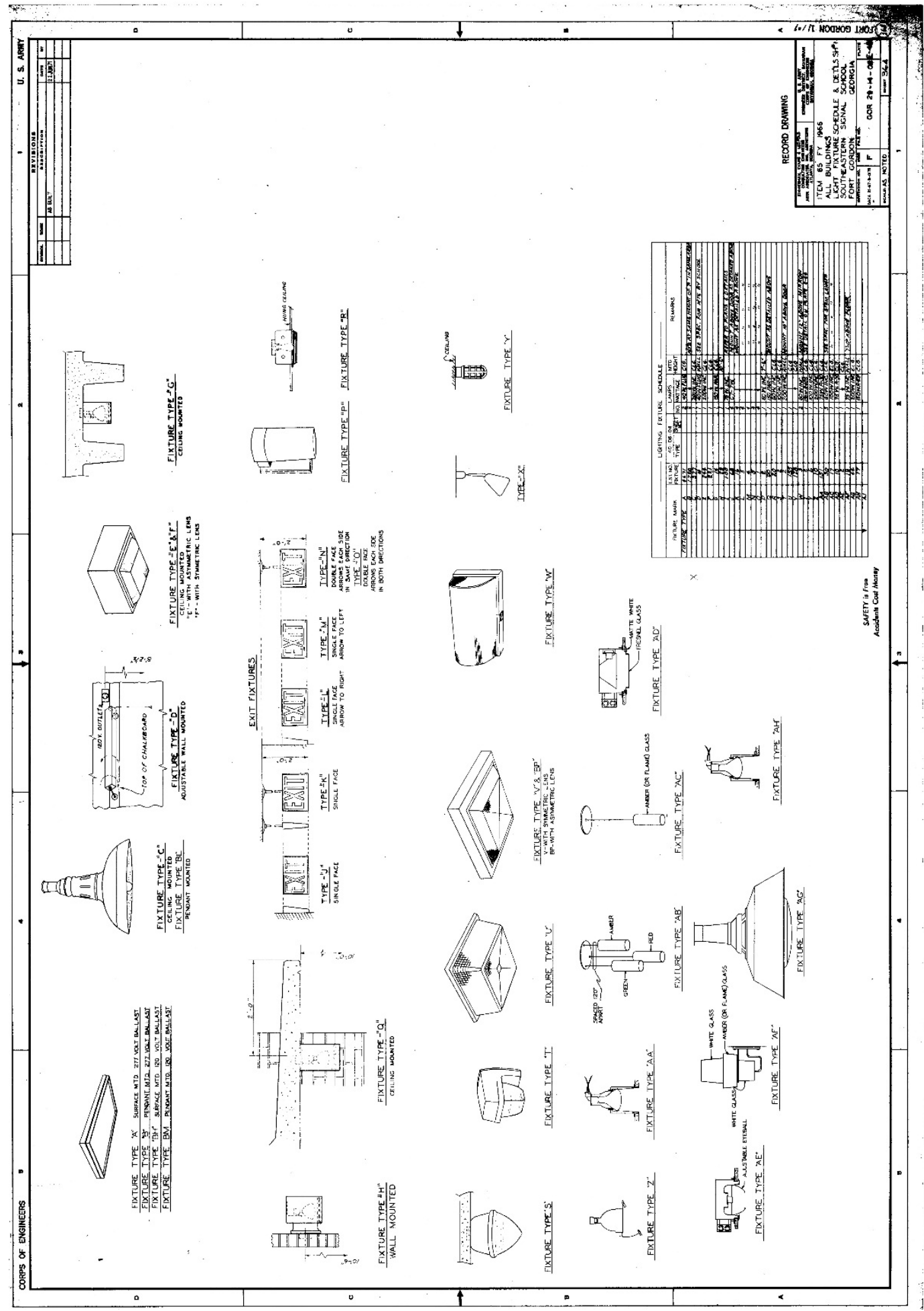


Figure 361. Landscape plan for Building 29813, Allen Hall, 1966 (Fort Gordon DPW).

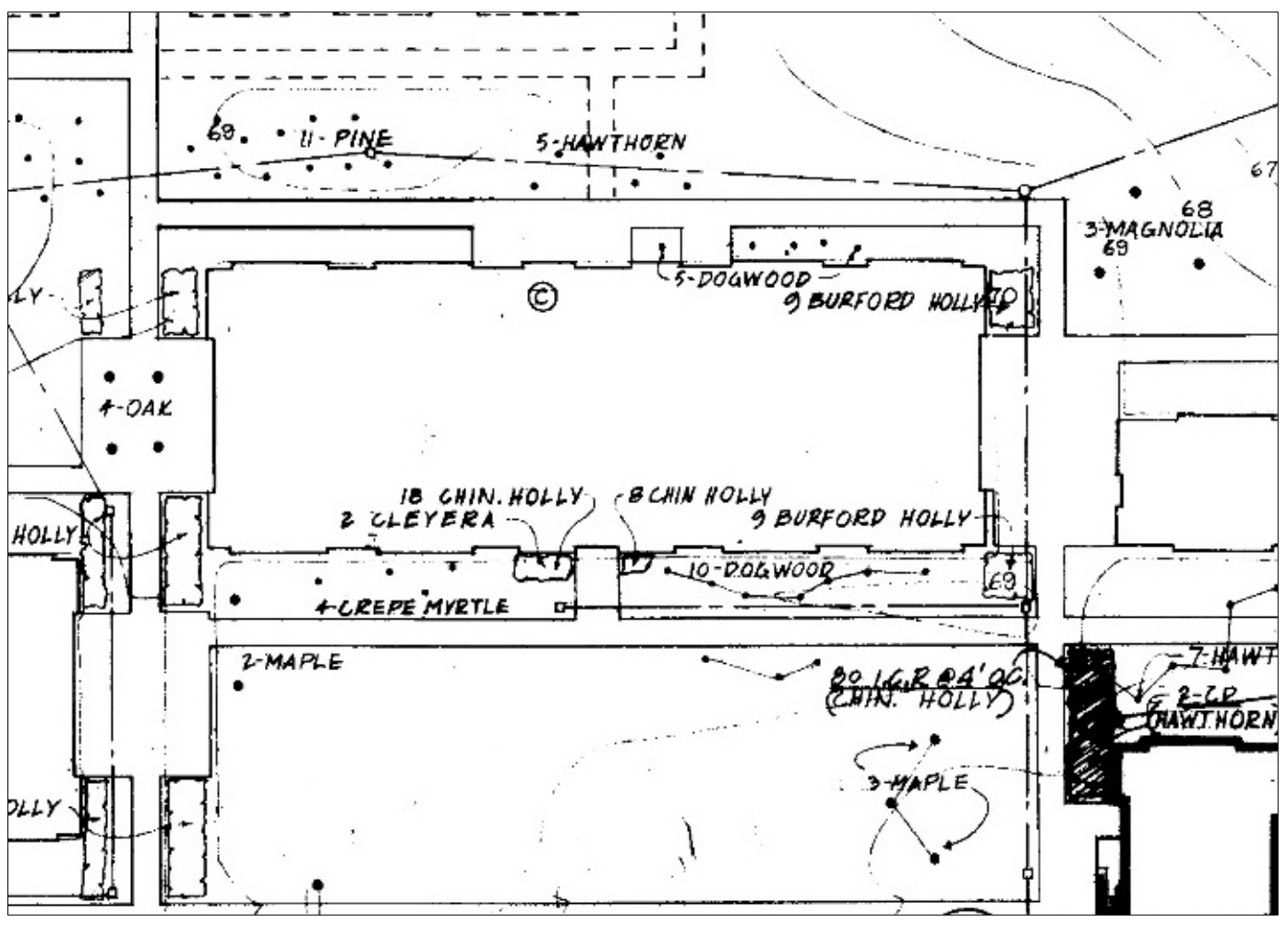

\subsubsection{Character-defining features}

Repair, renovation, and replacement of Building 29813, Allen Hall must be coordinated with the GA SHPO (Table 13).

\section{Exterior:}

- Overall massing

- Footprint

- Roof shape

- Brick veneer

- Relationship to other Signal School Campus buildings

- Overhanging eaves with perforated waffle construction casting "light pattern" on exterior brick walls

- Exposed concrete structure framing window and door openings

- Flat concrete canopy above entries

- Window pattern

- Recessed groups (two, three, or six) of bright-aluminum sash windows with three-pane awning-style windows sandwiched between insulated panels

- Metal doors with large pane 
- Metal doors with plate glass on east and west elevations

- Perforated brick walls on east and west elevations

- Ceiling-mounted exterior light fixtures set within the waffle overhang on the east and west elevations

- Lettering

- Metal handrails

- Landscaping

\section{Interior:}

- Overall plan

- Courtyards

- Main stairwells

- Main hallways

- Lighting

- Doors

- Display cases

- Signage

- Vending machine alcove

- Telephone alcoves

- Tiled water fountain alcoves

Table 13. Images of character-defining features of Building 29813, Allen Hall (ERDC-CERL, 2015).

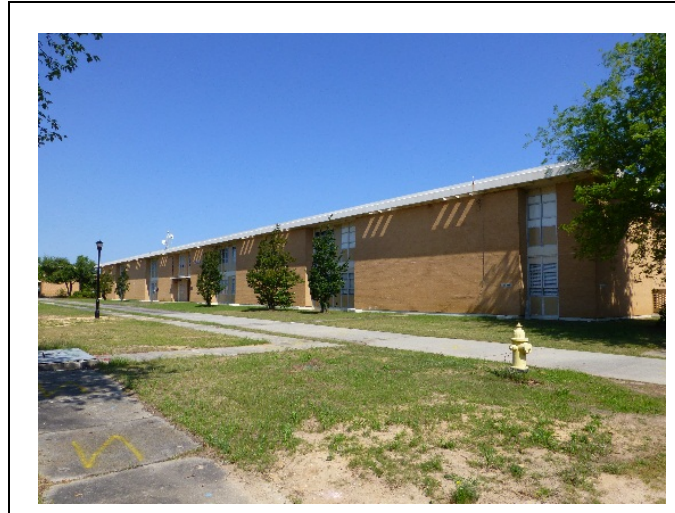

Overall massing, footprint, roof shape, and brick veneer.

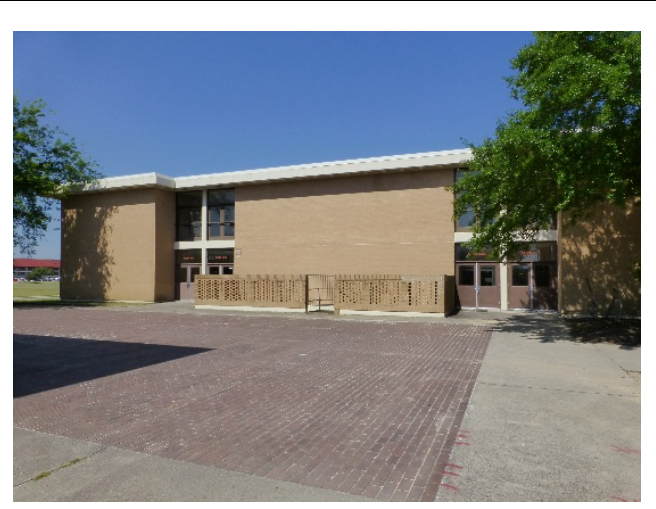

Metal doors with pane and transom on first floor and metal and plate-glass doors on second floor, separated by exposed concrete structural system. Perforated brick wall encasing the basement opening. 


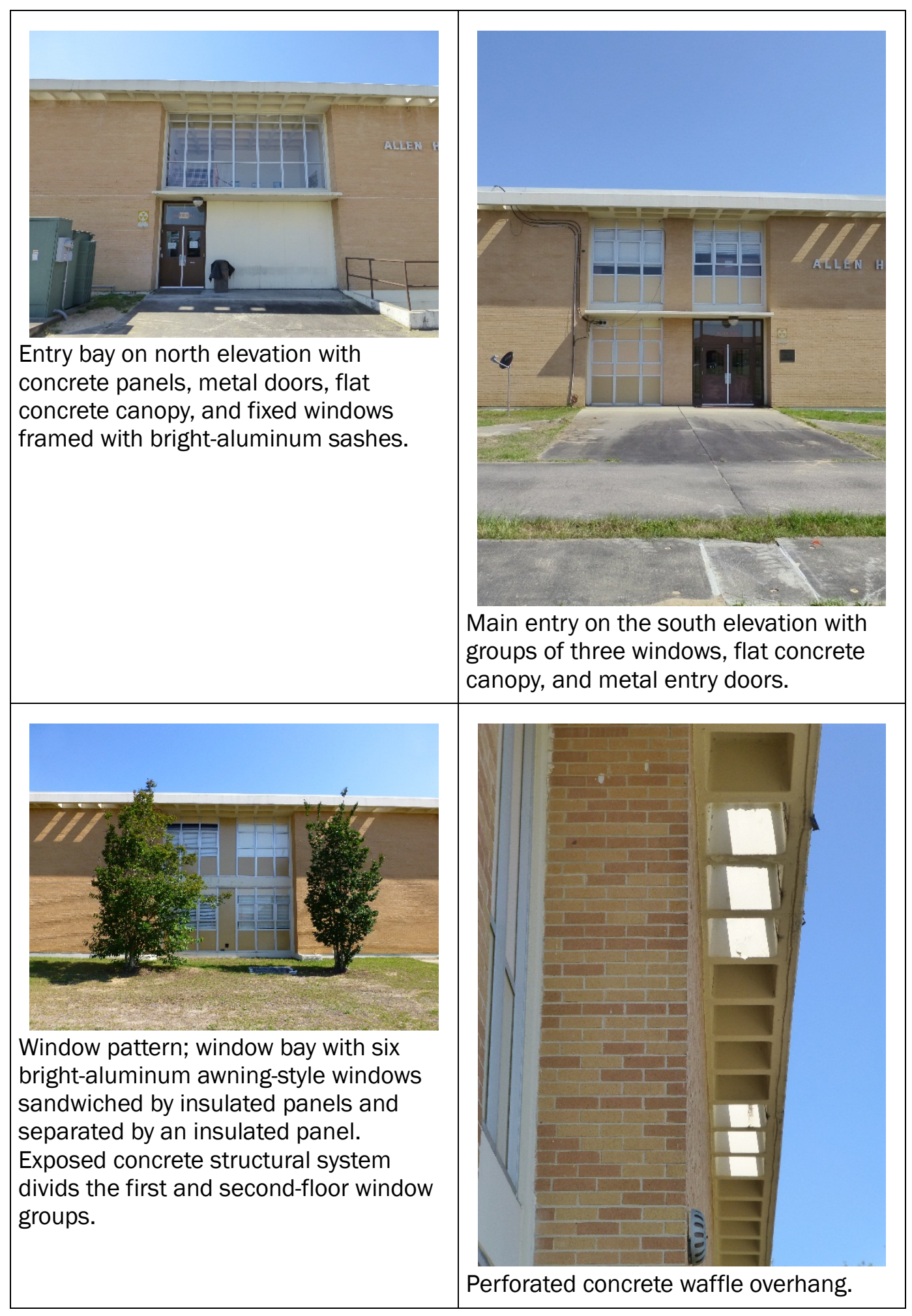




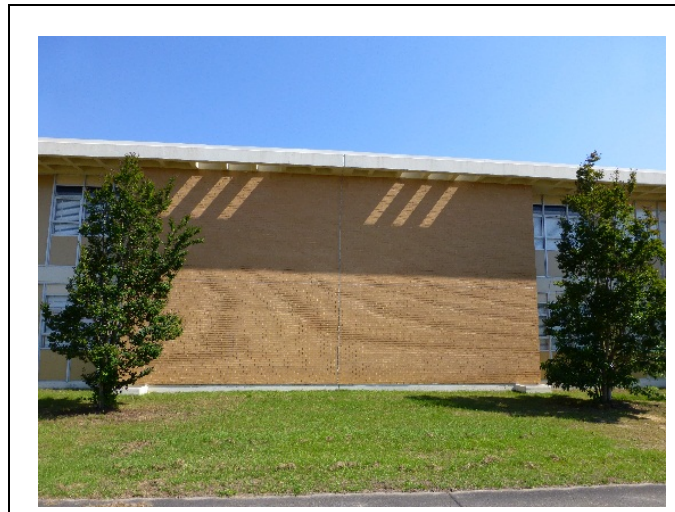

"Light pattern" created by the perforated concrete waffle overhang.

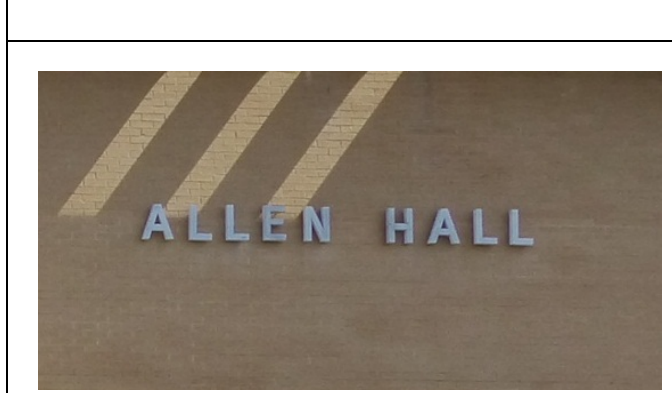

Lettering on the north and south elevations.

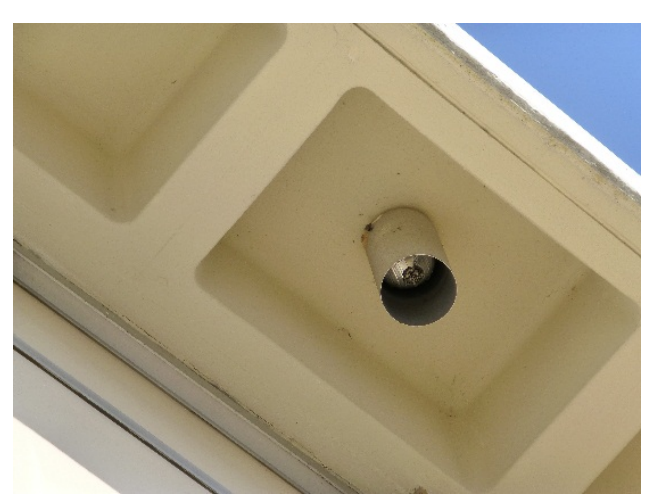

Ceiling-mounted light fixture under the waffle overhang on the east and west elevations.

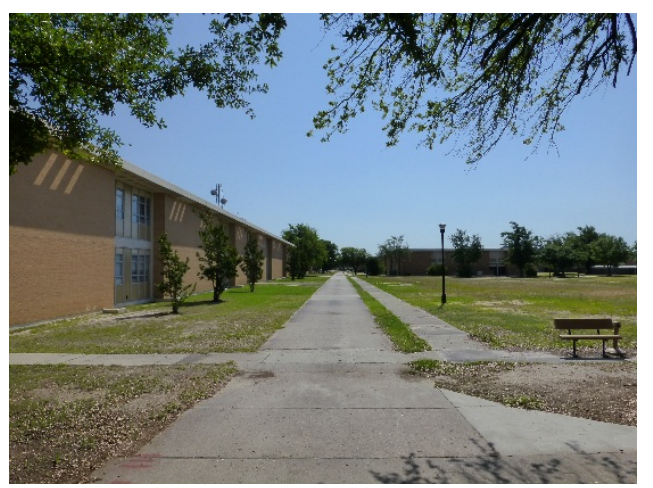

Relationship to other Signal School Campus buildings and campus layout.

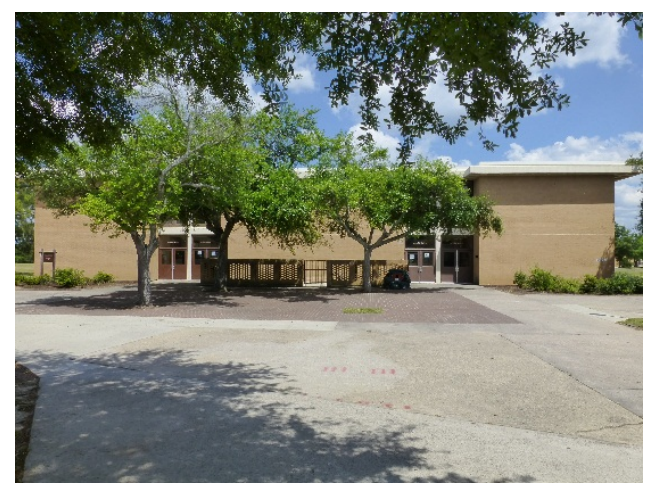

Landscaping and brick plazas on the east and west elevations.

\subsubsection{Character-defining features that have been removed}

\section{- None.}




\subsubsection{Nonhistoric features}

- None.

\subsubsection{Comparison images}

Comparison images utilizing either the original drawings or historic photographs, when juxtaposed against present-day images, are a useful tool in developing the historic "feel" of a property and how much of that historic feeling is still present today (Figure 362-Figure 369).

Figure 362. Southeast oblique - comparison of the original design and materials for Building 29811 and construction in 1966 [left] to the current condition of the south elevation of Building 29813, Allen Hall [right] (ERDC-CERL, 2015).
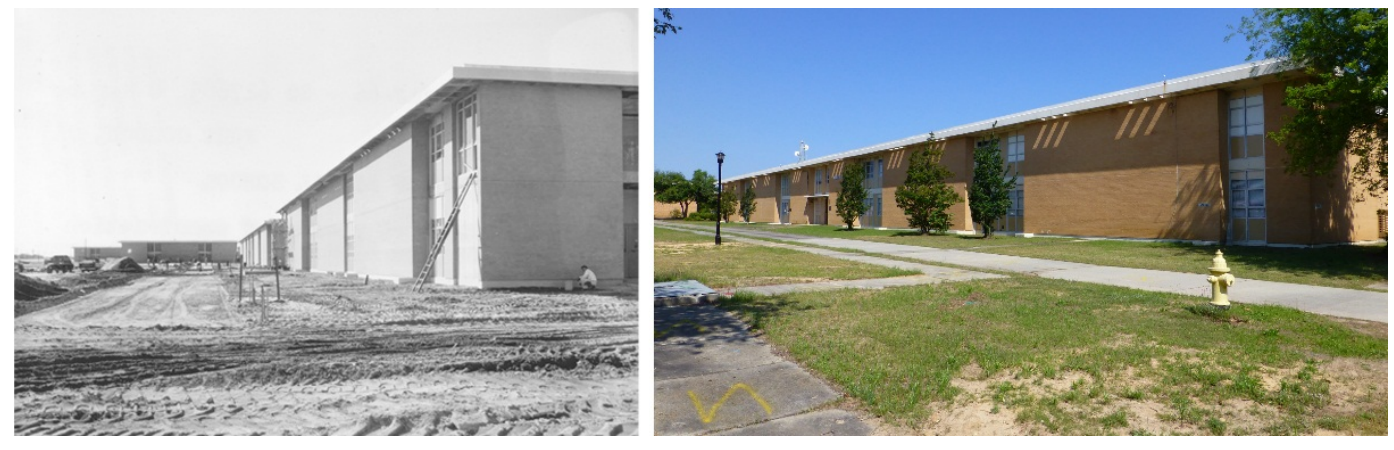

Figure 363. Second-floor window bay on the north and south elevations comparison of the original design and materials from 1964 [left] to the current condition of bright-aluminum three-pane awning style-windows and insulated panels [right] (ERDC-CERL, 2015).
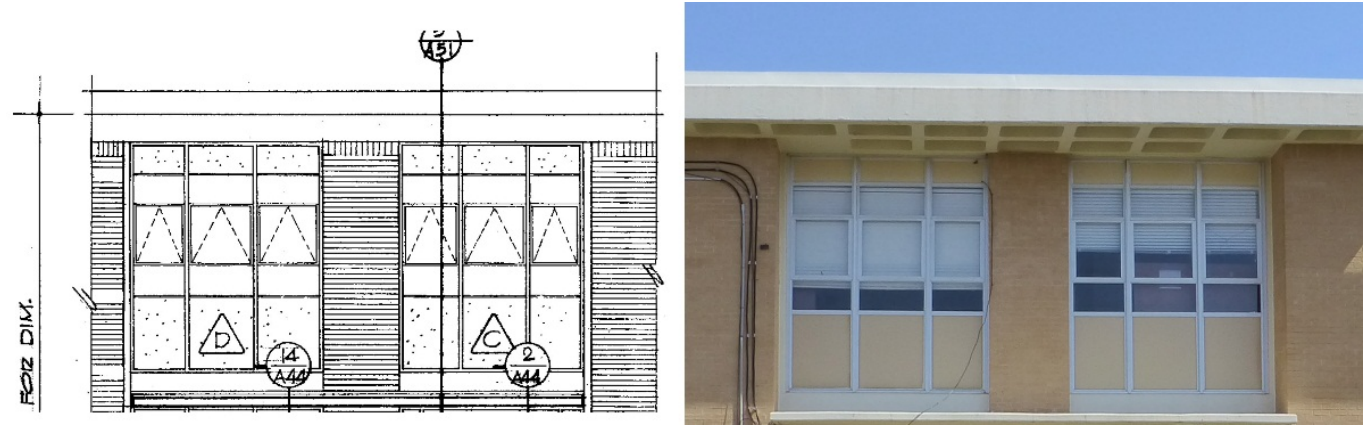
Figure 364. Window bay located on the left and right sides of the north and south elevations - comparison of the original design and materials from 1964 [left] to the current condition of the three-pane awning-style windows sandwiched between insulated panels [right] (ERDC-CERL, 2015).

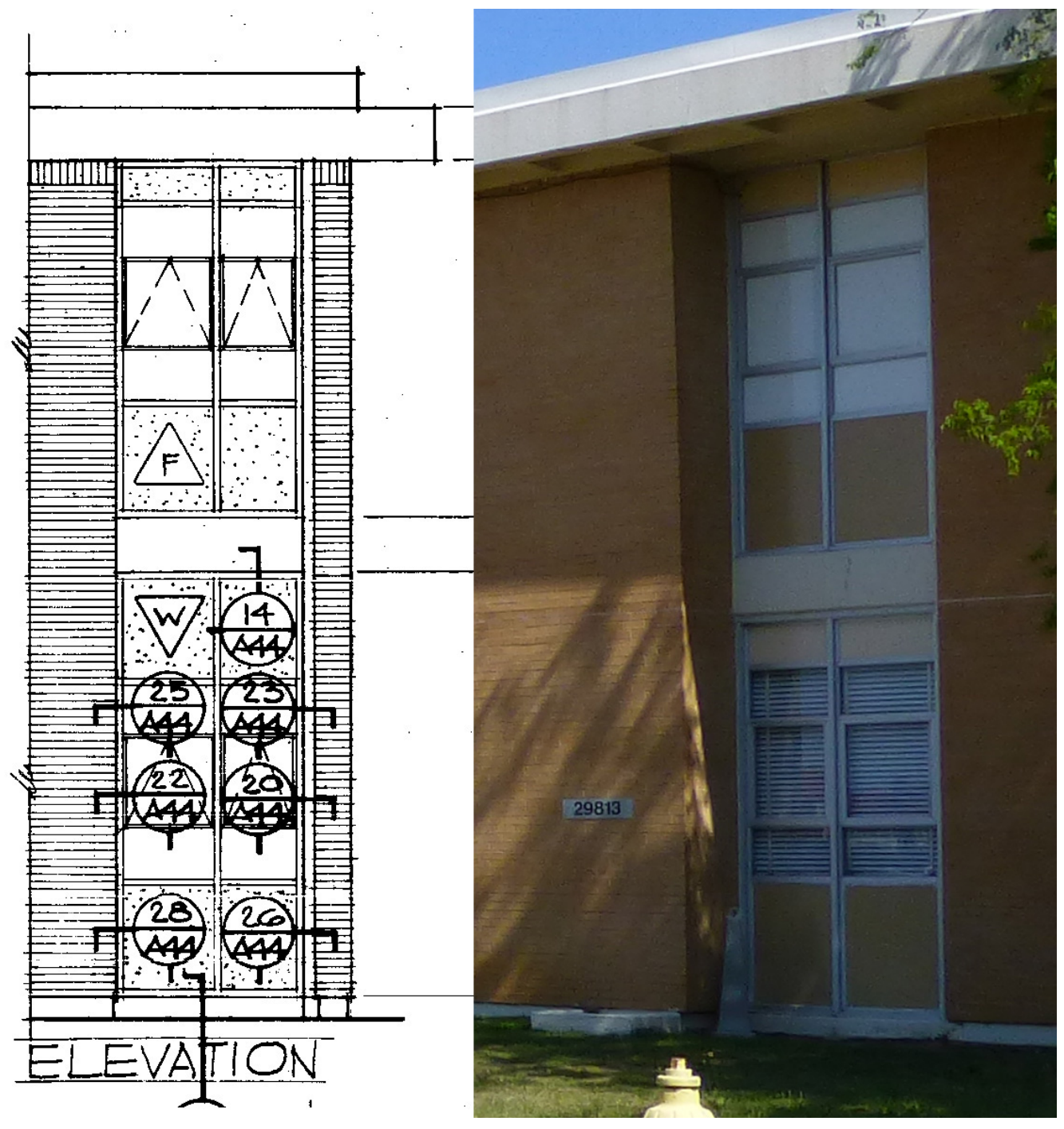


Figure 365. Doors on the east and west elevations - comparison of the original design and materials from 1964 [left] to the current condition of the metal doors with pane and transoms on the first floor and the metal and plate-glass doors with security bars on the second floor [right] (ERDC-CERL, 2015).
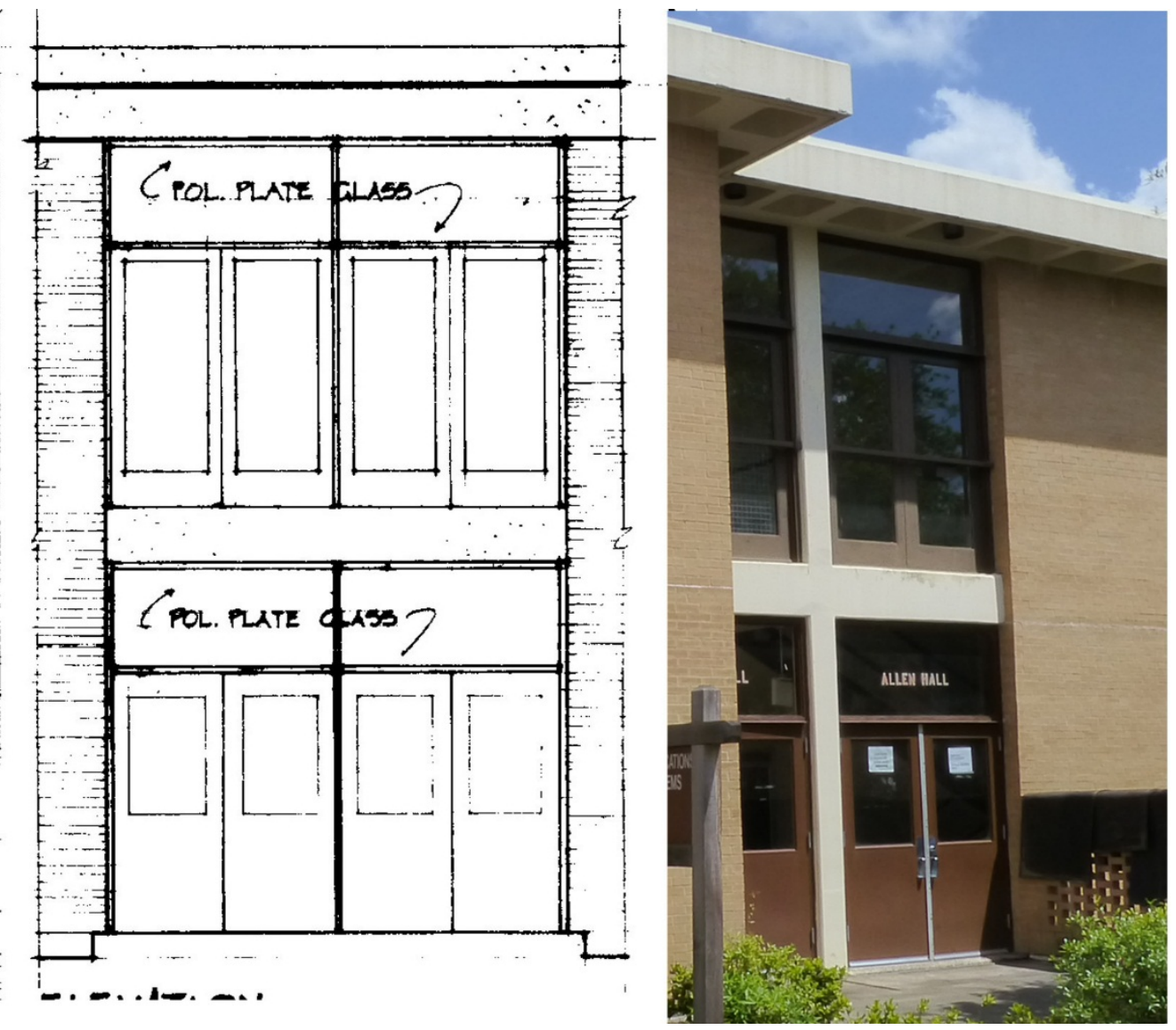

Figure 366. North wall of the right courtyard comparison of the original design and materials from 1964 [left] to the present-day [right] (ERDC-CERL, 2015).
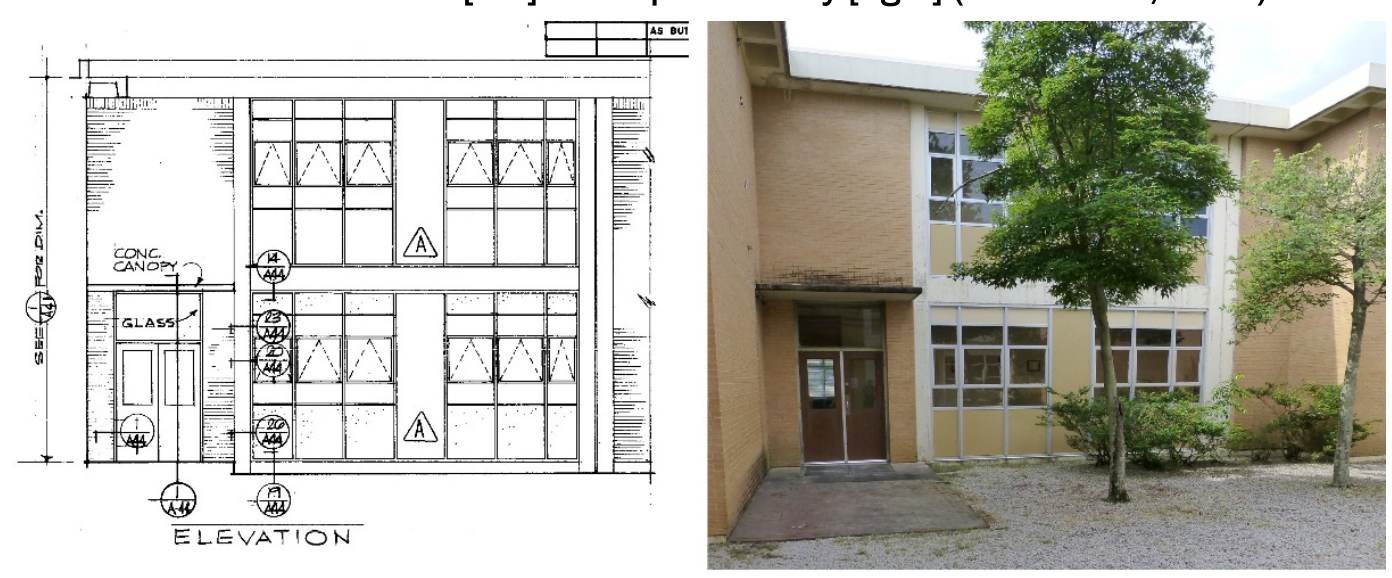
Figure 367. East and west walls of the courtyards - comparison of the original design and materials from 1964 [left] to the present-day [right] (ERDC-CERL, 2015).
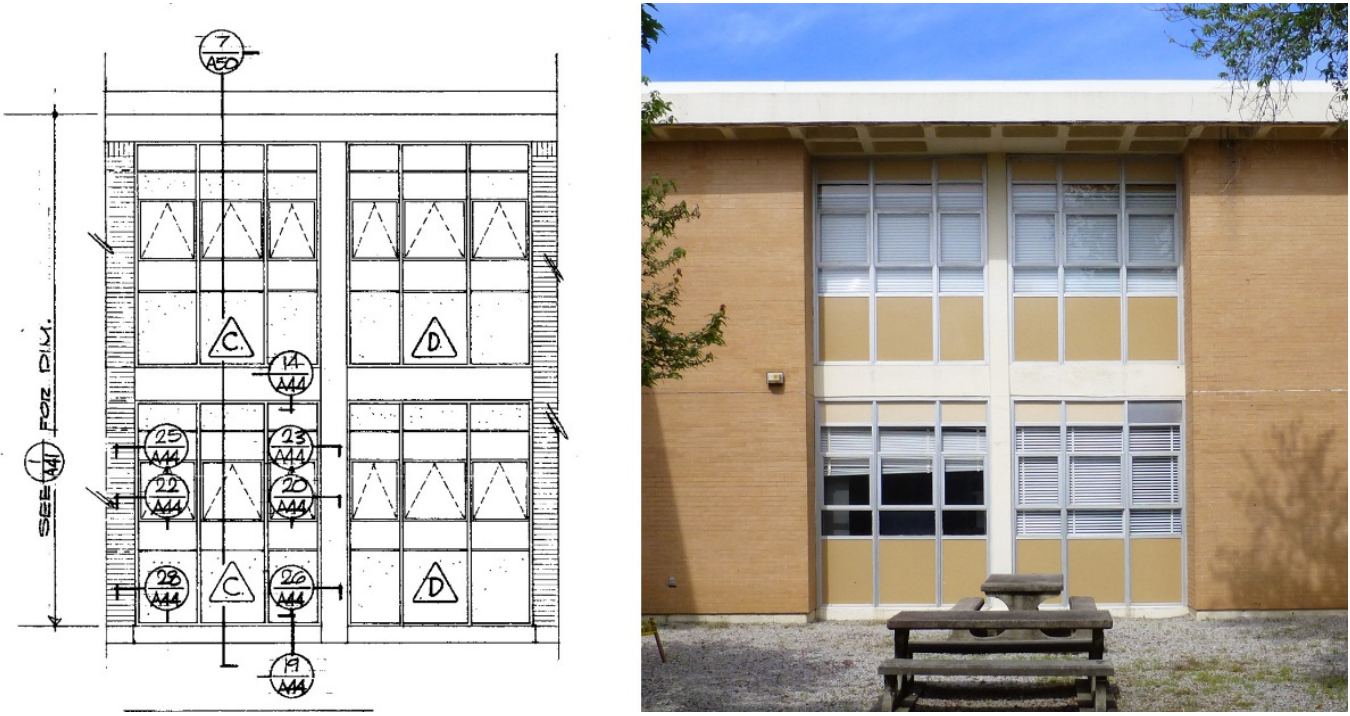

Figure 368. Ceiling-mounted light fixture under the waffle overhang - comparison of the original design and material from 1966 [left] to the current condition of the ceiling-mounted light fixture [right] (ERDC-CERL, 2015).
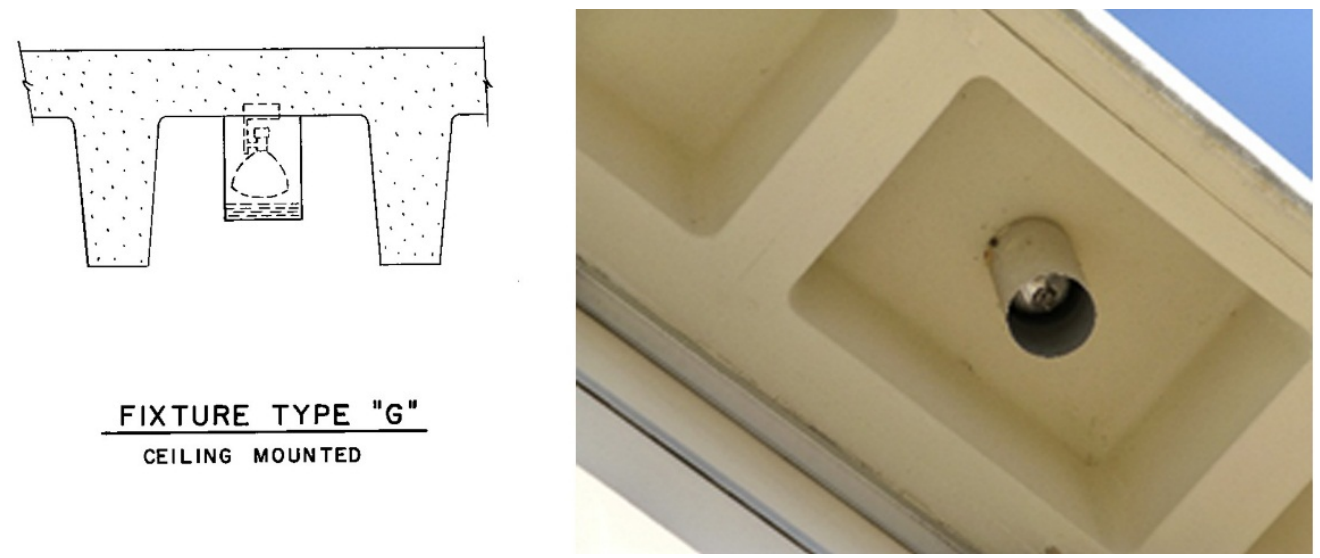

Figure 369. Ceiling-mounted light fixture under flat concrete canopy - comparison of the original design and material from 1966 [left] to the current condition of the replacement ceiling-mounted light fixture [right] (ERDC-CERL, 2015).
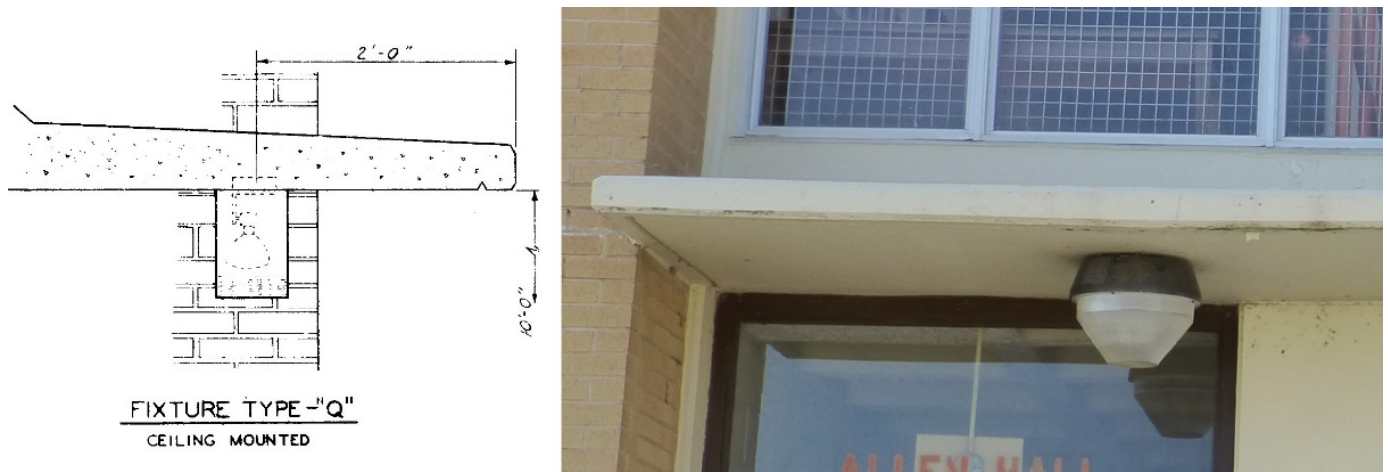

FIXTURE TYPE -"Q" 


\subsubsection{Building 29815, Hazen Hall (1966)}

Building 29815, Hazen Hall, is a contributing feature to the Signal School Campus Historic District. The interior is contributing. It was constructed in 1966 as part of Phase I construction of the campus and was designed by Aeck Associates from Atlanta, Georgia, and Zimmerman, Evans, and Leopold Consulting Engineers from August, Georgia. The building is a long rectilinear classroom building on the southeastern edge of the school, southwest of the eastern parking lot. It is two stories high with a partial basement. The structure is cast-in-place concrete columns with a waffle floor/ceiling system. The second-floor waffle system is set within the structure, but the roof has the waffles extend out to form an overhang. Some of the waffles have been perforated creating a "light pattern" on the second-floor brick exterior walls. The window systems extend the full height of the building and are inset into the brick veneer. The window systems are composed of bright-aluminum window frames that enclose insulated panels and three-pane awning windows. Tan-colored panels are above and below the window. The window bays are in groups of two, three, and six. The south elevation is symmetrical. The main entry is centrally placed and consists of two sets of metal doors with panes and transoms above. Exposed concrete structural system separates the two sets of doors and the doors from the second-floor windows. The second-floor windows are two groups of three. Two shrubs flank either side of the entry bay. The two bays that flank the entry bay are divided by a brick column detail. Each of these bays consists of two groups of three window per floor. However, the bay to the right has concrete panels filling the bottom of one of the bays. There are two larger groups of windows on either side of the entry bay. These groups consists of six windows per floor, divided by an insulated panel. The left and right sides of the south elevation have a bay of three windows and a bay of two windows. Original lettering spelling out "HAZEN HALL" is located on the south wall. Other entrances are on the east and west elevations. These entries are recessed under the second floor, and each consists of two sets of metal doors with panes and transoms above. The second floor of these entry bays consists of two sets of metal and plate-glass doors with a transom above each set of doors. These doors are welded closed with a steel bar across the middle. It appears bridges were meant to connect the various buildings together at the second-floor level. There are brick-paved plazas in front of the east and west entrances. There are four trees framing the east plaza, and two trees framing the west plaza. The north elevation is symmetrical. There are six window bays. Each bay consists of six window divided by an insulated panel 
per floor, with the exception of the far right bay where the first floor openings have been modified to include an entry door. The left and right sides of the elevation each have two window bays. One bay consists of three windows per floor while the outside bay consists of three windows on the second floor and three concrete panels on the first floor. There are three outside access points to the basement on the north side of the building. Each point is defined by poured concrete retaining walls, concrete steps, and metal handrails (Figure 370-Figure 381).

Figure 370. Signal School Campus map, with Building 29815, Hazen Hall highlighted in red, 2015 (Fort Gordon DPW, modified by ERDC-CERL).

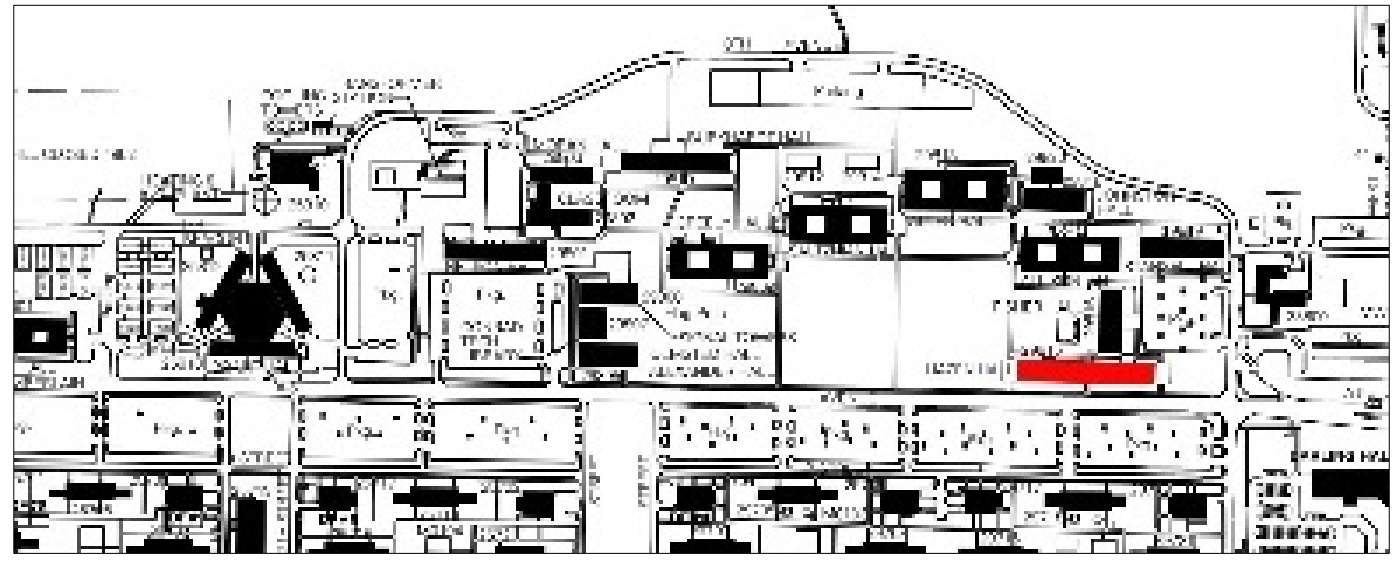

Figure 371. South elevation of Building 29815, Hazen Hall (ERDC-CERL, 2015).

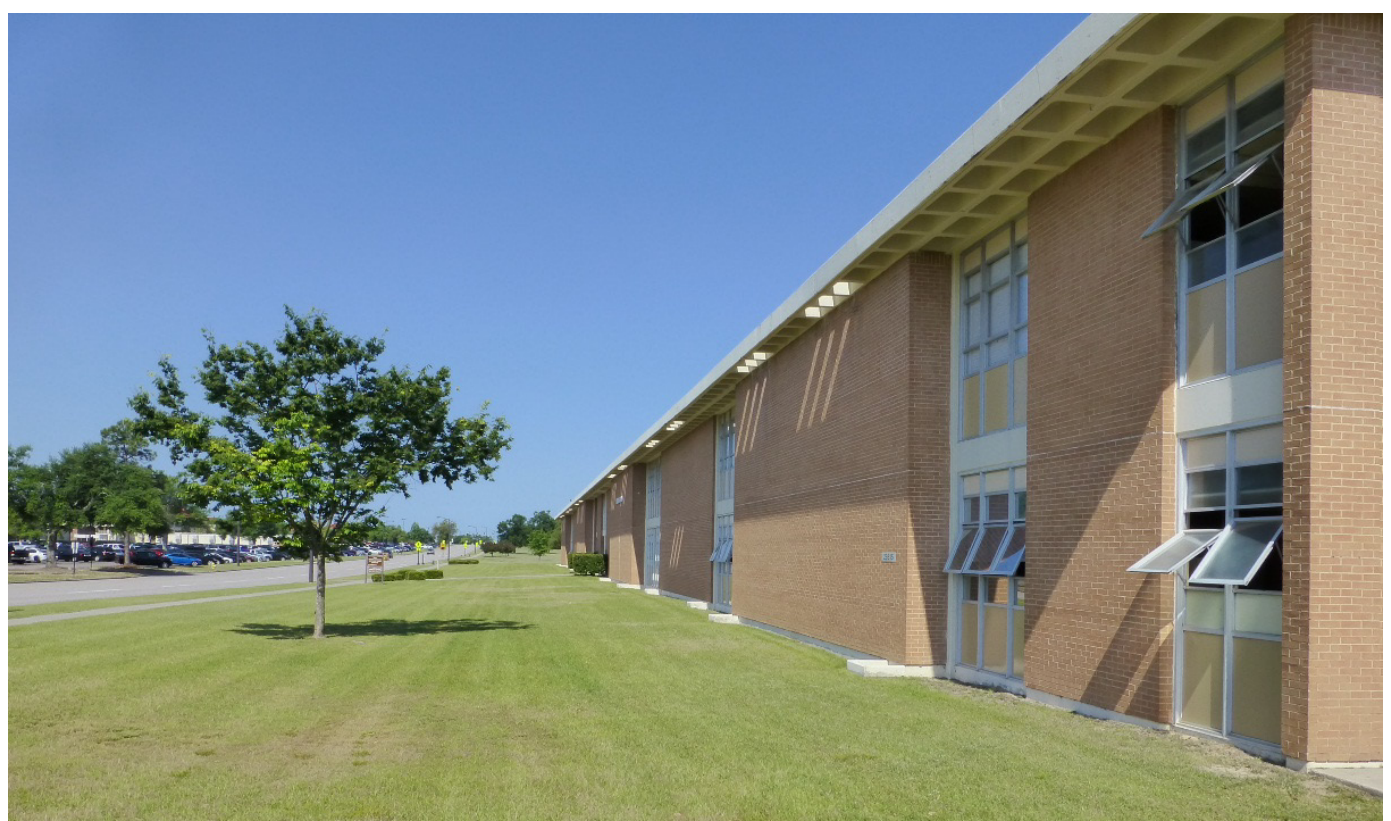


Figure 372. East elevation of Building 29815, Hazen Hall (ERDC-CERL, 2015).

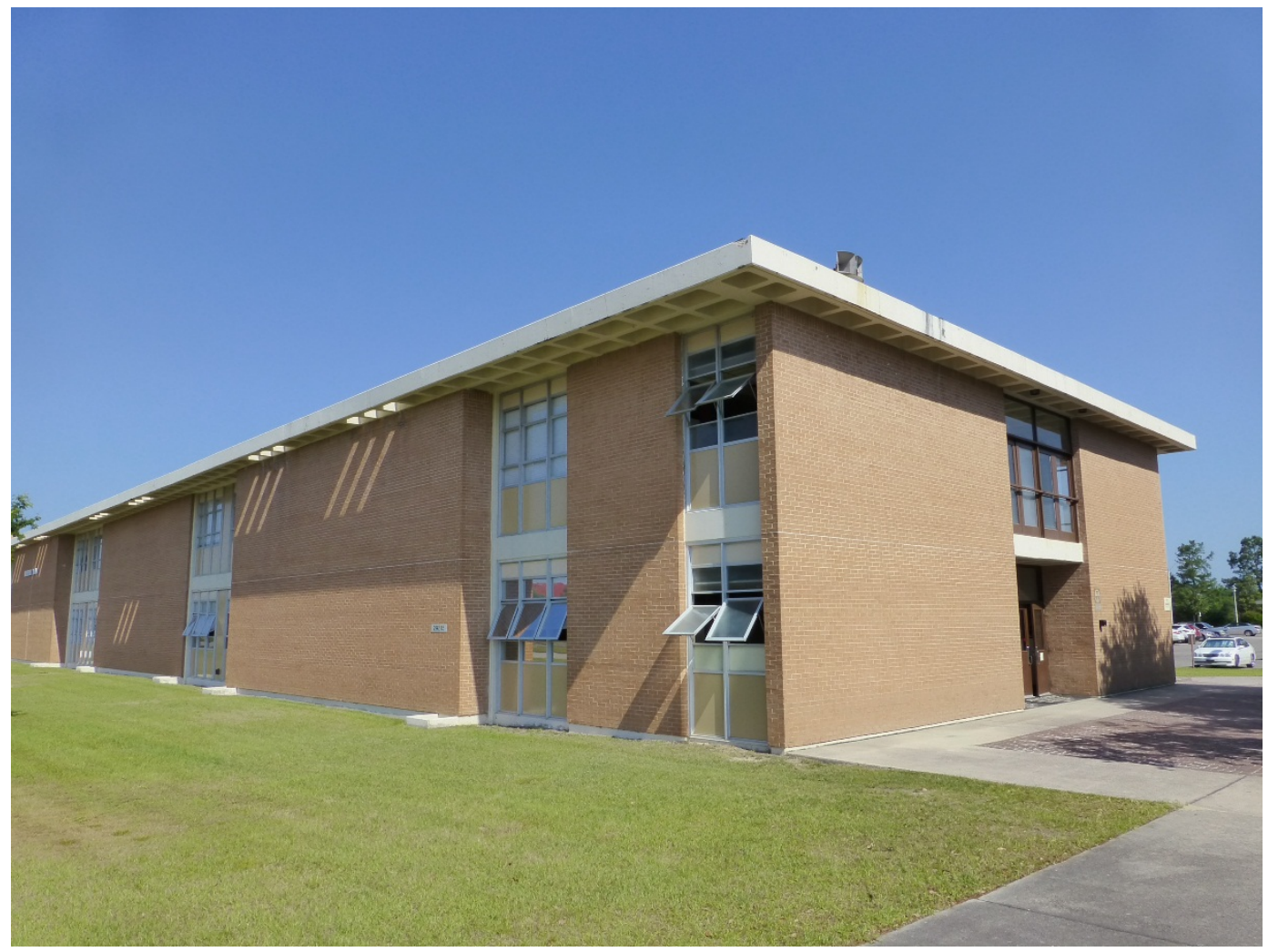

Figure 373. West elevation of Building 29815, Hazen Hall (ERDC-CERL, 2015).

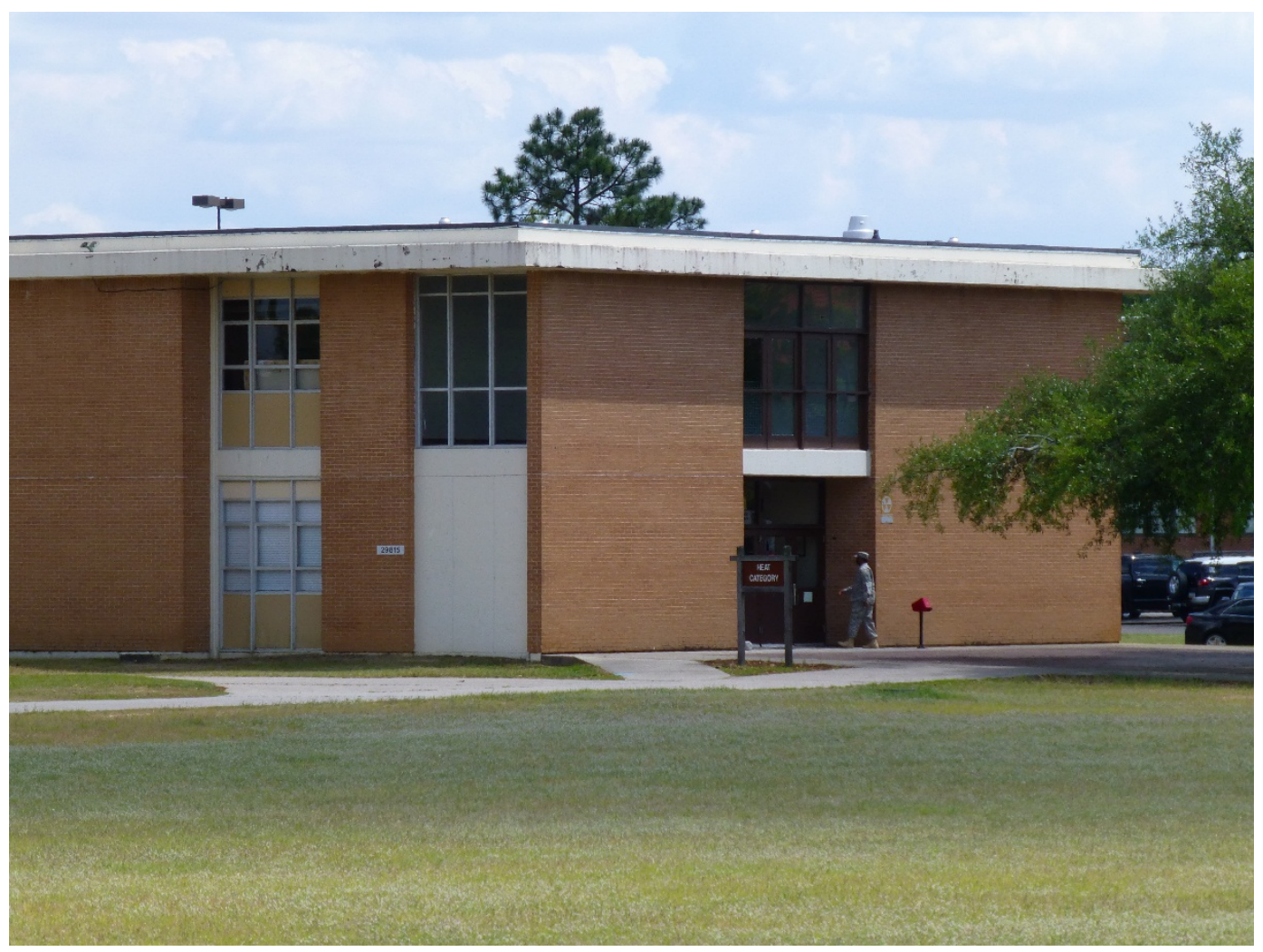


Figure 374. Construction of Building 29815, Hazen Hall, March 1966 (National Archives at College Park, MD).

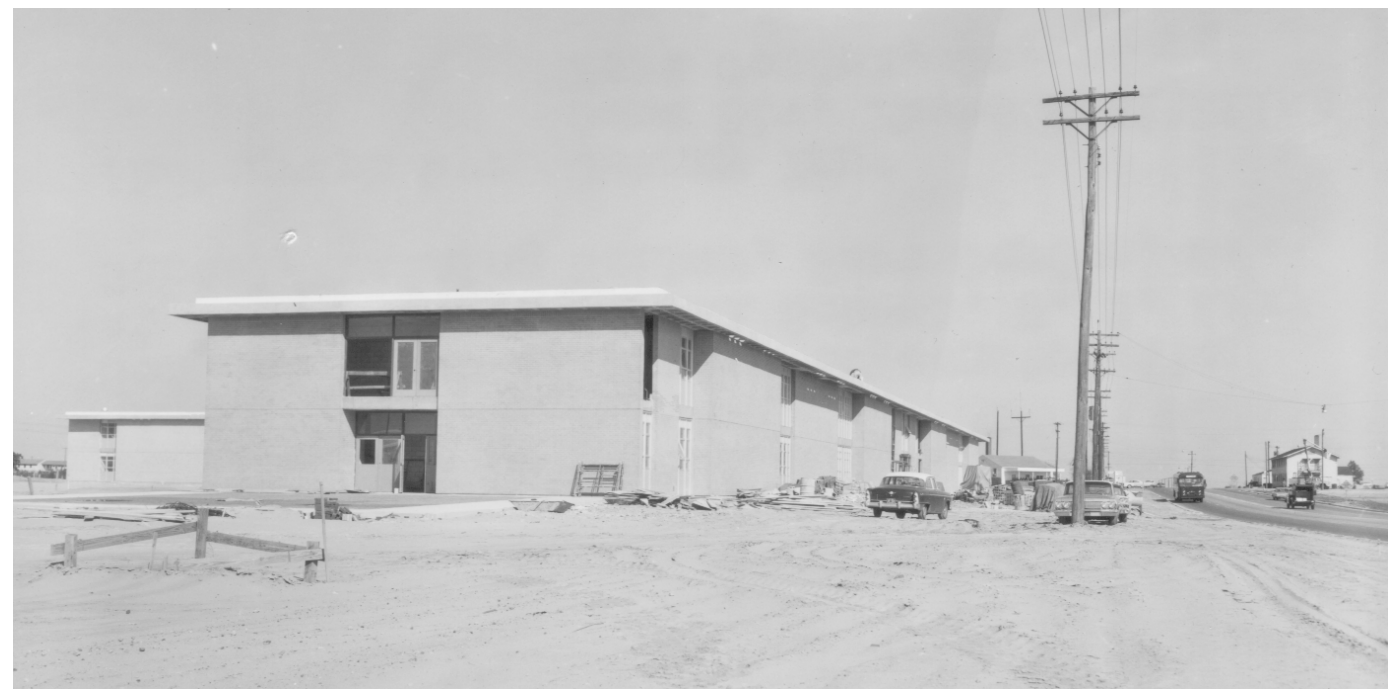

Figure 375. Section detail of concrete waffle ceiling and roof construction for Building 29815, Hazen Hall, 1964 (Fort Gordon DPW).

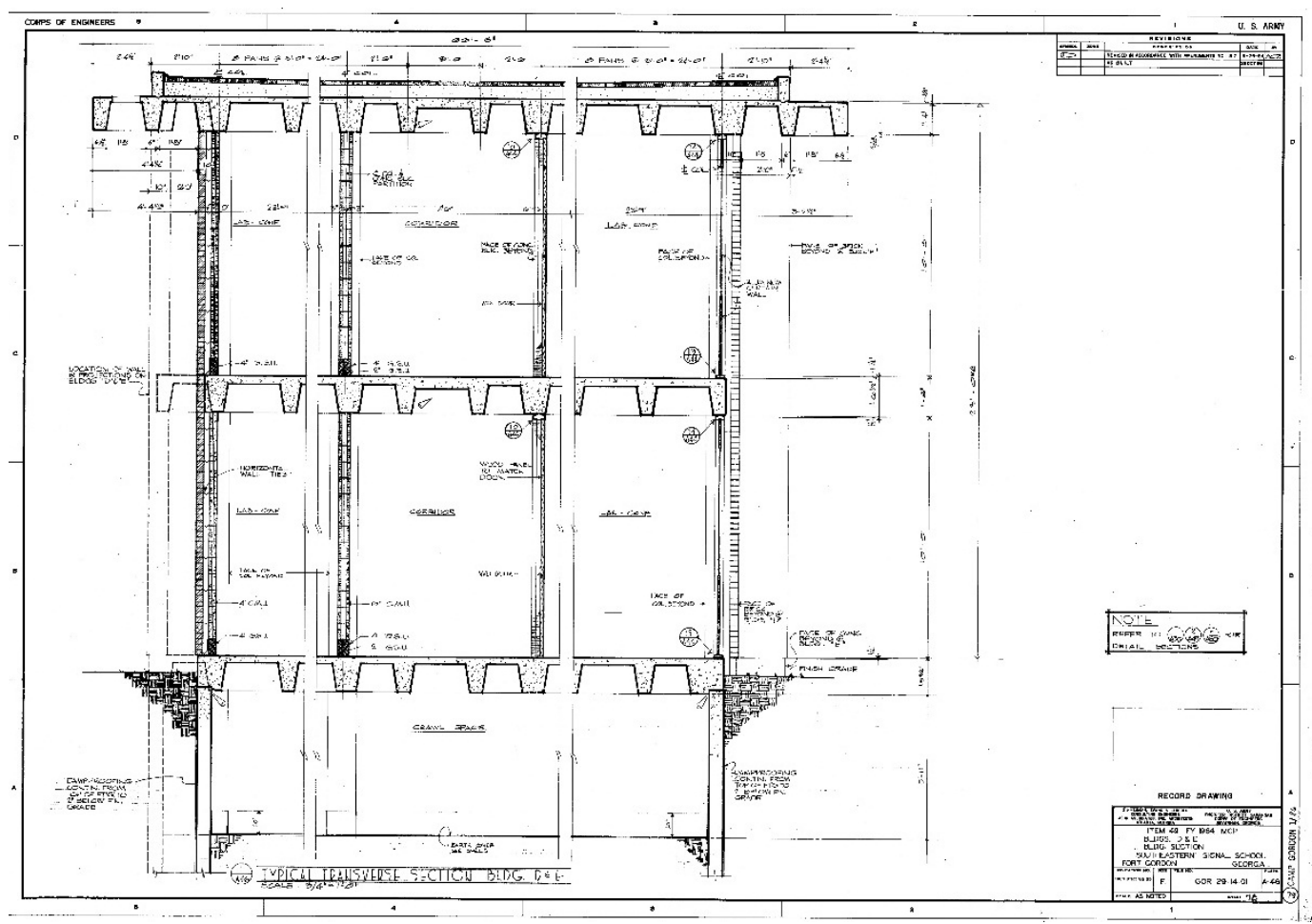


Figure 376. Elevations of Building 29815, Hazen Hall [right side], 1964 (Fort Gordon DPW).

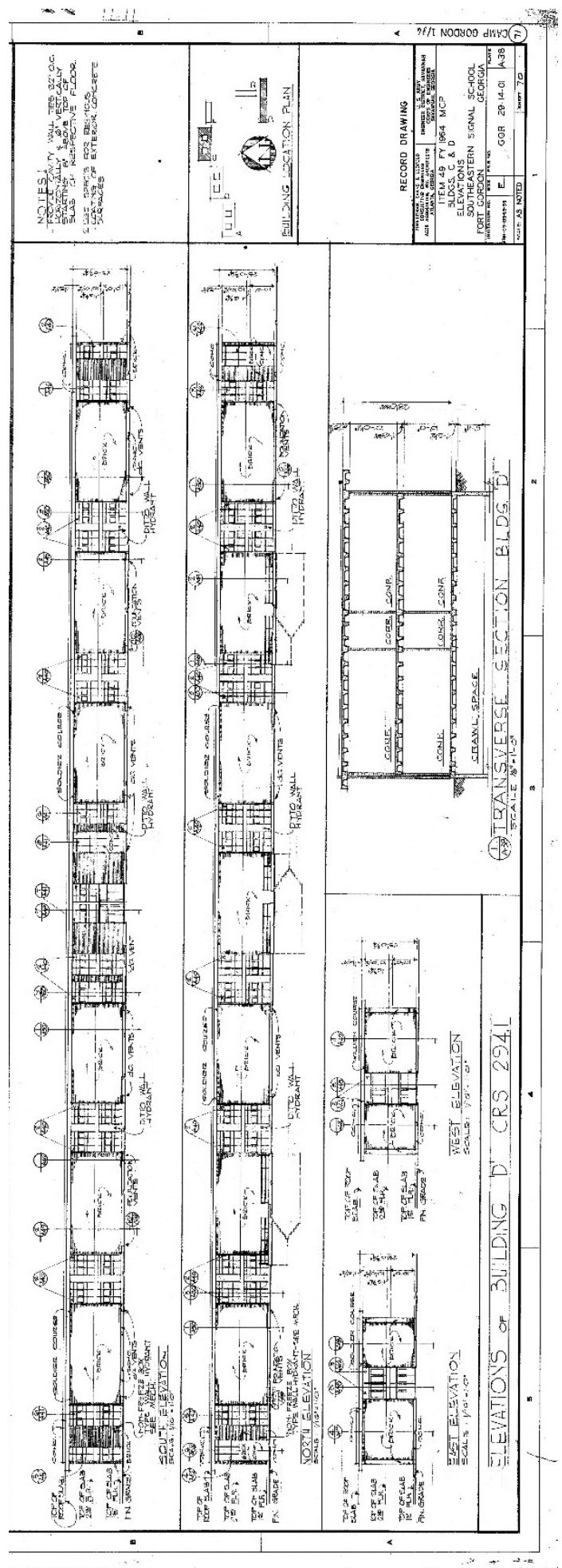


Figure 377. Stairwell details for Building 29815, Hazen Hall, 1964

(Fort Gordon DPW).

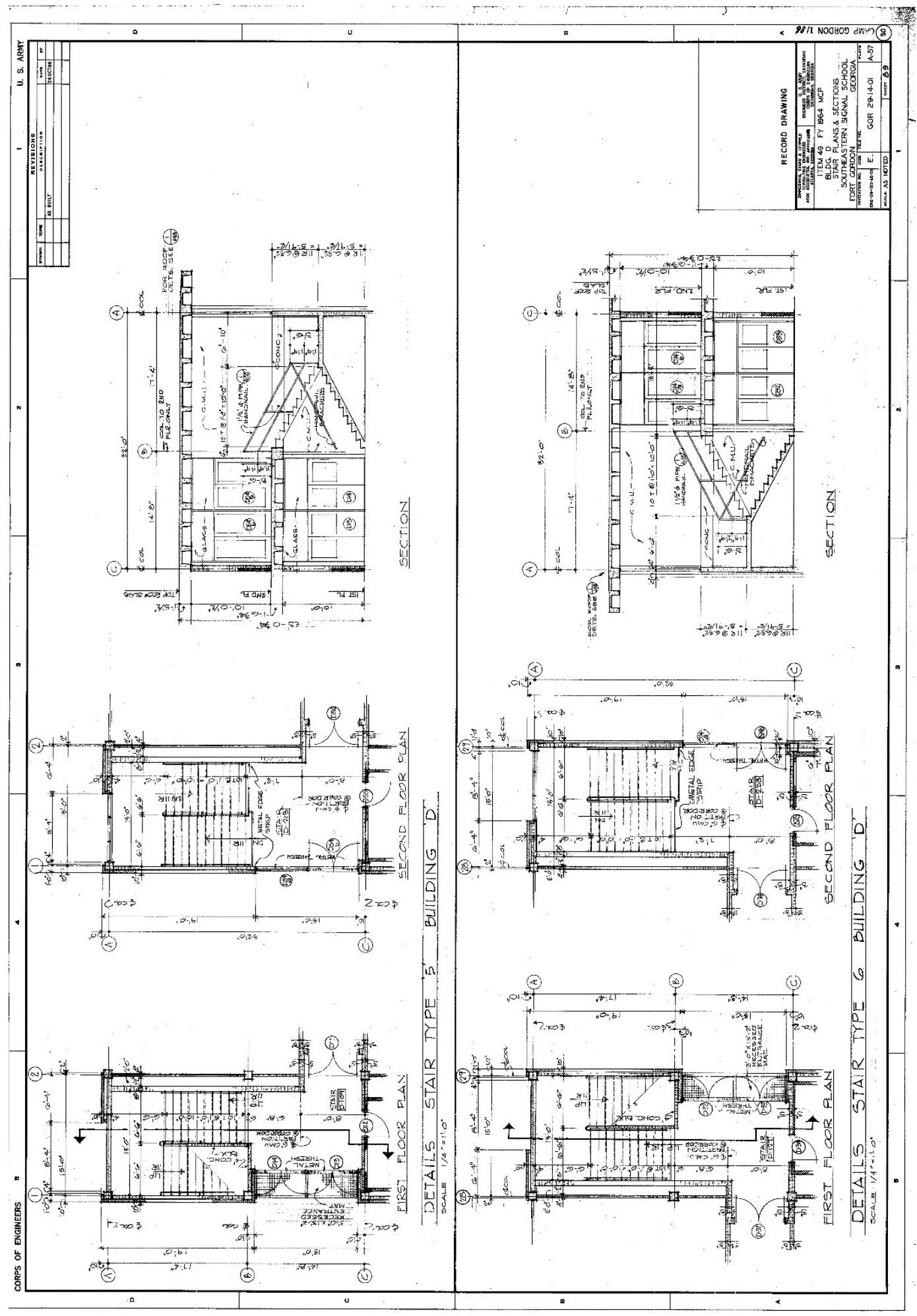


Figure 378. Typical classroom elevations and details for Building 29815, Hazen Hall, 1966 (Fort Gordon DPW).

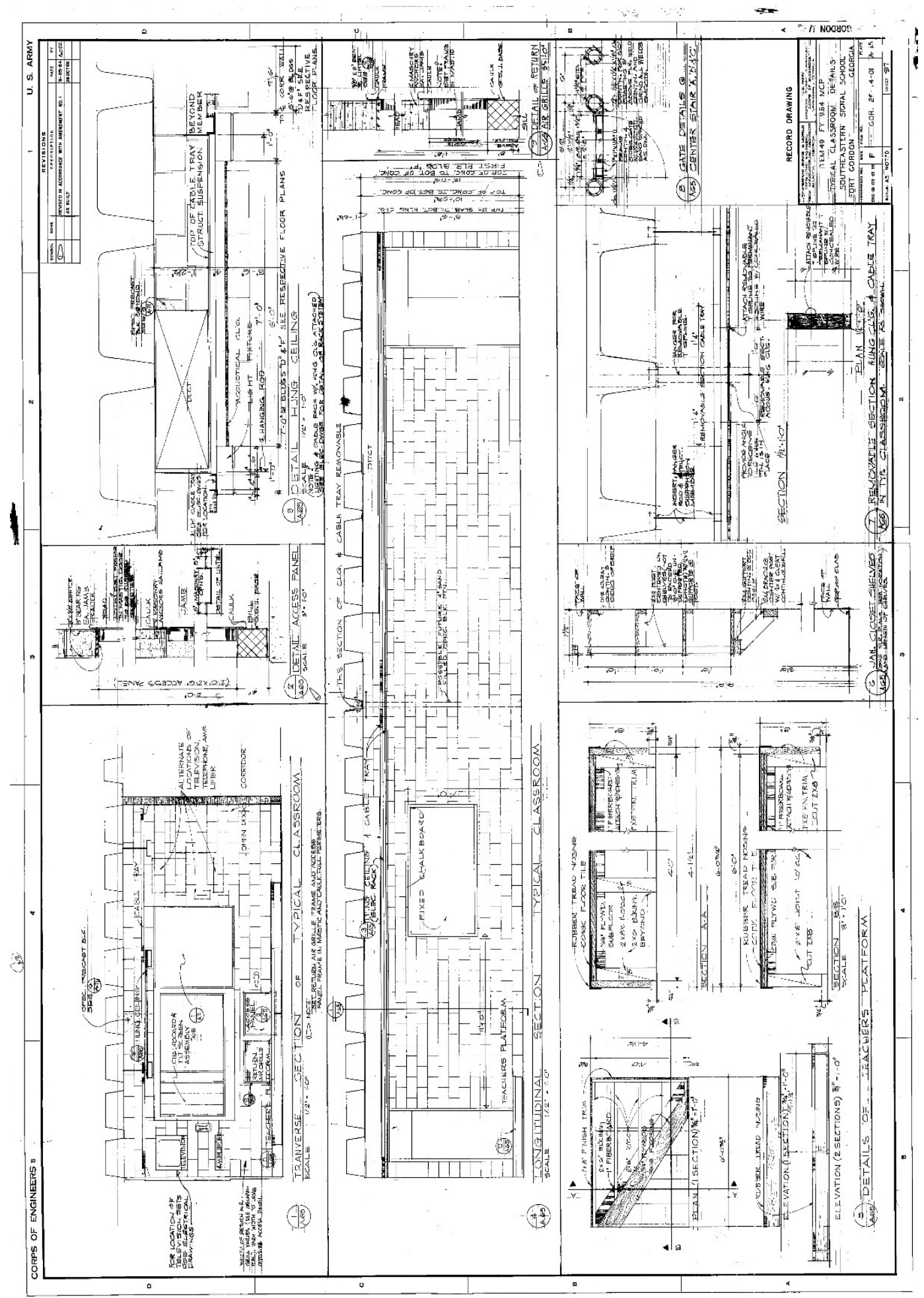


Figure 379. Latrine plans, elevations, and details for Building 29815, Hazen Hall, 1964 (Fort Gordon DPW).

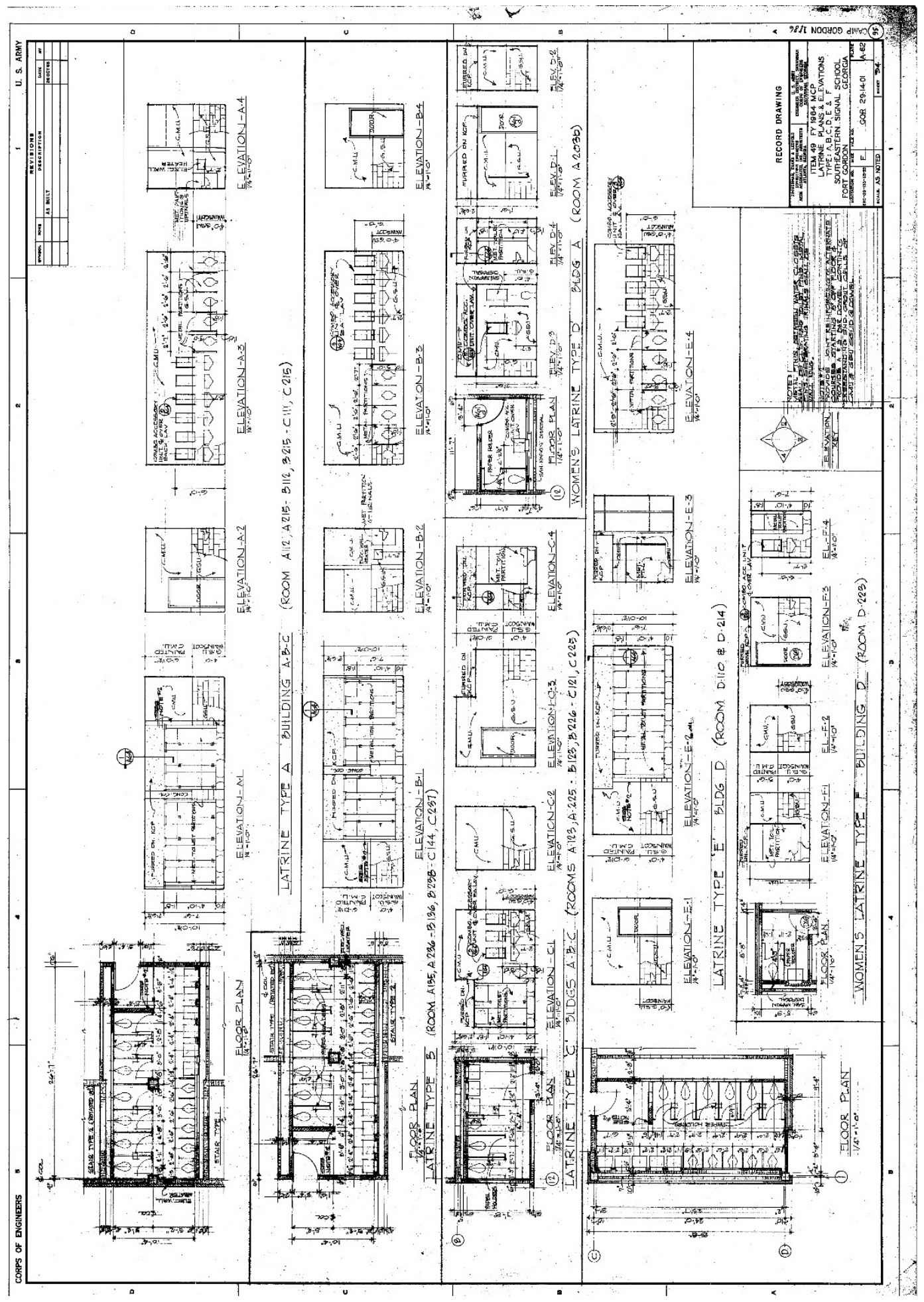


Figure 380. Light fixture types and schedule, 1966 (Fort Gordon DPW).

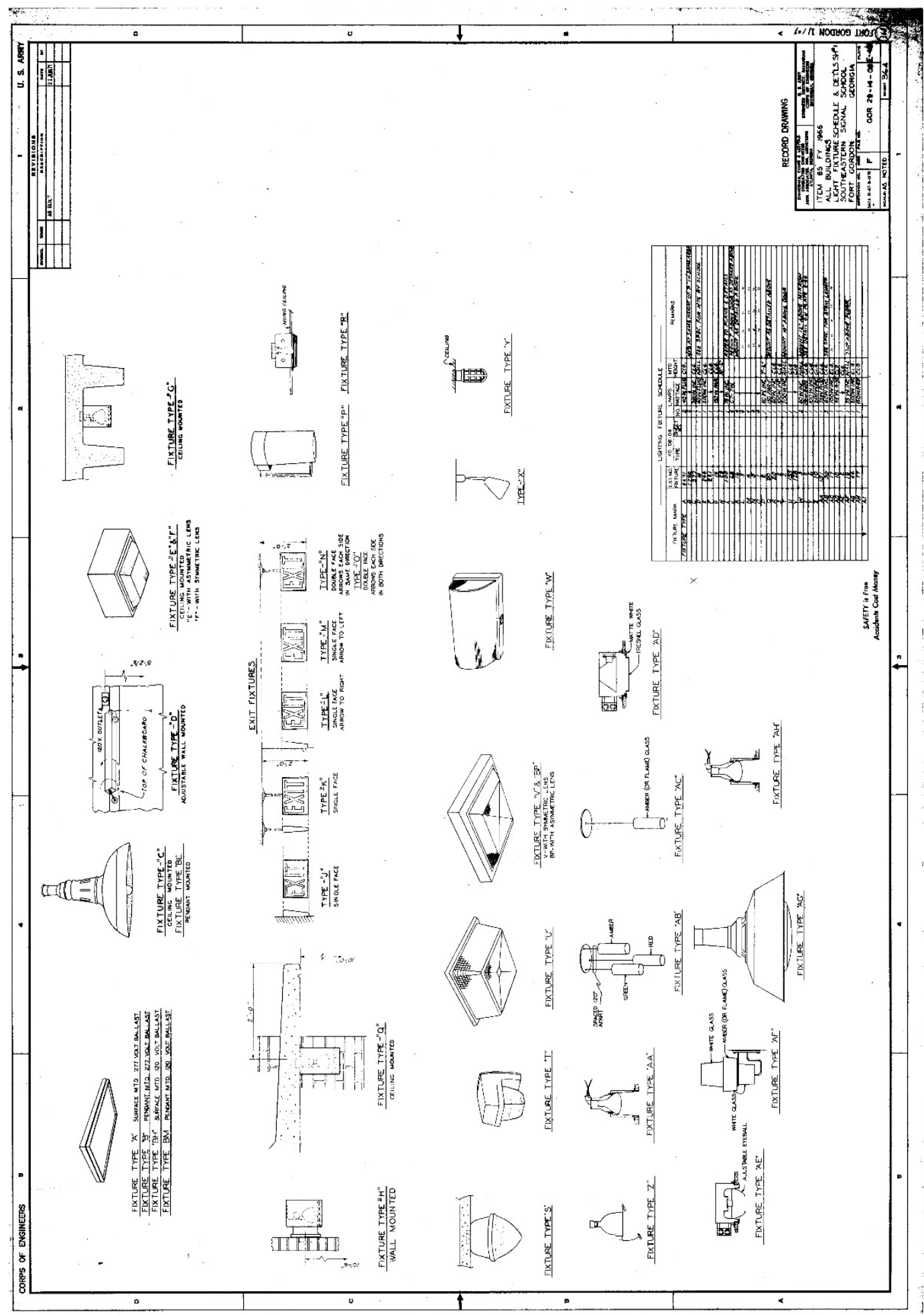


Figure 381. Landscape plan for Building 29815, Hazen Hall, 1966

(Fort Gordon DPW).

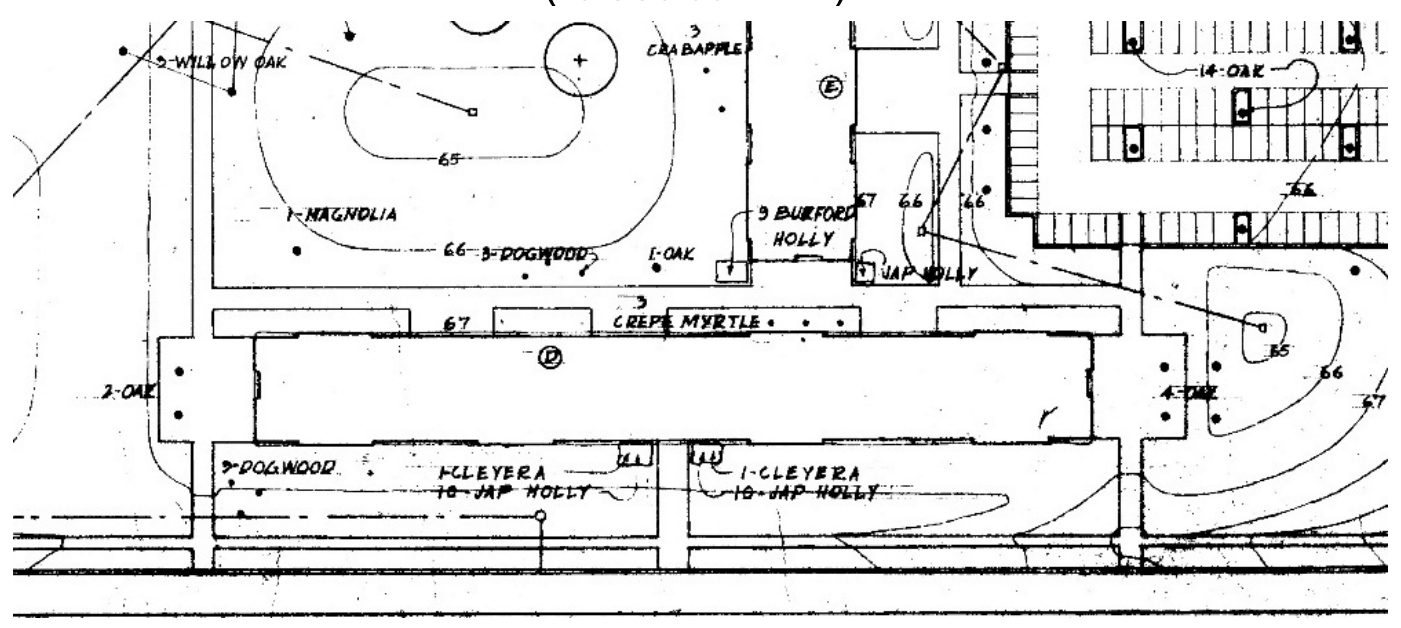

\subsubsection{Character-defining features}

Repair, renovation, and replacement of Building 29815, Hazen Hall, must be coordinated with the GA SHPO (Table 14).

\section{Exterior:}

- Overall massing

- Footprint

- Roof shape

- Brick veneer

- Relationship to other Signal School Campus buildings

- Overhanging eaves with perforated waffle construction casting "light pattern" on exterior brick walls

- Exposed concrete structure framing window and door openings

- Window pattern

- Recessed groups (two, three, or six) of bright-aluminum sash windows with three-pane awning-style windows sandwiched between insulated panels

- Metal doors with large pane

- Metal doors with plate glass on east and west elevations

- Ceiling-mounted exterior light fixtures set within the waffle overhang on the east and west elevations

- Lettering

- Metal handrails

- Landscaping 


\section{Interior:}

- Overall plan

- Main stairwells

- Main hallways

- Lighting

- Doors

- Display cases

- Signage

- Vending machine alcove

- Telephone alcoves

- Tiled water fountain alcoves

Table 14. Images of character-defining features of Building 29815, Hazen Hall (ERDC-CERL, 2015).

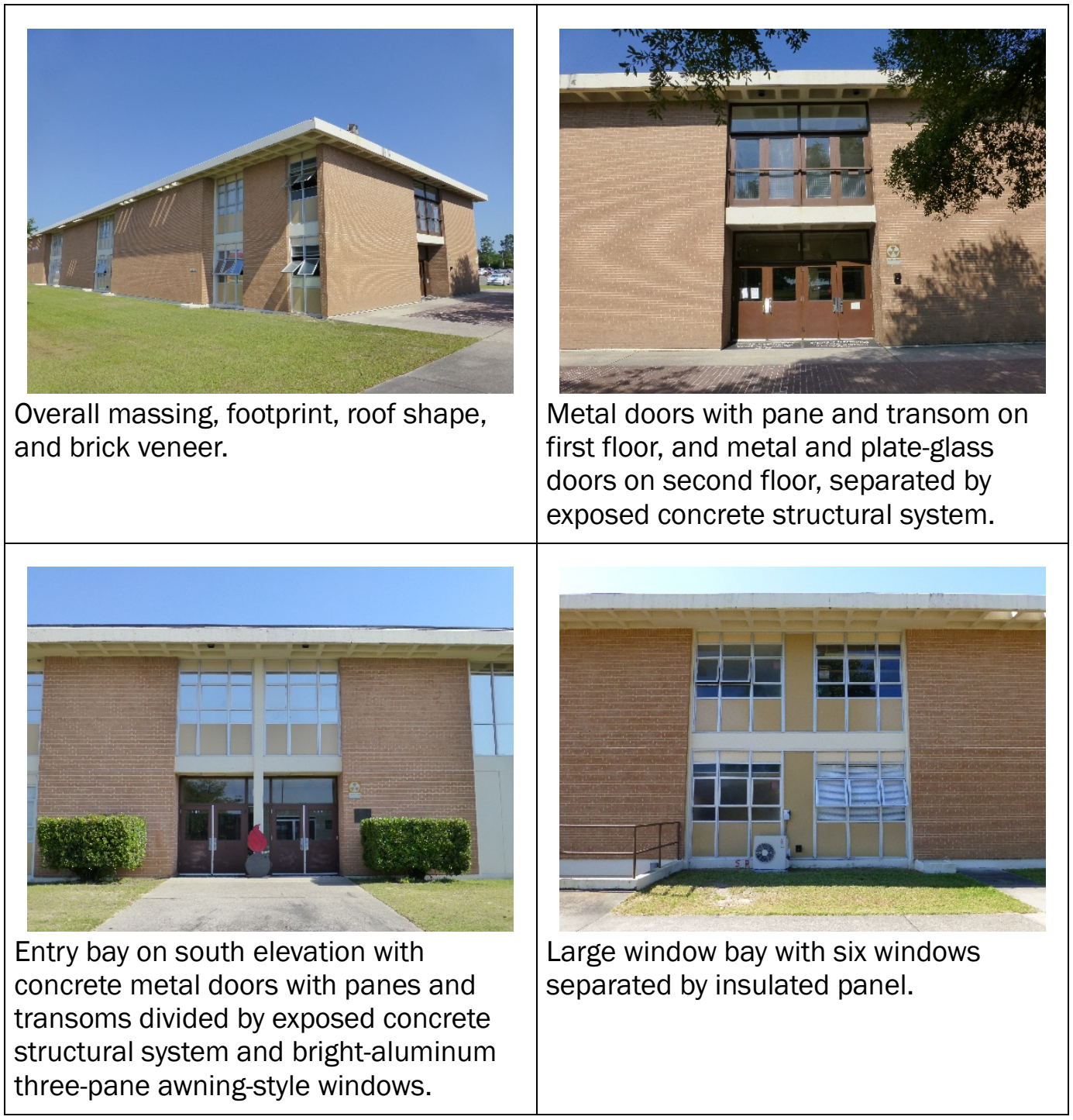




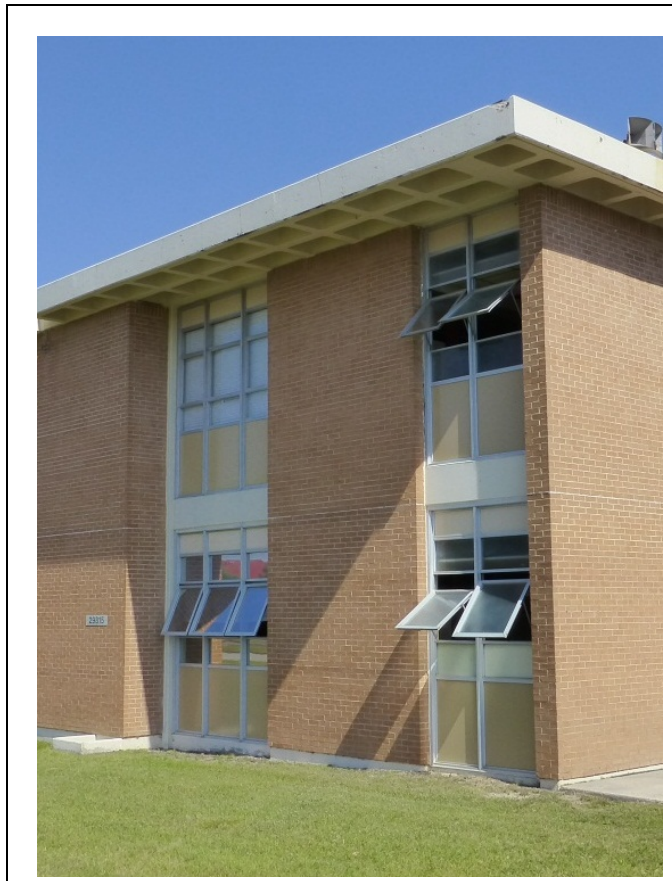

Window pattern; window bays on left and right sides of the south elevation.

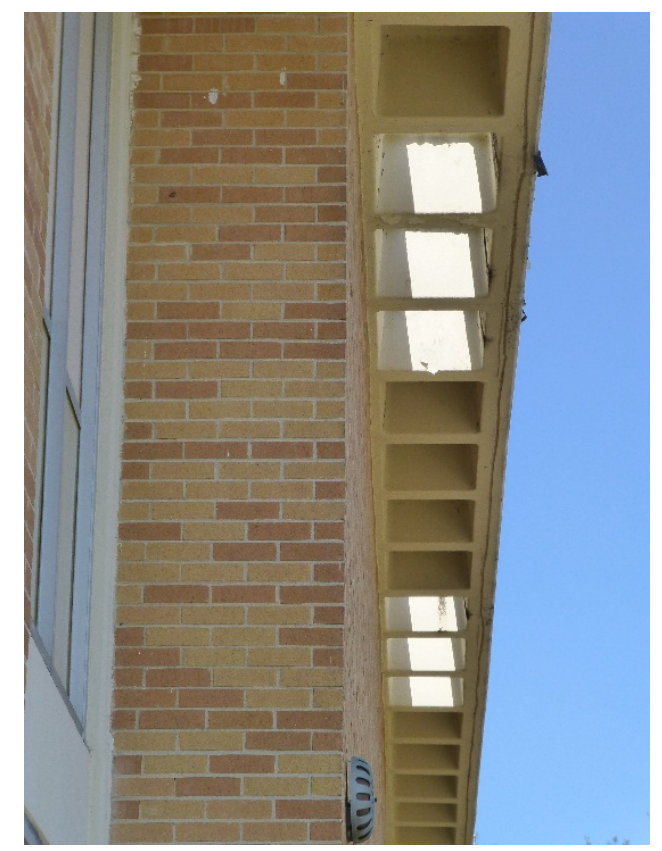

Perforated concrete waffle overhang.

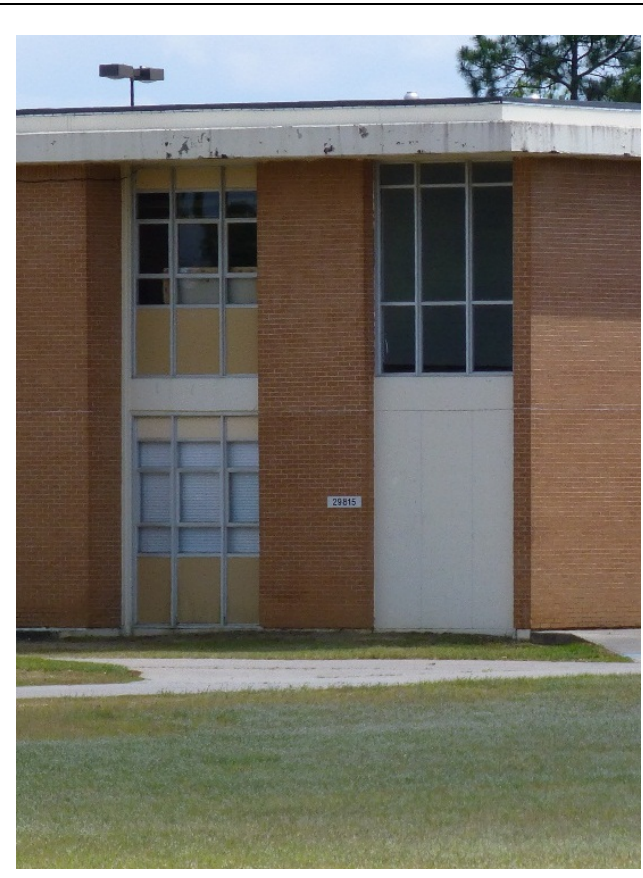

Window pattern: window bays on the left and right sides of the north elevation.

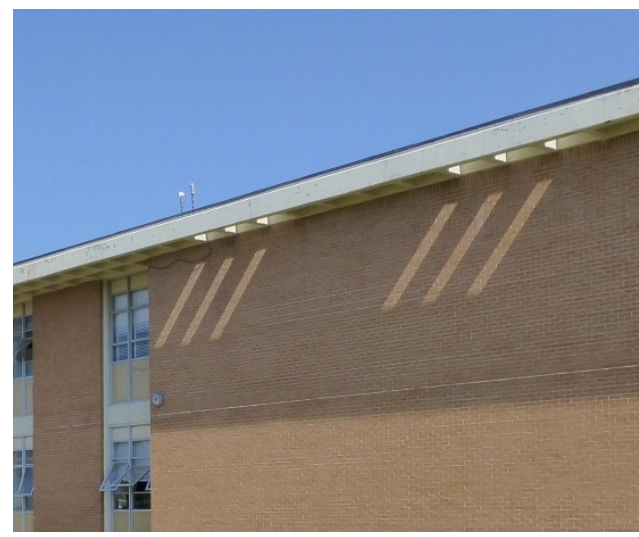

"Light pattern" created by the perforated concrete waffle overhang. 


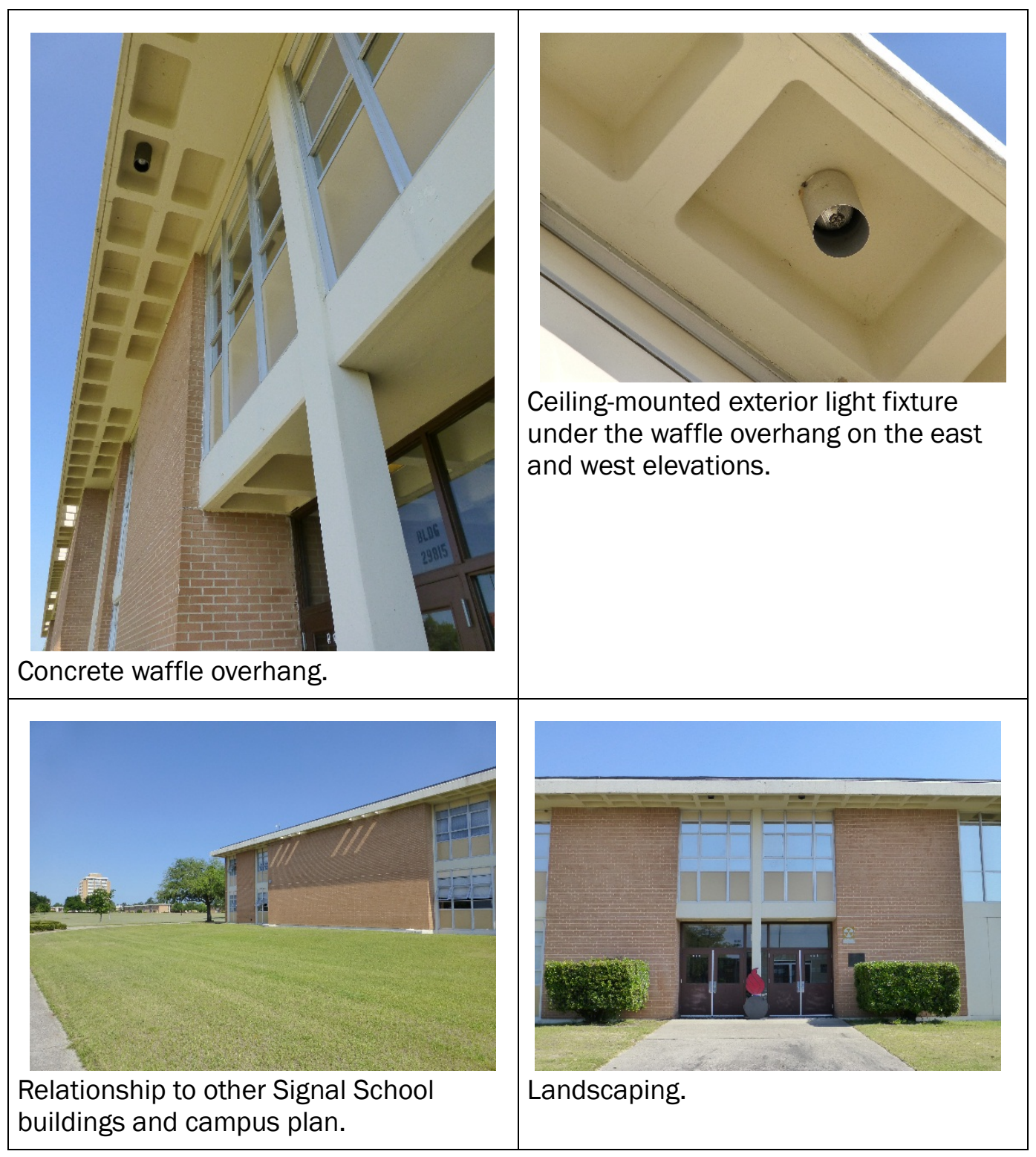

3.3.12.2 Character-defining features that have been removed

- None.

\subsubsection{Nonhistoric features}

- None.

\subsubsection{Comparison images}

Comparison images utilizing either the original drawings or historic photographs, when juxtaposed against present-day images, are a useful tool in 
developing the historic "feel" of a property and how much of that historic feeling is still present today (Figure 382-Figure 385).

Figure 382. Southeast oblique - comparison of the original design and materials for Building 29815 construction in 1966 [left] to the current condition of the southeast oblique of Building 29815, Hazen Hall [right] (ERDC-CERL, 2015).
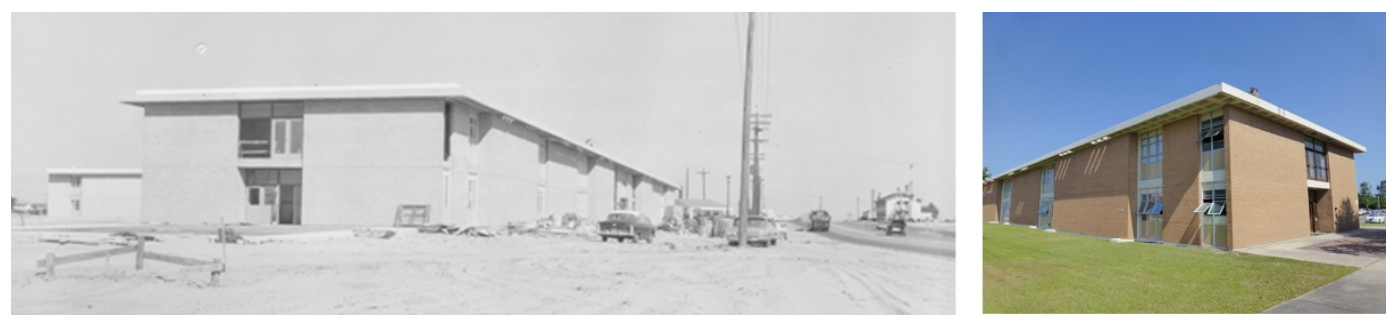

Figure 383. Large six-window bay - comparison of the original design and materials from 1964 [left] to the current condition of bright-aluminum three-pane awning-style windows and insulated panels [right] (ERDC-CERL, 2015).
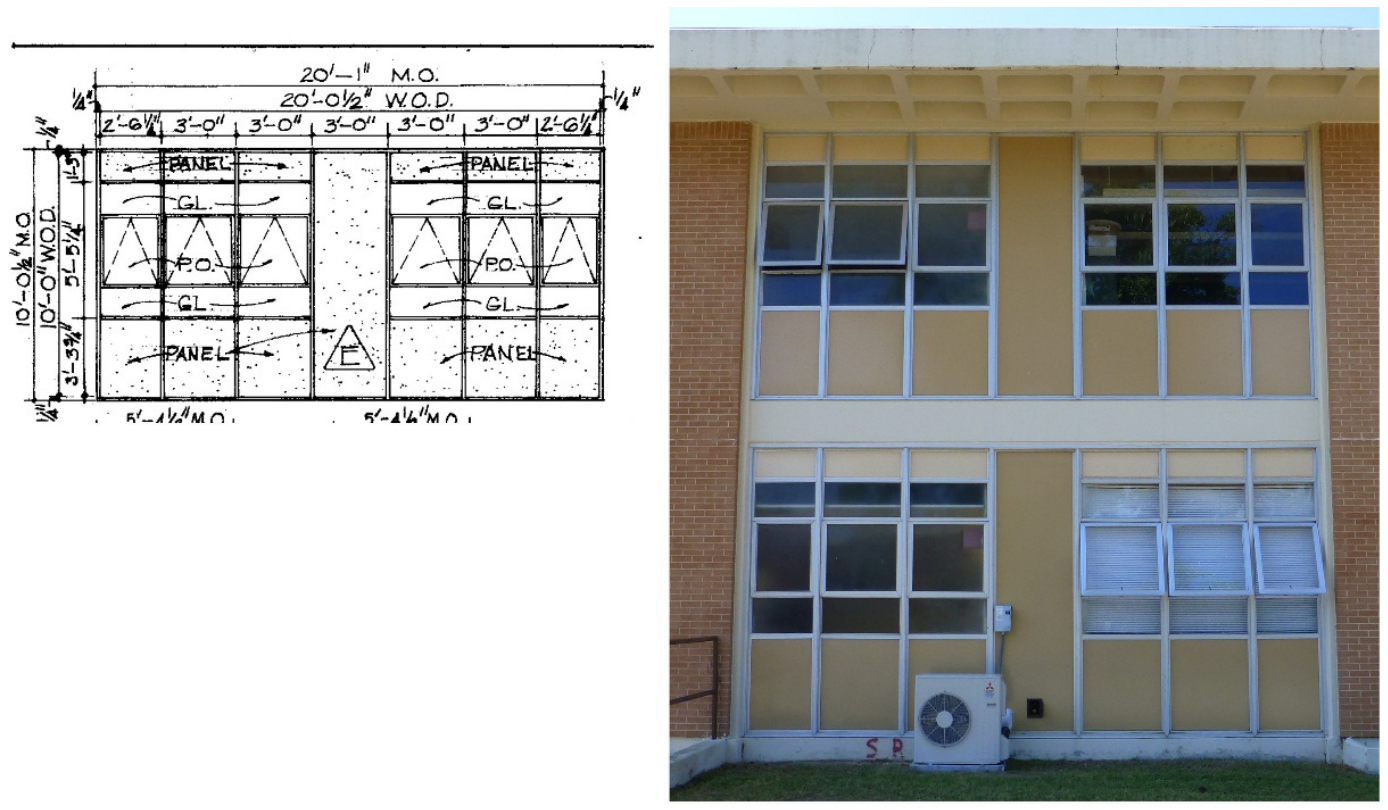
Figure 384. East and west elevations - comparison of the original design and materials from 1964 [left] to the current condition of the metal doors with panes and transoms above and the three-pane awning-style windows sandwiched between insulated panels on the second floor [right] (ERDC-CERL, 2015).

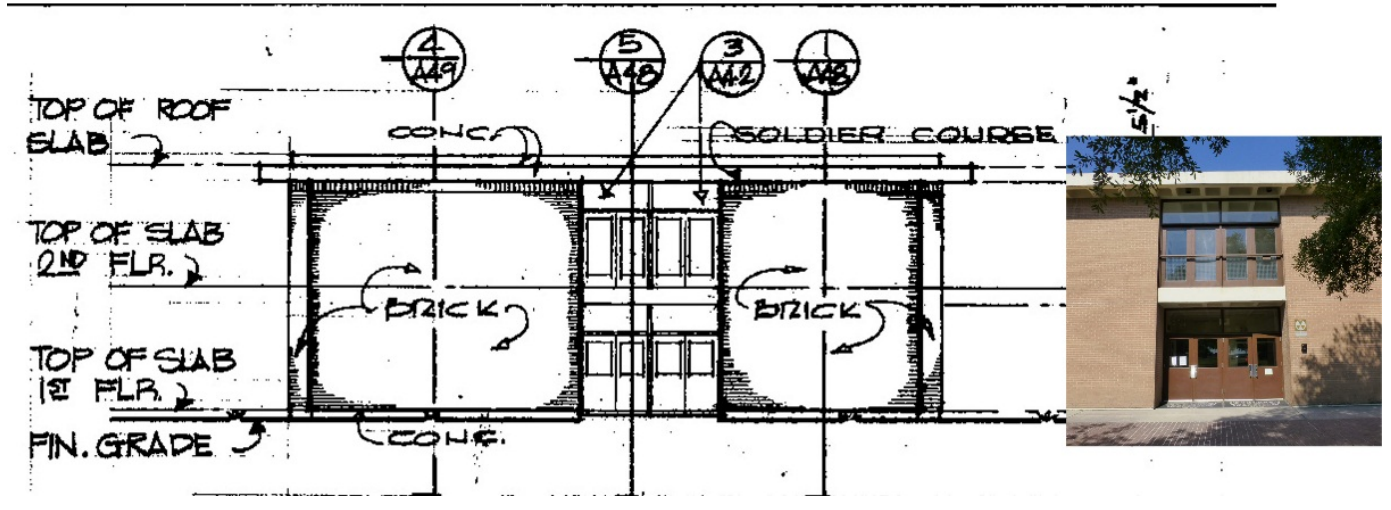

Figure 385. Ceiling-mounted light fixture under the waffle overhang - comparison of the original design and material from 1966 [left] to the current condition of the ceiling-mounted light fixture [right] (ERDC-CERL, 2015).
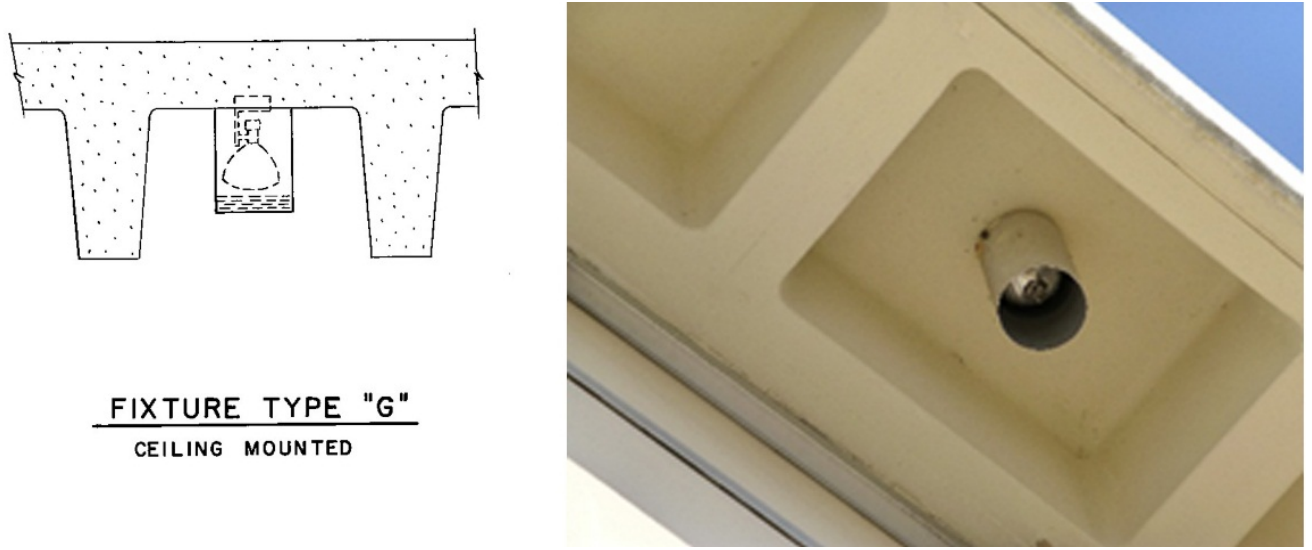

\subsubsection{Building 29816, Fisher Hall (1966)}

Building 26818, Fisher Hall, is a contributing feature to the Signal School Campus Historic District. The interior is contributing. The building was constructed in 1966 as part of the Phase I construction of the campus and was designed by Aeck Associates from Atlanta, Georgia, and Zimmerman, Evans, and Leopold Engineers from Augusta, Georgia. The building is a long rectilinear classroom building on the eastern edge of the school. Building 29816 is the only building in the complex in a north/south orien- 
tation, and it is directly to the west of the eastern parking lot. It is two stories high with a partial basement. The structure is cast-in-place concrete columns with a waffle floor/ceiling system. The second-floor waffle system is set within the structure, but the roof has the waffles extending out to form an overhang. Some of the waffles have been perforated, which creates a "light pattern" on the second-floor brick walls. The window systems extend the full height of the building and are inset into the brick veneer. The window systems are composed of bright-aluminum window frames that enclose insulated panels and awning windows. Tan-colored panels are above and below the window. An exposed concrete structural system separates the first and second-floor windows. The west elevation consists of two large groups of windows. Each window group has six windows separated by an insulted panel per floor. The right bay has been modified with the removal of some of the first floor windows and the addition of entry doors with a metal canopy. The left and right side of the elevation each have a smaller bay of windows that consists of three windows per floor. The lettering "FISHER HALL" is placed on the west elevation's wall. The east elevation has two large window bays similar to the ones on the west elevation. The left side of the elevation has concrete panels on the first floor and four bright-aluminum fixed-pane windows on the second floor. The right side of the elevation has two bays separated by a brick column detail. One bay has three windows/panels per floor, and the other bay has concrete panels on the first floor and three bright-aluminum three-pane fixed windows on the second floor. There is an outside access point to the basement on the east side of the building. The basement entry is defined by poured concrete walls, concrete steps, and metal handrails. The lettering "FISHER HALL" is placed on the east elevation's wall. The primary entrances to the building are on the north and south elevations. The entries are recessed under the second floor and consist of two sets of metal doors with panes and transoms above. The second floor of these entry bays consists of two sets of metal and plate-glass doors with a transom above each set of doors. These doors are welded closed, with a steel bar across the middle. It appears that bridges were meant to connect the various buildings together at the second-floor level (Figure 386-Figure 398). 
Figure 386. Signal School Campus map, with Building 29816, Fisher Hall highlighted in red, 2015 (Fort Gordon DPW, modified by ERDC-CERL).

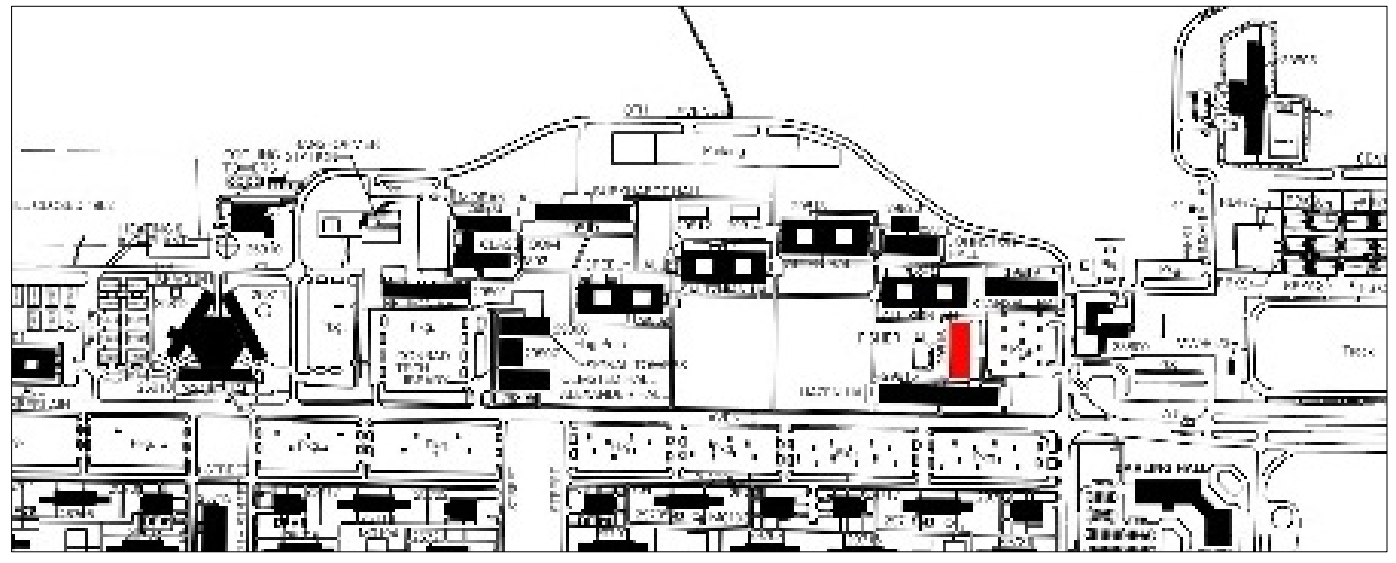

Figure 387. Southeast oblique of Building 29816, Fisher Hall (ERDC-CERL, 2015).

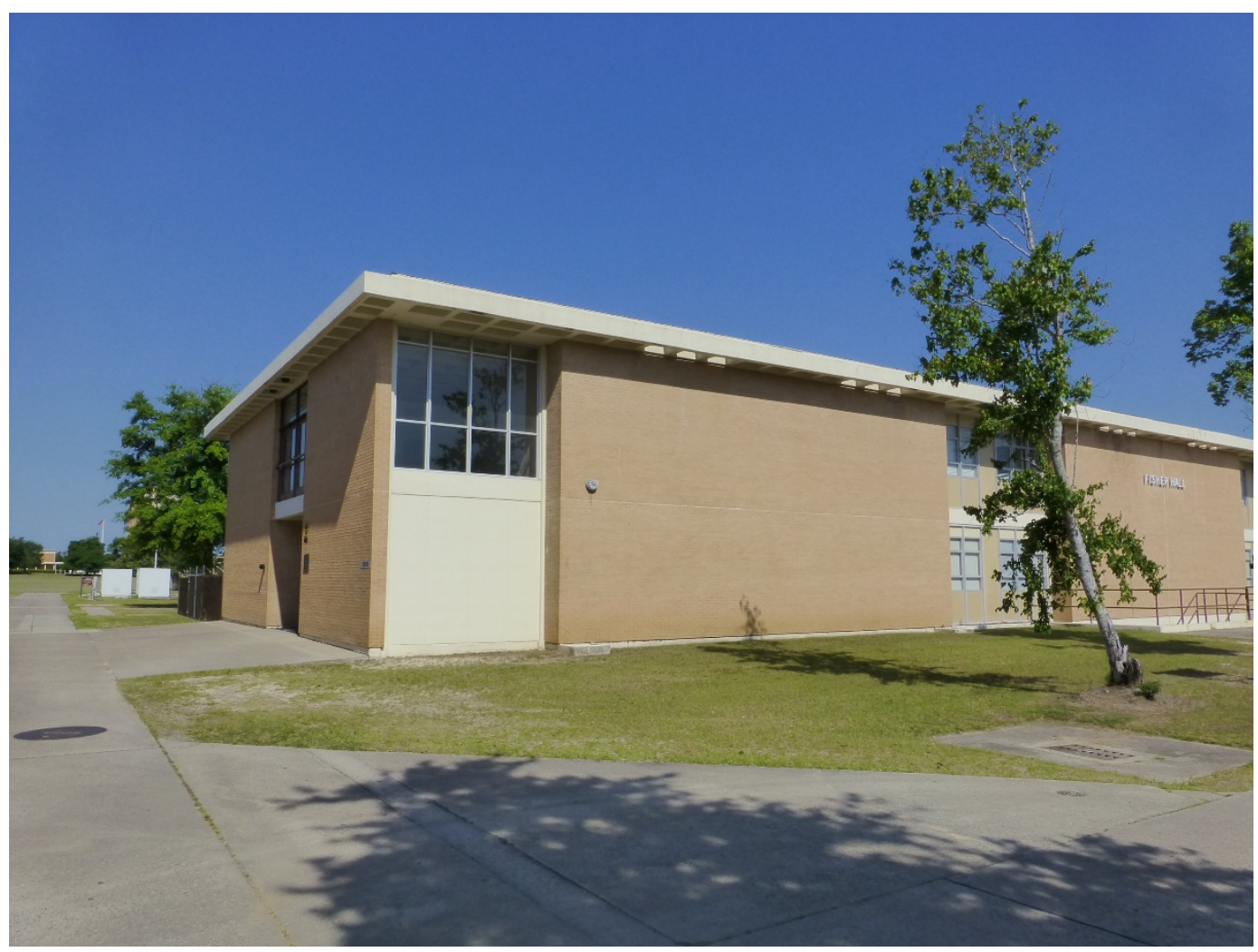


Figure 388. South elevation of Building 29816, Fisher Hall (ERDC-CERL, 2015).

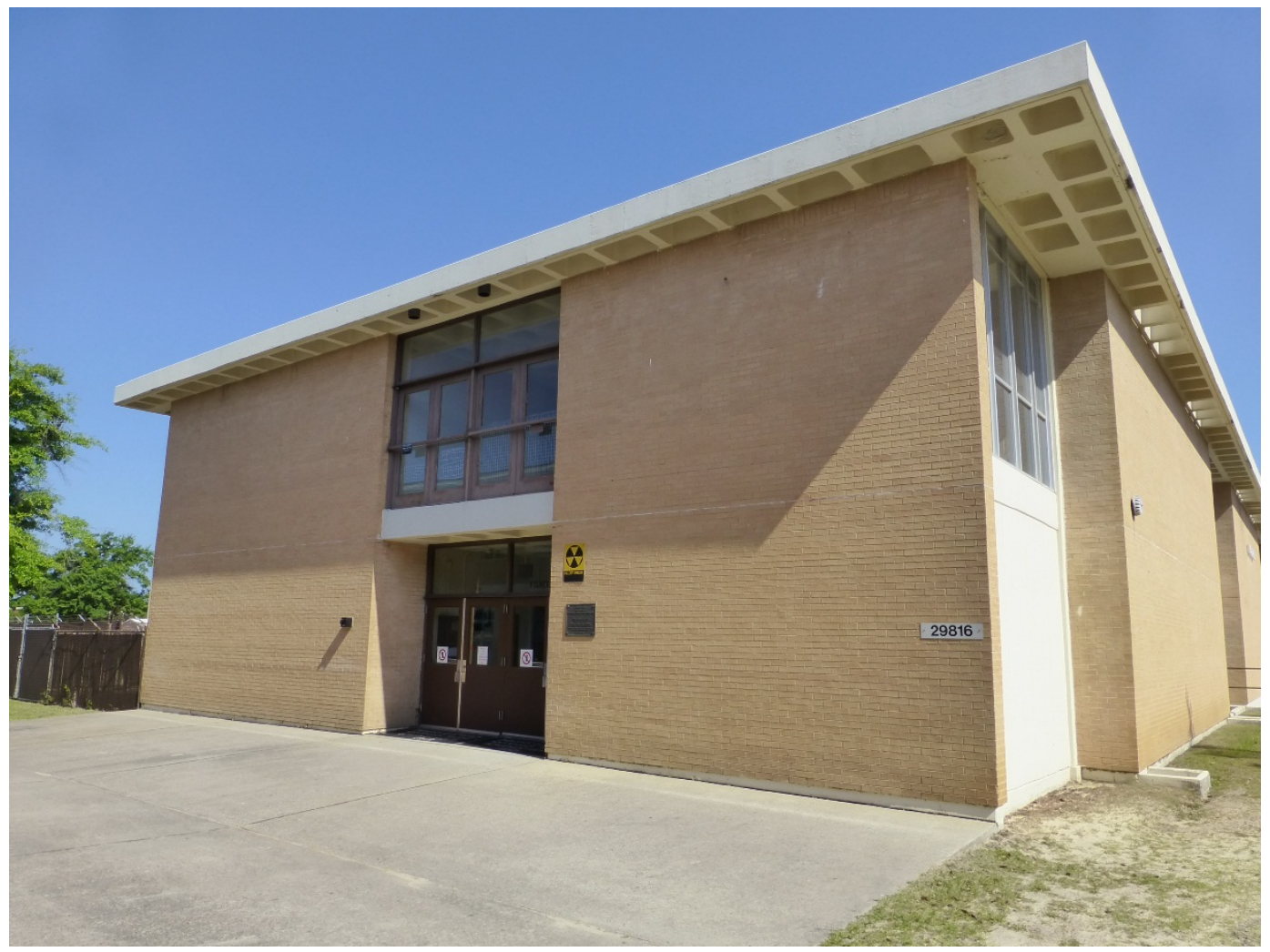

Figure 389. East elevation of Building 29816, Fisher Hall (ERDC-CERL, 2015).

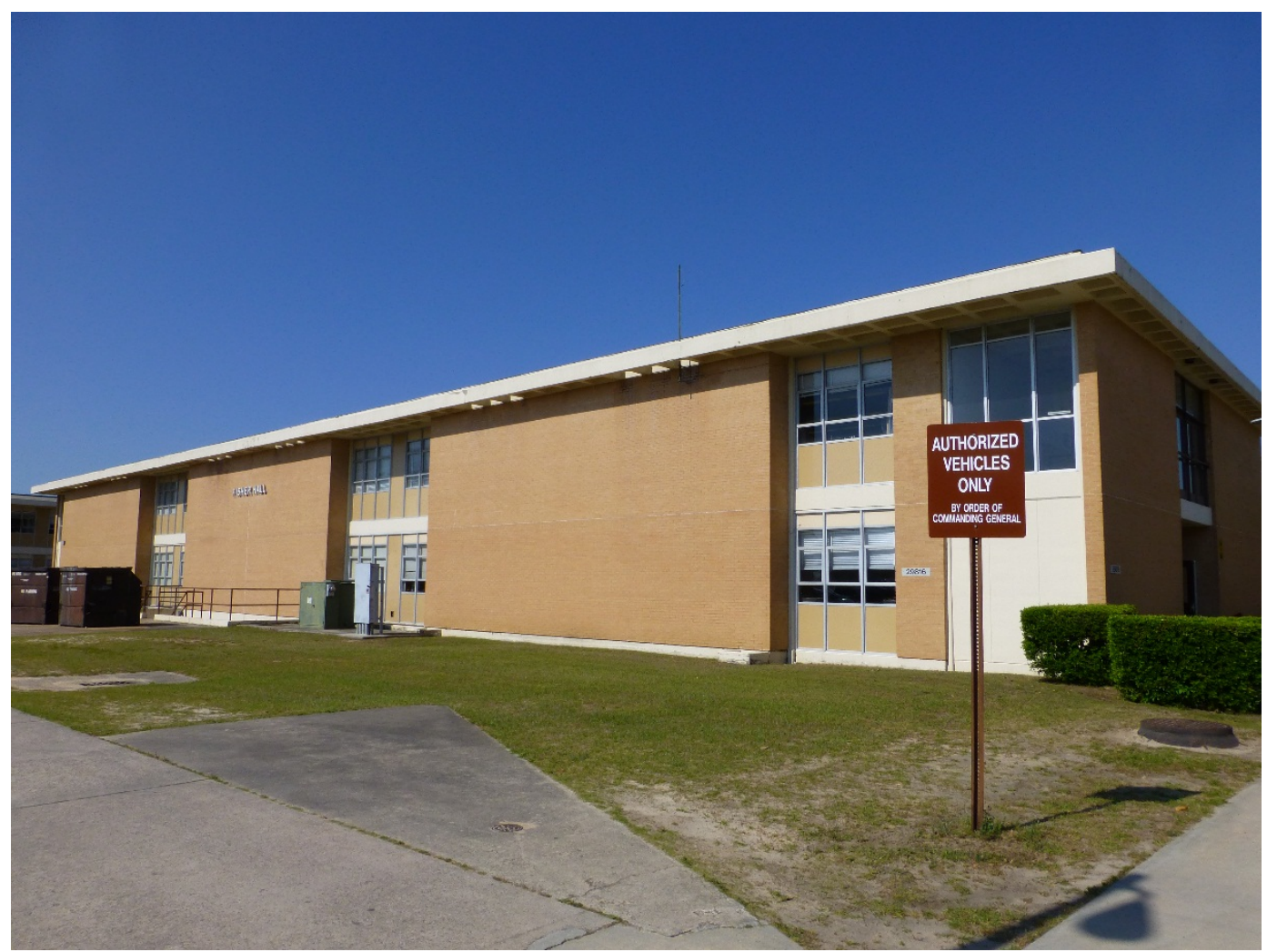


Figure 390. North elevation of Building 29816, Fisher Hall (ERDC-CERL, 2015).

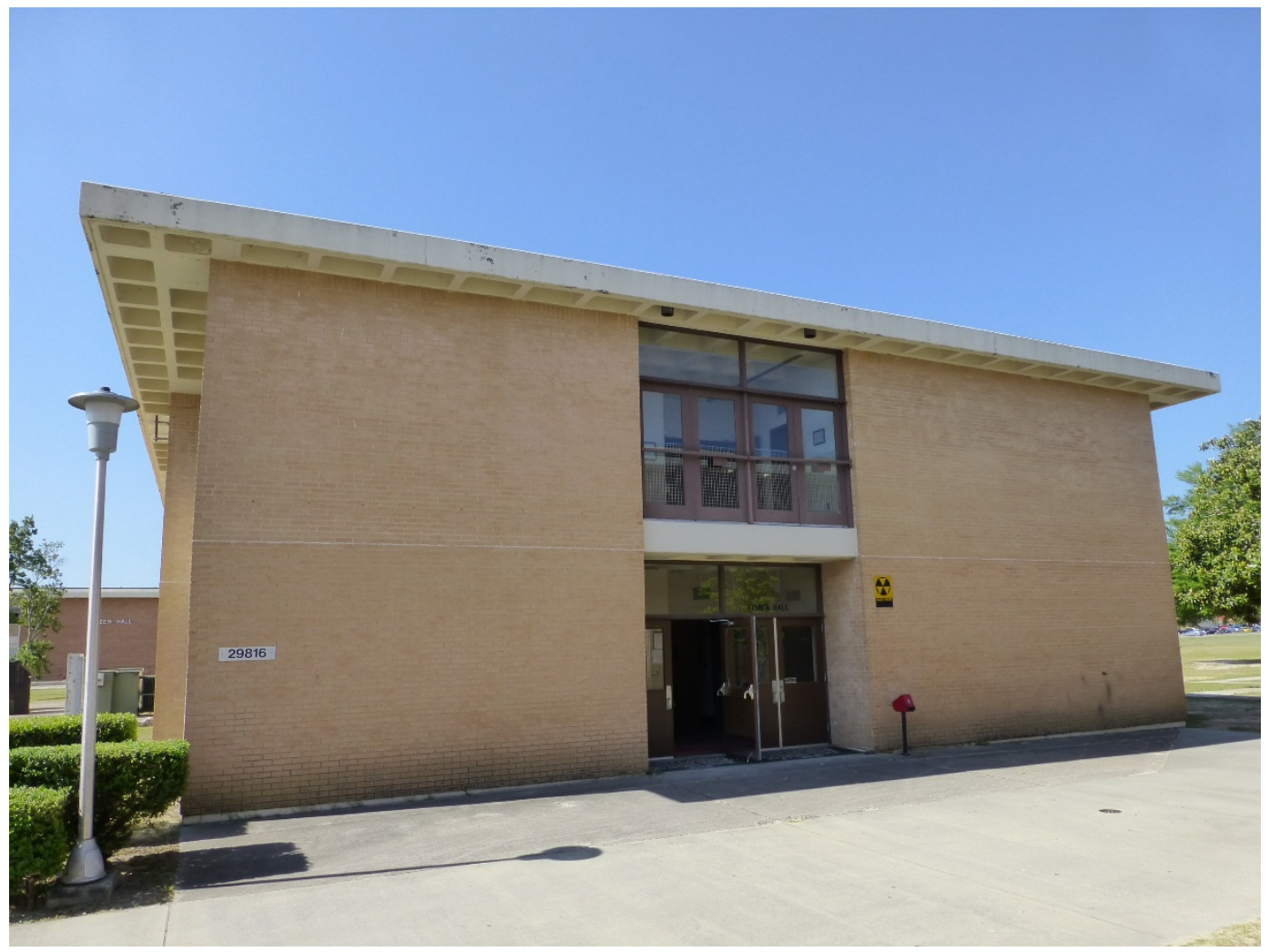

Figure 391. West elevation of Building 29816, Fisher Hall (ERDC-CERL, 2015).

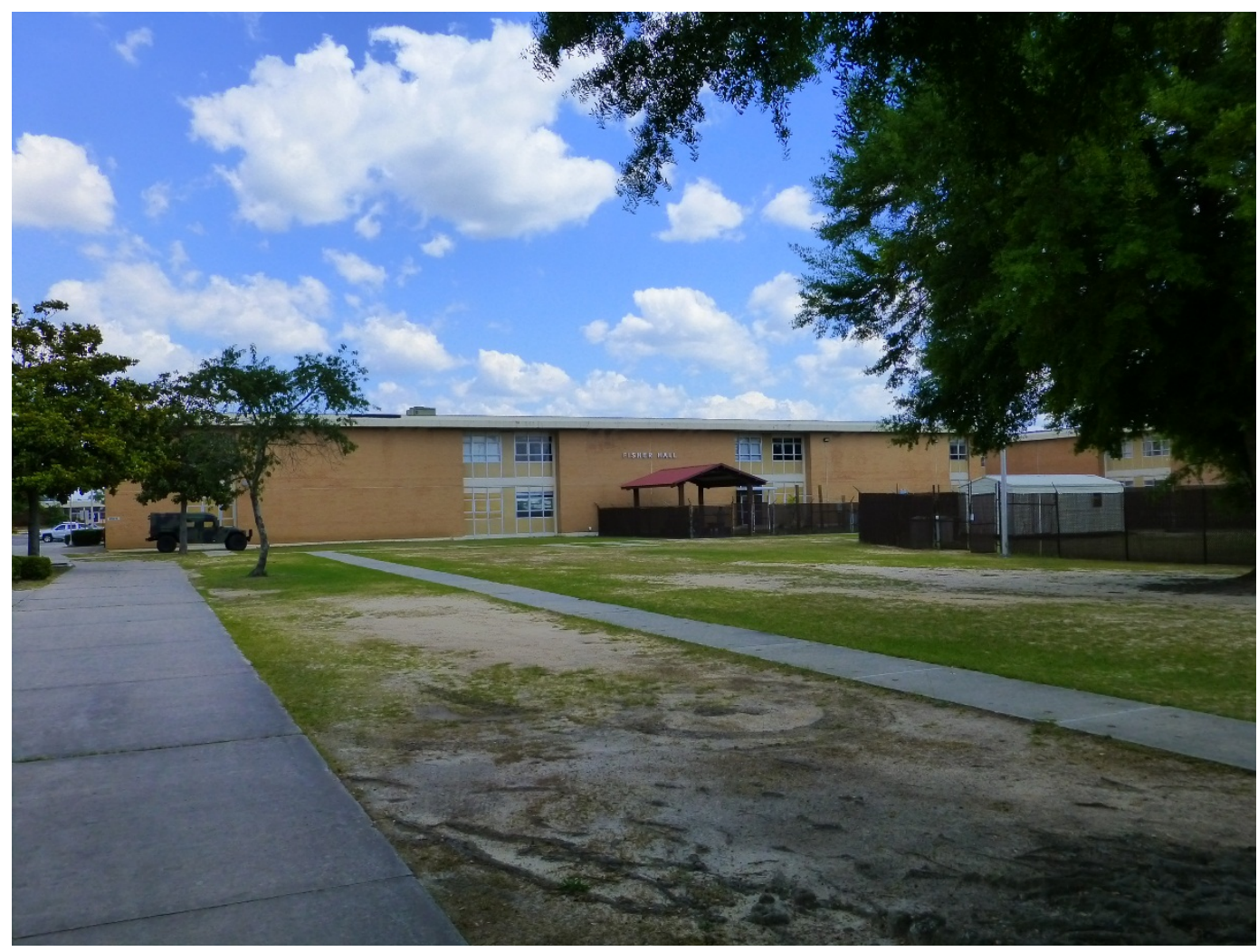


Figure 392. Elevations of Building 29816, Fisher Hall, 1964 (Fort Gordon DPW).

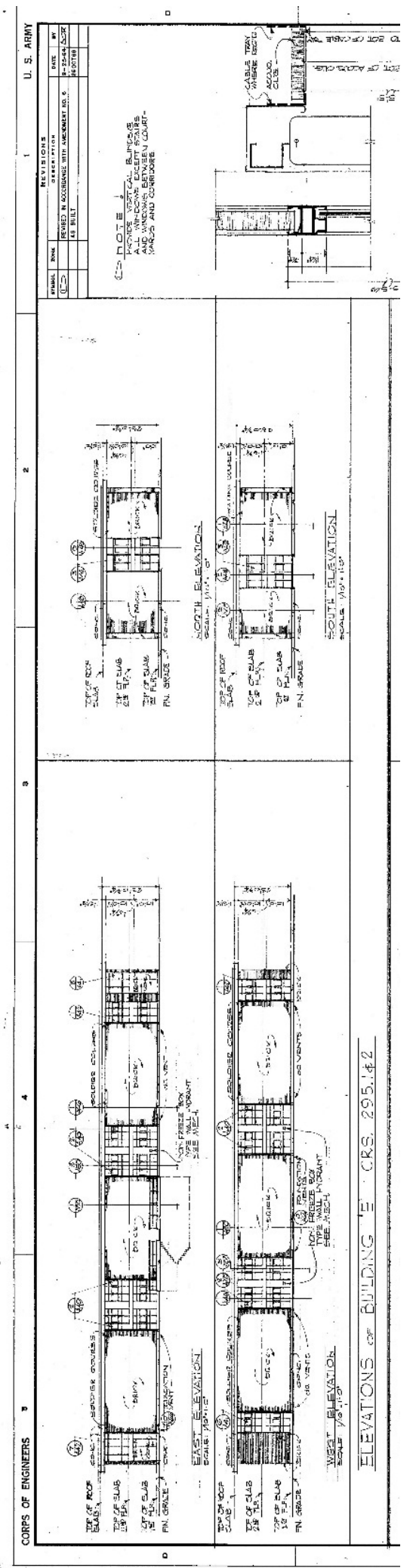


Figure 393. Section detail of concrete waffle ceiling and roof construction for Building 29816, Fisher Hall, 1964 (Fort Gordon DPW).

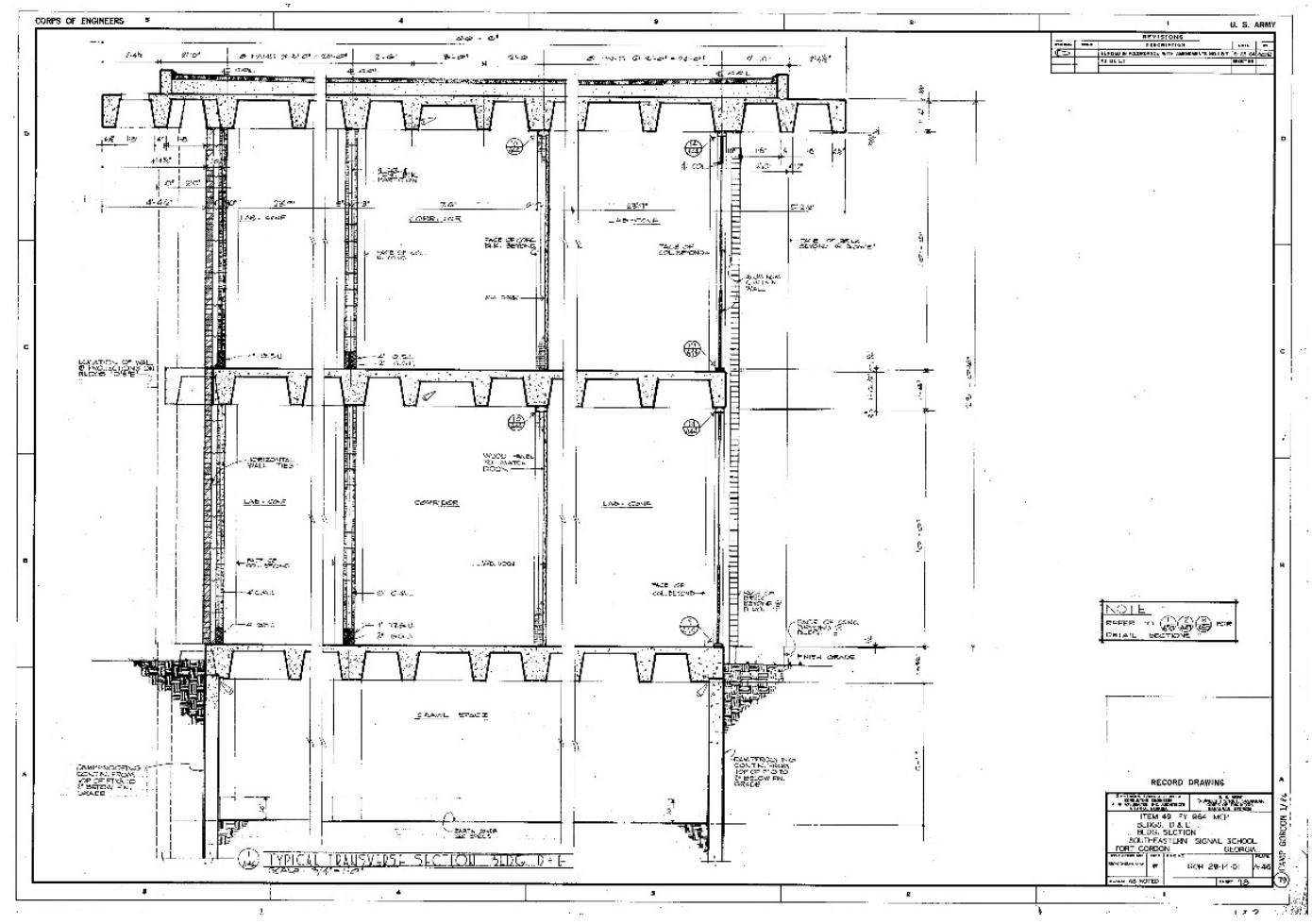


Figure 394. Stairwell details for Building 29816, Fisher Hall, 1964

(Fort Gordon DPW).

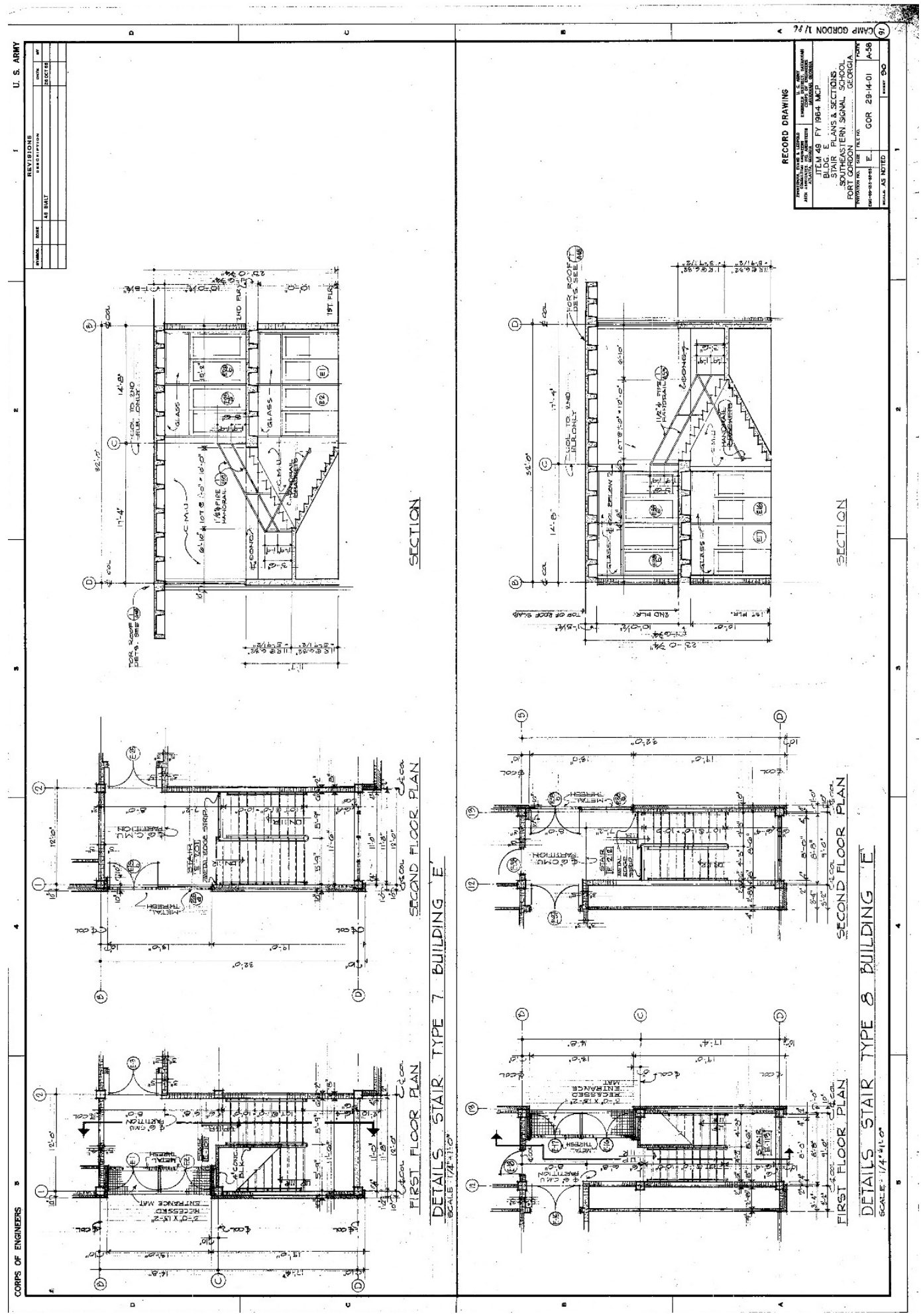


Figure 395. Typical classroom elevations and details for Building 29816, Fisher Hall, 1966 (Fort Gordon DPW).

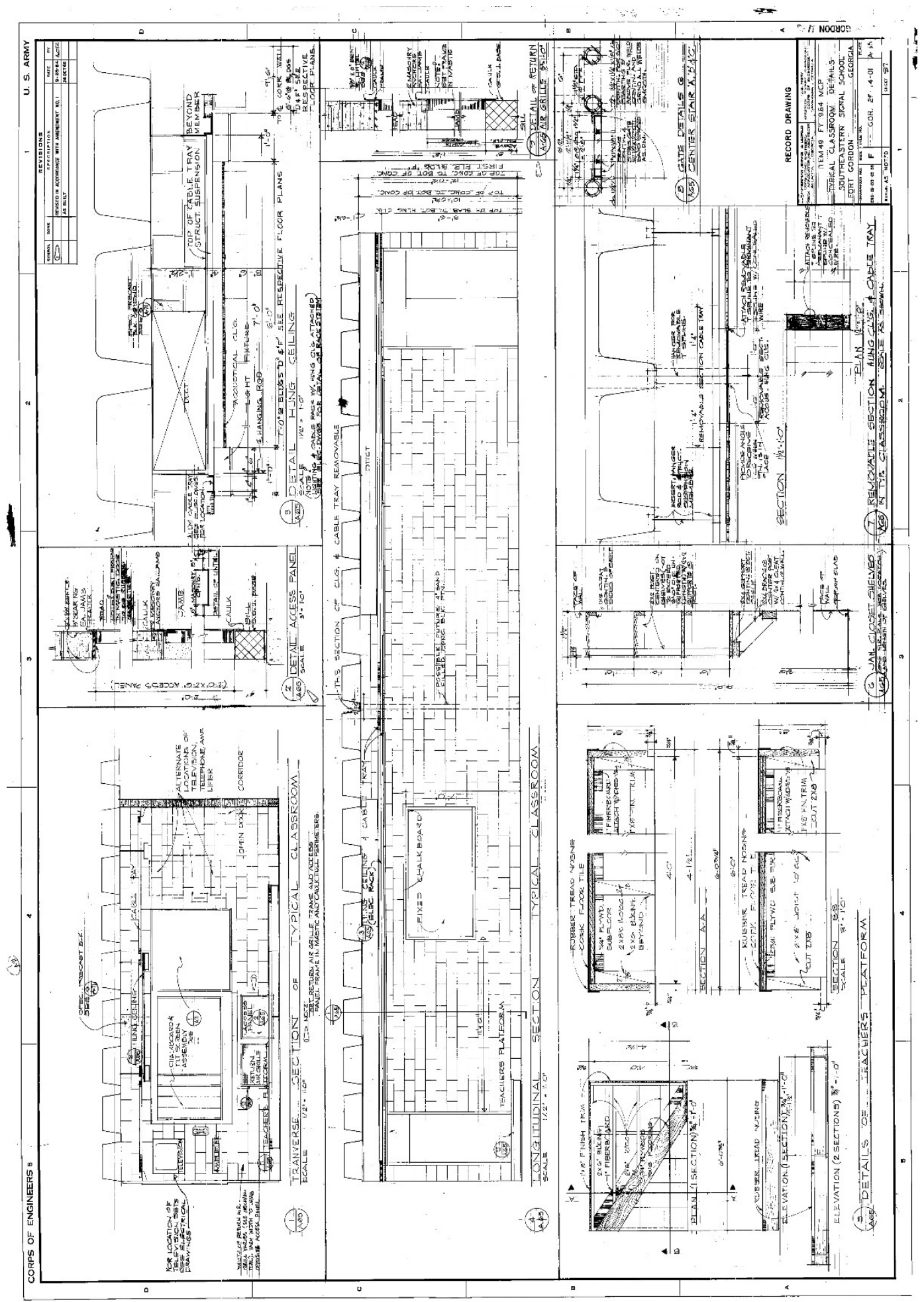


Figure 396. Latrine plans, elevations, and details for Building 29816, Fisher Hall, 1964 (Fort Gordon DPW).

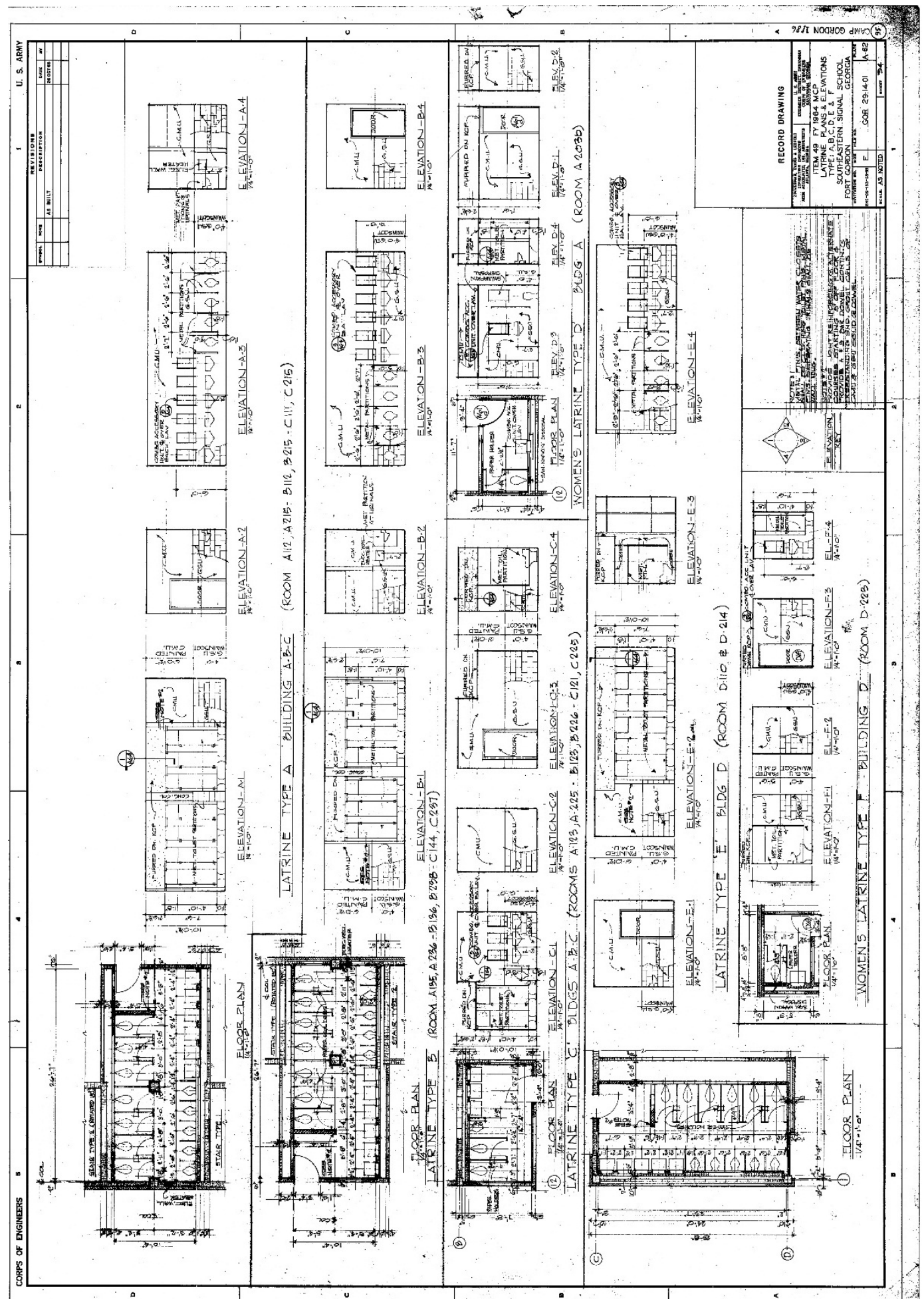


Figure 397. Light fixture types and schedule, 1966 (Fort Gordon DPW).

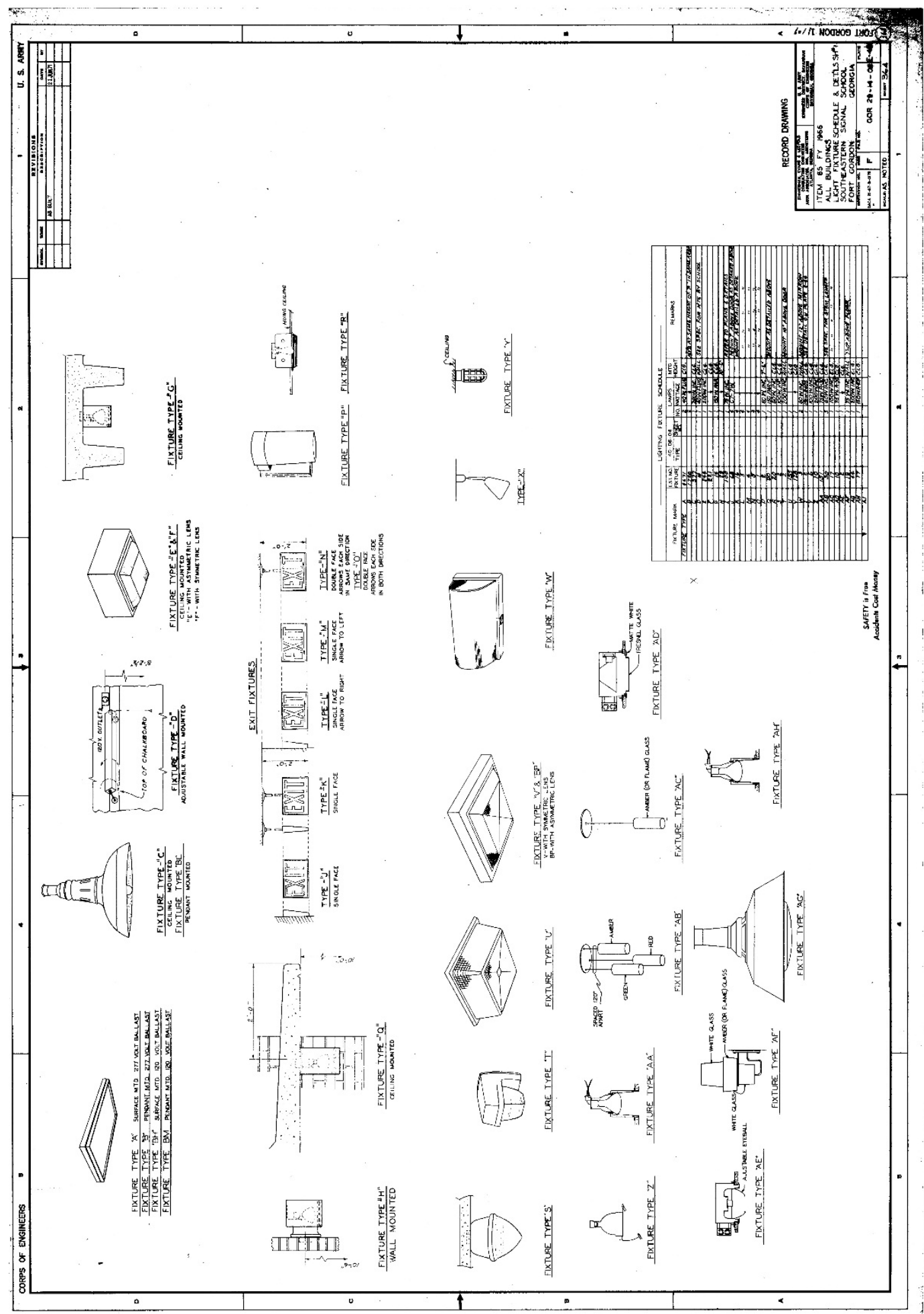


Figure 398. Landscape plan for Building 29816, Fisher Hall, 1966

(Fort Gordon DPW).

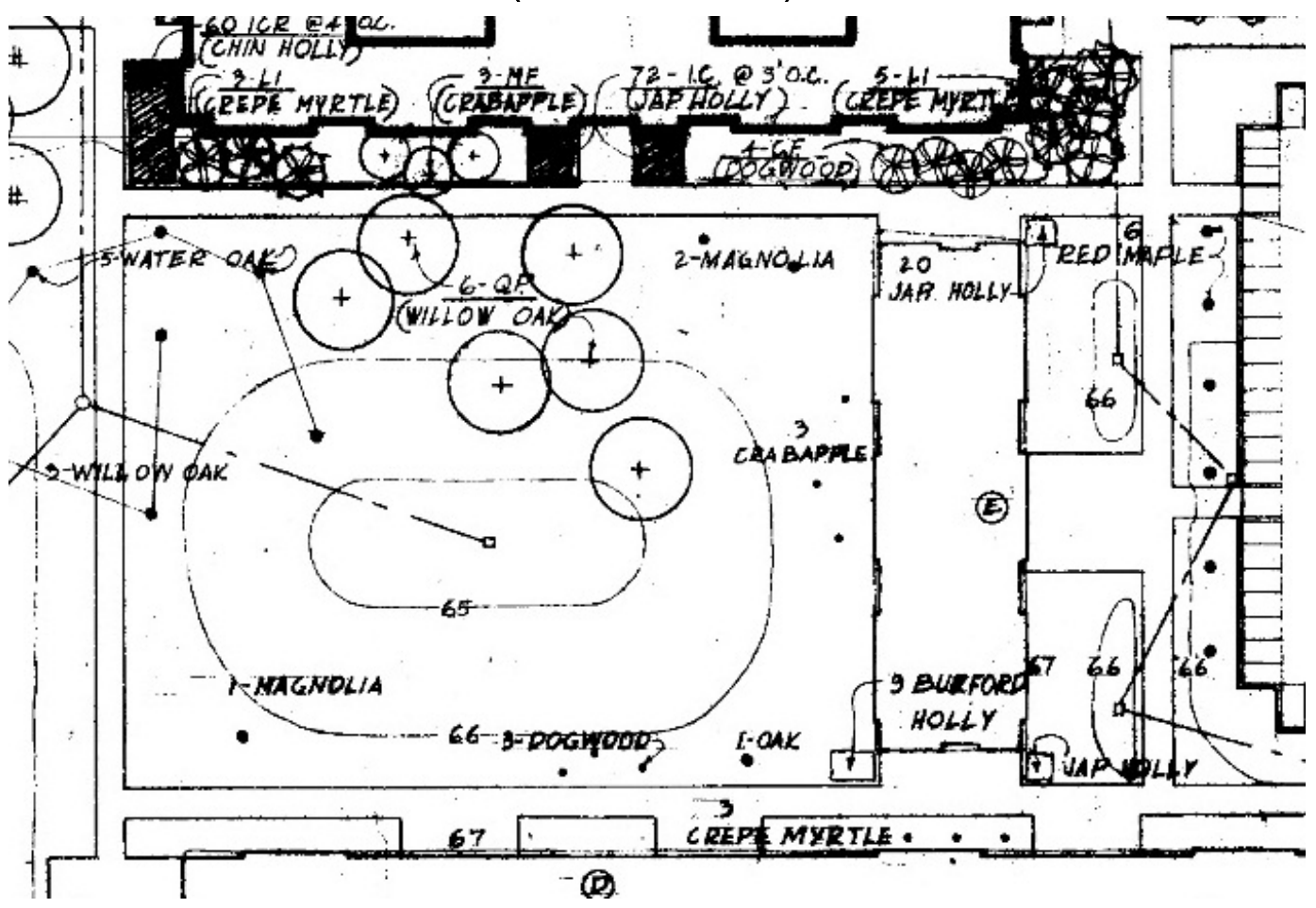

\subsubsection{Character-defining features}

Repair, renovation, and replacement of Building 29816, Fisher Hall, must be coordinated with the GA SHPO (Table 15).

\section{Exterior:}

- Overall massing

- Footprint

- Roof shape

- Brick veneer

- Relationship to other Signal School Campus buildings

- Overhanging eaves with perforated waffle construction casting "light pattern" on exterior brick walls

- Exposed concrete structure framing window and door openings

- Window pattern

- Recessed bays of bright-aluminum sash windows with three-pane awning-style windows sandwiched between insulated panels

- Bright-aluminum fixed-pane windows

- Concrete panel inserts

- Metal doors with large pane 
- Metal doors with plate glass

- Ceiling-mounted exterior light fixtures set within the waffle overhang

- Lettering

- Metal handrails

\section{Interior:}

- Overall plan

- Main stairwells

- Main hallways

- Lighting

- Doors

- Display cases

- Signage

- Telephone alcoves

- Tiled water-fountain alcoves

Table 15. Images of character-defining features of Building 29816, Fisher Hall (ERDC-CERL, 2015).

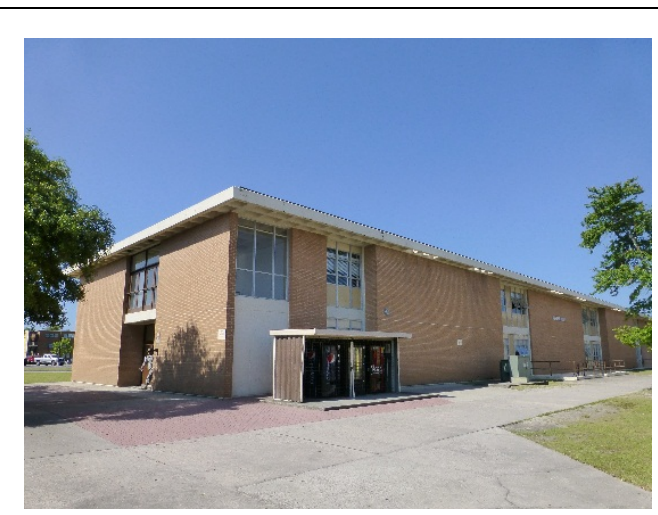

Overall massing, footprint, roof shape, brick veneer, and concrete waffle overhang.

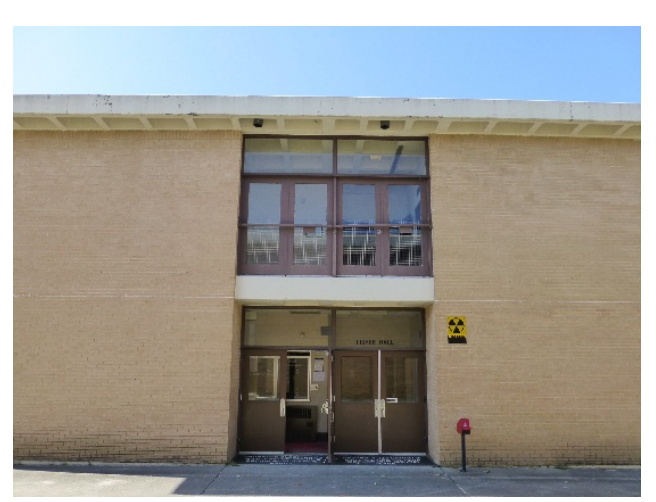

Metal doors with pane and transom on first floor, and metal and plate-glass doors on second floor, separated by exposed concrete structural system. 


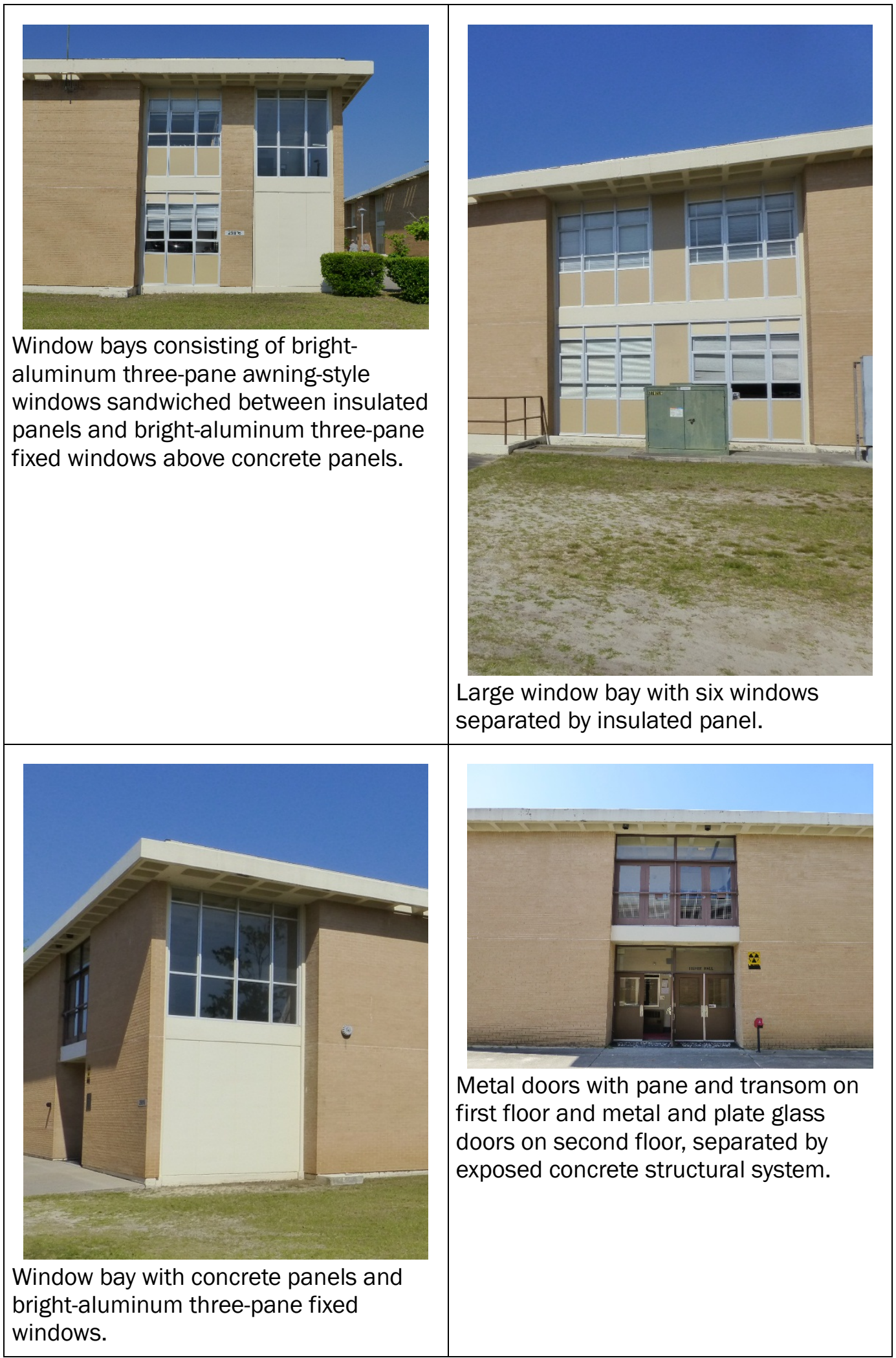




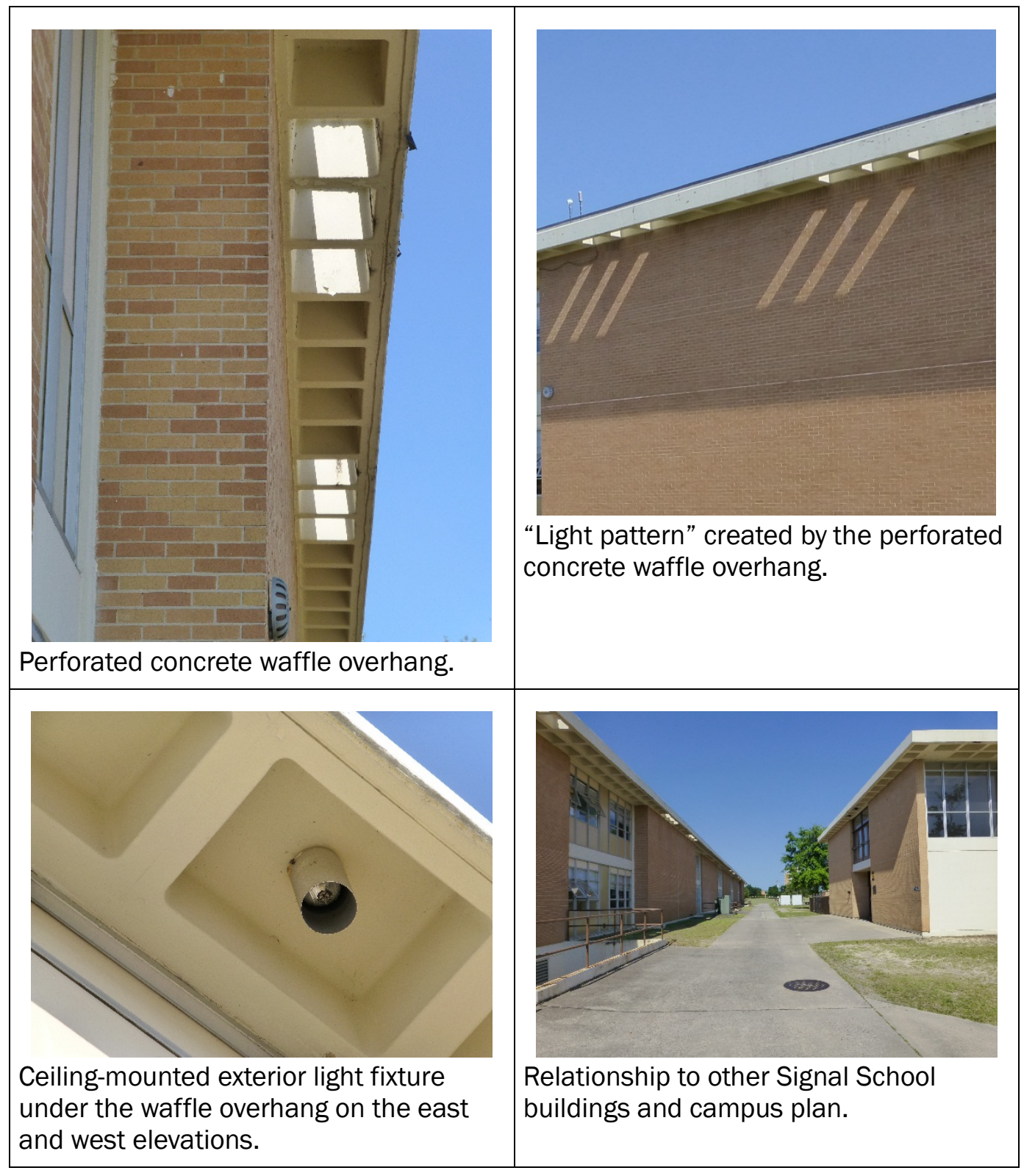

3.3.13.2 Character-defining features that have been removed

- None.

\subsubsection{Nonhistoric features}

- None.

\subsubsection{Comparison images}

Comparison images utilizing either the original drawings or historic photographs, when juxtaposed against present-day images, are a useful tool in 
developing the historic "feel" of a property and how much of that historic feeling is still present today (Figure 399-Figure 401).

Figure 399. East window group - comparison of the original design and materials from 1964 [left] to the current condition of the bright-aluminum sash windows, insulated panels, and concrete panels [right] (ERDC-CERL, 2015).

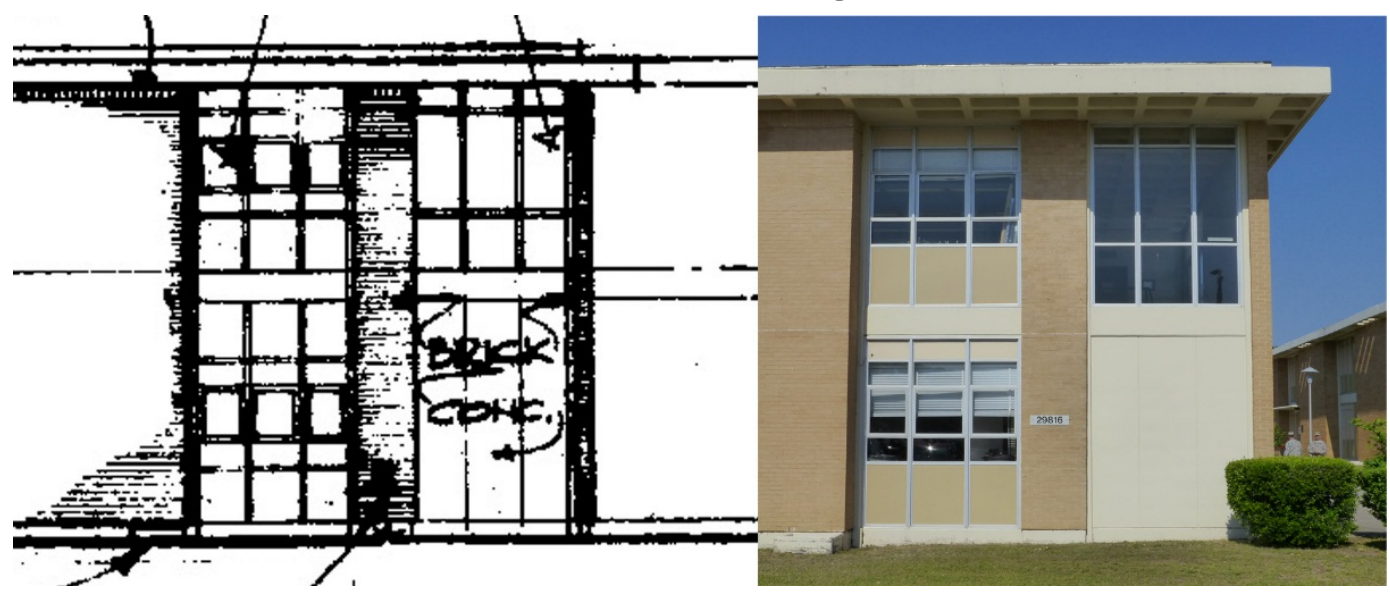

Figure 400. Large window group - comparison of the original design and materials from 1964 [left] to the current condition of the bright-aluminum three-pane awningstyle windows with insulated panels and exposed concrete structure [right] (ERDC-CERL, 2015).
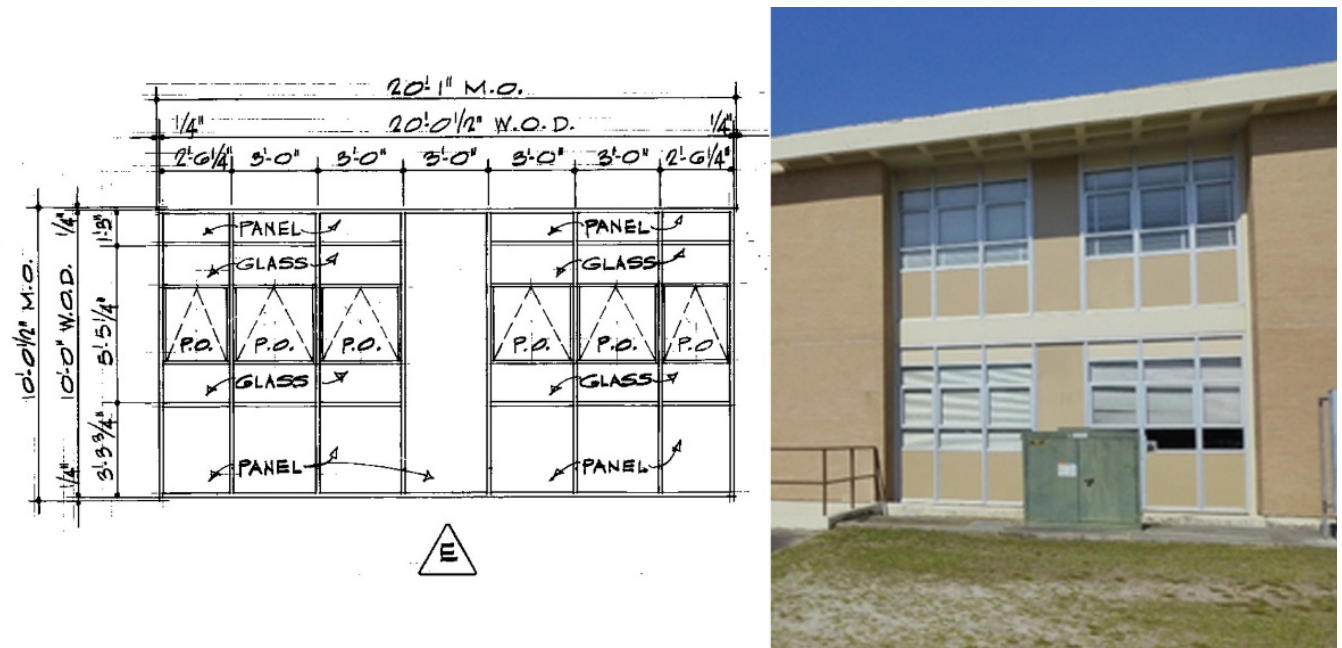
Figure 401. Ceiling-mounted light fixture under the waffle overhang - comparison of the original design and material from 1966 [left] to the current condition of the ceiling-mounted light fixture [right] (ERDC-CERL, 2015).
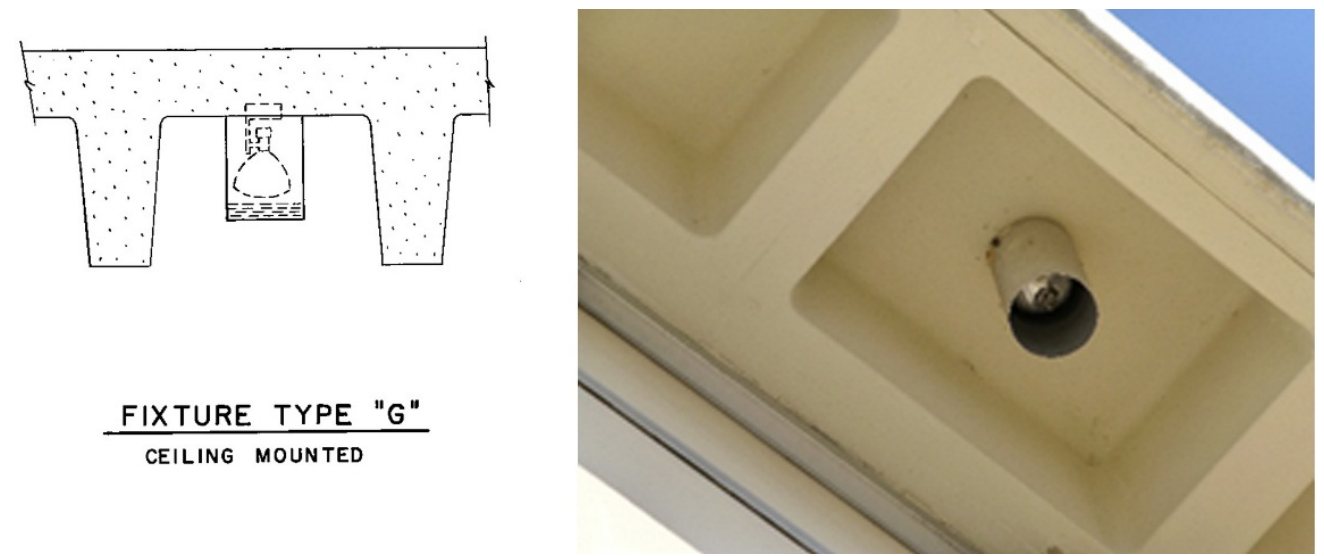

\subsubsection{Building 29817, Allison Hall (1970)}

Building 29817, Allison Hall, is a contributing feature to the Signal School Campus Historic District. The research team was not granted access to the interior; the interior character-defining features are unknown but for undertakings that effect the interior, the should use examples from the other interiors to guide identification and mitigation. The building was constructed in 1970 as part of the Phase II construction of the campus and was designed by Aeck Associates from Atlanta, Georgia, and Zimmerman, Evans, and Leopold Engineers from Augusta, Georgia. The building is a rectilinear classroom building with two large courtyards. It is on the eastern edge of the school, west of Building 29819, north of 29816, and south of 29819. It is two stories high with a basement. The structure is cast-inplace concrete columns with a waffle floor/ceiling system. The secondfloor waffle system is set within the structure, but the roof has the waffles extending out to form an overhang. Some of the waffles have been perforated. The window systems extend the full height of the building and are inset into the brick veneer. Building 29817 appears to have been constructed without actual windows, though. The window systems are composed of bright-aluminum window frames that enclose two different panels. A maize-colored panel is in lieu of awning windows, and a tan-colored panel is above and below. The window system is separated by the building's exposed concrete beam structural system. The south elevation is symmetrical, and it is defined by a central entry bay that consists of a set of metal entry doors, and a flat concrete canopy topped with a group of 
three windows that is adjacent a bay of windows. On either side of the central bay are two large bays of six windows, each with an insulated panel dividing them into groups of three. The far left and right sides of the elevation are slightly recessed, and a bay of two windows is located at the corners. Lettering spelling out "ALLISON HALL" is located on the left side of the south elevation. The entrances on the east and west elevations consist of two entry bays. Each consists of two sets of metal doors. Above these first-floor doors are bright-aluminum window frames, which have openings filled with the maize and tan panels. Basement access on the east and west elevations is located between the main sets of doors, and the opening is protected by a perforated brick wall in the same brick as the building. The north elevation is symmetrical. There are five large bays. The center bay is an entry bay with a set of metal doors with a large pane with transom above and five concrete panels on the first floor. A flat concrete canopy projects out above the doors and panels. Above the canopy on the second floor is a group of seven bright-aluminum three-pane fixed windows. The other four large bays consist of two groups of three windows divided by an insulated panel. The far left and right sides of the north elevation have smaller two-window bay systems and are recessed at the corners. There are two separate outside access points to the basement on the north side of the building. Poured concrete walls, concrete steps, and metal handrails indicate these points. Also on the north wall is lettering spelling out "ALLISON HALL" (Figure 402-Figure 415).The researchers did not have access to the floorplans for Building 29817, but a few details drawings for "Building H" were found. According to a 1966 site plan (Figure 5), Building 29817 was designated as "Building H."

Figure 402. Signal School Campus map, with Building 29817, Allison Hall, highlighted in red, 2015 (Fort Gordon DPW, modified by ERDC-CERL).

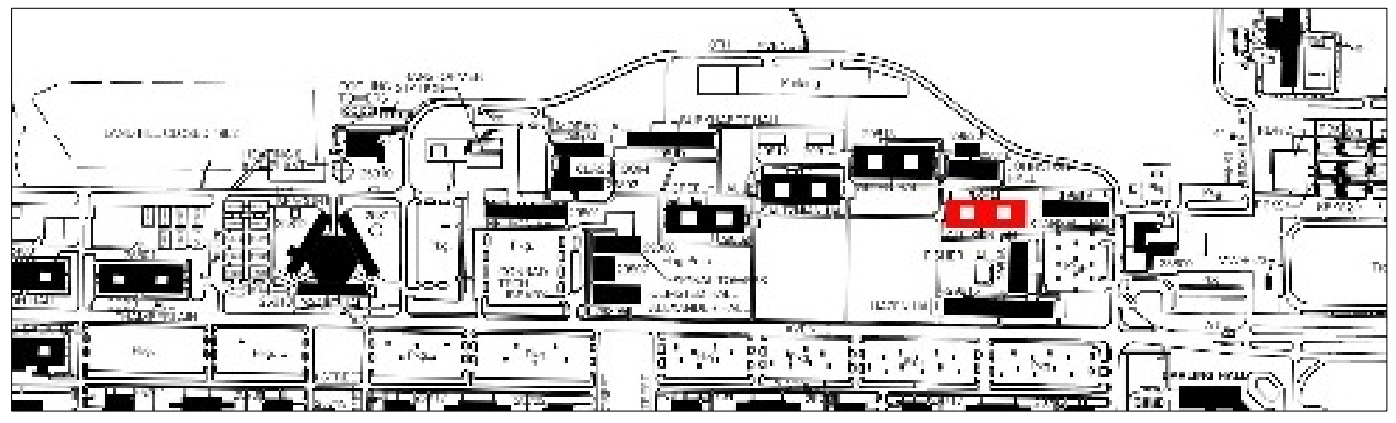


Figure 403. Northeast oblique of Building 29817, Allison Hall (ERDC-CERL, 2015).

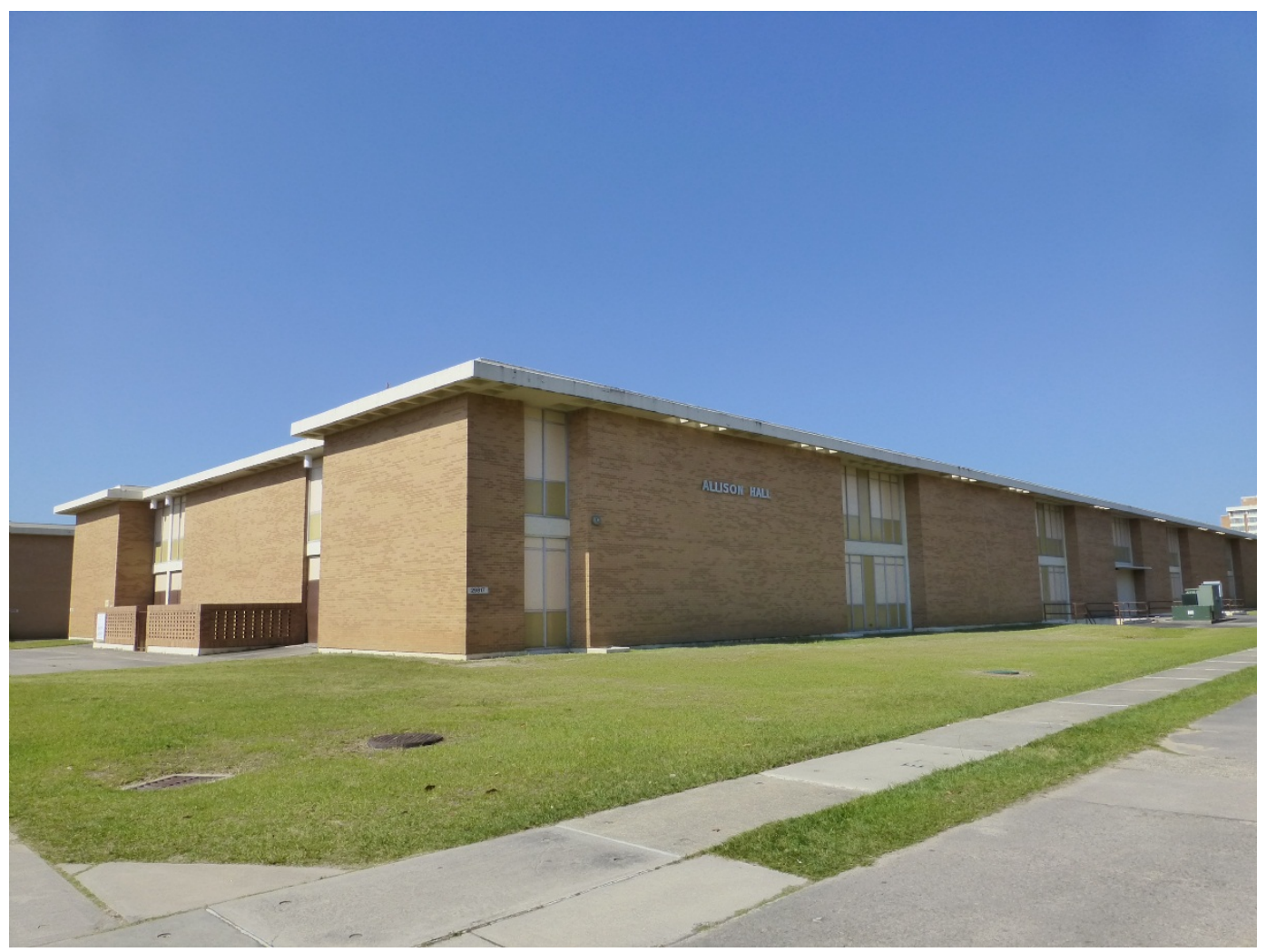

Figure 404. East elevation of Building 29817, Allison Hall (ERDC-CERL, 2015).

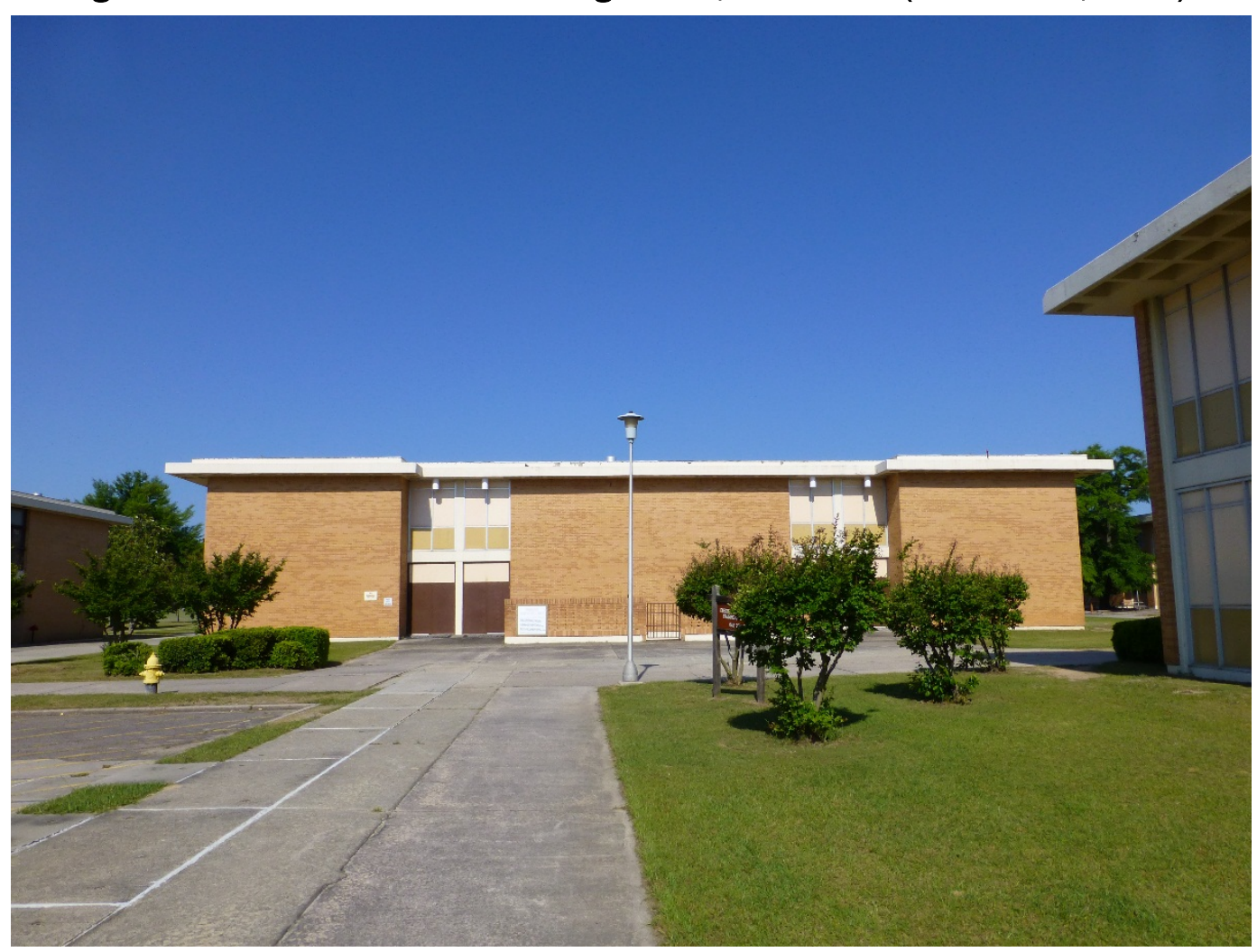


Figure 405. South elevation of Building 29817, Allison Hall (ERDC-CERL, 2015).

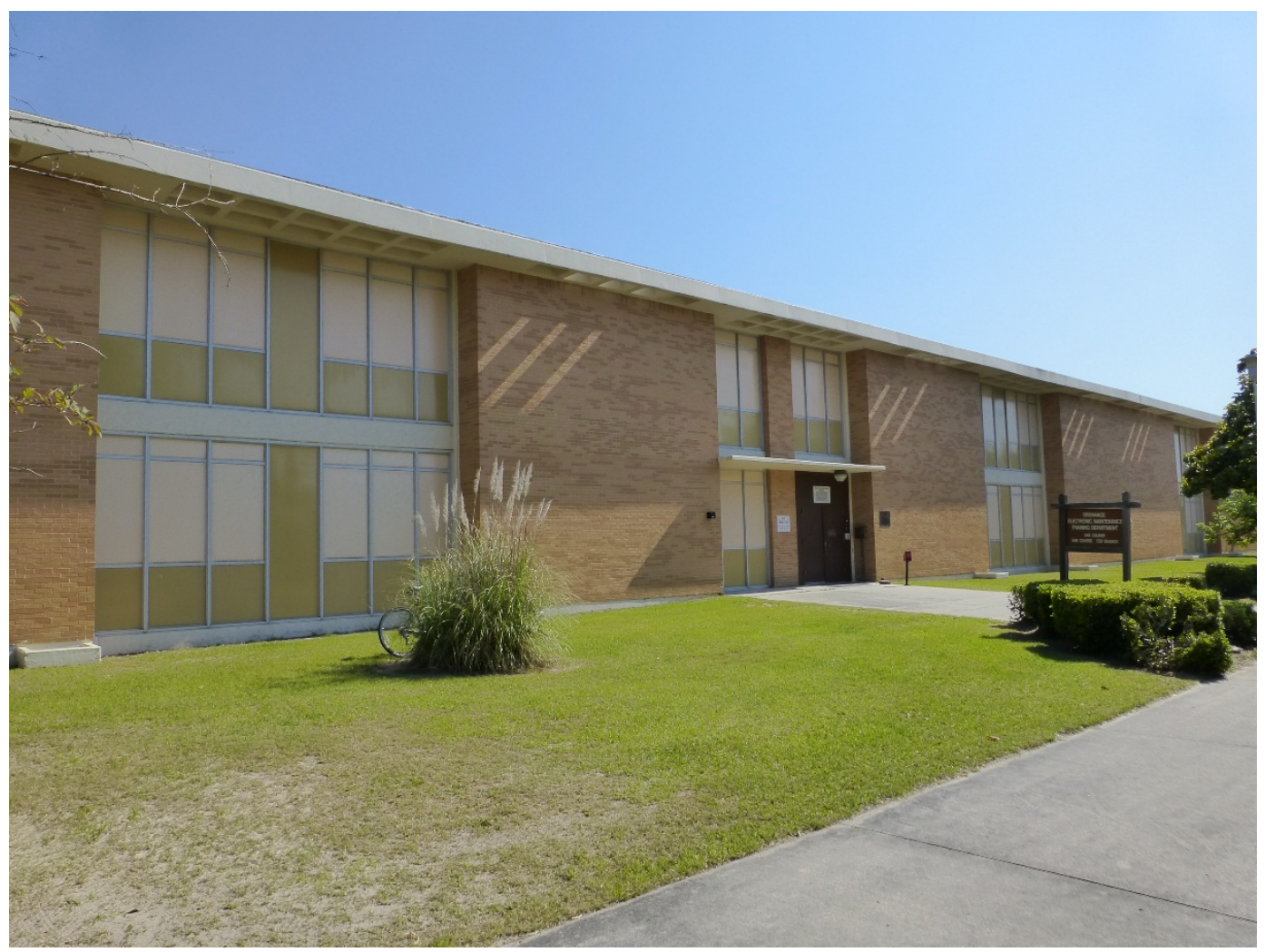

Figure 406. West elevation of Building 29817, Allison Hall (ERDC-CERL, 2015).

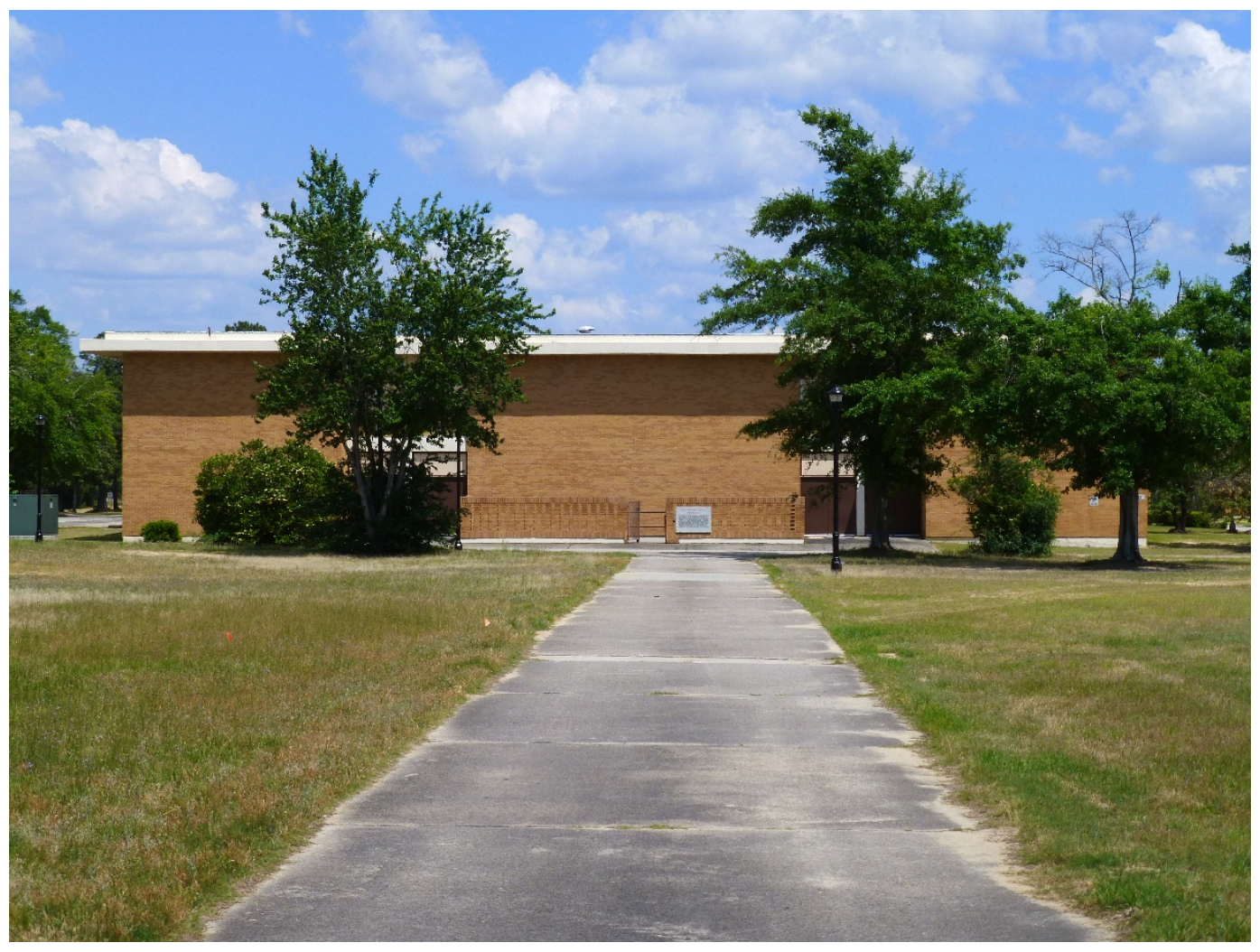


Figure 407. South elevation of Building 29817, Allison Hall, May 1970 (Signal Corps Historian Office).

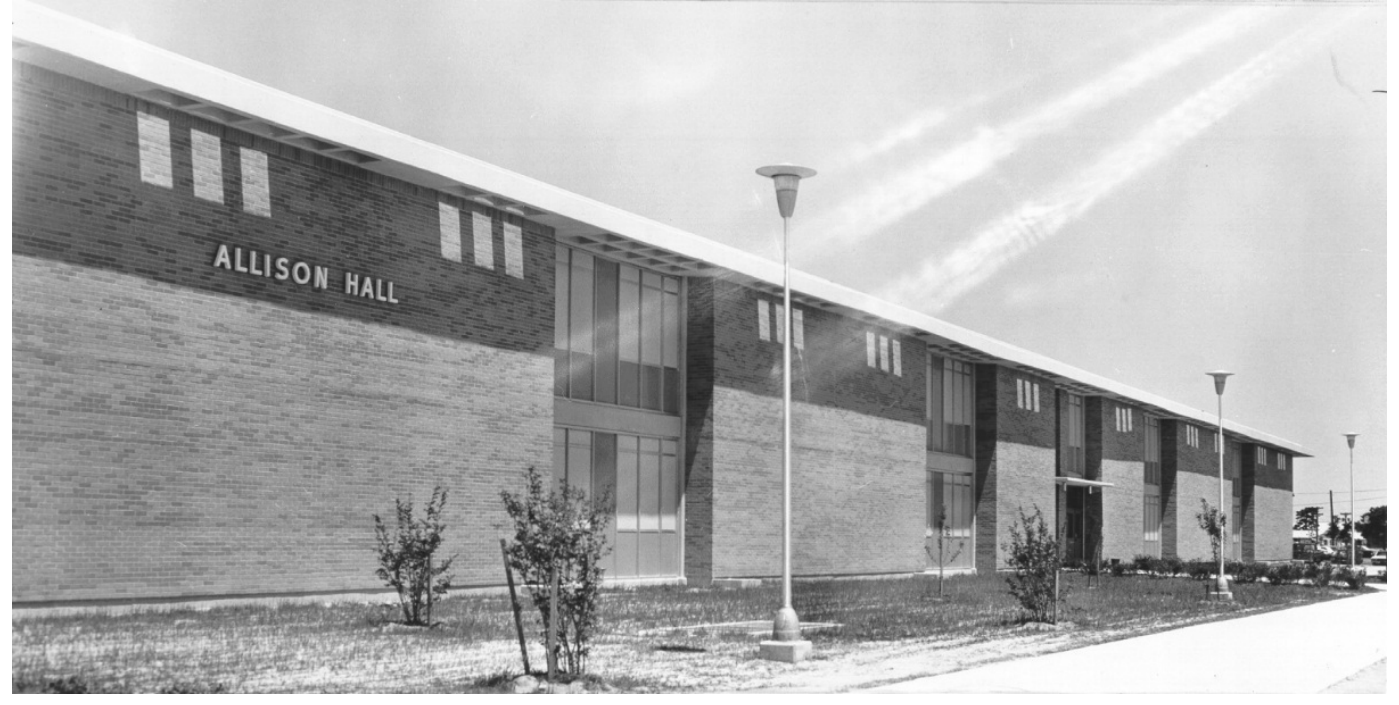

Figure 408. View looking northeast of the Signal School Campus, Building 29811, Saltzman Hall, is on the left and Building 29817, Allison Hall, is on distant right (Allen Hall is between), April 1978 (National Archives at College Park, MD).

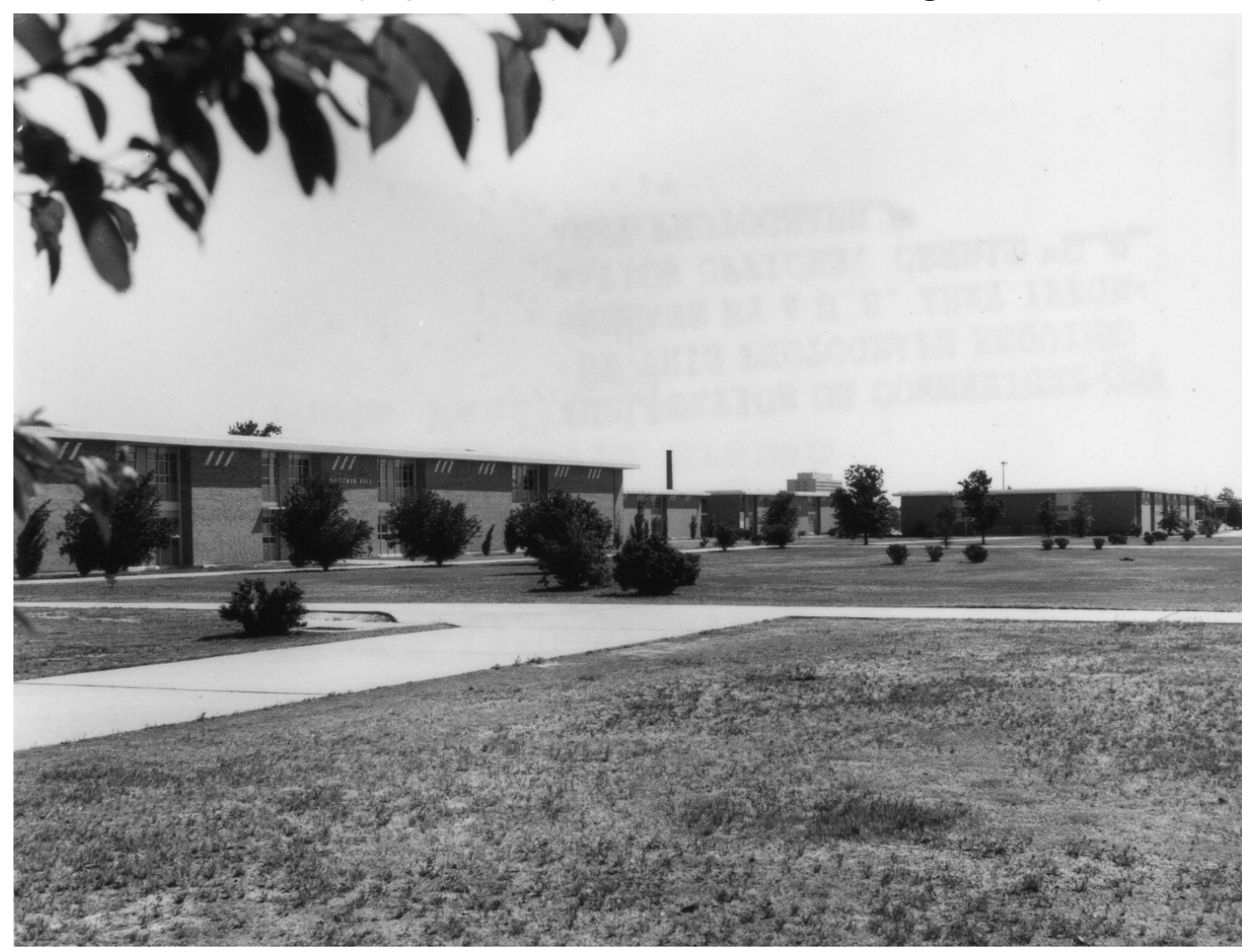


Figure 409. Window detail elevations for "Building H”, [future Allison Hall], 1966 (Fort Gordon DPW).

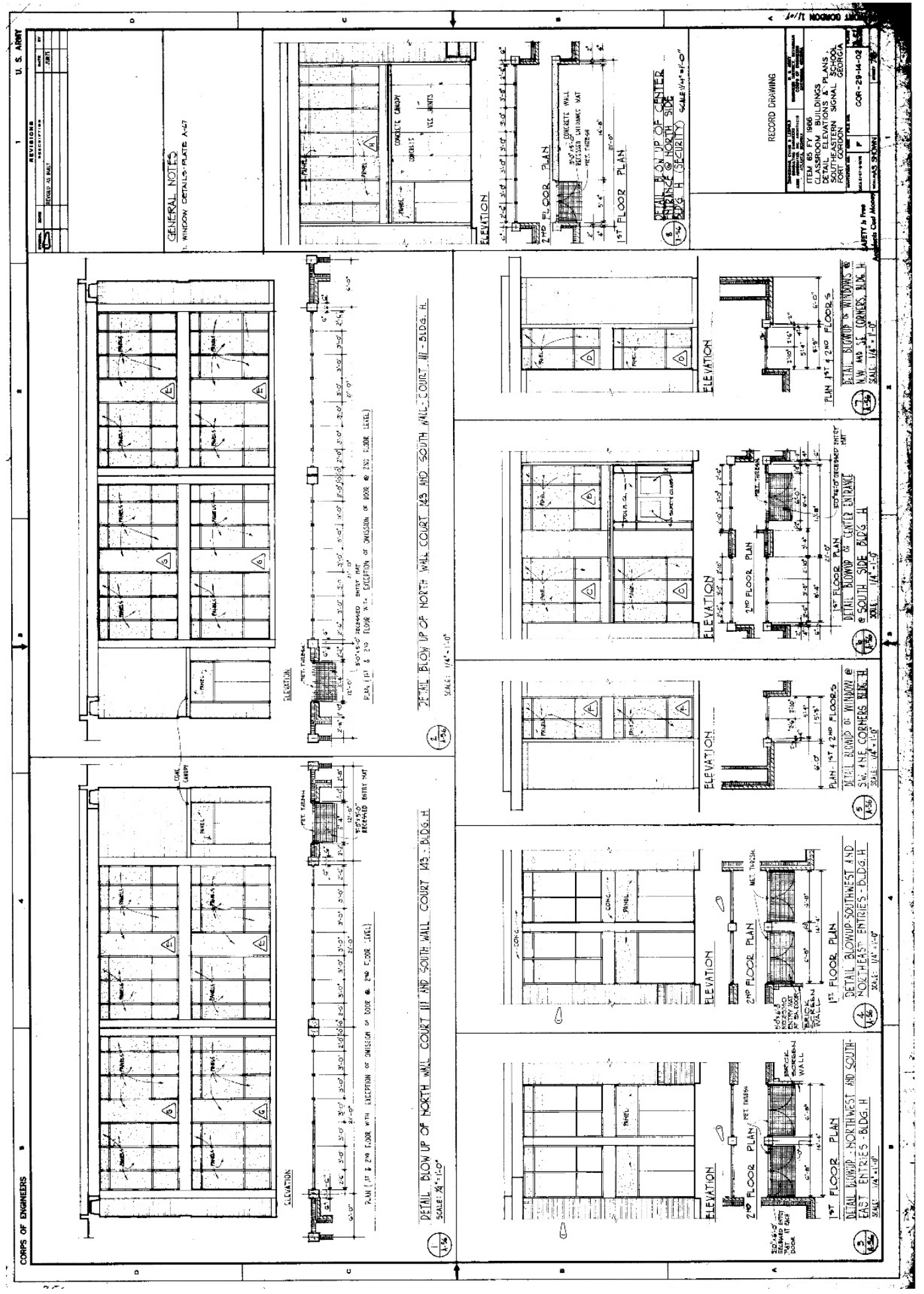


Figure 410. Section of Buildings A, B, and C, showing concrete waffle ceiling and roof construction (the design of Building 29817 followed this plan), 1964

(Fort Gordon DPW).

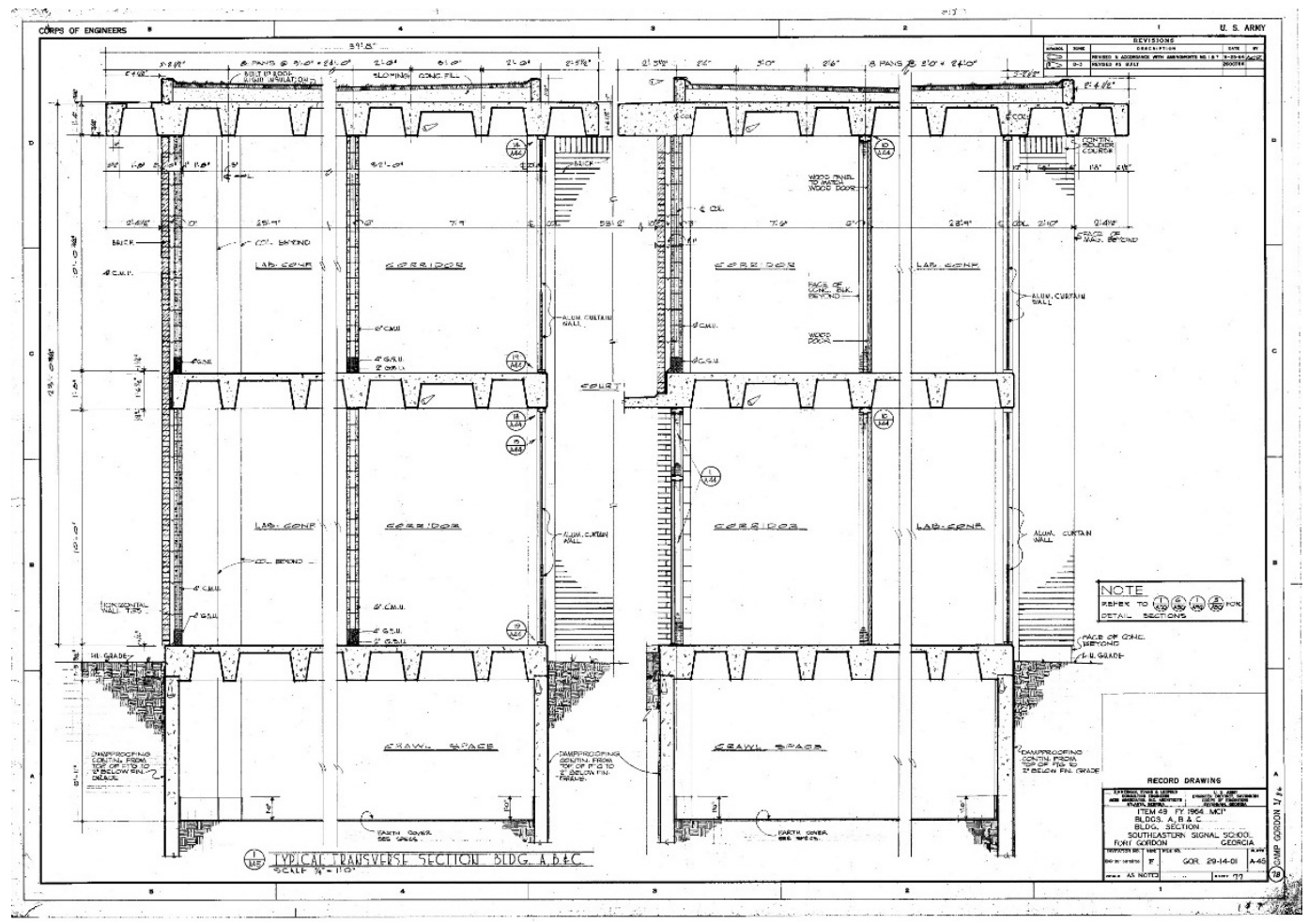

Figure 411. Window and door schedule for "Building H", [future Allison Hall], 1966 (Fort Gordon DPW).

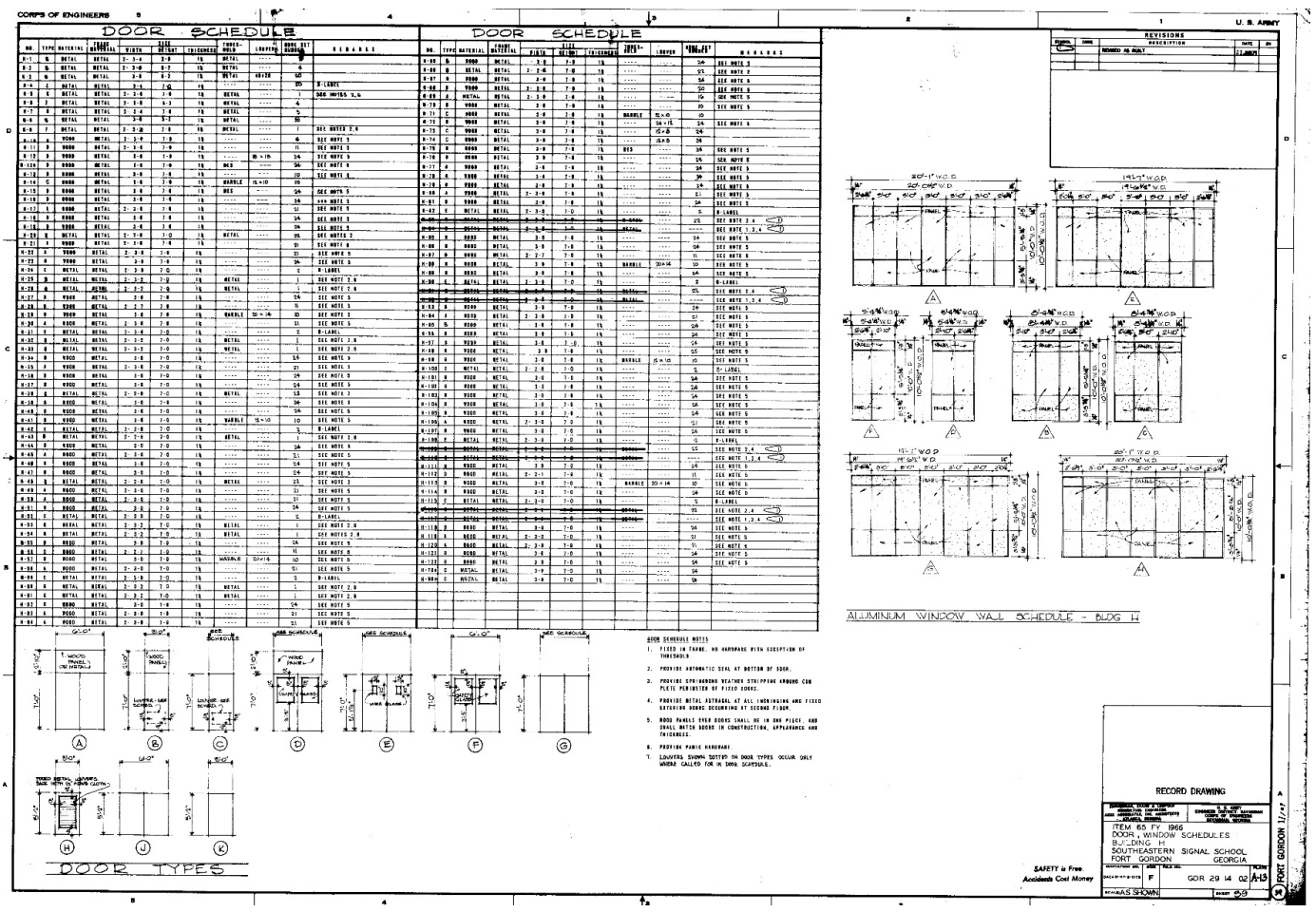


Figure 412. Brick screen detail for exterior staircases on the east and west elevations of Buildings A, B, and C (the design of Building 29817 followed this plan), (Fort Gordon DPW).

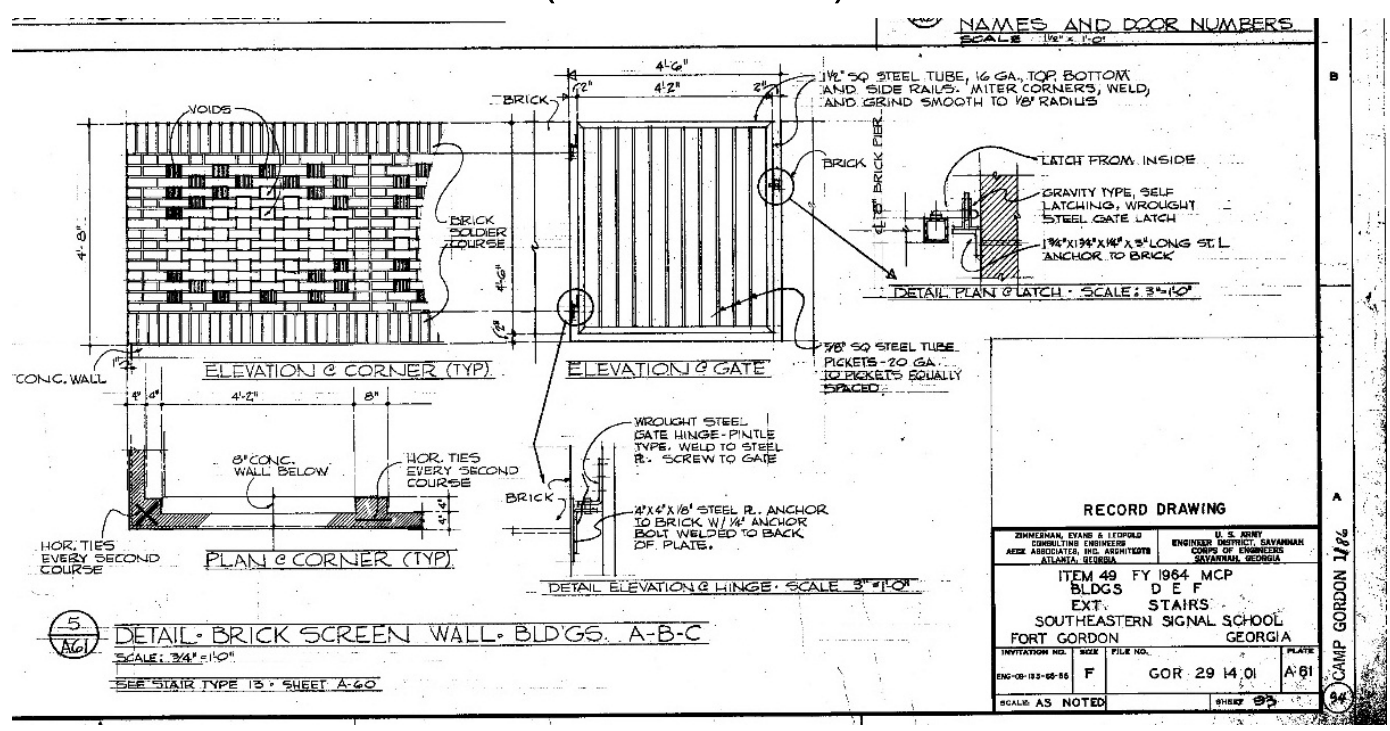

Figure 413. Courtyard plans and details “Building H”, [future Allison Hall], 1966 (Fort Gordon DPW).

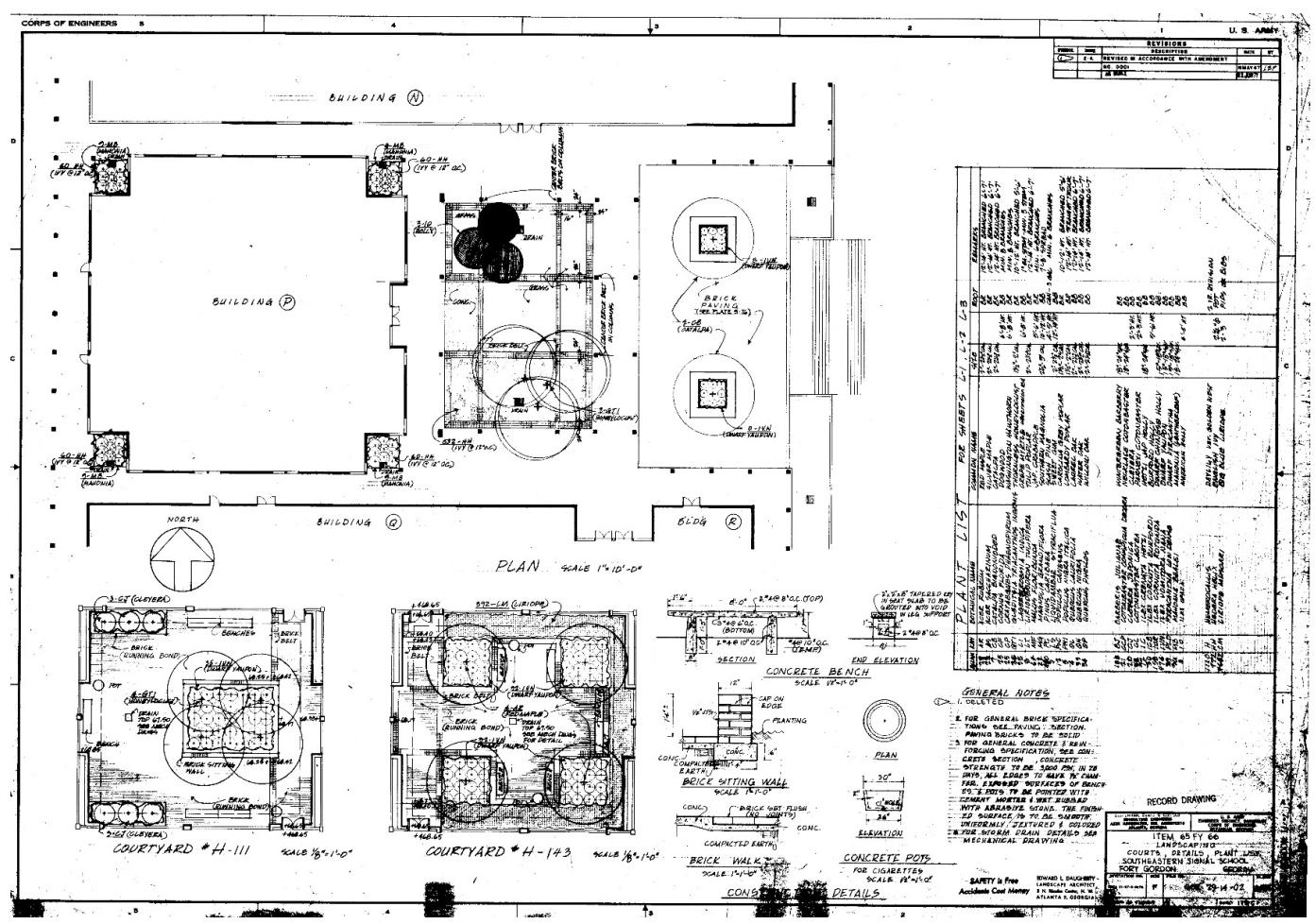


Figure 414. Typical classroom elevations and details, 1966 (Fort Gordon DPW).

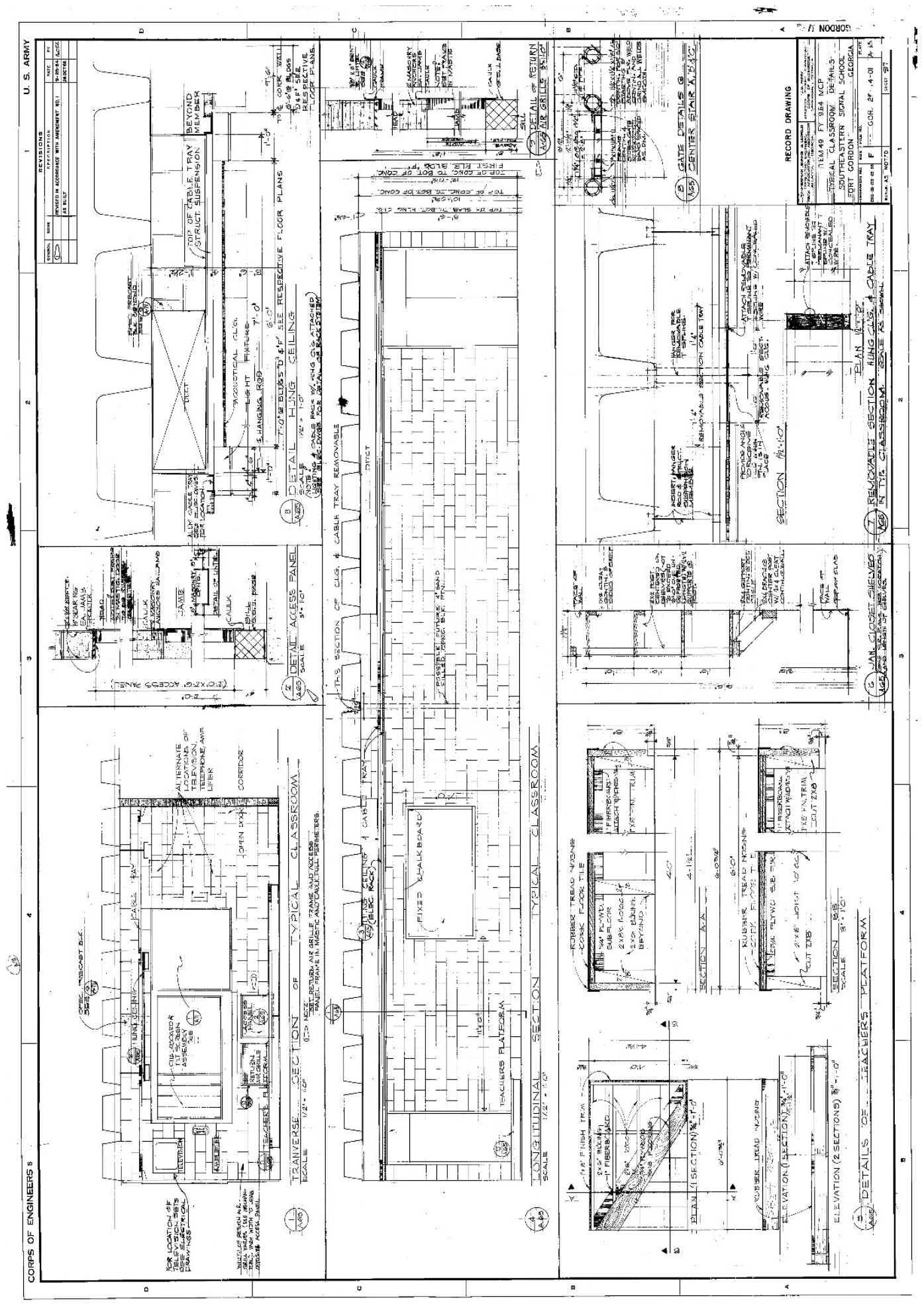


Figure 415. Landscape plan for “Building H”, [future Allison Hall], 1966

(Fort Gordon DPW).

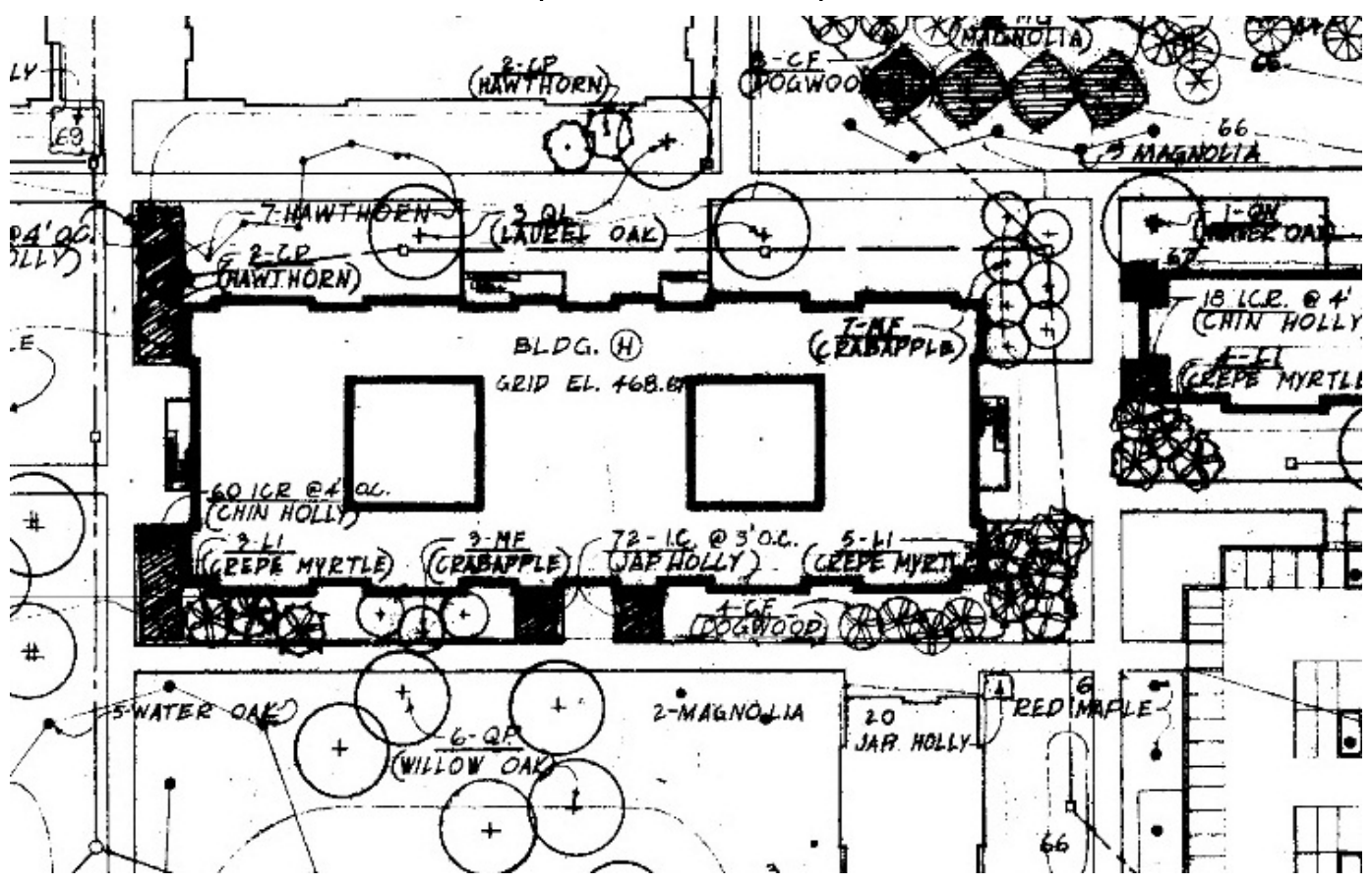

\subsubsection{Character-defining features}

Repair, renovation, and replacement of Building 29817, Allison Hall, must be coordinated with the GA SHPO (Table 16).

\section{Exterior:}

- Overall massing

- Footprint

- Roof shape

- Brick veneer

- Relationship to other Signal School Campus buildings

- Overhanging eaves with perforated waffle construction casting "light pattern" on exterior brick walls

- Exposed concrete structure framing window and door openings

- Flat concrete canopy above entries

- Window pattern

- Recessed groups of bright-aluminum sash frames with insulated panels

- Metal doors

- Metal doors with plate glass on east and west elevations

- Perforated brick walls on east and west elevations 
- Ceiling-mounted light exterior fixtures set within the waffle overhang on the east and west elevations

- Lettering

- Metal handrails

- Landscaping

\section{Interior:}

No interior access was given to the researchers.

Table 16. Images of character-defining features of Building 29817, Allison Hall (ERDC-CERL, 2015).

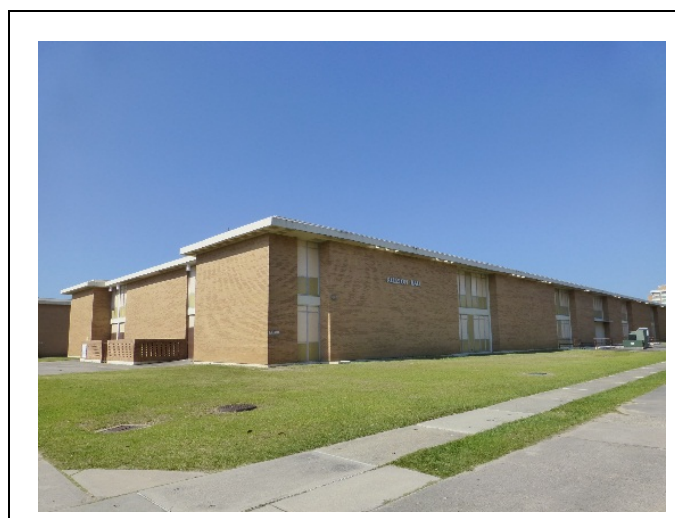

Overall massing, footprint, roof shape, and brick veneer.

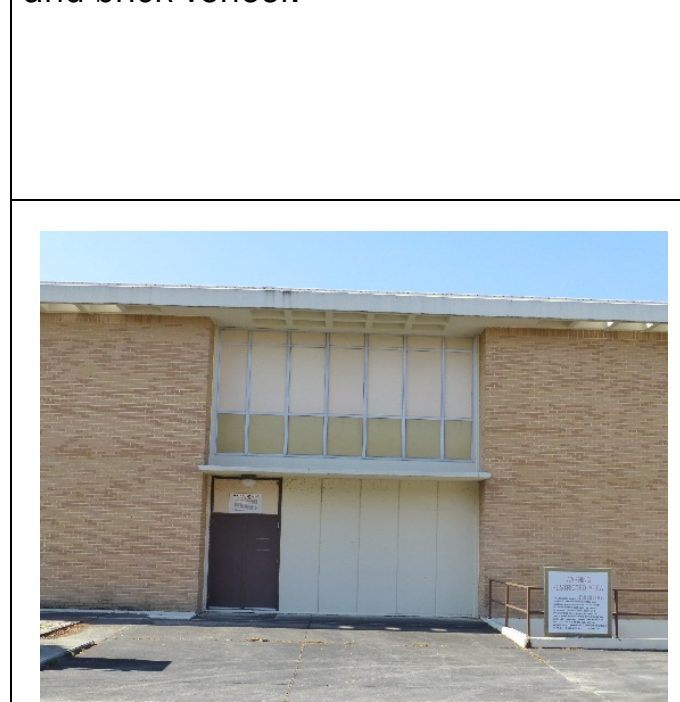

Entry bay on north elevation with concrete panels, metal doors, flat concrete canopy, and bright-aluminum sashes with insulated panels.

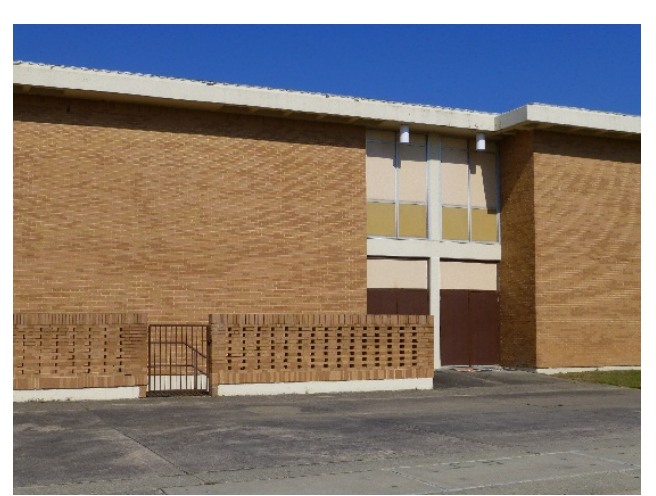

Metal doors on first floor and metal and bright-aluminum framing insulated panels on second floor, separated by exposed concrete structural system. Perforated brick wall encasing the basement opening.

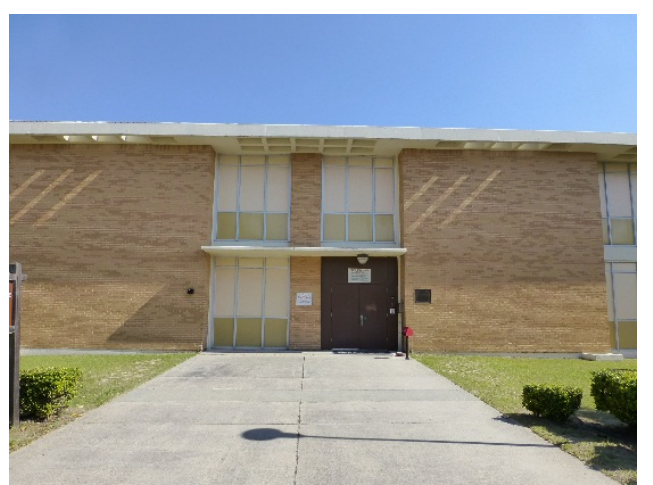

Main entry on the south elevation with bays of three insulated panels, flat concrete canopy, and metal entry doors. 


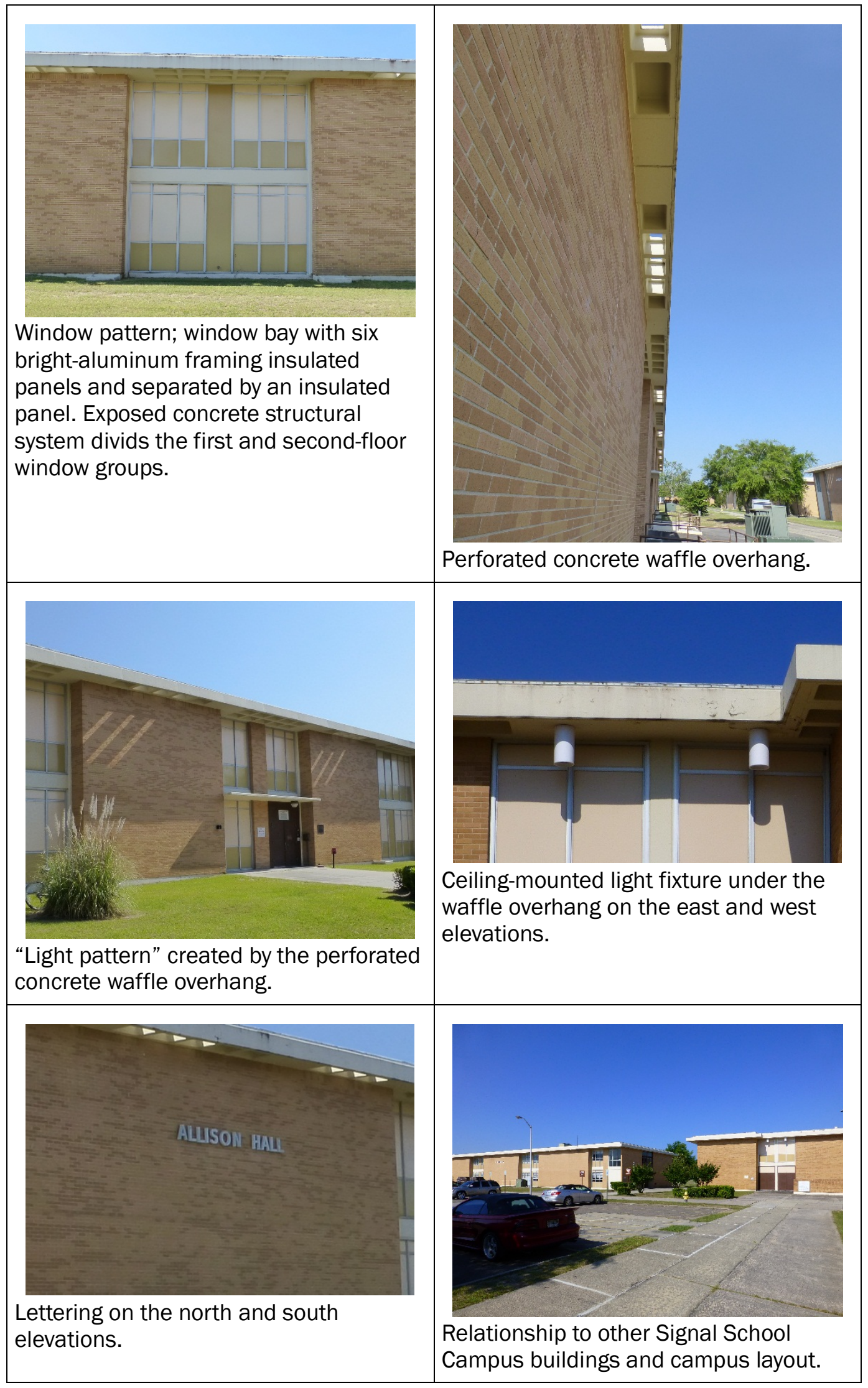




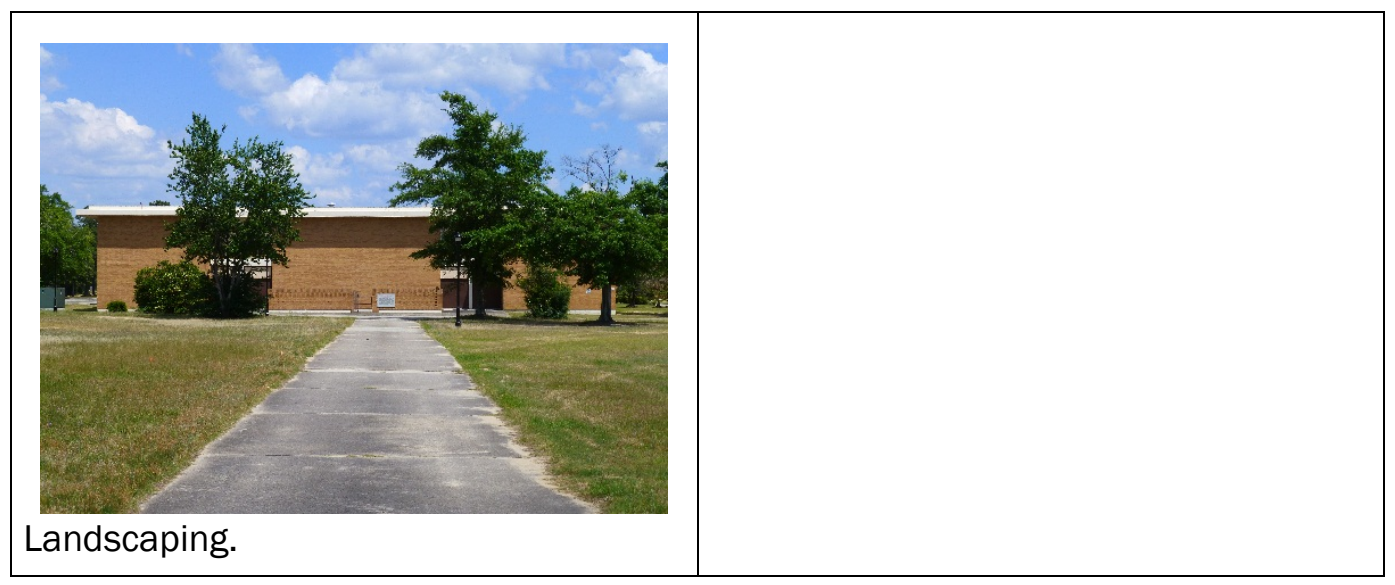

3.3.14.2 Character-defining features that have been removed

- None.

\subsubsection{Nonhistoric features}

- None.

\subsubsection{Comparison images}

Comparison images utilizing either the original drawings or historic photographs, when juxtaposed against present-day images, are a useful tool in developing the historic "feel" of a property and how much of that historic feeling is still present today (Figure 416-Figure 421).

Figure 416. South elevation - comparison of a historic photograph from 1970 [left] to the current condition of the bright-aluminum frames, insulated panels, “light pattern," entry, and concrete canopy [right] (ERDC-CERL, 2015).
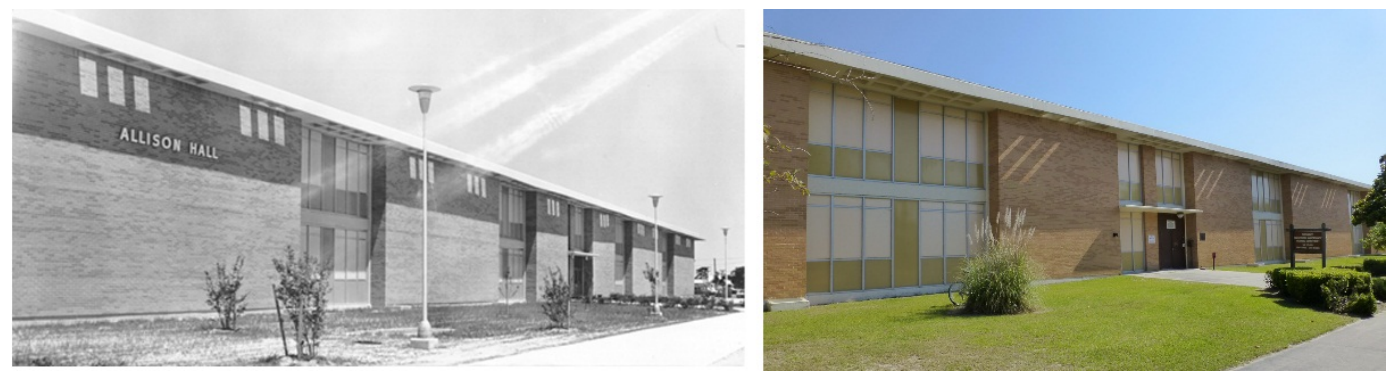
Figure 417. Main entry on the south elevation - comparison of the original design and materials detail drawing from 1966 [left] to the current condition of the concrete canopy, bright-aluminum framed insulated panels, and replacement metal entry doors [right] (ERDC-CERL, 2015).
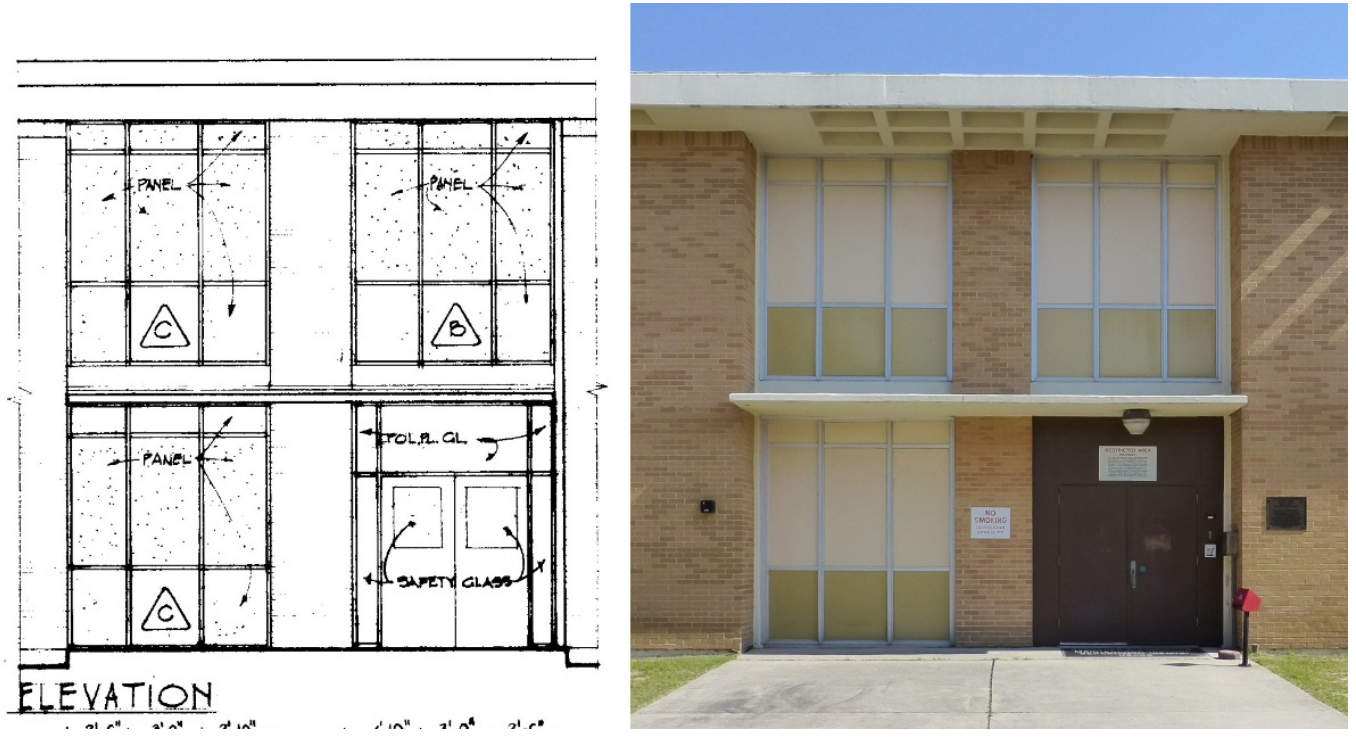

Figure 418. Entry bay on the north elevation - comparison or the original design and materials detail drawing from 1966 [left] to the current condition of the metal doors, concrete panels, concrete canopy, and bright-aluminum framed insulated panels [right] (ERDC-CERL, 2015).

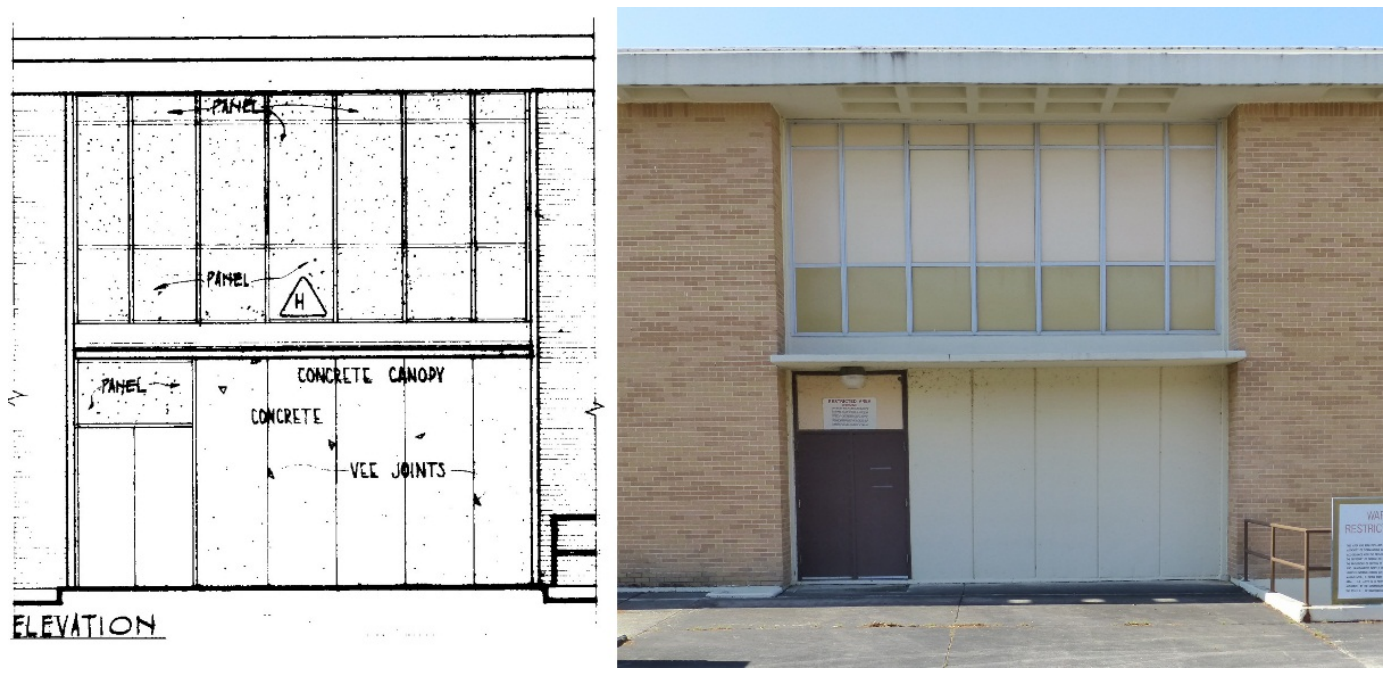


Figure 419. Entry bays on the east and west elevations - comparison of the original design and materials detail drawings from 1966 [left] to the current condition of the metal entry doors with insulated panels above and bright-aluminum framed insulated panels on the second floor [right] (ERDC-CERL, 2015).
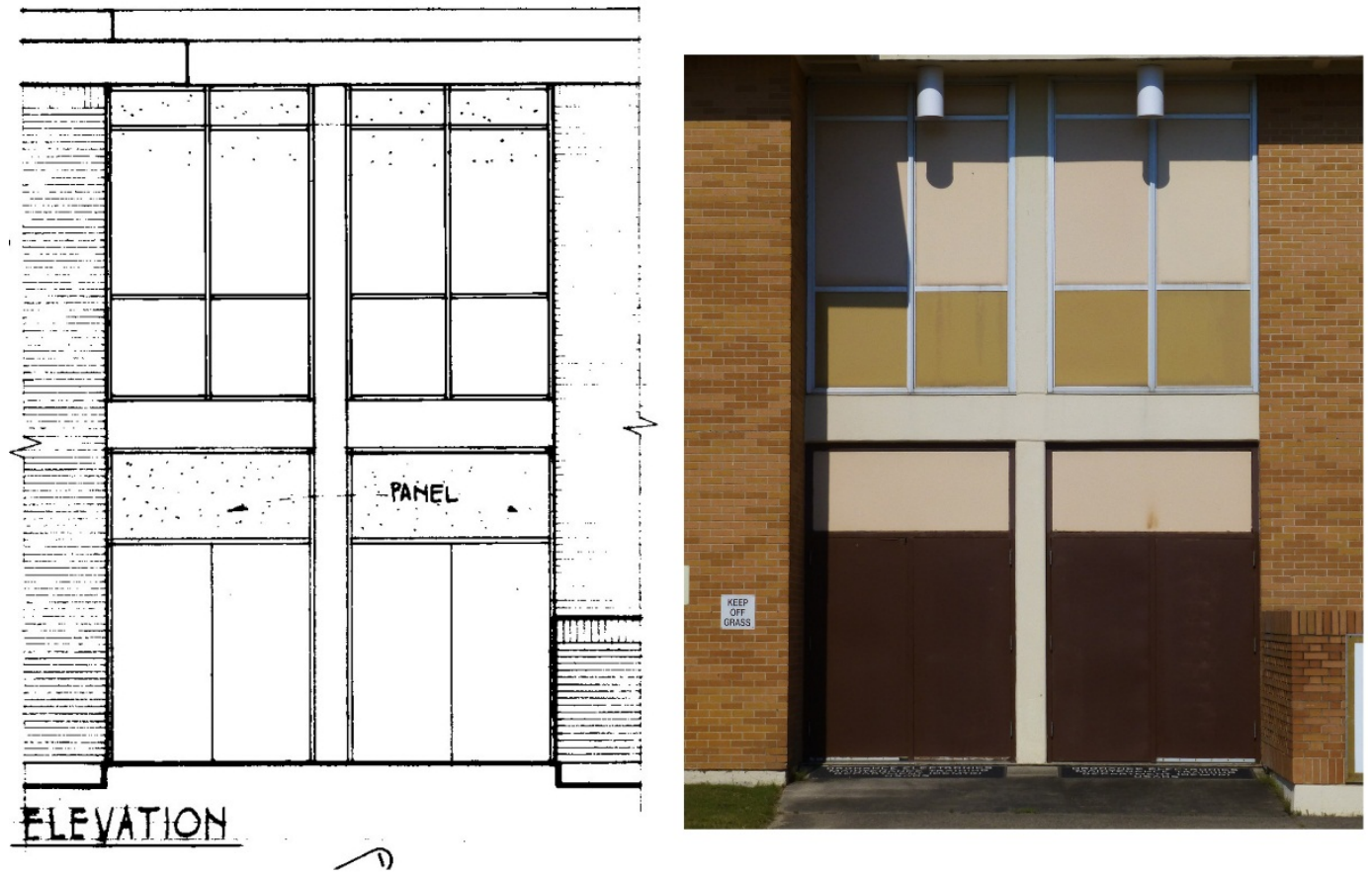

Figure 420. Large window bay on the north and south elevations - comparison of the original design and materials from 1966 [left] to the current condition of the brightaluminum framed insulated panels [right] (ERDC-CERL, 2015).
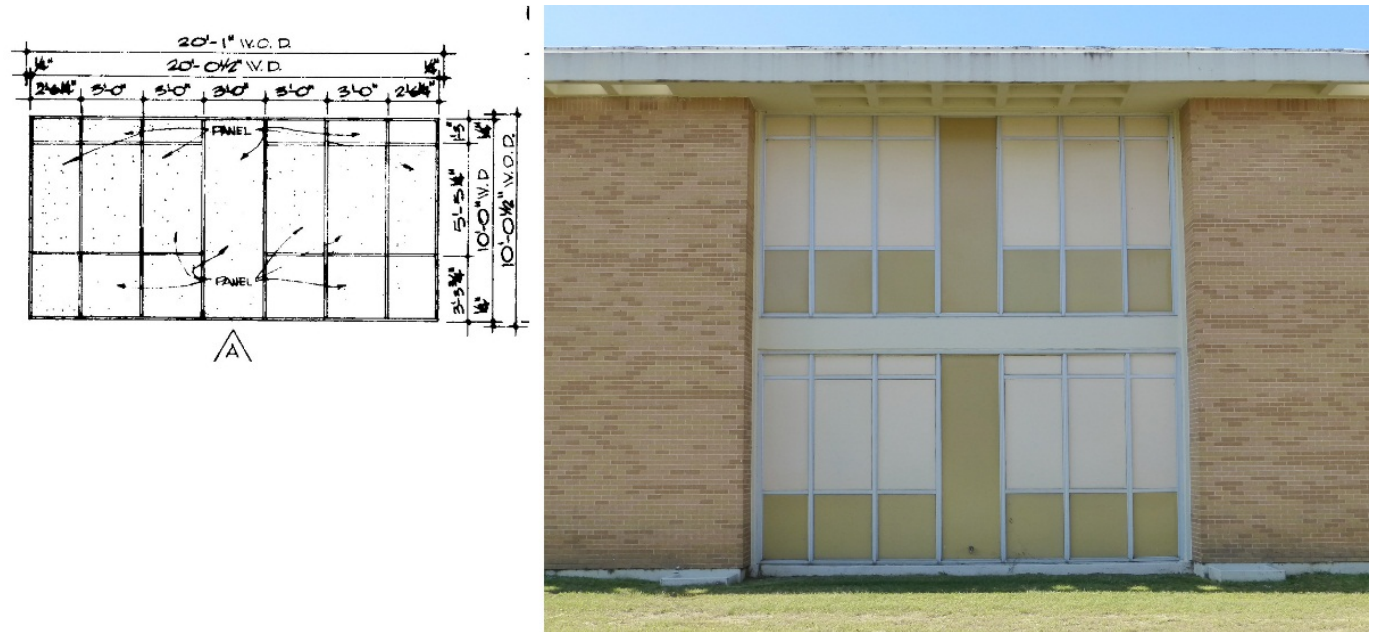
Figure 421. Ceiling-mounted light fixture under concrete canopy - comparison of the original ceiling-mounted light fixture detail drawing from 1966 [left] to the current condition of the replacement light fixture [right] (ERDC-CERL, 2015).

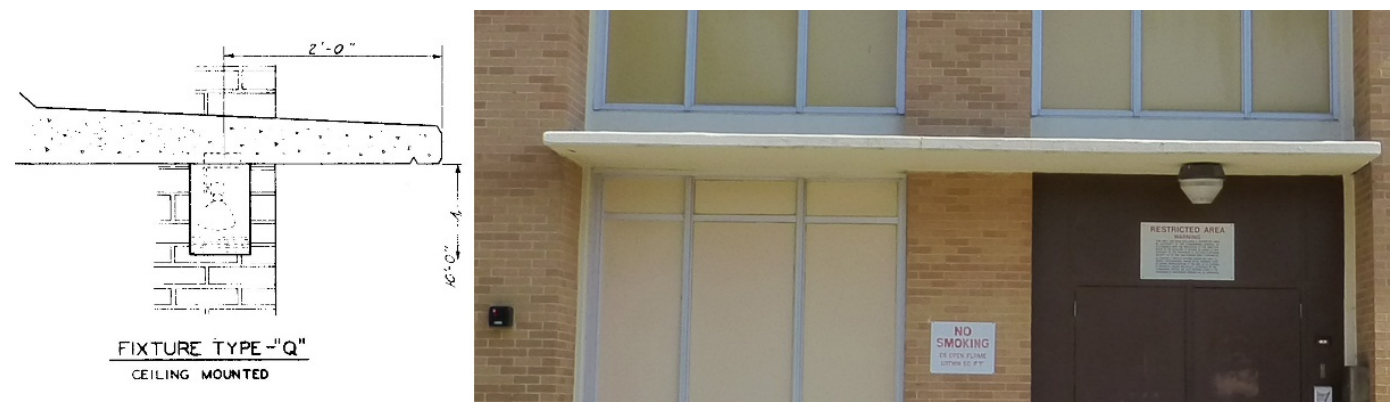

\subsubsection{Building 29818, Johnston Hall (1966)}

Building 29818, Johnston Hall, is a contributing feature to the Signal School Campus Historic District. The interior constructed in 1966 as part of Phase I construction from the campus by architects Aeck Associates from Atlanta, Georgia and Zimmerman, Evans, and Leopold Consulting Engineers from Augusta, Georgia. The building is a long rectilinear classroom building on the eastern edge of the Signal School's campus. Building 29818 is to the east of Building 29813. Building 29818 is two stories high with a basement. The structure is cast-in-place concrete columns with a waffle floor/ceiling system. The second-floor waffle system is set within the structure, but the roof has the waffles extend out to form an overhang. Some of the waffles have been perforated, which create a "light pattern" on the second-floor brick exterior walls. The window system extend the full height of the building and are inset into the brick veneer. The window system is composed of bright-aluminum window frames that enclose insulted panels and three-pane awning-style windows. Tan colored panels are above and below the window. Exposed concrete structural system separates the first and second-floor windows. The south elevation is symmetrical and consists of two large window bays that each have six windows separated by an insulted panel per floor. In addition, two smaller bays on the right and left side of the elevation. One of these smaller bays has three windows per floor, while the other bay has concrete panels on the first floor and three windows on the second floor. The lettering "JOHNSTON HALL" is placed on the south wall. The north elevation has two large window bays similar to the ones on the west elevation. The right side of the elevation has two window bays. One bay has three windows per floor the other bay has two windows per floor. The left side of the elevation has one window bay with three windows per floor. There is an outside access point to the basement on the north side of the building. The entry is defined by 
poured concrete walls, concrete steps, and metal handrails. The lettering "JOHNSTON HALL" is placed on the north wall. The primary entrances to the building are on the east and west elevations. The entries are recessed under the second floor and consists of two sets of metal doors with panes and transoms above. The second floor of these entry bays consists of are two sets of metal and plate-glass doors with a transom above each set of doors. These doors are welded closed with a steel bar across the middle. It appears bridges were meant to connect the various buildings together at the second-floor level. A brick plaza is located on the west side of the building (Figure 422-Figure 435).

Figure 422. Signal School Campus map, with Building 29818, Johnston Hall highlighted in red, 2015 (Fort Gordon DPW, modified by ERDC-CERL).

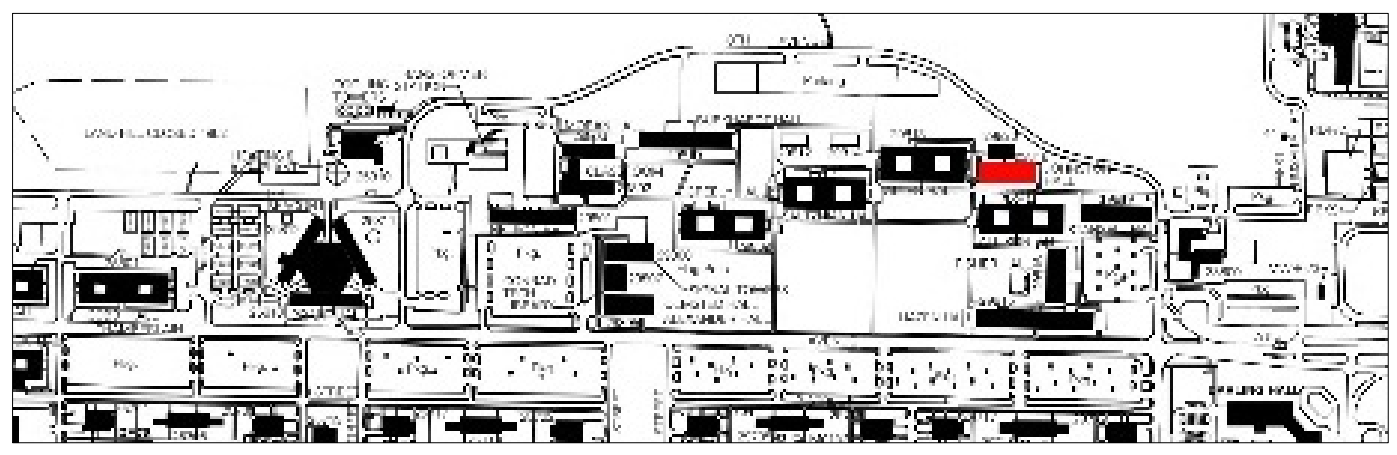


Figure 423. North elevation of Building 29818, Johnston Hall (ERDC-CERL, 2015).

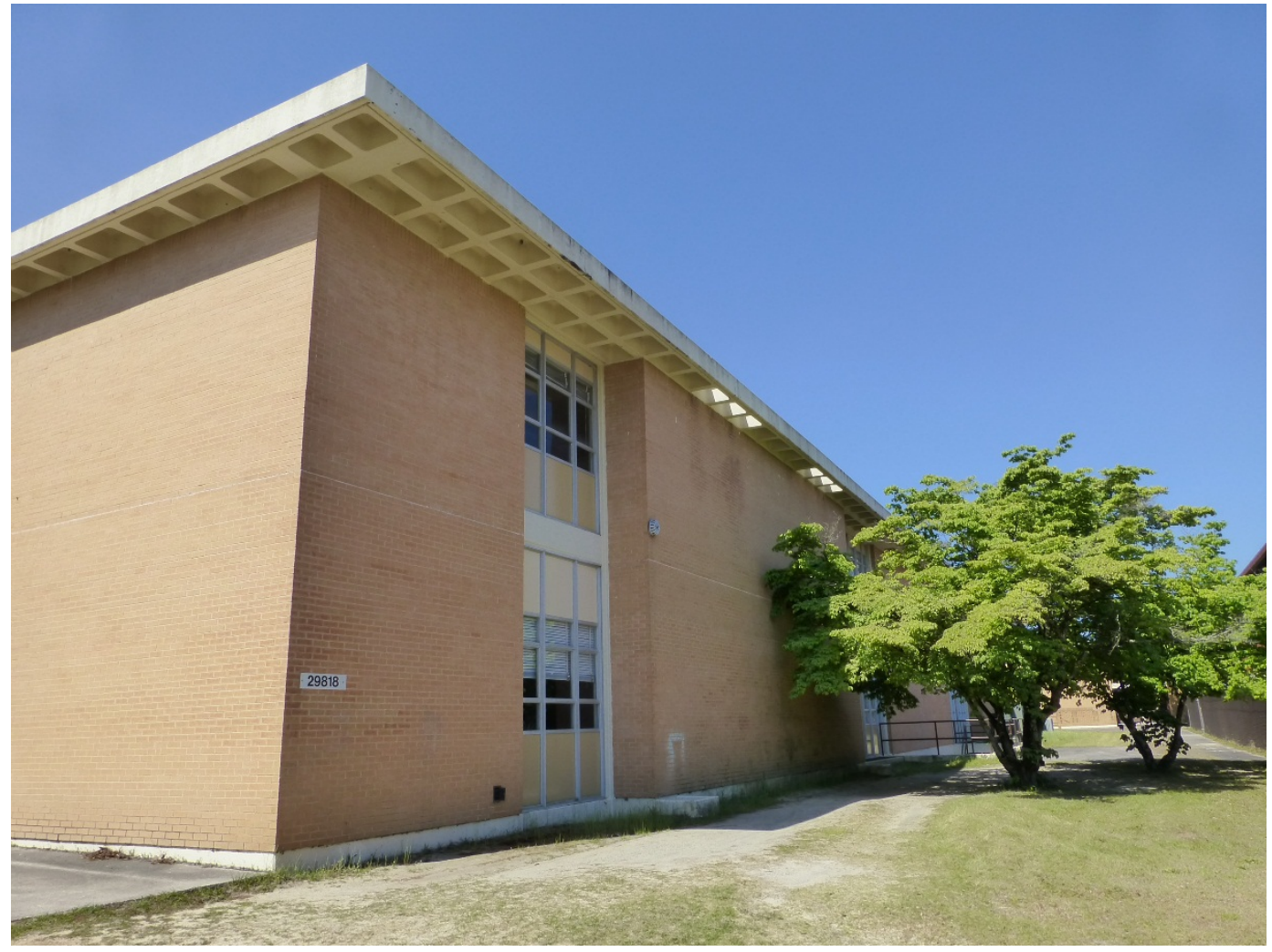

Figure 424. East elevation of Building 29818, Johnston Hall (ERDC-CERL, 2015).

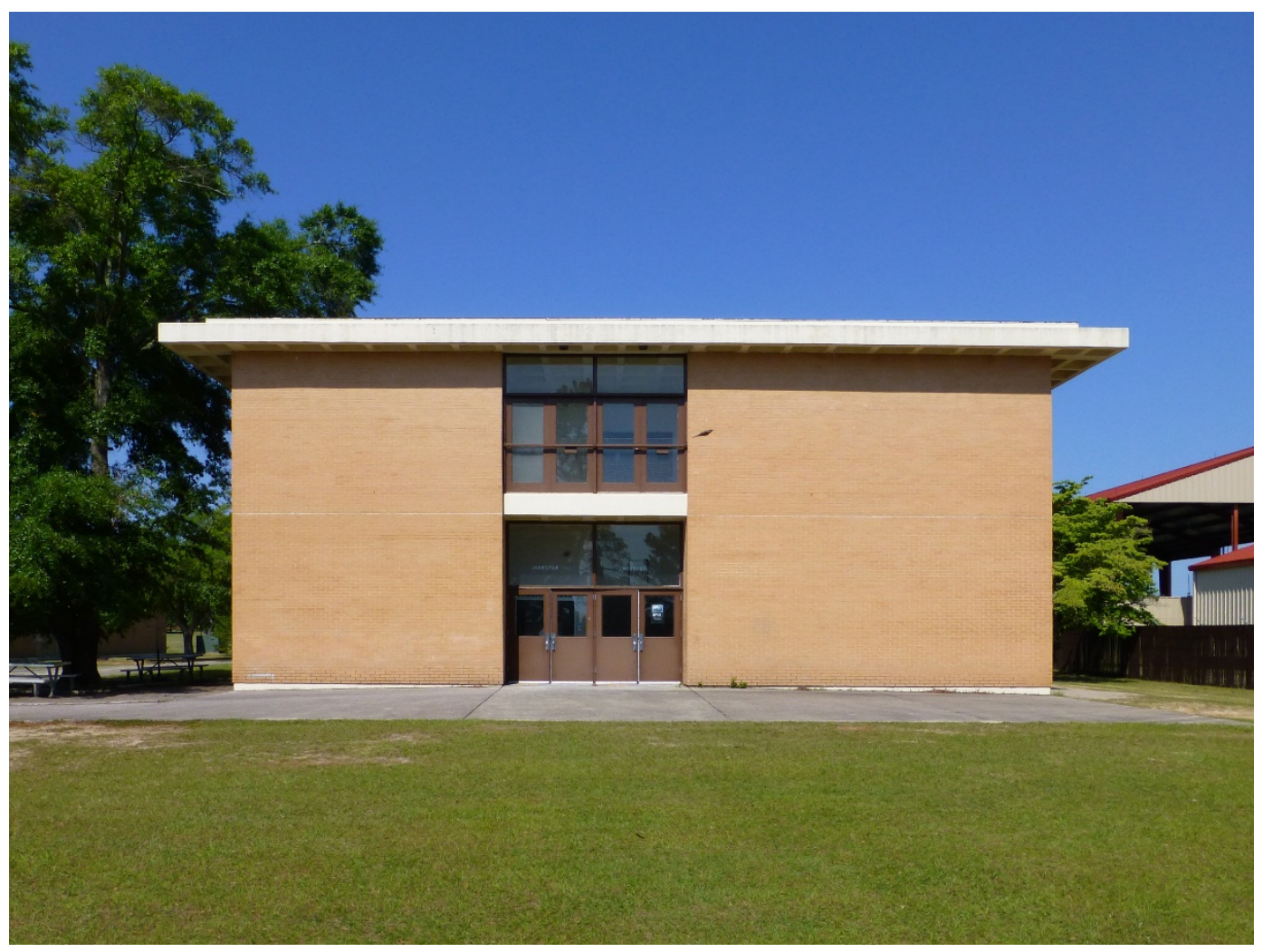


Figure 425. Southwest oblique, Johnston Hall (ERDC-CERL, 2015).

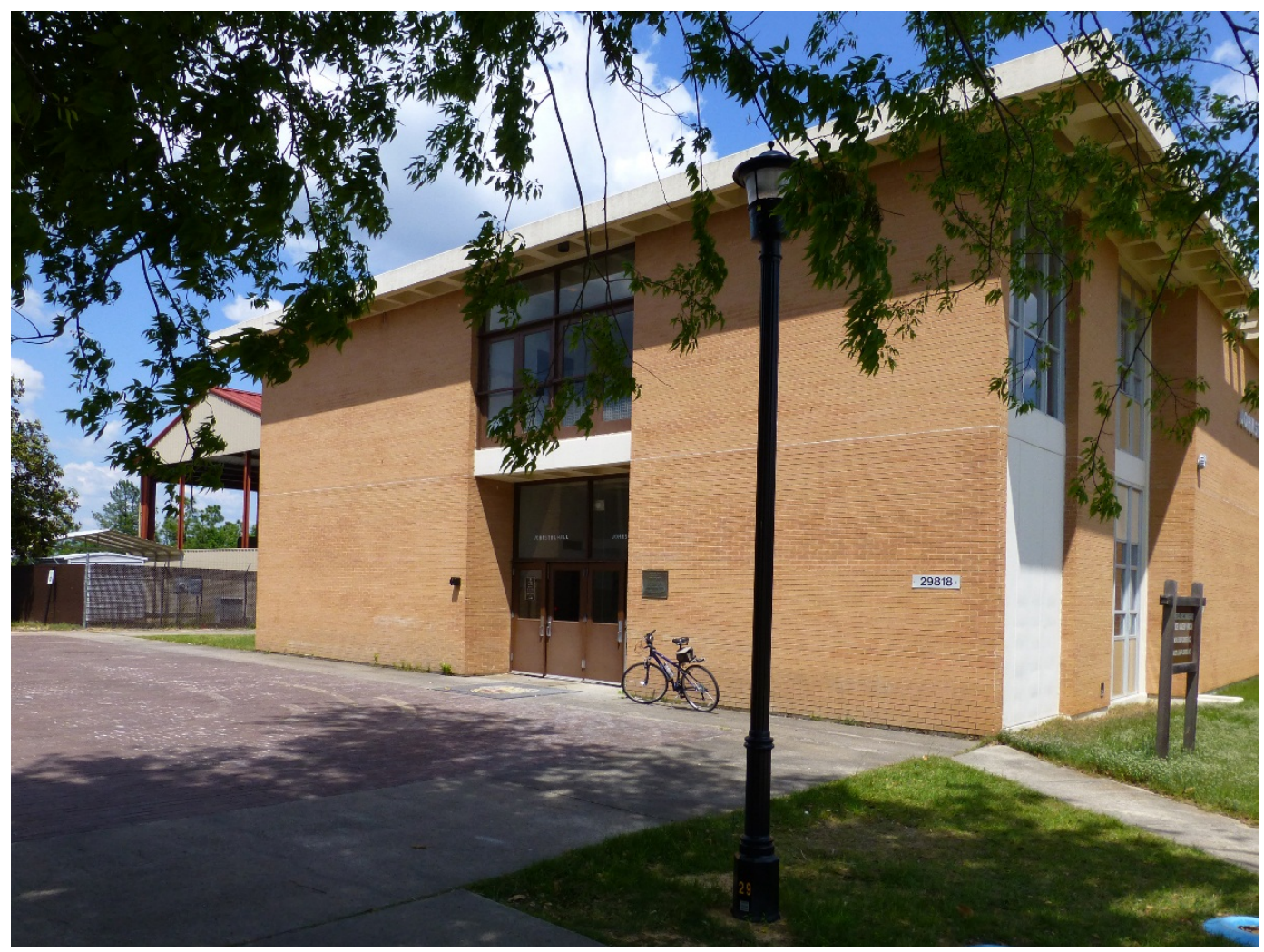

Figure 426. Left side of the south elevation of Building 29818, Johnston Hall (ERDC-CERL, 2015).

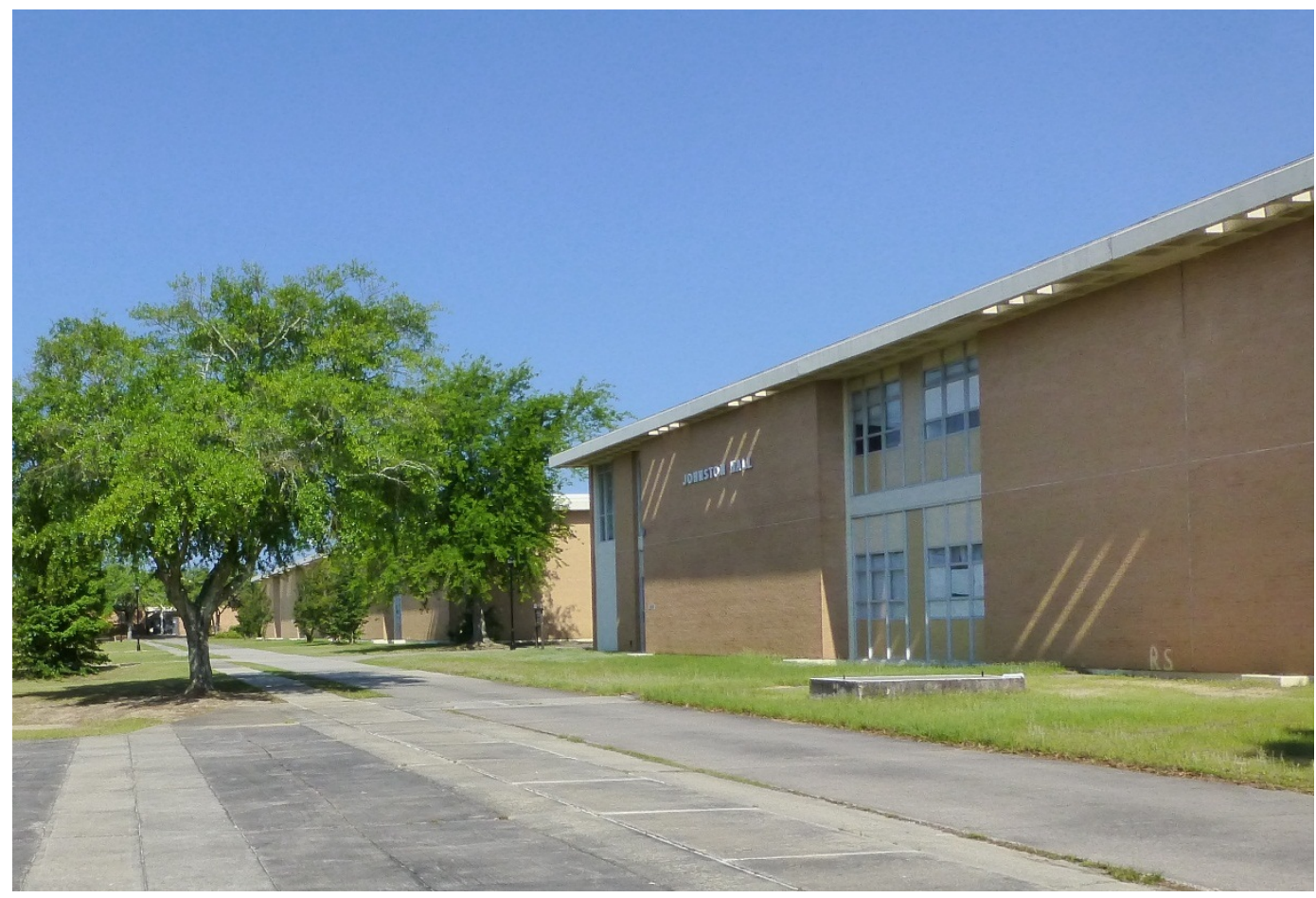


Figure 427. View of Signal School construction, southeast corner of Building 29818 in the front then 29813, 29811, and 29809 back left photo, March 1966 (National Archives College Park, MD).

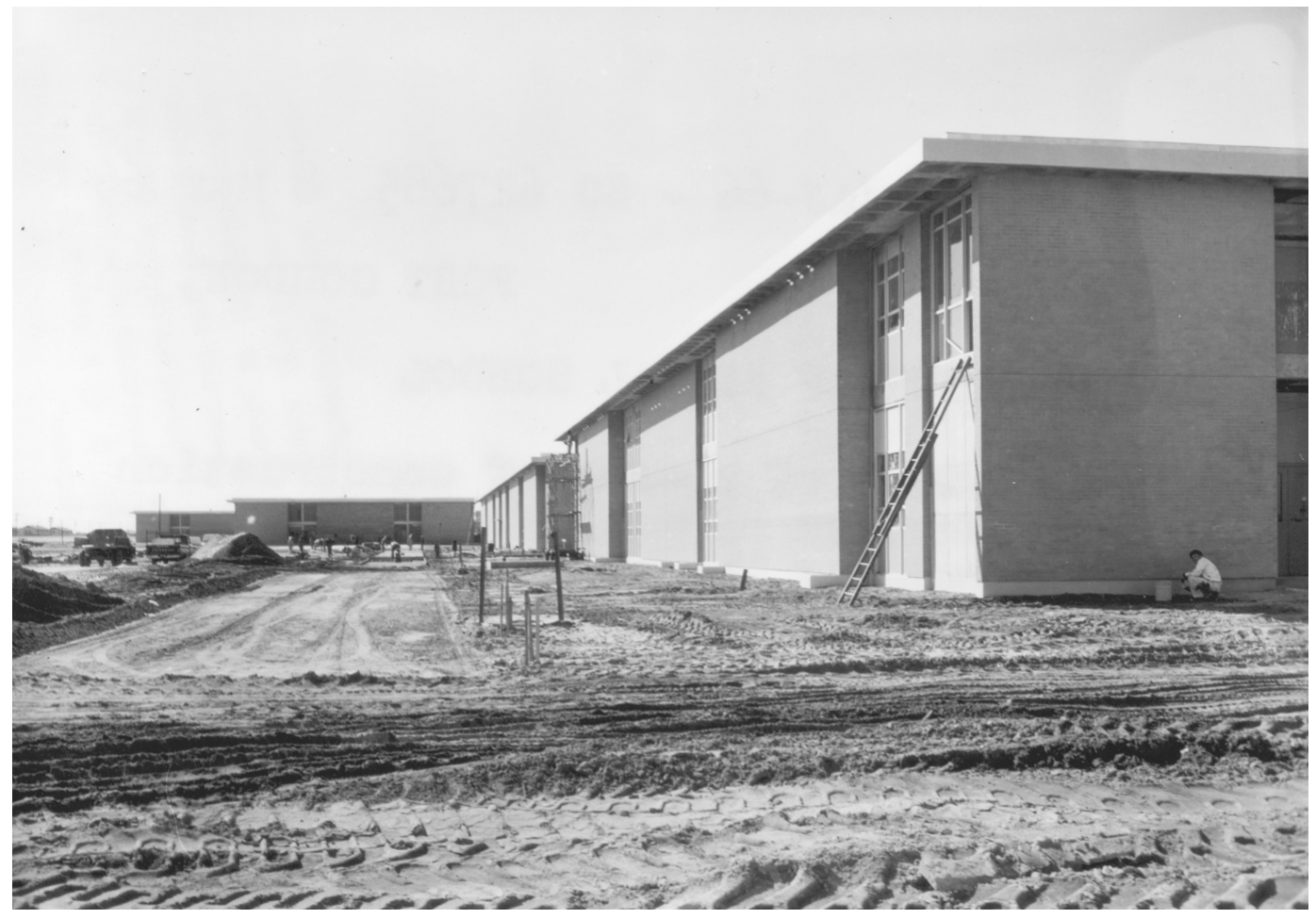

Figure 428. Elevations of Building 29816, Fisher Hall [left side] and Building 29818, Johnston Hall [right side], 1964 (Fort Gordon DPW).

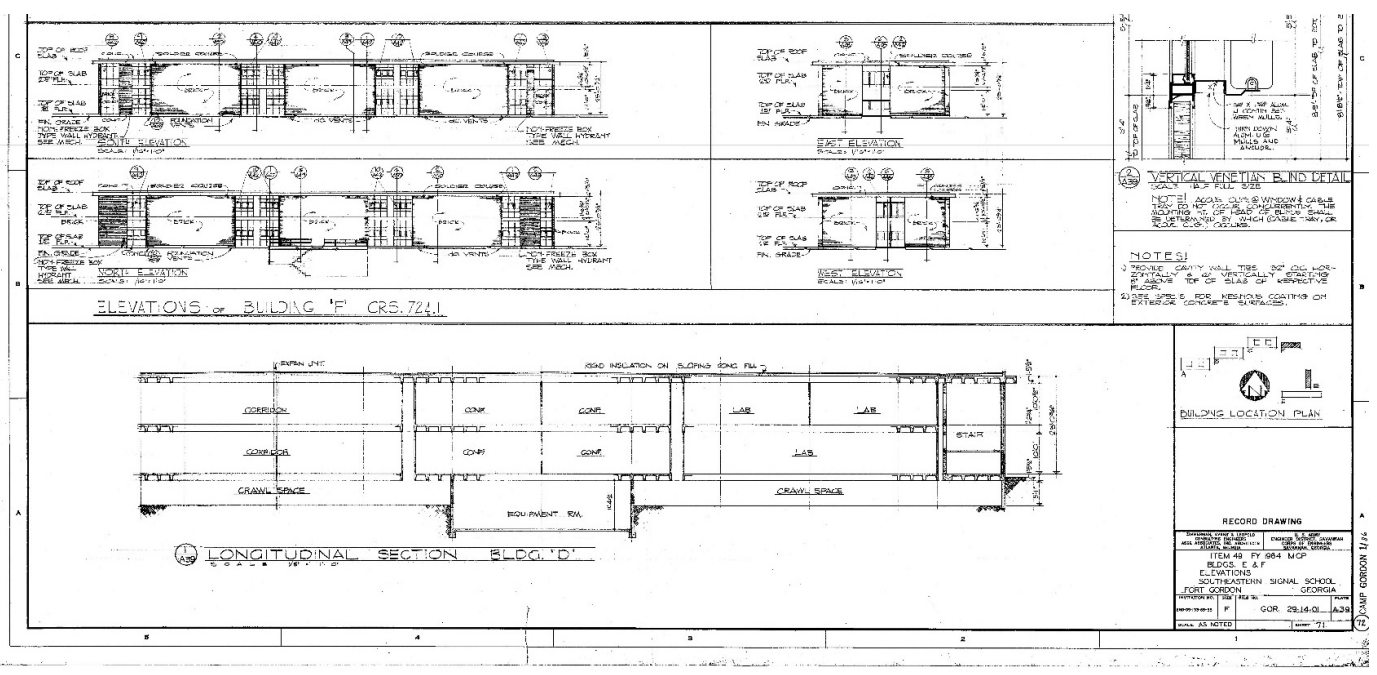


Figure 429. First-floor plan and window schedule for Building 29818, Johnston Hall, 1964 (Fort Gordon DPW).

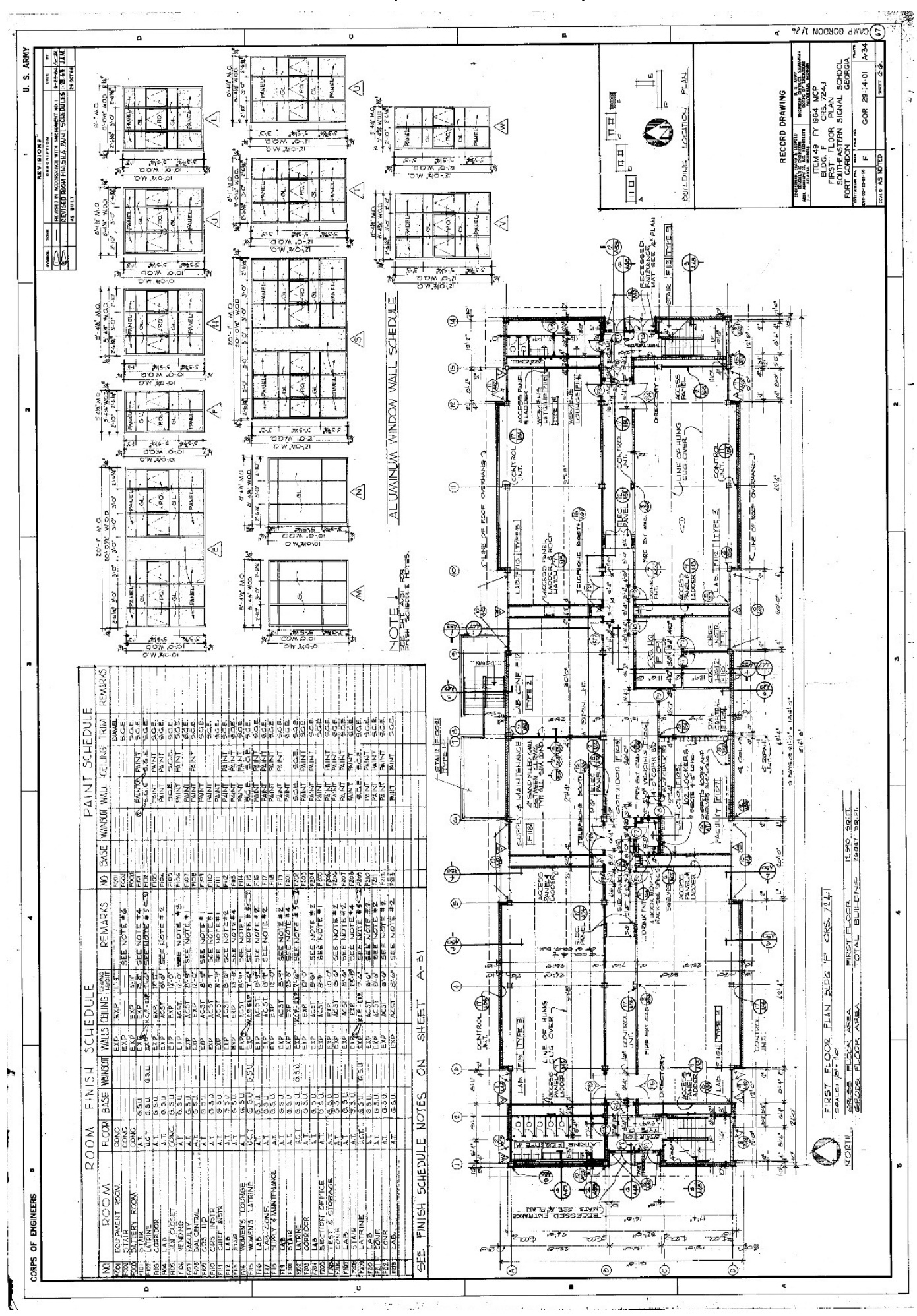


Figure 430. Section detail of concrete waffle ceiling and roof construction for Building 29818, Johnston Hall, 1964 (Fort Gordon DPW).

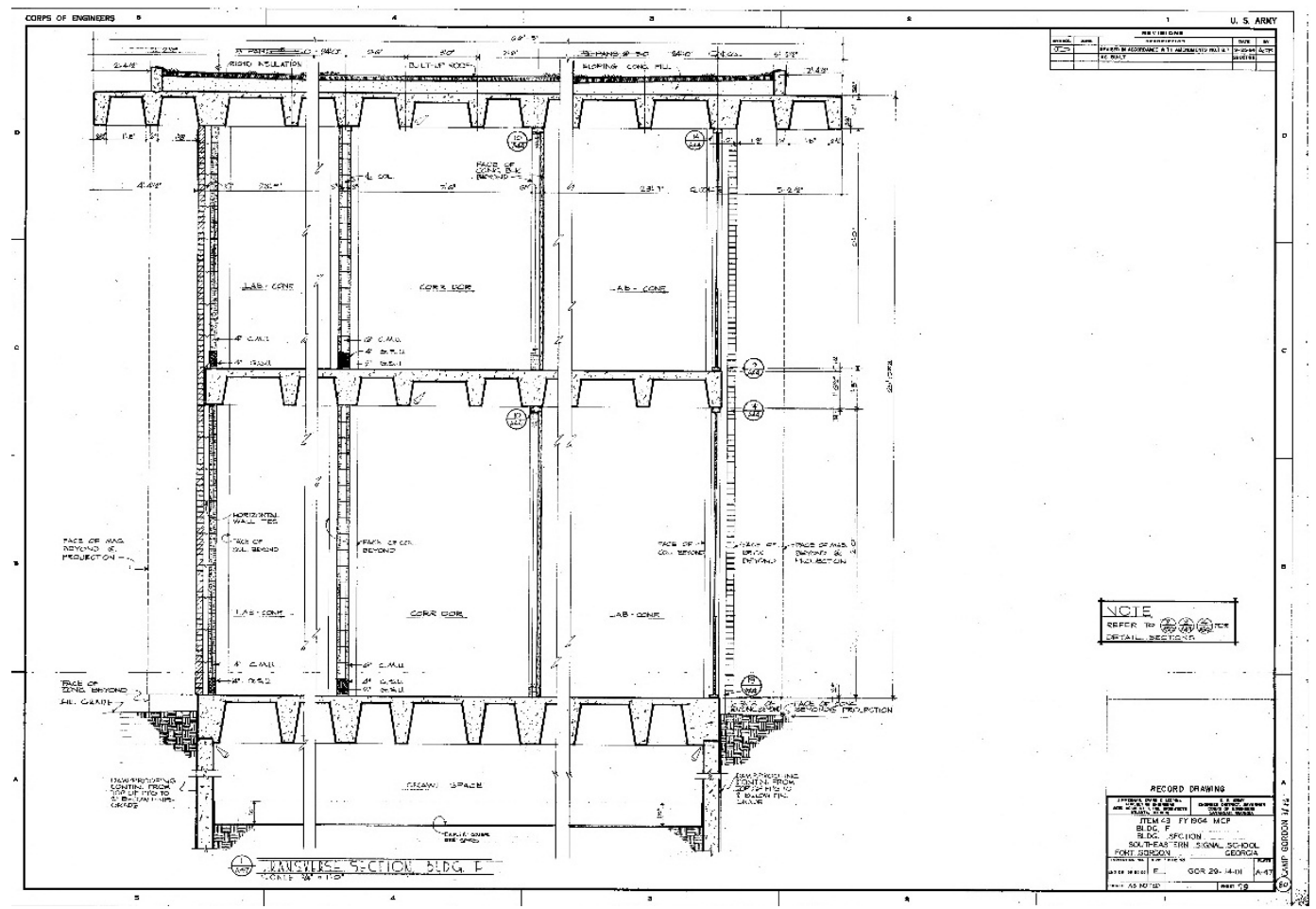

Figure 431. Stairwell plans and sections for Building 29818, Johnston Hall, 1964 Fort Gordon DPW).

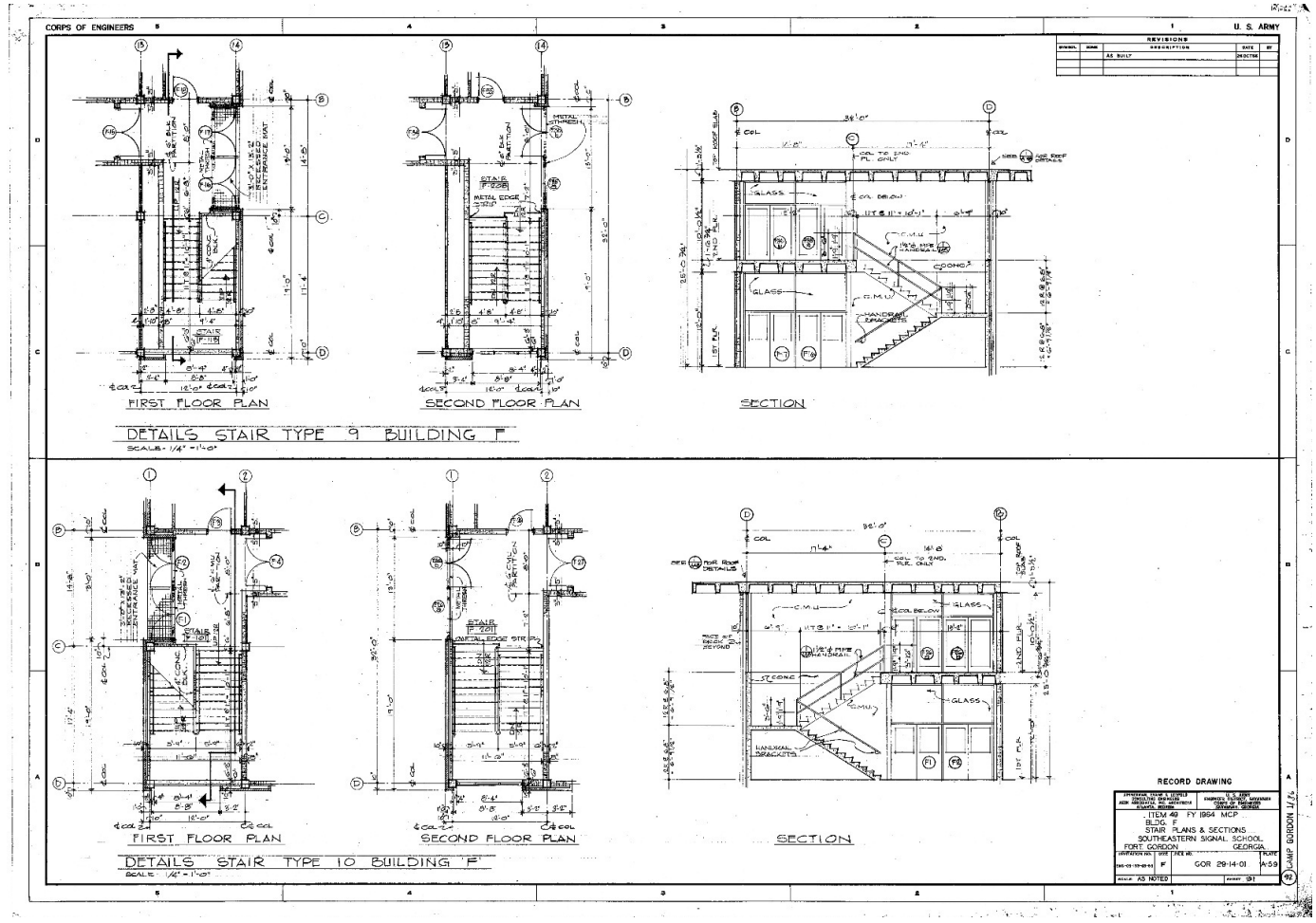


Figure 432. Typical classroom elevations and details for Building 29818, Johnston Hall, 1966 (Fort Gordon DPW).

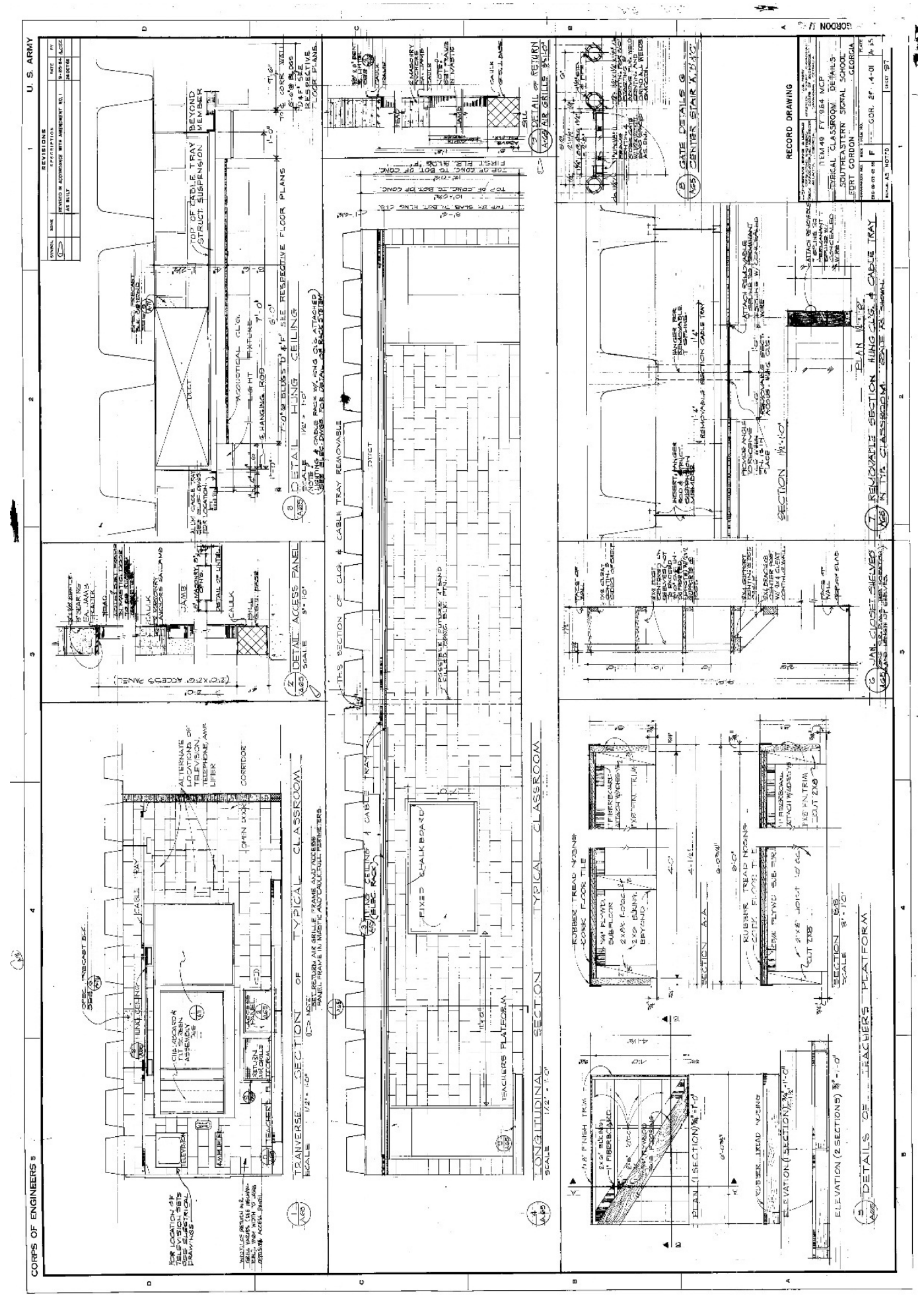


Figure 433. Latrine plans, elevations, and details for Building 29818, Johnston Hall, 1964 (Fort Gordon DPW).

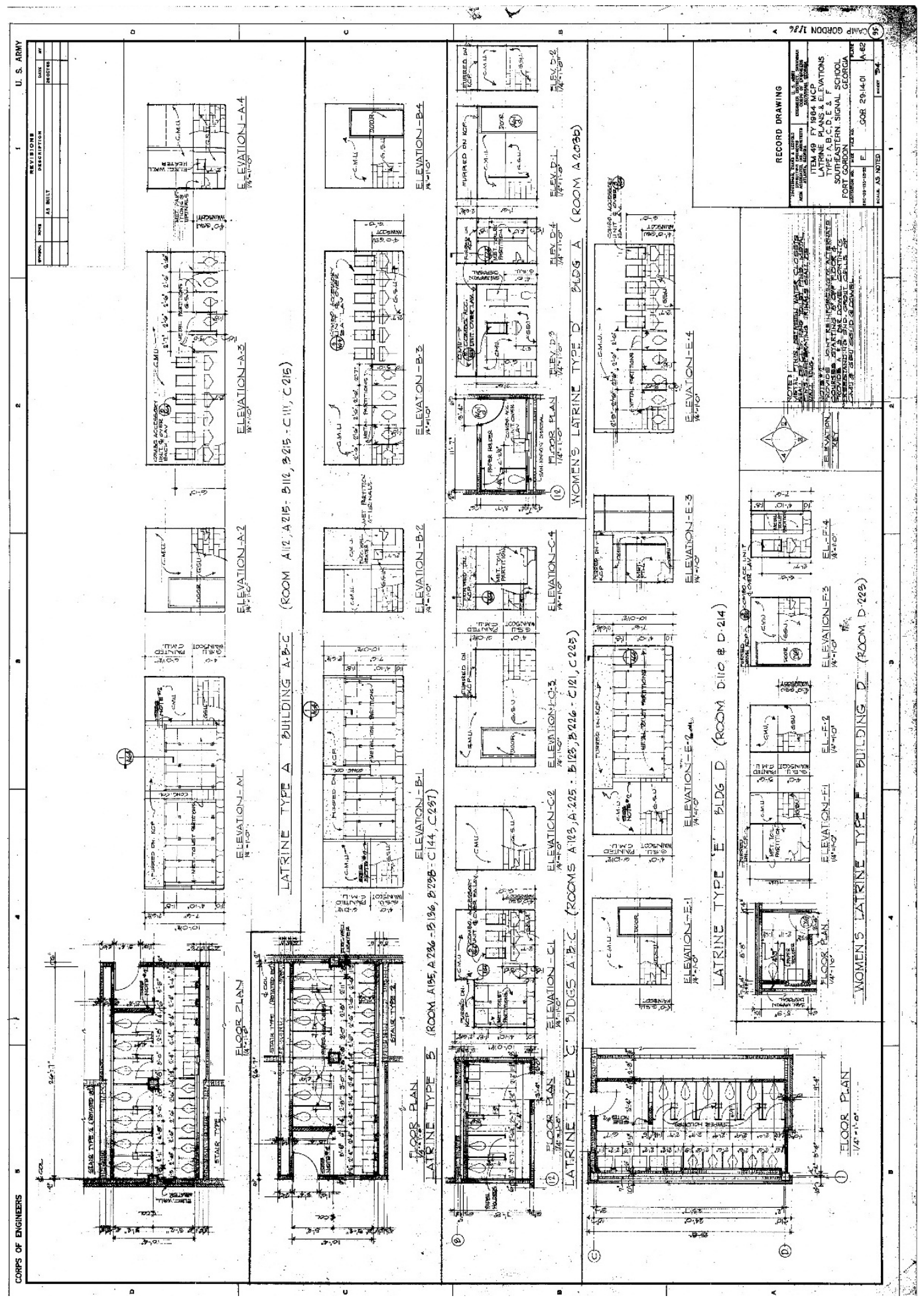


Figure 434. Light fixture types and schedule, 1966 (Fort Gordon DPW).

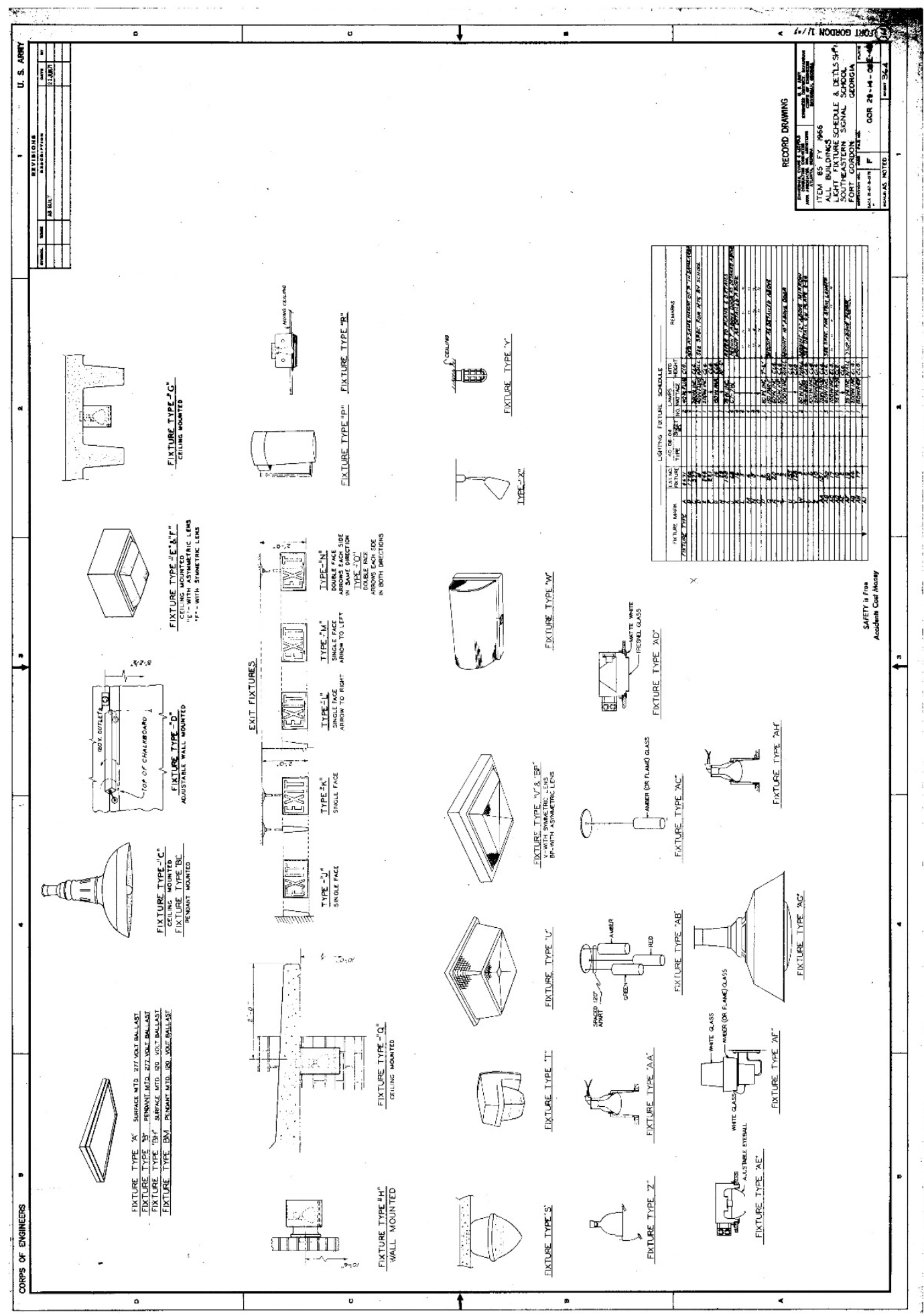


Figure 435. Landscape plan for Building 29818, Johnston Hall, 1966

(Fort Gordon DPW).

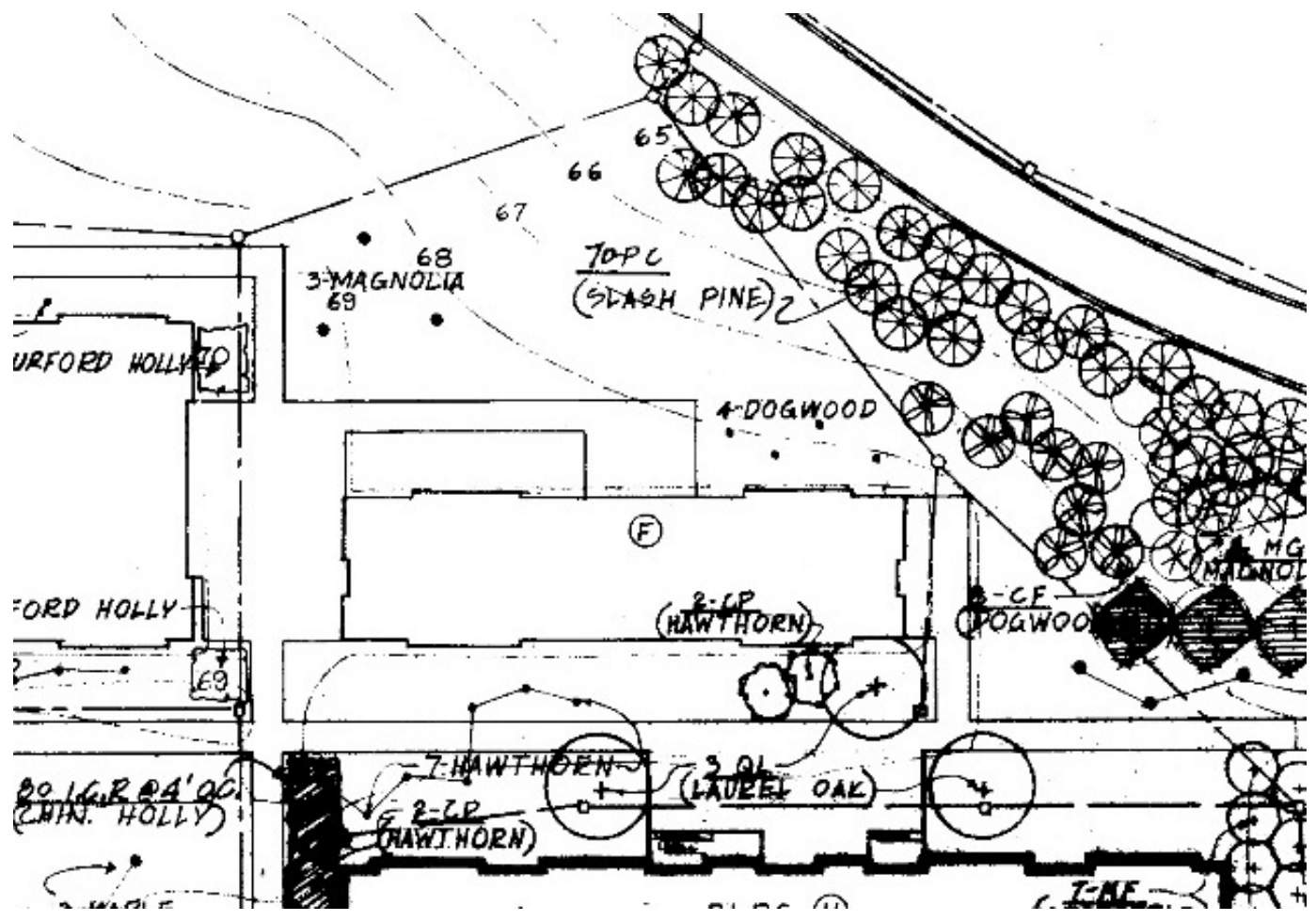

\subsubsection{Character-defining features}

Repair, renovation, and replacement of Building 29818, Johnston Hall must be coordinated with the GA SHPO (Table 17).

\section{Exterior:}

- Overall massing

- Footprint

- Roof shape

- Brick veneer

- Relationship to other Signal School Campus buildings

- Overhanging eaves with perforated waffle construction casting "light pattern" on exterior brick walls

- Exposed concrete structure framing window and door openings

- Window pattern

- Recessed bays of bright-aluminum sash windows with three-pane awning-style windows sandwiched between insulated panels

- Concrete panel inserts

- Metal doors with large pane

- Metal doors with plate glass 
- Ceiling-mounted light exterior fixtures set within the waffle overhang

- Lettering

- Metal handrails

\section{Interior:}

- Overall plan

- Main stairwells

- Main hallways

- Lighting

- Doors

- Display cases

- Signage

- Telephone alcoves

- Tiled water fountain alcoves

Table 17. Images of character-defining features of Building 29818, Johnston Hall (ERDC-CERL, 2015).

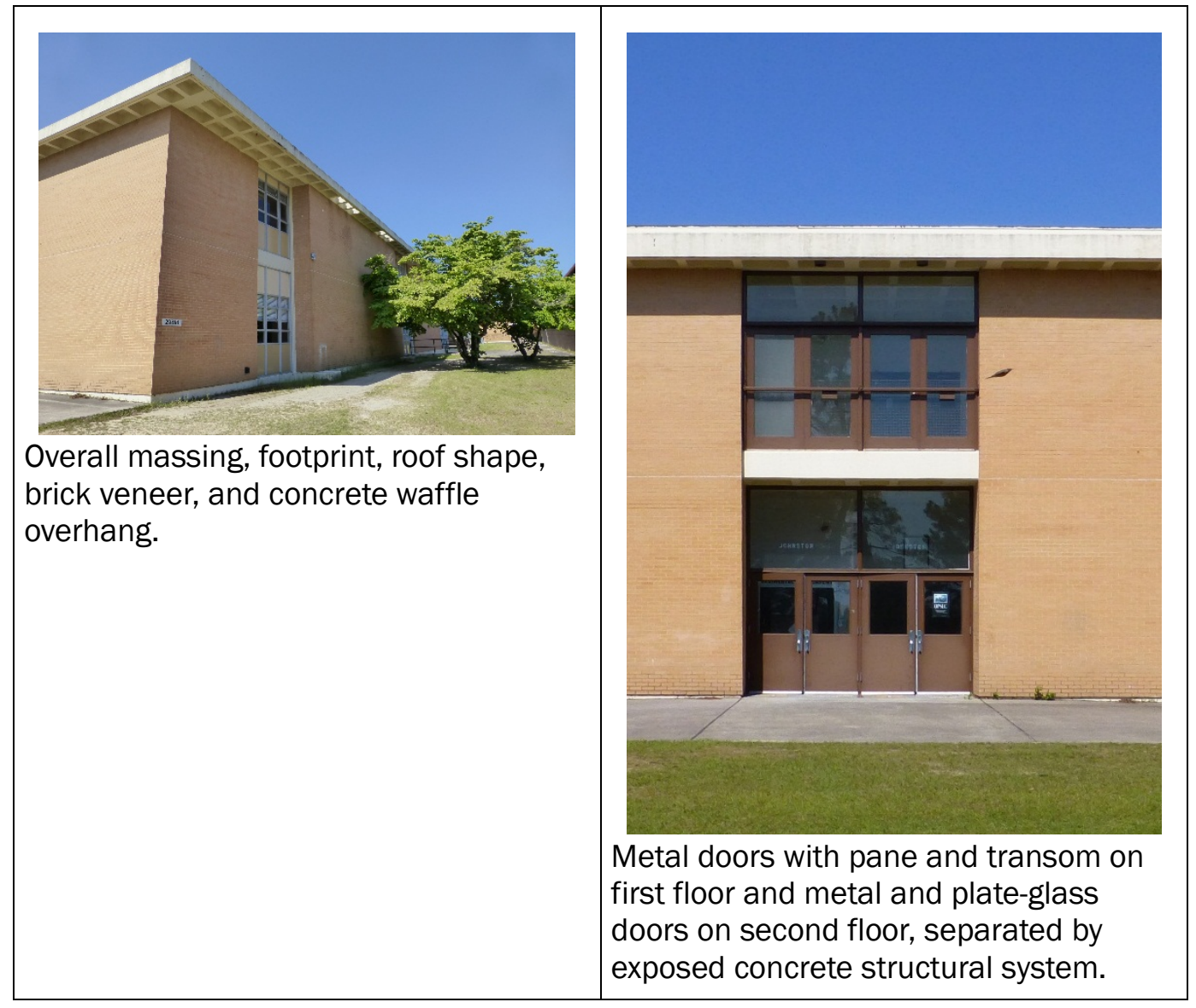




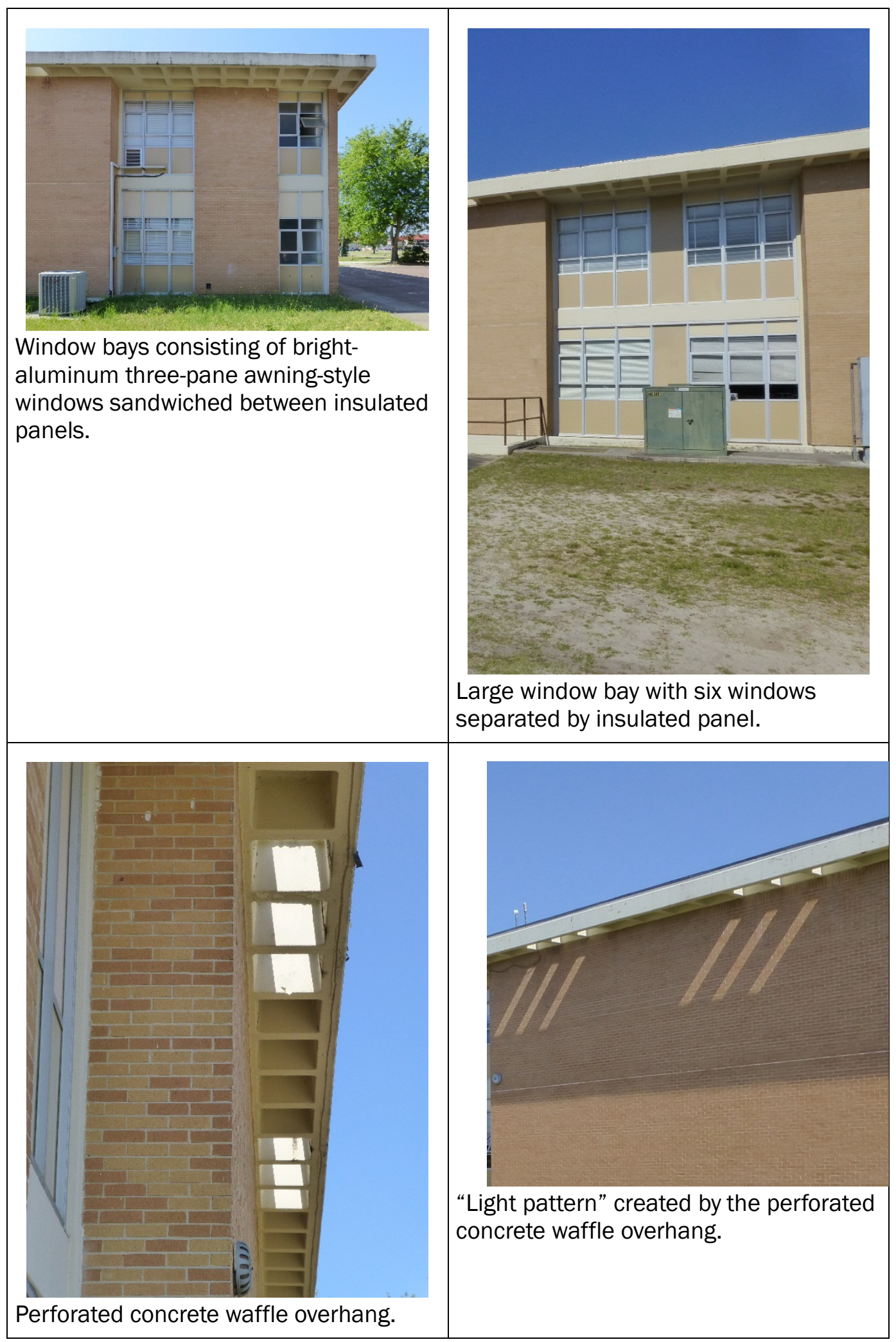




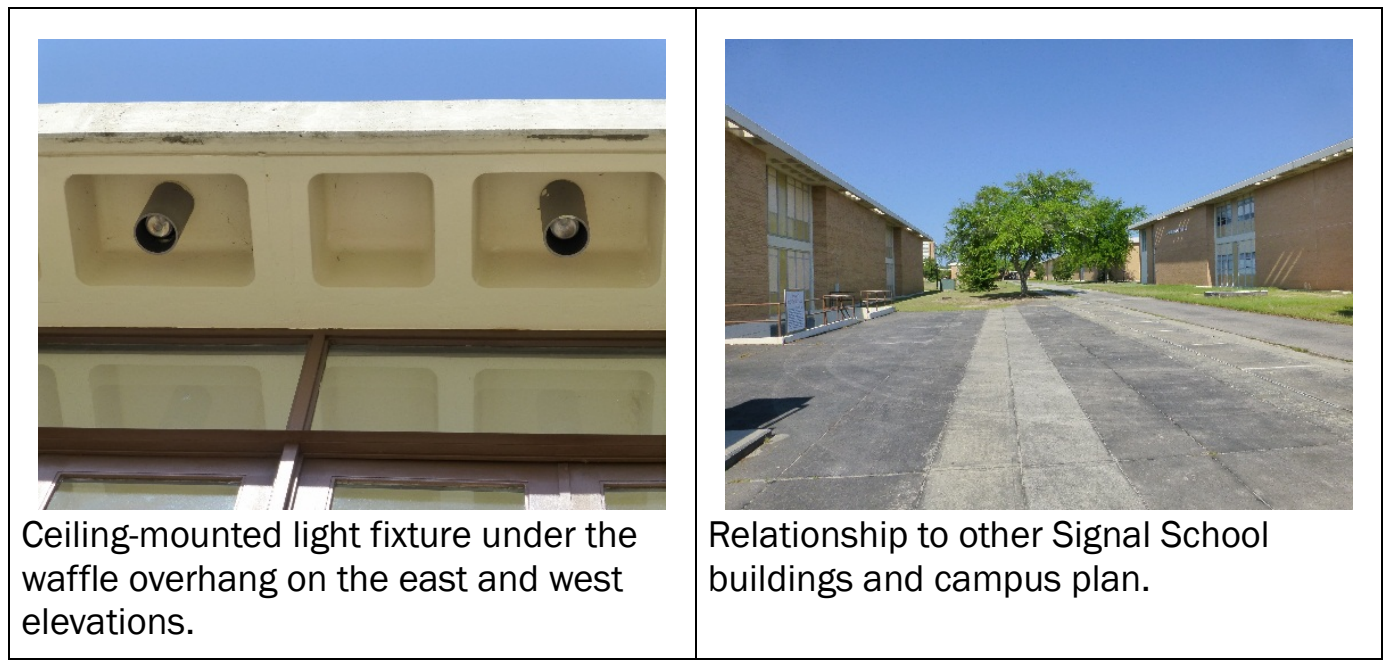

3.3.15.2 Character-defining features that have been removed

- None.

\subsubsection{Nonhistoric features}

- None.

\subsubsection{Comparison images}

Comparison images utilizing either the original drawings or historic photographs, when juxtaposed against present-day images, are a useful tool in developing the historic "feel" of a property and how much of that historic feeling is still present today (Figure 436-Figure 439). 
Figure 436. East window group - comparison of the original design and materials from 1964 [left] to the current condition of the bright-aluminum sash windows and insulated panels [right] (ERDC-CERL, 2015).

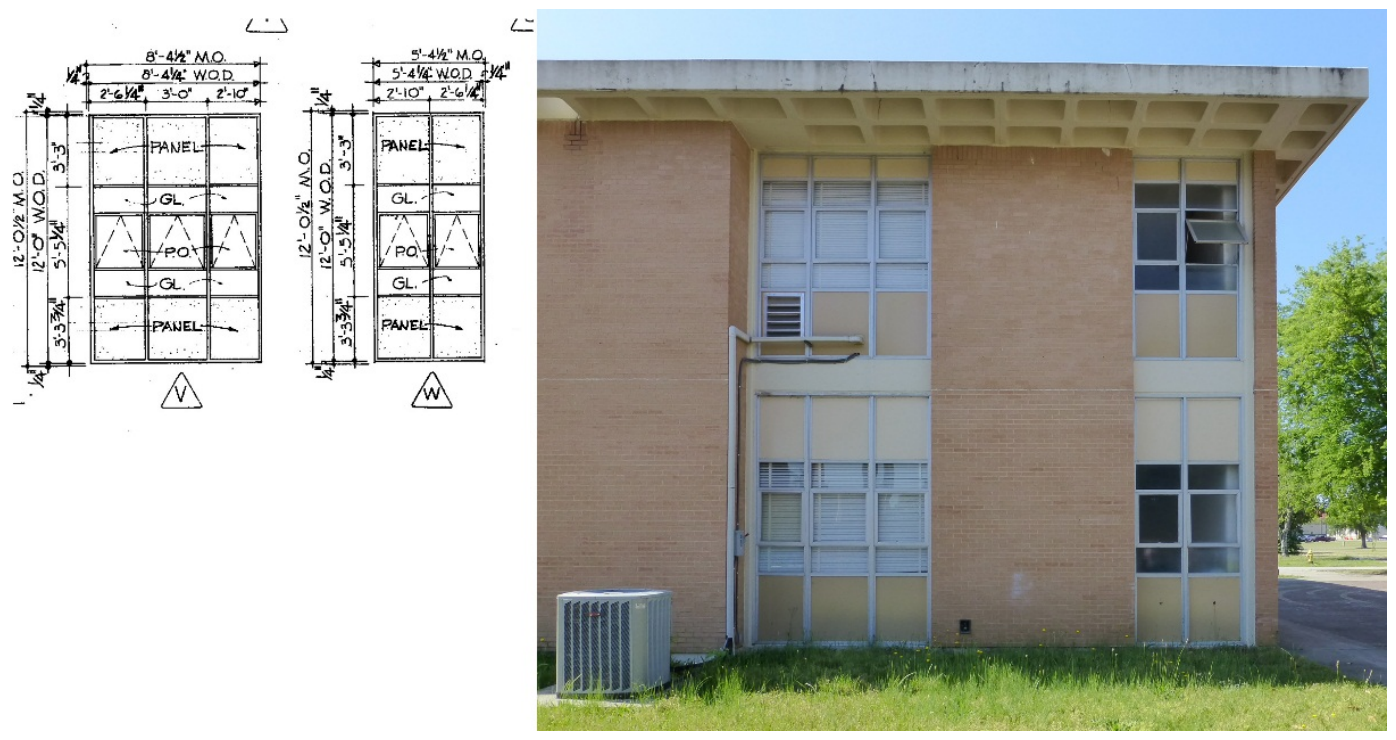

Figure 437. Large window group - comparison of the original design and materials from 1964 [left] to the current condition of the bright-aluminum three-pane awningstyle windows with insulated panels and exposed concrete structure [right]

(ERDC-CERL, 2015).

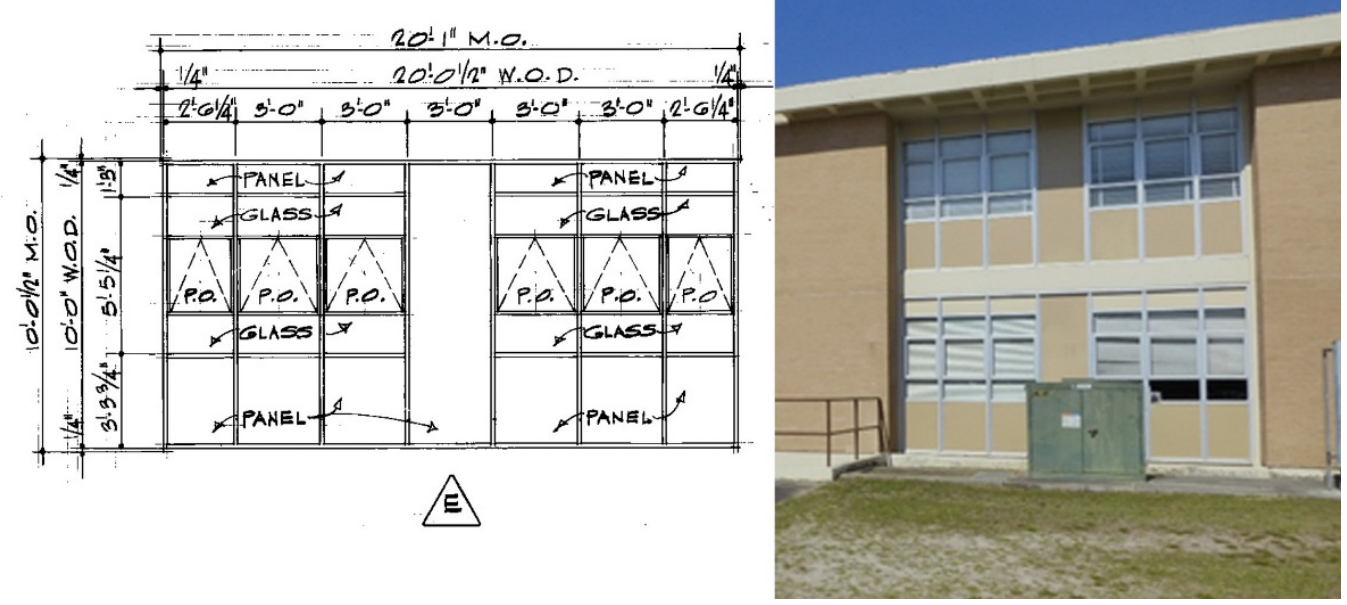


Figure 438. East and west entries - comparison of the original design and materials detail drawing from 1964 [left] to the current condition of the metal and pane doors with transom and the metal and plate-glass doors with transoms [right]

(ERDC-CERL, 2015).
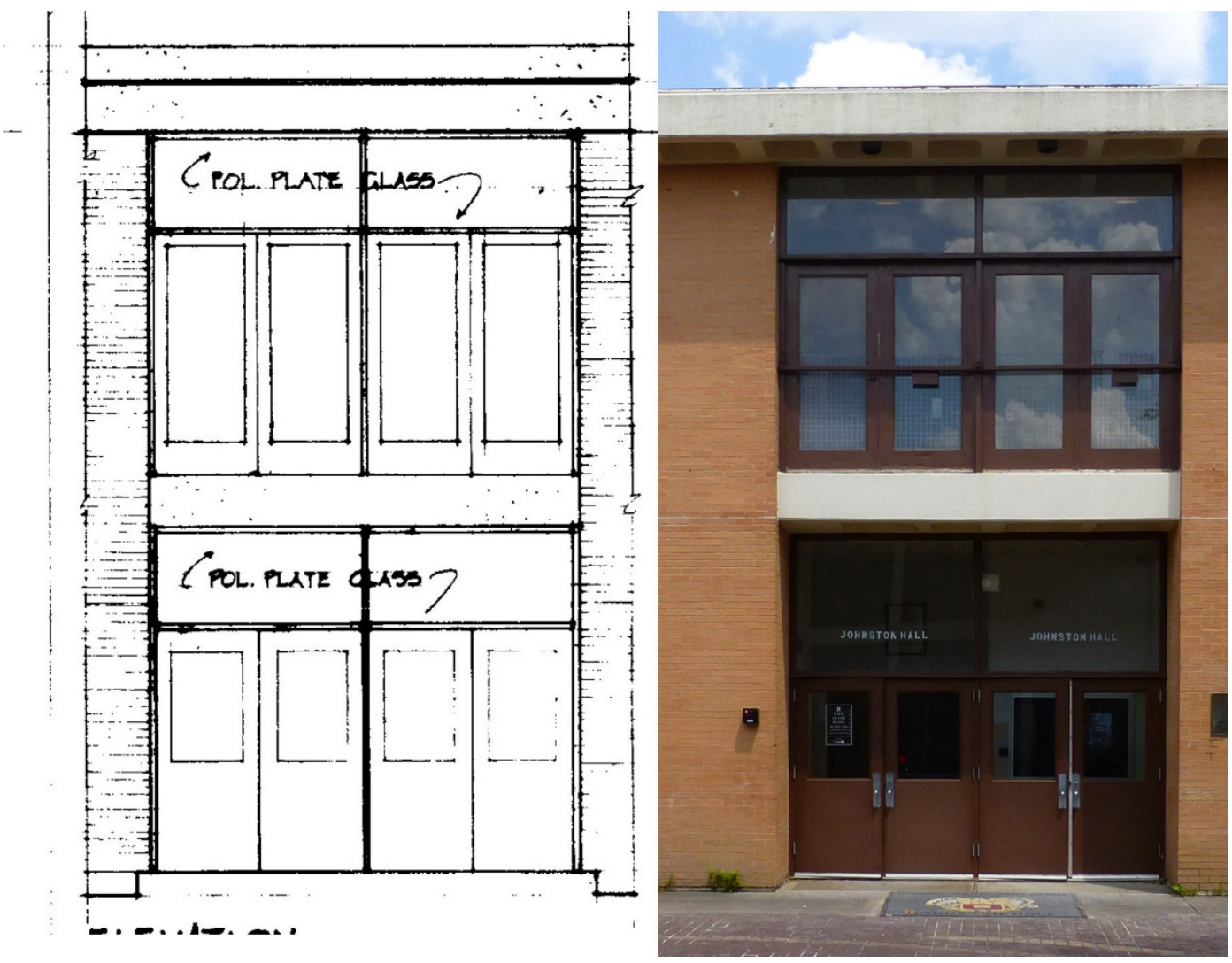

Figure 439. Ceiling-mounted light fixture under the waffle overhang - comparison of the original design and material from 1966 [left] to the current condition of the ceiling-mounted light fixture [right] (ERDC-CERL, 2015).
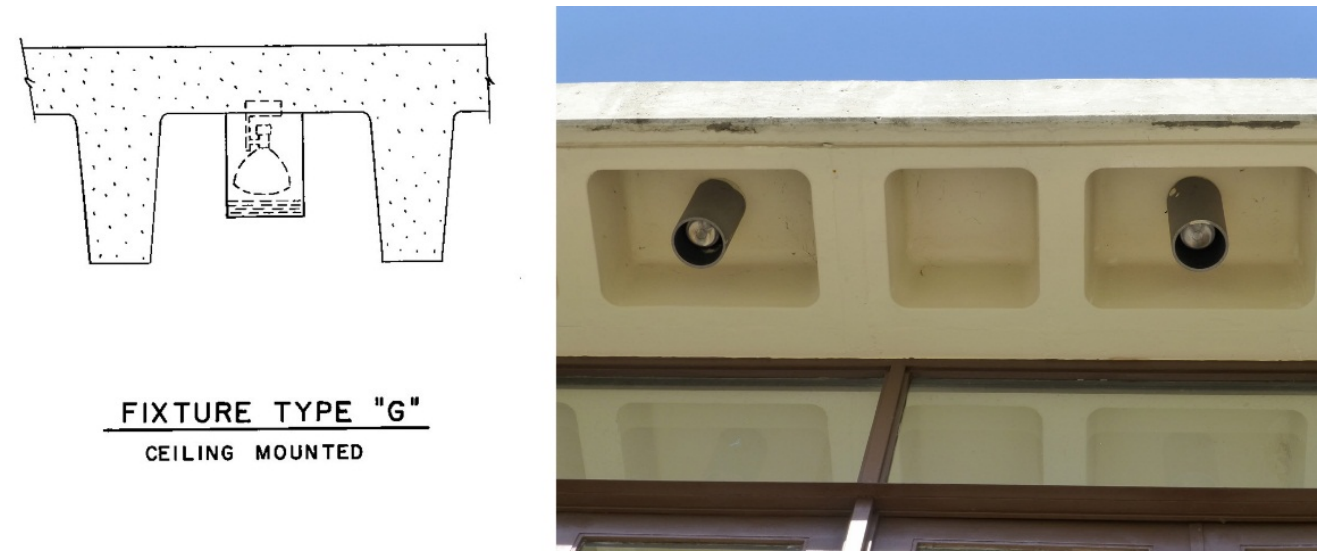


\subsubsection{Building 29819, Stansell Hall (1970)}

Building 29819, Stansell Hall, is a contributing feature to the Signal School Campus Historic District. The interior is contributing. It was constructed in 1970 during the Phase II construction of the campus and was designed by Aeck Associates from Atlanta, Georgia, and Zimmerman, Evans, and Leopold Consulting Engineers from Augusta, Georgia. Building 29819 is a long rectilinear classroom building on the eastern edge of the school, north of the eastern parking lot. It is two-stories high with a partial basement. The structure is cast-in-place concrete columns with a waffle floor/ceiling system. The second-floor waffle system is set within the structure, but the roof has the waffles extending out to form an overhang. Some of the waffles have been perforated. The window systems extend the full height of the building and are inset into the brick veneer. Building 29819 appears to have been constructed without actual windows, though. The window systems are composed of bright-aluminum window frames that enclose two different panels. A maize-colored panel is in lieu of awning windows, with a tan-colored panel above and below. The main entrance is on the west elevation and is composed of a one-story entrance vestibule with two sets of double steel doors. The south elevation consists of three large window bays that are placed in the middle of the elevation. Each bay is six windows, with a dividing panel insert. The left side has two small bays. Each bay is three windows/panels wide. The right side has two small bays. One bay is three windows/panels wide and the other is two windows/panels wide. The lettering "STANSELL HALL" is placed on the middle of the south wall. The east elevation consists of an entry bay which is two sets of metal doors, with panel inserts above and four bright-aluminum framed panels on the second floor. The north elevation is symmetrical. There are three large window bays similar to the ones on the south elevation. The left and right sides each have two smaller bays. One of the bays has concrete panels on the first floor and three windows/panels on the second floor. The other bay is three windows/panels wide. There are two outside access points to the basement on the north side of the building and each is defined by poured concrete walls, concrete steps, and metal railings (Figure 440Figure 449). 
Figure 440. Signal School Campus map, with Building 29819, Stansell Hall, highlighted in red, 2015 (Fort Gordon DPW, modified by ERDC-CERL).

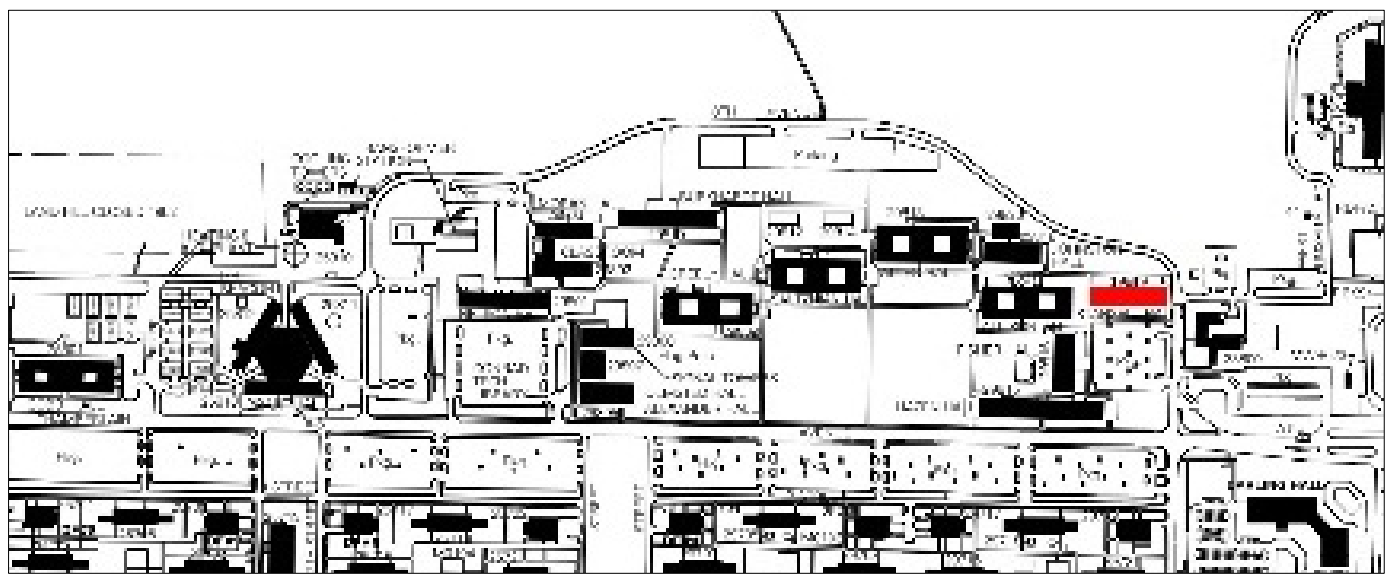

Figure 441. South elevation of Building 29819, Stansell Hall (ERDC-CERL, 2015).

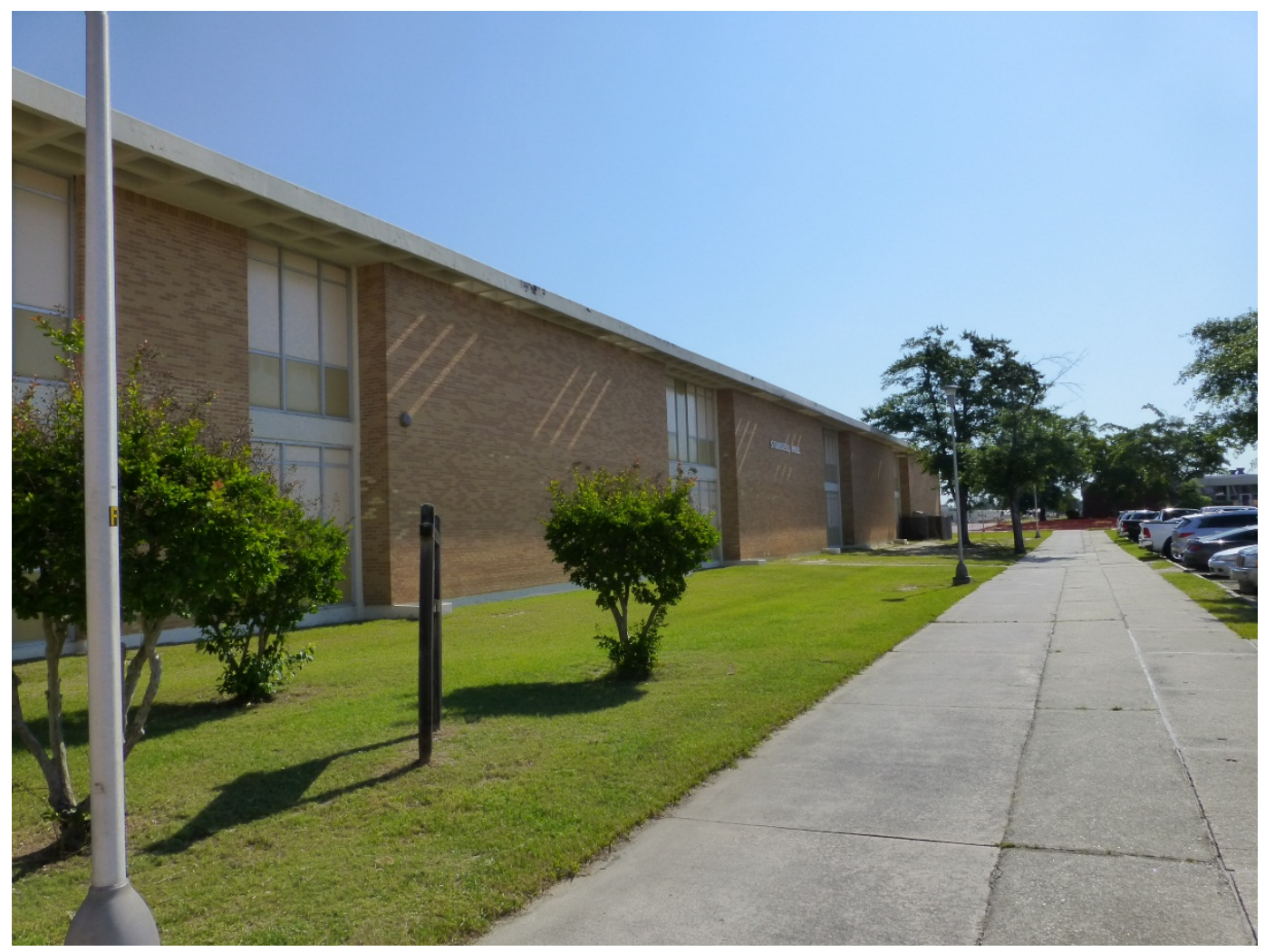


Figure 442. East elevation of Building 29819, Stansell Hall (ERDC-CERL, 2015).

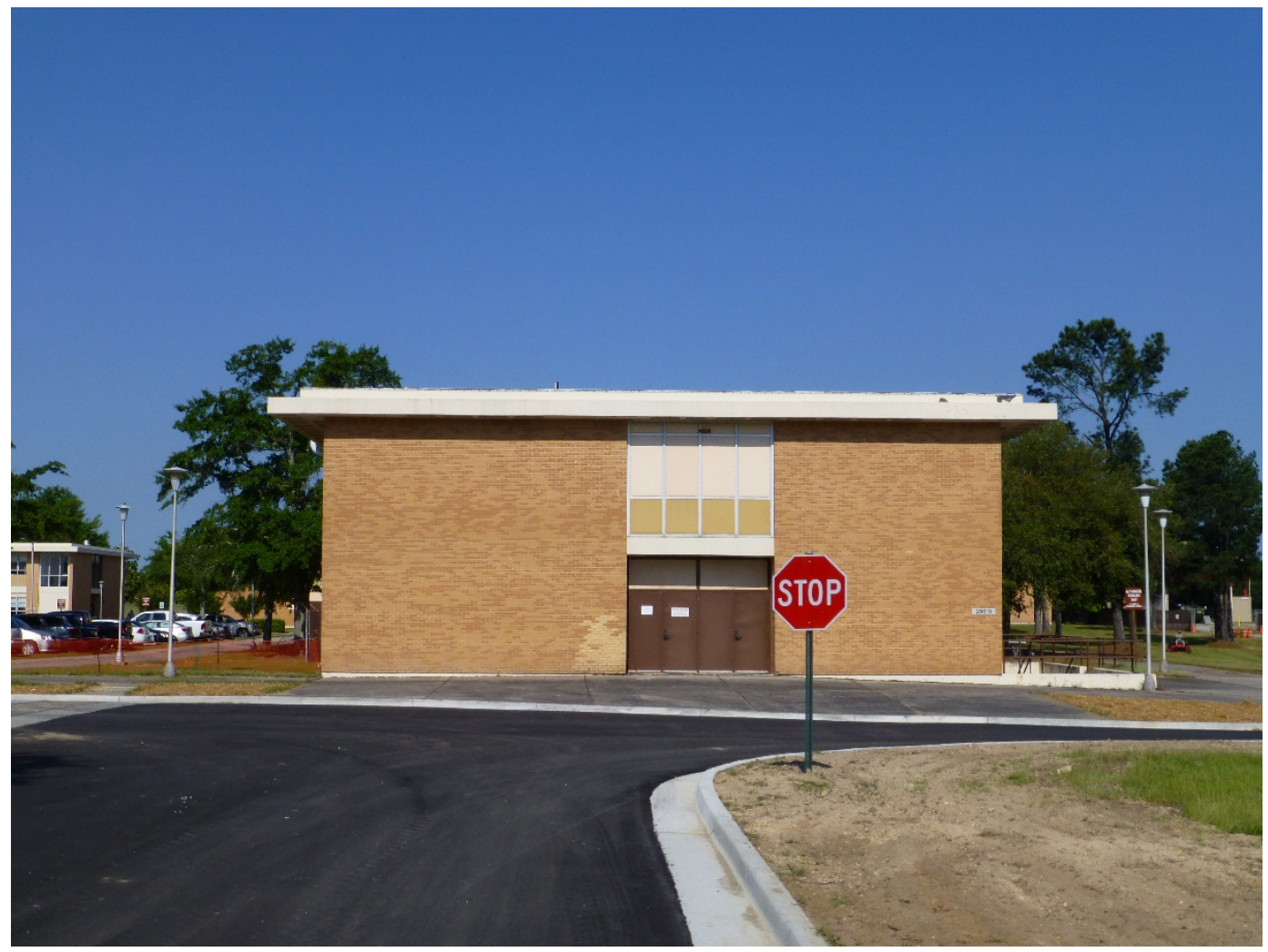

Figure 443. Southwest oblique of Building 29819, Stansell Hall (ERDC-CERL, 2015).

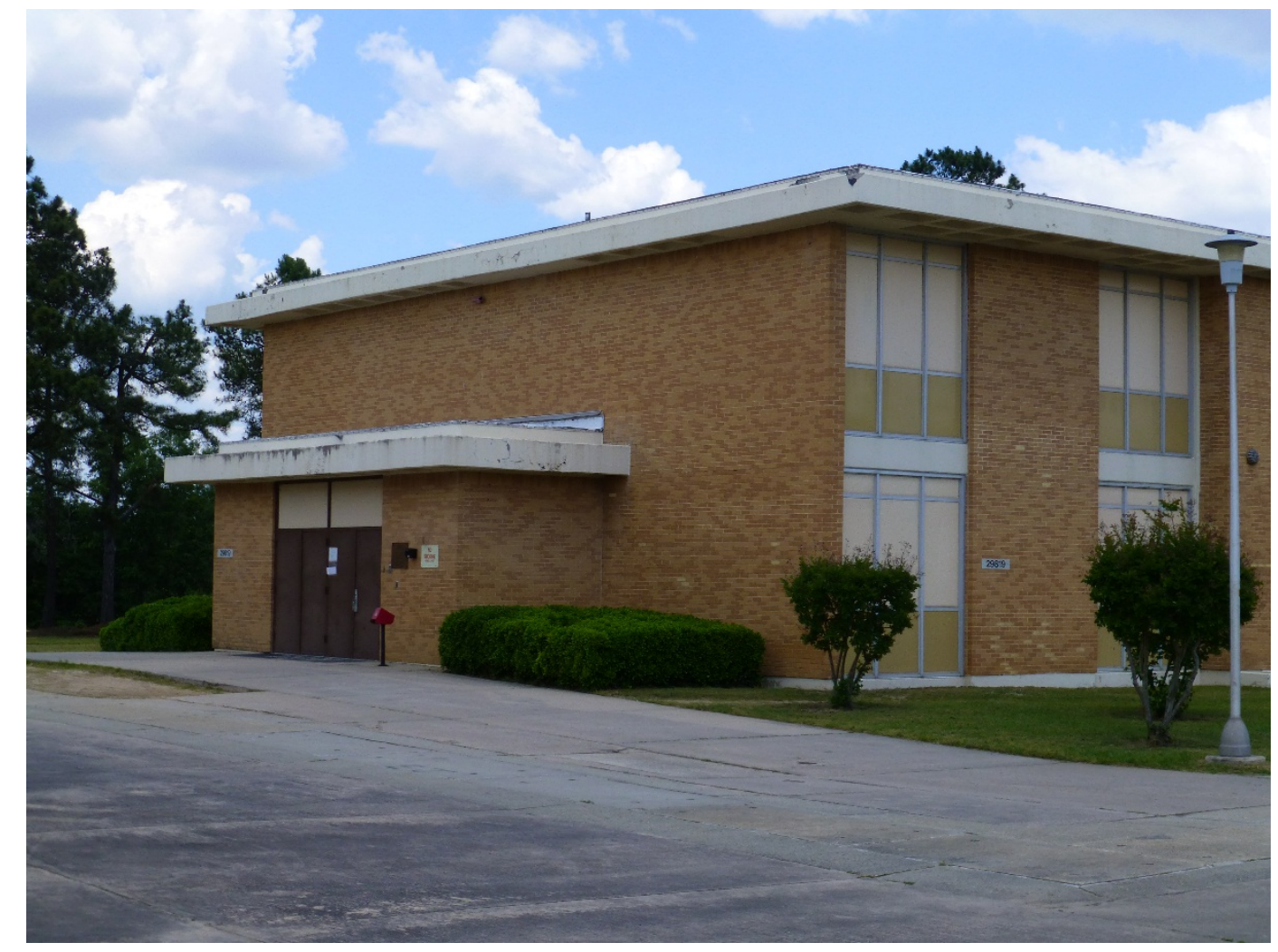


Figure 444. Elevations of Building 29819, Stansell Hall, 1966 (Fort Gordon DPW).

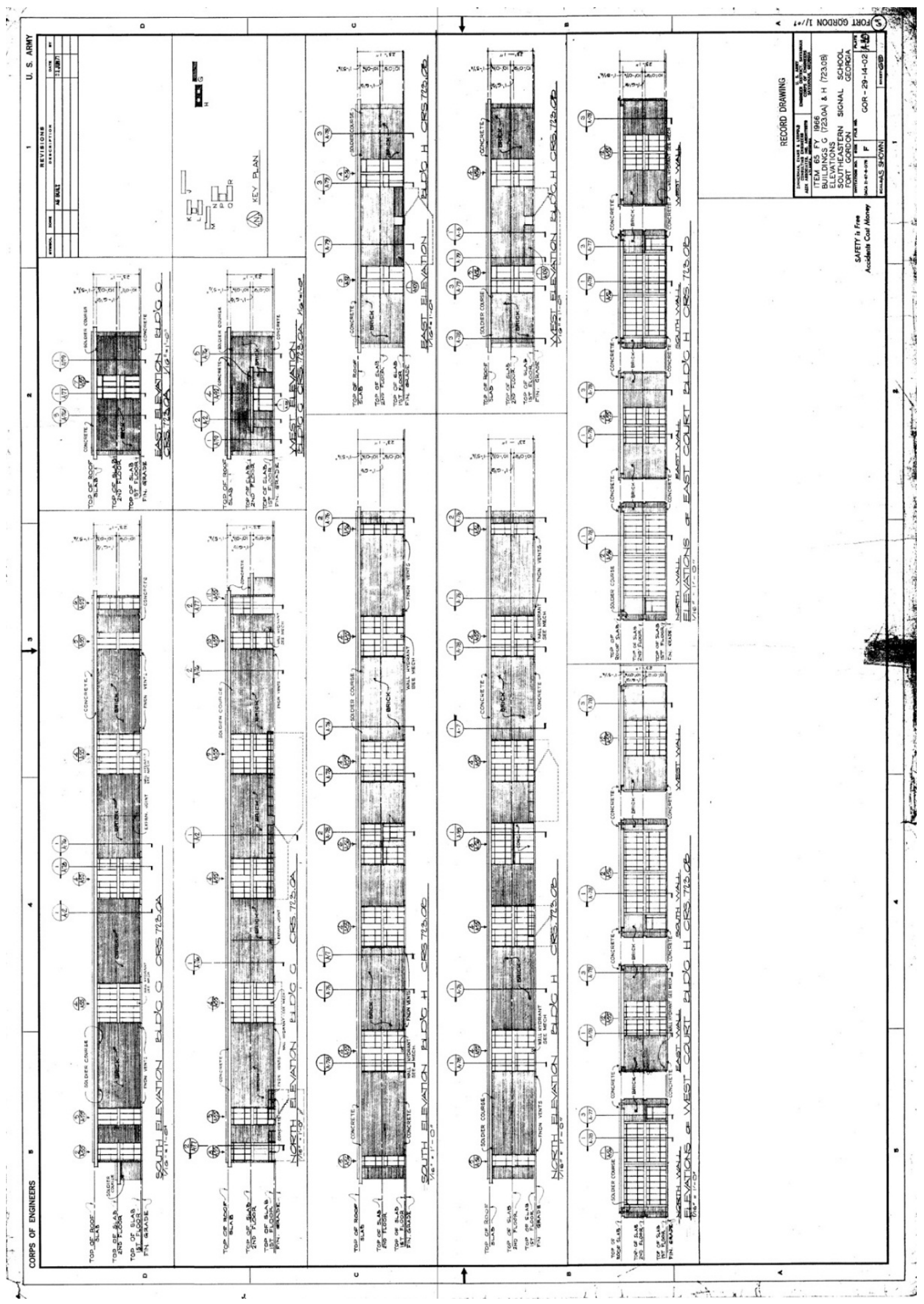


Figure 445. Window and door elevations for Building 29819, Stansell Hall, 1966

(Fort Gordon DPW).

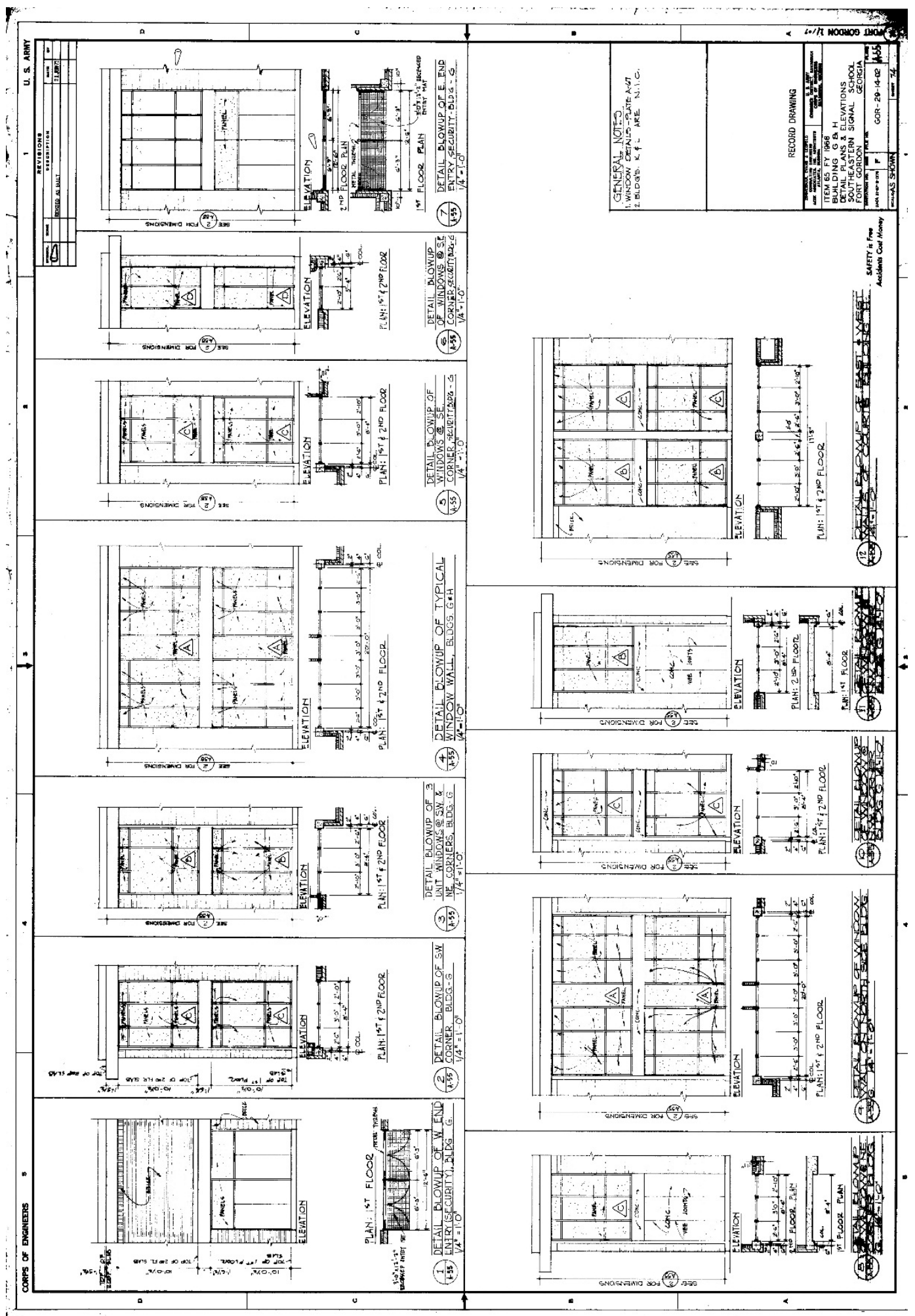


Figure 446. Window and door details and schedule for Building 29819, Stansell Hall, 1966 (Fort Gordon DPW).

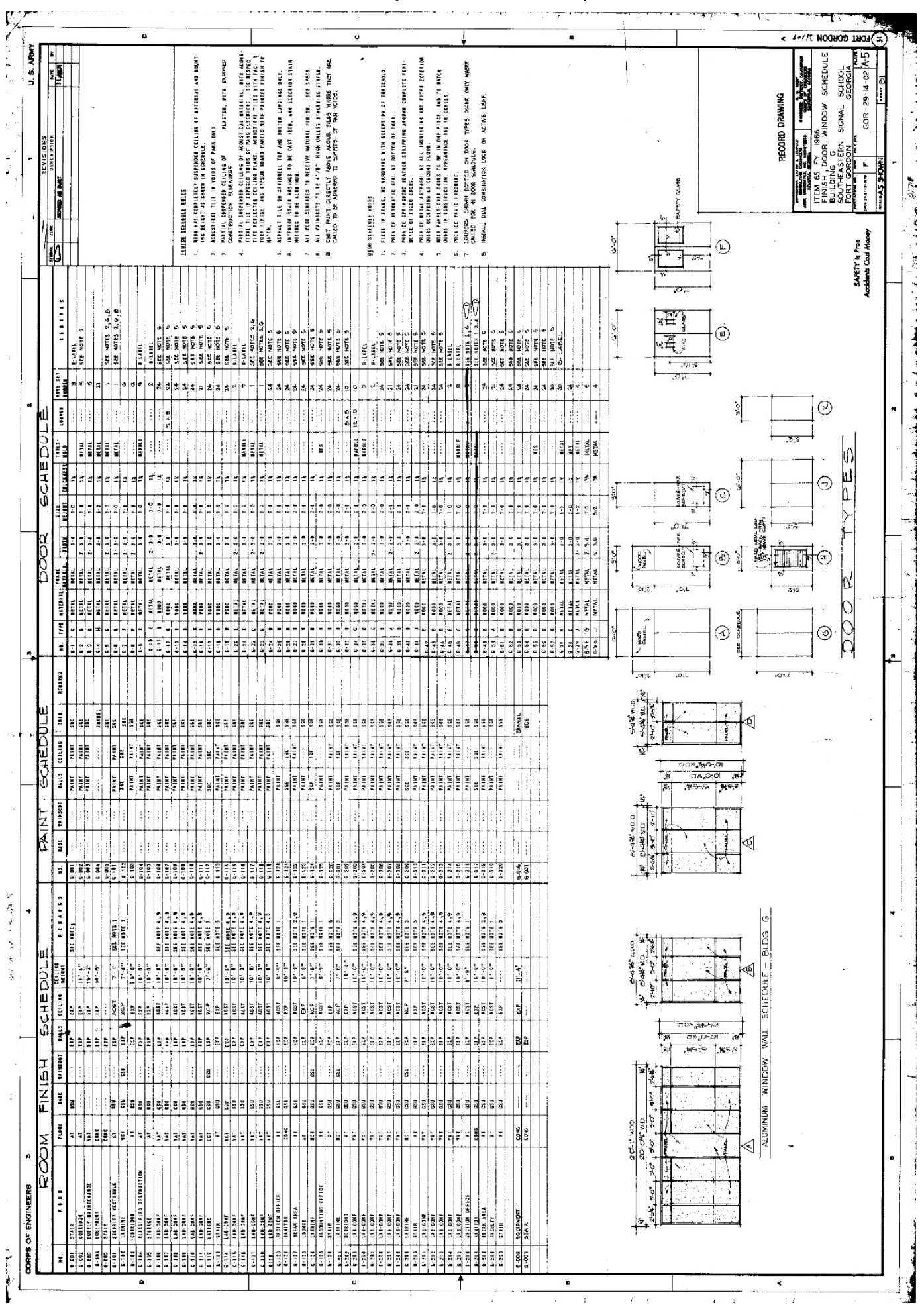


Figure 447. Typical classroom elevations and details, 1966 (Fort Gordon DPW).

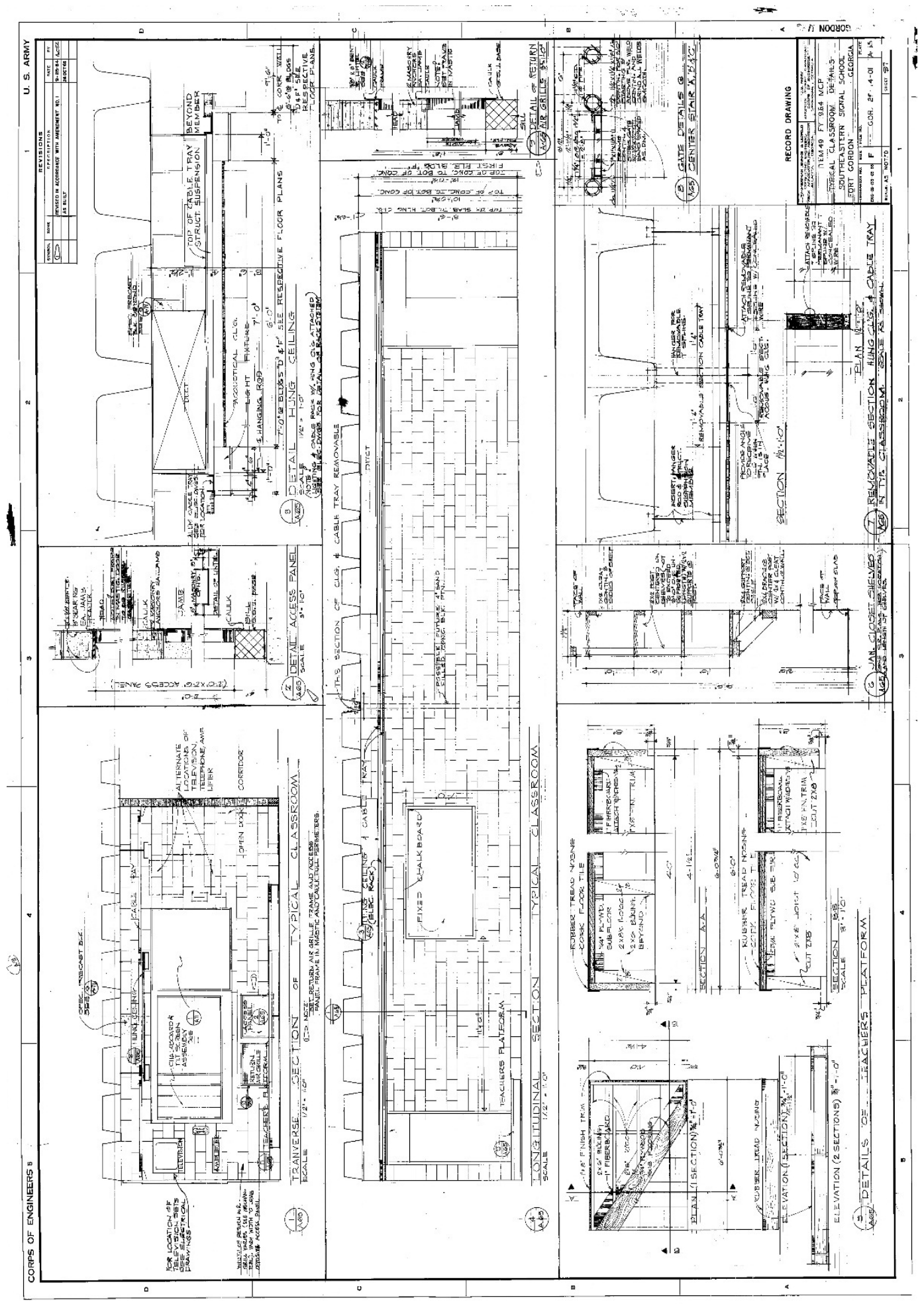


Figure 448. Light fixture types and schedule, 1966 (Fort Gordon DPW).

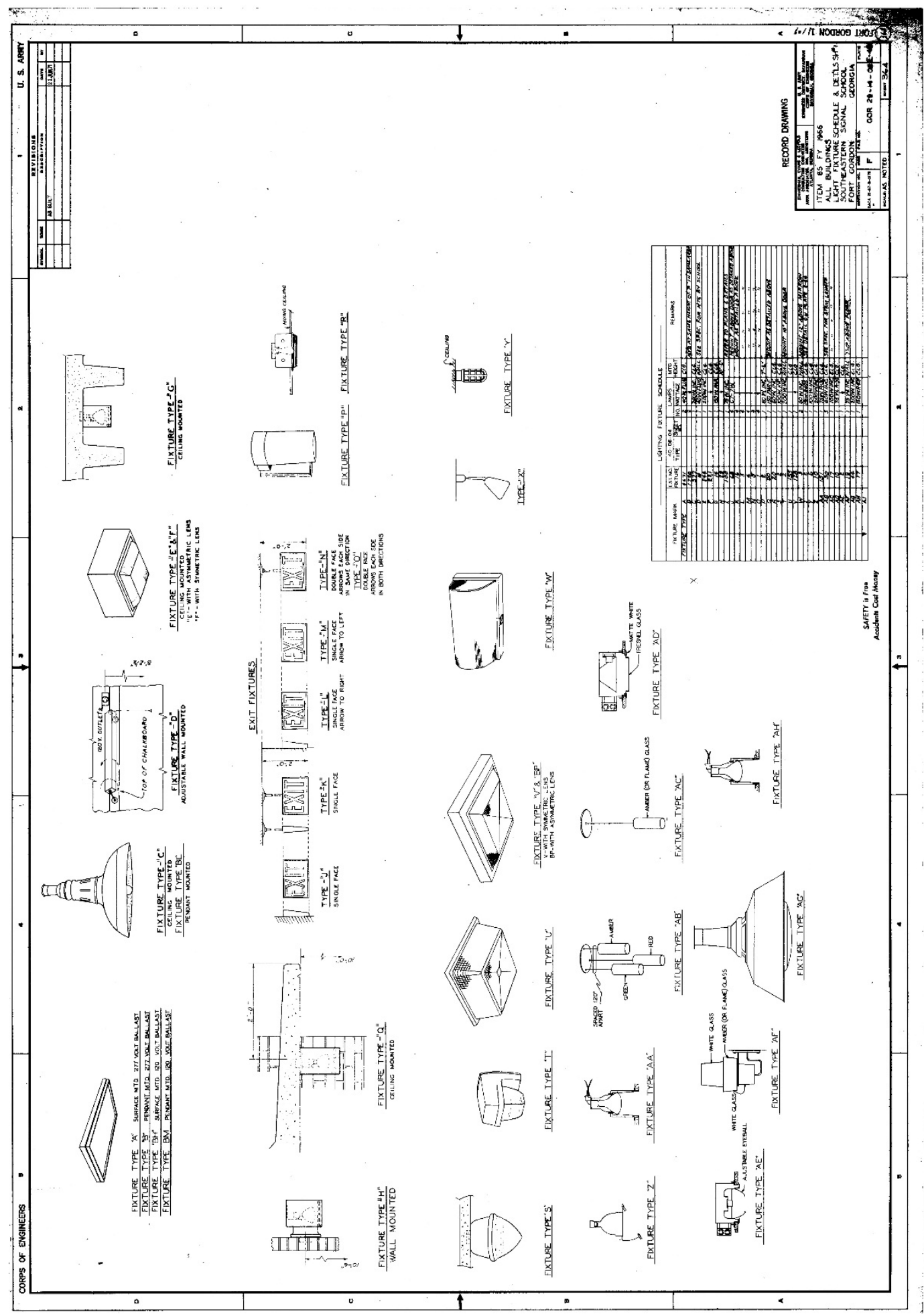


Figure 449. Landscape plan for Building 29819, Stansell Hall, 1966

(Fort Gordon DPW).

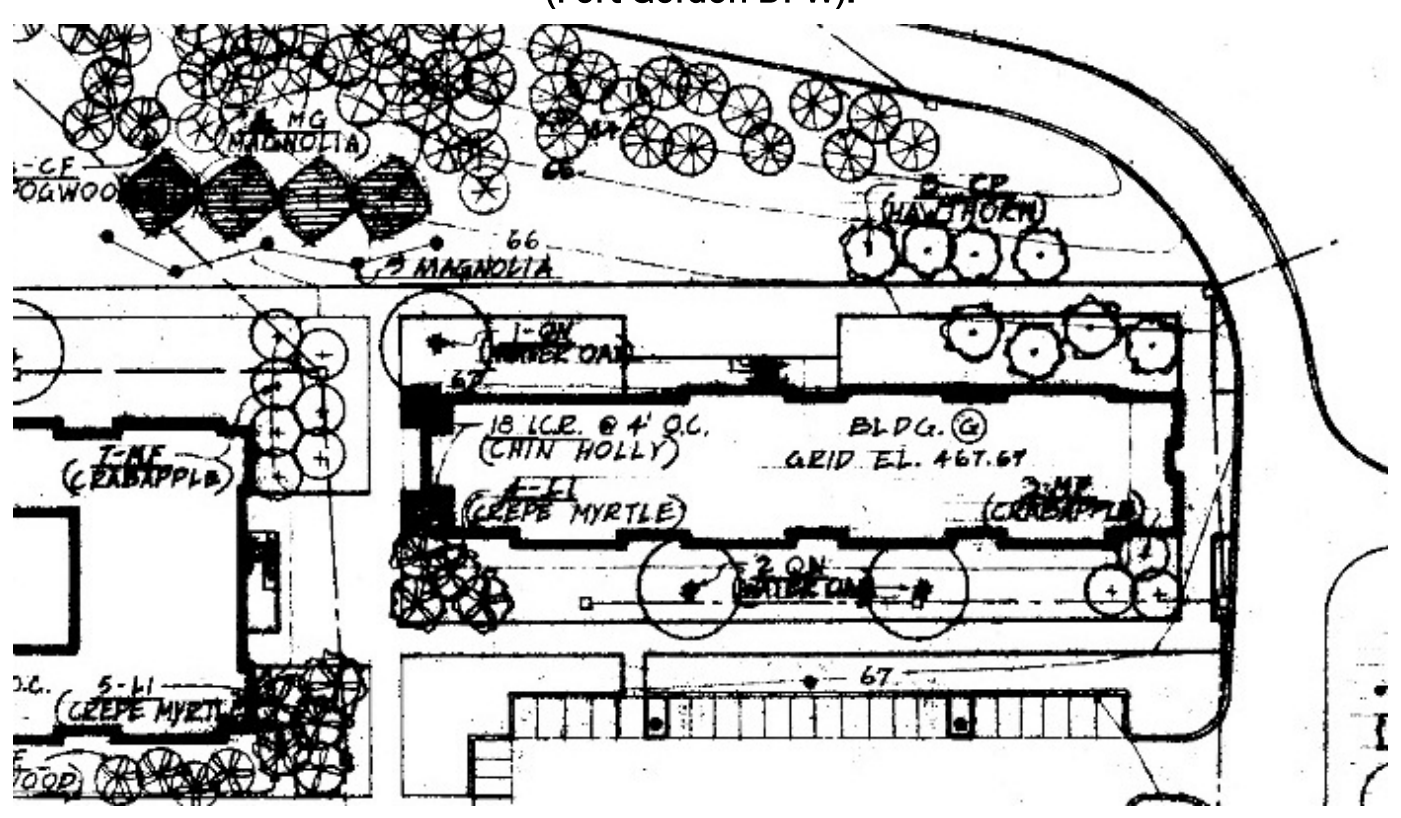

\subsubsection{Character-defining features}

Repair, renovation, and replacement of Building 29819, Stansell Hall, must be coordinated with the SHPO (Table 18).

\section{Exterior:}

- Overall massing

- Footprint

- Roof shape

- Brick veneer

- Relationship to other Signal School Campus buildings

- Overhanging eaves with perforated waffle construction casting "light pattern" on exterior brick walls

- Exposed concrete structure framing window and door openings

- Window pattern

- Recessed bays of bright-aluminum sashes framing insulated panels

- Concrete panel inserts

- Metal doors with large pane

- Ceiling-mounted exterior light fixtures set within the waffle overhang

- Lettering

- Metal handrails 


\section{Interior:}

- Overall plan

- Main stairwells

- Main hallways

- Lighting

- Doors

- Display cases

- Signage

- Telephone alcoves

- Tiled water-fountain alcoves

Table 18. Images of character-defining features of Building 29819, Stansell Hall (ERDC-CERL, 2015).

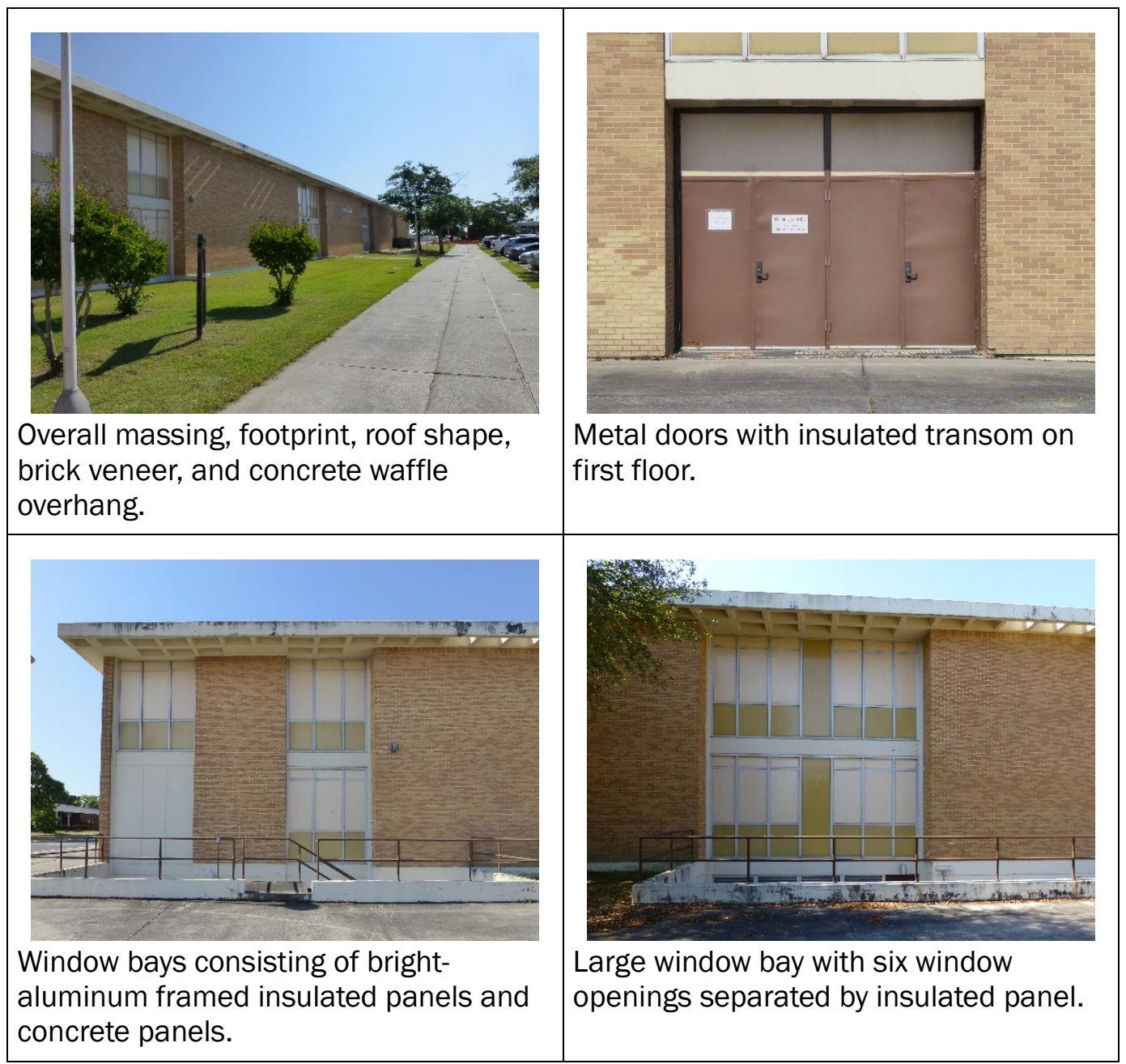




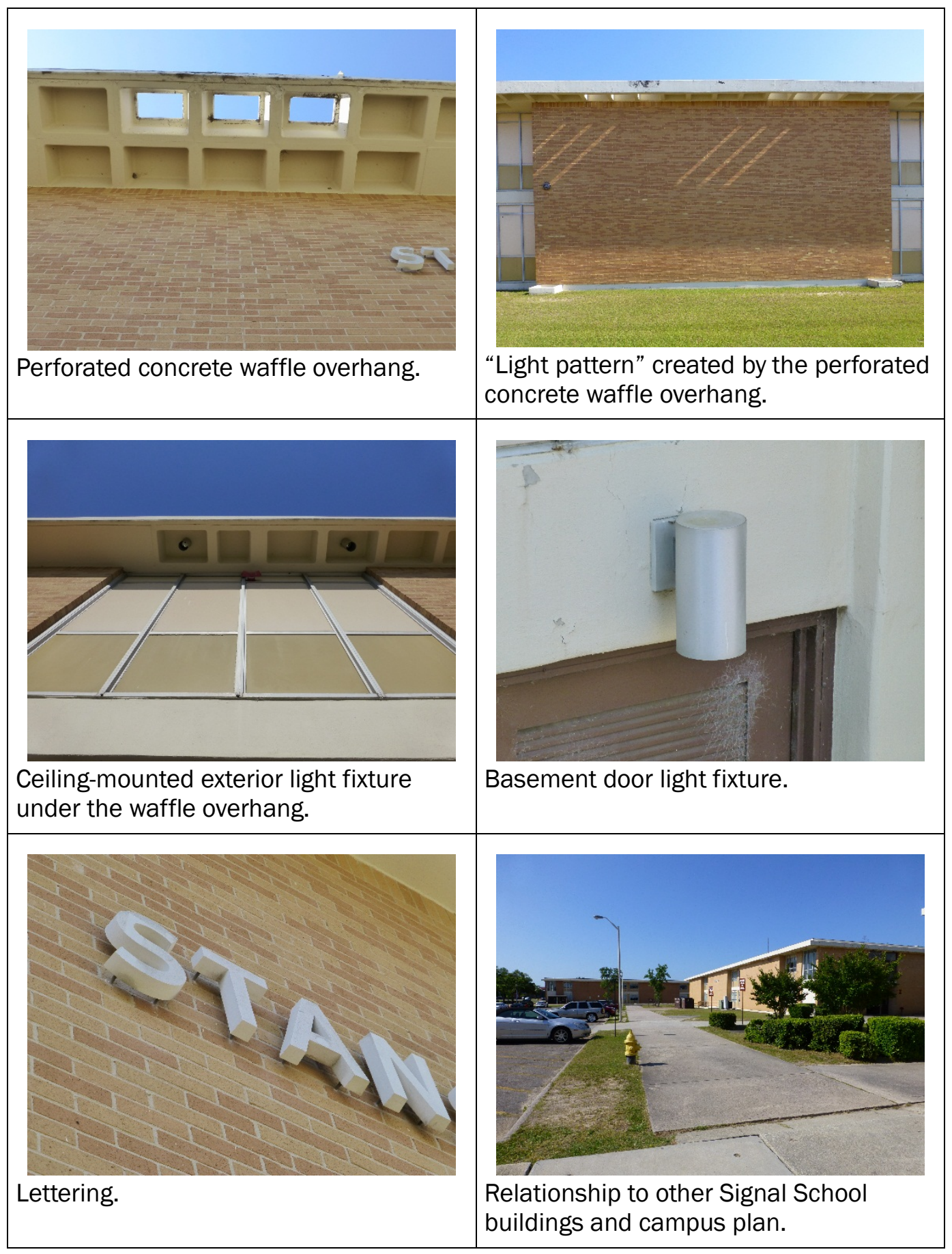

3.3.16.2 Character-defining features that have been removed

- None.

\subsubsection{Nonhistoric features}

- None. 


\subsubsection{Comparison images}

Comparison images utilizing either the original drawings or historic photographs, when juxtaposed against present-day images, are a useful tool in developing the historic "feel" of a property and how much of that historic feeling is still present today (Figure 450-Figure 454).

Figure 450. West entry vestibule - comparison of the original design and materials detail drawing from 1966 [left] to the current condition of the one-story brick vestibule, metal doors, and insulated panels [right] (ERDC-CERL, 2015).
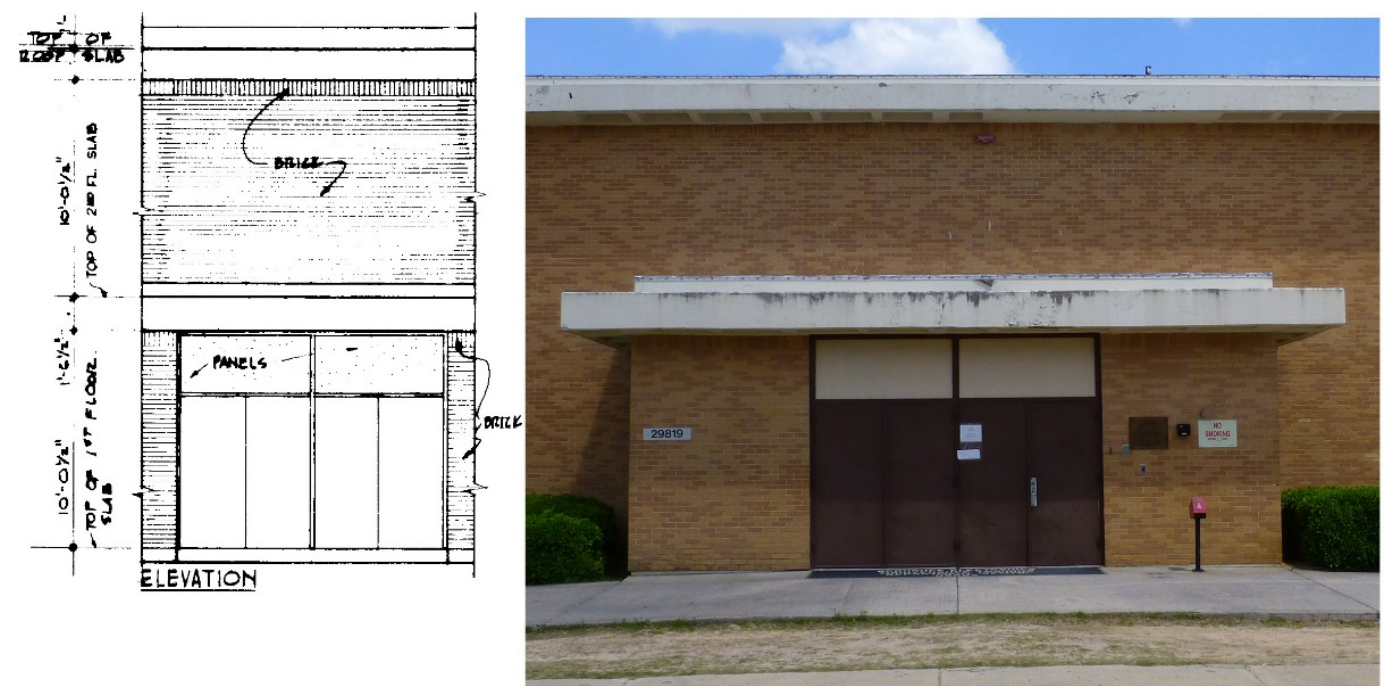

Figure 451. East elevation entry - comparison of the original design and materials detail drawing from 1966 [left] to the current condition of the metal doors and brightaluminum framed insulated panels [right] (ERDC-CERL, 2015).
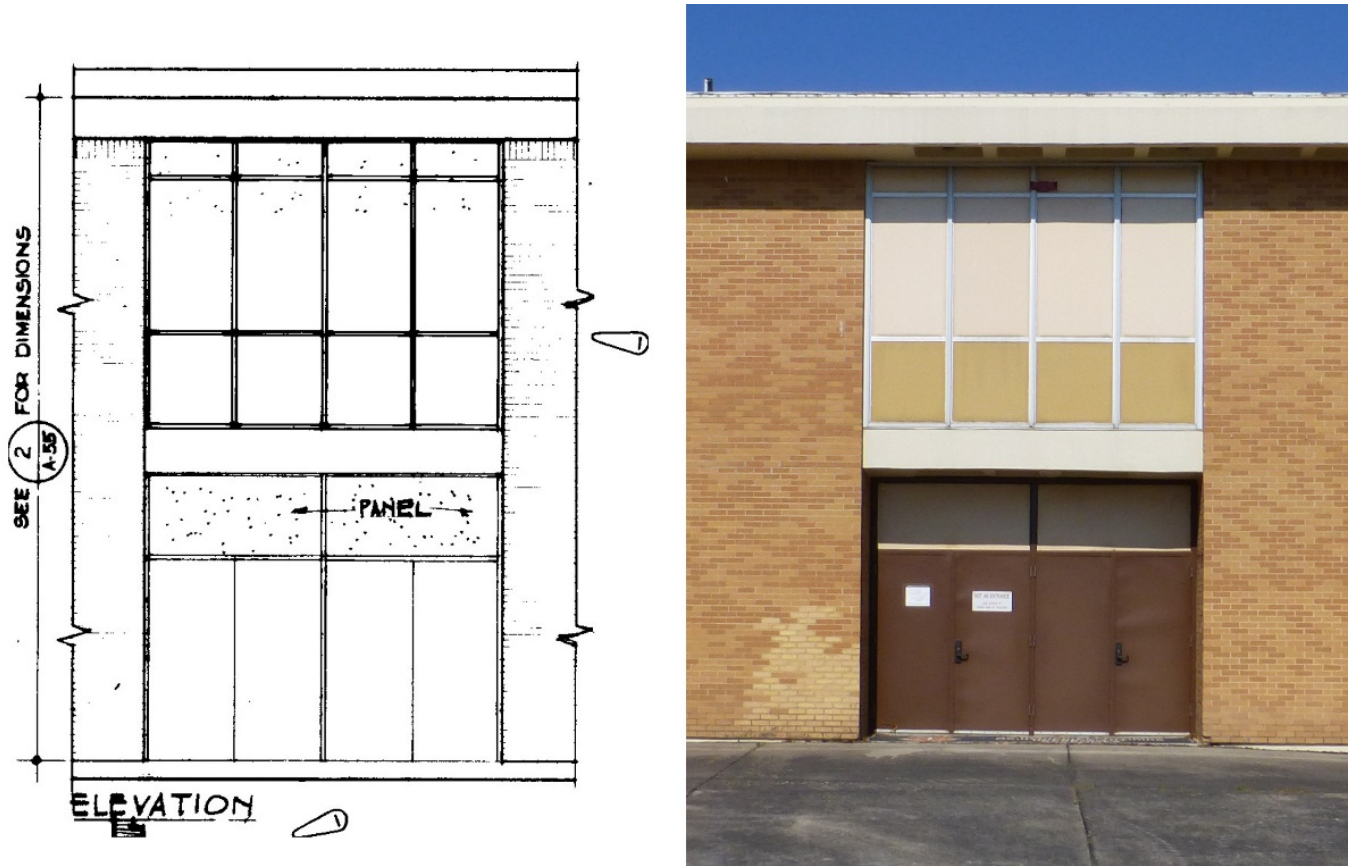
Figure 452. Northeast window bays - comparison of the original design and materials detail drawing from 1966 [left] to the current condition of the concrete panels and bright-aluminum framed insulated panels [right] (ERDC-CERL, 2015).
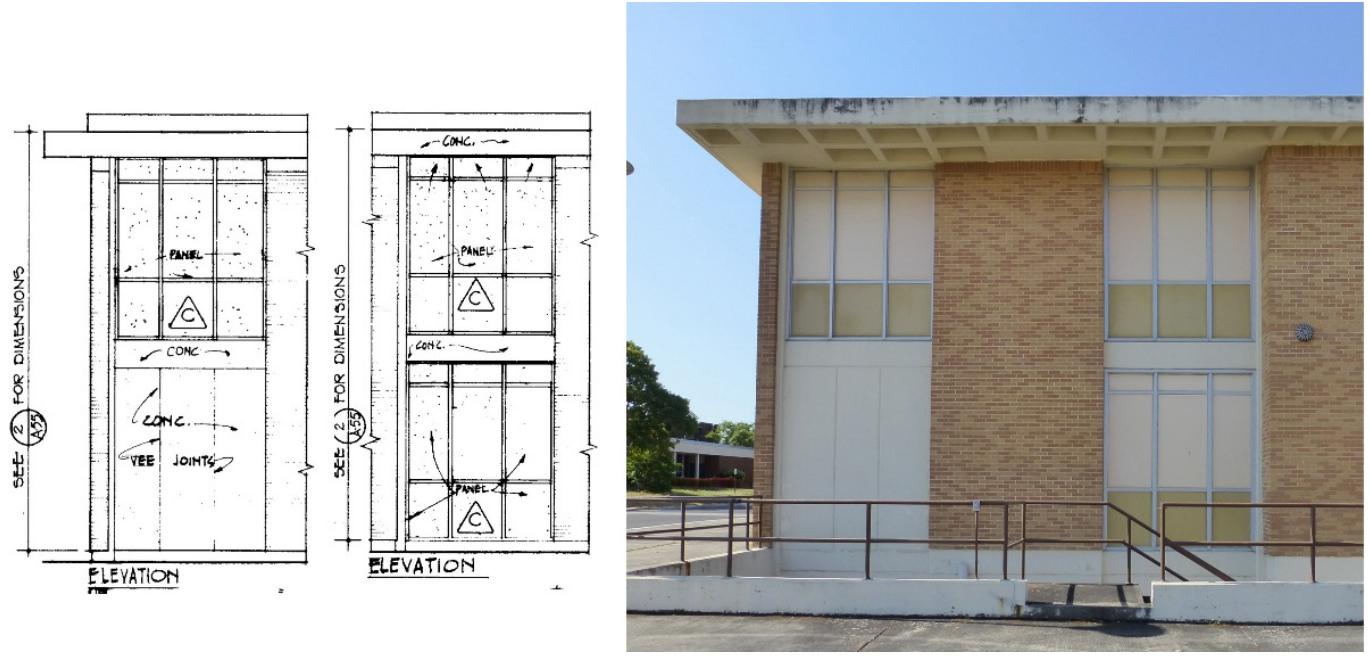

Figure 453. Large window bay on the north elevation - comparison of the original design and materials detail drawing from 1966 [left] to the current condition of the bright-aluminum framed insulated panels separated by exposed concrete structural system [right] (ERDC-CERL, 2015).
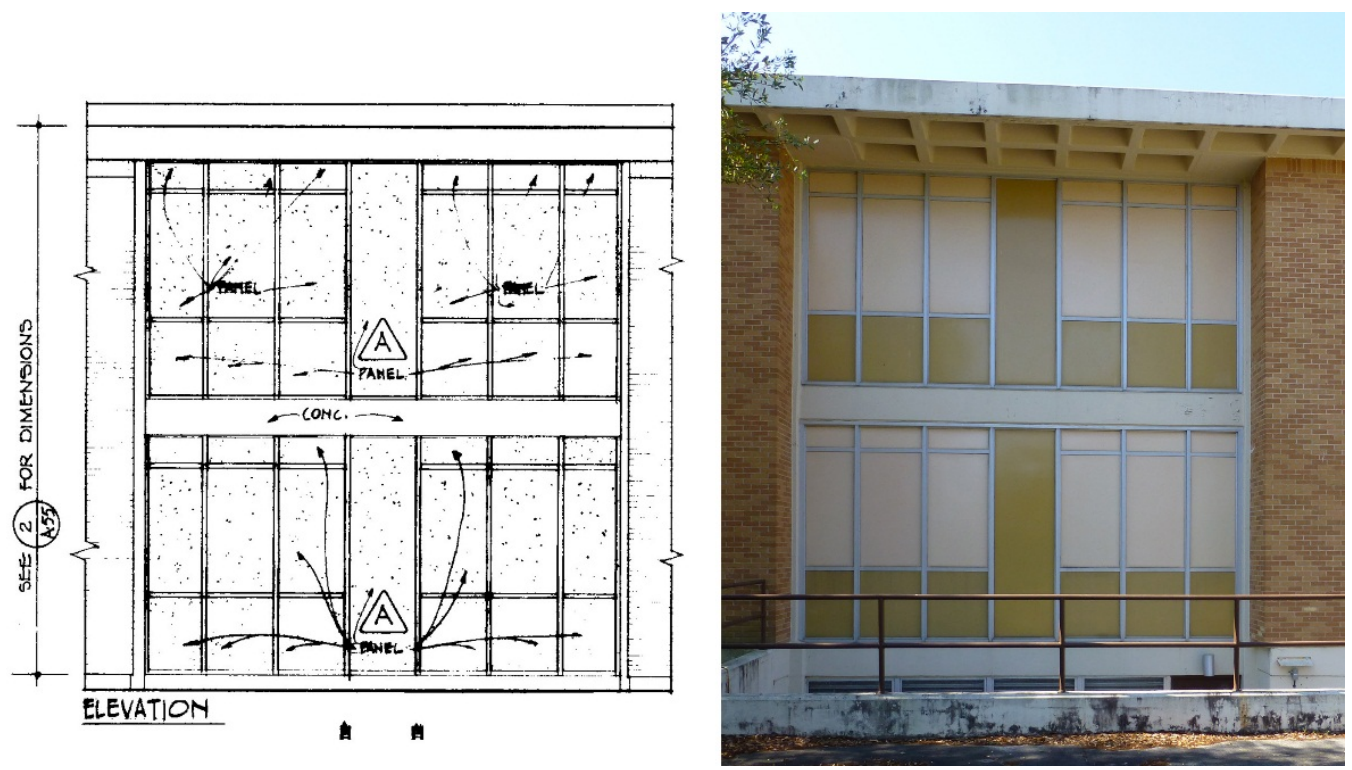
Figure 454. Ceiling-mounted exterior light fixture under waffle overhang comparison of the original design and materials details drawing from 1966 [left] to the current condition of the light fixture [right] (ERDC-CERL, 2015).

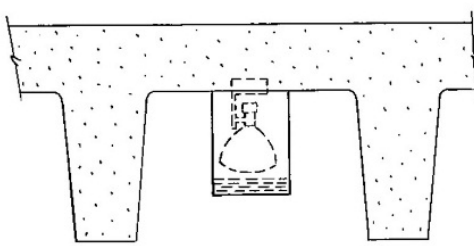

FIXTURE TYPE "G" CEILING MOUNTED

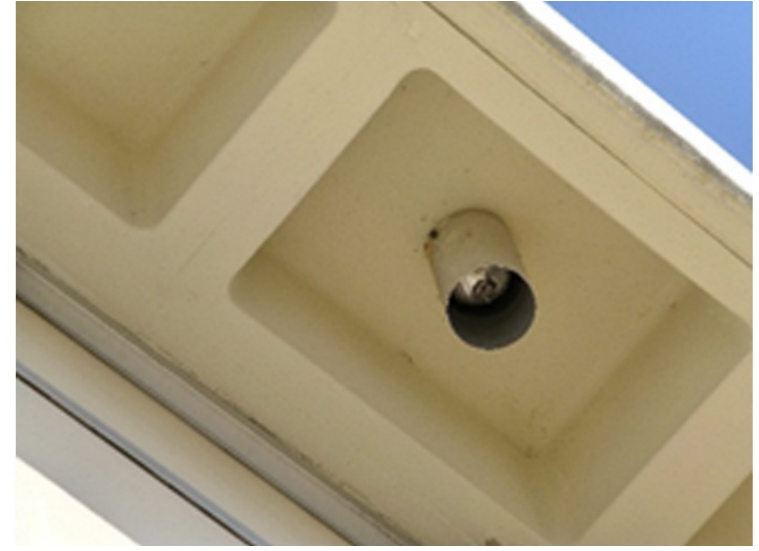




\section{Noncontributing Buildings}

There are 15 noncontributing buildings and structures within the Signal School Campus Historic District (Figure 455), and some moveable sheds that are not considered real property. Generally, these properties were either not part of the original Aeck master plan or were added to the district after the period of significance. One of the structures is a concrete pad (Figure 456), but most of the structures added after the period of significance are large shade structures near 25810 (Figure 457), north of 29811 (Figure 458), and east of 29813 (Figure 459). Additionally, Building 33800 was surveyed and researched for possibly being included within the historic district boundary, but it was determined that its design and mission were separate from the design and layout of the master plan for the Signal School (Figure 466).

Figure 455. Map of noncontributing buildings, indicated in red

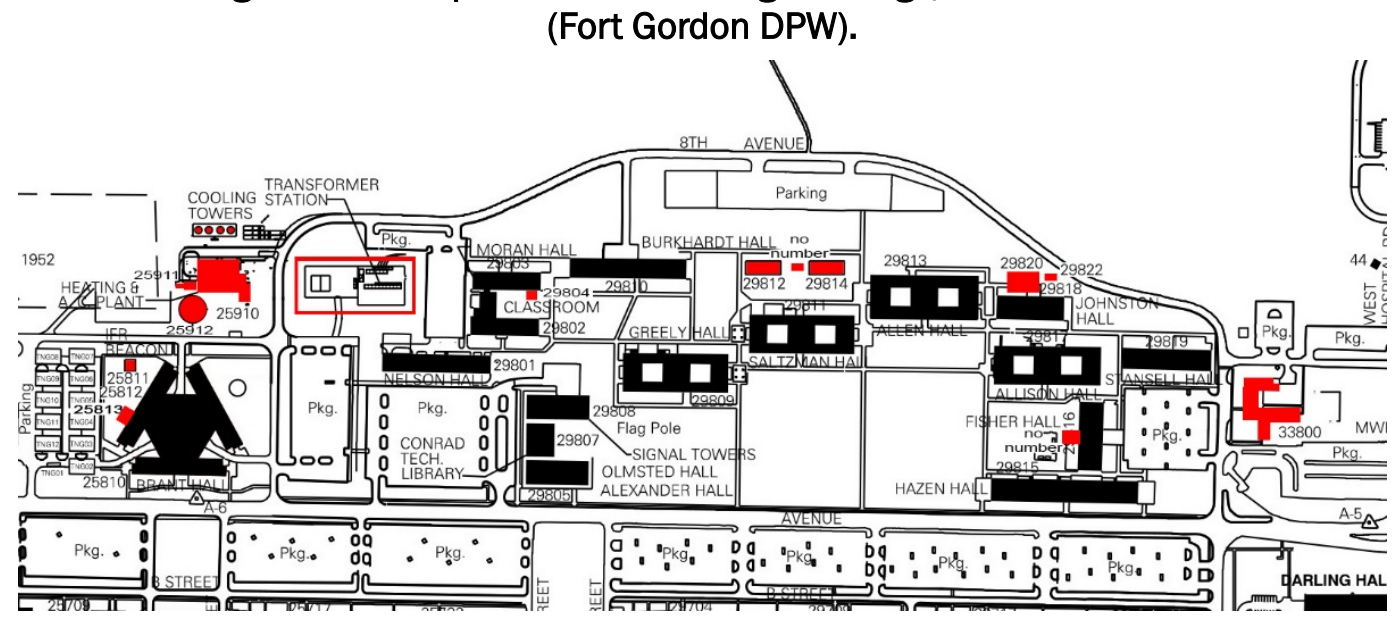


Figure 456. Building 25811 is a concrete pad supporting an IFR beacon that is not real property and was placed here in 1985 (ERDC-CERL 2015).

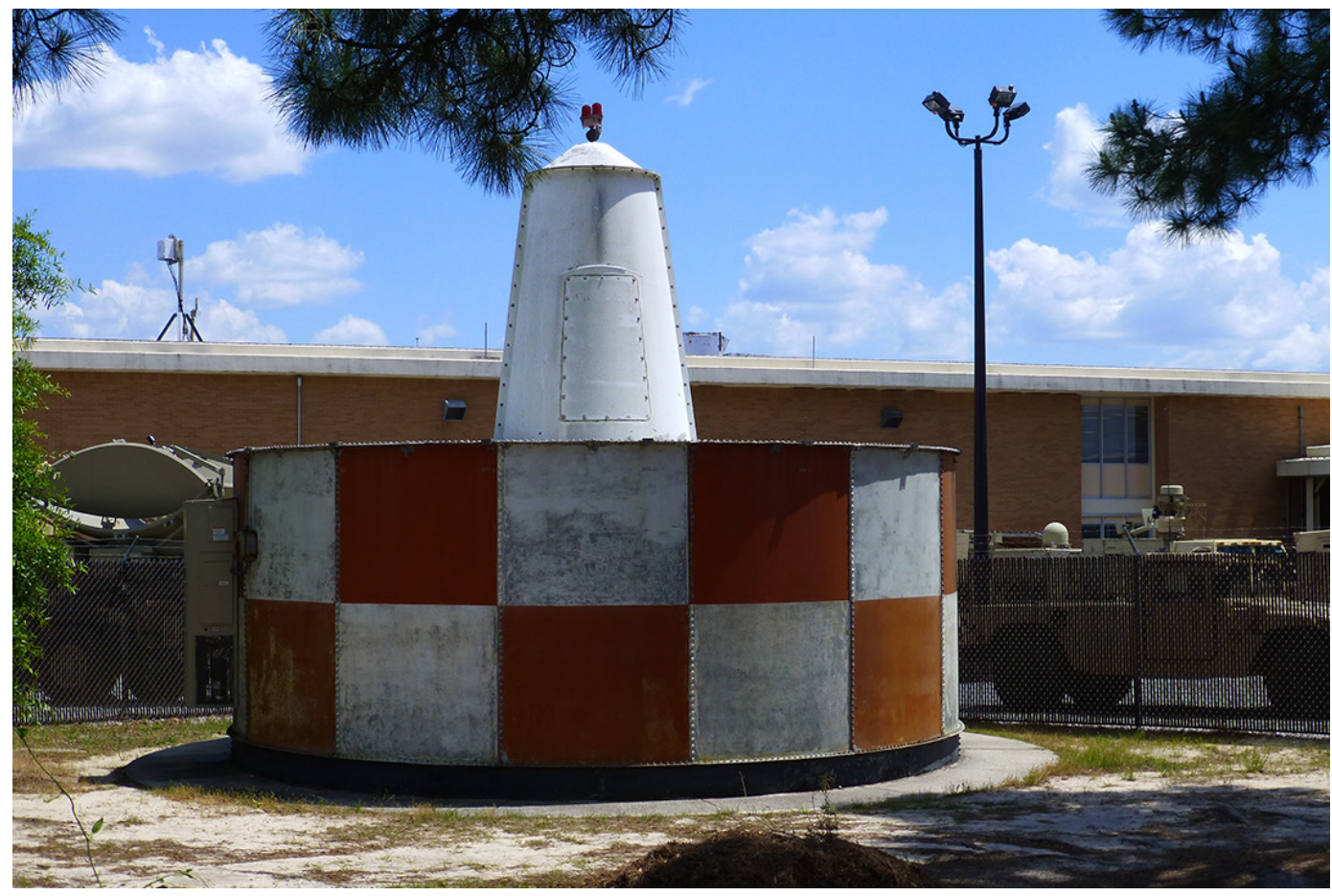

Figure 457. Buildings 25812 and 25813 are covered storage areas to the west of Building 25810 (ERDC-CERL).

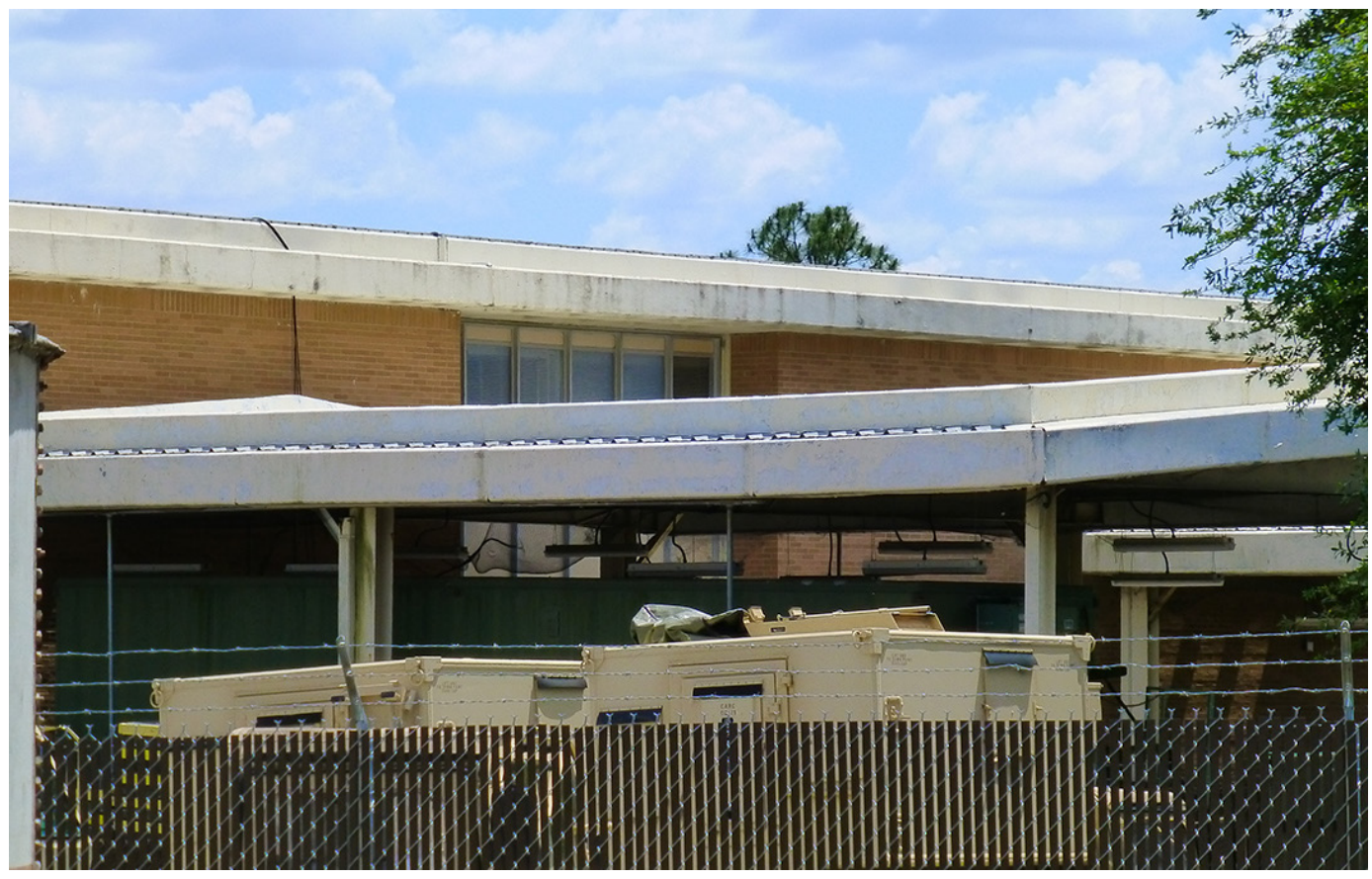


Figure 458. Building 29814 (left) is a covered training area, constructed in 1997; there is an unnumbered covered training area in the middle, constructed circa 2000; and 29812 on the right is a covered training area constructed in 2001

(ERDC-CERL 2015).

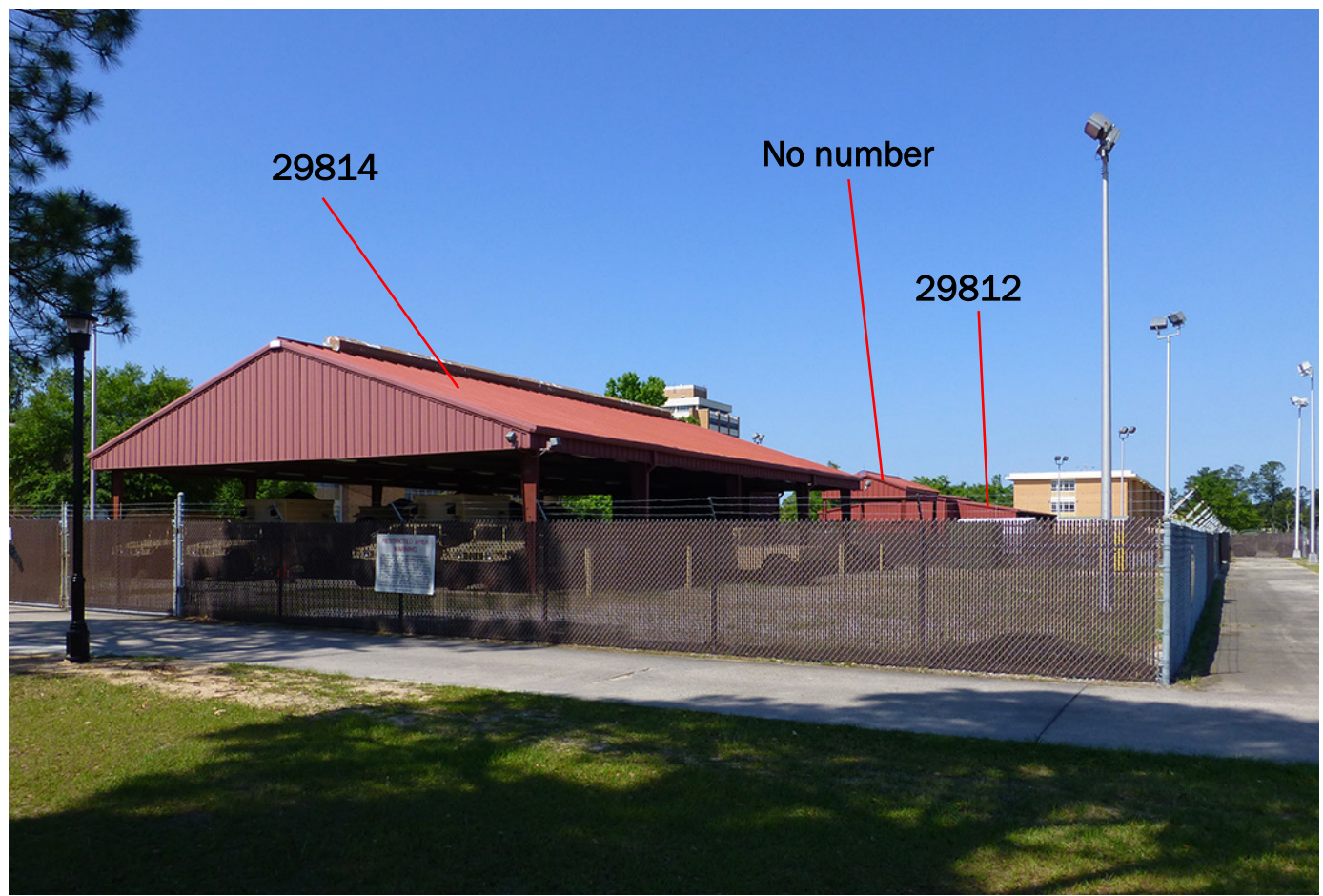

Figure 459. Building 29820 (to rear) is a covered training area constructed in 2009 and Building 29822 (in front) is a covered training area constructed in 2009 (ERDC-CERL, 2015).

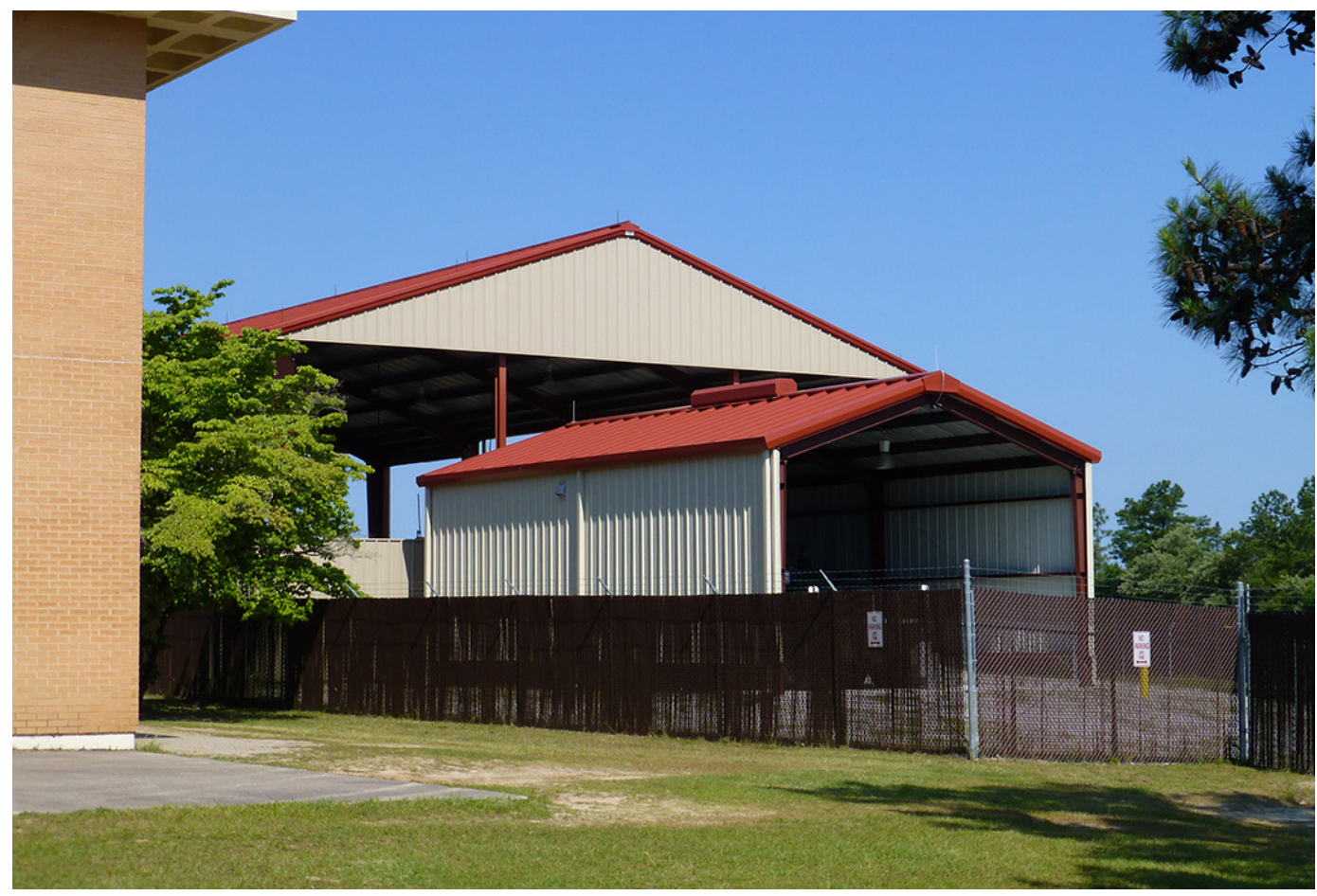


The Heat/AC Plant (25910) (Figure 460) was designed by Sewell and Associates and constructed in 1966. It and its associated cooling towers (Figure 461) were not part of the Aeck master plan. The cooling towers were replaced in 1985 and 2000. The water storage tank (25912) (Figure 462) was added to the Heat/AC Plant in 2000 and it has an associated mechanical room (25911). In 1975 an electrical substation was added to the complex to help with an increase in power needs for the complex (Figure 463).

Figure 460. Building 25910 Heating/AC Plant was constructed in 1966 and designed by Sewell and Associates (ERDC-CERL 2015).

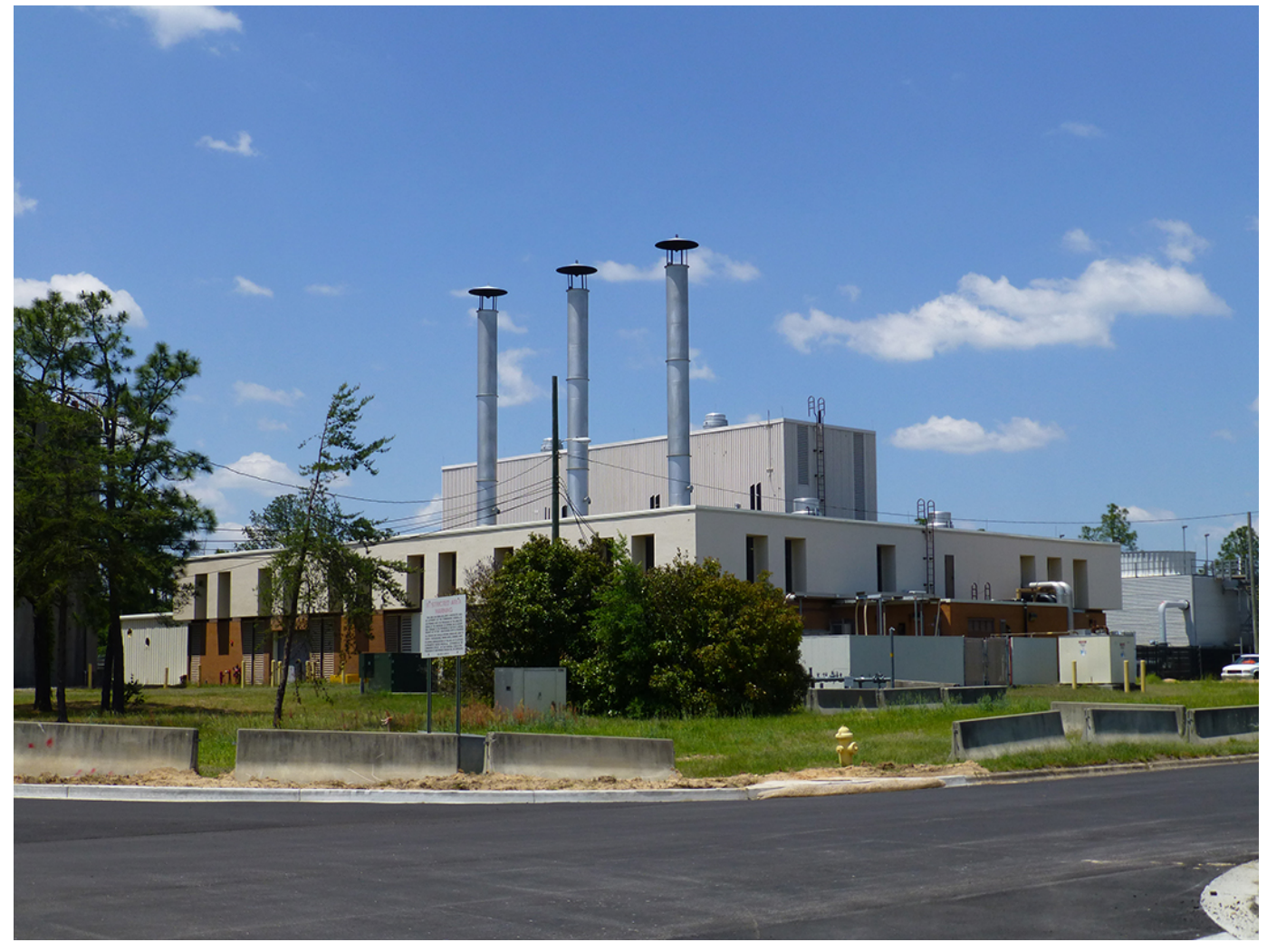


Figure 461. Building 25910 AC Cooling Towers, north of the Heating/AC Plant (ERDC-CERL, 2015).

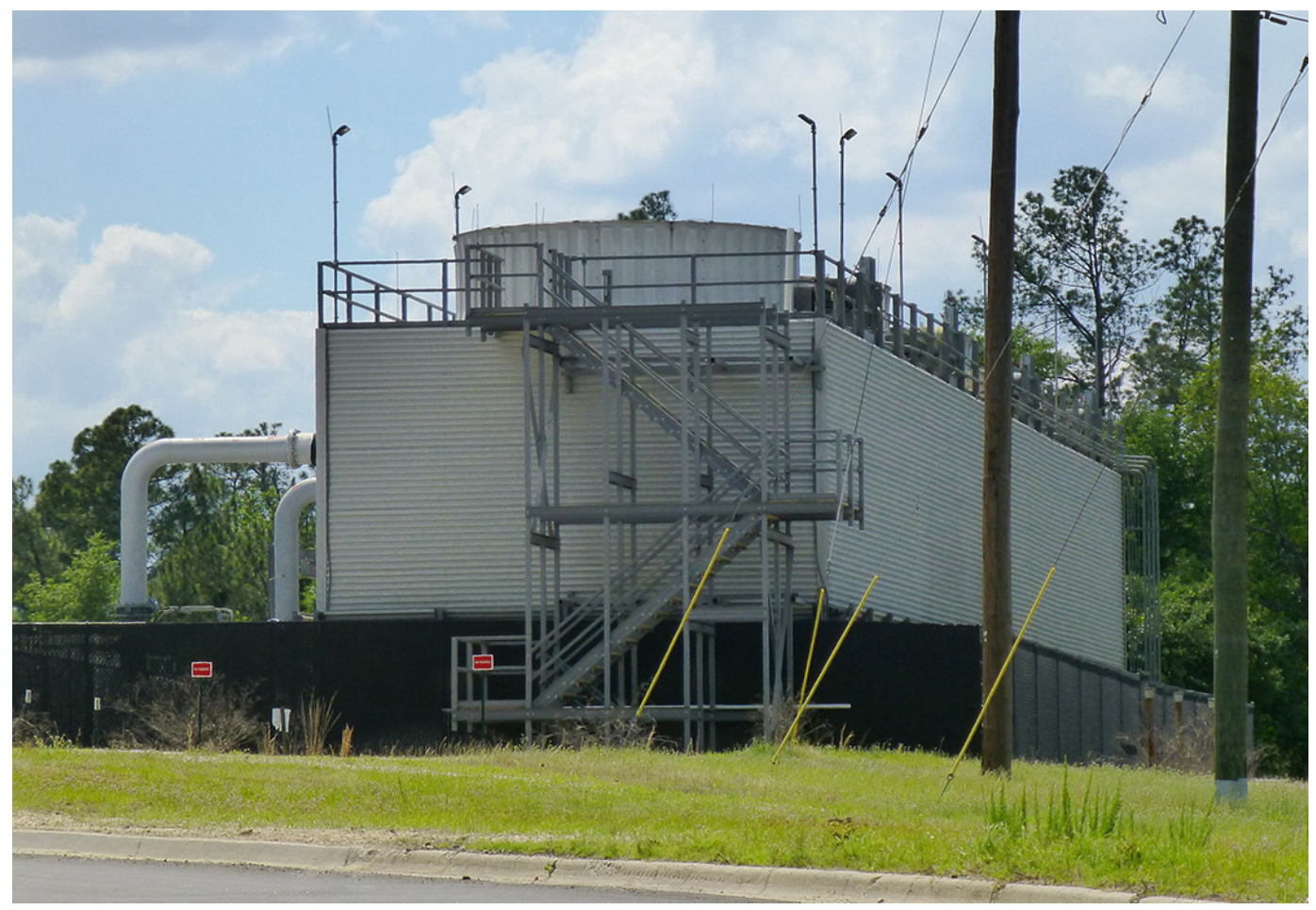

Figure 462. Building 25912 Water Storage Tank was constructed in 2000 (ERDC-CERL 2015).

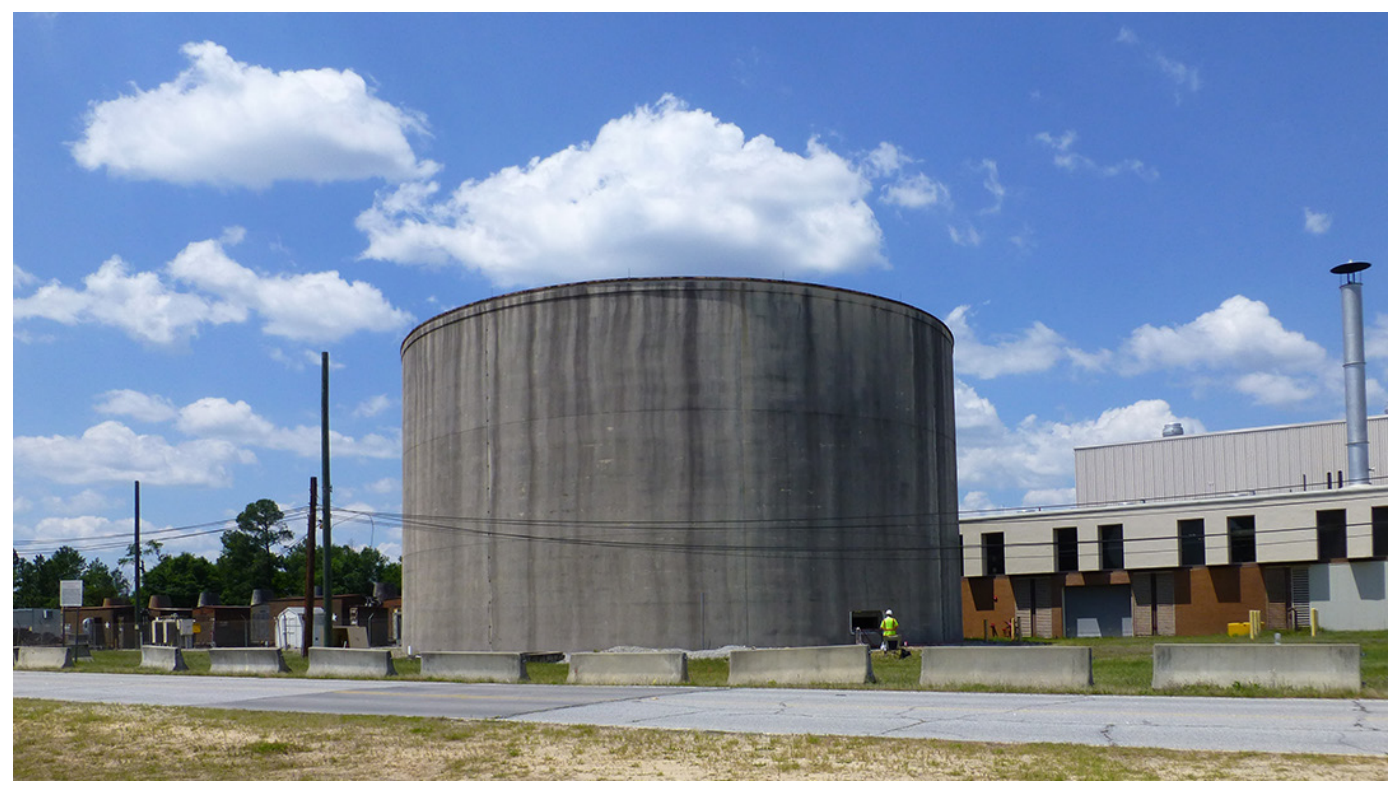


Figure 463. An electrical substation was added to the complex in 1975 (ERDC-CERL, 2015).

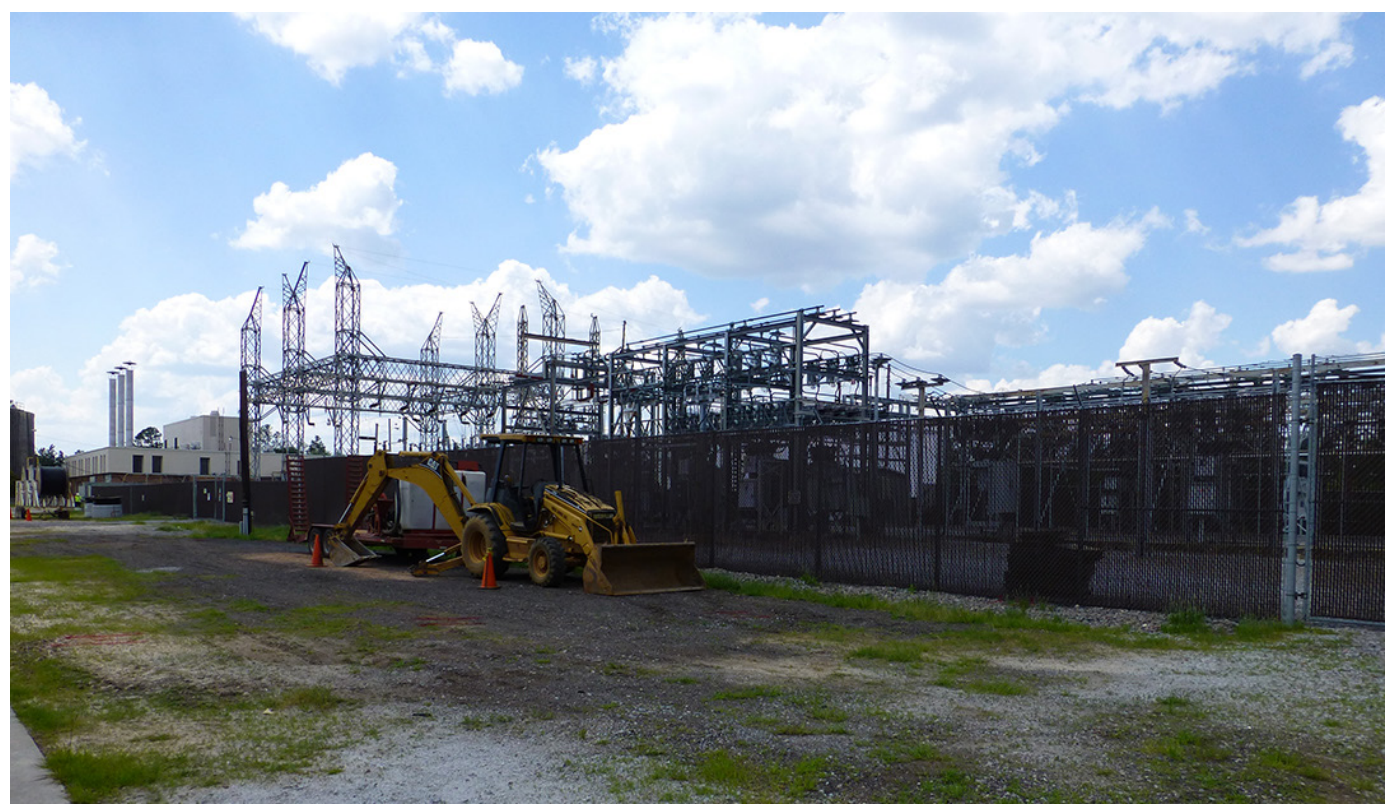

Spread throughout the historic district are moveable storage sheds (Figure 464 and Figure 465) that are not considered real property, were placed within the complex after the period of significance, and are moved around depending on needs.

Figure 464. Examples of moveable sheds that are not real property (ERDC-CERL, 2015).

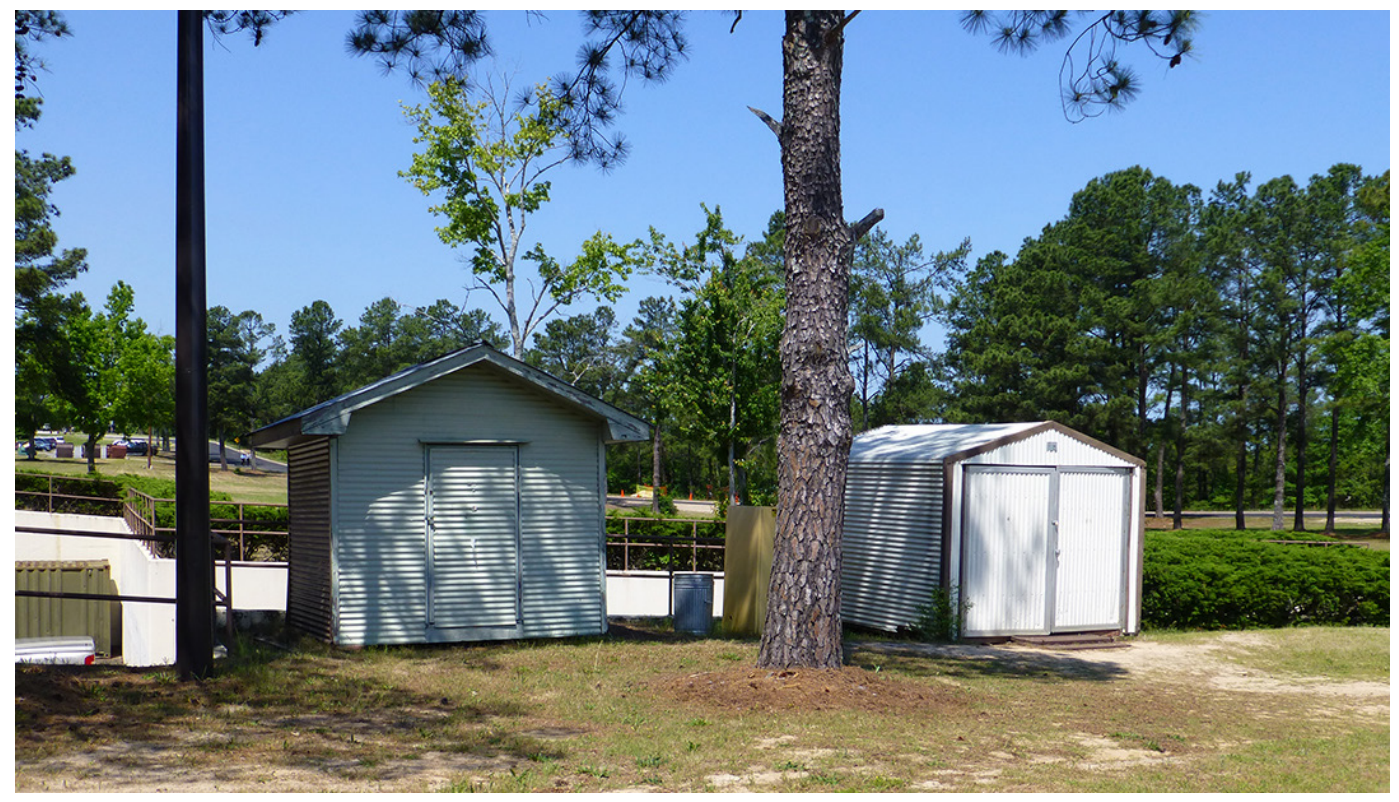


Figure 465. Covered Training Area (no number) on left, and two moveable sheds that are not real property in the center (ERDC-CERL, 2015).

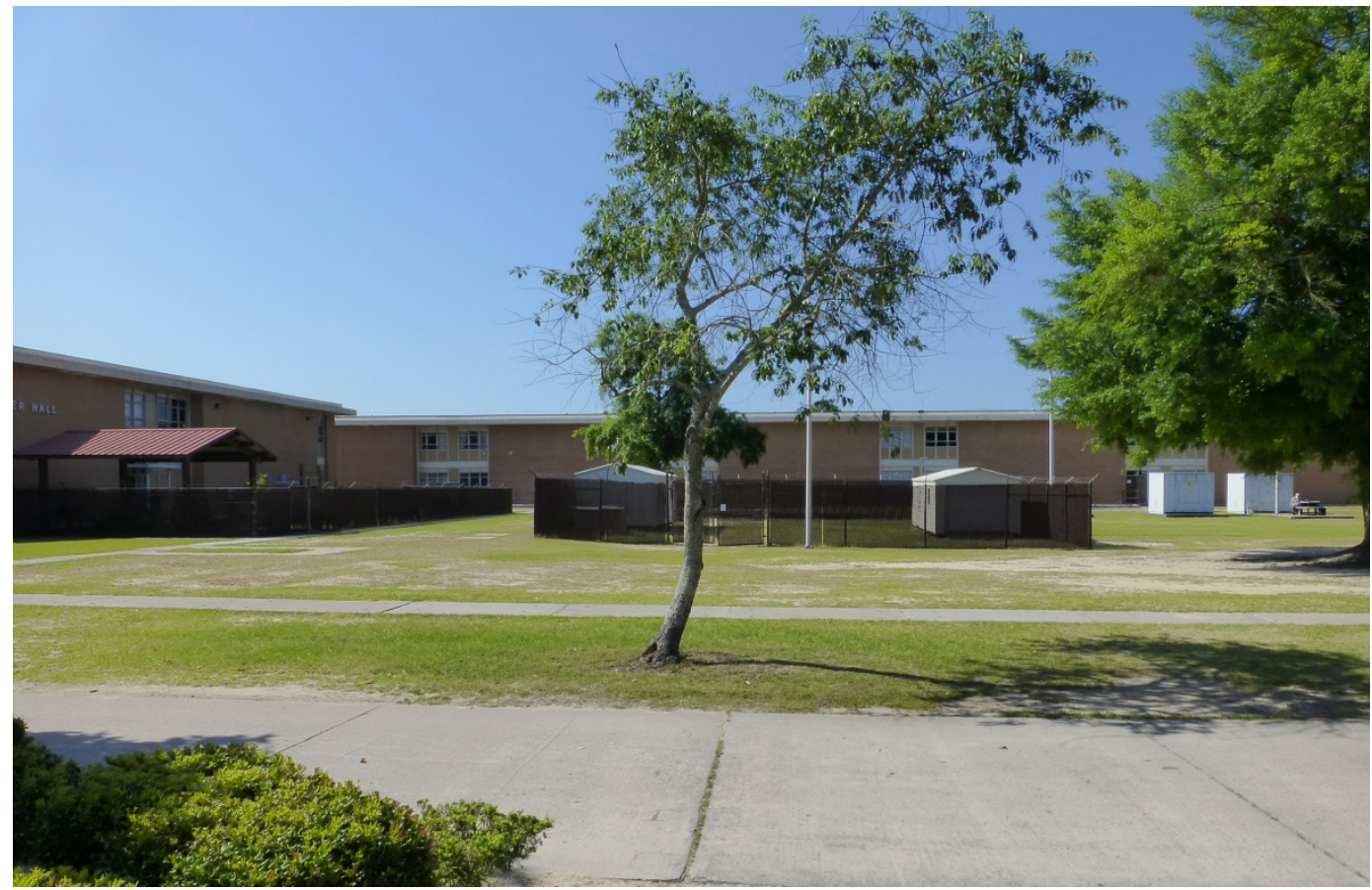

Figure 466. Southwest oblique of Building 33800 (ERDC-CERL, 2015).

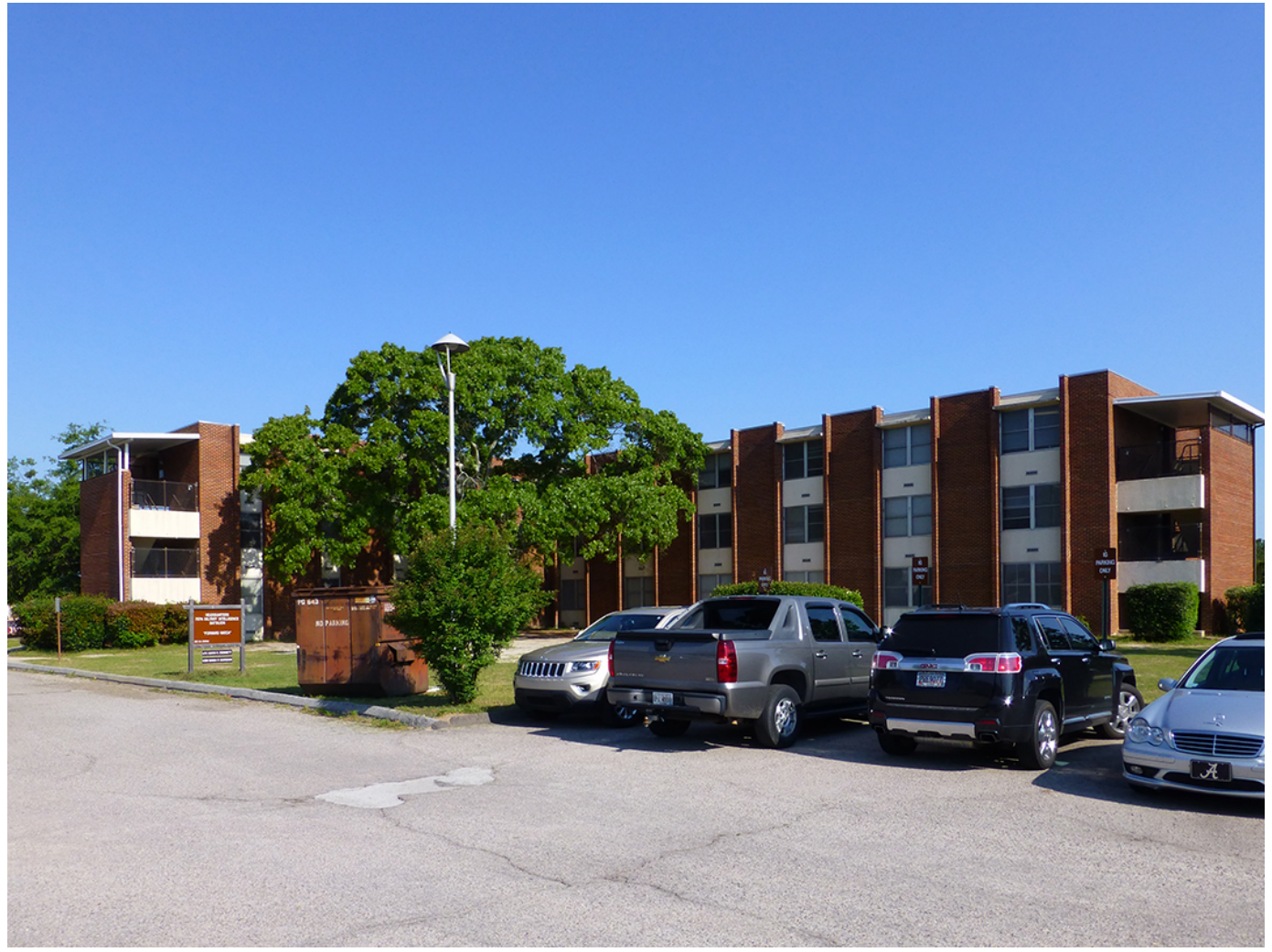




\section{References}

Craig, Robert M. 2015 (print) and 2016 (web). "Richard Aeck (1912-1996).” New Georgia Encyclopedia. Available at http://www.georgiaencyclopedia.org/articles/artsculture/richard-aeck-1912-1996

Nelson, Lee H. no date. "National Park Service Preservation Brief 17: Architectural Character-Identifying the Visual Aspect of Historic Buildings as an Aid to Preserving their Character." Washington, DC: U.S. Department of the Interior, National Park Service. Accessed March 2016: http://www.nps.gov/tps/how-topreserve/briefs/17-architectural-character.htm

NPS. 1995. Secretary of the Interior's Standards for the Treatment of Historic Properties with Guidelines for the Treatment of Cultural Landscapes. As amended and annotated. Washington, DC: U.S. Department of the Interior, National Park Service.

Smith, Adam D., and Sunny E. Stone. 2005a. Fort Gordon Architectural Survey 19421956. ERDC/CERL SR-05-1. Champaign, IL: Engineer Research and Development Center-Construction Engineering Research Laboratory. http://acwc.sdp.sirsi.net/client/en_US/default/search/detailnonmodal/ent:\$002f\$002fSD_IL S\$002f0\$002fSD_ILS:156780/ada

. 2005b. Fort Gordon Cold War Architectural Survey Volume 1: Historic Context and Survey Results. ERDC/CERL SR-05-7, Vol. I. Champaign, IL: Engineer Research and Development Center-Construction Engineering Research Laboratory.

http://acwc.sdp.sirsi.net/client/en_US/default/search/detailnonmodal/ent:\$002f\$002fSD_IL S\$002f0\$002fSD_ILS:176411/ada/?rt=CKEY\%7C\%7C\%7CCKEY\%7C\%7C\%7Cfalse . 2005c. Fort Gordon Cold War Architectural Survey Volume 2: Signal School Survey Forms. ERDC/CERL SR-05-7, Vol. II. Champaign, IL: Engineer Research and Development Center--Construction Engineering Research Laboratory. http://acwc.sdp.sirsi.net/client/en_US/default/search/detailnonmodal/ent:\$002f\$002fSD_IL S\$002f0\$002fSD_ILS:176412/ada

Stokes, Carol. 1993. A History of Fort Gordon, Georgia. Fort Gordon, GA: Command Historian Office. 


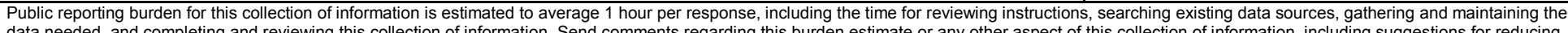

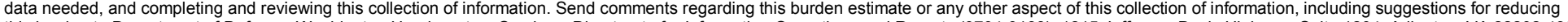

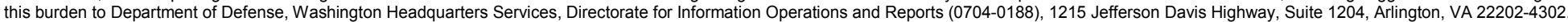

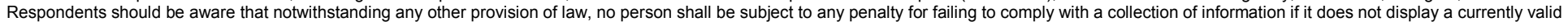
OMB control number. PLEASE DO NOT RETURN YOUR FORM TO THE ABOVE ADDRESS.

\begin{tabular}{l|l|l} 
1. REPORT DATE (DD-MM-YYYY) & 2. REPORT TYPE & 3. DATES COVERED (FrOm - To)
\end{tabular}

July 2016

4. TITLE AND SUBTITLE

Final Technical Report

Character-Defining Features of Contributing Buildings and Structures in the Fort Gordon,

Georgia, Signal School Campus Historic District

5a. CONTRACT NUMBER

5b. GRANT NUMBER

5c. PROGRAM ELEMENT NUMBER

6. AUTHOR(S)

Sunny E. Adams and Adam D. Smith

5d. PROJECT NUMBER

400142

5e. TASK NUMBER

5f. WORK UNIT NUMBER

8. PERFORMING ORGANIZATION REPORT NUMBER

U.S. Army Engineer Research and Development Center (ERDC)

ERDC/CERL SR-16-8

Construction Engineering Research Laboratory (CERL)

Champaign, IL 61826-9005

\section{SPONSORING / MONITORING AGENCY NAME(S) AND ADDRESS(ES)}

Cultural Resources Manager

Directorate of Public Works

Fort Gordon, GA 30905
10. SPONSOR/MONITOR'S ACRONYM(S)

11. SPONSOR/MONITOR'S REPORT NUMBER(S)

\section{DISTRIBUTION / AVAILABILITY STATEMENT}

Approved for public release. Distribution is unlimited.

\section{SUPPLEMENTARY NOTES}

Copies are available from the National Technical Information Service, 5285 Port Royal Road, Springfield, VA 22161.

\section{ABSTRACT}

This document is an architectural survey of character-defining features for the contributing features of the Signal School Campus Historic District located at Fort Gordon, Georgia. This survey satisfies Section 110 of the National Historic Preservation Act of 1966 as amended, and it was used to determine which elements of the buildings and structures of the historic district are character-defining features for the elements that are eligible for the National Register of Historic Places.

\section{SUBJECT TERMS}

Fort Gordon (Ga.), U.S. Army Signal School, Architectural surveys, Historic preservation, Character-defining features, Historic district, Historic management, National Register of Historic Places (NRHP)

\begin{tabular}{|c|c|c|c|c|c|}
\hline \multicolumn{3}{|c|}{ 16. SECURITY CLASSIFICATION OF: } & \multirow{2}{*}{$\begin{array}{l}\text { 17. LIMITATION } \\
\text { OF ABSTRACT } \\
\text { UU }\end{array}$} & \multirow{2}{*}{$\begin{array}{l}\text { 18. NUMBER } \\
\text { OF PAGES } \\
406\end{array}$} & 19a. NAME OF RESPONSIBLE PERSON \\
\hline $\begin{array}{l}\text { a. REPORT } \\
\text { Unclassified }\end{array}$ & $\begin{array}{l}\text { b. ABSTRACT } \\
\text { Unclassified }\end{array}$ & $\begin{array}{l}\text { c. THIS PAGE } \\
\text { Unclassified }\end{array}$ & & & $\begin{array}{l}\text { 19b. TELEPHONE NUMBER (in- } \\
\text { clude area code) }\end{array}$ \\
\hline
\end{tabular}

